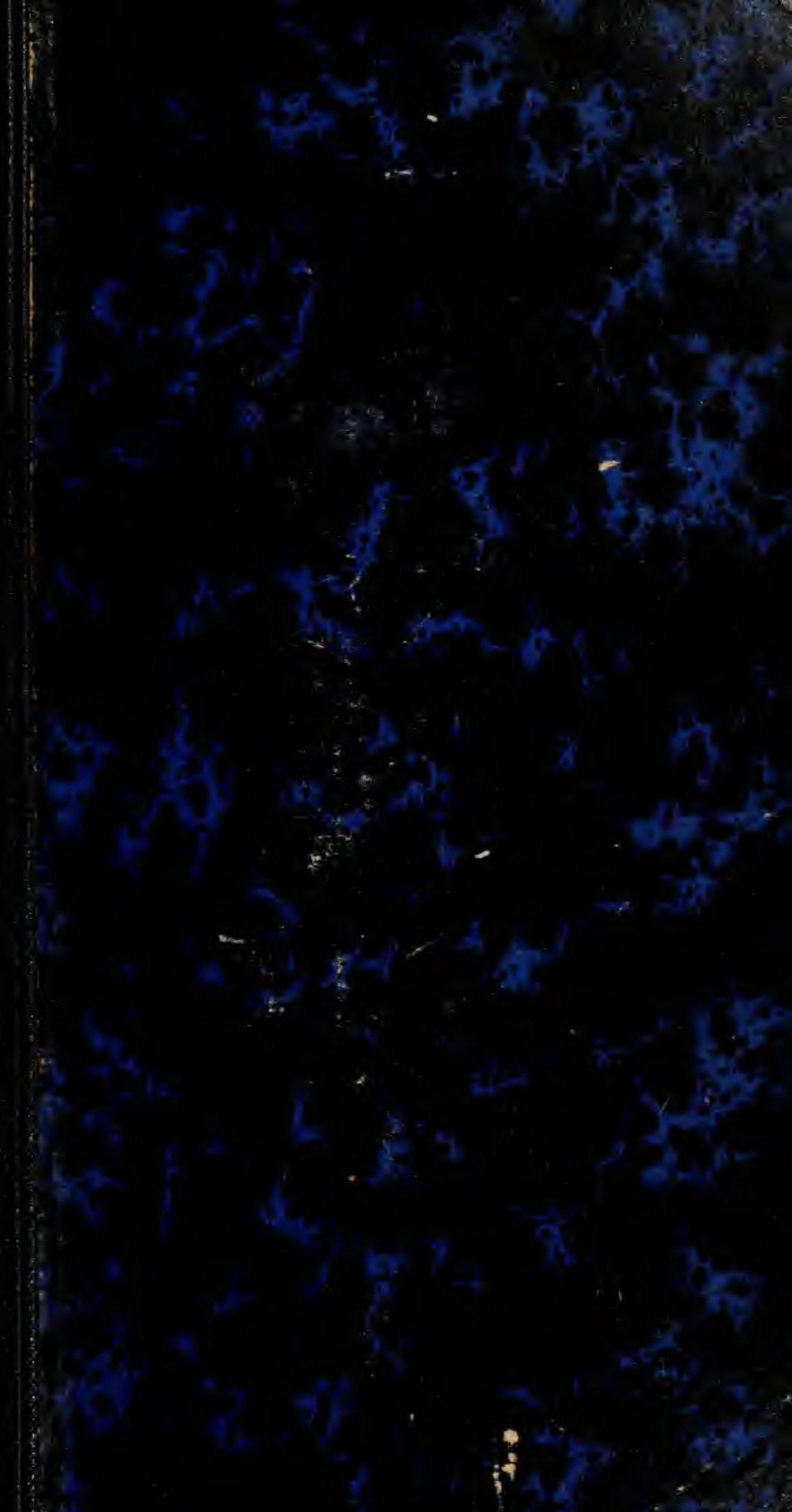




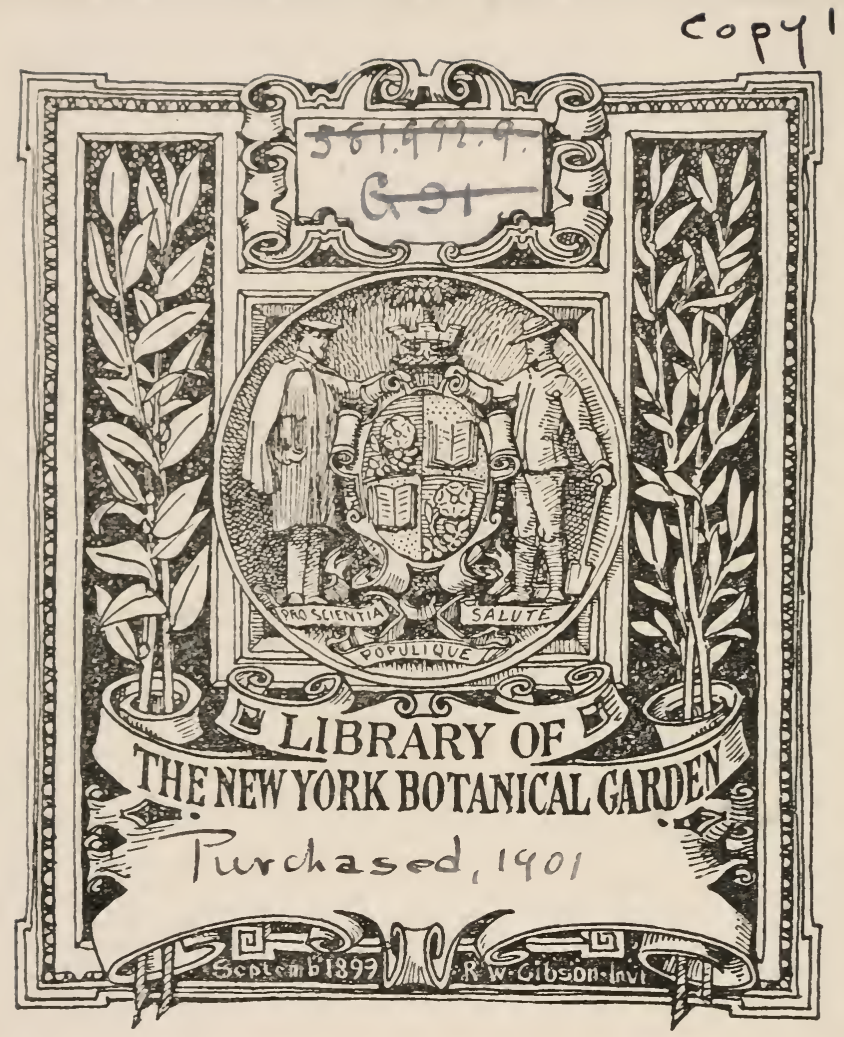








\section{EL MÉDICO BOTÁNICO GRIOLLO}

PARTE PRIMERA

FLORA MÉDIGA Y ÚTIL DE LAS ANTIJLAS 
Paris. - Imprenta de Poupart-Davyl y Ca, ealle du Bac, 30. 


\section{EL}

\section{MÉDICO BOTÁNICO}

G R I O L L O

POR

\section{Renato de GROSOURDY}

DOCTOR EN MEDiCINA DE LA FACULTAd DE MEdiciNa DE PARIS

EX-REPETIDOR DE QUIMICA EN LA MISMA FACULTAD, EX-PROFESOR PARTICULAR

DE QUíMICA Y BOTÁNICA MÉDICAS EN LA MISMA CIUDAd

socto CORREsponsal de varias CORPoraciones ciestificas francesas

Y ESTRANJERAS

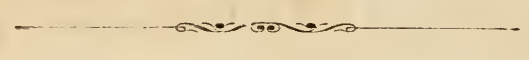

\section{PARTE PRIMERA}

\section{FLORA HÉDICA Y ÚTIL DE LAS ANTILLAS}

Y DE LA PARTE CORRESPONDIENTE DEL CONTINENTE AMERICANO

\section{TOMO I}

Conteniendo la Botánica elemental, el Método dicotómico, etc.

Con miras tan sublimes cóno sabias, la vida de las plantas y la de los animales están enlazadas, la una con la otra, por medios tan sencillos como durideros y que asonbran.

Lifbig, Introduccion a la Química organica.

\section{TOMO I (de la obra)}

\section{PARIS}

LIBRERIA DE FRANCISCO BRACHET

$$
\text { 8, Calle de l'abbate, } 8
$$





\section{DOGUMENTOS}

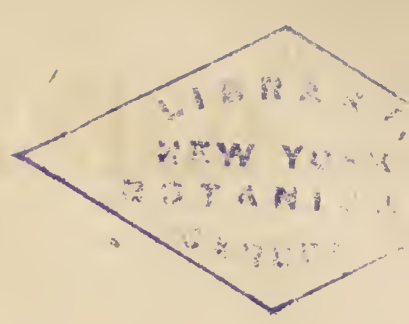

\section{REAL UNIVERSIDAD LITERARIA DE LA HABANA.}

La obra que con el título de El Médico bntánico criollo piensa V. dar á luz, fué examinada por una comision del claustro de esta real Universidad, lo que, al evacuar su informe, lo ha hecho en los términos mas satisfactorios para $\mathrm{V}$.

Segun la comision, la obra está escrita bajo un plan enteramente nuevo, es rica en datos importantes y puede considerarse como la mas completa de cuantas hasta la fecha se han publicado con referencia á las Antillas; la considera además útil y conveniente para toda clase de personas, porque abraza la ciencia bajo todos sus aspectos.

Enterado el claustro, y habiéndose conformado con el espresado dictámen, acordó se manifestase á V. que la Universidad coadyuvará á la circulacion del Médico boténico criollo recomendándolo del modo que considere mas á propósito.

Dios guarde á V. muchos años. - Habana, junio 6 de 1860. - El Rector, Antonio Zambrana.

\section{INFORME DE LA COMISION.}

Los catedráticos que tuvieron el honor de anunciar al claustro la obra de Botánica médica de Don Renato de Grosourdy, tienen hoy la satisfaccion de informar sobre ella y de repetir que es un verdadero tesoro para la ciencia. Su modesto título es El Médico botánico criollo, y se divide en dos partes : la Flora médica y útil de las Antillas y, el Compendio de terapéutica vejetal de las mismas.

La primera parte tiene una introduccion en que se esplica su objeto y plan, con citacion de las obras que para su formacion re han consultado; un discurso preliminar en que aparecen todos los datos científicos que tienen relacion mas ó menos directa con la botánica, de cuyo conocimiento se hacen aplicaciones diversas á la economía doméstica, á la agricultura, etc., terminándose con un resúmen muy completo de geografía botánica. Siguen á la introduccion y al discurso preliminar unos elementos de botánica igualmente completos, en que los ejemplos se toman de las plantas mas conocidas de las Antillas, con sus nombres vulgares: se comprende en esta parte el método dicótomo, y para él se describen las plantas, cuyo número pasa ya de 2,000 , y se termina por un apéndice de agricul- 
tura y tres índices alfabéticos, casteliano, francés y latino. Esta parte es el resúmen de mas de cincuenta volúmenes, conteniendo los trabajos orijinales del autor, y constará de dos tomos.

El Compendio de terapéutica, que constará así mismo de dos tomos, comprerde estudios prácticos hechos sobre las plantas de estos paises, consideradas ya como medicamentos, ya como renenos, ya como sustancias alimenticias, señalando además sus otros usos domésticos y sus varios empleos en las artes. Esta segunda parte es igualmente rica en datos y está severamente arregleda á los buenos principios científicos.

En una palabra, El Médico botánico criollo es la obra de un profesor de conciencia que posee los mas completos y exactos conocimientos en la ciencia, de un profesor conocido, doctor en medicina de la facultad de Paris, encargado durante seis años de las repeticiones químicas en la escuela práctica de la misma facultad, profesor particular de química é historia natural y miembro de muchas sociedades sabias, del cual tenemos en nuestro poder un tratado de química considerada en sus aplicaciones á la medicina, en dos volúmenes.

El Dr. de Grosourdy posee de un modo admirable el conocimiento práctico de las plantas de las Antillas, y su obra, repetimos, será una adquisicion preciosísima.

Los que suscriben se contentan con este breve pero exactísimo informe, pidiendo al claustro conceda al Dr. de Grosourds el permiso para anunciar que publica su obra bajo los auspicios de la real Universidad literaria. Esto es á cuanto aspira, dejando que los que deseen suscribirse, así catedráticos como alumnos, lo hagan espontáneamente. Quiere tener el honor de que la primera corporacion científica de América aparezca protejiendo sus esfuerzos, y seguramente el claustro, viendo que no hay que hacer el mas mínimo sacrificio, se complacerá en dar este nuevo testimonio de su ilustracion y de sus benéficas tendencias.

Habana y mayo 24 de 1860 . - Dr. Ramon Zambraná. - Dr. Joaquin F. de Aenlle.

Persuadido del mérito de la obra que piensa dar á luz el Dr. don Renato de Grosourdy, con el título del Mrédico botínico criollo, bajo los auspicios de la real Universidad literaria, cuyo claustro ha calificado aquel mérito, recomiendo á los Sres. Directores de los colejios y escuelas que están en relacion con la Universidad. la conveniencia de que se proteja la suscricion á dicha obra, de cuya publicacion deben resultar notables ventajas en favor de la ciencia $y$ de la instruccion pública.

Habana y junio 23 de 1860. - El Rector, Antonio Zambrana. 
Persuadido del mérito de la obra que piensa dar á luz el Dr. don Renato de Grosourdy, con el título del Médico botánico criollo, bajo los auspicios de la real Universidad literaria, cuyo claustro ha calificado aquel mérito, recomiendo á los Sres. profesores de farmacia con oficina pública ó sin ella, la conveniencia de que protejan la suscricion á dicha obra, de cuya publicacion deben prometerse notables ventajas en favor de la ciencia á que están dedicados y á la salud pública.

Habana y junio 26 de 1860. - Dr. Cayetano Aguilera.

GOBIERNO, CAPITANÍA GENERAL Y SUPERINTENDENOIA DELEGADA DE HACIENDA DE LA SIEMPRE FIEL ISLA DE CUBA.

\section{Secretaria del Gobierno.}

CIRCULAR.

Celoso siempre de todo adelanto que influya en bien del pais y de la humanidad en general, y penetrado al mismo tiempo de las importantes ventajas que reportarán el uno y la otra con la publicacion de la obra que trata de dar á luz el Dr. D. Renato de Grosourdy, con el título de El Médico botánico criollo, cuya primera parte comprende la Flora médica y útil de las Antillas, y la segunda el Compendio de terapéutica vejetal de las mismas, he tenido por conveniente impartirle la proteccion que de este Gobierno superior civil ha solicitado el promovente con el objeto de llevar á cabo su útil proyecto, que no es otro que estudiar concienzudamente las propiedades medicinales de cada una de las diversas plantas que produce esta isla.

Pero como quiera que para la investigacion delicada y científica que se propore, necesita adquirir los datos y noticias convenientes á la ilustracion de su obŕa, encargo eficazmente á todas las autoridades á quienes ocurra, con esta circular, que le faciliten los medios mas adecuados, obvios y posibles al esclarecimiento indicado, ya por la esperiencia que tengan del pais, ya poniéndole en contacto con personas capaces de ilustrar su propósito.

Habana 18 de marzo de 1860. - Serrano.

Sres. Gobernadores y tenientes Gobernadores de la isla á quienes esta circular fuere presentada. 
Su Escelencia el general Fernando Cotoner, gobernador general de la isla de Puerto-Rico, tuvo á bien otorgarnos una circular por el mismo estilo para las autoridades de la isla de Puerto-Rico, de la cual hemos sacado mayor utilidad y provecho, pero sentimos no poder transcribirla aquí por haberse estraviado.

\section{INFORME DE LA REAL SUBDELEGACION DE FARMACIA DE SAN JUAN DE PUERTO-RICO.}

\section{Escmo. Señor.}

Cumplida la órden superior de V. E. del 9 del mes próximo pasado, por la que se dignara disponer el exámen de la obra escrita por el Dr. en medicina D. Renato de Grosourdy, titulada: "Medicina popular y doméstica de las Antillas, ó Compendio de terapéutica vejetal de las mismas, " esta real Subdelegacion tiene el honor de informar á V. E., por lo que como constancia pudiere importar en el asunto, que, sometida dicha obra durante treinta dias al exámen, revision y censura de dos distintos comisionados, han evacuado estos su cometido en términos ciertíficos razonados tan satisfactorios, que como acto de deber, por de justicia, no vacila en suplicar á V. E. esta real junta, se digne prestar á su respetable autor toda la necesaria proteccion que merec n publicaciones tan importantes como esta, por los multiplicados beneficios que han de reportar á la ciencia, al pais y á la humanidad.

Dios guarde á V. E., etc. - Puerto-Rico y junio 15 de 18556 Escelentísimo Sr. - L. J. P. Rosello.

\section{REPÚBLICA DE VENEZUELA.}

SECRETARÍA GENERAL, DEPARTAMENTO DE REIAACIONES ESTERIORES, SECCION SEGUNDA.

Carácas, 18 de junio de 1862.

RESUELTO.

Deseoso el gobierno de conocer el mérito de la obra de botánica que ha compuesto el señor Renato de Grosourdy, doctor de la Universidad de Paris, y á la cual se refiere en su peticion anterior, nombra por comisionados para su exámen á los señores.doctor Antonio José Rodriguez y Manuel Vicente Diaz, á los cuales se recomendará que investiguen, no solo su valor intrínseco, sino tambien 
su aptitud para servir de testo en las universidades nacionales. Con el resultado de ese paso, S. E. decidirá sobre la demanda de auxilio que para la impresion del manuscrito ha menester el autor.

Por S. E., Manuel Porras.

\section{Carácas y agosto 19 de 1862.}

\section{RESUELTO.}

Sometida al exámen de una comision la obra de botánica que ha compuesto el señor Renato de Grosourdy y que se propone publicar en esta ciudad con el título de El Médico botánico criollo, se ha obtenido como resultado que semejante trabajo es á propósito para la enseñanza en Venezuela, porque no solo clasifica las plantas útiles del contiriente $y$ de las Antillas, sino tambien señala los usos que tienen en la medicina, como en la economía doméstica y en las artes, siendo el complemento de los ensayos de este género emprendidos por otros profesores. Demas de esto, la publicacion de observaciones acumuladas en el espacio de diez años que el autor ha invertido en estudiar los paises de esta zona, no puede dejar de dar á conocer á Venezuela en parte tan importante como el reino vejetal, y esto ha de contribuir por necesidad al adelantamiento de la República. Fundado en tales consideraciones, el Gobierno estima de mucha utilidad y digna del apoyo nacional la empresa del señor doctor de Grosourdy, y por vía de auxilio resuelve suscribirse á doscientos y cincuenta ejemplares de la obra.

Por S. E., Rojas. 



\section{PROLOGO.}

Si nuestra obra hubiera debido tener por lectores solo á los sabios y á los aficionados, ya al corriente de los conocimientos botánicos y prácticos en la determinacion del sinnúmero de vejetales que la botánica enseña á conocer y á clasificar, hubiéramos podido omitir sin inconveniente alguno escribir esa primera parte y pasar inmediatamente á las aplicaciones médicas, pero por desgracia no es así ; hubiéramos tambien podido pasar adelante si bastase señalar algunas obras de botánica con que nuestros lectores pudieran con facilidad y casi sin trabajo ponerse al corriente de la botánica teórica y práctica correspondiente á las Antillas y al continente vecino; unos pocos quizás habria que se tomarian el trabajo de hacer las diligencias á propósito para conseguir tales obras? Además sabemos en demasía cuánte es difícil y trabajoso, por no decir casi imposible, en los paises en que estamos escribiendo estos renglones, proporcionarse las obras mas conocidas y mas vulgarizadas, y por tal causa no se podrian pues proporcionar las obras de botánica que necesitarian y que de poco provecho serian para ellos, porque todas están escritas en idiomas estranjeros ó en latin, lo que es un obstáculo casi invencible á la vulgarizacion de los conocimientos botánicos en los paises intertropicales y tropicales de oríjen español ; además de lo ya dicho, una obra por el estilo de la nuestra tiene los datos que la forman esparcidos en un sinnúmero de tomos perteneciendo á muchas cbras diferentes, y no hay hilo conductor alguno para salir felizmente de tan molesto, fastidioso é intrincable laberinto. Para componer esa parte botánica nos hemos visto precisado á leer con mayor atencion y estudiar con cuidado las obras inglesas de Lindley, la Flora de Jamaica por Macfayden, la Flora de las Indias Occidentales británicas de Griesbach, no concluida todavía, etc., las latinas siguientes: Prodromus, de Decandole; Annalesbotanices systematice y Repertorium botairices systematica, de Guilelmo Gerardo Walpers : Plantarum vascularium, de Carolo Frederico Meisner; Sloane, Flora de Jamaica; la Flora de Cuba, por A. Richard; Endlicher, Genera plantarum, etc.; las francesas : de Aubelet, Flora de la Guyana; de Descourtils, el Diccionario de Historia natural; de d'Orbigny, Plumier, Tussac, etc., y un sinnúmero de memoriales y de monografías. Hemos tenido pues que sacar de todas estas obras y de muchas rocas calcureas y con la incesante accion de los vejetales: hasta que 
otras, como la de Knuth Flora equinoxial por ejemplo, lo que necesitábamos y que nos correspondia á nosotros para componer nuestra Flora médica y útil de las Antillas y del continente americano vecino, tarea larguísima y muy árdua, que hemos tenido la suerte de poder llevar á cabo á costa de mucha paciencia, pertinazia y de continuas vijilias. Hemos pues hecho todo lo posible para poner al alcance de todos el modo de lograr conocer con bastante facilidad los vejetales ó plantas útiles de los paises intertropicales y tropicales americanos, estudiados y conocidos hasta ahora de los hotánicos solos, y cuyo uso no ha podido hasta hoy dia entrar por tal causa en el dominio vulgar, y no han tomado en el hogar doméstico el lugar que sus propiedades bienhechoras les señala y les da derecho de ocupar.

Eso puesto, hemos hermanado en esta obra la teoría con la práctica, y para hacerlo nos ha costado reunir en esta parte de nuestros trabajos todos los vejetales que corresponden sea directa ó indirectamente á ia flora médica y útil de las Antillas y de la parte correspondiente del continente americano, tarea tanto mas árdua cuanto que hemos tenido que abrir una senda casi enteramente nueva, llena de escollos y de precipicios muy difíciles para evitar, porque no teniamos guia alguna; en fin hemos tenido la suerte de salir sano $y$ salvo de ese mal paso, pero á costa de esfuerzos sobrehumanos : $L a$ bor improbus omnia vincit.

Hemos dispuesto la Flora médica y útil de las Antillas y de la parte del continente vecino correspondiente á ellas como sigue : con la denominacion de discurso preliminar, hemos escrito un capítulo especial en que hemos agrupado cuantos datos y conocimientos útiles hay que no cabian en otra parte alguna y no podian sin embargo omitirse; hemos pues señalado en él la importancia y utilidad tan poco apreciada de los vejetales, lo provechoso que es su estudio y la utilidad que reporta el de la botánica aplicada; hemos dado razon de un sinnúmero de fenómenos que presenciamos diariamente y que por ser desconocidos pasan siempre desapercibidos, aunque su intelijencia sea muy útil tanto para la economía doméstica como para la agricultura, etc.

Con el nombre de Prolegómenos hemos escrito un resúmen de bctánica elemental, en que hemos recopilado lo mas sucinta y claramente posible los principios fundamentales de esta ciencia y reunido esplicándoles todas las palabras y vocablos que se emplean para designar los diferentes órganos y partes constituyentes de los vejetales; sigue despues el método dicótomo en que hemos dispuesto todos los géneros de tal manera que se puede llegar con mayor facilidad y con los mas escasos conocimientos botánicos á su determinacion ó nombre científico, trabajo muy árduo y enteramente nuevo. Al principiar pues tan difícil, tan larga y tan fastidiosa tarea no hemos tomado en cuenta nuestras fuerzas débiles y, quizás atrevidamente, nos hemos engolfado á estudiar y en averiguar detenida y cuidadosamente lo que habia sido escrito sobre el particular, y bastantes veces hemos señalado caractéres especificos que habian sido olvidados ó que se habian quedado desapercibidos. Hemos pues agrupado 
todos los géneros de las plantas útiles y médicas de las Antillas demas rejiones intertropicales americanas en una dicotomía botánica enteramente nueva, apropiada á esas comarcas y muchísimo mas completa que cuantas han sido publicadas hasta hoy dia para las plantas de algunas partes de Europa, como las de Francia verbigracia. Escusado es decir que para conseguir ese objeto no hemos nunca jamas escusado ningun trabajo, por fastidioso y penoso que fuera, cuando debia reportar provecho, proporcionando el modo mas fácil y mas sencillo para que uno pudiera lograr con poco trabajo conocer el nombre botánico de la planta que tiene en mano, cual poca práctica tuviera en la materia; y en este lugar siempre se halla la descripcion de la especie mas comun y mas conocida del género; al nombre del género sigue la letra F, que significa familia, con su numero correspondiente seguido de una cifra romana, señalando el del género ó el lugar en donde se hallan descritas todas las especies que le corresponden, las cuales están tambien dispuestas en dicotomías parciales, á fin de facilitar su estudio. No es necesario decir que en esta segunda parte de la Flora, los vejetales están colocados en sus familias, órdenes y tribus respectivos, cuyos caractéres estín estendidos con mayor cuidado. En seguida viene un apéndice ó resúmen de agricultura, dispuesto de tal manera que se tenga á la mano siempre la aplicacion práctica de los datos científicos contenidos en el discurso de la Flora, apropiados para el uso de esas comarcas; sigue en fin una noticia muy completa acerca de las maderas útiles de esos paises, su descripcion, sus usos, etc., trabajo enteramente nuevo. Escribiendo pues esa Flora para los que no saben nada de botánica, ha debido ser, como lo es en realidad, un profesor de botánica el que, tomando á uno por la mano, aunque no tenga ningun conocimiento, le acompaña, le guia por el camino florido de esta ciencia tan agradable como utilísima, y le llera así insensiblemente y casi sin trabajo ninguno hasta su cumbre, de donde, trasformado ya en aficionado, puede bajar solo, divertido $\mathrm{y}$ descansado de sus demas ocupaciones, con las manos llenas de plantas que ha reconocido y clasificado y que es capaz de utilizar tan pronto para sí mismo y para los suyos, como para los infelices que lo rodean. Echando entónces una mirada hácia atrás, se quedará admirado del sinnúmero de vejetales sembrados por el Divino Hacedor para que el hombre saque de ellos utilidad y provecho, pues que nada hizo en vano, ni tampoco solamente para hermosear su obra, porque tan sublime y tan perfecta salió de sus manos, que no necesitó nada mas! 


\section{ADVERTENCIA}

ACERCA DE LAS ABREVIATURAS EMPLEADAS EN EL DISCURSO DE ESTA OBRA.

C. T. V. Compendio de terapéutica vejetal.

F. significa (en el Compendio) formulario.

'pié: 1'.

"pulgada: $1 "$.

"' línea: $1^{\prime \prime \prime}$.

F. significa (en la Flora) familia

T. tribu.

S.-T. sub-tribu.

S.-F. sub-familia.

0 . órden.

S.-0. sub-órden.

G. género.

M. D. método dicotómico. 


\section{DISGURSO PRELININAR}

Antes de pasar mas adelante es preciso saber que el reino vejetal fué el principio de toda organizacion y que el primero salió de las manos bienhechoras del Criador; laboratorio de química viviente y organizadora que admirablemente dispuso para que se agrupasen entre sí las moléculas integrantes de un escaso número de cuerpos simples inorgánicos, y formasen así las partículas orgánieas, las cuales habian de producir mas luego los órganos de vejetales muy sencillos que habian de alimentar á los animales tambicn de organizacion muy sencilla que aparecieron los primeros.

Pareció en fin el dia en que hubo tregua en la lucha entre el fuego y el agua, repartiéndose el globo, teatro de su batalla; pero un mar sin límites cubria la tierra, en el cual sobresalian unas cuantas islas, que recibian calor, no del sol, cubierto de nieblas, sino del fuego interior; bajo aquella atmósfera hirviente, desprovista de oxíjeno y sobrecargada de vapor acuoso y de ácido carbónico, rasgada á cada instante por el rayo, ningun animal podia vivir, á no ser los peces, los pólipos y moluscos en la mar. Pero la vejetacion desplegaba una activiclad inmensa, $\mathrm{y}$ las islas enjutas se cubrieron entónces de arbustos vasculares de organizacion sencilla $\mathrm{r}$ de pronto incremento; colosales equisetos, helechos arbóreos, y algunas palmeras, poco diferentes en especies, pero cuyos individuos se multiplican, crecen y mueren con indecible rapidez; su vida descompone incalculable cantidad de ácido carbónico y de agua, a! paso que fija el hidrójeno y el carbono, con lo cual el aire se purifica arlquiriendo oxíjeno, y llega á ser posible la aparicion de los animales terrestres. Sobreviene entónces una revolucion en la faz de la tierra y los inmensos lechos de aquellos vejetales son sepultados y convertidos en carbon fosil ó ulla por la presion de los estratos sobrepuestos y por el calor del globo. Sucédense otras edades geolójicas, otros dias de la creacion, en los cuales las islas se estienden, se puebla la faz del mundo, primero de reptiles gigantescos, que viven en una atmósfera todavía impura, la cual se va sanificando con la precipitacion de los rudimentos de 
luego vienen los mamíferos, las aves, los insectos, á cada nueva re volucion, acercándose mas y mas á las formas actuales; y últimamente aparece el hombre, señor de todo lo creado.

La Génesis y los escritos de los geólogos prueban sin contestacion alguna que los vejetales fueron los primeros séres que aparecieron sobre la tierra. Enla Génesis selee en efecto : Dixit vero Deus : Congregentur aqua, qua sub ccelo sunt, in locum unum, et appareant ariala. Et factum est ita. Et rocavit Deus arida terram, congregationemque aquarum appellavit maria, et vidit Deus quodesset bonum, et ait: Germinet terra herbam virentem et facientem semen, et lignum pomiferum faciens fructum juxta genus suum, cujus semen in semetipso sit super terram. Et factum est ita. Et protulit terna herbam virentem et facientem semen juxta genus sunm, lignumque faciens fructum et habens unumquodque sementem secundum specien suam. Et vidit Deus quod esset bonum, et factum vespere et mane diei tertii. Llegó pues el momento en que el agua pudo comenzar á condensarse y permanecer líquida en la superficie de la tierra, reuniéndose en estensas masas para formar lagos mayores y vastos mares. Aparecieron entónces los primeros séres organizados, comenzando por los vejetales y siguiendo los animales acuáticos marinos que animaron la superficie de la tierra. Así piensa el geólogo Boubée, pero Lecocq admite como probable que debieron presentarse en este período animales de cuerpo blando y jelatinoso semejantes á los zoófitos actuales, al mismo tiempo que vejetales débiles, fáciles para descomponerse y sin formas bien determinadas. Estos séres primordiales, resultando de composiciones elementales superiores, debieron aparecer tan pronto como la temperatura del agua y de la superficie húmeda de la tierra dió lugar á su desarrollo, comprobándose así una verdad proclamada hace mucho tiempo por Hipócrates en el aforismo siguiente: Ignis omnia per omnia movere potest; aqua omnia per omnia nutrire. En esta época, pues, la vejetacion debió tomar un ascendente estraordinario y las plantas ser todas gigantescas, los animales acuáticos, los reptiles y los anfibios multiplicarse con espantosa facilidad; en efecto, el calor que reinaba entónces por toda la superficie del globo y que era igual todo el año debia favorecer muchísimo ese desarrollo de la organizacion con la influencia de la humedad y de una proporcion muy considerable de ácido carbónico en la atmósfera; vemos en efecto la vejetacion ser mucho mas activa y mucho mas lozana en los paises cálidos que en los templados.

Al tercer dia de la Génesis, que corresponde á la segunda época geolójica de Boubée, las aguas se han reunido, aparece la tierra seca, y los vejetales son al momento criados para habitar el globo, cuyos terrenos se hallan caracterizados especialmente por impresiones vejetales. En efecto, despues de un tiempo mas ó menos largo, la vejetacion, como tipo de la organizacion mas sencilla, debió aparecer bajo la influencia organizadora de los ajentes imponderables sobre los elementos que habian de combinarse; pero debemos advertir que en esta época solo los vejetales de organizacion mas sirnple pudieron presentarse por faltit de la accion benéfica del sol y 
porque el estado de la atmósfera y del globo no permitia que el desarrollo orgánico pudiese verificarse con toda su perfeccion. El Criador, que todo pudo haberlo hecho en un solo momento, graduó el desenvolvimiento $\mathrm{y}$ la aparicion de nuevas fuerzas que sucesivamente perfeccionaron las producciones orgánicas de la tierra.

Si comparará uno entre sí las varias formas de los vejetales que han vivido en la superficie de la tierra en las diferentes épocas de su formacion, reparará asombrado mayores diferencias en la naturaleza de los que se han sucesivamente desarrollado y que han reemplazado á los que las revoluciones del globo y los cambios en el estado físico de su superficie y químico de la atmósfera hacian desaparecer para siempre. Tales diferencias no solamente se observan en las especies. ni tampoco son modificaciones lijeras de los tipos, pero mas veces son tantas que géneros y familias enteras nuevas, pero siempre de una organizacion mas compleja y mas perfecta por consiguiente, vienen á reemplazar á otras familias muy distintas destruidas enteramente; otras reces sucede que una familia numerosa y muy variada se halla reducida á algunas especies que se quedan, mientras que al contrario otra que estaba señalada solamente por algunos raros individuos se vielve casi de repente muy numerosa y predominante. Lo que se observa de ordinario al pasar de una formacion geolójica á la siguiente; pero al considerar el conjunto de tales transformaciones, se presenta al espíritu del observador el resultado general incontestable de la preponderancia en los tiempos mas remotos de los rejetales criptógamos acrójenos, como Jos helechos, licopodiáceos, época que corresponde á los terrenos carboníferos y hasta á los de transicion, en ellos se hallan además algunas algas, hipoxilons $\mathrm{y}$ hongos, que á nuestro parecer debieron ser los primeros vejetales muy numorosos, pero cuyas huellas no se han quedado por causa de ser demasiado blandos y fáciles de descomposicion. Mas luego predominan en la tlora fósil los vejetales dicotiledóneos gimnospermos representados por cicádeas y coníferas únicamente muy numerosos, los cuales corresponden á los terrenos secundarios. En fin el período cretáceo ó de los terrenos terciarios, que parece la transicion entre los vejetales de los terrenos secundarios y los de los terciarios, produjo una flora fósil caracterizada por algas, helechos y monocotiledóneos que fueron palmeras; los dicotiledóneos fueron representados por cicádeas, coníferas, miricíneas, betulíneas. cupulíferas, salicíneas, aceríneas, juglandeas, etc. En fin, el período terciario contemporáneo de todos los depósitos terciarios y que se continua aun con la vejetacion que ahora cubre la superficie de la tierra contiene la flora fósil mas numerosa $y$ mejor caracterizada.

Para probar la utilidad incontestable de los vejetales para la existencia de los animales transcribiremos aquí lo que dice sobre 1o particular el ilustre catedrático del colejio de medicina de San Tago de Compostela, en su obra titulada : "Ensaro de Antropolojía ": Cuando los filósofos buscaron la causa de la creacion, cuando intentaron sorprender el Supremo Hacedor en su objeto, se admiraron al reconocer el prodijioso número de produc- 
tos orgánicos que, al parecer sin uso determinado, cubre la tierra;. y solo la gran idea de hermosura y de adorno del universo les ha resuelto su difícil problema. Pero el hombre no existiera sin esos seres, sin ese gran número de cuerpos vivos cuyo alto objeto puede sernos desconocido aun en gran parte, sin que por eso lo supongamos un juego de la naturaleza ni del acaso, porque siglos hace que esa naturaleza $\mathrm{y}$ ese acaso nada hacen en medio de los sucesos estraordinarios de tantos siglos que cuenta la historia del hombre. No se nutriera él de elementos si antes no se les presentase ya elaborados y despues de haber sufrido la accion poderosa de la vida. A la manera que cl hombre de nuestras sociedades no come la carne cruda y precisa que antes se disponga y se prepare para que su estómago la lleve bien y la dijiera mejor, así el reino vejetal y el animal son para el hombre grandes liboratorios en donde los elementos sufren una preparacion indispensable y necesaria para que no sean refractorios á la accion del organismo. Así es que los cuerpos simples no son alimentos ni los binarios tampoco, sino los ternarios y los cuaternarios? Porqué? Estos últimos son por lo comun combinaciones que se han efsctuaro bajo la accion rital y en cuyos fenómenos han intervenido ya. Toda combinacion elemental debe, pues, haber sido el efecto de la accion orgánica para que pueda ser alinenticia. Por otra parte el alimento vejetal $y$ animal es capaz de ser asinilado al hombre en el estado en que se halla, es decir, ise apropia la planta y el animal para nutrirse la misma albumina, el mismo mucílago que la tierra ó el alimento contienen? 'Todas estas partes son descompuestas en los órganos del hombre, tcdo se transforma, se combinan de nuevo sus elementos, se forma nueva fibrina, nueva jelatina, $y$ estas partes que entraban con $e l$ alimento no llevaron al hombre mas que los elementos necesarios para nuevas elaboraciones poco acondicionadas y aptas para responder a la accion de la vida. Así es que los que solo comen vejetales tienen por eso huesos, cerebro, músculos, sangre lo mismo que los que comen arimales que poseen estas partes; luego si el animal se nutre y saca re los vejetales igual resultado que alimentándose de otros animales, es bien claro que lo mismo suministran ambos reinos; ambos dan elementos dispuestos á combinaciones orgánicas, por esta razon dan en último análisis los mismos principios constitutivos ó elementos orgánicos los animales herbívoros que los carnívoros y que el hombre. De aquí inferimos que el alimento debe considerarse como una sustancia que reune cierto número de elementos combinados bajo la influencia de la organizacion, porque su gran receptáculo es el universo.

El hombre saca el alimento de las plantas ó de los animales herbívoros, porque los animales carnívoros ya presentan estos elementos en un estado poco propio para sujetarse á la accion de sus órganos; su influencia es penosa para el estómago é intestinos, su decomposicion es rápida al menor obstáculo; la sangre que se produce de su elaboracion es escitante y escesiramente vitalizada, todas las secreciones tienen un olor particular $y$ todo su físico parece demostrar que los elementos tienden á volverse al gran receptáculo 
comun de donde salieron. Toma pues, el hombre, el alimento por el intermedio del reino vejetal y de los herbívoros, y al tomar de ellos las partes que los constituyen sólo recibe elementos combinados para combinaciones nuevas? $\mathrm{x}$ cuál de estos alimentos es mas propio al hombre, el vejetal ó el animal? El género humano ni es herbívoro, ni es carnívoro esclusivamente, es polífago ú omnívoro. Su organizacion, las diversas posiciones en que puede hallarse; los diferentes climas en que reside, los hábitos que puede adquirir; en fin su carácter, los deberes sociales, todo le constituye un ser que precisaba unir la facultad de conformar sus necesidades á su variable posicion sobre el globo, $y$ el sinnúmero de modificaciones que tiene que sufrir bajo mil influencias variadas. Así lo vemos frujívoro en los paises calientes $\mathrm{y}$ en medio de una vida simple y natural, carnívoro inmediato á los polos, polífago en los paises templados, herbívoro en las frescas campiñas, voraz y carnívoro á las orillas de los mares; alimentándose de cereales los de ocupacion agrícola, de semillas y de animales herbívoros cuando pastores, de las fieras indomables en medio de las cazas, de peces cuando pescadores, y reuniendo todas las producciones del globo en sus espléndidos banquetes para ostentar su soberbia opulencia. Pero no impunemente desoye los gritos de la simplicidad; el castigo le amenaza cuando mas se estiende su poder para gozar, porque detras de los grandes placeres están !os grandes dolores. "

¿ Habrá quizás uno quien ignorará cuán dulces é inapreciables goces saca el aficionado al estudio de las plantas, y cuan mayor utilidad le reporta su aplicacion diaria? En demasía es sabido de todos cuán hermosos colores saca de los rejetales el arte de teñir; cuántos remedios enérjicos y muy poco costosos las plantas suministran al arte de curar; para todos es demasiado notorio que el agricultor laborioso é inteligente saca de los vejetales mas abundantes, mas variadas y mas ricas cosechas, que se vuelven para su familia un manantial inagotable de goces inocentes y de riqueza, á la par que reporta utilidad á la sociedad entera, cuyo comercio activa; ¿quién no habrá visto al horticultor instruido sacar de sus huertas las mas sabrosas y mas variadas hortalizas, los frutos mas deliciosos y las mas primorosas flores, que le dejan mucho provecho? ¿No son los rejetales que suministran al comercio sus mas abundantes productoś y hacen la riqueza de los paises que se dedican sea á su cultura, sea á la fabricacion y á la aplicacion de sus varios productos? En fin, ¿̇qué sucederia á esa asombrosa diversidad de animales ó de seres vivientes que hormiguean á la superficie del globo terresire y que sirven sea directa ó indirectamente al bien estar y al sustento del rey de la creacion, si todos los vejetales desaparecieran de repente?

La botánica, como lo tenemos ya dicho, no solo reporta provecho y utilidad á los que la cultivan y á los paises cuyas artes favorece muchísimo, sino que puede además suministrar datos históricos á sus aficionados; en efecto, por su medio se puede saber aproximadamente cuanto tiempo hace que un edificio está arruinado atendiendo á los vejetales que ya cubren sus ruinas. Los edificios abandonados y arruinados tardan poco tiempo en cubrirse de 
rejetacion como nadie lo ignora; lo que primero se presenta son los liquenes, sencillas manchas que cubren las piedras por acá y por acullá, al descomponerse forman una capa terrosa muy delgada en que los musgos pueden fácilmente introducir sus raices filamentosas, $y$ entónces una alfombrita verde y á veces rojiza reviste la mayor parte del edificio. Esos musgos se pudren á su vez y dejan en pos de sí un mantillo que basta para que broten algunas plantas herbáceas anuales, $y$ se van sucediendo así los vejetales los unos á los otros hasta que aparezcan los árboles, lo que sucede como á los 15 ó 20 años despues de la destruccion del edificio. Esos árboles forman, por decirlo así, como una cronolojía viva en que se leen los años del edificio arruinado, porque esta ciencia nos enseña y nos demuestra con la mayor claridad que los árboles forman cada año una capa nueva de madera: eso puesto, si se corta uno de ellos por la parte mas inferior se advertirá en el corte que su tronco se compone de un cierto número de capas concéntricas de madera, correspondiendo cada una de ellas con un año de edad; si el árbol tiene por ejemplo 60 capas, se podrá afirmar que las ruinas no tienen menor edad, y que el edificio no ha podido estar arruinado ó abandonado en una época mas reciente; pero como los árboles no han aparecido sino á los 20 ó 30 años de arruinado, se puede calcular que las ruinas tienen á lo menos 80 años de edad.

Antes de pasar mas adelante nos parece de mucha utilidad señalar aquí la ley de las analojías botánicas, tan fecunda en resultados he mayor consideracion y por desgracia muy poco conocida, y cura existencia está hasta enteramente ignorada por la mayor parte de los agricultores, bien que tenga para ellos mayor interés haciéndoles partícipes de conocimientos que les reportarian provecho. El estudio pues de la botánica es cosa muy útil no solo para los médicos, sino tambien para todos, porque á favor de las analojías botánicas se adivina á primera vista, si es lícito espresarnos así, como nos ha sucedido á nosotros tantas reces durante nuestros viajes, las propiedades de vejetales análogos. Las propiedades médicas de las plantas están pues, por lo regular, en relacion con sus formas esteriores ó botánicas; en efecto, la ley de analojía entre las propiedades y las formas esteriores ha servido de base á los trabajos interesantes de los médicos que han tratado, como estamos haciendo tambien hace ra mas de 10 años, de sustituir los medicamentos indíjenas á los exoticos. ¿Se hubiera intentado $\mathrm{y}$ hasta atrevido en mi:chos paises alimentarse con los tubérculos de los Aros, si no se hubieran conocido de antemano las propiedades nutritivas de la rautia, ocumo ó col de los Caribes, haciendo los ensayos con la debida prudencia y cautela, aconsejadas además por el conocimiento de las propiedades venenosas de muchísimas especies de esa familia? Si se estiende la vista veremos los centros nuevos de civilizacion y de colonizacion que se han formado ó que se van formando cada dia en cualquier lugar del mundo, aprovechar los conocimientos de los médicos botánicos; pero pocos lo son, bien que se lo figure así la sociedad, porque tiene el derecho de exijir de ellos tales conocimientos, no solamente indispensables al complemento de sus 
estudios médicos, sino tambien casi de utilidad pública, porque á ellos solos hay que dirijirse cuando se trata de datos científicos, cuya aplicacion es necesaria tan pronto á la vida material y agrícola de los pueblos como á sus adelantos futuros. La América, tanto septentrional como meridional, es sin duda alguna la parte del mundo en que la teoría de las analojías botánicas tendrá mas numerosas aplicaciones y por consiguiente será utilísima; en la primera, porque está situada casi en la misma latitud que Europa, esa analojía será mucho mas pronunciada y casi sobresaliente á primera vista, esos paises estando poblados casi de los mismos géneros pero con especies diferentes; no será tan simple ni tan patente para la segunda, porque difiere tanto de la Europa por su latitud y por su clima como por el aspecto general de su maravillosa vejetacion, de tal manera que las analojías botánicas se hallan mas disfrazadas y que necesitan ya de un ojo bastante práctico y botánico para manifestarse á primera vista, aunque sean tan numerosas y quizás en mayor número que en ninguna otra parte del mundo. Vemos pues los viajeros célebres lejos de su patria, cansados por larguísimas navegaciones, hallar en una costa estraña y desconocida vejetales parecidos á los de su pais ó teniendo con ellos analojías botánicas mas $\dot{o}$ menos pronunciadas; así fué como el célebre Forster halló una crucífera, el lepidio de hortaliza, en las islas del mar del Sur, y le aprovechó con muy buen éxito contra el escorbuto que acababa con la tripulacion de su buque, y Labillardière, reconociendo una nueva especie de perifolio en su viaje de circumnavigacion al rededor del orbe, proporcionó á todos sus compañeros un alimento sano y agradable á la par; nos ha sucédido lo mismo á nosotros muchísimas veces en la aplicacion médica de los vejetales intertropicales y tropicales, para reemplazar los sacados de Europa, y siempre con inmejorable efecto.

Se ha de aprovecharse tambien del instinto de los animales herbívoros para ayudarse en la busca de los vejetales útiles; pero entre los herbívoros hay que hacer dos clases de ellos; en efecto, los unos se alimentan indistintamente de todos los vejetales, mientras los otros están destinados á nutrirse de una sola planta ó de las de una familia única; entre los primeros observaremos no los rejetales. que están buscando, porque seria eso demasiado largo, trabajoso $Y$ hasta fastidioso, sino los que desechan, y podremos así notar con la mayor facilidad que, á escepcion de. las plantas que por sus espinas ó dureza se libran de la voracidad destructora de los animales, estos desechan ó codician igualmente todas las especies de un género ó de una familia; así los bueyes dejan intactas todas las labiadas y todas las verónicas; los caballos casi todas las crucíferas; los bueyes, los caballos, los carneros, los cerdos y las cabras no comen casi nunca las solaneas, mientras que con avidez devoran las gramíneas, las leguminosas, las compuestas, etc.; los animales limitados naturalmente á un solo alimento estienden solamente sus estragos á especies del mismo género ó de las mismas familias. Los inzectos especialmente pudieran presentar mil ejemplos de ese instinto, así vemos el curculio scrofularia, el cinips rosa, la psilla juncorum, el 
curculio rumicis, el cinips salicis, etc., atacar varias especies de los géneros de que toman su nombre, y algunos de entre ellos viven indistintamente en todos; si vamos mas lejos encontraremos algunos insectos cuyo instinto les hace traspasar los límites del género; así todos han observado en el mediodia de Europa que en los bosques las cantáridas atacan primero á los fresnos; despues de haber acabado con sus hojas se arrojan sobre los lilas y albeñas, que destrozan, y en fin llevan sus estragos hasta los olivos, únicos géneros de la familia de las jazmíneas que se cultivan generalmonte en mayor escala. En todos estos ejemplos parece decirnos la naturaleza misma que los jugos de las especies conjeneres gozan propiedades análogas y que debemos aprovecharlas siempre, como un aviso benévolo que nos ha regalado. Los mismos fenómenos que acaban de presentarnos los animales y los insectos, nos les ofrece tambien la historia $\dot{0}$ estudio de los vejetales parásitos : entre los parásitos lejítimos hemos de distinguir los que viven indistintamente sobre un gran número de vejetales, como el muerdago y sus hermanos intertropicales; los hongos parásitos están en la segunda clase y nos ofrecen mas notables ejemplos, pero no los que viven en los troncos muertos ó en la corteza de los árboles, sino los uredos, los cecidios, las puccinias que nacen bajo la epidermis, se alimentan del jugo de las plantas y están casi siempre limitados á una especie, si bien cuando les falta el alimento pasan de una especie á la otra y aun de un género á otro como si conocieran la clasificacion natural.

Cuando se habrá pues reconocido en un género una propiedad bien marcada se la encontrará siempre y seguramente, pero en grado mas ó menos pronunciado en todos los demas géneros de la misma familia, si es muy natural, ó al menos en los de la misma tribu ó grupo; casi todas las crucíferas se pueden reemplazar las unas con las otras; todo el género casia, así c:omo todos los géneros de la tribu de las casieas, tienen propiedades purgantes, etc.; la analojía es algunas veces tan pronunciada que la familia entera participa de la misma virtud; todas las gramíneas por ejemplo tienen semillas harinosas y nutritivas y los tallos llenos de una savia mas o menos azucarada; todas las labiadas son estomacales, cordiales y tónicas; torlas las umbelíferas tienen semillas tónicas y estimulantes; el jugo de las coníferas es resinoso, así como el de muchas terebentináceas; la corteza de las amentáceas es astrinjente y con bastante frecuencia febrífuga, etc.; además añadiremos á tales ejemplos que la lectura comparativa de los relatos de los viajeros prueba que las plantas del mismo género ó de la misma familia han sido, quizás por casualidad ó por una especie de intuicion natural, empleadas en iguales usos por pueblos muy distantes los unos de los otros y que nunca se habian comunicaro entre sí; así remos las raices de la diacena terminalis usadas en las indias orientales por sudorífico, lo mismo que las de la zarzapar illa, smilax salsuparilla y demas especies del mismo género en ia América meridional; la corteza del rhizophora gymnorrhiza sirve en las Indias orientales para teñir de negro y para el curtido, como en las Antillas la del rhizophora mangle, mientras los habitantes del Chile hacen igual uso de la de la loni- 
cera corymbosa, la eugenia malucensis ó manzana de malaca y varias mirtáceas se usan en el Perú contra la disentería, mientras que en las Antillas se echa mano, para cumplir iguales indicaciones terapéuticas, de los psidios ó guayabos y otras mirtáceas ; los convólvulos ó alboholes de las cinco partes del mundo tienen propiedades purgantes, y muchísimos pueblos les utilizan en tal concepto y corresponden siempre á lo que se está esperando de su administracion.

No se debe omitir sin embargo, en medio de esa multitud de hechos que tienden todos á confirmar la teoría, los que presentan algunas escepciones notables: ¿quién ignora, en efecto, que la peligrosa y venenosa cicuta se encuentra al lado de la útil y sabrosa zanahoria, pero en dos tribus distintas; que la dulce batata está junto á la acre y purgante jalajı ; que la amarguísima coloquíntida quiere engañar la vista por su semejanza con cierta clase de melon; que la venenosa cizaña se cria junto con los trigos, las cebadas y otras gramíneas útiles, y que el árbol mas proximo al ceroso produce uno de los venenos mas activos del reino vejetal, el ácido prúsico? pero el laurel cerezo tiene esa propiedad, solamente mucho mas desarrollada que las demas especies del género cerezo y de los demas géneros de la misma tribu; en efecto, escusado es decir que todos los cerezos, ciruelos, albaricoqueros y melocotoneros, etc., lo tienen tambien en sus huesos, flores y con frecuencia hasta en sus hojas y semillas. En fin la alimenticia papa se encuentra entre venenos y hasta su tallo lo es. Observaciones debidas al perfeccionamiento de la ciencia contribuirán ciertamente en lo sucesivo á disminuir el número de escepciones conocidas, y se puede ya notar en muchos casos que las plantas que se distinguen del grupo tipo por sus propiedades se diferencian tambien de él por algun carácter botánico mas ó menos importante y algunas veces hasta por su estructura, de manera qne muchas lian sido ya separadas de las familias en que se hallaban para formar familias nuevas. El terreno en que crecen y vejetan las plantas influye muchísimo en su composicion química y por consiguiente en sus propiedades, especialmente cuando es muy húmedo ó seco; el período de la vejetacion influye tambien mucho sobre la naturaleza de los principios constitutivos de los vejetales.

Aquí asentaremos consideraciones generales sobre la nutricion y demas funciones desempeñadas por los vejetales y tambien sobre el sinnúmero de metamórfosis que el corto número de elementos que les forman han de esperimentar durante el acto de la vejetacion para producir el sinnúmero de principios inmediatos que la química ha conseguido estraer de ellos y el número mucho mayor todavía que no ha podido aislar hasta ahora.

La facultad que tienen pues tales cuerpos elementales para solos formar tan numerosas combinaciones ó compuestos particulares que se producen sin cesar al favor do la vejetacion, ne es sino la afinidad química modificada por la fuerza vital, la cual impide que obedezcan á la tendencia que les solicita á unirse entre sí y les hace resistir á la atraccion continua que bajo otras circunstancias ó condiciones 
les llevaria los unos hácia los otros. Tal fuerza enteramente desconocida en su esencia se manifiesta continuamente por sus efectos. Si por casualidad y casi de repente cesaran ó desaparecieran las condiciones indispensables á la existencia de tales combinaciones, por causa de apagarse poco á poco la vida vejetal, sin embargo la mayor parte de las moléculas orgánicas se quedarian con su propia forma y con su naturaleza química, únicamente á causa de la inercia, propiedad inherente á la materia. En tal estado de causas el solo contacto del aire. la mas débil é insignificante accion química, á veces la sola presencia de otro cuerpo cuyas moléculas están ya en movimiento y esperimentando ya un principio de descomposicion ó de fermentacion, bastará para alterar ó para destruir el equilibrio; entónces saliendo de su inercia sus elementos se agrupan de otro modo, entran en nuevas combinaciones mas simples y todas minerales é inorgánicas en la formacion de las cuales predomina la fuerza química sola, de la misma manera que cada dia lo presenciamos en nuestros laboratorios de química. ¿Quién ignora que un solo movimicnto mecánico, un simple roce ó un golpecito, por débil que sea, basta para destruir el equilibrio de los elementos que forman cierta clase de cuerpos ó compuestos químicos, el fulminato de mercurio y de plata, el ioduro de azoe, el fulmicoton verbigracia? La electricidad, la luz y el calórico tienen poder para modificar continuamente y á cada instante los resultados de la afinidad química, además es sabido perfectamente de todos los que se han dedicado un tanto al estudio de la química, que la atraccion recíproca de los cuerpos está sometida á un sinnúmero de causas que siempre están prontas para hacer cambiar su estado tanto físico como químico y para modificar mas ó menos la tendencia recíproca de sus varios elementos. De igual manera la fuerza vital influye en estremo sobre la manifestacion de las fuerzas químicas obrando en medio de los actos de la economía viviente tan pronto vejetal como animal. La fuerza vital pues tan misteriosa y tan poco conocida en sí reparte su poder con las fuerzas químicas que mete en movimiento y que modifica á la par, para que se puedan verificar cuantas maravillosas y numerosas metamórfosis durante las cuales, la materia, cual nuevo Proteo, se va agrupándose, dedoblándose y volviéndose de mil maneras diferentes y sucesivas para formar el sinnúmero de productos vejetales que existen y tambien á la vez y acto continuo para hacer desarrollarse los varios organos que necesitan esos seres para vivir.

En efecto durante todo el tiempo que sigue la vejetacion se van verificándose sin cesar, entre los elementos de las combinaciones orgánicas ya existentes en los vejetales, movimientos moleculares, de que resultan metamórfosis, cuya consecuencia necesaria es la formacion de secreciones, tan pronto gaseosas, que se derraman en la atmósfera al salir de las hojas, flores y demas partes verdes, como sólidas ó líquidas, que despues de filtradas á través de la corteza se recoien, con forma de goma, de resina, de sustancias azucaradas, etc. Al mismo tiempo otras sustancias líquidas solubles están eliminadas por las raices y son mas abundantes en la estacion de la floracion que durante la fructificacion; esas escreciones radicales se ob- 
servan casi en todos los vejetales y consisten en productos orgánicos muy ricos en carbono, que se quedan en el suelo, enteramente inútiles para la nutricion ulterior de las plantas que les han producido, pero que están en depósito en la tierra para despues de podridas servir de abono para los vejetales venideros, lo que estamos presenciando diariamente, sin saberlo, en las praderas ó pastos naturales llamados saranas ó pampas, y tambien en los montes y selvas en donde las hojas, ramas muertas y caidas al suelo, pudriéndose, forman sin cesar humus que cada dia hace el terreno mas rico en carbono, de tal suerte, que en tales lugares vemos la vejetacion seguir tan lozana y tan vigorosa durante siglos enteros, como estuvo en los primeros años de su creacion, lo que llena al observador de relijioso asombro y de admiracion para con la divina sabiduría. De lo dicho resulta evidentemente que, en el estado normal de la vejetacion, las plantas no agotan ni empobrecen tampoco la riqueza del suelo, pero lo vuelven al contrario mas apto para otra generacion vejetal diferente venidera, porque restituyen á la tierra mayor cantidad de carbono en general que la que habian sacado de él: en efecto, en la atmosfera sola chupan todo el ácido carbónico que ha de proporcionarles el carbono que necesitan para el aumento de su masa total; pero sin embargo, á pesar de eso, para que los vejetales produzcan tanto cuanto pueden, es preciso cambiar las especies y hasta las familias cada año ó lo mas frecuentemente posible en el mismo suelo, porque las secreciones de las unas son abono para las otras, mientras que sin esa precaucion, indispensable en Eurnpa y en los terrenos entregados al cultivo hace siglos y por esa razon empobrecidos, que necesitan estercolarse, rejetarian raquíticos y no darian utilidad.

Los órganos de los rejetales no cesan de funcionar un solo instante en el estado normal de la vejetacion; en efecto, las raices $y$ demas partes que han de desempeñar las funciones de la nutricion absorben sin cesar agua y chupan sin interrupcion alguna ácido carbónico; esa propiedad orgánica de esos órganos es enteramento independiente de la accion de la luz del sol, de tal manera que durante el discurso del dia tan pronto á la claridad como á la sombra. el ácido carbónico se va acumulando y concentrándose en ellas, lo que sigue tambien de noche, pero cuando los rayos directos ó difusos del sol vienen á tocar las hojas ó demas partes verdes, entónces y acto continuo el ácido carbónico está descompuesto, como si estuviera sometido á la accion de la mas poderosa pila eléctrica, y principia á rerificarse la solidificacion y asimilacion del carbono al estado naciente $y$ vuelto libre que entra en la organizacion vejetal que alimenta: la mayor parte del oxíjeno así puesto en libertad se va derramándose sin cesar on la atmósfera cuyas pérdidas continuas remelia. En los paises intertropicales, en donde estamos escribiendo estos renglones, en los tropicales y en general en todas las comarcas cálidas, en donde las nubes no detienen sino nuuy raras reces los rayos del sol, cual lluvia abrasadora y á la par fecundadora caen directos sobre los vejetales, cuya maravillosísima vejetacion activan en sumo grado, están los manantiales inagotables y eternos del oxí- 
jeno del orbe entero, mientras que en las zonas templadas y en los paises frios. en donde un cielo nebuloso poniendo casi constante obstáculo á la accion de los rayos solares se produce ácido carbonico en mayor abundancia. Eso puesto se puede sin ningun inconveniente admitir que la misma corriente de aire que, por medio de la rotacion continua de la tierra, se va estendiéndo desde el ecuador hasta los polos, lleva consigo a Europa y otros paises del norte el oxíjeno producido en la zona tórrida, mientras que al favor de otro movimiento retrógrado, igual corriente lleva á los paises cúlidos el acido carbónico acumulado durante los inviernos.

De los trabajos físicos del célebre Teodoro de Saussure sale que las capas superiores de la atmósfera son siempre mas ricas en ácido carbónico que las inferiores, porque estas últimas están en continuo contacto con los vejetales, que lo chupan sin cesar, y además su proporcion es mayor de noche que de dia, por la razon que en este último caso hay mayor absorcion de oxíjeno, y aunque las descomposiciones siguen sin cesar, las reacciones son mas lentas y por otra parte todo el oxíjeno se queda acumulado en el vejetal, hasta que salga una parte bajo la infiuencia de la luz. Los vejetales purifican pues cl aire de la atmósfera, absorviendo sin cesar ácido carbónico y derramando casi sin interrupcion oxíjeno en ella para reemplazar al que está consumido por los animales. Con el movimiento horizontal de la atmósfera se nos viene tanto oxíjeno como se nos va de ese cuerpo; por otra parte las corrientes de aire, efecto de la variacion de temperatura, aunque muy útiles, son poca cosa en comparacion de los trastornos atmosféricos producidos por los vientos, que, mezclando las varias capas que forman la atmósfer'a, mantienen así el equilibrio de su composicion y'lo hacen siempre propio para la respiracion.

Sabido es perfectamente de los mas incultos, como de los mas sabios, que la cultura mejora muchísimo el estado sanitario de los paises, como lo tiene probado la observacion diaria de los hechos, y sin el cultivo se verian, como ya se ha observado demasiadas veces, las mas ricas y mas saludables comarcas volverse pronto perniciosas é inhabitables. Por otra parte, sin el concurso activo, continuo y benéfico de los vejetales, la espantosa cantidad de ácido carbónico derramada diariamente en la atmósfera, y por consiguiente en la superficie de la tierra, y que proviene tan pronto de la respiracion del sinnúmero de seres vivientes que la pueblan, de la combustion y de las artes químicas, como de la descomposicion jútrida de los cuerpos organizados murtos, porque sea cl reino í que pertenezcan, y además la proporcion incalculable de ese cuerpo que sale sin cesar de las entrañas de la tierra, no tardaria en viciar la atmósfera de tal manera, que el aire ya no serviria para la respiracion, y en lugar de dar la vida, se habria vuelto veneno y daria la nuerte.

Cuando falta á los rejetales la influencia de la luz, entónces el ácido carbónico absorvido no estí descompuesto, y por esa causa otra accion química principia al favor de la influencia del oxíjeno sobre las hojas, flores y frutos; pero tal reaccion, puramente quí- 
mica, no tiere nada que ver con la vida de las plantas, porque se presenta de la misma manera en los vejetales despues de muertos; en efecto, si pudiéramos conocer de antemano y préviamente la composicion química de varias plantas, nos seria fácil señalar á priori y con acierto cuales de entre ellas han de absorver mas cantidad de oxíjeno durante su vida y en la oscuridad. Por medio de esperimentos bien hechos se sabe, en efecto, que las hojas y demas partes verdes que contienen esencia ó principios aromáticos volátiles, que con el oxíjeno pueden volverse materias resinosas ó parecidas á las resinas, absorven mucha mayor proporcion de oxíjeno que las que no tienen esa composicion química: se sabe tambien que los vejetales cuya savia es muy rica en tanino ó en sustancias azoadas, chupan mucho mas oxíjeno que los que no contienen esos principios orgánicos. Los vejetales al descomponer el agua absorvida sea por sus raices, sea por sus hojas, asimilan el hidrójeno que se organiza $y$ entra en la formacion de la partícula orgánica, mientras que al mismo tiempo se derrama en lia atmósfera una proporcion correspondiente de oxíjeno. En la produccion del leñoso, del almidon, goma, azúcar, etc., cuya composicion elemental consiste en carbono y en los elementos del agua, oxijeno é hidrójeno, las plantas echan siempre en la atmósfera el oxíjeno que resulta de la descomposicion del ácido carbónico, cuyo carbono se junta al estado naciente ó molecular con los elementos del agua, que sin duda están en igual circunstancia, $y$ la molécula orgánica ya ha nacido, y segrun el modo con que se agrupa con las otras que sucesiva é incesantemente se forman, produee una de las sustancias señaladas. En la formacion de la cera, de los aceites fijos y volátiles, del caucho y demas principios orgánicos hidrocarbonados, los vejetales tienen la propiedad de descomponer el agua de tal manera, que su hidrójeno se organice, y reunido con el carbono y los elementos del agua, sin duda agrupados de otra manera que en ese líquido, forme los cuerpos orgúnicos mencionados. El amoniaco, que se halla casi en todas las aguas, en los terrenos, en los estiércoles, proviniendo de la descomposicion de las sustancias orgánicas, que se forma sin cesar en la superficie de la tierra y en la atmósfera bajo la influencia electro-química, suministra rio para la formacion de los principios azoados y quizás tambien una parte del hidrojeno que entra en la composicion de la albumina, fibrina, caseina, de las materias rojas y azules, de los álcalis rejetales, ete. Al examinar y estudiar con el debido cuidado los órganos de los vejetales, se observará que cada fibra del leñoso está envuelta con savia, conteniendo siempre alguna sustancia azoada, que los granitos de almidon ó fécula y el azúcar mismo están depositados en celdillas que contienen en su composicion una cierta cantidad de sustancia azcarla, en fin, que el suco sacado por espresion de todas las flores contiene siempre sustancias azoadas, junto con otras, que de lo dichoy de trabajos cientificos hechos con todo el cuidado deseable, resulta que el azoe tiene en el organismo rejetal un papel tan importante, que sin la presencia de ciertos principios azoados orgánicos, la mayor parte de los fenómenos de la vida ve- 
jetal no podrian verificarse; en efecto, el leñoso no se puede elaborar en las hojas al estado perfecto, pero estos órganos tienen poder para elaborar y preparar sustancias orgánicas especiales capaces, despues de haber esperimentado varias metamórfosis sucesivas, caminando por el vejetal, junto con sustancias azoadas, de volverse leño; será quizás muy probable que el leñoso y la gliadina, el almidon y el tejido celular se vayan organizando simultáneamente y al lado los unos de los otros, ya que no se diferencian sino por el agrupamiento diferente de las moléculas orgánicas, su composicion química siendo idéntica, y en tal caso una proporcion definida de cada uno de ellos será condicion esencial para su formacion recíproca. Por otra parte, todas circunstancias siendo iguales, las sustancias orgánicas formadas por las hojas no podrán estar asimiladas sino en proporcion ó en relacion con la cantidad de azoe que se encuentra con ella; pero, si por casualidad faltase ese cuerpo, cierta cantidad de sustancia no azoada formada se quedaria entónces sin empleo alguno y estaria eliminada tan pronto por las hojas y las raices, como por la corteza, etc. ; á esta clase de fenómenos, sin duda normales en la vida de ciertos vejetales, se han de atribuir las exudaciones de maná, de azúcar, de goma, de resina, etc., que diariamente se observan, y además corresponden quizás con ese órden de fenómenos los depósitos de fécula que se forman tan pronto en las raices y tubérculos, como en los troncos y semillas. Tales fenómenos parecen tener bastante analojía con lo que pasa en la dijeccion considerada en los animales mamíferos; en efecto, para restituir á cada parte del cuerpo lo que está perdiendo sin cesar por medio de las secreciones continuas, es preciso proporcionar á los órganos dijestivos alimentos formados á la par de sustancias azoadas y no azoadas, y cuando todas las pérdidas orgánicas estín remediadas, las sustancias no azoadas sobrantes, no encontrando empleo se depositan con forma de grasa; otras rẻces están eliminadas por el canal intestinal y botadas junto con los escrementos.

La produccion anómala de algunos principios vejetales hace suponer con razon en las hojas una fuerza asimilatriz mayor que cualquier accion química por poderosa que sea; en efecto, para formarse de ella una idea, por supuesto bien incompleta, es preciso tener presente que tal fuerza tiene mucho mayor poder que la batería eléctrica mas poderosa, porque con ese aparato cuesta mucho trabajo descomponer el ácido carbónico, fenómeno que se verifica sin cesar y con mayor facilidad en las hojas, no solamente vivas $y$ haciendo parte del rejetal, sino tambien en las que están separadas de él, las cuales siguen sin embargo, bajo la influencia de la luz solar á descomponer el ácido carbónico que tenian absorrido; en ese caso no son para nosotros sino un aparato electro-galvánico muy poderoso, puesto en accion por la luz del sol; todos los trabajos científcos publicados por muchos físicos y botánicos célebres demuestran con mayor evidencia que las hojas verdes, aunque separadas del vejetal y colocadas en agua cargada de ácido carbónico, el aparato espuesto á la accion de los rayos solares, la descomposicion principia inmediatamente y sigue hasta que todo el ácido carhónico haya 
desaparecido del líquido, el oxíjeno se recoje en una campana de vidrio dispuesta á propósito, mientras que el carbono se queda en ellas: lo que comprueba nuestro parecer. Para cumplir pues con una de sus principales funciones, las hojas no necesitan del concurso del azoe, cuya presencia parece al contrario necesaria, con forma de alguna sustancia azoada, para que se verifique la asimilacion de los nuevos productos resultando de esa descomposicion. El carbono pues del ácido carbónico así descompuesto por las hojas y organizado, se vuelve líquido ó soluble y está propio entónces para que la savia en su circulacion continua se le lleve consigo á todas las partes del rejetal que se le asimilan, segun sus necesidades, y entónces se forman el leño, el azúcar, las gomas, féculas y demas productos orgánicos y tambien los órganos.

En las hojas pues la savia ascendente se vuelve nutritiva, y despues desciende, principalmente por la corteza y tambien por el cuerpo leño, si bien en menos cantidad y en casos mas raros: tal materia no está, y no puede estarlo tampoco, organizada, ya en fibras ó en celdillas del tejido celular, sino que contribuye á su formacion local; su composicion química ha de ser aráloga á la de la goma: en efecto, en la corteza y en la albura de los rejetales rasculares hay una gran facilidad para producir esta sustancia. Se depositan pues á propósito en diferentes puntos interiores ó esteriores de los vejetales mas materiales, como la fécula, el azúcar, la liñina, que teniendo igual composicion química se transforman en ella por medio de metamórfosis muy sencillas y sin duda para nosotros tambien vice-versa. El célebre de Candolle dice que la goma es el jugo nutritivo descendiente, pero que para obrar convenientemente en la nutricion, debe trasformarse en fécula, en azúcar, en liñina y otros productos enteramente anর́logos, que han de permanecer algun tiempo almacenados ó depositados en ciertos órganos, y despues trasformar:e y disolverse de nuevo para entónces servir directamente á la nutricion. Esa disolucion se verifica con frecuencia al pasar la savia ascendente por esos depositos: de ese modo se esplica con mayor facilidad la' rejetacion tan activa de la primarera, el desarrollo casi espontáneo de las yemas, la nutricion de las flores y de las frutas, la prolongacion rápida de los tallos florales y la vida de las plantas jovenes. En todos esos casos la savia ascendente se carga de materia gomosa, acumulada anteriormente en los órganos situados debajo ó al lado de los que crecen; el líquido viscoso de donde proceden las nuevas capas de leñoso y de corteza, es una mezcla de ambas savias, que constituye el cambium de unos autores de botánica. Kinght ha probado tal mezcla examinando el peso específico de la savia ascendente á diferentes alturas, $r$ ha obserrado que se va cargando de moléculas nutritivas al subir por el tronco de los árboles; supone además que una parte de ella se dirije horizontalmente por los radios medulares y va á contribuir á la formacion de las capas nueras. Por la misma razon las plantas pueden vivir algun tiempo sin elaborar alimento alguno, entónces su vida sigue á espensas suyas y acaban por estenuarse; lo mismo :ucede diariamente á los animales puestos á dieta severa y que viven algunos 
dias de su gordura y se van enfiaqueciendo á medida que se va prolongando, hasta que por fin se mueren estenuados. Si las plantas bulbosas y carnosas viven mucho mas tiempo en tal estado, es porque tienen un depósito de materia alimenticia mucho mas surtido que las demás. Las hojas no se producen, ni se pueden presentar tampoco, sin que antes el alimento que han de necesitar haya sido almacenado de antemano; es preciso pues que siempre otras hojas les hayan precedido en su desarrollo, sea el mismo año, sea el anterior. Las especies perennes producen cada verano lo que han de necesitar para la florescencia del año siguiente, mientras que las anuales, al contrario, se mueren estenuadas despues de haber dado su fruto; pero en la primera categoría de plantas las flores pueden en la primavera desarrollarse antes de las hojas, porque hay alimento depositado á propósito y de antemano, mientras al contrario las plantas anuales, no tenienrlo sustancia alimenticia guardada, no pueden florecer antes que las hojas la hayan preparado. De todo lo diclio sobresale con mayor evidencia que, segun la proporcion de sustancia nutritiva suministrada simultáneamente á una planta, se puede variar mucho la cantidad y la naturaleza de los productos de su vejetacion.

Hay en la ciencia razones suficientes para admitir sin inconveniente ninguno que los aceites esenciales cuyo oxíjeno está reemplazado por azufre, provienen de la metamorfosis que tuvo lugar entre los elementos de los principios orgánicos azufrados y de su naturaleza poco conocida hasta ahora; en efecto, algunos cuerpos azufrados, como la albumina, febrina, caseina y emulsina, se hallan en todos los vejetales.

Aunque de todo lo que acabamos de referir sobresalga que el ácido carbónico, el agua y el amoniaco sean cuerpos indispensables para la vida de los vejetales, porque tales cuerpos inorgánicos contienen los elementos, no solamente de sus organos, sino tambien de los productos que han de elaborar despues, sin embargo no bastan, $\mathrm{Y}$ se necesita además la presencia de otras sustancias minerales para que se pueda efectuar el desarrollo normal de ciertos órganos vejetales; tales sustancias son el ácido silícico, los oxidos de yerro y de manganeso, la potasa, la sosa, la cal y la magnesia, y por fin los fosfatos, sulfatos y cloruros de cal, potasa y sosa, que los vejetales sacan del suelo por medio de sus raices. Los álcalis están siempre en los vejetales al estado de sales orgánicas, que serán tan pronto tartratos, malatos y oxalatos, como acetatos, quinatos, citratos, etc., segun la clase de vejetal que se estudia, las cuales son indispensables para su normal y completa vejetacion. Por otra parte se sabe muy bien que los alcaloídeos están siempre en los vejetales en proporcion inversa de la de los álcalis minerales, cuya mayor cantidad escluye siempre su presencia y vice-versa.

Todos los órganos de las plantas, tanto las hojas, nodrizas naturales y necesarias de la madera ó leño, como las raices que han de proporcionar lo necesario para el primer desarrollo de dichas hojas y que además elaboran los principios que han de servir para la formacion de los frutos, contienen sin escepcion alguna sustancias 
azoadas cuya proporcion varia muchísimo; las raices y los frutos son mucho mas ricos en tales sustancias que las demas partes de los vejetales y son por esa razon mucho mas alimenticios para los animales. La atmóstera sola suministrarí pues todo el azoe primitivo que para su normal desarrollo puedan necesitar las plantas, y se le apropian solamente despues de haberse vuelto amoniaco, curos elementos sufren, cual los del agua y delácido carbónico, en la economía vejetal, bajo la influencia poderosa de la fuerza vital, un sinnúmero de metamórfosis. El desarrollo de los vejetales es tenido por normal ó completo solamente cuando han parido semillas perfectas ó capaces de propagar la especic; pero si eada vejetal no produjera sino uno ó algunos frutos y semillas, en número nada mas que suficiente para la conservacion de la especie en la superficie de la tierra, no cumpliria enteramente con el sabio objeto para que fueron criados; en efecto, el Supremo Hacedor no lia formado el sinnúmero de rejetales que se hallan en la superficie del orbe sino para servir sea directa, sea indirectamente á la alimentacion de los animales, y con una disposicion llena de sabiduría les ha dotado de la maravillosa propiedad de volver el azoe de la atmósfera sustancias organizadas azoadas apropiadas á la constitucion de los animales que habian de sustentarse; esas sustancias son la fibrina, albumina y caseina vejetal, cuya composicion química elemental es idéntica á la de las mismas suttancias contenidas en los animales, solamente difieren las unas de las otras. ¿́ nuestro corto parecer, por su agrupamiento molecular diferente. Las plantas anuales, despues de cumplido el resarrolló completo de sus frutos, cesan de rejetar, sus ramas se vuelven algo leñosas, se amarillentan y marchitan sus hojas que no tardan en morir, mientras que los vejetales vivaces, al contrario, cuales los arbustos y árboles llegados á igual periodo de su vida y aunque paridos sus frutos no se mueren, porque se establece desde luego en su interior una nueva vejetacion oculta, pues que no se manifiesta de ninguna manera esteriormente, y sin embargo sigue así á escondidas hasta el principio del invierno en los paises frios y templados, lo que sucede tambien en los paises cálidos para el corto número de vejetales que se despojan de su follaje sea en correspondiente estacion ó en otra: entónces parecen muertos ó descansándose en apariencia, pero no es así ya que su savia está todavía en movimiento y sale abundante por las heridas que reciben. Durante ese aparente descanso ó sueño, las capas leñosas del tronco siguen formándose, se vuelven mas compactas, mas duras las que existian y la madera se va perfeccionando. Desde el mes de agosto en adelante el ácido carbónico absorvido por las hojas ra no sirve para la formacion de nuevas capas leñosas: entónces se lo aprovecha el vejetal para preparar una provision suficiente de sustancias nutritivas, que se quedan almacenadas para despues proporcionar lo necesario al principio de la vejetacion del año venidero ó al desarrollo de las primeras hojas; en tal caso, en lugar de leñoso se forma almidon, que llevado por la savia de agosto se va depositando en todas las partes del vejetal, en donde se le puede ver con un buen lente de aumento. Entónces á medida que se va manifestando 
la vida por la salida y el desarrollo mas ó menos rápido de los órganos contenidos en las yemas, se va tambien desapareciendo la fécula, poco á poco, de los órganos que la tenian guardada, como se observa en las raices y tubérculos que la contenian con abundancia, pero que despues de salido de su sueño el vejetal para vivir de nuevo, se marchitan ó se ablandan y ya no la contienen mas. ¿Qué mayor prueba se puede desear del papel de ese cuerpo orgánico en el acto de la vejetacion? Quiẻn no tendrá presente que la caña de azúcar pierde la mayor parte de su dulce durante la florescencia ó cuando está echando su guajano ó flecha? Las plantas anuales producen, recojen y tienen tambien guardados unos principios nutritivos para suministrar alimento al individuo naciente, pero con la diferencia que esos principios son á la par sustancias azoadas y no azoadas, mientras que para los rejetales perennes son siempre no azoadas y repartidas por todas sus partes; los de las yerbas al contrario se hallan solamente en las semillas, en donde se quedan depositados hasta que, llegada la estacion favorable para la germinacion, sus elementos, esperimentando entónces las metamórfosis necesarias bajo la influencia vital que tiene sobre ellas el embrion, suministran el alimento necesario para el desarrollo de la radícula $y$ de las hojas primordiales del feto vejetal, para que se vuelva niño vejetal, si así puede espresarse, ra capaz de distrutar un tanto de su vida propia. Despues de la formacion de esos primeros órganos indispensables, principia solamente su nutricion, propiamente dicha, porque cuando el gérmen empieza á salir del suelo, á reverảecerse poco á poco desde arriba hácia abajo, entónces solo la plantita principiará á sacar algo de afuera para tormar las materias que han de ayudar á su desarrollo y al aumento gradual de su masa. Si el grano de trigo en germinacion, verbigracia, contuviera solamente almidon y gluten, evidente seria entónces que ambos tomarian parte por medio de sus eiementos, sufriendo metamórfosis á propósito, con la infiuencia necesaria del aire, de una temperatura suficiente, de hastante humedad y tambien de la electricidad, porque cuando en la atmósfera hay movimientos eléctricos insólitos, especialmente acompañados de lluvia, cuya agua está sin duda cargada de electricidad ó llevando consigo una cierta proporcion de ozona, la germinacion es mucho mas activa y se pueden casi seguir sus progresos con la vista. El resultado de las reacciones o metamorfosis que tienen lugar durante la germinacion, en ese caso. consiste en ácido carbónico que se exhala en la atmósfera, un poco de ácido acético y azúcar; entónces el gluten se ha vuelto soluble y ha producido algunas sustancias azoadas, quizás óxido de amonio ó alguna otra sustancia análoga cuya existencia es hipotética, pero probable, y cuyo papel, por no ser bien conocido, no está menos evidente para nosotros: los elementos pues de ambas sustancias siguen así esperimentando metamórfosis sucesivas hasta que hayan salido las fibras de la radícula r las hojas primordiales; pero si sobrase despues de eso una cicrta cantidad de uno de ellos, se quedaria entónces sin empleo hasta que se le necesitara, y en tal caso esperimentará las metamórfosis necesarias para volverse alimenticia ó asimilable. Sa- 
bido es perfectamente que durante la germinacion de los cereales, como el trigo, cebada, arroz, maiz, etc., la transformacion del almidon en glucosa se verifica á favor de la influencia de la diastasia sobre él y constituye quizás la primera manifestacion físico-química de la vida del nuevo ser ó del feto vejetal. El gluten, la albumina, etc., y demas sustancias azoadas ya señaladas mas arriba pueden suplir la diastasia en los actos de la germinacion, con la sola diferencia que su efecto es un poco mas lento y hace por consiguiente la germinacion algo mas tardía; la diastasia que se halla sobrante en la cebada germinada no se debe tener por inútil, porque sin duda alguna junto con los de la fécula, sus elementos toman parte activa en las metamórfosis que producen el azúcar ó glucosa. En la primavera, estacion en que las plantas en germinacion no tienen todavía órganos que las proporcionan alimenio sacado de la atmóstera, las semillas han de suministrarlo, y la plantita recibe en cada fibra radícular en que nace una boca, un pulmon y un estómago á la vez, si podemos espresar así nuestro parecer; en efecto, las primeras raices han de desempeñar casi en el acto de su nacimiento las funciones de las hojas que faltan todavía, y tienen que suministrar pues a la planta recien nacida lo que chupan en la atmósfera subterránea que las envuelve y que se compone de ácido carbónico proviniendo de la reaccion continua sobre el humus del oxíjeno de la atmósfera, cuyo aire contenido en la tierra movediza que penetra sin cesar, $y$ en que se condensa sin interrupcion, obedeciendo en eso á la porosidad y á la capilaridad, propiedades inherentes á la materia inerte, suministra otro oxíjeno á medida que el ácido carbónico formado está absorvido, y se sigue así hasta que tenģa organos suficientes para sacar alimento de la atmósfera; entónces el jóven vejetal se alimenta á la vez y simultáneamente por las raices y por las hojas de tal suerte, que se desarrolla con mayor ó menor prontitud segun sus órganos funcionen mas ó menos normalmente. Cuando hayan llegado á su perfecto y completo desarrollo sus órganos, no necesitarán ya mas del ácido carbónico del suelo, ni hasta cierto punto de su humedad, porque sus hojas bastarán para sacar de la atmósfera lo que necesiten, el aire y el rocío suministrarán de ordinario bastante humedad para que se puedan verificar los actos de la nutricion vejetal. Sabido es que durante los estíos mas cálidos y en los paises intertropicales, los vejetales sacan de la atmósfera casi todo lo que necesitan; es notorio en las comarcas de América, en las cuales no llueve nunca, como en la isla de Margarita verbigracia, que los copiosos rocíos que caen de noche bastan para la vejetacion; pero sin embargo, cuando la estacion seca se prolonga en demasía, entónces los vejetales padecen mucho, la vejetacion está parada y sus productos se hallan muy modificados. El ácido carhonico, el amoniaco y el agua son pues las tres sustancias inorgánicas cuyos elementos, despues de haber sufrido reacciones químicas y metamórfosis sucesivas, son capaces de formar la molécula orgánica que constituye el alimento que necesitan los vejetales para su desarrollo normal, mientras el almidon, la glucosa, y la goma, junto con una sustancia azoada cualquiera que sea, pero sicmpre orgánica, tie- 
nen igual papel para con el feto rejetal naciente o ya recien nacido.

El feto de los animales mamiferos que se alimentan de la sangre de su madre no necesita del aire $y$ no esperimenta pues ningun perjuicio por su falta; pero no es así para con los huevos de las aves, de los reptiles, etc., cuyo germen, como el de las semillas de los vejetales, necesita del oxíjeno del aire y no puede desarrollarse sin su presencia, y se muere ó no germina cuando le hace falta; por esa razon el agua pura hace mas provecho á las plantas recien nacidas que la cargada de áçido carbónico, lo que es contrario para el vejetal adulto.

Reasumiendo pues todo lo dicho, diremos que el reino mineral ó inorgánico es el manantial inagotable con que cuentan los vejetales para proporcionarse el alimento y los elementos necesarios para remediar sus continuas é incesantes necesidades y perdidas. Tenemos que volver á señalar en primer lugar el ácido carbónico y el amoniaco de la atmósfera, de los cuales sacan los rejetales todo su carbono, todo su azoe, una parte de su oxíjeno y de su hidrójeno, mientras los que necèsitan mas oxíjeno é hidrójeno se los proporciona el agua, que sin descomponerse entra en su composicion, ó bien cuyas moléculas, quedándose en igual proporcion atómica, se agrupan de otra manera ó se organizan sufriendo metamórosis á propósito, junto con el oxíjeno y el carbono, para formar la partícula orgánica, que al agruparse convenientemente, da la celdilla, principio de toda organizacion vejetal. La atmósfera les suministra tambien una cierta proporcion de oxíjeno. Por otra parte los sulfatos terrosos y alcalinos, obedeciendo á la fuerza vital, se hallan quizás del mismo modo que lo vemos suceder diariamente en nuestros laboratorios químicos, cuando estas sales, sometidas á la accion de una pila eléctrica, sus dos elementos compuestos se separan de manera que el uno, la base, se va al polo negativo, mientras el otro, el ácido, se encuentra al positivo; las primeras se combinan con los ácidos orgánicos, mientras el ácido sulfúrico, esperimentando mas íntima descomposicion, análoga á la del ácido carbónico, suministra azufre, que al estado naciente entra en la composicion de la molécula orgánica, y de esas metamórfosis salen ciertas sustancias orgánicas ó principios inmediatos especiales, el aceite esencial de mostaza, por ejemplo, la albumina, caseina, etc. Además, para la formacion de sus órganos, los vejetales necesitan siempre de las sustancias inorgánicas ó minerales ya señaladas mas arriba y tambien de sales orgánicas cuyo ácido es muy variado, combinado sea con las basesi norgánicas ú orgánicas mencionadas. Un suelo será fértil ó feraz cuando, conteniendo los elementos minerales propios álos vejetales, tendrá además poder para condensar el aire de manera que se forme en su seno amoniaco y ácido carbónico, y bastante humedad para que los vejetales se desarrollen en él con toda la lozanía deseada y suministren un alimento copioso y perfecto para el sustento de los animales. Los vejetales, tan indispensables á la vida de los demas seres vivientes, son pues los productos últimos y constantes de la descomposicion pútrida de todos los cuerpos organizados 
muertos y perteneciendo á las generaciones anterioles. Todos lo: productos, sin escepcion ninguna, tan variados y tan numerosos de la fuerza vital, despues de muertos los seres que les contenian se vuelven á sus primitivas formas ó se trasforman en ácido carbonico, hidrójeno carbonado, amoniaco, agua y en humus ó resíduo orgánico, cuya transformacion es lentísima. La muerte, disolucion o descomposicion completa de una generacion, se vuelve pues el manantial inagotable de donde han de salir las generaciones futuras; de la muerte de los unos zale pues necesariamente la vida de los otros. Con miras tan sublimes como sabias, la vida de las plantas y la de los animales son enteramente enlazadas la una con la otra por medios tan sencillos como duraderos y que asombran. Se puede muy bien figurar una vejetacion abundante y lozana sin el concurso ni li presencia de ningun individuo del reino animal, mientras al contrario no puede ser así de los animales, cuya existercia depende necesaria y esencialmente de la presencia y del desarrollo normal de los vejetales, sin los cuales no podrian encontrar alimento alguno.

Aunque la fecundidad de las plantas sea frecuentemente asombrosa: en efecto Lineo ha visto una mata de tabaco producir 40,320 semillas y una adormidera 32,000 , etc., y que la naturaleza tan proveedora no haya puesto límites á tan enorme multiplicacion de los vejetales, su número es sin embargo casi siempre igual, porque una porcion bastante limitada de las semilias sinve para la conservacion de las especies, mientras otra se utiliza para la alimentacion de los animales, para los usos domésticos, para las artes, y en fin la mayor parte de ellas perece sin reproduccion por faltarle las circunstancias á propósito para la germinacion. Las semillas pueden sin embargo conservarse aptas para germinar durante larguísimo tiempo, especialmente cuando no son oleojinosas; en efecto, la superficie de la tierra está llena desemillas en depósito que no esperan para desarrollarse sino circunstancias favorables: despues de tumbado un monte o una selva se presentan plantas cuya existencia no se sospechaba en esa comarca, en donde parecen nuevas. Los medios de diseminacion que emplea la naturaleza para repartir las semillas por la superficie del orbe son los siguientes: los rios se las llevan desde la cumbre de las montañas con sus aguas hasta la mar que las transporta á los paises mas lejanos; los vientos las esparcen en la inmensidad cuando están provistas de vello ó de alas; los animales mamíforos y las aves que se tragan los frutos enteros para alimentarse con su carne, sin dijerir las semillas las arrojan con sus escrementos; en fin, algunas semillas provistas de ganchitos se pegan al pelo de los animales que se las llevan consigo hasta que se caigan al suelo, etc.

Además de las semillas la naturaleza emplea accidentalmente otros medios de propagacion de los vejetales; en efecto, cuántas veces hemos visto ramos enteros separados del tronco, llevados mas ó menos lejos, sea por las tormentas, sea por las crecientes y avenidas de los rios, producir un vejetal; otras veces ramitas dobladas accidentalmente $\mathrm{y}$ en parte cubiertas de tierra, han echado tambien raices $\mathrm{y}$ se han vuelto otro vejetal, etc. Entónces el observador 
atento ha aprovechado esas lecciones de la naturaleza, las ha sometido á las reglas de la ciencia, ha perfeccionado los procedimientos y les ha aplicado á la propagacion de las espiecies útiles con muchísimo provecho.

Propagacion arlificial de los rejetales. - 1० Por estaca, esquejes ó cogollos : ese primer modo consiste en tomar lina rama provista de algunas yemas por su parte inferior, $y$, despues de haberla hendido por la base, en introducirla en la tierra bastante húmeda como de unas 6 á 8 pulgadas, de manera que algunas yemitas estén enterradas, á fin que de ellas salgan raices, como sucede de ordinario; es preciso para eso escojer la estacion en que la savia principia á estar en movimiento; el semillero ó almaciga debe estar dispuesto de manera que esté al abrigo de los rayos fuertes del sol ó casi á la sombra y en un terreno bastante húmedo. Ese procedimiento se aplica á la propagacion de los árboles de madera blanda y tambien de las plantas herbáceas, $y$ surte muy buen efecto ; la caña de azúcar, la caña brava, etc., se propagan así; las hojas de algunas plantas son igualmente susceptibles de arraigar por su inves á lo largo del peciolo, como se ve en las del naranjo y otras bastante coriáccas para mantenerse vivas durante algun tiempo despues de clavadas en la tierra. - 2. Por margullo ó acodo: consiste en sacar del pié del vejetal que se quiere propagar ramitas ó retoños que tengan raices, $y$ en sembrarles; otras veces se les prepara artificialmente como sigue : se aplica á la parte inferior de una rama baja escojida para la propagacion una ligadura bien apretada ó se le quita un anillo de corteza, para obligar á la savia descendiente á pararse en este lugar y á formar un rejuelgo ó rodete circular de donde mas tarde han de salir las raices; eso hecho se dobla la rama y se entierra en el suelo la parte correspondiente á la ligadura, sujetándola así para que se quede enterrada durante algunos meses; al cabo de ese tiempo y cuando ya tendrá bastantes raices, se la corta sea de una vez sea poco á poco si es delicada y se la sembrará en el lugar á propósito. Ése método es muy bueno y con él se pueden propagar muchos rejetales; pero como hay muchos árboles que no tienen ramas bastante bajas, se suple á ese inconveniente de la manera siguiente: la ramita escojida $y$ la ligadura aplicada como conviene, se la aplica una hoja de zinc, una yagua, un trozo de bambú, etc., dispuesto á manera de embudo y sujetado sólidamente como pulgada y media por debajo de la ligadura; eso hecho se llena el aparato de tierra buena $y$ desmenuzada, pero bastante apretada y suficiente húmeda: cl único cuidado que hay que tener es, en la estacion seca, echarle a grua de cuando en cuando y á los 3 ó 4 meses de colocado, algo mas ó menos, se corta el ramo, se le siembra y ya se tiene otro individuo de la especie ó variedad que se quiere propagar: los naranjos, los nísperos y la mayor parte de los árboles se pueden propagar así con facilidad; es pues un procedimiento que se deberia emplear diariamente y vulgarizarse muchísimo en los paises intertropicales para la multiplicacion de las buenas especies frutales. - 3. Por injerto : tres modos principales hay de practicarle: 1 . injertar de canutillo ó de pua, llamados tambien injertos de vástago ó vareta; 2 . de escu- 
dete ó de yema; 3 . en fin, por aproximacion. El primero consiste en introducir una pua ó rástago de un árbol en otro para injertarle, y esta operacion se practica como sigue: despues de escojido el patron ó sujeto, que siempre debe ser bien vigoroso, de una especie mas duradera y fuerte que la que hay que propagar, pero siempre muy vecina de ella ó teniendo con ella la mayor analojía botánica posible; se le corta transversalmente á una altura mayor ó menor del suelo, segun el tamaño y el objeto que se propone el agricultor, y eso hecho se le hace una hendidura vertical por la parte mediana o segun su diámetro transversal ó solamente uno de sus radios, con un instrumento cortante $y$ al sacarle se le reemplaza por una cuña de madera á propósito que tenga la liendidura abierta por la circunferencia especialmente; todo así dispuesto, se corta triangularmente ó a manera de la hoja de un cuchillo la base de la ramita escojida para injertar, de tal manera, que la cara mayor del triángulo corresponda con la corteza, que ha de ser bien sana, bien viva, fina y de igual espesor que la del patron; se introduce esa parte despues en la hendidura de modo que la corteza de la pua corresponda perfectamente con la del patron; entónces, quitando la cuña se cierra la hendidura y la pua está cojida de manera que sus partes herbáceas estén en contacto íntimo con las del sujeto, cuya savia no solo la va á soldar íntimamente con él, pero le va á llevar la vida y el alimento, de tal suerte, que ya no serán mas sino un solo individuo. Eso hecho hay que preservar la herida del aire, lo que se consigue cubriendo la herida del patron y la parte inferior de la pua con una mezcla hecha con barro, bosta de buey y yerba seca, fina y bien flexible, $y$ bastante agua: se la aplica de manera que forme un cono cuya base, mucho mas ancha que el sujeto, envuelva bien como una pulgada y hasta mas de su parte superior; se la puede sujetar con un trapo, ó dejarla sin él, si la mezcla está bastante pegadosa. Se ha de escojer para hacer esta operacion la estacion en que la savia principia á entrar en movimiento; se debe dar la preferencia á los sujetos jóvenes del tamaño como del dedo pulgar ó algo mas, $\mathrm{J}$ cojer la pua ó vástago en un árbol de buena especie que ha producido frutos; debe tener la corteza fina, lisa y ser casi tan espesa; debe además tener yemas sin hojas $\mathrm{y}$ ha de ser del año anterior. El injerto en corona ó cabeza no es sino una variedad del precedente, del cual se diferencia solo en que se practica sobre árboles ya adultos que han salido de mala especie; entónces se cortan horizontalmente sus ramas gruesas y se aplìca por su circunferencia un número mayor ó menor de puas; de esa manera el patron es multiple en lugar de ser único como en el primer caso: ordinariamente sale bien, pero no con tanta facilidad; solamente, en lugar de henderle, se despega su corteza con cuidado y se introduce la pua, cortada á manera de escarbadientes, entre ella y la madera, y despues se aplica la mezcla como lo tenemos dicho. Se debe practicar cuando la savia está ya en completo movimiento; de esa manera se renueva un árbol entero y se le hace producir frutos muy buenos y muy sabrosos, en lugar de los malos que paria antes; 2 . injerto de escudete ó de yema: se practica haciendo en la corteza del patron, 
cuando la savia está en movimiento ó cn la estacion de las lluvias en los paises intertropicales, una incision con figura de $\mathrm{T}$, eso hecho se toma del árbol que hay que propagar una yemita con su corteza y hoja correspondiente, despues de cortado el limbo, dejando solamente el peciolo á veces con la base de la hoja, de quitado una parte de la leña que se queda pegada á la yema, de cortada horizontalmente la parte superior de la corteza del escudete, cuya inferior es puntiaguda, se le introduce con precaucion por la parte vertical de la $\mathrm{T}$, despegando al mismo tiempo con mucho cuidado la corteza del sujeto; introducido así se aplica esactamente el corte horizontal del escudete al de la $\mathrm{T}$, de manera que las cortezas se correspondan perfectamente; eso hecho se le sujeta con un pávilo de algodon ó un hilo de lana, apretando bastante para que la incision esté casi cerrada; es preciso darle sombra, los que se debe hacer tambien para los demas injertos, porque el sol lo mataria con mayor prontitud. Se reconoce que ha pegado ó que estí para salir felizmente cuando el peciolo se despega con facilidad, que la yemita es bien verde y viva; es preciso vigilarla y cuando principiará á brotar se soltará el pávilo y se quitarán las principales ramas del sujeto, á fin de que reciba mayor cantidad de savia, y á veces hasta todas, pero dejándole hojas. Es preciso tener mucho cuidado en sacar todos los retoños que se presentan por debajo del cscudete; el injerto de corteza no es otra cosa para nosotros sino una variedad del de escudete; 'en efecto, se diferencia solamente en que se quita de la rama escojida para injertar, despues de cortado el vértice, un anillo de corteza largo como de una pulgada, teniendo á lo menos una yema y mejor algunas; al sujeto escojido de antemano y del mismo tamaño que la rama se le quita tambien un anillo de corteza igual al de la ramita que ha de reemplazarle; eso hecho se aplica el anillo sacado del ramo en el lugar le el que se ha quitado al patron, de manera que los cortes de las dos coltezas se correspondan perfectamente, y despues se le sujeta con un pávilo y se le da sombra; las higueras se injertan de esa manera; 3. por aproximacion : consiste en hacer sobre dos ramas vecinas dos cortaduras triangulares iguales, de manera que, aplicándolas la una á la otra, la parte cortada de la corteza corresponda perfectamente, y se les sujeta así leña contra leña, y se cubre de mezcla. Esta sencilla operacion ha de practicarse durante la estacion de la savia, y al cabo de algunos meses de contacto, cuando ya la soldadura se habrá verificado y que estará sólida, se separará la rama que constituye el injerto $y$ se cortará el vértice de la que es el sujeto, y asunto concluido. Los injertos yor aproximacion son los únicos que puede verificar la naturaleza sin el auxilio del arte, bastando que cualesquiera parte similar cuya corteza llegue á rozarse ó desprenderse, se ponga en contacto por algun tiempo. Para que los injertos salgan bien es necesario que haya siempre analojía botánica entre el vejetal que hay que propagar y el sujeto ó patron; deben ser pues á lo menos de la misma camilia natural y en la misma tribu, de géneros muy vecinos, y mejor, si se puede verificarse esa operacion, entre especies del mismo género. Esta operacion es no solamente muy 
util, pero á nuestro pobre parecer, de absoluta necesidad para la agricultura: en efecto, por su medio se pueden multiplicar á su gusto las especies y variedades de los vejetales útiles, se mejoran y perfeccionan las especies $\mathrm{y}$ se consiguen mejores $\mathrm{y}$ mas prontos productos ó frutos. Se habrá pues de injertar el níspero sobre las especies silvestres del mismo género, como balatas, ausubos, etc., tan comunes en los paises intertropicales; las mameyes dulces sobre sujetos que no han parido todavía, á fin de tener seguridad que darán buenos frutos; hacen lo mismo con los naranjos, los mangos, etc., $y$ repitiendo esa operacion durante algunos años de seguida, con el cuidado de escojer siempre para injertar el último palo injertado y por consiguiente cuyo producto ya está mejorado, se conseguirán frutos deliciosos y se hará desaparecer sea el sinnúmero de pepitas que contienen, como las guayabas, guanabanas, etc., ó los huesos tan giuesos que forman casi todo el fruto, como sucede en el mamey, ó esas fibras tan desagradables que visten el de los mangos. Se podrá muy bien injertar la parra de Europa sobre la vid silvestre de las Antillas, la higuera de Europa, tan raquítica en los paises intertropicales, sobre una de csas higueras tan vigorosas y tan abundantes en las Antillas, y sin duda para nosotros se consecuirán muy buenos resultados; el lechi, fruta deliciosa de la China, que hemos comido en T'rinidad, sobré el mamon. Se puede además con el injerto volver los árboles dioicos monoicos, dando al pié masculino ramas femeninas que le hagan fecundo $y$ al femenino algunas masculinas que aseguren la fecundacion.

Esplanacion de los fenómenos que los frutos esperimentan al madurarse, T de los cambios químicos que de eso resultan en su composicion. Los fonómenos químicos que pueden servir para plantar la teoría de la maduracion de los frutos, han sido estudiados pocos años hace por los señores Decaisne y Fremy; por los trabajos de esos sabios se sabe ahora: 1. que la proporcion de agua contenida en el pericarpio ó parte carnosa de los frutos es siempre mayor y varia desde 75 hasta 90 por 100 ; en algunos frutos esa proporcion se queda igual durante los varios períodos que han de transcurrir para llegar á la madurez completa; sin embargo, por lo comun, al principiar tales novimientos orgánicos, la proporcion de agua se va aumentando poco á poco y gradualmente, para mas tarde ir disminuyendo de la misma manera y asaz notablemente; 2 . que los frutos de la misma clase, analizados en igual estacion del año, contienen constantemente igual proporcion de agua; las varias partes del pericarpio del mismo fruto lian dado siempre al análisis igual proporcion de agua; 3. que la proporcion de sustancia sólida contenida en el pericarpio de los frutos puede variar desde 10 hasta 25 por 100 , y consiste en principios orgánicos solubles que, unidos con el agua, forman el suco de los frutos y tambien en otras sustancias insolubles que forman la membrana azoada ó no que forra las celdillas y cuyo papel tenemos esplicado mas arriba, fibra vejetal, etc.; 4 . que la cantidad de las sustancias solubles se va siempre aumentando con los adelantos de la madurez, mientras al contrario y necesariamente el peso de la parte insoluble del pericarpio va al mismo tiempo dis- 
minuyendo. Se puede decir pues que una parte de los principios so. lubles contenidos en el suco de los frutos se forma á espensas de la parte no soluble del pericarpio. Los cuerpos que se vuelven entónces solubles son el almidon, la pectosa y otro principio particular llamado gomosa y que se transforma en goma. A tales reacciones ó metamórfosis se puede sin duda alguna atribuir los varios cambios que se observan en el color, la transparencia y el ablandamiento que esperimentan los frutos al madurarse. La presencia de la pectina en los frutos maduros proviene de la accion de los ácidos orgánicos y de la pectasa sobre la pectosa; 5 . muchas veces vemos salir de los frutos ácidos un suco neutro que despues de seco parece goma, constituye la gomosa, sustancia insoluble en el agua, y que, bajo la influencia de las sustancias azoadas, tiene papel de fermento y quizás al favor de los ácidos se modifica y se vuelve goma, que mas luego ha de transformarse en azúcar en el interior del pericarpio; la parte que de ella sobra sale por afuera, por las grietas naturales de las frutas y se solidifica en su superficie; 6 . el azúcar que se halla en los frutos maduros proviene de varias metamórfosis que han esperimentado los elementos de algunos principios inmediatos; así el almidon, que se halla en proporcion mayor en los frutos verdes, como verbigracia el plátano, el mamey, el mango, etc. desaparecerá mas ó menos completamente cuando habrán llegado á su completa madurez y se habrá vuelto glucosa, que lo reemplaza y que proviene sin duda de la reaccion de los ácidos orgánicos sobre él ; la goma tambien debe volverse azúcar ó concurrir á su formacion. El tanino ó curtiente, que existe con tanta abundancia en la mayor parte de los frutos no sazonados y especialmente en los ya mencionados, va disminuyendo poco á poco y gradialmente á medida que se van madurando los frutos, que despues de maduros no tienen sino una corta cantidad de ese cuerpo que ha sido reemplazado tambien por glucosa. En efecto, ese principio orgánico puede, obedeciendo á la influencia de los demas ácidos que están junto con él en las frutas, de los fermentos y tambien del oxíjeno del aire, dedoblarse y volverse glucosa; 7. la desaparicion de la acidez en los frutos maduros ó solamente sazonados es un hecho de que se puede dar razon de varios modos. En efecto, los esperimentos hechos á propósito han probado que ese fenomeno no se puede atribuir ni á la saturacion de los ícidos orgánicos contenidos en ellos, por las bases sea terrosas sea alcalinas, porque analizado el zumo en varios períodos de la maduracion, se ha siempre hallado en él igual proporcion de las bases minerales, y nunca ha aumentado aunque vayan desapareciendo los ácidos libres; ni tampoco la acidez está disfrazada por el azúcar ni por la presencia de las sustancibs mucilajinosas que se hallan siempre en mayor ó menor cantidad en los frutos maduros. Si se aprecia comparativamente la acidez de los frutos verdes con la de los ya sazonados ó maduros, esos últimos son siempre mucho menos ácidos ó contienen menor proporcion de ácidos libres, cuyos elementos sin duda esperimentan metamórfosis tales que se vuelven otros cuerpos y quizás glucosa y mucílago.

Cuando los frutos privados de la influencia de la luz se van madu- 
rando en la oscuridad, entónces la clorófila ó resina verde y el hidrójeno disminuyen al absorber el oxíjeno del aire y unas materias colorantes rojas y amarillas salen de esta reaccion; entónces los ácidos tartárico, málico y tánico desaparecen y están reemplazados por azúcar, fécula ó goma; esta reaccion aunque maravillosa se puede esplicar con facilidad como sigue: en efecto, 6 equivalentes de ácido tartárico pueden, con otros tantos equivalentes de oxíjeno atmosférico, volverse glucosa, y 12 equivalentes de ácido carbónico nacidos de esa metamórfosis se exhalan en la atmósfera, de la misma manera 2 equivalentes de ácido tánico con 8 de oxíjeno y 4 de agua pueden trasformarse en 1 equivalente de almidon y 6 de ácido carbónico que se evaporiza, y el almidon así formado se vuelve azúcar mas tarde. Se podria pues, siguiendo así, interpretar con bastante facilidad la formacion ó produccion de la mayor parte de los principios inmediatos orgánicos que nacen en iguales circunstancias y por consiguiente dar razon de las varias metamórfosis 6 transformaciones ulteriores que han de sufrir sus elementos; pero lo que acabamos de escribir sobre el particular nos parece suficiente para que se comprendan bien tan numerosos y tan maravillosos fenómenos. Durante el tiempo que los frutos gastan para llegar á su madurez completa, su pericarpio tiene que esperimentar tres modificaciones principales ó ha de pasar por tres períodos distintos que se pueden caracterizar del modo siguiente : en el priméro, los frutos obran sobre el aire atmosférico á manera de las hojas, de tal suerte que se forman entónces los principios solubles, y su proporcion se va aumentando cada dia mas y á medida que se desarrolla el fruto, los principios inmediatos formados en ese período son el tanino, el azúcar, la pectina, goma, ácidos cítrico, tartárico, oxálico, etc. El segundo período consiste en la madurez completa y lejítima de los frutos que ya no tienen igual accion sobre el aire, porque en ese último caso, al absorber el oxíjeno, que se transforma en ácido carbónico, sus principios solubles esperimentan una especie de combustion lenta y succesiva, cuyo efecto consiste, en primer lugar, en que los ácidos orgánicos estén destruidos, ó mejor, sus elementos sufren las variadas metamórfosis que tenemos señaladas algo mas arriba, y se han vuelto pues azúcar y demas cuerpos que no tardan á su vez á desaparecer ó á descomponerse ellos mismos; en efecto, en el último período que principia cuando el fruto ya bien maduro se ha vuelto ya muy blando y que su naturaleza ha cambiado ra, como sucede para los nísperos de Europa, ciertas clases de peras, etc., y que se concluye al podrirse el fruto; el aire penetrando entónces en la celulosa, las sustancias azoadas se vuelven prietas y se trasforman en fermentos alcohólicos, y la celulosa está destruida. Tales fenómenos tienen por objeto final destruir y desagregar completamente el pericarpio para que, puesta en libertad, la semilla pueda cumplir con su objeto que es germinar y producir un vejetal nuevo.

Accion del calórico artificial sobre los frutos y formacion de las jaleas vejetales. La pectina, que se halla, como todos lo saben muy bien, en mayor abundancia en el caldo de los frutos cocidos, que en 
ese líquido esprimido sin la intervencion prévia de un calor graduado y á la par manso, resulta de la accion química que tienen los áciclos orgánicos del fruto sobre la pectosa contenida adentro de sus celdillas. La formacion de las jaleas vejetales se ha pues de atribuir: 1. a la transformacion de la pectina en ácido péctico, mețamórfosis que se verifica por medio de la pectosa; 2 . á la formacion del ácido pectoso al favor de la accion menos prolongada de dicha pectosa sobre la pectina; 3 . en fin á la disolucion del ácido péctico formado bajo la influencia de las sales orgánicas contenidas en las frutas. Diariamente vemos cuajarse y rolverse jalea con mayor facilidad, el caldo de grosellas de Europa al mezclarle con el de frambuesas, lo que se esplica porque este último tiene una gran proporcion de pectosa que haciendo papel de fermento obra de tal manera sobre la pectina que la vuelve acto continuo ácido pectórico jelatinoso, el cual constituye la jalea vejetal. Cuando un fruto carnudo, como las guayabas ó guanabanas por ejemplo, se pone al fuego con bastante agua, entónces esperimenta las modificaciones siguientes : su parte ácida formada por los ácidos vejetales málico, cítrico, tartárico, tánico y agálico tiene en primer lugar sobre la pectosa una accion química tal que la vuelven pectina, la cual hace el caldo viscoso y de esta manera disfraza la acidez del fruto, lo que diariamente sucede con las limonadas ó naranjadas cocidas; en segundo lugar la otra parte de pectina formada produce una cierta cantidad de ácido pectósico que, disuelto en el líquido caliente, se cuaja en jalea por su enfriamiento; y además si la accion de la pectosa estuviera mas prolongada el ácido pectósico formado se podria á su vez volverse ácido péctico. Si al contrario el fruto esturiera espuesto á la accion casi repentina de una lumbre fuerte, de tal manera que su coccion se verificase con mucha prontitud, en tal caso la pectosa estaria cuajada acto continuo y perderia por consiguiente su poder catalítico y seria incapaz de obrar sobre la pectina, la cual no esperimentando las metamórfosis señaladas el caldo vejetal al enfriarse no se rolveria jalea. Durante el cocimiento de un fruto la pectosa sola está esperimentando las reacciones mencionadas, mientras la celulosa se queda tal cual sin sufrir nada de la accion del calórico.

Las plantas parásitas teniendo mayor interés para la agricultura por causa del perjuicio que sufren de ellas los agricultores, nos parece no fuera de propósito echar sobre ellas al paso algunas consideraciones. Tienen, como todos lo saben muy bien, sobre los vejetales que atacan, una influencia mas ó menos funesta y siempre perjudicial, que tiene relacion íntima con su manera de vivir. En efecto las unas son parásitas lejítimas, es decir que viven á espensas de los vejetales sobre los cuales están pegadas, mientras las seudoparásitas no sacan nada de los vejetales sobre los cuales viven, tales son ciertos musgos, líquenes, muchas orquídeas, muchas tillandsias, etc., solamente están pegados en la superficie del vejetal que han invadido, y el inconveniente que tienen consiste en que está siempre mas ó menos húmedo, tapan con sus raices las estomas, entorpeciendo así la respiracion cutánea; ocultan los insectos nocivos, comprimen o aprietan con sus raices las ramitas que necesitan engrosar 
é incomodan las hojas porque se desarrollan con demasiado vigor, por esas razones se recomienda quitarlas con cuidado de todos los vejetales útiles. Las verdaderas parásitas al contrario viven siempre ¿ i espensas de los vejetales sobre los cuales están pegadas y sanguijuelas rejetales sacan de ellos mas ó menos sangre vejetal ó saria; no estando en general provistos de órganos completos, no pueden bastarse á sí mismos, y por consiguiente no devuelven nada nutritivo á los que les cargan, de módo que no hacen mas que perjudicarlos. Todas las parásitas fanerógamas, como los lorantos, los muerdagos, etc., atacan las plantas por el esterior y por consiguiente se sacarán del mismo modo que las falsas parásitas, y bastará para eso limpiar con cuidado de ellas los vejetales que tienen acometidos. Pero no es así para las parásitas criptógamas, cuya mayor parte nacen en el interior de los vejetales, sino cerca de la superficie, lo que hace que se necesita mucho mas cuidado $y$ atencion para poder destruirles.

Para que sobresalga todavía mas la analojía que existe entre los seres organizados de la naturaleza asentaremos aquí algunas consideraciones generales sobre el envenenamiento de los vejetales. En efecto, los animales no son los solos que se pueden envenenar: los vejetales están casi sujetos á iguales leyes y los venenos tienen sobre ellos una accion análoga cuyo efecto es tambien la muerte. Escusado es decir que los animáles se pueden envenenar ya sea por la introduccion directa del tósigo en las vias dijestivas, ya en la circulacion de la sangre, á consecuencia de las heridas, ya indirectamente por medio de los pulmones ú órganos análogos respiratorios. Tales distinciones se pueden tambien establecer para los vejetales: en efecto la absorcion por las raices puede muy bien considerarse como correspondiendo al primer modo; la introduccion forzosa de una siustancia tósiga en una herida practicada en una parte á propósito del vejetal corresponderá pues con la segunda manera, y en fin, la accion de los gases deletéreos en la superficie entera del vejetal representará perfectamente el último modo. Cada veneno puede obrar con mas ó menos intensidad y puede ser ó no venenoso, segun se emplea de una ó de otra de esas tres maneras, lo que sucede lo inismo tambien en el reino animal: el ácido carbónico, verbigracia, respirado en cierta cantidad es veneno, mientras que al contrario, introducido en el estómago, no pasa mas allá entónces de ser un escitante agradable y muy empleado; el veneno de las culebras bravas ó ponzoñosas puede tragarse sin peligro alguno, mientras que el animal mismo que lo tiene puede ser muerto por su propia mordedura. Casi todas las sustancias venenosas para los hombres y los animales lo son tambien para los vejetales, y hay además sustancias muy inocentes para los primeros que son venenos para los segundos. La intensidad de la accion tósiga no es la misma pues para los dos reinos, y eso no podia ser tampoco; así vemos diariamente el alcohol, los éteres, los aceites, las aguas aromáticas, las materias amargas lejítimas, no dañar por lo regular á los animales, sino tomados en dósis muy fuertes, mientras que para los vejetales son sustancias muy venenosas; los óxidos de plomo, venenosos para los hom- 
bres, no lo son ó lo son muy poco para los vejetales. Los venenos obran con mayor proutitud en los vejetales que en los animales, pero su accion se queda limitada á los órganos á donde llegan, mientras que se estiende á toda la economía aninal; se puede decir pues que en los rejetales el envenenamiento es local, mientras que en los animales es siempre general. De lo dicho se ha de inferir que no se deberá omitir cuidado alguno para preservar los vejetales útiles de los vapores y de los gases que vician artificial o naturalmente el aire atmosférico; en efecto, basta visitar una sola vez los alrededores de lina de las numerosas fúbricas que echan en la atmósfera gases ó vapores ácidos ó solamente mucho humo de ulla prara convencerse al momento de la influencia innet: de tales emanaciones sobre la vejetacion.

To pasaremos adelante sin estender aquí algunos renglones sobre la geografía botínica, eiencia enteramente nueva y por dicha razon muy poco conocida y estudiada solamente por los cabios, muy vasta por supuesto y del mayor interés, porque, como la botúnica su madre, está íntimamente enlazada con las demas ciencias, y cuando se trata de los rejetales útiles, tiene para la agricultura mayor importancia para la aclimatacion de las especies exóticas. Apenas hace 60 años que los magníficos trabajos del célebre $A$. de Humboldt han echado los cimientos de esta ciencia, que ha sido desrues cultivada en Inglaterra, en Francia y especialmente en Alemania por muchos sabios cuyos trabajos la han hecho adelantar mucho, y sin embargo hoy en dia apenas ha salido de sus mantillas.

La geografía botánica es pues aquella parte de la botínica que trata de la distribucion de los vejetales en la superficie del globo. Los rejetales espontáneos, en efecto, no están repartidos uniformemente en toda la tierra; cada cual tiene su patria ó su pais de predileccion en que se le encuentra siempre, y los límites que tienen asignados dependen de algunas leyes ó causas tan pronto físicas como fisiolojicas, de tal manera que no pueden vivir y multiplicarse sino en los lugares en donde las varias circunstancias ó condiciones correspondientes con su organizacion, tan diversamente modificada en el sinnúmero de vejetales diferentes conocidos y clasificados, están reunidas; espresándonos de otra manera diremos que la diversidad de las numerosísimas circunstancias que les rodean y que son especiales á cada lugar, ha dado nacimiento á vejetales mas ó menos distintos los unos de los otros, y una vez ya nacidos se han esparcido en otras comarcas en donde habrán hallado casi iguales condiciones, modificándose sin embargo con el tiempo en aquellas nuevas eircunstancias climatéricas y demas que les tienen constantemente rodeados. La observacion pues demuestra con mayor claridad que todos los vejetales no han salido de un único centro de creacion, de donde despues de nacidos se habrán esparcido por todo el orbe, $\mathrm{y}$ cada dia se va reconociendo mejor por los trabajos de los botánicos que cruzan por todos los paises del mundo, que al principio hubo muchos centros de creacion para los vejetales, teniendo cada uno su flora propia, bien que algunas especies parezcan haber salido á la vez de algunos centros diferentes. La distribucion de lo: 
vejetales en la superficie de la tierra resulta pues del concurso simultáneo ó sucesivo de una multitud de causas muy complicadas; las unas, puramente físicas, provienen de la naturaleza misma de los vejetales y á la par de la presencia de los ajentes físicos que les rodean sin cesar: mientras las otras ocultas á nuestras investigaciones porque están enlazadas con algun misterio del oríjen de los seres; y además á tales causas ya demasiado numerosas so ha de añadir el hombre, que combinando y disponiendo tan pronto á su gusto como ́́ pesar suyo $\mathrm{y}$ con mayor frecuencia hasta sin saberlo, las condiciones necesarias á la existencia de las plantas, va cada dia naturalizando ó aclimatando en ciertas comarcas nuevos vejetales estranjeros, pero que encuentran en ellas bastantes circunstancias análogas á las de su pais natal, para que puedan vivir y hasta prosperar en esta patria de adopcion y salirla muy provechosos.

La existencia de unas plantas con preferencia y esclusivamente en un lugar mejor nue en otro sitio, resultando de la naturaleza física de tal parage en donde se hallan estos vejetales, constituye su estacion, mientras que se ha dado el nombre de habitacion al pais en donde viven; cada planta ó vejetal tiene pues siempre y recesariamente una estacion y una habitacion, porque se cria espontáneo en una tierra ó valdío de un pais conocido; al decir por ejemplo que una planta crece en los arenales de las cercanías de San Juan de Puerto-Rico, Cangrejos verbigracia, la estacion es los arenales y la habitacion las cercanías de San Juan de Puerto-Rico, ó Cangrejos. Tal distincion se puede hacer tan pronto hablando de individuos y de especies, como de géneros, de tribus y hasta de familias; se dirá pues que las algas, familia, viven en las aguas tan pronto dulces como saladas, estacion, de Europa, de Asia ó de América, etc., habitacion; que el bejuco amargo, aristolochia trilobata, se halla en la boca de los rios ó en los manglares, estacion, de Cangrejos ó del Dorado, habitacion. pueblos de la isla de Puerto-Rico. Cuantas preguntas se nos han hecho que se podian resolver y contestar casi á favor le los solos conocimientos que proporciona esta ciencia? tal será, por ejemplo, la siguiente: ¿Cuáles vejetales se crian en tal estacion ó en tal pais de que estamos tratando, y cuáles serán los que en él se podrán aclimatar y cultivar con provecho? ¿En qué pais habrá nacido y vivido la planta tal ó el género cual que tenemos en mano ó que se nos prosenta?

Es preciso pues, para que una planta pueda vivir en un pais ó en una localidad dada, no solamente que exista allá la semilla ó el gérmen de la especie, pero tambien es necesario que el clima, el terreno, etc., y en una palabra que todas las circunstancias ó condiciones esteriores tanto físicas como geográficas estén tales como conviene á su organizacion; sin la reunion de tales circunstancias no se puede efectuar el desarrollo normal, y cuanto menos la planta vive lánguida, enfermiza y no se reproduce. La relacion pues entre la organizacion de cada planta y las condiciones esteriores en que se puede encontrar es lo que al parecer determina en gran parte su existencia en un lugar con preferencia á otro, ó quizás uno se aproximaria mas a la verdad diciendo que las condiciones esteriores tanto físicas 
como geográficas de una localidad preexistiendo al nacimiento de los vejetales de tal region, tienen preparado de antemano lo que por su presencia la de determinar necesariamente su organizacion particular y apropiada á las necesidades de su vida en esa comarca.

Los vejetales están repartidos de una manera muy desigual por la superficie de la tierra; en efecto, ciertas especies se hallan reunidas en un espacio muy limitado, mientras otras, al contrario, están esparcidas en muchos lugares á la vez; algunos hay que son especiales de unos paises, á veces bastante limitados: otros aparecen al contrario en muchas comarcas á la vez; los límites entre los cuales está contenido ó encerrado un vejetal, una especie, un gुenero y hasta una familia, se llaman area, y las especies cuya area se va estendiendo mucho en latitud cono en lonjitud, no pueden servir para caracterizar una rejion especial; al contrario, aquellas cuya area está muy limitada caracterizan muy bien la rejetacion de tal comarca, cuyos límites no traspasan; se ha de considerarlos pues como estando con el clima y con las condiciones físicas del pais ó de tal sitio en correspondencia mas íntima que los rlemas vejetales; se de. berán pues elejir con preferencia tales vejetales para caracterizar las rejiones botánicas á que pertenecen, y además, entre aquellas especies se habrá siempre de dar la preferencia á los árboles, porque estando espuestos todo el año í las muchas vicisitudes del clima, suministran una designacion mucho mas exacta; las plantas herbáceas, en efecto, especialmente las anuales, que viven durante una sola estacion del año, no pueden pues esperimentar todas las influencias climatéricas, y por esta razon no deben ni pueden tampoco tomar parte en la formacion de la fórmula representativa del clima y de la rejion botánica. El señor A. de Candolle dice que los góneros que contienen mayor número de especies tienen tambien area mayor, así tambien, la area de las tribus y hasta de las familias es tanto mas vasta cuanto mas considerable es el número de géncros que la componen. Cuando una especie vejetal se cria espontínea en dos ó en algunas comarcas separadás por crrandes intervalos, en los cuales se hallan paises en que faltan, se puede decir que su patria es multiplice y su area disjunta; hay pues algunas especies que viven á la vez en las rejiones polares, verbigracia, y en las cumbres nevosas de los Alpes, tanto europeos como americanos y hasta asiáticos. Con mayor frecuencia, cuando unos climas, bien que lejanos, se parecen, se encuentra en los paises que les tienen vejetales de iguales géneros, pero rarísimas veces las mismas especies; si la analojía climatérica está ya menos íntima, se hallan solamente los de las mismas familias. Algunos géneros hay cuyas especies todas están agrunadas en una comarca única, y otros por el contrario cuyas especies, bien que poco numerosas, están muy esparcidas. La area de las familias y de los géneros puede estar dispuesta así como la de las especies, y aun con mayor razon y mayor frecuencia lo es, porque es habitualmente mucho mas vasta. Unos géneros se pueden llamar sociales, así como algunas familias y tambien ciertas especies, porque sus individuos viven siempre juntos, casi agrupados y poco esparcidos. La zona intertropical, en donde estamos escribiendo estos 
renglones, así como la tórrida ó equatorial, presentan una vejetacion enteramente diferente de la de Europa, tanto por su asombrosa lozanía y por la maravillosa variedad de las especies que la forman y por el sinnúmero de formas mas estravagantes las unas que las otras que afectan, como por los carácteres particulares de un gran número de los vejetales que la constituyen, cuyas leñosas estáll en proporcion bastante mayor en aquellos paises, y si, lo que sucede con frecuencia, la humedad y la riqueza del terreno se hallan junto con el calor continuo de la temperatura elevada de tales paises, se ven monstruosos árboles formando vastísimas selvas de un aspecto particular y característico, compuestas de una multitud asombrosa de especies diferentes que todas concurren á porfía para hermosear tan grandiosos paisajes. Se observan pues en tales montes, cuya existencia remonta casi á los primeros dias del mundo, tan larga es la vida de la mayor parte de los árboles que la forman, un sinnúmero de bejucos ó enredaderas cuyos tallos, mas ó menos gruesos, mas ó menos largos, tan pronto volubles como trepadores, se van enlazando por encima de los estipes y de los troncos para formar impenetrables retiros nunca jamás pisados por la planta del hombre y en donde la naturaleza todavía vírjen reina como dueña absoluta. En las rejiones ó climas mas templados, en donde las estaciones del año están bien marcadas, en la una se ven aparecer las flores, la otra hace madurar los frutos, en la cuarta se ve con mayor placer la naturaleza salir del sueño letárjico en que se encontraba sepultada durante algunos meses de la tercera, para adornar casi de repente con una hermosísima alfombra verde la tierra ya descansada. Durante esta triste estacion parecia vestida de luto, porque la mayor parte de los vejetales que la adornan, habiendo perdido todas sus hojas, se quedaban palos desnudos que parecian muertos, pero que en realidad no estaban sino dormidos, porque durante ese período seguian vejetando interiormente y sus funciones orgánicas se verificaban sin interrupcion ninguna, aunque á escondidas, como sucede diariamente á los animales y tambien á los hombres cuando despues de una larguísima carrera se caen como muertos de cansancio y se quedan como privados, durante el tiempo necesario para el descanso de sus órganos, y entónces vuelven en sí listos para volver muy luego á emprender iguales trabajos ó carreras.

En las zonas equatorial é intertropical, como el año no tiene sino una sola estacion, que se suele sin embargo dividir en dos, la del calor seco y la del calor húmedo ó de las lluvias, todas las fases de la vejetacion están por consiguiente confundidas, y por otra parte la fuerzade la vejetacion, estimulada casi siempre porlosajentesesteriores físicos es tanta, que siempre tienen tendencia los vejetales á brotar hojas ó á echar flores; las primeras por lo comun nose desprenden y no, se caen simultáneamente, lo que se ve suceder sin embargo por algunas especies; por esta razon habrí siempre menos ảbundancia de flores abiertas $\hat{i}$ la vez en un tiempo y en un espacio dado, que en los paises templados, en donde casi todas las plantas se adornan á la vez de sus flores, que no tardan en desaparecer por la mayor 
parte, porque á unos vejetales privilejiados solamente toca echarlas casi todo el año; tales son cierta clase de rosales, por ejemplo, mientras que en las afortunadas comarcas en donde estamos asentando esas consideraciones, la mayor parte de los vejetales están casi todo el año con flores, con frutos verdes y hasta maduros á la vez. Numerosas escepciones hay sin embargo: en efecto, bastantes árboles y arbustos pierden sus hojas y se desnudan como los de los paises templados, y tienen entonces, $\mathrm{y}$ por consiguiente, su estacion de descanso, de rejetacion y de floracion, y son esas dos últimas mucho mas largas que en los climas templados.

Pero si el suelo, bien que bastante rico en sí para el desarrollo normal de las especies arborescentes, no está pol su propicia naturaleza y por la favorable distribucion de las suficientes aguas en su superficie $y$ en su interior, bastante y contentamente húmedo; además si tales aguas son solamente suficientes por intervalos, por medio de las lluvias mismas que dependen de ciertas alternativas regulares en el estado de la atmósfera, se observan entónces unos cambios análogos á las estaciones de los paises templados; en efecto, la seca hace detenerse la vejetacion y unos árboles se despojan de su follaje y parecen así como muertos durante algun tiempo, para volver á echar nuevas hojas y flores tan luego como las abundantes lluvias periodicas les rieguen con sus fecundantes aguas, lo que hemos presenciado en la costa Sur de la isla de Cuba, que parece privada de rejetacion durante los meses de diciembre, enero, febrero, marzo y hasta de abril; eso sucede tambien para los catingas del Brasil, para la Guayana, Upata, por ejemplo, etc. Un suelo arenoso é irregularmente regado no puede producir sino plantas frutescentes y herbáceas, cuya vejetacion, detenida durante la seca, se va reanimando con las lluvias y cubre como de paso de una preciosa alfombra verde sembrada de primorosas flores, la tierra que pocos dias antes desnuda parecia estéril y casi muerta. Durante otra parte del año se observa lo mismo en vastísimos raldíos de las rejiones tropicales, tan pronto llanos como ondulosos y privados de la irrigacion natural y continua que resulta siempre de la vecindad de las altas montañas. De tales espacios, los unos crian muchísimas especies cuya variedad infinita produce el mas maravilloso aspecto y tiene al viajero asombrado de tanta lozanía, mientras los otros están cubiertos de una vejetacion tan vigorosa, pero muy uniforme y por eso mismo monótona, como sucede en los campos del Brasil, en las pampas del Paraguay, en los llanos del Apure, etc.

Las palmeras y los demas monocotiledóneos arborescentes, así como los helechos arbóreos, contribuyen notablemente por su presencia á dar á la vejetacion tropical su fisonomía particular y específica, las Escitámineas y las Cácteas además la caracterizán todavía mejor. Se han llamado Escitamíneas á los vejetales que forman las familias de las Musáceas, caracterizadas por el plátano, y de las Amomáceas; "además esa rejion contiene un cierto número de familias que no se cricuentran mas allá de sus límites y cuyo maximum de aspecies se halla entre ellos, tales son : las Bromeliceas, Miristíceas, Anonáceas, Bombáceas, Esterculiáceas, Ternstræniáceas, Bixá- 
ceas, Gultíferas, Maregraviáceas, Maliáceas, Ochnáceas, Anachoildáceas, Connáreas, Vochisiáceas, Mirtáceas, Turneráceas, Cactáceas, Mirsináceas, Sapotáceas, Ebenáceas, Verbenáceas, Cisthandráécas, Acantáceas y las Gesneriáceas, etc. Hay algunas grandes familias que existen á la vez en las rejiones templadas y tambien en las tropicales, pero en estas últimas sus especies están en mucho mayor número, tales son las Gramíneas, Cyperáceas. Orquídeas epifitas ó parasitas, porque pocas terrestres hay en comparacion del sinnúmero de las primeras; otras se distinguen por carácteres particulares y propios para formar tribus enteras, tales serán, verbigracia: las Mimóseas y las Cesalpíneas, entre las leguminosas; las Cinchóneas y las Cofeáceas, etc., entre las Rubiáceas. Las plantas enredaderas ó bejucos constituyen uno de los principales elementos de las selvas vírjenes de la América meridional, que hermoscan tanto con sus primorosas guirnaldas de flores entrelazadas las unas con las otras y formando así el conjunto mas estravagante y mas elegante que se pueda uno imajinar, pertenecen á las familias siguientes: Malpighiáceas, Sapindáceas, Menispérmeas, Bignoniáceas, Apocíneas, Asclepiádeas, Pasifloráceas, Ampelíleas, Esmiláceas, Dioscóreas, etc. Las plantas parásitas, lejítimas como falsas, que tambien se encuentran muy numerosas en tales rejiones, pertenecen especialmente á las familias de las Lorantáceas, Raflesiáceas. Balanofóreas, Orquídeas, Bromeliáceas, etc.

Por debajo del Equador unos grados hácia el Norte y otros tantos hácia el Sur, el clima es, como lo tenemos ya señalado, siempre cálido é invariable, peroá medida que se va uno alejando de esta zona, la distincion de las estaciones climatéricas se va haciendo mas sensible y se pronuncia mas; la zona tórrida se puede dividir en tres partes ó zonas secundarias, como sigue : la Equatorial, que corresponde comoá unos 15 grados de cada lado del Equador y corresponde á los paises cuyos nombres siguen: al Norte del Equador corresponde toda la parte Sur de la provincia de Honduras, principiando por el cabo Gracia de Dios, todo el pais de los Indios Mosquitos, la República de la Nueva Granada, y especialmente las provincias de Panamá, Cartajena y Santa María, la República de Venezuela, las Guyanas inglesa, francesa y holandesa; en fin, la parte Norte del Brasil correspondiendo à la Guyana portuguesa; las Antillas siguientes están tambien en esta zona: la Martinica, Sta. Lucía, Tabayo, Barbadas, San Vicente, Trinidad, Curaçao, Margarita, etc. Al Sur del Equador la zona tórrida comprende una parte del Brasil, de la República de Nueva Granada, el Perú, etc. Las dos zonas intertropicales que principian al grado 15 y se estienden hasta el 24 de cada lado del Equador comprenden: la del Norte, la República de Méjico desdo la parte Sur de la provincia de Tamaulipas, la de Veracruz, de Tabasco y el Yucatan, la República de Guatemala y especialmente las provincias Verapaz y la parte Norte de Honiluras; además corresponden á esta zona todas las grandes Antillas, que son Cuba, Santo Domingo, Jamaica y Puerto-Rico, y tambien la mayor parte de las pequeñas, como Santómas . Bieques, Tortola, Anguilla, Sta. Cruz, Antigoa, Nevis, San Cristóbal, Monserrate, Guadalupe, Maric-Ga- 
lande, etc. La del Sur contiene el Brasil desde la provincia de $\mathrm{Ba}$ hía y la de Riojaneiro, solamente algo mas acá de la capital. Hemos senalacio en esta enumeracion solamente las provincias bañadas sea por el mar de los Caribes, sea por el Océano, porque á esta sola parte corresponde nuestra obra; la flora de las provincias interiores haciendo parte del gran continente americano, tiene un flora distinta y mucho mas abundante, pero la parte indicada de esos paises es la mas poblada y por consiguiente la que puede aprovechar mejor nuestros desvelos, su flora diferiendo muy poco de la de las Antillas, por estar estas en las mismas zonas botánicas. La zona equatorial está, como ya lo tenemos dicho, caracterizada especialmente por la presencia en ella de las Palmeras, de las Escitamíneas, que desde el nivel del mar se estienden hasta como 600 metros de altura; pero si sigue uno elevándose mas en los Andes hasta alcanzar una altura como de unos 1,200 metros, entónces se halla en una zona que corresponde á las tropicales, caracterizadas principalmente por la presencia en ellas de los Helechos arborescentes, de las Quelastomáceas, de las Piperáceas, etc.

Las grandes zonas, llamadas templadas, que señalamos solamente de paso, porque no corresponden de manera alguna con el objeto de nuestra obra, se van estendiendo desde los trópicos hasta los polos y presentan necesariamente en tall vasta estension y entre sus límites estremos diferencias muchísimo mas marcadas, tan pronto por el clima, como por la vejetacion, que las que se observan en la zona tórrida; por esa razon se la ha subdividido en mayor número de zonas secundarias, cliyos límites no están determinados, tanto por la latitud como por las líneas isoternas que han de tomarse en mayor cuenta, porque á medida que se aleja mas del Equador, van ellas coincidiendo de menos en menos con las paralelas. Los límites de dos zonas vecinas se van confundiendo entre sí á medida que se acercan mas la una de la otra; en primer lugar se encuentran solamente algunos individuos esparcidos de la mas al Norte, que centinelas avanzadas han invadido la tropical, señalando por su presencia en ella que está ya pronta para desaparecer, mientras que en la otra los pocos individuos que se hallan mas acá de los límites son la retaguardia del ejército vejetal del Sur que ya ha vuelto á sus eternos campamentos. Eso supuesto, se ve que nuestra obra, escrita especialmente para las Antillas tropicales $y$ equatoriales, se habrá de aprovechar en los paises americanos que corresponden á ellas del otro lado del Equador, los cuales tenemos ya señalados algo mas arriba.

El botanista que va subiendo uno de los Andes de la América meridional despues de haber salido de las tierras calientes, en donde ha dejado las palmeras y los plátanos y haber alcanzado hasta como 600 metros de altura, se encuentra en medio de la vejetacion tropical que se estiende como hasta los 1,200 metros de altura, en donde se hallan los helechos arbóreos ylos cenchonas; se pasa entónces álas tierras frias, en donde se encuentra en primer lugar el Ceroxilonandicola, que parece como la transicion de las zonas tropicales á las templadas, caracterizadas por la presencia de las Encinas, Rododendron, 
Wintherias, Escallonias; se hallan tambien en ellas los Retamos, Vibumos, Clematides, Zumaques, Ívonimos, las Rubias, etc. Tal zona pues corresponde á la templada de Europa, cuyo aspecto tiene, y se encuentran en ella, como ch la otra, las Encinas, Ceceres ó Acres, Carpes, Alamos, formando bosques enteros; el Boj, el Torvisco y el Almez allí forman maleza; en fin, se encuentran hasta algunos árboles frutales europeos, como Duraznos, Manzanos, Cerezos, Morales, que se crian silvestres y espontáneos, mientras otros, como Albaricoqueros, Melocotoneros, así como muchas hortalizas europeas, están perfectamente bien aclimatadas; en fin, mas arriba se hallan hasta los vejetales alpestres, los Ranunculos, las Gencianas. los Astrágalos, etc., entónces ya se ha llegado como hasta 4,000 á 4,500 metros de altura, y casi al límite de las nieves perpetuas. Lo mismo será pues elevarse uno hícia la cumbre de una montaña muy alta, como viajar por mas altas latitudes, porque en ambos casos las metamorfosis rejetales y el empobrecimiento de la rejetacion se verifican siguiendo las mismas leyes.

De todo lo dicho se debe interir pues que el calor es siempre la causa principal que determina la distribucion geográfica de los vejetales; así vemos cada dia que los medios de aclimatacion y de naturalizacion que el hombre pone en obra están basados en estas consideraciones, y que han hecho decuplar las riquezas vejetales de ciertos paises, lo que para todos puede suceder. Los vejetales de los paises tropicales van ganando de año en año mas hácia los climas templados, mientras que muchísimos de las rejiones frias no abandonan sino con mucho sentimiento su patria glacial. Hemos visto pues que las montañas de la zona tórrida presentan con bastante frecuencia desde su base hasta su cima los vejetales que se encuentran desde el Equador hasta los polos, y además, sabido es que en Europa se ha logrado reproducir en las sierras, segun la temperatura, el grado de humedad y la naturaleza de los terrenos que las forman, una infinidad de vejetales perteneciendo á todos los climas del mundo. Las diferencias geogríficas que presentan los vejetales dependen pues, casi únicamente, como lo tenemos ya señalado algo mas arriba, de los diferentes grados de calor y demas circunstancias como la luz y la humedad que reciben en mayor ó en menor cantidad, así como de la naturaleza delos terrenos en que vejetan, $y$ además de la influencia de diversos fenómenos meteorolójicos que vemos en la naturaleza; tenemos que añalir no obstante, que existe un gran número de plantas cosmopolitas, ó que se acomodan á todos los climas y á todas las localidades. Se sabe que la facultad de resistir al frio aumenta en los árboles en razon del número y de la densidad de las capas leñosas, así como de la naturaleza resinosa de sus jugos propios, etc. Sin emibargo, bien que en los paises cálidos la corteza de los árboles sea por lo regular mucho mas delgada que en los climas frios, algunos de aquellos pueden aclimatarse en estos últimos, especialmente cuandotienen sus yemas ó capullos provistos de escamas y reuniendo en sí, por otra parte, 'as demas circunstancias favorables ya señaladas. Como lo tenemos ya mencionado algo mas arriba, las estaciones de los vejetales varian muchísimo, pero 
se ha de advertir que siempre serán las mismas para los mismos féneros o familias en cualquiera pais que se le observe, lo que se habrá de tomai' siempre en mayor consideracion cuando se tratal'i de la aclimatacion provechosa de algunas especies útiles; en efecto, los vejetales viven, los unos tan pronto en el mar ó en sus orillas, como en las aguas dulces y en las márjenes de los rios, quebradas, arroyos, y á la vez en los lugares pantanosos; los otros, al contrario, no necesitan para vivir sino una cierta cantidarl de humedad, $y$ por consiguiente se les encuentra mas ó menos distantes de los cursos de agua, como sucede en los prados y en los terrenos cultivados; se crian tambien algunas especies en las rocas, murallas $\mathrm{y}$ sitios pedregosos; ciertos vejetales viven especialmente en los arenales, en los lugares estériles, en los escombros; muchos habitan los bosques, los matorrales, los sotos, los vallados, etc. Algunas especies se hallan en los subterráneos, en las cavidades o cuevas únicamente, y hay aligunos que no se encuentran sino dentro del suelo mismo, sin salir nunca á su superficie; por fin, y en una palabra, la localidad hace rariar muchísimo, no solamente las especies y los géneros, sino tambien las familias; en efecto, los vejetales que se crian espontáneos en las montañas varian muchísimo, segun su elevacion, como lo tenemos ya señalado, y tambien segun su posicion geográfica, y por consiguiente deben ser, comolo son en realidad, muy diferentes de los que se crian en las llanuras. La posicion geográfica de los paises influye pues mucho en los vejetales; en efecto, el número de las especies criptógamas aumenta, relativamente á la de las fanerógamas, á medida que se va uno alejando del Equador, mientras la proporcion de las dicotiledoneas, al contrario, se va aumentando, relativamente á las monocotiledoneas, á medida que se van acercando del Equador, en donde el número absoluto y la proporcion de las especies leñosas es siempre mayor que en cualquiera otra parte del globo. La reunion de las especies rejetales que se crian espontáneas en un pais determinado con:tituye la flora propia de aquel pais: asi se dirá pues la flora de Francia, de Inglaterra, del Brasil, de las Antillas, etc. Las familias rejetales son mas ó menos abundantes y numerosas bajo las diferentes latitudes y en los diversos lugares de la tierra; si uno marcha pues de los polos hácia el Equador, verá aumentar el número de las Malváceas, de las Euforbiáceas, de las Compuestas, de las Mirtáceas, etc., mientras las Labiadas, las Amentáceas y las Crucíferas que pertenecen especialmente á las zonas templadas, ran disminuyendo y casi desaparecen en la zona tórrida.

Como lo tenemos ya señalado mas arriba, la humedad ó el agua obra sobre los vejetales de un modo muy notable; los unos en efecto absorben mucho de ese líquido, mientras los otros necesitan muy poca agua para vivir; los primeros, que viven en las localidades húmedas, tienen un tejido flojo y esponjoso, hojas glandulosas que presentan mayor superficie y son desprovistas de pelos, mientras los segundos, que habitan lugares secos, son de una testura dura, tienen hojas pequenas y velludas, su vejetacion es muy lenta; desde luego se debe concebir que los primeros no podrán accmorlarse mu- 
cho á la localidad de los segundos, y que estos no podrán habituarse á vivir en los lugares húmedos. El suelo arlemás, por su composicion química y su consistencia, debe necesariamente influir en la rejetacion; pero esta influencia puede estar modificada por algunas de las causas ó circunstancias esteriores; se sabe, en efecto, que ciertas plantas prosperan á pesar de la naturaleza desventajosa del suelo, si este tiene una buena esposicion, mientras que otro terreno semejante, mal espuesto, se quedará estéril. Las Saliconias, las Salsolas, etc., no pueden vivir sino en las orillas del mar ó en los lugares en donde el suelo contiene la sal de comer ó cloruro de sodio necesario á su vejetacion y que transforman en oxalato de sosa indispensable á su constitucion; las Gramíneas crecen con preferencia en un terreno silíceo y algo calcáreo á la vez, las Soláneas, las Crucíferas y los Hongos prefieren un suelo impregnado de materias orgánicas descompuestas ó reducidas á detritus. Estos pocos ejemplos bastan para hacer comprender que una planta orijinaria ó natural de una localidad que se transporta á otra y que vive en ella. debe sufrir una especie de aclimatacion que puede modificar mas $o$ menos considerablemente su tamaño, su consistencia, su color, su desarrollo y hasta la forma misma de sus órganos; además otras muchas causas que están ocultas á nuestro alcance, tienen una influencia muy marcada en la distribucion geográfica de los vejetales. Las plantas que viven en el seno de las aguas del mar no son tan numerosas como las que vejetan en la superficie de la tierra, y las familias que contienen las primeras son muy poco numerosas y ocupan el grado mas inferior de la escala botánica; la zoolojía marina, al contrario, es mucho mas rica, de manera que no hay relacion entre la cantidad de animales y la de rejetales marinos, así como tampoco la hay entre los vejetales terrestres y los animales que viven en la superficie del globo.

Los vejetaies influyen mucho los unos sobre los otros, como cuerpos estraños, con la sombra que dan, con sus raices, con los restos de sus hojas, etc.; se dañan ó se favorecen recíprocamente. La sombra de los árboles hace en efecto que unas plantas pueden vivir en sitios en donde las otras están escluidas; pero en general debajo de ellos hay poca vejetacion; las raices no se dañan solamente por su entrecruzamiento, sino tambien por sus secreciones, que son perjudiciales á las plantas de la misma familia, como lo tenemos ya mencionado, mientras que al contrario favorecen á las de otras. Las plantas que crecen mucho y se desarrollan con mayor prontitud, como las Gramíneas, verhigracia, escluyen á las demas, especialmente á los árboles, cuyo crecimiento es mucho mas lento, de modo que las ahogan cuando jóvenes. En los paises en que el cultivo no ha cambiado todavía la distribucion natural de los vejetales, no se hallan en efecto sino bosques estensísimos y prados muy dilatados, y es porque la sombra de los árboles mata las plantas herbáceas, las que á su vez impiden á las semillas de los primeros germinar ó mejor aho_ gan casi siempre el arbolito naciente. Las especies mas vigorosas perjudican siempre á las plantas herbáceas ó delicadas, como diariamente se observa; las parásitas matan frecuentemente y siempre 
dañan mas ó menos á los vejetales que tienen acometidos; en fin, las que crecen de prisa perjudican á las que con mayor lentitud se desarrollan y hasta las ahogan. Se puede decir pues que las plantas se hallan casi en guerra abierta y constante unas con otras, poco mas ó menos, cuales los animales que se disputan el alimento o se devoran mutuamente: mientras los vejetales en su pelea pasiva, se disputan solamente el sitio y el sol.

El estudio de la geografía botánica tiene pues por objeto no solamente distribuir los paises en un cierto número de rejiones vejetales, sino tambien detorminar, en cada uno de ellos, los pisos $\dot{0}$ localidades que corresponden con las rejiones botánicas de las otras comarcas, lo que es de mayor interés para la parte de la agricultura que se ocupa de la aclimatacion de los vejetales exóticos ó estranjeros al pais en que se trata de aclimatarles. Si se comparan entre sí las varias rejiones botánicas del orbe, se quedará asombrado uno al ver la gran analojía que presentan entre sí las que se encuentran colocadas en iguales ó análogas condiciones climatéricas; como rarísimas veces hay identidad perfecta entre las condiciones, se esplica por eso mismo porque es tan raro hallar en comarcas diferentes y muy lejanas las unas de las otras algunas especies idénticas, pero sí con mayor frecuencia especies del mismo género. De esta diferencia se ha sacado la conclusion que cada pais ha recibido, en los primeros dias de la creacion, sus vejetales especiales y no los de las demas comarcas, aunque los de estas últimas hubieran muy bien podido vivir en ellas; es muy fácil, en efecto, averiguar casi diariamente ese hecho, porque vemos plantas de un pais llevadas á otro, en donde se aclimatan y se van naturalizando de tal manera, que despues de algun tiempo mas ó menos largo salen espontáneas en ese pais y se van confundiendo mas cada dia con las indíjenas.

La comparacion del número de las especies, de los gréneros, de las familias, de las clases especiales á cada rejion, la determinacion de su relacion entíe sí, el cálculo de los coeficientes numéricos que son casi la medida del poder vejetal de cada rejion, de cada zona. de cada paralelo, constituye la aritmética botánica, uno de los ramos mas importantes de la geografía botánica; el exámen de los límites propios á cada género, á carla especie, la determinacion de la area de cada tipo, de cada vejetal, constituye otro ramo de esta ciencia, inverso con el estudio de las rejiones, pero que es su complemento indispensable; tal estudio, aplicado á los vejetales útiles, enlaza la geografía botánica con la agricultura; pern los límites de nuestra obra nos prohiben dilatar mas ese párrafo quizís ya domasiado estenso.

Hos queda para concluir ese discurso preliminar hablar de las herborizaciones y de la preparacion de los herbarios. Todos los botanistas célebres están acordes en que el medio mas seguro para conseguir el conocimiento completo de las plantas consiste en herborizar y en componer herbarios, y lo tienen escrito y aconsejado en sus obras; en efecto, la descripcion mas completa y los dibujos mas perfectos no pueden reemplazar sino de un modo muy imper- 
fecto los vejetales conservados con todo el cuidado posible, á fin de que la muerte no les prive de sus carácteres distintivos y específicos; pero para formar una hermosa y útil coleccion de plantas secas es preciso primeramente saber herborizar, y esta parte de la botánica tiene sus reglas y exijencias particulares.

Las escursiones que se hacen pues en busca de las plantas tan pronto para estudiar como para conservarlas se llaman herborizaciones, para las cuales se necesitan unos útiles ó ustensilios indispensables. Tales útiles consisten pues primeramente en una caja de hoja de lata para colocar las muestras o ejemplares á medida que se recojen, á fin de poder conservarles durante el dia y á veces por mas tiempo sin peligro que se marchiten $y$ sequen, $y$ á fin de poder á la vez transportarles consigo sin que se estropeen y por consiguiente se vuelvan inútiles para el estudio posterior; tal caja suele tener unas 18 pulgadas de largo y como 6 de ancho, la forma cilíndrica comprimida, que es la mas cómoda tanto para la colocacion de las plantas recojidas como para llevarla al hombro, la tapadera ó puerta ha de ser lateral y poco menos larga que la caja, y es preciso que se cierre de un modo tan fácil como seguro; debe disponerse de modo que se pueda llevar á la espalda colgando de una correa dispuesta á propósito y sugetar los cabos por sus dos estremos, hácia el costado izquierdo, para poderla alırir cómodamente é ir colocando las plantas conforme se recojen; en segundo lugar hay que tener una pequeña podadera y una azadilla que puedan engastarse y asegurarse por medio de una rosca en un baston fuerte provisto de un robusto y puntiagudo regaton, que estando enroscado sea fácilmente sustituido por una pequeña pala, la azadilla ó podadera ya señaladas; tales instrumentos, con una navaja fuerte, son muy necesarios, pues que llenan á la vez mas de un objeto. En efecto, liay que arrancar de raiz muchas plantas, mientras que el tamaño de otras solamente permite cortar ramitas á veces demasiado altas ó lejanas, y además al trepar por las montañas ó al saltar todas las veces que el terreno lo exije, presta apoyo y seguridad el baston convenientemente dispuesto. En fin un buen lente de aumento, una aguja botánica, papel de estraza y algun blanco, papeletas y cortadas y dispuestas á propósito, lápiz ó tintero y plumas, un libro de memoria y una botella algo aplastada y de boca ancha, con espíritu de vino ó alcohol cualquiera debilitado, ron blanco, para conservar ciertos objetos, y otra con aguardiente ó ron añejo y lejítimo, por ser mas saludable, para mezclar con el agua que se bebe durante el calor, completan lo mas indispensable que se debe llevar consigo en las escursiones; además, si se han de prolongar, es preciso no olvidar algunas provisiones para comer. El que en Europa herboriza suele cargar con todo lo que tenemos señalado y llevarlo así consigo, pero no puede hacerlo así en los paises tropicales sin que se esponga á enfermarse muy pronto por la demasiada fatiga que esperimenta muy pronto y porque todo eso le estorbaria muchísimo para penetrar en el monte, además no debe ir solo pero sí siempre acompañado de un peon de confianza bien baqueano ó práctico y conocedor del pais, quien cargará con lo mas indispensable dejando con los ca- 
ballos ó mulas lo que no es de absoluta é inmediata necesidad llevar consigo; hay además para mayor seguridad que andar con armas : un buen revolver basta por io comun, pero una buena escopeta de dos tiros no seria de mas, especialmente cuando recorre uno el continente americano, y nunca se ha de olvidar su buen cuchillo de monte, indispensable para abrirse camino á través de las malezas y bejucos; escusado es decir que se debe siempre llevar consigo el estuche de que hemos hablado en las generalidades sobre los contravenenos, C. T. V., T. 2, páj. 27, para preservarse de las consecuencias de la mordedura de las culebras ponzoñosas.

Esos pormenores indispensables cumplidos se ha de ocuparse del modo con que se deben cojer las plantas; escusado es decir que las muestras de las plantas que se recojen han de reunir en cuanto sea posible todos los caractéres genéricos y específicos, lo cual se logra comunmente respecto de muchas plantas pequeñas que pueden colocarse enteras en el herbario; pero relativamente á las demas hay que suplir esto por medio de ramitas que á la vez tengan flores y frutos, si es posible, y siempre hojas, ó si no solo una cosa, y aguardando en tal caso la época oportuna para conseguir las otras; si las hojas se desenvolvieren despues de salidas las flores se conseguirán cuando se coja el fruto; pero hay especies cuyas hojas se presentan al tiempo que el fruto se cae y entónces de aquellas se necesitan tres ramitas cojidas en distintas épocas para completar los caractéres; no deben estar enteramente maduros los frutos cuando son. carnudos, porque se podririan en el herbario ; entónces se les conserva en espíritu de vino ó ron blanco; los capsulares ó secos han de serlo al contrario, con la precaucion de sujetar sus valvas con un hilo á fin de que no se abran. Todos los ejemplares recojidos de una planta se colocan en la caja conforme se cojen, procurando siempre que las raices $\dot{o}$ las partes inferiores de los ramos estén todas á un solo estremo con su tapa á propósito para poner con facilidad un poco de musgo mojado que la sustente cuando hayan de permanecer mucho tiempo en la caja; y por este medio, cuidando de no abrirla con demasiada frecuencia, se logra conservarlas bastantes dias sin que las flores sufran aun. Pero algunas plantas hay cuyas corolas son muy fugaces y caedizas, las de otras se cierran y se marchitan al momento y únicamente colocándolas entre papel de estraza en el acto mismo de cojerlas es como se consigue conservarlas; ofrece pues ventaja para estas la cartera grande con papel de estraza, que soliamos llevar siempre con nosotros con muchísimo provecho en nuestras herborizaciones ; tambien se podria no necesitarla haciendo abrir los botones ó flores en casa, pero no siempre es posible hacerlo así.

Las plantas criptógamas, si bien no todas, necesitan cuidados especiales al cojerlas; sin embargo, las semivasculares tales como las Equisetáceas, Azóleas, Rizocárpeas, Licopodiáceas, Musgos, Hepáticas, Líquenes, etc., casi no necesitan otro sino aguardar que se hayan desarrollado sus organos reproductores, porque se secan con la mayor facilidad y prontitud; tienen las Charáceas el inconveniente de hacerse muy friables cuando se desecan. Entre las plantas 
puramente celulares, hay que cojer una multitud de líquenes adheridos á ramos, pedazos de corteza, piedras, etc., sobre que se encuentran; muchos hongos son tan frájiles, tan blandos y putrecibles ó se desecan con tanta prontitud, que es necesario submerjirlos en espíritu de vino en el acto de cojerlos; en fin, la hermosa familia de las Algas, $y$ principalmente las marinas, exigen mucha paciencia y minuciosidad. Con las mayores, los fucus por ejemplo, no se hace otra cosa mas sino aprovechar el influjo del sol hasta lograr la desecacion; muchos se encuentran en las orillas del mar en buen estado despues de una tormenta, pero no sucede lo mismo con las pequeñas y blandas : las hay, en efecto, tan finas y delicadas que apenas bastan los cuidados mas esmerados para no echarlas á perder. Antes de sacarlas del agua, es necesario observarlas bien, porque fuera de ella no se presentan del mismo modo y para que no se rompan debe buscarse el punto por donde están adheridos, cortándolas con toda precaucion ó mejor despegándolas. Algunas se pegan de las manos y primero se rompen que desprenderse; por el contrario otras se escurren con mucha facilidad; para cojer unas y otras se ha de usar pues una vasija de vidrio con boca ancha, submerjiénilola de manera que la planta quede dentro; sacándola luego y tapando con la mano la boca, se hace salir por un pequeño espacio toda el agua que contiene, dejando la planta sola, y despues rle repetida igual operacion bastantes veces, se llega á tener suficiente número de estas delicadas algas dentro de la vasija, que se puede transportar llena de agua y tapada sin temor que se echen á perder; y tambien convendrá conducir en agua las grandes confervas para conservar sus órganos reproductores en buen estado. Muchas plantas marinas se descoloran y se pudren tan pronto como se hallan en contacto con el aire, y este inconveniente se evita espolvoreándolas con arena gruesecita y seca, despues de haberlas dejado escurrir, y colocándolas de ese modo en la caja de herborizacion, ó mejor en otra de madera dispuesta á propósito; en casa se esponen al aire pero no al sol, y se conservan así secas y con la arena hasta que llegue el momento de la preparacion para colocarlas en el herbario.

Despues de haber examinado la planta cojida y escrito sobre una de las papeletas á propósito su nombre científico, si se ha llegado á determinaile, así como el vulgar cuando lo tenga en el pais, el lugar en que se haya cojido, la altura sobre el nivel del mar, la naturaleza del terreno en que se cria, y en una palabra, cualesquiera observaciones que no pudiesen hacerse cuando la planta estuviera seca, como por ejemplo si es árbol ó frutice, su altura, tamaño, etc.; todo eso cumplido, lo que hay que hacer entónces se reduce á colocar la planta fresca entre papeles de estraza sin cola, siendo su tamaño igual al que tenga el herbario y someterla á una conveniente compresion; sin embargo, ciertos cuidados, los unos comunes á todas las plantas y los otros aplicables á algunas solamente, se necesitan. En efecto, al colocar la planta en el papel de estraza se debe abrir y estender con cuidado todas las partes de la muestra, y al estender cada parte sobre el papel se sujetará con un pequeño peso, un pedazo de plomo ó una moneda, para que no se vuelvan á doblar 
o á ponerse debajo de las otras ; todas así arregladas se las deja hasta que se hayan marchitado, y entónces, al quitar la moneda se aplica por encima una hoja de papel; las partes que se sobropusieren han de separarse con papel de estraza fino; se procurará dejar algunas flores bien abiertas, poniéndolas adentro un papel plegado con su correspondiente peso encima, y se hará de modo que se hallen á la vista en algunas los órganos sexuales; otras se dispondrán de manera que presenten su forma natural miradas por debajo y por encima, cosa mas fácil en las de corola regular que en las irregulares, pero se procurará tambien dejarla patente; se tratará que los pétalos y otras partes arrolladas o plegadas naturalmente subsistan del mismo modo, mientras que se habrá de impedir el arrollamiento de otras mojando un poco el papel; se procurará que no se cierren las corolas que lo verifican, valiéridose de un papel alggo mas fuerte ó mejor de un pedacito de carton sin cola, y de ese modo se conservará la situacion de los pétalos. No son necesarios por lo comun tantos cuidados y basta ordinariamente estender sellcillamente cada planta entre hojas de papel, procurando que las partes de la misma no queden unas sobre otras, al menos en cuanto lo permite la conservacion de su natural postura; sin embargo, á nuestro parecer. será siempre mejor tomarlos cuando habrá lugar de hacerlo. Si las plantas fuesen grasas ó bulbosas no seria suficiente esto, porque su vida es bastante tenaz para que continuen vejetando en el herbario, lo que suele suceder para las Orquídeas epititas y otras parásitas tan comunes en los paises tropicales; para evitar tal inconveniente $y$ para que lleguen á desecarse completamente y con bastante facilidad, no hay mas sino zambullirlas durante unos minutos, cuyo número hahrá de variar segun su grado de espesor y su tamaño, en agua hirviendo, preservando tan solamente las flores, operacion que producẽ una muerte segura y además hace la desecacion muchísimo mas pronta; si las plantas son muy carnosas ó que se ennegrezcan, como álas orquídeas teriestres suele suceder, tambien se recomienda secarlas, pasándolas diestramente una plancha caliente. sin omitir la precaucion de cubrirlas con un papel de estraza antes de proceder á esta operacion. Conviene aplastar con el pulgar los tallos y ramas de las plantas herbáceas $\mathrm{y}$ tambien las costillas $\mathrm{y}$ nervaduras de las hojas, para que pierdan mas fácilmente su humedad, y el volúmen de las leñosas se disminuirá con estraer el leño por una hendidura lonjitudinal de la corteza, no siendo perjudicial en algunos casos colocar tan solo la mitad de un tallo ó de otro órgano voluminoso. Reunidos así convenientemente los ejemplares en eada pliego ó entre dos pliegos de papel y puestos entre cada dos pliegos ocupados algunos otros vacíos, ó mejor, como solemos hacerlo, una hoja de carton sin cola, se forman paquetes de poco espesor, que deben entónces someterse á la compresion, que ha de ser moderada, á lo menos al principio, porque siendo demasiada se pegarian los órganos unos á otros de un modo tal, que no serian fáciles de examinar ó de estudiar despues de secos. Puede hacerse de distintas maneras esta compresion, y la prensa que se solia usar otras veces con mas frecuencia no es muy preferible á los pesos, libros, 
piedras, etc., con que se suele cargar el paquete puesto entre dos tablas; pueden tambien estas ser apretarlas por medio de algunas correas provistas de sus correspondientes hebillas, lo cual es muy ventajoso y sobre todo muy cómodo para cuando en el discurso de una herborizacion larga ó de algunos dias, se quiere secar andando las plantas recojidas y que con dificultad se conservarian tanto tiempo en buen estado, conviene pues cargar en los caballos algunos pares de esos aparatos guarnecidos de su correspondiente papel y cartones: hemos adoptado ese método de compresion durante nuestras herborizaciones en las Antillas y en el continente americano, y siempre ha salido muy bien. De cualquier modo que se haga la compresion es necesario mudar el papel todos los dias, con el cuidado de arreglar las partes que se encuentran mal dispuestas. Una pronta desecacion es muy ventajosa por la razon de que conservan mejor los colores, y por esto deben ponerse las plantas en un sitio seco y ventilado y aun caliente, con tal que no pase de como 35', porque las haria friables. Tambien favorece mucho la desecacion el descomponer el paquete en otros paquetitos, que se dejarán al aire sueltos y desparramados, sin comprimirlos despues de los primeros dias. En verano bastan dos ó tres dias para secar laś plantas, si el papel que se sustituye no tiene humedad alguna, lo que se procurará poniéndole al sol ó al fuego; en tiempo húmedo se puede obtener una pronta desecacion poniendo el paquete en un horno, algun tiempo despues de sacado el pan, lo que nos ha siempre surtido inmejorable efecto.

En lugar de papel de estraza solemos usar el primer dia hojas de carton gris sin cola alguna, colocando entre ellas las plantas con tanto cuidado como cuando se emplea el papel, separando las varias partes de ellas con papel de estraza, á fin de hacer la superficie mas igual posible, y especialmente entre las hojas y flores, á fin de que su espesor llegue á igualar el de los tallos y ramos, mas frecuentemente empleamos para eso tiras ó pedacitos de carton gris mas delgado; despues de 12 á 15 horas de compresion se las. muda en pliegos de papel de estraza y los paquetes dispuestos se ponen cada uno en una redecilla de alambre doblada á manera de pliego de papel y del mismo tamaño que él, se sujeta ese sencillo aparato con tres correas provistas de sus correspondientes hebillas, de las cuales hay dos transversales y una lonjitudinal, las correas apretarlas como conviene se cuelga el aparato al sol y por único cuidado basta voltearle dos ó tres veces al dia, y la desecacion se verifica perfectamente bien y con prontitud; es preciso colocar siempre las plantas mas delicadas y mas fáciles para secar en el centro del paquete y las mas carnosas y mas difíciles de desecar á la superficie. Éscusado es decir que antes de volver á poner el aparato al sol es preciso abrirle para sacar las que ya están secas. Tal método nos ha salido siempre perfectamente bien y no empleamos otro porque nos parece ser ese el mas pronto y además porque da tan buenos resultados como el horno y la coqueta del botanista Lecocq.

La mayor parte de las plantas no necesitan nunca para su buẹna desecacion mas cuidados sino los ya señalados; pero no sucedẹ 
siempre lo mismo con gran número de plantas acuáticas, tanto fanerógamas como criptógamas y con otras de esta última clase; sin embargo en tales circunstancias nuestro método ha siempre cumplido muy bien con el objeto. Los musgos y los líquenes podrán colocarse en el herbario casi al momento mismo de ser cojidos y no habrá inconveniente en estenderlos despues de secos, teniendo la precaucion de humedecerlos un poco antes; los hongos podrán secarse si no fuesen muy carnosos, y siéndolo se necesitará entóncss conservarlos en espíritu ú otro líquido conservador, agua con sal de comer y alumbre verbigracia. Son las algas plantas que exijen minuciosísimas precauciones, compensadas solamente por el gusto de poseer una bella coleccion de tan curiosos vejetales.

Una vez preparadas y secas las plantas, no está hecho aun todo lo que exije su conservacion, si el herbario ha de ser duradero, si no ha de ser mas ó menos pronto pasto de los insectos; deben pues envenenarse las plantas, por mas que algunas puedan haber sido atacadas en ciertos casos, á pesar de tal precaucion. Cuando el herbario no es muy numeroso $\mathrm{y}$ se visita con frecuencia hay menos peligro, así es que generalmente no se envenenan sino los ricos herbarios ó los que han llegado á ser interesantes; sin embargo esta precaucion es siempre necesaria y hasta indispensable en los paises tropicales sobre todo, en donde tantísimos insectos hay, porque en tales paises no basta visitar frecuentemente su herbario para evitar que sean carcomidas sus plantas, como lo tenemos esperimentado tantas reces; familias hay que son las víctimas preferidas de los insectos, y otras al contrario que no atacan casi nunca ; en el primer caso se hallan á la cabeza de todas las compuestas, las umbelíferas r las crucíferas, despues vienen las euforbiáceas y algunas otras familias; bien que habiéndose librado en los primeros años de la voracidad de los insectos, suelen verse menos atacadas en lo sucesivo. Se hace el envenenamiento de las plantas zambullendo o sumerjiéndolas en alcohol teniendo sublimato corrosivo en disolucion, como media onza por cada botella y media de líquido, al cual se puede añadir además algunas veces alcanfor ó una esencia cualquiera, pero esa adicion no es indispensable; escusado es decir que no se les volverá á colocar en el herbario sino despues de secas, y además que se deben tomar las precauciones que exije tan peligrosa preparacion.

Así preparadas falta colocar las plantas metódicamente y disponer el herbario en regla; pero eso tambien necesita sus instrucciones particulares, las cuales tenemos que esponer ahora: para facilitar la colocacion se deben primeramente separar los ejemplares por familias, reuniendo todos los correspondientes á cada especie, de manera que no se confundan los que provendrán de localidades diferentes. El tamaño del papel, elejido y con cola, vale mas que peque por grande que por pequeño; debe ser siempre igual, estando plegado en dos hojas cada pliego; no ha de contener este mas que los ejemplares de una sola especie, los cuales nunca deben estar sin su correspondiente papeleta, hecha del modo ya enseñado mas arriha, en la que se debe anotar de quien procede, cuando no sea es- 
crita por uno mismo, la espresada papeleta podrá fijarse en el ejemplar con una tirita de papel engomado ó solamente por una ó por dos hendiduras, si hubiese varios ejemplares de la misma especie que se diferenciasen por las localidades, no hubiera inconveniente en reunirlos todos, lo mismo que los cojidos en diversos estados ó ćpocas y aun las variedades; pero cuando se prefiere tenerlos en hojas distintas, babrá que meterlas todas dentro de un pliego doblado á manera de cubierta comun. Como quiera, cada ejemplar con su papeleta fija en él debe quedar libre y no pegado al papel, como lo hacian los antiguos y preceptuó Linneo, porque además de otras desventajas, tenia este método la de no poderse examinar bien las plantas, mientras que con el otro se concilia todo, sujetando el ejemplar al papel á favor de tiritas prendidas con alfileres. Además de la papeleta que va siempre unida al ejemplar es bueno poner dentro del pliego otra independiente en la que se escriba la sinonimia científica, vulgar, etc., pudiéndola sujetar en el ángulo inferior de la izquierda, de manera que sin abrir el pliego y aunque se halle entre otras, pueda verse pronto cuál es la especie contenida en él ; se reunen despues los pliegos por secciones, géneros, tribus y familias formando paquetes parciales, que podrán segun su volúmen formar un solo ó mas por familia; y para hallar fácilmente los diversos grupos que cada familia contiene, se pondrán rótulos salientes que los indiquen, colocándolos en una regular sucesion. Hecho eso, hay que aplicar cartones ó tablas superior é inferiormente y atarlo todo en cruz con una cinta fuerte, ó al traves con dos correas provistas de hebillas ó por otro medio adecuado; finalmente, los paquetes de las familias se colocan aproximándose segun su analojia en un armario ó estante, poniéndolos vertical ú horizontalmente, variando segun la posicion que se adopte la situacion de los rótulos salientes, y el herbario se halla entónces en disposicion de ser consultado con la mayor facilidad y de ir sucesivamente en aumento con la intercalacion de nuevas plantas.

Además de los herbarios generales, hay otros particulares, sea compuestos de plantas aplicables á la medicina, á las artes ú otros, y siempre á las que deposite para los cambios. Además de los herbarios de especies hay otros de géneros y carácteres siendo de menor. tamaño, que suplen con ventaja á las mejores láminas para la intelijencia de los términos botánicos, y cuando reunen los carácteres bien manifiestos de las.familias constituyen uno de los mas eficace: medios de aprender la botánica; por lo tanto aconsejamos con mayor empeño á los aficionados que quieren aprender pronto y con facilidad esta ciencia principien por hacer un herbario de la última clase y despues de hecho con el debido cuidado sabrán ya la parte elemental, y entónces podrán con mayor provecho hacer el herbario de la comarca en donde viven, ó bien podrán, si quieren, y quizás será mejor así, á la vez que van herborizando y coleccionando, hacer á la par el herbario de géneros y carácteres de familias que llamaremos elemental, destinado á ser consultado diariamente, y el general; de este modo harán adelantos muy rápidos en esta agradable, instructiva y utilísima ciencia. 
Para hallar las plantas en el herbario se necesita un órden riguroso, que se ha de establecer desde el principio, porque las dificultades se van aumentando á la par que la coleccion, y por eso dehe formarse desde luego un catálogo dispuesto como sujiera á cada uno su jenio, atendiendo que con los aumentos diarios habrá de esperimentar muy frecuentes alteraciones. A. de Candolle dice que conviene establecer: 1 . un registro de entradas en que se mencionen brevemente las plantas desecadas por sí mismo ó recibidas con la indicacion general de su pais ó de su orijen; 2 . otro alfaliético de los nombres de los géneros, con la indicacion de la familia donde se hallail colocados en el herbario, segun el autor que se siga ó segun sus propias observaciones. 


\section{PROLEGONENOS}

ó

\section{RESÚMEN DE BOTÁNICA ELEMENTAL}

\section{LIBRO I}

CAPÍTULO PRIMERO

PORMENORES 6 CONSIDERACIONES GENERALES SOBRE LQS VEJETALES COMPARADOS Á LOS ANIMALES.

Al principiar esta primera parte enteramente botánica de niuestra obra, que hemos tenido por esta razon que titular "Flcra médica y útil de las Antillas y de la parte del continente americano correspondiente á ellas, »nos ha parecido necesario, antes de pasar adelante, asentar aquí algunas consideraciones generales sobre los vejetales $\mathrm{y}$ entrar en algunos pormenores mily necesarios y hasta indispensables para mayor intelijencia del estudio botánico de las plantas tropicales, cuyo estudio terapéutico tenemos hecho en la segunda parte enteramente médica de esta obra y por tal razon titulada "Compendio de terapéutica vejetal de los mismos paises." Empezaremos pues nuestra tarea señalando las diferencias principales que existen entre los animales y los vejetales, porque han de servir para caracterizarles. Escusado es decir, porque todos en demasía lo saben, que todos los cuerpos de la naturaleza han sido agrupados en dos grandes divisiones ó secciones o reinos, de las cuales una contiene los cuerpos inorgánicos ó quizás mejor inorganizados, porque no teniendo organo alguno son por consiguiente en- 
teramente privados de vida, tales son todos los minerales, los flúidos y los gases, que constituyen el reino inorgánico ó mineral; mientras en la otra, llamada reino orgánico, se vienen á agrupar y colocar todos los cuerpos orgánicos, es decir todos los seres que, dotados de órganos á propósito, tienen vida, tales son los animales y los rejetales; ese reino ha sido además partido en dos grandes clases ó secciones, de las cuales una, con el nombre de zoolojía, se ocupa del estudio y de la clasificacion de los animales, mientras la otra, que se llama botánica, trata de los vejetales. La botánica es pues esta parte de la historia natural que trata de los vejetales ó plantas consideradas como seres dotados de vida y constituye esta tan interesante y tan agradable ciencia cuyo objeto consiste en el conocimiento racional del reino vejetal; tal estudio, muy vasto por supuesto, es muy agradable, divertido y sobre todo tiene mas poderoso interés y á la vez muchísima utilidad por causa de sus aplicaciones diarias tan pronto á las artes y á la medicina doméstica como á la agricultura y por consiguiente á la alimentacion del hombre y de los animales útiles. Los vejetales que constituyen la parte mas notable y mas numerosa de los seres organizados ó vivientes se diferencian de los animales porque se alimentan y pueden reproducirse pero no sienten ni se mueven voluntariamente tampoco. El célebre Linneo decia en su estilo tan enérjico y tan conciso: los minerales crecen, los vejetales crecen y viven, los animales crecen, viven y sienten: Mineralia crescunt; vegetabilia crescunt et rivent; animalia crescunt, vivent et sentiunt. Los vejetales están fijos en el suelo; tienen el carbono por base principal de su composicion; están compuestos de 4 ó de 5 elementos, encuentran y toman en derredor de sí sus elementos; los animales al contrario se mueven en la superficie de la tierra; tienen el azoe por base de su composicion; están á menudo compuestos de 8 ó 10 elementos; tienen necesidad de obrar sobre los alimentos para hacerlos nutritivos. Considerados respecto á sus actos quírnicos, se diferencian los animales porque queman carbono, hidrójeno y amonio ; exhalan ácido carbónico, agua, óxido de amonio y azoe; consumen oxíjeno, materias azoadas neutras, crasas, féculas, azucares y gomas; producen calor y electricidad; devuelven sus elementos al aire y á la tierra ; transforman las materias orgánicas en materias minerales; pueden pues considerarse como un aparato de combustion locomotor; mientras los vejetales al contrario reducen carbono, hidrójeno y amonio; fijan ácido carbónico, agua, oxido de amonio y azoe ; producen oxíjeno, materias azoadas neutras, crasas, féculas, azúcares y gomas ; absorben calor; atraen electricidad; toman sus elementos al aire 0 á la tierra; transforman las materias minerales en orgánicas : constituyen pues aparatos de reduccion inmóviles.

Los vejetales son formados de sustancia homójena mas ó menos diáfana, flexible y sin color, dispuesta ó no en masas, pero en la cual no se han distinguido órganos propiamente dichos, pero eso no es especial de los solos vejetales menos perfectos, porque suele suceder tambien para los animales mas inferiores, de tal manera que en este último grado de la escala orgánica, la transicion del reino 
rejetal al reino animal es tan insensible y tan poco apreciable que uno pasa al otro sin que se lo pueda casi reparar y que en esos últimos límites se confunden el uno con el otro. La pequeñita alga llamada protococcus pluvialis produce un infusorio llamado anastasia nivalis, el cual á su vez da nacimiento á una alga; tales seres son pues el punto de transicion del reino vejetal al reino animal. Pero las mas veces esta sustancia va dilatándose y estendiéndose con figura de membranitas que se vuelven las unas tan pronto tubos como las otras celdillas, para constituir por su conjunto el tejido celular vejetal y sus diferentes variedades ó formas, de las cuales saldrán mas tarde los varios organos que han de constituir el vejetal perfecto.

Las plantas, como lo tenemos ya dicho en el discurso preliminar. se alimentan siempre de sustancias inorgánicas tan pronto gaseosas como líquidas, que son el agua, el ácido carbónico, el óxido de carbono, el hidrójeno carbonado, el oxíjeno, el amoniaco, el hidrójeno. el azoe y algunas bases y ácidos minerales. En efecto, como los vejetales no teniendo ningun aparato dijestivo ni órganos de locomocion tampoco, debian hallar su alimento preparado de antemano $y$ vivir siempre envueltos y bañados sin cesar en él, para que se lo pudieran sin interrupcion alguna chupar por medio de todos sus órganos á propósito ; la gran funcion de la nutricion resulta pues para tales seres del cumplimiento continuo y regular de actos orgánicos secundarios que consisten en la absorcion y en la transpiracion, en la espiracion o exhalacion. $y$ por fin en la escrecion o secrecion. Mientras la mayor parte de los animales pueden ir cuando les conviene ó mejor cuando lo necesitan en busca de su alimento que consiste siempre en sustancias orgánicas tan pronto vejetales como animales, y cada especie animal sabe perfectamente escojer el que me jor corresponde á su organizacion: despues de escojidas y cojidas las sustancias que han de alimentarle, el animal las hace sufrir una preparacion preliminar al mascarlas y despues se las va depositando ell un órgano á propósito llamado estómago, verdadero laboratorio de química viviente, en donde estas sustancias encontrándose en contacto con ciertos reactivos á propósito salidos de sus paredes y preparados en ellas, los cuales, obrando á manera de un fermento. determinan en ellas por su presencia y concurso un sinnúmero de reacciones y metamórfosis elementales sucesivas que tienen por objeto presentar á la asimilacion los elementos casi desagregados y listos para entrar en nuevos agrupamientos moleculares que les harản aptos á remediar, vueltos quilo, las necesidades y pérdidas orgánicas del animal, cuya alimentacion ó nutricion se verifica por absorcion interna ó intus-suscepcion; mientras en los vejetales la nutricion se verifica por absorcion esterna ó extus-suscepcion, como sucede tambien para los animales inferiores cuyo volúmen se aumenta pues por la parte esterior.

Los vejetales no tienen ningun sistema circulatorio lcjítimo; en efecto, la savia, que constituye la sangre de tales seres, corriendo por lo largo de tubos repartidos por todas sus partes y mas ó menos anastomosados entre sí, obedeciendo á la capilaridad ayuda á los fe- 
nómenos de la vida ó quizás les determina por su piesencia, sube primelamente por los que ocupan el centro del vejetal, $y$ al favor de sus muchísimas anastomosis penetra por todas partes, por todos los obranos, y así se estiende del centro hasta la circunferencia en donde llega en los pulmones vejetales ú hojas y se halla sometida á la influencia vivificadora del oxíjeno, y entónces se verifica la hematosis vejetal, y sale de estos órganos ya dotada de vida ú organizada ya que se presentan en ella glóbulos que no existian antes; se ha vuelto pues capaz al bajar de llevar la vida ó el alimento en todas las partes ú órganos del vejetal que necesitan remediar sus pérdidas ó desarrollarse para cumplir con su objeto. Tal líquido ó la savia descendiente, llamada latex ó cambium, es pues el análogo de la sangre arterial de los animales mamíferos ó superiores, pues que tiene jgual papel que ella; en efecto, bajo la influencia de la luz y sin duda de la electricidad, la savia ascendiente, análoga á la sangre venosa, cargada de todas las sustancias que ha cojido en el trayecto transcurrido, llegada en las hojas ó pulmones vejetales, esperimenta varias y sucesivas metamórfosis que le comunican propiedades físicas y químicas tales que la vuelven propia para desempeñar la nutricion del vejetal en toda su plenitud, suministrando pues los varios elementos orgánicos necesarios para que se puedan verificar las varias secreciones vejetales, cuyos productos especiales ó principios inmediatos orgánicos particulares deben un dia ó en lo venidero, cuando la química orgánica, mucho mas adelantada, habrá hallado reactivos á propósito para hacerlos reconocer con facilidad, caracterizar así químicamente los varios géneros de plantas.

Los vejetales no están tampoco provistos de sistema nervioso alguno; sin embargo, muchas plantas de la familia de las leguminosas y perteneciendo á las sub-familias de las cesalpíneas y de las mimóseas, hay cuyus hojas compuestas ó surdecompuestas tienen una especie de sensibilidad, que llamaremos orgánica, la cual se manifiesta por ciertos movimientos automáticos que tienen lugar bajo la influencia directa de los ajentes físicos esteriores; así por ejemplo, cuando se tocan con los dedos las hojas del morivivi ó mimosa pudi$c a$, casi acto continuo sus hojuelas se inclinan las unas hácia las otras, se aplican á los peciolos secundarios, que á su vez se aplican los unos á los otros á manera de los dedos de la mano cuando se cierra, y por fin la hoja entera así cerrada se inclina y se viene á aplicar al ramo que la lleva; el viento, una nube opaca que obscurece el sol producen ignal efecto; la falta de luz produce un efecto anílogo en muchas plantas de las mismas familias, las cuales al anochecer cielran sus hojas como si quisieran dormir, lo que Linneo Liabia llamado el sueño de las plantas; no se debe tener ese fenomeno por nada mas que un efecto físico de la irritabilidad orgánica, mas pronunciada y mas desarrollada en tales vejetales que en los demás, enteramente independiente de la voluntad y que difiere esencialmente de una lejítima sensibilidad de parte de la planta, que carece de los órganos á propósito, manifestándose además esteriormente por una simple contractibilidad organica sin nada mas particular, enteramente diferente por consiguiente de la sensibilidad de 
los animales, los cuales poseen los órganos á propósito que constituyen su sistema nervioso mas ó menos complicado ó perfecto, segun el grado que ocupan en la escala animal, de tal manera que los mas inferiores parecen tan pronto vejetales como animales, porque tampoco tienen sistema sanguíneo lejítimo.

Escusadó es decir, porque nadie lo ignora, que en general, para cumplir el importantísimo acto de la generacion, los animales necesitan del concurso y de la union íntima de ambos sexos, que casi siempre están separados sobre individuos diferentes y que, incitados por el instinto irresistible de la conservacion y de la propagacion de la especie, los machos, en la sazon oportuna, huscan con empeño á las hembras, se acercan á ellas y las fecundan á favor de un líquido particular depositado directamente por el órgano masculino en el femenino; pero tambien animales hermafroditas hay, ó que, dotados de los dos sexos, se bastan á sí mismos sin necesitar del concurso de otro individuo de su clase para que se verifique la fecundacion, tales son las ostras, las almejas, etc.; además animales andrójinos hay, los cuales, bien que teniendo ambos órganos sexuales, no se bastan á sí mismos y necesitan, para que se verifique la fecundacion, del concurso activo de otro individuo de su especie, de tal manera que uno sirve de hembra al que es su macho; se verifica pues así una doble y mutua fecundacion : en ese caso están los caracoles, las lombrices de tierra, etc.; pero estos dos últimos modos de fecundarse los animales son casi escepcionales, porque el major número de ellos tienen los órganos sexuales aislados en individuos especialos, los cuales, dotados de locomocion, pueden buscarse en la sazon de los amores para, obedeciendo á las leyes de la naturaleza, cumplir con un acto tan sencillo á primera vista, pero tan complicado $\mathrm{y}$ tan maravilloso, que asombra á quien lo quiere profundizar. Los vejetales, al contrario, condenados á vivir y á quedarse siempre en el lugar donde han nacido, siendo enteramente desprovistos de órganos de locomocion, han debido ser, como lo son, en efecto, hermafroditos y mas raras veces unisexuales; bastantes vejetales hay sin embargo unisexuales, cuyas flores femeninas y masculinas, situadas en un mismo individuo, las hace corresponder á los animales andrójinos; los vejetales unisexuales cuyas flores masculinas y femeninas están colocadas en individuos distintos pueden por esa disposicion considerarse como análogas á la mayor parte de los animales, con la diferencia esencial que no pudiendo acercarse los unos á los otros, no hay ni puede.haber nunca reunion voluntaria ni inmediata tampoco de ambos sexos, la fecundacion será pues siempre mediata y casual, los órganos con que se desempeña esta funcion siendo por otra parte casi siempre pasivos, bien que algunas raras veces se hayan observado algunos fenómenos particulares é insólitos al verificarse el acto de la fecundacion; en algunas flores, en efecto, hay aumento muy notable de calor; en otras hay una especie de sensibilidad y unos de sus órganos sexuales ejecutan ciertos movimientos, etc. La fecundacion en los vejetales se hace al favor de una sustancia pulverulenta ordinariamente, mas ó menos fina ? siempre muy sutil, que se llama pólen ó polvo fecundante, cuyo ve- 
hículo natural es el aire atmosférico, que llevándole consigo lo der'rama en las flores femeninas abiertas; en las flores hermafroditas, al contrario, está casi mediata cuando las anteras están aplicarlas al estigma al reventarse ó cuando echan su pólen antes de abrirse la flor, como sucede frecuentemente; pero si las anteras están algo distantes del estigma y especialmente estrosas, es decir vueltas hácia afuera, entónces el aire ha de intervenir para que se efectue la fecundacion; los insectos, al buscar alimento en las flores favorecen mucho esa funcion llevando mucho pólen consigo y esparciéndole en las flores.

Si se estudiase esa importante funcion detenidamente y con todo el cuidado posible en todos los seres de la naturaleza se repararia pronto que, aunque los varios modos de generacion parezcan á primera vista muy diferentes los unos de los otros, las diferencias van poco á poco desapareciendo, están casi todos unidos entre sí. En efecto, cualquiera que sea la clase en que está colocado el ser que se estudia, se hallan siempre algunas capas mas ó menos resistentes y á reces muy duras que tienen el embrion ó feto encerrado, protejido y escondido; colocado entónces en una cajita ó cavidad á propósito, cuarto reservado en donde se desarrolla poco á poco con el alimento que por medio de vasos particulares recibe de su madre. Además siempre algunas sustancias nutritivas están en depósito aguardando el momento en que listas sufrirán las metamórfosis necesarias para hacerlas propias á remediar las primeras necesidades del ser nacedero ó recien nacido, ú órganos hay prontos para prepararle el primer alimento que ha de necesitar. Todas las plantas pues producen huevos vejetales ó semillas, cualquiera que sea su clase, de forma y organizacion bastante rariada $y$ hasta desconocida para algunas de ellas; del mismo modo todos los animales producen huevos, cualquiera tambien que sea su clase, lo que es evidente para las aves, peces, moluscos, insectos, etc.; tocante á los mamíferos o animales vivíparos, se puede muy bien admitir que, como los ovíparos, han producido huevos, pero con la diferencia que, en lugar de estar puestos, se han quedado en un órgano á propósito en donde se han desarrollado, sufriendo en él una especie de incubacion interna mucho mas larga y mas perfecta que la de los huevos propiamente dichos despues de puestos, pero enteramente análoga, cuyo resultado es la salida afuera del chiquillo desarrollado y apto para vivir, como sucede diariamente para los de las aves, peces, reptiles al romper la cáscara de los huevos que les contienen despues de la incubacion necesaria ó sin ella. Existen tambien plantas cuyas semillas ó huevos vejetales germinan en el interior mismo de la fruta. pegada todavía al vejetal, sea por ejemplo el mangle sapatero, vizophora mangle, el lirio sanjuanero, pancratium caribœum, etc.

Muchas plantas como muchos animales no paren ninguna semilla ni huevos algunos, y las unas como los otros se propagan ó multiplican por separacion espontánea de trocitos de su propia sustancia, y se llaman entónces gemíparos; en ese caso se liallan algunas alras, las diatomáceas por ejenılo, así como muchos zoófitos. En efecto, nadie ignora que, picado un polipo, cada pedacito se vuelve 
un ser nuevo enteramente parecido al que ha sido así dividido, de la misma manera una hoja, una yema, una rama ó estaca separadas de una planta y puestas en ciertas condiciones indispensables se desarrollan y producen un vejetal.

De todo lo dicho en ese capítulo se ve claramente que los vejetales y los animales son muy estrechamente unidos los unos con los otros y casi enlazados por medio de la analojía que existe entre las funciones que desempeñan sus principales órganos, de tal manera que diferenciarles con un carácter seguro, específico y constante es cosa casi imposible, á lo menos ahora, especialmenle cuando se trata de las especies mas imperfectas y que ocupan los grados mas inferiores de la série de los seres, mientras que los carácteres diferenciales y específicos se hacen tanto mas numerosos y sobresalientes culanto mas elevados estén en la escala orgánica. Los animales y los vejetales pueden pues considerarse como formando dos séries graduales ó como dos cadenas ascendientes saliendo de un punto ó de un oríjen comun; pero á medida que se ran apartando la una de la otra, los seres que forman sus eslabones se van modificando gradual é insensiblemente, de tal manera, que no tardan á parecer seres enteramente distintos y que á primera vista no se pueden comparar los unos á los otros por ser tan notables las diferencias que entre ellos existan. 


\title{
LIBR0 II
}

\section{ORGANOGRAFIÁ Ó DE LOS ÓRGANOS DE LOS VEJETALES}

DE LAS FUNCIONES QUE TIENEN QUE DESEMPEÑAR

Un vejetal perfecto se compone de las raices, por medio de las cuales se queda pegado y sugetado en el suelo; del tallo que carga con las ramas y ramitas, las cuales llevan las hojas, las flores y los frutos; el estudio de tales órganos constituye pues la organografía ó descripcion de los órganos vejetales.

Los vejetales así como los animales presentan al estudio dos grandes funciones que en sí reunen todas las demas, y que tienen por objeto, la una, la conservacion del individuo; y se llama nutricion, mientras que á la otra, que es la de la generacion, toca la conservacion de la especie.

\section{SEGGION I}

\section{DE LA NUTRIGION Y DE LOS ÓRGANOS GON QUE SE HA DE TERIFIGAR}

\section{CAPÍTULO PRIMERO}

\author{
DE LA RAIZ.
}

Se llama así al órgano con que el vejetal está sujetado al suelo y en que penetra mas ó menos, segun la clase de planta á que pertenece, pero que siempre saca de la tierra, por medio de los chupaderos que terminan sus divisiones mas delgadas, los líquidos y los gases que necesita y á la vez las sales y otras sustancias terrosas y 
alcalinas indispensables á su existencia, como lo tenemos dicho en el Discurso preliminar, Se llama base á la parte superior que se continua con el tallo, y el punto de juntura ha recibido el nombre de cuello ó nudo vital, porque es la parte de la raiz en donde reside la vida y de donde ha de salir siempre el tallo; el ápice será pues la parte diámetralmente opuesta ó inferior, la intermedia se dice cuerpo de la raiz ó nabo, como se ve en las zanahorias. G. 1137. La raiz se divide poco ó mucho, dando oríjen á raices secundarias, ramas y ramos radicales dirijiéndose siempre de arriba abajo, que adelgazándose cada vez mas, producen el conjunto de filamentos que se denomina hebras ó cabellera. Hay fibrillas ó barbillas diferentes de las ramillas radicales, sin que puedan convertirse en estas por ser perecederas, cuyas funciones absorben el jugo de la tierra, etc., como lo hacen las estremidades celulares tiernas, pero no siempre desprovistas de película epidérmica, á las que se ha dado el nombre de esponjillas. Iguales órganos absorbentes tienen en sus estremidades las raices compuestas ó que proceden de muchas bases, formando un manojo de raices simples con frecuencia, mientras que son casi siempre ramosas las de base única.

Es el primer órgano que se desarrolla en la vejetacion y tiene una tendencia manifiesta á huir de la luz. Plantas hay cuyas raices nunca penetran en la tierra, pero sí en los vejetales sobre los cuales viven, mas no son raices lejítimas pero chupaderos mas ó menos desarrollados que sacan de los otros vejetales su alimento, tales son las parásitas lejítimas, los viscos y lorantos. F. 47. Las raices suelen faltar muy raras veces; sin embargo se conocen plantas pegadas en las rocas ó en la corteza de los árboles que no tienen raices lejítimas : tales son los líquenes, F. 3, ciertos hongos, F. 2. Las algas no tienen raices lejítimas tampoco, porque son garras que las sujetan en las piedras, F. 1. Las orquídeas epifitas tienen raices lejítimas á veces muy largas con que se quedan sólidamente sujetas en los troncos ó ramas de los árboles sin penetrar de ninguna manera en su corteza y sin sacar por consiguiente nada de ellos, no penetran nunca jamas en el suelo pero chupan el agua y el alimento de la especie de humus formado por medio de las sustancias vejetales que se amontonan mas ó menos en su derredor y en donde se descomponen.

La duracion de las raices determina la de las plantas á que pertenecen, y de aquí se suelen dividir unas y otras en anuales, bienales y perennes ó perenales, segun si duran un año, como el maiz, G. 172; dos años, floreciendo y fructificando en el segundo, como la zanahoria, G. 1137, o mas de dos años, lo que sucede para muchísimos vejetales. La consistencia de las raices variando en diversas plantas se las ha llamado herbúceas, leñosas, carnosas, huecas y sílidas ó macizas.

Segun su direccion, su forma y su estructura se les ha dado los nombres siguientes: 1 . segun su direccion relativa con el suelo se dicen perpendiculares ó verticales, oblicuas ó inclinadas, horizontales y descendentes : en ese último caso bajan despues de haber caminado horizontalmente; consideradas en sí mismas se llamarán rectas, en- 
corvadas, ondeadas ó tortuosas y retorcidas; 2. atendiendo á sus formas se les ha impuesto los epítetos de filiformes, cilindvicas; tuberosas, cuando tienen bultos mas ó menos redondeados, en oposicion de las simplemente fibrosas, que no les presentan pero se ramifican mucho; ahusadas ó fusiforimes, las que parecen como huso; nabiformes asemejándose á un nabo; engrosadus cuando se hacen abultadas; redondas ó esféricas; nudosas ensanchándose de trecho en trecho, juncos santos, ciperus juncifolius, por ejemplo, G. 341 ; articuladas, formadas de artejos soldados entre sí; granujientas ó granosas, es decir formaulas de granos ó cuerpecillos redondos mas o menos numerosos y reproductores; troncadas cuando su estremo parece como roido; capilares, las que consisten en un hacecillo de fibras ó barbillas llamadas radículas o raicitas, tales son las de las gramineas, F. 10, y de muchos otros vejetales; las tuberosas ó turmosas : se llaman así á las que llevan tubérculos mas ó menos gruesos saliendo de sus fibras, las batatas, G. 582; las papas, G. 622; á ellas pertenecen las globosas ó redondas, las nodosas ó pendoleras, las moniliformes ó dispuestas á manera de rosario; las agamonadas ó fasciculadas y amanojadas, la mellia tuberosa, G. 534 , las cuales son compuestas de muchas piernas mas ó menos carnudas y pareciendo tuberculitos; las didimas, compuestas de dos tubérculos redondeados, el género orquis, G. 430; las palmeadas ó digitadas, cuando los dos tubérculos están divididos á manera de los dedos de las manos, algunos orquis; se llaman bulbosas cuando consisten en una $\dot{o}$ en algunas cebollas reunidas, de cuya parte inferior salen las raices propiamente dichas $y$ capilares siempre; lirio sanjuanero, $G$. 452. Por la superficie se distinguen las raices en lisas, rugosas, tubercuosas y anilladas, segun si la tienen limpia, cubierta de arrugas, de proeminencias dispersas ó de eminencias circulares.

Nunca jamas las raices son verdes en su estado normal, pero pueden tornar este color en las partes espuestas á la accion del aire; ordinariamente son mas blandas que los tallos y carecen siempre de médula. Algunas tienen la propiedad rle echar retoños cuando separadas del árbol su parte superior está en contacto con el aire durante bastante tiempo. Su epidermis difiere de la de los tallos por faltar siempre en ella las estomas.

Plantas seudo-parísitas hay que tienen raices aéreas, la euscuta por ejemplo, G. 585, perdiendo pronto la raiz primitiva y subterránea, presentan en el tallo verrugas llamadas chupadores, que son otras tantas raices suplementarias destinadas á la absorcion de los jugos que hallan dentro de los vejetales sobre los cuales se encaraman; no pierie sus raices lejítimas la margravia de flores en umbela, (4. 683; pero sus larguísimos tallos se apoyan fijándose por medio de infinidad de raices asidoras lo mismo en las piedras que en los árboles; muchos higuerotes ó higueras americanas, G. 111; la clusia rosea o cupey, 874 , echan raices aéreas muy largas que no principian á engrosar sino cuando han alcanzado el suelo, tales raices se llaman adventivas, se las observá ordinariamente saliendo de los últimos nudos de la caña del mais, G. 172. Con frecuencia la vainilla echa raices adventivas muy largas; las raices de las orquu?- 
deas epifitas se han de agrupar en la clase de las aéreas, G. 440 443 , etc.

Dos son pues los usos á que están destinadas todas las raices en general : fijar las plantas y absorver las sustancias que se necesitan para su nutricion. Hay vejetales, sin embargo, que no tienen ó ne necesitan raices, porque pueden verificar la absorcion por otros medios, y las hay cuyas raices son muy pequeñas y casi solamente destinadas á sujetar los tallos. Otras veces sirven solamente para la absorcion y no para fijar las plantas: tales son las de la lenteja de agua. F. 31 .

\section{CAPÍTULO II}

\section{DEL TALIO.}

El tallo es esta parte del vejetal que sale siempre del cuello de la raiz, de la cual es la continuacion aérea, su direccion siendo pues siempre opuesta á la suya; tiene por objeto llevar las hojas, flores y frutos. Hay plantas cuyos tallos son tan cortos que parecen faltar, entónces se las llama acaules, mientras que las provistas de un tallo se dicen caulescentes.

Los botánicos han repartido los tallos en 5 clases ó divisiones diferentes, á las cuales han impuesto nombres específicos:

I. El tronco; se llama asíal tallo leñoso mas ó menos grueso, mas ó menos largo y que se eleva á veces hasta 80 piés de altura, cónico, mas ó menos ramoso y que pertenece á los árboles ó á los arbustos, sean por ejemplo el jobo, G. 276, 273, 270; el mamey, G. 876, 877, 295. Su parte inferior ó base es siempre desnuda y simple, mientras la superior se va dividiendo y subdividiendo en ramas, ramos y ramitas mas ó menos numerosos, los cuales á su vez se ramifican mas ó menos. Es cilíndrico y mas ó menos cónico á la vez, ordinariamente duro y resistente, constituye las maderas de construccion, de carpintería y de ebanistería y es susceptible con frecuencia de un hermoso pulimento; su color varia muchísimo, así como su dureza y su fuerza o resistencia; esa clase de tallo pertenece especialmente á los vejetales dicotiledóneos y es formado de dos partes bien distintas, cuya parte esterior ó cortical constituye la corteza y se compone de la epidermis, la capa ó envoltura corchosa, la envoltura herbácea y las fibras corticales ó liber que ocupan la parte interior y son contiguas á la parte interior leñosa ó madera, que es compuesta del léno y de la médula.

1. La epidermis es una membrana delgada, algo diáfana, que cubre ó viste todas las partes de la planta, de las cuales se la puede separar con mas ó menos facilidad; esta membrana está formada de una parte esterior película delgada, continua y mas duradera, estendiéndose sobre toda la superficie vejetal, mientras la otra mas interior ó la epidermis, propiamente dicha y lejítima, se compone de celdillas justapuestas, formando una capa única y de un espesor 
uniforme. Se observa ordinariamente en la epidermis mayor ó menor número de aberturas ó boquillas organizadas, visibles solamente con el lente, llamadas estomas, que establecen comunicacion entre la atmósfera y el parénquima mas superficial de las plantas en que existen $y$ con cuyos intersticios corresponden, sirviendo así á la respiracion y sin duda á la vezá la espiracion de los fluidos que salen de los vejetales; son unas liendiduras ó aberturas ovales prolongadas, cuya forma determina un rodete generalmente compuesto de dos células semilunares que se tocan por sus estremidades, y varia en las diferentes plantas, desde la circular hasta la oval tan estrecha, que se aproxima á la lineal, y en un mismo vejetal varia tambien, segun el grado de humedad de la atmósfera y la accion mas ó menos intensa de la luz solar. Lo que es un efecto higrométrico solamente, porque se efectua tambien en pedazos de epidermis aislados, bajo el influjo de iguales causas. Esos órganos no se encuentran indiferentemente en todas las partes espuestas al aire, y son mucho mas numerosas en las hojas, en especial por su cara inferior; su número varia muchísimo, segun las plantas, $\mathrm{y}$ son tarto mas abundantes cuanto mas pequeñas; su disposicion varia tambien mucho; en efecto, están ya esparcidas sin órden ninguno, ya dispuestas por séries rectas, á veces esparcidas por trechos iguales; otras veces parecen agruparse, etc. Pero si las plantas están sumerjidas del todo, no tienen estomas, pues les falta la epidermis organizada, cual corresponde á los vejetales superiores, y tampoco las hay en las sencillas plantas celulares, donde quiera que vivan, los hongos, por ejemplo, F. 2, los líquenes, F. 3. La cara inferior de las hojas de las nínfeas, aplicada en la superficie del agua, está desprovista de estomas, mientras la superior las tiene bastante numerosas, F. 91; el medio en que viven las plantas determina pues la presencia ó la falta de epidermis, y por consiguiente de los estomas. En los vejetales semivasculares, como las licopodíaceas y los helechos, F. 6-5, cuya epidermis es distinguible del tejido vascular subyacente, comienzan á presentarse esos órganos, que faltan en las raices, los peciolos no foliáceos, los pétalos, los frutos carnosos, las semillas, etc. La epidermis de las raices difiere mucho menos del tejido subyacente que la de los tallos, y á veces esa diferencia desaparece del todo. La película epidérmica ó cutícula existe hasta en los vejetales desprovistos de epidermis lejítima, y en los acuáticos: consiste en una membrana continua agujereada en los lugares correspondiendo con los estomas. Los progresos de la edad la hacen desaparecer, así como la epidermis misma, y quedan entonces solamente capas de un tejido celular endurecido, que viene á ser la epidermis de los troncos y ramas viejas. La dilatacion que esperimenta la epidermis por el crecimiento de los órganos que cubre, llega á resquebrajarla, y si á esto se agrega su desecacion por la accion atmosférica, se esplicará con facilidad por qué se cae á pedazos en muchas plantas, sucediendo lo mismo en las capas celulares que van apareciendo en su lugar, sea por ejemplo la Péndula, G. 560; los Guayabos y otras Mirtáccas, G.1112, 1122.

2. La enroltura suberosa ó corcho de color mas ó menos moreno, 
á veces se desarrolla mucho, pero ordinariamente está muy poco pronunciada y generalmente falta mas ó menos.

3. La envoltuva herbcicea, celulosa ó mesodermis de color verde, suculenta especialmente en la estacion en que la savia está en moviento, envuelve toda la superficie del vejetal y comunica con la médula por medio de los radios medulares, cuya parte mas interna está formada por las capas corticales ó liber que se hallan entre la parte celulosa, compuesta del tejido celular y la madera, mientras que ella está formada de laminitas aplicadas las unas á las otras, constituyendo el liber lejítimo, cuya capa interior se forma todos los años, de manera que las mas viejas son las mas esteriores. Se observan en las cajas corticales los vasos por donde circula la savia, los que contienen los sucos propios á cada clase, llamados propios ó lactíferos; en esa porcion del vejetal es en la que se verifican la mayor parte de los fenómenos de la vida vejetal, y en la que se identifica el injerto con el sujeto.

4. El leño ó madera que constituye la parte dura y sólida de los árboles y arbustos, sigue á la corteza y se divide en albura ó parte mas esterior, mas ó menos blanda y de ordinario blanca, y en madera lejítima ó corazon cuyo centro está ocupado por la médula. La albura no es otra cosa sino la madera imperfecta, cuya capa mas interior se vuelve cada año madera, mientras que esteriormente se forma una capa nueva, volviéndose el liber albura, y así se efectua el crecimiento de los árboles, por medio de una nueva capa ó cono que torlos los años envuelve á los anteriores, tanto mas cortas cuanto mas viejos; esa disposicion se puede muy bien representar con cartuchos de papel desiguales puestos los unos dentro de los otros, y con la base sobre una mesa y cuyo mas esterior y mas largo, por consiguiente, represente la última capa de albura formada. Los arcos que en el corte de un árbol representan cada capa leñosa, corresponden pues á los años que haya vivido ese vejetal; su número dará pues su edad. Todas las capas leñosas no son iguales, lo que proviene de la reparticion mas ó menos igual de la savia organizatriz ó cambium; ordinariamente las capas que corresponden á las ramas grueśas y á las raices muy desarrolladas son mucho mas espesas, lo que modifica mas ó menos la forma cilíndrica del vejetal, sea por ejemplo la ceiba, G.918. El aumento ó crecimiento de los árboles se hace pues entre la corteza y la madera ó en su punto de contacto por donde circula la savia descendiente ú organizatriz, suministrando á la par los elementos necesarios para la capa mas interior del liber y la mas esterior del leño ó de la albura.

La médula consiste en una sustancia esponjosa compuesta de células, cuyo tamaño va disminuyendo desde el centro hasta la circunferencia, á la vez que se pronuncia mas su color verde, están llenas de sucos abundantes que faltan casi en el centro, y gozan durante el primer año de mucha vida, que disminuye los años siguientes y no tarda en desaparecer del todo, y entónces es blanca generalmente y á veces morena, rojiza, amarillenta, etc. Está contenida en un arco leñoso que constituye el canal medular, que representa una estructura particular en la parte en contacto inmediato con la 
médula y sé compone de muchas tráqueas que se pueden desarrollar, mientras su parte esterior está formada de vasos anulares, rayados ó puntiagudos, cuyo diámetro es mucho mayor. La médula se amolda siempre sobre la forma del canal medular, ordinariamente mas ó menos anguloso y raras veces enteramente cilíndrico. Las plantas herbáceas cuyo desarrollo es muy rápido y la vida muy corta, son formadas solamente por la médula y el canal medular, que algunas veces toman un poco mas de consistencia.

II. El astil ó estipe es cilíndrico, nunca cónico, pero bastantes veces algo fusiforme, casi siempre sencillo y sin ramos, mas ó menos alto, derecho, coronado por las hojas y terminado por una yema que ocupa el centro de ellas, sean por ejemplo el cocotero, la palmera real, etc., G. 91, 95, 99, 101, 205; pertenece pues esa clase de tallo á los vejetales monocotiledóneos especialmente, y su estructura difiere mucho de la del tronco; en efecto, su parte mas dura está en la circunferencia, mientras la mas blanda ocupa el interior; no tienen capas concéntricas distintas y la médula, en lugar de ocupar el centro, forma toda la parte interior, pero atravesada verticalmente por un sinnúmero de fibras mas ó menos gruesas, $y$ anastomosadas entre sí, mas ó menos paralelas, dirijiéndose de la base hácia el vértice, de cựo centro sale todos los años una rema nueva que aumenta así la altura del estipe; en la parte esterior no se puede distinguir ninguna corteza lejítima, pero sí una zona mas ó menos. espesa, muy dura, compacta, morena, formada de haces fibrosos muy apretados, que corresponde á la madera de los troncos, cuya fuerza y resistencia posee. El estipe se observa tambien en ciertos vejetales acotiledóneos, los helechos arborescentes por ejemplo, G. 53; pero en ese caso su estructura es muy diferente de la del astil de las monocotiledóneas; en efecto, cortado transversalmente se le ve reforzado hácia la circunferencia por una zona leñosa compuesta de diferentes trozos mas ó meros distantes y algunas veces unidos, cuyo tamaño $\mathrm{y}$ forma irregular varian mucho, y compuestos de hacecillos leñosos cuyo color es ordinariamente moreno, y constituyen una especie de canal medular conteniendo mucho parénquima que representa la médula; al esterior de este anillo que resulta de la aproximacion de los hacecillos enteros ó de su reunion, presentan ordinariamente la forma de una cinta, que, plegada ó encorvada diversamente sobre sí misma, hace dibujos mas ó menos bizarros y elegantes; se halla una zona celular cubierta por la epidermis durante la primera edad del vejetal, y mas luego por una envoltura dura que proviene de la soldadura de la base de las hojas que se han caido á medida que se ha ido elevando el estipe.

III. La caña consiste en un tallo, por lo comun cilíndrico, pero tambien algunas veces triangular, mas veces herbáceo 'pue leñoso: con mayor frecuencia hueco ó acanutado: sin embargo lo hay á veces lleno, como en el maiz y en la caña de azúcar por ejemplo; casi siempre simple y raras veces ramoso, como en el bambú, provisto de nudos y tabiques, cuando hueco, dispuestos á trechos casi iguales; de esos nudos salen hojas sencillas cuya base, ó mejor cuyo peciolo se ha vuelto vaina; esta clase de tallo pertenece á las mono- 
cotiledóneas, y en especial á las gramíneas y á las ciperáceas, G. $172,324,326$.

IV. El rizoma ó cepa, se llama así á los tallos subterráneos, ordinariamente horizontales, otras veces oblícuos, de cuyo estremo y de su cara superior salen hojas $\mathrm{r}$ tallos aéreos ó bojordos, mientras que de su inferior salen raices son mas ó menos escamosos y con frecuencia marcados de anillos; son carnudos ó leñosos, cilíndricos, cónicos, radiciformes, etc., sean por ejemplo el genjibre, G. 339, 477; la yuquilla ó maranta, G. 480, 476, 341 .

V. El tallo lejítimo ó propiamente dicho pertenece á los vejetales dicotiledóneos; se habrán pues de agrupar en esa clase todos los tallos que no vienen á colocarse en las divisiones anteriores. Es mas ó menos largo, por lo regular delgado y con figura de varita, simple ó ramoso. Se llama herbáceo cuando blando y mas ó menos carnudo, no vive mas que un año; pertenece pues á las plantas herbáceas ó anuales, la verdolaga por ejemplo, G. 1127: la mostaza, G. 830. Se dice semi-leñoso ó sub-leñoso, cuando su base dura y vive algunos años, mientras sus ramas herbáceas se mueren $y$ se renuevan todos los aĩos: en ese caso se llama tambien sub-fiuticoso, subfrutescente ó fruticuloso, y el vejetal á que pertenecerá tomará el nombre de sub-frutice, mata pequé̃a ó matita; la salvia de Europa, G. 501: son raros en los paises cálidos. Lleva el nombre de leñoso cuando vive algunos años $\mathrm{y}$ se vuelve como madera, cuya dureza y estructura anatómica tiene; su tamaño $\mathrm{y}$ su altura varia mucho, pero no pasa de 8 á 10 piés lo mas y tiene 1 á 2 pulgadas de diámetro: su forma es muy variada, sea por ejemplo el cariaquillo, G. 550,510 .

Pueden ser los tallos anuales. bienales y perenales ó perennes, como ya hemos visto para las raices; se han impuesto á los vejetales perennes nombres especiales para diferenciarlos entre sí, atendiendo á la altura del tallo; en primer lugar vienen los árboles de que ya hemos tratado al hablar del tronco y del estipe, despues los arbolitos, que se diferencian de los árbolés solamente por ser mas bajitos y mas ramosos; los arbustos se ramifican desde la base y rara vez esceden de 5 á 8 piés de altura, los arbustitos son mas bajitos, pero enteramente semejantes, los frutices ó matas mas ramosos, saliendo algunos vástagos de la misma cepa y cuya altura no escede 3 á 4 piés; matitas ó sub-frutices son mas pequeñas todavía, y por fin las yerbas, cuyo tallo, cuando existe, tiene poca consistencia y nunca es leño. Atendiendo á la direccion, el tallo ha recibido los nombres de recto, de inclinado, oblícuo, lerantado, si despues de inclinado mas ó menos hácia el suelo recobra la posicion vertical; decumbente ó acostado, aplicado en la superficie del suelo, sin echar raices en él; tendido ó postrado, el que por débil está caido y solo tiene erguidos los estremos; rastrero, cuando hallándose tendido enraiza por sus nudos; cundidor ó estílonifero, cuando rastrero echa estolones ó hilos delgados prendiendo en la tierra á cierta distancia y produciendo en este lugar una nueva planta, sea por ejemplo el fresal, F. 132, - G. 744; reclinado ú doblado, el que al elevarse de la tierra forma recorvándose un arco desde la base hasta el vértice; 
decumbente ó tendido, al que sin formar arco alguno, despues de hat berse elevado un poco se recorva prolongándose; ascendente ó incorporado, cuando por la base toca la tierra, enderezándose despues de manera que el vértice mire al cielo; cabizbajo, cuando derecho su vértice se dobla hácia la tierra; flexuoso ú ondeado, cuando forma zigzag; arrodillado, sarmentoso ó pareciendo sarmiento; trepador, el que se encarama sobre algun cuerpo, mediante órganos asidores ó raices aéreas, sean por ejemplo la parra, G. 818; el bejuco de jabon ó de sopla, G. 847; la margravia umbelada, G. 683; voluble, cuando sube en los otros vejetales, en roscándose constantemente sea de la izquierda á la derecha, como el lúpulo, sea de la derecha á la izquierda, los albójoles, los frijoles, etc., G. 1077, 1070. Se da vulgarmente en América el nombre de bejucos á los vejetales leñosos, volubles ó trepadores que en los bosques primitivos de los paises intertropicales y tropicales se estienden asombrosamente y producen las mas veces un efecto maravilloso.

Segun su forma, los tallos han recibido los nombres de cilindricos, la mayor parte de ellos son así : comprimidos ó aplastados, sin formar ángulos salientes por los bordes; ancípites ó de dos filos; triangulares ó tricuetros, los carices, etc., G. 339, 341; cuadrangulares ó tetrágonos, las labiadas, F. 76 ; pentágonos, hexágonos y polígonos, segun tienen 5, 6 ó mayor número de ángulos; en el último caso se les llama solamente angulosos; acanalados, asurcados, cuya superficie está señalada lonjitudinalmente con surcos anchos y hondos, provistos ellos mismos de surquitos; estriados ó rayados, cuando la superficie presenta surcos poco profundos y numerosos; punta$d o s$, cuando hay puntos esparcidos por su superficie; escabrosos ó ásperos, muchas plantas de la familia de las borrajíneas, F. 66; agrietados, nudosos, articulados, muchas plantas de la familia de las cariofíleas, F. 148; membreados ó con forma de varita. Atendiendo á la vestidura de los tallos se les ha llamado lisos cuando su superficie está sin asperidades; lampiños ó sin pelo alguno; alisados, cuando están desprovistos de asperidades y de pelo; pulverulentos, verdemar, manchados, pubescentes, cuando están cubiertos de pelo suave, corto, distinto y denso; sedosos ó seder̃os, con pelo suave, largo, lustroso, aplicado al tallo y no entremezclado; pelosos ó peludos con pelo blando, largo, aproximado, no aplicado y distinto; afelpados, tomentosos ó bozosos, cuyo pelo largo y blando está entremezclado á manera de fieltro; lanudos ó lanosos, cuando el pelo es largo y rizado en abundancia y no suave; hirsutos ó peludos, hirtos ó pelierizados, hispidos ó pelitiesos, cuyo pelo mas ó menos abundante, poco largo, duro y recto es mas ó menos apretado, las borrajíneas, F. 66; picantes, quemantes ó pruriosos, cuando la picadura de los pelos que les cubren causa quemazon ó escozor, las ortigas, G. 249; el guaritoto, G. 134; aguijonosos, pinchudos ó erizados, cuando están provistos de aguijones, sea por ejemplo los rosales, G. 1151 ; la zarzaparrilla, G. 236, etc.; desnudos, es decir, sin hojas, escamas, ni zarcillos tampoco, como la cuscuta, G. 585; afileos ó sin hojas; escamosos ó provistos de escamas, como se observa diariamente en muchas plantas parásitas; envainados, cuando están 
cubiertos por las vainas de las hojas, las gramíneas y ciperáceas, F. 10, 11; empizarrados é imbricados, escondidos por hojas dispuestas á manera de las tejas de los techos de las casas; alados, glandulosos, aterciopelados, etc.

Se llama simple al tallo cuando no tiene ramos; al contrario, se llama ramoso cuando se va dividiendo en ramas mas ó menos numerosas, las cuales son simples ó se van subdividieıdo á su vez en ramitas: los tallos ramosos han recibido algunas denominaciones que indican su disposicion; en efecto, se llaman fastijiados ó arramilletados, cuando están formados de ramos que todos llegan á la misma altura; bifurcados ó ahorquillados, cuando tienen solamente dos ramos; dicitomos, en ese caso los ramos se van bifurcando sucesivamente, la siciliana, G. 397; tricútomos, cuando se dividen por á tres y siguen así sucesivamente los ramos, sea por ejemplo la adelfa, G. 656; proliferos, cuando echan ramos solamente por el vértice.

La disposicion de los ramos sobre el tallo varia bastante y ha recihido nombres á propósito para espresarla. Son alternos, cuando saliendo de varios puntos del tallo tienen entre sí una distancia casi igual, las hojas siguen siempre la misma disposicion : muchísimos vejetales los tienen así; opuestos, salen de dos puntos opuestos: en las labiadas son así, F. 76 ; verticilados, cuando salen de tres ó mas puntos formando anillo en derredor del tallo: muchísimas rubiáceas están en ese caso, G. 732; dísticos, si están situados de dos lados opuestos en una direccior lateral; diverjentes, se llama así á los que se apartan del tallo, formando un ángulu muy abierto y con frecuencia derecho; esparcidos, los que salen de muchos puntos del tallo sin órden alguno: muchísimos árboles les tieren así; amontonados, cuando están aproximados por la base, como el naranjo, G. 977 ; recojidos, acercúndose del vértice y afectando la forma piramidal: el sauce blanco, G. 213; cabizbajos, incinados, acorimbados, cuando llegan todos casi á igual altura; pendoleros, péndulos ó colgantes, los que están doblados hácia la tierra: el sauce lloron, G. 213; patentes, estendidos ó abiertos, apartados los unos de los otros y mas ó menos horizontales; divaricados ó desparramados, cuando se estienden repentinamente sin direccion fija; horizontales, los hay doblados por adentro y otros hácia afuera del vejetal á que pertenecen. Los ramos inferiores están siempre mas apartados del tallo que los superiores y forman con él un ángulo mas abierto, y acaban por destruirse, porque los superiores les quitan la luz $\mathrm{y}$ el aire que necesitan para vivir.

Yemas, bulbos y tuberculos.-I. Yema, se llama así al boton escamoso que termina los vejetales y que encierra el rudimento de los órganos que han de desarrollarse para hacer el vejetal, sea mas alto, sea mas ramoso, etc., llevan tambien losnombres de boton y de ojo; sellaman ter'minales cuando salen de las axilas de las hojas, fuera de las mismas axilas y hasta sobre las hojas, pueden salir, en especial siendocrasas, como en las de la yerba bruja, G. 677 ; pueden, mediante circunstancias favorables, desarrollarse yemas llamadas adventivas ó fortuitas. Las yemas normales ó salierdo de un modo regular y de antemano pre- 
visto, faltan en las raices; pero no es así en las adventivas, por que $\delta$ veces aparecen en ellas. La yema encargada de una germinacion de hojas que han de suceder á la axila, de la cual se ha producido, so-brevive naturalmente á ella, y cuando se marchita ó se desprende, se queda en el tallo en un estado estacionario hasta que llegue la estacion en que ha de desarrollarse. En los paises cálidos en que estamos escribiendo estos renglones, pocos vejetales esperimentan ese intervalo de descanso, y en ellos está siempre sin peligro para la yema, que por causa de la temperatura no está provista de las envolturas que tiene en los paises templados y hasta frios, de manera que sus primeras hojas son casi tan completas é iguales á las que han de salir en seguida: en ese caso se llaman foticiceas; serán escamosas cuando estarán provistas de escamas mas ó menos grandes, mas ó menos numerosas é imbricadas, al cunas veces como barnizadas esteriormente por una sustancia resinosa, otras veces forrada interiormente por una borra mas ó menos abundante; en los árboles tropicales las yemas están generalmente desnudas; las hojas esteriores que les forman presentan muy pocas modificaciones. Los tegumentos ó las escamas de las yemas pueden ser peciolíceas, estipulciceas, fulcríceas ó folicíceas, denominaciones que se aplican á las yemas que visten: serán pues formadas por la parte inferior de los peciolos, ó por las estípulas, otras veces por las estípulas y el peciolo juntos, y en fin por el limbo solo de la hoja, mas ó menos metamorfoseado. Segun su forma se llaman globosas, aovadas, oblongas, etc. Se distinguen en folíferas, floriferas y mistas, segun contengan hojas, flores ó ambas cosas á la par, lo cual se conoce de antemano por la forma mas prolongada que tienen las primeras.

La prefoliacion ó rernacion, que es la disposicion del limbo de las hojas en el interior de las yemas, es susceptible de muchas modificaciones, y de tal manera estín dispuestas las hojas, que ocupan muy poco lugar. Decandolle agrupa todas estas modificaciones en las tres divisiones siguientes: $1^{\circ}$ plegadlas: pueden estarlo de varios modos y se llaman entónces reclinadas, la parte superior hallándose doblada sohre la inferior, acercándose así el vértice de la base; conduplicada, cuando la mitad derecha está aplicada á la izquierda, las estremidades y la nervadura no esperimentando nada; replegadas: están en ese caso dobladas al contrario, de manera que la parte superior se aplica á la inferior; plegadas algunas veces ordinariamente á lo largo de las nervaduras y á manera de abanico; $2^{\circ}$ ar'rolladas, presentan tambien algunas modificaciones que se espresan con vocablos á propósito; se llaman pues convolutas, cuando arrolladas sobre sí mismas á manera de cartucho, su eje se queda recto; superrolutivas ó sobre-arrolladas, las que conservando derecha la costilla, tienen arrollada una de las mitades hácia dentro y sobre esta la otra en sentido contrario, como en el plátano, G. 448; revueltas, cuando tienen los bordes arrollados hácia fuera sin que la costilla cambie de direccion: el romero, G. 500 ; envueltas, las que lo están lijeramente; circinadas, cuando están arrolladas sobre su eje de arriba abajo á manera de báculo de obispo, como los helechos, F. 5. Tales modificaciones pueden combinarse ó complicarse la una 
con la otra, como por ejemplo, cuando un limbo plegado está reclinado sobre el peciolo, etc. Considerando ahora las hojitas en la misma yema, las unas respecto de las otras, se las ve dispuestas de varios modos, lo que ha necesitado que se les aplique epítetos á propósito para designar tales disposiciones; se dicen pues ralvadas, las que permaneciendo planas ó estando poco corvadas, se tocan por sus bordes, lo que es la vernacion valvada; empizar'radus ó recargadas. siendo igualmente poco corvadas, pero cubriéndose parcialmente unas á otras, y por los bordes en muchos casos, lo cual constituye la vernacion espiral, que corresponde á igual disposicion en las hojas; $V$. induplicada, cuando las hojas, estando dobladas lonjitudinalmente sobre sí mismas, se tocan por sus caras mas próximas, y tambien doblándose menos, lo hacen por sus bordes únicamente. Se llaman equitantes, las hojas cuando conduplicadas se conjen unas á otras, resultando la central ó primera dentro de la segunda, y esta dentro de la tercera, etc.; obcolutas, semi-equitantes ó semiabrazadas, siendo hojuelas igualmente conduplicadas que se cojen á medias, quedando la mitad de cada una dentro del pliegue de la otra. Como estas diversas maneras de disponerse las hojas dentro de las yemas pueden presentarse tambien en todas las demas partes planas de los vejetales, como por ejemplo en las flores contenidas todavía en el boton, se deben conocer bien esos términos, porque se aplican á todos los casos en que tales disposiciones se observan. Las yemas de muchas raices perennes, ó quizás mejor las de cepas y rizomas se llaman turiones, tales son por ejemplo los del espárrago, G. 246, del bambú, G. 324, etc.

II. El bulbo ó cebolla no es otra cosa sino una yema, pero separada del rejetal, la cual, puesta en circunstancias adecuadas ó sembrada, puede vivir de su propia vida y desarrollarse para producir un vejetal perfecto. Se compone de tres partes distintas, cuya superior está formada de escamas mas ó menos distintas y mas ó menos suculentas, destinadas á suministrar á la parte mediana, en la cual está dormido el ser que está pronto para despertarse y vivir, el alimento que necesita en ese primer período; esa parte se llama escudo ó corona, y tambien disco ó platillo; del bulbo y de su parte inferior salen las raices siempre fibrosas.

Las varias formas de los bulbos los han hecho denominar globosos ó casi globosos, aorados, prolongados, apeonzados, campaniformes, etc., adjetivos cuyo significado, siendo de todos conocido, no necesita esplicacion alguna. Se diferencian además entre sí segun su estructura, y entónces se llaman tunicados, cuando las escamas grandes y numerosas se envuelven enteramente: la cebolla comun, F. 16; escamosos ó empizarrados, las escamas en ese caso son pequeñas, numerosas é imbricadas, sea verbigracia el del jacinto y de muchas otras liliáceas, F. 16 ; sólidos ó macizos, las capas que les forman parecen intimamente adheridas: la cipura de Martica, G. 467 ; atendiendo al número, se distinguen los bulbos en solitarios, hermanados, agregados y duplicados. De la axila de las escamas mas ó menos desarrolladas, salen del disco yemas ó búlbulos, que desentolvientose so ruelven bulbos lejítimos y se separar de la ma- 
dre, que se ha marchitado. En los bulbos sólidos, las yemas ó bulbillos salen lateralmente. Los bulbos se llaman simples, múltiples ó compuestos, en ese último caso están formados de algunas cebollitas ó dientes, como verbigracia en el ajo comun, G. 414. Los búlbulos no se diferencian de los bulbos lejítimos sino por su tamaño mucho menor y porque pueden salir de todas las partes del vejetal y considerarse como la transicion entre la yema y el embrion. de que hablaremós mas luego. Los bulbos ó cebollas pertenecen siempre á las plantas monocotiledóneas.

III. Se ha dado el nombre de tubérculos á unos bultos mas ó menos gruesos y carnosos ó feculentos, de aspecto, forma, color y tamaño muy variados, que se presentan en la raiz de ciertas plantas, y merecen esa denominacion solamente cuando están provistos de yemas, como las papas, G. 622; los que no presentan ojos, como las batatas, G. 582, no serán tubérculos lejítimos, pero sí raices tuberculosas. Algunas veces los tubérculos lejítimos salen de la axila de las hojas, como sucede para con algunas dioscóreas: la gunda, G. 243 .

ORGAYOS ACCESORIOS Ó trANSFORMA DOS.-I. Zarcillos: se llama así á unos órganos generalmente filiformes, herbáceos ó leñosos, simples ó ramosos, mas ó menos largos, flexibles y susceptibles de arrollarse en derredor de los cuerpos que se encuentran, proviniendo de la transformacion de otrosórganos, y sirviendo á los vejetales provistos de ellos para sostener sus débiles tallos y trepar por ese medio por encima de los árboles mas altos. Unas veces la estremidad de sus ramos sola está así modificala y el zarcillo es terminal; otras veces es el ramo entero y el zarcillo ocupa su lugar, como sucede en las pasífloras, G. 1085; ya los pedúnculos se vuelven zarcillos, ya es la costilla de las hojas, como en los guisantes, F. 130, S.-F. 1; en la parra y en los cisos, G. 815,818 , los zarcillos están opuestos á lás hojas; en las cucurbitáceas, F. 141, salen del lado del peciolo; en algunas leguminosas nacen del ápice del peciolo ó del raquis; en la zarzaparrilla, F. 17 , están los dos zarcillos situados uno á cada lado de la insercion del peciolo; en las pasífloras, G. 1085, salen de la axila de las hojas. Fn ciertas plantas son mas cortos y se clavan á manera de garra en la corteza de los demas vejetales y se llaman entónces asideros, G. 683: el bejuco de palma.

II Espinas: se ha dado ese nombre á puntas fuertes y muy punzantes que adhieren con la madera y provienen de la transformacion ya de los ramos, ya de las nervaduras de las hojas, ya de las stípulas endurecidas, etc. Son solitarias, apareadas, ó dispuestas por a tres ó á cuatro, etc., simples ó ramosas, iguales ó desiguales, etc.

III. Aguijones : no son otra cosa sino la continuacion de la parte corchosa de la epidermis, no teniendo pues adherencia alguna con la madera, se despegan con facilidad, no ocupan en los vejetales un lugar fijo, están apartados ó agrupados sin órden alguno, y se presentan, no solo sobre los tallos y sus ramificaciones, sino tambien sobre las hojas y los cálices, pero sin embargo, en especial en los peciolos y en las nervaduras : el solano mamoso y otros, G. 622; su 
forma general es la de un cono, algunas reces rectos, pero frecuentemente á manera de gancho y de ordinario comprimidos, sean verbigracia los rosales, G. 1151; son simples ó ramosos, solitarios ó agrupados y dispuestos en pincel, como en los cardones á cirios, F. 146 .

IV. Pelos: provienen de la epidermis y pueden hallarse en todos los órganos, sin escluir las raices jóvenes, y tambien en las cavidades interiores de algunas plantas; pero mas comunmente cubren los tallos, ramas y hojas, notándose que aun cuando falten en la cara superior de estas, se hallan muchas reces en la inferior, particularmente sobre las nervaduras o los nervios. Las plantas que crecen en parajes secos, ventilados y espuestos al sol están mas provistas de ellos. Se llaman pelos lejítimos á los que son ásperos, tiesos, simples y aislados: las borrajíneas, F. 66 ; cerda, los que, muy distintos, son suares y blandos; tomento, cuando las cerdas son numerosas y muy cortas; lanosidad : en ese caso las cerdas son largas, muy entrelazadas y parecen algodon; lana, cuando las cerdas, muy espesas y numerosas, son largas. Los pelos son simples ó ramosos, huecos óllenos, cilíndricos, alesnados, ganchosos ó en forma de anzuelo; bulbosos ó con la base abultada y á veces glandulosa; cabezudos ó terminados por una cabezuela; mazudos ó con la estremidad libre y á manera de maza; cupulados ó con una cabecita en el ápice. Los pelos ramosos se llaman policéfalos, si tienen algunas cabezuelas; malpiguiciceos ó anavetados, los que presentan dos ramas horizontales colocadas sobre una base glandulosa y cuyo conjunto parece una naveta pegada por su parte inferior y mediana, G. 948; ahorquillados ó bifurcados, cuando parecen una $Y$; trifurcados, los que tienen tres ramas saliendo de un punto; dićtomos, cuando se ahorquillan mas de una vez; dentados, amanojados, si saliendo de las ramas inferiormente se elevan en forma de manojillo; verticilados, cuando tienen antes de su punta las ramas dispuestas en uno ó mas círculos; apincelados, ramificándose cerca de la punta $\mathrm{y}$ asemejándose á un pincel; agarabatados, si se terminan por dos ó mas ganchitos: estrellados ó radiados, cuando están dispuestos á manera de estrella sobre la superficie de la planta; algunas veces los radios de tales pelos se soldan entre sí y la epidermis parece cubierta de escamitas, sostenidas por el centro á manera de escuditos, y se llaman.en ese caso escamosos ó escudados; moniliformes ó con figura de rosario. Se llaman pestañas, cuando algo tiesos y apartados los unos de.los otros, los pelos están situados sobre los bordes de los órganos. La direccior de los pelos, aunque muy comunmente perpendicular, puede ser oblícua inclinándose hácia arriba ó hácia abajo: en ese caso se llaman retrorsos y adpresos ó arrimados; cuando están paralelos á la superficie, presentan igualmente mucha variedad en su color y consistencia, $y$ aunque por lo comun sean lisas sus paredes, tienén á veces porcion de granillos que les dá un aspecto particular. La existencia y las funciones de los pelos parecen en relacion con las partes jovenes y con el aflujo de los líquidos y la actividad de la evaporacion, que es la consecuencia de él y la cual probablemente están destinados á moderar, 
raras veces se hallan en la corteza de las ramas adultas de los vejetales leñosos.

V. Gléndulas: se llaman así en los vejetales, po" analojía con esos organos de los animales, á unos aparatos contcniendo un líquido de naturaleza particular y distinto de los demas de la planta y siempre elaborado á espensas de los que abundan en ella. Pelos glaiduliferos: conservan í veces sin modificacion alguna una de las formas que acabamos de estudiar y difieren de los demas pelos solamente porque sus últimas células contienen un líquido, pero las mas reces están abultadas por el ápice. La transicion de los pelos glandulíferos á las glándulas pediceladas especialmente es casi insensible. De las dos modificaciones notables que pueden presentar las glándulas lejítimas, la una consiste en ahuecarse y presentar paredes formadas de varias células, $y$ la otra en permanecer macizas, sin cavidad central, tengan ó no la base adelgazada de modo que parezcan sostenidas por un piececillo en el primer caso $y$ sentadas en el segundo. A veces están húndidas en la corteza, pero se quedan casi superficiales é inmediatamente debajo de la epidermis, en cuya superficie sobresalen todavía algunas veces. Entre las interiores se han de notar las vesiculares, que contienen en paredes trasparentes un aceite esencial, sin color. y que seven con mayor facilidad en las hojas de muchos vejetales, mirándolas interpuestas á la luz: las del naranjo, 977, de muchas mirtáceas, 133, y aparecen entónces mas ó menos numerosas. Otras glándulas hay que se llaman rasculares, consistiendo en espansiones del tejido celular epidérmico destinadas á escretar algun líquido segregado : tienen vasos que comunican con el interior de las plantas, y varian por su forma y tamaño, pudiendo ser tambien pediceladas y sentadas : se observan en los peciolos de algunas pasífloras, G. 1085; de bastantes euforbiáceas : el ricino, G. 144; el manzanillo, G. 123; en los ráquices de muchas leguminosas, F. 130, S.-F. 3; de la tribu de las mimóseas, la guama, G. 1047. Entre las glándulas verdaderas y las vasculares, hay algunas que con dificultad pueden reducirse á cualquiera de esas clases, y otras forman el tránsito de las verdaderas ó superficiales á las vasculares. Por simples modificaciones de las superficiales se tienen las verrugas, los pezoncillos ó glándulas papilares, los pezones ó glíndulas utriculares.

VI. Lentejillas, llamadas otras veces glándulas lenticulares, se hallan únicamente en las ramas de muchos árboles y arbustos dicotiledóneos, y consisten en manchitas prolongadas algo proeminentes, mas ó menos abundantes, un poco de atencion basta para reconocerlas. Al engrosarse las ramas se ensanchan las lentejillas, se convierten en estrías transversales, y la corteza de los troncos comienza : resquebrajarse por ellas cuando produce corcho. 


\title{
CAPÍTULO III.
}

\author{
DE LAS HOJAS.
}

\section{\$ I. - CONSIDERACIONES GENERALES.}

Se ha dado tal nombre á unas espansiones membranosas, ordinariamente planas y verdes, mas 6 menos grandes, de tamaño, forma y figura muy variados, mas ó menos horizontales y de poca duracion; se las puede muy bien considerar como las raices aéreas o tenerlas por los pulmones de los vejetales cuya superficie multiplican de un modo asombroso. En efecto son á la vez los órganos de la respiracion, de la absorcion ó nutricion y tambien de la exhalacion vejetal. Se las puede definir unos órganos membranosos formados por la espansion mayor ö menor de un hacecillo de fibras vejetales saliendo de cualquier punto de la superficie de una planta, y cuyas divisiones, mas ó menos numerosas anastomosando entre sí, forman una redecilla llena de un tejido celular particular verde llamado parenquima. Cuando el hacecillo se prolonga antes de separarse sus fibras constituye una parte mas estrecha que se llama peciolo mientras que se da el nombre de limbo á la parte formada por sus fibras separadas, mas ó menos grande y sostenido por el peciolo de cuyo vértice sale; las hojas así formadas se dicen pecioladas, la mayor parte de los vejeta!es las tienen así; cuando las fibras del hacecillo peciolar se separan las unas de las otras al salir de la planta la hoja que forman estando inmediatamente aplicada al vejetal se llama sentada ó sesil.

El peciolo es simple ó ramificado, en cuyo caso se llama peciolo comun ó raquis y se da á sus divisiones y sub-divisiones los nombres de peciolos parciales ó secundarios y de peciolulos. El peciolo, sea simple sea compuesto, ha recibido los nombres de cilíndrico, comprimido, triangular, cuadrangular, acanalado, unido, espinoso, aguijonoso, pubescente, velludo, aterciopelado, afelpado, lampiño, escabroso, liso, recto, enderezado, horizontal, inclinado, desnudo, alado, tieso ó blando, delgado o filifurme, espeso ó carnudo, etc., segun corresponda por su forma, su vestidura, su posicion, su tamaño $\dot{o}$ su consistencia a la idea espresada por el sentido literal de los adjetivos calificativos empleados, y harto conocidos de todos para necesitar esplicacion. En el limbo o parte constitutiva de la hoja se distinguen dos caras, una base, un vértice ó apice y una circunferencia o márjen. De las dos caras una mira siempre al cielo ó está vuelta hácia el sol ó la luz y se llama superior, cuyo color es siempre verde mas o menos oscuro, las mas veces es lisa, como barnizada. mas rara vez pubescente, con pocas estomas, de epidermis mas adherønte, sirve especialmente á la exhalacion y á la transpiracion; en efecto, está con bastante frecuencia cubierta de una sustancia como viscosa. La otra, que mira al suelo. se llama inferior, la epidermis 
que la cubre es menos adherente, provista de mayor número de estomas, nunca lustrosa, siempre de un color verde mucho mas pálirlo, frecuentemente pube:cente, peluda o escamosa y sirve especialmente para la absoıcion. Se llama base la parte por donde la hoja está pegada al rejetal sea mediata ó inmediatamente, y ápice la parte diametralmente opuesta; en fin se da el nombre de circunferencia á la línea ficticia que delimita la figura ó la configuracion de la hoja cuyos lados se llaman bordes o márjen.

Entre la epidermis que cubre las dos caras del limbo de la hoja se halla un espesor mayor ó menor formado por el esqueleto fibrovascular y el parénquima, en que se observan vasos y tejido celular como en las demas partes del vejetal, pero modificado $y$ apropiado á ese órgano; los vasos son tráqueas que se pueden desenvolver, vasos anulares, rayados ó punteados, con fibras leñosas, y por afuera están los vasos propios $y$ las fibras corticales. El parénquima de las hojas en que se verifica la respiracion vejetal y por consiguiente la descomposicion química ó el análisis orgánico, si podemos espresar así nuestro parecer, del ácido carbónico está compuesto de dos rejiones ó capas, de las cuales una es superior y la otra inferior. En ambas las celdillas están en el estado normal y llenas de granulos colorados en verde por el clorúfilo, pero no tienen ni la misma forma ni la misma disposicion en la una y en la otra.

La organizacion de las hojas sumerjidas y que por consiguiente viven debajo del agua es muy diferente de la de las aéreas; en efecto, les falta la epidermis y por consiguiente los estomas; están tambien desprovistas del esqueleto fibro-vascular reemplazado solamente por algunas celulas prolongadas : son pues únicamente compuestas de parénquima.

Al separarse los hacecillos de filoras forman las nerraduras o nervios mucho mas pronunciados por la cara inferior de las hojas que por la superior, en donde son raras veces notables, $y$ su disposicion se dice nervacion; ordinariamente uno mayor y mas pronunciado sigue la direccion del peciolo cuya continuacion parece, $y$ llega hasta el ápice de la hoja despues de haber dividido su limbo en dos mitades iguales por lo ordinario, se llama costilla; de sus lados salen otros ordinariamente simétricamente dispuestos, los cuales se llaman nervios secundarios ó solo nervaduras, las cuales, continuando dividiéndose, dan lugar á divisiones terciarias que se dicen venas, $\mathrm{y}$ las divisionds de estas se llaman venillas y sc anastamosan las unas con las otras.

En las hojas de las plantas monocotiledóneas casi siempre las nervaduras salen junto á la base y caminan á lo largo rectas por lo comun y aproximalas sin ramificarse sensiblemente, mientras que en las de las dicotiledóneas nacen unas nervaduras de otras, aun cuando algunas salgan juntas de la base, se van dividiendo y acaban por anastomosarse entre sí. Pero esa diferencia no es tan marcada en todos los casos. porque hay plantas monocotiledóneas cuyas hojas son enerves o sin nerraduras, mientras que en otras participan de la disposicion que tienen en las dicotiledóneas: el plátano, G. 448 , cuyas hojas son provistas de una costilla muy pronunciada, de 
la cual sale lateralmente una multitud de nervaduras horizontales; en los yaros, G. 156, 160; en los esmilaces, F. 17, las nervaduras se ramifican y las venas se anastomosan.

Atendiendo a la nervacion, las hojas han recibido nombres particulares para espresarla; se dicen pues peninerrias cuando de la costilla salen nervaduras transversales dispuestas á manera de las barbas de una pluma, las del plátano, G. 448; retineroicus, si tienen rectas y casi paralelas todas las nervaduras lonjitudinales procedentes de la base: se dicen tambien en ese caso basinervias: así están las de las gramíneas, F. 10 ; de las ciperáceas, F. 11 ; liliáceas, F. 16 ; curvinervius, cuando las nervaduras lonjitucinales se encorvan, como se observa en las del canelo, G. 352, y en casi todas las de los vejetales de la familia de las nielastomáceas, P. 136; segun el número de nervaduras se dicen tri, quinque, septem ó noiem nervias; digitinervias sellaman cuando en lugar de converjer las nervaduras diverjen, afectando la disposicion de los dedos de la mano abierta; pellinervias cuando salen todas del ápice del peciolo é irradiando hacen tomar á la hoja la forma de un escudo: las de la capuchina, G. 843, y las de la yerba de cuarto, G. 1177 ; palminervias, en ese caso están dispuestas á manera de abanico: muchas palmeras, G. 204 bis; la vid, G. 818; se dicen pedatinervias siempre que la costilla se queda sumamente corta. Todas las nervaciones no se pueden sin embargo referir con exactitud á estos tipos: hay hojas curvinervias cuyas nervaduras lonjitudinales no nacen precisamente de la base, sino de mas arrika, procediendo de la costilla, y entónces se dicen triplinerrias, quintuplinervias, septuplinervius, etc., segun el número de ellas.

La forma de las hojas depende de la disposicion de las nervaduras, aí como de ser simples ó compuestas; se llaman simples á las for madas de una pieza única mas ó menos grande, entera o mas ó inenos prolundamente dividida, pero cuya division alguna, por profunda que sea, no se puede quitar sin lastimar mas ó menos á sus vecinas, tales son las de todas las plantas monocotiledóneas y de muchísimos vejetales perteneciendo á las dicotiledóneas, las familias 14, 20, 51, ete.; la figura del limbo ó de la hoja simple varia tanto que puede decirse no existen dos especies de plantas que la tengan exactamente igual, y hasta especies hay cuyos individuos están lejos de ofrecer uniformidad entre sus hojas : el carlillo de jaquiman ó triunfeta heterofilla, G. 867 .

Las hojas compuestas, al contrario, resultan de un número mayor o menor de piezas distintas en uno o en algunos peciolos comunes y se puede quitar una de ellas sin lastimar de modo alguno las demas; e: as piezas se llaman hojuelas $y$ se las ha de aplicar todo lo que estamos para decir de las hojas sencillas; las plantas de la familia de las leguminosas son compuestas, muchas terebintáceas, etc., están tambien en ese caso, F. 130, 125, 126, etc.; para la formacion de tales hojas el hacecillo fibro-vascular secundario al separarse de la costilla se comporta, relativamente á la costilla, del mismo modo que el peciolo lo hizo con el tallo ó la rama de donde ha salido, y si la espansion del hacecillo no se hace sino á alguna distancia, entón- 
ces la nervadura toma el aspecto de una ramita adornada de hojitas, y ya habrá nacido la hoja compuesta.

0

\section{\$I II. - HOJAS SIMPLES Ó SENCILLAS.}

Consideradas segun su posicion 0 insercion en las varias partes de los rejetales las hojas se llaman: radicales cuando salen del cuello de la raiz, sea las de la yautia, G. 160, 159 ; caulinares si nacen del tallo, las del rábano cimarron, G. 156; del maiz, G. 172; ramales, las que salen de las ramas y ramitas. como se observa diariamente para la mayor parte de los vejetales dicotiledóneos; en fin florales, si, acompañando a las flores, han sin embargo conservado su configuracion y carńcter es especiales, sea la albejaca, G. 516. Atendiendo á la edad del vejetal que las lleva se les ha dado los nombres como sigue: seminales, cuando salen de la tierra en el acto le la germinäcion; en ese caso son formadas por los cotiledone's; primordiu'es las que se presentan inmediatamente despues de las seminales y que tienen, sin embargo, la estructura anatómica comun á las demas, de las cuales se diferencian por su figura siempre diferente; caracteristicus, se llaman así á las de los vejetales adultos y que sirven para diferenciarles, las cuales lian recibido por consiguiente nombres adecuados para espresar su forma, su disjnsicion, su vestidura, etc., á fin de hacel les entrar con mayor facilidal en las descripciones botánicas. En atencion á su disposicion relativa en los vejetales que las llevan se las ha dado los nombres de opuestas cuando salen de dos puntos diametralmente opuestos del tallo ó de las rainitas : todas las labiadas, F. 76; el café, G. 738; verliciladas o estrelladas las que opuestas están en número mayor que dos y forman así un anillo en derredor del tallo o de la ramita: muchas plantas de la familia de las rubiáceas están en ese caso, como el bálsamo real, 732 ; borrerias, spermacoces, G. 704, 705, etc., serán verticiladas por á tres, por á cuatro, por á cinco, etc., y entonces se. dirín ternas, cuaternas, quinas, senas, octonas, etc : cruzadas, así se llaman las opuestas cuyos pares unos á otros se cortan en ángulos rectos, como se ve en algunos euforhios, G. $1: 2$; alternas, cuando salen de puntos que no se corresponden siendo á alturas diferentes, como en muchísinos vejetales, como verbigracia las cruciferas, las coles, G. 828 ; mostaza, G. 829; las anonáceas, el guanálıano, G. 900; las borrajiuáceas, F. 66: disticas son las alternas que forman dos carreras opuestas; esparcillas ó dispersas, las alternas que á primera vista no parecen serlo por hallarse próximas ó por haber aborta lo alguna; amontonadas cuando siendo muy numerosas casi cubren los ramos y parecen desordenadas; fasciculadas ó en hacecillos las que los forman en apariencia por estar muy proximas ó por pertenecer á ramitas muy corras procedentes de la axila de una de las hojas que entra en el hacecillo, como en los pinos; coronantes las que, estando nuny próximas en las estremidales de los ramos. forman 111 manojillo: arrosetadas las alternas numerosas y aproximadas formandc una roseta, como el maguey, G. 460, el aloes, (†. 413; 
geminadas ó mellizas: en ese caso dos salen del mismo punto, de las cuales la una es casi siempre mayor que la otra: el sacabuche, G. 618 ; trabadas ó reunidas son las opuestas que están unirlas por las bases: muchas rubiáceas están en ese caso, F. 62 ; perfoliudas, traspasadas, cuando una hoja única está atravesada por el tallo; escurridas ó decurventes cuando, sentadas, su base parece prolongarse en el tallo con forma de alas, G. 1045 .

Segun su posicion sobre el eje de que proceden se les llama horizontales, lo que es el caso mas comun, erguidas, derech:s, veriicales; arrimadas cuando lo están al tallo ó ramo; pegadas ó apoyadas estando sentadas y unidas al tallo ó ramo por la cara superior de la base; empizarradas ó imbricadas cuando hallándose muy proximas se cubren unas á otras á manera de las tejas; entónces pueden preesentarse imbricadas de todos lados ó ser biseriudus, triseriadas, cuadriseriadas, etc.; abiertas si estando separadas del tailo no llegan á formar con él un ángulo recto; oblicuas, cuando tal es su direccion; enderazadas cuando han principiado por ser inclinadas ú horizontales; encorradas formando un arco cuya estremidad libre mira hácia arıba; reflejas cuando se encorvan hácia ahajo; dobladas las que se doblan hácia abajo; inflexas estando doblarlas hácia arlentro; colgantes cuando estín como colgadas á causa de la debilidad del peciolo; envueltas las que se arrollan hácia dentro; recueltas arrollíndose hácia fuera; arolludas si lo están y forman un hilo; intersas cuando pre:entan hácia arriba el envés; humifusas ó tendidas en la tierra; nadadoras; sumevijidas ó que no salen del agua. Atendiendo á su figura han recibido los nombres como sigue: lineares. cuyos bordes casi paralelos distan muy poco; acintadlas o gramineas las que teniendo sus bordes casi paralelos son mas anchas $y$ largas que las lineares. G. 321 ; alesnadcus las que siendo lineares se terminan insensiblemente en punta; cabelludas ó capilares y filiformes las que son delgarlas y largas: el espárrago, G.246; aciculares o cerdosas las lineares, persistentes y piuchudas: los pinos, G. Ir 5 ; ensiformes o en forma de estoque. teniendo sus bordes paralelos al tallo, estando acanalada por la base con las dos mitades aproximadas mas alriba y por fin unidas por la superficie superior: la cipura de Martinica, G. 467; falciformes las que se asemejan á una hoz; espatuladas las que :e parecen á una espitula; oblongas ó prolongadas las que, pre:entanrlo la forma de olipse prolongarla, son tres veces mas largas que anchas : parab'licas las que son oblongas, redondeadas por arriba y truncadas por la base; elipticus ú ocales; trasoradus o aovadas al revés, es decir, con la base estrechada; lanceoladas ó alanceadas las que van estrechándose insensiblemente hácia ambos estremos: la adelfa, G. 656; redondas y circulares, las de esta forma con corta diferencia; aredondeadas las que son casi redondas; cuneiformes las que parecen una cuña; deltrídeas cuando se parecen á la letra griega llamada delta; triangulares, cuudrangulares, rombeas ó romboidales teniendo estas formas geométricas; trapeciformes las cuadrangulares que se alroximan mas bien á la figura de un trapecio: angulosas cuando tienen ángulos en número indeterminado. Respecto á la punta se calitican las hojas de agudas, 
puntiagudas, ganchosas, rnmas ú obtusas, truncadas, mordidas, escotadas, remelladas ó sea obtusn-escotadas, trascorazrnadas ó sea acorazonadas al revés, bifidas, bilobadas, bipartidas, términos todos de fícil intelijencia y que no necesitan por consiguiente esplicacion alguna. En atencion á la base toman las hojas los nombres de acorazonadas o cordiformes cuando siendo escotadas yor la base. presentan dos porciones salientes y obtusas, terminando sujeriormente en punta mas ó menos aguda; ariüonadas cuando son mas acorazoradas por la base y arredondeadas por la punta: el bejuco de guaba, G. 744; semitunadas ó en media luna; aflechadas las que estando terminadas en punta aguda tienen en la base dos tiras. agudas tambien, largas, casi paralelas al peciolo ó poco diverjentes: la espadaña, G. 174; alabardadas cuando son triangulares con dos porciones salientes en la hase casi perpendiculares al peciolo: la yautia, G. 160; la base puede, como la punta, ser aguda, puntiaguda, obtusa, etc.; abroquelarlas cuando el peciolo sale poco mas ó menos del centro del limbo: la capuchina. G. 843; inequilaterales st llaman cuando su limbo está desigualmente dividido por la costilla.

Las hojas son enteras y estérvimas ó mas ó menos profundanente divididas, $\mathrm{y}$ á veces lo son tanto y sus divisiones parecen tan iuclependientes en algunos casos, que el tránsito de ellas á las compuestas es casi insensible. Estos varios grados de division que pueden presentar las hojas simples se indican por medio de los términos adecuados siguientes: identadas las que presentan dientes agudos separados por senos obtusos; festoneadas si los dientes al contrario son obtusos y los senos aqudos: aserradas, cuando los senos y los dientes son agudos é inclinados estos últimos hácia la punta de la hoja ; duplicado-dentadas, duplicado-festoneadas, duplicado-asevadas, siempre que los dientes ó festones se hallan á su vez dentados, festoneados ó aserrados; incisas las que tienen dientes grandes ? desiguales con senos agudos intermedios; rasgadas cuando tienen en la márjen recortes desiguales y poco profundos; sinuosas si los senos $\mathrm{v}$ las partes salientes son igualmente redondeadas y en número indeterminado; sinuadas con escotaduras ó senos redondeados $y$ en numero determinado: panduriformes ó en forma de violin. cuando á los estremostienen dos siandes lobos redondeados y separados por dos senos laterales: culebreadus ó serpeadas si la márjen forma tortnosidades: roidas cuando, además de ser sinuadas, tieneu otros senos marjinales, pequeños, obtusos y desiguales: quebrantadas, gajientas ó lobadas, si, teniendo su contorno mas ó menos redondeado, presentan senos agudos que sin penetrar hasta el medio separan partes salientes, tambien redondeadas. que se llaman gajos ó lobos; bilobadas, trilobadas, cuadrilobadas, quinquelobadas. etc., segun el número de lobos: pinaitlobadas. palmatilobadas, pedatilobadas, estando lobadas con la nervacion indicarla por esas palabras; liratilobas si terminan por un grande lobo; hendidas si presentando en su contorno partes salientes agudas, llamadas divisiones, lacinias ó tiras, no penetran mas allá del medio los senos ižualmente agudos que las separan : sea el ricino, G. 144; se dirán pues bifidas, trifidas, cuad,vifidas, quinquefidas y por fin multifidas o recortadisi- 
mas, segun el número de tiras que tengan, sean pocas ó muchas; pinatifidas ó almenadas, palmatifidas, peltatifidas y pedatifidas, cuando afectan las divisiones, la disposicion indicada; lr radas ó de hechura de laud, cuando, á pesar de hallarse hendida al través, difiere de la pinatífida por tener una gran porcion terminal indivisa; vuncinadas: no difieren de las pinatífidas en otra cosa mas que por estar dirijidas sus lacinias hácia abajo; pectinadas, cuando están hendidas á manera de peine; bipinatifidas, estando nuevamente hendirlas las lacinias que ofrecen lateralmente; laciniadas, siempre que están hendidas en tiras mas ó menos profundas que se subdividen de varios modos; partidas se dicen las hojas cuando penetran mas allá del medio los senos que separan las divisiones, llamadas tan pronto lobos como lacinias y permaneciendo siempre unidas por la base: bipartidas, tripartidas, cucdripartidas y multipartidas, segun el número de divisiones; pinatipartidas, palmatipartidas, pedatipartidas, las que están partidas segun la nervacion espresada por esas denominaciones; bipinatipartidas, tripinatipartidas cuando las divisiones, que presentan lateralmente, están divididas una y otra vez; cortadas estando divididas de modo que tengan sus segmentos independientes unos de otros, aunque carezcan de rabillo: el berro, G. 830; trisectas, cuadrisectas, multisectas, segun el número de los segmentos; pinatisectas, palmatisectas, pedatisectas y en fin liratisectas cuando el segmento terminal es grande; pestañosas, cuyos bordes son provistos de pelo sedoso y paralelo; espinosus, aquellas cuya márjen tiene espinas; agudas las que se terminan por una punta delgada; acuminadas, puntiagudas ó aguzadas cuando se van terminando gradualmente en una punta blanda; arrejonadas o mucronadas y mucríneas, las que se terminan de repente en una punta pequeña y recta; cuspidadas cuando la punta que las termina es tiesa y corva; zarcillosas ó terminadas en zarcillo; estipuláceas ó acompañadas de estípulas: las de las papilionáceas, F. 130, S. F. I; orejudas cuando hay en el peciolo, cerca de la base del limbo, unos apéndices foliáceos llamados orejas. Atendiendo á la superficie las hojas han recibido denominaciones adecuadas para espresarlo; se dicen pues unidas, lampinas, lisas, ísperas, pubescentes, sedosas, velludas, algodonosas, pelierizadas, hispidas, aguijonosas, espinosas, pertusas ó aqujereadas; arrugadas, ampollosas ó abolladas, ondeadas, plegadizas y rizadas; iustrosas cuando parecen barnizadas; viscosas aquellas cuya superficie es algo pegadosa; coloridas cuando su color es diferente del propio á las hojas; enerves ó desnerviadas, si ningun nervio parece en su superficie; nerviosas ó nervudas las que tienen nervaduras salientes que se estienden de la base hasta el ápice sin ramificarse: muchas monocotiledóneas; trinervias las que tienen tres nervaduras principaies; rayadas cuando están con muchos nervios poco pronunciados; venosas aquellas cuya superficie presenta muchas nervaduras poco salientes, muy ramificadas y anastomosándose las unas con las otras ; rugosas ó arrugadas cuando las nervaduras al ramificarse y anastomosarse cortan la superficie en arrugas; punteadas aquellas cuya superficie está provista de muchísimos puntitos sea opacos sea transparentes : los naranjos, G. 
977; glandulosas, cuando están provistas de glándulas; planas ó llancis, curas dos superficies superior é inferior son llanas y paralelas; acanaladas, las provistas de un surco á manera de canal dispuesto á lo largo de ellas; c'ncaras cliando está un poco hueco el disco con sus bordes mas elevados; convexas aquellas cuyos bordes se acercan del peciolo; cuculiformes ó acogolladas cuando los bordes se acercan por arriba; plegadas ó plegadizas, cuando las nervaduras hacen sobre el disco partes mas salientes y otras mas hondas alternativamente y principiando al peciolo.

Consideradas segun la sustancia que las forma, las hojas se denominan: membranosas cuando casi sin parćnquima, son casi secas y transparentes; escaviosas ó aviteladas las que parecen secas; apergaminadas si parecen pergamino; cartáceas ó papiráceas las que tienen la apariencia del papel; crasas ó gruesas cuando la sustancia que las forma es bastante resistente y sólida: la sabila, el maguey, G. 413 y 460 ; carnosas ó pulposas las que á la par que espesas son jugosas : la yerba bruja ó de patria, G. 677; las hojas crasas se llaman segull su forma como sigue : cilindricas cuando tienen esa forma geométrica, bien que el ápice se termine por una punta: la cebolla comun, G. 414; ovoideas las que tienen la forma de un livevo; deprimidas aquellas cuyo disco es mas achatado que los bordes: comprimidas, achatadas y aplastadas, redondas y achatadas á la par; tricuetras ó de tres caras : el ajo comun, G. 414; tetragonas á con tres caras; lingüiformes, alengï̈etadas ó alenguadas, las lineares carnudas y convexas por la cara inferior; dolabriformes, las carnosas sub-cilíndricas en la base, aplastadas en la cima y que presentan dos bordes, uno espeso y rectilíneo y otro ensanchado, circular y cortante. En atencion á la duracion, las hojas han recibido las denominaciones siguientes: caducas cuando se desprenden y se caen á fines del estío: la mayor parte de los vejetales están en ese caso; deciduas las que se caen durante el otoño; marcescentes, marchiías las que en lugar de desprenderse y de caer despues de secas persisten pegadas lasta la primavera; siempreverdes, quedándose verdes durante todo el año: en los paises tropicales é intertropicales muchísimos vejetales están en ese caso. Son concolores las hojas cuando tienen igual color por ambas caras, y discolores, al contrario aquellas cuyo color es diferente por ambas superficies : la sanguinaria, G. 411; verdes: la mayor parte de los vejetales las tienen así blanquecinas las que tienen un color pálido que tira al blanco; abigarradas ó jaspeadas cuando son matizadas de varios colores.

\section{S III. - hoJas COMpuestas.}

Se llaman así las hojas formadas de un número mayor ó menor de piezas sueltas o de hojas sencillas pegadas de un peciolo comun llamado raquis; se las ha dado el nombre de hojuelas, son sentadas ó pecioladas, llamando peciolulo á su peciolo, y afectan las mismas formas é iguales maneras de ser que las hojas simples que acabamos de estudiar, por consiguiente se les aplicarán iguales denominacio- 
nes. Se dividen las hojas compuestas en las simpleinenie compuestas, en las recompuestas y por fin en las mas que recompuestas.

1. Hojas simplemente compuestas : en estas las hojuelas son insertas en un raquis simple y siempre único y se dicen, segun su disposicion en él : articuladas cuando hay una sola hojuela y que est articulada en el ápice del peciolo: el naranjo, G. 977 ; conyugada.s, ayı gadas y apareadas aquellas cuyo raquis lleva en los lados y casi en el ápice un solo par de hojuelas; binadas ó hermaneadas cuando las dos hojuelas estín situadas en el ápice del raquis; ternudas, trifolindas ó sea de tres en rama, aquellas cuyo raquis lleva tres hojuelas: los gandules, la picapica, G. 1054; digitudas ó arentalladas las compuestas de cinco hojuelas $\mathrm{y}$ hasta mas saliendo del vérvértice del raquis : el baobab, el castaño de América. G. 951, 950: pero puede indicarse el número de las hojuelas usando las calificaciones de quinquefolioladas, septemfolioladas, mullifolioladas, y la disposicion de ellas en algun caso se espresa por el término de peltado-digitadas o umbeladas: cuaternadas 6 de cuatro en rama las que tienen dos hojuelas á cada lado en la estremidad del raquis. En todos los casos en que la hoja compuesta presenta sus hojuelas situadas de uno y otro lado á lo largo del raquis, como en el zantoxilo clave de hércules, G. 2:29, 835, y muchas terebentáceas, G. 276. Se llama pinada ó alada, y es susceptible de varias modificaciones que se designan como sigue: se dirá pues alternatiramente pinadu. ó pinada con oposicion, es decir, cnnyugada, si sus hojuelas son alternas ú opuestas, y en el primer ca=o puede ser bifoliolada, irifoliolada, multifoliolada, etc., conforme al número de sus hojuelas, asi como en el segundo uniyuguda, biyuda, triyugada. multiyugada, etc.. segun el número de pares que la forman; pinado-trifoliada la uniyugada compuesta de un solo par de hojuelas laterales y de una terminal que le da el aspecto de hoja ternada sin serlo rigurosamente, porque es menester para esto que las tres hojuelas procedan de la estremidad del peciolo; imparipinadas o pinadas con impar son las conyugadas que terminan por una hojuela 'solitaria: el nogal, G. 140; paripinadas las que no tienen hojuela terminal; pinadas con intervupcion ó interpoladas las que tienen hojuelas alternativamente grandes y pequeñas; pinadn-escurridas o pinado decurrentes son las que tienen alado el raquis por prolongarse las hojuelas sobre él, de manera que son hojas profundamente divididas mas bien que compuestas; articulado-pinadas cuando las hojuelas son articuladas sobre el raquis; en esas hojas se observa el sueño de las plantas: las varias senes, el tamarindo, etc., G. 1019, 1039.

2. Hojas recompuestas : se diferencian de las primeras porque su raquis, en lugar de tener hojuelas á cada lado, lleva peciolos secundarios provistos de hojuelas por sus lados, de manera á constituir con ellas tantas hojas compuestas llamadas pinulas, que reemplazan las hojuelas en el raquis y forman así la hoja reconıpuesta que recibe las denominaciones siguientes: pedíleas, pedarias y apedadas cuando el raquis bifido lleva hojuelas situadas únicamente en el lado esterior de sus divisiones: bigeminadas ó dos veces hermaneadas, si cada uno de los peciolos secundarios que salen del vértice del raquis 
sostiene un solo par de hojuelas: el pitecolobio uña de gato, G. 1050 ; biternadas ó dos reces ternadas, siendo tres los peciolos secundarios que nacen del estremo del raquis y tres las hojuelas que hay en el vértice de cada uno; digitado-pinadas cuando del ápice del raquis salen varias hojas pinadas ó pinulas, como en la vergonzosa, G. 288 ; pinado-conyugadas ó binado-pinadas, pinado-ternadas o ternado-pinadas, pinado-cuaternadas ó cuaternado-pinadas, segrun si son dos, tres ó mas las hojuelas pinadas que proceden del estremo del raquis; bipinadas ó dos veces pinadas cuando del raquis salen lateralmente peciolos secundarios en número variado, constituyendo con las hojuelas correspondientes tantas pinulas: sea el aromo, G. 296.

3. Se ha dado el nombre de mas que recompuestas ó surcompuestas á las hojas compuestas por lo menos bipinadas situadas por cada lado del raquis, y se las ha denominado como sigue : trigeminadas ó tres reces hermaneadas cuando de la estremidad del raquis salen dos peciolos secundarios y del vértice de estos otros dos terciarios con su par de hnjuelas cada uno; triternadas ó tres veces ternudas siendo tres los peciolos secundarios nacidos del estremo del raquis, tres los terciarios saliendo del ápice de los secundarios y tres las hojuelas que aquellos sostienen; tripinadas ó tres reces pinadas cuando del raquis salen lateralmente los secundarios é igualmente de estos los terciarios que llevan las hojuelas; decompuestas si el raquis lleva otros raquises secundarios mas de tres veces pinados: el perifolio, G. 1135.

\section{CAPÍTULO IV}

ESTÍPULAS, BRÁCTEAS, FILLODIOS, ETC.

1. Estipulas. Se ha llamado así á unas producciones foliáceas y á veces escamosas que están de ordinario situadas á los lados de la base de los peciolos ó de la insercion de las hojas; pero en algunas plantas se hallan entre las hojas. Las plantas monocotiledóneas carecen siempre de estípulas que no se encuentran sino en una porcion de dicotiledóneas, las otras faltando tambien de ellas, sin embargo faltan con menor frecuencia que lo que se cree comunmente: on efecto á veces son tan pequeñas que para verlas se necesita del lente; otras veces no se las puede observar por causa de ser demasiado fugaces ó demasiado corta su duracion, sin embargo buscándolas con cuidado y en las hojas muy tiernas y hasta contenidas en las yemas prontas para abrirse, entónces se las halla en muchos vejetales que se creia desprovistos de ellas. Atendiendo al tamaño varian muchísimo; en efecto, con frecuencia están reducidas á una puntita, á un hilito, á una escamita : otras veces se desarrollan de tal manera, que parecen casi hojas pequeñas con sus nervaduras, dientes, lóbulos y cuya base está estrechada y forma una especie de peciolo. de tal suerte que á primera vista se las puede confundir ço 
las hojas lejítimas. Hay familias numerosas, tales como las malváceas, leguminosas y rosáceas, en que jamás faltan estando notables bajo mas de un aspecto $\mathrm{y}$ sirviendo por consiguiente para caracterizarlas.

Son enteraniente libres ó soldadas con el peciolo, y en ese último caso se liaman peciolares: el rosal, G. 1151 ; cuulinares : el café, G. 738; laterales se dicen cuando están situadas á los lados del peciolo, y axilares las que parecen nacer de la parte interna de la base de las hojas, pero ordinariamente proceden del tallo en la axila de ellas: no muchas plantas las ticnen así: pueden, como las laterales, rodear el tallo o el ramo, segun se observa en las higueras, G. 111. cuyas estípulas caducas y memhranosas, dando la vuelta completa, cubren enteramente las yemas. Son libres en casos análogos las estípulas axilares periféricas, pero hay otros en que se hallan adheridas á la base de la cara interna del peciolo, como en los polígono y romazas, G. 384,247 ; son pues.estípulas envainadoras tubulosas llamadas orreas características de ayuella familia y susceptibles de varias modificaciones de forma y de consistencia que se espresan por términos comunes; las estípulas ertrofoliviceas no son otra cosa mas que las axilares; estrufoliricers son law que salen en el tallo o en los ramos; interpeciolayes se llama:1 lí que perteneciendo á dos hojas opuestas al encontrarse las dos de carla lado se sueldan entre sí y forman así una sola intermedia á los dos peciolos. Las estípulas son permanentes ó caducas. Además de las estípulas ya estudiadas hay plantas cuyas hojas compuestas llevan otras estípulas mas pequeñas ó estipulillas acompañando á la insercion de los peciolulos en el raquis: las avichuelas, $C^{\prime} .1077$; la consistencia de las estípulas varia mucho y no está siempre igual á la de la hoja á que corresponden; las hay con forma de glándulas, otras filiformes sencillas $\dot{i}$ ramosas, las hay tambien mas o menos duras y hasta vueltas espinas, algunas se transforman en zarcillos, etc. Son soliturias, geminadas ó mellizas, rerticiladas, etc. En las hojas de las plantas monocotiledóneas la parte del peciolo llamada vaina está con frecuencia muy desarrollada $\mathrm{y}$ rodea el tallo en un trecho hastante largo: el plátano, G. 448, las gramíneas, F. 10: en estas últimas se repara bastantes veces al separarse el limbo de la hoja una especie de gorguera frecuentemente membranosa $y$ blanquecina, tan pronto entera como franjeada o partida, y las mas veces dividida simétricamente en dos partes laterales, la cual termina la vaina; ese órgano se llama lígula y ha sido comparado á las estípulas. Pegada con el tallo en la mayor parte del contorno del tallo cuya direccion sigue la vaina, no se articula y la hoja no se cae antes de morir; sin embargo en algunas orquídeas tropicales el limbo de la hoja se separa de la vaina persistente : el cirtopodio de Anderson, G. 44:3.

2. Brícteas y de los irganos que formair. Se ha dado tal denominacion á unas hojuelas acompañando á las flores que de ordinaric salen de su axila, las cuales no son sino modificaciones de las hoja: lejítimas de que difieren por ser casi siempre coloridas y muy raras veces verdes, tener su máljen casi siempre entera, una forma y mas reces una consistencia diferente: se dicen bracteolas cuando pertę- 
necen á rauiticaciones del pedúnculo. Varian bastante en plantas difer entes, la figura y tamano de las brácteas, bajo ese punto de vista, snn muy curiosas las que vienen forma de capucha: sea la margravia, G. 683, y suministran carácteles genćricos y especíticos muy buenos y nuy útiles. En una misma planta se desarrollan las lorácteas diferentemente, y siempre crecen mas las que no tienen flores en su axila, formando á veces una corona terminal, como en la piña, G. 46:; se dicen racías cuando nada presentan en su axila y fértiles las que tienen flores, pero abortan con bastante frecuencia, de manera que las flores de muchos rejetales son desprovistas de ellas. Son libres, como en las labiadas, F. 76; asoldadas entre sí y con el ovario como en las piñas, G. 462; su posicion respectiva es jor lo comun igual á la de las hojas de la misma planta, aunque bastantes veces las brácteas estén opuestas ó alternas, siendo las hojas verticiladas y opuestas ó verticiladas cuando las hojas son alternas. Las brácteas son persistentes ó las mas veces callucas y hasta fugaces, por causa de estar alt culadas. Al reunirse mayor ó menor número de brácteas por la proxinidad de los nudos de que procedelı, constituren conjuntos de aspecto diferente, que han recibido nombres palticulares como si fueran otros tantos or ganos distintos. El calículo resulta de un pequeño número de brácteas arrimadas al cáiiz de una flor, libres o soldadas entre sí : muchas malváceas, G. 959, 964, 962; el ime'lucro ó gorguera se compone de pocas ó muchas brácteas muy abiertas, que se hallan í cierta distancia de ana porcion de flores: los euforbios, G. 132; la zanahoria, G. 1137. El periclinio ó perifoiantio está formar!o de brícteas mas ó menos numerosas, dispuestas por séıies, mas ó menos escamosas ó apergaminadas, aproximadas, imbricadas y verticales que rodean las florecillas reunidas para formar una flor compuesta, F. 59. La cúpula se halla formada por muchas brácteas empizarıadas, que se han soldado y endurecido, como en las bellotas.

El involucto es propio ó unifloro cuando acompaña á una sola flor. como en la parcha, G. 1085"; comun ó multifloro el que corresprinde á muchas flores : el eringio, G. 1131 ; la yerba de cuarto, G. 1132 ; mon filo ó polifilo, segun las hojuelas ó brácteas que lo torman están soldadas ó libres; difilo, trifilo, tetrafilo, cuando tiene 2, 3 o 4 hojuelas, universal es el invólucro cuyas hojuelas presentan en su axila ramos que á su vez sostienen jtros involucros proximos á las flores que se llaman parciales ó inv'lucrillos: las umbelíferas, F. 149. Puede ser el involucro simple ó doble, llamado tiserial $\mathrm{y}$ tambien multiserial segun está compuesto de dos ó de muchas hileras de brácteas; culiculado ó reforzado el que tiene en la base unas cuantas hojuelas muy disminuidas de tamaño : la achicoria, F.119; empizarrado ó apiñado las brácteas cubriéndose en parte unas á o1ras; desparramado aquel cuyas hojuelas están muy abiertas y apartadas; unifloro, bifloro, triftorn, multifloro, conforme al número de flor es que encierra; cilindrvico, c'nicı, ovoideo, ventricnso, etc. atendiendo á su figura; cuando es monófilo puede ser partido, hendido ó dentado.

3. E'sputa. En muchos vejetales monocotiledóneos hay una espe- 
cie de zurron que envuelve las flores antes de abrirse y se llama espata ó garracha, formada por una bráctea única envolviendo en parte 6 del todo la inflorescencia, como se ve en los yaros, G. 160, 158 bis, en el coco y palma real, G. 99, 91; algunas veces se divide en dos piezas ó valvas, por ser formada de dos brácteas distintas $\delta$ soldadas; en otros puntos mas á lo largo del espádice se hallan algunas veces por la base de las flores ó de los grupitos que forman brácteas mas pequeñas, que se llaman espatillas. La espata es unicalce, biralre ó multiralte, segun el númeı de piezas que la componen aparentemente; uniflora ó multiflora cuando envuelve una o muchas flores; universal o parcial: el plátano, G. 448; carvuda, membranosa, apergaminada, leñosa, etc.

La gluma es otra especie de espata bivalve propia de las gramineas, que consiste en dos brácteas alternas aviteladas ó escamosas, colocadas en Ja base de las espiguillas, cualquiera que sea el número de las flores, F. 10.

4. Fillodio. Se llama así al peciolo dilatado y presentando la apariencia de un limbo, de manera que se le suele considerar vulgarmente como una hoja: el palo rayo, G. 1012. Se distingue del limbo porque en lugar de nervaduras secundarias penadas saliendo de una costilla, está recorrido por algunas nervaduras lonjitudinales repartidas por toda su superficie y casi iguales entre sí, desde la base hasta el ápice; otra diferencia tiene que consiste habitualmente en ser situado en el tallo en sentido inver so a las hojas lejítimas, es decir que su plano es casi vertical en lugar de horizontal.

\section{CAPÍTULO V}

FUNCIONES DE IA NUTRICION.

Absorcion, respiracion, circulacion, etc. Como ya lo tenemos dicho algo mas arriba y tambien en el discurso preliminar, páj. 19 , las raices, por medio de sus chupadores, sacan del suelo el agua mas ó menos carırała de sustancias minerales salinas y de ácido carbónico que necesitan; tal líquido, caminando por los largos tubos ó vasos que acompañan á la médula y por sus ramos y anastómoses, lleva cousigo al paro lo que suministran las varias partes ú órganos por donde pasa y llega mas ó menos pronto á las partes verdes ó pulmones vejetales, que á la par $y$ al mismo tiempo chipan en la atmósfela los gases que han de nec ’sitar y esas dosabsoruiones, aérea J terrestre. van velificándose simultáneamente y sin cesar, lo que con:tituye la vida vejetal.

Eso supuesto, á favor de la influencia de ajentes físicos poderosisimo:, la luz que obra por sus rayos químico y eléctrico á la vez, que zon el violícro y ril verde, los cuerpos absorvidos, es decir el agua, el ácido carbónico, el carburo de hidrójeno, el amoniaco, etc., están descompuestos, ó quizís mejor, esperineatan reacciones moleculares quimicas ó metamórfosis muy variadas sucesivas y siempre 
nurnerosísimas, de tal suerte que sus elementos, hallándose en presencia $r$ contacto inmediato al estarlo naciente, es decir, en el acto mismo en que al salir de una combinacion para entrar en otra, estản libres, entónces obedeciendo á la fuerza vital ú organizatriz, se agrupan molecularmente y dan orijen á la materia organizada y orgánica á la par, y asi de un modo insensible, pero con: tante y continuo, se ran formando los varios tejidos que lian de constituir los diferentes organos de estos seres; además de eso, estas reacciones, siguiendo entre los elementos, dan lugar á metamórfosis ulteriores que, ayudadas por el concurso necesario de los órganos corresponilientes, producen las varias secrcciones y escreciones vejetales.

La savia pıes, despues de llegada á los pulmones vejetales, es decir, en las hojas, y de hallarse sometida como corresponde á la accion vivificante del oxíjeno del aire, se vuelve mucho mas viscosa, aparecen globulos en ella: ya principia á organizarse ó á volverse líquido orgánico, que toma el nombre de cambio o latex, habiendo adquirido propiedades nuevas que le hacen nutritivo y reparador; entonces bajando por los vasos de la corteza ó por entre la albura y el liber, lleva consigo los elementos necesarios para la formacion de las nuevas capas de liber y de albura que han de aumentar anualmente el tamaño del vejetal; al paso y á la vez distribuje por donde se necesita los elementos nccesarios para la nutricion y para remediar las necesidades y pérdidas continuas que está esperimentando la planta. La savia descendiente corresponde pues á la sangre arterial ó reparadora de los animales, cuyo papel llena para los vejetales, mientras que la ascendente enclientra su análogo en la sangre venosa despues de recojidos los productos de la dijestion y antes de haber sufrido en los pulmones vejetales la hematosis.

Saluido es que bajo la influencia de la luz solar mas ó menos directa, las hojas, descomponiendo en su parénquima el ácido carbónico absorbido por su cara inferior se apropian el carbono, mientras el oxíjeno, saliendo por su cara superior se derrama en la atmósfera; lo mismo sucede á veces para con el agua, pero no siempre; en la oscuridad, al contrario, el oxíjeno atmosfërico está absorvido y una proporcion correspondiente de ácido carbónico se halla eliminada. Véase para maror intelijencia y mas estensa esplicacion del particular el discur=o preliminar, páj. 22. Los vejetales tienen sobre el aire dos acciones diferentes y hasta inversas; la una cs la que las partes verdes, con la infiuencia de la luz, ejercen sobre ese flúido, mientras la otra se verilica desde el momento en que ha principiado la germinacion de la semilla que haproducido el vejetal y siguiendo así sin interrupcion en todas sus partes; en efecto, segun el seĩor Garreau, las hojas durante el dia exhalan una cierta cantidad de ácido carbónico; en ese caso seria eso la lejítima respiracion vejetal enteramente semejante á la de los animales, y consistiendo en la combinacion del oxíjeno con los flúidos vejetales, para que se vevifique la hematosis vejetal, del todo semejante á la animal. Segun los magníficos trabajos del célebre botánico A. Brogniard, la respiracion de los vejetales que viven sumerjidos en el agua se hace de un modo análogo á la de los peces, sacando del agua el aire atmos- 
férico que tiene disuelto, descomponiéndole de la misma manera que los vejetales aéreos y quedándose con su oxíjeno y devolviendo ácido carbónico al agua. La luz influye siempre sobre ese fenómeno; en efecto, á una cierta profundidad las plantas se vuelven pálidas y lánguidas.

Por espiracion $i$ emanacion gaseosa de los vejetales se ha de entender el desprendimiento ó exhalacion de los flúidos que no han sido utilizados y tambien el de los que provienen de las reacciones ó metamorfosis verificadas que están de sobra y por tal razon inútiles, ó cuya presencia y permanencia en el organismo dañaria al vejetal. Como acabamos de decirlo, todas las partes verdes de las plantas espuestas á la luz desprenden mucho oxíjeno, mientras que en la oscuridad dejan salir ácido carbónico y tambien azoe y absorven oxíjeno.

Las partes no verdes, como por ejemplo los frutos maduros, en las mismas circunstancias, nunca desprenden oxíjeno, pero sí áciùo carbúnico; la mayor parte de los vejetales viejos ó enfermos exhalan azoe casi puro: Discurso preliminar, páj. . Esta exhalacion se verifica siempre, como lo tenemos ya señalado algo mas arriba, por la cara superior de las hojas y á la vez por todas las partes verdes.

Escreciones : se deben considerar tres clases de materias así botadas afuera ó eliminadas por los vejetales: $1^{\circ}$ las que aplicadas a su superficie á manera de barniz parecen destinadas á protejerlos y por consiguiente tienen papel en la vida rejetal : son sustancias resinosas que por su presencia se oponen á la accion de la humedad sobre los tejidos; 2 las materias que demasiado abundantes para las necesidades de las plantas no están utilizadas, y entónces salen afuera por las grietas de la corteza: las gomas y resinas, verbigracia; $3^{\circ}$ las escreciones lejítimas son las sustancias impropias á la nutricion, pero es muy difícil determinar cuáles están en ese caso: de las raices solas saldrian pues las escreciones verdaderas. (Véase el Discurso preliminar, páj.

Evaporacion : la evaporacion ó exhalacion acuosa que tiene lugar por las partes espuestas al aire, constituye la fuerza mas podeiosa de la ascension continua de la savia en los vejetales, y se veriîca casi enteramente por via de los estomates, aunque se haga por toda la superficie y especialmente por las verdes, pero de un modo casi insensible. Es jues tanto mas pronunciada y mas activa, cuanto mayores son el calor y la luz; de noche se para enteramente. 


\section{DIVISION II}

DE LA GENERACION Ó DE LA REPRODUCCION NATURAL DE LOs VEJETALES Y DE LOS ÓKGANOS QUE TIENEN QUE DESEMPEÑAR ESTA FUNCION

\section{SCGION I. - DE LOS ÓRGANOS DE LA GENERAGION.}

\section{CAPÍTULO I}

\section{GENERALIDADES $0 ́$ CONSIDERACIONES GENERALES.}

Los vejetales, así como todos los demas seres organizados, son capaces de reproducirse ó tienen poder para procrear otros seres idénticos á ellos, $\mathrm{y}$ de ese modo se puede perpetuar y mantener el naravillozo equilibrio de la obra maestra de la creacion; el importantísimo fenómeno que constituye la generacion se verifica por medio del concurso mutuo y pasivo de dos órganos especiales, que son el estambre ú órgano masculino y el pistilo ú órgano femenino, los cuales se suelen con muchísima razon comparar I asimilar á los corréspondientes órganos en los animales. Véase mas arriba, páj. , lo que tenenos dicho sobre el particular. Se llama flor á la parte del vrjetal que contiene tales órganos sea reunidos, sea separados. Generalmente se consideran hor dia todas las partes que constituyen las flores, aunque diferentes por las formas, colores y consistencia, como otras tantas hojas mas o menos moditicadas, $y$ se tienen pues las flores por un monton ó conjunto de hojas modificadas y amontonadas ó agrupadas en un eje acortado ó casi nulo; pero estas liojas, que constituyen las rarias partes de la flor, difieren de las lejitimas, no solo por la forma, por el color y por algunos puntos de su estructura íntima, sinn tambien porque nunca jamás salen yemas de sus axilas, ni tampoco del eje que las lleva, lo que constituye una diferencia esencial entre las ho- 
jas que forman las flores $y$ las otras partes de la planta. La vejetacior de una ramita cargada de hojas habrá de seguir indefinidamente produciendo nuevas yemas si la muerte, el aborto ó alguna otra causa esterior no vienen á pararla; mientras la vejetacion de una ramita terminarla por una flor se para naturalmente por causa de esa yema terminal que no es capaz de echar otra.

Los vejetales cuyas flores se ven y se pueden estudiar con mayor facilidad sin tener que valerse del lente de aumento, se llaman fanerógamos: sin embargo, este instrumento indispensable facilita muchísimo el estudio $\mathrm{y}$ hace visibles carácteres que sin él no se pueden averiguar: la mayor parte de los vejetales están en ese caso; al contrario, se llaman criptógamos aquellos cuya existencia de las flores ú órganos reproductores es mas bien sospechada y problemática que claramente demostrada y averiguada por las observaciones directas: en ese caso están los musgos, licopediáceas, F. 6; los helechos, F. 5; los líquenes, F. 3, etc.; pero esos vejetales tienen órganos de que trataremos mas luego, que son considerados como los análogos ó reemplazantes de los órganos reproductores lejítimos. En fin, se ha dado el nombre de ágamos, á aquellos en los cuales hasta ahora no se ha liallado ó descubierto ni órganos sexuales lejítimos, ni tampoco ninguno análogo: las algas, F. 1 .

La presencia de un solo estambre ó de un pistilo único, sin ningun otro órgano floral que le acompañe, basta para constituir una flor, incompleta por supuesto, pero capaz de cumplir con su objeto. Vulgarmente son los órganos que acompañan á los sexuales, sin tenerlos en cuenta, que se consideran como la flor, por ser ordinariamente mas vistosos y adornados de los mas hermosos colores y tener las formas mas elegantes y á veces muy bizarras. Cuando uno estudia una flor completa ó la analiza principiando por el centro hasta la circunferencia, halla sucesivamente los órganos siguientes: $1^{\circ}$ en el centro el órgano femenino ó pistilo, que se compone del ovario conteniendo los óvulos, del estilo y del estigma; $2^{\circ}$ viene despues el órgano masculino ó los estambres, que constan del filamento y de la aritera, que contiene el pólen; $3^{\circ}$ en fin, la cubierta floral doble, que se compone de la corola y del cáliz, que raras veces está acompañado de un calículo ó invólucro situado por su base, que tiene mas ó menos envuelta.

Las flores son sentadas ó pedunculadas, es decir, que son insertas inmediatamente en el vejetal, sin órgano intermedio en el primer caso, mientras que en el segundo su insercion es mediata $y$ se efectua por medio de un sosten mas ó menos largo, de figura y tamaño muy variados, que se llama pedíncílo; es simple ó ramoso y sus divisiones se llaman pedícelos. El pedícelo se llama epiffiln cuando sale de las hojas, como en la yerba de hicotea, limnanthemum humboltianum, G. 588; los filantos, phyllanthus nuriri, G. 149; caulinar ó tallino, cuando sale del tallo ó de los ramos, como sucede con el cacao, 923 ; axilar, el que sale de las axilas: el café por ejemplo, G. 738, y muchos otros vejetales, como el níspero, achras sapota, G. 635, etc. ; estraxilar, cuando sale por afuera de la axila de las hojas mas ó menos cerca de la insercion del peciolo; 
terminal, si termina la ramita que lleva la flor; epirvizo, al que sale de la raiz: el genjibre, gengibre officinalis, G. 477, y cuando el pedúnculo sale del centro de las liojas radicales de las plantas bulbosas y otras, como el lirio sanjuanero, pancratium cariboum, G. 452; la bretónica de Puerto-Rico : levia nutans, G. 755.

Se llaman hermafroditas las flores que tienen reunidos en la misma cubierta floral ambos órganos sexuales: así las tienen la mayor parte de los vejetales, sean el arroz, orriza sativa, G. 321; el aji, capsicum annuum, 620; el añil, indigofera añil, G. 1060, etc., $\mathrm{y}$ los vejetales que las tienen así se llaman tambien hermafroditas. Las flores que contienen el órgano femenino solo se llaman femeninas, y masculinas las que están provistas solamente de estambres, y los vejetales que las llevan se llaman unisexuales; cuando las flores femeninas y masculinas se hallan en una misma planta se llama monóica, mientras que se ha dado el nombre de dioicos á los vejetales que tienen una sola clase de flor en un pié y la otra clase sobre otro individuo, como la lechosa, carica papaya, G. 204; el marunguey, zamia intermedia, G. 231; el dátil, phoenix dactilifera,G. 205; el maiz, zea mais, G. 172; el ricino, vicinus communis, G. 144; el cocotero, cocos nucifera, G. 91; en fin, se han llamado polígamos á los vejetales cuyo mismo individuo lleva á la vez flores unisexuales, sea masculinas sea femeninas, con flores hermafroditas, ó ambas clases á la vez: el mango, G. 274; el almendro, G. 270.

\section{CAPÍTULO II}

\section{DE LA INFLORESCENCIA.}

Se ha dado esta denominacion á la disposición general de las flores en el tallo ó ramas de los vejetales. Se la ha dividido en 4 clases principales, que son como sigue: la la inflorescencia axilar; $2^{\mathrm{a}}$ la terminal; $3^{\mathrm{a}}$ la mista, y por fin la $4^{\mathrm{a}}$ ó anómala.

\section{S I. - INFLORESCENCIA AXILAR.}

Tiene lugar cada vez que las flores salen de la axila, tan pronto de las hojas como de las brácteas; las flores se llaman entónces axilares y pueden ser solitarias, como las del pedo de fraile, datura stramonium, G. 601; geminadas ó mellizas, como las del fisálide de las barbadas, physalis barbadensis, G. 618; verticiladas, las que están agrupadas muchas en las axilas de las hojas ó las brácteas opuestas, tales son las de la mayor parte de las labiadas: el leonitis nepetafolia ó molinillo, '523, 516.

La espiga es un conjunto de flores que con brácteas ó sin ellas nacen á lo largo de un eje comun, á veces desnudo por la base, como en el llanten, plantago major, G..394; puede ser cilindrica, aovada, cónica, además de floja, compacta ó densa; se llama empizar- 
rada cuando las flores caen unas sobre otras por razon de su proximidad, segun sucede en el llanten. Entre las espigas deben colocarse algunas inflorescencias que han recibido nombres particulares por circunstancias cuyo valor no es suficiente para constituir clases esencialmente distintas, tales son: el amento ó trama, el espádice, que suele ser ramoso y se llama entónces tímara : en las palmeras, cocos nucifera, G. 91; y en fin, el estrobilo ó piña antes de la fructi ficacion: son meras espigas modificadas, pero cuyos nombres deben ser conservados, porque espresan cada una la modificacion particular que le corresponde. El amento está articulado por la base y formado de flores unisexuales é incompletas, con las brácteas intermedias, como en los sauces, salix alba, G. 213; el higuillo, artante adunca, G. 315; en el primer caso es femenino ó masculino, segur las flores que lo forman, y hermafrodito en el segundo: se le ha dado los nombres de precoz. tardio, coetíneo ó casi coetáneo, conforme á la época en que aparece, relativamente á las hojas. El espúdice tiene su eje carnoso, con flores unisexuales anidadas sobre él y está acompañado de una espata, como en los yaros, F. 8; es sencillo y su parte inferior está cubierta de flores femeninas y masculinas separadas ordinariamente por nectarios, mientras que la superior, de ordinario desnuda, se prolonga en forma de maza; las palmeras tienen tambien sus flores dispuestas en espádice, pero con la diferencia que comunmente es ramoso, con eje que se vuelve leñoso, envuelta en una ó algunas espatas leñosas y toma el nombre de támara; el maiz, entre las gramíneas, produce mazorcas llenas de fruto que deben su orijen á flores femeninas dispuestas en espádice, rodeadas de una multitud de espatas. La piña, en fin, considerada en su principio, es verdaderamente un amento de flores femeninas, cuyas hojas carpelares, pegadas y endurecidas, forman las escamas leñosas que se observan despues de la fructificacion.

Las espigas de las gramineas y de las cipericeas, F. 10, 11, deberian distinguirse quizás con un nombre particular, aunque en apariencia se asemejan á las espigas lejítimas; pero del eje comun ó raspa nacen lateralmente unos grupitos de flores llamados espiguillas, constituyendo así espigas compuestas : la cebada verbigracia.

El racimo difiere de la espiga en que de su eje principal ó comun salen ejes secundarios 6 pedúnculos terminados cada uno por una flor y son casi iguales en lonjitud, como la rivina humilis, Gr. 362; el covimbo simple no es mas que un racimo cuyos pedúnculos inferiores crecen lo bastante para que todas las flores formen una superficie plana ó algo convexa, como en el peral, y tambien se vuelven las flores racimos acorimbados.

La panoja se diferencia de las precedentes inflorescencias porque tiene muchos ramos subdivididos, que saliendo á varias alturas se elevan diferentemente sin llegar al nivel del eje primitivo, como las flores masculinas del maiz y de la lechosa, G. 172, 204; el arroz, G. 321 ; pero los ramos ó brazos de la panoja, en unas plantas presentan racimos, en otras espigas, corimbos, umbelas, cimas ó glomérulas, y de estas varias disposiciones resulta la gran variedad que ofrece esta inflorescencia y que se caracterizan por los nomb-es 
correspondientes. Es simple ó poco ramosa la panoja, otras veces ramosa; cabizbaja como en muchas gramíneas, recojida o apretada, y tanto que se hace espiciforme, ó al contrario abierta, divaricada, desparramada. El tirso ó toba no es otra cosa sino una panoja de forma aovada, cual se observa en la vid, G. 818 .

La umbela ó parasol simple está formada por una porcion de pedúnculos saliendo de un mismo punto; sostienen flores cuyo conjunto presenta ordinariamente una superficie convexa, como en el ajo, allium sativum, G. 414; se llama desnuda cuando en su base no hay bráctea alguna, y al contrario, espatada ó involucrada, teniendo alguna espata ó invólucro; llámase además pauciflora, multíflora, floja, densa ó apretada, segun las circunstancias, y aunque por lo comun es convexa, no es raro que sea plana si los pedúnculos llegan exactamente á la misma altura. En la umbela compuesta, al contrario, los pedúnculos ó radios nacidos de un mismo punto producen en sus estremos muchos pedunculillos, que formando umbelillas sostienen flores colocadas, poco mas ó menos, á la misma altura, y cuyo conjunto constituye la umbela compuesta, como en la zanahoria, dancus carota, en el hinojo, F. 1137; la umbela es sentada ó pedunculada, compacta, densa ó rara, desnuda ó involucrada : todas estas calificaciones no necesitan esplicacion alguna.

La certula ó corona difiere de la umbela porque sus pedúnculos, aunque simples $\mathrm{y}$ saliendo del mismo punto, son desiguales entre si y llegan todos casi á ig̣al altura: es casi la umbela simple de que hemos ya tratado.

La cabezuela está compuesta de flores apenas pedunculadas ó sentadas sobre un eje deprimido y ensanchado, de modo que forman un conjunto esférico ó hemisférico : las flores de la sensitiva, mimosa púdica, del cují ó aromo, vachelia farnesiana, etc., G. 296, 291; la cabezuela puede ser aovada, aorado-oblonga, espiciforme, será tambien desnuda ó bracteada.

La calátide ó receptúculo, esa inflorescencia que pertenece únicamente á las flores compuestas, F: 59, y que consiste en muchas florecitas situadas en un crecido mas ó menos pronunciado del estremo del pedúnculo y envuelto en escamas ó brácteas mas ó menos foliformes, el cual se llama receptáculo comun, forantio, clinantio, etc., cuyas modificaciones merecen ser señaladas y estudiadas, porque de ellas se sacan carácteres genéricos muy buenos: es cilíndrico y delgado en algunas compuestas, en otras es oblongo, oviforme, cínico, hemisférico, y por consiguiente tanto mas ancho cuanto mas corto; algunas lo tienen convexo; pero sea cual fuere su forma, y prescindiendo de las pajitas, pelos o cerdas que tenga por alteracion de las brácteas, puede presentarse el receptáculo punteado, hoyoso y alveolar, despues de caidas las flores conforme á su modo de union con él.

El hipantodio ó cenantio puerle hasta cierto punto considerarse como un clinantio, cuya cavidad se ha aumentado mucho, hasta contener las flores: es propia esa inflorescencia ie las higueras é higuerotes, G. 111: de las dorstenias, G. 167. Asi es que el higo, 
lejos de ser fruto, como se cree comunmerte, no es otra cosa sino un receptáculo cóncavo, parecido á una copa, de la superficie interior, del cual nacen muchas florecillas y que por la aproximacion de sus bordes toma el aspecto de una pera ahuecada, y presenta un curioso ejemplo de esa inflorescencia, mientras que se halla abierto á manera de copa en la dorstenia, lo que demuestra las transiciones que ha sufrido ese pretendido fruto.

\section{§II. - INFLURESCENCIA TERMinal.}

La cima ó copa tiene lugar cuando las flores terminan siempre los ramos, dispuestos del modo siguiente : el ramo o pedúnculo principal está terminado por una flor, cuya base ó punto de insercion está acompañado de dos ó de mayor número de brácteas mas ó menos grandes, opuestas o verticiladas, de cuya axila puede salir otra flor o una ramita terminada del mismo modo, y va siguiendo así la vejetacion sucesivamente, de tal manera que esta inflorescencia consiste en una série de bifurcaciones sucesivas, terminándose siempre sus brazos por una flor única, como el sauco blanco, sambucus vi ${ }^{\circ}-$ giniana, G. 734. Tomará los nombres de corimbifor'me, apanojada, espiciforme, racemiforme, escorpioidea, segun el conjunto de cimas afecte una de estas disposiciones generales.

\section{S III. - INFLORESCENCIA MISTA.}

El tirso: en este caso el eje central ó el pedúnculo principal se va ramificando de tal manera, que á primera vista parece un racimo enderezado y piramidal, cuyos pedúnculos son desiguales y dispuestos de tal manera, que los de la parte mediana estén algo mas largos que los demas, como en el mamoncillo, meticocca bijuga, G. 854; la vid, vilis labrusca, G. 818 .

El corimbo: en esta inflorescencia el eje comun se divide y subdivide muchas veces á diferentes alturas, y sin embargo llegando casi á la misma todas las flores, de manera que forman una superficie plana ó convexa: es casi propia de las sinanthéreas, la salvia de las Antillas, coniza lobata, G. 782; á primera vista parece umbela, pero difiere de ella por la insereion graduada cie sus pedúnculos y pedícelos.

\section{\$S. IV. - INFLORESCENC'IA ANÓMALA.}

En esta última clase se han agrupado las inflorescencias que no corresponden á las anteriores.

A veces las flores salen opuestas á las hojas, entónces se llaman opositifolias, como sucede en muchas cucurbitáceas; otras veces salen por fuera de la axila de la hoja y mas ó menos cerca de ella, y se llaman en este caso extra-axilares. Son radicales las que salen de 
la raiz, como en muchas liliáceas : la amapola de las Antillas, amavillis punicea, G. 455; el lirio sanjuanero, pancratium caribceum, G. 452 ; tan pronto se las halla soldadas con los peciolos ó saliendo te ellos, como situadas en las hojas, como ya lo tenemos señalado rablando de la disposicion relativa de los pedúnculos.

Todas las inflorescencias que se han distinguido no son tan diversas unas de otras que sea imposible agruparlas bajo algun punto de vista. Considerando los grados de vejetacion que presentan, se pueden establecer diferencias muy marcadas, pero no suficientes por sí solas para servir de base á una buena clasificacion de ellas. Rœper dividió las inflorescencias en definidas, determinadas ó terminales, y en indefinidas, indeterminadas, laterales ó axilares, segun si el eje primitivo se termina ó no por una flor : pertenecen pues á la primera clase las inflorescencias que consisten en una sola flor terminal. llamada cima uniflora, y todas las demas especies de cima, así como á la segunda todas las demas inflorescencias. En las inflorescencias definidas la evolucion principia siempre por el centro, siendo la flor terminal del eje primitivo la que se abre la primera, $y$ al contrario, en las indefinidas son las flores inferiores ó mas lejanas del centro las primeras que florecen; la inflorescencia en aquellas se llama centrífuga, y en estas centripeta.

\section{CAPÍTULO III}

\section{PREFLORACION Ó ESTIVACIUN}

Los botánicos han llamado así á la disposicion particular que las varias partes constituyentes de la flor todavía contenidas y encerradas en el capullo ó boton afectan antes de la florescencia ó antesis. Tal disposicion se observa por supuesto casi siempre en las flores de todos ó á lo menos de la mayor parte de los vejetales de la misma familia, ó mejor en las plantas de la misma tribu, pero siempre y constantemente en todas las especies de un mismo género, lo que suministra frecuentemente muy buenos carácteres.

Se llamará ratrada cuando se tocan las piezas sea del cáliz ó de la corola por los bordes, en torla su lonjitud, como en el achiote , bixa orellana, G. 890 ; se llama indupticada siempre que las piezas contiguas, se junten por una porcion de su cara esterna, como sucede en la clemátide, G. 417; reduplicada, siempre que lo hagan por una porcion de su cara interna, como se ve en la corola de muchas umbeladas, F. 149.

La torcida difiere de la valvada en que las piezas, sobrejoniéndose circularmente, se cubren unas á otras en bastante estension, como en muchas apocíneas, malváceas, etc.: la adelfa, nerium oleander, G. 656; la empizarrada es aquella cuyas piezas se cubren parcial y sucesivamente desde la primera ó esterior hasta la última ó interior, formando una espiral, como en la de las verónicas, las rosas, G. 1151; pero si las piezas son tan largas y anchas que se 
cubren casi del todo, se la llama convolutiva; la quincuncial se verifica entre 5 piezas colocadas de tal modo, que dos se hallen al esterior, dos al interior y la otra, cubierta en parte por una de las esteriores, se sobrepone á una de las interiores, como en el cáliz de la rosa y en el de la jara, G. 1151, 861; siendo de notar que en esta prefioracion forman las piezas del verticilo floral dos vueltas de espiral, como corresponde á un ciclo de 5 hojas. Esta prefloracion es susceptible de algunas perturbaciones, particularmente en la corola: el estandarte ó vexilo de las amariposadas, que deberia ser una de las piezas interiores, se hace comunmente esterior y cubre á las dos esteriores, formando así la prefloracion llamada vexilar : el quinchoncho, cajanus bicolor, G. 1015; una de las piezas esteriores, al contrario, se hace interior en algunas corolas labiadas y en varias personadas; esta prefloracion se llama coclear.

La prefloracion, propiamente dicha, consiste pues en la posicion relativa de las piezas de cada rerticilo floral, que como se habrá notado, puede ser diferente en cada uno de los que pertenecen á la misma flor; pero las piezas aisladamente tambien pueden tener una disposicion propia que complique la prefloracion del verticilo correspondiente. Las piezas de la corola crecen tanto en algunas plantas, que se arrugan irregularmente, y la prefloracion, sea la que fuere, se llama corrugativa, como en la amapola lejítima, papaver rheas, F. 90; se llama plicativa si se doblan lonjitudinalmente por dentro, como en las campanulas, ó por fuera, como en algunos solanos; las del cáliz pueden estar arrolladas sobre sí mismas, formando así una prefloracion enruelta; los estambres en algunas plantas se hallan encojidos, encorvados ó doblados de fuera á dentro, como en el llanten, G. 408, cuya estivacion se llama implicativa, etc.

El boton organizado, como se ha visto mas arriba al hablar de las remas, y cubierto por las piezas del cáliz, no siempre se abre por la separacion de estas, puesto que hay plantas donde es tal su soldadura, que solo rompiéndose el boton pueden salir al esterior los órganos dentro de él contenidos: así acontece en la catalpa, G. 526, y en otras plantas, con la particularidad de formarse en algunas un opérculo ó tapadera á consecitencia de la ruptura transversal del cáliz. Tambien las piezas de la corola están fuertemente adheridas entre sí por sus estremidades superiores en algunos vejetales, como la vid, por ejemplo, ritis labrusca, G. 818, de modo que no llegan á separarse. 


\section{SEGGION II.}

\section{IDE LOE ORGANOS ESENGIALES A LA GENERACION VEJETAL}

\section{CAPÍTULO I}

DEL, ÓRGANO FEMENINO Ó PISTILO.

\section{S I. - GENERALIDADES.}

Como lo llevamos ya dicho mas arriba, este órgano ocupa sienpre el centro de las flores y se compone de 4 partes bien distintas, $\therefore$ saber: los óvulos ó huevecillos que constituyen el embrion vejetal naciente ó rudimentario, con sus varias envolturas, siempre ó casi siempre contenidos dentro de una cavidad particular llamada ovario. que constituye la parte mas inferior del pistilo y es el análogo de la matriz de los animales mamíferos, cuyo papel tiene; en efecto, sirve para alojar el ser nacedero y para protejerle contra las influencias esteriores que pedrian, sino matarlo, á lo menos estorbar y entorpecer su desarrollo; además de eso le suministra el alimento que necesita, elaborado como corresponde, por la placenta que lo recibe de la planta madre. El estilo, cuerpecito por lo comun filiforme, mas ó menos largo, cuyo papel consiste solo en hacer comunicar el estigma, que está de ordinario situado en su ápice, con el ovario, de cuyo vértice sale ordinariamente, es pues el análogo de la vajina en los mamíferos; en fin, el estigma, órgano glanduloso, de forma, tamaño, color $y$ consistencia muy variados, sin epidermis y casi siempre provisto de un líquido viscoso, corresponde con la vulva de las hembras de los animales ó quizás mejor con el orificio vajinal, llamado vulgarmente boca de la matriz; su papel consiste pues en recibir, agarrar como al vuelo y á chupar, si se puede espresar así, el pólen, llevado por el aire para que se verifique la preñez ó fecundacion vejetal.

Los huevecillos, el orario y el estigma son pues las partes esenciales y necesarias, porque su falta hace las flores estériles é incapaces por consiguiente de cumplir con su objeto, mientras que el estilo puede y hasta suele faltar algunas veces, sin que por eso resulte perjuicio para la fecundacion.

Segun el número de pistilos que contienen las flores, se llaman monojjinas, trijinas, tetrájinas y polijinas; se llaman isijinas teniendo tantos carpillos como sépalos, anisújinas habiendo menos carpillos, y por fin políjinas siendo mas los carpillos. El pistilo está aplicado en el ápice del pedúnculo sobre el torus, trilamo, veceptcículo 
o asiento, que no es otra cosa sino el eje de la flor cuyo tamaño, forma, consistencia, etc., varian muchísimo. Cuando está muy prolongado, formando así un sosten mas ó menos largo al ovario, ha recibido el nombre de carpiforo y de giniforo.

\section{$\$$ II. - DE LOS HUEVECILLOS.}

Los huevecillos contenidos en el ovario son solitarios ó muchos r situados solsre un órgano particular mas ó menos desarrollado, de donde proceden, llamado placenta ó trofospermo, que les pone en comunicacion con la planta madre y tiene su análogo en la placenta de los animales mamíferos. No siempre está unido el huevecillo á la placenta mediante un funiculo ó cordoncito umbiticado, llamado tambien podospermo, porque hay plantas donde falta, y por consiguiente se halla sentado; pero siempre tiene un punto por el que se verifica su union con la placenta, llamado hilo ú ombligo; principia el óvulo por una eminencia celular que aparece en la superficie de la placenta, y arece pronto, tomando la forma de un pezoncito destinado á ser el nicleo donde debe desarrollarse el embrion: poco despues se observan por dehajo del ápice del núcleo dos bordecillos circulares, uno interno y el otro esterno, correspondientes á dos envolturas del huevecillo, designadas con varios nombres, y que Mirbel indica sencillamente con las de primina y secundina, siendo esta la interna y aquella la esterna. El cordoncito umbilical está adherido á la prinina; dentro de ella y pegada á su fondo se encuentra la secundina y el núcleo tiene su base fija sobre el fondo de esta otra envoltura. Así es como los vasos del cordorito umbilical llegan hasta el núcleo, atravesando el hilo ú ombligo que corresponde á la primina ó testa y en la secundina ó tegmen; la chalaza está situada en el punto de union de la misma secundina con la primina. Superiormente presenta esta la abertura circular ya indicada, llamada exostoma ó micropila esterior, en oposicion al nombre de indostoma ó micropila interior, que corresponde á la abertura de la secundina.

Cuando el crecimieto del óvulo continua uniformemente en su contorno, lo cual sucede en pocas plantas, se conservan en línea recta el ombligo, la chalaza, la micropila esterna é interna y el ápice del núcleo; entónces el huevecillo en que eso sucede se llama ortotropo: las poligóneas, F. 50. Por lo comun el crecimiento no se efectua con tanta uniformidad, de manera que se desvian mas ó menos los objetos señalados; en efecto, puede llegar á encorvarse todo el óvulo, de modo que el ápice de su núcleo se acerque al ombligo y entónces el huevecillo se llama camptótropo ó campulitropo, segun si se desarrolla igualmente por ambos lados, ó mas por el uno que por el otro, como se observa en las crucíferas, F. 89; muchas leguminosas, F. 130 ; otras veces se encorva solamente por la base el ovulo y se acerca al cordoncito umbilical hasta encontrarlo y soldarse con él, formando un conjunto; entónces el huevecillo se llama anatropo. El cordoncito umbilical, cubierto por la primina en este caso. 
suele notarse esteriormente, y toma el nombre de ligamento ó rafe la línea que forma desde el ombligo hasta la chalaza, que en el huevecillo anátropo no coinciden como en el átropo ó en los camptótropo y campulítropo. Hay además otras disposiciones intermedias del óvulo, de manera que se observan huevecillos hemianátropos y anfitropos.

En cualquiera caso llega un momento en que se ahueca el núcleo del huevecillo, viniendo á orijinarse de ese modo el saco llamado tercina, que desaparece ó se adhiere á la secundina; pero en cambio suele agregarse otro nombrado cuartina y todavía otro que se dice quintina: este último constituye el saquito embrional ó membrana del amnios constante y duradera, mientras que la cuartina, formada á veces al rederdor del saco y despues de él, es tan perecedera é inconstante, que no ha llamado la atencion de muchos observadores. En la cavidad del saco aparece la vesícula embrional ó utriculo primordial, que desarrollándose por la adicion de nuevas células, forma el embrion unido al ápice del núcleo por un hilillo llamado suspensor, hasta tanto que este desaparece, atrofiándose. No es dudoso tampoco que el embrion se nutre á espensas del tejido celular semifluido que le rodea dentro del saco, I la parte sobrante del mismo tejido que persiste á veces despues de estar perfectamente formada la semilla, constituye lo que se llama albumen, endospermo ó perispermo.

El huevecillo puede ser solitario ó único en la celdilla del ovario, la cual toma por esta razon el nombre de uniovulada y se fija entónces de cinco modos en ella: puede hacerlo en el fondo del ovario, como en la ortiga, F. 39, y entónces el óvulo está derecho; si procede del ápice ó de un punto muy próximo á él, se dice inverso; se llama ascendente al que saliendo de una placenta axil ó parietal se dirije hácia arriba; colgante, pendiente ó suspendido, si en iguales circunstancias se dirije hácia abajo; se dice peritropo siempre que el punto de union diste igualmente de los dos estremos del huevecillo; cuando el cordoncito umbelical, nacido del fondo del ovario, es muy largo y que el huevecillo mas bien parece suspendido que derecho; dícese entónces que el óvulo está suspendido de un funículo derecho ó se le califica de reclinado; pero puede alargarse el cordoncito umbilical del óvulo ascendente, y entónces lo es mediante un funículo colgante. Siendo varios los huevecillos contenidos en una celdilla, todavía se observa bastante constancia en el modo como se hallan dispuestos, si su número no llega á ser indefinido, y mayor seguramente cuando es corto; así es que en las celdillas bioviladas están muchas veces los huevecillos uno al lado del otro, y entónces se llaman colaterales, ambos colgantes, ó uno ascendente á la vez que colgante el otro; pueden tambien desprenderse á diferentes alturas $y$ en este caso hallarse sobrepinestos. Lo mismo sucede cuando son tres los huevecillos colocados á la misma ó en diferentes alturas; pero siendo multiorulada la celdilla, no pudiendo crecer con igual libertad los huevecillos, se dirijen hácia arriba los superiores, hácia abajo los inferiores $y$ en el medio se desarrollan los demas, todos ellos comprimidos y por consiguiente angulosos en lugar de ovoí- 
deos, á no verificarse que siendo la celdilla muy larga estén sobrepuestos los huevecillos como en las leguminosas y crucíferas, F. 89, 130.

\section{$\S$ III. - DEL OVARIO.}

La estructura anatómica del ovario revela su orijen, puesto que presenta como la hoja un parénquima atravesado de hacecillos fihro-vaseulares y revestido de epidermis. Las tráqueas se dirijen de lo bajo á lo alto, converjiendo en el punto de donde sale el estilo, y la epidermis esterior está provista de estomas como la cara inferior de las hojas, mientras que la epidermis interior, mas pálida ó blanquecina, carece de ellas. Pero el parénquima del ovario es de ordinario mas abundante y jugoso que el de las hojas, sin que en el mismo haya capas celulares bien distintas. En el ovario se distinguen el dorso, dirijido hácia la circunferencia de la flor, $y$ el vientre que corresponde al centro de la misma, ambos con una juntura ó sutura mas ó menos pronunciada. El ovario compuesto es comunmente re gular, sin embargo algunas plantas hay en que no lo es; pero al ovario simple le sucede todo lo contrario, porque estando formado de dos mitades de hoja necesariamente irregulares, nunca en rigor deja de presentarse irresular. Por esto, sin necesidad de mayor exámen, puede tomarse por compuesto cualquiera ovario perfectamente regular, mientras que el irregular es en muchos casos simple $\mathrm{y}$ en algunos solamente compuesto. Tanto el ovario simple como el compuesto son susceptibles de formas diversas que se espresan con los adjetivos calificativos siguientes: globoso, aovado, elipsoideo, cilíndrico, oblongo, etc.; comprimido ó deprimido el que esté aplanado de arriba abajo ó lateralmente. El ovario compuesto, segun la soldadura mas ó menos completa de sus carpillos, presenta lobos en número iqual ó doble. Cuando el ovario está dividido en dos ó mayor número de celdillas, están estas separadas por tabiques que serán lejítimos ó espurios. Todo tabique Jejítimo alterna necesariamente con los estilos, los estigmas y los lóbulos estigmáticos, lo cual no sucede jamás respecto á los espurios, cualquiera que sea su direccion. Por esto los tabiques que se observan en las cruciferas y tambien en algunas papareráceas, F. 90, cuyas placentas parietales se prolongan hácia el .eje, hallándose colocados en el mismo plano que los estilos, jamás pueden tomarse por lejítimos. Los tabiques lejítimos son incompletos si no llegan al eje del ovario, y completos cuando lo alcanzan y son formados de dos membranas adheridas, y están por consiguiente siempre verticales, y de ellos se distinguen los espurios incompletos, formados por las márjenes entrantes de cada carpillo, en que saliendo del eje del ovario no llegan á su circunferencia y que llevan las placentas. Hay otros tabiques lejítimos tambien, pero cuya estension se limita á la parte inferior del ovario, de modo que este es multilocular inferiormente y unilocular superiormente.

El ovario se dice uni, bi, tri, cuadri, quinque, etc.; multilocular, 
segun el número de celdillas que tiene, las cuales se llamarán uni, $b i$, tri, cuadri y multioruladas, segun el número de óvulos contenidos en ellas; se califica tambien de didimo, tridimo, ó de dicoco, tricoco, cuadricoco, multicoco, cuando la soldadura que reune los diferentes carpillos del ovario ocupa un trecho muy corto, y á medida que se va estendiendo mas la adherencia se denomina bi, tri, cuadri, quinque y multicostado, en consideracion á las divisiones ó proeminencias mas ó menos pronunciadas que se observan esteriormente.

El ovario compuesto unilocular siendo un verdadero conjunto de carpillos donde cada cual tiene sus bordes soldados, claro es que llegando todos al medio, deben formar un eje colocado sobre el receptáculo ó disco á manera de coíumilla, á cuyo alrededor parezcan colocadas las placentas, puesto que la de cada carpillo se halla sobre su correspondiente sutura ventral, y todas las suturas se confunden en el eje del ovario perfectamente multilocular, resultando ser las placentas axiles y hallarse unidos los huevecillos al ángulo interno de las celdas, como en las naranjas, G. 977, los libiscos, G. 970, las malvas, G. 959. Pero separando los dos bordes de un carpillo aislado, suele llevarse cada cual la mitad de los huevecillos, como sucede en muchas leguminosas, F. 130; y de eso se puede inferir que las placentas axiles son generalmente dobles. No llegando á cerrarse los carpillos en el ovario compuesto unilocular, se concibe que prendidos los correspondientes huerecillos á los bordes inmediatos de cada par de carpillos, resulten las placentas parietales é igualmente dobles. Entre las placentas axiles y las perfectamente parietales hay grados que corresponden á los que median entre el ovario multilocular y el compuesto verdaderamente unilocular; los tabiques incompletos sostienen placentas semejantes á las parietales, que se llaman casi parielales ó casi axiles, segun si se aproximan á una ó á otra de esas dos disposiciones. La placenta central libre suele constituir un todo sin vestijios de partes distintas.

Se llama ginobase á la columilla mas ó menos deprimida ó poco desarrollada, como se observa en las borragíneas y en las labiadas, F. 66, 76, situada en el medio de las cuatro celdillas del ovario, como si fuera continuaeion del receptáculo ó disco. Pero además de la ginobase puede existir un ginóforo debajo de ella, lo que se ve claramente en el escordio, porque generalmente tienen ambas cosas las labiadas y las ocnáceas, F. 76, mientras que solo presentan una ginobase las borrajíneas en general, F. 66.

Las placentas están diferentemente desarrolladas en los ovarios de diversas plantas, y no es de estrañar que se llamen huevecillos sin placenta los unidos á las que sean muy poco notables, y por el contrario, placentas hay que son proeminentes, crasas ó carnosas, hállense enteras ó bilobadas. En algunas plantas son tan voluminosas, que llenan las celdas, $y \cdot n o$ por eso se hallan siempre adheridas en mucha estension á la parte que parezca producirlas : en el llanten, F. 67. Hay dos que parecen componer una sola central libre, porque se destruye fácilmente el tabique delgado que las separa. Respecto á su forma han recibido las placentas proeminentes varias 
denominaciones, tales como las de hemisféricas, elípticas, ćnicas, globosas, etc., que la indican suficientemente.

La disposicion relativa del ovario con los demas órganos florales proporciona muy buenos carácteres diferenciales, de manera que ha necesitado palabras á propósito para espresarla: el ovario se dice pues libre ó supero cuando pegada en el fondo del cáliz su base, sea mediata ó inmediatamente, ocupa así el centro de la flor sin tener ninguna otra adherencia con sus demas partes constituyentes; muchas familias de plantas y hasta quizás la mayor parte de ellas lo tienen así, como la caña fístola, cathartocarpus fistula, G. 1005; el guingombo ó quirbombo, abelmoschus esculentus, G. 970 ; la berenjena, solanum berengena, G. 622; el borrajon, heliotropium americanum, G. 671; el arroz, orriza sativa, G. 321. Se llama infero ó adherente al que en lugar de hallarse en el fondo de la flor ocupa su parte mas inferior y tiene los otros órganos florales colocados por su vértice; en tal caso está enteramente soldado por su superficie con la cara interna del tubo del cáliz que entónces es siempre monosépalo y cuyo limbo corona siempre el fruto maduro; se observa así en el plátano, musa paradisiaca, G. 448; en las amomáceas, la yuquilla, maíanta arundinacea, G.480; en las unbelíferas, el culantro del monte, eryngium fetidum, G. 1131; en las rubiáceas, coffea arabica, G. 738; en las narciseas, el lirio sanjuanero, pancratium caribcum, G. 452 ; en las myrtáceas, la pomarosa, jambosa vulgaris, F. 133. Semi-ínfero el que no está enteramente soldado con el tubo calizinal y cuya mitad superior está por consiguiente libre: las campanuláceas, el tibey, hippobroma longiflora, G. 687. Parietal, se dice así el ovario cuando muchos óvulos están pegados por la base en la parte interna de las paredes del cáliz que está casi siempre con figura de odre y cuya garganta es muy estrecha y carga con los demas organos florales, de tal manera que á primera vista parece ínfero: los rosales. G. 1151.

El ovario es único y simple ó multiple y compuesto; sesil ó sentado, otras veces estipitado ó sostenido por un piececillo mas ó menos largo saliendo del fondo del cáliz: los alcaparros, capparis cinocephala, G. 883; el melembe, cleome pentaphylla, G. 825. Segun su forma ó figura se dice el ovario cilíndrico, redondo ó esférico, oblongo, aovado, fusiforme, etc. Segun su vestitura ha recibido los nombres de pubescente, afelpado, aterciopelado, lampiño, liso, áspero, glanduloso, espinoso, etc.

\section{S IV. - DEL ESTILO.}

Como lo tenemos ya dicho algo mas arriba, este órgano ocupa las mas veces el ápice del ovario que hace comunicar directamente con el estigma ; sin embargo algunas veces sale de las partes laterales y hasta de la base del ovario, y en este caso se dice lateral, como en el icaco y en el fresal, F. 132. Revístele una epidermis que es continuacion de la del ovario, y aunque á simple vista suele parecer sólido, con mas îrecuencia que hueco, pero siempre corre interier- 
mente á lo largo de él un conductito desde el estigma hasta el ovario, en algunas plantas vacío y en otras relleno de tejido celular comunmente flojo, que deja numerosos espacios, siendo diferente del tejido propio del estilo. Tiene el conductito en sus paredes porcion de celdillas salientes á manera de papilas, y llega un momento en que otras blarıdas y húmedas se prolongan á lo largo de él en forma de hilillos, constituyendo lo que se llama el tejido conductor. de cuya separacion resulta el estigma. Nunca el estilo simple tiene ángulos ni estrías en su esterior, siendo mas veces rollizo y otras comprimido, mientras que el compuesto puede presentar ángulos, estrías y hasta costillas mas ó menos proeminentes, como en la capuchina, tropcelum majus, G. 843. Si los estilos parciales de cuya union resulta no se sueldan del todo en el sentido transversal, se llama costillado ó estriado; pero si la soldadura es completa será rollizo, lo que sucede siempre que corresponde á un ovario sin costillas. Es central y terminal el estilo compuesto en todos los casos y mas comunmente lateral que apicular el estilo simple, pero á veces está situado tan bajo que se llama basilar. Muchos estilos pueden unirse por la base ó hasta mas arriba, formando en apariencia uno solo que se califica entónces de bi, tri, cuadri, quinque y multipartido en otro. Siempre que los estilos simples se hallan libres del todo ó parcialmente, pueden separarse unos de otros mas ó menos, y por consiguiente recibir las denominaciones de diverjentes, abiertos y revolutos, ó sea reflexos; pero existiendo un solo estilo simple, puede doblarse al contrario hácia dentro y llamarse inflexo y hasta horizontal, segun se observa en muchas leguminosas, F. 130. Sea simple ó compuesto el estilo varia bastante en cuanto á su direccion para que se le apliquen los epítetos de derecho, arqueado, flexuoso ú ondeado, levantado, inclinado, sigmoideo ó con forma de S, ganchoso ó en forma rle anzuelo, circinado ó arrollado sobre sí mismo, torcido. La forma del estilo es tambien bastante variable : en efecto, es grueso ó craso en algunas plantas y filiforme en muclias, mas ó menos cilíndrico de ordinario, otras veces cónico, alesnado o subiilado, ovoídeo, apeonzado, clavifarme ó mazudo, em $u$ udado ó infundibuliforme, adelgazado, fusiforme, articulado, petaloideo, etc.; es corto ó largo, pubescente ó lampiño; si se desprende el estilo poco tiempo despues de verificada la fecundacion se dice caduco y persistente en el-caso contrario, y á veces sigue creciendo y vejetando durante algun tiempo: se llama en tal caso acrescente : la clematide de la Habana, clematis havanensis, G. 417; forma en el ápice de la silicua de algunas crucíferas un pico característico. Tiene ordinariamente tantas divisiones ó lóbulos el estilo cuantas celdillas hay en el ovario; lo mismo sucede para con los estilos múltiples; sin embargo en las lechetreznas los estilos están divididos en seis ramitas y no presentan mas que tres celdas los ovarios, lo que indica la bifurcacion de cada estilo.

Una flor puede tener pues sea un estilo único y simple mas ó menos partido hácia su ápice, correspondiendo tan pronto con un ovario único como con igual número de ovarios; otras veces, al contrario, un ovario único lleva en su ápice algunos estilos. Como ya lo tene- 
mos dicho establece paso el estilo entre el estigma y el ovario, hágalo prolongándose mucho ó poco, porque lo esencial consiste en que los cordones pistilares tengan comunicacion para que la materia fecundante pueda penetrar hasta los óvulos.

\section{$\mathfrak{S}$ V. - DeL estigna.}

Sobre el estilo, cuando existe, se halla el estigma, y en caso contrario está sentado encima del ovario. Puede ser el estigma una notable prolongacion del estilo, ó consistir meramente en una porcion de su superficie convenientemente modificada, y por esto se distingue en completo y en superficial; siendo completo, presenta forma propia y es terminal, hemisférico, globoso ó cabezudo, discoideo, semi-lunar, oblongo, clariforme ó mazudo, cilindrico, cónico, alesnado ó subulado, ganchudo, capilar ófliforme, linear, etc. Tambien puede ser agudo ú obtuso, mas corto ó mas largo que el estilo, mas ancho ó mas estrecho que él. Si el estigma es superficial, nunca podrá recibir calificaciones que lleven envuelta la idea de un sólido, ya el estigma superficial será terminal, como en las labiadas, F. 76, ó lateral como en otras plantas; en ese último caso mira casi siempre hácia el centro de la flor con una hendidura cuyos bordes mas ó menos separados presentan la superficie estigmática, cuando esta no se halla entre los mismos bordes ó en el interior de la curvatura del estilo. Se llama lamelado el estigma cuya hendidura es muy corta y la separacion de sus bordes formando una laminilla. En todo caso presenta el estigma un tejido celular generalmente flojo, prolongacion del tejido conductor del estilo con células alargadas esteriormente en forma de papilas y hasta de pelos que no deben confundirse con los de los estilos, ó sin nada de esto, pero siempre empapado de un jugo viscoso, que mantiene húmeda la superficie estigmática. El estigma es simple, partido, hendido ó lobado; en algunas plantas es peloso, pubescente, aterciopelado, apincelado, etc. Los pelos que acompañan al estigma de las compuestas y de las campanuláceas, F. 57, 59, contribuyendo al acto de la fecundacion, se llaman colectores; las lobelias y otras plantas tienen los pelos debajo del estigma formando un collarcito que se llama indusio, G. 687,689 .

\section{CAPÍTULO II}

DEL ÓRGANO MASCULINO Ó ESTAMBRE.

\section{S I. - DEL PÓLEN.}

El pólen ó la materia fecundante ordinariamente pulverulenta de los vejetales está compuesta de una multitud de granos independientes y aislados. Mucha diversidad de forma ofrecen los granos 
polínicos en plantas diferentes. y no varian menos por las desigualdades en la superficie que presentan á la vista ayudada de un buen microscopio: hay granos globosos, aorados, elipticos ó elipsoídeos, cilíndricos, trigonos, potiédricos, pezoncillosos, tuberculados, granujientos, erizados, espinulosos, reticuladlos, punteados, etc.; pueden además tener pliegues lonjitudinales, como tambien poros ú úsculos, y ambas cosas á la vez se observan en algunos. Por diminutos que sean los granos de pólen, están lejos de ofrecer tanta sencillez como pudiera creerse y se ha pensado durante mucho tiempo: compónense de una, dos ó tres membranas sobrepuestas que rodean una cavilad llena de cierto líquido llamado fovilla, donde nadan los granillos tenidos por fecundantes con algunas gotitas de aceite y á veces granitos de fécula. Generalmente son dos las membranas que tienen los granos de pólen maduro, cuya esterna se llama eschimenina y la interna endhimenina, segun Richard: tres hay en los de muchas coníferas, F. 33, 34, y una sola en la de las asclepiádeas, F. 62, páj. 142; pero por una comienzan todos, aunque despues presenten otra ú otras dos mas en su interior. La forma, color, desigualdades y poros de la superficie de los granos de pólen, se deben enteramente á su membrana esterior, transparente y desprovista de color si estando tersa y lisa no trasuda el líquido aceitoso, que se lo da amarillo ordinariamente y en varias plantas azulado, azul, rosado, rojizo, negruzco, etc.

L̊ fovilla ó líquido que llena los granos de pólen es algo espesa y contiene principalmente unos cuerpecillos á que se ha dado mucha importancia atribuyéndoles la accion fecundante; granillos de estos hay que son esféricos $y$ pequeñísimos, otros no lo son tanto y varian por su forma, que es esférica, elipsoídea ó cilíndrica con las estremidades adelgazadas. Todos ellos están dotados de cierto movimiento bastante notable, que algunos consideran como vital, pero que quizás mejor depende solamente de una propiedad general de la materia muy dividida. Es indudable que, sea por los granillos, por cl líquido en que nadan, o por ambas cosas á la par, es la fovilla lo activo y fecundante del pólen. La salida de la fovilla al través de las aberturas accidentales ó existentes de antemano en la membrana esterna del pólen constituye la deliscencia de este, determinada siempre por la accion de la humedad sobre sus dos membranas, que se dilatan desigualmente atravesando de la interna á la esterna, siempre menos estensible. Cuando esta no tiene solucion alguna de continuidad, ni partes mas débiles que el resto, se rompe por el punto que la humedad reblandece á impulso de la membrana interna dilatada en la parte correspondiente é igualmente húmeda, que sale formando al esterior una ampollita. Pero por lo comun los granos polínicos tienen perforada su membrana esterna ó á lo menos arlelgazada en varias partes; los poros, sin embargo, son mas bien puntos mas débiles que soluciones de continuidad, y las partes adelgazadas forman generalmente pliegues hácia dentro, existiendo solos ó con los poros, que tambien pueden estar sin pliegues. Con la humedad se inflan los granos polínicos, sus pliegues desaparecen. mientras que los poros se hacen mas visibles en forma de circulillos 
transparentes, esté ó no verdaderamente perforada la membrana esterna, que en algunas plantas conserva su consistencia menos en el contorno de carla poro, cubierto así por una tapaderita que al fin se desprende, y en tal caso el pólen se dice operculado. A medida que la humedad se introduce en los granos polínicos, seguramente por efecto de la endosmosis, la dilatacion de las membranas se aumenta y la interna, como mas estensible, sale al través de los poros ó partes débiles, formando otras tantas ampollas que al fin se rompen dejando salir á chorro la fovilla: esto es lo que sucede cuando so somete el pólen á la accion del agua; pero colocado sobre el estigma, sean como fueren los granos polínicos, no suele presentar mas de una ampolla en la parte que toca á la superficie estigmática, y esta ampolla, alargándose al penetrar en el estigma, toma el nombre de tubo polínico.

El pólen de las orquídeas y el de las asclepiádeas difiere mucho por su disposicion de el de los demas vejetales: por esta razon debemos estudiarlo. En las orquídeas, F. 27, se hallan frecuentemente aglutinados los granos polínicos, formando una masa ślida como cera, por eso tales masas polínicas se llaman cercíceas, y no es menos comun ballar plantas de la misma familia, cuyos granos de pólen, sin estar confundidos, se encuentren pegados unos á otros por hilillos elásticos, de modo que forman masas pulverulentas ó granujientas; pero la mayor parte de las orquíleas europeas tienen los granos de pólen unidos cuatro á cuatro, como en los utrículos polínicos sucede, y forman cuerpecillos que, adheridos entre sí por una redecilla elástica, constituyen la sola musa lobulada. existente en cada celdilla de la antera; esta masa sectil es mas ó menos ovoídea con su estremidad inferior adelgazada á manera de un piececillo llamado estipite, caudicula ó prolongacion filiforme, que se apoya en una glándula denominada retináculo. Los dos piececillos de las dos masas que hay en la antera proceden á veces de una sola glándula; pero cada piececillo puede tener la suya particular desnuda ó cubierta por una capucha, antes epidermis del estilo, y tambien es procedente del mismo la glándula cuyo jugo, solidificándose, orijina el piececillo de cada masa polínica. Las asclepiádeas son bastante semejantes á las orquídeas por lo que toca á las masas polínicas, siempre compactas y parecidas á cera, que existen en sus anteras; pero tienen un estigma grueso y pentágono de cuyos ángulos, entre cada par de estambres, nace un cuerpecillo ovoídeo y cartilajinoso, igualmente llamado retináculo, de donde salen dos hilillos denominados prolongaciones laterales ó piernas, que terminan en las dos masas polínicas inmediatas, cada una de diferente antera.

En la sazon de su madurez ó de la fecundacion el pólen no tiene en general ninguna adherencia con el utrículo ó saquito que lo contiene: se desprende y se derrama en la atmósfera, que se lo lleva consigo cual nube vivificadora que va esparciendo la vida por el espacio; echado á la candela el pólen se inflama á manera de la pólvora con mucha facilidad y prontitud. 


\section{S II. - ANTERA.}

Este órgano consiste, como lo tenemos ya dicho, en una especie de saquito membranoso, de figura y tamaño muy variados, formado por lo comun de dos celdas y raras veces de una única, que de:pues de secretado ó elaborado por su superficie interna el pólen, lo tiene guardado y como en repósito, hasta que llegado el momento en que se necesita, entónces se abre por si misma y lo deja salir afuera para cumplir con su objeto. La antera en su totalidad ofrece una cara en la cual se repara un surcolonjitudinal mas ó menos pronunciado; el dorso será pues la parte diametralmente opuesta; tiene además lados ó bordes, una base y un ápice, y se debe tomar en cuenta su lonjitud y su latitud, entendiendo por latitud la dimension que va de uno á otro borde, pasando por el punto de apoyo de la antera; la lonjitud se estiende desde la base hasta el ápice, pasando tambien por su insercion. La antera se dice introrsa cuando su cara mira hácia el centro de la flor, y estrorsa, al contrario, si está vuelta hácia fuera; es sesil ó sentada cuando faltando el filamento, como suele suceder bastante á menudo, está pegada sin intermedio ninguno; ordinariamente está situada en la parte superior ó ápice del filamento, que se termina sin debilitarse ni estrecharse, ó que al contrario se adelgaza articulándose á veces con ella; se dice esta, en el primer caso, inmícil, conlinua, adherida ó apoyada, y en el segundo móvil ó verssitil, G. 1085. Sea la antera móvil ó inmóvil, puede estar fija por su base sobre el filamento, ó apoyada en el mismo por su dorso, hallándose fija por el ápice, por debajo del ápice, por el medio, por debajo del medio ó por encima de la base; se dirá pues basifija, dorsifija, apicifija, etc. Por su figura se llama la antera globosa, oblonga, elíptica, aovada, subglobosa ó esferoidtea, linear, lanceolada, ondeada ó meandriforme, y además asaetada, arriñonada, cordiforme ó acorazonada, didima, tetrégona. Todas estas denominaciones habiendo sido ya esplicadas son bien conocidas de todos, y por consiguiente no necesitan de otra esplanacion. Las celdillas son susceptibles de presentar, tanto en la punta como en la base, apéndices que consisten en cerdas, puntitas, cuernecillos ó crestas, y entónces viene á ser la antera en el ápice ó en la base bicuspidada, bisetosa, bicorne, unicorne. Las dos celdillas, en lugar de ser aplicalas la una á la otra, pueden estar separadas por un cuerpo mas ó menos largo y de forma muy variada, que se llama conectivo, el cual está á veces prolongado por su base y otras por su ápice, $\mathrm{y}$ en este último caso orijina sobre la antera un apéndice que varia por su tamaño, consistencia y forma : tiene la de una cerda plumosa en la adelfa, nerium oleander, G. 658; es ancho y peludo en la pervenca, G. 648; bractiforme en el pino, G. 105; siendo carnoso, está como truncado en muchas anonáceas, F. 95 ; tiene color y aspecto petaloídeo en los jonidios, G. 812; es membranoso en las compuestas, F. 76. Tanto por abajo como por arriba suele no prolongarse con bastante frecuencia el conectivo hasta los $\epsilon$ stremos de la antera, y entónces, además de faltar los indicados apéndices, 
quedan libres las celdillas en aloun trecho por uno ó ambos extremos, lo cual se espresa calificando la antera de bifida ó escotada por el ápice, de bifida ó escotada por la base. La prolongacion del conectivo puede verificarse tambien á lo ancho, de manera que, alejando una de otra las celdillas, estén estas separadas por un travesaño mas ó menos largo, como en las salvias, donde estí articulado con el filamento sobre el cual se balancea, sosteniendo una celdilla completa y otra abortada, G. 501; ese conectivo así prolongado entre las dos celdillas se llama distractil y no es siempre horizontal, pues que en algunas plantas toma la figura de $\mathrm{Y}, \mathrm{Y}$ entónces el filamento parece bifurcado; puede ser espolonado y por to tanto la antera se llama tambien espolonada, como sucede á las dos que corresponden con el pétalo espolonado de las violárieas, F. 86. Por su figura se llama el conectivo oblongo, asoado, circular, semicircular, lunulado, securiforme. Dícese que es nulo el conectivo cuando las celdillas de la antera parecen unidas inmediatamente, como en las gramineas, F. 10, y segun si la union se verifica de costado ó por los dorsos, se llaman allegadas ú opuestas; además la parte superior del filamento sirve de conectivo muchas veces, como en los renúnculos, F. 98. Las celdillas son generalmente largas y estrechas, pero las hay de forma mas ó menos globosa y de otras que median entre esta y la $l i$ near. Ordinariamente las celdillas son paralelas, pero, de las diferentes maneras como el conectivo las une $v$ de las modificaciones que este esperimenta, resulta que en algunas plantas, sean diverjentes y horizontales o transversas, no siempre tiene dos celdillas la antera, en efecto es unilocular en las malváceas, F. 100, páj. 234; las poligáleas, F. 107; algunas veces es unilocular por causa de haber abortado una de las celdillas, $y$ en este caso su figura no es jamás regular como en el primer caso; á veces la antera es cuadrilocular, como en el aguacatero y otras lauríneas, G. 224; en fin es multilocular en el tejo. Las celdillas se abren por lo comun lonjitudinalmente, separándose las dos valvas distinguibles antes de la dehiscencia, segun el surco que se halla en la cara; pero la hendidura no se estiende siempre á todo lo largo, de manera que la antera en vez de ser lonjitudinalmente dehiscente, puede serlo por el ápice, hasta el medio, casi hasta la base; á veces se abre por un agujero lateral y oblongo, otras veces por poros, uno correspondiente al ápice de cada celdilla, como en los solanos, G. 622 : se llama entónces biporosa por el ápice la antera y puede serlo tambien por la base; en las melastomáceas; F. 136, se abre por un poro único comun ¿a las dos celdas y la antera se dice uniporosa en su ápice ; otras veces se abren por un opérculo, como en el aguacate. Los estambres deben tenerse por imperfectos, así como por castrados ó estériles siempre que nada haya en lugar de la antera y existiendo solamente los filamentos; abortan á veces del todo los estambres, y en algunas plantas están reemplazados por unos apéndices de forma variable que se llaman estciminodios.

Por lo comun las anteras son libres, como sucede en la mayor parte de las flores, como las gramíneas, F. 10; las borrajíneas, F. 66 ; las mirtáceas, F. 133. Sin embargo algunas veces están solda- 
das entre sí, como se observa en las plantas de la familia de las compuestas, llamadas por cita razon sinanthéreas ; en las lobeliáceas, F. 59, 57. Otras veces están soldadas con el organo femenino, formando así una columna que se llama ginostemo, como en las orquídeas, F. 27 ; así sucede tambien para los aristoloquios, F. 45, y las plantas que las tienen así se califican de ginandras. La antera es por lo comun mas gruesa que el filamento que la sostiene.

\section{$\mathfrak{S}$ III. - FILAMENTO.}

Este órcano, que suele faltar bastantes veces, no es otra cosa sino el sosten de la antera y nada mas, mas ó menos largo, de ordinario delgado y cuya forma varia mucho y segun ella se dice capilar, como en el arroz, orriza sativa, G. 32l; filiforme, como en el clavel, en la exostema de muchas flores, G. 719 ; alesnado ó subulado; en vez de ser rollizo puede estar aplastado y notablemente ensanchado y denominarse entónces plano, membranoso, comprimido, dilatado, petaloídeo, como en la ninfea, G. 4l6; en la caña de Indias, G. 4\$1; cuneiforme, abovedado, triangular, pubescente ó lampiño; colorado ó amarillo, blanco ó pintado; ordinariamente simple ó algunas veces con el ápice terminado en dos ó tres puntas, y por esta razon se llama bifido y tricuspidado el ajo comun, G. 4i4. Tambien se presentan en algunas plantas ciertos apéndices hícia la base ó hícia la punta, de manera que se ha llamado espolonado, apendiculado ó provisto de un diente ó prolongacion en la base el romero, G. 500, el zalan de noche, cestrum nocturnum, G. 626; bicuspidado, bifurcado ó ahor'quillado refiriéndose á la punta. En algunas plantas parece salir de una escama ó apéndice colocado por la parte interior del e:tambre, como en la simaruba, G. 864, ó por la esterior. como en la borraja, donde tiene la forma de un cuernezuelo, G. 672 ; y el filamento se dice, segun los casos, alado, corniculado ó picudo. A lo largo del filamento pueden existir dientecillos ó nuditos y se llama denticulado, nudoso ó toruloso; está articulado en algunas plantas y parece en otras arrodillado, porque se inclina de repente. Además en cuanto á su direccion se le distingue en recto y corvo hácia dentro ó encorrado; corvo hácia fuera ó recorrado: será tambien flexuoso ú ondeado, torcido, colgante, ascendente, decumbente ó recostado, etc., términos todos aplicables á los estambres en totalidad.

Li filamento es simple como en la mayor parte de los vejetales: el maiz, G. 172; la yerba mora, G. 622; el rosal, G. 1151, etc., ó compuesto $\mathrm{y}$ formado entónces por la reunion de un número mayor ó menor de filamentos sencillos soldados entre sí tan pronto por la base como por la mayor parte ó toda su lonjitud y formando así en el fondo de la flor uno ó algunos hacecillos ó falanjes que se llaman andr'foro, que es susceptible de varias formas, $y$ entónces se dice cupiliforme, campanudo, tubuloso, etc. Algunas raras veces en rez de ser soldados entre sí son solamente mas ó menos unidos, y en tal caso se llaman aglutinados ó coherentes, lo que se aplica tambien á los estambres que, en el caso de ser soldados los filamentos, se ca- 
lifican de monadelfos cuando forman una sola falanje, como en las malvíceas, F. 100, páj. 234; diadelfos si se hallan en dos hacecillos, como en el quinchoncho, G. 1065, y muchos vejetales de las leguminosas, tribu de las anıariposadas, F. 130, S.-F. 1; en las poligaláceas, F. 107 ; triadelfos, siendo tres los falanjes; en fin poliadelfos cuando hay varios hacecillos ó andróforos, como en el azalıar, G. 977, en el homalio racimoso, G. 1149.

Varia muchísimo el número de los estambres, y segun si la flor tiene uno, dos, tres, etc., ó muchos, se denominará monandra, diandra, etc. y poliandra ; cuando tiene tantos estambres como pétalos se llama isostemone; siendo mas ó menos los estambres se dice anisostemone, distinguiéndose en diplostemone y polistemone, segun si los estambres son en número doble ó mas que doble, y además en meiostemone si está igual al de los pétalos. Haya muchos ó pocos estambres, pueden ser iguales ó desiguales, lo que depende únicamente de la lonjitud relativa de los filamentos; didínamos se llaman los estambres siendo cuatro con dos filamentos largos y dos mas cortos. como en la mayor parte de las labiadas: el molinillo, G. ち23; tetradínimos sierdo seis, cuatro largos y dos cortos: el mastuerzo, G. 833; puedell ser tambien iguales ó desiguales entre sí, sin haber recibido denominaciones especiales. Están colocados los filamentos en una sola hilera cuando su número no es mayor que el de los pétalos ó sépalos, pero forman dos ó mas en caso contrario, y por eso se dicen los estambres uni, $b i$, etc., multiseriales; á veces algunas bileras aproximándose mucho se confunden y parecen una sola. Pueden inclinarse hácia un lado y se dicen unilaterales, pero las mas veces son derechos y siguen la direccion de las envolturas florales pudiendo ser iguales, mas largos ó mas cortos que ellas; se dicen inclusos los estambres: el pedo de fraile, G. 601, cuando la corola ó el cáliz formando un tubo los tienen escondidos, y salientes cuando salen por afuera : la menta, G. 564.

La insercion de los estambres y por consiguiente de los filamentos, cuando existen, ó el modo con que están situados con respecto del cáliz, de la corola ó en fin del ovario, suministrando muy buenos carácteres distintivos, nos debe ocupar.

Los estambres se insertan de tres maneras diferentes; hay pues tres inserciones diferentes, que se denominan como sigue : 10 hipojinica : cada vez que los estambres se hallan pegados por debajo del ovario ó al disco que lo sostiene: en tal caso el ovario es siempre libre ó súpero, como en las labiadas, F. 76; en las liliáceas, F. 16; en las gramíneas, F. 10; en las apocíneas, F. 63 , etc.-20 Perijínica: en este ca:o los estambres están insertos sea mediata ó inmediatamente en derredor del ovario, que puede ser tan pronto libre como parietal y liasta ínfero : en estos dos últimos casos están pegados los estambres en la garganta del cáliz y por consiguiente aparentan ser situados por encina del ovario, cono sucede en los rosales, G. 1151; en las myrtáceas, F. 133; las plantas de la familia de las poligóneas tienen el ovario libre, F. 50 . Se dice epijínica la insercion cuando son insertos los estambres en el ápice del ovario ínfero, cono sucede para las umbelíferas. F. 149; las orquídeas, 27, etc.; en fin en 
estos últimos años se ha admitido una cuarta insercion llamada hipo-perijinica, y que llamaremos nosotros mista, porque participa i la par de la hipojínica y de la perijínica, como se observa en bastantes vejetales de la familia de las leguminosas, F. 130.

Los estambres correspondientes á tales inserciones se dirán pues 7. 'pójinos, períjinos, epíjinos é hipo-períjinos.

\section{SEGGION III}

DE LOS ÓRGANOOS ACCESORIOS DE LAS FLORES Ó DE AQUELLOS CUYA FALTA NO ES OBSTÁCULU PARA FL CUMPLIMIENTO DE LA PEC'UNDACION.

\section{CAPÍTULO Iº}

Antes de pasar mas adelante es preciso mencionar unos órganos que suelen faltar bastantes veces, pero cuya presencia, no muy rara en las flores de muchas plantas, suministra con frecuencia buenos carácteres distintivos, sea genéricos, sea específicos: se llaman nectarios; se ha dado esta denominacion á unos órganos glandulosos, de forma mur variada, agrupados en el fondo de las flores de ciertas plantas, y que parecen tener por papel único de secretar un líquido azucarado y meloso, como en muchas plantas de la familia de las crucíferas, F. 89. Durante mucho tiempo esta palabra ó rocablo no ha tenido un sentido botánico bien determinado, de tal manera que se llamaba nectario á cualquiera parte accesoria de las flores procediendo las mas veces de órganos abortados aunque sin secretar líquido alguno.

El disco: se ha dado ese nombre á un crecido mas ó menos pronunciado que de ordinario se halla en el fondo del cáliz sosteniendo al ovario y sobre el cual se in forma de rodete, de anillo, copilla ó tubo, segun las plantas; algunos lo han llamado tambien tor's. En los cissus, G. 815, el disco tiene dientes que indican que está formado de piezas soldadas entre sí. Hay plantas en que el disco está reducido á una sola glándula, segun se ve en la tercianaria y en algunas polígalas, G. 975. La pervinca presenta dos glándulas opuestas, faltándole tres para completar el número de las que corresponden á su disco, y muchas crucíferas lo tienen limitado á dos glándulas por falta del desarrello de otras dos; puede ser doble; cuando está muy desarrollado toma la denominacion de receptáculo ó asiento de la flor. 


\title{
CAPÍtulo II
}

\author{
DEL CÁLIZ.
}

Cuando las flores tienen una sola envoltura o cubierta floral se denomina periantis ó perigonio, si es doble al contrario entónces á la mas esterior se la llama cáliz, mientras la mas interior se dice corola, como ya lo tenemos mencionado algo mas arriba. Este órgano no es pues otra cosa sino el primer verticilo de la flor ó su envoltura mas esterior formado de hojuelas libres ó soldadas entre sí que se llaman sépalos; varian en número y se dice el cáliz disépalo, trisépalo, cuadrisépalo y polisépalo, ó difilo, trifilo, tetraiflo y polifilo, cuando son dos, tres, cuatro ó muchos los sépalos que lo constituren; cuando estín soldadas entre sí de manera que formen un todo, el cáliz se llama monófilo ó monosépalo y quizás mejor gamosépalo. Se distingue en el cáliz monosépalo tres partes diferentes, que son el $t i b$, mas ó menos largo que constituye su parte inferior limitado por la parte á donde principian sus divisiones, que se llama gargan$t a, y$ ellas constituyen el limbo ó parte libre mas ó menos partida, y sus divisiones se llaman tiras ó lacinias, lobos y dientes, segun su tamaño y forma; se dirá pues el cáliz bipartido, tripartido, cuadripartido cuando está dividido mas abajo de la mitad; bificido, trifido, cuadrifido y en general hendido si lo está hasta la mitad solamente; bilobado, trilobado, cuadrilobado cuando la division no pasa del tercio superior; bidentado, tridentado, cuadridentado cuando las puntas de las divisiones están solamente libres; se llama tambien entero y l’uncado. El cáliz es regular ó invegular : para que sea regular no es necesaria la total igualdad de sus partes componentes, siempre que la haya entre las que alternan con otras iguales entre sí, y por esto tan regular es el cáliz desigual ordenado del marrubio con sus einco dientes grandes y cinco pequeños alternados, como el del jazmin ó de otra planta cualquiera en que sean iguales. La irregularidad del cáliz proviene tan pronto de no estar soldados los sépalos á la misma altura, como de una soldadura menos estensa que las demas, de manera que parece hendido por un lado; el cáliz irregular se llama bilabiado cuando sus cinco sépalos se unen dos hácia un lado y tres hícia otro mas ó menos completamente, formando así dos labios, el uno superior y el otro inferior, como en muchas plantas de la familia de las labiadas, F. 76, y de las leguminosas, F. 130.

La nerracion de los sépalos ú hojuelas calicinales se distingue bastante por lo comun, y el nervio medio sobre todo suele estar muy marcado; pueden además presentarse otros entre cada par de hojuelas que se unen, y por esto el cáliz compuesto de 5 ś́palos se puede llamar unas veces quinquenervio $\mathrm{y}$ otras decemnervio; cuando se forman ángulos en la direccion de los nervios lonjitudinales de los sépalos, el cáliz se hace angula ó prismático, como sucede al del estramonio, G. 601, y si en cualquiera caso los nervios se pro- 
longan fuera de los bordes de las hojuelas se dicen apiculadas, arrejonadas, espinosas, segun la lonjitud y la agudeza de las puntas. in las florecillas de las compuestas, la parte libre del cáliz toma la forma de rilano, que se llama pajoso, plunoso, peloso, aristado ó membranoso, segun si consiste en un conjunto de pajitas mas ó menos diferentes, de hojuelas, plumillas que son nervios divididos, pelos que son nervios simples, aristas que difieren de los pelos por su rigidez, ó membranitas soldadas formando una circular, F. 59. Los sépalos, considerados independientemente del todo que constituyen o del cáliz, son susceptibles de figuras tan variadas como las que de ordinario presentan las hojas, de manera que se les ha dado los mismos nombres; por esta razon no volveremos á referirlos aquí, pero solamente añadiremos que estando soldadas pierden ordinariamente la integridad, de manera que sus jiartes libres, que constituyen las divisiones del cáliz, suelen ser semi-lanceoladas, semi-aoradas, etc. Tambien las desigualdades marjinales, que pieden tener las mismas hojuelas, son análogas á las de cualesquiera hojas, y al unirse las del cáliz mas ó menos divididas, hacen que este presente en algunas plantas mas puntas que sépalos componentes. Considerado él cáliz en su totalidad ofrece formas diversas y bastante notables, especialmente si es monófilo; y se llama cupuliforme ó en forma de cubeta, globoso, aorzado ó en forma de orzuela, apeonzado ó turbinado ó con figura de trompo; campanudo o campaniforme, embudado ó infundibuliforme, mazudo ó claviforme, cilíndrico, tubuloso ó acañutado; tambien puede ser ventrudu, rejigoso ó hinchado, y al contrario comprimido; en cuanto á la direccion de los sépalos, se dice connivente si al inclinarse unos sobre otros se juntan; cerrado cuando sus bordes están inmediatos, y abierto, al contrario, cuando se desvian ; abiertísimo desviándose mucho; revuelto estando las hojuelas echadas hácia abajo, de modo que presentan esteriormente su cara superior. En la mayor parte de los vejetales su consistencia es foliácca y herbácea y su color verde, pero algunas veces puede tener el aspecto y la consistencia mas delicada de la corola y estar tambien pintado de los mas primorosos colores, como en muchas plantas monocotiledóneas; pero en este caso constituye por sí solo la envoltura floral y es un periantio ó perigonio y se dice petaloiden: las liliáceas, F. 16; las narcíseas, F. 21; las orquídeas, F. 27.

Hay en los cálices de ciertas flores prolongaciones ó apéndices llamados jorobas, sacos, espolones, segun su forma, como se observa en las orquídeas, F. 27; en las violariáceas, F. 86-60; en las tropeoláceas, F. 109 ; y en tales casos el cáliz se dice apendiculado, jorobado, espolonado, con saco, etc. A veces los apéndices son descendentes y forman como alas: entónces los cálices se califican de dipteros ó tripteros, bialados ó trialados, segun el número de alas que presentan. Algunas veces el cáliz está acompañado de un calículo, órgano ya descrito al hablar de las brácteas y del invólucro, como sucede en las malváceas, F. 100, páj. 234.

La duracion del cáliz es varia: caduco ó fugaz se llama cuando cae al abrirse la flor, como en las papaveráceas, F. 90 ; caedizo si lo 
hace despues de la fecundacion y al mismo tiempo que la corola, como en muchas cricíferas, F. 89 ; permanente el que dura tanto que preste proteccion al fruto, como sucede para muchas plantas: las labiadas, borrajíneas, F. 66 y 76 ; en algunas plantas, como en el estramonio, G. 601, se rompe horizontalmente cerca de la base que sola persiste hasta la madurez del fruto. Fl cáliz permanente se dice marcescente cuando se marchita y se seca sin desprenderse: otras veces dura mucho tiempo tal cual sin nıarchitarse y por fin puede crecer y á veces mucho, como sucede en la belladona, F. 6i. y entonces se denomina acresciente ó acrecentable, y rejigoso el que adquiriendo gran tamaño se vuelve mernbranoso y encierra el fruto. como en el alkequenje ó vejiga de perro, G. 618. Segun está su superficie se llama el cáliz bosnzo, aterciopelado, felpudo, pubescente. velludo ó lanudo, lampiño, glanduloso, liso ó áspero, eslriado, anguloso, espinoso, etc. Se dice sípero cuando está adherido con el ovario cuýo vértice está acompañado ó coronado por el limbo calicinal inas 6 menos desarrollado, como lo tienen las plantas de las familias siguientes: irídeas, F. 20; myrtáceas, F. 133; cucurbitáceas, F. 141: compuestas, F. 59 ; semi-infero si está por su parte inferior soldado con el ovario y que se vuelva fruto: las lobeliáceas, F. 57 ; infero. en este caso está enteramente libre y situado por debajo del ovario: la mayor parte de las plantas lo tienen así : las labiadas, F. 76; las soláneas. F. 67; las sapotáceas, F. 84; las leguminosas, F. 130, etc.

El cáliz suele faltar algunas raras veces, como en las plantas to las familias de las nayádeas, F. 29, y de las saurúreas, etc., y entónces las flores se llaman desnudas.

\section{CAPÍTULO III}

\section{DE LA COROLA.}

\section{\$ 1. - Generalidades.}

La corola es, como lo tenemos dicho ya algo mas arriba, la parte mas interior de la cubierta floral doble, $y$ se halla por consiguiente inmediatamente despues del cáliz, de consistencia mas blanda, de tejido mucho mas fino que este último y adornada de ordinario de los mas ricos y lindos colores, y por consiguiente muy raras veces verdosa, como en la vid, G. 818. La corola es siempre compuesta de hojuelas sueltas ó libres llamadas pétalos ó soldadas entre sí que presentan una nervacion análoga á la que hemos señalado en los sépalos. En cada pétalo hay que distinguir la base y el cípice, la superficie superior ó cara y la inferior ó dorso; se llama uña la parte mas ó menos larga y estrecha con que la base se inserta, y limbo la parte ancha; se dice pues el pétalo unguiculado cuando está provisto de una uña, como en los claveles, F. 148; en las papilionáceas, F. 130, $\mathrm{J}$ =entado, al contrario, cuando está desprovisto de 
ella; la uña es á veces glandulífera ó nectarífera, como en los ranúnculos, G. 897 bis; la corola se dice fugaz ó caduca si, sin marchitarse, se desprende $y$ se cae inmediatamente despues de verificada la fecundacion, sea el burro, capparis jamaicensis, y demas especies, G. 883; el cardo santo, argemone mexicana, G. 873; marchitable ó marcescente, al contrario, cuando se queda todavía pegada bastante tiempo despues de verificada la fecundacion y va marchitándose poco á poco ántes de desprenderse y de caerse.

\section{SII. - COROLA moxopétala.}

Se llama así y tambien gamopéiala á la que es formada de una sola pieza ó pétalo que proviene de la solḋadura entre sí de un número mayor ó menor de pétalos. Se distinguen en la corola monopétala tres partes distintas, á saber : el tubo, la garganta y el limbo, que tenemos ya definidas al hablar del cáliz monosépalo. Segun sus varias modificaciones se califica de partida, hendida, lobada, dentada, á la manera del cáliz, y las divisiones se llaman liras ó lacinias, lobos ó dientes, segun su tamaño y lonjitud, cuyo número se indicará del mismo modo y con los mismos vocablos empleados para el cáliz. La corola monopétala es regular o irregular : en el primer caso se compone de partes iguales é igualmente soldarlas, pero puede sin embargo ser regular con iobos desiguales, siempre que en número igual alternen los mayores con los menores, como sucede en muchas gencianas, F. 64, y tambien siendo irregulares los lobos resulta un todo regular, siempre que aquellas sean perfectamente iguales, como en la arlelfa, G. 656. Sus formas muy variadas se espresan por los términos de globosa, aovada, aorzada, campanuda, calatiforme ó hemisférica, ciatiforme ó semejante á una copa; tubuInsa ó sea acañutada en toda su estension, como la espijelia, G. 597, y tubulada, es decir, formando tubo inferiormente; claviforme ó mazuda, embudada o infundibuliforme, como en ei tabaco, G. 599; asalvillada si forma superiormente como un platillo: el jazmin, G. 492: enrodada la que se parece á una rueda : la borraja, G. 672; la Terba mora, G. 622, y demas solanos; estrelladc cuándo parece estrella, la borreria, G. 704; escuteliforme ó con forma de escudo. En las corolas tubuladas el tubo puede ser ventrud), delgado y hasta cupilar ó cuando menos filiforme: el galan de dia, cestrum diurnum, G. 626. El limbo es plano, ćncavo, derecho, abierto, revuelto, como para el cáliz, y segun se halla mas o menos profundamente dividido se llama partido, hendido, lobado, dentado, etc. La garganta puede estar ensanchada ó estrecha, prismática, desinuda, peluda ó apendiculada, glandulosa, etc.

La corola monopetala irregular que proviene de partes desiguales ó desigualmente unidas, presenta tambien muchas formas diferentes, de las que algunas son muy notables, principalmente las que dependen de la soldadura desigual de los pétalos, como sucede cuando hay dos labios formados el uno de dos pétalos y el otro de tres; entónces se llama labiada ó mejor bilabiada, curo labio supe- 
rior se dice galea y el inferior lav la, y tiene la boca ó garganta abierta como el romero, G. 500 ; el labio superior puede ser entero, ascendente, alierto, aboredado: las salvias, G. 501 ; plano o comprianido, y tambien bifido, escotado, etc.; el inferior se llamará trifido, tripartido ó trílobo, con los lobos ó lacinias laterales generalmente menores que la intermedia, algunas veces dividida de modo que el labio viene á parecer cuadrilobado; á reces es plano, otras veces sus lobos laterales son revueltos, el intermedio es cúncavo, festoneado y hasta festoneado y escutado á la par. La corola per'sonada ó enmascarada se distingue de la bilabiada en que tiene la boca cerrada por una eminencia del labio inferior, que se llama paladar; pero cuanto á la composicion de uno y otro labio no hay diferencia entre las dos. La corola boqui-vasgada ó boqui-abierta es una simple modificacion de la corola bilabiada; tales modificaciones. orijinan las corolas monopétalas anómalas, entre las cuales citaremos la dijitaliforme. Se llama la corola volteada ó resupina cuando hay un solo labio abajo y los demas están unidos arriba, como en la albahaca, ocymum anericanum, G. 516; tambien ofrece un aspecto notable la corola bilabiada cuando los dos pétalos superiores, siendo pequeños, se sueldan menos entre sí que con los inmediatos, como en el teucrio, G. 512.

Las florecillas que constituyen las compuestas son monopétalas, regulares ó irregulares, segun si sus 5 pétalos están soldados igual ó desigualmente; tales corolas pueden ser bilabiadas, tululosas. ó liguladas, nombres que corresponden á sus formas; las últimas tienen figura de cintillas, porque sus dos pétalos superiores apenas se unen entre sí, mientras que forman un todo con los demas. Ordinariamente se llaman flúsculos las fiorecillas tubulosas y semi-fl'sculos las liguladas, F. 59 .

\section{S.III. - COROLA FOLIPÉtala Ó DIALIPÉtala.}

Se llama así á la formada de pétalos libres, cuyo número varia bastante, de tal manera que atendiendo á él se llama dipótala, tripétala, tetrapétala, pentapétala, etc.

Los pétalos son regulares ó irregulares segun si, lonjitudinalmente doblados, coinciden con exactitud ó no con sus dos mitades; segun su forma y figura propia. se han calificado de ćncavos, de naviculas'es, de coclearifor'mes ó parecidos á una cuchara, de tubulosos, de labiados, de guleiformes ó en forma de casco, de cuculiformes ó dispuestos en cucurucho, etc. En muchos pétalos las márjenes presentan desigualdades mas ó menos notables, comparables á las que hemos seilalado en las hojas, de manera que se espresan con iguales términos: se llaman pues fimlidos ó franjeados, apendiculados; el apéndice puede ser un espolon, alguna escama ó laminilla, ranunculus, F. 96, páj. 224, ó una cresta, como en muchas poligáleas., F. 107.

La corola polipétala puede ser regular ó irregular, segun sean iguales ó desiguales en tamaño y forma los pétalos que la constitu- 
yen: algunas corolas polipétalas regulares han recibido nombres especiales: cruciforme aquella cuyos 4 pétulos están dispuestos en cruz: las crucíferas, F. 89; carinfilea ó aclavelada la de İas clavellinas sencillas y de las cariofíleas en general, F. 148; 10osícea la de cinco pétalos sentados ó de uñas cortísimas, como en la rosa simple, G. 1151 ; las paparerúceas, la de las adormideras y amapolas sencillas. argemone mexicana, G. 873; las mirtáceas, F. 133.

La corola polipétala irregular se llama papilioncicea ó amariposada cuando es formada de 5 pétalos mas ó menos ungüiculados. cuyo superior, de ordinario mayor que los otros y doblado por arriba, se denomina vexilo ó estandarte; dos inferiores frecuentemente soldados entre sí, forman la quilla, y dos laterales, intermedios ó libres, mas ó menos desarrollados, que han recibido el nombre de alas: los dólicos, mucuna, canavalia, etc., G. 1069, 1054, 1031; anómala, como en la capuchina, F. 843; en el pensamiento, F. 86, formada de 5 pétalos desiguales, pero cuyo aspecto es particular.

\section{S IV. - COROLA SEUdO-POLIPÉtala Ó ĐRUdO-MONOPÉTALA, LLAMADA TAMBIEN CATAPYQC.I.A.}

Llamaremos así á las corolas cuyos pétalos están soldados entre sí por medio de sus uñas, haciendo cuerpo con la base del andróforo, y que se desprenden y caen en una sola pieza á manera de las corolas monopétalas lejítimas: las malváceas, F. 100, páj. 234, la tienen así.

\section{SEGGION III}

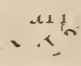

CAPÍTULO I CONSIDERACIONES GENERALES SOBRE LA FECUNDACION,
EL EMBRION Y LA SEMIILA.

Artículo $\overline{1}^{\circ}$. - Fecundacion. - Aunque en la mayor parte de las flores permanecen inmóviles los órganos sexuales, son muchas sin embargo las dotadas de una marcada escitabilidad, que de ordinario se manifiesta por movimientos de los estambres y de los pistilos, pero con menos frecuencia : en muchas liliáceas hay aproximacion de los estambres al pistilo; en los geranios se encorvan los filamentos para que la antera se aplique al estigma; en los claveles y en la ruda los estambres se van aproximando sucesivamente al estigma, haciéndolo en primer lugar los alternos con los pétalos, y en segundo los opuestos á ellos. 
La capuchina ó espuela de galan tiene 8 estambres que turnan con bastante regularidad durante ocho dias, acercándose uno á otro; en el tabaco todos sus estambres se aproximan simultáneamente: flores hay tambien cuyos filamentos necesitan ser escitados mecánicamente para moverse, como los del nopal, G. 1103. No faltan flores cuyos estigmas, de ordinario inmovibles, esperando como órganos femeninos la accion de los masculinos, se inclinan liácia los estambres, como sucede en las pasionarias, G. 1085; en algunas los estigmas bilamelados se abren para recibir el pólen, como en la escorzonera, G. 547; en el totumo, G. 556, cerrándose despues de cojido y tambien cuando se escita mecánicamente. La posicion relativa de los estambres $\mathrm{y}$ pistilos es casi siempre la mas ventajosa para que el pólen caiga sobre los estigmas á falta de movimiento que lo facilite. Frecuentemente los estambres son mas largos que los pistilos, cuando las flores hermafroditas están derechas, pero si las flores igualmente hermafroditas se hallan inversamente colocadas ó á lo menos inclinadas, suelen ser los pistilos mas largos que los estambres, cuyas anteras respecto de los estigmas toman de este modo la mas favorable posicion; pero muchas flores hermafroditas hay con los estambres y pistilos de igual lonjitud, y en tal caso los movimientos propios de estos órganos, ó los producidos por el viento y los insectos, pueden contribuir poderosamente á que el pólen caiga convenientemente cuando por su abundancia no se halla asegurado el aprovechamiento de alguna parte de él. Pueden ademas ser. fecundadas unas flores por el polen de otras inmediatas, especialmente cuando dispuestos en cabezuelas los dos órganos sexuales no llegan á sazon al mismo tiempo en cada una de ellas. Generalmente las plantas monoicas tienen las flores masculinas mas altas que las femeninas, ya sea en la misma espiga, cono el ricino, G. 144, ya en espigas distintas, como en el maiz, G. 172; y como esta sea mas eventual en las dioicas, sus flores femeninas tienen muy salientes y muy duraderos sus estilos y además las flores masculinas son numerosísimas. Las precauciones para evitar la accion de la humedad sobre el pólen son varias y muy notables en diversas plantas, mientras que en otras faltan del todo, quedando la fecundacion. abandonada al influjo de circunstancias no siempre propicias, como sucede siempre para con las plantas no acuáticas, porque las que lo son nunca se hallan desprovistas de medios para impedir la esterilidad. Entre las plantas que viven en el aire hay muchas cuyas.corolas se cierran de noche, poniendo así los organos sexuales á cubierto de la humedad atmosférica, y lo mismo se observa en varias plantas al prepararse el tiempo para llover; los pedúnculos de otras se encorvan al anochecer, y quedando sus corolas vueltas hácia abajo, no entra tan fácilmente la humedad; tambien se libran de ella algunas flores ocultándose debajo de las hojas; en fin, para mayor seguridad se verifica la fecundacion dentro de los botones de muchas flores, ó estas se abren en ticmpo seco, pudiendo aun así prestar un buen abrigo sus envolturas florales, y en especial la corola, en virtud de algunas de las disposiciones que le son propias. Pero en las plantas acuáticas suele ser mas complicado el modo de 
verificarse la fecundacion, sin que el contacto del agua pueda impedirla, ejerciendo los órganos sexuales sus funciones en una cavidad llena de aire ó saliendo entónces las flores fuera del agua.

Como ya lo tenemos dicho al hablar del estigma y del pólen, la caida de este último sobre el estigma es lo que determina la fecundacion; entónces los tubos emitidos por los granos de polen pegados en el estigwa se introducen á traves de los intersticios del tejido conductor del canalito del estilo y continuan alargándose á cuusa de una especie de germinacion, al principio de la cual se ha podido observar en la fovila que contienen el movimicnto giratorio, acaban por llegar al interior de la celdilla, en cuya cavidad están algunas veces colgantes libremente y otras veces se van arrastrando por encima de las placentas. Entónces encuentran los óvulos que se les presentan con la boca abierta de su micrópilo, por donde penetran poniéndose así en contacto con el saco embrional directamente cuando está algo saliente por fuera, ó en el caso contrario va penetrando entre las células del núcleo y se hallan en relacion con las vesículas embrionales mediatamente á través de las paredes del saco, y raras veces agujereándolas inmediatamente. Con tal contacto, sin duda las reacciones establecidas á través de esas membranas delgadísimas entre los flúidos contenidos en el tubo polínico, y por otra parte en las vesículas, se verifica el fenómeno misterioso de la fecundacion; entónces se marchita y se ve desaparecer el tubo polínico, á la par que una de las vesículas embrionales, rarísimas veces algunas, se desarrollan á la vez, multiplicándose por division: de tal desarrollo resulta el embrion. Puede suceder que algunas vesículas embrionales no se hallen en contacto con el tubo polínico, y entónces abortan y no se desarrollan, lo que se observa con frecuencia: en efecto, algunas llegan á la madurez perfecta, mientras que otras abortan, aunque contenidas las unas y las otras en la misma celdilla.

En su principio el embrion no es mas que una célula globosa llena de materia mucilajinosa sin apariencia de granillos, y poco á poco en el mucílago se organizan utriculillos que se multiplican y componen una masa celulosa. Nuevos utrículos se presentan dentro de los primitivos, y la forma del embrion varia porque se alarga y adquiere un eje mas largo, de cuyas estremidades corresponde la superior á la chalaza y la inferior al micrópilo, viniendo á constituir la una el cuerpo cotiledonar y la otra el cuerpo radicular. Sigue organizándose el embrion y marcándose mas su forma propia, notándose en el dicotiledóneo que los dos cotiledones nacen del eje como apéndices.

Verificada pues la fecundacion del modo señalado, la flor se marchita, inutilizándose los estambres y desecándose el estilo y el estigma, mientras que el ovario solo, ó á veces acompañado del cáliz y rara vez de la corola, comienza á tomar incremento para llegar por fin al estado de fruto perfecto.

Art. 2. - Semilla. - Los huevecillos, fecundados ya, principian á desarrollarse y á crecer al mismo tiempo que el ovario y adquieren sucesivamente mayor consistencia, hasta tomar la que corres- 
ponde á las semillas completamente desarrolladas en que se ha vuelto, siendo entónces capaz de orijinar otra planta semejante á la de que procede. Esperimenta el huevecillo fecundado cambios sucesivos que en lo esterior alteran mas ó menos su organizacion primitiva, de manera que se pueden conservar todas las envolturas que se pueden hallar en la semilla madura; pero con mayor frecuencia se confunden en una sola la primina y la secundina; el núclco, empujado tambien por el saco embrional y el embrion, desaparece con frecuencia, porque se suelda con los tegumeutos ó está absorvido; el mismo saco embrional, por fin sufre modificaciones, quedando convertido en una capa celular sustituida á una célula única, que lo constituia primitivamente. Así es por lo comun como se hallan en la semilla madura dos tegumentos en lugar de los cuatro que se contaban en el óvulo, cuyo esterno se llama testa, y el otro interno denominado endopleura ó membrana interna. Al mismo tiempo se verifican en su interior otros cambios, de los cuales resulta que el líquido mucilajinoso que existia en el saco embrional, y que tenemos señalado mas arriba, se organiza poco á poco y se convierte en tejido celular, que aumenta sucesivamente el espesor del saco sobre cuyas paredes se va depositando ; puede suceder lo mismo fuera del saco, ó sea dentro del núcleo, porque este no siempre desaparece. El jóven embrion se alimenta de estas materias semilíquidas susceptibles de organizarse, y absorviéndolas llega á ocupar el sitio que dejan : es la absorcion completa en muchos casos, y entónces el embrion queda inmediatamente cubierto por las envolturas; pero otras veces continua rodeado de la materia ya organizada contenida en el núcleo, ó con mayor frecuencia en el saco embrional.

\section{S I. - ENDCSPERMO.}

Esta materia solidificada que cubre inmediatamente el embrion de muchas semillas, ha recibido los nombres de perispermo, de endospermo ó albímen, sin reparar que se haya formado dentro del saco embrional ó en la superficie interna del núcleo. No tiene con el embrion ninguna continuidad de tejido: está pues enteramente independiente de él, á lo menos en apariencia, pero lo rodea, lo envuelve mas ó menos, ó esta situado á su lado, y siempre dispuesto de tal suerte que se halle listo para suministrarle el alimerito cuando lo necesitará; su tamaño es muy variable y siempre en razon inversa de el de los cotiledones que debe suplir ó reemplazar cuando demasiado delgados son incapaces de cumplir con su objeto, que consiste en remediar las necesidades del embrion nacidero ó recien nacido. El endospermo consiste pues en una masa organizada que no es para nosotros mas que un depósito natural de materias alimenticias, de figura, tamaño y consistencia muy variados: puede ser carnoso, cínneo, como en el café, en los dátiles, G. 205; harinoso, como en las gramíneas, F. 10, 11 ; cartilajinoso, coriciceo, huesoso, lapideo, caseoso, mucilajinoso, oleajinoso : en el ricino, en el coco, etc., G. 144, 
91. De ordinario forma una masa continua; en algunas rubiáceas es grumoso, en ctras plantas está compuesto de láminas y tambien puede hallarse arvugado, hendido, ruminado, cuando presenta arrugas ó pliegues numerosos, penetrando mas ó menos profundamente en él como en las anonáceas, F. 95 ; en el arequiero, G. 100, y hasta lobado, pero raramente. Las semillas de las ninfeas, G. 416, tienen dos endospermos, el uno está formado por el núcleo y el otro interior por el saco embrional. No existe en las senillas de todas las plantas, tiene una base y una punta que corresponden a las mismas partes de la semilla donde se halla.

\section{S II. - SEmilla propiamente dicha ó MadURa.}

Se llama así al huevo vejetal llegado á su completo desarrollo, a su perfeccion, y por consiguiente capaz, despues de puesto sea natural sea artificialmente, en ciertas condiciones particulares y necesarias al desarrollo de la vida, de crecer y de volverse un ser semejante al de que proviene. Contiene pues envuelto y encerrado en una ó algunas capas ó envolturas especiales, llamadas epispermo, el embrion. gérmen preciosísimo que constituye la parte vital del huevo vejetal y que es el mismo feto rejetal lejítimo cuya existencia asegura la conservacion y la propagacion de las especies. La semilla se halla en el fruto y es formada del epispermo y de la almendra, compuesta del endospermo, cuando existe, y del embrion. De ordi. nario se nota una cicatriz de color mas bajo ó mas subido que e] general de la semilla, marcándose así el punto por donde se hallaba unida á la placenta inmediatamente ó mediante el cordon umbilical: es el hilo ú ombligo, en cuyo centro ó hácia un lado hay uno ó mas agujeril!os que se llaman onfalodio y señalan el tránsito de los vasos destinados á la semilla. Segun su posicion y forma. que son bastante variadas, se dice el ombligo semilunado, acorazonado, lineai, oblongo, orbicular, etc. Además puede reconocerse la chalaza diametralmente opuesta al ombligo en muchas semillas que la presentan lajo la forma de una cminencia mas ó menos pronunciada, ó de un pezoncito que tiene á su alrededor cierta depresion circular ó de una simple mancha que se nota en el tejido del teguinento con límites poco determinados. Desde la chalaza hasta el ombligo corre una línea á veces proemineate, como en las pepitas de limon, G. 977, que se llama rafe, no siempre visible esteriormente, pero cuya existencia es consiguiente á la distincion de la chalaza. Las semillas procedentes de óvulos ortótropos ó campulítropos no presentan una chalaza distinta, siempre que en cllos no haya habido alteraciones suficientes para separarlos algun tanto de sus respectivos tipos; en las de huevecillos anátropos el ombligo se a jarta mas ó menos de la chalaza.

La micr'pila es otro punto notable que puede verse con el ombligo y la chalaza, o con el primero solo, distinguiéndose meramente por su color blanquecino cuando no presenta una pequeña abertura, como sucede en las habichuelas, guisantes, etc., G. 1077. Proviene 
la micrópila de las aberturas del huevecillo, llamadas endostoma y exostoma, ó sea micrópila interior y micrópila esterior, que llegan á cerrarse del todo ó casi enteramente á favor de un tejido poco apretado, variando en cuanto á su posicion respecto al ombligo, como varia la del ápice del núclen en el huevecillo, segun su modo de crecer. Las escrecencias carnosas ó callosas que presentan varias semillas en diferentes puntos de la superficie se señalan por las denominaciones de carúncula, callo, tubérculo : en las semillas del ricino, f. 144, está la carúncula por encima del ombligo, y debe su orịjen á los burdes engrosados y sobresalientes de la micrópila, que al principio formaban un embudo, en cuyo fondo estaba dicho agujero. Los granos de trigo y demas gramíneas presentan esteriormente una mancha morena llamada espilo, correspondiente al ombligo de la semilla. Algunas semillas están además rodeadas de una especie de envoltura mas ó menos incompleta, sobrepuesta á sus tegumentos, proviniendo del cordon umbilical, ó del rafe, llamada arilo, y aunque no llega á cerrarse completamente por el ápice, puede desarrollarse mucho, como sucede en el bonetero, evonymus venucosus, F. 124; pero aun entonces se le ve abierto por la punta, á pesar de ser mas largo que la semilla: la del nenufar ó ninfea blanca, G. 4l6, tiene un arilo cerrado del todo, puesto que presenta una abertura estrecha, la cual por el contrario es ancha en las pasionarias, G. 1085. A veces el arilo está teñido de colores mas ó menos brillantes y su borde elegantemente dividido; está calado, ceráceo y de un color rojizo moradusco, el de la nuez moscada, llamadovulgarmente macias, G. 205. El de la blighia sápida es grande, carnudo y comestible, G. 851. Otras plantas hay en que el arilo, lejos de crecer mucho, no pasa del estado rudimentario, presentándose al rededor del ombligo á manera de un tubérculo carnoso de color diferente de la semilla, y por esta razon se le ha llamado arilo falso o ariloide; se llama estrofilla al que resulta de la prolongacion del rafe.

La semilla tiene un ápice y una base conforme á su posicion en el fruto: la segunda corresponde con el ombligo, mientras el ápice es la parte diametralmente opuesta á él. Se distinguen además la cara y el dorso, é importa hacerlo cuando se hallan suspendidas las semillas y tambien si están ascendentes ó peritropas, correspondiendo entónces la cara á la placenta y el dorso á la parte opuesta; puede el ombligo hallarse sobre una de las dos anchas superficies de la semilla, siendo aplanada, y en ese caso se distinguen fácilmente la cara del dorso; pero si se halla sobre el borde ó márjen que separa las dos superficies, vienen á ser estas mas bien que cara y dorso, los lados de la semilla, que se llama comprimida, y deprimida en el primer caso. La semilla puede tener tegumento simple, doble ó triple, distinguiéndoles entre sí cuando están reunidos por los términos de tegumento esterior ó testa, tegumento interior ó endoplema, y tegumento intermedio ó mesospermo: el interior es generalmente delgado, membranoso y transparente, mientras que el esterior, crustáceo, huesoso ó acorchado, ofrece mas resistencia y determina los límites de la semilla, dándole además el color que presenta. 
El color de las semillas es tan variado como el de las flores y de las frutas, sin tener sin embargo ninguna relacion con ćl; unas tienen color de escarlata: la peronilla, abrus precatorius, G. 1014; otras son amarillas: el maiz, zea mais, G. 172; las hay parduscas, matizadas, pintadas, disciplinadas, pero la mayor parte de ellas son blancas ó prietas. Presenta gran diversidad respecto á sus dimensiones la semilla, guardando relacion con el fruto cuando es única, pero si están muclias en un frato su tamaño mengua en proporcion del número. Atendiendo á la forma, que es tambien muy variada, se la ha denominado globosa, ovoídea, arriüonada, oblonga, cilíndrica, apeonzada, recta ó rectilínea, encorvada, redoblada, aplanada, lenticular, angulosa, etc. Las semillas aplanadas pueden tener sus hordes salientes, ya gruesos, ya membranosos, y en este caso mas ó menos rasgados; se llaman entónces las semillas eleradas, membranosas, exostema floribunda, G. 719, ó rasgados mas ó menos: cuando la membrana marjinal es bastante ancha, toma el nombre de ala y se llama alada la semilla, séalo circularmente ó en determinados puntos, y se llama entónces peripterada: la moringa pterigosperma, G. 1001 ; trialada ó unialada; atendiendo á la superficie se llama la semilla lisa, lustrosa, arvugada, estriada, reticulada, escavado-punteada, hoyosa, alveolada pezoncillosa, tuberculada, muricada, aguijonosa, lampiña ó vellosa, penachuda, cuando está provista de una cabellera ó penacho: la adelfa, el asclepiade de Curaçao, G. 656, 664; rugosa y no lustrosa, como la de la secua, G. $23 \%$.

\section{\$ III. - DEL EIBRION.}

El embrion ó feto vejetal, parte esencial de la semilla, es verdaderamente la planta nacedera en miniatura, es decir que constituye un individuo, cuya vida dormida todavía necesita para salir de su letargo y despertarse, es decir, principiar á vivir, del concurso de algunas circunstancias que estamos prontos á señalar y esplicar, al hablar de la germinacion. Se compone el embrion de 4 partes distintas, que son: la raicita ó rejo, el tallito, blastema ó ejecillo, el cuerpo contiledonar ó los cotiledones, y por fin la yemecita ó plumilla. En todo embrion se distinguen una base y un ápice, correspondiendo la primera á la estremidad de la raicita y el segundo á la superior de los cotiledones, mas alta que la estremidad de la yemecita, verdadero ápice orgánico de que se prescinde por hallarse oculto. Comunmente hay un solo embrion en cada semilla, pero pueden hallarse mas, como sucede en las pepitas de naranjo, en los piñones y en muchas semillas de las coníferas y cicídeas, G. 977. - F. 33,

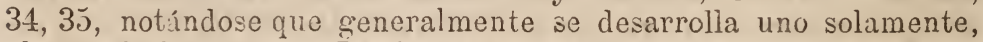
abortando los demas. La forma del embrion no es siempre semejante á la de la semilla, especialmente cuando está acompañado por un endospermo voluminoso: es de ordinario asvado, cilíndrics, mazudo; puede ser tambien globoso, lenticular, cordiforme, etc. Varia todavía mas su forma cuando tiene un solo cotiledon, entónces es 
fusiforme, piramidal, filiforme, pateniforme, fungiforme, y otras: veces está engrosado por un estremo y alelgazado por el otro, ó engrosado por ambos. Atendiendo á su direccion propia se denomina recto, encorrado, arqueado, flexuoso ú ondeado, semi-circular, espiral y apelotonado.

Respecto al endospermo, toda vez que exista, no es constante la posicion del embrion, pudiendo estar añadido en su interior. y se denomina incluso ó intravio y ha recibido los nombres de axil, basilar, apicular ó escéntrico, segun el lugar que ocupa; cuando al contrario está situado fuera del endospermo se llama estrario ó esterior, entónces puede rodear al endospermo á manera de anillo, ó estar aplicado á un solo lado y se dencmina periférico y lateral. Segun su posicion relativamente al lado de la semilla, disposicion muy importante y bastante constante en ciertas familias, se llama el embrion derecho ú hom'tropo; cuando su raicita corresponde al ombligo de la semilla, estando los cotiledones dirijidos hácia el punto opuesto; en otros casos es inver'so o antitropo, porque se hallan los cotiledones hácia el ombligo, y al contrario la raicita; se llama anfitropo el embrion cuyos dos estremos corresponden al ombligo, y por fin heievítropo, no dirijiéndose á la base de la semilla estremo alguno del embrion. Esto último sucede siendo unas veces transverso el embrion y otras oblícu, con respecto al ombligo, porque en ambos casos los cotiledones y la raicita pueden no hallarse enfrente de él. Algunos botánicos han señalado la posicion del embrion respecto del fruto, llamando la raicita sipera, infera, centripeta ó centrifuga, considerando que si se prolongase, se dirijiria sea hácia el ápice, sea hácia la base ó hácia el centro ó la circunferencia del fruto.

Raicita. No puede fijarse con exactitud antes de la germinacion donde se halla el cuello ó sea donde empieza, pero suele decirse que esta es toda la parte del ejecillo situada debajo de los cotiledones que al germinarse las semillas ha de volverse raiz y penetrar en ol suelo. Su posicion relativa con los cotiledones suministra con frecuencia muy buenos carácteres: dóblase en muchos casos sobre los cotiledones, aplicindose á la comisura que estas forman, ó bien cae sobre el dorso de alguno de ellos, que se llaman acumbentes, mientras que ella se llama lateral sucediendo lo primero, así como verificindose lo segundo se denominan incumbentes los unos, y dorsal la otra. En algunas semillas la raicita está resguardada por una vaina que presentan los tegumentos, siempre única en su oríjen, aun cuando los cotiledones sean muchos: pero puede tener en su base los rudimentos de raicillas secundarias, como sucede en muchas gramíneas. Ls tan larga como los cotiledones ó mas corta, y la iguala á veces en lonjitud; sucede frecuentemente cuando existe un solo cotiledon, que la raicita sea mas voluminosa que él, se llama macropodio el embrion, entónces falta el endospermo. Segun su forma la raicita se llama cilindrica ó c'nica, arrada, globosa, filiforme; fusiforme, mazuda, complanado-triangular, aguda, obtusa por la base, muy engrosada en el ápice ó tubercularla en el mismo. Puede tener al principio una vaina llamada coleos'riza, ó carecer de ella, $y$ 
hay casos en que la raicita se halla adherida al perispermo: el embrion se ha denominado enclórrizo, exórvizo y sinúrrizo, conforme á tales circunstancias.

\section{$\mathfrak{S}$ IV. - Cotilenunes.}

Se llama así á uno ó á dos apéndices que salen del ejecillo ó tallito, mas ć menos desarrollados y gruesos y siempre en razon inversa del tamaño del endospermo, cuando existe, y constituyendo la mayor parte de la almendra cuando falta este. Se tiene ese órgano por el análogo de las tetas de los animales mamíferos, porque su objeto consiste tambien en suministrar al vejetal nacedero ó recien nacido su primer alimento, que preparan ó elaboran á favor de los principios inmediatos que tenian guardados á propósito, lo que corresponde al período de lactacion de los animales: véase el Discurso preliminar, páj. , lo que tenemos dicho sobre el particular. Todos los vejetales provistos de flores propiamente dichas ó de organos sexuales lejítimos tienen semillas, y por consiguiente cotiledones que son dos ó uno solamente; sin embargo, plantas hay que debiendo contar entre las provistas de cotiledones, carecen de ellos, y está reducido su embrion al ejecillo sin apéndice alguno: hállanse en ese caso la cuscuta, G. 585, las orquídeas, F. 27. Cuando hay dos cotiledones están opuestos y aplicados uno á otro, con la yemita en el medio de ellos, sin dejar de quedarse libres; si hay un solo cotiledon en muchos casos, parece el embrion homojéneo á primera vista, y es menester buscar la yemita en el fondo de una pequeña cavidad que se halla en el cotiledon abierto. A veces los cotiledones pasan de dos y llegan hasta doce ó quince, como se observa en algunas coníferas, F. 33, 34; pero siempre se hallan dispuestos en verticilo. De ordinario los cotiledones son carnosos, teniendo convexa la superficie esterna, y plana la interna, ó planas a mbas, siempre lampiñas, y solo en algunos casos con glándulas vesiculares; pueden hallarse sentados, estar reducidos á un peciolo ó componerse de peciolo y lámina; algunas veces se soldan entre sí de tal manera que se confunden y se llaman conferruminados, pseudo-monocotiledóneos: el embrion en ese caso se llama macrocéfalo y el conjunto de los cotiledones adheridos se denomina cuerpo cotiledó$n e o$. Son generalmente iguales siendo dos; pero hay plantas en que difieren por su tamaño y figura, estando ambos independientes ó abrazados, de manera que el mayor, plegado, contenga al menor tambien plegado. En cuanto á los dobleces de que son susceptibles los cotiledones apareados, se nota que presentándolos uno y otro á un tiempo, varia la manera segun los casos; si están los cotiledones plegados lonjitudinalmente y abraza al interior el esterior, se llaman conduplicados, reclinados, cuando la parte superior se halla doblada sobre la inferior; presentando los pliegues lonjitudinales, puede suceder que la mitad de un cotiledon se halle entre las dos mitades del otro: se llaman en ese caso obvolutos ó semi-abrazados, y tambien los hay equitantes o abrazados; circinados se llaman los 
que se arrollan en espiral desde el ápice á la base, y convolutos haciéndolo de un borde al otro; cuando están doblados á manera de abanico se llaman plegados, y arrugados estándolo con menos regularidad.

La forma de cada cotiledon está muy marcada y se diferencia de la del embrion respectivo, $r$ atendiendo á ella se denominan lineares, oblongos, aovados, lanceolados, orbiculares, reniformes, acorazonados, falciformes, etc. Los cotiledones pueden tener orejuelas en su base, como sucede en el olmo, ulmus campestris; raras veces en fin se hallan divididos, y si lo están se califican de escotados, lobados, pinatifidos $y$ hasta de partidos, segun los casos. Bastantes reces el embrion tiene un cotiledon único, cuya forma no se diferencia de la suya propia. Segun su consistencia y composicion química, los cotiledones se dicen membranosos ó carnudos, gruesos ó delgados, feculentos ó harinosos : las hichuelas, G. 1077 ; oleajinosos: la secua, feriles cordifolia, G. 237.

Atendiendo á la existencia ó á la falta de los cotileciones en las semillas de los vejetales, se les ha calificado de cotiledineos y de acotiledíneos, y esa consideracion ha servido de base á las dos grandes divisiones del reino vejetal en vejetales ó plantas acotiledóneas, agamas ó esexuales, inembrionadas y criptígamas, llamadas tambien celulares, mientras que la otra grande division contiene las plantas cotiledíneas, fanerógamas r vasculares: esta última se ha divido en dos, segun si los vejetales tienen un cotiledon único, y entónces se llaman monocotiledíneos, $\dot{o}$ dos y hasta algunos, y se califican de decotiledóneos.

\section{S V. - yemecita ó Plumilla.}

Se llama así á aquel cuerpecito simple ó compuesto que sale de entre los dos cotiledones en las plantas dicotiledóneas, siempre escondida entre ellos, que principia al nivel de ellos, y que constituye el rudimento de las partes que han de vivir en el aire libre, y que la germinacion hace siempre bien manifiesta; en las plantas monocotiledóneas está contenida en la concavidad formada por el cotiledon y muy á menudo se ve bien solo despues de germinada ó de puesta en germinacion la semilla.

\section{$\mathfrak{S}$ VI. - tallito, Blastema ó ejecililo.}

Se ha dado esta denominacion á la parte del embrion que reune la base de cuerpo cotiledóneo con la raicita; bastantes veces parece no existir y se vuelve aparente solo durante la germinacion y se lleva consigo los cotiledones á fuera de la tierra y sostiene la yemita. 


\section{CAPÍTULO II}

\section{DE LA GERMINACION.}

Como lo tenemos dicho mas arriba, fecundados los óvulos y vueltos así seres vivientes, aunque gozando de una vida latente, el ovario que les contiene recibe mayor impulso vital, y se desarrolla con mayor ó menor prontitud, pero siempre poco á poco y gradualmente, esperimentando durante esta especie de gestacion morlificaciones que, cambiando su naturaleza, su figura y su composicion quimica primitiva, lo vuelven fruto perfecto que, maduro bastantes veces, se abre espontánea y naturalmente, echando á fuera la semilla ó el huevo vejetal, capaz entonces de vivir de su vida piopia ó de germinar : así se verifica el parto vejetal, si es lícito espresarse así, para mayor intelijencia de los hechos. Así sucede tambien para los reptiles, las tortugas y caimanes, y tambien ciertas aves comolas avestruces, las del mar y de las playas, como lo hemos visto en las del Orinoco, cuyos huevos, puestos y abandonados en la arena, echan los chiquillos despues de haber sido espuestos á la influencia dicl aire, de la humedad y del calor solar durante cierto tiempo, lo que constituje una especie de incubacion solar análoga é igual á la que necesitan tambien los liuevos vejetales para echar. Si no hay parto vejetal, es decir si los frutos llegados á su estado perfecto ó á su madurez no se abren naturalmente, entónces, despues de desprendidos de la planta que les produjo y caidos al suelo, sus partes accesorias ó las envolturas de la semilla se van destruyendo poco á poco, esperimentando reacciones químicas ó metamórfosis ya señaladas y esplanadas mas arriba en el Discurso preliminar, páj. 28, y el huevo vejetal se halla despues de esto en las mismas circunstancias que los del primer caso; esta segunda clase tiene su análogo entre los insectos; en efecto, en algunos los hueros echan en el cuerpo ó cadáver de su madre y entónces salen de él: tales son las cochinillas, los alacranes, las niguas, etc.

Se llama pues germinacion al conjunto de fenómenos tanto físicos como químicos, que se va esperimentando en la semilla fecundada y madura, despues de separada ó de desprendida de la planta madre y puesta sea natural ó artificialmente en un suelo húmedo y tal que pueda gozar la influencia del calor solar y del aire atmosférico. Con la influencia poderosa de los tres ajentes físicos electricidad, calórico y alguna luz difusa, obrando á la vez y quizás supliéndose el uno por el otro á fin que sea continua su accion, despues de absorvida mecánicamente el agua suficiente y correspondiente con las necesidades de la semilla, lo que se hace manifiesto por el aumento de su tamaño y porque se pone mas blanda, principia entónces su vida propia el feto vejetal, $y$ el ser nuevo dispertíndose sale poco á poco de su letargo, pero careciendo todavía de los organos á propósito para sacar $\mathrm{su}$ alimento de afuera, le halla preparado $\mathrm{y}$ apropiado á su debilidad en el endospermo ó en los cotiledones cuyas 
materias constituyentes han esperimentado metamórfosis sucesivas para rolverse solubles $\mathrm{y}$ tales como las necesita para su primer desarrollo. Los fenómenos físicos que se observan entónces despues del aumento general y notable de la semilla consisten en que se revienta el epispermo, la raicita se presenta al esterior, se alarga con mucha prontitud y penetra en el suelo, en donde, sencilla al salir de la semilla, no tarda en ramificarse, nacen sus chupadores y comienza su papel el tallito se alarga en sentido contrario y los cotiledones salen îuera de la tierra y, apartándose poco á poco y gradualmente el uno del otro, aparece la yemecita y las primeras hojas se desarrollan con una prontitud maravillosa en ciertos vejetales, como en las habichuelas.

¿Pero qué habrá sucedido para que tales cambios físicos se manifiesten, y que el recien nacido haya podido principiar á desarrollarse y á vejetar? En tal caso, bajo la influencia poderosa que la presencia del ser nacedero tiene sobre las rarias partes que constituyen la semilla, ó bajo la influencia vital ó catalítica del embrion vuelto feto rejetal nacierdo, las sustancias puestas en depósito en los cotiledones y en el endospermo, segun la clase con que corresponde la semilla, esperimentan ciertas reacciores químicas sucesivas y análogas á las señaladas mas arriba al hablar de la nutricion en los vejetales, pero quizás menos perfectas y menos complicadas, porque tienen lugar entre los elementos de unas sustancias orgánicas y formadas que han solamente que volverse otras ó de sufrir algunas metamórfosis despues de las cuales salen mas á propósito para cumplir con $s u$ objeto, mientras que las primeras se rerificaban entre los elementos ó moléculas de unos cuerpos inorgánicos solicitadas por la fuerza vital í entrar en nuevos agrupamientos de los cuales debia salir la molćcula orgánica para formar mas tarde los varios órganos que tienen que desempeñar las varias funciones cuyo juego ó cumplimiento regular y normal constituye la vida vejetal. Las sustancias contenidas pues en los cotiledones ó en el endospermo son principios inmediatos rejetales por la mayor parte insolubles en el agua y por consiguiente capaces de conservarse en depósito bastante tiempo sin dañarse, pero por esa misma razon incapaces en su estado normal de estar absorvidas y por consiguiente de servir así á la alimentacion del recien nacido ó del ser nacedero, pero sí con el concurso del agua, del oxíjeno de la atmósfera y de cierto grado de calor son susceptibles de volverse solubles y por consiguiente alimenticios. Tales principios son generalmente el almidon ó fécula, la sustancia córnea del endospermo o celulosa, unas sustancias grasas ó aceitosas, la albumina, la fibrina rejetal y demas materias; tocante $\{$ las sustancias oleosas ó aceites que contienen las semillas, si estuvieran absorvidos así en su estado normal matarian el feto vejetal, pero despues de haber sufrido sus elementos las reacciones y metamórfosis sucesivas y necesarias se transformarán en sustancias solubles alimenticias. Todo eso puesto, agua y oxíjeno absorvidos, los diferentes principios que contiene la semilla bajo la influencia del calor y de la electricidad, siendo formados tambien de oxíjeno, hidrójeno, carbono y algunos de azoe en proporcion gue varia segun 
su clase, esperimenta reacciones químicas ó metamórfosis que hacen encontrarse sus elementos al estado naciente con el oxíjeno atmosférico y con los elementos del agua, y entónces se agrupan de otra manera sus moléculas y se vuelven glucosa, goma, carbonato de amoniaco, ácido carbónico y acético; la glucosa y las materias gomosas absorvidas entónces alimentan al recien nacido : véase para mayor intelijencia y esplanacion del particular, el Discur'so preliminar, páj. 28.

Entre el frio que hiela y el calor que deseca hay una multitud de temperaturas propias para la germinacion de las diversas semillas, porque difieren mucho en cuanto al grado de calor que exijen para germinar, cuyo mínimo es siempre muy superior á cero para cada una, $y$ el aumento de calor acelera la germinacion ventajosamente, no lleçando á ser mucho, porque en este caso las plantas resultan débiles y mal nutridas; comunmente necesitan mas las semillas de las plantas de los paises cálidos, así como las gruesas ó cuya consistencia es carnosa, mientras que las muy pequeñas germinan fácilmente y con poco calor. Durante la germinacion daña la superabundancia de agua, porque ocasiona la putrefaccion de las semillas, $y$ en ese concepto es muy farorable el buen suelo por cuanto modera los efectos perjudiciales de la demasiada humedad; además facilita el contacto del aire cuando no es ni demasiado compacto ni demasiado lijero. Las semillas deben enterrarse en el suelo tanto menos cuanto menores sean; en los terrenos lijeros deben quedar todas ellas á mayor profundidad, respecto de la conveniencia, que en los compactos, y han de sembrarse superficialmente en los muy liúmedos, mientras que en los muy secos han de cubrirse mas. El tiempo que las semillas, bajo el influjo de los ajentes ordinarios, necesitan para germinar difiere mucho segun las especies : algunas germinan en un dia ó dos, otras en pocos mas; tardan una semana la mayor parte de las gramíneas, otras un mes, algunas especies hay que necesitan un año y otras hasta dos; aun respecto de las semillas de igual especie varia el tiempo necesario para la germinacion, segun las circunstancias en que durante ella se hallan y particularmente segun los grados de calor y humedad bajo cuya influencia se verifica. Circunstancias anteriores á la germinacion hay que pueden acelerarla ó retardarla, tales como el grado de desecacion de las semillas y el tiempo que tienen, fundándose en esto la práctica de ponerlas á remojo por algunos dias, cuando están muy duras ó son viejas. La grande tardanza proviene generalmente de ser muy duros los tegumentos de las semillas ó de hallarse revestidas de un endocarpio leñoso, que necesita mucho tiempo para ser destruido. Sustancias hay que aceleran mucho la germinacion de las semillas, tales son la disolucion de cloro, los ácidos nítrico y sulfúrico convenientemente diluidos, el iodo, el bromo, los ácidos fosfórico, tártrico, benzoico, cítrico, oxálico, acético, etc., mientras que los álcalis tienen una accion contraria : así es del azoe, etc. La conservacion de las semillas depende de su grado de madurez, siendo lo mejor que esta sea completa, y tambien favorece mucho que se hallen protejidas por involturas secas y duras, que se opongan al influjo de los ajentes es- 
teriores, así como las blandas y pulposas pueden ser perjudiciales en cuanto facilitan la putrefaccion. Bien rnaduras las semillas se conservan largo tiempo capaces de germinar, siempre que se hallen privadas del contacto del aire y de la humedad; entónces se para la vida sin apagarse sin embargo : por eso en ciertos paises se las suele enterrar á una gran profundidad en cavidades dispuestas á propósito, llamadas silos. Su conservacion espontánea se observa con bastante frecuencia en la naturaleza, porque se hallan en profundidad ó en paraje donde falta alguno de los ajentes indispensables para la germinacion, y así se esplica la aparicion de algunas plantas en terrenos removidos, $o$ en lugares desmontados que casi siempre se cubren de una vejetacion nueva diferente de la que antes existia en ellos. La facültad de germinar dura efectivamente mas ó menos, segun las especies: las hay cuyas semillas nacen aun despues de muchos años, y otras, al contrario, se inutilizan muy pronto, tales como las del café, del cacao, de la serapia, del monodora mirística, etc.

\section{CAPÍTULO III}

\section{DE LOS FRUTOS EN GENERAL.}

El pericarpio, solo ó con las partes que pueden adherírsele, crece á la vez que los huevecillos, pero no siempre es precisa la fecundacion de estos para que se desarrolle el fruto, y puede hacerlo en muchos casos de aborto de las semillas con ventaja, respecto del tamaño, como sucede en las piñas, en los plátanos y otros frutos cultivados, ó con disminucion de él, como sucede en la vid de Corinto. Atraen los frutos una gran cantidad de savia desde que cuajan y empiezan á crecer hasta alcanzar la madurez, que llega mas ó menos pronto y varia considerablemente, segun las especies; tardan, en efecto, pocos dias los de algunas, meses los de otras, un año ó algo mas los de varias, sin guardar relacion con el tamaño ú otra cualquiera circunstancia apreciable, aunque en general á la florescencia tardía parezca corresponder una mas rápida maduracion. Es lo mas comun que los frutos maduren dentro del mismo año de su aparicion, pero los hay que no lo hacen hasta el siguiente, como se observa en varias coníferas. El tamaño y aun la calidad de los frutos de muchos árboles están en razon inversa del número, siendo por tanto muy conveniente disminuirlo oportunamente, cuando pareciere escesi o. La madurez es el resultado de los cambios químicos que en los frutos se verifican bajo el influjo de los ácidos en ellos existentes y del calor atmosférico : véase en el Discurso preliminar la esplicacion de esos fenómenos, páj. 37.

El color, tamaño y forma de los frutos carnosos varian muchísimo; su sabor y consistencia se diversifican tambien asombrosamente segun las especies y variedades, siendo en las células del parénquima de los mismos frutos donde los jugos se elaboran y adquieren las cualidades de cada especie ó variedad, que además dependen de la 
naturaleza de las materias acarreadas por la savia, y de la accion de las circunstancias atmosféricas. Estas sobre todo ejercen un conocido influjo, y á ellas se deben las notables diferencias que ofrecen unos mismos frutos, segun los años y las localidades. El calor es causa muy principal de la buena madurez de los frutos, llegando á ser mas ó menos azucarados, segun su mayor ó menor intensidad, que acompañado de la luz produce al mismo tiempo la coloracion total ó parcial de ellos. El esceso de humedad, quc puede provenir del clima, suelo ó año en que se verifica la fructificacion y tambien de la demasiada juventud de los árboles, se opone á la buena madurez de los frutos, y es incompatible con las cualidades de sabor y consistencia apetecibles, porque no se puede elaborar completamente en su parénquima una cantidad tan considerable de savia y mucho menos siendo muy acuosos. Por eso es favorable á la maduracion cierto grado de sequedad en tiempo oportuno, y parece lo mejor que antes de la época próxima á la completa madurez reciban la suficiente humedad para que engruesen, y no así durante aquella, siendo entónces lo conveniente mas calor y menor agua. No es otro el fundamento de la rráctica que siguen los cultivadores de arroz, retirando el agua al aproximarze el tiempo de la madurez. Compréndese tambien por qué ciertos frutos maduran mejor separados de los árboles con alguna anticipacion, que permaneciendo sobre ellos. Algunas circunstancias especiales hay que apresuran la maduracion de los frutos, consistiendo la mas comun y natural en las picaduras de los insectos: sabido es, en efecto, cuảnto mas pronto toman gusto los frutos atacados por ellos. Farorece tambien la maduracion de los frutos la lentitud en el descenso de la savia y por consiguiente cualquier medio de moderar su movimiento, si es demasiado rápido; tal resultado se obtiene mediante una incision anular de la corteza en la rama florida, lográndose al propio tiempo que cuajen los frutos en plantas poco propicias á ello. Dícese además que los frutos carnusos crecen mejor cuando se hallan sobre algun apoyo, y que por otra parte les son favorables los sacudimientos que produce el viento. Los cálices permanentes y carnosos, los receptículos jugosos, $y$ hasta los pedúnculos, que en consistencia y volúmen se asemejan á los frutos, esperimentan modificaciones parecidas á las que se observan en la maduracion de los frutos lejítimos, sean los higos, G. 111, los pajuiles, G. 991.

Sean cuales fueren los frutos, se les ha de aplicar las varias calificaciones del ovario, setrun el numero de sus carpillos, la soldadura mas ó menos estensa de ellos, las celdillas que resultan. la situacion de las placentas, etc. La base, el cje y el cípice del fruto corresponden tambien á iguales partes del ovario y como en éste hay que distinguir el ápice orgánico del geométrico, porque el estilo puede encontrarse lateralmente situado ó cerca de la base, $y$ por consiguiente en uno y otro caso, lejos del punto mas alto que geométricamente es el ápice. Además de la cicatrícula estilar ó señal que en el fruto suele quedar despues de haberse destruido el estilo, hay otra basilar ó correspondiente á la union del fruto con el receptáculo, la cual se llama hilo cárpico. Si el cáliz estuviere soldado al ovario conti- 
nuará del mismo modo cuando este llegare á ser fruto, y tambien puede suceder que cntónces contraiga alguna adherencia el cáliz antes libre; se reconocerá siempre el cáliz adherido al fruto por la corona que sobre él forma la parte supericr y libre de aquel, como en la granada, G. 1106, ó por la cicatriz circular que deja dicha corona cuando se desprende.

Es simple el fruto cuando resulta del desarrollo de un ovario igualmente simple; compuesto si lo es el ovario de que se orijina; multiplice ó multiple cuando los varios carpillos de la flor permanecen independientes unos de otros, aun despues de haber adquirido todo su desarrollo, como en los ranúnculos, cabellos de ánjel, G. 41\%; siendo compuesto ó multiple se llama simétrico ó asimétrico, segun si tiene sus hojas carpelares en número igual al de los sépalos ó pétalos ó en número diferente, pudiendo el asimétrico serlo por esceso ó por defecto. Tambien se puede decir, como el ovario, regular ó ivregular el fruto, sea simple sea compuesto; pero la irregularidad suele aumentar en él con el mayor desarrollo, y por consiguiente se hace mas notable á medida que adelanta la maduracion. No se debe confundir con el fruto propiamente dicho, sea simple, compuesto ó multíplice, cl agregado de frutos pertenecientes á flores distintas muy aproximadas, como son las piñas, G. 462, y las de morera ó del moral, G. 220.

Todo fruto lejítimo es formado del pericarpio, que no es otra cosa mas que el ovario desarrollado, y de la semilla, que es lo mismo respecto del óvulo. Siempre que las semillas faltan por haber e caido ya,ó por aborto consiguiente á las alteraciones producidas á propósito ó no por el cultivo, se dice incompleto el fruto, y completo en el caso contrario. El pericarpio es siempre formado de tres partes diferentes bien distintas en los frutos carnudos, y soldadas entre sí en los secos, cuya esterior ó epidermis del fruto se llama epicarpio, la interior que limita la cavidad de la celda ó de las celdillas y tambien muy delgada aunque adherida algunas veces á la parte huesosa de la tercera se denomina endocarpio, y en fin la tercera, mas ó menos espesa é intermedia, se dice sar'cocarpio ó mesocarpio, que constituye la parte comestible de los frutos carnudos, cuya porcion mas interior se vuelve á veces huesosa : las ciruelas de Euroja, las guindas, G. 1024; el mango, G. 273. El pericarpio es seco en unos frutos y carnoso en otros; el primero, segun su consistencia se ha derominado mcmbranáceo, papiráceo, apergaminado, coriáceo, crustáceo, huesoso, leñoso, acorchado y fibroso; la del segundo, variando mucho menos, se dice solamente jugoso o suculento cuando en él predominan los líquidos; hay además otros grados intermedios de consistencia que no han recibido denominaciones particulares. Conteniendo el pericarpio una sola semilla puede soldarse con ella durante la madurez, como sucede generalmente en las gramíneas; por esta razon se ha llamado semilla desnuda á todo fruto cujo pericarpio muy delgado no se conserva separado de ella; estendiendo esta denominacion á los frutos de.las umbelíferas, borrajíneas, labiadas, etc., F. 149, 66, 76, que no son mas que partes de frutos, mas bien que frutos enteros, y que lian recibido el nombre de mericarpio; 
pero esceptuando las cicádeas y las coníferas, F. 33, 34, 35, no hay familia alguna cuyas plantas tengan las semillas al descubierto, y las que lo parecen son verdaderos frutos pseudospermos. Los tabiques lejítimos son verdaderas dependencias del pericarpio, y se distinguen de los espurios en el fruto como en el ovario; son tan delicados en ciertos frutos que desaparecen muy temprano, de modo que se les puede llamar fúgaces ó evánidos. Algunos de los tabiques espurios se forman durante la madurez, y quizás suceda así respecto á todos los transversales ú horizontales, como en las casias, G. 1029 , comparando sus frutos y ovarios.

El fruto formado de un carpillo único tiene dos junturas ó suturas, la dorsal ó esterior y la ventral ó interior, que existen constantemente en el fruto simple, pero no sucede así para la dorsal. Cuando proviene de un ovario compuesto las suturas ventrales no son visibles al esterior, aunque existan, mientras que pueden distinguirse tantas dorsales como carpillos, á no ser que alguno de ellos carezca de sutura dorsal, ó no la tenga marcada. Las suturas llamadas parietales resultan de la union de los carpillos entre sí, y por consiguiente son en número igual al de estos, pudiéndose reconocer tanto mas fácilmente cuanto menor es la estension de la adherencia. Estando el cáliz adherido al fruto tienen que desaparecer las suturas, pero suelen existir otras debidas á los nervios de làs hojas calicinales. Las placentas se desecan ó endurecen y hasta llegan á desaparecer cuando el fruto es seco ó tiene hueso ; pero siendo enteramente carnoso se llenan aquellas de jugo y aumentan su volúmen : son entónces comunmente mas blandas que el pericarpio, y las semillas se hallan anidadas en su masa, como en los tomates, G. 624, las guayabas, G. 1112, las sandías, G. 193. La sustancia de que se forman, cuando es jugosa, y cualquiera otra que rodea inmediatamente las semillas, toma el nombre de pulpa, distinguiéndola así de la carne del fruto; las naranjas y limones deben su abundante pulpa á multitud de celdillas fusiformes que provienen de la superficie interior del pericarpio, y se llenan de jugos creciendo hasta ocupar enteramente las ccldas. La pulpa varia mucho en los diversos frutos que la presentan, tanto respecto á la consistencia como relativamente á sus cualidades : la caña fístola, G. 1005, los tamarindos, G. 1039, los frutos del cacao, G. 923.

Los frutos varian muchísimo y á veces las diferencias son tales, que hacen distinguir con facilidad los que pertenecen á plantas diversas de las cuales son característicos. En cuanto al tamaño hay mucha variedad seguramente; pero no guarda constante relacion con el de las plantas ni el de las flores tampoco; la forma suministra carácteres de importancia y se espresa por los términos de globoso, aovado, piriforme, apconzado, oblongo, cilindrico ó rollizo, linear, alesnado, el fruto, y segun si está aplastado lateral ó verticalmente se dice comprimido ó deprimido, puede ser tambien arriñonado; si en lugar de ser redondeados sus contornos son angulosos se le llama tri, cuadri, quinque, sexangular, segun las circunstancias ; si se abulta de trecho en trecho se denomina toruloso y moniliforme, ó en forma de collar cuando los bultos están separados por 
estrecheces que le hacen parecer á una série de cuentas de rosario; segun su direccion ha recibido el fruto los nombres de recto, arqueado. falciforme, vermicular, espiral y acaracolado; atendiendo á la forma de su ápice ó de su base se dice escotado, truncado, redondo, obtuso, agudo, aguzado, umbilicado, mucronado, etc.; respecto á la superficie se califica de liso, punteado, tuberculoso, verrugoso, arrugado, reticulado, estriado, asurcado, escabroso, muricado ó erizado, lampiño, peludo, aterciopelado, pubescente, etc.; encrestado, cornudo, alado, segun si los apéndices que presenta son crestas, cuernos ó alas, y con atencion á su número se dice el fruto bi, tri, cuadri corne, unialado bialado ó diptero, trialado ó triptero, cuadri alado ó tetrúptero, alado por el ápice ó alado por los lados. Modificándose el limbo del cáliz adherente se orijina la corona, como en las mirtáceas, las guayabos y granados. F. 133, 134 y el vilano, como en las compuestas y valeriáneas, F. 59, 60; entónces el fruto recibe las denominaciones de coronado y de vilanoso; se dice picudo y coludo cuando el estilo persistente se endurece ó se cubre sin endurccerse, pero alargándose, de pelo sedoso que le hace parecer una cola : el rábano, G. 828, la clemátida de la Habana, G. 417. De ordinario los frutos no tienen olor, pero algunos suelen ser muy fragantes: la pomarosa, el ananas, etc., G. 1119, 1112, 462, y entónces puede ser un indicio de cualidades buenas ó malas.

Algunas veces sin adherir al fruto persisten á su alrededor las invólturas formándole vestiduras mas ó menos duraderas, y entónces se dice desnudo ó vestido y por consiguiente involucrado ó cubierto; por lo comun es el cáliz que forma á cada uno de los frutos su vestidura, contribuyendo á veces la corola y estambres ó estos sin aquella; como quiera, tanto el cáliz como la corola, en algunas plantas no persisten enteramente, mientras que en otras el cáliz continua creciendo y se eleva mucho mas que el fruto: la hernandia sonora, G. 142. Las vestiduras toman además en varias plantas color y consistencia que no tenian en su oríjen, desfigurándose de este modo lo bastante para ser tomadas á primera vista por pericarpios, si no se recurre à la flor.

Maduro ya el fruto y las semillas que contiene, se abre el poricarpio ó se destruye en seguida, si no es permanente, porque entónces dura tanto como los tegumentos seminales, cuyo desprendimiento se verifica solamente por la germinacion. Se llama dehiscencia el acto de abrirse espontáneamente un fruto, y como todos no lo hacen se dividen en dehiscentes ó indehiscentes. No es obstáculo á la dehiscencia que el cáliz se halle soldado con el ovario, y proporcionalmente hay de los frutos adherentes tantos que se abren como de los libres, pudiendo unos y otros presentar condiciones de tejido mas ó menos semejantes é incapaces de impedirla. La dehiscencia no es uniforme en todos los frutos y por consiguiente se verifica de diferentes modos: en muchas plantas los frutos simples se abren por la sutura ventral, en otras se efectua la dehiscencia por la sutura dorsal, y se hallan tambien muchas en las cuales tiene lugar por una y otra sutura, como sucede en una multitud de leguminosas, F. 130. Se llama valvas ó veintallas á la pieza ó piezas que suelen aparecer 
en el pericarpio despues de abierto el fruto, sea simple ó compuesto, $\mathrm{y}$ se dice $u n i, b i$, tri, multivalve siempre que la dehiscencia no fuere incompleta, porque en tal caso podrá ser el fruto semibivalve, semitrixalve, etc., ó hasta el medio, el tercio ó la cuarta parte bivalve, etc. Frutos hay en que no se verifica la separacion de las valvas por las suturas, pero sí á favor de hendiduras paralelas á las mismas, de manera que, entre valva y valva, queda un arco formando un replum ó pilar, como sucede en las orquídeas, F. 27. Cuando las hendiduras son muy poco estensas entónces presentan dientes los pericarpios, como en las cariofíleas, F. 147.

Muchos frutos compuestos y multiloculares se abren por las suturas parietales, como sucede en las escrofularias, F. 68, y en ese caso la dehiscencia se llama septícida, aun cuando la separacion no sea completa ú ofrezca cualquiera modificacion. Otros, por las suturas dorsales de sus carpillos componentes se resquehran, resistiendo á ello las parietales, y resulta que cada una de las valvas formadas de dos mitades de hojas carpelares distintas con el correspondiente tabique en medio, esa dehiscencia se denomina loculicida, sean cuales fueren sus modificaciones y ẹ grado á que llegue la separacion; se dice septifraga siempre que, desprendiéndose los tabiques de las valvas, subsistan unidos á la placenta. Otras particularidades presentan los frutos compuestos, cuya dehiscencia es valvar: frutos hay di, tri, cuadri, multicocos, procedentes de ovarios así denominados, y en ellos la dehiscencia se verifica mediante la separacion de los cocos; pero no difiere rigurosamente tal dehiscencia de la septícida, aun siendo dos las partes componentes, como en las euforbiáceas, F. 106. La dehiscencia se dice transversal la que se efectua por la parte media y transversa del fruto, como sucede para el llanten, G. 408, los amarantos, G. 197, y en tal caso el fruto se dice circunciso, y si estando adherido al cáliz se abre del mismo modo la parte libre del fruto se califica de operculado; en ciertas plantas de la familia de las leguminosas, F. 130, las legumbres son dehiscentes en artejos, lo que se hace transversalmente. Utras veces se hace por madio de poros la dehiscencia y se dice apicilar, lateral ó basilar : las adormideras, F. 90, las lobeliáceas, F. 57 ; plantas hày tambien cuyos frutos madiros tienen agujeros que se abren en puntos determinarlos, como en los dragoncillos, F. 63. En fin la dehiscencia se puede verificar de una manera irregular por rotura, y los frutos en que sucede así se llaman ruptiles. 


\section{CAPÍTULO IV}

CLASIFICACION DE LOS FRUTOS.

Seccion 1a. - Frutos apocarpios ó simples.

Art. $1^{\circ}$. - Secos. - $\$$ I. - Ixdehiscentes. - Cariopside. Fruto monospermo cuyo pericarpio muy delgado está íntimamente uniclo á la semilla: las gramíneas, F. 10.

Aquenio. - Fruto monospermo, cuyo pericarpio no adhiere íntimamente á la semilla, como en las compuestas, F. 59, en los polígonos, F. 50. Se dice diaquenio cuando dos están reunidos para formar el fruto. como en las umbelíferas, F. 149; tetraquenio cuando son cuatro, como en las barrajíneas, F. 66.

Samaru. - Fruto unilocular conteniendo una sola ó muchas semillas, y presenta lateralmente apéndices del garlos ó alas membranosas, como en la secudiraca scandens, G. 976, cuyo número variable corresponde de ordinario con el de las celdillas, tales son los frutos de muchas sapindáceas, F. 121, de muchas malpighiáceas, F. 120 , de las hipocrateáceas, 123.

Odrecillo. - Fruto unilosular con una sola ó con algunas semillas, cuyo pericarpio merabranoso se rompe á veces transversalmente, por efecto de choque mas bien que por dehiscencia natural, como en los amarantos, F. 55.

$\mathfrak{S}$ II. - Dehiscextes. - Folícuto. - Fruto unilocular abriéndose lonjitudinalmente por la sutura ventral, y presentando una sola valva exactamente igual á su unica hoja carpelar, raras veces aislado por causa de aborto, pero de ordinario doble : las apocíneas, F. 63, ó en número mayor, como en el camaruco, sterculia cartagenensis, F. 103.

Legumbre. - Fruto unilocular bivalve con una sola ó muchas semillas pendientes de las dos márjenes de la sutura ventral : las abichuelas y guisantes, F. 130. Las hay sin embargo biloculares ó multiloculares, mediante los tabiques espurios que en ellas se forman, sin que por eso dejen de ser legumbres: muchas casias las tienen así, G. 1029.

Art. 2. - Frutos apocarpios carnosos. - Drupa. - Fruto carnoso conteniendo un solo hueso ó núcleo unilocular, como en el mango, G. 273. La nuez difiere muy poco de la drupa, solamente porque su sarcocarpio es mas bien coriáceo que carnoso: juglans cinerca, G. 140; á veces la drupa es dehiscente, como on la nuez moscada, G. 245. 


\section{Seccion 11. - Frutos policarpios ó multiplices.}

Tales frutos son formados por la reunion de pocos ó de muchos frutos simples proviniendo de una sola flor, y por lo tanto pueden ser unos conjuntos de aquenios, como en las fresas, F. 132, ó de folículos, como en las esterculias, G. 265, ó de drupas, como en las zarzamoras, F, 132, ó de bayas, como en las madreselvas; y rigurosamente no scria preciso darles nombres particulares, bastando espresar que los carpillos forman cabezuelas ó espigas.

Eterio. - Conjunto de carpillos libres y secos colocados sobre un receptáculo seco, como en los ranúnculos, F. 96, páj. 228, ó sobre un receptáculo carnoso, como en las fresas, F. 132 ; o bien carnosos los carpillos sobre un receptáculo seco, como en las zarzamoras, F. 132 .

Sincarpio. - Resulta del conjunto de carpillos libres en la flor, que soldándose despues toman la forma de un solo fruto pezonoso: las magnolias, G. 906, las anonáceas, G. 900.

Cinarrodon. - Se llama así al conjunto de carpillos duros é indehiscentes encerrados dentro de un receptáculo cóncavo adherido al cáliz, como en la rosa, G. 1151.

Seccion III. - Frutos sincarpios ó compuestos.

Art. $1^{\circ}$. - Secos. - $\$$ I. - Indehiscentes. - Polaquenio. Se llama así á un fruto que despues de maduro se divide en dos ó mas partes monospermas é indehiscentes, que parecen otros tantos aquenios que han recibido el nombre de mericarpios; siendo dos forman un diaquenio, como en las umbeladas; tres un triaquenio: la capuchina, G. 843, cuatro un tetraquenio, como en las labiadas y en las borrajíneas, F. 66, 76 .

Samaridio ó samara, compuesta de varias simples íntimamente unidas: muchas malpighiáceas y sapindáceas, F. 120, 121.

Bellota. - Fruto indehiscente unilocular por aborto, cuyo pericarpio coriáceo ó leñoso es soldado con el periantio y contiene una ó mas semillas, formando un todo parcial ó enteramente cubierto por un invólucro llamado cúpula, sea esta propia de cada fruto, como en la encina y en el avellano, ó comun á varios, como en el castaño y. la haya de Europa.

Carcérulo. - Se llama así á un fruto seco plurilocular, polispermo é indehiscente, cuyas celdas no se separan unas de otras, como sucede en el tilo; puede igualmente tenerse por carcérulo la granada, distinguida como fruto particular y que se ha calificado de balausta.

\$I II. - Dehiscentes. - Silicua. - Se ha dado tal nombre á un fruto prolongado y bivalve, cuyas semillas nacen de dos placentas suturales, unidas por un tabique espurio y opuestas a los lobos del estigma: las crucíferas, como la mostaza, el berro de los rios, etc., G. 829, 830; algunas veces está indehiscente, como sucede en el rábano, y otras veces se quiebra en partes distintas por estar ar- 
ticulada ó lomentúcea, como se suele decir. La silícula difiere de la silicua solamente por no tener el largo cuádruplo del ancho, como la silicua, el mastuerzo, G. 833.

Pixidio. - Fruto uni ó multilocular transversalmente dehiscente. que proviene de muchos arpillos soldados, como en la verdolaga, G. 1127 .

Elaterio. - Asíse denomina un fruto que suele presentar costillas salientes y se divide naturalmente en tantos cocos bivalves como celdas tiene : las euforbiáceas, G. 132, el aranillero, G. 126. Se dice dicoco, tricoco ó multicoco, segun el número de cocos que tiene.

Caja ó cápsula. - Es un fruto seco uni ó multilocular, que se abre de varios modos y presenta una multitud de modificaciones, de manera que se da ese nombre á cualquiera fruto sincarpio seco y dehiscente que no se viene á colocar entre los ya denominados; su forma es por consiguiente muy variada; atendiendo á su dehiscencia se dividen las cajas en póricidas, como lo son las de las adormideras, F. 90, de las campanuláceas, F. 57 ; denticuladas y valvícidas, como la del estramonio, G. 601.

Art. 2. - Frutos sincarpios carnosos. - Nuculanio. - Se denomina así un fruto contenierdo muchos huesecillos llamados núculas, como en el sauco blanco, G. 73t; pueden á veces soldarse entre sí los huesecillos.

Anfisarca.- Fruto multilocular, polispermo indehiscente, duro ó leñoso esteriormente, carnoso y pulposo en su interior, como la totuma ó güira, 556 .

Peponida.- Es un fruto carnoso unilocular polispermo, cuyas semillas proceden de placentas parietales gruesas y pulposas, de ordinario en número de 3 , que ocupan todo el interior del pericarpio, ó dejan en el centro un hueco considerable, como en el melon, las auyamas, pepinos, ete., G. 191, 193.

Pomo ó melonida. - Ese fruto carnoso es formado de 5 ó mas carpillos con endocarpio cartilajinoso y que juntos forman otras tantas celdas, estando cubiertos por el tubo del cáliz engrosado y jugoso que se confunde con ellos; se divide en melonida con pepitas las manzanas, y la con huesccillos los nísperos de Europa, F. 132.

Hesperidio. - Se da tal nombre á un fruto carnoso provisto de una corteza gruesa y dividido interiormente en muchas celdas por tabiques membranosos, cuyas dos hojas pueden separarse con facilidad, logrando así dejar libres sus carpillos llenos de un tejido utricular muy jugoso, donde, se encuentran anidadas las semillas: las naranjas, limones, G. 977.

Baya. - Se llama así á un fruto carnoso sin hueso alguno, mas ó menos jugoso, mas ó menos grueso, de forma muy variada, proviniendo de un ovario libre ó adherente, pero que no puede colocarse entre los ya definidos: las uvas, G. 818; los tomates, G. 624, y multitud de frutos.

\section{Seccion IV. - Frutos poliantocarpios ó agregados.}

Piña, cono ó estróbilo. - Resulta de la agregacion de carpillos sin 
estilos ni estigmas, arrimados los unos á los otros á manera de escamas, siendo estas leñosas, como en los pinos, G. 105, ó carnosas, como en el enebro, G. 103, en cuyo caso se soldan y toman el aspecto de baya.

Sorosis.-Se llama así al agregado de muchos frutos perteneciendo á flores diferentes soldadas entre sí por el intermedio de sus envolturas florales carnosas, muy desarrolladas y unidas: las piñas o ananas, G. 462, fruta de pan, G. 113.

Sicono. - Agregado de frutos muy pequeños procedentes de otras tantas flores femeninas y colocados en el interior de un receptáculo carnoso á reces casi plano, como en las dorstenias, G. 167, ú ovoídeo y cerrado, como en el higo, G. 111.

\section{APÉNDICE}

Todo lo que hemos escrito, tanto en el libro primero como en el segundo, perteneciendo casi esclusivamente á los rejetales fanerógamos ó cotiledóneos, no podemos pasar adelante sin estender aquí algunas consideraciones sobre los criptógamos ó agamos, porque su organizacion $y$ su reproduccion difieren muchísimo de las de los primeros.

Las plantas criptógamas no están tan aisladas como pudiera creerse, y al contrario se hallan unidas á las fanerógamas por mas de un punto : las marsiliáceas enlazan las agamas con las aroídeas, que son monocotiledóneas, y las cicádeas, que son fanerógamas, tienen á la vez semejanza con las dicotiledóneas, entre las cuales están colocadas las monocotiledóneas y las criptógamas: liay además ciertas plantas fanerógamas, tales como las lentejas de agua, F. 31, y las nayas, que son celulosas, y al contrario son semi-vasculares una porcion de criptógamas: los helechos, F. כ. Aunque sean celulares estos vejetales, su organizacion es muy poco uniforme, y por lo que toca á los órganos nutritiros no cabe en los criptógamos inferiores una distincion real entre ellos pero sí entre los reproductores: pero en los superiores están separados unos de otros, como en las plantas fanerógamas.

Las raices son fibrosas en los criptógamos semi-vasculares, como los helechos: licopodiáceas, F. 5, 6; capilares en los puramente celulares : hepáticas, F. 4, á no ser que carezcan de ellas, como sucede en las confervas, F. 1, S.-F. 3. Sus tallos son muy rariados, pero muchísimas plantas criptógamas están desprovistas de ellos, ó en su lugar existen ya filamentos ya membranas celulares, que apenas ofrecen una remota analojía con los tallos de las fanerógamas. Se llama estipe al tallo de los helechos, tallo ó caute el de las marsiliáceas, licopodiáceas, esquisetáceas, musgos y hepáticas que lo poseen; con la denominacion de thallus ó talluelo se designan los filamentos ó membranas celulares cuyos utrículos contienen la materia colorante llamada endúcromo, como sucede tanto en las algas 
como en muchas hepáticas, y se reserva el nombre de micelo para los filamentos cuyos utrículos no encierran endócromo, como se ve en la base de los hongos que principian á desarrollarse, y así empiezan tambien los líquenes. Algunos han llamado fronde al talus de las algas y de las hepáticas.

La organizacion del talus es homojénea en las algas inferiores y en varias plantas análogas, mientras que en las algas superiores y ne las hepáticas es bastante heterojénea, pudiéndose distinguir en él partes esteriores ó corticales, intermedias ó sub-corticales, é interiores ó medulares, aunque no se debe dar á estas espresiones igual significacion, tal cual la tienen hablando de los vejetales fanerógamos.

En las criptógamas las hojas están dispuestas en espiral, lo cual deja de suceder en las plantas celulares. Los helechos llevan en sus hojas llamadas frondes sus fructificaciorres, designando el peciolo por la denominacion de estipite, $y$ de raquis el nervio medio de cada fronde; tales hojas son bastante semejantes á las de las palmeras, y mas todavía á las de las cicádeas, arrolladas como ellas en su juventud de arriba abajo. Entre las licopodiáceas y algunas coníferas se nota, respecto á las hojas, tanta analojía que se podrian tomar por ramos de sabina los de ciertos licopudios, mientras que otros mas bien parecen musgos. Las hojas en las equisetáceas están reducidas á unos dientes verticilados y soldados por la base, formando así una vaina situada en cada articulacion. En las marsiliáceas varian las hojas segun los géneros, estando arrolladas durante su jurentud las de algunos y no las de otros, ya presenten analojía con las de ciertas fanerógamas, ya les falte enteramente esta circunstancia. Los musgos tienen sus hojas sentarlas y simples, decurrentes ó no, de ordinario regulares y siempre alternas, de modo que forman espiral, atravesadas por una costilla que puede llegar hasta el ápice, que darse atrás ó sobresalir á manera de punta ó de pelo. Por último, en las hepáticas se hallan las hojas manifiestamente desarrolladas, ó al contrario confundidas, constituyendo un todo con el tallo y los ramos ó formando un thallus.

\section{ÓRGANOS DE LA REPRODUCCION EN LOS VEJETALES CRIPTÓGAMOS.}

Anteridios. - Así llamados porque se les ha comparado á las anteras, órganos masculinos de las plantas fanerógamas, porque se cree que tienen igual papel entre los criptógamos. Consisten generalmente en un saquito cuya forma y situacion varian segun las plantas; al principio perfectamente cerrados, mas tarde y á cierta época se abren en un punto de su superficie, dejando salir por esta abertura las materias que contienen y que consisten en un monton de cuerpecillos de ordinario unidos mediante un líquido mucilajinoso. En los órganos mas simples no es sino una vesícula; en otras de organizacion mas adelantada consiste en un saco membranoso compuesto de pocas ó de muchas células; su forma es tambien muy variada, tan pronto globosa y ovoídea como mazuda y abotellada; su situacion varia igualmente mucho, de manera que en unas plan- 
tas están zambullidos y escondidos en el tejido, mientras que en otras se presentan en la superficie. La materia que contienen consiste en utrículas diversamente agrupadas, segun las diferentes familias, y tales vesículas suelen contener en muchas de ellas, en lugar de fovilla, cuerpecillos elongados en forma de arco y pareciendo lombricillas, ó en espiral, y otras veces desarrollados; y tambien como en los fucos, la vesícula simple, formando el antiridio, contiene y emite inmediatamente un gran número de cuerpecillos globuloso-ovoídeos ó adelgazados por uno de sus estremos, con un punto colorido situado mas abajo. En todo caso, tales cuerpecillos son dotádos de movimientos muy rápidos, al menos durante cierto tiempo de su vida.

Arquegonios, esporanjios y esporos. - Esos órganos son tenidos por los análogos del órgano femenino de los vejetales fanerógamos, atendiendo que de ellos se orijina la fructificacion. Se observan en el espesor del tejido mismo de las plantas, ó en su superficie, otras veces sobre ciertas espansiones distintas por su forma y su situacion, como en la marchancia por ejemplo, F.4, unos órganos pequeños celulosos con figura de botella, porque dilatados inferiormente se van adelgazando repentinamente en un cuello con un canal central, al priricipio con el estremo cerrado, pero despues abierto, por haberse apartado las células terminales las unas de las otras, mientras que en los musgos se hallan situados en la estremidad de los ramos ó en la axila de las hojas. En una célula central mucho mayor que las demas se desarrolla un artejo libre, que no tarda en desdoblarse por division, y mas tarde se multiplica, desdoblándose sucesivamente. Tales células están llenas de una materia granulenta, de un protoplasma que da un aspecto opaco á ese grupo central que se ve á través de la membrana esterior trasparente. Algo despues la materia contenida en cada célula se parte en 4 pequeñas masas que no tardarán en revestirse de una membrana propia. Al mismo tiempo que eso sucede está reabsorvida la membrana de la célula madre, y las 4 masitas al principio reunidas se separan y se hallan libres en una cavidad comun. Cada una de esas masitas ó granos constituye una espora, y el cuerpo que las contiene se llama esporanjio. Se han asimilado pues los esporos que germinando reproducen las plantas á las semillas, y los esporanjios á los frutos; pero esa comparacion es muy inexacta: en efecto, ese saco celuloso conteniendo una multitud de utrículos libres, no presenta de ninguna manera carácteres de ovario, ni tampoco los utrículos formados 4 á 4 dentro de otros utrículos madres nos ofrecen los de los óvulos y semillas. En la mayor parte de las criptógamas los esporos se forman como acabamos de señalarlo, tales como en los musgos, rizocárpeas, licopodiáceas, helechos, equisetáceas; pero sin duda los esporanjios presentan modificaciones tanto en su forma como en su situacion, aunque las esporas se organizan en ellos á consecuencia de semejantes cambios ó metamórfosis, en grupos cuaternarios dentro de las células madres, llenando los esporanjios y desapareciendo en seguida por causa de su reabsorcion. Se halla tambien, pero de un modo mas oscuro, en familias de organizacion mas sencilla, como los líquenes, 
ÓRGANOS DE LA FRUCTIFICACION DE LOS CRIFTÓGAMOS. 149

verbigracia. y algunos hongos; pero la cavidad esporífera no parece entónces otra cosa mas que la célula madre que se ha quedado $y$ cuya pared, que toma el nombre de teca, forma el saco esporífero, lleno al principio por una masa semiflúida y granulenta que acaka por partirse en cierto número de esporas: dos, cuatro, seis, ocho ó mas. Algunas veces tales esporos están divididos ellos mismos cada t1no por un tabique en dos compartimientos, ó en mayor número, pero simples ó múltiples: de tal manera que puede suceder una subdivision secundaria, como nuevas tecas adherentes á sus esporos y juntamente alojadas en una teca comun. Tales tecas están agrupadas, sea en la superficie de la espansion que forma el vejetal, sea en su espesor. La formacion cuaternaria de los esporos ha sido tambien observada en muchas algas, cuyos esporos son dotados de movimiento á cierto período de su vida, el que sigue inmediatamente su salida del utrículo madre. Tales movimientos son iguales á los de los animales infusorios, efectuándose por medio de cerdas moviéndose en el agua á manera de aletas; pronto el movimiento se para, el esporo pasa de la vida animal á la vejetal y entónces principia á germinar. 


\section{LIBRO III}

\section{CLASIFIGACION DE LOS VEJETALES}

Se ha dado en la historia natural el nombre de especies á la coleccion de todos los individuos que se parecen entre sí mas que á ningunos otros; tienen pues algunos carácteres comunes que les diferencian de los demas, y que á favor de la germinacion reproducen seres semejantes á ellos, de tal suerte que por analojía se les puede considerar como orijinados por un solo individuo. Se llama variedad á las plantas que en una misma especie presentan ciertas diferencias que hacen distinguir á los individuos unos de otros y bastante constantes, de tal manera que los sujetos que provienen de sus semillas las ofrecen tambien. Por género se entiende un grupo de plantas que tienen entre sí una notable analojía y que se aproximan unas á otras por ciertos carácteres comunes.

\section{SISTEMIA DE LINNEO}

Tal sistema, injeniosísimo y tan simple que por su medio se consigue con mayor facilidad el conocimiento del nombre científico de las plantas ó su determinacion botánica, es sin duda alguna el mas á propósito para los que principian el estudio de la botánica. Ese celebérrimo naturalista lo estableció sobre las consideraciones que sacó de los órganos sexuales de los vejetales, y para formar sus clases, sus órdenes, sus géneros, etc., se aprovechỏ del número de los estambres, de su posicion relativa, de su proporcion entre sí, de su mutua adherencia y tambien de la que tienen con el órgano femenino.

Seccion I : PLANTAS ó VEJETALES FANERÓGAIIOS. bres.

Division I: flores hermafroditas. - Sub-division I : estambres 7 -

$\mathbb{S}$ I : estambres iguales entre sí r en número variado.

Clase I: Moxaxdria. Un estambre único: las geujiberáceas y marantáceas, G. $477,480$.

Cl. II - Draxdria. Algunas plantas de la familia de las labiadas, como el romero, la banderilla, etc., G. 500, 501. 
Cl. III : Triandria. Tres estambres: las gramíneas, las ciperáceas è irídeas, G. 326, 341, 467.

Cl. IV : Tetrindria. Cuatro estambres : las plantajíneas, las rubiáceas, las verbenácas, G. 567, 738, 509.

Cl. V : Pentandria. Cinco estambres : las borrajíneas, soláneas, convolvuláceas, apocíneas, etc., G. 605, 599, 65 6.

Cl. VI : Hexandria. Seis estambres : las liliáceas, las amarillídeas, las esmiláceas, etc., G. 414, 448, 460.

Cl. VII : Hertandia. Siete estambres : el anamú,petiveria alliacea, G. 285.

Cl. VIII : Octandria. Ocho estambres: las timéleas, las rutáceas, las sapindáseas, etc., G. 839, 854, 848.

Cl. IX : Exeandria. Nueve estambres: algunas lauríneas, F. 46, páj. 97, el merey ó pajuil, G. 277.

Cl. X: Decandria. Diez estambres: muchas leguminosas, F. 130; las simarúbeas, G. 864; la mu»raya exotica, G. 866; el almendro, G. 270 .

Cl. XI : Dodecandria. En esa clase, Linneo agrupó las plantas que tienen desde 12 hasta 19 estambres: rizophora mangle, G. 1149; verdolaga comun, G. 1127.

Cl. XII : Icosandria. Contiene los vejetales cuyas flores tienen desde 20 hasta 100 estambres, insertos en el ápice lel tubo calizinal : el fresal, F. 132; los rosales, G. 1151; las mirtáceas, F. 133.

Cl. XIII : Poltandria. Las plantas que forman esta clase tienen en sus flores mas de 20 estambres insertos debajo del ovario ó en el fondo del cáliz : las ranunculáceas, F. 96; clusiáceas, G. 874; anonáceas, G. 940.

Los órdenes correspondientes á cada una de esas clases han sido establecidos atendiendo al número de pistilos que contienen las flores y para espresarlo se ha empleado la terminacion jinia, que viene de la palabra griega gune, que significa mujer, como la terminacion andria de las clases se ha sacado de aner, que significa hombre; de tal modo que se les ha denominado mono-di-tri-cuadri-polijinia, segun si las plantas que les forman tienen uno, dos, tres, cuatro ó muchos pistilos, sea la pentandria monojinia, el café, G. 738; pentandria dijinia, la cuscuta, G. 585 ; las umbelíferas, F. 149; pentandria trijinia, el sauco blanco, G. 734 , etc.

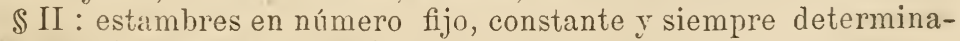
do, pero desiguales entre sí.

Cl. XIT : Drdiramis: Los vejetales agrupados en esta clase tienen sicmpre 4 estambres, cuyos dos anteriores son siempre mas cortos que los posteriores. Esta clase se divide en dos órdenes, segun si su fruto es un aquenio, porque se consideraba la semilla como estando desnuda, ó una cápsula, y en ese caso se la tenia por estar contenida en una envoltura.

Orden I : Didixisia grmasosprara ó con fruto desnudo las labiadas, F. 76; las borrajíneas, F. 66.

Or. II : Didinamia a cigrosperima ó de fruto cubierto: las bignoniáceas, F. 70; las acantácèas, F. 72; las crecenciáceas, F. 69.

C]. XV: Temradivami. Las plantas que han sido colocadas on 
esta clase tienen 6 estambres, cuyos 4 son mayores y opuestos por pares, y dos menores, solitarios y opuestos tambien : las crucíferas, F. 89. El autor del sistema sexual la dividió en 2 órdenes atendiendo al fruto, siendo una silicua ó una silícula.

Or. I : Tetradinamia silicuosa. Contiene aquellas cuyo fruto es una silícua : el berro, la mostaza, etc., G. 830, 829.

Or. II: Tetradinamia siliculosa. Aquí están aquellas cuyo fruto es una silícula: el mastuerzo, G. 833.

Sub-division II : estambres reunidos y mas ó menos pegados entre sí.

$\mathfrak{S}$ I : reunidos por medio de sus filamentos.

Cl. XVI: Monadelfia. Se han agrupado en esa clase las plantas que tienen los estambres reunidos entre sí por los filamentos, formando así un solo andróforo, quedando libres las anteras: las malváceas, F. 100, páj. 234.

Cl. XVII : Diadlefia. En esta clase los estambres forman dos andróforos, quedándose libres todas las anteras : la mayor parte de las amariposadas, F. 130, S.-F. 1.

Cl. XVIII : Poliandelfía. Cuando los filamentos reunidos forman tres ó mayor número de andróforos contenidos en la misma flor, estando siempre libres las anteras: el naranjo, G. 977; el ricino ó higuereta, G. 144.

Los órdenes se han establecido en tales clases atendiendo al número de estambres: MONADELFIA-DIANDRIA-TRIANDRIA : tamarindo de Indias, G. 1039; PENTANDRIA, strumphia americana, G. 718; ochroma lagopus, G. 919; Pasiflora laurifolia, G. 1085; HEPTANDRIA, pelargonium; OCTAN$D R I A$, pistia occidentalis, G. 154;DECANDRIA, cacao, G. 923; DODECANDRIA, guazuma, G. 922; heticteres ó tornillo, F. 100, G. 915 ; POLIANDRIA, algodonero y todas las demas malváceas, páj. 234, y así de las otras dos clases.

$\$$ III : estambres reunidos por medio de sus anteras.

Cl. XIX : Sinjenesia. Las plantas agrupadas en esa clase tienen las anteras reunidas y soldadas entre sí por los lados, de manera que forman un tubo por donde pasa el estilo y superado por el estigma, mientras todos los filamentos se quedan libres: la familia de las compuestas, F. 59. Dicha clase se divide en seis órdenes, que se llaman :

Orden I : S. poligamia rgual. Aquí están agrupadas las plantas cuyos flósculos ó semi-flósculos, es decir las florecillas ó las medias fiorecitas que componen los calátides ó cabezas, son todos fértiles: la lechuga, G. 770, 768; mikania guaco, G. 780, G. 777, 799.

Or. II : S. Foligamia superflua. En tal caso los flósculos del disco son hermafroditos y fértiles, mientras los de la circunferencia son femeninos: salvia de América, G. 782, 804, 801.

Or. III : S. poligamia Frustánea. Cuando los flósculos ó semiflósculos del disco siendo hermafroditos fértiles, los de la circunferencia están desprovistos de estigma y son por consiguiente estériles: helianthus, F. 59.

Or. IV : S. poligaitia Necesaria. En ese caso los flósculos ó semi fósculos del disco hermafroditos se hallan sin embargo estéri- 
les por causa de la imperfeccion del estigma, siendo femeninos los de la circunferencia : parthenium histerophorus, G. 784.

Or. V : S. POligamia SEPARADA. Cuando los flósculos ó semi-flósculos están dispuestos por grupos contenidos en invólucros ó cálices comunes parciales, ó cercados por escamas ó pajitas que les separan; elephantopus scaber, G. 806.

Or. VI : S. POLIGAMIM MONOGAMIA. Las flores son solitarias: lobelia longiflora, G. 687, 689 .

$\$$ IV : estambres soldados con el pistilo, con los cuales forman un cuerpo único.

Cl. XX : Givandria. Los sexos son inmediatamente reunidos. estando los estambres insertos sobre el pistilo : las orchídeas y aristoloquieas, F. 27, 45; los órdenes de esta clase han sido sacados del número de los estambres.

Or. I : Ginandria diandria. Dos estambres pegados en el pistilo : orchídeas, F. 27.

Or. II : G. TRIANDria. Cuando hay tres estambres insertos en el pistilo : rhopium salacia.

Or. III : G. HEXANDRIA. En este caso hay 6 estambres: los aristoloquios, G. 420 .

\section{Sub-division II. - Flores unisexuates ó diclines.}

Cl. XXI: Monoecia. Los vejetales agrupados en esta clase tienen todas las flores unisexuales y separadas, pero situadas en el mismo individuo: el ricino ó higuereta, G. 144; el maiz, G. 172; el araijan, G. 214.

Cl. XX: Diofcia. En ese caso las flores masculinas se hallan sobre un individuo, mientras las femeninas están sobre otro: la lechosa, carica papaia, G. 204; el dátil y el moriche, G. 204 bis, 205.

Cl. XXIII : Trioecia ó poligamia. Cuando hay flores hermafroditas sea solas sea acompañadas de flores unisexuales sobre unas plantas, mientras que flores unisexuales, sea masculinas sea femenirıas, se hallan sobre dos otras, G. 265, 270, 273, 303, 202.

Los órderes de la monoecia han sido formados atendiendo al número de estambres ó á su reunion en andróforos; los de la dioecia se han sacado igualmente del número de los estambres y de su adherencia entre sí, sea por medio de los filamentos o de las anteras.

Or. I : Monoecía movandria. Hay un estambre único : cinomorio, G. 164; castaño de las Antillas, G. 113.

Or. II : M. DIANDRIA. Cuando hay 3 estambres : auguria pedata, G. 239 ; Temna macrorthiza, F. 54.

Or. III : M. TRIANDRIA. Si las flores tienen 3 estambres: tipha angustifolia, G. 163; maiz, G. 172.

Or. IV : M. TETaxdria. Siendo 4 los estambres: roekmeria, G. 195 ; dorstenia, G. 167.

Or. V : M. pFinta NDria. En ese caso hay 5 estambres : esponja de pobre, luffa cilindrica, G. 179; amarantus blitum, G. 197.

Or. VI : M. HeXandria. Tienen las flores 6 estambres: pharus lapulaccus, G. 171; el cocotero, G. 91. 
Or. VII : M. POliandria. Cuando en las flores hay mas de 7 estambres: sagittaria obtusifolia, G. 174; begonia nitida, G. 177.

Or. VIII : M. MONA DELFIA. Estando los estambres reunidos en un andróforo único : areca oleracea, G. 100 ; yuca brava, G. 135 ; aranillero, G. 126; melon, G. 191.

Or. IX : M. GINANDRia. En este caso los estambres están insertos sobre el pistilo, G. $420,434,422,443$.

La poligamia se divide en 3 órdenes : 10 P. moxoecra. Flores hermafroditas y masculinas ó femeninas sobre un mismo individuo: acacia, G. 298, 289; $2^{\circ}$ P. DroEcia. En este caso una planta lleva las flores hermafroditas, mientras que las masculinas ó las femeninas están sobre otra, G. 203, 302; 30 P. TRIoEcía. Cuando las flores hermafroditas, solas ó acompañadas de flores unisexuales, se hallan sobre una planta, mientras las unisexuales solas están sobre dos otras: los higuerotes, 101.

\section{Division II. - Vejetales Criptóganios.}

Cl. XXIV: Las plantas agrupadas en esta última clase no tienen órganos sexuales lejítimos, es decir que no se les ha visto con ninguna flor propiamente dicha, y su reproduccion ó propagacion tiene lugar á faror de cuerpecillos particulares llamados esporos. Ha sido dividida en 4 órdenes: 1 las algas ó hidrofitas, F. 1; $2^{\circ}$ los hongos, F. $2 ; 3^{\circ}$ los helechos, F. $5 ; 4^{\circ}$ los musgos, F. 3.

\section{GLASIFIGAGioN ó HÉTODO NATURAL DE A. L. DE JUSSIEU.}

Ha formado ese método atendiendo á la falta ó á la presencia de los cotiledones, á su número y á la insercion de los estambres, de tal suerte que los vejetales se hallan agrupados segun sus afinidades naturales; teniendo tambien en cuenta la ausencia ó la presencia de la corola, la soldadura ó la libertad de los pétalos, la separacion de los sexos, er fin la union o la separacion de los estambres, formó 15 clases, como sigue:

Seccion I : Vejetales acotiledóneos.

Clase I: ACOTILEDONIA. Corresponde á la criptogamia de Lineo y contiene las mismas familias.

Seccion II : Plantas cotiledóneas.

$\mathfrak{S}$ I : MONOCOTILEDONIA. Las plantas agrupadas en esta subdivision tienen un cotiledon único ó son monocotiledóneas, $\mathrm{y}$ han sido repartidas en 3 clases, segun la insercion de los estambres.

Cl. II : MONOHIPOJINTA. En esta clase los estambres son hipójinos ó insertos por debajo del ovario : las gramíneas, ciperáceas, etc., F. 10, 11, 16, 14 .

Cl. III : MONOPERIJINIA. En tal caso los estambres son períjinos ó insertos en el cáliz: las bromeliáceas, F. 23.

Cl. IV : MONOEPIJINIA. Las plantas agrupadas en esta clase 
tienen los estambres epíjinos ó situados sobre el orario: las canneas, las orquídeas, etc., F. 26, $24,27$.

$\mathfrak{S}$ II : Vejetales dicotiledóneos ó dicotiledonia. Que se subdivide en 4 sub-secciones, las cuales están partidas á su vez en clases.

Sub-seccion I : APETALIA. Comprende los vejetales cuyas flores no tienen corola y han sido repartidos en 3 clases, formadas atendiendo á la insereion de los estambres.

Cl. V : EPISTAMINIA. En este caso los estambres son epíjinos : las aristoloquiáceas, F. 45.

Cl. VI : PERISTAMINIA. Estambres perijinos: poligóneas, timéleas, lauráceas, etc., F. 50, 49, 47, páj. 97.

Cl. VII : HIPOSTAMINIA. De estambres hipójinos: amarantáceas, plantajíneas, plumbajíneas, F. 55, 77, 78 .

Subseccion II : MONOPETALIA. Bajo esta denominacion se han agrupado los vejetales dicotiledóneos cuyas flores son monopétalas, y han sido repartidos en 4 clases, establecidas atendiendo á la insercion de los estambres y tambien á su reunion por las anteras.

Cl. TII : HIPOCOROLIA. En esta clase los estambres son hipójinos y pegados sobre la corola : las labiadas, las soláneas, las borrajíneas, etc., F. 76, 67, 66 .

Cl. IX : PERICOROLIA. De estambres períjinos: las lobeliáceas, F. 57 .

Cl. X : EPICOROLIA SINANTERIA. En ese caso los estambres, además de ser epíjinos, están reunidos por las anteras: las compuestas ó sinantéreas, F. 59.

Cl. XI: EPICOROLIA CORISANTERIA. Difiere esa clase de la anterior porque las anteras son libres: las rubiáceas, F. 62.

Sub-seccion III : POLIPETALIA. Contiene las plantas cuyas flores son polipétalas, las cuales han sido repartidas en 3 clases.

Cl. XII : EPIPETALIA. En esta los estambres son epíjinos: las umbelíferas, F. 149.

Cl. XIII : HIPOPETALIA. Las plantas que la forman tienen los estambres hipójinos : crucíferas, renunculáceas, malváceas, F. 218, 96, páj. 226, 100, páj. 234.

Cl. XIV: PERIPETAL1A. Estambres períjinos: las myrtíceas, rosáceas, leguminosas, etc. F..132, 133, 130.

Cl. XV: DICLINIA. En esta última clase el autor agrupó los vejetales dicotiledoneos, diclinos, irregulares, ó que son monoicos, dioicos y polígamos : las amentáceas, coníferas, cucurbitíceas, euforljiáceas, urtíceas, etc., F. 43, 42, 33, 34, 106, 39.

No nos engolfaremos en el estudio de los varios métodos ó clasificaciones, bastante numerosas, que han sido propuestas $\mathrm{J}$ publicadas, porque tal estudio nos llevaria demasiado lejos de nuestro objeto sin provecho ninguno para nuestros lectores $\mathrm{y}$ suscritores; nos limitaremos pues á mencionar de paso los principales, que son los siguientes: el de Tournefort, de R. Brown, de Decandolle, de Endlicher, del profesor Lindley, de A. Richard y por fin los dos últimos, y por consiguiente mas al corriente de los adelantos incesantes de la ciencia botánica, publicados pocos años liace por los célebres catelráticos de botánica del Museo de historia natural de Paris, los 
Sres. D. A. Brogniat y D. Ad. de Jussieu. Tocante al método que sigue y que tenemos adoptado para nuestra flora, confesaremos humildemente que nos hemos atrevido á disponerle así á favor de los dos de los célebres catedráticos susodichos, como mas conformes con el estado actual de la botánica, hemos tenido pues que hacerles sufrir algunas lijeras modificaciones, á fin de hermanarles de tal suerte, riue de ellos saliera un método único.

\section{Division I. - Vejetales CRiptógayos ó acotiledóneos.}

Seccion I: Vejetales celulares anjiospermos sin ningun eje, ni órgano apendicular distinto, cuyo desarrollo es periférico y cuya reproduccion se verifica por medio de esporos desnudos.

Clase I: ALGAS. - Familia 1: fucáceas, fucus, G. 16.

Cl. II : FUNGACEAS. - F. 2: hongos, agaricus boletus, G. 22,24 .

Cl. III : LIQUENEAS. - F. 3 : liquenáceas, usnea licken, G. 33,30 .

Seccion II.-Aquí están agrupados los vejetales vasculares gimnósporos, provistos de un eje ó de órganos apendiculares distintos, cuyo desarrollo ó crecimiento es terminal y cuya reproduccion o propagacion se efectua por medio de esporos contenidos en un tegumento, haciendo papel de cápsula, pero sin adherencia alguna con ellos.

Cl. IV : MUSCINEAS. - F. 5 : hepáticas, marchantia, G. 40. - F. 6: junjermánieas, jungermania. - F. 7: musgos, bryum.

Cl. V: FILICINEAS. - F. 8: helechos, polypodium, G. 52, 59. - F. 9: marsiliáceas, marsilia. - F. 10: licopodiáceas, lycopodium, G. 47. - F. 11 : equisetáceas, equisetum, G. 41. - F. 12 : charáceas, chara.

\section{Division II. - Vejetales fanerógayos ó Cotiledóneos.}

Seccion I : monocotiledóneos. - Série I.

Orden I : albuminados : en este órden se hallan agrupados los vejetales cuyo periantio es tan pronto nulo ó simple como petaloídeo, de semillas siempre con un endospermo mas ó menos desarrollado y farináceo.

Sub-órden I: vejetales monoicos y espadicífloros.

Cl. VI. A ROIDEA S.-F. 13: Aráceas, caladium, G. 161, 160. - F. 14: oronciáceas, orontium. - F. 15: tifáceas, tipha, G. 163. Sub-órden II : vejetales de ordinario hermafroditas y nunca jamás espadicífloros.

Cl. VII : GLUMACEAS, es decir cuyo periantio nulo está reemplazado por una gluma. - F. 16: gramíneas, holcus, orriza, zea, G. 259, 321, 172. - F. 17 : ciperáceas, ciperus, G. 341, 339. 
Sub-órden III : ENANTIOBLASTEOS. Vejetales cuyo embrion tiene la raicita antípoda ú opuesta al hilo.

Cl. VIII : JONCINEAS. - Grupo I : enantioblústeos lejítimos. - F. 18: comelíneas, tradescantia, comelina, G. 411, 410. - F. 19: centrolepídeas, centrolepis. - F. 20: restiáceas, restia. - F. 21: eriocíuleas, eryocolon. - F.22: xirídeas, xyris.

Grupo II: vejetales lıomoblásteos ó de raicita mirando al hilo. F. 23: joncáceas, juncus.

Orden II : EXALBUMINADOS. Se han colocado en él los vejetales de periantio tan pronto nulo como doble, sepaloídeo ó petaloídeo, con semillas de endospermo ordinariamente córneo y rara vez farináceo.

Sub-órden I: ESPADICIFLOROS.-Grupo I: A PERIANTEOS.

Cl. IX: PANDANOIDEAS. - F. 24: pandáneas, pandanus, G. 206. - F. 25: ciclántheas.

Grupo II: PERIANTEOS. - Cl. X: FENOCOIDEAS.F. 26: palmeras, phconix, cocos, etc., G. 205, 91, 95, 101, 204 bis.

Sub-órden II : ASPADICIFLOROS ó cuyas flores no están dispuestas en espádice.

Cl. XI: IIRIOIDEAS. - Grupo I: SUPEROVARIADOS y HOMOBLASTEOS á la par. - F. 27 : colchicíceas ó melánteas, veratrum, G. 418. - F. 28: liliáceas, allium, scilla, G. $414,413$. - F. 29: asparijíneas, usparragus, G. 246. - F. 30: esmilacíneas, smilax, G. 236. - F. 31 : gillésieas, gillesia.

Grupo II : INFEROVARIADOS y HOMOBLASTEOS. - $\$$ I : DIOICOS. - F. 32: dioscóreas, dioscorea, G. 243, 242.

S II : HERMAFRODITOS. - F. 33: taccáceas, tacca. - F. 34: irídeas, cipoura, G. 467.-F. 35: amarillídeas, amarillis, G. 455.F. 36: narcíseas, pancratium, G. 452.- - F. 38 : homodoráceas, anigosanthes.

Orden III. Vejetales de periantio doble, cuyo interior está petaloídeo alguna vez que otra, mientras que otras veces ambos periantios, ó mejor, las dos séries de divisiones que lo forman son petaloídeas; semillas con endospermo farináceo.

Sub-órden I. Periantio interior solo petaloídeo y simulando una corola.

Cl. XII: BROMELINEAS. Grupo Io: Superovaridos. F. 39: Pontederiáceas, pontederia, G.

Grupo II: Inferovariados. F. 40: Bromeliáceas, G. 462, 463, 460. - F. 41: tilandsieas, tillandsia, G. 459.

Sub-órden II. En este se hallan agrupados los vejetales cuyas ambas séries perigoniales son petaloídeas, pero cuya esterior está sin embargo alguna vez que otra glumácea.

Cl. XIII: ESCITAMINEAS. Grupo I: periantio siempre petaloídeo del todo. F. 42: musáceas, musa, etc., G. 448, 447.

Grupo II. Série esterior del periantio á veces glumácea. F. 43 : zinjiberáceas, zingiber, G. 478. - F. 44 : canneas, canna, G. 481.

Cl. XIV: ORQUIDIOIDEAS ó Aschidoblasteas. - Grupo I: 
GINANDROS. F. 45 : orquídeas, orchis, G. 430, 431, etc. F. 46 : vanillaceas, vanilla; G. 422 .

Grupo II: AGINANDROS ó vejetales cuyos estambres no están nunca insertos sobre el pistilo y con él soldados. F. 47: burmaniáceas, burmania. - F. 48: apostasieas, apostasia.

Orden IV. En este se han agrupado los vejetales acuáticos desprovistos de periantio ó cujo periantio único está alguna vez que otra petaloídeo; semillas de endospermo tan pronto farináceo como córneo.

Cl. XV: FLUVIALES. - Sub-órden I: exalbuminados ó aspadicifloros. - Grupo I: periantados. - Tribu I: monoperiantados.F. 49: butomáceas, butomus. - F. 50: potámeas, potamogeton.G. 306 .

Tribu II: diperiantados. - Sub-tribu I: siempre hermafroditos.F. 51: juncajíneas, trigolichin.

Sub-tribu II: tan pronto hermafroditos como monoicos. - F. 52: alismáceas, sagittaria, G. 174, 898.

Sub-tribu III : siempre monoicos ó siempre dioicos. - F. 53: naiádeas, naias. - F. 54: hidrocharideas, hydrocharis.

Sub-órden II: aperianteos.-F. 55: zosteráceas, zoster $a$.

Sud-órden III : albuminados y espadicífloros.-F. 56: pistiáceas, pistia, G. 151.-F. 57: lemnáceas, lemna, G.

Seccion II: DICOTILEDONEOS.-Sub-seccion I: GIMNOSPERMOS, es decir cuyos óvulos ó semillas son desnudas ó sin ovario que las contenga.

Cl. XVI: CONIFERAS. - F. 58 : abietíneas, pinus, G. 105.F. 59: cupresíneas, juniperus, G. 103. - F. 60: taxíneas, taxus. F. 61 : gnetáceas, ephedra.

Cl. XVII : CICADOIDEAS. - F. 62: cicádeas, zamia, G. 231.

Sub-seccion II : anjiospermeos, ó cuyos óvulos ó semillas están siempre contenidas en un ovario cerrado.

SÉrie Ia. - Apétalos. Orden I: aperianteos. - Sub-órden I: hipójinos.

Cl. XVIII : PIPERINEAS. - F. 63 : piperáceas, artante, G. 315, 316, 311.- F. 64: saurureas, saururus.

Cl. XIX : URTICINEAS. - F. 65 : urticáceas, wrtica, G. 249. - F. 66: artocarpeas, artocarpus, G. 113, 114. - F. 67: moreas, morus, G. 136, 220.- F. 68: celtídeas, celtis, G. 272. - F. 69: cannabíneas, cannabis. - F. 70: platáneas, platanus.

Sub-órden II: períjinos. - Cl. XX: $A M E N T A C E A S$. - Grupo I: exalbuminados. - F. 71 : juglándeas, juglans, G. 140. - F. 72: cupulíferas, quercus. - F. 73: salicíneas, salix, G. 213. - F. 74: betulíneas, betula. - F. 75 : miricáceas, myrica, G. 214. - F. 76 : casuaríneas, casuarina, G. 211.

Grupo II: albuminados.-F. 7\%: balsamífluas, liquidambar.

Orden II: perianteos.-Sub-órden I: epíjinos.

Grupo I : ginandros. - Cl. XXI : A RISTOLOQIACEAS. - F. 7S: aristoloquieas, aristolochia, G. 420 . 
Grupo II: aginandros. - Cl. XXII : ASARINEAS. - F. 79: citíneas, citinus. - F. 80 : azíreas, asarum.

Sub-órden II: períjinos.-Grupo I: albuminados.

Cl. XXIII : BALANOFORINEAS. - F. 81 : balanoforeas, G. 164, 165. - F. 82 : apodanteas, apodanthea. - F. 83 : raflasieas, raflasia. - F. 84: nepenteas, nepenthes. - F. 85: hidnoráceas, hidnora.

Cl. XXIV : SANTALINEAS. - F. 86 : santaláceas, santclum. - F. 87: olacíneas, olax. - F. 88: loránteas, loranthus, G. 233, 234 .

Grupo II : exalbuminados. - Cl. XXV: DAFNOIDEAS. - F. 89: lauríneas, cinnamomum, persea, G. 352, 224. - F. 90 : hernandiáceas, hernandia, G. 142. - F. 91: cirocarpeas, cyrocarpus.-F. 92: timéleas, daphnopsis, G. 218. - F. 93 : anterospermeas, antherospermum.

Cl. XXVI : PROTINEAS.-F. 94: proteáceas, protea.-F. 95: eleagneas, eleagnus.-F. 96 : aquilaríneas, aquilaria.-F. 97 : peneáceas, penea. - F. 98: monimieas, monimia.

Grupo III : albuminados ó cuyo endospermo es farináceo.

Cl. XVII : POLIGONOIDEAS. - F. 99 : poligonáceas, G. 384, $347,38 \%$.

Cl. XXVIII: QUENOPODINEAS. - F. 100 : atriplíceas ó salsoláceas, salsola, G. 400.-F. 101 : Batídeas, batis, G. 244.-F. 102: rivíneas, virinea, G. 362.-F. 103 : baséleas, basella, G. 389. -F. 104: fitolacáceas, phytolacca, G. 361.-F. 105: petiveriáceas, peticeria, G. 385.-F. 106 : tetragoníeas, tretragonia.

Sub-órden III: hipójinos. - Cl. XXIX: AMARANTINEAS.F. 107 : amarantáceas, amaranthus, G. 403, 407, 378. - F. 108 : nictajíneas, mirabilis, G. 391, 386.-F. 109: paroniquieas, paronichia.

Série II. - Gamopétalos ó Mionopétalos. - Seccion I: EUGANOPÉTALOS Ó EUMONOPÉTALOS, es decir vejetales cuya corola estaminífera es siempre bien y enteramente monopétala.

Orden I: períjinos, ó de estambres y corola insertos sobre el cáliz adherido al ovario inferior.

Cl. XXX : CAMPANULINEAS.- F. 110: lobeliáceas, lobelia, G. 687, 689. - F. 111: campanuláceas, campanula. - F. 112: goodeniáceas, spigelia, G. 595, 749, 614. - F. 113 : estilidieas, styllidia. - F. 114: brunnoniáceas, brunnonia.-F. 115: calicéreas, calicera.

Orden II: epíjinos.-Sub-órden I : SINANTÉREAS.-Cl. XXXI: ASTEROIDEAS. - F. 116: compuestas ó sinantéreas lejítimas, G. $768,773,7834,794,801$.

Sub-órden II : ASINANTÉREAS ó de estambres libres. - Cl. XXXII : LONICEROIDEAS.-F. 117: valerianáceas, valeriana, G. 691.-F. 118: dipsáceas, dipsacus.-F. 119: esfenocleas, sphenoclea.-F. 120: caprifoliáceas, sambucus, G. 734.-F. 121: columeláceas, columella. 
Cl. XXXIII : COFEINEAS.-F. 122: rubiáceas, cofea, etc., G. $738,719,741,728$.

Orden III: hipójinos.-Sub-órden I: ANISOJINOS, es decir cuyo pistilo está formado de carpillos en igual número que los sépalos, y con ovario de ordinario bilocular.

Tribu I: ISOSTÉMONOS ó ISANDROS: vejetales cuyos estambres son todos semejantes, en número igual á las divisiones de la corola y alternando con ellas.

Cl. XXXIV: ISCLEPIADINEIS.-F. 123 : loganiáceas, potalia, G. 650.-F. 124: estrícneas, strychnos, G. 614.-F. 125: asclepiadáceas, asclepias, G. 664.-F. 126: apocíneas, allamanda. cerbera, etc., G. 580, 610,656, 653. - F. 127 : gencianáceas, gentiana, etc., G. 575, 593, 594.-F. 128 : meniánteas, limnanthemum, G. 588.

Cl. XXXV: CONVOLVULINEAS. - F. 129 : polemoniúceas, polemonium.-F. 130: dicondráceas, dichondra.-F. 131 : convolvuláceas, convolvulus, etc., G. 583, 582.-F. 132: cuscutáceas, cuscuta, G. 585 .

Cl. XXXVI: ASPERIFOLIAS.-F. 133: borrajíneas, borrago, etc., G. 672, 671, 667, 605 .

Cl. XXIVII : SOLANINEAS.-F. 134 : solanáceas, solanum, etc., G. $622,620,624$ - F. 135 : cestríneas, cestrum, G. 626. - F. 136: noláneas, nolana.

Tribu II: ANISASTEMONOS ó ANISANDROS : en ella se hallan agrupados los vejetales cuyos estambres algunos abortan siempre, de tal manera que sus flores tienen algunas veces 4 estambres didínamos ó desiguales y otras veces solo dos.

Cl. XXXVIII: PERSONADAS.-F. 137: crescencieas, crescentia, G. 556, 555.-F. 138: antirríneas ó escrofulariáceas, herpestres, etc., G. 539, 570, 541.-F. 139 : orobánqueas, orobanche.-F. 140: gesneriáceas, gesneria.-F. 141: citándreas, cytandra.-F. 142: biñoniáceas, bignonia, etc., G. 528, 526, 530.-F. 143 : pedalíneas, sesamum, etc., G. 540, 547.-F. 144 : acantáceas, justicia, etc., G. $534,497,498$.

C1. XXXIX : SELAJINOIDEAS. - F. 145 : jasmíneas, jasminium, G. 491, 492. -F. 146 : utricularieas, utvicularia. - F. 147: globularieas, globularia.-F. 149: mioporíneas, bontia, G. 551.F. 149. stilbíneas, stilbium.

Cl. XL : VERBENINEAS. - F. 150 : verbenáceas, lantana, etc., G. 550, 510, 509. - F. 151 : labiadas, ocymum, etc., G. 501, 512, 516, 564, 563.-F. 152: plantajíneas, llanten, G. 567.

Sub-órden II : semi-monopétalos. - Sub-seccion I : hipójinos.Cl. XLI : PRIMULINEAS. - F. 154: teofrásteas, teophrasta, G. 262.-F. 155: primuláceas, primula.-F. 156: plumbajíneas, plumbago, G. 590 .

Sub-seccion II: períjinos.-Cl. XLII : ERICOIDEA S.-F. 15\%: ericáceas, befaria.

Sub-seccion III : peri-hipójinos, ó cuyos estambres están tan pronto períjinos como hipójinos.-Cl. VLIII : DIOSPIROIDEAS. 
TASCONOMÍA. - MÉTOdO PARA ESTA OBRA.

-Grupo I: HIPOJINOS.-F. 158 : oleáceas, olea, G. 489.—F.159: sapotáceas, sapota, G. 635, 634, 638.

Grupo II : PERIJINOS.-F. 160 : diospíreas, dyospiros, G. 301. -F. 161 : aquifoliáceas, ilex, G. 821

\section{Série II. - Diapétalos ó Polipétalos.}

Division I: HIPOJINOS.-Orden I: PLEUROSPERMOS ó de placentacion parietal.-Sub-órden I : flores cuyo cáliz persiste despues de verificada ya la fecundacion.

Cl. XLIV: VIOLINEAS.-F. 162: violárieas, jonidium, G. 819. -F. 163: droseráceas, drosera.-F. 164: sauvagesieas, sauvagesia, G. 820.- F. 165 : franquenieas, frankenia.-F. 166: raumurieas, raumuria.-F. 167: tamaricíneas, tamarix.-F. 170: bixíneas, G. 890,889 .

Sub-órden II : de flores cuyo cáliz se desprende tan pronto durante la florescencia como despues de verificada ella. - Grupo I : semillas sin endospermo ó con uno muy delgado.

Cl. XLV: CRUCIFERINEAS.-F. 171 : resedáceas, reseda.F. 172: capparídeas, capparis, cleome, G. 883, 825.-F. 173: crucíferas, sinapis, lepidium, G. 829, 830, 833.

Grupo II : semillas con endospermo espeso, cornudo ó como córneo. - Cl. XLVI : PAPAVERINEAS. - F. 174 : papaveráceas, argemone, G. 873.-F. 175 : fumariáceas, fumaria.

Orden II : CLAMIDOBLASTEOS ó vejetales cuyo embrion está envuelto en el saco embrional que al condensarse se ha vuelto endospermo: tienen pues sus semillas un endospermo doble cuyo esterior es farináceo.

Cl. XLVII : NINFINEAS. - F. 176 : ninfeáceas, ninphea, G. 416.-F. 177: nelombóneas, nelumbo, G. 415.-F. 178: hidropeltídeas, cabomba.

Orden III : AXOSPERMOS, vejetales de placentacion axil ó situada de tal manera la placenta que ocupa siempre el centro del fruto. - Sub-órden I : de flores cuyo cáliz se desprende tan pronto durante la forescencia como despues de verificada.

Cl. XLVIII : BERBERIDINEAS.-F. 179 : berberídeas, berberis.-F. 180 : menispérmeas, cisampelos, G. 240, 241.-F. 181 : lardizabáleas, lardizabala.

Cl. XLIX: MAGNOLINEAS.-F. 182: esquisándreas, schysandva.-F. 183: miristíceas, myristica, G. 215. - F. 184: anonáceas, anona, etc., G. 900, 898, 885. - F. 185 : magnoliáceas, talaum G. 894 bis.

Cl. L : RANUNCULINEAS.-F. 186 : dilleniáceas, tetracera, G. 896 bis, 897. - F. 187 : ranunculáceas, ranunculus, G. 897 bis, 417.

Sub-órden II : flores cuyo cáliz persiste de ordinario despues de 
la florescencia. - Grupo I : POLISTENIONOS, ó vejetales cuvas flores tienen muchos estambres, pero siempre en número indefinido.

Cl. LI : GUTTIFERINEAS.-F. 188: guttíferas, clusia, etc., G. 874, 876, 936, 877.-F. 189: hipericíneas, hypericum.-F. 190: ternstremiáceas, thea. - F. 191 : dipterocárpeas, dipterocarpus. F. 192: marcgraviácéas, marcgravia, G. 683.

Cl. LII : MALVOIDEAS. - F. 193 : tiliáceas, corchorus, etc., G. 891, 881, 897. - F. 194: malváceas, hibiscus, etc., G. 970, 962, 967, 971, 972.-F. 195: hermanníeas, melochia, G. 911.-F. 196: bombáceas, bombax, G. 915, 918, 919.-F. 197: esterculiáceas, sterculia, G. 265. - F. 198: bitneriáceas, oadao, guazuma, etc., G. 923, 922, 908 .

Grupo II: OLIGOSTEMONOS, ó vejetales cuyas flores tienen ordinariamente pocos estambres y en número determinado.

S I : UNISEXUALES.-CI.'LIII: CROTONINEAS.-F. 199: euforbiáceas, euphorbia, etc., G. 132, 144, 147, 135, 146, 134.

S II : HERMAFRODITOS. - Cl. LIV: POLIGALINEAS. - F. 200: vochisieas, vochisia. - F. 201: tremándreas, tremandra.-F. 202 : poligáleas, polygala, G. 974,976. - F. 203: kramerieas, kvameria, G. 975 .

Cl. LV: GERANIOIDEAS.-F. 204: oxalídeas, oxalis, G. 846, 949.-F. 205 : líneas, limum. - F. 206 : limánteas, limanthus. - F. 207: topoeóleas, tropoeolum G. 843. - F. 208: balsamíneas, balsamina.-F. 209: geraniáceas, geranium.

Cl. LVI: RUTINEA\& - F. 210: coriarieas, coriaria.-F. 211: ochnáceas, ochna. - F. 212: simarúbeas, simaruba, etc., G. 861, 865, 272. - F. 213 : cupparieas, cusparia, G. 836. - F. 214: diosmeas, moniniera. G. 669.-F. 215: rutáceas, ruta, G. 839.-F. 216: zigofíleas, zygopluyllup, etc., G. 860, 861.-F. 217 : zantoxíleas, zanthoxyllum, G. 229, $83 \pm$ bis.

Cl. LVII: HESP ERIDINEAS.-F. 218: hesperídeas ó auranciáceas, citrus, G. 97t, 866.-F. 219 : olacíneas, ximenia, G. 842. - F. 220: meliáceas, melia, etc., G. 941, 929.-F. 221: triquilieas, triquilia, G. 931, 932. - F. 222 : cedréleas, cedrela, etc., G. 942, 943.-F. 223: eritroxileas, erytvoxylon, G. 950.

Cl. LVIII : A ESC ULINEAS. - F. 224: malpighiáceas, malpighia, G. 948. - F. 225:-aceríneas, acer.-F. 226: hipocastáneas, cesculus. - F. 227 : sapindáceas, sapindus, etc., G. 853, 848, 854 .

Division II: PERIJINOS.--Seccion I: PERI-HIPOJINOS, ó cuya insercion de los estambres está tan pronto hipójina como períjina, de manera que no rara vez se halla ambigua.

Cl. LIX: CELASTROIDEAS. - F. 228 : ampelídeas, vitis, G. 815, 818.- F. 229: evonímeas, evonymus. - F. 230 : celastríneas, celastrum.-F. 231 : estafíleas, staphylea.-F. 232: hipocrateáceas, hippocratea, G. 984.

Cl. LX: RHAMNOIDEAS.-F. 233 : rhamneas, colubrina, G. 1193,1145 bis.

Seccion II : EUPERIJINOS. - Sub-seccion I: EXALBUMINADoS, ó vejetales cuya semilla está sin endospermo. 
Orden I : placenta central ó axil. - Cl. LXI : TEREBENTINEAS.-F. 234: burseráceas, bursera, etc., G. 996, 997.-F. 235: connaráceas, connarus. - F. 236: espondiáceas, spondias, G. 276, 273.-F. 237: sumacíneas, rhus, G. 988.-F. 238: amirídeas, amyris. G. 998, 997.-F. 239: anacardiáceas, anacardium, G. 277. F. 240: humiriáceas, humirium.

Cl. LXII : LEGUMININEAS.-F. 241: legumíneas ó fabáceas, cajanus, etc., G. 1065, 1059, 298, 289, 1016.-F. 242 : browneáceas, brownea, G.934.-F. 243: moringáceas, moringa, G. 1001.

Cl. LXIII : ROSINEAS. - F. 244 : rosáceas, rosa, G. 1151, 1024.-F. 245: chrisobaláneas, chrysobalanus, G. 1023. - F. 246 . homalíneas, homalium, G. 1149.

Cl. LAIV: MIRTOIDEAS.-F. 246 : calicánteas, calycanthus. -F. 247: mirtáceas, psidium, etc., G. 1112, 1114, 1122. - F. 248: lecitídeas, lecythis.-F. 249: granáteas, punica, G. 1106.

Cl. LXV: ENOTERINEAS.-F. 250 : salicarieas, cuphea, G. 1022, 993. - F. 251 : melastomáceas, melastoma, G. 1021, 1090.F. 252: memecíleas, memecyle.-F. 253: napoleóneas, napoleone.F. 254: rhizophóreas, rhizophor a, G. 1149. - F. 255 : halorájeas, hippuris.-F. 256: onagrarieas, jussieuea, G. 1092.-F. 257: combretáceas, terminalia, G. 270, 269.

Cl. LVI : CLCURBITINEAS. - F. 258 : cucurbitáceas, cucurbita, etc., G. 193, 191, 185, 193 bis.-F. 259: begoniáceas, begonice, G. 177.-F. 260: pangiáceas, hydnocarpe.-F. 261: nepenteas, nepenthes.-F. 262: darticáceas, dartica.-F. 263: podostémeas, podostema.-F. 264: lacistémeas, lacistema.

Orden II : PLEUROSPERMOS, ó de ovario cuya placenta es parietal.-Cl. LXVII: PASIFLORINEAS.-F. 265 : loáseas, mentzelia, G. 1129.-F. 266: libesieas, ribes.-F. 267: papayáceas, carica, G. 204.- F. 268: pasiflóreas, passiflora, G. 1085.- F. 269 : samídeas, samyda.-F. 270 : turneráceas, turnera, G. 819.

Sub-seccion II : ALBUMINADOS. - Orden I : CICLOSPERIOS ó de semilla cuyo embrion está enroscado al rededor del endospermo.-Cl. LXVIII : CACTOIDEAS.-F. 27l: cacteas, cereus, etc., G. 1102, 1103, 1104.-F. 2\%2: mesembrientémeas, mesembrientemum.

Cl. LXIX : CARIOFILINEAS.-F. 273: cariofíleas, dvymaria, G. 780 bis. - F. 274 : portulacáceas, portulaca, etc., G. 1121 . 381 .

Orden II : AXOSPERMOS. - Cl. LXX : SAXIFRAJINEAS.F. 275: francoáceas, francoa.-F. 276: saxifrájeas, saxifraga.-F. 277: hidránjeas, hortensia.-F. 278: cunnoniáceas, cunnonia.-F. 279: escalonieas, scalonia.-F. 280: filadélfeas, phyladelphus.

Cl. LXXI : CRASULINEAS.-F. 281: crasuláceas, bryophyllum, G. 67\%.-F. 282: cefalóteas, cephalotus.

Cl. LXXII : HAMAMELINEAS.-F. 283: hamamelídeas, $h a-$ mamelis.-E. 284: alanjieas, alanjia.-F. 285 : gumeriáceas, gitmeria.-F. 286: bruniáceas, brunia.

Seccion III: EPIJINOS.-CI. LXXIII: UMBELIF ERINEAS. - F. 287 : umbelíferas ó umbeladas, claucus, etc., G. 1137, 1143, 
1140.-F. 288 : eringieas, eryngium, G. 1131.-F. 289 : hidrocoti leas, hydrocotyle, G. 1132.-F.290: araliáceas, aralia.

Hemos seguido para nuestra Flora ese metodo, solamente nos hemos visto precisados á omitir algunas clases y muchas familias, por no suministrar nada al arte de curar ni á las artes tampoco, de tal suerte que los números de las clases y los de las familias son diferentes. 


\section{MÉTODO ANALÍTICO Y DICOTÓMICO}

PARA CONSEGUIR CON MAYOR FACILIDAD LA DETERMINACION 6 EL NOMBRE BOTÁNICO DE LOS VARIOS GÉNEROS DE PLANTAS DE QUE SE TRATA EN EL COMPENDIO DE TERAPÉUTICA VEJETAL DE LAS ANTILLAS Y DE LA PARTE CORRESPONDIENTE DEL CONTINENTE AMERICANO.

1. Vejetales fanerógamos ó de flores visibles, cuyos órganos sexuales se pueden estudiar casi sin valerse de la lente ó del microscopio, 2. - Vejetales agamos, criptógamos ó acotiledóneos, ó sin flores lejítimas, ó cuyos órganos que las reemplazan no se pueden observar ni estudiar sin emplear una buena lente ó el microscopio, 6.

2. De flores separadas ó solitarias; estambres de ordinario libres y raras veces soldados entre sí por las anteras, 3.- De flores compuestas o reunidas en número variable sobre un receptáculo comun, contenidas en un invólucro formado de hojuelas o de escamas mas $\delta$ menos numerosas y dispuestas por séries; anteras casi siempre reunidas ó soldadas entre sí, 719.

3. Hermafroditas ó unisexuales y rarísimas veces polígamas, 4 . - Tan pronto hermafroditas como polígamas, monoicas ó dioicas, 251.

4. Siempre hermafroditas, 5.- Siempre unisexuales, 84 .

๑5. Completas, es decir provistas de las dos cubiertas florales, cáliz y corola bien distintas, y de los dos órganos sexuales, estambres y pistilo, 465.-Incompletas, sin ninguna cubierta floral y desnudas ó con una sola cubierta floral, á veces reemplazada por escamas, 295.

6. Agamos ó criptógamos : vejetales desprovistos de flores, sin hojas ni tallo bien manifiestos, pero sí provistos de un thallus ó talluelo y formados de una sustancia homojénea celular, sin órganos bien manifiestos ó particulares, 7.-Con hojas y tallos mas ó menos bỉen caracterizados y exójenos ó endójenos, 36 .

7. Siempre acuáticos ó viviendo en lugares muy húmedos, fila- 
mentosos, filiformes, lameliformes ó foliáceos, provistos de una fronde: mas ó menos coloridos, propagándose por zoosporos, esporos coloreados ó por tetrasporos; alimentíndose por toda su superficie del merlio en que viven y pegados al suelo ó á las rocas á favor de garras, 9. - Nunca jamás acuíticos lejítimos y viviendo en el aire del cual sacan su alimento por toda su superficie; tienen un talluelo, 8.

8. Fungosos, pulverulentos, vejigosos ó con fluecos, crustáceos ó carnosos, de forma, tamaño y semblante muy variados; viviendo en el suelo ó como parásitas sobre los rejetales y á veces los animales, ó saliendo de las sustancias orgánicas en descomposicion sea principiante sea ya bastante avanzada; nunca jamás verdes, pero sí brunos ó coloridos; propagándose por esporos sin color ó brunos interiores ó esteriores y desprovistos de gonidias verdes, 18. - Con frondes de forma muy variada, vivaces, crustáceos, pegados en la tierra ó en los demas rejetales por medio de fibrillas celulares; multiplicándose por esporos ordinariamente encerrados en odres ó sacos ocupando espacios limitados y entremezclados con gonidias verdes, 29.

9. Cuerpos cristalinos, angulosos, fragmentarios, cerdosos, y cuya multiplicacion ó propagacion se verifica por espontánea separacion de sus propias sustancias, F. 1, S.-F. 1 y 2. - Nunca cristalinos pero celulares, vasculares ó tululareś, 10 .

10. Vasculares, filamientosos ó membranosos, propagándose por zoosporos, formados en su interior á espensas de la sustancia verde, 13.-Celulares o tubulares, 11 .

11. Celulares ó tubulares, pero nunca simétricos, 12. - Siempre tubulares únicamente, con ramitas ó brazos simétricamente dispuestos, multiplicándose por medio de núcleos dispuestos á manera de espira y llenos de una sustancia sebácea: carcíceas.

12. Propagándose por esporos simples formados esteriormente, 15. - Multiplicándose á favor de tetrasporos, 17.

13. Una fronde membranosa, llana ó tubulosa, verde ó purpurina, formada de uns sola ó de algunas capas de utrículas justapuestas; esporos ó zoosporos con frecuencia cuaternarios: ulva, F. 1, S.-F. 3, T. XIII.-Ninguna fronde, 14.

14. Células globosas ó elípticas agrupadas por séries filiformes, simples ó ramosas y reunidas dentro de una masa mucilajinosa diversamente conformada; viven sobre la tierra húmeda: nostoc, F. 1, S.-F. 3, T. III.-Filamentos simples o ramosos articulados; gonidias verdes, color de aceituna ó brunas; esporos simples nacidos de la concentracion de las gonidias, de un solo endocromo ó de los dos endocromos vecinos : conferva, F. 1, S.-F. 3, T. IX.

15. Aerocistos ningunos; fronde continua, membranosa ó plana, las mas veces flabeliforme; esporos esteriores esparcidos ó agrupados en soros y acompañados ó no de parasporos : dictyota, F. 1, S.F. 5, T. XII.-Siempre ó frecuentísimamente provistos de aerocistos, 16.

16. Fronde célulo-filamentosa continua y color aceitunado; frecuentemente provistos de aerocistos que suelen faltar bastantes ve- 
ces; con conceptáculos esparcidos ó agrupados por el vértice de los ramos , pero nunca jamas reunidos dentro de un receptáculo distinto de la fronde : fucus, F. 1, S.-F. 5, T. XI.-Aerocistos siempre presentes $\mathrm{y}$ dispuestos á manera de cadena ó contenidos en el interior de la fronde, que es muy variada, ó distintos y pedunculados; receptáculos distintos, simples ó ramosos, solitarios ó agrupados, axilares ó terminales: sargassum, F. 1, S.-F. 5, T. IX.

17. Frondes monosifóneas, articuladas, raras veces celulosas; receptáculos desnudos ó involucrados; tetrasporos frecuentemente salientes por afuera, color rojo mas ó menos oscuro: ceramium, F. 1, S.-F. 4, T. I. - Frondes continuas compuestas de celdillas redondeadas ó poliédricas; receptáculos esteriores; tetrasporos agrupados ó agregados con forma de manchas ó colocados sobre esporófilos : plocamium, F. 1, S.-F. 4, T. X.

18. Un himenion sea esterior y desnudo, sea interior y contenido en un peridio, 19. - Sin himenion ó membrana fructífera alguna visible, 27.

19. Himenion desnudo; esporos generalmente cuaternarios, sostenidos por esporanjios distintos; hongos carnosos, esponjosos, etc., y de forma muy variada, 20. - Himenion ó membrana fructífera contenida en un peridio; esporos generalmente cuaternarios sostenidos por esporanjios distintos; hongos mas ó menos redondeados, al principio cerrados y mas luego reventándose desigualmente, para que salgan los espórulos con forma pulverulenta ordinariamente, 26.

20. Himenion formado de láminas ó plemado, poroso ó sinuoso, subulado ó tuberculado, 21. - Himenion lampiño confluente con el receptáculo, anfíjeno y liso, pero nunca jamás laminoso, poroso, subulado ni tuberculado tampoco, 25.

21. Laminoso y plegado, 22. - Poroso ó sinuoso, subulado ó tuberculoso, 23 .

22. Siempre laminoso: hongos perfectos con figura de paraguas, de somirerillo mas ó menos redondeado, de color variado, convexo, sostenido por un pedúnculo mas ó menos largo "“ láminas verticales cubriendo toda la cara inferior del sombrillo y dispuestas á manera de radios desde el centro ocupado por el pedúnculo hasta la circunferencia, completas ó incompletas, con ó sin-velo: agaricus, F. 2, S.-F. 2. - Himenion plegado, cuyos pliegues son dispuestos á manera de radios y ramosos, sub-paralelos; sombrillo carnoso ó membranoso, sentado ó estipitado: cantharellus, F. 2, S.-F. 2.

23. Himenion poroso ó sinuoso, 24. - Himenion subulado ó tu berculado, homojéneo y concreto con el sombrillo y como aguijonoso, cuyas puitas cerradas son libres ó reunidas por la base; ascijeros esteriormente; hongos terrestres de sombrilla estipitada ó sentada, mas veces irregular: hydnum, F. 2, S.-F. 2.

24. Homojéneo con la sombrilla concretada, porosa, cuyos poros sub-redondeados y simples son ascíferos interiormente: hongos terrestres ó parásitas, de sombrilla hemisférica, carnosa, blandita, con pedúnculo central á veces reticulado: boletus, F. 2, S-F. 2.

2う. Hongos terrestres que parecen árboles en miniatura, mas ó 
menos blancos; receptáculo derecho, cilíndrico, homojéneo, confundido con el estipe; himenion concreto superficial con los sacos superficiales, distintos y delgados : clavaria, F. 2, S.-F. 2 .

26. Terrestres de ordinario, provistos de raicitas y sin pedúnculo bien manifiesto: lycoperdon, F.2, S.-F. 3.

27. Esporos simples, frecuentemente tabicados, situados sobre esporóforos mas ó menos distintos, copos fructíferos mas ó menos pedunculados, 28. - Esporidias contenidas en odres y generalmente en número de 4; vejetales subterráneos y pareciendo como tubérculos, casi globosos, mas ó menos parduscos, esteriormente lisos ó papiloso-verrugosos, indehiscentes ; interiormente coriáceo-venosos y reticulado-venosos y casi de aspecto de marmol el corte: $t u$ ber, F. 2, S.-F. 3.

28. Parásitas en las semillas ó en los ovarios fecundados de algunas gramíneas, cuyo gérmen destruyen y reemplazan, presentándose entónces con forma de masa sólida mas ó menos alargada ó hemisférica, cuyos espórulos se hallan en el interior: spermoedia, F. 2, S.-F. 3 .

29. Núcleo ó thallus cargando con odres ó apotecias bien manifiestos, 30. - Núcleo ó thallus sin sacos ó apotecias tampoco visibles, pero al reventarse se presentan esporos desnudos; thallus pulverulento y núcleo coetáneo, F. 3, T. I.

30. Thallus homojéneo jelatinoso o cartilajinoso, F. 3, T. II. Thallus heterojéneo pulverulento ó celular, 31 .

31. Duplo, cuyo primario es horizontal, crustáceo ó escamosofoláceo, mientras el segundo es vertical y se vuelve como ramitas cartilajinoso-fistulosas ó huecas, todas subuladas; apotecias libres, desnudas, con receptáculo propio; orbiculares terminales ó esféricas, convexas y con figura de cabeza, sin ribete, pegadas por la circunferencia, con los lados uniformemente hácia adentro : cladonia, T.3, T.IV.-Thallus simple ó único, y receptáculo thaliforme, 31 bis.

31 bis. Horizontal, estendido desde el centro, diferente por la base, frecuentemente velludo; receptáculo al principio connivente y por fin abierto, 32. - Thallus vertical-cosimile, receptáculo abierto desde el principio, 33 .

32. Cartilajinoso y estendido por ambos lados, provisto de un hipothallus abultado; receptáculo con un disco subceráceo y provisto por la márjen de una membrana; apotecias con figura de escudo y horizontales : parmetia, F. 3, T. IV.-Foliáceo, velludo por debajo, sin hipothallus ninguno; receptáculo con un disco carnosito inato y al principio dispuesto á manera de velo; apotecias peltiformes; vejetales terrestres subiendo de entre los musgos: peltigera, F. 3, T. IV.

33. Thallus mas ó menos cartilajinoso, 34. - Thallus nunca cartilajinoso; vejetales criándose ordinariamente sobre la corteza de los árboles y que se presentan con forma de espansiones crustáceas, cilíndricas y ramosas, con una especie de apéndice central filamentoso ; apotecias terminales ó abroqueladas ; receptáculo thaliforme, con disco semejante por la márjen : usnea, F. 3, T. IV.

34. Nunca jamás membranoso, 35.-Cartilajinoso y membranoso 
á la par; vejetales terrestres saliendo de entre los musgos; apotecias con figura de escudo, pegadas oblícuamente en la márjen del thallus; receptáculo thaloídeo teniendo por la márjen un disco por fin desigual : cetraria, F. 3, T. IV.

35. Thallus blandito esteriormente como estóposo ; apotecias escutiformes y marjinales; receptáculo thaloídeo llevarıdo por la márjen un disco semejante : evernia, F. 3, T. IV. - Thallus tieso, planta que se cria sobre los peñascos marítimos; apotecias escutiformes y laterales; receptáculo propio con figura de cúpula, thaloí-

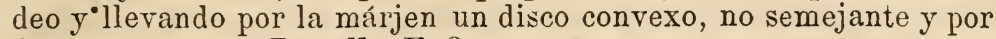
fin evanescente : Roccella, F. 3.

$36^{\circ}$. Celulares ó vasculares, con las cajillas esporíferas sea inmersas en la sustancia de la fronde, sea encerradas en una especie de capucho con figura de gorra, 37.- Siempre vasculares, con las cajillas esporíferas nunca jamás inmersas en la sustancia de la fronde, ni envueltas tampoco por capucho alguno, 46.

37. Cajillas esporíferas, sin opérculo alguno, pero casi siempre con un elaterio ó filamento en espiral echado entre los espórulos en el interior de ellas, 38. - Capsulitas esporíferas siempre provistas de un opérculo, pero sin elaterio, 42.

38. Abriéndose por ventallas en un número definido é iguales; yerbitas rastreras pareciendo musgos, con hojitas celulares cercando un eje central; otras veces la hoja y el eje se confunden para formar una espansion membranosa; cajilas esporíferas con 4 valvas ó 4 partidas, con ó sin columela central; esporos entremezclados con los elaterios : jungermanieas, F. 4. - Cajillas esporíferas sin valvas, 39 .

39. Siempre provistas de un elaterio, 40.- Sin elaterio siempre; yerbecitas acuáticas y nadantes, cuyas hojas y tallo se hallan confundidos en una especie, de fronde celular, conteniendo las anteridias, cura boca aparece al esterior con forma de papila ó de cono delgadito; pistilidias mono ó dioicas inmerjidas en su propia sustancia ó superficiales; sentadas ó pedunculadas; invólucro comun escamoso ó nulo; involúcelos nulos ó con figura de vejiguita agujereada por el vértice; cajillas esporíferas unidas con la cofia ó distintas de ella, globosas y reventándose desigualmente; esporos triangulares ó piramidales : ricciaceas, F. 4.

40. Peltadas ó abroqueladas; rajándose por un solo lado, y con cada esporo provisto de su elaterio propio, 41. - Reventándose irregularmente ; yerbecitas estendidas sobre la tierra húmeda ó sobre la corteza de los árboles, con figura de espansiones foliáceas ó membranosas ; cajillas esporíferas pedunculadas abriéndose por medio de grietas irregulares ó de dientes separados; esporos globosos entremezclados con elaterios, anteridias inmersas en la fronda 0 colocadas sobre receptáculos disciformes y sesiles ó abroquelados : marchancieas, F. 4.

41. Yerbas mas ó menos altas y ramosas, de tallo compuesto de artejos huecos ceñidos por una membrana envainadora y dentada, sin hojas; fructificacion terminal formando conos ó cabezas compuestos del agrupamiento de escamas abroqueladas cuya cara infe- 
rior carga con las cajillas esporíferas que se abren por medio de una grieta situada en su lado interno : equisetum, F. 7 .

42. Abriéndose por medio de valvas, 43. - Sin valva alguna, 44.

43. Terbecitas ramosas que parecen musgos, rojizas ó parduscas, de hojitas imbricadas con o sin costilla; cajilla esporifera provista de un capucho con figura de gorra, sentada sobre una especie de tubérculo ó de apófisis espeso, rajándose lonjitudinalmente en cuatro valvas iguales, de vértice reunido por el opérculo persistente; esporos pegados en derredor de una columna central : andríceas.

44. Musgos lejítimos : pequeñas plantas herbáceas de eje cubierto de hojitas imbricadas enteras ó aserraditas: dos clases de órganos reproductores tienen: $1^{\text {a }}$ las anteridas, especies de sacos axilares, cilíndricos ó fusiformes y pedicelados, conteniendo muchos corpúsculos esféricos ú ovales; 2 a las pistilidias, con figura de botella y encerrarlas en una bráctea enrollada y cabalmente situadas por encima de la punta de las cajillas esporíferas, sostenidas por una cerda ó pedícelo y cubiertas por un capucho membranoso y cerrado por una tapa ú opérculo, por debajo del cual se hallan apéndices tiesos y dispuestos en una sola ó en algunas séries, y formando así el perístemo, cuyos dientes son pocos, muclios ó solamente 4 y reunidos entre sí de varios modos; por el centro de la cajilla hay una columnita y la parte que se queda libre está llena de esporos: F. de las bryeiceas, 45.

45. Caliptra ó capucho de base persistente y reventada por la parte mediana; esporanjios situados por el vértice cortísimo de las ramitas, pedunculados, sin anillo; opérculo llano; boca abierta : esfagnúceas. - Caliptra circuncisa por la base ; esporanjios operculados, anulares, indehiscentes ó abiertos, con el opérculo echado de lado; boca variada: brificeas.

46. Cajillas esporíferas axilares ó radicales, con una sola ó con muchas celdillas y cuyos esporos son de dos clases, 47. - Cajillas esporíieras marjinales o dorsales uniloculares y de ordinario ceñidas ó rodeadas por un anillo elástico; eśporos de una sola clase, 50.

47. Uni ó 3-loculares, axilares y con los espórulos de una sola clase; plantas herbáceas muy bonitas anuales ó vivaces; alguna vez que otra fruticulosas, con muchísimas hojitas imbricadas y casi escamosas, muy angulosas y todas semejantes, dispuestas por á 3 ó por á 4, cuyas laterales son mayores; esporanjios de una sola figura o de dos, cuyos farináceos son sub-reniformes ó algo arriñonados y con dos valvas, mientras los globulíferos son subglobosos 3,4 lobos ó con 3, 4 valvas, formando amentos cuyos últimos ocupan la parte inferior: lycopodium, F. 6.-Cajillas esporíferas radicales y multiloculares, con los cuerpos reproductores de dos clases diferentes, 48.

48. Yerbecitas acuáticas con hojas pecioladas, á veces sentadas y escamiformes, enrolladas al nacer. Organos reproductores encerrados en un invólucro, los unos agrupados y pedicelados ó apiñados muchos, sentados y distintos de los otros, con que están entremezclados ó en contacto y que consisten en cuerpos ovales, provistos á veces de un pezoncito terminal de donde sale la germinacion : marsiliciceas, 49. 
49. Prefoliacion de los peciolos en báculo: esporocarpios libres uniformes y con valvas. Yerbecitas de tallo delgadito, filiforme, rastrero y echando raices en los lugares de suelo anegadizo; cuyas hojas largamente pecioladas tienen fuera del agua su limbo compuesto de 4 hojuelas : marsilea.-Prefoliaciơn nunca jamás en báculo; esporocarpios de dos formas diferentes en el mismo tallito y situados cerca de la base de las hojas; yerbecitas nadadoras ramosás á manera de pluma ó de estrella, cuyas hojas alternas son frecuentemente papilosas : salvinieas.

50. Cajillas esporíferas ó esporanjios provistos de un anillo, pero ni marjinales ni dorsales tampoco, 51. - Cajillas esporíferas sin anillo, marjinales ó dorsales, $7 \%$.

51. Sentadas sobre un receptáculo mas ó menos pronunciado, con anillo vertical ancho y escéntrico, conteniendo esporos triquetros ó trílobos; vejetales arborescentes mas ó menos altos, con semblante de palmeras, cuyas primorosas frondas que coronan su estipe son pinadas, bi-tripinadas ó bi-pinatífidas, F. 5, T. IV., 52. - Nunca colocados los esporanjios sobre un receptáculo, pero pedicelados ó sesiles, 54 .

52. Esporanjios saliendo del lado de una vena simple y formando soros ó grupos sub-redondeados y esparcidos; indusio pegado en el receptáculo por su parte inferior y por debajo, mientras la esterior es libre y por fin inclinado : hemitelia. - Esporanjios saliendo de la lifurcacion de una vena ó de la parte mediana, 53.

53. Receptáculo globoso ú oblongo ; soros esparcidos ó por séries á veces confluyentes; indusio formado de pelos ó de escamas laciniadas: alsopliila. - Receptáculo siempre globoso; soros ó grupos hemisféricos ó sub-globosos ; indusio situaro por debajo del receptáculo, cerrado y por fin abriéndose por lacinias ó circunciso irregularmente: cyathea, F. 5, T. IV.

54. Esporanjios pedicelados provistos de un anillo rertical perfecto; esporos redondos ú oblongos, F. 5, T. VI, 55. - Esporanjios sesiles, muy delgados y ceñidos por un anillo imperfecto ancho y á veces apenas notable, F. 5, T. VII.

55. Indusio ó escama membranosa, especie de camisa que cubre mas ó menos los esporanjios y los acompaña, ó uula 56. - Esporanjios siempre provistos de un indusio mas ó menos lejítimo, cuya forma y figura son variadas, 63 .

56. Esporanjios situados sobre la cara inferior de las hojas, que la cubran ó no, pero nunca jamás saliendo de las venas ó de sus divisiones, 57. - Esporanjios siempre colocados sobre las venas ó sus divisiones, 59 .

57. Agrupados en la cara inferior ó algunas veces por ambas caras á la par, que tienen mas ó menos cubiertas, pero nunca jamás situados sobre las venas ó sus divisiones; tallo rastrero simple ó ramoso, con frondas ternadas, pinadas ó tripinadas, pero las mas veces simples, cuyas fructíferas son semejantes á las demas ó mas estrechas y contraidas : acrostichum. - Esporanjios situados por la cara inferior que no cubren y cuyos soros son dispuestos en líneas continuas ó interrumpidas, 58. 
58. Solitarios entre la costilla y la márjen, con que están paralelos, y reunidos por la parte contraria á las venas; tallo herbáceo, corto y de fronda simple : taenitis. - Marjinales y escondidos por las cerdas ó pelos de las frondas; tallo herbáceo, corto, con frondas simples, pinadas ó tripinadas, "pelierizadas : nothochlena.

59. Saliendo de las venitas dispuestas en redecillas por la cara inferior de las frondas, cuyas fructíferas son mas largamente pecioladas y menores que las estériles acorazonadas, palmeado-quinquelobas, velludas y de cuyos senos salen yemas; tallo herbáceo: hemionitis. - Saliendo mas ó menos de las venas no dispuestas á manera de redecilla, 60 .

60. Esporanjios agrupados en soros lineares, 61. - Esporanjios nunca dispuestos en soros lineares, pero sí sub-redondeados ó con figura de semi-luna, 62 .

61. U oblongos situados sobre las vềnas primarias ahorquilladas ó pinadas; tallo herbáceo las mas veces abreviado, cuyas frondas compuestas o descompuestas son raras veces simples, y frecuentemente velludas, de dos colores y furfuráceas á la vez : gymnogramme.-O sub-rotundos situados sobre las venitas ó sobre el brazo superior de las bifurcaciones; tallos rastreros ó raras veces formando como cepas, de frondas simples intejérrimas ó repandas y pinatífidas; rarísima vez bífidas ó pinadas : grammitis.

62. Soros algo semi-lunares situados sobre las venas transversales; rizoma rarísima vez de tallo arbóreo y recto, de frondas pinadas ó trifoliadas: meniscium. - Soros sub-rotundos y esparcidos ó dispuestos por séries sobre las venas; tallo rastrero ó derecho las mas veces herbáceo, raras veces arbóreo, con frondas simples enteras ó pinado-compuestas y descompuestas : polypodium, F.5, T. I.

63. Indusio simple, 64. - Indusio doble : esporanjios situados en el vértice de las venas y formando soros marjinales sub-redondeados ; indusio lejítimo membranoso y continuándose con las venas, mientras el falso saliendo del lóbulo de la fronda cubre el primero. Tallo arbóreo derecho con frondas pinadas, bipinadas ó triplicadopinadas : dicksonia, F. 5, T. I.

64. Lejítimo, 65.-Falso y redoblado sobre la márjen de la fronda de donde nace; esporanjios saliendo de los ápices distintos de las venas y agrupados en soros sub-rotundos y aproximarlos á la márjen de las frondas; tảllo herbáceo y rarísimas veces arborescente con frondas pinatífidas, bipinadas ó sobre-descompuestas: cheilanthes, F. 5, T. I.

65. Mas ó menos continuo con la márjen de la fronda, 66. - No continuo con la márjen de la fronda con la cual no tiene relacion alguna, 68 .

66. Adherido al receptáculo y libre interiormente; esporanjios saliendo de los ápices distintos de los venas y colocados sobre receptáculos lineares ó puntiformes y agrupados en soros marjinales. Ta1 lo herbáceo, las mas veces rastrero y rizoma, con frondas compuestas, sobre-descompuestas, rarísima vez simples, blandas ó coriáceas, lustrosas: adiantuin, F. 5, T. I. - Nunca adherido al receptáculo, 67 . 
67. Arrollado; esporanjios colocados sobre los ápices anastomosados de las venitas y agrupados en soros semilunares que se hallan en los senos de las frondas; tallo herbáceo pelierizado ó aguijonoso, con frondas bipinatífidas, laciniado-festoneadas ó sinuadas: lonchitis, F. 5, T. I. - Nunca arrollado pero escarioso y abovedado ó no, 68 .

68. Nunca abovedado, 69. - Siempre abovedado, escarioso y libre por la parte que mira á la costilla; esporanjios agrupados en soros lineares mellizos continuos y paralelos de cada lado de la costilla. Tallo herbáceo, alguna vez que otra alto y arborescente, con frondas pinatífidas ó pinadas, rarísima vez simples, cuyas fértiles son casi conformes o algo contraidas : blechnum.

69. Membranoso ó avitelado, 70. - Escarioso y de base ancha ó pegado de la márjen y con el vértice libre esteriormente; esporanjios situados sobre el ápice de las venas y en soros sub-redondeados y aproximados á la márjen; tallo herbáceo rastrero ó derecho, con frondas simples pinadas ó descompuestas : davallia.

70. Avitelado ó no, con dos ventallas ó con una sola, 71.-Membranoso y abrazando la fronda, libre esteriormente; esporanjios situados en el ápice de las venas y reunidos en soros continuos, con la márjen de la fronda que abrazan; tallo herbáceo con frondas simples pinadas ó descompuestas: lindsaea.

71. Avitelado y con una sola valva, libre interiormente; esporanjios saliendo de los ápices de las venitas, agrupados sobre receptáculos nerviformes abrazando la márjen de la fronda y en soros marjinales por consiguiente; vejetales de aspecto muy variado con rizoma ó con tallo derecho, alguna vez que otra arborescente, con froudas compuestas ó raras veces simples : pteris. - No avitelado con una sola ó con dos valvas, 72 .

72. Con dos ventallas, sea lejítimas sea falsas, 73. - Nunca con dos ventallas, pero sí con una sola, 74 .

73. Las dos valvas lejítimas y de igual testura que la fronda; esporanjios agrupados en soros lineares continuos y paralelos con la costilla ó la nervadura; frondas entejérrimas y lineares : vittaria. - Membranoso y saliendo lateralmente de la rena, connivente por encima de los soros y con dos valvas falsas; esporanjios situados sobre los brazos de la bifurcacion de las venas y agrupados en soros oblongos, mellizos por estar en los brazos contiguos de varias venas; frondas lanceoladas, acorazonadas ó alabardiformes y siempre enteras : scolopendrium.

74. Esporanjios en soros arriñonados y situados en un seno de la fronda, 75. - Nunca jamás arriñonados los soros, ni situados tampoco en un seno de la fronda, 76.

75. Sub-redondeados y dispuestos en séries, formados por esporanjios colocados sobre un receptáculo saliendo de un crecido que se halla en la parte mediana de la vena; tallo herbáceo de frondas pinadas ó bi-pinatífidas : nephrodium. - Soros sub-globosos formados de esporanjios situados en un receptáculo proviniendo del ápice abultadito del brazo superior de las venas; tallo rastrero con frondas pinadas ó bipinadas : nephrolepis. 
76. Indusios redondeados, abroquelados, libres por la márjen y continuos con el receptáculo; esporanjios colocados sobre un receptáculo columnar formado por el abultamiento del ápice ó de las anastomosis de las venas y agrupados en soros sub-rẹdondeados esparcidos ó dispuestos por séries; vejetales de semblante y aspecto muy variados : aspidium. - Indusios nacidos de la vena, tan pronto confluentes entre sí como libres; esporanjios situados sobre venas bifurcadas ó dicotomas y agrupados en soros lineares mellizos, cerca de los brazos de las venas; tallo rastrero ó derecho, alguna vez que otra arborescente, con frondas simples pinadas ó bipinadas : diplazium.

77. Las mas veces dorsales ó raramente apanojadas, 78. - Siempre marjinales y situadas sobre una vena que se va dilatando á lo largo del borde de la fronda; anillo horizontal completo; esporos convexo-tetraedros; esporanjios sentados sobre una columnita filiforme formada por la vena prolongándose algo mas allá que la márjen de la fronda, ceñidos por un indusio continuo con la fronda y ciatiforme; yerbecitas de tallo rastrero ó rizoma con frondas esparcidas ó agrupadas, lobadas, pinadas ó descompuestas : trichomanes, F. 5 , T. II.

78. Siempre dorsales y nunca apanojadas, 79.-Tan pronto dorsales como apanojadas y pediceladas; anillo ancho, dorsal é incompleto, abriéndose por el vértice; esporos redondeados ú oblongos; indusios variados; frondas bipinadas, cuyas fértiles son con mayor frecuencia recojidas : osmunda, F. 5, T. III.

79. Anillo completo, ancho, estriado, transversal ó sub-oblicuo, abriéndose interior y transversalmente; esporanjios hipófilos y sentados; esporos oblongos ó arriñonados; indusio nulo ó falso saliendo de la márjen de la fronda y arrollarlo hácia fuera; tallo rastrero con frondas estipitadas, pinadas, dicótomas con las pínulas frecuentemente pinatífidas: gleicheniáceas, F. 5. - Anillo completo estrecho ó recojido, terminal, abriéndose esterior y lonjitudinąlmente; esporanjios hipófilos sesiles, con esporos piramidales ó cónicos, pro vistos de esporodermos crestados ó erizados; indusios variados; á veces volubles, de frondas variadas cuyas fértiles son contraidas: esquizcíceas, F. 5, 80 .

80. Indusio nulo, 81. - Indusio escamiforme acogollado, pegado transtersalmente de las venas y tapando cada uno de los esporanjios diispuestos en dos séries alternadamente sobre las lacinias marjinales de las frondas y abriéndose lonjitudinalmente. Tallo roluble, escandente ó trepador con frondas conyugadas, palmeadas, lobadas ó pinadas: lygodium.

81. Esporanjios sesiles y dispuestos en dos séries sobre las lacinias laterales y mellizas de las irondas y recojidas en raquis multiplicado apanojado y no marjinado ; desnudos y abriéndose esterior y lonjitudinalmente. Yerbecitas de rizoma ascendente ó rastrero con frondas estipitadas, cuyas estériles son ternadas, pinadas, bipinatífidas ó descompuestas, mientras las fértiles son ternado-pinadas ó sobre-descompuestas : aneimia.-Esporanjios situados sobre las lacinias lineares y provistas de una membrana marjinal, opuestos en 
el ápice de las frondas en donde están dispuestos á manera de los dientes de un peine, dijitadoş ó dispuestos en dos ó en 4 séries, sostenidos por pelos, abriéndose esterior y lonjitudinalmente. Rizoma cerdoso con frondas simples estipiformes dicótomo-partidas ó con forma de abanico : schiznea.

82. Esporos elipsoídeos; indusio nulo, superficial ó concreto, con los esporanjios bipófilos, sesiles, distintos ó reunidos entre sí y abiertos sea por el vértice, sea por el lado; frondas simples, pinadas ó 3 veces pinadas, con las hojuelas siempre elongado-lanceoladas y enteras, F. 5, T. VIII, 83.-Esporos farináceos; esporanjios sentados uniloculares ó provistos de un tabique transversal é incompleto que les hace casi biloculares, coriáceos, sin vasitos, distintos ó conatos entre sí, semi-bivalves. Frondas saliendo mellizas de un rizoma, derechas al nacer, la una estendida y la otra recojida en raquis y fructífera, F. 5, T. IX.-Esporanjios trabados y dispuestos en espigas dísticas y articuladas, uniloculares y abriéndose transversalmente; yerbecitas de fronda estéril foliácea y anchamente oval, de cuya vajina sale la fértil : ophioglossum.

83. Indusios superficiales ciñendo los soros lineares formados por esporanjios trabados, dispuestos en dos séries aplicadas á las renas transversales y abriéndose por medio de un poro. Tallo derecho ó erguido con fronda simplemente pinada de divisiones enteras: danaea. - Indusios coriáceos trabados con los soros y lonjitudinalmente bivalves; esporanjios dispuestos en dos séries, aplicados al ápice de las venas transversales, conatos entre sí y formando soros oblongos que se abren transversalmente por medio de una grieta vertical f frondas estipitadas, bipinadas ó tres veces pinadas: marattia, F. 5, T. VII.

\section{VEJETALES UNISEXUALES}

81. Monoicos ó dioicos, 86. - Polígamos ó seudo-polígamos, 85.

85. Polígamos lejítimos ó provistos de flores hermafroditas y unisexuales, tan pronto sobre el mismo individuo como sobre dos sujetos distintos, pero siempre de la misma especie, 251. - Seudo-polígamos, es decir monoicos y dioicos á la par.

86. Vejetales monoicos, 87. - Vejetales dioicos, 200.

87. Arboles, arbustos ó matas, 88. - Yerbas ó plantas herbáceas de ordinario, 153.

88. Cuyo tallo es un astil ó estipe, 89. - Con tronco ó tallo lejítimo, 103.

89. Monoicos lejítimos, 93. - Andrójinos ó monoicos, con flores teniendo ambos órganos sexuales, pero que necesitan del concurso de otra flor mas perfecta para salir fecundada, 90 .

90. Todos los espádices ó támaras andrójinos, cuyas flores superiores son masculinas, mientras las inferiores son femeninas; espádices sentados en un eje escamoso; espata monófila, mucronada y asurcada por el dorso, 91. - De los espádices ó támaras que sobre el mismo árbol se hallan los unos son andrójinos, mientras los otros son 
masculinos, con las flores densamente dispuestas en los brazos; espata monófila, leñosa, espesa en forma de curiara ó de canoa, asurcada, persistente y cuyo ápice se prolonga en pico largo, 92.

91. Grandes y primorosas palmeras de frondas muy largas pinadas ó pinatífidas, de estipe desnudo y á veces muy alto; flores femeninas con un periantio único partido en 9 divisiones en 2 séries, cuyas 3 esteriores parecen un cáliz á algunos autores, mientras las 6 interiores segun ellos representan la corola; ovario único trilocular, pero unilocular y con un solo óvulo por causa de aborto, ovoídeo, sentado y algo hueco; las flores masculinas, al contrario, constan de un periantio con 6 divisiones dispuestas tambien en 2 séries, conteniendo 6 estambres y á veces los rudimentos del ovario. Fruto drupáceo muy grueso, cuya base acompaña el periantio persistente y algo crecido : coccos, F. 14, T. IV.

92. Palmera que se eleva hasta 10 y 15 varas de altura, de estipe sin espinas, pero que se queda durante mucho tiempo con la base de las frondas que no se desprende sino despues de podrida, lo que le da un aspecto particular; sus frondas no son muchas, algo distantes, derechas, muy grandes y largas de 3 á 5 varas y hasta mas, pinadas ; támaras muy grandes, muy furnidas de flores, axilares y con eje grueso y fuerte, del cual salen una multitud de brazos largos como de 6 á $7^{\prime \prime}$, horizontales, que cargan con flores sentadas cuyas femeninas ocupan la parte inferior; de periantio con 6 divisiones en 2 séries; en las flores masculinas las 3 divisiones esteriores del periantio son membranosas y óvalo-triangulares, mientras las 3 interiores son lanceoladas y sub-coriáceas, y contienen 6 estambres, con anteras lineares y pegadas al dorso; en las femeninas, al contrario, las divisiones periantiales son membranosas, poco largas y todas semejantes, acrescentes y persistentes, ovario ceñido por una cupulita membranosa, óvalo-cónica, de cuyo ápice sale un estilo corto cilíndrico, terminado por 3 estigmas arrollados y abiertos; drupa oval del tamaño como de un huevo grueso de paJoma, con epicarpio cartilajinoso, cubriendo un mesocarpio mucilajinoso ácido y fibrosito; hueso durísimo fusiforme ; endospermo duro, oleajinoso, con el embrion lateral : maximiliana, F. 14, T. IV.

93. Espádices con una, dos ó mayor número de espatas, 94. Espádices sin espata alguna; estipe no muy alto, vestido de fibras dispuestas como en redecilla; frondas bastante grandes, inermes, pinadas, con las divisiones dobladas y cuya base del raquis está á veces provista de fibras negras muy fuertes y pareciendo crin; espádices densos color de orin y apanojados, con las flores sentadas adentro de los alveolos de sus brazos, provistos de brácteas y de bracteitas; série esterior del periantio formada de 3 piezas ovales é imbricadas, las de la interior son tambien ovales y á su base están insertos 6 estambres inclusos, de filamentos planos y reunidos por la base, de anteras ovales y erguidas, con el rudimento del ovario en el centro de las flores; en las flores femeninas las divisiones de la série esterior periantial son anchamente ovales, con las de la interior iguales; ovario turbinado sub-trígono, con estigma sentado, 
cortísimo y abierto; baya drupiforme, comprimido-globosa, de color amarillento-verdoso, monosperma, de endospermo igual y córneo, con el embrion lateral y situado cerca de la base : leopoldina, F. 14, T. V.

94. Espatas dos ó una sola, 95. - Espatas muchas : primorosísimos árboles de estipe alto, sostenido ordinariamente por un cono de raices sobresaliente en el suelo, inerme, anuloso, frecuentemente mas crecido por la parte media; frondas eleçantemente pinadas, cilíndrico-convolutas por la base de los raquises, con divisiones ú hojuelas deltoídeas anteriormente dentadas ó como roedas; espatas pronto decíduas saliendo por debajo de las frondas, envolviendo espádices ramoso-tomentosos, de flores densas, amarillentas, acompañadas de brácteas y de bracteitas poco desarrolladas; periantio de las masculinas, de série esterior 3-fila, cuyas divisiones son cóncavas y ovales, mientras la série interior, de 3 piezas tambien, las tiene ovales y erguidas; estambres 12-24 con filamentos cortísimos y cilíndricos, cuyas anteras tetrágonas acompañan á los rudimentos del ovario. El periantio de las femeninas difiere por ser orbiculares é imbricado-conrolutas las divisiones de la série esterior, mientras las de la interior son conformes con las masculinas; ovario trilocular y unilocular por causa de aborto, cuyo ápice lleva tres estigmas sentados. Baya monosperma, de color aleonado-verdoso, de mesocarpio poco fibroso y jelatinoso; hueso durísimo moradusco amariliento; endospermo igual un poco huesoso, embrion basilar: iriartea, F. 14, T. V.

95. Dos espatas, 96. - Una espata única: estipe alto de 15 á 20 varas $\mathrm{y}$ hasta mas, con aguijones fuertes, frecuentemente ventrudo por la parte media, coronado por frondas grandes, pinarlas, sub-erizadas ; espádices axilares simples y persistentes, con las flores masculinas situadas en la parte superior de los brazos y sentadas en los alveolos, mientras las femeninas ocupan la parte inferior que es como reticulada; periantio de las flores masculinas cuyas 3 divisiones esteriores y pequeñas son ovales, mientras las 3 interiores prismático-cilíndricas por la base son lanceolado-oblongas; 6 estambres inclusos, de filamentos comprimidos con anteras lineares, sub-asaetadas, acompañando al rudimento del ovario que ocupa el centro de la flor, mientras el de las femeninas tiene sus divisiones esteriores redondeadas y las interiores ovales y de estivacion imbricada; ovario 3-locular pelierizado, envuelto en una especie de cúpula anular 6-dentada: estilo corto con 3 estigmas lanceolados y vueltos hícia fuera. Drupa redonda de epicarpio mucilajinoso fibroso, algo comestible; hueso espeso lenticular, con 3 poros laterales; endospermo oleajinoso muy durn; embrion ocupando uno de los ojos laterales: acrocomia, F. 14, T.IV.

96. Las dos espatas completas ó incompletas, pero nunca partiéndose en fibras lonjitudinales que las hace parecer muchas, 97.-Las dos espatas completas, pero por fin partiéndose en fibras lonjitudinales, cuya esterior, comprimida y de márjen como con dos filos apenas pronunciados, está ábierta por el ápice. Estipe de altura mediana, grueso, derecho o inclinado, con escamas ó cicatrices: fron- 
das bastante grandes, pinadas, casi derechas, cuyos raquises son espinoso-aserrados por la márjen; espádices densamente corimbosoramosos y tomentosos, con alveolos conteniendo las flores cuyas masculinas son densamente imbricadas y las femeninas esparcidas; periantio de las primeras cuyas 3 divisiones esteriores papiraceas son lineares ó lanceoladas, mientras las 3 interiores membranosas, lanceoladas y conniventes, contienen 6 estambres inclusos, de filamentos formando una especie de odrecita de vértice 6-fido, con anteras ovales ú oblongas y abiertas, conteniendo en el centro un ovario rudimentario. Las tres divisiones del periantio de las femeninas son membranosas, ovales é imbricado-convolutas, las interiores, en número de 3 ó de 6 , son ovales ú oblongas é imbricado-con-volutas; ovario oval ó sub-cilíndrico 3-locular, con dos celdas abortadas; estigmas 3 como ganchosos y abiertos; drupa angulosa y oval, monosperma, cuyo sarcocarpio fibroso es á la vez como fongoso y oleajinoso; endospermo córneo, con el embrion lateral y situado cerca del ápice : elais, F. 14, T. IV.

97. Las dos espatas completas, cuya esterior no se revienta por la barriga; frondas provistas de una vaina coriácea cilíndrica y muy larga, 98. - Espata esterior solamente completa, mientras la interior, de ápice abierto, se revienta por la barriga; frondas de base apenas envainadora, 101.

98. Flores masculinas y femeninas entremezcladas sobre el ápice; las primeras mas abundantes en la parte superior de los brazos, mientras las segundas lo son por la base de ellos; endospermo nunea ruminado y las divisiones calizinales nunca aquilladas, 99. Igual disposicion de las flores, periantio de estivacion valvar en las masculinas $y$ arrollada en las femeninas; endospermo siempre ruminado, 100 .

99. Estipe de tamaño regular bastante alto, anilloso é inerme; frondas pinadas con divisiones pectinadas, desiguales y bífidas por el ápice; espata interior sub-leñosa, envolviendo el espádice entero, y por fin abriéndose por el rértice; flores sentadas, bracteadas y bibracteoladas; periantio de las masculinas 6-filo, cuyas divisiones esteriores, anchamente ovales, son imbricadas y por fin reunidas, mientras las interiores son libres, oblongo-lanceoladas y de estivacion valvar, conteniendo por su fondo $6,9,12$ estambres de filamentos subulados, con anteras lineares dorsífijas y por el centro un ovario rudimentario. El de las femeninas es conforme y contiene una especie de corona 6-dentada formada por los estambres rudimentarios, en el centro de la cual está el ovario trilocular, terminado por tres estigmas sentados y conniventes. Drupa pequeña oval, bacciforme, de sarcocarpio fibroso; hueso de testa coriácea y delgada; endospermo córneo é igual con el embrion basilar : oreodoxa, F. 14, T. V.

100. Estipe fuerte, delgado, derecho, alto, anillado ó liso, inerme ó á veces aguijonoso, con frondas pinadas, de divisiones pectinadas, abiertas, lanceoladas y aguzadas, cuyo raquis está á veces provisto de aguijones; espatas membranosas ó fibroso-coriáceas; flores sentadas en los alveolos de los brazos de los espádices y brac- 
teoladas; periantio de las flores masculinas 6-partido, cuyas tres lacinias esteriores son aquilladas y las 3 interiores sueltas, son lanceoladas y de estivacion valvar, conteniendo en su fondo $3,6,12$ estambres, de filamentos subulados y reunidos por la basc con anteras ovales y asaetadas, en cuyo centro está el rudimento del ovario; en las femeninas el periantio es conforme, pero la estivacion de la série interior es arrollado-imbricada, con el rudimento de los estambres y en el centro el ovario oval trilocular, de cuyo ápice salen 3 estigmas sentados y abiertos. Drupa bacciforme, monosperma, de sarcocarpio fibroso; hueso de testa delgada, crustácea y membranosa; endospermo ruminado, con el embrion basilar ó lateral cerca de la base : areca, F. 14, T. V.

101. Espata esterior mas corta, abierta por el ápice y membranosa, interior fusiforme, coriácea o sub-leñosa; estambres $6,9,12$ saljendo de un disco basilar, 102. - Espata esterior corta, cilíndrica $y$ de ápice bífido, interior leñosita y fusiforme; estambres 6 , dispuestos por pares opuestos á las divisiones interiores del periantio; primorosos árboles de estipe largo de 10 á 15 varas y hasta mucho mas, delgado, derecho, con zonas circulares y provisto de aguijones dispuestos á manera de espiral; frondas bastante grandes, aproximadas en el vértice, de raquis aguijonoso, pestañoso por la base, pinadas y con hojuelas lineares. Espádices bastante grandes, axilares, simples, cuyos brazos alveolado-tomentosos cargan con flores sentadas y bracteoladas, de periantio con la série esterior en ambos sexos monófila; en las masculinas es sub-globosa y sus 3 lóbulos profundos son orbiculares ú obovales; en las femeninas es al contrario sub-campanuda ó turbinada y de boca troncada: la série interior en las masculinas es algo plana, con tres ángulos algo membranosos y sub-agudos, conteniendo los estambres cuyos filamentos subulados llevan anteras lineares, oblongas y acostadas, con cl rudimento del ovario en el centro; en las femeninas es aniliforme, membranosa y 3 -dentada; ovario de base al principio triangular y despues subglobosa, con 2 celdas rudimentarias abortadas, de cuyo ápice salen 3 estigmas sentados. Drupa oval, color amarillo anaranjado, de tamaño ordinariamente de un huevo de paloma, con el sarcocarpio fibrosito, carnoso y algo oleajinoso; hueso duro con 3 poros por el vértice, conteniendo un endospermo cartilajincso: guilelmia, F. 14, T. IV.

102. Palmeras ordinariamente pequeñas, cuyo estipe mas ó menos largo tiene solame̊nte $1^{\prime \prime}-2$ " de diámetro y es muy aguijonoso; frondas pinado-pectinadas, pocas, terminales ó esparcidas á lo largo del estipe por trechos inermes; espádices terminales ó laterales y á veces axilares, simples ó formados de brazos simples, cuya parte inferior está ocupada especialmente por las flores femeninas, mientras las masculinas, mucho mas numerosas, están esparcidas y hasta entremezcladas con ellas, sentadas y bracteadas todas; periantio de las masculinas 5-partido ó trífido, con las divisiones esteriores sublanceoladas; las interiores, al contrario algo planas, son estriaditas, de base frecuentemente reunida, con los filamentos subulados que cargan anteras sub-asaetadas, mientras el de las femeninas es ur- 
ceolado ó aniliforme; ovario oval ó prismático-trígono, con un estigma y formando al principio una especie de pirámide en el fondo y centro de la flor. Drupa de epicarpio crustáceo, con el mesocarpio mucilajinoso-ácido y pulposo; hueso muy duro: bactris, F. 14, T. IV.

103. Vejetales resinosos siempre verdes, cuyo fruto es un cono, 104. - Vejetales resinosos no siempre verdes y cuyo fruto no es nunca ni un gálbulo ni un estróbilo tampoco, $10 \%$.

104. Gálbulo ó sícono cuyas escamas carnositas se han soldado entre sí para formar una especie de drupa escamosa por la base, ombligada por el ápice, con 1 ó 3 semillas erguidas y de testa huesosa; árboles pequeños ó arbustos á veces dioicos, con hojas linear-lanceoladas, tiesas, las mas veces diminutas y escamiformes; flores masculinas en amentos axilares ó sub-terminales, globosos y pequeños; estambres algunos, desnudos, insertos en un eje, de filamentos escéntricamente abroquelados y empizarrados, celdillas de las anteras 3,6 , abriendose lonjitudinalmente, reunidas inferiormente por la márjen; amentos femeninos ovales, con brácteas imbricadas por la base, invólucro formado de 3, 6 escamas reunidas por la base, $\mathrm{y}$ conteniendo 1 ó 3 óvulos : juniperus, F. 34. - Estróbilo ó cono lejítimo formado de escamas leñosas ó coriáceas, de vértice incrasado, areoladas ó mas veces aguzadas, persistentes y libres; 1, 2, 3 semillas alojadas en una escavacion que se halla en la base de las escamas, inversas y bastantes veces provistas de una especie de ala; árboles de ordinario altos y corpulentos, 105.

105. Hojas lineares, amanojadas ó fasciculadas, cuyos hacecillos están envueltos separadamente por la base con una vaina membranosa; anteras biloculares abriéndose lonjitudinalmente, 106. - Hojas tambien lineares, de ordinario menos largas, no fasciculadas, pero sí siempre solitarias, esparcidas ó dísticas; celdillas de las anteras abriéndose transversalmente; amentos masculinus axilares, agrupados hácia el ápice de las ramitas; amentos femeninos laterales y esparcidos; brácteas persistentes; escamas aguzadas por el ápice; estróbilo oblongo formado de escamas sub-leñosas, lisas, de base no hueca, con las semillas libres del eje y siempre aladas: abies, F. 33 .

106. Amentos masculinos numerosos, dispuestos en espigas terminales; amentos femeninos 2, 3 solitarios y terminales; brácteas fugaces; escamas superiormente y por debajo del ápice arrejonadas ó mucronadas, decíduas; estróbilo cónico formado de escamas leñositas, de ápice engrosado y angulosas, huecas por la base, por fin desparramadas y persistentes; testa de las semillas leñosa; ala decídua: pinus, F. 33.

107. De savia lechosa, 108. - De savia nunca lechosa, 137.

108. Arboles mas ó menos grandes, 109. - Arbustos, matas ó plantas herbáceas, 129.

109. Flores mas ó menos desnudas y por consiguiente incompletas, siempre insertas sobre un receptáculo de forma y tamaño muy variados, 110. - Flores nunca desnudas ni tampoco colocadas sobre un receptáculo, 116. 
110. De inflorescencia andrójina, flores colocadas en la parte interior hueca de un receptáculo ó invólucro que se vuelve carnudo y simula un fruto, con escamitas situadas en la boca que se halla en su ápice, 111.-De inflorescencia monoica ó raras veces á la par dioica por causa de aborto ; flores situadas por toda la superficie esterior de un receptáculo mas ó menos cilíndrico, nunca hueco y mas ó menos carnudo, 112.

111. Arboles á veces muy corpulentos, muy altos, muy ramosos, cuyas ramitas se terminan siempre por una yema mas ó menos cónica, puntiaguda y siempre envuelta en una especie de espata membranosa; de hojas simples, ordinariamente alternas, y rarisimas veces opuestas, mas ó menos pecioladas, enteras mas ó menos luhadas, coriáceas, lisas y lustrosas ó ásperas y opacas. Las flores masculinas situadas algo por debajo de las escamas que tapan la boca del invólucro, á la parte superior é interna, del cual se las halla formadas de un periantio de 2, 6 divisiones desiguales y conteniendo $1,2,3$ y hasta 6 estambres salientes; las femeninas al contrario están colocadas sobre toda la parte interna del invólucro y constan de un periantio 5-partido y membranoso, que se aplica á un carpelo simple que contiene un óvulo colgante y terminado por un estilo lateral que lleva dos estigmas filiformes. El invólucro, llegada la sazon de la madurez, es un higo y contiene en su interior muchos aquenios muy pequeños, lenticulares, que contienen un embrion encol'vado alojado en un endospermo carnudo: ficus, F. 41, G. III.

112. Flores siempre monoicas, sentadas sobre un receptáculo mas ó menos largo ó globoso, nunca desnudas y cuyas masculinas son dispuestas en amento y las femeninas en cabeza globosa, 113. Flores monoicas ó dioicas por causa de aborto, siempre desnudas, sentadas sobre un receptáculo globoso que se vuelve abayado, axilar y pedunculado y separadas las unas de las otras por una bráctea abroquelada, 114 .

113. Arboles muy grandes, corpulentos, ramosos, de hojas mas ó menos grandes, enteras ó lobado-sinuadas, pecioladas, alternas, aproximadas al vértice de las ramitas especialmente, las cuales se terminan por una yema puntiaguda algo corva, cónica y envuelta en una membrana espatiforme y caduca. Amentos masculinos casi cilíndricos, bastante gruesos y largos de $5^{\prime \prime}-6$ ", con muchísimas flores sentadas y de periantio con 2 valvas, conteniendo un estambre único; los femeninos al contrario, mas ó menos esféricos, son formados de muchas flores desnudas, con un solo pistilo compuesto de un ovario ovoídeo, unilocular, de cuyo ápice sale un estilo filifor'me simple 2, 3-partido y que se termina por un estigma único y simple por cada brazo. Tales ovarios, soldándose con el receptáculo en que están pegados, constituyen una fruta muy gruesa que contiene pepitas envueltas en una carne abundante, las cuales abortan en una especie, de manera que la fruta es una masa enorme de pulpa comestible: artocarpus, F. 39, T. I, G. I.

114. Arboles grandes y corpulentos, á veces muy alios, coposos, de hojas simples alternas, coriáceas, pecioladas, estipuladas, oblongo-lanceoladas, enteras ó á veces aserraditas, alampiñadas ó pubes- 
centes; pedúnculos solitarios ó mellizos, nunca ramosos; estambres solitarios saliendo de entre las escamas del receptáculo, cuyos filamentos cortos se terminan por anteras orbiculares, abroqueladas, bilameladas y abriéndose por toda la circunferencia; invólucro de las flores femeninas bífloro, urceolado y provisto de escamitas abroqueladas ó de cerdas; ovarios uniloculares reunidos entre sí y á la par con el invólucro; estilo terminal bífido, cuyos brazos filiformes se terminan en estigma plumoso ó lobulado. Fruto abayado, apenas carnosito, erizado ó mucronadito, con una semilla única sub-globosa: galactodendron, Zrosymum, F. 39, T. III, G. III.

116. Arboles algo lechosos solamente; flores femeninas y masculinas amentáceas y cuyo fruto es un sorosis, 136. - Arboles muy lechosos, de flores amentáceas ó no, pero cuyo fruto no es nunca un sorosis, 117.

117. Hojas siempre simples y con glándulas peciolares, 118. Hojas siempre compuestas, con ó sin glándulas peciolares, 127.

i18. Flores en espigas amentiformes masculinas, llevando por la base algunas flores femeninas solitarias saliendo de la base de und bráctea biglandulosa mayor que las que acompañan á las flores masculinas, pero conforme, ó en amentos lejítimos con una sola flor femenina hácia la base ó axilar sin bráctea glandulosa, 122. - Flores siempre apanojadas, 119.

119. Cuyas femeninas están dispuestas en panojitas parciales inferiores, raras y con un pedúnculo grueso, mientras las masculinas superiores son acompañados de muchas brácteas, con pelo estrellado, diminutísimo y farináceo-blanquecino; están tambien en panojitas, cuyo conjunto con las primeras forma panojas grandes compuestas: hay dos glándulas situadas por el vértice del peciolo, 120. - Una sola flor femenina terminal, las masculinas inferiores provistas de bracteitas, formando panojitas parciales cortas, acompañadas de una estípula ó bráctea larguísima estipitado-glandulosa, cuyo conjunto forma una panoja grande comun $y$ terminal: hay dos glándulas situadas por la base del peciolo, 121 .

120. Arboles de mediana altura y tamaño, de hojas alternas, largamente pecioladas, lobuladas, alampiñadas y cuyo lóbulo mediano mayor es deltoídeo, á veces aovadas y enteras ; flores con cáliz tubular 2, 3-fido, de lacinias con estivacion valvar; corola con 5 pétalos un poco mas largos que el cáliz, de estivacion torcida en espiral sobre sí mismo, las cuales alternan con 5 escamas ó glándulas; las masculinas tienen muchos estambres de filamentos cortos, monadelfos, saliendo de un disco, con anteras adheridas é introrsas; en las femeninas hay un ovario envuelto en una especie de túnica distinta, velluda y abierta por el ápice, 2, 3-locular, cada celdilla monosperma; 2, 3 estilos bipartidos, cuyas lacinias son aguzadas. Fruto carnoso, abriéndose por el vértice, con 2 ó 3 cajillas cartáceas, interiormente abiertas por debajo del ápice, bivalves y monospermas, aleurites, F. 106, T. III, S.-T. II, G. III.

121. Arboles bajitos ó arbustos sarmentosos, con hojas alternas, bi estipuladas, pecioladas, entejérrimas, espesitas, con las nervaduras pronunciadas y lispuestas en redecilla por la cara inferior; 
cáliz 4-partido, conteniendo en el fondo un disco glanduloso color de sangre, de cuyo centro sale una columnita morada con 2, 3 lóbulos, cargando cada uno con su correspondiente antera de celdillas distintas casi alojadas en el lado correspondiente del lóbulo; las flores femeninas constan de un periantio conforme, conteniendo un ovario obtuso trígono, con 3 celdillas uniovuladas, de cuyo ápice sale un estilo corto, espesito, con estigma trilobulado; fruto como drupáceo, formado interiormente de 3 cajillas monospermas, tripartible por fin; semillas sub-globosas, de concha bastante sólida, rugosa, negruzca y persistente : omphalea, F. 106, T. III, S.-T. V', G. III.

122. Fruto drupáceo, pareciendo una manzanita, cuyas semillas ovoídeas tienen el tegumento persistente, leñoso y rugoso; estambres 2,4 monodelfos, de filamentos con 2 anteras adheridas y estrorsas, 123. - Fruto nunca drupáceo, 124.

123. Arboles bajitos, coposos, criándose en las orillas del mar, de hojas simples, alternas, pecioladas, ovales, aserradas ó festoneadas, puntiagudas, coriáceas, de cara superior lustrosa, lampiñas, como algo apinadas por el vértice de las ramas, que conservan largo tiempo la cicatriz de la insercion del peciolo, acompañado de dos estípulas, y cuya base lleva por su cara inferior unas glándulas pequeñas, discoídea, de color rojo oscuro. Amentos terminales formados de unos 20 grupos de flores masculinas situadas en la axila de una bráctea bastante grande, cóncava, con los bordes ondulosos, acompañada por la base de 2 glándulas semejantes á las del peciolo, secretando un licor que chupan los insectos, y especialmente las hormigas; tales grupos son alternos ó esparcidos sobre un eje cilíndricn y algo carnudo, largo de como $2^{\prime \prime}-3^{\prime \prime}$; las flores masculinas constan de un periantio campanudo, emarjinado, escamoso, algo bífido, de cuyo centro sale una columnita que lleva los estambres; las flores femeninas al contrario, solitarias y en número de 3,5 , y situadas por la base del amento, cuya parte masculina se desprende y se cae despues de verificada la fecundacion, constan de un periantio trífido o 3 dentado, de divisiones algo escamosas y glandulosas; ovario piriforme con 5 , 7 celdillas y de cuyo ápice salen 4, 8 estilos largos y doblados hácia fuera: hippomane, F. 106, T. III, S.-T. V, G. III.

124. Especie de cápsula formada de 3 carpelos ó 3 cajillas abriéndose cada uno por 2 ventallas y sin elasticidad, 125. - Cápsula leñosa ó elaterio, dèprimida, orbicular, lobulada y formada de 12,8 cajillas pegadas de una columna central y entre sí por los lados, abriéndose con elasticidad, bivalves y monospermas, 126.

125. Arboles bastante corpulentos y coposos que se elevan de $20^{\prime}$ á $50^{\prime}$, con hojas alternas, simples, pecioladas, lisas, ordinariamente glandulíferas, mas ó menos coriáceas, lanceolado-oblongas, oblongas, elípticas, ob-aovadas ó redondeadas, suł-enteras, dentaditoglandulosas, repando-enteras ó algo festoneadas, con ó sin puntitos transparentes; estípulas caducas y de forma variada; flores en racimos espiciformes ó amentáceos, terminales ó laterales, glandulíferos, cuyos primeros son masculinos, los otros andrójinos, mientras las flores femeninas ocupan la base; flores masculinas en grupos 
de á 3 o mas en la axila de una bráctea, con 2 glándulas por la base semejantes á las que se hallan por debajo del ápice del peciolo; caliz bífido ó 3,4-dentado con 2, 3 estambres monadelfos por la base, esertos, de anteras globosas y estrorsas; las femeninas, solitarias, conston de un periantio 3-fido ó 4-dentado, con un ovario globoso, 3 -locular, de cuyo ápice sale un estilo 3,2 -fido, cuyos brazos simples se doblan hácia fuera y se terminan en estigma algo dilatado. Cápsula cuyas cajillas contienen una sola semilla sub-globosa, sin carúncula y de tegumento esterior persistente y áspero: sapium, F. 106, 'T. III, S.-T. V.

126. Arboles altos, corpulentos, muy ramosos y coposos, de tronco armado de aguijones; hojas acorazonadas por la hase, redondeadas, acuminado-puntadas por el vértice, sub-enteras ó algo aserraditas, lisas, lustrosas, coriáceas, anchas de 4-5 1 $[2,2$, -3 " y largas de $6-5-3-4$, cuyo peciolo frecuentemente mas largo que ellas carga con 2 glándulas situadas por encima de la base ó hácia el vértice, y con la insercion acompañada de 2 estípulas anchas, ovales, foliáceas y caducas. Flores masculinas en amentos o espigas ovales ú oblongos, largamente pedunculados, largos de como $2^{\prime \prime}$, bastante gruesos, cubiertos de una epidermis muy fina que al reventarse durante la florescencia nos lia parecido forman el periantio de cada flor, las cuales son muchas y densamente imbricadas, terminales, de periantio cupuliforme, desigualmente dentado, envolviendo la base de un andróforo ó columna central claviforme que carga con 20 ć 25 estambres sentados, cuyas anteras están pecadas en la parte esterior y algo inferior, de tuberculitos dispuestos en espiral, estrorsas, cuyas 2 celdillas están un poco separadas la una de la otra; cada androforo coustituye pues una flor masculina que va floreciendo sucesivamente desde la base del amento hácia el vértice. Las flores femeninas al contrario son solitarias, axilares y mas ó menos distantes de las masculinas, erguidas, con pedúnculo simple y largo de 6 a $8^{\prime \prime \prime}$ y de periantio monófilo, cilíndrico y asurcado, entero ó 3-partido, largo de 4 á 5"', conteniendo un ovario discoídeo, deprimido, estriado, polilocular, uniovulada cada celdilla, de cuyo centro sale un estilo simple, largo de 1 " $1_{l} 2$, moradusco, infundibuliforme por el ápice, terminado á manera de la boca de una trompa, con 12 á 16 lobulitos, y con tantos bracitos pendientes, ancho de 10 á $14^{\prime \prime \prime}$. Semillas comprimidas, discoídeas, cuya testa leñosa y bruna es lisa $y$ lustrosa: hura, F. 106, T. III, S.-T. V, G. IV.

127. Hojas con 5 hojuelas, de peciolo biglanduloso por el vértice; flores terminales en panojas, cuyas masculinas perlunculadas y bibracteadas son glandulosas, mientras las femeninas son subsesiles; tienen una corola, 128. - Hojas de 3 en rama, reunidas hácia el vértice de las ramitas; peciolo sin glíndulas; flores axilares ó terminales en panoja arracimada, con una sola flor femenina terminal en cada racimo; corola nula. Arbol muy alto, corpulento y coposo, con hojas largamente pecioladas y dijitadas, cuyas hojuelas lanceolado-oblongas, enteras y lampiñas tienen la cara inferior blanquecino-venosa. Flores masculinas con periantio campanudo 5 -fido ó 5 dentado, de estivacion valvar; estambres monadelfos reunidos en 
una especie de columna anterífera por debajo del ápice, cuyas 5,10 anteras adheridas y estrorsas están dispuestas en 1 o en 2 séries; las femeninas constan de un ovario colocado sobre la hase del cáliz circular y persistente 6-lobulado, con 3 celdas uniovuladas, de cuyo ápice salen 3 estigmas sesiles y sub-bilobulados. Cápsula grande, fibroso-corticosa, formada de 3 cajillas que por causa de aborto se vuelven dos ó una, elásticamente bivalves y monospermas: herea, Aubl.; siphonia, Rich., F. 106, T. III, S.-T. II, G. IV.

128. Arbol mediano, de hojas alternas, cuyas hojuelas entejérrimas son nerrosas y lustrosas; cáliz campanudo, 5-dentado, pétalos mas larğos que él, ungüiculados, abiertos y de estivacion torcida en espira sobre sí mismo, alternando con 5 glándulas; en las flores masculinas hay 8 estambres monadelfos por la base, cuyos filamentos son distintos superiormente y filiformes, los 3 interiores mas largos y con anteras incumbentes; las femeninas de periantio conforme, con un ovario de 2,3 celdas monospermas, de cuyo ápice sale un estilo corto, 2, 3-fido, cuyos estigmas son enteros ó dentaditos. Drupa carnosa, pulverulenta, con un hueso de 2, 3 ángulos, fenestrado por los ángulos y por debajo del ápice, con 2,3 celdas monospermas : anda, F. 106.

129. Inflorescencia andrójina involucrada; flores apétalas ó siempre desnudas, muchas masculinas y una sola femenina largamente pedunculada y eserta, contenidas todas en un involucro comun mas ó menos caliciforme y mas ó menos colorido; vejetales siempre muy lechosos, 130. - Inforescencia centrífuga andrójina; flores cimosas, pediceladas, nunca jamás desnudas, ni involucradas tampoco; centro de la cima ocupado por una flor femenina; vejetales mas ó menos lechosos, 133.

130. Invólucro rojo, bilabiado, con figura de chinela china ó de cabeza de pájaro, cuya division esterior mas corta y gibosa lleva interiormente y por la base 4 glándulas; abierto superiormente y provisto de lacinias dispuestas á manera de bóreda y tapando la abertura; hojas sin estípulas, 131. - Invólucro caliciforme, mas o menos campanudo y turbinado, de limbo 4, 5-fido, provisto esteriormente de 5,1 glúndulas, con mayor frecuencia diseoídeas, amarillentas ó blancas, estipitadas, espesitas y alternando con las lacinias; hojas mas veces estipuladas, 132 .

131. Matas fruticosas, con ramos carnosos, verdes, lustrosos, cilíndricos y herbáceos, bastante blandos, mas o menos largos, de base leñosa y color ceniciento, lampiñas, como de $3^{\prime}$ á $6^{\prime}$ de altura, con hojas espesas, simples, casi sentadas, bastante coriáceas, dísticas, lampiñas ó alampiñadas por ambas caras cuando tiernecitas, ondulosas por los bordes enteros, aovado-redondeaditas, elípticas ó espatulado-lanceoladas, de cara inferior dispuesta á manera de canoa, segun la costilla, á veces aguzadas por ambos estremos, largas de $4-31_{1} 2-2^{\prime \prime}$, con el peciolo muy corto, $y$ anchas de $11_{[} 3-1 l^{\prime} 2-1^{\prime \prime}$; flores terminales cimosas, de las 4 glándulas amarillas 2 están situadas por la base de la division superior, una de cada lado y las 2 otras ocupan la base de cada division inferior; las flores masculinas consisten cada una en un pedunculo sin brácteas, en cuyo ápico ostś 
articulada una antera desnuda y saliendo por el pico del invólucro, en donde se presenta con forma de un punto amarillo ó castaño, son desiguales, mas ó menos numerosos y se presentan sucesivamente, pegados todos en las paredes interiores del invólucro, de cuyo centro sale la flor femenina largamente pedunculada, con un periantio obsoleto ó apenas notable, ovario trilobulado, trilocular, pendiente ú horizontal, de cuyo ápice sale un estilo único, terminado por 3 divisiones bífidas, cada una con su correspondiente estigma glanduloso, diverjente y puntiagudo. Fruto capsular formado de tres carpelos, pegados por el ángulo interno de un eje central, con una celdilla conteniendo una sola semilla provista de una carúncula, abriéndose por dos ventallas con elasticidad: pedilanthus, F. 106, T. III, S.-T. I, G. II.

132. Arbustos, frutices, matas ó plantas herbáceas anuales, algunas raras veces muy carnosas, sin hojas ó con muy pocas y armadas de muchas espinas á primera vista pareciendo un cirio, pero casi siempre con hojas simples, enteras, mas ó menos pecioladas ó sentadas, de forma y tamaño muy variados, lampiñas ó pubescentes, á veces glaucas, con ó sin estípulas, cuyo peciolo está ó no articulado con la vaina que termina la base, opuestas, verticiladas y á veces alternas inferiormente; flores en cabezuelas formando cimas umbeliformes, rarísimas veces polígamas por causa de aborto, axilares ó terminales; tales flores constan: las masculinas de un solo estambre, cuyo filamento es articulado por la parte mediana y acompañado bastantes veces de algunas cerdas situadas en rededor de su insercion, en número indefinido y variado ; están pegados en el fondo del invólucro en rededor de la flor femenina que sale de su centro, con un ovario largamente pedunculado, saliendo fuera del invỏlucro, ordinariamente un poco pendiente ú horizontal, trilobulado y formado de 3 cocos uniloculares monospermos, de cuyo ápice salen 3 estilos bífidos. Fruto capsular, cuyos carpelos pegados del eje central, se abren con elasticidad por dos valvas, tirando así una semilla provista ó no de carúncula : euphorbia, F. 106, T. III, S.-T. I, G. I.

133. Cáliz 8-partido ó 5-lobulado, imbricado; corola torcida; estambres $10,8,15$ monadelfos, de los cuales 3,5 son mas largos; 5 glándulas situadas por la base del andróforo; cápsula seca formacia de 3 carpelos; estípulas persistentes; flores de ordinario coloradas, 134. - Cáliz colorido, 5-lobulado ó 5-partido é imbricado; corola ninguna; 10 estambres distintos y libres, saliendo de un disco central, cuyos 5 esteriores soll mas cortos; estilos multilobulados; cápsula abayada, estípulas caducas, 135 .

134. Arbustos ó frutices mas ó menos ramosos, raras veces plantas herbáceas ó árboles bajitos, apenas lechosos, de hojas simples, mas ó menos pecioladas, alternas, mas ó menos lobuladas, partidas ó dijitadas, á veces enteras, de figura y tamaño muy variados; á veces las estípulas están reemplazadas por glándulas ramosas, ó son simples, glandulosas, multífidas ó setáceas, raras veces decíduas; flores amarillentas ó coloradas y dispuestas en cimas ó racimos axilares ó terminales, mas ó menos pedunculadas, pediceladas, sa- 
liendo de la axila de una bráctea, que suele faltar bastantes veces; anteras asaetadas; en las femeninas el ovario es oblongo-trilocular, mas ó menos trígono, mas ó menos liso, de cuyo ápice salen 2 ó 3 estilos cortos terminados por un estigma bífido mas ó menos velludo. Fruto capsular, trígono, trilocular, cuyos carpelos, pegados al eje central por su ángulo interno, son monospermos y se abren por dos valvas: jatropha, F. 106, T. III, S.-T. II, G. I.

135. Arbustos de raiz tuberculosa mas ó menos gruesa, de tallo como de $6^{\prime}$ á $8^{\prime}$, ramoso superiormente, mas ó menos tuberculado, lampiño, de color ceniciento ó achocolatado; hojas largamente pecioladas, alternas, simples, dijitadas ó palmeadas, cuyas divisiones ó lóbulos, en número de 7,5 , raras veces 3 , son mas ó menos profundos, oblongo-lanceolados, aguzados y bien enteros, lampiños, de cara superior lustrosa, mientras la inferior es mas ó menos glauca, con el peciolo y las nervaduras moraduscas, verdes ó moraditas; estípulas caducas, pequeñas y lanceolado-aguzadas; flores amarillentas, algo purpurinas ó blanquecinas, dispuestas en panojas pequeñas ó racimos compuestos axilares ó terminales y paucífloros, largos de $4^{\prime \prime}-6^{\prime \prime}$, á reces únicamentẹ masculinos, otras veces formados de flores de ambos sexos entremezcladas sin órden sobre los brazos, en fin algunas veces solamente femeninos; tales flores cuelgan de pedícelos bastante largos saliendo de la axila de una bracteita subulada; en las masculinas el fondo del cáliz 5-lobulado está ocupado por un disco de color anaranjado, carnudo, aniliforme y con 10 radios con que alternan los estambres, de filamentos filiformes, libres, mas cortos que el periantio, blancos y llevando anteras linear-oblongas y amarillas; en las femeninas el periantio es 5-partido y contiene un ovario purpúreo, de base envuelta por un disco anaranjado, trígono y con 3 celdillas con un óvulo único; de su ápice sale un estilo corto con 3 estigmas doblados hácia fuera, asurcados y blancos, Fruto capsular abayadito formado de 3 carpelos monospermos, colgante, ovoídeo y con 6 alas estrechas; semillas elípticas, negras, lustrosas, con una carúncula blanca : manihot, Pl., janipha, Kth., F. 106, T. III, S.-T. II, G. II.

136. Arboles no muy grandes y muy ramosos, de hojas simples, alternas, pecioladas, enteras ó aserraditas, ásperas y lampiñas ó pubescentes, cuyos peciolos están acompañados de dos estípulas mas o menos oblongas y membranosas; amentos masculinos cilíndricos, axilares, pedunculados, formados de muchas flores, de periantio monófilo, con 4 divisiones estendidas y membranosas y de 4 estambres mas largos que él, acompañando al ovario rudimentario, mientras los femeninos son esféricos ú oblongos y compuestos de muchas flores con periantio de 4 sépalos que parecen escamas, y son imbricadas, conteniendo un ovario lenticular, monospermo, que lleva en el ápice dos estigmas filiformes, sentados y glandulosos, óvulo-solitario y suspendido; los periantios de las flores femeninas volviéndose carnudos y soldándose entre sí constituyen la fruta, cuyas semillas colgantes tienen un embrion encorvado á manera de herradura. alojado en un endospermo espeso; radícula ảirijida hácia el hilo: morus, F. 41, G. II. 
'137. Flores masculinas, amentáceas y desnudas, 138. - Flores amentáceas ó no, pero nunca jamás desnudas, 141.

138. Flores femeninas en espigas bracteadas; un solo estambre; drupa pequeñita; arbustos de hojas simples y aserradas, 139. Amentos masculinos de flores bracteadas con 18, 24 estambres; flores femeninas solitarias; nuez de tamaño regular; hojas compuestas, 140 .

139. Arbustos mas o menos ramosos, cuyas hojas opuestas, simples, mas ó menos aserradas, mas ó menos lanceoladas, son elípticas ó lineares, lampiñas, bastante grandes, de $5^{\prime \prime}-2^{\prime \prime}$ de largo sobre $18^{\prime \prime \prime}$ á $8^{\prime \prime \prime}$ de ancho, mas ó menos aguzadas, pecioladas é insertas por dentro de una vaina estipular. Flores masculinas en amentos á veces como racimosos y sin brácteas : hedyosmum, F. 36.

140. Arboles corpulentos, altos y frondosos, de hojas imparipinadas, con hojuelas articuladas, pecioladas y alternas; flores masculinas en amentos axilares, pedunculados, largos y cilíndricos, formadas de una especie de periantio compuesto de escamas soldadas entre sí, de manera que parece con 6 divisiones; estambres con fiìmentos muy cortos, de anteras cuyas celdillas reunidas por un conectivo ancho se abren lonjitudinalmente; las femeninas están agrupadas algunas hácia la sumidad de las ramitas y axilares, de periantio doble 8-partido, dispuesto en dos séries, adherente con el ovario ínfero, unilocular, ovoídeo, de cuyo ápice salen dos estigmas espesos, diverjentes y corvos hácia fuera. El fruto es una especie de drupa cuyo sarcocarpio, espeso y algo cornudo se abre espontáneamente en dos ventallas irregulares y se desprende de la nuez, que contiene una sola semilla erguida y de cotiledones profundamente arrugados: juglans, F. 42 .

141. Drupa monosperma con 8 surcos, contenida en el tubo del periantio crecido y ventrudo, esponjosa esteriormente; flores ternadas contenidas en un invólucro tetráfilo, cuyas dos laterales pediceladas son masculinas, mientras la del medio, sentada, es femenina, 142. - Fruto capsular formado de 3 carpelos ó cajillas pegadas de un eje central, bivalvares y monospermas, nunca jamás drupáceo, 143 .

142. Arbol bajito y ramoso, de hojas simples alternas, aovadas, con una punta y redondeadas por la base, abroqueladas, casi tan largas como el peciolo, que lo es como de $6^{\prime \prime}$; flores en cimas sostenidas por un invólucro de 4 hojuelas corimbosas, cuyas masculinas se componen de un periantio de 6 divisiones profundas dispuestas en 2 séries, de manera que las 3 menores son internas y las 3 mayores esternas; 3 estambres monadelfos de filamentos biglandulosos por la base, cortos, derechos, con anteras abriéndose lateralmente: las flores femeninas de periantio monófilo 8-partido, caduco, apretado por encima del ovarió y caduco, contenido en un invólncro cupuliforme, urceolado y acreciente; 4 glándulas hay en el fondo del cáliz, en cuyo centro está el ovario unilocular, con un óvulo único pendiente, de cuyo ápice sale un estilo incluso terminado por un estigma ancho é infundibuliforme. Drupa única movible en el interior del invólucro avejigado, con nna abertura por el ápice y an- 
cho de $11_{1} 2^{\prime \prime}$, amarillo $y$ dos veces mas largo que ella; semilla con embrion sin endospermo, volcado y cuyos cotiledones grandes son lobulados : hernandia, F. 48.

143. Hojas grandes abroquelado-palmeadas, 7, 11-lobuladas, con peciolo largo y glandulífero; estambres muchos y poliadelfos; cápsula erizada, 144. - Hojas ni grandes ni pequeñas, pero sí de tamaño regular, nunca abroqueladas ni palmeadas; estambres en número definido y nunca poliadelfos; cápsula lisa, 145.

144. Arbusto ó arbolito ramoso, pero no frondoso ni corpulento tampoco, que se eleva de $15^{\prime}$ á $25^{\prime}$ de altura, de corteza lampiña color ceniciento ú rojizo, glauca ó rojiza en las partes herbáceas; de hojas alternas simples, estipuladas, cuyos lóbulos bastante largos y anchos son puntiagudos y aserrarlito-glandulosos, con peciolo largo de como 6 " á $7 "$ y acompañado por cada lado de su base y en su insercion de una glándula, una ó dos otras están situadas como hácia la parte mediana de su cara superior aplanada, y tambien por su ápice hay dos glándulas ó una sola, pero melliza, y algo mas pequeñas que las demas; tales glándulas son discoídeas, hemisféricas, algo cóncavas, de color rojo oscuro ó amarillento y secretan un líquido cristalino y sin color, inferiormente convexas y pegadas por el centro. Las hojas al salir de la especie de espata membranosa que las contiene y forma la estípula caduca cuya cicatriz anular se observa sobre las ramitas, son dobladas á manera de abanico, y sus dientes son representados entonces por glándulas amarillentas ó moraduscas, semi-trasparentes, algo ovoíleas, las cuales terminan las nervaduras secundarias, y va disminuyéndose poco á poco su tamaño á medida que va desarrollándose el limbo de la hoja y que se pronuncian mas los dientes de la circunferencia, y acaban casi por desaparecer: tienen mucha analojía con las otras. Flores en espigas ó racimos estra-axilares y piramidales, cuya mitad superior es fe-menina, mientras la base es masculina; los grupos de flores., sea masculinas sea femeninas, salen de la axila de una bráctea bastante grande, cuya insercion está ácompañada por cada lado de una glándula pequeña semejante á las peciolares; periantio conforme en ambos sexos: es 3,5-partido, sus divisiones son valvares y decíduas; en las masculinas los andróforos son muchos, desiguales y con muchos filamentos saliendo de su vértice, de anteras estrorsas, biloculares é insertas por debajo del ápice del filamento; las dos celdillas son distintas; en las femeninas el ovario es trígono, trilocular, erizado ó liso, glauco ó rojizo, algo oval, de cuyo ápice sale un estilo muy corto 3-partido, cuyos estigmas bítidos son peludos ó glandulosos, lineares y mas ó menos moraduscos. Fruto capsular erizado ó no, formado de 3 carpelos uniloculares, pegados por el ángulo interno de una columnita central, monospermos, abriéndose por 2 valvas, con semillas oblongas, ovales y algo achatadas, lustrosas, brunas y con manchas mas oscuras ó negras, provistas de una carúncula blanca: ricinus, F. 106, T. III, S.-T. IV, G. I.

145. Flores en corimbos largamente pedunculados, nunca jamás dioicas, con 10 estambres; savia abundante no enteramente lechosa, pero sí algo turbia, 146. - Flores nunca en corimbos, pero sí en 
espigas amentáceas $\delta$ en racimitos, algunas veces dioicas; con 8 , 10 , 16 y hasta 20 estambres; savia cristalina no muy abundante, pero bastantes veces balsámica, 147 .

146. Arbustos muy ramosos, altos de $6^{\prime}-12^{\prime}-15^{\prime}$, lampiños y de corteza como cenicienta en las partes leñosas, verde y lustrosa en las herbáceas, con hojas simples, alternas, pecioladas, aovadooblongas ó angulosas, sub-panduriformes ó apenas 3, 5-lobuladas. abroqueladas por la base acorazonada, y mucronadas ó no por el vértice, reticulado-nervosas por la cara inferior, lampiñas, verdes y lustrosas cuando adultas y coriáceas, mientras que siendo tiernecitas son algo moraduscas y alampiñadas; estípulas muy pronto decíduas. Flores de cáliz 5-partido, corto, imbricado; corola monopétala dos ó tres veces mas larga que el cáliz 5-partido ó 5-lobulado, lampiño ó velludo interiormente; estambres monadelfos por la base y dispuestos de tal manera que 5 son esteriores y alternan con tantas glándulas conoídeas que acompañan á la base del andróforo, de cuyo vértice salen filamentos filiformes con anteras estrorsas y biloculares ; ovario ovoídeo, 3-locular, de celdas uniovuladas, de cuyo ápice salen 3 estilos reunidos por la base, terminados por un estigma espeso y bilobulado. Fruto capsular casi globoso, algo trígono, formado de 3 carpelos uniloculares y conteniendo una semilla negra, asperita, no lustrosa. Los corimbos ó cimas tienen los brazos pubescentitos y son formados de corimbitos de 6 á 8 flores verrloso-amarillentas, cuyos pedícelos son bracteados por la insercion, con una sola flor femenina solitaria en el centro de la bifurcacion de los brazos y de pedúnculo sin brácteas : curcas, F. 106, T. III, S.-T. II, G. III.

147. Flores de ambos sexos apitilas, 148. - Flores masculinas con una corola de 5 pétalos, mientras las femeninas son de ordinario apétalas; semillas con una carúncula biglandulosa; estambres 10 , 20,5 ó muchos; flores en espigas amentáceas ó en racimos axilares ó terminales, cuyas femeninas ocupan la base, ó en espigas diferentes. Arbustos frutices, matas y plantas herbáceas, ramosas, raras veces resinosos y aromáticos; de hojas simples, no muy grandes, enteras, lobuladas ó aserradas, pecioladas, á veces glandulosas, de un solo color ordinariamente, pero raras veces discolores, pubescentes ó velludas por ambas caras, ó por la inferior solamente, cuyo pelo es á manera de estrella; estípulas ordinariamente caducas ó á veces persistentes y glandulíferas, filiformes ó foliáceas; periantio de limbo dividido en $5,4,12$ segmentos ó lóbulos valvares ó algo imbricados; en las masculinas hay una corola de 4,5 pétalos, los cuales son pequeños ó enteramente abortados en las femeninas; estambres distintos de anteras erguidas é introrsas; ovario ovaltrígono, trilocular, cuyas celdillas son uniovuladas, y de cuyo ápice salen 3 estilos de ordinario dicótomos, con los brazos arrolladitos. Fruto capsular formado de 3 carpelos monospermos, pegados de una columna central, de semillas convexo-biglandulosas y provistas de una carúncula, con el rafe distinto: croton, F. 106, T. III, S.T. VII.

148. Hojas compuestas, cargando con las flores situadas á lo 
largo del raquis y colgantes; carpelos con dos semillas; estambres de 2 á 4, 149. - Hojas nunca jamás compuestas; flores axilares ó terminales en espigas ó racimos mas ó menos bracteados y amentáceos; flores femeninas ordinariamente ocupando la base ó á veces en grupos separados, 151 .

149. Periantio 4-partido con las divisiones desiguales; estambres 4 distintos ; ovario 5:2-locular, de cuyo ápice salen $8-5$ estilos bífidos; fruto drupáceo ó abayado, con semillas angulosas, colgantes del vértice de la celdilla y provistas de una carnúcula diminuta; estípulas decíduas, 150.-Periantio 6-5 ó 4-9-partido: estambres 3 ó 2-15-monadelfos; ovario 3-10-locular, acompañado por la base de 5, 6 glándulas ó de un disco glanduloso ó membranoso; estípulas ordinariamente persistentes: árboles bajitos, arbustos, frutices ó plantas herbáceas lampiñas ó pubescentes, de ordinario ramosos, de hojas mas ó menos grandes, cuyas hojitas son enteras ordinariamente y dísticas ; flores solitarias axilares ó fasciculadas, situadas á lo largo de los raquises provistos ó no de sus hojuelas, á veces andrójinas; anteras introrsas; del ápice del ovario salen ordinariamente 3 estilos y á veces 10, mas ó menos cortos y bífidos ó laciniados. Fruto capsular, raras veces abayado, formado de 3 carpelos, con una semilla trígona, de ordinario pegada por debajo del ápice y sin carnúcula : phyllanthus, F. 106, T. II, S.-T. IV, G. Il.

150. Arbustos ó árboles de como $20^{\prime}$ á $25^{\prime}$ de altura, bastante ramosos y algo frondosos, lampiños; cuyas hojuelas dísticas, enteras y lampiñas son largas de 2 á 3 pulgadas, obtusitas ó puntiagudas, aovadas, elíptico-lanceoladas ú obovado-lanceoladas, casi sentadas; flores monoicas ó dioicas, fasciculadas, axilares ó laterales, pedunculadas; filamentos de los estambres alternando con glándulas esteriores ó ceñidos por un disco. Fruto globoso ó deprimido-globoso con ángulos obtusos mas ó menos pronunciados: cicca, F. 106, T. II, S.-T. I, G. I.

15l. Flores en racimos especiformes, ó en espigas amentáceas axilares ó terminales, con brácteas mas ó menos grandes acompañando á las flores, monoicas ó á veces dioicas ; periantio de las masculinas 4-partido y el de las femeninas 3-5-partido; estambres 8, 16 saliendo de un disco central, con anteras estrorsas, celdillas libres colgando del ápice del filamento, ordinariamente oblongas y torcido-plegadas á la par, 152. - Flores siempre monoicas en racimos andrójinos axilares, cuyas flores femeninas sub-solitarias y largamente pediceladas, ocupan la parte inferior; de periantio 3-8partido, con los segmentos lanceolados y bien enteros; ovario trilocular, trígono, cuyo ápice lleva un estilo 3 -fido con los brazos arrollados; las masculinas se componen de un periantio 3-partido, con 3, 1 estambres cuyas anteras oblongas ó globosas son introrsas: fruto capsular formado de 3 carpelos con una sola semilla globosa $y$ sin carnúcula, globoso-trígono y erizado. Mata fruticosa de tallo largo, delgado y ramosísimo, trepadora ó abejucada, pelierizada ó alampiñada, cuyo pelo blanco tieso es punzante y causa mucho escozor, de hojas simples oblongo-lanceoladas, pecioladas, aguzadas, aserradas ó festoneadas, acorazonadas; racimos filiformes, amentáceos, 
tan largos como el pedícelo de las flores femeninas ó mas; brácteas setáceas tan largas como el pedícelo de las flores masculinas : tragia, F. 106, T. III, S.-T. VI.

152. Arbustos, frutices ó plantas herbáceas ordinariamente muy ramosas superiormente, lampiñas ó pubescentes, de hojas mas ó menos aovadas, oblongas, oblongo-lanceoladas, elípticas, de ordinario aserradas, pecioladas y con estípulas. Flores femeninas en grupos ó en espigas acompañadas de una bráctea grande acrescente frecuentemente, en forma de cartucho y festoneada, cuyo ovario algo trígono y trilocular lleva en su ápice 3 estilos multífidos, raras veces bífidos, con los brazos setáceos. Fruto capsular formado de 3 carpelos, conteniendo una semilla diminuta sub-globosa, sin carnúcula ó con una apenas visible : acalypha, F. 106, T. III, S.-T. VI, G. I.

153. Flores dispuestas en espádice, 154.-Flores nunca jamás en espádice, 166.

154. Espádice siempre distinto de la espata cuando existe y formado de muchas fiores, 155. - Espádice adherido á la espata en forma de cartucho, con 2 a 3 flores solamente, de las cuales una sola es femenina; anteras 3-8 adheridas al ápice del espádice y abriéndose por un surco transversal y sentadas; ovario unilocular : pistia, F. 32.

155. Desnudo y amentiforme ó no, 162.-Provisto de una espata única con figura de cartucho ordinariamente y que le cubre casi á manera de caperuza, rarísimas veces enteramente cubierto de flores, 156.

156. Libre, continuo ó interrumpido, andrójino y de vértice desnudo ó sin flores; su parte median nen!nada por nectarios; conectivo de las anteras muy espeso y abruyueiado; ovarios 1 ó pluriloculares, 157. - Espádice libre ó adherido inferior y posteriormente á la espata, andrójino y con los nectarios entremezclados con las flores femeninas, rarísimamente de vértice sin flores; conectivo de las anteras que se abren por poros, espeso pero no abroquelado; ovarios 1 ó pluriloculares : plantas herbáceas de tallo leñoso inferiormente y que parece una caña, de base un poco acostada en el suelo y despues derecho, alto de $3^{\prime}$ á $5^{\prime}$, lleno y cuyo diámetro es de $2^{\prime \prime}$, nunca ramosa y criándose en los lugares húmedos; hojas alternas, largamente pecioladas, envainadoras por la base, oblongo-ovales, cuspidadas, nervosas, al principio aproximadas por el vértice del tallo y mas luego apartadas de él, pero siempre derechas, enteras, algo undulosas por los bordes enterus, coriáceas, largas de 12 á 15" sin el peciolo que lo es de 5 á 8 y anchas de 5 á $51_{1} 2$; espádices pedunculados, axilares, superiores y dispuestos en una especie de verticilo de á tres. Espata larga de $5^{\prime \prime}-66^{\prime \prime}$, oblongo-arrollada por adentro, verde pálido, pegada con la parte esterior é inferior del espádice cuyo vértice blanco amarillento sale apenas por fuera de ella, inferiormente seudo-hermafrodito, ó andrójino y de vértice masculino, no enteramente libre. Estambres muchos de anteras 3-4-loculares oblongas y pegadas en un conectivo truncado verticalmente, cuyas celdillas paralelas se abren por el ápice á favor de un poro comun; ovarios muchos, libres y acompanados cada cual por tres estamino- 
des sub-adheridos por la base, con un óvulo único, parietal hácia la base, y aścendente de un funículo corto, ortótropo; estigma discoídeo sentado; bayas uniloculares monospermas, de semilla sub-globosa con testa coriácea, espesita y de ombligo basilar, ancho: dieffenbachia, F.8, T. I, S.-T. II.

157. Tubo de la espata persistente; parte mediana del espádice las mas veces desnuda, con el apéndice estéril y algunas veces apenas notable ó nulo; algunas anteras co-adheridas; ovario 1-1locular; savia á veces como lechosita; sin estípulas; raices frecuentemente tuberculosas, 159.-Espata persistente enteramente ó decídua, 158.

158. Espata persistente, 158 bis. - Espata decídua enteramente, convoluta ó arrollada; vejetal de tallo recto, alto de $5^{\prime}$ á $6^{\prime}$, leñoso, con grandes hojas aflechadas y largamente pecioladas; espádice libre continuo, andrójino, sin órganos estériles ningunos, ni apéndice estéril tampoco; anteras 4-loculares, pegadas por el lado de un conectivo conoídeo y truncado, cuyas celdillas son dispuestas por pares y confluentes por el ápice, $\mathrm{y}$ dehiscentes por una grieta ; ovarios muchos, libres, uniloculares con un solo óvulo ortótropo ascendente y con funículo corto; estigma terminal, sentado, no simétrico, festonerdo y marjinado. Baya esponjosa, sin endospermo por causa del embrion que va creciendo y llena la celda: montrichar. dia, F. 8, T. I, S.-T. III.

158 bis. Espata persistente entera y cerrada despues de verificada la fecundacion; espádice continuo andrójino, de apéndice estéril nulo; anteras libres; ovarios multiloculares; savia nunca lechosita; estípulas elongadas, opositifolias y decíduas, raiz no tuberculosa: plantas herbáceas de tallo larguísimo trepador, ramoso y carnudo, con hojas apartadas, alternas, mayores, pecioladas y envainadoras por la base del peciolo, enteras, lobuladas ó partido-laciniadas. Espata de base rollada por adentro ó en espiral sobre sí misma; nectarios por debajo de los estambres; anteras biloculares distintas 2, 7 , de dorso areolado y cuyas celdillas se esconden en el conectivo, abriéndose por el ápice; ovarios muchos aproximados y libres 5, 15loculares, óvulos incorporados desde el ángulo central de la celdilla y ortótropos; estilo cortísimo ó nulo ; estigma cabezudo, truncado ó radiado subulado; bayas discretas polispermas: philodendron, F. 8, T. I, S.-T. III.

159. Espádice interrumpidamente anđ̄ỏjino, 159 bis. - Espádice andrójino sin interrupcion con nectarios rarísimos situados por debajo de los estambres, de apéndice estéril nulo, con espata derecha y enrollada por la base. Anteras 4,5 biloculares pegadas en un conectivo troncado y anguloso, cuyas celdillas salen por los ángulos opuestos, abriéndose por poros situados en el ápice; ovarios muchos uniloculares, enteramente reunidos entre sí, con órulos solitarios. basilares, sentados y ortótropos; estigmas distintos, sentados y blanco-glutinosos; bayas plurimas reunidas y monospermas. Plantas herbáceas trepadoras, cle tallo mas á menos largo y blando, carnoso, de hojas grandes palmeado-partidas, pecioladas; pedúnculos 
cortos y desnudos; espatas de color suciamente amarillento-verdosas: syngorium, F. 8, T. I, S.-T. II.

159 bis. Espata enrollada en espiral sobre sí misma, derecha; nectarios situados siempre por debajo de los estambres; apéndice estéril del espádice siempre nulo; anteras uni ó biloculares; ovarios muchos, aproximados y nunca uniloculares, 160. - Espata derecha, acogollada y nunca enrollada; nectarios situados tan pronto por debajo como por encima de los estambres; apéndice estéril del espádice claviforme ó aguzado; anteras biloculares siempre, plurimas, pegadas á manera de verticilo en los conectivos conoídeo-troncados, sentadas ó sub-estipitadas y distintas, cuyas caldillas contiguas se abren por un poro comun; ovarios aproximados, plurimos, libres y siempre uniloculares, con óvulos colocados sobre tres placentas parietales y hácia la base, derechos y ortótropos. Plantas herbáceas de rizoma tuberculífero ó caulescente, $y$ en este último caso con tallo trepador; hojas mas ó menos grandes abroqueladas, redondeadas mas ó menos $\mathrm{y}$ pecioladas; pedúnculos solitariơs ó saliendo algunos de la misma axila, acostados $\mathrm{y}$ vajinados: colocasia, F. 8, T. I, S.-T. III.

160. Espata enteramente enrollarla; anteras muchas uniloculares, distintas, pegadas en verticilo en los conectivos claviformes y troncados, abriéndose por un poro situado en el ápice, 161.-Espata convoluta solamente por la base ; anteras biloculares, muchas, distintas, pegadas á manera de verticilo sobre conectivos conoídeotroncados, cuyas celdillas contiguas se abren por grietas situadas por el ápice; ovarios muchos aproximados, con estilos espesísimos placentiformes y coherentes, sub-cuadriloculares, cuyas celdillas contienen muchos óvulos horizontales é insertos por la parte mediana del eje; los estigmas, anchos, deprimidos y lobulados, son amarillento-glutinosos; baya. Plantas herbáceas, de rizoma caulescente derecho, tuberculífero, con hojas radicales grandes, largamente pecioladas y asaetadas; pedúnculos sub-solitarios saliendo de la vaina de los peciolos; espata amarillenta : xanthosoma, F. 8, T. I, S.-T. III.

161. Plantas herbáceas de rizoma tuberculoso ó no, con ó sin tallo mas ó menos falso, con hojas radicales largamente pecioladas abroquelado-alabardadas ó multífidas, de cara superior muy lisa y lustrosa, mientras jor la inferior las renas forman una especie de redecilla; bojordos solitarios, sin brácteas $\mathrm{y}$ elongados; espata blanquecina; ovarios libres biloculares, con estigma sentado, terminal y discoídeo; óvulos 2-4 en cada celdilla y situados sobre las suturas, ascendentes con funículo corto y ortótropos. Bayas uni ó biloculares, oligospermas, cuyas semillas angulosas tienen testa coriácea y espesita; ombligo basilar y ancho : caladium, F. 8, T. I, S.-T. III.

162. Vejetales parásitas sin hojas, mas ó menos coloridos pero nunca verdes. Flores femeninas con el periantio tubuloso y trilobulado, mientras el de las masculinas es apenas notable, 161.- Vejetales nunca parásitas y con hojas verdes, de espádice amentiforme cubierto de flores, interrumpido por hojas pequeñas que unos tienen por espatas; cáliz escarioso ó piliforme, 163.

163. Plantas herbáceas bastante altas, cuya caña delgada y de- 
recha sale, así como las hojas radicales, de una especie de rizoma poco desarrollado y que se crian en los lugares húmedos y se elevan á $4^{\prime}$ ó $6^{\prime}$ de altura; hojas radicales alternas, largas de $2^{\prime}-3$ ' y mas, de base envainadora, lanceoladas, muy largas, derechas y estrechas; boyordo ó tallo saliendo del centro de las hojas, cilíndrico, largo y derecho, terminándose por una espiga amentiforme ó espádice, continuo ó interımpido por algunas espatas foliáceas caducas, cilíndrico, bastante grueso, cuyo vértice es masculino y la base femenina; muchas anteras sostenidas por filamentos filiformes y de vértice cortamente 2 ó 3 -fido ó ahorquillado, basifijas, oblongas, biloculares y con 4 celdillas, echando mucho pólen amarillo por afuera del espádice. Las flores femeninas son formadas de un ovario saliendo inmediatamente del eje, y agrupadas sobre protuberancias á propósito y acompañadas de muchas cerdas sud-claviformes, al principic sentado y por fin estipitado, unilocular, con un óvulo único, anátropo y colgante del vértice de la celda; estilo simple continuo con él y de estigma unilateral linguiforme ; el fruto es una especie de cariópside ó drupáceo, con la semilla inversa, de base soldada con el endocarpio : typha, F. 9.

164. Espádice ovoídeo ó globoso, andrójino, cubierto de brácteas abroquelado-hexágonas", 165. - Espádice oblongo cilíndrico, con brácteas imbricadas decíduas; rizoma espeso y ramoso, de donde sale un tallo rojo largo de como $6^{\prime \prime}$, cubierto de escamas aplicadas sobre él, dispuestas por 4 ó por 6 séries opuestas, las cuales se vuelven brácteas tambien aorado-deltoídeas tuberculadas por el vértice y con rudimentos de flores; espádice largo de $1^{\prime \prime}-2 l_{[} 2^{\prime \prime}$; columna anterífera dividida en 3 brazos por debajo del cuerpo globoso, formado por las anteras reunidas, con 6 celdillas y abierto por el ápice : prytlocoryne, F. 46.

165. Rizoma ramoso de cuyos nudos salen tallos desnudos altos de $2 "-6 "-12^{\prime \prime}$, cuya base está envuelta por una raina anular $3-4$ ó 5-7-lobulada; espádice encerrado en el invólucro rajinal antes de desarrollado el tallo; flores masculinas tardías; columna con tres estambres, dividiéndose en 3 brazos por debajo del cuerpo formado por la reunion de las anteras, con 6-12 celdillas insertas en la garganta del cáliz; anteras introrsas; cáliz de las femeninas apenas notable; ovario simple, con un óvulo erguido desnudo; estilos 2 ; semillas adherentes con el pericarpio crustíceo : helosis, F. 46.

166. Flores desnudas de inflorescencia andrójina y colocadas muchas en la superficie de un receptáculo mas ó menos llano alveolar $y$ terminal en el ápice de un boyordo mas ó menos largo ; estambres 2-4; estilo lateral bi-dentado, 167. - Flores nunca desnudas ni agrupadas tampoco sobre un receptículo, pero sí siempre provistas de envoltura floral mas ó menos completa, 168.

167. Plantas herbíceas pequeñas sin tallo lejítimo, pero con un rizoma mas ó menos desarrollado, escamoso, nudoso, simple, del ápice del cual salen hojas simples, alternas, largamente pecioladas, palmatítidas ó palmati-partidas, repando-enteras ó espatuladooblongas y solamente festoneadas, mas ó menos acorazonadas por la base, ásperas, alampinadas o lampiñas, membranosas; estípulas 
persistentes ; receptáculo abroquelado cuadrangular, orbiculardentadito ó ciatiforme-orbicular ; fruto capsular irregularmente bivalve; embrion ganchoso sin endospermo: dorstenia, F. 41, G. IV.

168. Flores siempre glumáceas ó sin cubierta floral lejítima, 169.

Flores nunca glumáceas, pero cuya envoltura floral lejítima es simple ó doble, 173.

169. Masculinas en panojas terminales, mientras las femeninas son en espigas cilíndricas axilares, mazorcas ; 3 estambres, 172. Flores masculinas y femeninas en panojas terminales, 170.

170. Estambres seis, 171. - Estambres 3 : yerbas pequeñas, de tallo delgadito, alto de $6^{\prime \prime}$ á $8^{\prime \prime}$, con hojas alternas, envainadoras $y$ de vaina cerrada, á veces alada, linear-lanceoladas ó lineares; flores en espigas ó panojas fiojas, formadas de espiguitas multífloras para las masculinas $\mathrm{y}$ unífloras para las femeninas; constando de glumas dísticas ó trísticamente imbricadas, cuyas inferiores son ordinariamente menores, alado-aquiladas; ovario con estilo continuo, bi ó trífido; disco distinto, ciatiforme, sub-cilíndrico, lobulado, repando ó troncado, coriáceo, corchoso ó membranoso cartáceo, á veces cerdoso, pubescente, adherente sólidamente á la cariópside huesosa, sub-globosa, en forma de botella ó lenticular blanca ó atropurpúrea : scleria, F. 11, T. II.

171. Yerba de como $l^{\prime}$ á $2^{\prime}$ de alto mas ó menos, segun la feracidad del suelo en que vejeta, de caña delgada, ramosa y derecha, cuyas hojas envainadoras y alternas son lanceoladas, puntiagudas, nervosas, largas de como $8^{\prime \prime}$ á $10^{\prime \prime}$ sobre $2^{\prime \prime}-3^{\prime \prime}$ de ancho, de vaina abierta cuya parte superior está prorista de una lígula membranosa acompañada de una hilera de pelos. De adentro de la vaina de las hojas superiores sale una panoja pequeña parecida á la que termina el tallo, formada de 15 á 20 espiguitas largas como de $2^{\prime \prime}-3$ ", compuestas de grupos de 4-5 fiores situados sobre cada diente del eje, de suerte que cada espiguita lleva como 30 ó 40 flores ovales, amarillas que constan de una gluma uníflora de 2 valvas, que contiene una glumela muy delgadita y tambien de 2 ventallas, y dos escamitas ó pajitas lampiñas acompañando el rudimento del ovario; las flores femeninas no tiencn las escamitas; ovario sentado con un estilo con 3 estigmas peludos. Cariópside linear encerrado en la palea inferior de la glumela: pharus, F. 10, T. I.

172. Planta herbácea anual cuya caña, hastante gruesa, llena $\mathrm{y}$ simple, se eleva á $4^{\prime}-6^{\prime}$ de altura, con hojas alternas, envainadoras por la base, bastante grandes, sentadas, lanceoladas, basinervias, cuya vaina abierta está provista interiormente y por el ápice de una lígula corta $y$ pestañosa. Pannjas masculinas terminales grandes, amarillentas, con flores á veces polígamas y que constan de una gluma con 2 flores y bivalves, de una glumela con dos ventallas sin arista; estambres de filamentos filiformes sosteniendo anteras grandes $y$ colgantes; las espigas femeninas ó mazorcas de 1 á 3 por cada caña, blancas, largas de $1^{\prime \prime}$ á $2^{\prime \prime}$ y formadas de flores solitarias y dispuestas por séries verticales, están encerradas en vainas foliáceas bastante numerosas, formando así una especie de estuche cónico, por el ápice del cual sale como un penacho blanco ó barba, pendiente, 
formado por los muchos estilos larguísimos y filiformes que llevan así afuera dos estigmas subulados y pubescentes que les terminan; las flores femeninas asi alineadas simétricamente en un eje central grueso y bastante carnudo al principio son formadas de una gluma de dos ventallas obtusas y membranosas, de una glumela con dos valvas redondeadas provistas de una arista muy pequeña; ovario único grueso y globoso. La mazorca madura es larga de $3^{\prime \prime}$ á 6 " o hasta mas, con 12 á 16 séries verticales de cariópsides ó granos gruesos, redondos, lisos, lustrosos, como crustáceos, de ordinario amarillos, otras veces blancos y mas raras veces moraduscos, etc., de base cuneiforme, y mas ó menos comprimidos y á veces un poco, con 4 caras, lo que proviene de la compresion mutlial que esperimentan durante su desarrollo, porque los de las dos estremidades son bien redondos en número de 3-5-700 y hasta mas por cada mazorca : zea, F. 10, T. II.

173. Flores femeninas conteniendo muchos ovarios pequeños, libres y agrupados á manera de cabeza sobre un receptáculo esférico; vejetiles de los lugares pantanosos, 174.- Flores femeninas con un ovario único ínfero ó súpero, 175.

174. Yerbas lampiñas sin tallo pero con un bojordo de $1^{\prime}$ á $3^{\prime}$ y mas de alto, con hojas simples, largamente pecioladas, todas radicales, alternas, envainadoras por la base del peciolo, asaetadas, ovales y elíptico-lanceoladas. Flores blancas cuyas superiores son masculinas, dispuestas en panojas ó racimos terminales y cuyos pedícelos son en umbelas ó verticilos; de cáliz con 3 sépalos y de corola con 3 pétalos mas grandes que los sépalos, é imbricados; muchísimos estambres amarillos en el centro de las flores masculinas hay cuyas anteras son tan pronto mas largas como mas cortas que los filamentos, los cuales estín reemplazados en las femeninas por muchos ovarios uniloculares, 1-ovulados, dispuestos por séries sobre un torus convexo, sentados; estilo ventral cortísimo terminado por un estigma obtuso. El fruto es un aquenio comprimido, mucronadito y alado: sagittaria, F. 30 . 194.

175. Siempre adherente ó ínfero, 176. - Siempre libre ó súpero,

176. Periantio doble lejítimo ó formado de un cáliz y de una corola; plantas de ordinario herbúceas, provistas de zarcillos estrapeciolares simples o ramosos; estambres $3-5$ de ordinario triadelfos; fruto carnoso, bacciforme mas ó menos grueso, 178. - Periantio simple, de sépalos dispuestos en dos séries, cuyas esteriores ordinariamente mayores son coloridos mas ó menos; muchos estambres libres; fruto capsular alado; siempre sin zarcillos, 177.

177. Vejetales herbáceos, sub-leñosos o sub-leñositos, cuyas partes herbáceas son suculentas, lampiños ordinariamente ó pubescentes y hasta peludos, cuyos mas altos se elevan como de $6^{\prime}$ á $8^{\prime}$ de altura y los mas bajitos á $2^{\prime \prime}-6^{\prime \prime}$; de hojas mas ó menos espesas y carnosas, alternas y mas frecuentemente dísticas, simples, pecioladas, enteras, angulosas, dentadas ó festoneadas, oblícuas, con frecuencia acorazonadas por la base, algunas veces de dos colores, con estípulas decíduas y á veces persistentes. Flores en cimas dicótomas 
axilares, pediceladas, de un periantio cuyos sépalos algo coloridos son en igual número en ambos sexos ó diferente, $2,3,4,5$ dispuestos en esos dos últimos casos en dos séries, distintos y desiguales, de los cuales 2 son mayores, opuestos y mas esteriores y ordinariamente coloridos; estambres muchos. Ovario ínfero $3,2,5$-locular, poliovulado, de cuyo vértice salen 3 estilos bipartidos ó bífidos, torcidos, enteramente papilosos ó provistos de una faja continua ó semilunar y papilosa ; cápsula con 3 alas mas ó menos desiguales, con los placentas bilamelados ó enteros, abriéndose por 3 ventallas, conteniendo muchas semillas diminutas de embrion sin endospermo; hojas ordinariamente de sabor ácido bien pronunciado: begonia, F.137.

178. Frutos siempre indehiscentes, 181.-Frutos dehiscentes sea que se revienten en valvas desiguales, sea que se abran naturalmente por un opérculo ó tapa situado en su ápice, 179.

179. Reventándose despues de maduro con elasticidad por el ápice en 3 partes desiguales y quedándose carnudo, 180.-Fruto volviéndose seco despues de maduro y conteniendo entónces una masa fibrosa dispuesta en redecilla y con 3 celdas lonjitudinales, conteniendo muchas semillas; abriéndose por una tapa que se desprende naturalmente llevando consigo el ápice : flores masculinas en racimos axilares ó terminales, largamente pedunculados y con pocas flores sentadas ó cortamente pediceladas formadas de un cáliz 5fido, de tubo cortamente campanudo, corola profundamente 5-partida; 5 estambres 3, 2-adelfos, de anteras distintas con las celdillas flexuosas y situadas por la márjen del conectivo sinuoso; en las flores femeninas que son solitarias y axilares, el cáliz es adherente tambien 5-fido, pero con el tuljo claviforme; corola conforme; ovario trilocular, multiovulado, de cuyo vértice mas ó menos prolongado sale un estilo corto trífido, de estigma espeso arriñonado, bilobulado ó bipartido. Fruto bacciforme mas ó menos largo, cilíndrico ó algo trígono, ovoídeo y provisto de puas; semillas negras comprimidas, reticuladas ó escrobulíferas. Plantas herbáceas anuales, de tallo largo, delgado, ramoso, áspero, mas ó menos pubescente, trepador, anguloso ó cilíndrico, con hojas alternas, largamente pecioladas, mas ó menos lobularlas, acorazonado-redondeadas, alampiñadas ó lampiñas y ásperas; zarcillos 3-fidos ó sencillos: luffa, F. 141, T. II, G. IV.

180. Plantas herbáceas enredaderas y trepadoras, de tallo herbáceo mas ó menos largo, muy ramoso y alampiñado, con hojas alternas, largamente pecioladas, mas ó menos lobuladas, con los lóbulos sinuoso-aserrados ó dentaditos; zarcillos simples pelierizados o lampinos. Flores solitarias largamente pedunculadas, con una bráctea redondeada y entera ó acorazonada y dentadita situada hácia la parte mediana ó el vértice del pedúnculo, constando las masculinas de un cáliz campanudo 5-fido, cuyos lóbulos óvalo-lanceolados son mas largos que el tubo muy corto; corola profundamente 5 -partida y casi 5-petalea-campanuda; estambres 5-triadelfos, de anteras uniloculares, todas adheridas y cuyas celdillas lineares son dobladlas por arriba y por abajo; flores femeninas de cáliz adherente 5-fido, con tubo mas ó menos largo y estrecho; ovario con tubércu- 
los ó crestas mas ó menos ovoídeo, 3-locular, con muchos óvulos dispuestos en una série en cada celda; un estilo 3-fido terminado por un estigma recortado. Fruto oblongo ó elíptico con tubérçulos, ú oblongo-elíptico largo de 5 á 6 pulgarlas y con crestas lonjitudinales muy pronunciadas; semillas comprimidas mas ó menos lobuladas y envueltas de carne á manera de arilo: momordica, F. 141, T. II, G. II.

181. Estambres triadelfos, 182.- Estambres monadelfos, 184.

182. Fruto pequeño elíptico-oblongo color de aurori cuando maduro, unilocular polispermo ; fiores pequenas agrupadas y entremezcladas las de ambos sexos; estambres 3, 183. - Fruto mas ó menos grueso 3, 5, 6-locular; estambres 5 triadelfos, 185.

183. Vejetales vivaces de tallo muy largo, muy ramoso superiormente, con ó sin un crecido cónico á veces bastante grueso por la base, de cuya parte inferior salen las raices fibrosas, del tamaño del dedo pulgar hasta el del brazo de un niño de un año, muy blando, que se corta y rompe con mayor facilidad, casi cilíndrico un poco asurcado, algo nudoso, de corteza muy agrietada; en su corte transversal las fibras están dispuestas en haces triangulares formando como una estrella; los ramos nuevos están en zig-zag y salen dicótomos de un crecido ó nudo mas ó menos pronunciado; en cada ángulo saliente formado por tal disposicion se observa una especie de nudo ó pezon de donde salen las hojas, las fiores y uno ó á veces dos zarcillos estraxilares persistentes despues de desprendidos los dos otros órganos y que sostienen el bejuco en lał̣cima de los árboles que habrá alcanzado, como suele hacerlo; los ramos tiernos son cilíndricos, lampiños, de un color verde mas subido y como teñido de bistre; los otros ramos parecen estriados por causa de las muchas grietas lonjitudinales de la epidermis; tal bejuco presenta hácia su parte inferior muchas estomas que están sin embargo esparcidas por toda su superficie; es bastante carnudo; en su corte transversal se ve una especie de estrella con 10 á 12 radios mas ó menos, según su tamaño, y en caso de ser bastante grueso son bífidos hácia la circunferencia. Hojas simples, alternas, largamente pecioladas, bastante grandes mas ó menos, 5-lobuladas, denticuladas, hlanquecinas y pubescentes, así como el peciolo, que es algo estriado, de cara superior lustrosa, verde oscuro con algunos pelos blancos; zarcillo simple, fuerte y de vértice en espiral. Flores pequeñas color de bistre o un poco mahon, cuyas femeninas muchas, sentadas y dispuestas en grupos bien furnidos situados en derredor del pezon señalado en el ángulo saliente de las ramitas, en dondo se va alargando mas ó menos para formar el eje grueso de la espiguita de flores masculinas pediceladas y dispuestas en espiral, cuya base está ocupada por las femeninas raras veces entremezcladas con las masculinas, se van floreando sucesivamente y poco á poco, de tal manera que sobre el mismo pezon se ven con frecuencia frutos maduros, flores abiertas y otras en capullo naciente; las masculinas constan de un cáliz ciatiforme por la base, con 5 divisiones profundas, abiertas al principio, pero mas tarde dobladas por afuera, de tal manera que su ápice alcanza casi la base, lanceolado-ovales, de bordes algo arrolladitos, de 
cara superior que fué interior como aterciopelada y convexa, mientras la inferior es cóncava con algunos raros pelos blancos que se hallan tambien en la base calicinal color de bistre; capullo oboval, de ápice truncado y con 5 estrías bien pronunciadas y salientes, color bistre subido ; prefloracion valvar; corola de 5 pétalos alternos, con las divisiones calizinales; iusertas en la garganta del cáliz, conniventes y formando así casi una pirámide en el centro de la flor, algo mas pálidos, lanceolados, puntiagudos, con los bordes y el ápice un poco arrollados, cuya cara esterior es lampiña y cóncava, mientras la interna ó superior es convexa, y con unos pelos blancos, larguitos y algo tiesitos; estambres 5 triadelfos, erguidos, libres, opuestos á los pétalos correspondientes é insertos un poco por debajo de ellos, de filamentos cortos, erguidos y con pelo blanco por la base, mientras la mitad superior de ellos es lampiña, cilíndricosubulados, converjentes de manera que están situados oblícuamente de afuera por adentro, con anteras color de oro, uniloculares y separadas por un conectivo algo carnudo, verde, oblongo y cuyo ápice se prolonga un poco mas allá que ellas, de ápice terminado en pico algo doblado hácia fuera, cuya cara superior con pelo blanco en sus $2\left[3\right.$ superiores tiene $1_{[3} 3$ inferior lampiño así como el dorso, que se inserta perpendicularmente un poco mas arriba de la base en el ápice del filamento; uno de los 3 conectivos lleva una sola antera, faltando siempre la otra; tales anteras se abren por medio de un surco lateral tan largo como ellas. Si al contrario se consideran los estambres como no triadelfos, entónces serán 3 solamente, de los cuales 2 tienen una antera bilocular, mientras el tercero la tiene unilocular por causa de aborto de una celdilla. Mientras las flores femeninas, mas pequeñas pero mas largas, cuya parte inferior ó correspondiente al ovario, alargada, cilíndrica y lisa, es lampiña ó alampinada, lustrosa, color bistre algo mas claro que el del capullo ovoídeo y con 5 estrías salientes y mucho mas pequeño que el de las masculinas, separado del ovario por el tubo calizinal mas estrecho, son formadas de un cáliz adherente de limbo campaundo, cuyos 5 segmentos y los 5 pétalos de la corola son conformes con los de las flores masculinas y de igual inflorescencia : en el centro se observa un cuerpo glanduloso, como-semi-diáfano y de color amarillento algo mas pálido que las demas partes de la flor y lobulado, que constituye el estigma terminando un estilo simple saliendo del ápice del ovario ínfero, pero cuyo ápice bífido lleva en cada brazo un estigma glanduloso multilobulado; ovario elongado, cilíndrico, algo cónico, unilocular y con muchos óvulos. Fruto abayado aovado ó elíptico, largo de como $3^{\prime \prime \prime}-4^{\prime \prime \prime}$ sobre $1^{\prime \prime \prime}-1\left[2^{\prime \prime \prime}\right.$ de ancho, algunas veces algo mas estrechito por la base y como anguloso por causa de haber sido comprimido por los vecinos, de ápice umbilicado; al principio su color es uniforme $\mathrm{v}$ mejor teñido de bistre, pero luego se vuelve mas oscuro y está àdornado de unas 10 listas lonjitudinales color verdusco oscuro; la parte que las separa está salpicada de puntitos rojizos; siguiendo sazonánáose se matiza de morado y por fin se vuelve color amarillo rojizo ó color aurora, y entónces ya está maduro. Contiene una especie de pulpa amarilla-canario poco abun- 
dante, que se halla entre las semillas, la cual se va desecando y la fruta se seca, y entónces es torrulosa, conteniendo muchas semillas pequeñas, separadas las unas de las otras por una especie de membrana semi-transparente y muy delgada, son de color gris oscurito, irregularmente piriformes $\mathrm{y}$ de superficie asperita : doyerea, $\mathrm{F}$. 141, T. II, G. V.

184. De anteras distintas con las celdillas encorvadas por arriba $\mathrm{y}$ tambien por abajo; flores masculinas en racimos axilares espiciformes y largos de 8 á $12^{\prime \prime}$. con una flor femenina solitaria saliendo de la misma axila, amarillentas, de como $3^{\prime \prime}$ de diámetro, mientras las femeninas son anchas de $5^{\prime \prime \prime}$ á $6^{\prime \prime \prime}$, y de cáliz 5-dentado adherente en las femeninas; corola rotácea cuyo tubo carga con 10 glándulas nectaríferas; ovario unilocular con un solo óvulo pendiente; fruto ob-aovado-oblongo, algo comprrimido, lampiño y de ordinario erizadito con pelos algunos blancos algo punzantes, y con 5 surcos lonjitudinales, largo de como $4^{\prime \prime}$ á $6^{\prime \prime}$ y ancho de $2^{\prime \prime}-212^{\prime \prime}$, cuya semilla única aparece por la base y con frecuencia germina antes que se desprenda y colgado todavía del bejuco, pedunculado color blanco amarillento ó verdoso. Planta vivaz cuyos tallos herbáceos muy largos y muy ramosos salen de una raiz carnosa perpendicular bastante gruesa, lisa y lampiña, con hojas simples largamente pecioladas acorazonado-5-angulosas, puntiagudas, largas de $5^{\prime \prime}$ hasta el seno $y$ de $7^{\prime \prime}$ hasta la parte mas inferior del lóbulo basilar; peciolo largo de 4-5", y anchas de 7"; zarcillos 3 ó 5-fidos : sechium, F. 141, T. III.

185. Estambres de anteras biloculares; fruto con 3 o 5 celdas, 185 bis. - Estambres de anteras uniloculares, de celdilla linear, adherida como al revés y casi en espiral por la márjen dorsal del conectivo inciso y trílobo; ovario 3-6-locular. Yerbas anuales, de tallos largos, ramosos, pubescentes, tendidos por el suelo, con hojas alternas, simples, pecioladas, erguidas, de base acorazonada, lobadas con los lobulos pinatisectos, pubescentes ó enteros; zarcillos 23-fidos. Flores solitarias, axilares, pedunculadas, cáliz de limbo profundamente 5-fido, llanito, con las lacinias lanceolado-lineares, de cuyo fundo sale la corola 5-partida, plana, sub-enrodada; estambres 5 insertos en la base de la corola, triadelfos y de filamentos cortos. Las flores femeninas difieren de las masculinas solo porque tienen el ovario ínfero $o$ adherido con el tubo calizinal globoso, y estambres rudimentarios; ovario con las placentas parietales y multiovuladas; estilo cilindráceo, trífido con los estigmas convexos. reniformes acorazonados. Fruto á veces muy grueso, de carne sólida y colorada ó color de carne, polisperma, con las semillas prietas obaovadas, comprimidas, troncadas por la base y obtusas por la márjen; embrion sin endospermo con los cotiledones foliáceos, plano-convexos, y la raicilla contísima y centrífuga : citrullus, $\mathrm{F}$. 141, T. II, G. X.

185 bis. Siempre con 3 celdas ó á veces 4 , con algunas semillas, 186. - Con 5 celdas polispermas; planta herbácea de tallo larguísimo y muy ramoso qué trepa por encima de los mas altos árboles, estriado, pelitieso, con hojas alternas, largamente pecioladas, 
simples, de limbo bastante ancho, con 5 lóbulos desiguales, undulosos, enteros y poco profundos, como arriñonadas por la base; largas de $5 "$, sin el peciolo, que lo es de 21 [ 2 á $3^{\prime \prime}$, y anchas de $7^{\prime \prime}$; seno ancho de $11 \Gamma^{2 \prime}$; flores masculinas en espigas ó racimitos pedunculados, mientras las femeninas son solitarias, todas axilares y amarilias, las primeras constan de un cáliz campanudo sostenido por un pedícelo corto, con 5 segmentos amarillentos, triangulares, puntiagudos, pubescentes, largos de como $1\left[2^{\prime \prime}\right.$, abiertos, casi horizontales $\mathrm{y}$ estendidos, pero que doblándose mas luego por afuera de su ápice se aplica al pedícelo y así envuelven y tapan la base calicinal; corola de prefloracion torcida é imbricada, de manera que el capullo es casi como una flor ó capullo de granada amarilla; cuando abierta es campanuda, bastante grande, con 5 lobulos ovoídeos algo aguzados, espesos, undulosos, pubescentes, de color mas pálido esterior que interiormente é insertos en la garganta calizinal, conteniendo 5 estambres 3 adelfos que aparecen en el fondo de la flor con figura de una esfera gruesa con tantas circonvoluciones; la base del cáliz está forrada interiormente por un disco de color amarillo anaranjado carnudo y que se estiende hasta la garganta en donde se insertan los estambres. Las flores femeninas se componen de un cáliz adherente, de tubo estrechadito sosteniendo un limbo infundibuliforme de color amarillento, con 5 segmentos derechos triangulares, verduscos hácia la puıta ó ápice que se dobla por afuera, pubescentes, sinuosos y venosos; corola saliendo de la garganta del cáliz, de prefloracion torcida, campanuda y con 5 lóbulos profundos ó pétalos, espesitos; ovario largo grueso; cilíndrico, al principio velludo, pero que mas tarde se vuelve lampiño, lustroso y amarillento, con una línea circular mas verde que indica su insercion con el pedúnculo casi tan grueso como él y bastante larguito, de cuyo ápice sale un estilo corto, simple, que se termina por un estigma grueso, amarillento, con un surco verde que se va diliatando hasta alcanzar al estilo, de 3 lóbulos muy gruesos, como arriñonados y anfractuosos á la par. Fruto liso, lustroso, de color moradusco, con matices colorados, largo de $12^{\prime \prime}$ á $18^{\prime \prime}$ y ancho de $3^{\prime \prime}-4^{\prime \prime}$, color amarillo-canario interiormente; con 5 celdas casi triangulares y cuya cara esterna es casi acorazonarla, conteniendo muchas semillas; que parecen casi un insecto, chatas, ovales, obtusas, de base algo acorazonada, mientras el ápice es algo aguzado, con el ombligo por el lado, provistas de un ribete negro por la circunferencia, que es delimitada por una cintita amarillenta, no lustrosas, con una de las caras algo convexa y la otra llana, negruzcas con vetas algo mas claritas : sicana, F. 141, T'. II, G. XII.

186. Corola formada de 5 pétalos distintos, 187. - Corola siempre monopétala, mas ó menos 5-partida, 189.

187. Ovario con 3 celdas, conteniendo muchos órulos, 188. Ovario con 4 celdas recojido ó estrechado por debajo del limbo calizinal, y conteniendo muchos óvulos; planta herbácea vivaz cuyos tallos delgados abejucados y lampiños salen del ápice de una raiz tuberculosa muy gruesa, ancha de $4^{\prime \prime}-6^{\prime \prime}$, con hojas membranosas, largamente pecioladas, alternas, ásperas y alampiñadas, partidas 
en 3-5 lóbulos aovados, puntiagudos y sub-enteros, anchas de $3^{\prime \prime}$ $1^{\prime \prime}$; zarcillos simples. Flores masculinas en racimos ó corimbos pedunculados, mientras las femeninas son solitarias; en arnbos sexos se componen de un cáliz claviforme, de una corola cuyos pétalos blanquecinos son bífidos, con los lóbulos corvos lateralmente y aguzados, largos de $4^{\prime \prime \prime}$, las masculinas contienen 5 estambres insertos por la parte interior del tubo calizinal, con 3 anteras, sub-sentadas y oblongas, cuyas celdas derechas son situadas en la márjen de un conectivo entero. Fruto abayado con semillas globosas : ceratosanthes, F. 141, T. II, G. XIII.

188. Planta herbácea anual muy velluda, de tallo largo rastrero y muy ramoso, delgado y saliendo de una raiz fibrosa, con hojas simples, alternas, acorazonado-redondeaditas, sub-enteras, dentaditas, biglandulosas por la base, muy velludas y blanquecinas, largas de $31_{[} 2$ hasta el seno, $7 l_{1} 2$ hasta la parte mas inferior, del lóbulo basilar, sin el peciolo, que lo es de $3,4,5$ y anchas de 51 [ $2^{\prime \prime}$; zarcillos dividido:; flores blancas solitarias largamente pedunculadas, de cáliz monosépalo campanudo, cortamente 5-fido ó 5-dentado; corola ancha de $2^{\prime \prime}$, con pétalos obaovados y estendidos; anteras distintas con las celdas flexuosas y situadas en la márjen de un conectivo sinuoso. Fruto de tamaño y de forma muy variados y siempre provisto de un casco ó concha leñosa muy fuerte : lagenaria, $\mathrm{F}$. 141, T. II, G. VII.

189. Cáliz 5-fido, 190. - Cáliz 5-dentado, 192.

190. Corola 5-partida campanuda; flores siempre amarillas, cuyas masculinas son solitarias ó fasciculadas y las femeninas siempre solitarias, fruto á veces bastante grueso y de forma muy variada, 191. - Corola profundamente 5-lobulada, infundibuliforme y enrodada á la par; flores de color verdusco-blanco bastante grandes 1 $1_{[} 2^{\prime \prime}$ de diámetro y todas solitarias; fruto ovoídeo del tamaño de una naranja, lampiño, amarillento y con 9 semillas solamente. Tallo delgado, anguloso y lampiño, abejucado, trepador y muy ramoso, de hojas membranosas, lampinas, anchas de $4^{\prime \prime}-2^{\prime \prime}$, lijeramente acorazonadas por la base, redondeaditas ó aovadas cuando enteras, puntiagudas, 3-fidas, con los lóbulos laterales abiertos, deltoídeos y con dientecitos apartados y diminutos, pecioladas; zarcillos simples; pedúnculos sin brácteas, largos de $2^{\prime \prime}$ en las flores masculinas y mas cortos en las femeninas; el cáliz de las primeras, largo de $8^{\prime \prime \prime} \mathrm{y}$ pubescente, tiene el tubo turbinado mitad tan largo como los lóbulos y por fin mas grande, de lóbulos abiertos aovado-lanceolados, por fin distantes y separados por un seno truncado y lijeramente dentado; el de las segundas es cupuliforme con el tubo alto de $5^{\prime \prime \prime}$ y ancho de $6^{\prime \prime \prime}-8^{\prime \prime \prime}$ por el ápice, dos reces tan largo como los lóbulos lanceolados y distantes; corola papilosa esteriormente y pubescente, con pelo esparcido y gruesito interiormente, larga de $11\left[2^{\prime \prime}\right.$, con lóbulos aovado-oblongos, enteros, 3 veces tan largos como el tubo; estambres 5 -triadelfos; 3-5 filamentos distintos, peludos é insertos por la base de la corola, cuyas anteras reunidas en una columna cilíndrica, larga de $4^{\prime \prime \prime}$ y ancha de $2 l_{[} 2^{\prime \prime \prime}$, son cortamente escedidas por 5 lóbulos del conectivo, de celdillas inclinadas por arriba y por abajo y con 3 an- 
fractuosidades paralelas; sstilo ensanchado por el ápice, terminado por un estigma 3-lobulado, redondeadito, foliáceo, verde, alampiñado, ancho de $5^{\prime \prime \prime}-6$ "' y doblado hácia afuera : cionosicys, F. 141, T. II, G. VI.

191. Vejetales herbáceos, anuales, de tallos mas ó menos largos, ramosísimos, delgados, estriados ó cilíndricos, ásperos y polierizados, rastreros, con hojas simples, alternas, largamente pecioladas, mas ó menos profundamente lobuladas y á veces hasta profundamente partidas, de lóbulos enteros ó aserrados; zarcillos simples; estambres con 3 filamentos distintos, de anteras conniventes, distantes ó lijeramente reunidas, escedidas por los lobulos del conectivo y cuy as celdillas son inclinadas por arriba y por abajo: cucumis, F. 141, T. II, G. III.

192. Corola nunca enrodada, 5-partida o 5-fida; estambres cuyas anteras no son connatas en una columna cilíndrica; ovario contraido por debajo del limbo calizinal y cuyas celdas contienen algunos óvulos, 193. - Corola siempre enrodada, cuyas divisiones simulan pétalos distintos; todas las anteras están adheridas en una columna cilíndrica, cuyas celdillas están dobladas por arriba y por abajo; celdas del ovario con 2 óvulos solamente. Plantas herbáceas de tallo delgado, largo, ramosísimo, trepador, áspero y anguloso, pubescentes, alampiñadas ó lampiñas, con hojas largamente pecioladas, simples, alternas, 3, 5-lobuladas, mas ó menos acorazonadas por la base, de lóbulos enteros, sinuoso-sub-enteros ó dentaditos. Flores en racimos axilares ó solitarios; ovario 3-locular recojido por debajo del limbo calizinal; baya oligosperma : cionandra, F. 141, T. II, G. I.

193. Corola 5-partida; estambres insertos en el tubo calizinal, con 3 anteras subsesiles y oblongas, cuyas celdas derechitas están situadas sobre las márjenes de un conectivo entero; fruto ovoídeo pequeño y purpúreo, 193 bis. - Corola 5-fida con los lóbulos induplicados en la estivacion, campanuda y adherida con la parte inferior del tubo calizinal; estambres 5, insertos en la base de la corola, triadelfos, conniventes, en columna, con anteras uniloculares, de celdas lineares, conectivo apenas engrosado, adheridos por el dorso y con muchas anfractuosidades lonjitudinales. Fruto á veces muy grueso, de forma, tamaño y color muy variados. Plantas herbáceas anuales, de tallos larguísimos, rastreros y muy ramosos, con zarcillos, de hojas simples, alternas, pecioladas, acorazonadas, enteras ó 3,5-lobuladas, mas ó menos pelitiesas, de peciolo largo, cilíndrico y hueco; pedúnculos axilares, con una sola flor amarilla, de cáliz con tubo corto, campanudo y 5 -fido en las masculinas, mientras que en las femeninas tiene el tubo aovado ú oblongo, con el ovario adherido, el limbo 5-fido; la corola es conforme con la de las masculinas; hay estambres estériles con frecuencia; ovario ínfero $3,5-$ locular, con las placentas parietales multi-ovuladas y situadas de cada lado de los tabiques; 3 estigmas engrosados y bilobulados. Peponida 3,5-locular, con muchas semillas aovado-comprimidas, ceñidas por una márjen tumida; cotiledones foliáceos; endospermo nulo; raicilla cortísima y centrífuga: cucurbita, F. 141, T. II, G. XI. 
193 bis. Plantas herbáceas trepadoras, de tallo delgado, largo y muy ramoso, alampiñadas, con hojas membranosas, acorazonadas, con un seno profundo y abierto, puntiagudas, sinuoso-repandas ó 3 , 5-lobuladas, anchas de $1^{\prime \prime}-2^{\prime \prime}$, lijeramente ásperas, con pintas blancas ó alampiñadas y pecioladas; zarcillos simples; flores masculinas en racimos pequeños; tubo del cáliz tan largo como la corola, dientes diminutos; segmentos de la corola escotados en las flores masculinas y enteros en las femeninas, todas amarillas $\mathbf{y}$ anchas de $2^{\prime \prime \prime}-3^{\prime \prime \prime}$; semillas pubescentes : melothria, F. 14l, T. II, G. VII.

194. Flores monoicas, andrójinas ó dioicas; fruto aqueniforme; plantas herbáceas ó fruticosas, 195.-Flores monoicas ó polígamas, pero ni andrójinas ni dioicas tampoco; fruto capsular ó utricular; plantas herbáceas siempre lampiñas y á veces espinosas, 197.

195. Segmentos del cáliz de las flores femeninas ordinariamente en número de 3; estigma apincelado; hojas opuestas, 196. - Cáliz de las flores femeninas contraido por el ápice 2, 4-dentado ó entero: á veces suele faltar; frutices ó arbustillos de hojas simples, opuestas ordinariamente, pero á veces alternas, largamente pecioladas, aovadas, oblongas ó mas ó menos lanceoladas y bastante grandes, con estípulas axilares; flores en grupos axilares ó formando espiguitas interrumpidas y amentiformes, sin invólucro, cuyas masculinas constan de un cáliz 4, 3,5-partido, conteniendo 3, 4 estambres; las femeninas se componen de un cáliz 2, 4-dentado conteniendo un estigma filiforme persistente, peludo por uno de sus lados nada mas: bcehmeria, F. 39, T. I, G. IV.

196. Plantas herbáceas, lampiñas, pubescentes ó velludas, de tamaño muy variado, mas ó menos ramosas, de tallo carnoso ó herbíceo, desparramado ó recto, de hojas opuestas, desiguales en cada par, de manera que la una es casi siempre mas grande que la otra, ordinariamente provistas de rafidias, nervosas, de forma, tamaño y consistencia muy variados, enteras ó aserradas, lampiñas ó pubescentes y velludas, pecioladas, con estípulas axilares. Flores en cimas axilares mas ó menos pedunculadas, cuyas masculinas constan de un periantio 4, 2-partido, conteniendo 4 estambres, mientras las femeninas se componen de un periantio 3, 2, 4-partido, con uno de los segmentos mayor $y$ giboso por debajo del ápice; ovario único, unilocular, monospermo: pilea; F. 39, T. III, G. I.

197. Flores siempre monoicas; estambres $3,2,5$; estilos 2, 3 ; fruto utricular, 198. - Flores polígamas ó monoicas; estambres 5, 3; fruto capsular circoncisible o pixidio, que á veces se revienta irregularmente por la base; plantas herbáceas anuales, lampiñas ó pubescentes, de hojas simples, alternas, pecioladas y á veces decurrentes, enteras, romboídeas, mas ó menos oblongas, lanceoladas ó aovadas, con estípulas espinosas; flores ordinariamente en espigas axilares ó terminales, mas ć menos elongadas y cuya reunion forma racimos ó panojas terminales mas ó menos largas; tales flores están acompañadas cada una de su bróctea aquilada y persistente, de un cáliz con 5, 3 segmentos iguales, derechos. lampiños y persistentes; flamentos de los estambres subulados con anteras biloculara y 
oblongas; en las femeninas hay un ovario ovoídeo, unilocular, monospermo, coronado por 2, 3 estigmas sesiles, filiformes, alesnados y anchitos. El.fruto consiste en un pixidio oval y cuyo vértice tiene ¿ 2 ó 3 piquitos, imperfectamente envuelto por el periantio á veces membranoso; semilla única vertical, lenticular y arriñonadita, de testa crustácea, con endospermo central farináceo, embrion cíclico y periférico, de radícula ínfera: amarantus, F. 55, T. III, G. II.

198. Flores ordinariamente monoicas; estambres $3,2,5$; estilos 3, 199. - Flores siempre monoicas; estambres 3 siempre; estilos 2,3 ; planta herbácea cespitosa anual, alampiñada, de hojas alternas, espatuladas, retusas, arrejonadas, enteras; flores verdosoblanquecinas, pequeñas, dispuestas en grupos axilares, cuyas masculinas tienen el periantio de 3 sépalos, los estambres distintos con las anteras biloculares; en las femeninas al contrario está 5-fido, de tubo urceolado, sosteniendo un limbo de segmentos espatuladolineares, obtusos y trinervios : amblogyne, F. 55, T. IIl.

199. Plantas herbáceas anuales, de tallo recto, ramoso y mas ó menos alto, segun la feracidad del terreno en que se crian, altas de $1^{\prime}-2{ }^{\prime}-3$, con hojas simples, alternas, mas ó menos grandes, pecioladas, mas ó menos aovadas y remalladas, enteras y lampiñas. Flores en grupos axilares ó dispuestas en espigas terminales, pequeñas y verduscas, siempre acompañadas de brácteas mas ó menos largas y formadas de un periantio con 3,5 sépalos; ovario ovoídeo ó redondo, unilocular, monospermo : euxolus, F. 55, T. III, G. I.

200. VEJETALES DIOICOS, 201.

201. Arboles ó arbustos, 202. - Plantas herbáceas, fruticulosas 0 frutices, 231.

202. Cuyo tronco es un astil ó estipe, 203. - De tronco lejítimo, 206.

203. Estipe lejítimo mas ó menos alto y con hojas compuestas; fruto drupáceo monospermo, 204 bis. - Seudo-estipe ó tallo estipiforme, de poca dureza y fuerza, lechoso y con hojas simples; fruto carnudo polispermo, 304 .

204. Vejetales que á primera vista parecen casi palmeras, porque su tronco es desnudo, cilíndrico, con muchas cicatrices algo triangulares, de color ceniciento, sin ramos y coronado por hojas como ellas, del tamaño como del muslo de un hombre, y alto de $15^{\prime}$ á $25^{\prime}$; hojas simples, palmatinervias, largamente pecioladas, alternas ó esparcidas, de limbo grande, palmatífido ó profundamente 7 ó 5-lobulado, con los segmentos pinatífidos ó enteros, lampiñas, sin estípulas. Flores masculinas en corimbos simples ó apanojados, axilares y de cáliz monosépalo diminutamente centadito; corola infundibuliforme, mucho mayor que el cáliz, cuyo tubo cilíndrico y delgado sostiene un limbo dividido en $\breve{J}$ lacinias imbricadas, con el ápice arrollado por fuera, conteniendo 10 estambres dispuestos en dos séries é insertos en la parte superior de la garganta, de los cuales 5 senta; dos son opuestos á sus divisiones, mientras los otros 5 alternos, tienen filamentos blancos, peludos $y$ algo espesos inferiormenteanteras biloculares, linear-oblongas y estriadas: en el centro está el rudimento del pistilo; las femeninas al contrario en racimitos axi- 
lares formados de 3 á 5 flores sentadas sobre un pedúnculo comun grueso y corto, algunas veces solitarias, .con el cáliz conforme al de las masculinas; corola mucho mayor, amarillenta tambien, 5-partida y cuyos segmentos parecen pétalos oblongos, algo estendidos y doblados hácia fuera, campanuda; ovario ovoídeo, ancho, oblongo, verdusco, unilocular, con 5 placentas parietales cargando con muchos óvulos, de cuyo ápice sale un estilo cortísimo con 3 ó 5 estigmas dispuestos á manera de radios de rueda, franjeados y de color amarillo verdoso. Se hallan algunas flores hermafroditas entremezcladas con las masculinas especialmente, pero son casi siempre estériles. Fruto bacciforme mas ó menos grueso, amarillo subido, oboroídeo mas ó menos, largo de $4^{\prime \prime}$ á $8^{\prime \prime}$ y $10^{\prime \prime}$, aovado, con una punta y largo de $3^{\prime \prime}$ ó globoso y del tamaño de una nuez. Las muchas semillas dispuestas por séries verticales son ovoídeas, pequeñas y envueltas en una membrana diáfana, conteniendo un líquido como mucilajinoso, y dentro está la semilla, negra, áspera ó asurcadita : carica, F. 113.

201 bis. Drupa carnosa, cuyo hueso parece un grano de trigo gruesísimo; frondas pinadas; espata leñosa simple; estambres 6,3 , de filamentos cortísimos, con anteras lineares; flores nunca polígamas, 205. - Drupa redonda apenas carnosa, cubierta de una concha dispuesta á manera de coraza y formada de muchas escamas leñosas, color castaño y lustrosa; espata comun nula, pero muchas parciales incompletas; espádice ramoso con divisiones amentíferas; estambres 6 ; flores polígamo-dioicas; frondas grandes flabeliformes : primorosa palmera mas ó menos alta, cuyo estipe desnudo ó armado de aguijones, bastante grueso y cilíndrico, contiene una médula feculenta; frondas largamente pecioladas y derechas, de limbo en forma de abanico multífido; flores en espádices dísticamente ramosos, situadas entre las escamas ó brácteas escamosas de los amentos, cuyas masculinas son formadas de un periantio con 2 séries, cuya esterior es con 3 piezas sueltas, lineares y derechas; filamentos de los estambres llanitos, con anteras lineares erguidas; en las hermafroditas, el periantio es campanudo, tridentado ó trífido esteriormente, mientras la série interior es 3-partida, con lacinias lanceoladas y derechas; 6 estambres dispuestos á manera de pirámide central, de anteras orales y sub-bilobuladas por la base; ovario globosito, 3-locular, cuyo véitice lleva un estigma sentado y trilobulado. Drupa globosa monosperma, conteniendo una pulpa espesa de como $1^{\prime \prime \prime}$, situada entre la concha esteriormente formada de muchas piececitas desigualmente cuadrangulares, cuyo ángulo mas agudo mira hácia la base y el mas obtuso hácia el vértice, algo mas anchas que largas, imbricadas por los lados que salen del ángulo agudo o inferior, algo membranosas y como franjeadas por esos bordes, presentan además un surco lonjitudinal que va de la base hasta el vértice, pasa por la parte mediana y las divide en dos partes iguales, y una capa esponjosa interiormente, blanca, espesa de como 1"'$2^{\prime \prime \prime}$, á la cual adhiere, y que contiene el hueso redondito, lustroso, prieto y con una puntita doblada; endospermo cartilajinoso y oleajinoso : mauritia, F. 14, T. I. 
205. Grandes y hermosas palmeras cuyo estipe conserva pegada durante algun tiempo la base de las frondas ya caidas, y despues liso; frondas grandes, largas como de $7^{\prime}$ á $9^{\prime}$, pinadas y derechas. Flores en panojas ó támaras axilares contenidas en una espata leñosa y monofila, cuyas masculinas de periantio doble, con 6 divisiones de las cuales 3 son esteriores y mas largas y 3 mas interiores, con tantos estambres, conforme en las femeninas que contienen 3 ovarios, de los cuales 2 abortan casi siempre, terminados por un estigma sesil y torcido, uniloculares monospermos; las támaras cargan con muchísimos frutos del tamaño del dedo pulgar, ovoídeo-oblongos y de color amarillo oscuro cuando maduros, pero no todavía pasas : phœnix, F. 14, T. II.

206. Flores nunca dispuestas en espádices, 207. - Flores siempre dispuestas en espádice; árboles de aspecto particular y característico, bastante altos y no muy ramosos, de tallo cilíndrico desnudo, marcado de semi-anillos, con las hojas pareciendo casi las de piña y agrupadas hácia el vértice de los ramos, poco numerosas, alternas y casi en espiral, lanceoladas, verdes, rosadas ó amarillentas, puntiagudas, acanaladas, sentadas, algo envainadoras por la base, abiertas y de bordes espinosos. Flores en espádices amentiformes amarillos saliendo del centro de las hojas, cuyas masculinas consisten en una antera única cuspidada y situada en la axila de una bráctea; en las femeninas el ovario está dispuesto del mismo modo y se termina por un estilo bífido. El fruto es una especie de drupa: pandanus, F. 13.

207. Desnudas ó sin envoltura floral, 208. - Nunca desnudas y siempre provistas de una cubierta floral, sea simple sea doble, 215.

208. Vejetales lechosos, las mas reces monoicos, cuyas flores masculinas, formadas por un estambre acompañado de una bráctea abroquelada, cubren toda la superficie de un receptáculo globoso, 114. - Vejetales nunca jamás lechosos; flores en amentos; estambres 4, 2, 209.

209. Flores sesiles sobre la superficie de un receptáculo ramoso y cilíndrico; tronco y ramos huecos y con tabiques trasversales, 212. - Flores nunca jamás situadas sobre un receptáculo; tronco y ramos nunca huecos, 213. 211.

210. Vejetales con hojas siempre; 212. - Vejetales sin hojas,

211. Flores amentáceas provistas de un inrólucro, un solo estambre escrecente; ovario unilocular, con un órulo pendiente; estigma bipartido: árbol muy alto, de tronco derecho, liso, color ceniciento, ramoso, sin hojas, cuyas ramitas filiformes son estriadas, simples, con 6,8 surcos, cuyos nuditos están envueltos en una vainita foliácea pluridentada. Flores masculinas en amentos terminales, claviformes y lineares, amarillentos, muy pequeños; flores femeninas en amentos laterales cortamente pedunculados, $y$ por fin cilindricoovoídeos; el fruto consiste en una especie de estróbilo ovoídeo de como l" de largo, conteniendo una cariópside lenticular, de semilla inversa, con el embrion sin endospermo y ortótropo, de raicilla cortísima y súpera : casuarina, F. 44, T. II. 
212. Flores nunca jamás situadas en la superficie de un receptículo cualquiera, pero sí amentáceas, tronco y ramos nunca liuecos, 213. - Flores sesiles y situadas en la superficie de un receptáculo ramoso y cilíndrico, tronco y ramos huecos y cuyo canal central está dividido por tabiques membranoso-transversales: árboles ramosos superiormente y de ramos poco numerosos, apartados y estendidos, altos de como $45^{\prime}-50^{\prime}$ de tronco derccho no muy grueso y color ceniciento; hojas bastante grandes, largamente pecioladas, alternas, simples, abroquelado-redondeaditas, ordinariamente palmeado-lobuladas, con 7, 9, 11 lóbulos mas i menos profundos, sub-enteros, obovado-oblongos y olitusos, ó aovacios y puntiagudos, de cara superior verde oscuro y lampiña ó alampiñada y áspera, mientras la inferior tomentosa y blanca, es suave: cuando tiernas son bastantes veces teñidas de morado ó hasta moraduscas, anchas de 12-14-116" y largas de 12 á $15^{\prime \prime}$, con el peciolo de 8-10-12", cuya base está acompañada de dos estípulas pequeñas, escamosas y pronto caducas; pedúnculos axilares largos de 2-4-6", de cuyo ápice salen muchos receptáculos dispuestos en especie de umbela, cortamente estipitados, larços de $11_{\left[2^{\prime \prime}\right.}$ sobre $1^{\prime \prime}$ de diámetro, envueltos todos en una bráctea comun espatiforme antes de la florescencia $y$ pronto decídua, cuyas flores constan de un periantio tubular anguloso, que parece formado de unas escamas turbinadas, soldarlas entre sí, algo tetrágono, con dos poros por el ápice, por donde salen dos estambres, mientras que los femeninos, mas espesos, sesiles en el vértice del pedúnculo én número 4 ó 2 , son largos de $2^{\prime \prime}$ solıre 3 "' de diámetro y llevan flores que se componen de un periantio ó invólucro bífido, conteniendo un ovario monospermo, de cuyo ápice sale un estigma apincelado. Baya, monosperma, sentada en el receptáculo : cecropia, F. 39, T. V, G. IV.

213. Estambres siempre 4; fruto drupáceo pequeĩo, cubierto de cera; vejetales aromáticos, 214 . - Estambres 2 solamente; fruto capsular con semillas peludas; vejetales nunca aromáticos : árboles mas ó menos altos y muy ramosos, o arbustos con hojas simples, alternas, muy cortamente pecioladas, lanceoladas, coriáceas, lustrosas, enteras ó aserradas, acompañadas de estípulas persistentes o escamosas y decíduas; flores en amentos saliendo ordinariamente antes que las hojas, otras veces despues de ellas, y entonces son axilares, cuyos masculinos con escamas enteras en la axila de las cuales se halla un disco glanduloso, de donde salen los estambres de filamentos libres ó reunidos por la base; los femeninos se diferencian de los primeros solamente por tener en lugar de los estambres un ovario unilocular oroídeo que se termina por un estilo cortísimo con dos estigmas bilobulados; muchos órulos, parietales y situados hácia la base de la celda. Cápisula unilocular abriéndose en dos valvas, cuya base carna con muchas semillas derechas y cabelludas: salix, F. 43 .

214. Ar bustos ó árboles bajitos que se elevan á 150 25 ' de altura, ramosos, resinosos y aromáticos y produciendo cera, de hojas simples alternas, cortamente pecioladas, enteras ó sub-enteras, ó aserradas por arriba de su parte mediana, espatuladas ó lanceoladas, de 
cara superior pubescentita ó alampiñada, las nervaduras de la inferior solas son pubescentitas, provistas de puntitos resinosos transparentes; amentos tardíos, sub-solitarios y axilares, cuyos masculinos cortamente cilíndricos, con brácteas cuneiformes; estambres 4 , 5 , cuyos filamentos reunidos por la parte mediana forman una columna filiforme y peluda con anteras verticales largas, biloculares r bilobuladas; los femeninos, tambien axilares, ovoídeos, son formados de brácteas caducas, ovalagudas; ovario oval algo achatadito por el vértice, de cuyo ápice salen dos estigmas sentados filiformes, estendidos y mas largos que las brácteas. Fruto drupáceo, unilocular, ovoídeo, pequeño y largo de $1^{\prime \prime \prime}$, monospermo, cuya cáscara verde está cubierta de muchos tuberculitos moraduscos que parecen como granitos de pólvora, reunidos entre sí ó envueltos por una capa mas ó menos espesita de cera mas ó menos blanca; el huesecito contiene una semilla prieta y algo elongada; myrica, F. 44. T. I.

215. Fruto drupáceo ó no drupáceo, cuyo hueso cuando drupáceo no está nunca cubierto por un arilo; estambres nunca monadelfos tampoco, 216. - Fruto drupáceo dehiscente, pareciendo casi un albaricoque de Europa, cuyo hueso ovoídeo y de casco lustroso y pardo está cubierto por un arilo ramoso color rojizo ó anaranjado moradusco; estambres monadelfos. Arboles mas o menos grandes, muy ramosos, que se elevan á $25^{\prime}$ y $60^{\prime}$ de altura, de hojas simples, pecioladas, alternas, enteras, elíptico-oblongas ó linear-oblongas, alampiñadas, mas ó menos cuspidadas, de cara inferior con las nervaduras dispuestas por pares en número variable de 8 á 30 , sin estípulas. Flores axilares cuyas masculinas, fasciculadas ó arracimadas, pediceladas y acompañadas de una bráctea mas ó menos grande situada por el vértice de los pedícelos y decídua, constan de un periantio ovoídeo ó infundibuliforme, 3-fido, valvar, conteniendo 3 , 9,12 anteras estrorsas adheridas en tubo monadelfo, linear-oblongas, con dos celdillas que se abren lonjitudinalmente; mientras las femeninas, casi siempre solitarias, pediceladas, difieren de las otras solamente por tener un ovario único, unilocular, con un solo óvulo erguido, y de cuyo ápice salen dos estilos cortísimos con estigma cabezudito. El casco crustáceo, lustroso y poco espes̃o del hueso contenido en la drupa, encierra una semilla formada de un endospermo voluminoso, bastante duro, de corte jaspeado, oleajinoso y aromático á la par, con el embrion alojado por la base: myristica, F. 94 .

216. Flores provistas de una envoltura floral simple ó con un periantio, 217. - Flores cuya cubierta floral doble se compone de un cáliz y de una corola, 229 .

217. Periantio asalvillado, con invólucro pequeño, conteniendo 4 escamas hipójinas; 8 anteras subsesiles; fruto abayado, 218. - Periantio nunca asalvillado ni involucrado por la base tampoco, sin escamas hipójinas; fruto ordinariamente drupáceo ó abayado, 219.

218. Arbustos ó arbolitos ramosos, cuyas ramitas pubescentes ó lampiñas llevan hojas simples, alternas, enteras, coriáceas ó subcoriáceas, elíptico-lanceoladas ó elípticas, discolores ó concolores, enteramente lampiñas ó cuya superior es lampiña, mientras la in- 
ferior es blanquecino-pubescente, largas de $4^{\prime \prime}-3^{\prime \prime}$ y anchas de $18^{\prime \prime}$ $8^{\prime \prime \prime}$. Flores dispuestas en cabezas ó en umbelas, con pedúnculos sim. ples, di ó tricótomos, pediceladas ó sentadas, mas ó menos sedosas; las masculinas constan de un cáliz monosépalo asalvillado, cuyo tubo delgado, 2 ó 3 veces mas largo que el limbo 4-partido, sostenido por un invólucro diminuto $\mathrm{y}$ dentadito, tiene en su fondo un pistilo rudimentario, 4 escamas hipójinas, y 8 estambres subsesiles; en las femeninas el periantio es infundibuliforme ó campanudo, con sus 4 lóbulos obtusitos y encorvados, contiene un ovario ovoídeo unilocular, ordinariamente con un óvulo, latcralmente inserto, de cuyo ápice sale un estigma terminal y subsesil: daphnopsis, F. 49, G. II.

219. Estambres nunca dispuestos por séries, de anteras que no se abren nunca por poros, fruto abayado y sorosiforme ó drupáceo, 219 bis.-Estambres dispuestos en 2, 3 ó mas séries, y en número variable de $9,12,15,18$, de las cuales algunas suelen abortar, cuyas anteras de 2, 4 celdas se abren siempre por medio de poros cuyas ventallas se levantan de abajo por arriba. Fruto abayado ó drupáceo, pero sin hueso y sí con una pepita, 222 .

219 bis. Estambres 4 ó 6; fruto abayado ó sorosiforme, 220.-Estambres 2, 3, 5 insertos en un disco anular; fruto drupáceo. Arbolitos ó frutices de hojas simples, alternas, cortamente pecioladas, coriáceas, entejérrimaș ó anguloso-dentadas, con estípulas caducas. Flores axilares, espigado-amentáceas; perigonio 3, 5-partido en ambos sexos; en las masculinas los filamentos de los estambres son filiformes $\mathrm{y}$ con anteras biloculares, cuyas celdas son divaricadoabiertas: hay un ovario rudimentario En las femeninas el disco anular ciñe á la base del ovario aovado, libre y unilocular, con dos óvulos colgantes del ápice de la celda, colaterales y anátropos; estigma sentado y 3,5 -radiado. Drupa monosperma, coronada por el estigma, cuyo hueso es espinosito interiormente, conteniendo una semilla pendiente, de endospermo espeso, carnoso y hoyoso; embrion ortótropo, axil, con cotiledones grandes y foliáceos y raicilla corta y súpera : antidesma, F. 38.

220. Estambres 4; fruto abayado ó sorosiforme; árboles ó arbustos nunca jamás trepadores, sarmentosos ni zarcillosos tampoco, 220 bis. - Estambres 6; fruto abayado pisiforme; rejetales abejucados sarmentosos y provistos de dos zarcillos acompañando á la insercion del peciolo: un rizoma con bastante frecuencia, 236 .

220 bis. Flores masculinas y femeninas en espigas axilares y pedunculadas y nunca jamás colocadas sobre un receptáculo, 221. Flores masculinas espigadas ó racemosas, sin receptáculo alguno, mientras las femeninas están agrupadas sobre un receptáculo globoso. Fruto compuesto de drupitas reunidas entre sí y formando así una especie de sorosis. Arboles bastante grandes, lechositos, corpulentos y coposos, con ó sin espinas axilares; de hojas simples, alternas, pecioladas, sub-enteras ó aserradas, oblongas y aguzadas ó aovado-oblongas con una punta, de base sub-truncada, redondeada ó sub-acorazonada, alampiñadas ó pubescentes ó solamente en las nervaduras de la cara inferior; flores masculinas en espigas cilíndricas, amentiformes y formadas de un periantio 4-partido, lijera- 
mente imbricado, conteniendo 4 estambres esertos, mientras las femeninas son en cabezas mas ó menos globosas, con el periantio de 5 segmentos que por fin se vuelven sólidos y duros por el ápice connivente; ovario libre, unilocular, con un solo óvulo pendiente y campilotropo, de cuyo ápice sale un estilo simple, filiforme, eserto, tan ó mas largo que el diámetro de la cabezuela y estigmatífero interiormente. Fruto sorosiforme, formado de muchos aquenios cubriendo un receptáculo globoso y algo carnudo: maclura, F. 41, G. I.

221. Arbolito de ramos alampiñados, de hojas simples, alternas, oval-oblongas ú oblongas, con una punta, bien enteras y lampiñas, redondeadas por la base, con las nervaduras 6,8 -yugadas y arqueadas, pecioladas y largas de $8-4^{\prime \prime}$ sobre $3-21_{[} 2-2$ "' de ancho, de peciolo corto, 5 á $6^{\prime \prime \prime}$ solamente; flores masculinas en espigas cilíndricas amentiformes, pubescentitas $y$ de ordinario mellizas, constando de un periantio 4-fido, valvar y conteniendo 4 estambres esertos, inclinados en el capullo y saliendo de él con elasticidad, mientras las femeninas, mas cortas, tienen solamente $4^{\prime \prime \prime}$ de largo y se componen de 4, 8 flores cujo periantio tubular es contraido hácia el limbo 4 -dentado y contiene un ovario atherido unilocular, con un ovulo pendiente y campilotropo, de cuyo ápice sale un estilo 2-partido. Baya monosperma, larga de $4^{\prime \prime \prime}-6^{\prime \prime \prime}$, de semilla globosa y colgante, cuyo embrion no tiene endospermo : troplics, F. 39, T. I, G. II.

222. Flores siempre dioicas; 9 estambres de anteras 4-loculares; flores femeninas con 9 estambres estériles, 223. - Flores tan pronto dioicas como polígamas y hasta á veces polígamas, 224 .

223. Arboles pequeños y frondosos, cuyas flores salen antes que las hojas, que son sencillas, alternas, membranosas, de forma $y$ tamaño variados, de manera que las unas son enteras y las otras trilobadas á veces de un solo lado, pubescentes, pecioladas y caducas. Flores amarillentas en corimbos opuestos á las hojas, lampiños o pubescentes y con brácteas subuladas y caducas, constando de un periantio 6-partido, con segmentos membranosos, iguales y cuya base sola persiste; estambres dispuestos en 3 séries; las flores femeninas difieren de las masculinas solamente por tener un pistilo formado de un ovario unilocular, uniovulado, terminado por un estigma asentado y cabezudo, rodeado por 3 séries de filamentos estériles. Drupa suculenta, azulada, pisiforme, engastada en la base persistente y algo crecida del periantio y situada en el ápice crecido, como carnoso y colorado del pedúnculo, claviforme: sassafias, F. $46, \mathrm{~T} . \mathrm{X}$.

224. Dioicas ó polígamas y hermafroditas á la par, 225. - Dioicas $\dot{o}$ las mas veces hermafroditas : arboles bastante grandes, ramosos, frondosos y que se elevan á $40^{\prime}$ ó $50^{\prime}$ de altura, con hojas simples, alternas, largamente pecioladas, coriáceas, enteras, de cara superior lampiña y lustrosa, mientras la inferior, mas pálida, pubescentita ó alampiñada, tiene las nervaduras proeminentes 4,5 ó 4 , 6 -yugadas y arqueadas, no aromáticas. Flores fasciculado-apanojadas, cuyos pedícelos son mas cortos que ellas, con periantio 6-partido, cuyos segmentos son casi iguales á los 3 esteriores, pequeñitos 
y tres veces mas cortos que los interiores, y por fin enteramente decíduo; estambres fẻrtiles 9, 12. Baya mas ó menos gruesa de forma y tamaño muy variados, tan pronto oval y redondeada como piriforme, desnuda, lustrosa, verde, mas ó menos amarillenta ó moradusca, áspera ó lampiña, de carne amarillo pálido y comestible; semilla globosa enteramente libre en el centro: persea, F. 46, T. VII.

225. Arboles ordinariamente bastante grandes, y á reces muy altos, corpulentos y coposos, siempre verdes y le hojas alternas, peciolarlas, enteras, papiráceas, lustrosas, lampiñas y con las nervaduras arqueado-reticuladas. Flores densamente arracimadoapanojadas, terminales, á veces en tir'sos y hasta casi en umbelas y formadas de un periantio 6 -fillo, cuyo tubo turbinado.lleva un limbo decíduo; en las femeninas hay estambres mas ó menos desarrollados y á veces enteramente abortados, y las masculinas tienen con bastante frecuencia un pistilo en igual estado; estambres 9,12 dispuestos en 3 ó 4 séries, de los cuales 9 esteriores son fértiles y higlandulosos por la base algunos, con anteras de celdillas sobrepuestas, dispuestas por pares, oblongas é introrsas las de la $l^{\text {a }}$ y $2^{\mathrm{a}}$ série, mientras las de la $3^{\text {a }}$ son estrorsas; los 3 estambres anteriores ó formando la 4 a série son estériles ó enteramente abortados; ovario unilocular, uniovulado, de cuyo ápice sale un estilo corto, terminado por un estigma discoídeo ó deprimido mas ó menos cabezudo. Drupa abarada monosperma, acompanada por el tubo calizinal que se ha vuelto una especie de cúpula, mas ó menos espesa y carnosita por el pedúnculo que se ha engrosado : ocotea, Aubl., oreodaphne, Tees, F. 46, T. XII, G. I.

226. Fruto drupáceo ó abayado, no proviniendo nunca de un ovario ginobásico, 227. - Fruto drupáceo ó capsular proviniendo siempre de un ovario ginobásico y formado á lo menos de 4 carpelos mas ó menos separados, 229.

227. Fruto drupáceo y casi seco, sicmpre unilocular; cáliz 5-partido ó 5 -lobulado; corola con 5 pétalos insertos por debajo del disco; 5 estambres; 3 estilos, 228. - Fruto abayado proviniendo de un ovario con 2,3 celdillas conteniendo 2 óvulos; cáliz 3,5 -fido; corola con 3,5 pétalos y á veces nula ; estambres 3,5 opuestos á los pétalos é insertos tambien por debajo del disco; estigmas 2, 3 subsesiles. Arboles pequeños ó arbustos, de hojas alternas imparipinadas, con 5-9, 5-7 ó 7-9 hojueląs elípticas ú oblongas, entejérrimas, mas ó menos papiráceas y lustrosas, lampiñas o alampiñadas, con las nervaduras bastante pronunciadas por la cara inferior á veces pubescentita. Flores en racimos mas ó menos largos y á veces como algo apanojados. Bayas pequeñas ordinariamente, coloradas ó prieto-azuladas y lustrosas, con una sola semilla colgante: picramnia, F. 110, G. İ.

228. Arbustos y árboles bajitos, de hojas alternas imparipinadas ó con 2, 3 ó 1 par de hojuelas ó de 3 en rama, oval-redondeaditas, escotadas ó redondeadas por el ápice, bien enteras, largamente pecioladas y lampiñas, largas de $1^{\prime \prime}-11_{\Gamma} 2^{\prime \prime}$. Flores en panojas pequeñas, las hermafroditas siendo en corimbos axilares; estigmas sub 
sesiles; drupa ovoideo-oblonga y color de escarlata : rhus, F. 128. 229. Diez estambres saliendo cada uno de una escama hipojínica; fruto bien ginobásico formado 5 drupitas, 230. - Cinco estambres solamente; fruto apenas ginobásico formando de 5 ó 1 folículos pequeños ó cajitas dehiscentes : árboles mas ó menos altos, á veces bastante corpulentos y frondosos, ó arbustos inermes ó de ordinario armados con aguijones gruesos cónicos ó punzantes, de base como. esponjosa aunque fuerte en los troncos y ramos gruesos, mientras que los de las ramitas y peciolos no tienen nada de particular; hojas imparipinadas y formadas de $10,5-9,6-6,2$ pares de hojuelas ó de una sola hojuela, lanceolado-oblongas, lanceoladas, elípticas ú oblongas, bien enteras, aserraditas, festoneado-aserradas, festoneadas, subsesiles o pecioladas, enteramente lampiñas, de cara superior lampiña, mientras la inferior es alampinada ó pubescentita solamente por las nervaduras, provistas siempre de puntitos transparentes mas ó menos abunàantes. Flores pequeñas en panojas densas, axilares ó terminales, pubescentes y lampiño-verrugosas, de cáliz corto, monosépalo, con $3,4,5$ divisiones derechas, de corola que suele faltar algunas veces, con 5 pétalos iguales á los segmentos calizinales o mas largos que ellos; las masculinas tienen 5,6 estambres salientes, alternos, iguales con los pétalos, mas largos que ellos é insertos en rededor de la base del disco ginofórico, en cuyo centro están los rudimentos del pistilo abortado; en las femeninas se observan á veces estambres muy cortos, representados por los filamentos, sin ó con anteras mas ó menos abortadas, y siempre un pistilo formado de 5 carpelos ú ovarios distintos ó coherentes por medio del eje, á veces hay uno solo, uniloculares y con dos óvulos colaterales y colgantes, sentados sobre un disco globoso ó cilíndrico hipójino, mas ó menos desarrollado y que constituye así una especie de ginóforo pooo pronunciado; del ápice salen tantos estirmas conniventes ó coherentes. El fruto consiste en 5 , 1 folículos, cuyo endocarpio es adherente á las valvas ó se separa por las márjenes uniloculares, abriéndose por dos valvas, sentados ó algo estipitados, largos de $3^{\prime \prime \prime}-2^{\prime \prime \prime}$ sobre 11 [ 2 de diámetro, conteniendo 1,2 semillas negras, esféricas, mas ó menos lustrosas, de embrion derecho ó encorvado: zanthoxylum, F. 114, G. II.

230. Arboles mas ó menos altos que alcanzan á veces hasta $50^{\prime}$ de altura, mas ó menos corpulentos y frondosos; hojas alternas, compuestas y pinadas sin impar y formadas de muchos pares de hojuelas alternas, pecioladas, coriáceas, enteras, oblongas ó lanceolado-oblongas, espatulado-oblongas ó lanceoladas, obtusas ó con una puntita obtusita, de cara superior lustrosa y verde oscuro, mientras la inferior es á veces mas pálida y glauca, lampiñas y decíduas. Flores en panojas terminales formadas de cimas pequeñas y paucífloras, mas cortas ó apenas tan largas como las hojas, de cáliz 5 -fido y mucho mas corto que los pétalos, que son 5 y abiertos; en las masculinas los estambres son inclusos, con anteras introrsas, biloculares, acorazonado-ovales y lonjitudinalmente dehiscentes; en las femeninas hay los rudimentos de las 10 escamas, y 5 ovarios situados sobre un ginóforo corto, distintos, uniloculares y con un óvulo 
único; de los ápices sale un estilo continuo, cada cual con su correspondiente estigma. Fruto formado de carpidios drupáceos en número de 5 ó menos, sentados, uniloculares, monospermos; embrion sin endospermo y con los cotiledones semi-oroídeos : simaru$b a$, F. 110, G. I.

231. Flores nunca jamás desnudas ni en cono terminal tampoco; siempre un tallo bien manifiesto y mas ó menos largo, 232 bis. Flores siempre desnudas, 231 bis.

231 bis. Nunca en cono ó amento ó estrobiliforme terminal, pero sí en amentos filiformes ó pequeños opuestos á las hojas; arbustos trepadores, 232. - En cono ó amento estrobiliforme terminal, cuyo tallo es una especie de estipe subterráneo ó rizoma perpendicular, ordinariamente largo de $1^{\prime}$ á 1 l $2^{2}$ sobre $3^{\prime \prime}$ á 4" de diámetro, cscamoso solamente pôr el vértice que se halla á la superficie del suelo y del cual salen 4 ó 5 frondas que les hacen parecer á primera vista palmeras jóvenes, largas de $2^{\prime}$ á 3 ', derechas, cuyas hojuelas, articuladas por la base y sentadas, son alternas ó á veces casi opuestas, lanceolado-aguzadas por ambos estremos, o redondeadas por el vértice, cuneiformes por la base, enteras ó aserradas hácia el vértice, basine1vias, caducas, como estriaditas, lampiñas y lustrosas, raquis inerme ó provisto de aguijones, quedándose desnudo bastante tiempo y con aspecto como de una varita ó espina larga, derecha, algo comprimida, de cara interior llana, mientras la esterior es convexa. Flores masculinas en conos terminales simples ó ramosos, ó mejor algunos saliendo del mismo pedúnculo, largos de $2^{\prime \prime}$ á $3^{\prime \prime}$ y bastante gruesos, formados de escamas truncado-abroqueladas, cuyas floríferas estipitadas y de ápice engrosado y como abroquelado, subbilobulado, llevan por la cara inferior muchas anteras sentadas; los conos femeninos son mucho mas gruesos, mas cortos, de pedúnculo largo de como $3^{\prime \prime}-4$ " y como estriado tambien, aterciopelado y color castaño, formado de escamas algo carnosas, prismáticas y de 6 caras, dispuestas por séries verticales y alternando las unas con las otras, de ápice aterciopelado-moradusco como el de las masculinas, algo estipitadas tambien, cargando con 2 ovarios desnudos rolcados cabizbajos y dispuestos á manera de T, cuya base está vuelta hácia la circunferencia, mientras el ápice, terminado por un puntito negro con una boquita, es el estigma sentado, situado por la base de las escamas, que así como las masculinas se apartan un poco las unas de las otras en la estacion de la fecundacion y despues se vuelven á cerrar, mientras las primeras se quedan abiertas. El fruto es una especie de drupa abayada, con poca carne colorada, del tamaño de una avellana pequeña, situada entre las escamas del cono y por debajo de ellas; semilla ovoídeo-sub-globosa de testa huesosa; embrion inverso contenido en el eje de un endospermo carnoso: $z a-$ mia, F. 35.

232. De hojas simples, alternas, pecioladas, enteras, tri-multinervias ó costilludas, membranáceas ó coriáceas, lampiñas ó pubescentes; amentos saliendo de los nudos, cuyos masculinos son delgados, los femeninos algo mas gruesos y los fructíferos como arracimados; flores sentadas, acompañadas las masculinas de brác- 
teas oblongas sentadas é imbricadas; estambres 2, 5, de filamentos rollizos, con las anteras aovado-reniformes; en las femerinas las brícteas son abroqueladas, sub-sentadas, persistentes, oblongas ú orbiculares, frecuentemente hirsutas inferiormente; ovario sentado, aovado, con 3, 5 estigmas sesiles, cortos, espesos é hispiditos superiormente. Bayas estrechadas por la base, con pedúnculo falso, sub-globosas, de pericarpio delgado, con la semilla subredonda, de tegumento coriáceo-membranáceo ó córneo; endospermo harinoso: cubeba, Miq., F. 37.

232 bis. Vejetales siempre parásitos; flores apétalas; inflorescencia en espigas filiformes axilares, articuladas, cuyas flores numerosas estín anidadas en escaraciones correspondientes situadas en el eje, cuyos artejos ó piezas son sostenidos por un invólucro truncado y bífido; periantio de limbo 3, 2, 4-partido, adherente en las femeninas, anteras 4 sentadas ; ovario ínfero ovoídeo-unilocular, con un estigma sentado y obtuso; baya unilocular monosperma. Tallos muy ramosos, leñosos, de como $1^{\prime}-2$ ' de larço algo mas ó menos, con ó sin hojas, de color verde mas ó menos amarillento, 233. - Vejetales nunca parásitos, 234 bis.

233. Tejetales con hojas; anteras sentadas transversalmente biloculares, cuya celda se abre por un poro ó una grieta, 233 bis. Vejetales afíleos, pero sí escamosos; anteras sentadas por la parte media de las divisiones calizinales, uniloculares y transversalmente dehiscentes, 234.

233 bis. Tallos articulados r nudosos, de ramitas mas ó menos comprimidas, tetrágonas, sub-cilíndricas ó cilíndricas, con hojas opuestas bastante dobles, coriáceas, enteras, cortamente pecioladas, de tamaño variado, anchas y largas de $]^{\prime \prime}-21\left[2^{\prime \prime}\right.$ ó pequeñas y largas de $6^{\prime \prime \prime}$ á $2^{\prime \prime \prime}$, aovadas, ob-aovadas, espatuladas, oblongas, elípticas, linear-lanceoladas, mas ó menos obtusas por el ápice, mas ó menos aguzadas por la base; las flores constan de un periantio cuyo limbo es ordinariamente 3-lobulado, y raras veces con 2 ó 4 lobulos; anteras transversalmente biloculares y cuyas celdas se abren por un poro ó una grieta : phoradendron, F. 47, T. II, G. I.

234. Tallos dicótomos nudoso articulados, muy ramosos, largos de $6^{\prime \prime}-1{ }^{\prime}-2$ ', con las ramitas estriado-cilíndricas, comprimidas y por fin mas ó menos cilíndricas, mas ó menos quebradizas, sin hojas, que están reemplazadas por escamas mas ó menos trabadas y formando una raina, ó reducidas á puntas ó apenas notables y mas ó menos decíduas; las flores constan de un periantio 3, 2-lobulado ó partido $y$ raras veces con 4 segmentos ; en las masculinas está el rudimento del pistilo; anteras sentadas en la parte mediana de las divisiones calizinales, uniloculares y transversalmente dehiscentes : arceuthobium, F. 47, T. II, G. II.

234 bis. Matas de tallos mas ó menos largos y delgados, enredaderos ó volubles, leñosos ó herbáceos, con ó sin zarcillos, con ó sin aguijones, 235. - Tejetales ni enredaderos ni volubles tampoco, 244.

235. Con zarcillos, 236. - Sin zarcillos, 239.

236. Plantas de tallos leñosos abejucados ó herbáceos, sin aguijo- 
nes; zarcillos solitarios estraxilares, simples o ramosos; periantio siempre dolıle; ovario ínfero, 237. - Bejucos de tallos larguísimos, fortísimos, muy aguijonosos, con 2 zarcillos acompañando á la inscrcion del peciolo; periantio único; ovario libre ó súpero; vejetales perennes, cuyos tallos lampiños salen á veces de una especie de rizoma, sarmentosos $y$ trepando por encima de los demas vejetales, en donde se sostienen con sus zarcillos muy iuertes, de aguijones negros, cortos, ganchosos y muy fuertes; hojas simples alternas, asaz largamente pecioladas, enteras, basinervias, de nervaduras sencillas y paralelas, mas ó menos ovales, de base acorazonada y de vértice mas ó menos puntiagudo, mas ó menos anchas, como membranosas, lampiñas, lustrosas y de un color verde oscuro. Flores en especies de umbelas axilares largamente pedunculadas, pequeñas y verdoso-amarillentas, cuyas masculinas constan de un periantio monosépalo, campanudo, con 5 segmentos casi iquales abiertos y estendidos; 6 estambres de anteras erguidas, biloculares; en las femeninas el periantio es persistente, marcescente $\mathrm{y}$ conforme al de las masculinas; ovario libre, mas ó menos globoso, con 3 celdillas monospermas y de curo ápice sale un estilo corto que se termina por 3 estigmas. Baya esférica, pisiforme, rojiza, lustrosa y con 3 celdas conteniendo cada una una semilla redonda: á veces algunas suelen abortar : smilax, F. 17.

2:37. Zarcillos estraxilares y simples; fruto abayado y carnudo; estambres diadelfos insertos por la base del tubo calizinal, 2 anteras subsesiles, oblongas, cuyas celdas son rectas y marjina!es, 238. - Zarcillos axilares proviniendo de ramitas abortadas y simples; fruto crueso, corticoso, con una especie de surco transversal y casi en la parte mediana por donde al caerse al suelo se abre á manera de los pixidios ó de jabonera ; estambres 5 centrales, alternando con 5 filamentos estériles, de anteras marjinales; vejetales semi-leñosos, de tallos larguísimos y sarmentosos, mur ramosos y que se crian de ordinario en las cercanias ó en las orillas de las quebradas, con hojas grandes, alternas, sirnples, largamente pecioladas, algo corííceas, sub-acorazonado-redondeaditas, angulosas, 3-5-lobuladas ó enteras, lisas, de cara superior lustrosa, con ó sin glándulas $y$ anchas de $3^{\prime \prime}-4^{\prime \prime}$ y largas de $5^{\prime \prime}$ sin el peciolo, que lo es de 4 á $6^{\prime \prime}$; flores masculinas amarillentas fasciculadas y dispuestas en panojas,

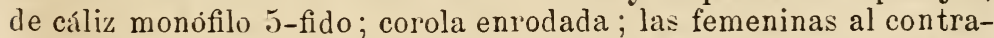
rio son solitarias con el cáliz adherente 5 -lobulado; corola cuyos 5 petalos son distintos y oblongos; 5 filamentos estériles alternan de ordinario con los pétalos; ovario ínfero, globoso, con 3 celdas conteniendo algunos óvulos, de cuyo ápice salen 3 estilos terminándose en un estigma, espesito, obtuso y bífido. Fruto globoso, lampiño, de como $4^{\prime \prime}-6^{\prime \prime}$ de diámetro, con 3 celdillas en las cuales las semillas casi horizontales son pegadas del placenta central bastante grueso y triangular y aplicadas las unas por encima de las otras oblícuamente, discoídeas, achatadas, undulosas, de testa espesa bastante fuerte y de color gris sucio esteriormente, blanca y como corchosa interiormente, anchas de $11\left[2^{\prime \prime}-2^{\prime \prime}\right.$ y espesas de como $6^{\prime \prime}$ : feuillea, F. 14l, T. I. 
238. Plantas herbáceas cuyos tallos, largos, delgados, ramosos y alampiñados, salen de una raiz tuberculosa bastante gruesa, y tienen hojas simples, alternas pecioladas, con 5 lóbulos profundos y pedáleos, á veces son 7 ú 8 , sub-enteros, cuyos tres medianos son oblongos y mucronados, mientras los esteriores son semi-aovados, acorazonadas por la base con un seno grande y anchas de $5^{\prime \prime}-6^{\prime \prime}$. Flores ordinariamente rojas, cuyas masculinas son en racimos cortos, con los pedúnculos tan largos como las hojas, pedícelos sin bráctea y del lárgo del cáliz monosépalo, 5-dentado, tubular-campanudo, de tubo verde mas largo que los pétalos, que son 5; tubo calizinal largo de 7-8"', dientecitos recorvos y largos de $5^{\prime \prime \prime}-6^{\prime \prime \prime}$; mientras las femeninas son solitarias y tienen un ovario con 2 celdillas conteniendo algunos óvulos : anguria, F. 141, T. II, G. IX.

239. Raiz siempre fibrosa; flores á veces provistas de una corola; ovario libre ó súpero; embrion encerrado en un endospermo en forma de herradura; hojas de nervaduras no paralelas simples pero anastomosadas entre sí; fruto drupáceo, 240. - Raiz siempre tuberosa mas ó menos gruesa; flores sin corola siempre; ovario ínfero; embrion contenido en un endospermo nunca dispuesto á manera de herradura; hojas basinervias y de nervaduaas simples paralelas $y$ no ramificadas; fruto capsular, 242.

240. En ambos sexos cáliz con 6 sépalos dispuestos en 2 séries, $y$ corola de 6 pétalos; las masculinas contienen 6 estambres y las femeninas 3 ovarios, 241. - En las flores masculinas el cáliz es de 4 sépalos y la corola cupuliforme, sub-entera, con 4 estambres cuyas anteras se abren transversalmente; el cáliz de las femeninas es monófllo, como espatiforme, de ordinario escotado, sostenido por una bracteita; pétalos nulos; ovario único con 3 estilos; vejetales sarmentosos, sin embargo algunas veces no lo son ó solo muy poco, sin duda por ser demasiado cortos los tallos pubescentes, velludos y hasta afelpados; de hojas simples, alternas, pecioladas, acorazonado-redondeadas, cuyo peciolo es situado por la base ó como abroqueladas, lijeramente velluditas por ambas caras ó por la inferior solamente, pubescentes ó afelpadas por ambas caras, membranosas ó cartáceas ; flores masculinas muy pequeñas dispuestas en racimos compuestos ó corimbos axilares cuyos pedícelos son tricótomos ó simples, estambres monadelfos; mientras las femeninas son fasciculadas y dispuestas en racimos ó espigas y sostenidas por una brác-tea bastante grande. Drupa pequeña casi esférica, roja y envuelta en la base del cáliz, monosperma unilocular : cissampelos, F. 93, T. II.

241. Vejetales sarmentosos ó bejucos de hojas mas ó menos coriáceas, alternas simples, pecioladas, oblongas, elíptico-oblongas ó acorazonado-triangulares, lampiñas ó algo pubescentitas enteras, con las nervaduras bastante pronunciadas por la cara inferior. Flores dispuestas en racimos axilares á veces apanojados, delgados y mas largos que el reciolo; drupas comprimidas, cuya semilla está situada sobre un ápice discoídeo y saliendo del pericarpio; enclospermo espeso y no ruminado, conteniendo el embrion anular, cilíndrico y casi tan largo como él : cocculus, F. 93, T. I. 
242. Ovario con 3 estilos ; fruto capsular de 3 celdillas con 2 semillas aladas en cada una, 243. - Ovario con 5 estilos; el fruto es una especie de sámara y por consiguiente unilocular y monospermo; tallos muy ramosos, delgados, larguísimos, enredaderos y herbáceos, saliendo de una raiz perpendicular carnosa no muy gruesa, con hojas simples, alternas, pecioladas, óvalo-lanceoladas, de base acorazonada y con una punta por el ápice. Flores en espigas axilares en la sumidad de las ramitas formando así especies de guirnaldas apanojadas algo amarillentas; en las masculinas el periantio es de 6 divisiones iguales y abiertas, con 6 estambres cuyos filamentos son mas cortos que él y por consiguiente inclusos : rajania, F. 19.

243. Tallos anuales, semi-leñosos, largos, ramosos, no muy delgados, volubles, mas ó menos alados, saliendo de una raiz tuberosa que se vuelve á veces muy gruesa y llega á pesar mas de una arroba, con hojas sencillas, alternas, pecioladas, enteras, á veces bastante grandes, membranosas, ovales ú oblongo-aovadas, acorazonadas por la base y aguzadas por el vértice, lampiñas y lustrosas. Flores pequeñas, blanquecinas, á veces bastante fragrantes, en espigas ó racimos axilares delgados y pendientes, cuyas masculinas constan de un periantio 6-partido, algo coloradito, con 6 estambres; en las femeninas es adherente y tambien 6-partido; ovario no enteramente ínfero, cuyo vértice lleva 3 estilos con estigma cabezudo: dioscorea, F. 19 .

244. Estambres pocos y en número determinado; plantas herbáceas o matas, 244 bis. - Estambres muchísimos é indeterminados ; árboles ó arbustos frutices con frecuencia espinosos, de hojas simples alternas, algo coriáceas, cortamente pecioladas, sub-redondeadas, aovadas, festoneadas y agudas. Flores pequeñas en glomérulos axilares, de cáliz con 4-5 sépalos escamiformes pestañosos é imbricıdos ; en las femeninas están diminutos ó reducidos á brácteas subdistantes; corola nula; estambres á veces ceñidos por glándulas, de anteras versátiles y cortas. Ovario ceñido por un disco lobulado o por glándulas, 2 ó plurilocular, con óvulos las mas veces mellizos en las celdas, en cuyas paredes están pegados; estilos 2 ó muchos, libres ó adheridos por la base; estigmas remellados ó bílobos. Baya indehiscente con el endocarpio endurecido, cuyas semillas solitarias y obovoídeas tienen la testa lijeramente coriácea; embrion sin endospermo y con los cotiledones orbiculares: flacourtia, F. 87, T. IV.

244 bis. Flores nuncả amentáceas; tallos nunca jamás articulados ni suculentos tampoco; 4 ó mas estambres; el fruto es un aquenio, 245. - Flores siempre amentáceas, semi-anidadas las femeninas en el eje espeso; mata fruticosa inferiormente, desparramada ó derecha, con las ramitas tiernas herbáceas y suculentas, alta de $11_{l} 2^{\prime}$ á $3^{\prime}$, criándose en los sanitrales, lampiña y de un color verde amarillento; hojas simples, opuestas, pequeñas, espesas y carnosas, casi sentadas, oblongo-lineares, cuya cara superior es llana $\delta$ algo cóncava á manera de gotera, mientras la inferior es convexa. Flores en amentos axilares ó terminales, los masculinos largos de como $1^{\prime \prime}$ á $11\left[2^{\prime \prime}\right.$ son imbricados y con 4 caras poco pronunciadas, cuyas flo- 
res constan de 4 estambres alternando con algunas escamas membranosas, encerrados en un invólucro bífido y delgado é insertos por la base de una bráctea orbicular; mientras que los femeninos sou mas cortos y oblongo-cilíndricos ú ovales, curas flores sin envólucro son semi-engastadas en el eje carnudo $\dot{y}$ sostenidas por una bráctea única, de ovario 4-locular coronado por un estigma lilobulado. El fruto consiste en algunas bayas reunidas entre sí formando un sincar pio, las 4 celdas de cada liara, de endocarpio coriáceo, contienen cada cual una semilla de testa membranosa, y un embrion arqueado $\mathrm{y}$ sin endospermo: Zatis, F. 52 .

245. Vejetales siempre herbáceos de raiz mas ó menos carnosa y perpendicular ó con un rizoma; flores dioicas, polígamas y hermafroditas á la vez; fruto aqueniforme ó abayado, 246 . - Frutices ó vejetales fruticulosos ó herbáceos, de raices siempre fibrosas $y \sin$ rizoma; flores dioicas ó andrójinas; siempre un aquenio, á veces contenido en el periantio carnudo, 248.

246. Hojas bastante grandes, cuya hase del peciolo está provista de una membrana envainadora ú ochrea: aquenio envuelto en el periantio mas ó menos vejigoso, 247. - Hojas lineares fasciculadas, cuyos haces son esparcidos, y sentadas; periantio coroliforme; bara pisiforme : vejetales de cuyo rizoma salen retoños mas ó menos gruesos, que se vuelven tallo derecho, ramoso superiormente y alto de $3^{\prime}$ á $5^{\prime}$, lampiño y cilíndrico; hojas pequeñas lineares, subuladas, caducas, lampiñas, de un color verde oscuro y lustrosas, derechas y cuyos haces salen de la axila de una bráctea membranosa. Flores axilares de ordinario mellizas, cuyo pedúnculo, bastante largo y pendiente, es articulado hácia la parte mediana, de periantio petaloídeo, partido en 6 divisiones içuales, sub-campanudo ; en las masculinas hay 6 estambres inclusos cuyos filamentos cortos se insertan en el $l_{[} 3$ inferior del periantio, mientras que en las femeninas hay un ovario globoso trilocular, uni-orulada cada celdilla, $y$ de curo ápice sale un estilo único y trígono terminándose por 3 estigmas. Baya roja pisiforme, lampiña y lustrosa con 2 y raras veces 3 sesemillas : asparagus, F. 16, T. V.

247. Plantas bisanuales cuyas raices perpendiculares son á veces bastante gruesas y mas ó menos carnudas, de las cuales sale un tallo único, derecho, mas o menos estriado, ordinariamente lampiño, poco ramoso, alto de $1^{\prime}, 2^{\prime}, 3^{\prime}$ algo mas ó menos; hojas bastante grandes, de figura y tamaño muy variados, alternas y largamente pecioladas cuando son radicales, mientras que las caulinares son tanto mas cortamente pecioladas cuanto mas superiores son, enteras y frecuentemente undulosas por los bordes. Flores pequeñas rerduscas en panojas terminales muy furnidas, de un periantio membranoso con 6 divisiones, desiguales ordinariamente, cuyas interiores son sinuosas, á veces glandulosas, membranosas, persistentes y a veces rejigosas, mientras las 3 esteriores, mucho mas pequeñas $y$ caducas, alternan con las primeras; en las masculinas $\mathbf{6}$ estambres hay pegados en el fondo del periantio, de filamentos muy cortos y capilares, con anteras derechas, oblongas $y$ biloculares; mientras las femeninas contienen un ovario pequeño triangular ó turbinado, 
de curo ápice salen 3 estilos capilares, estendidos, bastante largos para salir afuera entre los sépalos y terminándose por un estigma apincelado ó ramoso y glanduloso á la par. Aquenio pequeño, triangular ú oval, mas ó menos lustroso, negro, lampiño, envuelto por los sépalos mas ó menos crecidos; embrion oblongo lateralmente situado en el endospermo feculento bastante desarrollado: rumex, F. 50, T. II, S.-T. III, G. I.

248. Aquenio enruelto en el cáliz que se lia vuelto carnudo; fruta simulando pues una baya; estambres 5,4 ; frutices con pelos de picadura que causa escozor ó aguijones que producen igual efecto, 249. - Aquenio mas ó menos envuelto por el periantio que no se vuelve nunca carnoso, 250.

249. Vejetales que á veces se vuelven arbustos de tallo ramoso, con hojas grandes alternas, peciuladas, aovadas, aovado-oblongas, elípticas ó elíptico-oblongas, ovales ó redondeaditas, acorazonaditas, escotadas, redondeadas ó cuneiformes por la base, mientras que por el ápice son obtusitas o provistas de uua punta obtusa, enteras, undulosas, aserradas, festoneadas ó festoneado-aserradas, pubescentes, lampiñas ó alampiñadas, de cara superior provista de rafidias puntiformes ó sin ellas, ó muchas y lineares; flores en cimas axilares ó laterales divaricado-dicótomas, tricótomas, ó en grupos dispuestos en espigas ó axilares, cuyas masculinas, de periantio 4 , 5 -partido, tienen 4 estambres; en las femeninas el periantio es 4 partido ó 4-lobulado, $y$ se vuelve carnoso y abayado; orario único oval ó redondeado, cuyo ápice lleva un estigma sub-sentado y apincelado: urera, urtibaca, Nohis, F. 39, T. II, G. I.

2.50. Frutices, matas ó plantas herbaceas sin pelo punzante ni aguijones tampoco, 250 bis.-Plantas herbáceas anuales, bisanuales o vivaces, de corteza muy fibrosa, fuerte y tejible, con frecuencia provistas de pelos muy punzantes y cuya picadura causa mucho escozor, de hojas simples, alternas, largamente pecioladas ordinariamente, mas ó menos grandes, de ordinario pulsescentes ó velludas, enteras, festoneadas ó aserradas, de base mas ó menos acorazonada, mientras el vértice es con una punta ó sin ella, acompañadas de estipulas que faltan con bastante frecuencia. Flores en racimos axilares bastantes veces como apanojados, pequeñas y separadas, de periantio con 4 divisiones, en las masculinas, profundas, concavas, obtusas, iguales y redondeadas, corteniendo 4 estambres, de filamentos alesnados, opuestos á los sépalos y direrjentes, mas largos que ellos, esertos y situados en el fondo del cáliz en derredor de los rudimentos del ovario; mientras que en las femeninas el periantio tiene solo dos sépalos de igual forma, persistentes; ovario súpero, unilocular, oval, de cuyo ápice sale un estigma sentado, formado de pelo glanduloso y dispuesto á manera de nudo ó de pluma. Aquenio oval ó mejor comprimido, liso $y$ envuelto en el periantio: urtica, F. :39, T. II, G. III.

2.50 bis. Plantas siempre herbáceas; flores con esti rma apincelado, 196. - Siempre frutices; flores cuyo estigma no está apincelado, pero sí filiforme, persistente y con pelo por uno de sus lados, 195. 
251. Vejetales polígamos monoicos; un solo individuo teniendo á la vez flores masculinas ó femeninas y hermafroditas, 252.-Polígamos, dioicos ó cuyas flores masculinas ó femeninas y hermafroditas se hallan en dos ó mas individuos ó sujetos vejetales diferentes, 299.

252. Plantas herbáceas, 253. - Arboles, arbustos, frutices y matas, 261 .

253. Flores nunca desnudas, 253 bis. - Flores desnudas y en espádice; plantas frecuentemente de tallo trepador, con hojas alternas, simples, bastante grandes, de ordinario aovado-oblongas, enteras ó agujereadas, cuyo peciolo, mas ó menos largo, está provisto por la base de una vajina algo floja y dilatada. Espata blancuzco-amarillenta, abierta y por fin decídua; espádice sentado femenino por la base, mientras que el vértice es hermafrodito; estambres sub-indefinidos, de filamentos lineares comprimidos, cuyas anteras terminales, aovadas y biloculares tienen las celdillas opuestas, abriéndose lonjitudinalmente, $y$ situados en derredor del ovario bilocular, rafidioforo, con 2 óvulos sub-colaterales, ascendentes, anátropos y situados por la base del tabique; del ápice sale un estilo cortísimo terminado por un estigma cabezudo: monstera, F. 8, T. II, S.-T. I.

253 bis. Flores glumáceas; una cariópside; una caña por tallo, 255.-Flores nunca glumáceas; fruto capsular que es un pixidio mas ó menos lejítimo, 25 4.

254. Flores en grupos ordinariamente espiciformes, todas ó las superiores solamente dispuestas en panojas terminales y de periantio con 5, 3 sépalos, con 5, 3 estambres; estilos $2 \dot{0} 3$; fruto es un pixidio, véase n. 197. - Flores pequeñas membranosas, en cabezas ó espigas; grupos dispuestos en panojas muy ramosas, con brácteas membranosas y ordinariamente cóncavas; plantas anuales, fruticulosas y hasta leñositas, rastreras, á veces algo trepadoras, lampiñas o pubescentes, de tallo ramoso, con hojas simples, alternas, pecioladas, aovadas, lanceoladas, aovado-lanceoladas y elípticas, aguzadas ó con una punta, lampiñas ó de cara inferior pubescente; periantio con 5 sépalos, ceñido en las femeninas y por fin envuelto en lana; estambres 5 cúpula basilar de ordinario sin dientes, anteras elípticas; estigmas 2,3 sub-sentados, algunas veces coadheridos cuando jóvenes. Pericarpio utricular y por fin reventándose irregularmente: iresine, F. 55, T. I.

255. Flores en panojas solas ó en panojas y en espigas á la par, 256. - Flores siempre en espigas delgadas y bastante largas, dispuestas á manera de los dedos de la mano; hojas con la lodicula hendida; las flores de las espiguitas lineares son mellizas, una estando casi sentada y la otra pedicelada; gluma de 2 valvas, ovaloblongas, cilíndricas y sin arista; glumela de 2,3 valvas cóncavas, cuya última, mas pequeña, falta á veces; la segunda varia bastante, mientras la primera es tan larga como la gluma misma. Yerba de como $8^{\prime \prime}$ á $10^{\prime \prime}$ de alto, con hojas linear-lanceoladas, de vaina hendida : digitaria, F. 10, T. X.

256. Todas en panojas terminales mas ó menos densas y grandes, 
257. - Las masculinas y polígamas en panojas grandes terminales, mientras las femeninas son en espigas axilares : véase 172 .

257. Formadas de espiguitas reunidas dos por dos, de las cuales una es femenina y la otra hermafrodita; glumela terminándose por una arista, 258.- Espiguitas solitarias; arista saliendo del fondo de la gluma; estigma sentado, 259.

258. Yerbas vivaces ó anuales, cuya altura varia de $1^{\prime}$ hasta $5^{\prime} \mathrm{y}$ $6^{\prime}$ de altura; hojas linear-lanceoladas ó lanceoladas y bastante anchas á la vez; las espiguitas que constituyen las panojas son frecuentemente dijitadas; flores masculinas pedunculadas sin arista, mientras las hermafroditas son al contrario sentadas, aristadas $\mathrm{y}$ provistas de pelo pegado por la parte esterior de la gluma. Algunas especies son aromáticas : andropogon. F. 10, T. II.

229. Gluma biflora, con dos valvas dentadas; arista torcida, 260. - Gluma uni o biflora, con valvas sin dientes, arista no torcida; Jerbas anuales de ordinario bastante altas, de hojas largas y lanceoladas envainadoras por la base; panojas ramosísimas compuestas de espiguitas masculinas con flores membranosas y sin arista, mientras que las de las hermafroditas son coriáceas y ordinariamente aristadas; las masculinas no están jamás contenidas en la misma gluma que las hermafroditas : holcus, F. 10, T. II.

260. Plantas anuales que tienen mucha analojía con el género anterior, de las cuales se diferencian porque una de las dos flores contenidas en la gluma es hermafrodita y sentada, mientras la otra masculina ó estéril es pedicelada. En las flores femeninas la glumela es formada de 2 valvas y la gluma de 3 , cuya segunda es aristada y la tercera pegada de una pajita velluda; la arista torcida sale de entre los dientes de la valva inferior'; gluma sin arista en las masculinas; cariópside bastante gruesa: sorghum, F. 10. T. II.

261. Cuyo tallo es un estipe ó á primera vista parece como un estipe pequeño, 262.-De tronco ó tallo lejítimo, 264.

262. Estipe lejítimo; flores con un periantio único; fruto drupáceo; una espata, 262 bis.-Estipe espurio ó tallo estipiforme; flores completas; fruto abayado; siempre espata nula. Arbol sin ramas algunas, de $20^{\prime}-2$ ' de altura, cuyo tronco delgado se termina por hojas grandes, simples, espatulado-lanceoladas, tiesas, lampiñas, que forman una roseta en su ápice, de base largamente aguzada, terminándose en un peciolo corto, obtusitas, con dientes apartados, espinescentes y encorvados ó sub-enteras, adornadas de venas acostilladas, delicadas, que las hacen reticuladas por ambas caras; de color verde pálido, largas de $1^{\prime}-11$ [ $2^{\prime}$ y anchas de $3^{\prime \prime}$, cuyo peciolo bruno, espeso y largo de 4-6"' solamente. Flores color de escarlata en racimos flojos, espiciformes, alargados, axilares ó situados en las axilas de las hojas mas adultas ó mas inferiores y mitad ó 4 reces mas largos que ellas, cuyosipedícelos son de lo largo de las flores que llevan; cáliz 5, 4-partido; corola enrodada, coronada por la garganta de 5, 10 apéndices redonditos, y con 3-4"' de diámetro; estambres 5 formando un tubo en las flores masculinas, mientras que en las femeninas son distintas, cuyas anteras estrorsas, cortas, ordinariamente truncadas, se abren por una grieta; ovario con pla- 
centas pluriovulados; estigma obtuso. Baya grande plurisperna: theophrasta o clavija, F. 80 .

262 bis. Una sola espata, 263.- Dos espatas completas, cuya esterior es comprimida y la interior lanceolada y con ápice abierto; por fin fibroso-laciniadas, 96.

263. Espata mucronada y asureada por el dorso; fruto muy grueso, 91.-Espata leñosa, persistente, espesa, muy largra, en forma de canoa y con un pico muy largo fruto pequeño. 92.

264. Estambres monadelfos, cura columna ó andróforo hipojínico lleva 10-20 anteras de celdas paralelas; 5 carpidios insertos en el vértice de un carpóforo, unidos solamente por el estilo simple; fruto de tantos folículos distintos ó de 2 o 3 , algunos de ellos abortando siempre. Flores incompletas ó con un solo periantio, 265. - Estambres monadelfos ó libres, hipojínicos ó pirijínicos, pero nunca con andróforo columnario coronado por anteras numerosas; fruto nunca formado de folículos, 266.

26วّ. Arboles grandes que se elevan á $40^{\prime}-500^{\prime}$ de altura, corpulentos $y$ frondosos; con hojas simples. alternas, largamente pecioladas, acorazonado-redondeadas, 5 , 3-lohuladas ó aovado-oblongas y ordinariamente enteras, de cara superior lampiña ó alampiñada, mientras la inferior es aterciopelada ó pubescentita, con las costillas, nervaduras y venas muy pronunciadas, cuyas anastomosis numerosas le dan un aspecto particular, anchas de 12" á 14" sobre 91 I de largo, con el peciolo un poco crecido tanto por la base como por el ápice aterciopelado ó pubescentito y largo de 6 á $8^{\prime \prime}$; con dos cicatrices acompañando á su insercion, una de cada lado, las cuales señalan la existencia de las dos estípulas que se observan solamente al abrirse la yema, son triangulares, derechas, largas de como $5^{\prime \prime \prime}-$ $6^{\prime \prime \prime}$ y anchas de $11_{\left[2-2{ }^{\prime \prime \prime}\right.}$ por la base, aterciojeladas y de color acanelado oscuro por la cara esterior. Flores en racimos apanojados axilares largos de $8^{\prime \prime}$ á $10^{\prime \prime}$, de brazos alternos y bozosos como el ejc principal y las ramitas que les llevan, en número de 3 á 5 y largos como de 21 [ $2^{\prime \prime}$ á $3^{\prime \prime}$, con una bráctea por su insercion, con las flores dispuestas sobre ellos por grupos de á 3 ordinariamente y por el vértice, cuyo pedúnculo cortito y bastante grrueso, comun á cada grupo, sale de la axila de una bráctea igual á la ya señalada, membranosa, pubescente y triangular, tambien larga de como $1^{\prime \prime \prime}$; del ápice de ese pedúnculo $\mathrm{y}$ de cada lado sale un pedícelo gruesecito tambien con 3 bracteitas por la base, de las cuales la del medio es mucho maror que las dos laterales opuestas, despues de ellas sigue el pedícelo mas delgado y largo de como $4^{\prime \prime \prime}$ á $6^{\prime \prime \prime}$, terminándose por una flor primorosa de como $10^{\prime \prime \prime}$ á $15^{\prime \prime \prime}$ de diámetro y larga de 6 á $\mathbf{9}^{\prime \prime}$, de color amarillento teñido de morado esteriormente, y mas pálido interiormente con manchas moradas ; periantio campanudo ó rotáceo-acampanado, Ј-fido, con los segmentos ovales y puntiagudos, arrolladitos hácia fuera; en las flores hermafroditas la columna no existe, pero está reemplazada por una membrana corta que forma por la base del ovario una especie de invólucro con 5 lóbulos poco pronunciados ó quizás solamente 5 ángulos que cargan cada uno con 3 estambres cuyos 2 laterales son casi sentados, mientras 
que el del centro tiene el filamento algo mas larguito, anteras amarillas, biloculares y casi escondidas por la base del ovario bastante desarrollado en relacion con ellas. El pistilo se compone pues de un ovario bastante grueso formado de 5 carpelitos, estipitado, pubescente; estigma con 5 lóbulos y amarillento; los carpelos se separan los unos de los otros, toman la figura de una estrella, y se vuelven folículos de un color ceniciento aleonado despues de caido el bozo que cubria los ovarios; son algo estipitados, desigualmente ovales y algo fusiformes, largos de como $4^{\prime \prime}-41_{[} 2^{\prime \prime}$ y $2^{\prime \prime}-21_{[} 2^{\prime \prime}$ de diámetro en la parte mediana, contienen algunas semillas pegadas de cada lado de la sutura, situada por la cara interna de los ovarios que se ha vuelto superior en los folículos por causa de su posicion horizontal; se abren por esa sutura principiando por el ápice; los bordes de la abertura son de un hermoso color agamuzado, el interior algo mas pálido y de aspecto sedoso por estar cubierto de una peluza blanca, tiesa, lustrosa y punzante ; las semillas, en número de 6 por causa de aborto, son insertas en la placenta sutural alternativamente por medio de un podojino bastante desarrollado, discoídeo, amarillo, son negras, lustrosas, ovoídeas ó quizás mejor elípticas, largas de como $13^{\prime \prime \prime}$ á $14^{\prime \prime \prime}$ y anchas de $5^{\prime \prime \prime}-7^{\prime \prime \prime}$, de epispermo ó tegumento como coriáceo y bastante espeso : sterculia, F. 105.

266. Fruto mas ó menos carnudo, drupáceo 6 abayado, 267... Fruto seco capsular ó no capsular, $27 \%$.

267. Fruto siempre drupáceo, 268. - Fruto no drupáceo como abayado ó formado de 2 o 3 carpelos, de los cuales 1 ó 2 suelen abortar ; árboles bajitos ó arbuistos pubescentes ó lampiños, con hojas de 3 en rama ordinariamente, cuyas hojuelas pecioladas ó subsesiles son elípticas, enteras y repandas, sinuado-aserradas ó aserraditas, mas ó menos obtusas ó con una punta, coriáceas, enteramente lampiñas ó solamente por la cara superior lustrosa, mientras la inferior es pubescente ó alampiñada. Flores en racimos axilares con frecuencia ramosos ó fasciculados, frecuentemente con una bráctea por la insercion del pedícelo, de cáliz con 4 sépalos mas ó menos ovales ú orbiculares, sub-campanudo y pubescente; corola de 4 pétalos ordinariamente mas largos que el cáliz y cuya uña lleva algunas veces una escamita peludita situada por la cara interior; estambres 8 mas largos que la corola é insertos en el disco cuya parte interna tiene pelo, de filamentos subulados mas ó menos derechos, lampiños ó pubescentes, cuyas anteras introrsas son ovoídeo-oblongas, biloculares y dorsifijas. Ovario dídimo, ovoídeo, mas ó menos velludo, con un estilo bífido saliendo de su ápice: schmidelia, F. 121, T. I, G. V.

268. Drupa lejítima mas ó menos gruesa, 271. - Drupa nuciforme ó una nuez, 269.

269. Flores apétalas, drupa nuciforme elíptica puntiaguda, biconvexa, ú oval-oblonga y obtusa por ambos estremos, comprimida, márjen mas o menos aguda y prolongada, 270. - Flores completas; nuez obaovada, lijeramente alada ó de márjen comprimida y algo dilatada; árboles bajitos o arbustos ramosos, que se crian en los lugares pantanosos de las orillas del mar, con hojas simples, opuestas, 
bien enteras, sin venas, de peciolo biglanduloso por el vértice, ovaloblongas ú ovales, lampiñas; flores en espigas pedunculadas ordinariamente compuestas por la base y blanquecino-pubescentes, de cáliz persistente 5-lobulado, cuyo limbo es corto, con el tubo campanudo en las femeninas; corola con 5 pétalos diminutos y decíduos; estambres 10 inclusos; nuez larga de 6"' : laguncularia, F. 139, T. II, G. III.

270. Arboles muy altos, corpulentos y frondosos, que se elevan á $40^{\prime}, 60^{\prime}, 80^{\prime}$ y $100^{\prime}$ de altura, de hojas simples, alternas, bien enteras ú ondulosas, obaovado-oblongas ó cuneiformes, oblongas, aguzadas por la base en peciolo largo y sub-acorazonadas ó redondeadas por la base algo aguzada, sub-glandulosa ó biglandulosa inferiorments. lampiñas por la cara superior, mientras que la inferior es alampiñada ó pubescente; flores en espigas axilares delgadas, simples, pedunculadas y cilíndricas, cuyo vértice lleva flores masculinas, mientras la base está ocupada por hermafroditas, cuyo periantio 5-fido y de limbo ciatiforme es decíduo; 10 estambres lijeramente esertos: terminalia, F. 139, T. II, G. I.

271. Flores provistas de un cáliz y de una corola, 272. - Flores apétalas : árboles bajitos ó arbustos sarmentosos inermes ó con espinas estipulares, de hojas simples, alternas, 3-nervias, aovadas, aovado-oblongas, oblícuas por la base, aserraditas hácia el vértice ó enteras, alampiñadas, pubescentes ó lampiñas, pecioladas; flores fasciculadas ó como algo cimosas y axilares, pediceladas y formadas de un cáliz decíduo 5, 6-partido, con 5 estambres inclusos y de anteras introrsas ; ovario unilocular glołoso ó aovado, de cuyo vértice salen 2 estilos divaricados; óvulo campilótropo y suspendido. Drupita globosa ó aovada, pedicelada: celtis, F. 40.

2\%2." Ovario único, 273.-3 ovarios distintos, que se vuelven carpidios, drupáceos, con una semilla solitaria y ascendente; árbol alto, bastante corpulento y frondoso, con hojas alternas, imparipinadas, formadas de 9, 11 hojuelas, opuestas, pecioladas, oblongas ú oblongo-lanceoladas, con una punta obtusa, coriáceas, lampiñas, bien enteras y largas de $4^{\prime \prime}-2^{\prime \prime}$ sobre $21_{1} 2-3^{\prime \prime}$ de ancho; hoja entera, larga de 12 á $15^{\prime \prime}$; flores en cimas corimbiformes ó apanojadas, axilares, pubescentes, mucho mas cortas que las hojas, y de cáliz diminuto 5, 4-fido; corola con 5 pétalos largos de $1^{\prime \prime \prime}$, oblongos, de color amarillento pálido y verdusco á la par; estambres 5, 4, esertos, saliendo de un disco ; estilo 3 -partido ; drupitas globosas, negras, de $6^{\prime \prime \prime}-3^{\prime \prime \prime}$ de diámetro; semillas con embrion sin endospermo. picrena, F. 110, G. V.

273. Hojas compuestas, 274. - Hojas simples; árboles grandes, corpulentos, muy coposos y que se elevan á $40^{\prime}-50^{\prime}$ de altura, de hojas alternas, coriáceas, lampiñas, oblongo-lanceoladas ó lanceoladas, con una punta, cortamente pecioladas y bien enteras, de un color verde oscuro y lustrosas cuando adultas, mientras que cuando tiernas son moraditas, un poco undulosas por los bordes, largas de $10-8^{\prime \prime}$ sobre $21_{[} 23-3^{\prime \prime} 1_{[} 2$ de ancho, algo aguzadas por ambos estremos; flores pequeñas amarillento-verdosas, en panojas terminales pubescentes, y formadas de un cáliz 5, 4-partido decíduo, de una 
corola con 5,4 pétalos mas largos que el cáliz; estambres 5 perijinos y algo esertos, de los cuales 1,2 solamente son fértiles, mientras los demas se quedan estériles; ovario 1 locular con 1 solo óvulo ascendente, de cuyo ápice sale un estilo simple corvo terminado por un estigma algo cabezudo. Drupa aovada ú ovoídea un poco arriñonada, larga de $2^{\prime \prime}-4^{\prime \prime}$ sobre 1 1 2 a a $2^{\prime \prime}$ de diámetro, lampiña y glauca antes de madura, despues mas ó menos amarilla ó rosada; semilla contenida en una especie de hueso no muy duro comprimido oval, cubierto de muchísimas fibras que penetran en la carne amarilla y con dos valvas ; radícula inferior y ascendente : mangifera, F. 126, G. II.

274. Ovario con 5-1 celdas, de las cuales algunas abortan siempre, conteniendo 1 ćvulo solitario, 275. - Ovario con 5-1 celdas todas ovulíferas y conteniendo dos óvulos ; árbol alto, corpulento y muy coposo, de cuya corteza del tronco sale una resina blanca muy aromática, con hojas imparipinadas, largas de 6 á $8^{\prime \prime}$, cuyo raquis lo es de $4^{\prime \prime}$ con la mitad inferior sin hojuelas, y formadas de 9-3 0 de 13-1 hojuelas opuestas y pecioladas, aovado-oblongas, ordinariamente con una punta, de cara superior lampiña y lustrosa, mientras la inferior es peluda ó alampiñada; largas de $3^{\prime \prime \prime}-21_{[} 2^{\prime \prime \prime}$ con un pe"ciolo largo de 8 á 10" ; flores fasciculadas y dispuestas en racimos axilares ó terminales, cuyo raquis es lampiño ó velludo-pubescente; de cáliz 3,5-partido; corola con 3,5 pétalos valvares, oblongos, largos de $1^{\prime \prime \prime}$ y mucho mas que el cáliz; estambres $6-10$ períjinos con anteras oblongas; ovario 3-locular, con un estilo 3-lobulado por el ápice. Drupita con 3, 2 valvas, conteniendo una sola semilla por causa de aborto; embrion con los cotiledones arrugados; putamen ó huesecito largo de $3^{\prime \prime \prime}$, con una area proeminente, aovada y larga de $112^{2 \prime \prime}$, situada por el lado interno: bursera, F. 125, G. II.

275. Drupa de tamaño regular ovoídea ú obovoídea amarilla ó moradusca, larga de $1^{\prime \prime}-2^{\prime \prime}$; estambres 10-8 insertos por debajo de un disco hipójino; cáliz 5, 4-fido ; corola con 5, 4 pétalos, 276. Drupa siempre pequeñita, de color purpúreo oscuro ó roja; estambres 3,4 , insertos en un disco períino ; cáliz 3, 4-partido y colorido; corola con 3, 4 pétalos : arbustos ordinariamente de $4^{\prime} 1$ [ 2 á 3 , de alto, pero á veces se elevan á 10', 15' y hasta $30^{\prime}$, muy ramosos, y al cortar los ramos dejan salir una leche amarilla; hojas alternas, imparipinarlas, aproximadas hácia el vértice de las ramas ó tallos, formadas de $8,10,5$, o 9,10 pares de hojuelas sesiles ó pecioladas, de cara superior lampiña ó alampiñada, mientras la inferior es alampiñada ó peluda color de orin ó por fin lampiña, bien enteras, ó con 3 ó 5 espinas saliendo de la costilla y de las principales nervaduras, oblongas obtusas ó con una punta, sub-truncadas por la base, ó aovado-deltoídeas y sub-acorazonadas, largas de $1^{\prime \prime}, 2^{\prime \prime} 6$ ". Flores purpúreo-oscuras, pequeñas, fasciculadas ó agrupadas á lo largo de brazos distantes y racemiformes formando una panoja floja, pubescente ó alampiñada $y$ peluda color de orin, tan larga ó mas corta que las hojas; ovario unilocular con un óvulo pendiente de un funículo central y ascendente; del ápice salen 3 estigmas sentados: comocladia, F. 128, G. II. 
276. Arboles bastante grandes ó bajitos muy ramosos y á veces bastante corpulentos, con hojas decíduas imparipinadas, lampiñas y formadas de 3-8 ú 8-10 pares de hojuelas mas ó menos pecioladas, aovado-lanceoladas ó lanceoladas, elíptico-oblongas aguzadas ú obtusitas, sub-enteras á aserradas; flores amarillentas ó purpúreas, dispuestas en racimos ó en panojas terminales o laterales y saliendo antes que las hojas, largas de $6^{\prime \prime}$ a $12^{\prime \prime}$ o solamente de $3^{\prime \prime}-4^{\prime \prime}$, entónces mas ó menos que las hojas. Ovario con $5-3$ celdas todas fértiles, de cuyo ápice salen 5-3 estilos cortos. En el ápice de la drupa se ven los rudimentos de los estilos; hueso lobulado: spondias, F. 126, G. I.

277. Fruto capsular ó leguminoso, 278. - Fruto consistiendo en una especie de nuez de concha coriácea lisa, seca, arriñonada y situada en el vértice del pedúnculo carnudo, piriforme simulando una fruta, largo de $3^{\prime \prime}-5^{\prime \prime}$, con $2-3^{\prime \prime}$ de diámetro, amarillo ó colorado y lustroso. Arboles de $15^{\prime}$ á $30^{\prime}$ de altura, muy ramosos, de hojas simples, alternas, bien enteras, coriáceas, lampiñas, obaovadas ú ovales, redondeadas ó escotadas por el ápice, cortamente pecioladas, largas de 5-4" $1_{[} 2-61_{[} 2^{\prime \prime}$, con el peciolo de $8^{\prime \prime \prime}$ y anchas de $31_{[} 2-$ $31_{[} 4-2^{\prime \prime}$; flores acompañadas de una bracteita aovada y aguzada, en panojas terminales cuyos brazos distantes son corimbíferos, siempre una flor es mas larga ó escede á las demas ; de cáliz J̌-partido decíduo y pequeño; corola con 5 pétalos, mucho mas largos que el cáliz, lineares, aguzados, recorvados y arrollados hácia fuera; estambres 10, 9-períjinos, de los cuales 1-4 solamente se hallan en las flores fértiles; ovario unilocular, cuyo óvulo es ascendente; estilo simple y corvo. Nuez comprimida, algo arriñonada, larga de como l" y color aplomado mas ó menos oscuro; cuya concha bastante esyesa, coriácea por afuera, tiene el mesocarpio celuloso y con un aceite cáustico ; semilla cilíndrico-arriñonada, con la raicilla superior y ascendente: anacardium, F. 129.

278. Una legumbre con ó sin tripa ó pulpa, 279. - Una cápsula septícida, 3 o 4, 6-locular, ordinariamente samaroídea, cuya ala dorsal suele ceñir la celda, con semillas crustáceas y sin arilo; arbustos ramosos, altos de $6^{\prime}$ a $10^{\prime}$ de ordinario viscosos, con hojas las mas veces formadas de una hojuela única, obovada-lanceolada ú ob-lanceolada, espatulado-lanceolada, oblongo-lanceolada, ó en fin linear-lanceolada, entera y algo coriácea f flores pequeñas en racimos ó corimbos terminales flojos, de periantio único con 4 ó 5-3 sépalos; estambres 8, 6, 10 insertos en un disco hipojínico; ovario con dos óvulos en cada celda, cuyo superior es erguido, mientras el inferior es pendiente, del ápice sale un estilo central 3-tetrágono, de ápice 3, 4-fido, cuyos lóbulos llevan el estigma por la parte interna : dodoncea, F. 121, T. III.

279. Estambres cuyas anteras llevan una glándula por el ápice, 280. - Estambres de anteras sin glándula alguna en el ápice, 286.

280. Glándula de la antera constante, 281. - Glándula faltando alguna vez que otra: árboles bastante grandes, corpulentos y coposos que se elevan á $30^{\prime}-45^{\prime}$ de altura, y son armados con espinas axilares, lampiñas; hojas bipinadas, con 1,2 pares de pínulas formadas 
de 20,15 pares de hojuelas, linear-oblongas, obtusas, lampiñas, largas de $4^{\prime \prime \prime}-6^{\prime \prime \prime}$ y anchas de $1^{\prime \prime \prime}-2^{\prime \prime \prime}$; una glándula orbicular algo deprimida y aentada está entre la insercion de los raquises de las pínulas. Flores en espigas amentiformes largas de como $2^{\prime \prime}$ y blancas, de cáliz con 5 dientes; corola con 5 pétalos velludos por la cara interna; legumbre falciforme, entera, comprimida y por fin espesita, indehiscente, cuyo endocarpío se parte en una série de artejos, larga de $6{ }^{\prime \prime}-8^{\prime \prime}$, ancha de $6 " \prime$ y por fin espesa de $3^{\prime \prime \prime}-4^{\prime \prime \prime}$ : prosopis, F. 130, S.-F. 3, T. II, G. IX.

281. Glándula terminal, 284. - Glándula no terminal, anteras ovoídeo-oblongas, 282.

282. Legumbres muy largas de $2^{\prime}-8^{\prime}$ y anchas de $3^{\prime \prime}-4^{\prime \prime}$, comprimidas y llanas y formadas de artejos que se desprenden los unos də los otros y del borde continuo que se queda entero y persistente, 283. - Legumbre anchamente linear, llano-comprimida, larga de $6^{\prime \prime}-3$ ", bivalve y con semillas comprimidas: árbol alto inerme, de hojas bipinadas, cuyo raquis lleva glándulas, con 15 á 20 pares de pínulas de 30-80 pares de hojuelas cada una, diminutas, lineares, largas de 1"'-2"' alampiñadas; flores blancas sesiles dispuestas en cabezas ó espigas axilares, mas cortas que los pedúnculos pubescentitos, de cáliz 5-dentado conteniendo 10 estambres; legumbre monoliforme, sinuosa, estipitada, cuyas valvas son coriáceas y ásperas: piptadenia, F. 130, S.-F. 3, T. II, G. VII.

283. Arbustos sarmentosos cuyos numerosos ramos abejucados alcanzan hasta la cumbre de los árboles mas altos, inermes y cirríferos, de hojas bipinadas con frecuencia cirríferas ó provistas de un zarcillo, formadas de 1-2 ó de 4-6-2 pares de pínulas con 2-5 á 6-8 pares de hojuelas oblongas ó elíptico-oblongas, mas ó menos inequilaterales, redondeadas por el ápice, lampiñas ó alampiñadas inferiormente; flores en racimos espiciformes axilares solitarios ó mellizos, ó terminales y apanojados y formadas de un cáliz 5-dentado con 10 estambres: entada, F. 130, S.-F. 3, T. II, G. I.

284. Estambres monadelfos por la base, de los cuales 5 solamente son fértiles y $\check{5}-15$ estériles; anteras oblongas con la glándula sentada, 285. - Estambres no monadelfos 10-8 todos fértiles, anteras ovoídeo-oblongas con la glándula estipitada: árbol de hojas bipinadas con 2-5 pares de pínulas distantes, y formadas de $6-10$ pares de hojuelas, alternas, ovales ú oval-oblongas, lampiñas y largas de $1^{\prime \prime \prime}$; flores en racimos de cáliz 5, 4-dentado, conteniendo los estambres inclusos cuya glándula sola sale por afuera; legumbre lijeramente falciforme, larga de $6^{\prime \prime}-8^{\prime \prime}$ y ancha de $6^{\prime \prime}$, linear-comprimida, un poco crecida por causa de las semillas biconvexas que contiene, y bivalve : adenanthera, F. 130, S.-F. 3, T. II, G. VIII.

285. Arbol alto, corpulento y coposo, de hojas bipinadas con 20 , 10 pares de pínulas formadas de 50, 30 pares de hojuelas liueares, falcadas por el vértice y prolongadas por la base, lampiñas y lustrosas, largas de $3^{\prime \prime \prime}$ á $4^{\prime \prime \prime}$ y anchas de $1\left[2^{\prime \prime \prime}\right.$ : flores blancas, en espigas largas de $6 "-8^{\prime \prime}$, frecuentemente agrupadas ó apanojadas en el vértice de las ramitas, con el eje tomentoso color de orin, de cáliz 5dentado, cuyos dientes anchos son lijeramente imbricados; corola 
profundamente 5-fida, larga de $2^{\prime \prime \prime}$; filamentos estériles, 8 . Legumbre comprimida larga de 10 á $15^{\prime \prime}$ y ancha de 2 á $3:$ pentaclethru, F. 130, S.-F. 3, T. I.

286. En número definido é indefinido á la par, 290. - Siempre en número definido, 287.

287. En número de $8,10,6,12$, de anteras globosas; legumbre comprimida dehiscente, cuyas valvas se separan del borde entero, articulado ó continuo; raquis sin glándula ordinariamente, hojas sensibles, 288. - Estambres 10, de anteras ovoidoblongas, legumbre anchamente linear, estipitada, llano-comprimida, cartácea y biralve; raquis glanduloso, 289 .

288. Arbustos ó matas muy ramosas, á veces plantas semi-leñosas, aguijonosos ó inermes, lampiños 6 pubescentes, de hojas ordinariamente bipinadas, sensibles, por lo comun desprovistas de glándulas peciolares, formadas de pínulas cuyo número de pares varia de $1,2,3,4$ á $5,7,8$, y 15 y con $3,4,5,6$ á 30 , 15, 20,60 pares de hojuelas mas ó menos oblongas, obovales, obaovado-oblongas, elípticas, lineares, obaovado-redonditas, con una punta ú obtusas, lampiñas ó pubescentes, etc., pequeñas siempre; flores en cabezas pedunculadas y axilares, de cáliz dentado ó abortivo; corola con 4,5 ó mas, rara vez con 3, 6 segmentos; estambres ordinariamente esertos de anteras globosas, comunmente rosadas ó blancas; legumbre comprimida, dehiscente, con las valvas articuladas ó continuas: mimosa, F. 130, S.-F. 3, T. II, G. II.

289. Arboles no muy altos, bastante ramosos y frondosos, inermes, cuyas ramitas y peciolos son pulverulento-pubescentes, con hojas bipinadas formadas de 4,8 pares de pínulas, de 10, 20 pares de hojuelas, oblongo-lineares, con una puntita, oblícuas por la base, alampiñadas y glaucas inferiormente, largas de $3^{\prime \prime \prime}-4{ }^{\prime \prime \prime}$. Flores blancas en cabezas pedunculadas ordinariamente fasciculadas en la axila de las hojas superiores, de cáliz 5-dentado; corola con 5 pétalos distintos mitad mas largos que el cáliz. Legumbre larga de $5^{\prime \prime}-$ $6 "$ y ancha de $8^{\prime \prime \prime}-10^{\prime \prime \prime}$, con las semillas comprimidas, lustrosas, color castaño y situadas transversalmente á las valvas : leuccena, $\mathrm{F}$. 130, S.-F. 3, T. II, G. II.

290. Estambres siempre muchos ó en número indefinido, 291. Estambres tan pronto muchos como algunos y en número definido. 297.

291. Legumbre torcida á manera de caracol ó espiralmente, abriéndose en dos valvas; semillas con ó sin arilo; hojas bipinadas de raquis sin glándula, 295.- Legumbre nunca jamás torcida, 292.

292. Legumbre hinchada, ó espesa y comprimida, mas ó menos pulposa, indehiscente ; estambres sub-distintos ó monadelfos; espinas axilares, 296. - Indehiscente ó reventándose irregularmente; semillas envueltas por un arillo pulposo o no, pero entónces legumbre algo pulposa; hojas pinadas ó bipinadas, de raquis glandulífero, 293.

293. Legumbre recta ó apenas arqueadita, comprimida y bastante espesa, ó sub-prismática, de márjen engrosada ó ensanchada, angulosa ó sub-cilíndrica, indehiscente o reventándose desigual é jr- 
regularmente; semillas envueltas en pulpa suave; hojas pinadas, 294. - Legumbre comprimida, bastante ancha, lustrosa y lampiña, arqueada de manera á simular como una oreja, y de tal suerte que sus dos estremos redondeados se juntan casi, y del medio de la concavidad así formada sale el pedúnculo, un poco undulosa y con crecidos correspondiendo con las semillas, separadas por tabiques falsos; árbol muy alto, muy corpulento y bien coposo, inerme; de hojas bipinadas, cuyo raquis lleva dos glándulas situadas la una entre las pínulas mas inferiores y la otra entre las mas superiores, formada de 4, 9 pares de pínulas con 20, 30 pares de hojuelas inequilaterales, oblongas, con una puntita, lampiñas y lustrosas, un poco glaucas inferiormente. Flores subsesiles, verduscas en cabezas pedunculadas y de cáliz 5-dentado, pubescentito, mitad mas corto que la corola de 5 pétalos; estambres reunidos por la base, blancos y largamente esertos. Legumbre ancha de $11_{1} 2^{\prime \prime}-2^{\prime \prime}$ y cuyo diámetro, siendo cerrado el seno de la base, es de $3^{\prime \prime}-4^{\prime \prime}$; coriácea y enteramente dehiscente, lustrosa y como undulosa: enterolobium, $\mathrm{F}$. 130, S.-F. 3, T. II. G. VI bis.

294. Arboles mas ó menos altos y corpulentos, mas ó menos frondosos, con las ramitas lampiñas, pubescentes ó bozosas, ásperoalampiñadas ó pubescentitas, con hojas pinadas, cuyo raquis alado 6 no es siempre glanduloso, con $1,2,3,4,5$ pares de hojuelas bastante grandes, elípticas, aovado-lanceoladas, mas ó menos aguzadas ú obtusitas, lampiñas y lustrosas superiormente, alampiñadas, pubescentes ó bozosas inferiormente. Flores en cabezas, umbelas y espigas ó racimos axilares, de cáliz diminuto; corola tubular con 4 , 5 y á veces solo 2 dientes; estambres monadelfos y largamente esertos. Legumbre comprimida y bastante espesa, algo erecida en los lugares correspondiendo con las semillas, ó con 4 costillas ó ángulos 2 por cada sutura y como cuadrangular ó sub-cilíndrica, ordinariamente pubescente ó bozosa y color de orin ó aleonado : inga, F. 130, S.-F. 3, T. II, G. VI.

295. Arboles grandes, corpulentos y coposos ó arbustos aguijonosos ó inermes, pubescentes o lampiños; hojas bipinadas cuyo raquis está provisto de glándulas situadas entre las pínulas en número de $1,2,4,8,16$ pares, cargando con $1,2,3,4,12$ y hasta 20,60 pares de hojuelas generalmente bastante pequeñas y de forma muy variada, pero mas comunmente aovadas ó romboídeas, de cara superior lustrosa y lampiña, mientras la inferior es frecuentemente alampiñada; las mayores son largas de como $10^{\prime \prime \prime}$ y las menores de $1^{\prime \prime \prime}-2^{\prime \prime \prime}$. Flores sentadas o subsesiles, dispuestas en cabezas ó en espigas axilares mas ó menos pedunculadas solitares ó aracimadas, pubescentes ó lampiñas y que constan de un cáliz diminuto y de una corola 5, 6-dentada; estambres monadelfos esertos blancos ó rosados: pithecolobium, F. 130, S.-F. 3, T. II, G. V.

296. Arboles no muy altos ni muy corpulentos, pero sí muy frondosos y muy coposos, ó arbustos espinosos y cuyas ramitas pubescentes, tomentoso-pubescentes, alampiñadas ó lampiñas llevan hojas bipinadas con raquis glanduloso ó rarísima vez sin glándulas y formadas de $2,6,8,4,9,1,5,3,40$ pares de pínulas que cargan con 
$10,15,20,3,5,30,9$ pares de hojuelas de ordinario diminutas ó pequeñas, lineares, oblongo-lineares, oblongo-elípticas ú oblongas, obtusitas ú obtusas, lampiñas ó alampiñadas, de cara superior lustrosa, mientras la inferior está á veces pubescentita. Flores amarillas de ordinario en cabezas globosas, sub-fasciculadas ó solitarias, pedunculadas, pubescentitas ó alampiñadas y formadas de un cáliz diminuto 5-dentado y de una corola con 5, 4 y mas rara vez 3,6 divisiones : vachelia, F. 130, S.-F. 3, T. II, G. III.

297. Estambres muchos ó 10 de pólen compuesto, poco esertos y distintos ó sub-distintos; legumbre comprimida y raras veces subcilíndrica, de márjen no engrosada y abriéndose sin elasticidad, 298. - Estambres muchos, pero con mayor frecuencia en número determinado, 20, 25, 10, 15, 40 largamente esertos y monadelfos; legumbre de ordinario comprimida, con los bordes ó márjen muy salientes y espesos, ordinariamente acabando para abrirse con elasticidad y bivalve : arbustos inermes ó aguijonosos, ó á veces árboles de los cuales uno es muy alto, muy corpulento y muy frondoso, de ramitas y peciolos lampiños, alampiñados, pubescentes, lanudos y aterciopelado-pubescentes; hojas bipinadas, de raquis ordinariamente sin glándulas, formadas de $1,2,3,4.6,8$ pares de pínulas que cargan con $1,11_{[} 2,2.21_{\lceil} 2,3,4,10,8,7,15,20,40$ pares de hojuelas oblongo-lineares, falcado-lineares, oblongas, elípticooblongas, aovadas, etc., obtusas, obtusitas ó con una punta, lampiñas, alampiñadas, y de cara inferior alampiñada y bastantes veces pubescente, alguna vez que otra pestañosas. Flores sesiles ó pediceladas, solitarias ó fasciculadas y axilares, y de cáliz pequeño; corola 5-dentada, raras veces 5, 3-fida con estambres purpúreos ó blancos; algunas raras veces la legumbre contiene pulpa : callian$d r a$, F. 130, S.-F. 3, T. II, G. II.

298. Arboles no muy altos, pero sí muy frondosos, ó arbustos, ordinariamente inermes, pero sin embargo algunos están provistos de aguijones, de ramitas y peciolos pubescentes, pubescentitos, velludo-pubescentes, tomentoso-pubescentes, alampiñados ó lampiños, con hojas bipinadas, cuyo raquis está con ó sin glándulas, y compuestas de $4,5,6,7,8,9,10,12,16,20,30$ pares de pínulas que llevan $5,6,9,10,12,15,16,20,25,30,50,60$ pares de hojuelas lineares, oblongas, oblongo-lineares, obaovado-oblongas, obtusas, obtusitas ó con una punta, de base redondeada, inequilateral ú oblícua, lampiñas ó alampiñadas. Flores en cabezas, racimos ó grupos axilares mas ó menos pedunculados, ordinariamente amarillas, de cáliz diminuto ; corola con 5,4 y á veces 3,6 divisiones, con los estambres distintos, sub-distintos ó monadelfos : acacia, F. I30, S.F. 3, T. II, G. III.

299. Vejetales herbáceos cuyo tallo sale de un rizoma; hojas capilares y fasciculadas; florés solitarias ó mellizas, pedunculadas, de periantio coroliforme; fruto abayado, núm. 246. - Arboles ó arbustos, 300 .

300. De tronco que á primera vista parece un estipe; frutos gruesos, carnudos, uniloculares y con muchas semillas pegadas en 3 placenta verticales, envueltas en una membrana vesiculosa llena de 
líquido; vejetales lechosos, n. 203. - De tronco lejítimo; vejetales nunca lechosos, 301.

301. Flores apétalas; fruto contenido en el tubo calizinal vuelto duro ó abayado, glanduloso ó no, 302.-Vejetales cuyas flores constan de un cáliz 4, 6-lobulado ó partido, largo de $2^{\prime \prime \prime}$, de lóbulos redondeados é imbricaditos; corola campanuda ó tubular sedosa, amarillenta, cuyo tubo es largo de $4^{\prime \prime \prime}$ y los lóbulos redondeaditos de 1"'; estambres 8,10 y hasta 20 , insertos sin órden en la base de la corola, cuyos filamentos frecuentemente apareados alternan con sus lóbulos, tubo elipsoídeo-cilíndrico dos veces mas largo que el cáliz; anteras alesnadas y basifijas, mas largas que los filamentos; ovario con 4, 12 celdas conteniendo 1 óvulo cada una, y de cuyo ápice sale un estilo 4 -fido. Flores hermafroditas y masculinas ordinariamente en grupos, mientras las femeninas son solitarias, de pedúnculos tan largos como los peciolos y doblados hácia abajo; con 3 flores en las hermafroditas; baya ancha de 6 "', de testa áspera, endospermo nu ruminado; embrion cilíndrico; hojas acunado-espatuladas, simples, alternas, obtusas, lampiñas, de cara superior lustrosa, con puntos transparentes cuando tiernecitas, largas de $112^{\prime \prime} 3^{\prime \prime}$. Arbustos ó árboles bajitos de ramitas alampiñadas: diospyros, F. 82.

302. Arbustos ó árboles bajitos, inermes ó raras veces aguijonosos, con hojas opuestas, simples ó parcialmente alternas, elípticas, elíptico-oblongas, aovadas. aovado-oblongas, etc., mas ó menos pecioladas, obtusas ó con una punta, mas ó menos aguzadas por la base, lampiñas, alampiñadas ó pubescentitas. Flores agrupadas ó fasciculadas, sostenidas por 3,1 brácteas diminutas y dispuestas en cimas axilares ó terminales pedunculadas, pubescentitas ó velludopubescentes y formadas de un cáliz infundibuliforme en las masculinas, con ó sin glándulas dispuestas por séries, campanudo ó claviforme en las femeninas; de limbo 5-lobulado ó 5-dentado, con 6, 8, á veces 5,10 estambres esertos en las masculinas; estigma multífido; embrion recto: pisonia, F. 56, T. I.

\section{VEJETALES FANERÓGAMOS HERMAFRODITOS APÉTALOS.}

303. Flores casi enteramente desnudas ó cuya cubierta floral está reemplazada por escamas ó cerdas, 304. - Flores nunca jamás desnudas y siempre con una cubierta floral propia, 320 .

304. De inflorescencia en espádices con ó sin espata, 305. - De inflorescencia nunca jamás en espádices, 320 .

305. Espádices provistos de una espáta abierta mas ó menos foliforme ó cerrada y membranosa, 306. - Espádices nunca jamás provistos de espata, amentiformes y ordinariamente opuestos á las hojas, 310 .

306. Espata abierta coloreada ó foliforme, 307.-Espata cerrada, membranosa, que se revienta para que salga el espádice; plantas herbáceas acuáticas y nadantes, de tallo delgado, cilíndrico, mas ó menos largo, ramoso, con hojas cartáceas ó membranosas, alternas, oblongas ó lanceolado-oblongas, mas ó menos pecioladas, provistas de estipulas: flores constando de 4 sépalos 6 escamas conteniendo 4 
estambres insertos en su uña, y 4 ovarios uniloculares, cada uno con su estigma sentado; aquenio lijeramente suculento; embrion corvo: potamogeton, F. 29, páj. 52.

307. Espata foliácea ó acortada, 308. - Espata colorida, ni foliácea ni acortada y con figura de cartucho, persistente; espádice subsentado, cilíndrico y cubierto de flores que corstan de un periantio 5,8 -fido, conteniendo 5, 8 estambres, insertos por la base de las lacinias calizinales, esertos y de filamentos lineares y alesnados que llevan anteras biloculares de celdillas transversales; ovario trilocular, con un óvulo pendiente del ápice del eje y solitario en cada celda; del ápice sale un estilo subulado alargadito, terminado por un estigma trígono; bayas distintas mono ó trispermas, cuyas semillas son sin endospermo. Plantas herbáceas acaulas, cuyo rizoma tuberoso, placentiforme, lleva hijos; hojas radicales sub-solitarias pedáleo-descompuestas, de peciolo largo mas ó menos envainador por la base : dracontium, F. 8, T. II, S.-T. II.

308. Espata acortada, doblada hácia fuera y persistente ; estambres, 4, 309. - Espata foliácea persistente ; estambres 5, 8 opuestos á las divisiones calizinales y en número igual; ovario trilocular, con 2 óvulos mellizos en cada celda, colaterales $\mathrm{y}$ pendientes del eje; del ápice sale un estigma 3-lobulado y sentado. Espádice pedicelado, acortado y cubierto enteramente de flores. Plantas herbáceas acaulas, vivaces, de hojas radicales, bastante grandes, coriáceas, asaetadas ú oblongas, y oblongo-asaetadas, con peciolos largos de base envainadora, y geniculados por el ápice : spatiphyllum, F. 8, T. II, S.-T. II.

309. Plantas herbáceas vivaces, sub-acaulas ó algo trepadoras, de hojas dijitado-palmeadas, ó frecuentemente con los lóbulos laterales abortados, y entónces enteras, cuyo peciolo mas ó menos largo es hinchado por el ápice; vajinas estipulares alternas con los peciolos y persistentes, pero solo en los individuos floríferos; espádice subsentado, cilíndrico y enteramente cubierto de flores que constan de un periantio 3-filo, cuyas divisiones son opuestas á los estambres de filamentos lineares y achatados llevando anteras biloculares; ovario plurilocular, con 2 óvulos apareados en cada celda, colaterales, anátropos y colgantes del ápice del eje; estigma sentado y oblongo. Baya bilocular, con 2, 3 semillas, inversas, cuyo embrion está alojado en el eje del endospermo algo carnoso, ortótropo y de estremidad radicular súpera : anthurium, F. 8, T. II, S.-T. II.

310. Flores siempre perfectas y nunca diclines ó unisexuales, 311. - Flores diclines ó perfectas, amentáceas y apartadas en los amentos. Brácteas coriáceas, oblongas, lineares adheridas, aproximadas, sobrepuestas por la base y de márjen encerrada por dos colaterales, rarísima vez redondeadas y pegadas por el centro ó abroqueladas. En las flores perfectas hay 2 estambres laterales, de filamentos espesos, frecuentemente adheridos con la base del ovario, algo persistentes, con anteras acorazonado-reniformes, de celdillas distintas. Ovario sentado y aovado, con estigmas 3,4 y rara vez 5 , espesamente lanceolados ú oblongos, pubescentitos y encorvados. En las flores masculinas hay 2, 3 estambres mas delgados, y en las 
femeninas un ovario igual al de las perfectas y sin estambres rudimentarios. Bayas sentadas oblongas ó globosas, pulposas, de semillas conformes con el tegumento membranáceo o espesamente coriáceo; endospermo corneo-harináceo, radiado. Frutices trepadores y raras veces arhustos de hojas simples, alternas, enteras, pecioladas. las mas veces coriáceas, multipli ó mas rara vez dijitinervias, lampiñas ó pubescentes; estípulas peciolares adheridas y las opositifolias libres y decíduas. Amentos opositífloros, pedunculados, mas vereces colgantes, filiformes; bayas apartadas, sentadas; semillas aromático-acres y quemantes : piper, F. 37, G. I.

311. Frutices, arbustos ó arbolitos, 312.-Plantas herbáceas mas ó menos suculentas y generalmente pequeñas, cuyos tallos mas ó menos delgados son rastreros y arraigantes, largos de $6 "-12^{\prime \prime}-15^{\prime \prime}$, $\therefore$ veces ascendentes ó derechos y altos de $1^{\prime}-11^{1} 2^{\prime}$, mas ó menos ramosos, mas ó menos carnudos, lampiños ó pubescentes, con hojas simples, pecioladas, enteramente ó á veces parcialmente alternas ó toras opuestas, de forma, tamaño y consistencia muy variados; flores en espádices amentiformes delgados terminales ó axilares, solitarios ó á veces mellizos mas ó menos pedunculados, y formadas de 2 estambres acompañados de una bráctea abroquelada, y situados al lado del ovario sentado, unilocular, globoso ú ovoídeo, con un estigma apincelado ó diminuto situado por el ápice ó en la parte anterior del pico subulado que termina el ovario. Fruto abayado pequeño globoso ú ovoídeo sub-sentado, sentado, ó estipitado, con $\dot{0}$ sin apéndice ó pico por el ápice : peperomia, F. 37, G. III.

31 2. Brácteas abroqueladas acompañando á las flores, 313. Brácteas florales con figura de cartucho, 317.

313. Estambres en número constante, 314. - Estambres en número variable, 315 .

314. Siempre 2 estambres, 316. - Siempre 5 estambres, 319.

315. 4 estambres, de los cuales 2 son superiores y 2 inferiores o 2 solamente situados al lado del ovario que lleva 3, 5, 2 estigmas sesiles; anteras conniventes : arbustos ó arbolitos de tallos con nudos mas ó menos pronunciados, rectos, mas ó menos ramosos, cilíndri$\cos$, con las ramitas lampiñas, alampiñadas, pelierizaditas, peludas, lisas, ásperas ó verrugosas; hojas uninervias con venas arqueadas mas distantes del ápice de la hoja que entre sí, otras veces igualmente distantes entre sí como del ápice de la hoja, alternas, simples, mas ó menos pecioladas, opuestas á una hoja abortada que falta muchísimas veces, insertas por la base de los nudos, aovadas, aovado-ovales, elípticas, elíptico-oblongas, aovado-oblongas, oblongas, oblongo-lanceoladas y lanceolado-oblongas, aguzadas ó con una punta por el vértice mas ó menos obtuso, de base igual ó desigual, redondeada mas ó menos acorazonadita, pubescentes, lampiñas ó alampiñadas, lisas ó ásperas y verrugosas, con ó sin puntos transparentes, enteras, papiráceas ó membranosas, largas de $10^{\prime \prime}-8^{\prime \prime}-6^{\prime \prime}-4^{\prime \prime}$ y anchas de $4^{\prime \prime}-3^{\prime \prime}-2^{\prime \prime}$; de peciolo desnudo mas o menos acanalado, o alado, lampiño, alampiñado, pubescente, liso ó verrugoso y largo de $12^{\prime \prime \prime}-6$ "'t- $^{\prime \prime \prime \prime}$; amentos pedunculados, solitarios, opuestos á las hojas y saliendo de la axila de una bráctea espatiforme que constituye 
sin duda la hoja abortada, lanceolada, cóncava, puntiaguda, larga de $4^{\prime \prime \prime}-6^{\prime \prime \prime}$, aquilada y convexa esteriormente, pronto caduca, rectos ó arqueados, mas ó menos delgados, mas ó menos largos y de $1^{\prime \prime}-1$ $1_{1} 2^{\prime \prime}-2^{\prime \prime}-3^{\prime \prime}-4^{\prime \prime}-5^{\prime \prime}-6^{\prime \prime}-7^{\prime \prime}$, cuyas flores muy numerosas son de ordinario sentadas á lo largo del eje. Baya con una semilla angulosa : artanthe, F. 37, G. V.

316. Arbustos poco ramosos, altos de 4'-6', de tallo con nudos, en la base de los cuales se inserta la base envainadora del peciolo, largo de $6^{\prime \prime}-8^{\prime \prime}-10^{\prime \prime}$, lampiño ó pubescentito, estriado ó no; hojas alternas simples, grandes, acorazonadas ó abroqueladas, membranosas, acorazonado-redondeadas con puntita, con 11, 13 nervaduras, de las cuales uno ó dos pares son insertas por encima de la base de la costilla, anchas de $12^{\prime \prime}-8^{\prime \prime}-10^{\prime \prime}-6^{\prime \prime}$, con puntitos transparentes; amentos cortamente pedicelados, delgados, largos de $4^{\prime \prime}-3^{\prime \prime}-2^{\prime \prime}$ y situados en el ápice de un pedúnculo axilar bastante grueso, generalmente poco largo, $6^{\prime \prime \prime}$ á $12^{\prime \prime \prime}$, en donde forman umbela; flores sentadas cuyo ovario se termina por 3 estigmas sesiles y recorvados; fruto abayado monospermo : potomorphe, F. 37, G. II.

317. Estambres 4, 3 insertos en rededor del ovario pedicelado, con 4 estigmas sesiles; bráctea situada de ordinario por la base del pedícelo; fruto abayado, tetrígono, 318. - Estambres 5, 6, raras veces 4,7 , insertos en rededor del ovario sentado y con 3,5 estigmas sesiles; anteras confluentes por arriba ; fruto abayado ovoídeo, aovado, ovoídeo-oblongo, mas ó menos estriado ó asurcado, obtuso ó con un piquito, conteniendo una semilla asurcada. Arbustos ordinariamente y alguna vez que otra arbolitos lampiños, de tallo y ramos con nudos pronunciados; hojas simples, alternas, palmatinervias, con una hoja abortada opuesta á ellas, mas ó menos grandes, membranosas ó papiráceas, aovadas, aovado-oblongas, aovadolanceoladas, de base redondeada, oblícua ó sub-acorazonada, mientras el ápice es obtuso ó con una punta obtusita, enteras, de cara superior lampiña $y$ lustrosa, mientras la inferior es lampiña, alampiñada $y$ pubescente por las nervaduras, largas de $10^{\prime \prime}-8^{\prime \prime}-66^{\prime \prime}-$ $4^{\prime \prime}-3^{\prime \prime}$ y anchas de $\left.8^{\prime \prime}-5^{\prime \prime}-4^{\prime \prime}-31_{[} 2^{\prime \prime}-2^{\prime \prime}-2 l_{[} 2^{\prime \prime}-1\right]_{[} 2^{\prime \prime}$, ordinariamente con puntitos transparentes, con peciolo lampiño ó pubescentito, largo de $8^{\prime \prime \prime}-6^{\prime \prime \prime}-4^{\prime \prime \prime}$. Amentos solitarios opuestos á las hojas, obtusos, mas ó menos pedunculados y rectos, largos de $6^{\prime \prime \prime}-4^{\prime \prime \prime}$ ó de $3^{\prime \prime}-4^{\prime \prime}$. $112^{\prime \prime}$ : enkea, F. 3\%, G. IV.

318. Arbustos lisos y lampiños, de tallos y ramos con nudos mas ó menos pronunciados; hojas simples, alternas y opuestas á una abortada, uninervias, con las venas arqueadas, aovadas, con una punta por el ápice, mientras la base es anchamente cuneiforme, papiráceas, largas de $8^{\prime \prime}-6^{\prime \prime}, \mathrm{J}$ anchas de $31[2-3$, con 12,15 pares de venas equidistantes, de peciolo acanalado, desnudo y largo de $6^{\prime \prime \prime}-$ $4^{\prime \prime \prime}$; amentos opuestos á las hojas, solitarios, mucronados, largos de $3^{\prime \prime}-2^{\prime \prime}$ y con pedúnculo de $3^{\prime \prime \prime}$ á $4^{\prime \prime \prime}$, formados de flores pediceladas saliendo de la axila de la bráctea y con 4,3 estambres insertos en rededor del ovario, de cuyo ápice salen 4 estigmas sesiles; baya tetrágona pedicelada, un poco mas larga que el pedícelo, redondeada por la base y mucronada por una punta obtusita : ottonia, F. 37. 
319. Arbusto bastante alto, de tallo y ramos nudosos ó crecidos bien pronunciados y hojas abortadas, hojas alternas, simples, largamente pecioladas, acorazonadas, palmatinervias, redondeaditas, de ordinario con una punta, membranosas, con 9,11 nervaduras, de seno basilar ordinariamente abierto, con puntitos transparentes, alampinadas y raras veces pubescentitas, anchas de $6^{\prime \prime}-4$ ", cuyo peciolo es alado inferiormente y largo, de amentos solitarios cortamente pedunculados, arqueados, mucronados y casi tan largos como las hojas : estambres insertos en rededor del ovario, con 3,5 estigmas sentados; anteras cuyas celdas son distintas. Fruto abayado conteniendo una semilla angulosa : schilleria, F. 37, G. V bis.

320. Flores siempre glumáceas, 321. - Flores nunca glumáceas, pero con un periantio lejítimo, 344 .

321. Flores siempre glumáceas lejítimas, 322. - Flores glumáceas no lejítimas porque la gluma está reemplazada por algunas cerdas o escamitas, 328.

322. Con 3 estambres, 325. - Con 6 estambres, 323.

323. Plantas de caña leñosa, bastante gruesa y muy altas, cuyas flores en panojas axilares tienen un estilo único, 324. - Plantas herbáceas anuales, cuyas flores en panojas terminales tienen 2 estilos : altas de $2 l_{[} 2^{\prime}-3^{\prime}$, con la caña derecha, de hojas simples, alternas, sentadas, envainadoras y con la vaina abierta, cuya lígula membranosa, bastante desarrollada, es puntiaguda, lanceolado-linear y largo el limbo de 6 á 10" sobre 1 á 12 de ancho, con la costilla muy pronunciada inferiormente; las panojas son formadas de espiguitas unifloras, con la gluma de dos valvas, pequeñas y lineares, la glumela tambien de dos valvas comprimidas y estriadas, cuya inferior, aquilada y algo mayor que la otra, lleva una cerda ó arista sedosa que suele faltar algunas veces, cariopside comprimida y ovoídea á la par : oriza, F. 10, T. I.

324. En ese género se halla el gigante de las gramíneas, ya que sus gruesas cañas se elevan hasta $40^{\prime}-50^{\prime}$ de altura, huecas y echando ramitas de sus nudos y de la axila de sus grandes hojas, alternas. simples, basinervias y lanceoladas. Las panojas son formadas de espiguitas agrupadas 3 por 3 y conteniendo cada una tres flores, cuya base está envelta en una escama á manera de invólucro que constituve la gluma; glumela de 2 valvas conteniendo un ovario ovoídeo: bambusa, F. 10, T. XII.

325. Ovario con 2 estilos ó 2 estigmas, de ordinario saliendo por fuera de la gluma, 326. - Ovario con un estilo único: yerba de como $6 "$, perenne, de rizoma ramoso, nudoso, sólido y rastrero, con muchas escamitas situadas entre los nudos, de donde salen las raices; hojas oblongas, estrechas, tiesas, estriadas y ásperas por la márjen, envainadoras, de vaina cerrada; panojas subsesiles, terminales, cortas y densas á la vez; gluma bivalve, glumela bivalve tambien y menor; paịitas acompañando á la semilla: remirea, $\mathrm{F}$. $11, \mathrm{~T} . \mathrm{V}$.

326. Gluma siempre sin pelo, 327. - Gluma con pelo por su cara esterior: plantas herbáceas ó de caña leñosa, bastante gruesa, larga de algunas varas, llena, derecha ó de base estendida 
por el suelo y de vértice ascendente, con hojas simples, alternas, envainadoras, ásperas, pelitiesas, enteras, lanceoladas, derechas y largas de $2^{\prime}$ á $3^{\prime}$ y anchas de $2^{\prime \prime}$ á $3^{\prime \prime}$, basinervias; flores en panojas terminales, moradusco-pálidas, piramidales, de brazos estendidos y horizontales, descompuestos y surdescompuestos, alternos, sobre el eje estriado, largas de $11\left\lceil 2^{\prime}\right.$ á $3^{\prime}$, con el pedúnculo; las muchísimas flores que las forman son espiguitas paucífloras $y^{*}$ mellizas; una de las dos flores es sentada y la otra pedicelada, pero ambas son hermafroditas y articuladas por la base; gluma bivalve con pelo sedoso larguísimo, persistente y moradito; glumela univalve y membranosa; pajitas subuladas, pequeñas é iguales; ovario liso, de cuyo ápice salen 2 estilos largos, terminados por un estigma franjeado, con pelo sencillo y dentadito: saccharum, F. 10, T. V.

327. Flores en espigas lejítimas y rarísimas veces apanojaditas, pero sí sencillas ó compuestas, 329.-Flores en panojas lejítimas, 328.

328. Plantas herbáceas anuales ó vivaces, de caña derecha o estendida por el suelo, y hasta rastrera algunas veces, con hojas simples, alternas, envainadoras, con la vaina abierta, triquetras y algo cortantes, punzantes ó llanas y blandas, con la lígula peluda ó desnuda; panojas flojas ó densas, de gluma uníflora formada de 2 valvas, cuya esterior se termina por una arista, lampiña; estigmas lonjitudinalmente pelierizados ó plumosos : agrostis, F. 10, T. VIII.

329. Gluma cuya valva inferior lleva una arista muy poco pronunciada, 330. - Pajita esterior provista de una arista bastante larga y torcida; yerbas anuales, de hojas alternas, envainadoras, lanceoladas, bastante largas; flores en panojas ó en espigas formadas de una gluma con 2 valvas, multíflora, glumela, bivalva, sin arista, pajita estericr con una arista torcida situada por su dorso: avena, F. 10, T. IV.

330. Espigas sencillas ó algo compuestas; vaina abierta, 331.Espigas compuestas ó sencillas; vaina cerrada, 338 .

331. Eje de las espiguitas con pelo, 332. - Eje de las espiguitas sin pelo, 333 .

332. Yerbas anuales ó vivaces, á veces muy altas y con caña leñosa, pero ordinariamente de tamaño regular ó pequeñas, con hojas alternas, simples, envainadoras, de vaina abierta, lanceoladas y mas ó menos grandes y largas. Gluma con 2 valvas conteniendo algunas flores; eje de las espiguitas con algunos pelos que envuelven la glumela, provista de algunos pelos interiormente : arundo, F. 10, T. IX.

333. Gluma con 2 valvas; flores unilaterales, 334. - Gluma con 3 valvas, cuya tercera está por la parte esterior de las flores y parece así como sobreañadida, 337.

334. Espiguitas largas y delgadas saliendo por debajo de una bráctea y formando por su reunion una especie de escoba, 335. Espiguitas bastante largas, delgadas tambien, pero no tanto, sin bráctea, mas ó menos estendidas y dispuestas á manera de los dedos de la mano, 336.

335. Yerbecita á veces rastrera, cuva gluma contiene algunas 
flores; glumela de 2 valvas lanceolado-lineares y muticas : cynosurus, F. 10, T. XII.

336. Yerbas pequeñas como de $6^{\prime \prime}$ á $12^{\prime \prime}$ de alto, con hojas alternas, envainadoras, lanceolado-lineares; gluma comprimida, con 2 valvas desiguales, puntiagudas y aquiladas, cuya mayor contiene 3 flores; glumela con 2 valvas agudas y tambien aquiladas : dactylis, F. 10, T. XII.

337. Yerbas anuales de tamaño variado, cuya caña llena se eleva á veces á $3^{\prime}$ ó $4^{\prime}$ de altura, terminadá por una espiga apanojada, tan pronto densa como floja, cuyas flores están frecuentemente provistas por la base de una especie de invólucro con aristas ó barbas bastante largas; valvas de la gluma tambien á veces aristadas; glumela de 2 valvas persistentes envolviendo la semilla y haciéndola como una capa crustácea : panicum, F. 10, T. III.

338. Glumas 4 , dísticamente imbricadas; flores diandras, 339. Nunca 4 glumas ni flores diandras tampoco, 340 .

339. Yerba vivaz cuya caña, delgada y alta de como 6 á $8^{\prime \prime}$, sale de un rizoma delgado, bastante largo y escamoso; hojas bastante tiesas, lanceolado-lineares, envainadoras, radicales o alternas, mas cortas que la cañita; flores en espigas redondeaditas ú oblongas y sentadas, á veces con una especie de invólucro trífilo y mas largo que la cabezuela, ó en especie de umbela formada de espiguitas apretadas é imbricadas; espiguitas unífloras; gluma con dos valvas desiguales estriadas y pestañosas; glumela tambien bivalva y mayor; estilo bífido, aquenio lenticular: kyllingia, F. 11, T. III.

340. Espigas comprimidas mas ó menos largas y dispuestas á manera de umbela en el ápice de una caña triangular mas ó menos larga, acompañadas de un invólucro situado en su ápice, cuyas hojas, ordinariamente en número de 3 , son mas ó menos largas, 341 . Espigas cortas mas ó menos redondeadas y como en cabezuela, 342 .

341. Yerbas mas ó menos grandes, vivaces y cuyo tallo triangular mas ó menos largo sale de ordinario de un rizoma mas ó menos desarrollado yá veces con tubérculos; hojas radicales ó alternas, lanceoladas, mas ó menos largas y ásperas, de vajina siempre cerrada, cuyos bordes aserraditos son muy cortantes algunas veces. Invólucro formado de una ó de algunas hojas florales; espigas amarillentas, delgadas, mas ó menos largas, mas ó menos pedunculadas, mas ó menos estendidas, mas ó menos numerosas, con escamas dísticas é imbricadas á la vez, en cuya axila está la flor que consta de 3 estambres y de un ovario unilocular, monospermo, de cuyo ápice sale un estilo con 3 estigmas; aquenio desnudo: ciperus, F. 11, T. IX.

342. Semillas enteramente desinudas ó á veces acompañadas de cerdas; escamas fasciculadas cuyas esteriores blanquecinas son estériles, 343. - Semillas desnudas, envueltas en pelos ó en cerdas; escamas imbricadas por todos lados y todas fértiles; yerbas siempre de los lugares inundados ó pantanosos, de caña cilíndrica, desnuda, larga de $11{ }^{2} 2^{\prime}$ á $2^{\prime}$, torulosa, tabicada interiormente y hueca por consiguiente; hojas todas radicales, cilíndricas, cónicas, lustrosas y lampiñas, diferenciándose de la caña solo por no terminarse por una 
cabezuela ovoídea; especie de espiga densa mas ó menos pardusca, formada de espiguitas un poco desarrolladas y agudas, cuyas flores constan de 3 estambres saliendo de la axila de una escama y de un ovario casi esférico, unilocular, monospermo $\mathrm{v}$ de cuyo ápice sale un estilo terminado por 3 estigmas; aquenio: scirpus, F. 11, T. VIII.

343. Yerbas tambien de los lugares húmedos, de caña sin ó con hojas simples, linear-lanceolodas, alternas, las mas veces radicales todas, envainadoras, con la vaina cerrada. Flores en espiguitas reunidas en cabezuela ó fasciculadas, formando espigas ó panojas, uni ó paucífioras, con paleas ó pajitas dísticas, de varios modos imbricadas ; estambres 3 ; ovario con estilo 3 -fido, simple por la base, piramidal ó bulbosa, engrosada y decídua; cariópside trígona, mutica ó mucronadita : schœenus, F. 11, T. VIII.

344. De ovario libre ó súpero, 345. - De ovario infero ó adherente, 419 .

345. Siempre único ó solitario, 346. - Nunca jamás único, pero en número variable, 417.

346. Estambres en número constante y determinado ó variable, 347. - Estambres indeterminados ó mas numerosos por consiguiente, 415 .

347. En número siempre constante y determinado, 388. - En número variable, sea por causa de aborto ú otra, 348 .

348. Fruto drupáceo ó abayado, 349. - Fruto nunca drupáceo, 363.

349. Fruto drupáceo, 350. - Fruto abayado ó baya, 361.

350. Flores polígamas, díclines ó unisexuales, 351. - Flores siempre hermafroditas, 353.

351. Hermafroditas ó polígamas, 352. - Hermafroditas ordinariamente, pero algunas raras veces dioicas ó unisexuales, $35 \%$.

352. Arboles grandes y ramosos, de hojas alternas, simples, pecioladas, con 3 nervaduras pronunciadas por la cara inferior, lustrosas, lampiñas, coriáceas, aromáticas y enteras. Flores amanojadoapanojadas y terminales, constando de un periantio 6-partido, de limbo decíduo y con la base persistente ; estambres fértiles 9 , cuyas anteras son 4-loculares. Drupa sostenida por una cúpula endure-cida, 6-fida ó sub-truncada: cinnamomum, F. 46, T. III.

353. Anteras con 2 ó con 4 celdillas, 354. - Anteras siempre 4loculares, 359 .

354. Anteras con 2 ó 4 celdillas, 355. - Anteras biloculares solamente, 357 .

355. Limbo calizinal siempre persistente; hay glándulas estaminiformes, 356. - Limbo calizinal persistente ó caduco y articulado; flores con ó sin glándulas estaminiformes; anteras de los estambres interiores estrorsas; fruto seco ó carnudo y encerrado en el tubo calizinal vuelto carnoso ó endurecido: árboles con hojas simples, alternas, pecioladas, peninervias, coriáceas; yemas con escamas foliáceas aquiladas; inflorescencia apanojada, axilar ó sub-terminal, flojita y algunas veces flexuosa: criptocarya, F. 46, T. IV.

356. Arbol grande, corpulento, alto y coposo, cuyas ramitas y panojas son pubescentes; hojas alternas, simples, pecioladas, aova- 
das ó aovado-lonceoladas, de cara superior lustrosa, mientras la inferior es pubescentita ó alampiñada, largas de $3^{\prime \prime} \mathrm{y}$ anchas de $21 \mathrm{l}$, coriáceas, con las nervaduras bastante proeminentes inferiormente y cuya parte mas inferior es opuesta y distante de $2^{\prime \prime}-33^{\prime \prime \prime}$ de la base; flores fasciculadas, apanojadas, con pedículos tan largos como ellas, de periantio 6 -partido y enteramente persistente, largo de $1^{\prime \prime \prime}$; estambres fértiles 9 , de anteras oblongas y tan largas como los filamentos, cuyos 3 de la série interna son biglandulosos por la base y tan largos como los estambres estériles, pubescentitos y oblongos; drupa elipsoídeo-oblonga, obtusa, larga de $6^{\prime \prime \prime}$ y ancha de $3^{\prime \prime \prime}$, y mucho mas larga que la cápsula abierta que la sostiene y que proviene del cáliz endurecido, alta de $1^{\prime \prime}$ y escondiendo el pedícelo turbinado : phobe, F. 46, T. III.

357. Tres estambres fértiles contiguos, cuyas anteras subsesiles se abren por 2 ventallas terminales; drupa sostenida por una cúpula truncada, 358. - 9 estambres fértiles, periantio de limbo 6-partido y tardiamente decíduo y desprendiéndose del tubo persistente : árboles altos ó medianos, mas ó menos corpulentos y coposos, cuyas ramitas son alampiñadas, tomentosas ó pulverulento-sedosas, así como las panojas; hojaş simples, alternas, pecioladas, cartáceas ó coriáceas, enteras, lanceolado-oblongas, oblongas ó elípticas, elíptico-oblongas, obtusitas ó con una punta, enteramente lampiñas, ó de cara inferior plateado-sub-sedosa, con las nervaduras mas ó menos proeminentes, mientras la superior es lustrosa y mas ó menos lisa; flores en haces apanojados; drupa sostenida por una cúpula troncada: aydendron, F. $46, \mathrm{~T} . \mathrm{V}$.

358. Arboles mas ó menos grandes, altos ó medianos, lampiños ó pubescentes, con hojas alternas, simples, pecioladas, enteras, coriáceas, con las nervaduras arqueadas, lanceoladas, oblongas, elípticas, lanceolado-oblongas ó elíptico-oblongas, aguzadas, con una punta mas ó menos obtusa, de cara superior lustrosa y lampiña, mientras la inferịor, lampiña, alampiñada ó sedosa, tiene las nervaduras bastante pronunciadas y las venas con frecuencia dispuestas en redecilla; flores fasciculadas y dispuestas en panoja, constando de un periantio 6-fido ó 6-dentado, de limbo decíduo: acroclidium, $\mathrm{F}$. 46, T. V.

359. Yemas de las ramitas incompletas, 360. - Yemas de las ramitas completas: árboles grandes y altos, ó medianos, mas ó menos corpulentos y coposos, de ramitas purpúreas, parduscas ó verdes, lampiñas ó pubescentes, con hojas cartáceas ó coriáceas, simples, alternas, pecioladas, lanceoladas, lanceolado-oblongas, lampiñas ó alampiñadas, de cara superior lustrosa, mientras la inferior, lam. piña ó alampiñada, tiene barba en la axila de las nervaduras, dispuestas en redecilla; flores amanojado-apanojadas, de periantie 6-partido y enrodado; 9 estambres fértiles, á veces 3 tienen 2 glándulas por la base del filamento; anteras anchas subsesiles; drupa sostenida por una cúpula troncada: nectandra, F. 46, T. I.

360. Arboles con hojas simples, alternas, triplinervias; flores en panojas pequeñas sub-tricótomas y sin invólucro, formadas de un periantio cartáceo 6-fido, cuyo limbo es deciduo; estambres dispues- 
tos en 4 séries, de los cuales 9 esternos son fértiles, mientras los 6 mas internos son estériles; los 3 mas interiores fértiles tienen la base estipitada por estaminodes apareados y estipitados; los de la la y $2^{a}$ série tienen las anteras introrsas, mientras las de la $3^{3}$ son estrorsas, $\mathrm{y}$ todas aovadas, cuadriloculares y dehiscentes por tantas valvas ascendentes; ovario unilocular, uniovulado, con un estigma discoídeo; drupa sentada en la base obcónica y entera del periantio: camphora, F. 46, T. II.

361. Arbustillos cuyo ovario es formado de un solo carpillo unilocular, 362. - Matas herbáceas ó fruticosas, cuyo ovario es formado de algunos 20, 10 carpillos formando una baya única; estambres $8,10,12,20$ casi períjinos; tallo herbáceo ó fruticoso salienclo de una raiz carnuda bastante gruesa, ramoso superiormente y alto de $4^{\prime}$ á 6', asurcado ó estriado, lampiño; hojas alternas, simples, grandes, elípticas ó elíptico-lanceoladas, aovadas ó aovado-lanceoladas, con una punta ó cortamente aguzadas, pecioladas y sin estípulas, lampinas y lustrosas; flores pequeñas amarillento-blanquecinas ó rojizo-blancuzcas, pediceladas, dispuestas en espigas mas ó menos racimosas, pedunculadas, deliradas yo largas de $3^{\prime \prime}$ á $4^{\prime \prime} \mathrm{y}$ de periantio 5-partido coroliforme. Baya asurcada, redondo-achatada, plurilocular, de color purpúreo casi prieto, carpelos uniloculares, cuya semilla contiene un embrion anular ciñendo el endospermo: phytolacea, F. 54, S.-O. III, T. II.

362. Arbustillos de tallo delgado, ramoso, altos de $6^{\prime}-10^{\prime}-15^{\prime}$, con las ramitas herbáceas, lampiñas ó pubescentes, de hojas aovadas, elípticas ó elíptico-lanceoladas, con una punta, lampiñas ó á veces pubescentes, pecioladas, con estípulas. Flores pediceladas, pequeñas, rojizo-blancuzcas ó blanquecinas solamente, en racimos terminales ó laterales pedunculados, con los pedícelos acompañados de una bráctea mas ó menos decídua situada por la base ó por encima de ella; de periantio petaloídeo 4-partilo; 4, 8, 12 estambres casi hipójinos, alternos con los segmentos calizinales, curas anteras son aovadas é introrsas ó aflechadas y estrorsas; pistilo formado de un ovario casi esférico, unilocular, cuyo óvulo único es basilar, de \&u ápice sale un estilo oblícuo $\mathrm{y}$ corto que suele faltar, terminado por un estigma cabezudo á veces sentado. Baya pequeña largamente pedicelada, globosa, roja ó purpúreo-negrusca y lustrosa; semilla con el embrion anular ciñendo el endospermo : rivina, F. 54, S.-0. I, T. II.

363. Fruto capsular ó no capsular, pero nunca una legumbre, 383. - Siempre una legumbre lejítima, 364.

364. Estambres muchos ó en número definido á la rez, 367. Estambres siempre en número definido, pero mas ó menos variables, 365 .

365. Cuyas anteras estản provistas de una glándula, 366. - De anteras siempre sin glándula. (Véase núm. 230.)

366. Estambres 5, 15, de los cuales algunos abortan siempre, quedándose los filamentos estériles, monadelfos y esertos, n. 277. - Estambres 10, 8 libres no esertos, todos férti'es; glándula de la antera terminal y estipitada, n. 276. 
367. En número indefinido y definido á la vez, 368. - Siempre muchos é indefinidos por consiguiente, 370 .

368. Libres, muchos ó 10 , de anteras globosas, cuyo pólen es compuesto, n. 200. - Monadelfos, 369.

369. Muchos $8,10,15,20,40$, legumbre bivalve $\mathrm{y}$ abriéndose con elasticidad, siempre recta, n. 290. - Muchos ó i0, legumbre indehiscente, con pulpa, comprimida, ancha y doblada en areo casi completo, segun sus bordes, n. 285.

370. Siempre monadelfos, 371. - Sub-distintos; legumbre hinchada, sub-cilíndrica ó espesito-comprimida, con alguna pulpa interiormente, n. 288.

371. Legumbre dehiscente torcida ó dispuesta á manera de caracol, n.287. - Legumbre indehiscente reventándose desigualmente, mas ó menos recta, con semillas siempre envueltas en un arilo pulposo, n. $286^{\circ}$.

372. Fruto capsular, 373. - Fruto no capsular, pero un aquenio á veces envuelto en el cáliz vueltu ó no carnudo, 383.

373. Arboles ó arbustos, 374. - Vejetales subfruticosos y frutices ó plantas herbáceas, 375 .

374. Con hojas simples, alternas, lampiñas ó alampiñadas, elípticas, aovadas, lanceoladas, elíptico-lanceoladas, oblongo-lanceoladas, enteras ó mas veces aserradas, y provistas de líneas y de puntos transparentes, persistentes y siempre verdes ó decíduas, pecioladas y con estípulas. Flores pequeñas en hacecillos axilares ó en corimbos y de periantio 5, 4 -partido y raras veces 5 -fido, coroliforme y marcescente, con los segmentos imbricados; estambres distintos 8, 10,15 , insertos sobre un disco perijínico alternando con escamas velludas; anteras redondeaditas; ovario unilocular con 3 ó 4 placentas, de cuyo ápice sale un estilo simple terminado por un estigma cabezudo, o trífido con igual estigma en cada brazo. Scmillas provistas de un arilo : casearia, F. 87, T. III.

375. Plantas herbáceas, 376.-Arbustitos ó vejetales sub-fruticosos, altos de $4^{\prime}$ á $9^{\prime}$, no muy ramosos, lechosos: en efecto, por las heridas dejan salir una leche amarilla; de hojas grandes, alternas, simples, pecioladas, largas de $6^{\prime \prime}-18^{\prime \prime}$ y anchas de $41\left[2-5^{\prime \prime}\right.$, ovaloblongas, sinuoso-pinatífidas, cuyas superiores son á veces casi enteras, de cara inferior algo glauca; flores en panojas terminales largas de como $1^{\prime}-112^{\prime}$, flojas y de cáliz con 2 sépalos coriáceos, cóncavos y caducos; 8,24 estambres hipójinos; ovario formado de 2 carpelos, con 2 estigmas opuestos á las placentas. Cápsula unilocular. bivalve por la base, con las placentas situadas entre las valvas, filiformes y reunidas por el ápice; semilla solitaria erguida: bocconia, F. 90 .

276. Pericarpio utricular, 377. - Fruta capsular lejítima, 379.

377. Estambres 5, 4, reunidos por la base, de anteras biloculares, y alternos con los apéndices de la cúpula, 378. - Estambres 3, 5, monadelfos, de anteras uniloculares y ovales, alternos con los dientes de la cúpula que á veces es entera; yerbas ordinariamente vivaces y á veces anuales, lampiñas, alampiñadas ó pubescentes, de tallos rastreros ó arraigantes, muy ramosos y de vértice mas ó menos 
ascendente; hojas opuestas, simples, bien enteras, aguzadas por la base, ob-aovado-lanceoladas ó lanceoladas, elíptico-lanceoladas. ob-lanceoladas, ovales ú ob-aovadas, cortamente pecioladas. Flores en cabezas sub-globosas, comunmente sesiles, axilares ó terminales, de periantio con 5 sépalos; 3,5 estambres; ovario unilocular, cuyo estigma es sub-sentado y cabezudo ó sub-escotado, retrículo-obacorazonado, marjinado por la parte superior y escediendo la semilla: alternanther'a, F. 55, T. I.

378. Planta mas ó menos fruticulosa, peluda ó alampiñada, cuyos ramos mas ó menos tetrágonos llevan hojas simples, opuestas, pecioladas, aovadas ó redondeadas, aguzadas ú ob-aovado-sulb-redondas, mucronaditas. Flores rerduscas, subsesiles, ordinariamente dispuestas en espigas simples y alargadas y por fin reflexas, cartilajinosas, largas de $13^{\prime \prime \prime}-12^{\prime \prime \prime}$, cuyas brácteas son comunmente membranosas por la márjen y provistas de una costilla espinosa y de un periantio can 5,4 sépalos y tantos estambres; ovario unilocular con un óvulo único y de cuyo ápice sale un estilo simple terminado por un estigma cabezudo, achyranthes, F. 55, T. I.

379. Un pixidio ; estambres períjinos, 380.-Una cápsula, estambres hipójinos, 382 .

380. Flores solitarias semi-engastadas en la axila envainadora de las hojas y cuyo periantio 5-partido y colorado interiormente tiene sus divisiones mucronadas por debajo del ápice, 381. - Flores tambien solitarias y axilares, pero pedunculadas, de periantio 5-partido, campaniforme, petaloídeo, persistente, colorado ordinariamente y á veces blanco interiormente; yerbecita vivaz muy bonita y que se cria en los sanitrales $y$ en las orillas del mar, de tallito algo carnudo, cilíndrico, lampiño, delgado, largo de $6^{\prime \prime}$ á $8^{\prime \prime}$, estendido en el suelo y como rastrero, mas ó menos ramoso; hojas opuestas, simples, entejérrimas, algo carnosas, casi sentadas, aguzadas por la base algo envainadora, lanceoladas ó lanceolado-oblongas, de un color verde teñido de morado; fiores con 5, 15, 30 estambres insertos en el tubo calizinal muy corto; ovario sentado con 3 , 5 celdillas conteniendo algunos óvulos, cuyo ápice lleva $3,5,6$ estilos; pixidio 3,5 -locular polispermo, con el eje placentario persistente : sesuvium, F. 148, T. IV.

381. Yerba vivaz, lampiña, cuyo tallo suculento, rastrèro ó estendido por el suelo y largo de $1^{\prime}-2^{\prime}-3$ ', es muy ramoso; hojas simples, opuestas, bastante espesas y suculentas, cuya base del peciolo corto se dilata en vajina, ordinariamente una es menor en las pares, redondeadito-ob-aovadas, largas de 1 1 2 á $2^{\prime \prime}$ sobre 12 á $15^{\prime \prime \prime}$ de ancho; flores pecueñas axilares y agrupadas ó sub-solitarias, con $10,5,20$ estambres, cuyos esteriores alternan con los segmentos calizinales; ovario con dos celdillas 3,4 -ovuladas, de cuyo ápice salen 2,1 estilos con estigma cabezudo. Cápsula ó pixidio con 6,8 semillas cubiertas por líneas lameliformes, de opérculo cóncavo por el ápice y con dientes obtusitos por la márjen, endurecido é incompletamente cerrado por la base del pixidio; es persistente y membranoso: trianthema, F. 148, T. IV.

382. Cápsula trilocular, loculícida, trivalve y con algunas semi- 
llas lisas 3,5-costilladas ó granujientas. Yerbas anuales, altas de $6^{\prime \prime}$ á 10", de tallo ramosísimo derecho y nudoso, lampiñas, con hojas espatuladas ú ob-lanceoladas, ó espatulado-oblongas, simples y como verticiladas en cada nudo ó solamente en el mas inferior; flores pequeñas, con pedícelos filiformes unífloros, dispuestos á manera de umbela ó en panojas corimbiformes, y de periantio 5-partido, coloreado interiormente con 2, 3, 5 estambres; ovario 3-locular, con algunos óvulos y de cuyo ápice salen 3 estilos con su correspondiente estigma cada uno:pharnaceum, Sw.; mollugo, L., F. 148, T. III.

383. Flores nunca agrupadas, como en cabezuela; aquenios nunca marjinados ni escamiformes tampoco; plantas siempre herbáceas, 383 bis. - Flores pequeñas herrumbrosas agrupadas como en cabezuelas pedunculadas; aquenios marjinados escamiformes á la par. Arboles bajitos ó arbustos de la costa y muy ramosos; hojas alternas, simples, pecioladas, lanceoladas ó elípticas, de ordinario con 2 glándulas por la márjen y hácia la base, lampiñas ó sedosas. Flores pequeñas cuyas cabezuelas están en racimos ó panojas, de cáliz con el limbo 5-fido y decíduo, cuyo tubo no se estiende sobre el ovario unilocular, cuyos óvulos mellizos y colgantes de la celda son anátropos, de estilo filiforme con estigma agudo; estambres perijínicos 5,10 , biseriados, insertos en el limbo calizinal, esertos, con las anteras biloculares y lonjitudinalmente dehiscentes. Aquenios imbricados, cimbiformes, redondeaditos, cóncavos y aquillados por arriba, convexos inferiormente y agudos por la márjen : conocarpus, F. 139, T. II, G. IV.

383 bis. Aquenio mas ó menos libre del cáliz, 384. - Aquenio contenido en el cáliz acrescente, vuelto ó no carnudo, que le hace parecer una cápsula ó una drupa, 386.

384. Aquenio casi enteramente desnudo y fuera del perigonio, con 2 ó 4 ganchitos terminales, uno en cada ángulo y doblados hácia abajo, 385. - Aquenio triangular ó biconvexo mas ó menos escondido por el cáliz marcescente; plantas herbáceas anuales ó bisanuales y hasta vivaces, de tallo cilíndrico, á veces estriado, mas ó menos ramoso, alto de $1^{\prime}$ á $2^{\prime}$, algunas veces mas largo, lampiño ó pubescente, derecho ó divaricado; hojas simples, alternas, lanceoladas, oblongo-lanceoladas, aguzadas por la base, cuyo peciolo mas ó menos corto está acompañado por la base de una estípula membranosa envainadora llamada ocrea, mas ó menos tubulosa, pestañosa, cerdosa ó desnuda y entera; flores pequeñas blancas ó rosaditas, en racimos espiciformes terminales o axilares, solitarios o mellizos, de pedícelo articulado y de periantio petaloídeo, 5, 3-partido y marcescente; estambres $8,7,4$, de filamentos cortos y subulados; ovario redondeado ó triangular, unilocular y uniovulado, de cuyo ápice salen 3,2 estilos muy cortos y filiformes terminados por un estigma sencillo. Aquenio mas ó menos lustroso, prieto, conteniendo un embrion arqueado en rededor de un lado del endospermo : polygonum, F. 50, S.-O. IV, T. II, S.-T. III, G. I.

385. Mata sub-fruticosa de tallo derecho, poco ramoso, alto de $2^{\prime}-3^{\prime}-4^{\prime}$, pubescente, con hojas simples, alternas, cortamente pecio- 
ladas, elípticas, oblongas ú oblongo-lanceoladas, ásperas por los bordes, puntiagudas y enteras, glandulosas hácia el peciolo tambien glanduloso y pubescentes, lampiñas, acompañadas por dos estípulas pequeñas, cilíndrico-subuladas, carnositas y pronto caducas. Flores pequeñas blancas, á veces algo teñidas de color de rosa, unilaterales y en espigas largas y delgadas, axilares y de ordinarin terminales, algunas veces formando una especie de panoja, porque el eje principal es la prolongacion del tallo ó del ramo, de manera que se ramifica, de vértice arqueado hácia el suelo, con muchas flores esparcidas y mas ó menos distantes las unas de las otras, sentadas y acompaúadas de 3 brácteas; de periantio 4-partido, coroliforme, blanquecino, largo de $2^{\prime \prime \prime}$ y cuyas divisiones son lineares y obtusas; estambres $4,6,8$, casi períjinos y de anteras asaetadas; ovario pequeño unilocular con un solo óvulo basilar, algo cuadrangular, de cuyo ápice mas ancho que la base sale un estigma sentado, lateral y apincelado. Aquenio cuadrangular cuya base está acompañada por el cáliz, mientras el vértice, mucho mas grueso, lleva un ganchito por cada ángulo; toda la planta exlıala olor de ajo: petiveria, F. 54, S.-O. I, T. I.

386. Aquenio contenido en el cáliz vuelto carnudo, de manera que la fruta parece carnuda, pero visible por el ápice abierto: árboles ó arbustos, 387. - Aquenio contenido en el tubo calizinal endurecido, cuyo ápice se cierra por fin, y así simula una especie de cápsula; plantas herbáceas anuales ó vivaces y sub-fruticosas, algo trepadoras, de tallos muy ramosos, derechos ó estendidos por el suelo y desparramados, de vértice mas ó menos ascendente, lampiños ó pubescentes, con nudos mas ó menos pronunciados, de los cuales salen las hojas ordinariamente opuestas, simples, aovadas, aovado-lanceoladas, acorazonado-redondeadas, mas ó menos puntiagudas ú obtusas, concólores ó de cara inferior blanquecina, mas ó menos pecioladas; flores pequeñas blancas ó rojizas, fasciculadas, pediceladas y acompanadas de brácteas diminutas y dispuestas en umbelas ó panojas flojas bastante grandes, axilares ó terminales, y de periantio estrechado por arriba del tubo persistente, por fin claviforme, anguloso, troncado y obtusamente mucronado por el ápice, otras veces redondeado, con 5 estrias ó costillas mas ó menos pronunciadas y mas ó menos glandulosas, ó sin ellas, pero en ese caso el ápice es glanduloso, de limbo cortamente 5-lobulado; estambres. 1, 3, 4; semilla de embrion conduplicado: boerhaavia, F. 56, T. I.

387. Arboles bastante grandes ó bajitos y arbustos mas ó menos ramosos, de hojas alternas mas ó menos grandes, coriáceas ó papiráceas algunas veces, lampiñas y á veces alampiñadas, mas ó menos. cortamente pecioladas, con una ocrea, acorazonado-orbiculares, redondeaditas, aovado-oblongas, anchamente elípticas, oblongo-lanceoladas, elípticas ó elíptico-oblongas, mas ó menos obtusas, aguzadas ó puntiagudas, de base mas ó menos aguzada, acorazonada.o redondeadita, de cara superior lustrosa, lisa o áspera, mientras la inferior tiene las nervaduras ordinariamente bien pronunciadas y las venas mas o menos en redecilla. Flores pequeñas blanquecinas $\sigma$ verdoso-amarillentas, de pedícelo articulado sea por la base, sea 
por el ápice, sea con el raquis y saliendo de la axila de una bráctea mas o menos diminuta o á reces sentadas, dispuestas en racimos o en espigas mas o menos largos, axilares ó terminales, y de periantio 5 -fido o 5-partido, que se vuelve por fin espeso y carnudo creciendo bastante para envolver el aquenio, sea enteramente, sea por partes solamente; estambres ordinariamente 8 y á veces 12 ; ovario unilocular, mas ó menos redondo y de cuyo ápice salen 3 estilos; embrion axil, recto y alojado en un endospermo, ruminado: coccoloba, F. 50, S.-O. V, T. II, S.-T. V, G. II.

388. Fruto mas ó menos carnudo, 388 bis.-Fruto siempre seco, 390 bis.

388 bis. Fruto abayado; 5 estambres hipójinos; plantas herbáceas, 389 bis. - Fruto drupáceo; estambres \&, 10 hipojínicos ó perijínicos; árboles mas ó menos altos, 389.

389. Estambres 8 hipojínicos; liber que se puede desenvolver en capas delgaditas que parecen encaje, 390. - Estambres perijínicos 10, desiguales y cuýos 5 mas largos se insertan mas arriba; árboles de $30^{\prime}$ a $60^{\prime}$ y mas de altura, muy ramosos y bastante corpulentos, cuyo liber es compacto, de hojas.simples, alternas, pecioladas, aproximadas hácia el vértice de las ramitas, ob-aovadas ó espatuladolanceoladas, de cara superior lampiña, mientras la inferior es sedosa ó alampiñada, espatuladas ú ob-aovado-oblongas, lampiñas superiormente $\mathrm{y}$ alampiñadas inferiormente, con vello herrumbroso persistente $\mathrm{y}$ situado por la costilla y márjen, enteras y obtusas. Flores pequeñas verdosas en espigas axilares mas ó menos pedunculadas, cilíndricas ú aovadas, de cáliz con el limbo acubileteado, diminutamente 5-dentado, persistente ó tardiamente decíduo; algunas raras veces las flores se trasforman en un cuerpo largo, cilíndrico y arqueado; estambres mas o menos esertos, biseriados insertos en el fondo del cáliz, de anteras sub-globoso-dídimas, lonjitudinalmente dehiscentes. Ovario unilocular, con 3 óvulos colgantes del ápice de la celdilla y anátropos, de estilo alesnado, agudo y terminado por un estigma simple. Drupa casi seca, pequeña, aovadoconica ú ovoídea, coronada por el limbo persistente del cáliz ó desprovista de él. Semilla de embrion sin endospermo y con cotiledones foliáceos y convólutos : bucida, F. 139, T. II, G. II.

389 bis. Flores solitarias, pediceladas, de periantio coroliforme y con 6 estambres; hojas capilares, fasciculadas y esparcidas; un rizoma de donde salen turiones que se vuelven un tallo derecho; baya pisiforme roja, 246.-Flores nunca solitarias, pero en espigas sentadas en un eje grueso, carnudo y cilíndrico y saliendo de la axila de una bráctea espesa y suculenta bastante grande. Plantas herbáceas, de tallo muy largo ordinariamente, muy ramoso, enredadero y trepador, mas o menos delgado, con hojas alternas, simples, pecioladas, enteras, mas ó menos grandes, oval-redondeadas ó lanceoladas, mas ó menos puntiagudas, lampiñas, verdes ó rojas, bastante espesas y suculeutas; flores blancas, rosaditas ó teñidas de rosado; de periantio suculento 7-partido, cuyas divisiones cóncavas mas o menos puntiagudas son bastante carnosas; estambres 5 ; ovario casi esférico, unilocular, de cuyo ápice sale un estilo muy corto 
tripartido o con 3 estigmas largos y lineares. Baya globoso-achatada, estriada, lustrosa, negra y pegada en el eje de la espiga; :emilla única: basella, F. 53, S.-O. I.

390. Arbol de 25 á $30^{\prime}$ de altura, muy ramoso y poco corpulento, cuyo liber está formado de fibras entremezcladas y separables, lampiño; hojas alternas, simples, pecioladas, anchamente aovadas, $\in n-$ teras, con una punta, cortamente pecioladas, siempre rerdes y largas de $3-5^{\prime \prime}$. Flores pequeñas blanquecinas, en espigas flojas y sin brácteas, de cáliz campanudo, espeso y 4-dentado. Ovario pelierizado, prolongándose en un estilo ter minal, corto, que lleva un estigma troncado. Drupa envuelta en el periantio ahayado y velludo, con 1, 3 hue:os crustáceos y frájiles, cuyas semillas en número de 1,3 son inversas; embrion ortótropo sin endospermo, con los cotiledones plano-convexos y la radícula corta y súpera : lagetla, F. 49, G. 1 .

390 bis. Una legumbre mas ó menos lejítima, 391. - Fruto capsular ó utricular, 397.

391. Legumbre no muy lejítima; 10 estambrcs distintos, 392. Legumbre lejítima, 394.

392. Periantio colorido y 5-partido, ceñida la base por un inrólucro diminuto lijeramente bilobulado, 393. - Cáliz colorido 4 partido y sin invólucro alguno: árbol resinoso muy alto, ramoso y corpulento, de hojas paripinadas, con 5,1 pares de hojuelas coriáceas, inequilaterales, oblícuamente aovadas, con una punta obtusita, lampiñas, con puntitos transparentes, de ordinario alternas y largas de $3^{\prime \prime}-1 "$ : una de las mas superiores aborta frecuentemente. Flores blancuzcas con racimos compuestos y espiciformes, terminales; periantio campanudo de divisiones imbricadas, algo desiguales, abiertas y diverjentes; estambres inclinados distintos; ovario redondeado y comprimido á la vez, con 2 óvulos, de cuyo ápice sale un estilo terminado por un estigma entero. Legumbre estipitada, oblícuamente ovoídea, coriácea, bivalve y monosperma, inequilateral, con una punta obtusita, lampiña y provista de puntos transparentes, con una semilla única provista de un arilo lateral carpóforo muy corto: copaifera, F. 130, S.-T. II, T. VII.

393. Arbol muy grande, alto, corpulento, coposo y de ramos estendidos, lampiño; hojas siempre verdes y coriáceas, pinadas y formadas de 4,2 pares de hojuelas oblícuamente elípticas ó elipticaloblongas, pecioladas, obtusitas, de cara inferior con las venitas en redecilla, lampiñas y con puntos transparentes, largas de $6^{\prime \prime}-4^{\prime \prime}, y$ anchas de $4^{\prime \prime}-2 "$. Flores en panojas terminales, ordinariamente largas de $\mathrm{l}^{\prime}$, interrumpidas y formadas de espigas subsesiles, alternas, distantes de como $4^{\prime \prime \prime}-6^{\prime \prime \prime}$ las unas de las otras y largas de $4^{\prime \prime}-2^{\prime \prime}$; tales flores agrupadas y solitarias salen de la axila de una bráctca diminuta y redondita y constan de un invólucro mas largo que la bráctea, de $1_{1} 3^{\prime \prime \prime}$, con lo lóbulos redondeados ó sub-troncados; tubo calizinal tuı binado mas largo que el invólucro, segmentos calizinales ovales, pestañosos, iguales, imbricados, largos de $1^{\prime \prime \prime}$ y mitad menos que los filamentos peludos é iguales, cuyas anteras incumbentes, oval-oblongas y de celdillas distintas son arqueadas; ovario 
peludo sentado en la parte superior del tubo calizinal, lleno por el disco, perijínico, oblícuamente oval, $1_{[} 3$ tan largo como el estilo filiforme y terminado por un estioma diminuto, unilocular y con un solo óvulo homótropo y colgando de la parte superior de la sutura: prioria, F. 130, S.-F. 2, T. VII.

394. Estambres cuyas anteras están provistas de una glándula, 395. - Estambres de anteras sin glándula, n. 281.

395. Glándula constante, 396. - Glándula no constante, pero las mas veces. (Véase n. 280.)

396. Legumbre comprimida, muy larga y bastante ancha, sepárándose por artejos articulados por la márjen, quedándose entera y persistente, n. 275 bis.-Legumbre anchamente línear, plana y comprimida, bivalve, no separándose nunca por artejos, n. 2?5.

397. Fruto utricular ó capsular, 401. - Fruto ni utricular ni capsular tampoco, 398.

398. Aquenio libre en el fondo del cáliz que lo tiene encerrado y no simula nunca una cápsula, 400. - Aquenio contenido en el tubo calizinal persistente, endurecido y simulando así una cápsula, 399.

399. Primorosas plantas herbáceas cuyos tallos muy ramosos, nudosos y lampiños salen de una raiz napiforme, carnosa, mas ó menos desarrollada; ramos dicótomos y como articulados; hojas simples, de ordinario opuestas, enteras, pecioladas, aovadas ó sub-acorazonadas, ovalo-lanceoladas, puntiagurlas, largas de $3^{\prime \prime}$ a $31{ }^{2} 2^{\prime \prime}$ sobre 11 l 2 á 2 " de ancho; flores fasciculado-terminales moradas, amarillas, blancas y disciplinadas, bastante. grandes y formadas de un periantio coroliforme ó tubuloso, de limbo con 5 pliegues y tantos ángulos correspondientes, de base y tubo persistente, envuelto en un invólucro unífloro y 5-lobulado mucho mas corto que el tubo; estambres 5 salientes y cuyos filamentos largos pegados á lo largo de la parte interna del tubo se insertan con el cáliz á un disco. Ovario sentado sobre el disco, unilocular y con un solo óvulo basilar, de cuyo ápice sale un estilo capilar cilíndrico mas largo que los estambres y que se termina por un estigma simple y capitado. Aquenio de tamaño regular ovoídeo, truncado por el ápice, asurcado ó áspero, negro, cuya semilla tiene un endospermo grueso, feculento y central, con el embrion corvo y escentrico: mirabilis, F. 56, T. II.

400. Periantio de 6 segmentos membranosos, desiguales, mas ó menos conniventes; estambres 6 ; estigmas 3 . Plantas herbiceas cuya base del peciolo está acompañada de una ocrea; flores en panojas terminales; embrion no anular, n. 247. - Periantio 5, 3-partido, cuyos segmentos son membranosos por la márjen y con frecuencia aquilados, no conniventes é iguales; estambres 5 , de filamentos alesnados, opuestos á las divisiones perigoniales y casi tan largos como ellas é insertos por debajo del ovario globoso, algo deprimido y de cuyo ápice sale un estilo muy corto terminado por 2 estigmas lineares y obtusos mas ó menos largos. Aquenio lenticular con endospermo hariiloso; embrion completa ó incompletamente anular. Plantas herbáceas anuales o vivaces, á veces fruticulosas ó leñositas, con tallos ramosos derechos ó desparramados, mas ó me- 
nos tendidos, lampiñas, verdosas ó pubescentes, altas de 6-12-18" ó algo mas, hojas simples, alternas, lancenlado-oblongas o espatuladas, eliptical-oblongas, deltoídeo-aovadas, sinuoso-dentadas ó solamente sinuosas, otras veces desigualmente dentadas sin estar sinuosas, á veces enteras, glandulosas ó no y mas ó menos pecioladas. Flores pequeñas verdes ó verdoso-amarillentas, en grupos dispuestos en espigas terminales ó axilares, ́́ veces arracimadas ó apanojadas: chenopodium, F. 5l, S.-O. I, T. IV, S.-T. V.

401. Fruto utricular, 402.-Fruto capsular, 406.

402. Estambres 5 monardelfos, 403.-Estambres 5 ó 6 libres, 405.

403. Estambres enteramente reunidos, cuyas anteras oblongas alternan con los dientes bipartidos que terminan el tubo calizinal alargadito, 404. - Estambres de anteras oblongas ; cúpula basilar corta y sin dientes. Planta herbácea vivaz, de tallos largos, cilíndricos, acostados sobre el suelo y desparramados, muy ramosos y bastante largos, lampiños, moraduscos, con riuditos arraigantes; ramitas floríferas ascendentes y derechas, largas de como 6". Hojas simples, opuestas, enteras, lineares, suculento-carnositas, lampiñas, de cara inferior convexa, mientras la superior es llana y lustrosa, de base aguzada, mientras el ápice obtuso es un poco espatulado; flores pequeñas, blancas, escariozas, en espiguitas agrupadas y dispuestas en cabezuelas sub-globosas, ó globosas y por fin aovadas ú oblongas, terminales y cuya base está acompanada de hojas ; brácteas escariosas, aquiladas, conduplicadas, cuyas inferiores están á veces estériles; periantio con 5 sejpalos, cuyos dos interiores son mas estrechos, pero tan largos como los demas, trinervios por debajo de su parte media, casi iguales con la bráctea lateral, los esteriores lampiños; las nervaduras laterales se juntan con la costillita hácia su medio; estambres 5; estilo bipartido: philoxerus, F. 55, T. I.

404. Planta herbácea anual pubescente, de tallo derecho como de $11_{1} 2^{\prime}$ á $2^{\prime}$ de alto, como articulado, de ramos cortos, opuestos y axilares; hojas simples, opuestas, óvalo-lanceoladas ó lanceoladooblongas, enteras, pubescentes y verdes; flores capitadas, formando ordinariamente cabezas globosas, por fin envueltas en pelo, terminales y con dos hojas florales situadas por su base, de ordinario solitarias; tales flores numerosas rojas ó rosadas secas y escariosas se componen de un periantio petaloídeo persistente formado de 5 divisiones profundas y uninervias, rodeado por 3 brácteas carenadas y con una ala aserrada y mas largas que el pelo lanudo; estambres 5 monadelfos; estigmas dos lineares terminando un estilo saliendo del ápice del ovario ovoídeo y unilocular: gomphrena, F. 55, T. II.

405. Eje de la espiga delgada y no carnosa; flores pediceladas; periantio casi caroliforme y 6-partido; estilo 5-fido: planta lierbácea de tallos larguísimos, ramosísimos, lampiños, verdes ó moraduscos, enredaderos y saliendo de una raiz perpendicular carnosa y del tamaño del dedo pulgar ó mas, y vivaz por supuesto ; hojas bastante grandes, pecioladas, algo suculentas, óvalo-lanceoladas, undulosas por los bordes enteros, de base decurrente en el vértice del peciolo, bastante largo y de cara superior moradusca y lampiño, 
lustroso, así como las hojas. Flores pequeñas verdoso-amarillentas, en espigas simples ó ramosas, delgadas, largas de $3^{\prime \prime}-2$ ", pedunculadas, axilares, á reces como apanojadas y terminales, cuyos pedúnculos, mas ó menos morados y lampiños, salen de la axila de una hojita floral; pedícelos cortos, filiformes, rosados, unífloros y saliendo de la axila de una bracteita caduca; un periantio 6-partido, un poco campanudo, cuyos segmentos orales y algo puntiagudos son imbricados en la estivacion, dispuestos al abrirse como en dos séries y de los cuales uno está algo mas esterior que los demas, casi iguales, marcescentes; estambres 5 derechos, de filamentos subulados $\mathrm{y}$ un poco dilatados y comprimidos por la base; anteras dorsifijas, oscilantes y transversales, biloculares. Ovario globoso, de cuyo vértice sale un estilo 5 -fido, con estigmas glandulosos. Fruto utricular coriáceo y comprimido; semilla basilar, con la testa membranosa; embrion anular: anredera, Juss.; devenischia, Nobis, F. 53, S.-Or. II.

406. Una cápsula lejítima, 409. - Pixidio, $40 \%$.

40\%. Estambres 4 ; Jerbas siempre sin tallo lejítimo, 408. - Estambres 5 , con una cúpula basilar corta y sin dientes, plantas herbáceas ó leñositas siempre provistas de un tallo propiamente dicho, alto de $1^{\prime}-2^{\prime}-3^{\prime}$; hojas simples, alternas, lanceoladas, aoradas, aguzadas ó no por la base, lampiñas, mas ó menos pecioladas; flores en espicas, con brácteas peristentes coloridas; periantio con 5 sépalos mucho mas largos que las brácteas; ovario ovoídeo unilocular y con algunos óvulos, de cuyo vértice sale un estilo corto, terminado por 2 ó 3 estigmas pequeños y recorvados. Semillas verticales lenticulares y arriñonadas, de testa crustácea, cuyo endospermo es central y farináceo, y el embrion anular periférico, con la radícula aproximada al hilo : celosia, F. 55, T. II.

408. Plantas herbáceas anuales o bisanuales sin tallo lejítimo, reemplazado ordinariamente por un bojordo; hojas radicales simples, enteras, basinervias, enteras, mas ó menoz óvalo-lanceoladas, largamente pecioladas, aguzadas por la base y algo puntiagudas por el ápice. Flores en espiga larga terminando un pedúnculo largo y axilar, formada de muchas flores pequeñas esparcidas sin órden por la superficie del eje, casi sentadas y saliendo de la axila de una escama membranosa; de periantio doble, cuyo esterior ó invólucro es 4 -partido y cortito, mientras el interior es tubuloso, escamoso y de 4 divisiones dobladas por afuera; 4 estambres, esertos, cuyos filamentos muy largos y capilares llevan anteras biloculares; ovario ovoídeo, unilocular, con 2 óvulos, de cuyo ápice sale un estilo corto terminada por un estigma subulado: plantago, F. 77.

409. Siempre 6 estambres; periantio mas ó menos petaloídeo, con segmentos soldados ó libres, 411. - Solamente 3 estambres fértiles. 410.

410. Plantas herbáceas vivaces ó anuales, cuyos tallos simples ó ramosos, cilíndricos, suculentos, nudosos, son rastreros, tendidos por el suelo, desparramados ó rectos; hojas simples, alternas, hasinervias, mas ó menos suculentas, lampiñas, sentadás, envainadoras por la base, de cara superior ordinariamente cóncava y á manera 
de gotera; flores azules, blancas ó á veces amarillas, en grupos axilares ó terminales, envueltas en una especie de espata foliácea, formada de dos hojas redondeadas y trabadas; de periantio con 6 divisiones profundas de las cuales 3 son petaloídeas simulando así una corola; tres nectarios cruciformes situados entre los filamentos de los tres estambres estériles; ovario globoso 3-locular y poliovulado, de cuyo vértice sale un estilo simple terminado por un estigma sencillo : cápsula casi globosa, trilocular, trivalve y con muchas semillas : commelina, F. 12.

411. Periantio enteramente petaloídeo, cuyas 6 divisiones mas ó menos profundas son reunidas entre sí por la base ó á veces libres y simulando petalos, 412. - Periantio cuyas 3 divisiones esteriores menores son verdes y foliáceas, mientras las 3 interiores son petaloídeas; flores en gruros axilares muy fornidos y encapotadas por una especie de espata foliácea. Plantas herbáceas vivaces, de tallo mas ó menos suculento, con hojas simples, alternas y frecuentemente dísticas, sentadas y de base algo envainadora, lanceoladas, mas ó menos largas y puntiagudas, de cara superior de ordinario cóncava y á manera de gotera, lampiñas, mas ó menos lustrosas, ordinariamente concolores, ó á veces de dos colores distintos, la cara superior estando verde y la inferior morada. Flores pediceladas en grupos axilares ó terminales, envueltas cada una en una espata particular membranosa y pedicelada, con 6 estambres cuyos filamentos son cubiertos de pelo articulado; ovario globoso trilocular y de cuyo ápice sale un estilo simple alesnado, terminándose en un estigma algo cabezudo y glanduloso; cápsula 3-locular, trivalve, globosa y polisperma : tradescantia, F. 12.

412. Raiz bulbosa ó que consiste en una cebolla mas ó menos gruesa, 413 lis. - Raiz nunca bulbosa, pero sí fibrosa siempre, 412 bis.

412 bis. Plantas terrestres y de los lugares muy secos y arenosos, con las hojas carnosas y arrosetadas, 413. - Plantas herbáceas siempre acuáticas, cuyo tallo recto ó nadante lleva hojas alternas, simples, ovales ó acorazonadas, cuyo peciolo largo es envainador por la base, entejérrimas y con nervaduras paralelas. Flores azules ó azulado-rosaditas primosas, en espigas ó racimos, á veces subumbelarlas, saliendo del peciolo hendido ó solitarias, cada una espatáceo-bracteada; periantio coroliforme persistente, infundibuliforme, de tubo anguloso, mas veces encorvado, con el limbo 6 -fido, sub-igual ó sub-bilabiado. Estambres desiguales insertos 3 por el ápice y 3 por la base del tubo, ó todos en el vértice pegados. Ovario sub-trígono, 3-locular, de celdillas todas fértiles, multiovuladas, cuycs ovulos pendientes son anátropos, de estilo.terminal y subulado, que se termina por un estigma engrosado y apenas trílobo. Cápsula vest da con la base del periantio ó á veces con la misma acresciente, trilocular, loculícido-3-valve y polisperma, otras veces unilocular monosperma é indehiscente; semillas aovadas, inversas, de testa papirácea, costillado-estriada. Embrion ortótropo, axil en un endospermo farináceo, cuya radícula engrosada mira al vértice del fruto: pontederia, F. pontederiáceas. 
413. Plantas vivaces herbáceas ó cuyo tallo cortito es sub-leñoso, con hojas grandes radicales ó caulinares, alternas, arrosetadas, á veces dísticas, muy espesas, lanceoladas, lampiñas, á veces aguijonosas por los bordes, mas ó menos largas y puntiagudas, glaucas ó no, de cara superior llana, mientras la inferior ó esterna es convexa. Flores en espigas largas terminando un bojordo mas ó menos largo, saliendo del centro de las hojas ordinariamente sencillo, amarillo-anaranjados, derechos antes de abrirse, horizontales durante la florescencia y pendientes ó cabizbajos despues de la fecundacion, cuyo pedícelo corto sale de la axila de una b̧ráctea escamosa; de periantio cilíndrico, tubuloso, como campanudo, nectarífero por la base, petaloídeo y cuyas 6 divisiones son conniventes por el vértice de manera que está casi cerrado, imbricadas y de ápice un poco encorvado por afuera; 6 estambres hipójinos desiguales, un poco esertos y pegados en la base del periantio con que se insertan, de anteras biloculares. Ovario ovoídeo, trilocular, poliovulado, cuyo ápice lleva un estilo corto terminado por un estigma trilobulado. Cápsula membranoso-escariosa, de 3 celdillas, cuya dehiscencia loculícida se efectua por 3 valvas, conteniendo cada una bastantes semillas redondeadas ó angulosas y dispuestas en dos séries: aloes, F. 16; T. IV.

413 bis. Muchas flores reunidas en el ápice de un bojordo mas ó menos largo y hueco en cabezuelas ó cimas, envueltas antes de la floracion por una espata comun membranosa que se revienta pảa que floreen, 414. - Muchas flores dispuestas en espiga floja y terminal que ocupa la mitad superior de un bojordo nunca hueco, mas ó menos carnoso, á veces escamoso y por lo regular de 6 " á 12 ", nunca envueltas en una espata comun. Plantas herbáceas ó vivaces, de bulbos ó cebollas simples, tunicados, mas ó menos desarrollados, con hijos ; hojas radicales, sentadas, largas, estrechas, mas ó menos derechas, alternas, envainadoras por la base, ó arrosetadas $y$ mas ó menos estendidas por el suelo, de cuyo centro sale un bojordo con flores azules ó de otro color, segun las especies, pediceladas y acompañadas por la base del pedícelo de una bráctea como articulada y vuelta hácia fuera; de periantio suculento, con 6 divisiones profundas abiertas $\mathrm{y}$ dobladas hácia fuera; estambres 6 , de filamentos lisos, enteros, subulados y mas ó menos comprimidos por la base, siempre mas cortos que el periantio con que están soldados; o vario trilocular poliovulado algo trígono y ovoídeo á la vez, de cuyo ápice sale un estilo corto terminado por un estigma pequeño algo trilobulado y glanduloso; en el vértice del ovario se reparan unas glándulas nectaríferas. Cápsula redondeada y algo trígona á la par, trilocular, polisperma y abriéndose por 3 valvas, de semiilas redondeatas y algo aplanatas, dispuestas en 2 séries y con epispermo membranoso : scilla, F. 16, T. II.

414. Plantas herbíceas vivaces ó bisanuales con bulbos ó cebollas simples, ó compuestos y truncados, sin tallo; hojas radicales, sencillas, mas ó menos largas y estrechas, ordinariamente derechas, sentadas y envainadoras, alternas, cilindricas y huecas, triquetras ó lanceolado-lineares. Flores en cabeza ó cima en el vértice de un 
bojordo mas ó menos largo saliendo del centro de las hojas, algunas veces entremezcladas con bulbillos; de periantio campanudo ordinariamente blanco, verdoso ó rosadito y raras veces amarillo, con 6 sépalos distintos marcescentes, otras veces iguales; está 6 -partido; de los filamentos de los 6 estambres 3 son simples y 3 terminados por 3 puntitas cuya mediana sola es anterífera, y todos insertos en la base calizinal é hipójinos; ovario globoso, trilocular, pauciovulado y algo trígono á la vez, de cuyo ápice sale un estilo subulado terminado por un estigma simple cabezudito. Cápsula algo trígona ó trilobulada, un poco deprimida, con 3 celdas de dehiscencia septífragaque se efectua por 3 valvas, con 1 o 2 semillas negras, angulosas y redondeadas á la vez en cada una : allium, F. 16, T. II.

415. Plantas siempre acuáticas y.herbáceas, en cuyas flores se puede distinguir un cáliz y una corola con muchos pétalos, 415 bis. - Arboles mas ó menos grandes y corpulentos, y que se elevan á veces liasta $100^{\prime}$ de aitura, con hojas simples, alternas, pecioladas, oblongo-aguzadas ú ovales, sub-enteras ó apenas dentaditas, lampiñas ó alampiñadas, acompañada la insercion del peciolo por dos estípulas pequeñas caducas ordinariamente. Flores en racimos ó corimbos axilares mas cortos que las hojas, ó solitarias y axilares con los pedícelos doblados hácia abajo; cáliz decíduo ordinariamente con 4,5,8 segmentos uni ó biseriados; estambres muchos pubescentes, de anteras alargadas corniculadas por el ápice y abriéndose poŕ poros infraterminales ú ovales, que por fin se vuelven grietas. Ovario 4, 5-locular, con algunos óvulos en cada celda, de cuyo ápice sale un estilo simple o 4, 5 -fido, incluso ó eserto. Fruto capsular, leñoso, erizaảo, loculícido y con semillas provistas de un arilo; embrion recto, con cotiledones grandes y sub-carnosos; endospermo delgado: solanea, F. 99, T. II, G. I.

415 bis. Fruto capsular 1-locular y polispermo, mas ó menos grueso, coronado por el estigma con figura de escudo; endespermo harinoso muy grueso; flores blancas ó amarillas, 416. - Fruto consistiendo en nuecesitas $\dot{0}$ carpelos anidados en un disco carnoso; semillas sin endospermo; flores de ordinario rosadas o purpúreas; hojas largamente, pecioladas, derechas y saliendo por fuera del agua, alternas en gruesos rizomas pegados en el fondo de la madre de los riachuelos, escutiformes, enteras ó recortadas; flores solitarias en el ápice de un bojordo muy largo, derecho y axilar; periantio con muchas divisiones todas coloridas y dispuestas por séries, desiguales, anchas, ovales, algo aguzadas y abiertas ; muchísimos estambres insertos en el receptáculo; ovario unilocular, con 1, 2 óvulos pendientes, turbinado y anidado en el receptáculo, coronado por un estilo persistente terminándose en un estigma lobulado; receptáculo apeonzado, con alveolos conteniendo los frutos aqueniformes: nelumbo, F. 92.

416. Yerbas de cuyos rizomas gruesos salen hojas alternas, simples de peciolos larguísimos, cilínd ricos, acompañados por la insercion de estípulas, y cuyo ápice lleva un disco grande acorazonado, algo abroquelado, sinuado-dentado ó entero, aplicado á la superficie del agua por su cara inferior como esponjosa, con las venas dis- 
puestas en redecilla, de ordinario blanca teñida de rosadito, mientras la superior es verde y lustrosa; periantio de muchas divisiones dispuestas por séries, cuyas esteriores son verdes y las interiores blancas, petaloídeas, mas o menos largas, lanceoladas y puntiagudas ú oblongo-lanceoladas inzertas en el torus junto con los estambres cuyos esteriores son mucho mas largos que los internos, y con apéndices mas largos, linєares y obtusos, de anteras con las celdillas apenas mas estrechitas que el conectivo; apéndices de los estigmas cortos, conicos y puntiagudos ó claviformes y por fin reflexos; ovario globoso, de ápice truncado, unilocular, con muchos óvulos esparcidos por la superficie de su cara interna: nymphea, F. 91.

417. Fruto capsular, estambres 6 ; plantas herbáceas, 418. - El fruto consiste en aquenios numerosos agrupados en el centro de la flor, sesiles y con un penacho mas o menos largo que no es otra cosa sino el estilo persistente y crecido; bejıcos larguísimos, de tallos delgados, leñosos y ramosísimos, pubescentes ó alampiñados, sarmentosos y sosténiéndose por medio de los peciolos de las hojas, que se enroscan en los vejetales vecinos; hojas alternas muy partidas, de manera que parecen compuestas, envainadoras por la base del peciolo, tęrnadamente divididas con los segmentos aovados y enteros ó pinatisectas; flores en panojas polígamas ó dioicas, mas ó menos pubeascentes, de periantio coroliforme con 4,8 sépalos, cuneiformes, oblongos, abiertos y peludos ó pubescentes, de inflorescencia valvar; estambres muchos, hipojinos, cuyas anteras adheridas tienen sus celdillas estrorsas ó laterales; embrion diminuto alojado en el ápice del endospermo : clematis, F. 96, T. I.

- 418. Plantas herbáceas de tallo bastante ramoso superiormente y alto de $3^{\prime}$ á $5^{\prime}$, con hojas simples, alternas, basinervias, enteras, sentadas $y$ amplexicaules cuando caulinares, mientras que cuando son radicales tienen un peciolo bastante largo, son mayores, aovado-lanceoladas y tambien basinervias, lampiñas; flores pequeñas, á veces polígamas y en panojas grandes, flojas y terminales, constando de un periantio 6-partido, de segmentos iguales, abiertos y glandulosos por la base, 3 son mas esteriores; 6 estambres derechos insertos en la base de las divisiones calizinales, con filamentos subulados, cnyas anteras arrinonadas tienen sus dos celdillas confluentes. Pistilo formado de 3 ovarios distintos, uniloculares, con 1 ó 3 óvulos, cuyo ápice divaricado y aguzado se termina en un estigma casi sentado; el fruto se compone de 3 carpelos oblongos, algo puntingudos, abriéndose jor la parte interna y que contienen de 1 , 3 semillas: veratrum, F. 15, T. I.

419. Flores ginandras, es decir cuyos estambres están soldados con el pistilo, 420.-Flores nunca jamás ginandras, 445 .

420. Con dos 6 tres estambres íntimamente unidos al pistilo, de manera que forman con él una columna llamada ginostemo, de anteras operculadas cuyo pólen es en masa o en granitos aglutinados, 421. - Estambres 6,5 soldados y confundidos en el centro de la flor con el estilo y con el estigma y formando así una columna en que están subsesiles; plantas herbáceas, matas fruticosas algo enredaderas, bejucos ó arbustos sarmentosos y volubles, de tallo mas ó 
menos grueso, muy largo, muy ramoso, de corteza mas ó menos corchosa, ó lisa y lampiña ó alampiñada en las partes herbáceas; hojas simples, alternas, á veces muy grandes, pecioladas, enteras ó lobuladas, arriñonadas, acorazonadas, con una punta, acorazonadooblongas, obtusas, como aflechadas, con una estípula cordiforme mas ó menos grande, persistente ó sub-persistente, pero que suele faltar á veces, pedatinervias. Flores ordinariamente axilares y solitarias, otras veces en especies de racimos y no axilares, pedunculadas y de color triste, oscuro, pintadas de bruno y de amarillento mas ó menos oscuro, á veces muy grandes y de periantio cuya figura y forma son características, monosépalo con la base mas ó menos hinchada, el tubo mas estrecho $\mathrm{y}$ derecho y el limbo mas ó menos dilatado, irregular ordinariamente, con uno ó con dos labios y algunas raras veces sin ninguno ó á lo menos cuyo labio superior está apenas prónunciado ; ovario largo y siguiendo al pedúnculo ordinariamente como claviforme y asurcado, con 6,5 celdas con muchos óvulos, pegados en una placenta central ó axil, estilo corto con el canal visible, terminado por un estigma 6,3-lobulado. Cápsula mas ó menos gruesa y elíptica ó sub-aovada, de dehiscencia superior $y$ septícida, con 6 celdas conteniendo muchas semillas achatadas, de embrion diminuto, situado en el ápice de un endospermo carnudo: aristolochia, F. 45.

421. Dos estambres ó dos anteras, 422. - Tres estambres, de los cuales los dos laterales solos son fértiles, mientras la tercera intermedia es estéril; mitad del estilo libre; estigma con 3 areolos opuestos álas anteras; plantas herbáceas terrestres, de raices fibrosas, y tallos con hojas alternas, simples, envainadoras ; flores en.espigas terminales, de periantio abierto con 6 divisiones desiguales, de las cuales 3 son interiores algo mas estrechas, y 3 esteriores, de las cuales dos son laterales, uninervias, mientras la tercera ó mediana es mucho mayor, con figura de zapato y se llama labelo. Ginostemo corto, inclinado hácia abajo, de ápice trífido, cuyos lóbulos laterales son anteríferos por su parte inferior, mientras el intermedio es estéril y petaloídeo ; anteras de celdas separadas y sub-bivalves; pólen pultáceo-granujiento ; ovario ovoídeo unilocular poliovulado, con estigma deltoídeo situado en la cara de la columna, por debajo de las anteras : cypripedium, F. 27, T. I.

422 . Cípsula mas ó menos ovoídea ó fusiforme, con 3 ángulos mas ó menos pronunciados, unilocular, conteniendo muchas semillas muy pequeñas insertas á lo larýo de 3 placentas persistentes y correspondiendo á los 3 ángulos persistentes saliendo del pedúnculo y reunidos en el ápice por el periantio marcescente, mientras las 3 valvas 0 . ventallas intermedias se desprenden y se caen, 423. - Cápsula silicuiforme, larga de $6^{\prime \prime}$ á $8^{\prime \prime}$, indehiscente $\mathrm{y}$ como pulposa interiormente: plantas suculentas sarmentosas, de tallos como herbáceos, larguísimos y ramosísimos, lampiños, mas ó menos asurcados, cilíndricos ó algo elípticos, provistos de zarcillos ópuestos á las hojas, simples, enteras, coriáceas, alternas, sentadas, no envainadoras, articuladas con el tallo ó los ramos, mas veces reticuladas, lampiñas, ovales, elípticas ó aovado-oblongas, de cara superior algo cón- 
cava. Flores rosadas ó blancas grandes y en espigas ó racimitos axilares y paucífloras, cortamente pediceladas y de periantio coroliforme, con 6 divisiones desiguales cuya inferior ó labelo es cóncava, cuculiforme, con el limbo dilatado en lámina undulosa por los bordes, los demas son subiguales, conformes y libres; antera terminal opercular, con 2 polinias bilobuladas y granujientas : vanilla, F. 28 .

423. Polinias ó masas polínicas ceráceas, 428. - Polinias nunca ceráceas, pero mas ó menos pulverulentas, ó aglomeradas en lobulitos coherentes por medio de una sustancia elástica, 424 .

424. Antera terminal opercular, persistente ó caduca; estigma sin pico ninguno, 425.-Antera dorsal persistente, casi paralela con el estigma que frecuentemente se prolonga en pico pequeño agrietado, ó paralela con la cara del ginostemo, 426 .

425. Plantas herbáceas terrestres, cuyo tallo con hojas simples envainadoras y alternas sale de un rizoma rastrero y se termina por una espiga de flores verdosas, coloridas y pubescentitas, de un periantio con 6 divisiones abiertas, conformes, cuyas interiores y esteriores son subiguales; de labelo estendido, interrumpido y formado de dos partes sobrepuestas, cuya una es inferior y cóncava, mientras la otra superior, alargada y petaloídeo-entera, ginostemo semi-cilíndrico, con la antera situada por el ápice de su cara posterior, y cordiforme, bilocular, conteniendo masas polínicas pulverulentas y cuya cada celda es dividida en 2 partes por un surco lonjitudinal : epipactis, F. 27, T. VI, S.-T. II.

426. Polinias cuatro, 427. - Polinias 2, lineares, claviformes y fijadas en la glándula comun; jerbas de hojas radicales, óvalo-lanceoladas y nerviosas; bojordo de base provista de brácteas envainadoras, mientras que el vértice desnudo es peludo; flores en espiga floja, de periantio algo endurecido con 6 divisiones, cuyas laterales puestas por debajo del labelo y adheridas con su base se vuelven por fin conniventes con las 3 interiores; labelo sentado, estendido, entero y paralelo con el ginostemo que abraza con sus márjenes y se prolonga en espolon; ginostemo corto ; antera terminal estipitada, bilocular y escotada, piquito laminiforme y recto: pelexia, F. 27, T. VII.

427. Juntas con la glándula comun; antera posterior incompletamente cuadrangular, 428. - Encorvadas por la base y coherentes por el ápice; antera terminal provista de un piquito; yerbas de tallo derecho con hojas alternas, oblongo-lanceoladas y estriadas, simples enteras; flores grandes hermosas y dispuestas en espigas terminales, de un periantio con 6 divisiones cuyas esteriores son erguidas, con las dos laterales obovales, tiesas, papilosas y volviéndose por fin ovales y planas; mientras las 3 interiores son casi semejantes á las laterales; labelo cortamente unguiculado, anchamerte oblongo, encrespado, papiloso y con el disco provisto de laminitas; ginostemo erguido, semi-cilíndrico; antera termina apendiculada: ulantha, F. 27, T. VII.

428. Polinias en número definido, 429. - Polinias en número indefinido y muchísimas por consiguiente, 431 . 
429. Antera erguida, con las celdas contiguas y paralelas; polinias con dos glándulas distintas, encerradas en la plegadura bilocular y acogullada del estigma, 430. - Antera erguida tambien, de celdas sueltas, diverjentes por la base y adheridas á los canales estigmáticos ; piquito plano y adheıido á la antera ; estigma provisto de dos prolongamientos: plantas terrestres herbáceas, de raiz tuberculosa, con hojas radicales lanceoladas, de flores en espigas terminales en el vértice del tallo, cıyo periantio 6-partido es galeiforme, con los segmentos sub-equilongos, cuyos esteriores son mucho mas angostos que los interiores bi ó trífidos y conniventes; labillo alargado, colsante, entero, bi ó trífido y prolongándose en espolon: habenaria, F. 27, T. V.

430. Plantas herbáceas terrestres de raices con dos tubérculos dídimos, redondeados, enteros ó palmeados; hojas radicales blandas y algo suculentas, alternas, sesiles y lanceoladas ; flores en espigas terminales en la sumidad del bojordo á veces foliáceo, con ó sin brácteas; periantio galeiforme, cuyas divisiones son casi iguales; las 2 esteriores laterales, converjentes ó encorvadas, se vuelven por fin converjentes á manera de bóveda, con los 3 interiores semejantes á ellas; labelo anterior, adherido con la base del ginostemo, entero, tri ó 4-lobulado y de base prolongada en espolon; antera erguida, de celdas paralelas y contiguas:orchis, F.27, T. V, S.-T. I.

431. Con úna especie de membrana celular coherente en colitas elásticas pulverulentas y con mayor frecuencia redobladas, 432. Sin tejido celular accesorio alguno: yerbas epifitas de rizoma filiforme y monófilas, de flores axilares solitarias amanojadas ó racimosas; periantio cuyas divisiones esteriores conniventes son subiguales, las laterales ó todas adheridas y mayores que las interiores; labillo libre paralelo al ginostemo, diforme é intejérrimo; ginostemo libre $y$ aptero, continuo con el ovario; antera bilocular $y$ membranosa por el ápice; polinias dos, frecuentemente reunidas por el ápice á favor de una colita pulverulenta : pleurothalis, F. 27, T. II, S.-T. I.

432. Polinias reunidas por medio de una membrana celulosa coherente á favor de colitas elásticas pulverulentas, frecuentemente redobladas, sin glándula alguna; antera terminal opercular, 433. - Polinias aglutinadas al momento de la florescencia, con una colita elástica y á la vez con la glándula del estigma; antera terminal y rara vez dorsal, opercular. 441.

433. Antera bi ó 4-locular; polinias cuatro, 434. - Antera con 8 celdas, polinias 8 : yerbas terrestes de hojas ensiformes y plegadas, enteras y sencillas; bojordo ramoso con muchas flores ordinariamente grandes y preciosas, de periantio cuyas divisiones esteriores son abiertas é iguales, mientras las internas son subiguales, abiertas ó conniventes; labillo a:1iculado con la base del ginostemo con fị̂ura de capuz o de saco, trilobulado y cuyo limbo está adornado de laminitas ó de tubérculos; ginostemo alargado y semi-cilíndrico; antera carnosa; polinias iguales y coherentes por medio de 4 colitas pulverulentas : blettia, F. 27, T. IV, S.-T. III. 
434. Anteras biloculares carnosas; colitas de las polinias atro tanto redobladas, 435 . - Anteras 4-loculares earnudas y con tabiques marjinales inembranosos; colitas de las polinias otro tanto redobladas: yerbas epifitas con hojas solitarias ó mellizas, coriáceas y situadas en el ápice del seudo-bulbo; flores grandes y hermosas, saliendo con frecuencia de una espata grande y membranosa; de periantio cuyas divisiones esteriores membranosas ó carnositas son abiertas é iguales, mientras las interiores san con frecuencia mayores; labillo articulado con el ginostemo claviforme, semi-cilíndrico $\mathrm{J}$ alado, envuelto en el labelo de figura de capuz, entero ó trilobulado : cattleya, F. 2 i, T. IV, S.-T. I.

43.5. Antera completa ó incompletamente bilocular, 436. - Antera unilocular; plantas herbíceas epifitas de hojas solitarias y estriadas; flores poco notables dispuestas en espigas y de periantio llano, cuyas divisiones esteriores é interiores son iguales, mientras las laterales connatas están por debajo del labillo, libre, sin espolon, muy abierto y entero, pero con callos situados por su parte media; ginostemo erguido, cilíndrico, aguzado, con la boca ó abertura del estigma vertical; antera dorsal paralela con el estigma; ginostemo plano algo calloso, marjinado ó como alado posteriormente; polinias dos, enteras con las colitas alargadas y cuneiformes; glándula diminuta: notylia, F. 27, T. III, S.-T. IV.

436. Antera completamente bilocular, 437. - Antera incompletamente bilocular, 410 .

437. Ginostemo erguido, semi-cilíndrico, aptero, con ó sin pico pequeño, 433.- Ginostemo corto, acanalado, alado hácia el ápice y sin pico; plantas herbáceas, de hojas dísticas en el vértice del seudo-bulbo, carnosas, ensiformes é envainadoras por la base; flores solitarias axilares y acompañadas de una bráctea ó en espigas, de periantio profundamente 6-partido, cuyas divisiones carnosas y abiertas son cinco, subiguales, oblongas, esteriormente aquiladas y planas interiormente, mientras la sexta ó labillo, algo mas larga, presenta intęriormente dos líreas salientes ó es tuberculosa; antera terminal opercular; polinias dos : pachyphyllum, F. 27, T. III, S.T. III.

438. Ginostemo sub-cilíndrico rara vez alargado y semi-cilíndrico, sin pico alguno, 439. - Ginostemo provisto de un pico: yerbas epífitas acaules, de hojas coriáceas; bojordos apanojados provistos de brácteas envainadoras; flores pequeñas y pálidas, de periantio cerrado, cuyas divisiones esteriores son connatas con la base del labillo, las laterales aproximadas inferiormente y semejantes á las interiores; labillo mucho mayor y dispuesto á manera de saco por la base, con la uña callosa y paralela al ginostemo, de limbo estendido, abierto y bilobulado; polinias dos, asurcadas posteriormente; colita linear encerrada; glándula obaovada : inopsis, F. 27, T. III, S. -T. II.

439. Yerbas seudo-parásitas, de periantio abierto, cuyas divisiones esteriores é interiores son subiguales; labillo continuo æon la base del ginostemo, sentado, earnoso, entero, mucho mas ancho que las otras divisiones, y provisto de un espolon recto y con 
figura de cuerno. Antera troncada; polinias 2-bipartibles de colita corta yestrecha; glíndula triangular: angrecum, F. 27, T. III, S.-T. I.

440. Ginostemo de vértice sin alas, 441. - Ginostemo erguido, semi-cilíndrico, de vértice alado por sus ambos lados; plantas herbáceas epifitas, seudo-bulbosas, de hojas coriáceas, planas, dobladas sobre sí, triquetras y á veces como cilíndricas; bojordos mas ó menos largos, apanojados ó espigados, con flores ordinariamente muy primorosas y de figura muy variada, cuyo periantio estendido tiene las divisiones esteriores frecuentemente ondulosas y semejantes á las interiores y cuyas laterales libres son un poco connatas con el labillo máximo, continuo con el ginostemo, espolonado, lobulado y de base adornada de tuberculitos ó de crestitas; antera con un piquito corto ó alargadito y puntiagudo ; polinias dos, asurcadas posteriormente y con colitas planas; glándula oblonga : oncidium, F. 27, T. III, S.-T. V.

441. Erguido, libre del labillo y de base ó de ápice por ambos lados franjeado, rizado ó mútico, 442.- Semi-cilíndrico, sin franjas y de base prolongada en que se articula el labillo; yerbas epifitas seudo-bulbosas, caulescentes ó acaulas, de hojas pelegadas y coriáceas; pedúnculos radicales axilares ó terminales, y entónces saliendo del ápice del seudo-bulbo, uni ó multífloros; periantio abierto ó connivente, cuyas divisiones esteriores y laterales tienen la base prolongada á manera de saco y connata con el ginostemo; interiores casi semejantes; labillo articulado con la base del ginostemo, antera opercular; polinias dos, bipartibles ó enteras; colitas cortas y pegadas á una glándula transparente : maxilaria, F. 27, T. III, S.-T. VII.

442. Labillo continuo con la columna, de pié alargado unguiculado, plano, nunca con figura de saco por el ápice tripartido, desnudo, 443.-Labillo espeso, carnosito, desnudo, ventrudo ó estriado y llano á la vez, onduloso y con forma de saco por debajo del ápice algo trílobo, 444.

443. Plantas terrestres ó seudo-parásitas, cuyos seudo-bulbos, á veces largo hasta de una vara y mas, son fusiformes, bastante gruesos y terminados por 5 á 7 hojas gramíneas, bastante largas, dísticas, cuyo limbo está articulado con el vértice de la vaina, por una articulacion escamosa, de manera que despues de desprendido el ápice del seudo-bulbo se queda espinoso, la parte de las nervaduras correspondiente á la articulacion teniendo papel de espinas. Del pié y lado de la cebollota ó seudo-bulbo mas nuevo y mas tierno sale uno ó algunos bojordos altos de 3 á 5 ', derechos, cilíndricos y del tamaño del dedo meñique por la base, con nudos poco pronunciados, de cada cual sale una bráctea grande, foliácea y envainadora; son largas de $31_{[} 4$ á $21_{[} 2^{\prime \prime}$, enderezadas, aplicadas al tallo que tienen envuelto y algo avejigadas, dispuestas casi á igual distancia las unas de las otras, y terminándose por un racimo apanojado y bastante fornido de flores amarillas bastante grandes, pedunculadas y saliendo de la axila de una bráctea semejante á las ya mencionadas, pero mas pequeña. 'Tales flores tienen 2 á $21_{[} 2^{\prime \prime}$. de diámetro, con 6 
divisiones perigoniales algo desiguales y dispuestas en das séries; columna erguida semi-rolliza, y sin embargo algo abovedada y como espatuladita á la par; antera bilocular con 2 polinias bilobuladas posteriormente, de colita linear corta; glándula aovada. Cápsula de pericarpio algo carnoso ovoídeo-trígona y del tamaño de un huevo pequeño de gallina: cyv•topodium, F. 27, T. III, S.-T. VI.

444. Yerbas epifitas ó terrestres seudo-bulbosas ó de tallos mas 6 menos cortos; hojas plegadas, coriáceas ó gramíneas, cuya base envainadora se queda vistiendo el seudo-bulbo mas ó menos largo á manera de membrana, dejando á veces en el ápice, al desprenderse, pujas ó espinas en número de 3 para cada vaina que se queda y con que se articulaban las nervaduras y costillas del limbo caido; bojordos radicales y axilares mas ó menos largos terminados por hermosas flores dispuestas en espigas ó en racimos, mas ó menos verdusco-amarillentas y bastantes veces disciplinadas, con color purpúreo mas ó menos oscuro; periantio globoso connivente ó estendido, con las divisiones esteriores casi iguales con las interiores; ginostemo libre y aptero; antera troncada por su parte anterior; polinias dos bilobuladas ó asurcadas posteriormente ; colitas máximas y desnudas y por fin elásticamente contractiles; glándula cartilajinosa sub-cuadrangular: catasetum, F. 27, T. III, S.-T. VI.

445. Flores envueltas en una ó algunas espatas, 446. - Flores desprovistas de espata, ó con una membranosa, 449.

446. Dos espatas, cuya una comun grande y coriácea es colorada, mientras la otra, pequeña y membranosa, es propia á cada flor, 447. - Una espata única monofila ó polífila, petaloídea ó membranosa, 448.

447. Plantas herbáceas vivaces, bastante grandes, de los lugares húmedos y pantanosos, de cuyo rizoma bastante grueso salen hojas grandes, largamente pecioladas y que parecen las del plátano enano, derechas, elípticas, lanceoladas, envainadoras por la base del peciolo, de cuyo centro sale un bojordo derecho de como $2^{\prime \prime}$ á 2 1 2 " de diámetrø por la base y alto de $4^{\prime}$ á $5^{\prime}$, cuya mitad superior está provista de espatas coloradas con figura de canoa, dispuestas dísticamente, y conteniendo en su axila muchísimas flores agrupadas, cortamente pedunculadas y envueltas cada una en su espata particular membranosa: de periantio monófilo, bilabiado, con el labio superior bífiào; estambres cinco; un nectario bífido ó de dos hojas ; pistilo cuyo ovario trilocular pauciovulado se termina por un estigma casi sentado. La fruta es una cápsula oblonga, trilocular monosperma : heliconia, F. 24, T. I.

448. Espata mono ó polífila, siempre membranosa y nunca jamás petaloídea, única ó multiple, 449. - Espata monófila, única, grande, cóncava, carnuda, petaloídea y pronto caduca. Grandísimas y primorosísimas plantas herbáceas de cuyo rizoma salen grandes hojas de base envainadora cuyas vainas juntas forman una especie de tronco bastante grueso y mas ó menos alto, segun la clase, de $3^{\prime}$ á $8^{\prime}$ y se prolongan superiormente en peciolos mas ó menos cortos sosteniendo limbos elípticos, obtusos, enteros, delgados y muy grandes, cuyas nervaduras muy finas son todas paralelas $y$ salen 
horizontalmente de la costilla gruesa y que es la continuacion del peciolo; prefoliacion convoluta ó enrolladas sobre sí mismo en cartucho, el eje quedándose derecho. Del medio de las hojas sale un bojordo bastante grueso, verde, muy fuerte, derecho al principio, llevando en su ápice una yema del tamaño corno del puño ó algo menos, ovoídea y moradusco-rojiza, mas tarde se dobla el bojordo, de tal manera, que la yema se halla por afuera y cabizbaja: entonces su espata superior, la cual ocupaba antes su base, se abre y se dobla por arriba, de tal manera que aparecen las flores que se hallan en su axila, las cuales, en número como de 15 , son bastante grandes, por ser muy largo y grueso su ovario proporcionalmente á la parte libre del periantio, dispuestas en dos séries insertas sobre un diente único del pedúnculo que sigue alarğndose á medida que nuevos grupos de flores van saliendo y abriéndose, de tal manera que forma así una espiga monstruosa que se termina por flores estériles. Despues de verificada la fecundacion, la espata se desprende y se cae al suelo, mientras que las flores casi sentadas y cabizbajas se enderezan y su pedúnculo se alarga un poco, de tal wanera que los frutos están siempre mas ó menos enderezados y mas ó menos arqueados; flores de periantio monófilo, bilabiado, petaloídeo, cuyo labio superior enderezado y recto es cuadridentado, mientras el inferior, al contrario entero, es algo mas corto, cóncavo y nectarífero; 6 estambres, de los cuales uno solo está fértil y algo mas largo que los demas estériles, lo que se observa solo en las flores de la base de la espiga, porque en las del vértice al contrario uno solo es e:téril, mientras todos los demas son fërtiles; ovario largo, grueso, fusiforme, algo trígono y poliovulado, llevando en su ápice un estilo simple terminado por un estigma cahezudo ob con 3 surcos ó lóbulos muy poco marcados. El fruto es una baya de color variando segun las especies, amarilla ó mas ó menos morada, carnuda, mas ỏ menos larga y gruesa, fusiforme, lijeramente trígona, mas ó menos arqueada : musa, F. 24, T. II.

449. Flores con 6 estambres, 450. - Flores con menos de 6 estambres, 465 .

450. Raiz bulbosa ó una cebolla, 451.-De raiz nunca jamảs bulbosa, 456 .

451. De estambres salientes, diverjentes y cuya base de los filamentos está reunida por un nectario membranoso coroniforme, 6-lobo é inserto en la garganta del periantio, 452. - Estambres tambien salientes ó esertos, no diverjentes pero inclinados ó solamente derechos, sin nectario, 453 .

452. Primorosa yerba que se halla en los pastos, de hojas todas radicales, sentadas, anchas de como ] $12^{\prime \prime}$ á $2^{\prime \prime}$ y largas de $6^{\prime \prime} \mathrm{y}$ mas, como dísticas, algo tendidas por el suelo, de su lado sale un bojordo alto de como $2^{\prime}$ algo mas ó menos, que lleva en su ápice de 6 a 8 flores blancas, bastante grandes, muy lindas, de fragancia deliciosa, saliendo de una espata membranosa que se revienta en dos piezas desiguales; periantio monosépalo infundibuliforme, de tubo larguísimo y con el limbo partido en seis divisiones estendidas, bastante largas y estrechas; seis estambres insertos en el vértice del 
tubo y cuyos filamentos están soldados entre sí por medio de un nectario bilobado, formando en el centro de la flor una hermosa corona hexágona; vértice de los filamentos verde y algo encorvado, terminado por anteras grandes y dorsifijas; pistilo de ovario, algo largo, trígono y un poco fusiforme, de cuyo vértice sale un estigma sencillo, troncado, glanduloso y casi cabezudo. El fruto es una cápsula trilocular polisperma, cuyas semillas están á veces reemplazadas por una especie de bulbillo que se va desarrollando en su lugar : pancratium, F. 21, T. II.

453. De periantio infundibuliforme y tubuloso, con tres divisiones cuya punta se termina como en gancho, sin escama alguna en la garganta ; estigma único; espata membranosa partida en algunas divisiones desiguales é irregulares, 454.-De periantio campanudo con las divisiones á veces reflexas, provisto de seis escamitas situadas en la entrada del tubo; tres estigmas; espata reventándose en 2 ó algunas piezas, 455 .

454. Planta herbácea, con hojas radicales, simples, sentadas, bastante largas, estrechas y lanceolarlas, derechas, dentaditas ó aserraditas por los bordes, de cujo lado sa!e un bojordo cilíndrico, alto como de $1^{\prime}$ á $11_{1} 2^{\prime}$, con dos espatas bastante grandes, algo carnudas, coloradas, situadas en su vértice y conteniendo 6 á 8 primorosas fores blancas algo teñidas de color de rosa, de periantio infundibuliforme, cuyo tubo largo lleva un limbo de 6 divisiones abiertas, alesnadas, algo acanaliculadas $\mathrm{y}$ dobladitas hácia fuera $; 6$ estambres de filamentos colorados, largos, distintos, libres, salientes é insertos en la garganta del periantio; pistilo de ovario algo trilobado, oval, un poco trígono, trilocular, poliovulado, de cuyo vértice sale un estilo filiforme algo mas largo que los estambres, terminándose por un estigma bífido. Fruto capsular ovoídeo, membranoso, algo trígono, trilocular y polispermo, cuyas semillas globosas ó esféricas tienen la testa algo carnosita : crinum, F.21, T. I.

455. Plantas herbáceas vivaces pequeñas ó bastante grandes, con flores ordinariamente bastante grandes y lindas, de hojas radicales, sentadas, derechas, bastante largas, mas ó menos estreclias ó lanceoladas, de cuyo centro sale un bojordo de $6^{\prime \prime}$ hasta $1^{\prime}$ á $11^{\prime} 2^{\prime}$ de alto, segun las especies, y que lleva en el vértice una sola ó algunas flores mas ó menos rosadas, algunas raras veces amarillas ó coloradas, envueltas por lo comun por una espata membranosa que se revienta en algunas piezas irregulares, de manera que parece corno polífila; periantio petaloídeo, campanudo, partido en 6 divisiones derechas ó á veces dobladas hácia fuera, con 6 escamitas en la boca del tubo, correspondientes á la insercion ó mejor á la salida de los filamentos, desiguales tanto en proporcion como en direccion; ovario pedunculado, trígono y algo ovoídeo, trilocular poliovulado, de cuyo ápice sale un estilo filiforme, cilírdrico, mas largo que los estambres, y terminándose por un estigma trífido. Cápsula trilocular polisperma: amarillis, F.21, T. I.

456. Un rizoma mas ó menos desarrollado, 464. - Ningun rizoma $\mathrm{y}$ raices fibrosas, 457 . 
457. Fruto capsular, 458.-Fruta bacciforme ó sincarpio, 461.

458. Vejetales parásitas; cápsulas uni ó triloculares, con muchas semillas velludas ó peludas, 459. - Vejetales nunca parásitas y por consiguiente siemprc terrestres; cápsulas triloculares siempre, polispermas, y cuyas semillas desnudas son llanas y dísticas, 460 .

459. Vejetales herbáceos vivaces que se nutren á espensas de los demas vejetales en que viven, raras veces son terrestres; hojas radicales de ordinario arrosetadas, alternas ó dísticas y entónces un poco caulinares, coriáceas, mas ó menos estrechas, á veces filiformes, con frecuencia arqueadas hácia fuera, de cara superior cóncava $y$ dispuesta como á manera de gotera, ordinariamente enteras, sin embargo algunas veces espinosas por los bordes, lustrosas y lampinas ó bozosas y blanquecinas, mas ó menos largas $\mathrm{y}$ lanceoladas, aljrazadoras por la base. Del centro de las hojas sale un bojordo mas ó menos largo, filiforme y corto ó bastante grueso y provisto de algunas hojitas á veces reemplazadas por unas brácteas y terminándose en una espiga ó en una panoja de flores con periantio de 6 divisiones, de las cuales 3 son esteriores algo enrolladas y persistentes mas ó menos verdes, mientras las 3 interiores son petaloídeas y caducas ; 6 estambres. Cápsula oblonga, linear, trilocular y á vecés unilocular, con muchas semillas alargadas y velludas: tillandsia, F. 18.

460. Grandes y primorosas plantas vivaces de los lugares arenosos y pedregosos, cuyo tallo corto es sub-leñoso y del tamaño como del muslo ó menos, segun la especie y el terreno en que vejeta; hojas al principio todas radicales y arrosetadas, pero algo mas tarde caulinares y esparcidas, carnosas, derechas, lanceoladas, sentadas, largas de $212^{\prime}$ á $3^{\prime}$ y anchas de $3^{\prime \prime}$ á $4^{\prime \prime}$ en el medio ó parte mas ancha, algo undulosas por los bordes algo dentados y terminándose en una espina fuerte y prieta, de cara superior cóncava, mientras la esterior es convexa, basinervias y lampiñas; del centro sale un bojordo mas grueso que la pierna, que se eleva á 15 ó $20^{\prime}$ y mas, derecho, provisto de algunas hojas pequeñas, volviéndose arriba como brácteas grandes, y entónces de su axila salen brazos mas ó menos largos, mas ó menos estendidos y simples, que cargan con las flores, dispuestas en grupos ó primorosas cimas, cuya reunion constituye un tirso muy grande ó panojas; de periantio coroliforme ó petaloídeo, monosépalo, tubulado, infundibuliforme, con 6 divisiones profundas mas ó menos abiertas; estambres salientes de filamentos largos, con anteras largas, movibles, pegadas en su punta por el medio de su dorso $\mathrm{y}$ así transversales; ovario algo trígono $\mathrm{y}$ oblongo, trilocular, poliovulado y de cuyo vértice sale un estilo filiforme tan largo como los estambres y terminado por un estigma caDezudo. Cápsula algo trígona, con tres celdas conteniendo muchas semillas dispuestas en dos séries: algunas veces las cápsulas no existen y están reemplazadas en las ramitas por yemas que despues de bastante desarrolladas se caen al suelo en donde echan raices: agare, F. 21, T. IV.

461. Frutos agregados formados de muchas bayas soldadas entre 
sí y constituyendo un sorosis, 462. - Bayas sueltas ó libres dispuestas en panojas derechas, 463.

462. Plantas herbáceas vivaces, con hojas todas radicales $y$ ar1.osetadas, casi rectas ó un poco diverjentes al principio, sentadas, envainadoras por la base, lanceoladas, largas de $2^{\prime}$ á $21_{[} 2^{\prime}$, de cara superior cóncava, con aguijones mas ó menos numerosos y ganchosos por los bordes, lampiñas y anchas de $2^{\prime \prime}$ á $3^{\prime \prime}$, puntiagudas y de cuyo medio sale un bojordo corto bastante grueso y cilíndrico, mas ó menos foliáceo ó solamente escamoso, largo de $11_{[} 2^{\prime}$ á $2^{\prime}$, algo inas ó menos, terminándose por una espiga gruesa, cilíndrica ú ovoídea, formada de muchísimas flores moradas ó rosadas, sentadas en la axila, de brácteas que no tardan en volverse carnudas y soldarse entre sí y tambien con los ovarios de las flores antes libres y sueltos, lero su punta se queda libre, bastante grande y aserradita, acompaña á la base de cada baya y despues se vuelven de nuevo hojas para formar la corona que se halla en el ápice de la fruta ó de la piña. Tales flores sentadas y cuyo ovario está como un poco engastado en el eje espeso y carnudo, se componen de un periantio libre por su limbo, partido en 6 divisiones, cuyas 3 esternas, mas cortas y mas estrechas, simulan un cáliz, mientras las 3 interiores, mas gran!es, petaloídeas y coloridas, parecen corola, con una escama nectariforme situada por la base ; 6 estambres insertos en la garganta del periantio, con anteras aflechadas; ovario ovoídeo, libre solamente antes de la floracion, terminándose por un estilo simple. Despues de la floracion y de la fecundacion, la parte interior del periantio se cac y el ovario ombligado ó coronado entónces se queda engastado en el eje florífero, que se vuelve mas carnoso á medida que se va acercando mas la madurez de las frutas, que soldadas entre sí, como ra lo tenemos dicho, forman un conjunto regular de bayas polispermas y ombligadas, que tienen al aspecto de una piña, cuyo nombre llevan vulgarmente, y al madurarse se vuelven amarillas ó moradas : bromelia, F. 23.

463. Plantas herbáceas vivaces, cundidoras como las anteriores, á las cuales parecen enteramente $\mathrm{y}$ de las que se diferencian solamente por las flores y frutas; en la estacion de la floracion las hojas mas interiores de la roseta se vuelven de un hermoso color rojo, especialmente por la cara interna, $y$ del centro sale entónces un bojordo grueso, blanco, bozoso, con algunas hojas pequeñas, alternas, de hase membranosa y envainadora; blanca y pubescente, mientras el limbo es rojo, lustroso, lampiño y aguijonoso por los bordes como las demas hojas, cuyo vértice se termina en una especie de racimo grueso, como de $1^{\prime}$ de largo, formado de unas espiguitas compuestas de como 6 hasta 10 flores casi sentadas al nacer, ó cuyo pedícelo muy corto sale del vértice de un pedúnculo comun bastante grueso $\mathrm{y}$ que se va alargando á medida que las flores se desarrollan y se abren, Y en especial despues de la fecundacion, de tal modoque el racimo se vuelve muy luego una panoja mas ó menos grande y fornida segun la especie, derecha y cuyas divisiones salen de la axila de las hojas florales. Además las flores salen de la axila de una bráctea membranosa propia y constan de un periantio campanudo, con 6 divisio- 
nes muy profundas y dispuestas casi en hélice: se pueden quitar sin lastimar las demas, son triangulares, algo abiertas, subuladas y unidas entre sí por la base, no petaloídeas y’ blanquecino-grisáceas, mas cortitas que las interiores, con las cuales alternan, y que son petaloídeas, blancas con la punta rosada, derechas, conniventes y formando así una especie de tubo triangular cuyo ápice está algo abierto; el ápice de cada division se dobla un poco hácia fuera; los estambres son 6, derechos, inclusos y con sus filamentos unidos ála base de los pétalos; anteras aflechadas, basifijas, tan largas como los filamentos y terminándose en una punta cuadrangular; ovario trígono, algo fusiforme, pubescente ó bozoso y blanco como los pedúnculos, trilocular poliovulado, de cuyo ápice sale un estilo bastante grueso, triangular por la base, cuyos 3 lados están pegados con la garganta del perigonio y la divide en 3 celdillas triangulares y bastante profundas; su ápice se termina por un estigma trífido, glanduloso y cuyas divisiones están pegadas entre sí, bayas sueltas del tamaño de un huevo de paloma ó menor, segun las especies, y á veces largas y fusiformes, ombligadas, amarillas cuando maduras, uniloculares y polispermas, de semillas lentiformes, lustrosas y negras : malla, F. 23.

464. Yerbecita vivaz, de hojas sencillas, sentadas, alternas en el rizoma, basinervias, largas como de $3^{\prime \prime} \mathrm{y}$ anehas de $1_{[} 2^{\prime \prime}$, pubescentes y algo puntiagudas, de cuya axila salen hojordos mas cortos que ellas, llevando en su ápice 3 á 4 flores amarillas, pedunculadas, contenidas antes de la floracion en una espata foliácea dífila, y formando así una especie de umbela pequeñita; de periantio petaloídeo, hipocrateriforme, con tubo larguísimo y delgado que sostiene un limbo partido en $\mathbf{6}$ divisiones algo desiguales, profundas y puntiagudas; estambres 6 , insertos en la garganta del periantio, cuyos filamentos cortos llevan anteras aflechadas; pistilo compuesto de un ovario turbinado trilocular, poliovulado, de cuyo ápice sale un es-tilo simple, filiforme y bastante largo, terminado por un estigma simple y ovoídeo. Cápsula trilocular, polisperma, trígona, ovoídea y coronada: hypoxis, F. 22.

465. Tres estambres, 466. - Un solo estambre, 469.

466. Estambres de filamentos distintos insertos en el tubo perigonial, con anteras oblongas no escotadas y basifijas; raiz siempre bulbosa, 467. - Estambres insertos en el fondo del perigonio, de filamentos reunidos en tubo por la base ó segun toda su lonjitud; anteras escotadas y basifijas ; raiz de ordinario fibrosa, á veces bulbosa y raramente fasciculada, 468 .

46\%. Plantas herbáceas, con hojas simples, alternas, sesiles, envainadoras por la base, ensiformes y basinervias; flores contenidas en espatas terminales, elongadas é imbricadas, amarillas, pedunculadas, de periantio corolino, con el tubo cortísimo; limbo 6-partido con las lacinias interiores menores. Ovario obtusamente trígono, trilocular, poliovulado, cuyos óvulos están en dos séries, pegados por el ángulo central de las celdillas, ascendentes y anátropos; estilo cortísimo con 3 estigmas petaloídeo-dilatados y no divididos, alternos con los estambres, erguidos ó estendidos; cápsula membra- 
nosa ob-aovado-claviforme, trilocular, loculícido-trivalve, con muchas semillas angulosas : ciprı’a, F. 20.

468. Plantas herbáceas vivaces, altas de 8 á $18^{\prime \prime}$, lampiñas, con hojas simples, lanceolado-lineares, sentadas y envainadoras por la base, bifarias ó en dos filas opuestas y alternas á la par; tallo las mas veces ramoso y ancípite, terminado por flores blancas ó amarillas muy fugaces, en espigas ó cimas pequeñas acompañadas de una espata comun bivalve, foliácea, conteniendo las parciales en la valva esterior; perigonio corolino 6-filo ó 6-partido, con las lacinias subiguales, abiertas ó conniventes en tubo por la base. Ovario obtusamente trígono, trilocular, con muchos óvulos bi-pluriseriados en el ángulo central de la celdilla, horizontales y anátropos; estilo corto con 3 estigmas envoluto-filiformes, agudos y alternos con los estambres. Cápsula membranácea, ob-aovado-claviforme, trilucular, loculícido-trivalve, con muchas semillas sub-globosas ó angulosas, de testa coriácea y dura; rafe obsoleto; embrion axil ó sub-lateral algo mas corto que el endospermo cartilajinoso; estremidad radicular alcanzando casi el ombligo y centrípeta : sisyrinchium, F. 20.

469. Flores en espigas simples, gruesas, escamosas y claviformes, 470. - Flores nunca en espigas claviformes y escamosas, pero si en panojas ó espigas flojas mas ó menos largas, 479 . 478.

470. Semillas provistas de un arilo, 471. - Semillas sin arilo,

471. Cápsulas mas ó menos carnositas, 472. - Cápsulas nunca carnosas, 475 .

472. Cápsula no siempre, pero con frecuencia carnuda; filamento del estambre prolongándose mas allá de la antera y formando una cresta entera ó lobulada, 473.-Cápsula siempre carnuda; filamento del estambre prolongándose apenas mas allá de la antera escotada, 474.

473. Plantas herbáceas vivaces, de cuyo rizoma articulado y rastrero salen tallos herbaceos cilíndricos, largos de $2^{\prime}$ á $5^{\prime}$, algo mas ó menos, con hojas sencillas mas ó menos grandes, lanceoladas, sentadas, envainadoras por la base y alternas ó radicales, membranosas, basinervias y bastantes veces dísticas. Flores asaz grandes y primorosas, por lo comun muy fragantes, blancas ó violáceas, de periantio con 3 divisiones esteriores foliáceas simulando el cáliz, y de 3 internas petaloídeas, soldadas entre sí y desiguales. Segun el profesor Blume, tales flores son formadas de un cáliz de ordinario claviforme, con el tubo cilíndrico, mas ó menos pubescente, tan largo como el tubo delgado y encorvado de la corola, cuya série esterior consta de 3 divisiones casi iguales y como transparentes, mientras la série inferior tiene una sola pieza labiiforme mas ó menos grande, recortada, con los bordes undulosos y frecuentemente pintada de los mas bonitos colores. A r.cees el estambre único casi sentado, está formado de una antera muy voluminosa, cuyas dos celdas dejan entre sí un espacio vacio, especie de canal por donde pasa el estilo filiforme saliendo del ápice de un ovario mas ó menos ovoídeo 6 globoso y terminándose por un estigma cabezudo que se halla al nivel del ápice de la antera. El fruto es una cápsula fre- 
cuentemente bacciforme, de 3 celdas con muchas semillas, y que se abre por 3 ventallas : amomum, F. 26, T. II.

474. Plantas herbáceas vivaces, de raices mas ó menos tuberculosas, ó rizomas horizontalcs á veces aromáticos, de los cuales sale una especie de mata alta de $2^{\prime}$ hasta $6^{\prime}$ y mas, segun la especie, con hojas bastante grandes, radicales ó caulinares, y entónces alternas, mas ó menos ovales y lanceoladas, sentadas y envainadoras por la base, cuya vaina hendida está provista de una lígula. Flores tan Fonto en panojas y racimos flojos como en espigas terminales, sit:iadas en la axila de una bráctea escamiforme asaz grande y de ordinario melliza, floreciendo sucesivamente, $\mathrm{y}$ de periantio tubuloso ulue sale fuera de la bráctea, partido en 6 divisiones, cuyas 3 estepiores pequeñas é iguales parecen dientes, mientras las 3 internas mucho mas grandes, cuya media constituye un labillo muy grande $\because$ trílobo. Segun los profesores Blume $y$ Lindley, tales flores constan de un cáliz liso con 3 dientes blancos casi tan largos como la corola, cuyo tubo es algo corto $\mathrm{y}$ su limbo interior es formado de un labio único entero ó con un diente de cada lado de su base; estambre cuyo filamento linear y petaliforme sirve de vaina á la parte superior del estilo, de punta en forma de gancho, apenas mas prolongada que la antera, que es escotada por el ápice. El fruto consiste en una cápsula bacciforme, trilocular, cuyas muchas semillas están provistas de un arilo que á veces deja su punta lihre: alpinia, F. 26, T. III.

475. Filamento ancho, pero no prolongándose en pico mas allá de la antera que lleva dos espolones por la base, 476. - Filamento prolongándose en forma de pico algo encorvado mas allá de la antera sin apéndices, 477 .

476. Plantas herbáceas vivaces, de cuyo rizoma palmeado ó á veces tuberculífero, salen las hojas sea radicales, sea alternaś y dísticas, sobre una especie de tallo herbáceo, pecioladas, envainadoras, simples, mas ó menos largas y lanceoladas; bojordo escamoso alto de $1 l_{1} 2^{\prime}$ á $2^{\prime}$ algọ mas ó menos, terminándose por una espiga gruesa ó mazorca oval, claviforme, simple y formada de grandes escamas bracteiformes que tienen en su axila dos flores envueltas cada una en su espata propia, corta y membranosa; de periantio tubulado, con limbo de 6 divisiones, de las cuales 3 son interiores y cortas, mientras las otras 3 internas, son soldadas entre sí por la base, con un labillo bífido mucho mas grande que las demas. Segun los señores Blume y Lindley, tales flores se componen de un cáliz mas corto que la corola, con 3 dientes desiguales é irregulares, de una corola infundibuliforme cuyo tubo algo encorvado se va ensanchando gradualmente hácia la garganta, sostiene un limbo con dos labios tripartidos; filamento ancho llevando una antera incumbente $y$ provista de 2 espolones que acompañan á su base, $\mathrm{y}$ con las 2 celdillas regadas en los lados de la hendidura del filamento; ovario ovoídeo algo trígono, trilocular, poliovulado, de cuyo ápice sale un estilo capilar largo que se termina por un estigma algo corvo. La fruta es una cápsula mas ó menos oval, de 3 celdillas, abriéndose por 3 valvas y conteniendo muchas semillas ariladas: curcuma, F. 25.

477. Plantas herbáceas vivaces, de rizoma articulado, palmeado, 
rastrero y á veces casi tuberculoso, de cuyo vértice sale un tallo falso anual de como $2^{\prime}$ a $3^{\prime}$ cle alto, con hojas simples, alternas y dísticas, enteras, lanceoladas, algo puntiagudas, envainadoras por la base y por consiguiente sentadas, con una lígula bífida. Bojordo escamoso, cuyas escamas son envainadoras, alto de como $6^{\prime \prime}$ a $12^{\prime \prime}$, y mas ó menos distante del tallo herbáceo, terminándose por una espiga gruesa simple, conoídea ó claviforme, escamosa y formada de brácteas grandes, ovales, imbricadas, que tienen en su axila 2 flores que florean sucesivamente, con una espata membranosa $y$ particular á cada una de ellas que envuelve antes de su entero desarrollo; de periantio doble, cuyo esterior, de 3 divisiones cortas, encierra el interior, tubuloso y petaloídeo, con 3 divisiones irregulares y desiguales, cuya inferior ó labillo es tríloba y colorada, mientras las superiores son amarillas. Segun Blume, esas flores son completas y formadas de un cáliz tubulado, que se abre de un solo lado y partido en 3 dientes; corola cuyo limbo doble tiene el esterior con 3 segmentos casi iguales y oblongos, mientras que el interior consta solarnente de un labio trilobado. El estambre consiste en una antera partida en dos partes y cuyo filamento se prolonga en una especie de pico simple y subulado. Pistilo formado de un ovario algo oval que lleva en su ápice un estilo filiforme largo y que pasa por dentro de la hendidura de la antera y va á salir por el ápice del pico hueco $\mathrm{y}$ abierto del filamento por donde se presenta el estigma cabezudo. El fruto es una cápsula coronada y ovoídea, de 3 celdillas y abriéndose por 3 ventallas, con muchas semillas ariladas : zingiber, F. 25.

478. Plantas herbáceas vivaces, de rizoma á veces tuberculoso: se parecen mucho á la curcuma; hojas simples, pecioladas, derechas $\dot{0}$ estendidas por el suelo, ovales ó acorazonadas, entre agudas y obtusas, basinervias y algo envainadoras. Flores en espigas radicales, otras veces en grupos de 6 á 10 flores contenidas en la vaina de las hojas y floreando sucesivamente; están acompañadas de 3 brácteas, de las cuales la una es mas larga y esterior, mientras las dos otras, interiores y laterales, son imbricadas; periantio doble cuyo esterior tubulado y monófilo es abierto lateralmente, mientras que el interior tiene el limbo tambien doble, de tal manera que la série esterior está formada de 3 divisiones estrechas y la interior, tambien formada de 3 segmentos, tiene el mediano mayor $\mathrm{y}$ bífido; pero segun los profesores Blume y Lindley, estas flores se componen de un cáliz tan largo como las brácteas y de una corola monopétala y tubulada, cuyo tubo largo. y filiforme lleva un limbo formado de 2 séries tripartidas cada una, cuyas divisiones esteriores son lineares y puntiagudas, mientras que de las interiores 2 son superiores, ovales y derechas, y la tercera inferior mas ó menos estendida y bífida. Filamento corto, pero dilatándose por encima de la antera doble con forma de cresta bífida. Pistilo compuesto de un ovario oval, trilocular, poliovulado y de cuyo ápice sale un estilo largo, filiforme y que se termina en un cstigma bilamelado. Cápsula de 3 celdas con algunas semillas : kcempferia, F. 25.

479. Filamento petaloídeo y provisto solamente de una media antera ó de una antera unilocular situada por su borde; estilo casi 
con figura de capucho y adherido al borde de un filamento estéril; cápsula frecuentemente monosperma por causa de aborto, y siempre lisa, 480. - Filamento petaloídeo con una media antera ó una antera unilocular situada en su borde; estilo bien plano y casi libre; cápsula membranosa con puas ó tubérculos caducos y conteniendo siempre algunas semillas, 481 .

480. Plantas herbáceas vivaces, con un rizoma ó tubérculos que salen de las raices, de tallos delgaditos herbáceos, anuales, nudosos y frecuentemente dicótomos, altos como de $11_{1} 2^{\prime}$ á $21_{1} 2^{\prime}$, saliendo del medio de hojas simples, pecioladas, envainadoras por la base, enteras, lanceoladas, pero no muy estrechas y un poco ovales, alternas, algo pubescentes por ambas caras ó lampiñas, basinervias y membranosas; flores blancas, pəqueñas, en panojas flojas y contenidas en brácteas glumiformes y decíduas, mellizas y largamente pedunculadas; de un periantio doble con 6 divisiones, de las euales 3 esteriores son verdes, foliáceas, ovales, puntiagudas y cóncavas, tenidas por un cáliz lejítimo al parecer de algunos botánicos, mientras las 3 interiores, petaloídeas y blancas, simulan una corola monófila tripartida. Pistilo formado de un ovario trilocular, con óvulos solitarios en cada celdilla : marantha, F. 26, T. II.

481. Primorosas plantas herbíceas vivaces, con rizomas rastreros, no raras veces tuberculíferos, de donde salen hojas grandes, pecioladas, lanceoladas y oblongas á la vez, obtusas, algo aguzadas por ambos estremos, alternas en los tallos altos de $5^{\prime}$ á $6^{\prime}$ algo mas ó menos, derechos y ramosos superiormente, cuyas divisiones llevan primorosas flores encarnadas ó amarillas, en espigas flojas, cuya reunion forma grandes panojas; los grupos que constituyen tales espigas salen de la axila de una bráctea espatiforme y bastante grande. Tales flores mellizas están envueltas por una bráctea propia membranosa y oboval, de manera que están acompanadas de brácteas glumáceas y constan de un periantio con 9 segmentos, á veces mas, otras veces menos, cuyos tres esteriores profundos, ovales, cóncavos, puntiagudos y foliáceos, son mucho mas cortos que los interiores, petaloídeos, colorados ó amarillos y en número de 6 , de los cuales 5 son derechos, mientras el sesto es reflejo y mucho mas grande; pero segun el profesor Lindley, estas flores son formadas de un cáliz monosépalo con 3 divisiones ovales y pequeñas y de una corola cuyos segmentos desiguales varian en número y en forma, de tal suerte que en ciertas especies los 3 esteriores son lineares, lanceolados y derechos, 2 de los 3 mas interiores son oblongos y recortados, mientras el tercero, rnas ó menos arrollado, está recortado por la punta. Filamento petaloídeo con una antera unilocular y sentada á lo largo de su borde. Pistilo formado de un ovario casi globoso, algo trígono, tuberculoso, trilocular y pluriovulado, de cuyo ápice sale un estilo casi lanciforme, casi libre y que lleva un estigma lateral; cápsula membranosa, erizada ó tuberculosa, cuyas puas son á veces caducas, globoso-trígona, trilocular, abriéndose por 3 ventallas y con algunas semillas : canna, F. 26, T. II: 


\section{VEJETALES DE FLORES COMPLETAS}

482. De corola monopétala, 483. - De corola polipétala, 808 . 684.

483. Ovario libre ó súpero, 484. - Ovario adherente ó infero,

484. Estambres 5 ó menos, 485. - Estamhres 6 ó mas, 673.

485. Menos de 5 estambres, 486. - Cinco estambres, 576.

486. Dos estambres, 487. - Cuatro estambres, 502.

487. Fruto carnudo drupáceo ó abayado, 488. - Fruto seco tan pronto capsular como aqueniforme, 493. 490 .

488. Una drupa cuyo mesocarpio es aceitoso, 489. - Una baya,

489. Árboles pequeños, pero á veces bastante grandes, muy ramosos, con hojas simples, alternas, pecioladas, lanceoladas, óvalolanceoladas, coriáceas, aguzadas por ambos estremos y puntiagudas. Flores pequeñas, blancas, dispuestas en racimos axilares mas ó menos cortos y de cáliz monosépalo, corto, 4 dentado; corola corta en forma de copa ó de rueda, cuyo limbo es partido en 4 segmentos planos y algo ovales; los dos estambres son opuestos, algo esertos o salientes; ovario oval, con uno ó dos óvulos, de cuyo ápice sale un estilo muy corto terminado por un estigma bífido, cuyos brazos son escotados. Drupa mas ó menos oval, de tamaño variado, pero siempre pequeña y raras veces mayor que el dedo pulgar, conteniendo un hueso monospermo por causa del aborto de un óvulo; color verde amarillento ó de aceituna cuando madura : olea, F. 74.

490. Cáliz y corola con 8 divisiones, 491. - Cáliz y corola de 5 segmentos, 492 .

591. Arbusto ramosísimo que se eleva á $3^{\prime}$ ó 5 ' lo mas, con hojas simples, muy cortamente pecioladas, ovales, algo puntiagudas, un poco acorazonadas cuando tiernas, opuestas ó verticiladas por á cuatro, enteras y lampiñas. Flores blancas bastante grandes, solitarias y terminales, muy cortamente pedunculadas, con brácteas filiformes situadas por la base del cáliz y tambien algunos pelos blancos; cáliz tubular, de limbo 8 á 12 dividido ó con lacinias casi filiformes; corola tubulada á veces con muchísimos segmentos, en número igual á los del cáliz, ó como formada de algunas corolas contenidas mas adentro de las otras: entonces faltan los órganos sexuales que se han vuelţo pétalos al v́olverse doble la flor, ó que habrán abortado: mongorium, F. 74.

492. Arbustos casi sarmentosos ó no, con muchos ramos opuestos de ordinario, pero algunas veces alternos, algo estriados, estendidos, delgados y muy largos, cuyas hojas opuestas y pecioladas son compuestas é imparipinadas ó á veces simples, las superiores de 3 en rama $y$ las otras de 7 . Flores blancas ó amarillas, pedunculadas y saliendo de la axila de una bráctea pequeña, en especies de panojas terminales, y de cáliz monófilo tubulado, de limbo partido en 5 lacinias filiformes muy profundas; corola hipocrateriforme, largamente tubulada, cuyo limbo partido en 5 segmentos ovales, grandes 
y puntiagudos es estendido, de prefloracion torcida; estambres inclusos cuyos filamentos cortos é insertos en el tubo llevan una antera grande, oval y puntiaguda; un ovario globoso, de cuyo ápice sale un estilo filiforme terminado por un estigma glanduloso, espeso, ovalalargado y verdusco. Baya con dos celdas, semilla solitaria y arilada: jasminium, F. 74.

493. Cápsula, 494. - Aquenio ó tetraquenio, 499.

494. Cápsula loculícida ó mas raramente septícida, pero sin elasticidad, polisperma; corola enrodada y con 4 divisiones, 495. Cápsula claviforme, abriéndose con elasticidad, provista de retináculos, unilocular, polisperma; corola bilabiada ó boquiabierta y rasgada: 495 bis.

495. Plantas herbáceas anuales ó vivaces y entónces sofruticosas, mas ó menos ramosas, altas de $4^{\prime \prime}$ á $10^{\prime \prime}$, tendidas ó derechas, cuyas hojas enteras, festoneadas, dentadas ó lobadas, lampiñas ó pubescentes y coriáceas, son opuestas y alguna vez que otra alternas, en especial hácia la sumidad de las ramitas, sentadas ó muy cortamente pecioladas. Flores blancas, azules ó moraduscas, en espigas terminales ó casi solitarias y axilares, de cáliz monosépalo con 4, 5 ó raras veces 3 divisiones profundas, aguzadas y persistentes; corola de limbo 4, 5-partido y lijeramente desigual; en la yema los segmentos laterales son esteriores; estambres esertos alternando con el lóbulo superior de la corola; pistilo formado de un ovario ovoídeo, comprimido, bilocular y multiovulado, de cuyo ápice sale un estilo filiforme terminado por un estigma obtuso y bífido. Cápsula comprimida, obcordada, con 2 ventallas y 2 celdas conteniendo muchas semillas: veronica, F. 68, T. IV.

495 bis. Anteras cornudas ó espolonadas, mucronadas ó callosas, 496. - Anteras mochas, barbudas ó lampiñas por la base; 496 bis. -496. De celdillas cuya inferior sola es callosa ó mucronada por la base ; cípsula 4, 2-esperma, claviforme, con los segmentos de los tabiques quedándose adheridos á las valvas, 498. - De celdillas iguales, cornudas ó espolonadas; cápsula 4-esperma deprimida por la parte media. Plantas herbáceas ó frutices, ramosas, de hojas simples, opuestas, pecioladas, entejérrimas y lampiñas. Flores en espigas opuestas, axilares ó en espiga terminal bracteadas y á la par con bracteolas grandes, persistentes, mas largas que el cáliz, valvar y ocultándole, profundamente 5 -fido, con las lacinias iguales; corola boquiabierta, con el tubo corto y mediocre, bilabiada y cuyo labio superior es concavo, mientras el inferior es trílobo; estambres ins.ertos por debajo de la parte media del tubo de la corola, cuyas anteras biloculares tienen las celdillas insertas oblícuamente en el conectivo y sobrepuestas; estigma obtuso: adhatoda, F. 72. Or. II, T. V, G. II.

496 lis. Mochas por la base, de celdillas desiguales y lampiñas; cápsula claviforme 4, 2-esperma, cuyos segmentos de los tabiques se quedan adheridos á las ventallas, 497. - Nochas por la base, de celdillas paralelas, cuya inferior es barbuda; cápsula deprimida y polisperma desde la base. Plantas herbáceas anuales ó vivaces, á veces matas y hasta frutices, con hojas simples, opuestas, laricco- 
ladas, aguzadas por la base hasta volverse peciolo, lampiñas y enteras. Flores en racimos axilares, delgados, simples, 2 ó 3-chótomos, unilaterales, con 2 brácteas opuestas mas cortas que el cáliz, y dos bracteolas mínimas situadas hácia la base del pedícelo, despues nulas; cáliz pubescente y con glandulitas pediceladas entremezcladas, de lacinias filiformes; corola blanco-purpúrea á veces disciplinada. mas ó menos hirsuto-glandulosa. Filamentos de los estambres peludos; cápsula lanceolada conteniendo 12, 16 semillas : andrographis, F. 72, Or. II, T. IX.

497. Plantas herbáceas ó frutices y hasta arbustillos, muy ramosos, derechos ó divaricados y hasta tendidos por el suelo, cuyos tallos y ramos tienen con frecuencia 4 caras; hojas simples, sentadas ó muy poco pecioladas, ovales ú óvalo-lanceoladas, aovadas ó aovadolanceoladas, lanceolado-aguzadas ú oblongo-lanceoladas, obtusitas ó algo puntiagudas, lampiñas. Flores en racimos terminales compuestos, en espigas ó axilares, acompañadas de brácteas pequeñas, de cuya axila salen; de cáliz monosépralo 5 ó 4-partido, con los segmentos iguales ó cuyo superior es menor; corola mas ó menos tubulada, con los labios aproximados, el superior sub-entero ó escotado y el inferior 3-festoneado ó no aproximados y cuyo inferior está estendido y anchamente trílobo; estambres de anteras cuyas celdas están ó no separadas por un conectivo: dianthera, F. $72, \mathrm{~T} . \mathrm{V}$, G. I.

498. Plantas fruticosas, sofruticosas, herbáceas ó á veces arbustillos mas ó menos ramosos, de tallos algo nudosos, altos de $3^{\prime}$ á $6^{\prime}$, con hojas simples, opuestas, sentadas ó apenas pecioladas, lanceoladas, aovadas ó aovado-lanceoladas, elíptico-lanceoladas, obtusas ó puntiagudas. Flores en espigas, de ordinario de 4 caras, provistas de brácteas bastante grandes, de cuya axila salen, de cáliz 5-partido, cuyos segmentos son iguales ó á veces el superior mas pequeño; corola colorada ó purpúreo-pálida, con el lábio inferior abierto $\mathrm{Y}$ estendido, de lóbulos oblongos mas ó menos obtusos, mientras el superior es escotado: justicia, F. 72, T. V.

499. Estambres cuyos filamentos largos y arqueados son provistos de un diente lateral, con anteras biloculares $y$ sin conectivo alguno, 500. - Estambres cuyo filamento cortito está articulado con un conectivo largo y transversal, del cual un brazo ascendente se termina por una celda fértil de la antera, mientras el otro, mas cortn y de ordinario descendente, lleva la otra celdilla, pero rudimentaria y estéril, 501.

500. Primorosísimo arbusto muy ramoso, derecho, que se eleva ă $3^{\prime}$ ó $4^{\prime}$ de alto, con muchísimas hojas sentadas, lineares, enteras, lampinas, pero de cara inferior blanquecina y glauca, mientras la superior es de un color verde subido, enteras, de bordes doblados por fuera. Flores azuladitas ó blancas, teñidas de azulito, con el cáliz algo purpuráceo, dispuestas en racimos cortos paucífloros ó en grupos axilares opuestos y casi sentados, saliendo de la axila, de brácteas ó de hojas florales mas cortas que el cáliz, cortamente pedunculadas y de un cáliz monosépalo oval, campanudo y bilabiado. cuyo labio superior es entero, mientras el inferior es híido; corola 
no campanuda, pero solamente algo crecida lıácia la garganta, bilabiada é iqual, cuyo labio superior es entero ó escotalo y derecho, mientras que el inferior es bífido, con el lóbulo mediano muy ancho, cóncavo y algo doblado hácia abajo; anteras líneares de celdillas confluentes; estilo simple saliendo del medio de los cuatro ovarios reunidos en el fondo del cáliz, tan largo como los estambres y terminado por un estigma bífido, cuyo lobulo superinr es mas cortito; al fruto es un tetraquenio: rosmarinus, F. 76, T. I, G. II.

501. Primorosos rejetales tan pronto herbiccos como sofruticosos, de tallo siempre de 4 caras, mas o menos ramoso, derecho y que se eleva á l'o ${ }^{\prime} 3^{\prime}$ de altura, con hojas simples algo pecioladas; un poco dentadas, opuestas, pubescer tes, así como las demas partes. Flores en espigas terminales mas ó menos flojas, compuestas de verticilos mas ó merıos numerosos que salen de la axila, de hojas florales cuyo color varia tanto como el de las flores que acompanan, las cuales son tan pronto coloradas como azules y constan de un cáliz monosépalo tubulado, sul)..campanudo y bilabiado, cuyo labio superior es tridentado, mientras que el inferior es solamente bílobo; corola muchísimo mas grande y mas larga que el cáliz, largamente tubulada y bilabiada, con el labio superior muy grande, faleiforme, comprimido y escotado, mientras que el inferior es algo mas corto, tríloho, con lóbulos desiguales, de tal manera que el mediano es maror que los demas y redondeado. Pistilo compuesto de 4 ovarios uniloculares y nniovulados, ginobásicos, de cuyu centro sale un estilo simple, largo, filiforme, arqueado y terminado por un estigma bífido. El fruto consiste en 4 ó en 2 aquenios, porque con frecuencia abortan 2: salvia, F. 72, T. I, G. I.

502. Estambres siempre 4, didínamos, 503. - Estambres 4, nunca jamás đidínamos, $55 \%$.

503. Fruto siempre seco, capsular ó aqueniforme, etc., 504. Fruto mas ó menos carnudo, 548.

504. Aqueniforme ó capsular, 505. - Una especie de drupa no carnuda y cuyo hueso es ganclioso, 545 .

505. U̇no solo ó algunos aquenios contenidos en el cáliz persistente, 506.- Una cápsula, 524.

506. Flores de corola labiada; tallo con 4 caras, 512. - Flores de corola labiarla ó no; tallo no cuadrangular, 507.

507. Fruto dicoco, 508.- Un tetraquenio, corola no labiada, 511.

508. Flores en espiga; nuecesitas lineares contenidas en una escavacion del eje de la espiga, monosperma; corola no labiada, 509. - Flores en cabezas ó espigas ; fruto formado tambien de dos cocos, o de dos nuecesitas coherentes y monospermas, 510 .

509. Plantas herbíceas anuales ó vivaces y sofruticosas, cuyos tallos ramosos, derechos ó divaricados se elevan de $l^{\prime}$ á $3^{\prime}$ y $4^{\prime}$ de altura ; lampiños, pubescentes ó velludos, con hojas simples, cortamente pecioladas, aovalas ú ovales, aserradas, de ápice obtuso ú obtusito y de base aruzada y pareciendo volverse peciolo, opuestas. Flores azules de ordinario ó á veces coloradas, en espigas terminales delgarlas, largas, derechas ó algo arqueadas, cilíndricas, cuyo eje bastante grueso presenta huecos ó escaraciones en las cuales se 
hallan las flores solitarias y sentadas en la axila de una bráctea bastante grande, que despues de la fecundacion tapa dicha cavidad en donde se van malurando las semillas; de cáliz monosépalo, tubulado $r$ con 4 dientes, marcescente ó persistente y que envuelve las semillas; conrola de tubo muy largo, un poco arqueado, llevando un limbo partido en 5 segmentos desiguales; estambres inclusos, de los cuales dos solos son fértiles; de anteras cuyas celuas son direrjentes; un ovario unilocnlar biovulado, de cuyo vértice sale un e-tilo largo, filiforme $y$ terminándose en un estigma simple y cabezudo. Las dos semillas que constitigen el fruto están aplicadas la una á la otra por la cara, de tal manera que forman así una especie de aquenio ovoídeo, prieto y mueronado : stachytarpha, F. 75, T. VI.

510. Plantas herbíceas o arbustos que se elevan de $2^{\prime}$ hasta $6^{\prime \prime}$ de altura, mas ó menos ramosos, miry aromáticos, desparramados, arraighntes ó derechos; hojas simples, opuestas, mas ó menos pecioladas, pubescentesi ó peludas, romboíleo-aovalas, espatuladas, espatulivlo oblongas ó elíptico-oblongas, aovado-oblongas ó lanceolailo-lineares, de ordinario aserradas y algunas veces sub-enteras. Flores en cabezas ó espigas mas ó menoz pedunculadas y de: cáliz mono:épalo 2, 4-dentado; corola bilab:ada, con el limbo abierto; estambres inclu=os, de anteras con las celdillas paralslas. Estigma oblicuamente cabezudo: lippia, F. 75 , T. I, S.-T. I, G. I.

511. Plantas herbíceas ó sofruticosas, de tallo ramoso derecho, tendido ó divaricado, alto de $2^{\prime}$ á ' $3^{\prime}$, con hojas sencillas, opuestas ó verticilaras, mas ó menos pinatífilas ó festoneadas, muy cortamente pecioladas, aovadas ó aorado-lanceoladas. Flores sentadas, azules, en espigas y formadas de un cíliz monosépalo 5-dentado, con uno de los dientes de ordinario mas corto, la bráctea de cuya axila sale la flor es mas larga que el cáliz; corola oblícuamente 5-loba, infundibuliforme, y cuyos segmentos son desicuales. Estambres inclusos, de los cuales 2 abortan algunas veces. Pistilo formado de un ovario 4-lobo, de cuyo centro sale un estilo simple terminado por un estigma obtuso, cuya segunda division está abortada. Fruto formado de 4 cocos contenidos en el fundo del cáliz persistente y urceolado: verbena. F. 75, T. I, S.-T. VI.

512. Corola bilabiada siempre, 513. - Corola monolabiada, cuyo labio superior falta y está reemplazarlo por una hendidura pur donde saler con frecuencia los estambres. Plantas herbáceas ó á veces sofruticosas, de tallo derecho simple ó algo ramoso, alto de $11_{1} 2^{\prime}, 2^{\prime}$ ó $3^{\prime}$, lampiñas, pubescentes ó alampiñalas; hojas simples, opuestas, peciola las mas ó menos, cuneiformes y elípticas á la vez ó aovadas y aova lo-lanceoladas, pinatífilo aserradas, con los lóbulos ó dientes oblongos, ó aserrarlas solamente. Flores en espigas delgadas formadas de verticilos aproximados, ó axilares y en grupos bífloros, de cáliz moriosépalo 5-dentado ó 5-fido; corola como dos veces mas larga que el cíliz, cuyo lóbulo inferior ó mediano del labio inferior es mucho mas grande que los laterales; los estambres inferiores. son los mas largos. Pistilo formado de 4 ovarios uniloculares, uniovulados, de cuyo centro sale un estilo tan largo camo los estambres, con los cuales sale á fuera y terminado por un estigma bífida. El fruto 
consiste en 4 aquenios ó nuecesitas oblícuamente situadas, ordinariamente reticulado ásperas, raras veces lisas y una vez que otra glandulosas : teucrium, F. 76, T. IV.

513. Cáliz y corola ambos bilabiados, 514. - Corola sola bilabiada, cáliz con 5 ó 10 dientes, 517 .

514. Cáliz cuyo labio superior está provisto de un apéndice escutiforme, 515. - Labio superior formado por el diente superior mas largo y decurrente y sin apéndice alguno, 516.

515. Plarıta herbácea desparramada, ramosa por la base, alanpiñada o pubescente y alta de $6^{\prime \prime}, 12^{\prime \prime}$, con hojas opuestas, simples, pecioladas, aovadas ó deltoídeas, obtusas, algo aserradas, cuyas florales son mínimas, elípticas y enteras; flores en racimos cortos, flojos $y$ unilaterales, formados de verticilos distantes y bífloros, cuyo vértice las lleva esparcidas y solitarias; de cáliz con dos labios bien pronunciados y enteros, cerrado sobre el fruto, pero reventándose por la base, mas largo que el pedícelo y por fin algo acrescente; corola azul, pubescente, larga de $6^{\prime \prime \prime}-8^{\prime \prime \prime}$, cuyo tubo delgado, cilindrico, dilatado hácia la garganta es mucho mas largo que el cáliz y eserto. Estambres paralelos, cujos 2 inferiores son mas largos, anteras peludas uniloculares en los largos y 2-loculares en los mas cortos. Lóbulos del estilo desiguales; nuecesitas tuberculosas : scutellaria, F. $76, \mathrm{~T}$.

516. Planta herbácea anual que se vuelve casi como fruticosa, de tallo ramoso, alto de $l^{\prime}$ á $1 l_{l} 2^{\prime}$, alampiñada, con hojas simples, pecioladas, aovadas y aserraditas, elípticas ó elíptico-lanceoladas. Flores en racimos ó espigas formados de verticilos de á 6 o 10 flores, de cáliz monosépalo muy desigual y por último arqueado, cuyo diente supcrior aovado, obtuso y cóncavo, es decurrente por la base del tubo, mientras los cuatro inferiores son subulados. Corola de labio superior 4-fido, mientras el inierior es entero y de ordinario llano; estambres arqueados, inclusos y con los filamentos desnudos : ocymum, F. 76, T. VII, G. II.

517. Cáliz 5-dentado, con 5 ó 13 nervaduras, 518.- Cáliz 10, 8dentado y con 9 nervaduras; estambres paralelos, cuyos dos inferiores son mas largos; celdillas de las anteras diverjentes, 521.

518. Dientes subiguales; 13 nervaduras; tubo de la corola subcilíndrico; lóbulos llanos, 519. - Dientes calizinales espinosos: labio superior de la corola entero, mientras que el inferior es trílobo, 520 .

519. Plantas herbáceas ó fruticosas, de tallo tendido, delgado y lampiño, otras veces desparramado, pubescente y alto de $1^{\prime}$ á $12^{\prime}$; hojas pequeñas, obaovadas ó aovado-redondeadas, revolutas por la márjen, enteras y de cara inferior blanquecina, ó deltoídeo-redondeaditas, obtusamente algo aserradas. Flores blancas ó purpúreoblancas, axilares ó racemosas, cuyos verticilos son de á 2 ó de á 4 , pediceladas ó sub-sentadas; estambres distantes, ascendentes, de anteras inclusas y con las celdillas paralelas; estilo eserto terminado por un estigma bífido: micromeria, F. 76, T. II, S.-T. IV.

520. Vejetal bienal, de tallo herbáceo, fuerte, derecho, pubescente ciampiñado, con hojas palmatipartidas ó las mas superiores 
enteras; flores en espigas terminales, de cáliz alampiñado, corola roja, pubescente, cuyo labio superior es cóncavo, el tubo recto y no anillado; estambres paralelos, esertos, cuyos dos inferiores son mas largos. Lóbulos del estigma subiguales. Nuecesitas 3-gonas y truncadas : leonurus, F. 76, 'I'. III, S.-T. III.

521. Corola blanca inclusa y no anillada, cuyo labio superior cóncavo y entero es lanudo, 522. - Corola carmesí, como dos veces mas larga que el cáliz, velluda y cuyo labio superior elongado y mucho mas largo que el inferior, que es trífido, 523.

522. Planta herbácea anual, de tallo derecho algo ramoso, alto de $11_{[} 2^{\prime}$ á $3^{\prime}$, pubescente, con hojas aovado-lanceoladas ú aovadas, obtusamente aserradas, opuestas y pecioladas. Flores en verticilos axilares como de $1^{\prime \prime}$ de diámetro, ylobosos, distantes y formados de algunas flores, saliendo de la axila de brícteas lınear-aguzadas, y de cáliz oblícuo hácia arriba y arqueado, cuyos dientes son espinosocerdáceos desde la base subulada, con el superior mucho mas largo. Lóbulos del estigma desiguales, el superior mas corto; nuecesitas 3-gonas y obtusas: leucas, F. 76, T. III, S.-T. III.

523. Planta herbácea anual, cuyo tallo de 4 caras, derecho, lampiño, se eleva de $2^{\prime}$ á $6^{\prime}$ de altura, poco ramoso, con hojas largamente pecioladas, bastarte grandes, aovadas, con la base un poco acorazonada, festoneado-aserradas, cuyas superiores son mas lanceolarlas y casi sentadas. Flores primorosas en verticilos terminales, distantes, muy gruesos y con muchísimas flores, de $2^{\prime \prime}$ á $21_{[} 2^{\prime \prime}$ de diámetro y de cáliz monosépalo arqueado y oblícuo, con dientes espinosos, desiguales, lanceolado-lineares, cuyo superior ès mucho mas largo y subulado. Anteras aproximadas por pares, cuyas celdillas divaricadas son agudas y á veces paralelas; lobulo superior del estigma cortísimo : leonitis, F. 76, T. III, S.-T. III.

524. Cápsulas mas ó menos comprimidas, mas ó menos largas y con frecuencia silicuiformes, biloculares y con muchas semillas aladas situadas en una placenta central muy desarrollada, 525. - Cápsulas ni comprimidas ni silicuiformes tampoco, biloculares, y cuyas semillas no son nunca aladas, 532 .

525. Cáliz profundamente 2-lobo; dos estambres fértiles solamente, con una celdilla de las anteras erguida y la otra pendiente; semillas con lana, ó una franja por sus dos estremos. 526, - Cáliz tubuloso ó campanudo; todos los estambres fértıles, semillas aladas, 527.

526. Arbol granảe que se eleva á como $50^{\prime}$ ó $60^{\prime}$ de altura, bastante coposo superiormente, lampiño, con hojas simples, opuestas $\dot{0}$ verticiladas, aovado-oblongas ú oblongo-lanceoladas, obtusitas, enteras, largamente pecioladas, anchas de $3^{\prime \prime}$ á $5^{\prime \prime}$. Flores primorosas blanco-rosadas y saliendo antes que las hojas, en panojas tlojas $\mathbf{Y}$ terminales, de cáliz monosépalo largo de $2^{\prime \prime \prime}$, con los labios enteros, redondeadito-mucronados; corola mucho mas grande, campanuda, pronto caduca, de limbo desigualmente 5-lobo, laı ga de $15^{\prime \prime}$ á $16^{\prime \prime}$ y ancha de $10^{\prime \prime \prime}$ á $8^{\prime \prime \prime}$. Ovario bilocular, multiovulado y de cuyo vértice sale un estilo filiforme terminado por un estigma bilanelado; cápsula silicuiforme, sub-cilíndrica, loculícida, larga de $2^{\prime}$ y col- 
gante, cuyas semillas, lineares, aguzadas por sus dos estremos, son sin ala, pero provistas de un poco de lana sedosa por la punta : catalpa, F. 70, T. II, S-T. II, G. II.

527. Cáliz campanudo, de ordinario eerrado en el boton; Tejetales trepadores ó bejucos, con hojas 2,3 -folioladas y terminadas por un zarcillo, 528.-Cáliz tubulado; hojas compuestas, dijitadas ó pinadas, sin zarcillo alguno, 529 .

528. Vejetales leñosos, abejucados, de tallos largnísimos, ramosísimos, trepadores, lampiños ordinariamente y á reces pubescentes, tomentosos ó alampinados; con hojas opuestas, compuestas de 2 ó 3 hojuelas aovado-oblongas ú aorado-aguzadas, elípticas ó elípticooblongas, enteras, lampiñas, pubescentitas por la cara superior $\mathrm{y}$ tomentoso-veno:as por la inferior. Flores primorosas rosadas, moraduseas ó amarillas, en racimos, cimas, panojas y gi upos terminales ó axilares a'gunas veces, de chrliz monosépalo truncado ú ondeado, otras veces con dientes mínimos, ó anchamente campanudo, oblícuamente 5-festoneado, cuyos festones son anchins; corola campanuda ó infundibuliforme con 5 lóbulos, frecuentemente desiguales, lampiña ó pubescente; celdillas de las anteras diverjentes; cápsula silicuiforme, llana, comprimida y marjenicida, nıas o menos larga y estrecha, con semillas aladas por wmbos estremos, situadas en una série á lo largo de los bordes de la placenta planos, formando tabique, y paralelas con ella: bignonia, F. 70, T. I, S. T. I.

529. Cáliz tubuloso unicamente; el quinto e-tambre estéril y barbudo por el ápice; celdillas de las anteras direrjentes pendientes 0 una de ellas abortada, 530. - Cáliz tubuloso, de limbo ordinariamente con dos labios cortitos, 531 .

530. Primoroso árbol, bastante grande y ramoso, de lindísimas hojas imparibipinadas, curas pínulas son 4 á 8 , con 8 á 17 pares de hojuelas oblícrlamente romboídeo-oblongas, obtusitas y largas de $8^{\prime \prime \prime}-10^{\prime \prime \prime}$; flores azules en panojas terminales, de cáliz perqueño 5 dentado, largo de $2^{\prime \prime \prime}-3^{\prime \prime \prime}$ solamente; corola campanuda por arriba de la base delgada, lampiña, large de $1112 "$, con el linilio desigualmente 5-lobo. Cápsula leñosa, llana y comprimida, loculícida, ovalredondeadita y escotada por el ápice redondeado, larga de $2^{\prime \prime} \mathrm{y}$ anclia de $8^{\prime \prime \prime}$ á $10^{\prime \prime \prime}$; semillas aladas insertas á lo largo de la línea media de las ventallas y jaralelas á ellas, tabique apenas visible ö abortado: jacaranda, F. 70. T. II, S.-T. II, G. III.

531. Arboles ó arbustos raras veces trepadores, de ordinario lampiños, algunas veces tomentosos, de hojas compuestas opuestas, dijitadas ó imparipinadas, con escamitas ordinariamente distantes ó desprovistas de ellas, formadas de $3,5,7,8,4,6$, hojuelas coriáceas, bastante tiesas, ó cartáceas, de figura bastante variada y de ordinario lampinas. Flores ordinariamente en corimbos terminales, rosadas, blancas ó amarillas; de cáliz monosépalo cuyo limbo es desigual, otras veces igual y 5 -dentado; corola infundibriliforme, cujo tallo se va gradualmente dilatando, ó rentrudo por encima de la base, con 5 lóbulos lijeramente desiguales. Celdillas de las ariteras diverjentes. Cápsula silicuiforme, loculícida, con semillas aladas por los dos estremos, dispuestas en una sola série á lo largo del 
borde del tabique placentario y paralelas con él : tecoma, F. \%0, T. II, S.-T. II, (r. I.

532. Cáp:ulas abriéndose con elasticidad y de dehiscencia loculícida, y con retináculos, 532 bis.-Cápsulas abriéndose sin elasticidad, y desprovistas de retináculos, 536.

532 bis. Cápsula cuyos retináculos nunca dentados son mas ó menos obtusos, 533. - Cápsula de retináculos escotados 2, 3-dentados. Plantas herbáceas ó sub-leñosas, con tallo 4-angular y lampiño; hojas opuestas, simples, anchitas, serpeadas ó festoneadas, aovadooblongas, adelgazado-obtusas, obtusamente dentadas, aguzadas por la ba:e, pecioladas y rayadas superiormente. Flores color grana, sub-ternadas en ramitas mas ó menos alargadas, pedunculadas y como en cabezuelas, cuyas brácteas comunes lanceoladas y sentadas son mas largas que la cabezuela, mientras que las particulares ó propias, ovales, obtusas y enterísimas, son mas cortas; cáliz 5partido, de lacinias subiguales, lineares y obtusas; corola sub-hipocrateriforme, de tubo encorvado que se vuelve garganta ó es angostamente obcónico, con el limbo =ea mayor 5-partido, de lacinias abiertas y aovadas, sea menor enderezado, siendo entonces angostamente infundibuliforme la corola; estambres 4 , algo esertos, mas rara vez algo mas cortos que la gar@anta é insertos hácia el ápice del tubo corto, pero hasta el limbo están casi apareados y membranoso-adheridos entre sí, cerca de la division del limbo están libres - de las fauces y siguen diadelfos todavía durante un trecho corto; anteras oblongas cuyas celdas situadas en un conectivo mediocre y asaetado son diverjentes por la base. Estigma bilabiado, con los labios espesos y planos, cuyo superior es mas corto. Cápsula contraida desde la base hasta el medio, sin celdas ni semillas tampoco, que están por encima de su parte media y en numero de 8, 12, llanas : arrhostoxylum ó barleria, F. 72, Or. II, T. I.

533. Celdillas de las anteras paralelas, no diverjentes y siempre mochas, 533 bis. - Celdillas de las anteras moraduscas, paralelas, pero diverjentes por la kase aflechada, mocha ó sub-mucronada. Plantas herbiceas de los lugares húmedos y hasta algo pantanosos, de tallo derecho ó tendido y cuadrangular, con hojas opuestas, jecioladas, sinıples, entejérrimas, lanceoladas, oblongas ó algo fesioneaditas, con lineas densas por la cara superior, peludas ó lampinas. Flores axilares cimoso-aglomeradas, formando verticilos enteros y diminutos; brácteas pestañosas; cáliz tubuloso, semi-5-fido, con las lacinias iguales y por fin. 5 -partido, con las divisiones pelierizadas o barbudas; corola de garganta abierta, con el labio superior bitido, mientras el inferior, convexo y rugosito hasta el medio, es trífido. Estambres 4 didínamos, todos fértiles, á veces apareados por la base insertos en el tubo de la corola é inclusos. Ovario bilocular, con celdillas polioruladas, estilo simple con el estigma indiviso, alesnado y enco'vado. Cápsula angosta, rollicita, 6-estriada, bilocular, polisperma, loculícido-bivalve, con las valvas medio septíferas, cuyas semillas pequeñas, circulares, comprimidas y lisas; retinaculos cortos y obtusos : hygrophylla, F. 72, Ur. II, T. VI.

533 bis. Cápsula mas o menos sub-comprimida con $4,21,2$ semi- 
llas, cuyos segmentos de los tabiques se quedan adheridos á las valvas, frecuentemente por fin reducidos por encima de las semillas, 534. - Capsula ovoídea con 8 semillas insertas desde la base, con los segmentos de los tabiques separándose de las ventallas, 535 .

534. Plantas herbáceas, con raices fasciculadas y algo tuberculosas, ó vejetales fruticosos, siempre vivaces, de tallos derechos, hastante ramosos y altos de 11 [ $2^{\prime}$ á $3^{\prime}$, con hojas opuestas, cortamente pecioladas ó casi sentadas, simples, lanceoladas, ó lanceoladooblongas, aovado-lancéoladas ó elípticas, lampiñas, alampiñadas $\mathrm{y}$ á reces pubescentes; flores axilares, racemosas ó en cimas axilares, de cáliz monosépalo 5-partido ó profundamente 5-fido, subigual y mucho mas pequeño que la corola, con bastante frecuencia acompan̄ado de dos brácteas situadas por debajo de las flores laterales; corola infundibuliforme, azulada, mucho mas grande que el cáliz, de limbo casi igual ; estambres inclusos, con las celdillas de las anteras paralelas: ruellia, F. 72 , Or. II, T. VII.

535. Plantas herbáceas anuales ó sub-fruticosas, lampiñas ó alampiñadas, altas de $l^{\prime}$ á '2', ramosas y con hojas opuestas, simples, peciolarlas, aovadas, aovado-lanceoladas, lanceolado-lineares, aguzadas; flores fasciculadas y dispuestas en espigas, sostenidas por brácteas foliáceas y cruzadas; de cáliz ら-partido igual y bibracteado; corola infundibuliforme, lijeramente arqueada y casi reg"ular; estambres inclusos, de anteras con las celdillas paralelas: blechum, F. 72 .

536. Corola bilabiada, 537.- Corola nunca bilabiada: cápsula de dehiscencia loculícida, 542.

537. Corola enrodada, provista de apéndices sacciformes situados en su garganta; cápsula locuíícida, 541. - Corola nunca enrodada ni con apéndices tampoco; cápsula no loculícida, 538.

538. Cáliz 5-partido, desigual, con el segmento superior mas ancho que los laterales; lábio superior de la corola esterior en la prefloracion, 539. - Cáliz 5-partido, con el segmento superior mas pequeño ; cápsula con muchas semillas y picuda, 540 .

539. Yerbecitas anuales ó vivaces de los lugares húmedos, cuyos tallos herbáceos, largis de $4^{\prime \prime}$ á $6^{\prime \prime}$, muy ramosos, son desparramados, rastreros, arraigantes ó derechos, lampiños ó puluescentes; con hojas opuestas, pecioladas ó subsesiles, aovadas, lanceolado-lineares, ovales, espatuladas ú obaovadas, enteras ó aserraditas. Flores axilares cuyo pedícelo mas ó menos largo está algunas reces provisto de dos brácteas situalas hácia el ápice; celdillas de las anteras paralelas de ordinario, raras veces diverjentes; estigma obtuso, bífido ó cabezudo. Cápsula con 2 ó 4 val vas separándose de la placenta central : herpestis, F. 68, S.-O. II, T. VII.

540. Planta herbácea anual, de tallo cilíndrico, derecho, mas ó menos ramoso, alta de $3^{\prime}$ á $5^{\prime}$, segun la riqueza del suelo en que vejeta, guarnecido de muchas hojas simples, peciolalas, alternas, aovado-lanceoladas, aguzadas, enteras ó un poco dentadas inferiormente, pubescentes y con puntitos por la cara inferior, bastante grandes. Flores axilares, cortamente pedunculadas solitarias, con 2 estípulas situadas hácia la base del pedúnculo y saliendo de la 
parte esterior de una glándula; de cáliz con divisiones casi lineares r mucho mas corto que la corola blanca teñida de rosado y larga de I" á $l_{1} 2^{\prime \prime}$, como campanurla, con 5 divisiones desiguales cuya inferior es mucho mas grande que las otras; estambres inclusos é insertos en el tubo corolar, en donde se observa un quinto filamento rudimentario. Pistilo formado de un ovario cónico y algo tetrágono, de cuyo vértice sale un estilo que alcanza solamente la garganta de la corola y se termina por un estigma bífido, cuya division superior es algo mas larga que la inferior. Cápsula ovoídeo-oblonga, algo tetrágona ó con 4 surcos, un poco picuda con bastantes semillas angulosas, $\mathrm{y}$ abriéndose por el ápice por 2 ventallas: sesamum, F. 71, T. I.

541. Plantas herbáceas anuales, lampiñas ó pubescentes, de tallo derecho, bastante ramoso y alto de $1^{\prime} 1$ [ $^{2}$ á $2^{\prime}$ algo mas ó menos : hojas simples cuyas inferiores son opuestas y á reces todas, simples, oblongo-lineares, lanceoladas ó linear-lanceoladas, puntiagudas, redondeadas for la base, sesiles ó subsesiles, sub-enteras ó un pcco aserradas superiormente. Flores axilares ó en racimos flojos; de cáliz monośn palo 丂̆-fido ó ŏ-partido; corola violada muy hermosa. ancha de $6^{\prime \prime \prime}$ á $8^{\prime \prime \prime}$, con los lóbulos inferiores oblongos, obtusos y los apéndices cortos; celdillas de las anteras diverjentes. Cápsula globosa loculícida por la base : angelonia, F. 68 , S.-Or. II, T. IV.

542. Corola rosada campanudo-infundibuliforme, con 5 lóbulos desiguales y los dos superiores interiores en la prefloracion; estambreis inclusos y peludos, de anteras aproximadas por pares, 543. Corola amarilla conniventc-campanuda ó sub-globosa, reticulada, con el limbo 5-fido oblícuo, cuyos 2 lóbulos superiores son esteriores en el boton; estambres inclusos ni velludos ni con las anteras apareadas, 544 .

543. Planta herbácea, anual, áspera y un poco pelierizada, alta de $1^{\prime}-112^{\prime}$, de tallo delgado y poco ramoso, con hojas opuestas, lineares, bien enteras y largas de $1^{\prime \prime}-2{ }^{\prime \prime}$. Flores rosadas en racimos ó espigas terminales flojos, cuyos pedícelos filiformes son mucho mas largos que ellas, con 2, 1 bracteita situada hácia el medio; cáliz casi mitad mas corto que el tubo zorolar, infundibuliforme y casi lampiño, con los dientes cortamente subulados. Estigma achatarlo y obtuso. Cápsula inclusa, ovoídeo-globosa : gerardia, F. 68, S.-Or. III, T. II.

544. Plantas herbáceas derechas, ásperas, pelitiesas, creciendo parásitas en las raices de łos otros vejetales: la caña de azúcar especialmente, que mata, de tallo tieso, poco ramoso y alto de $12^{\prime \prime}$ á $15^{\prime \prime}$; hojas subsesiles, simples, opuestas, aguzadas desde la base sub-acorazonada, aserrado-dentadas, híspidas y largas de $1 l_{[} 2^{\prime \prime}$ á $2^{\prime \prime}$; flores en racimos espiciformes terninales, axilares y coltamente pedunculadas. Estilo encorvado terminado por un estigma achatado y obtuso; cáliz sub-globoso, anchamente 5-dentado, con el diámetro de $4^{\prime \prime \prime}$ á $5^{\prime \prime \prime}$; corola inclusa ó cortamente eserta y poco abierta y amarilla : alectva, F. 68, S.-Or. II, T. VI.

545. Cáliz 5-fido y ohlícuo; corola bilabiada con el tubo oblícuamente campanudo, 546. - Cáliz espatáceo 5-dentado, corola hipo- 
crateriforme, de tubo largo, filiforme, campanurlo superiormente, de limbo lijeramente bilabiado, con ios segmentos sulignales, 547.

546. Plantas herbáceas annales, cuyo tallo poco ranıso se eleva a $3^{\prime}$ o $4^{\prime}$ de altura, pubescentes $y$ algo viscosas; hojas grandes, todas opuestas o solamente las inferiores, pecioladas, simples, acorazonado-redondeaditas, sinuoso-dentadas, y anchas de $6^{\prime \prime}$, culjiertas de pelos blancos riscosos. Flores en racimos cor tus raliendo de la dicotomia, sea del tallo sea de los ramos, pedunculados y cuyo pedúnculo sale de la axila de una bráctca moradusca, ovoídea y cóncava; de cáliz 5 -fido ó de 5 divisiones fuliáceas y profundas, obtusas, desiguales, aovadas y puntiagudas, con el tubo algo crecido; corola algo infundibuliforme anomala, de tubo muy colto, pero de garganta grande, cuyo limbo abierto es 5 -lobo, con segmentos redondeados, de los cuales el inferior es mayor que los demas y los dos superiores mucho mas peyueños; en la garganta se observan hermosas manclias purpúreas ó carmeí, con la corola blanquecina. Estambres 4 ó á veces 2 solamente: hemos además obselvado un 5 -estambre rudimentario. Orario oval algo comprimiclo y conico, pubescente, de cuyo vértice sale un estilo simple, filitorme y terminándose por un estigma con dos láminas apartadas una de otra y formando así una boca, pero que se cierran despues de cojido el pólen. El fruto es una especie de drupa leñosa, cuya cá=cala carnuda y poco e: pesa no tarda en desprenderse y se queda entonces una especie de cápsula leñosa negra, achatada, oblícuamente semi-elíptica, mucho mas larga que su pico ganchoso, medianícida, en 2 ventallas, 4-locular, con una sola senilla en cada una : martynia, F. 71, T. II.

547. Plantas herbáceas rivaces, cujo tallo, alto de 2 1 2 á 3 ', muy ramoso, sale de una raiz carnuda, perpendicular, bastante gruesa, peludo-vizcosas y exlialando un olor almizclado característico; hojas simples, cuyas inferiores son opuestas y las superiores alternas, largamente pecioladas, acorazrnado-redondeadas, palmatífidas, con los lobulos dentado-sinuo:os, cubiertas de muclio pelo algo tieso y terminado por una glandulita. Primorosas flores, color blanco teñido de rosado, grandes y con lindísimas manchas moradas situadas en el interior de la garganta abierta, en espigas o racimos simples paucífloros, axilares ó saliendo de la dicotonia de los ramos, pedunculadas y cujo pedánculo nace de la axila de una bríctea foliácea, algo cóncava, lanceolada, puntiaguda y larga de $4^{\prime \prime \prime}$ á $5^{\prime \prime \prime}$, articulado y con dos bracteitas, semejantes á la Ja mencionada y situadas como á 4 líneas de la insercion de la flor; de cáliz monosépalo, espatiforme, ovoídeo, herdido solamente de un lado, con 5 dientes en el ápice, provisto además de 12 á 15 estrias lonijitudinales al:o :alientes de color 10 jo oscuro y que ran desde, la bace hasta el ápice casi sin ramíficarse, largo de $1^{\prime \prime}$ á $1112^{\prime \prime}$; corola de tubo larguioimo, 6" á I" $^{\prime \prime}$, arqueado antes de la floracion, de tal manera que el limbo no abierto repre:enta entónces una esjecie de cabeza pentágona aplicada al lado del ovario; se endereza poco á poco y sale por la tiendidura del cáliz, entónces abierta la corola es grande y recta, de limbo con 5 divisiones jlanas redondeadas y un poco 
desiguales, de garçanta grande y abierta un poco pentígona como el tulıo qre la lleva. Estambres insertos en el tubo, aproximíndose todos de la parte supeilor de la garganta y quedándoze en el lugar correspondiente al seno que separa los dos segmentos superiores del limbo, con anteras mediifijas, cuyas celdas muy grandes estản dispuestas por pares una por encima de la otra, pendientes antes de la fecundacion y erguidas despues. Ovario cónico un poco comprimilo, sostenido por un discó hipojínico bastante desarrollado, con un surco de cada lado, que se continua sobre el ovario, de cuyo vértice sale un estilo filifor me muy largo terminado por un estigma lameliforme y que viene á parecer por encima de las anteras, con figura de lanza; tal estilo dura todavía algun tiempo despues de desprenilida la cosola. El fruto consiste en una especie de drupa cuya corteza =e desprende, y entónces se queda una especie de liue:o indehiscente, prieto, muy duro, semí-elíptico, achatado y terminándose por una punta ganchosa formada de dos cuernecillos que se separán poco á poco uno del otro, segun la sutura lonjitudinal y mediana, con dientecitos por donde sin duda han de salir las semillas - únicas en cada celda : craniolaria, F. 71, T. II.

548. Fruto drupáceo, 549.-Fruto abayado, 552.

549. Pequeñas drupas biloculares, agrupadas algunas en el centro del involucro y conteridas cada una en el cáliz acrescente; corola bilabiada y con el limbo ahierto; flores reunidas en cabezuelas esféricas pedunculadas, 550.- Una drupa única ordinariamente con 4 semillas, aovada y larga de $5 "$ "'; corola tubulosa lilabiada, peluda interiormente, con el labio inferior doblado hácia abajo, 55 51.

550. Arbustos aromáticos con ó sin aguijones, muy ramosos, altos de $3^{\prime}$ á 6', raras veces plantas herbácéas, con hojas simples, pecioladas, peninervias, ásperas, pulescentes, peludas, alampiñadas y raras veces lampiñas, opuestas, aovadas ó aovado-oblongas, ovales, aovado-lanceoludas ó lanceolado aguzadas, elípticas ó elíptico oblongas, etc., funtiagudas, obtusas ú ubtusitas, festoneadas ó aserradodentadas. Flores en cabezuelas pedunculadas y axilares, con la base del pedúnculo acompañada de una bráctea foliácea mas ó menos desar rollada; de cáliz mono: épalo 2 o 4-dentado, pequeño, tubulado y con dierstes obtusos; corola largamente tubulosa, con la garganta abierta y el linibo estendido y llano, partido en 4 sęmentos bastante profundos, obtusos y desiguales, amarillenta ó rojiza; estambres inclusos, con las celdas de las anteras paralelas. Ovario úuico esférico, 2-locular uniovulado, de cuyo ápice sale un estilo simple terminado por un estigma oblícuamente cabezudo. La fruta es una drupa pequeña, esférica. lisa, prieta y de hueso bilocular: Iantana, F. 7., T. I, S.-T. I, G. II.

551. Arbolito muy ramoso, alto de $15^{\prime}$ á $20^{\prime}$, lampiño, de hojas simples, alternas, casi sentadas, lanceolado-aguzadas, largas de 4 "$2^{\prime \prime}$, esparcidas y enteras, coriáceas, de cin hermoso color verde $y$ lustrosas. Flores axilares, amarillas, solitarias, situadas en especial hácia el vértice de las ramitas; pediceladas y de cáliz monosépalo 5partido, pequeño, campaniforme, larøo de $1^{\prime \prime \prime}$ y pestañoso; corola bilabiada, amarilla, disciplinada de purpúreo, larga de $10^{\prime \prime \prime}-12^{\prime \prime \prime}$, 
cuyo labio superior es recto y escotado, mientras el inferior al contrario tripartido, es algo doblado hácia abajo. Estambres inferiores esertos. Ovario bilocular, cuyas celdas contienen 4 óvulos separados por un tabique lonjitudinal incompleto, dispuestas por pares situadas la una por encima de la otra, de cuyo ápice sale un estilo terminándose por un estigma obtuso y bífido. Drupa aovada, amarillenta y puntiaguda: bontia, F. 73.

552. Fruto abayado de ordinario, pero á veces capsular y con dos valvas; algunas raras veces 5 estambres, 553.-Fruto siempre abayado; siempre 4 estambres didínamos, 554.

553. Arbustos ó árboles bajitos, ramosos y que se eleran hasta $25^{\prime}$ de altura, de hojas simples, algo pecioladas, alternas, elípticas, elíptico-oblongas ú obaovadas, lanceolado-oblongas, puntiagudas ú obtusas, con frecuencia venosas, lampiñas. Flores de ordinario solitarias, terminales o laterales, de cáliz 5-r i:tado ó 5-fido, campanudo; corola hipocrateriforme, doblada c el boton, con 5 lobulos lijeramente desiguales, redondeados, imbricados y cuyo superior se ha vuelto esterior. Estambres inclusos, de anteras reniformes, con las celdillas confluentes. Ovario globoso, de cuyo ápice :ale un es-. tilo simple, cilíndrico y cuyo tamaño va creciendo hasta el estigma bastante grueso y bilabiado. Baya esférica amarillo-anaranjada, unilocular y polisperma: brunsfelsia, F. 67.

554. Baya corticosa, pero nunca leñosa, de tamaño regular, larga como de $1^{\prime \prime}$; cáliz campanudo, 555. - Fruto muy grueso, de casco leñoso muy fuerte, de figura y tamaño muy variados; cáliz de dos sépalos, 556 .

555. Arbustos sarmentosos ó trepadores, ramosísimos y de hojas opuestas, compuestas de 2 ó 3 hojuelas membranosas ó coriáceas aovadas, elípticas ú ovales, obtusas, ó con una punta obtusita y lampiñas, largas de $3^{\prime \prime}-4^{\prime \prime}-5^{\prime \prime}$. Flores en corimbos axilares y terminales, con algunas flores de cáliz tubuloso-campanudo y sub-truncado, cerrado en la yema; corola intundibuliforme, larga de $4^{\prime \prime}-6^{\prime \prime}-$ $7^{\prime \prime}-8^{\prime \prime}$ y blanca, de tubo elongado, filiforme y claviforme á la vez, enteramente pubescente, con los lóbulos aovados, aovado-oblongos y obtusos ó deltoídeos, puntiagudos y ondulosos; anteras de celdillas diverjentes, de las cuales dos son esertas; ovario bilocular de cuyo véritice sale un estilo terminado por un estigma bilamelado. Baya oblonga, larga de $\mathrm{l}^{\prime \prime}$ : tancecium, F. 69, T. II.

556. Arboles bajitos 6 de mediana altura, ramosísimos, lampiños, de copa dispuesta á manera de paraguas, cuyas ramas cilíndricas y en varita son de ordinario todas horizontales; hojas simples, alternas ó fasciculadas, largas de $8^{\prime \prime}-4^{\prime \prime}$, subsesiles ó cortamente pecioladas, espatuladas, obaovado-oblongas ú oval-oblongas, cartáceas ó rijidas, lustrosas, enteras y obtusas. Flores bastante grandes saliendo del tronco y de los ramos, formadas de un cáliz decíduo, 2-partido ó 2-fido ; corola campaniforme, transversalmente plegada por su parte inferior, de limbo desigualmente 5-fido ó sub-entero, con lóbulos dentado-ondulosos, larga de $3^{\prime \prime}$ á $2^{\prime \prime}$. Estambres inclusos é insertos en el tubo de la corola, en donde se halla á veces un quinto estambre rudimentario; pistilo compuesto de un orario ovoí- 
deo, cuya base está envuelta en un disco amarillento bastante ancho y algo carnủdo, de cuyo ápice sale un estilo simple algo mas largo que la corola terminándose por un estigma bilamelado. Baya mas ó menos gruesa, indehiscente y de casco leñoso muy duro, de color verde amarillento cuando madura, lampina y lustrosa, de forma $\mathrm{y}$ tamaño muy variados, unilocular, conteniendo muchas semillas comprimidas y acorazonadas, anidadas en el trofospermo que se ha vuelto una pulpa abundante: crescentia, F. 69, T. II.

557. Fruto drupáceo, 558. - Fruto no drupáceo, 561.

558. Siempre 4 estambres, 559.-De ordinario 4 estambres, pero alcunas raras veces cinco, 560 .

559. Arbustos muy ramosos, altos de $3^{\prime}$ hasta $12^{\prime}$, con ó sin aguijones; hojas simples, opuestas, clípticas ó elíptico-lanceoladas, enteras, de base aguzándose liasta volverse peciolo, ó aovado-deltoídeas, desigualmente dentadas y largamente pecioladas, cuyo peciolo está articulado hácia la base, cartáceas ó membranosas, lampiñas ó pubescentes. Flores en cimas tricotomas, axilares, pedunculadas, 7 , 3 -floras, con los pedicelos estendidos, ó terminales, subsesiles y contraidas; de cáliz 5-fido ó 5-dentado, raras veces troncado; corola hipocrateriforme ó infundibuliforme, con el tubo delgado y los 5 lóbulos del limbo algo desiguales; estambres esertos y desiguales; estigma cortamente bífido, con los lóbulos puntiagudos. Drupa con 4 huesecitos, ó 3 y solamente 1 por causa de aborto, uniloculares monospermos, á veces apareados: clerodendron, F. 75, T. III.

560. Arboles altos hasta de 50', ó arbustos, muy ramosos, y cuyas ramitas son de cuatro caras; en los árboles el epidermis color de ceniza se desprende de ordinario en tiras muy largas y desiguales; hojas simples, opuestas, pecioladas, enteras, cartáceas ó raras veces membranosas y coriáceas, lustrosas y lampiñas, con las venitas formando redecilla visible por ambas caras, ó solamente por la inferior en donde forman arcos; obaovado-oblongas, eliptical-oblongas ó elípticas, lanceolado-oblongas, oblongo-lanceoladas, etc., mas ó menos obtusas. Flores olorosas blancas ó amarillas, en racimos espiciformes ó en espigas, sub-sentadas ó cuyos pedícelos son mas ó tan largos como la bráctea de cuya axila salen; flores esparcidas en el eje ó dispuestas por grupos, de cáliz monosépalo, troncado, como campanurlo y de limbo 5-dentado; corola hipocrateriforme, mas larga que el cáliz, de tubo corto y cuyo limbo está partido en 5 segmentos bastante profundos, iguales, obtusos, con pelo blanco por los bordes y en la garganta. Estam a inclusos y tapados por el pelo, iguales, cuyos filamentos cortos é insertos hácia la base de la garganta llevan anteras aflechadas y basifijas. Ovario pequeño, casi globoso, liso, verdusco y lustroso, de cuyo ápice sale un estilo casi tan largo como los estambres, verde, cilíndrico y que se termina por un estigma pequeño, oblícuo, de bordes glandulusos y violáceos, con una depresion en el centro. Drupa pisiforme prieta-moradusca, con dos huesecitos erguidos, cuya reunion forma una pirámide central: cada liuesecito es bilocular ó á veces unilocular por causa de aborto: citharexylum, F. 75, T. I, S.-T'. II.

561. Un tetraquenio, 562.-Fruto capsular, 565. 
562. Corola bilabiada, con el lóbulo inferior encorvado; estambres arqueadas é inclinarlos, 563. - Corola no labiada ; estambres derechos y diverjentes, 564 .

563. Vejetales de ordinario herbíceos, mas ó menos ramosos, comunmente muy aromáticos, cuyo tallo de 4 caras se eleva desde $I^{\prime}$ á $8^{\prime}$ de altura, con hojas simples, opuestas, pecioladas, aovadolanceoladas, a avado-oblongas, elíptico-oblongas, aovadas, aguzadas ó puntiagudas, festonearlas ó aserradas, de hase redondeada ó acorazonada, pubescentes, peludas ó alampiñadas; las hojas florales mucho mas pequeñas son oblongo-lirieares, lanceolado-agnzadas, aovadas, elípticas, elíptico-oblongas, muy pequeñas y setáceas, mas largas ó mas cortas que los verticilos que acompanan, las mas veces inclinadas. Flores sentadas en los verticilos formando espiga terminal, ó en cabezas axilares, ó cuyas cabezuelas son dispuestas en racimos, ó por fin subsesiles ó pediceladas y en cimas contraidas, de cáliz monosépalo 5 dentado ó 5 -fido; corola con el labio inferion inclinado; aquenios sin la márjen cóncava : llyptis, F. 76, T. VII, S.T. I, G. I.

564. Plantas herbáceas anuales ó vivaces, de tallos rastreros ó derechos, pubescentes ó alampiñadas, con hojas simples, ouestas, pecioladas, enteras ó festoneadas, á veces aserradas, pubescentes ó alampiñadas, á veces lampiñas. Flores pequeñas en verticilos axilares que bastantes veces forman espigas terminales, con hojas florales mas ó menos desarrolladas, de cáliz cilíndrico, campanudo ó tubulado, con 5 dientes casi igruales, á veces simulando dos labios, y cuy a garganta está tan pronto desnuda como provista de pelo; corola infundibuliforme, algo mas larga que el cáliz, tubulada, de 4 divisiones casi iguales, obtusas y derechas, cuya superior algo mas grande que las demas es escotada; estambres rectos, distantes, de filamentos lisos y lampiños, $y$ cayas anteras tienen las celdillas paralelas; estılo filiforme mas largo que la corola, terminado por un estiøma hífido: mentha, F. 76, T. II, S.-T. VII.

565. Fruto comprimido, coriáceo, por fin abriéndose en 2 valvas, con una sola semilla por causa de aborto; embrion desnudo, germinando en el fruto, 566.-Una cápsula lejítima ó un pixidio, 567.

556. Arboles bajitos de los sanitrales y manglares, con ramos derechos, de 4 caras, en forma de varita, mas ó menos blancos y lampiños; hojas opuestas, simples, enteras, lanceoladas ó lanceoladoelípticas, aguzadas ú obtusitas, coriáceas, de cara inferior como cubiertas de polvo blanco ó alampiñadas. Flores blancas en racimos axilares y derechos en la sumidad de las ramitas ; de cáliz monosépalo 5-partido ; corola sub-enrodada, con 4 lóbulos lijeramente desiguales, pubescente por ambas caras; estilo tan largo como las estambres. Embrion de raicilla inferior y ascendente entre los catiledones: aricennia, F. 75, T. II.

567. Un pixidio, 558.-Una cápsula lejítima, 569.

568. Planta herbácea con hojas simples bastante grandes todas radicales, arrosetadas, lanceoladas, basinervias; flores muy pequeñas en espiga cilíndrica ocupando la parte superior de un pedúnculo axilar y radical que parece bojardo y largo de 6" á 8", y de cáliz 4- 
partido; corola cuadrífida ó hipocrateriforme membranosa de limbo estendido y algo doblarlo hicia arriba, se desprende y se cae de una sola pieza llevando consigo los estambres insertos en su tubo, de filamentos largos, delgados, esertos y con anteras bastante grancies. Orario globoso de curo ápice sale un e-tilo mas corto: que los estambres, terminado por un estigma lateral : plantago, F.

569. Cuatro ó cinco estambres; cápsula loculícida ô septícida, cuadrivalve, 5\%0.- Siempre 4 estambres, $5 \% 1$.

570. Frutices mas o menos ramosos, alampiñados, peludos o lampiños, raras veces pubescentes, que se elevan á $2^{\prime}$ ó $5^{\prime \prime}$ de altura, con hojas simples, alternas, cortamente pecioladas, elíptico-lanceoladas ó elíptico-oblongas, lanceoladas, agizadas ó no, aserrarlas por encima de la base ó del medio, otras veces sub-enteras. Flores axilares, de ordinario mellizas, cuyos pedícelos no son acompañados de brácteas; de cáliz 5-partido; corola campanuda, regular, blanca, 5-fila, cuyo labio superior está interior en el boton. Estambres inclusos é insertos en la garganta de la corola, de anteras oblongas y bífidas por la base; estigma obtuso : capraria, F. 68, S.-Or. III, T. VI, G. I.

571. Corola de ordinario torcida por la derecha, 573. - Corola nunca torcida, pero cuyo lóbulo superior está inferior en el baton ; cápsula septícida, 572.

572. Planta anual sıb-leñosa, muy ramosa, lampiña, alta de $1^{\prime}$ á 3 , con hojas simples, casi sentadas, ternadas ú opuestas, punteaditas, lanceoladas, oblongo-lanceoladas ó linear-lanceoladas, ordinariamente aserralas por encima de la base cuneiforme ó agnzala. Flores pequeñas blancas, axilares y fasciculadas, cuyos pedícelos filiformes son numerosos, mellizos ó solitarios; de cáliz 4,5-partido, con divisiones un poco desiguales; curola enrolada, regilar, 4-fida y con pelo en la garganta; estambres esertos, iguales é insertos en la garginta de la corola: ovario aovaln, escotado por el ápice de donde :ale un estilo simple bastante largo, terminado por un estigma esférico: cápsula casi globosa. polisperma, con un surco de cada lado: scoparia, F. 68, S.-Or. III, T. VI, G. II.

573. Anteras aflechadas, rectas y esertas; cípsula semi-4-iocular, bivalve, cuyas semillas marjinales son situadas sobre las valvas inclinadas por adentro, 574. - Anteras no aflechadas, mas cortas que el limbo rle la corola, rectas y resostadas; cípsula unilocitar, con las semillas marjinales situadas en las valvas lijeramente ubbladas por adentro, 575 .

574. Plantas herbíceas anuales, de tallo en forma de rarita, alto de I' á $3^{\prime}$, con hojas simples, opuestas, sentadas, oblong.)-linceoladas y redond aditas ó acorazonadas por la base algo envainadora. Flores blancas ó rojizas ell espigas ó racimos, y acomp uñ ud is de 3 brícteas aproximadas á ellas ó cuya inferior estí algo mas distante; de cáliz monosépalo 4-fido 3 ó 2 bracteola lo, con las divisiones iģuales y algo puntiagudas: corola cortamente hipocrateriforme, marcescente, 4-dentada; estambres insertos en su gargınta al pis de una escamita, con filamentos muy cortos. Ovario oval de cuyo vér- 
tice sale un estilo capilar mas largo que la corola, decíduo y terminándose por un estigma bilamelado : coutoubea, F. 64, T. VII.

575. Plantas herbáceas anuales, cuyo tallo tetrágono se eleva á $6^{\prime \prime}$ y $10^{\prime \prime}$ de altura, poco ramo:o, derecho, con hojas simples, opuestas, oblongas, lanceoladas ó lineares, ó lanceolado-lineares; flores en cimas terminales ó solitarias, rosadas, purpúreas ó á veces amarillas, acompañadas de 2 brácteas situadas por debajo de la cima dicótoma, paucíflora; de cáliz monosépalo 4, 5-fido, cuyo tubo es 4,5 -alado ó aquilado, alas transversalmente venosas, senii-ovales ó semi-lanceoladas; corola infundibuliforme marcescente, de lóbulos anchamente redondeados ó sub-troncados, bastante grande; filamentos provistos inferiormente de 2 dientes ó subulados por la base. Estilo decíduo terminado por un estigma bilamelado ó globoso: schultesia, F. 64, T. II, S.-T. I, G. II.

576. Un ovario unico, 577.-Algunos ovarios, 642.

577. Fruto seco ó capsular, 578. - Fruto mas ó menos carnudo, drupáceo ó abayado, 602.

578. Vejetales lechosos, 579. - Vejetales nunca lechosos, 584.

579. Cápsula unilocular, erizada, con semillas aladas, 580 . Cápsula 2, 4-locular, 581..

580. Arbusto de ramas largas, delgadas, muy largas y como sarmentosas, lampiño, de hojas simples verticiladas, elíptico-oblongas ú oblanceoladas, puntiagudas, de costilla algo peluda por la cara inferior; flores amarillas, primorosas, en racimos paucífloros, axilares ó terminales, peduncularlas y de cáliz monosépalo 5-partido; corola larga de $3^{\prime \prime}-4^{\prime \prime}$, de tubo infundibuliforme largo de $1^{\prime \prime}$, repentinamente dilatado, con 5 lóbulos algo desiguales y redondeados; estambres inclusos, insertos en la garganta de la corola, pero cuya insercion parece salir del tubo y está señalada por una línea de pelos blancos, separados los unos de los otros por un grupo triangular de pelo blanco, sostenido por una escamita lipartida: anteras casi sentadas y aflechadas. Ovario oval, sentado sobre un disco anular, unilocular, poliovulado, de cuyo ápice sale un estilo filiforme muy largo terminado por un estigma carnudo, un poco estrechado por la parte mediana, con figura como de hisopo y terminado por dos puntitas. Cápsula orbicular, algo comprimida, coriácea, con largas puas, abriéndose por dos ventallas abarquiladas, polisperma, cuyas semillas di=coídeas, imbricadas y situadas por la márjen de las ventallas tienen sus bordes membranosos: allamanda, F. 63, T. I, S.T. I.

581. Ovario 2, 4-locular, con 4 ó 6 óvulos ; estigma 2, 3-lobado y cabezudo á la par, rara vez cabezudo solamente, 582. - Ovario 2locular, con 4 óvulos; estigmas 2 , diverjentes, filiformes ó claviforme-oblongos, 583 .

582. Plantas herbáceas raras veces sub-fruticosas, anuales ó las mas veces vivaces y de raiz no rara vez tuberculosa, de tallos larguísimos, ramosos y volublès ó solamente trepadores, con hojas simples, alternas, pecioladas, enteras. o mas ó menos lobuladas, de tamaño y de forma muy variados. Flores de ordinario bastante grandes : sin embargo las hay pequeñas, solitarias y axilares ó en 
racimos axilares ó terminales, de cáliz monosépalo, con 5 divisiones mas ó menos profundas é iguales, grandes, escariosas y por fin cartilajinosas, ó membranosas y por fin coriáceas, otras veces membranosas solamente, pero terminadas algunas veces por un apéndice filiforme y herbáceo, y por último foliáceas y aguzadas; corola grande infundibuliforme ó campanuda y de tubo ancho dilatado por la base ó no, otras veces ventruda por arriba de la base, ó pequeña y campanudo-infundibuliforme ó claviforme-infundihuliforme, disminuyendo gradualmente liácia la base, otras veces es hipocrateriforme mas o menos grande, con el tubo cilíndrico, o tubuloso-hipocrateriforme con el tubo sea cilíndrico, sea claviforme; estambres de anteras ordinariamente inclusas : sin embargo bastantes especies hay que las tienen esertas. Cápsula reventándose de manera que las valvas se separan de los tabiques: ipomaa, F. 65 , T. IV, S.-T. I, série V.-C. G. I.

583. Plantas herbáceas anuales ó vivaces, volubles, lampiñas o pubescentes, de hojas simples, alternas, pecioladas, enteras ú ondeadas, acorazonado-aovadas, ovales, oval-redondeadas, lanceoladolineares, obtusas, escotadas ó mucronadas; flores mas ó menos grandes, pedunculadas, solitarias y axilares ó en racimos axilares ó terminales, y de cáliz monosépalo persistente con 5 divisiones mas ó menos profundas é imbricadas; corola infundibuliforme, de prefloracion torcida, con 5 ángulos correspondiendo con sus pliegues; estambres cortos, inclusos, insertos en el tubo de la corola, desiguales y con anteras aflechadas. Ovario globoso, de cuyo vértice sale un estilo filiforme terminado por dos estigmas diverjentes. Cápsula abriéndose por 2,4 y hasta 8 valvas, bilocular, cuyas semillas son myosas, mas ó menos angulosas y á veces provistas de una ala estrecha : convolvulus, F. 65, T. IV, S.-T. I, série V.-C. G. III.

584. Vejetales sin hojas y como parásitos, 585. - Vejetales con hojas siempre y nunca pareciendo parásitos, 586.

585. Plantas herbáceas de semblante particular y característico, cuyos muchísimos tallos delgaditos, ramosísimos, pareciendo larguísimo, fideos, tanto por el color y el tamaño como por la forma, se arrollan $y$ enredan de mil maneras en los vejetales vecinos que han elejido para vivir, de tal manera que á veces les hacen desaparecer y hasta acaban con ellos. Flores pequeñas blanquecinas en grupos laterales, mas ó menos pediceladas y acompana las de 2 brácteas, y de cáliz monosépalo 5 ó raras veces 4 -fido, cuyos segmentos son iguales y algo imbricados; corola cortamente campanuda ó enrodada, marcescente, de limbo 5, 4-partido, de prefloracion imbricada; estambres 5, insertos en la garganta de la corola, tan largos como ellạ, alternos con sus divisiones 5 provistos de un apéndice escamiforme situado por la base, inclusos ó proeminentes. Ovario globoso, bilocular y biovulado, de cuyo ápice salen dos estilos terıninados cada uno por un estigma cabezudo. El fruto es un pixidio y raras vecesuna cápsula algo abayada; embrion indiviso y en espiral : cuscuta, F. 65, T. I.

586. Fruto capsular lejítimo, 587. - Fruto capsular no muy lejitimo, 590 . 
587. Unilocular, indehiscente, con semillas suturales; corola enrodada, decídua, de segmentos induplicativos y franjeados ó peludos, 588. - Cápsula uni ó bilocular siempre dehiscente, 589.

588. Yerba vivaz de los lugares húmedos y anegadizos, con una especie de rizoma del tamaño del dedo índice, largo como de $1^{\prime \prime}$, cilíndrico, de color moreno esteriormente, con surcos ó estrias circulares, blanco-amarillento interiormente; de su parte inferior salen raices simples del tamaño del cañon de una pluma de gallina, blancas ó parduscas esteriormente, esponjosas, largas y provistas de muchas raicillas capilares mas ó menos cortas y blancas, mientras que de su vértice nacen bastantes hojas, cuyo peciolo, largo como de unas $6^{\prime \prime}$ á $8^{\prime \prime}$, casi cilíndrico, lampiño, de base algo mas desarrollada y algo envainadora, tendido en el suelo búmedo ó derecho cuando anegado, llevando un limbo acorazonado-orbicular, bastante doble, sin ser carnoso, liso, lustroso y lampiño, de cara superior verde-amarillenta, con la costilla y nervaduras poco notables por causa de su color algo mas pálido, mientras la inferior, mas pálida, las tiene bastante pronunciadas y es como glandulosa ó esponjosa; tales hojas radicales y alternas, acorazonadas ó abroqueladas, salen dercchas, con sus dos lados enrollados, de tal manera que parecen como aflechadas de un hermoso color de rosa, son anchas de $2^{\prime \prime}-212^{\prime \prime}$; del vértice y de la cara superior del peciolo salen sucesivamente 2 á 5 flores, acompañadas de una bráctea membranosa, cuyos pedícelos desiguales son derechos, largos de como $10^{\prime \prime \prime}$ ó $12^{\prime \prime \prime}$ y unífloros; de cáliz 5-partido, cuyos segmentos oblongo-lineares son como dos veces mas cortos que la corola, trabados por la base, y algo mas largos que la cápsula; corola enrodada, decídua, blanca, con el tubo amarillo, cara superior de las divisiones ornada de muchas franjas ó apéndices capilares, blancos y marjinales, que desaparecen en la garganta, para volver despues á presantarse en el tubo, hay algunas glándulas pediceladas en la base. Estambres insertos en el tubo de la corola, inclusos, de anteras erguidas, rectas, introrsas y moraduscas, formando una especie de bóveda por encima del estigma que aparece en el fundo de la flor como una estrellita de muchos brazos, pero observado con mas cuidado se ve que es casi sentado, bílobo, con cada lóbulo crestado. Ovario unilocular en forma de botella, lustroso, lampiño, color verde teñido de pardusco, cuya base está cargada por 5 glándulas ó nectarios hipojínicos, alternos con las divisiones del cáliz en el fondo del cual están situadas, irregularmente cuadrangulares, elongadas, separadas las unas de las otras, de color como de hollin desleido, un poco mas oscuropor el vértice, provisto de unos pelos blancos cortitos y muy finos; tales glándulas tienen como l 44 de línea de largo. Cápsula sin ventallas, unilocular, polisperma y cuyas semillas suturales son globosas, lisas, algo aquilladas, reventánclose al favor de la maceracion en el agua. Por la cara inferior del peciolo, al nivel de su vértice, cuando no salen flores por su cara superior, entónces nacen raices que penetran en el suelo, y en lugar de flores se presenta una planta nueva, y á medida que crece se va marchitando el limbo de la hoja madre que no tarda en desaparecer enteramente, 
y entónces solo se queda el peciolo que la tiene unida á la planta madre, que á primera vista parece cundidora : limnanthemum, F. 64, T. I.

589. Cápsula no lejítima, pero pericarpio membranoso, reventándose por la base; cáliz tubuloso, 5-costilludo, con glíndulas estipitadas situadas especialmente sobre los ángulos, esféricas y pegajosas, 590. - Cápsula lejítima, 591.

590. Arbustos sarmentosos, lampiños, cuyos ramos muy largos, delgados y rollizos, son estendidos y llevan hojas simples esparcidas y alternas, mas ó menos peciolarlas, enteras, aovadas ú oblongolanceoladas, aguzadas ó puntiagudas. Flores blancas á veces teñidas de color de rosa ó azules en espigas terminales, cuya reunion forma á veces panojas arracimadas, de pedúnculo corto saliendo de la axila de 3 brácteas alternas, foliáceas y pequeñas casi iguales, pero cuya inferior es frecuentemente algo mayor que las demas; de cáliz monosépalo, tubulado, oblongo, pentágono, 5-dentado, cuyo tubo lleva glándulas situadas hácia la base de sus ángulos convexos, mitad mas corto que el tubo filiforme de la corola hipocrateriforme, con 5 lóbulos mucronados, cuya garganta es desnuda ó provista de pelo. Estambres inclusos, hipójinos, alcanzando apenas la garganta de la corola. Ovario pequeño, algo fusiforme, sentado en medio de un disco anular, unilocular, poliovulado, y de cuyo ápice sale un estilo capilar simple, muy largo y terminado por 5 estigmas erguidos, filiformes é inclusos: plumbago, F. 78, T. II.

591. Cápsulas uniloculares con las semillas marjinales en las valvas, 592. - Cápsulas biloculares, 595.

592. Enteramente unilocular; anteras erguidas, derechas y corniculadas por el ápice, 593. - Unilocular, pero hasta la mitad bilocular, 594.

593. Plantas herbáceas vivaces, de tallo un poco áspero y que se eleva á $l^{\prime}-3$ ' de altura, con hojas opuestas, simples, elíptico-lanceoladas y acuminadas por ambos estremos, trinervias y largas de $2 "-$ $4^{\prime \prime}$. Flores agrupadas y axilares compuestas de un cáliz monosépalo 5-fido, cuyos lóbulos subulados y esparramados son casi tan largos como la cápsula; corola infundibuliforme, azul, marcescente y larga de 3 " ; estambres inclusos y alternando con los dientes. Estilo decíduo terminado por un estigma cabezudo: slevogtia, F. 64, T. II, S.-T. IV.

594. Terba anual, glauca, erguida y alta de $I^{\prime}$ á $2^{\prime}$, con hojas simples, opuestas, elípticó-oblongas, algo acorazonadas y abrasadoras, por consiguiente sentadas; flores azules ó blancas disciplinadas en cimas terminales paucífloras, de cáliz 5 ó á veces 6 -partido; corola infundibuliforme y enrodada á la par, marcescente, cuyos seg-mentos elíptico-lanceolados y apendiculados son dos veces mas largos que el tubo campanudo. Anteras incumbentes y por fin recorvadas. Estilo tarde decíduo, terminándose por un estigma bilamelado: eustoma, F. 64, T. II, S.-T. IV.

595. Enteramente biloculares, 596. - Nodel todo biloculares, 601. 596. Formala de 2 carpelos abriéndose á lo largo de la línea dolsal, dídima, libre y por fin separándose del disco vuelto duro y que 
se queda casi con forma de escudo, 597. - Nunca dídima, ni formada tampoco de 2 carpelos bien distintos, 598 .

597. Yerba anual, cuyo tallo ordinariamente simple ó á veces algo ramoso y derecho se eleva á $8^{\prime \prime}-12^{\prime \prime}$ de alto, con 4 caras, lampiño, que lleva 2 ó 3 pares de hojas simples opuestas, aorado-lanceoladas, aguzadas, dispuestas á manera de cruz ó casi verticiladas por á cuatro por estar dos pares muy aproximados el uno del otro en el vértice del tallo o de sus divisiones, de las cuales 2 son mas anchas y mas largas que las demas; del medio de la especie de invólucro que forman así salen de 2 hasta 4 espigas simples, delgadas, estendidas horizontalmente ó arqueadas, formadas de flores pequeñas, rosadas, unilaterales y distantes, de cáliz monosépalo persistente, con 5 divisiones profundas, lineares y subuladas; corola infundibuliforme, con 5 lóbulos profundos de prefloracion valvar, como unas cuatro veces mas larga que el cáliz, con el tubo algo crecido y anguloso superiormente; estambres inclusos de filamentos cortos é insertos en la garganta de la corola y alternando con sus divisiones, de anteras oblongas y como cahezudas, converjentes; estilo simple mas largo que la corola, articulado hácia su parte mediana y torcido hasta el ápice, que se termina por un estigma cónico. Cápsula dídima, rugosa y erizada, cuadrivalve y oligosperma; despues de su caida se ve en el fondo del cáliz una especie de cápsula romboídea, leñosa, persistente en que estaba sentada, formarla por el disco endurecido, envuelta por las divisiones calizinales: spigetia, F. 61, Or. I.

598. Cápsula septícida, de valvas bífidas, con muchísimas semillas, muy pequeñas, prietas é irregulares: abierta ofrece 4 puntitas en su ápice, 599. - Cápsula bilocular por causa de estar las valvas dobladas hácia dentro, cujos bordes cargan con las placentas, en las cuales muchas semillas están imbricadas, 600 .

599. Plantas herbáceas anuales, pubescentes, viscosas y exhalando un olor viroso particular, cuyo tallo recto, poco ramoso y cilíndrico se eleva á $3^{\prime}-5^{\prime}$ piés de altura, con hojas simples, sentadas, alternas, decurrentes, oblongo-lanceoladas, un poco aguzadas por ambos estremos, largas de $\mathrm{l}^{\prime}$ á $3^{\prime}$ y anchas de $4^{\prime \prime}$ á $8^{\prime \prime}$. Flores rosadas en cimas terminales, corimbiformes ó arracimadas, pedunculadas y de cáliz monosépalo tubuloso 5-fido ó 5-dentado persistente, algo ventrudo; corola infundibuliforme ó hipocrateriforme, plegada en el boton, y de limbo doblemente duplicativo; partida en 5 divisiones poco profundas, iguales, bastante anchas y agudas, de tubo claviforme y no estrechado; estambres algo salientes é inclinados de un solo lado, insertos hasta el medio del tubo de la corola y por debajo de la garganta, cuyos filamentos son peludos inferiormente. Ovario bilocular, poliovulado, sentado en un disco amarillo, ovoídeo y de cuyo ápice sale un estilo filifor'me casi tan largo como los estambres y terminado por un estigma cabezudo y bílobo á la par. Cápsula ovoídea cuyas muchísimas semillas están en una placenta central : nicotiana, F. 67, T. II, S.-T. II, G. VII.

600. Plantas herbáceas anuales, sub-fruticosas y hasta arbustos, de tallo simple mas ó menos ramoso, cilíndrico, tetrágono ỏ 4-alado, 
con hojas simples, opuestas ó verticiladas y cortamente pecioladas, con las nervaduras arqueadas. Flores ordinariamente en cimas terminales, de cáliz 5-partido ó 5-fido, con las divisiones imbricativas y no aquiladas, derechas y con los bordes mas ó menos membranosos; corola infundibuliforme o hipocrateriforme, marcescente, de tubo contraido y de limbo abierto, con frecuencia oblícuo, otras veces decídua, cuyo tubo se va ensanchando gradualmente hasta desaparecer en el limbo; estambres insertos en la parte inferior del tubo de la corola, y frecuentemente desiguales, de anteras por fin recorvadas, con el conectivo de ordinario ensanchado; estilo persistente terminado por un estigma bilamelado: lisianthus, F. 64, T. II, S.-T. I, G. I.

601. Plantas herbáceas anuales ó arbustos, de tallos ramosos, con los ramos dicótomos, altos de $3^{\prime}$ á 6' y 10', lampiñas ó pubescentes y que exhalan un olor viroso bastante desagradable; hojas simples, alternas, pecioladas, aovadas ó aovado-oblongas, enteras con algunos dientes, ondeadas, ondeado-dentadas, puntiagudas, algunas veces meilizas, con una mas pequeña. Flores solitarias saliendo de las dicotomias y estra-axilares, pendunculadas, blancas ó moraditas y grandes, de cáliz monosépalo tubulado, 5-dentado ó hendido, con 5 ángulos, ventrudo, mitad mas corto que la corola, y por fin circonciso or la base que persiste, sigue vejetando y á veces se vuelve bastante grande; corola infundibuliforme, plegada en el boton y de limbo dos veces plegado, 5-dentado y abierto y cortamente 10-dentado, larga desde $3^{\prime \prime}-4^{\prime \prime}-5^{\prime \prime}-6^{\prime \prime}-7^{\prime \prime}-10^{\prime \prime}$ y hasta $12^{\prime \prime}$; estambres insertos en el tubo de la corola, inclusos, y sin embargo de filamentos largos de 1" á 4" y mas, de anteras coherentes y lineares ó distintas, oblongas ú oblongo-lineares. Ovario ovoídeo de 4 celdas incompletas, y 2 solamente hácia el vértice, poliovulado con la placenta central; del ápice sale un estilo filiforme muy largo, terminándose por un estignia bilamelado. Cápsula ordinariamente erizada ó espinosa y raras veces inerme, bilocular superiormente y 4-locular inferiormente, abriéndose por 4 ventallas, con muchas semillas pequeñas, prietas, rugosas y un poco arriñonarlas, de embrion encorvado: datura, F. 67, T. II, S.-T. II, G. VI.

602. Fruto drupáceo, 603 - Fruto abayado, 612.

603. Vejetales lechosos, 609. - Vejetales nunca lechosos, 604.

604. Estilo simple, cuyo estigma entero ó bílobo está sostenido por un anillo, 605. - Estilo bífido una ó dos veces, 606 .

605. Arbustos y rarísimas veces plantas herbáceas, pero sí con frecuencia vejetales fruticosos y sub-fruticosos, de tallos muy ramosos, bastantes veces sarmentosos, lampiños, pubescentes, peludos y pelierizados, con hojjas simples alternas, mas ó menos pecioladas, enteras, de forma bastante variada, elípticas, elíptico-oblongas, elíptico-lanceoladas, espatuladas, oblongas, oblongo-ciovadas, oblongo-lineares, lanceoladas, lanceolado-aguzadas, aovadas, aovadolanceoladas, obtusas, obtusitas, aguzadas o puntiagudas; su tamaño es tan variado como su forma: las hay en efecto de $1^{\prime \prime}-2^{\prime \prime}-3^{\prime \prime}-4^{\prime \prime}-$ $5^{\prime \prime}-66^{\prime \prime}$ lıasta $12^{\prime \prime}$ y $15^{\prime \prime}$ de largo, lampiñas, alampiñadas, pubescentes, velludas, pelierizadas, etc. Flores unilaterales en espigas del- 
gadas escorpioídeas, cuyo conjunto forma especies de umbelas ó panojas terminales, y de cáliz monosépalo 5 ó á veces 4-partido; corola hipocrateriforme, mas larga que el cáliz, de tubo bastante largo y cilíndrico, pubescente, pubescentito, alampiñado ó velludo, cuya base está algo crecida y de limbo 5 -fido, con los lóbulos córtos y mas ó menos iguales; estambres inclusos ó cuyas puntas de las anteras están algo esertas, insertos en el tubo de la corola. Drupa con 2 huesecitos biloculares ó 4 huesecitos uniloculares, monospermos, embrion recto ó encorvado: tournefortia, F. 66, T. II, G. II.

606. E- tilo dos veces bífido, 607. - Estilo solamente bífido, 608 .

607. Arboles ó arbustos, raras veces frutices, alampiñados, pubescentes, velludos, aterciopelados y siempre bastante ásperos, de hojas simples, alternas, pecioladas, de forma y tamaño muy variados, oblongas, oblongo-lanceoladas, elípticas, elíptico-oblongas, aovadas, aovado-oblongas, aovado-lanceoladas, oval-redondeaditas, elíptico-redondeadas, enteras, sub-enteras, ondeadas, ondeadodentadas, aguzadas, puntiagudas, obtusas y obtusitas, de base acorazonada, redondeada, aguzada etc., alampiñadas, pubescentes, velludas, pelierizadas, aterciopeladas y mas ó menos ásperas, largas de $3^{\prime \prime}-4^{\prime \prime}-5^{\prime \prime}-6^{\prime \prime}$ hasta $8^{\prime \prime}-12^{\prime \prime} \mathrm{y} 18^{\prime \prime}$. Flores de ordinario pequeñas y poco vistosas, en cimas abiertas ó contraidas, á veces polígamas ó en panojas corimbosas, otras veces en glomérulos, espigas ó cabezas, de cáliz monosépalo tubuloso y con frecuencia cerrado en el boton, 10, 12-costilludo, 5 ó 3 -dentado ó no costilludo y reventándose por el ápice cerrado ó regularmente 5 ó 4-dentado; corola infundibuliforme ó hipocrateriforme, marcescente ó decídua, de garganta desuuda ó peluda, con el limbo de 5 ó 4 segmentos casi iguales; estambres muy cortos é insertos en la garganta de la corola; ovario oval de 4 á I celdillas, uniovuladas, de cuyo ápice sale el estilo terminado por 4 estigmas cabezudos; drupa blanca ó á veces cerasiforme, con un hueso asurcado, 4, 1-locular monospermo: cordia, F. 66, T. I.

608. Arbustos ó árboles bajitos muy ramosos, Jampiños, alampiñados ó aterciopelado-pubescentes, pelierizaditos, de liojas simples, alternas, mas ó menos ásperas, ob-aovado-oblongas, oblongas ú obaovado-redondeaditas, elípticas, lanceolado-oblongas, ovales, obtusas, obtusitas ó puntiagudas y de base aguzada ó redonda, Jargas de $2^{\prime \prime}-3^{\prime \prime}-4^{\prime \prime}-5^{\prime \prime}$, enteras y mas ó menos pecioladas. Flores de ordinario en corimbos cimosos y blancas, de cáliz cerrado en el boton, 5, 2valve, cuyos dientes ó lóbulos son valvares; corola hipocrateriforme; estambres insertos por debajo de la garganta de la corola ó en la parte mas inferior de su tubo y esertos. Drupa globosa ú ovoídea con 4 huesecitos que se separan mas tarde, ó fruto drupáceo seco con 4 cocos que se separan de un carpóforo bipartído y filiforme: beuюria, F.66, T. II, G. I.

609. Drupa verde-amarillenta deprimida, algo trígona, ensanchada transversalmente, de hueso bilocular, incompletamente dehiscente y con 4 o 2 semillas; corola bastante grande de un primoroso color amarillo azufrado, 610. - Drupa redonda cerasilorme, moradusca; corola pequeña amarillenta, 611 . 
610. Arbusto ó arbolito bajito que se eleva á $10^{\prime}-20^{\prime}$ de altura, bastante ramoso ó coposo superiormente, con hojas simples, alternas ó esparcidas, sub-seritadas, lampiñas, coriáceas, lanceoladolineares, aguzadas por ambos estremos, puntiagudas, de un hermoso color verde subido y de cara superior lustrosa, largas de $3^{\prime \prime}$ á 6 ". Flores en racimos paucífloros y terminales, de cáliz monosépalo pequeño, con 5 divisiones muy profundas, lanceolado-aguzadas, casi mitad de la lonjitud de la parte cilíndrica del tubo de la coroia que es 3 reces mas corto que su parte ensanchada; corola larga de $3^{\prime \prime}$, grande, infundibuliforme, estrechada hícia la base, de tubo claviforme y cuyo orificio lleva 5 dientecitos escamosos, de garganta pentágona, con el limbo con 5 lóbulos oblícuos, de prefloracion torcida; estambres inclusos é insertos en la parte mediana del tubo de la corola, de anteras con conectivo mucronado; ovario trígono, bilocular, de cuyo ápice sale un estilo simple bastante largo, terminándose por un estigma espeso claviforme y con dos puntitas: thevetia, F. 63, T. II, S.-T. III.

611. Arbusto saliendo de una especie de cepa bastante gruesa: la lemos visto hasta de $6^{\prime \prime}$ de diámetro transversal, perpendicular, mas ó menos cilíndrica, y cuya parte inferior echa raices bastante gruesas y largas, de madera ni blandita ni dura tampoco, bastante liviana y de un color blanco lijeramente teñirlo de amarillento; la corteza que la cubre es poco espesa, de un color que á primera vista parece gris ceniciento, pero que despues de limpiada con agua y un cepillo aparece color de cacao, con muchas estrias verticales. Los vástagos, mas ó menos numerosos, que salen de ella son muy derechos y rectos, poco ramosos, en forma de varita y se elevan hasta $8^{\prime}$ 612 'de altura y alcanzan el diárnetro de $2^{\prime \prime}$ á $212^{\prime \prime}$, con ramos opuestos tambien y muy rectos y derechos que salen de la axila de lus hojas, de corteza lampiña, pardusco-achocolatada, mas ó menos pálida, con muchos puntitos ó manchitas blancas. Hojas simples, enteras, opuestas, subsesiles ó muy cortamente pecioladas, óvalolanceoladas, aguzadas por ambos estremos, mucronado-obtusas, algo orladas por la circunferencia, lampinas por ambas caras, cuya superior es verde casi manzana y lustrosa, mientras la inferior es mas pálida, de costilla muy pronunciada, con las nervaduras bastante proeminentes y en número de 11 á 13 de cada lado de la costilla, opuestas inferiormente y alternas superiormente en la misma hoja ó todas alternas, largas de 5" algo mas ó menos y anchas de 2$21_{[} 2^{\prime \prime}$. Flores ni grandes ni pequeñas tampoco, pero regulares, en grupos axilares, largamente pedunculadas, cuyo pedúnculo filiforme, unífloro, largo de unas $12^{\prime \prime \prime}$ á $15^{\prime \prime \prime}$, verde, lampiño, un poco crecido por el ápice, lleva un cáliz monosépalo, 5-partido, cuyas divisiones membranosas por los bordes, triangulares y puntiagudas, son largas como de $1^{\prime \prime \prime}$ escasa y derechas; corola hipocrateriforme mucho mas grande y larga que el cáliz, a marillen to-verdosa, cuyo tubo largo como de unas $6 "$ ", tiene la base ventrudita y algo pentígona, por encima de la cual sigue mas estrecho y pentágono y se encuentra otra vez al nivel de la garganta, de la cual sale el limbo partido en 5 lacinias bastante largas, abiertas y despues dobladas hácia abajo, de manera 
que su punta alcanza el cáliz, un poco ondulosas, esteriormente lampiñas, así como el tubo, mientras su cara interna, que se ha vuelto superior al abrirse la corola, está cubierta de pelo blanco como algodonoso y bastante largo: el interior del tubo es solamente pubercente; estambres de anteras conniventes, sentadas en la garganta de la corola y formando un cono amarillo-pardusco largo como de 1"' escasa; son puhescentitas esteriormente é inclusas. Ovario casi redondo y que sin embargo parece un poco lobado, por causa de un surco vertical muy poco pronunciado, sentado sobre un disco hipojínico, de cuyo ápice sale un estilo blanco, filiforme, bastante largo, terminado por un estigma glanduloso, grueso y pegado con la parte inte-rior é inferior de las anteras: guachamaca, F. 63, T. II.

612. Vejetales lechosos, 628. - Vejetales nunca lechosos, 613.

613. Baya grande con semillas abroqueladas, discoídeas, albuminosas y con los cotiledones foliáceos, 614. - Bayas mas ó menos grandes ó pequeñas, pero cuyas semillas no están nunca abroqueladas ni albuminosas, y de embrion con los cotiledones foliáceos, 615 .

614. Arbustos abejucados provistos de zarcillos leñosos ó sin ellos y entónces se agarran por el vértice de sus ramos nuevos que se enroscan sobre los vejetales vecinos, pelierizados ó pubescentes, con hojas simples, alternas, de ordinario triplinervias, aovadas ó elíptico oblongas ú oval-oblongas, coriáceas, aguzadas o con una punta obtusa con 3 ó 5 nervaduras pronunciadas, lustrosas y lampiñas ó pelierizadas. Flores pequeñas axilares ó en cimas corinubiformes, de cáliz monosépalo 5, 4-partido; corola hipocrateriforme ó enrodada, con 5 lóbulos estendidos, de prefloracion valvar, pubescente; estambres inclusos é insertos en la garganta lampiña ó pubescente de la corola, de anteras subsesiles y cuyo conectivo no está prolongado. Ovario bilocular, redondo, de cuyo ápice sale un estilo filiforme, con un estigma espeso algo cabezudo: strychnos, F. 61, Or. III.

615. Baya coriácea; corola con 5 apéndices situados en la garganta y opuestos á las divisiones del cáliz, 616. - Baya nunca coriácea; col'ola de garganta sin apéndice alguno, 617 .

616. Arboles bajitos ó arbustos y hasta frutices, muy ramosos y poco altos, de hojas simples, esparcilas, opuestas ó verticiladas y sub-verticiladas, coriáceas, entejérıimas, engrosadas por la már.jen, sub-revuelta, á veces mucronaditas, obtusas, alguna vez espinosas, con frecuencia provistas de puntitos diminutos, Jargas de $\left.4^{\prime \prime}-1\right]_{[} 2^{\prime \prime}$ y anchas de $21_{1} 2^{\prime \prime \prime}$ á $6^{\prime \prime \prime}$, lampiñas, acuñado-espatuladas ú obovales, lanceolado oblongas, obtusas ó mucronadaś, subsesiles. Flores blancas ó anararijadas, en racimos, en umbelas terminales ó solitarias, de cáliz monosépalo 5-partido, de lobulos obtusos, algo pestañosos por la márjen é imbricados; corola 5-fida, enrodado-hipocrateriforme o sub-campanuda, laminina, con los lóbulos obtusos, abiertos y de estivacion imbricada; estambres insertos en la parte mas inferior del tubo de la corola, libres y algo mas largos que él, cuyos filamentos de base algo dilatada y aplanada, y subulados, llevan anteras biloculares, anchas y nas cortas que ellos, elipsoídeas y tríquetras, $\mathrm{y}$ sin embargo esertas, cuyas celdillas adheridas y lon- 
jitudinalmente dehiscentes están reunidas por un conectivo grueso, de ápice troncado, que se prolonga por encima de ellas, entrorsas y abriéndose por medio de grietas. Ovario ovoídeo unilocular, con muchos óvulos insertos en una placenta central, ovoídeos y ascendentes; del ápice sale un estilo cilíndrico con la base cónica y terminandose por un estigma cabezudo sub-5-lobo, cuyos lóbulos son opuestos á las divisiones calizinales. Fruto globoso ú ovoídeo, con 10 o solamente 3 semillas anidadas en la sustancia gelatinosa de la placenta y casi cubiertas por ella, ovoídeas, algo comprinidas lateralmente, cuyo ombligo oval y ventral se estiende desde la base hasta la parte mediana: jacquinia, F. 80, T. II.

617. Cáliz avejigado mas ó menos desarrollado, y que encierra enteramente la baya, 618. - Cáliz nunca jamás rejigoso, baya no envuelta enteramente por el cáliz, 619 .

018. Plantas herbáceas anuales ó vivaces, velludas, pubescentes ó alampiñadas, muy ramosas y de ramos dicótomos, altas de $\mathrm{l}^{\prime}$ á $2^{\prime}$, con hojas simples, alternas ó mellizas, pecioladas, enteras, sinuosas, sinuoso-dentadas, sub-enteras, acorazonadas, aovadas, deltoídeo-aovadas, aovado-oblongas, puritiagudas ú obtusitas. Flores solitarias en la dicotomia de los ramos ó laterales, de cáliz monosépalo 5 -fido, avejigado y con 5 ángulos mas ó menos pronunciados; corola cortamente campanuda, de limbo plegado en el boton, amarillenta, con puntitos puruúreos por dentro ó pálida y sin ellos, larga de $3^{\prime \prime \prime}$ $4^{\prime \prime \prime}-6^{\prime \prime \prime}-8^{\prime \prime \prime}$; estambres inclusos, insertos en la parte inferior de la corola, de anteras de ordinario moradas y á veces amarillas, erguidas y lonjitudinalmente dehiscentes. Ovario casi esférico, bilocular, poliovulado, de cuyo ápice sale un estilo corto terminado por un estigma mny pequeño y cabezudo. Baya esférica, cerasiforme, de ordinario amarillenta, bilocular, con muchas semillas arriñonadas, situadas en dos placentas, insertas en los tabiques : physalis, F. 67, T. II, S.-T. I, G. II.

619. Baya muy poco carnuda, casi capsuliforme y á veces muy grande, 2 o raras veces 3 -locular, cuya placenta central lleva las semillas que se hallan como en una celdilla vacía y sin pulpa alguna, de sabor muy picante y hasta quemante, 620.-Baya mas ó menos gruesa y siempre llena de pulpa, mas ó menos abundante, sabor nunca picante, 621 .

620. Arbustos ó plantas herbáceas anuales, muy ramosos, lampiños ó pubescentes, que se elevan á $21_{[} 2^{\prime}-4^{\prime}$ y hasta $6^{\prime}$ de altura, con hojas simples, alternas ẙá veces mellizas, en especial hácia el vértice de los ramos, pecioladas, aovadas, ovales, sub-enteras, puntiagudas. Flores solitarias ó fasciculadas, situadas en la bifurcacion de los ramos ó laterales, blanquecinas y de cáliz monosépalo, 5-dentado o sub-entero; corola enrodada, de limbo plegado y con los 5 lóbulos valrados; estambres insertos en la garganta de la corola, inclusos, cuyos filamentos muy cortos é iguales llevan anteras conniventes y dehiscentes por una grieta lonjitudinal. Ovario ovoídeo ó redondo, bilocular, poliovulado, de cuyo ápice sale un estilo simple terminado por un estigma cabezudo. Baya seca mas ó menos voluminosa, tan pronto muy pequeña y larga solamente de $3^{\prime \prime \prime}$ ó $4^{\prime \prime \prime}$ y 
$6^{\prime \prime \prime}$, como del tamaño del puño y larga de $3^{\prime \prime}$ á 4 ", roja ó amarilla y lustrosa, con semillas amarillentas, comprimidas y casi discoídeas: capsicum, F. 67, T. II, S.-T. IV, G. III.

62i. Anteras conniventes y abriéndose por poros situados en el ápice, 622. - Anteras abriéndose lonjitudinalmente por una grieta, 623.

622. Plantas herbáceas, arbustos, vejetales fruticosos y sub-fruticosos, á veces sarmentosos ó abejucados, lampiños, alampiñados, pubescentes, velludos, aterciopelados, aguijonosos ó inermes, muy ramosos y con hojas simples, alternas, raras veces como compuestas, enteras, mas ó menos lobadas, sinuosas, angulosas, de forma y tamaño muy variados, pecioladas, algunas veces aguijonosas, pero mas comunmente inermes. Flores en racimos ó espigas terminales, otras veces en grupos paucífloros laterales, de cáliz monosépalo 5partido, algo campanudo, persistente, pubescente, peludo ó aguijonoso; corola enrodada, de limbo 5 ó mas rara vez 9, 4-fido, plegada por la base ó 5, 9, 4-partida, con sus divisiones valvadas ó induplicativas; estambres 5 de ordinario y algunas veces 9 ó 4 , insertos en la garganta de la corola, de filamentos cortos, con las anteras grandes, conniventes, raras veces coherentes, y sin conectivo proeminente, por fin abriéndose algunas veces lonjitudinalmente. Ovario mas ó menos globoso ú oval, 2 ó 4-locular, poliovulado, de cuyo ápice sale un estilo simple de lo largo de los estambres, terminado por un estigma cabezudo que se presenta por el ápice de la pirámide amarilla formada por las anteras. Baya mas ó menos gruesa, de forma y de color variados bi ó cuadrilocular, polisperma y cuya base está envuelta por el cáliz persistente : solanum, F. 67, T. II, S.-T. III, G. I.

623. Anteras coherentes; hojas piratisectas, 624. - Anteras nunca jamás coherentes; hojas siempre enteras, 625 .

624. Plantas herbáceas y anuales velludo-glandulosas, de tallos largos, muy ramosis, tendidos por el suelo ó algo trepadores, con hojas alternas pecioladas, de divisiones alternativamente pequeñas y grandes y pareciendo hojas compuestas, viscosas y exhalando un olor viroso bastante fuerte. Flores en cimas laterales largamente pedunculadas, amarillas y de cáliz monosépalo, 5-partido y á veces hasta 9-partido, mitad mas corto que la corola, cuyos segmentos lineares y puntiagudos son velludos como él; corola enrodada, de limbo plegado, con los lóbulos valvados y en igual número que las divisiones calizinales; estambres cuyo número corresponde al de los lóbulos de las cubiertas florales, insertos en la garganta de la corola, de filamentos cortos, anteras abriéndose á lo largo de su lado interior. Ovario globoso ú algo deprimido, como discoídeo y mas ó menos asurcado, de cuyo ápice sale un estilo simple que se termina por un estigma cabezudo que aparece en el vértice del cono formado por las anteras, algo bílobo y glanduloso. Baya colorada, lustrosa y lampiña, con 2 o 3 celdas conteniendo muchas semillas: lycopersicum, F. 67, T. II, S.-T. III, G. IV.

625. Corola siempre largamente tubulada y con frecuencia hipocrateriforme; filamentos bastantes veces con un diente, 626. - Co- 
rola siempre campanuda; fllamentos siempre sin dientes; baya pisiforme amarilla, $62 \%$.

626. Arbustos lampiños ó pubescentitos mas ó menos ramosos y cuyos ramos largos y delgados son en forma de varita, altos de $3^{\prime}$, $6^{\prime}$ y $8^{\prime}$, con hojas simples, alternas, lustroso-lampiñas, aovado-lanceolada:, elíptico-oblongas, oblongas, elípticas, oblongo-lanceoladas, aovado-oblongas, con venas delicadas ó con las nervaduras proeminentes inferiormente y por fin visibles por la cara superior, obtusitas, de base mas ó menos obtusa, alampinadas, cartáceomembranosas ó coriáceas, cortamente pecioladas, enteras. Flores en cimas estra-axilares ó en especie de panojas terminales no grandes, amarillentas, de ordinario muy olorosas, subsesiles ó largamente pediceladas, y de cáliz monosépalo pequeño, campanudo $\mathrm{y}$ algo tubulado, muy corto y 5-dentado; corola infundibuliforme ó hipocrateriforme, de tubo larguísimo, claviforme, delgado ó filiforme y cilíndrico, cuyo limbo corto, induplitativo y llano es abierto $\mathrm{y}$ con 5 divisiones agudas, iguales $\mathrm{y}$ escotadas, pubescente por las márjenes; estambres de filamentos muy cortos é insertos en la'garganta de la corola ó mas largos que las anteras é insertos entónces por encima ó en el medio del tubo de la corola, ordinariamente en número de 5 J á veces de 7 ó de 4 , de ordinario inclusos, de filamentos lampiños ó peludos por la base, alguna vez provista de un diente. Ovario aovado y pequeño, de cuyo ápice sale un estilo simple. largo, cilíndrico, un poco engrosado hácia el ápice que lleva un estigma cabezudò, algo bílobo y glanduloso. Baya ovoídea, oblonga, obovoídea ó sub-globosa, pequeña, azul ó prieta, bilocular, polisperma y cuyas semillas redondearlas tienen el embrion recto: cestrum, F. 67, T. II, S-T. IX, G. VII.

627. Arbusto ó arbolito muy ramoso y que se eleva de $8^{\prime}$ hasta $15^{\prime}$ y aun $25^{\prime}$, de tallo ó tronco cubierto de una corteza cenicienta, muy agrietada y un poco corchosa, con ramos muy largos, en varita y estendidos; hojas simples, alternas, enteras, á veces fasciculadas, pubescentitas cuando tiernas, pecioladas, elípticas, elíptico-oblongas, aguzadas por ambos estremos, puntiagudas y de base algo decurreste en el peciolo, largo como de 11 [ $2^{\prime \prime}$ á $2^{\prime \prime}$, de cara superior verde o:curo, algo lustrosa y lampiña, con líneas mas pálidas señalando la costilla y las nervaluras que están muy proeminentes por la cara inferior ; largas de $12^{\prime \prime}-8^{\prime \prime}-6^{\prime \prime}-4^{\prime \prime}$ y $2^{\prime \prime}$ y anchas de $5^{\prime \prime}-4^{\prime \prime}-3^{\prime \prime}-$ $1 \mathrm{I}[2 "$. Flores no muy pequeñas ni grandes tampoco, pedunculadas y saliendo por grupos de 10 á 20 , de especies de tubérculos que se hallan á lo largo de los ramos del año anterior, al lado de 2 á 3 hojas pequeñas que no se desarrollan sino despues de la fecundacion $r$ alcanzan entónces su tamaño regular; pedúnculo delgado, largo de cono $6^{\prime \prime \prime}$, de ápice un poco mas grueso, pendiente y unífloro; cáliz campanudo, 5 ó 4 -festoneado, blanquecino, largo de $11_{[} 2^{\prime \prime \prime}-2^{\prime \prime \prime} y$ persistente; corola campanuda blanco-verdusca, gradualmente dilatada hácia la base, 4 ó 5 veces tan larga como el cáliz, con 5, 4 lóbulos valvares y lijeramente induplicativos, obtusos, recorvados, con dos manchitas verdes, larga de 5 "' y pubescente. Estambres in- 
sertos en la parte mas inferior del tubo de la corola, alternos con sus divisiones, esertos y por fin casi dos veces tan largos como ella, con anteras derechas, gruesas, ovales, escotadas por la base, por donde están pegadas en los filamentos, un poco inclinadas hácia el pistilo y abriéndose lonjitudinal mente. Ovario ovoideo, amarillento por la base, y despues blanquecino, bilocular, poliovulado, con una depresion en el ápice, de donde sale un estilo mas largo que los estambres, terminado por un estigma verde, glanduloso, cabezudo y trílobo; el estilo está doblado en la prefloracion y despues se endereza al abrirse la flor. Baya pisiforme amarilla, bilocular y polisperma: acnistus, F. 67, T. II. S.-T. IV, G. V.

628. Corola sin estaminodios ó estamıbres estériles y abortados, que se han vuelto apéndices; anteras lateralmente dehiscentes; hojas de cara inferior color de oro, 629. - Corola siempre con estaminodios ó apéndices; hojas de cara inferior nunca dorado-serícea, 630.

629. Arboles frondosos, altos de $35^{\prime}$ á $45^{\prime}$ ó arbustos de $10^{\prime}$ á $15^{\prime}$, de hojas simples, enteras, alternas, pecioladas, coriáceas, ovales, oblongas, lanceolado-oblongas ó elíptico-oblongas, con una punta obtusita ó mucronadas, con las nervaduras casi perpendiculares ú oblícuas en la costilla, de cara superior lampiña, verde oscuro y lustrosa, mientras la inferior es dorado-sedosa y mas rara vez plateado-sedosa, largas de $5^{\prime \prime}-4^{\prime \prime}-3^{\prime \prime}$ y anchas de $2^{\prime \prime}-1 \mid 1\left[2^{\prime \prime}-8^{\prime \prime \prime}\right.$. Flores pequeñas pedunculadas, en grupos axilares, situadas en la sumidad de las ramitas y de cáliz monosépalo 5, 6-partido, campanudo, con los segmentos obtusos, casi iguales y escariosos ó membranosos por los bordes; corola 5, 7-lobulada, campanuda, cuyas divisiones zon iguales y estendidas; estambres inclusos insertos en la garganta de la corola y alternos con sus divisiones. Ovario esférico 5, 10-locular, con tantos óvulos ascendentes: del ápice sale un estilo corto terminado por un estigma 5-fido. Baya glohosa 10, 8-locular, del tamaño de una manzana, verdusca, rosado-purpúrea ó azul, otras veces mucho mas pequeña, aceituniforme y larga de $8^{\prime \prime \prime}-66^{\prime \prime \prime}$, prietoazulada ó negra, con semillas solitarias en cada celda, de casco duro, lustroso, prieto, con el ombligo blanco y lateral, muy largo, comprimidas y conteniendo un endospermo carnudo: chrysophyllum, F. 84, G. I.

630. A péndices de la corola ó estaminodios simples y situados entre sus lobulos, estambres fértiles en número igual á las divisiones calizináles, 631. - Apéndices de la corola dispuestos por pares, situados entre sus lóbulos, y además hay algunos utros mas interiores y alternos con los estambres, 637 .

631. Cáliz siempre con 5 segmentos imbricados, de los cuales 2 son interiores; corola semi-quinquétida ó casi 5 -partida, de estivacion imbricada, con los 5 apéndices alternando con sus lóbulos y con frecuencia partidos á manera de dientes; endospermo copioso, 636 . - Cáliz cuyo número de lóbulos no es fijo, pero varia bastante, 632.

632. Cáliz 4, 6 y hasta 12-partido, de segmentos imbricados, cuyos dos esteriores son algo mayores y abrazan á los demas; corola 
campanuda con 4, 5, 6 lóbulos profundos; endospermo nulo, 633. Cáliz formado de 5, 6 sépalos imbricados en la estivacion; corola tubuloso-campanuda, 5, 6 lobada, cuyos segmentos están partidos hasta el medio y aun mas allá; endospermo carnoso, 63.j.

633. Cáliz con 5 sépalos imbricativos; ovario 5-locular con óvulos ascendentes, 641.-Cáliz 4 ó plurisépalo ó partido é imbricativo; ovario 10,2 -locular con los óvulos pendientes, 634 .

634. Arboles grandes y coposos, con las ramitas sedoso ó velludoherrumbrosas ó alampiñadas, con hojas simples, alternas, pecioladas, cartáceas, obaovado-oblongas ú obaovadas, otras veces espatuladas, mucronadas ú obtusitas, con las venas distantes y dispuestas á manera de costilla, delicadamente reticuladas, lampiñas por ambas caras ó lampiñas superiormente, mientras la cara inferior es alampiñara. Flores fasciculadas ó sub-solitarias, pedicelarlas, axila. res ó laterales en las ramitas, cuyas hojas ya se han desprendido, de cáliz monosépalo con 4 , algunas veces 6 y hasta 12 segmentos; corola tubulosa, 6,4 8-lobada, á veces cilindrácea, y con tantos apéndices insertos en su tubo cuantos lobulos tiene; tantos estambres hay cuantos segmentos en la corola, á los cuales son opuestos y alternos pues con los apéndices, cuyas anteras oblongas ú ovoídeas son acorazonadas por la base, mientras que tienen el ápice agudo ú obtusito; estrorsas dehiscentes esterior ó lateralmente. Ovario pelierizado mas ó menos ovoídeo, con $2,6,10$ celdas opuestas á los lóbulos calizinales, con óvulos solitarios en cada una de ellas, oblongos y colgantes de su ángulo interno; del ápice sale un estilo simple, lampiño y que se termina por un estigma obtuso, deprimido ó discoídeo, lobulado ó tıbercularo. Baya carnuda mas ó menos gruesa, globosa ú ovoídeo-oblonga, larga de $6^{\prime \prime}$ y ancha de $3^{\prime \prime}$, con una sola semilla fusiforme, de casco duro, castaño-claro, larga de $21_{[} 2^{\prime \prime} \mathrm{y}$ con el hilo blanco muy grande y ventral, y mucho mas pequeña, con 5 á 8 semillas : lucuma, F. 84, G. III.

635. Arboles muy ramosos y bastante gruesos, que se elevan hasta $40^{\prime}$ de altura y mas, de ramitas, pedícelos 5 peciolos lijeramente sedosos ó herrumbroso-pubescentes, de hojas simples, alternas, coriáceas, enteras, pecioladas, de ordinario aproximadas hasła la sumidad de las ramitas, oblongas, elípticas o lanceolado oblongas, elípticas, puntiagudas por el vértice solamente ó por ambos estremos; enteramente lampiñas ó con la cara inferior alampinada, lustrosas superiormente, largas de $6^{\prime \prime}-8^{\prime \prime} 3^{\prime \prime}-4^{\prime \prime}$ y anchas de $3^{\prime \prime}-4^{\prime \prime}$. Flores en grupos axilares en la sumidad de las ramitas pedunculadas y de cúliz con 6,5 sépalos ó 6,5 partido, con las divisiones imbricativas, ovales o aovadas, obtusas, de las cuales las 3 interiores son á veces coloradas, sedosas ó herrumhroso-pubescentes; corola campanuda 6, 5-loba; estambres inclusos, de filamentos cortísimos é insertos en el interior del tubo de la corola, con anteras ovoídeas o deltoídeas, otras veces aflechado-lanceoladas y mas cort is que los apéndices de la corola, lateralmente dehiscentes. Ovario globoso con 12, 4 celdas. con óvulo ascendente: del ápice sale un estilo mas largo que la corola, terminíndose por un estigma obtuso. Baya bastante gruesa, redonda ú oval, cubierta de una concha áspera par- 
dusco-amarillenta, cuyo diámetro es de $3^{\prime \prime}$ á $4^{\prime \prime}$ ó mucho mas pequeña, segun las especies; semillas negras, comprimidas, ovales, lisas, lustrosas y de casco muy duro, largas de $8^{\prime \prime \prime}$ á $10^{\prime \prime \prime}$ : sapota, F. 84 , G. II.

636. Arboles de ordinario bastante grandes, ramosos y coposos, con los ramos las mas veces inermes; tienen hojas simples, alternas y raras veces opuestas, por lo comun nervosas, coriáceas, lampiñas ó pubescentes, de forma y tamaño poco variados, mas ó menos oblongas, ovales ó elípticas, aovado-oblongas, largas de $4^{\prime \prime}-2^{\prime \prime}-8^{\prime \prime}$, raramente fasciculadas. Flores fasciculadas ó á veces solitarias y axilares, de cáliz monosépalo 5-partido ó con 5 sépalos imbricados, y de dos cuales 2 son esteriores; corola enrodada, 5-partida ó 5fida, con los segmentos mas veces abiertos, de estivacion imbricada, quedándose uno mas esterior; los apéndices en una sola série se insertan junto á los estambres con que alternan en el tubo de la corola, con cuyos lóbulos alternan tambien : son petaloídeos inclusos y frecuentermente recortados á manera de dientes; anteras de ordinario estrorsas, ovales, obtusas y mediifijas, mas cortas que el filamento y oscilantes. Ovario 5, 2-locular, con los óvulos ascendentes, pelierizado, ovoídeo y de cuyo ápice sale un estilo simple algo mas largo que él y terminándose en un ápice agudito y por lo menos lobado. Baya de ordinario pequeña y las mas veces cerasiforme, ovoídea $\delta$ globosa, cuvas semillas son 3,1 por causa de aborto, globosas y raras veces ovoídeas, lustrosas, con 4 ó 5 crestas obtusas, de ombligo redondo, pequeño y algo deprimido; endospermo espeso y cartilajinoso, cotiledones grandes, planos y foliáceos: sideroxylon, F. 84, G. IV.

637. Hojuelas del cáliz 6, 8, dispuestas en dos séries; apéndices de la corola pareciendo sus segmentos, dobles que ellos ó mas numerosos y apareados entre ellos, 638. - Hojuelas calizınales nunca en dos séries, 5, 4, 8-imbricativas; apéndices de la corola no semejantes á sus divisiones, dispuestos en dos séries, cuya esterior está apareada entre ellas, mientras la interior alterna con los filamentos, 633.

638. Arboles no rara vez muy altos, corpulentos y coposos, de hojas simples, alternas, coriáceas, enteras, pulidas, con las venas poco notables, oblongas, obaovado-oblongas, obaovadas, ovales $\delta$ aovado-oblongas, retusas ó apiculado-obtusas, concóloras ó discóloras, enteramente lampiñas ó de cara inferior alampiñada, pubescentita, sedoso -plateada ó escamosita, largas de $2^{\prime \prime}-4^{\prime \prime}-5^{\prime \prime}-6^{\prime \prime}$. Flores con frecuencia fragantes y blancas, axilares, frecuentemente solitarias ó mellizas y pediceladas, de cáliz con 6,8 hojuelas; corola enrodara 6,8-partida; estambres insertos en el tubo de la corola, de filamentos delgaditos y cortos, alternos con los apéndices interiores, de anteras asaetadas mas largas que ellos, estrorsas, biloculares y lonjitudinalmente dehiscentes. Ovario pelierizado, mas veces anguloso, de celdillas en número igual á los segmentos calizinales con que están opuestas, con un solo huevecillo colgante de su ángulo interno y ascendente: del ápice sale un estilo cilindráceo, lampiño, algo asurcado y terminado por un estigma pequeño. Baya 
globosa ó sub-elipsoídea ó bilocular por causa de aborto, con pocas ó una sola semilla tambien por el aborto, derechas, obovoídeas ó elipsoídeas, de casco crustáceo y lustroso; ombligo oval y pequeño; endospermo carnoso; embrion central erguido, de cotiledones grandes foliáceo-carnosos y con raicilla cilíndrica é ínfera : mimusops, F. 84, G. V.

639. Semillas provistas siempre de un endospermo; cáliz con 5 y á veces 4,8 hojuelas ó divisiones foliáceas, 640 . - Semillas sin endospermo ; cáliz con 5 segmentos foliáceos, 641 .

640. Arboles altos y ordinariamente corpulentos, con las ramitas lampiñas, alampiñadas ó herrumbroso-sedosas, llevando hojas simples, alternas, enteras, cartáceas, con las venas arqueadas, pecioladas, aovado-oblongas, elíptico-oblongas, lanceoladas, elíptico-lanceoladas, obaovadas ú obaovado-lanceoladas, terminadas por una punta mas ó menos retusa ú obtusa, de base bastantes veces aguzada, no rara vez ondulosas, largas de $2^{\prime \prime}-33^{\prime \prime}-4^{\prime \prime}-5^{\prime \prime}$. Flores 4-10 dispuestas en especies de umbelas ó cimas axilares á veces muy fragantes, cuyos pedícelos mas largos que ellas son sedosos y herrumbrosos, así como el cáliz que es 5-partido y de estivacion imbricada; corola 5-partida enrodada ó infundibuliforme; estambres inclusos, opuestos á los lóbulos de la corola, cuyos filamentos se insertan en su tubo, con anteras estrorsas, redondeado-acorazonadas y mas cortas que el filamento, de pólen elipsoídeo. Ovario 5, 4-locular ovoídeo y con 5 ángulos, lampiño, con óvulos ascendentes, y en cuyo ápice está un estigma sentado y agiadito. Baya ovoídeo-globosa, por lo regular pequeña, larga de $6^{\prime \prime \prime}-8^{\prime \prime \prime}$ y ancha de $6 " '$, con una ó dos semillas ovoídeas ó sub-redondas, lisas, lustrosas, de casco crustáceo y con estrias poco marcadas, con el hilo sub-lateral, de embrion erguido y axil con los cotiledones planos: dipholis, F. 84, G. IV.

641 . Arboles bajitos, de madera durísima y muy fuerte, cuyas ramitas sub-sedosas, alampiñadas, enteramente lampiñas ó sedosoherrumbrosas, llevan hojas simples, alternas, obaovadas ó redonditas, oval-redondeaditas, oval-oblongas, redondeadas por ambos estremos ó solamente por el vértice obtuso ó retuso, enteras, cortamente pecioladas, largas de $8^{\prime \prime \prime}-1^{\prime \prime}-2^{\prime \prime}-3^{\prime \prime} \cdot 4^{\prime \prime}$, coriáceas, con las venas costilladas y oblícuas. Flores solitarias o fasciculadas, axilares, pediceladas, lampiñas ó bozosas; de cáliz 5-partido, con los segmentos obtusos, de los cuales dos son esteriores y de estivacion imbricada; corola 5 -fida enrodada o infundibuliforme, con apéndices angostos acompañando á eada lado de los lóbulos y por consiguiente en numero doble de ellos; estambres petaloideos, alternos con las divisiones de la corola; ovario 5-locular, ovoídeo, de óvulos ascendentes, pelierizado ó pubescente, de cuyo ápice sale un estilo corto filiforme y lampiño, terminado por un estigma agudo. Baya elipsoídea ú ovoídea, larga de $11_{[} 2^{\prime \prime}-1^{\prime \prime}-6^{\prime \prime \prime}$, con una semilla lisa, de casco crustáceo, de ombligo basilar y sub-redondo; cotiledones gruesos, ovales y aplicados por la cara, raicilla cortísima : Zumelia, F. 84.

642. Dos ovarios, 643. - Cuatro ovarios, 668.

643. Fruto drupáceo; vejetales muy lechosos, 644. - Fruto seco y capsular; vejetales mas ó menos lechosos, 645 . 
644. Arbustos ó árboles bajitos, muy ramosos, cuyos ramos son de ordinario dicótomos, de ramitas lampiñas, alampiñadas ó pubescentes que llevan hojas simples opuestas ó verticiladas por á 3 ó á 4 ; cortamente pecioladas, cartáceas ó membranosas, elípticas, lanceolado-oblongas, elíptico-oblongas, aovado-lanceoladas, puntiagudas ó aguzadas por el vértice y á veces por ambos estremos, de cara superior lustrosa y lampiña, mientras la inferior es alampiñada, lampiña ó pubescentita sobre las nervaduras, con venas delicadas peninervias, enteras y de ordinario desiguales en el mismo verticilo. Flores pequeñas, blancas ó rojizas, en cimas axilares pauci ó plurífloras, pediceladas, y de cáliz monosépalo 5-fido ó 5-partido, con los segmentos agudos é iguales ; corola hipocrateriforme, de tubo cilíndrico dos ó tres veces mas largo que el cáliz, de limbo con 5 divisiones iguales, de prefloracion torcida hácia la izquierda; estambres inclusos é insertos en la parte superior del tubo corolar. Dos ovarios distintos ó lijeramente coherentes, pauciovulados y envueltos inferiormente por un disco aorzado; estigma provisto de un indusio que con frecuencia encierra 2 puntitas. Drupa dídima por ser adheridos los dos carpidios, semi-ovoídeo-redonditos, escotada, redondeadita, troncada, elipsoídea, retuso-troncada, larga de $3^{\prime \prime \prime}-6^{\prime \prime \prime}$ y ancha de $4^{\prime \prime \prime}-5^{\prime \prime \prime}$, morada cuando madura : rauwolfia, F. 63, T. II, S.-T. II, G. IV.

645. Estigma indusiado; pólen no en masas ceráseas ó polinias ; anteras sin apéndice ó membrana por el ápice, 646. - Estigma sin indusio; pólen compuesto de polinias ó masas ceráseas ordinariamente en número de 10 , de las cuales 2 se unen á las anteras vecinas ó adyacentes por medio de una glandulita comun; anteras terminadas por un apéndice ó membrana, 655 .

646. Conectivo no presentándose por debajo de las celdillas de las anteras; semillas de ordinario no penachudas, 647.-Conectivo ensanchado y presentándose por debajo de las celdas de las anteras; semillas ordinariamente provistas de un penacho terminal, 654 .

647. Vejetales no ó apenas lechositos, 648. - Vejetales muy lechosos, 649 .

648. Planta casi leñosa ó matita, muy ramosa, derecha, pubescentita que se eleva á $11_{[} 2^{\prime}-21_{[} 2^{\prime}$ de altura, con hojas simples, opuestas, enteras, pecioladas, cartáceas, lustrosas, espatuladooblongas ú óvalo-lanceoladas, con 2 glándulas frecuentemente situadas por su base y tambien en la de las lacinias del cáliz, largas de $2 "-21[2 "$. Flores rosadas ó blanquecinas, bastante grandes y primorosas, solitarias ó con mayor frecuencia mellizas y axilares, de cáliz monosépalo 5-partido, con segmentos aguzados ó quiźs mejor dientes erguidos, mucho mas corto que el tubo filiforme de la corola, que es hipocrateriforme, y pubescente hasta la garganta estrecha, callosa y con 5 ángulos opuestos á los lóbulos 5 -obtusos, de prefloracion torcida, algo mas cortos que el tubo corolar largo de $1^{\prime \prime}$; estambres inclusos, insertos en la parte superior del tubo corolar, de filamentos muy cortos con el ápice dilatado á manera de escama cóncava que lleva una antera inclinada, oblonga, membranosa, con el ápice torcido y mucho mas larga que el filamento. Dos ovarios, 
erguidos, aproximados, lijeramente adheridos, alternando con las dos glándulas del disco oblongas y algo mas largas que ellos, multiovulados; el ápice se prolonga en un estilo terminado por un estigma indusiado, glanduloso, cónico, de ápice como pelierizado y cabezudo ó algo bílobo. El fruto consiste en dos folículos derechos, poco diverjentes, angostos, comprimido-cilíndricos, estriados, con muchas semillas oblongas, cilindráceas y troncadas por ambos estremos, morenas, tuberculadas, de ombligo asurcado y lateral; embrion recto, céntrico y mas corto que el endospermo carnudo, con la raicilia cilíndrica : vinca, F. 63 , T. IV.

649. Fruto samaroídeo, cuya ala terminal se dilata repentinamente por la base y reviste el carpidio, 650.-Fruto folicular, 651.

650. Arboles muy grandes y corpulentos ó arbustos, lampiños, de hojas simples, opuestas, membranosas, pecioladas, enteras, elípticas, lanceoladas ú oblongo-lineares, obtusas, á veces escotadas por el ápice ó con una punta, de venas dispuestas á manera de costillas, aproximadas y reunidas por un arco, continuo y justa-marjinal, ó delicadas y lispuestas en redecilla floja, largas de $18^{\prime \prime \prime}-12^{\prime \prime \prime}-10^{\prime \prime \prime}$ y anchas de $6^{\prime \prime \prime}-4^{\prime \prime \prime}-22^{\prime \prime}$. Flores en cimas terminales paucífloras y blancas, de cáliz 5-fido muy pequeño, largo solamente de 1"'; corola hipocrateriforme, de tubo sub-cilíndrico, algo crecido por ambos lados y pentágono, con el limbo de 5 lóbulos oblícuos, cuya prefloracion es torcida; estambres insertos en la parte superior de la porcion lijeramente ensanchara del tubo corolar, cuyas anteras subsesiles y converjentes se terminan por un apéndice cerdoso que es la prolongacion del conectivo. Dos ovarios, cuyo estilo simple y filiforme se termina por un estigma indusiado y bipartido, con 2 segmentos cónicos. Semillas obtusas, comprimidas, discoídeas, aladas é imbricadas: cameraria, F. 63, T. IV, S.-T. II, G. II.

65l. Folículos grandes, frecuentemente con pulpa, y cuyas semillas son asurcadas y sin alas. Anteras aflechadas y aguzadas, 652.Folículos largos comprimidos y un poco fusiformes, sin pulpa alguna y cuyas semillas imbricadas son aladas; anteras converjentes no aflechadas, 653 .

652. Arboles á veces hasta de 60' de alto, corpulentos y coposos, pero de ordinario arbustos mas ó menos altos, muy ramosos, ordinariamente lampiños, de hojas simples, opucstas, pecioladas, enteras, oblongas, ovales ú oval-oblongas, obaovado-lanceoladas, eliptical-oblongas, lanceolado-oblongas, ondulosas ó no, obtusas ó puntiagudas por ambos estremos, ó terminadas por una punta mas ó menos obtusa, mientras la base va aguzándose hasta confundirse con el peciolo, membranosas, largas de $66^{\prime \prime}-7^{\prime \prime}-5^{\prime \prime}-8^{\prime \prime}-4$ " y anchas de $4^{\prime \prime}-3^{\prime \prime}-2^{\prime \prime}-18^{\prime \prime \prime}-9^{\prime \prime \prime}$. Flores fragantes, blancas ó amarillas y bastante grandes, en cimas terminales, paucí ó plurífloras, mas ó menos pedunculadas ó sủbsesiles, de cáliz monosépalo 5-fido ó 5-partido, y glanduloso interiormente, con lus segmentos oval-oblong'os y obtusos, aovados y obtusitos, aovados ó aovado-lanceolados, de punta obtusa y recorvada; corola hipocrateriforme, con el tubo ordinariamente ensanchado en la línea de insercion de los estambres, con los 5 lóbulos del limbo linear oblongos, oblícuamente espatulados ú 
obaovados, otras veces aovado-lanceolados, mas largos, tan largos ó mas cortos que el tubo corolar cilíndrico; estambres inscrtos en el medio ó por encima del medio del tubo corolar inclusos ó con el ápice de las anteras eserto. Dos ovarios envueltos por un disco aorzado, apenas notable ó nulo: del vertice sale un estilo simple terminado por un estigma sostenido por un indusio anular : taberncmon$\operatorname{tana}$, F. 63, T. IV, S.-T. II, G. III.

653. Arboles bajitos de 25' de altura ó mas pequeños ó arbustos, de ramos dicótomos gruesos por el ápice obtuso y como carnudo, estendidos, lampiños ó tomentosos; hojas simples, enteras, alternas ó esparcidas, con las venas dispuestas á manera de las costillas y reuniéndose en un arco justa-marjinal, cartáceas, enteras, pecioladas, oblongas, oblongo-lineares, obaovado-oblongas, espatuladooblongas, con una punta, ó redondeadas y mucronadas por el ápice, largas de $8^{\prime \prime}-10^{\prime \prime}-12^{\prime \prime}-6^{\prime \prime}-4^{\prime \prime}$. Flores pediceladas, de ordinario fragantes, primorosas, bastante grandes, rosadas, blancas, amarillentas, de ordinario saliendo antes que aparezcan las hojas, en cimas terminales pedunculadas, abiertas ó cerradas, pubescentes, alampiñadas ó lampiñas, y de cáliz monosépalo anchamente 5-lobo ó subentero, pequeño, campanudo, con los segmentos sub-troncados, redondeaditos ó mucronadito-truncados, obaovados; corola grande, períjina, hipocrateriforme ó infundibuliforme, de tubo largo, estrecho y con frecuencia oblícuo, con el limbo partido en 5 segmentos anchamente ovales, obaovado-oblongos $\dot{u}$ obaovados, espatuladolineares ú oblongo-lineares, casi iguales, tan ó dos veces mas largos que el tubo de la corola; de prefloracion torcida; estambres insertos en la parte mas inferior del tubo de la corola, inclusos y de filamentos cortos. Dos ovarios libres ó lijeramente adheridos con el tubo estrecho del cáliz, terminados por un estilo sencillo, corto y terminado por un estigma bipartido. Folículos largos como de $5^{\prime \prime}$ á 6" $\mathrm{y}$ mas, aguzados, ventrudos y conteniendo muchas semillas, comprimidas, oblongas, empizarradas, con una ala bastante ancha aguda, dentada ó festoneada: plumeria, F. 63, T. IV, S.-T. II, G. III.

654. Arbustos ordinariamente abejucados $y$ raras veces plantas herbáceas, de tallos delgados, muy largos, ramosísimos, sarmentosos ó volubles, lampiños ó pubescentes; de hojas simples, opuestas, pecioladas, aovado-lanceoladas, aovado-oblongas, oblongo-lanceoladas, oblongas, aovadas, lanceoladas, eliptical-oblungas, aovadoredondeaditas, ovales, oval-oblongas, acorazonarlo-aovadas, con una punta, obtusas ú obtusitas, mucronadas, agnzadas, de base redonda, acorazonada ó algo aguzada, largas de $2^{\prime \prime}-3^{\prime \prime}-4^{\prime \prime}-6^{\prime \prime}-5^{\prime \prime}-1^{\prime \prime}-11_{1} 2^{\prime \prime}-2$ $1_{[} 2^{\prime \prime}$. Flores bastante grandes ó pequeñas blancas, amarillas ó rosadas, pediceladas y mellizas, dispuestas en cimas axilares de ordinario corimbiformes, las mas veces paucífloras y pedunculadas; de cáliz 5-fido con los segmentos glandulosos aovado-lanceolados, lanceolado lineares, aovados, subulados, etc., y sin escamas interiores ó sin glándulas y provistos de escamas interiores que faltan raras veces, mucho mas cortos que el tubo de la corola hipocrateriforme, desnuda ce lóbulos oblícuos y de prefloracion torcida por la dere- 
cha, con el tubo sub-cilíndrico, infundibuliforme por encima de la base cilíndrica, pelierizado entre y por debajo de los estambres, campanudo por encima de la base, pero lampiño; estambres de anteras conniventes, adheridas al estigma por su parte mediana, oblongas, obtusas, con un mucro inclinado y dos cornezuelos, acorazonadlas ó sub-acorazonadas pqr la base, tiesas, aguzándose desde la base aflechada ó acorazonada y aguzadas por la punta, oblongas, obtusitas y acorazonadas por la base, cornudas, aflechadas con aurejitas tiesas y obtusitas, aguzadas desde la base y contenidas en la parte mas baja de la porcion campanuda de la corola, otras veces provistas de un apéndice terminal y membranoso. Ovario sentado en un disco 5-glanduloso ó 5-lobo y raras veces sub-entero. Folículos lineares ó torrulosos, con semillas provistas de un penacho terminal: echites, F. 63, T. VII.

65.5. Vejetales apenas lechosos ó cuya savia es solo un poco turbia, 656.- Tejetales muy lechosos, 65\%.

656. Arbusto ramosísimo, alto de $8^{\prime}$ á 15', cuyos ramos largos y lampiños son en forma de varita, derechos, tricótomos y un poco triangulares cuando tiernos, con hojas simples, coriáceas, sub-sentadas, verticiladas por á 3 , enteras, lanceoladas, aguzadas por los dos estremos, lampiñas, lustrosas, con la costilla muy pronunciada inferiormente blanca, así como las nervaduras delgaditas, paralelas y pinadas, bastante proeminentes y notables en la cara superior por las líneas mas blanquecinas que corresponden á ellas; primorosas flores rosadas, algunas veces blancas, en corimbos terminales pedunculados y pediceladas, de cáliz muy pequeño, monosépalo, campanudo, de 5 divisiones profundas, lineares y derechas; corola grande, infundibuliforme, regular, de limbo partido en 5 segmentos oblícuos, profundos, obtusos y de prefloracion torcida; tubo largo cuyo orificio está adornado de 5 apéndices petaloídeos con el ápice franjeado ; estambres inclusos, distintos, insertos en la parte media del tubo corolar, y cuyas anteras adhieren con el estigma por su parte mediana, son aflechadas y se terminan por un apéndice en forma de penacho. Dos ovarios aplicados uno á otro, derechos, estriados, larguitos, y de cuyo ápice sale un estilo filiforme, un poco crecido hácia el ápice, que se termina por un estigma cilíndrico, truncado y obtuso; la base está acompañada de 5 apéndices muy cortos ó dientes que salen del fundo del cáliz, un poco por afuera de la inserción de la corola y representan el disco. Folículo cilindráceo, bilocular polispermo, derecho y estriado : nerium, F. 63.

657. Corona de la corola doble, cuya série esterior es anular ó cortamente ciatiforme, ondulosa ó festoneada, y reuniendo la columna con el tuho de la corola, mientras la interior mas grande es formada de 5 hojuelas situadas por debajo de las anteras, 658. Corona de la corola sencilla, 659 .

658. Plantas herbáceas pubescentes ó alampiñadas, de tallo muy largo voluble y abejucado, muy ramoso, de hojas simples, opuestas, enteras, aovado-oblongas o lanceoladas, aguzadas ó mucronadas, obtusas por la base glandulífera y pecioladas, largas de $1^{\prime \prime}-21\left[22^{\prime \prime}\right.$. Flores en umbelas laterales ó terminales, de pedúnculos mas largos 
que las hojas, pubescentes y formadas de algunas flores; de cáliz うेpartido; corola enrodada 5 -partida ó 5-loba, lijeramente torcida, blanca, con los segmentos aovados, obtusitos ú obtusos; corona esterior anular, sub-entera, mientras la interior, de hojuelas ovales $y$ abroqueladas por la base, escede un poco la columna. Polinias claviformes y cilíndricas á la par y colgantes, cuyo rabo corto y ascendente se inserta en el mucro basilar de la glándula deltoídeo-redondeadita; estigma cónico y sub-entero. Folículos aovado-lanceolados, lampiños, con semillas penachudas: sarcostemma, F. 62, T. IV, S.-T. VIII.

659. Formada de 5 hojuelas, 660. - Anular ó acubileteada; anteras transversalmente dehiscentes, 665 .

660. Insertas por dehajo de los estambres y sin apéndice interior, frecuentemente adheridas por debajo de ellos, 661. - Insertas en la columna, 662 .

661. Arbustos sarmentosos, trepadores ó bejucos, lampiños, ó con dos líneas de pelo en las ramitas, de hojas simples, opuestas, pecioladas, subsesiles, enteras, lanceolado-oblongas, lanceoladas ó espatuladas, aovadas ó anchamente aovado-oblongas, mucronaditas, obtusitas, aguzacitas ó algo acorazonadas por la base. Flores en cimas pedunculadas, á veces umbeliformes, pedunculadas ó sub-sentadas y

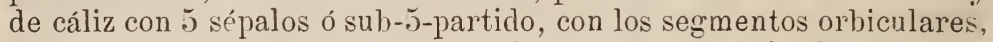
ú oval-oblongos y pestañosos; corola cortamente infundibuliforme, con 5 lobulos ovales dos veces tan largos como el tubo, barbudos por encima de la garganta, ú oval-oblongos, obtusos, pestañudos, interiormente lampiños y tres veces mas largos que el tubo; hojuelas de la corona redondeaditas y espesas ó lanceoladas. Polinias oblongas ú obovoídeas, y derechas; rabo horizontal é inserto en la base de la glándula. Estigma entero, plano ó convexo-cónico. Folículos lampiños y lisos, con semillas penachudas; marsclenia, F. 62. T. III, S.-T. I, G. I.

662. Verticalmente, dobladas sobre sí y provistas de un espolon ascendente situado en su dorso, 663. - En el vértice de un estipe corto, cuculiformes y provistas de un apéndice encorvado que sale de su concavidad, $6 \dot{64}$.

663. Arbusto que se eleva á como $10^{\prime}$ o $15^{\prime}$ de altura ó á veces se queda una mata, muy ramoso, de corteza blanco-cenicienta, con el epidermis espeso muy agrietado y algo corchoso, las ramitas herbáceas todavía son glaucas; hojas simples, opuestas, enteras, sub-sentadas, obaovado-oblongas ú obaovado-redondeaditas, muy anchas, acorazonadas por la base, largas de $8^{\prime \prime}-6^{\prime \prime}$, lampiñas y glaucas. Flores bastante grandes, de como l" de diámetro, blancas, teñidas por adentro de rojo moradusco, en corimbos axilares largamente pedunculados; cáliz monosépalo J-partido; corola campanuda 5-partida, abierta, con la punta de los segmentos doblada un poco hácia fuera, de prefloracion valvar; hojuelas de la corona encorvadas y tan largas como la columna prismática; polinias comprimidas, espatuladas, diverjentes y colgantes á la par; rabo corvo; horizontal por la base é inserto en la base de una glándula pequeña; estambres inclusos y morados; estigma deprimido. Folículos ventrudos, lampiños y lisos. 
glaucos, conteniendo muchas semillas penachudas: calotropis, $\mathrm{F}$. 62, T. IV, S.-T. TIII.

664. Plantas herbáceas perennes ó matas, de tallo derecho mas ó menos ramoso y que se eleva á $11\left[2^{\prime}-4^{\prime}\right.$ de altura, pubescentito ; hojas simples, opuestas, pecioladas, oblongo-lanceoladas ó lanceolado-aguzadas, alampiñadas; flores en umbelas, plurífloras, peduncularlas y saliendo de entre las hojas superiores ó terminales; pedícelos $5,12,3,4$ veces tan largos como las flores sea carmesí ó verdoso-blancas, de cáliz 5-partido, cuyos seğmentos muy pequeños son reflejos, pequeño y campanudo; corola 5-partida, enrodada con las divisiones reflejas y de prefloracion valvar, elípticas, puntiagudas ú obtusitas; columna repentinamente estipitada, apéndices de las cornetas anaranjadas ó blanco-rosaditas, lanceolado-falcados, aovado-falciformes y mas ó menos esertos. Polinias obaovadas, comprimidas, coludas y colgantes. Estigma deprimido. Folículos oblongo-lanceolarlos ó lanceolados, lisos y con semillas penachudas: asclepias, F. 62, T. IT, S.-T. T.

665. Corona anular reuniendo la columna con la garganta de la corola, 666. - Corona escuteliforme, 15 festoneada é inserta en la columna corta, 667 .

666. Matas trepadoras ó bejucos de tallos larguísimos y muy ramosos, peludos, densamente pelierizados, pubescentes, alampiñados ó lampiños, con hojas simples, alternas, pecioladas, enteras, aovado-oblongas y por la base acorazonadas, lanceolado-elípticas ó elípticas y puntiagudas por ambos estremos, puntiagudas, mucronadas o cuspidadas, largas de $4^{\prime \prime}-21_{1} 2^{\prime \prime}-1 l_{1} 2^{\prime \prime}-8^{\prime \prime}$ y anchas de 2 $1\left[2^{\prime \prime}-\right]^{\prime \prime}$. Flores en corimbos paucífloros pedunculados y axilares, raras veces solitarias, pediceladas y de eáliz monosépalo J-partido, con los segmentos aovado-puntiagudos, lanceolado-aguzados, lanceolado-obtusitos, aovado-oblongos y obtusos, lijeramente peludos, pelierizadítos ó lampiños; corola enrodada 5-partida ó 5-loba, de prefloracion torcida con los segmentos lanceolarlo-lineares, aguzados, peludos ó alaimpiñados, ó con los lóbulos aovardo-deltoídeos ó aovado-oblongos, obtusitos, papilosos hácia la punta ó lampiños; diámetro de la corola de $20^{\prime \prime \prime}-16^{\prime \prime \prime}-18^{\prime \prime \prime}-12^{\prime \prime \prime}-10^{\prime \prime \prime}-8^{\prime \prime \prime}$. Polinias obaovadas, coludas y horizontales. Estigma deprimido. Foliculos ventrudos, á veces del tamaĩo del puño y provistos de tres alas estrechas lonjitudinales, semillas muchas y penachudas: gonolobus, $\mathrm{F}$. 62, T. V, G. I.

667. Mata abejucada de tallos delgados muy largos y muy ramosos superiormente, muy pubescentes, así como las demas partes de la planta; hojas simples, alternas, pecioladas, acorazonado-deltoídeas, cuspidadas, pelierizaditas superiormente, mientras la cara inferior es blanquecino-tomentosa, anchas de $21_{[} 2^{\prime \prime}-3{ }^{\prime \prime}$. Flores fasciculadas, axilares y pequeñas, pediceladas y pubescentes, de cáliz monosépalo 5-partido; corola enrodada, 5-partida, ancha de $3^{\prime \prime \prime}$. lijeramente torcida, pubescente, y con los segmentos aorados y obtusos. Polinias ovoíleo-oblongas, paralelas á la glándula oblonga, coludas por su parte media, de cola corta, transversa é inserta en la base de la glándula. Estigma plano, de cuyo centro sale una 
punta larģa, suhuliforme y espesita. Folículos ventricosos, largos de como $3^{\prime \prime} y$ erizados de puas carnosas bastante gruesas y largas de $1^{\prime \prime \prime}-11\left[2^{\prime \prime \prime}\right.$, con muchas semillas penachudas: ibatia, F. 62, T. V, G. II.

668. Fruto capsular ó formado de 4 ó 5 cocos ó cajitas, 1 ó 2 espermas; estambres 5 ó mas, pero de los cuales algunos suelen abortar; rejetales provistos de glandulitas transparentes conteniendo una esencia. Arboles o yerbas, 669. - Fruto aqueniforme, formado de 4 aquenios ó nuecesitas monospermos; ovarios de base sentada en un disco lipojínico poco desarrollado; estambres siempre 5 y todos fértiles, $6 \% 0$.

669. Ovarios muy pequeños casi enteramente envueltas por el disco hipójino 12-lobo y muy desarrollado; estambres cuyo número vario de $\bar{\tau}, 5$ á 2 reemplazados siempre algunos por estaminodios; cáliz corto, tubo de la corola seudo-monopétala corto; árboles de hojas trifolioladas, 836.-Los 2 sépalos esteriores del cáliz ocultando la corola diminuta y cuyo limbo es bilabiado; yerbas altas de 8 á 12 ", ramosas superiormente, lampiñas ó algo velluditas anuales, con las ramitas rollizas; hojas alternas, pecioladas y con 3 hojuelas aovado-lanceoladas, entejérrimas, membranáceas, con muchos puntitos transparentes muy finos. Flores en especie de espiga unilateral melliza en el ápice de un pedúnculo axilar, blanquecinas, de las cuales las de la segunda série son mas pequeñas y sentadas; cáliz de 5 sépalos desiguales cuyos dos ó uno eștericres foliáceos y bracteiformes son mucho mas largos que la corola que tienen oculta, los dos interiores son mas pequeños $\mathrm{y}$ por último el mas interior de todos es diminuto; corola corta tapada por el cáliz, de tubo encorvado y con el limbo 2-labiado, cuyo labio superior es entero y escotado, mientras el inferior es 4-lobo. Disco escamiforme oblícuo ó unilateral; estambres 5 epipétalos, de los cuales 2 solos son perfectos y 3 sin anteras, de filamentos subulados y barbudos por la parte media; - anteras oblongas y sin apéndice. Ovario profundamente J-partido, con los lóbulos distintos uniloculares y adheridos solamente por medio del estilo cortito, terminado por un estigma cabezudo; óvulos dos sobrepuestos.Cápsula 1, 5 coca, con los cocos 2 valvares, 1-espermos, de endocarpio suelto elásticamente bílobo, de base membranácea y la semilla distante. Semilla reniforme, con el seno umbilicado; testa tuberculosa; embrion sin endospermo, de cotiledones lisos con orejitas por la base, cuya esterior envuelve la interior; raicilla inflexa monniera, F. 111, T. II.

6\%0. Corola hipocrateriforme, de garganta lampiña ó pubescente; estambres inclusos, 671. - Corola enrodada cuya garganta está adornada con ว̆ escamas derechas; estambres insertos en la garganta en donde forman un cono saliente y derecho, $6 \tau_{2}$.

671. Plantas herbáceas anuales, matas y raras veces arbustillos, peludos, pelierizados, sedoso-blanquecinos, pinchudos y rara vez lampiños, de 1' á 5' de alto, de tallos derechos, desparramados y tendidos, muy ramosos, y con hojas simples, alternas, mas ó menos pecioladas, subsesiles ó sesiles, aovadas ó sub-acorazonadas, aovadolanceoladas, oval-oblongas, lanceoladas, lanceolado-aguzadas ó li- 
neares, elíptico-oblongas, enteras, festoneado-ondulosas ó de márjen revuelta, con una punta ú obtusas. Flores unilaterales en espigas escorpioídeas terminales, ó solitarias; de cáliz 5-partido, y raras veces 5-dentado algo tubulado; corola hipocrateriforme, plegada, con 5 segmentos cortos, á veces separados por un dientecito, estrecharla al nivel de la garganta lampiña, ó de tubo alvierto, á veces de garganta pubescente, mucho mas larga que el cáliz; estambres inclusos de anteras distintas ó á reces coherentes por su punta pubescentita, insertos en el medio ó por debajo del tubo de la corola. Estilo simple terminal ó nulo, sostenido por un anillo abroqueladohemisférico, tan largo como el estilo y pubescentito. Aquenios 4, separados ó apareados : heliotropium, F. 66, T. III.

672. Planta herbácea bisanual, pelierizarla, cuyo tallo se eleva á 1'-1 1 [2' cuando está para florear, con hojas radicales, simples, enteras, pecioladas, bastante grandes y oval-lanceolardas, muy ásperas, en el tallo son mas pequeñas, sentadas y decurrentes, alternas. Flores azules ó á veces blancas en panojas terminales, pediceladas y pendientes, de cáliz monosépalo, 5-partido, con los segrmentos estendidos y lineares; corola enrodada, cuyas こ lacinias son muy estrechas y puntiagudas: de la garganta salen 5 apéndices obtusos, escotados, lisos, lustrosos y negros; estambres cuyo filamento muy corto se prolonga en un cuernecillo situado un poco por afuera de la insercion de las anteras, grandes y erguidas. Cuatro ovarios uniloculares, del centro de los cuales sale un estilo simple que se termina por un estigma cabezudo. El fruto consiste en 4 aquenios ó nuececitas converjentes, arrugados y de vértice redondeado: borrago, $\mathrm{F}$. 66, T. T, S.-T. I.

673. Estambres seis, 674. - Mas de 6 estambres, 675.

674. Cáliz 5-sépalo ó J-partido, de segmentos imbricados; corola campanuda 6, 5-loba; estambres opuestos á los lóbulos de la corola y alternando al contrario con algunos apéndices estériles. Ovario 12, 4-locular, con los óvulos ascendentes. Baya mas ó menos gruesa, de semillas crustáceas provistas de un endospermo, (535.-Cáliz con 6,8 sépalos dispuestos en dos séries; corola enrodada 6, 8-partida, con apéndices en número doble y pareciendo los segmentos entre los cuales están apareados, divisiones de la corola opuestas á los sépalos. Estambres opuestos á los lóbulos de la corola, alternando con tantos apéndices interiores, con anteras aflechadas y estrorsas. Ovario 6,8-locular, con óvulos ascendentes de los cuales la mayor parte abortan, algunos ó uno solo quedándose. Baya bastante gruesa oligo ó unisperma por aloorto, semillas con endospermo espeso, cartilajinoso y oleajinoso, 629 .

675. Menos de 14 estambres, 676.-Catorce estambres y mas, 681 .

676. Ocho estambres, 677. - Diez estambres, 678.

67\%. Mata suculenta, vivaz, de tallo corto, mas ó menos ramoso, que se alarga mucho para echar las flores, y entónces alcanza $2^{\prime}$ á $3^{\prime}$ de alto, con hojas compuestas é imparipinadas ó simples y opuestas, pecioladas, muy espesas, carnosas y suculentas, con 1,5 hojuelas aovadas festoneadas, lampiñas y como glaucas. Flores rojizoamarillentas, en panojas terminales, pediceladas y cabizbajas, de 
cáliz campanudo, infiado, membranoso, cortamente 4-fido; corola campaniforme, claviforme en la parte superior y mas ancha, de base prismática y cortamente 4 -fida, algo mas grande que el cáliz y de segmentos iguales y algo doblados hácia fuera; estambres insertos en el tubo de la corola é inclusos. 4 ovarios ovales puntiagudos y terminándose cada uno por un estigma; su base está acompañada de una escama nectariforme. El fruto consiste en 4 carpidios capsulares largos, puntiagudos, uniloculares y polispermos: bryophyllum, F. 147, T. I.

678. Cáliz acompañado de dos brácteas que mas luego se vuelven carnudas, envuelven la cápsula de manera á simular una baya; corola con 10 lacinias; anteras grandes de ápice bifido, 679. - Las dos bracteas escamosas que acompañan al cáliz no se vuelven nunca carnudas; corola con 10 lacinias; anteras grandes de ápice aguzado, cuyos filamentos salen de un anillo nectariforme; baya con 6 surcos, 680 .

679. Primorosos arlustos de $1^{\prime}$ á $5^{\prime}$ de alto, ramosísimas, con hojas simples, alternas, casi sesiles, ovales, aguzadas, enteras ó algo dentadas; flores en espigas axilares, pediceladas, pendientes, blancas mas ó menos teñidas de encarnado y que se componen de un cáliz monosépalo 5-dentado; corola oral, ventricosa, con 5 segmentos cuyos bordes están doblados por afuera; estambres inclusos, insertos en el tubo de la corola y cuyos filamentos aplanados llevan anteras de ápice bífido, terminándose por una cerda cada lóbulo, son acompañados de ordinario por la base de tantas escamas hipójinas reunidas con ellos. Ovario sentado sobre un disco glanduloso, casi semiínfero, de cuyo ápice sale un estilo simple y derecho que se termina por un estigma sencillo y algo cabezudito. Cápsula 5-locular, de dehiscencia loculícida, pero que parece baya á primera vista, contiene algunas semillas : gaulteria, F. 81, T. II.

680. Planta herbácea de tallo fruticoso, derecho, simple, nudoso, como del tamaño del dedo meñique, lleva hojas simples, opuestas, enteras, largas de $12^{\prime \prime} \mathrm{y}$ anchas de $5^{\prime \prime}$, con la base aguzada y volviéndose peciolo muy corto. Flores terminales, con pedúnculos tricótomos que tienen una raina por la base, pediceladas, opuestas, acompañadas de dos escamas, y de cáliz turbinado 5, 4-partido algo espeso y como dorado; corola tubulada, mas corta que el cáliz, con 10 segmentos empizarrados; estambres derechos, de filamentos mas cortos que las anteras é insertos en un anillo nectarífero; anteras grandes elongadas, verdes y de ápice algo aguzado. Ovario ovoídeo, 3-locular, poliovulado, de cuyo ápice sale un estilo corto que se termina en un estigma escutiforme. Baya casi redonda y un poco oval á la par, del tamaño como de una cereza, con 6 surcos, trilocular y polisperma : potalia, F. 61, Or. IV.

681. Siempre 14 estambres; cáliz y corola de 7 divisiones; cápsula 7-locular polisperma, 682. - Estambres muchos y en número indeterminado; cáliz de 6 sẻpalos cuyos 2 esteriores son mas pequeños; baya coriácea multilocular que, desprendida la concha, parece una fresa colgante. Flores entremezcladas con brácteas claviformes y ascidiformes ó casi pareciendo un jarrito, 683. 
682. Arbustos bajitos como de $4^{\prime}$ á $6^{\prime}$ de alto, peludos, mas ó menos ramosos, con hojas simples, alternas, sentadas, enteras, algo ovales y puntiagudas; flores coloradas en espigas terminales flojas, pediceladas, y de cáliz cuyas divisiones profundas, estrechas, obaovadas y obtusas son pendientes; estambres salientes insertos en la garganta de la corola. Orario ovoídeo, casi polígono, de cuyo ápice sale un estilo simple algo larguito que se termina por un estigma algo cabezudo. Cápsula de 7 celdas, polisperma : befaria, F. 81, T. III, S.-T. II.

683. Arbustos trepadores que parecen parásitos, sin serlo verdaderamente, cuyos tallos poco ramosos trepan derechos, especialmente en el estipe de las palmas de ragua subiendo así casi hasta su vértice, comprimidos, y con 4 caras, de las cuales la que está aplicada al árbol es algo cóncava y provista de garras con que se agarra de la corteza de los árboles á lo largo de los cuales sube, de corteza color ceniciento; hojas elípticas, simples, dísticas, subsesiles ó apenas pecioladas y aplicadas ó pegadas á la corteza de los árboles al favor de chupadores de que está provista su circunferencia; mas luego de tales tallos ordinariamente sencillos y larguísimos salen ramos cilíndricos estendidos, de ningun modo trepadores largos de 2' á 3 algo mas ó menos, dísticos ó esparcidos, con hojas alternas, algo teñidas de morado claro cuando tiernas, cortamente pecioladas, lanceoladas, aguzadas por ambos estremos y puntiagudas. Flores en umbelas ó racimos acorimbados, pediceladas, con brácteas espatuladas, convexas por arriba y concavas inferiormente, insertas algo por debajo del medio de los pedícelos, otras veces son con forma de urna, claviformes y saliendo de los pedícelos de las flores abortadas del centro de la umbela; tales flores son verduscas y de cáliz monosépalo con las divisiones interiores redonditas; corola caliptrœforme, circuncisa. Estambres de filamentos cortos, subulados y estendidos, con anteras lineares y articnladas con ellos, un poco por encima de la base, no mucronadas. Ovario con 12-4 celdillas incompletas, estriado lonjitudinalmente; estigmas decurrentes en la punta obtusita del ápice : marcgraaria, F.98.

684. Ovario semi-ínfero ó soldado solamente con la parteinferior del cáliz, 685. - Ovario ínfero ó soldado enteramente con el cáliz, 691.

685. Estambres soldados entre sí y epijínicos, 686

686. Corola bi ó unilabiada, 688.-Corola hipocrateriforme, largamente tubulada y blanca, 687 .

687. Planta herbácea vivaz, muy lechosa, pubescente, cuyo tallo herbáceo, blando y simple se eleva á $8^{\prime \prime}$ ó $15^{\prime \prime}$ y lleva muchas hojas, simples, alternas, lanceolado-oblongas, sinuoso-dentadas, aguzadas por la base sub-sentada, obtusas, largas de $3^{\prime \prime}-4^{\prime \prime}$. Flores solitarias, axilares, con dos brácteas lanceoladas situadas hácia el medio del pedícelo corto, y de cáliz monosépalo semi-adherente, turbinado, con 5 ángulos y cuyo limbo es partido en 5 segmentos lanceolados, puntiagudos, casi dos veces mas largos que él, dentados y velludos ; corola hipocrateriforme, oblícua, de tubo casi tan largo como las hojas $21_{1} 2^{\prime \prime}$ á $3^{\prime \prime}$, filiforme, cilíndrico, de base bastante crecida y como ventruda pegada en la garganta del cáliz y con 4 ángulos que 
no tardan en desaparecer, velludo y sosteniendo un limbo estendido $y$ de 5 divisiones casi iguales, lanceolado-lineares y puntiagudas; estambres 5 adheridas entre sí por los filamentos y de anteras coherentes, insertos en el medio del tubo de la corola en donde están libres sus filamentos que llegados á la garganta se reunen y se soldan entre sí para formar un tubo corto y cilíndrico, con 4 surcos poco pronunciados que corresponden con los que separan las celdas de las anteras oblícuas, bastante largas, cuyas dos superiores están mucho mas largas que las inferiores, con el ápice provisto de pelos blancos que antes de verificada la florescencia tapan el estigma, mientras que despues forman como una corona en deredor suyo. Ovario semi-ínfero, bilocular, poliovulado y de cuyo ápice oblícuo y puntiagudo sale un estilo filiforme, muy largo terminado por un estigma que se presenta por encima del ápice de las anteras y en medio de la corona blanca ya senalada, ancho, bilabiado, con el centro rerde y glanduloso-viscoso cuyo labio inferior es algo cóncavo y pareciendo la boca de una boccina. Cápsula como inflada, bilocular, bivalve y abriéndose por el vértice, conteniendo muchas semillas muy finas. Toda la planta exhala un olor viroso particular y bastante fuerte: isotoma, F. 5\%, T. II.

688. Corola bilabiada, 689. - Corola unilabiada, 690.

689. Plantas herbáceas anuales ó vivaces, muy lechosas, cujo tallo derecho y poco ramoso se eleva á $18^{\prime \prime}-12^{\prime \prime}-8^{\prime \prime}$, lampiñas, alampinadas ó pubescentes, con hojas simples, alternas, sulj-entcras, festoneadas ó dentadas, pecioladas ó sesiles y decurrentes, aovadas ó lanceoladas, largas de $2^{\prime \prime}-18^{\prime \prime \prime}-6^{\prime \prime \prime}$. Flores en espigas terminales, pediceladas y que salen de la axila de una bráctea foliácea de tamaño muy rariado, y de cáliz semi-adherente, anguloso, 5-fido, con segmentos bastante largos, lanceolado-subulados; corola muy irregular, cuyo tubo está hendido por su lado anterior, ruelto superior por torsion, bastante largo y de base como ventruda, de limbo con 5 lóbulos desiguales y bilabiado; estambres 5 , cuyos filamentos soldados entre sí y anteras coherentes forman un tubo atravesado por un estilo filiforme, largo, simple y terminado por un estigma 2-lobo que se presenta por el ápice del tubo formado por las anteras raras veces lampinas, pero con mayor frecuencia barbudas por el ápice, sea dos solamente sea todas. Cápsula bilocular, polisperma, bivalve y abriéndose por el ápice, coronada por el limbo calizinal : lobelia, F. 57, T. II.

690. Plantas herbáceas vigorosas ó matas y hasta arbustos muy lechosos, cuyo tallo mas ó menos ramoso y derecho se eleva á $1^{\prime}-4^{\prime}$, con hojas alternas, simples, á veces aproximadas hácia el vértice, mas ó menos decurrentes y sentadas, pecioladas ó subsesiles, lanceoladas, lineares, linear-lanceoladas, lanceolado-oblongas, con una punta, mas ó menos aguzadas á veces por ambos estremos, aserradas, con dientes espiniformes ó lineares, algunas veces mucronaditos, largas de $8^{\prime \prime}-5^{\prime \prime}-4^{\prime \prime}-3^{\prime \prime}-12^{\prime \prime}-6^{\prime \prime}-15^{\prime \prime}$. Flores de ordinario purpúreo-moraduscas, algunas veces amarillas ó azafranadas, en racimos mas ó menos foliáceos, largos, grandes, multífloros y que parecen espigas, pediceladas y saliendo de la axila de una bráctea foliácea 
mas o menos grande, con frecuencia unilaterales, y de cáliz semiínfero 5-lobo, de tubo hemisférico ó globoso, cuya cara anterior está lonjitudinalmente liendida, encorrada, plana ó concava, labio inferior 3-lobo, acompañado de dos lóbulos laterales mas ó menos diverjentes, al concluirse la fiorescencia : á menudo las 5 piezas ó pétalos que la forman se separan; estambres 5 adheridos, curas anteras todas son barbudas por el ápice ó solamente las dos inferiores. Cápsula semi-ínfera $\mathrm{Y}$ algunas raras reces libre, polisperma y abriéndose por dos ventallas : tupa, F. 57, T. II.

691. Anteras libres. 692. - Anteras soldadas entre sí 763.

692. Menos de 5 estambres, 693. - Cinco estambres ó mas, 709.

693. De 1 á 4 estambres; fruto aqueniforme penachudo, 694. Siempre 4 estambres; fruto seco ó carnudo, 695.

694. Plantas herbáceas de ordinario vivaces, de tallo derecho mas ó menos ramoso, alto de $2^{\prime}$ á $3^{\prime} \mathrm{y}$ saliendo casi siempre de un rizoma mas ó menos desarrollado, con hojas radicales simples, pecioladas, dentadas, opuestas, cuya base del peciolo es un poco envainadora, mientras las caulinares son compuestas ó pinatifidas. Flores pequeñas blancas $y$ dispuestas en corimbos ó en panojas terminales pedunculadas $y$ acompaíadas de hojas florales, pediceladas y saliendo de la axila de una bráctea; cáliz dentadito y á veces de limbo enrollado hácia dentro; corola tubulada, con 5 segmentos de ordinario desiguales, ovales, obtusos, algo oblícuos y cuya base está algunas reces provista de un espolon; $1,2,3,4$ estambres epíjinos por ser epijínica la insercion de la corola en la parte superior del tubo de la cual se insertan. Ovario unilocular ovoídeo, de cuyo ápice sale un estilo que se termina por ] ó 3 estignias. El fruto consiste en una especie de cápsula indeliscente, aqueniforme, con 3 celdas, de las cuales 2 abortan de ordinario, monosperma : raleriana, F. 60 .

695. Flores agrupadas en una especie de receptáculo peludo y formando așí una cabezuela, 696. - Flores nunca dispuestas en cabezuela, ó cúando lo son es sin receptáculo alguno, 697 .

696. Matas ramosas, de hojas opuestạs ó verticiladas por á 3 , acompañadas de estípulas distintas ó algo coherentes. Flores amarillentas en cabezuelas largamente pedunculadas, axilares ó terminales, sesiles en un receptáculo esférico y de cáliz monosépalo, anguloso y en forma de pirámide inversa, con 4 dientes; corola infundibuliforme con 4 segmentos iguales y enderezaditos; estambres insertos en la parte superior del tubo delgado de la corola $\mathrm{y}$ algo esertos. Ovario oroídeo, de cuyo ápice sale un estilo simple muy largo, eserto y terminándose en un estigma globoso y cabezudo á la par. El fruto consiste en una cápsula inveriamente piramidal, coriácea, coronada por los dientes del cáliz, bilocular, partible, cuyas celdas monospermas están frecuentemente vacías por causa de aborto, con semillas oblongas, cuyo embrion inverso y contenido en un endospermo algo cartilajinoso tiene su raicilla superior : cephalanthus, F. 62, Or. I, T. VII,

697. Fruto seco; óvulos pegados lateralmente; semillas provistas de endospermo, con embrion encerrado y la raicilla inferior; 
corola de lobulos valvares; estípulas trabadas opuestas á las hojas, divididas en cerdas y raras veces obsoletas, 698. - Fruto carnudo, 725.

698. Formado de cocos dehiscentes ó indehiscentes, 699.-Fruto capsular ó abayado, con 2 celdas, 706 .

699. Fruto formado de 3,4 cocos indehiscentes, asurcados por el lado interno y por fin adheridos con la semilla; limbo calizinal 6,4 Y raras veces 7, 3-partido y decíduo, 700.-Fruto compuesto de dos cocos dehiscentes ó indehiscentes; limbo calizinal con 4, 2 ó raras veces 10 segmentos persistentes, 701 .

700. Planta herbácea, pubescente, desparramada, de tallo peludo, con hojas simples, opuestas, lanceolado-oblongas ó elípticas; cerdas estipulares tan largas ó mas cortas que su vajina: flores en cabezuelas terminales, pero sin receptáculo, acompañadas de un invólucro formado de 4 hojas conteniendo algunas flores blancas, de cáliz monosépalo adherente, con 6 segmentos foliáceos, aovado-deltoídeos, tan largos como los 3 ó 4 carpidios troncado-obaovados y muricados; de una corola infundibuliforme, con 6 lóbulos valvares; estambres esertos; estigma 3, 4-fido: vichardsonia, F. 62, Or. I, 'T. VI, S.-T. I, G.IV.

701. Ambos carpidios indehiscentes, 702. - Ambos carpidios dehiscentes ó uno solo, 703.

702. Plantas herbáceas ó matas, de tallos tetrágonos ascendentes ó algo trepadores, mas ó menos pubescentes, lampiños ó pinchudos, con hojas simples, opuestas, sin venas y sentadas, ó con venas, rugosas y cortamenté pecioladas, lineares, lanceolado-aguzadas, con una cerda terminal ú oblongo-lanceoladas y puntiagudas, revueltas por la márjen; cerdas estipulares setáceas ó cerdozo-peludas, otras veces largamente filiformes y flexuosas, á veces mas largas que su vaina. Flores sub-solitarias, pocas ó una, otras veces 5 en las axilas de las hojas y de cáliz adherente, con lóbulos deltoídeo-lanceolados, obtusitos, lanceolado-lineares ó lanceolados, mucho mąs cortos que los carpidios, mitad tan largos como los carpidios ó una mitad o un tercio tan largos como ellos; corola blanca ó purpúreo-pálida infundibuliforme, con 4 segmentos valvares, de tubo delgado y obaovado, claviforme-campanudo escotado ó corto y casi tan largo como el limbo calizinal ; estigma escotarlo ó bífido. Fruto sub-globoso, lijeramente aquillado, duro y pelierizado, con los carpidios no costilludos lateralmente; sub-globoso tambien y alampiñado y de carpidios 3-costilludos, ú ovoídeo-oblongo, alampiñado, duro, no costilludo y de carpidios enteramente lisos : diodia, F. 62, Or. I, T. VIII, G. II.

703. Ambos carpidios igualmente deliscentes á lo largo de la cara interna, 704. - Uno solo de los carpidios dehiscente á lo largo de la márjen de la comisura, mientras el otro se queda cerrado por el tabique, 705 .

704. Plantas herbáceas anuales ó matas perenniales, lampiñas, alampiñadas, pubescentes, peludas ó pinchudas, con tallos ramosos, derechos ó desparramados. sub-cilíndricos ó de ordinario tetrágonos, con hojas elíptico-lanceoladas ó lanceoladas, oblongo-lanceoladas, elíptico-oblongas, aovadas, lanceoladas, linear-lanceoladas, 
lanceolado-lineares, lineares, aguzadas, agudas, puntiagudas ú obtusas, sentadas, subsesiles ó cortamente pecioladas, lampiñas, pubesceentes, peludas, escabrosas. pestañosas, curas venas son $5,1,7$, $5,1,2,4,2,3$ yugadas; cerdas estipulares setáceas mas largas, casi tan largas ó mas cortas que su vaina mas ó menos proeminente, lampiñas ó ásperas, ó lineares pestañudas y mas largas que su vaina. Flores en verticilos axilares, en cabezuelas y raras veces cimosas no muchas ó á reces solitarias involucradas ó no, blancas ó lijeramente teñidas de rosado, y de cáliz monosépalo adherente con 4 dientes diminutos iguales, aovados, lanceolado-subulados, ó deltoídeo-lanceolados iguales, mucho mas cortos, casi tan largos ó $l_{[} t$, $1_{[} 3$ tan largos como el fruto; con 2 ó 4 dientes lanceolados obtusos ó aguzados $1_{[} 2,1_{[} 3$ tan largos como el fruto, en fin con 2 dientes solamente lineares y por fin apenas notables, deltoídeos ó lanceolados $1_{1} 4$ ó $1_{[} 3$ tan largos como el fruto diminuto; corola infundibuliforme, con 4 lobulos valvares. Estigma escotado ó bífido. Fruto septícido por encima del medio, con el tabique persistente debajo de él, ó de dehiscencia septícida por la base, con el tabique desvanecido: borreria, F. 62, Or. I, 'I. VIII, G. XII.

705. Planta herbácea anual de tallo obtusangular', pubescentita ó alampinada, con hojas lanceoladas ó á reces lanceolado-lineares, aguzadas, de cara superior escabrosa o solo hácia la márjen, opuestas simples, subsesiles ó peciolarlas; cerdas estipulares filiformes, mas largas que su vaina. Flores en grupos axilares paucí o plurífloros, y de cáliz con 4 dientes diminutos, deltoídeos, mucio mas cortos que los carpidios, de los cuales 3 corresponden al cerrado y uno solo al abierto, ó apenas notables; fruto obaovado-oblongo, con semillas diminutamente rugosas : spermacocce, F. 62, Or. I, T. VIII, G. X.

706. Una cápsula, 707.- Una baya apenas carnuda, 708.

707. Plantas herbáceas anuales lampiñas o alampiñadas, de tallo delgado mas ó menos ramoso, con hojas lanceoladas, lineares ó linear-lanceoladas, 1-nervias, aguzadas, sentadas, opuestas, enteras y largas de $1 "-2$ " ; cerdas estipulares 3 , algunas ó reducidas. Flores pediceladas en umbelas y corimbos o sub-solitarias, pedícelos de ordinario mas cortos que los pedúnculos ó fasciculados cuando faltan aquellos, otras veces sub-solitarios, filiformes y mas cortos que las hojas; cáliz adherente con 4 dientes distantes del fruto; corola corta infundibuliforme o enrodada, con los lóbulos tan largos ó mitad de lo largo del tubo, valvares; estambres insertos en ó hácia la garganta de la corola, ó dioicamente cerca de la base rie la corola, cuyas anteras son ovoídeas. Cápsula delgada, loculícida por el ápice, troncada, sub-globosa ó globosa y contraida por la comisura, con dientes lanceolado-aguzados; semillas diminutas, angulares y no cóncavas : oldenlandia, F. 62 , Or. II, T. VIII.

708. Plantas herbáceas ó matas muy ramosas, de tallos rastreros mas ó menos largos, pubescentes ó velludos, con hojas simples, opuestas, pecioladas, enteras, aovado-subagudas ó aovado-redonditas subagudas ó mucronadas, con las venas arquearlas; estípulas pronto caducas linear-aguzadas ó cerdáceas nucho mas cortas ó tan 
largas como los peciolos, situadas sobre un ribete membranoso que une los dos peciolos. Flores azules ó purpurinas, mas ó menos pediceladas, en grupos axilares, y de cíliz adherente 4-partido, acompañado de dos brácteas lineares, tan largas ó mas cortas que él, con los segmentos lineares tan largos como la baya globosa ó lanceolado-lineares y mas cortos que ella; corola infundibuliforme; estambres insertos en ei tubo de la corola, inclusos y de anteras oblongas. Estilo simple tan largo como los estambres terminado por un estigma bífido, cuyas divisiones diverjentes, cilíndricas y glandulosas son un poco espesas y dobladas hácia fuera, y que sale del ápice de un ovario verdusco y velludo 2-locular, poliovulaclo y sentado sobre un disco verdoso algo 4-lobo. Baya globosa, algo comprimida y coronada, poco carnuda, azul, bilocular polisperma: coccocypselum, F. 62, Or. II, T. IV.

709. Cinco estambres, 710. - Mas de cinco estambres.

710. Fruto capsular, 711. - Fruto carnudo abayado ó drupáceo, 724.

711. Lóbulos de la corola valvados, 712.- Segmentos de la corola imbricados, 713 .

712. Arbol bajito ó arbusto de 10' á 15’ de alto, lampiño, con hojas simples, opuestas, grandes, pecioladas, obaovadas, casi tan largas como los pedúnculos axilares, y que tienen $6^{\prime \prime}$ á $10^{\prime \prime}$ de largo ; estípulas interpeciolares grandes y decíduas. Flores fragantes, en corimbos terminales ó en panojas axilares pedunculadas, y de cáliz adherente 5-dentadito, cuyos dientecitos son distantes; corola infundibuliforme con 5 lóbulos cortos, pubescentes por dentro, verdoso-blanca, de tubo claviforme, largo de $6^{\prime \prime \prime}$, con los segmentos reduplicados en el boton, aovado-redondeaditos y largos de 11 [ $4^{\prime \prime \prime}$. Estambres inclusos, insertos en el tubo de la corola, de filamentos velludos y con anteras recostadas. Estigma bilamelado. Cápsula oblonga loculícida desde el medio por arriba y por abajo, las valvas quedándose unidas por el ápice, conteniendo semillas diminutas, paralelas á la placenta, abroqueladas, comprimidas, marjinales y coludas por ambos estremos; larga de $1^{\prime \prime}$ : macrocnemum, F. 62, Or. II, T. V, G. XVI.

713. Cáliz con 6 ó raras veces 5 y 7 segmentos profundos subulados y filiformes; semillas ceñidas por una ala grande, entera y oblonga, 714. - Cáliz 5, 4-partido solamente, 715.

714. Arbol no muy grande ó arbusto de ramitas lampiñas, con hojas aovadas ó eliptical-oblongas, sub-agudas por la base, de cara superior lampiña, mientras la inferior es alampinada, puntiagudas ú obtusas, variables y largas de 1"-3". Flores grandes rosado-pálidas, ternado-solitarias y terminales, y de cáliz adherente; corola infundibuliforme, desigual inferiormente, con lóbulos imbricativos, aovados, puntiagudos, mucho mas cortos que el tubo, arqueado, claviforme y lampiño, que tiene $\mathbf{1}^{\prime \prime}-2$ ", mientras ellós son largos de $4^{\prime \prime \prime}$ solamente; estambres esertos, libres de la corola, de anteras lineares, erguidos y largos de $6^{\prime \prime \prime}$. Cápsula septícida y por fin loculícida por arriba, sub-comprimida, de ordinario negra, con puntitos 
blancos y larga de $8^{\prime \prime \prime}-12^{\prime \prime \prime}$ : coutarea, F. 62, Or. II, T. VI, G. XVIII.

715. Cáliz 5 ó 4-partido y semillas mas ó menos aladas, 716. Cáliz siempre de limbo 5-partido y semillas sin ala, 721.

716. Estambres esertos mas ó menos; semillas aladas, 718.-Estambres inclusos ó raramente semi-esertos é insertos en el tubo de la corola; semillas diminutas y apenas aladas, 717.

717. Arbustos y raras veces árboles bajitos, con hojas simples, opuestas, eliptical-oblongas, elípticas, aovadas, lanceolado-elípticas, lanceolado-oblongas, obaovadas, obaovado-oblongas, oblongas, espatuladas, oval-oblongas, espatulado-oblongas, puntiagudas por el ápice y á veces por ambos estremos á la par, con una punta obtusita, cuspidadas, obtusas y obtusitas, cortamente aguzadas o redondas y obtusas por la base, membranosas, cartáceas ó coriáceas, lampiñas, peludas por la cara superior y tambien por la inferior, que es además pubescentita, alampiñada ó pelierizadita sobre las nervaduras solamente, etc.; estípulas subulado-deltoídeas, deltoídeas, deltoídeosubuladas, subuladas, velludas, lanudas, peludo-pubescentes, pinchudas, pubescentes por dentro. Flores en panojas ó en cimas simples ó en grupos, raramente solitarias, con el último brazo de la cima frecuentemente 3-floro, y de cáliz adherente de ordinario bractearlo por la base, con los segmentos del limbo diminutos, dientiformes y mucho mas cortos que el tubo, ó estrechos tan ó mas largos que el tubo, en fin aovados ó lanceolados, tan ó mas largos que el tulo; corola infundibuliforme, raràmente enrodada, con un anillo calloso en la garganta, cuyos 5,4 lóbulos redondeaditos son imbricativos. Estigma 2-fido ó escotado. Cápsula sub-globosa, loculícida, con las valvas por fin frecuentemente 2-fidas: rondeletia, F. 62, Or. II, T. VI.

718. Cáliz 5, raramente 4-partido ó 5 -fido, 719. - Cáliz 4 y raras veces 5-partido, y frecuentemente con algunos dientes ó segmentos accesorios; estambres ordinariamente semi-esertos é insertos cerca de la garganta de la corola, 720 .

719. Cáliz כ̌ y raramente 4 -partido; estambres esertos y libres de la corola, 719 bis.-Cáliz de limbo apeonzado, con el limbo 5-fido y persistente. Arboles á veces muy grandes, de hojas alternas, simples, coriáceas, cortamente pecioladas, llanas por la márjen, acompañadas de estípulas aovadas ú oblongas, foliáceas, libres y decíduas. Flores terminales apanojado-corimbosas, blancas ó rosadas, teñidas de púrpura; corola de tubo rollizo con el limbo 5-partido, de lóbulos oblongos, cuya estivacion es valvar; filamentos de los estambres cortos insertos por la parte media del tubo, con anteras lineares enteramente inclusas. Estigma bífido sub-claviforme. Cápsula aovada ú oblonga con un surco visible por cada lado, bilocular, coronada por el cíliz y de dehiscencia septícida, cuyos mericarpios se separan de la base hácia el ápice, quedándose la parte introflexa risjunta. Placentas oblongas con muchas semillas erguidas y empizarradas hácia arriba: cinchona, F. 62, Or. II. T. V, G. XVII.

719 bis. Arboles altos, bajitos o arbustos de $10^{\prime}$ á 15', muy ramosos y lampiños, de hojas simples, opuestas, enteras, mas ó menos 
pecioladas, elípticas ú oblongas, obaovadas, lanceolado-oblongas ó lanceolado-elípticas, cartáceas, lustrosas y lampinas, largas de 4"$6^{\prime \prime}-3^{\prime \prime}-2^{\prime \prime}$. Flores en corimbos terminales á veces apanojados o axilares, pediceladas, cuyos pedícelos son tan largos como el tubo calizinal cilíndrico, aovado, y por fin tan largos ó los inferiores mas largos que él; cáliz adherente; corola hipocrateriforme, con el tubo filiforme y muy largo, casi tan largo como los lóbulos ó dos veces tan largo como ellos; estilo filiforme tan largo como los estambres y eserto tambien, terminado por un estigma un poco espeso. Cápsula septícida, con las valvas enteras y por fin bífidas, conteniendo semillas ovales y aladas : exostemma, F. 62, Or. II, T. VI, G. XIX.

720. Arbustos sarmentosos ó matas lampiños, pubescentes ó pelierizaditos, de hojas simples, opuestas, enteras, aovadas con una punta tiesa ó aguzadas, membranosas ó cartáceas, subsesiles ó cortamente pecioladas; estípulas cortamente subuladas, sub-troncadodentaditas ó deltoídeas y dentaditas. Flores en cimas acorimbadas axilares, paucífloras, sub-sentadas ó mas ó menos largamente pediceladas ó solitarias y de cáliz adherente, cuyos 4 segmentos lanceolado-lineares alternan con 4 dientes diminutos, 4, 5 aovados ó aovado-lanceolados y puntiagudos desprovistos de dientes alternando con ellos, en fin 8 subiguales, lanceolado-lineares $r$ sin dientes accesorios; corola hipocrateriforme azul, carmesí pálido ó roja, con 4, 5 lóbulos imbricativos, de tubo sub-cilíndrico, con pelo espareido por dentro, la garganta siendo lampiña o barbuda, ó claviforme por el ápice un poco peludo interior y esteriormente; estambres de filamentos cortos con anteras oblongo-lineares ó lineares y semi-esertas, otras veces inclusas. Estigma bífido. Cápsula contraida por la comisura y septícida: manettia, F. 62 , Or. II, T. VI, G. XXII.

721. Todas las divisiones calizinales quedándose semejantes; estambres inclusos, libres de la corola, de anteras lineares y erguidos, 72.2. - Uno de los lóbulos del cáliz en el corimbo transformándose en una hoja grande $\mathrm{y}$ peciolada; estambres esertos, insertos en la garganta de la corola $y$ de anteras incumbentes, 723.

722 . Arbustos de $3^{\prime}$ á $12^{\prime}$ de altura, lampiños, de hojas cortamente pecioladas, simples, opuestas, enteras, coriáceas, elípticas, eliptical-oblongas, oblongas ó aovadas, con una punta, lustrosas, renosas; estípulas deltoídeas ó aovadas, subulado-redondeaditas. Flores grandes blanquecinas ó carmesí, solitarias ó ternadas, cortamente pedunculadas y axilares; de cáliz con los segmentos foliáceos elíptico-lanceolados, linear-aguzados ó lanceolado-aguzados; corola infundibuliforme, cuyo tubo largo se va gradualmente aguzando hácia la base estrecha, con lóbulos plegados y recargativos redondeado deltoídeos, de los cuales uno es esterior, larga de $8^{\prime \prime}-$ $7^{\prime \prime}-5^{\prime \prime}-33^{\prime \prime}$. Anteras largas de $2^{\prime \prime}-14^{\prime \prime \prime}-8^{\prime \prime \prime}-6^{\prime \prime \prime}$. Estilo filiforme con un estigma espesito. Cápsula loculícida, elíptica, 5-costilluda ó lisa, otras veces oblonga y aguzarla por la base, larga de $1^{\prime \prime}-2^{\prime \prime}-8^{\prime \prime \prime}-10^{\prime \prime \prime}$, conteniendo semillas comprimidas, diminutamente hoyosas y sin ala : portlandia, F. 62 , Or. II, T. VI, G. XI.

723. Arboles de hojas obaovado-oblongas, simples, opuestas, enteras, puntiagudas, lijeramente pelierizadas sobre los nervios de la 
cara inferior y largas de $12,18^{\prime \prime \prime}$, anchas de $6^{\prime \prime \prime}$. Flores en corimbos contraidos y dispuestos en panojas largas, racemiformes, y de cáliz adherente cuyo lóbulo transformado es oval, obtuso por el ápice, cortamente aguzado por la base, reticulado, encarnado y largo como el peciolo, largo de $3^{\prime \prime}$ y ancho de $11\left[2^{\prime \prime}-11_{[} 4^{\prime \prime}\right.$; estigma bilobado. Cápsula septícida, conteniendo semillas fusiformes y no aladas: warszewiczia, F. 62, Or. II, T. VI, G. XX.

724. Fruto abayado, 725.- Fruto drupáceo, 748.

725. Baya con las celdillas polispermas, ó un nuculanio, 726. Baya con las celdas monospermas, 735.

726. Siempre una baya: hojas simples estipuladas, 727. - Un nuculanio, hnjas compuestas y sin estípulas, 734 .

727. Lóbulos de la corola retorcidos y recargativos; placentas parietales con algunas semillas, 728. - Segmentos de la corola rerargativos ó retorcidos ó valvados; muchas semillas, 729.

728. Arboles bastante altos, ramosos y coposos, ó arbustos, con hojas simples, opuestas, pecioladas, enteras, cartáceas, lanceoladooblongas ú obaovadas, á veces sub-troncadas por el ápice, lampiñas ó de cara inferior pubescente ó alampiñada, largas de $5^{\prime \prime}-10^{\prime \prime}-6^{\prime \prime}-8^{\prime \prime}-$ $4^{\prime \prime}-2 "$. Flores amarillas ó blanquecino-amarillentas, en cimas terminales pediceladas y cuyos pedícelos son mas cortos ó tan largos como el cáliz, y de cáliz con el limbo campanudo, troncado ó 5-dentado, á veces ondeado ó 5 -fido con los segmentos lineares y distantes; corola hipocrateriforme, de tubo cilíndrico, cortamente eserto y tan largo como los lóbulos en número de 5 y torcidos por la izquierda, sedosa y de garganta pelierizada, pinchudo-tomentosa por ambos lados, ó lampiña, larga de $1^{\prime \prime}-6^{\prime \prime \prime}-8^{\prime \prime \prime}$; estambres insertos por debajo de la garganta de la corola ó en ella con las anteras semiesertas ó salientes del todo, lineares y subsesiles. Estigma claviforme ó 2 -fido con los lóbulos lanceolado-cerdosos; ovario 1-locular, con dos placentas, casi tocándose el uno y el otro en el eje. Baya pareciendo 2-locular por ser contiguas ó enredadas las placentas, ovoídea, larga de $2^{\prime \prime}-3^{\prime \prime}$, troncada y de ápice ombilicado, cuyas semillas horizontales son contenidas en la pilpa, de endospermo cartilajinoso: genipa, F. 62, Or. II, T. I, G. II.

729. Lóbulos de la corola recargativos ó torcidos ; óvulos muchísimos ó dos solos anidados en las placentas centrales y espesos, 730 . - Segmentos de la corola recargativos solamente; muchísimos óvulos superficiales sobre las placentas centrales, 731 .

730. Arbustos muy ramosos, derechos, altos de 6' á 10', espinosos ó inermes, espinas opuestas y supra axilares ó por á 4 y situadas por debajo del vértice de las ramitas; hojas obaovadas ó elípticas, lanceoladas ó lanceolado-elípticas, simples, opuestas, enteras, pecioladas, membranosas, membranáceas y por fin á veces coriáceas, lampiñas del todo, alampiñadas, ó de cara inferior algo pubescente, largas de $1^{\prime \prime}-2^{\prime \prime}-3^{\prime \prime}$; estípulas interpeciolares subuladas, pequeñas, casi escamosas, solitarias. Flores blancas, fragantes, subsesiles ó pediceladas, solitarias, ternadas ó agrupadas, axilares ó terminales; cáliz adherente, de limbo campanudo con los dientes distantes, lanceolados, obtusitos y recorvados, 5 -partido ó 5 -fido con los segmen- 
tos lineares abiertos ó subulado-cerdosos, erguidos y distantes; corola hipocrateriforme, de tubo sub-cilíndrico ó cilíndrico tan largo, 4 ó 2 veces tan largo como los lóbulos aovado-oblongos ó aovados, aovado-lanceolados, velludo interiormente ó á reces esteriormente, de garganta lampiña ó relluda; torcidos ó torcido-recargativos. Estambres esertos, con anteras sentadas en la garganta de la corola. Ovario ovoídeo 2-locular poliovulado, de cuyo ápice sale un estilo simple tan largo como la corola, terminándose por un estigma bífido, cuyos dos lóbulos desiguales y oblongos son espesos. Baya bilocular globosa ú ovoídea, coronada, algo corticosa, conteniendo muclıas semillas comprimidas, sin alas y paralelas á las proyecciones de las placentas : randia, F. 62, Or. II, T. II, G. XIV.

731. Baya con 5 surcos, 732.-Baya con 10 surcos, 733.

732. Arboles ó arbustos lamniños ó pubescentes, muy ramosos, con los ramos opuestos ó rerticilados, de hojas simples, opuestas ó verticiladas por á 3 ó por á 4, enteras, membranosas, mas ó menos pecioladas, elípticas, lanceolado-elípticas, cuneiformes y elípticas á la par, con una punta ó cortamente aguzadas, lampiñas por ambas caras ó alampiñadas y pubescentes por la inferior, siendo con frecuencia lustrosa la superior, largas de $2^{\prime \prime}-3^{\prime \prime}-4^{\prime \prime}$; estípulas interpeciolares triangulares, algo foliáceas, derechas, aplicadas al tallo ordinariamente de 4 caras, con la punta frecuentemente vuelta hácia fuera. Flores rojas ó amarillas en cimas terminales, de las cuales algunas están situadas laterảlmente por el lado interno en los brazos racemiformes y escorpioídeos de las cimas, y de cáliz adherente, como eampanudo, de tubo turbinado por la base, aovado, aovado-sub-globoso ó campanudo, mucho mas largo que el pedícelo muy corto, de lo largo de él, ó solo del de las flores laterales, con J lóbulos ó dientes iguales, derechos, persistentes y puntiagudos; corola tubular ó campanuda por encima de la base, de tulso plegado, estrechado por encima de la base, lampiño ó lijeramente dilatado por encima de ella, sub-cilíndrico pubescentito ó alampiñado, en fin campanulado-tubular por encima de ella, cilíndrico y 6 veces mas largo que los segmentos del limbo sub-erectos, ó redondos y abiertos, otras veces aovados; y largo de $18^{\prime \prime \prime}-12^{\prime \prime \prime}-8^{\prime \prime \prime}-6^{\prime \prime \prime}$, con los lóbulos recargativos. Estambres insertos por encima de la base de la corola y hácia la garganta, inclusos, de filamentos muy cortos que llevan anteras lineares, erguidas, con el vértice algo eserto. Ovario único, oval, 5-locular, poliovulado y de cuyo ápice sale un estilo tan largo como los estambres y que se termina por un estigma entero, claviforme y 5-asurcado. Baya 5-locular, con 5 surcos, elevándose por encima del tubo calizinal, ovoídea ú oblonga y ancha de $6^{\prime \prime \prime}-5^{\prime \prime \prime}-2^{\prime \prime \prime}$, y larga de $8^{\prime \prime \prime}-6^{\prime \prime \prime}-3^{\prime \prime \prime}$, coronada por el limbo calizinal y de ápice umbilicado: hametia, F. 62, Or. II, T. III, G. XV.

733. Matas cilíndricas, ramosas, derechas, algo nudosas, de como $2^{\prime}-3^{\prime}$ de alto algo mas ó menos, con hojas simples, opuestas, aguzadas por ambos estremos, ovalo-lanceoladas, puntiagudas, enteras, coriáceas, cortamente pecioladas; estípulas interpeciolares, membranosas, con 2, 4 dientes, triangulares y puntiagudas, de base trabada con las hojas. Flores pequeñas blancas ó rosaditas en panojas 
terminales, cuyos pedícelos están acompañados hácia la insercion de 2 brácteas escamosas, largas y agudas, T de cáliz monosépalo adherente algo campanudo, cuyo tubo oval lleva un limbo 5-partido, con segmentos iguales, estrechos, largos y puntiagudos, acompañado de 3 escamas estrechas, largas y puntiagudas situadas por la base; corola infundibuliforme de tubo algo crecido y giboso, con 5 divisiones iguales, estendidas y agudas; estambres de filamentos cortos insertos en el tubo de la corola é inclusos. Ovario redondo, cuyo ápice está adecuado con 5 glándulas amarillentas, de cuyo centro sale un estilo simple terminándose en un estigma bífido ú abtuso. Bava 10-estriada : nonatelia, F. 62.

734. Arbol bajito ramosísimo, ó arbusto de ramos rollizos, estendidos y que parecen como algo nudosos, de corteza color ceniciento y con muchas grietas y estomas, centro del troneo y de los ramos con médula abundante én los tiernos. Hojas opuestas, con la base del raquis trabada en los ramos floríferos, imparipinadas y formadas de 4 pares de hojuelas opuestas, mas ó menos pecioladas, segun su posicion, ovales, aguzadas por ambos estremos y curo ápice se termina por una punta, con los bordes algo ondeados, aserrados por encima de la base, largas de $2-21\left[2^{\prime \prime}\right.$ sobre $11_{[} 2-1^{\prime \prime}$ de ancho, del todo lampiñas y lustrosas superiormente; la impar mayor y mas oval tiene el peciolo mas largo; raquis acanalado y estriadito. Flores blanco-amarillentas en cértulos ó cimas terminales formadas de algunas cimas parciales, ordinariamente 5 , cuyos últimos pedícelos se terminan por 3 flores pediceladas: una bracteita acompaña á la insercion de los brazos del cértulo. Cáliz pequeño de limbo 4, 5-lobo, con los segmentos ovales de bordes algo membranosos; su base está acompañada de dos bracteitas opuestas; corola enrodadla 4, 5-fida, con las divisiones iguales, obtusas y algo convexas; estambres 5 y á veces 4 insertos en la base de la corola, con cuyos segmentos alternan, un poco mas cortos que ellos y enderezados, con anteras casi mediifijas, de celdas diverjentes por la base, mientras la parte media está soldada á favor de la punta del filamento. Ovario oval cuyo ápice cónico y libre del cáliz lleva 3 estigmas formando una masa glandulosa verdusea $\mathrm{y}$ tríloba. Nuculanio unilocular 3 -espermo, liso, globoso, coronadito y prieto ó mejor morado oscuro, cuyos huesecitos arrugados y enderezados son pegados en el eje: sambucus, F. 61, T. I.

735. Corola recargada y empizarrada ó torcida, 736. - Corola de estivacion valvar, 739 .

736. Ovulos pendientes; embrion pequeño incluso en el endospermo; corola recargada ó imbricada, 737. - Ovulos pegados lateralmente; ombrion contenido en el endospermo; corola torcida, 738.

737. Arbustos sarmentosos cuyos tallos ramosísimos, delgados $y$ largos salen de una raiz tortuosa bastante gruesa, con hojas simples, opuestas, cortamente pecioladas, lampiñas, enteras, elípticas ó aovado-lanceoladas, aovadas ó aovado-oblongas, con una punta obtusa ó sin ella y cortamente cuneiforme porla base; estípulasmucronadas de punta mas corta que su vaina ó subuladas, con la punta mas larga que la vaina, trabadas con los peciolos. Flores amarillento-blancas 
en cimas racemiformes, axilares y de cáliz adherente algo campanudo, de tubo aovado, 5-dentado y persistente, cuyos dientes son iguales y deltoídeos; corola infundibuliforme, con 5 lóbulos iguales aovado-lanceolados ó lanceolados; estambres insertos en la base del tubo de la corola, algo monadelfos, de filamentos peludos, cuyas anteras son enteramente inclusas ó un poco esertas. Ovario globoso. algo comprimido, bilocular, cada celda monosperma, de cuyo ápice sale un estilo filiforme mucho mas largo que los estambres, terminándose por un estigma claviforme, con dos lobulos pegados ó diverjentes. Baya redondeadita, comprimida, blanca, casi dídima, coronada por las divisiones calizinales, con 2 o 3 huesecitos ó pirenas; semillas comprimidas, curo embrion axil está coutenido en el endospermo cartilajinoso: chiococca, F. 62, Or. I, T. III, G. III.

738. Arbusto o arbolito primoroso, de tronco recto, bastante ramosn, que se eleva de $15^{\prime}$ á.25' de altura, con hojas simples, opuestas, cortamente pecioladas, enteras y como algo undulosas por la márjen, lampiñas, coriáceas, oblongas, alq̧o aguzadas por los dos estremos, con una punta, largas de como $3^{\prime \prime}-4^{\prime \prime}$ y anchas de $11_{i} 2^{\prime \prime}$ á $2^{\prime \prime}$, de cara superior lustrosa y de un hermoso color verde oscuro; estípulas subulado-lanceoladas, solitarias y muy pronto caducas. Flores blancas, lindas y muy fragantes, en grupos axilares en los ramos del año anterior, cortamente pediceladas, cuyo pedúnculo comun lleva en su apéndice de ordinario 3 flores, con el pedícelo corto provisto de dos bracteitas situadas por su base, y de cáliz turbinado, de limbo con 5 dientes iguales, muy chiquitos y apenas marcados; corola hipocrateriforme, de tubo cilíndrico-infundibuliforme mucho mas largo que el cáliz, cuyo limbo torcido está partido en 4 , 5 lóbulos estendilos, iguales y obiongo-lanceolados; estambres salientes ó inclusos insertos hasta la parte mediana y un poco superior del tubo, alternando con las divisiones de la corola, cuyos filamentos cortos y derechos llevan anteras lineares, dorsifijas y vacilantes. Ovario ovoídeo 2-locular, con un huevecillo en cada celda, de cuyo ápice sale un estilo simple, filiforme, mas largo que los estambres, terminándose en un estigma 2-fido. Baya cerasiforme lisa, lustrosa, ovoídea, 2-locular, con las semillas pegadas en la parte mediana del tabique y con un surco lonjitudinal por el medio de su cara interna llana, mientras la esterna es convexa, envueltas en una concha apergaminada; embrion recto de raicilla ínfera y con los cotiledones foliáceos; endospermo cartilajinoso: coffea, F. 62 , Or. I, T. V.

739. Flores en cabezuelas y agrupadas sobre un receptáculo; fruto con ó sin pirenas, 740. - Flores nunca dispuestas en cabezuelas ni provistas de receptáculo tampoco; fruto siempre con pirenas, 743.

740. Ovario bilocular; receptáculo involucrado y pajoso; baya con 2 pirenas ó huesecitos, 741. - Ovario 2 ó 4-locular; receptáculo sin invólucro, globoso y no pajoso; baya con una semilla en cada celda, 742 .

741. Arbustos, matas ó plantas herbáceas, con las ramitas nudositas, tetrágonas, sub-tetrágonas ó cilíndricas entre los nudos, á 
reces velludas y con mayor frecuencia lampiñas y que llevan hojas opuestas, simples, sentadas, subsesiles ó cortamente pecioladas, elípticas, eliptical-oblongas, lanceolado-oblongas, con una punta mas o menos obtusa ó aguzada, largas de $8^{\prime \prime}-6^{\prime \prime}-5^{\prime \prime}-4^{\prime \prime}-3^{\prime \prime}$; estípulas mas largas que su vaina, 2 de cada lado, lanceolado-subuladas y larramente subuladas ó axilares, redondeadas, obtusamente bílobas y abiertas, otras veces tan largas como su vaina, aovadas y bílobas, por fin vaina estipular troncada y abierta, á veces bífida, con algunas aristas tiesas y decíduas. Flores en cabezuelas solitarias, de ordinario terminales, pedunculadas ó subsesiles, alguna que otra vez axilares y sentadas, de invólucro cuyos lóbulos son mucho mas largos que las flores, acorazonados ó aovados, puntiagurlos ú obtusos, otras veces mas corto que las flores $\mathrm{y}$-formado de brácteas aovado-redondeadas, cuadrado-oblongas y troncadas por el ápice ó redondeaditas; pajas del receptáculo redondeadas ó algo lobadas, cuadrado-oblongas y troncadas, y en fin obaovadas, laciniadas y pestaīosas por el áfice; cáliz con limbo persistente, elongadito y diminutamente J-dentadito; corola hipocrateriforme y cuyo limbo es lijeramente reduplicado; estambres inclusos, insertos en el tubo de la corola y con anteras oblongas. Ovario ovoídeo, 2-locular, con un huevecillo erguido en cada celda, de cuyo ápice sale un estilo terminándose por un estigma bífido. Baya casi lisa, de endospermo y pirenas llanos ó lijeramente encorvado por las comisuras, otras veces pirenas, obtusamente Jे-costilludas é involutas por las comisuras, cuyo endospermo es campilospermo ó siguiendo á la proyeccion de las pirenas : cephelis, F. 62, Or. I, T. VII, S.-T. II, G. VI.

742. Arbusto ó mata de tallo cilíndrico, muy ramoso y como nudoso, alto de $1^{\prime}-11_{[} 2^{\prime}$, arrastrándose por entre las raices de los demas vejetales, lampiño ó alampiñado, con hojas simples opuestas, cortamente pecioladas, lanceolado-oblongas, con una punta y largas de $3^{\prime \prime}-2^{\prime \prime}$; estípulas subuladas, membranosas y obtusas. Flores blancas olorosas en cabezuelas solitarias, axilares ó terminales, pedunculadas, pequeñas y mas largas que su corto pedúnculo, formadas de muchas flores, de cáliz adherente, de limbo corto, dentadito ó sub-enteı, con los lóbulos coherentes; corola infundibuliforme, de tubo cilíndrico y á la vez un poco cónico, cuyo limbo está partido en 5 , raras veces 4,7 segmentos jguales $y$ abiertos; estambres insertos en el tubo de la corola, inclusos y de filamentos cortísimos. Ovario de ordinario hexágono, bilocular, con un solo órulo erguido ó pegado por encima de la base en carla celda, de cuyo ápice sale un estilo simple bastante largo $y$ eserto, terminándose en un estigma bífido. Baya globoso-hexágona mas ó menos angulo:a ó comprimida, algo coronada, ancha de $4^{\prime \prime \prime}-6^{\prime \prime \prime}$ : morinda, F. 62, Or. I, 'T. VI, S.-T. II, G. VII.

743. Corola hipociateriforme, segmentos del cáliz recorvados. estrechos y abiertos, 744. - Corola infundibuliforme; cáliz dentadito ó con segmentos, raras veces entero, 745 .

744. Primorosa planta herbácea, vivaz, pequeña, de tallo filiforme, rastrero y arraigante, mas ó menos ramoso, alampiñado, con hojas simples que salen opuestas de trecho en trecho y como á unas 
$4^{\prime \prime}$ de distancia, y de la parte inferior del tallo correspondiente á su insercion nacen algunas raices que penetran en el suelo y mas tarde uno ó dos ramos, largamente pecioladas, acorazonadas, tan anchas como largas, redondeadas ú obtusitas por el ápice, con el seno basilar estrecho, de cara superior alampiñada, lustrosa y de color verde oscuro, mientras la inferior, mas pálida, es velluda y alg̨o teñida de moradusco, como de $1^{\prime} 12^{\prime \prime}$ de largo sobre $34^{\prime \prime}$ á $1^{\prime \prime}$ de ancho; peciolo erguido largo de $1^{\prime} 1^{\prime \prime} 1_{l} 2$, morado, con la cara esterior convexa y lampiña, nientras la interna, plana, lleva en ambos lados una hilera de pelo blanco y glanduloso; de su ápice cuelga el limbo de tal manera, que el ápice toca casi al suelo; estípulas interpeciolares bastante grandes, triangulares, cuya punta se desprerde asaz pronto, quedándose la base membranosa; de entre las dos hojas sale del tallo rastrero otro tallo derecho, alto como de $2^{\prime \prime}$, con '2 ó 4 hojas opuestas, de las cuales 2 están en su base y son caducas, mientras las del vértice persisten y de entre ellas sale un pedúnculo simple, recto, largo como de $1_{[} \gtrless^{\prime \prime}$ hasta $1^{\prime \prime}$, moradito, cujo ápice lleva de 2 á 6 flores que florean sucesiramente, pediceladas ó subsesiles, acompañadas de una especie de involucro formado por 3 brácteas foliáceas, linear-lanceoladas, aguzadas y casi tan largas como los pedícelos ó los cálices: flores preciosas y blancas, de cáliz adherente, cuyas divisiones lanceoladas, puntiagudas y de punta morada, son pubescentes y verduscas interiormente; corola hipocrateriforme un poco tubulada, cujos 5 segmentos espesitos, aovado-lanceolados, iguales, son pubescentes y un poco doblados hácia fuera, garganta peluda; estambres inclusos é insertos en el tubo de la corola, que es dos reces mas largo que las divisiones del cáliz, con filamentos cortísimos; estilo simple, filiforme, mucho mas largo que los estambres, terminado por un estigma bífido, cuyos lobulos bastante largos, diverjentes, cilíndricos y glandulosos son algo doblados hác:a fuera, saliendo del ápice de un ovario bilocular, de celdas uniovuladas. Baya lisa, lustrosa y de un primoroso color encarnado, coronada por las divisiones calizinales rerdes, aovada, conteniendo dos pirenas ó huesecitos lijeramente angulosos, de cara interna un poco en espiral y llana, mientras la esterior es convexa y con 3 crestas lonjitudinales: geophilla, F. 62, Or. I, T. VI, S.-T. II, G. VIII.

745. Corola infundibuliforme, de tubo corto y derecho, 746. Corola tambien infundibuliforme $\mathrm{y}$ de tubo corto, pero oblícua, con frecuencia gibosa por la base ó con los segmentos desiguales, 747.

746. Arbustos mas ó menos grandes ó matas, ordinariamente lampiños y algunas reces velludos ó pubescentes, mas ó menos ramosos, de $2^{\prime}$ ó $3^{\prime}$ de alto hasta $12^{\prime}-15^{\prime}$ y aun $25^{\prime}$. Hojas simples, opuestas, obaovadas, elípticas, oblongas, lanceolado-oblongas, lanceolado-elípticas, aovado-oblongas, lanceoladas, eliptical-oblongas, espatulado-lanceoladas, aorado-lanceolarlas, mas ó menos aguzadas ó con una punta, de ordinario cartáceas y algunas veces coriáceas, bastantes veces costilludas, mas ó menos pecioladas y largas de $15^{\prime \prime}$ $10^{\prime \prime}-8^{\prime \prime}-6^{\prime \prime}-4^{\prime \prime}-3^{\prime \prime}$, ordinariamente lampiñas; estipulas solitarias interpeciolares de base trabada con los peciolos y persistentes, mientras la parte libre es de ordinario decídua $y$ otras veces persistente, 
de tamaño y figura muy variados. Flores blancas, rojo-pálidas, color pajizo solo ó verdusco á la rez, amarillas, comunmente en panojas terminales ó á veces axilares ó en cimas terminales pedunculadas, acompañadas con frecuencia de bracteitas diminutas, y de cáliz adherente, de limbo persistente y con 5, 4 dientecitos ó segmentos, raramente sub-entero; corola infundibuliforme ó casi así, de tubo corto y con 5,4 lóbulos, con bastante frecuencia velluda en la garganta ó por debajo de ella; estambres insertos en el tubo de la corola, tan pronto inclusos como esertos y de anteras oblongas. Ovario aovado, bilocular, con un solo óvulo erguido en cado celda, y de cuyo ápice sale un estilo filiforme terminado por un estigma bífido. Baya ovoídea ó globosa, carmesí, amarillenta ó roja, larga de $3 "$ " $4^{\prime \prime \prime}$ y ancha de $2^{\prime \prime \prime}-33^{\prime \prime \prime}$, con las pirenas sea comprimidas por el dorso, 3-crestadas, cuyas crestas laterales son contiguas por los ángulos de las comisuras, sea semi-rollizas, 5, 3-crestadas, con las crestas equidistantes, otras veces lisas é involutas por las comisuras, alguna vez provistas de un surco largo situado por la comisura y 5, 3-crestadas ó angulo:as, y por último separadas la una de la otra en el eje, lijeramente encorvadas por la comisura, apenas 5 -crestadas ó 5-aguzadas por el dorso; endospermo cartilajinoso, llano, comprimido $y$ sin surcos, otras veces con surcos situados entre las crestas, plano, con dos surcos diminutos situados sobre el lado de la comisura ó campilospermo y siguiendo á la proyeccion de las pirenas, ó en fin sin surcos sobre el lado cóncaro ó llano de la comisura: psychotria, F. 62, Or. I, T. VI, S.-T. I, G. IV.

747. A rbustos lampinos, ramosos, de $3^{\prime}$ á $10^{\prime}$ de altura, de ramos nudosos y tetrágonos ó cilíndricos entre Ios nudos; hojas simples. opuestas, enteras, pecioladas, eliptical-oblongas, aovadas, elípticas, lanceolado-oblongas, oval-oblongas, con una punta, lampiñas por ambas caras ó algunas veces pubescentes ó alampiñadas por la inferior, membranosas; estípulas sea cortas, subuladas y tan largas como su vaina, sea diminutas y sub-distintas ó de tamaño regular, mas lartras que su vaina, lanceolado-lineares ó linear-aguzadas. Flores en panojas corimbiformes ó tirsoiformes, terminales, cuyos pedúnculos y brazos, ordinariamente bastante largos, son del color de las flores, blancas, azafranadas ó rosadas, y de cáliz adherente, de limbo persistente, y con 5, 4 dientecitos ó segmentos, rara vez sub-entero; corola infundibuliforme, tubulada, mucho mas larga que el cáliz, alampinado-pulverulenta, con el tubo claviforme y cilindrico, sub-cilíndrico $y^{*}$ giboso por la base ó filiforme $y$ claviforme á la par, con la garganta lampiña, de limbo 5-partido, con los segmentos aovados, oblongos y abiertos, oblongo-sub-agudos, iguales ó desiguales, ordinariamente mas cortos que el tubo, estambres insertos en el tubo, un poco esertos, pero algo mas cortos que las divisiones del limbo; estigma 2-fido; ovario 2-locular, con un solo óvulo erguido en cada celda. Baya con 2 pirenas 5 -crestadas é in rolutas por la comisura ó llanas por la comisura y casi lisas; endospermo de ordinario campilotropo y siguiendo la proyeccion de las pirenas, raras veces orthospermo: palicurea, F. 62 , Or. I, T. VI; S.-T. I, G. V. 
748. Corola unilabiada; hojas alternas sin estípulas, 749. - Corola nunca labiada, enrodada y de segmentos recargativos; hojas opuestas y con estípulas interpeciolares; óvulos pendientes, 750 .

749. Arbusto de las orillas del mar, poco ramoso y que se eleva á $2^{\prime}$ ó $3^{\prime}$ de alto, cuyo tallo de base tendida y de vértice derecho que lleva 9,12 hojas simples, alternas, obaovadas ó espatuladas, bien enteras, cuyo peciolo muy corto y blanco-amarillento es un poco mas ancho por la base, con barbas en la axila, carnudas, dobles, quebradizas y cuyas nervaduras son representadas por estrías lijeras visibles por ambas caras, lampiñas, lustrosas y un poco color verdemar, largas de $3^{\prime \prime}-4^{\prime \prime}$ y anchas de $2^{\prime \prime}-3$ ". Flores en cimas axilares trífloras, cuyo pedícelo largo de como $2^{\prime \prime}-3$ ", simple, derecho, un poco comprimido y de vértice algo mas grueso, que lleva 4 brácteas, de las cuales 2 son laterales, mas largas y lanceoladas, con una puntita amarillenta y carnuda, cóncavas interiormente y convexas esteriormente, la del medio al contrario es muy corta, redondeada y obtusa, la cuarta es rudimentaria, y de la axila de las dos laterales sale un pedícelo semejante al pedúnculo mas corto, mas delgado y unífloro; cáliz adherente, de limbo troncado y ondeado ó lijeramente dentadito; corola irregular largamente tubulada, hendida por el lado superior y representando los semi-flósculos de las synantéreas, de manera que el limbo horizontal que forma el labio es 5-lobado, con segmentos iguales, ovales, puntiagudos, cuyos bordes están provistos en su cara superior de una membrana petaloídea, ondulosa, blanca y erguida, que no alcanza hasta el ápice, reemplazado en la base por apéndices blancos, filiformes, que ocupan tambien la garganta y el tuho que son amarillentos; estambres inclusos insertos entre la corola y la base del estilo, de los cuales uno sale por la hendidura, á veces hay uno rudimentario, son libres, con los filamentos tan largos como el estilo, de cara interna, llana y estriada, mientras la esterna es convexa, de ápice mas ancho, cuyos dos lados llevan cada uno una celda de la antera, y despues de su insercion se termina en punta obtusa, y para que se efectue la fecundacion tales anteras se aplican sobre la copita ó indusio que acompaña al estigma. Ovario adherente 2-locular, con un óvulo en cada celda, globoso y de cuyo ápice sale un estilo derecho, largo, blanco, con la base verdusca y velluda, cuya parte superior, arqueada, sale por la hendidura, terminado por un estigma endusiado, verdusco, comprimido, glanduloso y lobado. La fecundacion se verifica en el boton antes de abrirse la flor. Fruto drupáceo subgloboso, amarillo, con un hueso, y cada celda es monosperma: sccevola, F. 58, T I.

750. Semillas sin endospermo, ordinariamente cilíndricas, operculadas por el cordoncito dilatado; raicilla larga; cotiledones cortos; lóbulos de la corola ordinariamente imbricativos, 751. - Semillas con endospermo; embrion pequeño encerrado; lóbulos de la corola siempre imbricativos, 753.

751. Limbo calizinal 5-partido, persistente; corola enrodada, profundamente 5-partida, de segmentos lijeramente imbricativos; anteras subsesiles adberidas entre sí y casi libres del tubo de la co- 
ruia, y formando una columna aovado-oblonga, membranácea por el ápice, algo mas corta que los segmentos de la corola; estilo bífido con los brazos contiguos; estípulas persistentes; hojas verticiladas por á 3, 752. - Limbo del cáliz troncado, lacerado-repando, repando ó lacerado y por último decíduo; corola hipocrateriforme con 6 , 4 y á veces 9 lóbulos bien imbricativos, de tubo cilíndrico lijeramente encorvado y ancho, mas largo que el cáliz, filiforme o claviforme, tomentoso, pubescente, velludo-tomentoso; estípulas de ordinario decíduas; liojas opuestas. Arboles bajitos, á veces de $30^{\prime}-40^{\prime}$ ó arbustos de $\mathrm{S}^{\prime}$ á $12^{\prime}$ de altura; hojas simples, enteras, mas é menos recioladas, cuyo capulio o yema está raras veces cnvuelto en una sustancia resinosa blanca, que se halla sobre los peciolos, ramitas y hojas, aovadas, acorazonadas ó sub-cordiformes, elípticas, oblongo-elípticas, elíptico-redonditas ó lanceoladas, á veces festoneadito-repandas, lampiñas del todo, alampir̃adas ó de cara superior lampiña, mientras la inferior es plateado-sedosa, tomentosa, pubescente, á veces solamente á lo largo de las nervaduras, de base acorazonada ú obtusa y con el ápice mas ó menos puntiagudo ú obtusito; con las venitas aproximado-reticuladas ó apenas marcadas; largas de 8-5", 3-6", 5-2", etc., sobre 5-3", 2-4, 3-1", etc. de ancho; estipulas aovado-lanceoladas, deltoídeo-subuladas, alesnadas, lanceoladas ó aguzadas, raras veces persistentes. Flores pequeñas blancas sentadas en la cara interior de los brazos especiformes ó contraidos, frecuentemente unilaterales, ó una entre ellos mas ó menos diverjentes; anteras lineares subsesiles por debajo de la garganta de la corola, enteramente inclusas y raras veces sub-inclusas; estigma cabezudo. Drupa globosa ó cortamente oblonga, con ángulos aqudos o sin ellos, tomentoso-venosa, pubescentita y lijeramente asperita, aterciopelada, alampiñada, asperita ó lisa $y$ ancha de $3-2^{\prime \prime \prime}$, con 6,3 y á veces 9 celdillas: guettarda, Aquilon, F. 62, Or. I, T. II.

752. Arbusto alto de $2^{\prime}-3^{\prime}$, ramoso y con muchas hojas simples, subsentadas, espesitas $y$ lineares, rerueltas por la márjen, puhescentitas, decíduas y largas de $44^{\prime \prime \prime}-8^{\prime \prime \prime}$. Flores blanquecinas, pubescentes, en grupos axilares y acompañadas de brácteas: cáliz adherente, con el tubo aovado y el limbo 5-partido y persistente; corola enrodada, profundamente 5 -partida, con segmentos oblongo-lanceolados, blanca y pequeña. Anteras subsesiles. Drupa elipsoídea 2, 1locular, conteniendo semillas ovoídeo-oblongas, colgantes y operculadas por un arilo basilar: strumpfia, F. 62, Or. I, T. II.

753. Arbustos resinosos ó arbolitos bajitos, lampiños, ramosos y altos de $2^{\prime}-3^{\prime}$ hasta $8^{\prime}-15^{\prime}$, con hojas simples opuestas, enteras, cortamente pecioladas, coriáceas, obaovadas, espatulado-lanceoladas. elíptico-lanceoladas ó solamente lanceoladas, obtusas ú obtusitas, aguzadas por los dos estremos, lustrosas, largas de $4^{\prime \prime}-3^{\prime \prime}-2^{\prime \prime}$; estípulas persistentes, apiculados, de vaina trabada entre los peciolos. Flores blancas en cimas pedunculadas, axilares o estraxilares, tricótomo-fastijiadas, cáliz adherente, de tubo aovado, con el limbo corto, sub-troncado, onduloso ó con う̌ dientẹcitoş deltoíleos, persistente; corola enrodada, profundamente 5 -fida con los segmentos 
oblongo-lineares ó lanceolado-ohlongos y aovado-lanceolados; estambres 5 ó 10 esertos. Drupa globosa, asurcada, con 5, 10, 20 pirenas comprimidas, así como las semillas que contienen; embrion situado en el ápice de un endospermo carnudo: erithatis, F. 62, Or. I, T. III, G. II.

754. Flores compuestas ó agrupadas en número mayor ó menor sobre un receptáculo comun de forma muy variada. 755 .

755. De ovario libre ó súpero; flores siempre monoicas, 756. De ovario adherente ó ínfero; flores ordinariamente hermafroditas, 759.

756. Arboles de suco lechoso, 75\%. - Plantas herbáceas ó matas de savia nunca lechosa, 758 .

75\%. Mas ó menos grandes, con hojas simples, coriáceas, de flores muy pequeñas, incompletas y contenidas en el interior de un invólucro mas ó menos desarrollado, piriforme, casi cerrado por el ápice, y situadas en su pared interna; 3 estambres solamente :ficus, 111.

758. Yerba de cuyo rizoma salen las hojas y los peclúnculos florales mas ó menos cortos, simples y terminados por un receptáculo llano mas ó menos cuadrilátero, sin invólucro y cuya parte plana lleva muchas flores muy pequeñas incompletas, situadas en sus alvéolos. Fruto capsular: dorstenia, 167.

759. Estambres libres; hojas simples opuestas, con estípulas interpeciolares; fruto abayado ó capsular, 760._Estambres 5, soldados por las anteras; hojas compuestas, alternas, sin estipulas, raras veces simples y opuestas; un aquenio, 763 .

760. Estambres 4; fruto capsular, 761. - Estambres 5; fruto abayado, 762 .

761. Flores amarillentas en cabezuelas, largamente pedunculadas, axilares ó terminales, sesiles, en un receptáculo esférico, 695.

762. Receptáculo involucrado y pajoso; cáliz de limbo persistente con $\check{5}, 4$ dientes pequeños ó segmentos, raramente sub-entero; corola infundibuliforme ó casi así y de tubo corto, lóbulos 5,4 valvados. Baya con 2, 3 pirenas, mas veces asurcadas y 3 , 5 -crestadas, 742. - Receptáculo ni involucrado ni pajoso tampoco; limbo calizinal corto, dentadito ó sub-entero; tubos calizinales concretos; corola infundibuliforme, de limbo con $5,4,7$ lóbulos. Baya conteniendo una semilla en cada celda y no pirenas, 741 .

763. Corola tubulada ó ligulada, pero solamente en las florecitas de los radios, 771. - Corola nunca tubulada, pero sí bilabiada ó ligulada, 764 .

764. Corolas bilabiadas o liguladas, pero solo en las florecitas de los radios, 765. - Corolas todas liguladas ó flores homógamas, 766.

765. Plantas herbáceas anuales, con todas las hojas radicales y arrosetadas, simples, pero mas ó menos lobadas, de manera que las unas son liradas, con el segmento terminal grande y aovado-oblongo ó liratc-espatuladas, can el segmento terminal contraido en la última sinuosidad, otras veces espatuladas ó espatulado-lanceoladas, agruzadas por la base, enteras y regularmente sinuosas por arriba ó puntiagudas, con algunos dientecitos distantes ó enteras, de cara 
inferior blanco-tomentosa. Del medio de la roseta sale un pedúnculo largo de 6 " á $10^{\prime \prime}$, que se termina jor una cabezuela solitaria heterógama; radios apenas esertos, con flores blancas ó purpurinas, cuyas flores femeninas son dispuestas en algunas séries, las esteriores liguladas, mientras las del centro son bisexuales ó hermafroditas; invólucro lijeramente imbricado, con pocas séries de escamas lanceolado-lineares y aguzadas o cortas, otras veces lineares y aguzadas; receptáculo desnudo; anteras coludas; brazos del estilo pubescentitos; aquenio sub-comprimido, con las caras costilludas, cuyo ápice se aguza en pico filiforme 2 ó 3 veces mas largo, tan largo ó mas corto que éí, con un penacho peludo y ordinariamente color pajizo teñido de purpuráceo : levia, F. 59, T. III.

766. Semillas de penacho sentado, 767. - Semillas de penacho subsesil ó pediceladito, 770 .

76\%. Flores amarillas, 768. - Flores azules, 769.

768. Plantas herbáceas anuales mas ó menos ramosas, de tallo derecho, con frecuencia estriado, pubescentes ó alampinadas, lampiñas ó velludas, de savia lechosa; hojas simples, alternas, sentadas, mas ó menos laciniadas ó partidas, runcinado ó sub-entero-dentadas. Flores ó mejor cabezuelas, dispuestas en corimbos, sin glándulas, con invólucro imbricado, algo ventrudo por la base $y$ formado de hojuelas estrechas; receptáculo desnudo; aquenio cilíndrico, estriado, transversalmente rugoso ó liso, troncado por el ápice, que lleva un pellacho blanco con pelos simples : sonchus, F. 59, T. I.

769. Plantas herbáceas bisanuales, de tallo en zig-zag, derecho, estriado y relludo, de $2^{\prime}$ á $3^{\prime}$ de alto, poco ramoso, con hojas alternas, simples, sentadas, runcinadas y á reces laciniadas, las radicales un poco pecioladas. Flores algunas veces blancas, cuyas cabezuelas, dispuestas en especies de espigas están en el ángulo saliente formado por el zig-zag del tallo, con invóluero doble ó formado de uno esterior compuesto de 5 hojuelas algo dobladas hácia fuera y mas cortitas, $y$ otro interno con 8 hojuelas soldadas entre sí por la base, erguidas y mucho mas largas; receptáculo alveolado y pajoso, plano; aquenio troncado, coronado por muchos dientecitos : chicorium, F. 59, T. I.

770. Plantas herbáceas anuales, tambien de savia lechosa, cuyo tallo derecho se eleva liasta $3^{\prime}$ de alto, de ordinario no ramoso, con hojas simples, alternas, sentadas, cuyas radicales algo pecioladas son grandes, oral-redondeadas, algo cóncavas y ondulosas, enteras, lampiñas, á veces manchadas de moradusco, otras veces dentadas ó enteras, cuyas inferiores, de ordinario roncinadas, tienen algunos lóbulos puntiagudos ó lanceolado-oblongos, un poco abrazadoras por la base aguzada, superiores, lanceoladas, aguzadas $y$ sesiles; cabezuelas en cimas ó panojas grandes abiertas, con los brazos racemiformes; invólucro imbricado, cilíndrico, cuyas hojuelas en pocas séries son algo membranosas por los bordes; receptáculo desnudo, plano, punteado, con 12 á 15 flores; aquenio comprimido, ovoídeo, blanco ó prieto, liso ó estriardo, abruptamente picudo y coronado por un penacho simple y estipitado: lactuca, F. 59, T. I.

7\%1. Sin receptáculo lejítimo, bien que á primera vista parezca 
existir; involucro talso tormado por las dos hojas mas superiores; florecitas saliendo de la axila de una bráctea escamiforme; estilo simple terminado por un estigma obtuso; aquenio liso, lustroso. desnudo y como ombligado por el ápice, 772. - Receptáculo lejítimo, acompañado de un invólucro formado de un número variado de hojitas escamiformes mas ó menos desarrolladas, mas ó menos foliáceas; flósculos ó florones y semi-flósculos pegados en un receptácalo de forma y tamaño muy variados, desnudo ó pajoso, peludo ó pubescente, plano ó convexo, liso ó alveolado; estilo siempre bífido; aquenio ordinariamente coronado, 773.

772. Del ápice de una raiz perpendicular, vivaz, bastante gruesa, nias ó menos ramosa, y de entre los restos de los tallos del año anterior salen tallos derechos, delgados, en número variable, bastante resistentes, pero no leñosos propiamente dicho, lampiños, de color que varia del rojizo al verdoso pálido y al gris pálido por la base, que es cilíndrica, mientras que no tardan en volverse comprimidos y algo estriados á lo largo de las caras llanas y no por las convexas, y de seccion elíptica; se ramifican por á tres. como á $6^{\prime \prime}$ del suelo, cuya division central, que es la continuacion del tallo, no tarda en morirse $y$ en desaparecer, mientras que las dos laterales salen opuestas de la axila de dos hojas correspondientes y de una especie de nudo crecido ó comprimido: siguen así hasta la altura de $8^{\prime \prime}$ á $10^{\prime \prime}$ Y vuelven á ramificarse de iǧual modo, haciéndolo dos ó tres veces mas, de tal suerte que la parte superior del tallo se encuentra bastante ramosa ; siempre la division del medio, cuando existe, es mucho mas corta que las laterales, pues que no alcanza sino á $3^{\prime \prime}$ o $4^{\prime \prime}$ de largo, teminándose por un grupo de flores. Hojas simples, opuestas, como connadas ô trabadas por la base, sentadas, lanceolailas, coriáceas, de base redonda y aguzado-puntiagudas por el vértice, enteras y algo membranosas por los bordes apergaminados y ondulosos, lampiñas por ambas caras, cuya superior, de un hermoso color verde pálido, es lustrosa, mientras la inferior, mas pálida y no lustrosa, tiene las nervaduras y venas muy pronunciadas, largas como de $3^{\prime \prime}-4^{\prime \prime}$ y anchas como de $1^{\prime \prime}-11_{[} 2^{\prime \prime}$, basinervias; la costilla va acompanada de dos nervaduras principales, saliendo una de cada lado, paralelas á ella, las cuales á su vez están acompañadas de venas afectando igual disposicion, las cuales se anastomosan con venitas, sin seguir entónces simetría alguna; las nervaduras son un poco visibles por la cara superior, cuyas dos mitades se doblan algo hácia arriba y á lo largo de la costilla, de manera que se vuelve cóncava y con figura de barca ó curiaza. Flores blanquecinas terminales dispuestas en grupos algo globosos ó en cabezuelas algo comprimidas, en número de 3 en el ápice de cada ramita o pedúnculo, cuya disposicion tricótoma afecta tambien, cortamente pediceladas y tormadas de muchas florecitas saliendo de entre dos escamas grandes, cóncavas y opuestas, cuyo ápice se va apartando un poco : están contenidas en una especie de invólucro falso formado por las dos hojas mas superiores. Cada florecita blanca, con el centro morado, sale de la axila de una escama espatuliforme concava por la cara interna que corresponde al flosculo y casi acucharada, con una puntita en el 
ápice y algunos pelos blancos por sus bordes y hácia su parte superior escariosita, mientras la cara esterior colvexa, blanco-verdusca, con 5 estrías verdosas paralelas, cuya mediana alcanza la puntita, mientras las laterales siguen por par paralelo á lo largo de la escama. No hay receptáculo lejítimo, sino solamente su simulacro; en efecto, despues de desprendidos los florones y de caidas las semillas, se quedan en el ápice de las ramitas 5 á 6 alvéolas, que no son otra cosa sino el ápice de los perlúnculos que sostenian los grupos florales ó cabezuelas en igual número y provisto de una especie de invólucro monófilo y trílobo simulando una salvilla. Corola infundibuliforme tubulada, blanco-verdusca inferiormente, de limbo con 5 divisiones profundas, oval-puntiagudas y blancas; estambres 5 , reunidos por las anteras morado-oscuras y un poco esertas, y alternando con los segmentos de la corola. Ovario pequeño, inversopiriforme, pegado con la corola, unilocular, uniovulado y de cuyo ápice sale un estilo filiforme cuya parte superior saliendo por el ápice del tubo formado por las anteras es peluda y se termina por un estigma obtuso. El fruto es una especie de aquenio negrusco, liso y lustroso, inverso-piriforme, enteramente desnudo y de ápice ombligado. Las hojas y tallos estrujados entre los dedos exhalan un olor algo aromático particular y característico que nos ha parecido análogo al del andrósemo oficinal de Europa: jarilla, Nobis; ichthyothere, Mart.; ichthyothere curvifolia, F. 59, T. II, S.--T. VI.

774. Brazos del estilo ordinariamente largos y subulados, casualmente cortos y obtusos, con la cara esterior enteramente pelierizada, 805. - Brazos del estilo nunca subulados, pero sí lineares ó claviformes, 775 .

775. Siempre mas ó menos lineares, 781.-Nunca lineares, pero sí claviformes y de cara esterior papilosa, 776 .

776. Cabezuelas ó calátides discoídeas, compuestas de flósculos en número de 8,12 y hasta 25 , y raras veces de 4 ; invólucro imbricado 2, 1-seriado; receptáculo desnudo, ordinariamente lam piño; corola claviforme ó campanuda, 777. - Cabezuelas discoídeas con 3 á 5 florones nada mas, 778 .

777. Arbustos, matas ó plantas herbáceas, algunas veces como sarmentosos, muy ramosos, pubescentes, velludos y alampiñados: hojas ordinariamente opuestas y raras veces alternas, simples, enteras ó mas ó menos lobadas, laciniadas ó dentadas, pecioladas ó subsesiles, aovadas ó aovado-lanceoladas, elíptico-oblongas ó lanceolado-oblongas, aovado-redondeaditas ó deltoídeas, lanceoladolineares, acorazonadas ó acorazonado-aovadas, oblongo-lanceoladas, romboídeo-aovadas, deltoídeo-aovadas, mas ó menos aguzadas, puntiagudas ú obtusas, aserradas ó sub-enteras, con frecuencia 3nervias, pubescentes, velludas, alampiñadas ó lampiñas. Flores en cabezuelas, cuyo invólucro cilíndrico es formado de algunas séries de escamas apretadas y alampiñadas ó tambien cilíndricas, y por fin turbinado, pluriseriado, con escamas abiertas ó desparramadas por el ápice, alampiñadas, otras veces abierto tambien, 1, 3 -seriado $y$ con frecuencia provisto de escamas esteriores mas cortas, las escamas de la principal série siendo sub-iguales; receptáculo forman- 
do un cilindro corto que se eleva entre las escamas del invólucro y aparece conrexo ó llano por encima de ellas, ó un poco dilatado entre las escamas del invólucro $\mathrm{y}$ de ápice llano que aparece por encima de ellas, otras veces es deprimido ó diminuto por encima de las escamas del invólucro y por fin deprimido y de ordinario diminuto. Aquenios 5, 3-gonos, con un penacho peludo: eupatorium, F. 59, T. II , S.-T. IV. G. III.

r78. Cabezuelas con 3, 5 flósculos, de invólucro imbricado; receptáculo diminuto y conrexo; corola claviforme; aquenio cortamente estipitado, 5-gono, aquillado por los ángulos, 779. - Cabezuelas ordinariamente con 4 florones; invólucro 1-seriado, formado de 4 hojuelas ó con una bráctea accesoria; receptáculo diminuto y desnudo; estilo provisto de un crecido lampiño y discoídeo situado por la base; aquenios 5-gonos y sentados, 780 .

779. Arbustos muy ramosos, lampiños ó pubescentes, que se elevan de $6^{\prime}$ hasta $16^{\prime}$ de altura, con hojas opuestas, simples, aserradas, lanceoladas ó elíptico-lanceoladas, aovadas, elípticas, aovadolanceoládas, aquzadas por ambos estremos, puntiagudas ó aguzadas, largas de $6^{\prime \prime}-8^{\prime \prime}-4^{\prime \prime}-3^{\prime \prime}-7^{\prime \prime}$ y anchas de $4^{\prime \prime}-2^{\prime \prime}-1 "-66^{\prime \prime \prime}-18^{\prime \prime \prime}$, cabezuelas en grupos sentados ó subsesiles y dispuestas en corimbos compuestos terminales, cuyas flores son blancas ó blanquecinas; invólucro 4, 3-seriado, con escamas estriadas ó sub-estriadas, obtusas, las interiores oblongas y las del medio gradual ó bruscamente mas cortas $\mathrm{r}$ aovadas, mientras las esteriores son muy cortas. Aquenios pelierizaditos ó alampiñados : critonia, F. 59, 'ं. II, S.-T. IV, G. IV.

780. Arbustos ó matas abejucados, de tallos delgados, muy ramosos y muy largos, con hojas opuestas, pecioladas, simples, lampiñas, alampiñadas ó pubescentes, alabardado-deltoídeas, aovadas, elíptico-oblongas, ovales, oval-redondeaditas, aovado-lanceoladas, acorazonadas ó sub-cordiformes, bien enteras, sub-enteras, dentadas, dentaditas, sub-sinuado-repandas ó repando-enteras; aguzadas, puntiagudas, obtusitas ú obtusas, de cara superior mas ó menos lustrosa, mientras la inferior es alampinada ó pubescente; mas ó menos pecioladas; 3 -nervias, triplinervias, quintuplinervias, I-nervias, 5-nervias 3, 5-nervias, con las nervaduras mas ó menos pronunciadas, membranáceas ó coriáceas, largas de $3^{\prime \prime}-4^{\prime \prime}-5^{\prime \prime}-2^{\prime \prime}-21\left[2^{\prime \prime}\right.$. Cabezuelas en espigas ó racimos compuestos y alargados, en corimbos racemosos cortos ó en corimbos ramosos y terminales, en fin pediceladas ó la del centro sola sentada, con ó sin bracteitas por la base del invólucro, cuyas escamas son oblongas, oblongo-lineares, espatulado-lanceoladas, elíptico-oblongas, obtusas, obtusitas, puntiagudas ó mucronadas, lisas, estriadas ó sulb-estriadas, lampiñas, alampiñadas ó pubescentes. Flósculos de corola con el limbo 5-fido, á veces mas corto que el tubo, como infundibuliforme, sub-claviforme ó campanuda. Aquenios ordinariamente lampiños, algo pubescentes ó glandulosos: mikania, F. 59, T. II, S.-T. IV, G. V.

781. Continuándose lineares hasta el vértice sin volverse planos, con apéndices cubiertos de pelo esteriormente, 182. - Estilo perfectamente cilíndrico, con los brazos lineares troncados por el vér- 
tice, adornado de un grupo de pelos, despues del cual se prolonga en un cono ó apéndice, 783.

782. Natas ó plantas herbáceas olorosas, cuyo tallo derecho y ramoso se eleva á como $3^{\prime}-4^{\prime}$ y hasta $6^{\prime}$ de altura, de ramos herrumbroso-pubescentes ó tomentosos, con hojas simples, alternas, pecioladas, oblongas ó elíptico-oblongas, oblongo-lanceoladas ó lanceoladas, bien enteras ó dentaditas, repandas, glanduloso-pubescentitas superiormente y blanquecino-pubescentẹs ó tomentosas inferiormente ó desigualmente aserradas, repandas, suavemente pubescentito-sub-tomentosas ó alampiñadas; cabezuelas purpúreas, corimbosas, pediceladas y hemisféricas ó sub-globosas, con el invólucro imbricado, de escamas aovadas ó aovado-oblongas, obtusitas y tomentosas: las de la série interior oblongo-lineares, aguzadas y escariosas ó herrumbroso-pubescentes y abiertas; las de la série esterior aovadas, obtusitas, gradualmente pasando á las de la interior, aovado-lanceoladas y puntiagudas. Flores esteriores de las cabezuelas discoídeas, femeninas, dispuestas en algunas séries y sub-troncadofiliformes, mientras las del centro, masculinas, campanudas, tienen el estilo sub-entero; anteras coludas; receptáculo desnudo. Aquenios sub-cilíndricos, con vilano peludo: pluchea, F. 59, T. II, S.-T. II, G. II.

783. Flores todas unisexuales, sea dioicas ó monoicas, heterocéfalas; receptáculo con mas frecuencia paleáceo; anteras sin cola; vilano nunca peludo; pelos colectores de los estigmas faltando con bastante frecuencia, 781. - Flores nunca jamas unisexuales y flores del disco hermafroditas. 785.

781. Planta herbácea anual, de tallo ramoso superiormente, alto de $111_{[} 2^{\prime}$ á $3^{\prime}$, pelierizadito, con hojas alternas, bipinatipartidas, cuyas superiores son enteras, simples y bastante grandes. Cabezuelas dispuestas en corimbos ó panojas abiertas, pequeñas y solamente de 11 [ $2^{\prime \prime \prime}$ á $2^{\prime \prime \prime}$ de diámetro, blancas, heterógamas, con J florecitas femeninas situadas esteriormente, diminutas y anchamente liguladas, mientras las interiores, mucho mas numerosas y flosculosas, son masculinas; invólucro 2-seriado; anteras pálidas; estilo simple y pubescente; receptáculo pajoso, de pajitas dilatadas por el vértice, mellizas, contra los aquenios comprimidos, cuyo vilano sale de dos escamas ó es apenas notable: parthenium, F. 59, T. II, S.-T. VI.

785. Aquenios siempre con vilano y nunca desnudos; 786. Aquenios desnudos, coronados ó aristados, 794.

786. Vilano peludo ó formado de escamas solamente, 787. - Tilano peludo ó formado de escamas indistintamente; receptáculo desnndo, 793. 791.

787. Vilano peludo, 788. - Vilano formado de escamas distintas,

788. Cabezuelas homógamas ó heterógamas discoídeas, rarísimas veces radiadas, á veces unífloras; anteras coludas; aquenios con vilano peludo ó cerdoso, raramente calvos; estilo de las flores hermafroditas de brazos troncados sin apéndices, pero con un pincelito de pelo; el de las masculinas frecuentemente indiviso; de corolas, tu- 
bulosas, 5-dentadas, mientras las de las hermafroditas son filiformes y rarísimas veces liguladas, 789. - Cabezuelas homógamas y mas veces heter óramas, radiadas ó no, con las flores del disco hermafroditas, lígulas con frecuencia uniseriadas; anteras no coludas; receptículo paleáceo; estigmas recorvados y terminados por un estípite calloso ; vilano uniseriado con cerdas tiesas, ásperas y persistentes, 790 .

789. Plantas herbáceas anuales ó matas blanco-tomentosas; muy ramosas y altas de $11{ }^{1} 2^{\prime}$ á $3^{\prime}$, con hojas simples, sentadas, alternas, linear-lanceoladas, sub-enteras, aguzadas por ambos estremos, tomentosas por ambas caras y blancas inferiormente ó lanceoladas, cortamente aguzadas, desigualmente festoneadas, de cara superior áspera y verde, mientras la inferior es blanco-tomentosa, y por último espatulado-lanceolada, las mas inferiores espatuladas solamente, de cara inferior blanco-tomentosa, con pelito muy apretado, anchas de 1"-2". Cabezuelas heterógamas en grupos terminales acorimbado-apanojados, escamas del invólucro blancas, aovadas ú oblongas, obtusitas ú obtusas: flores femeninas 20,30 , hermafroditas algunas ó en grupos dispuestos en corimbos arramilletados, con las escamas del invólucro blanco-pajizo, aovadas ó aovado-oblongas, obtusitas ú obtusas; flores femeninas 50,60 , hermafroditas 7,8 solamente, en fin en espigas, con los grupos inferiores de ordinario cortamente pedunculados y distantes; invólucro formado de pocas séries de escamas, cuyas interiores oblongas, puntiagndas ú obtusitas son parduscas ó blanquecinas. Aquenios sub-comprimidos ó cilíndricos, á veces lijeramente ásperos: gnaphalium, F. 59, T. II, S.-T. VII.

790. Arbustito ó mata de tallo muy ramoso, pubescente, que se eleva de $t^{\prime}$ á $\tau^{\prime}$ ó algo mas de altura, asperita, con hojas simples, alternas, aguzadas por la base, muy variables, oblongo-lanceoladas ó aovado lanceoladas, cuneiformes por debajo de los lóbulos, aserradas ó trífidas, pubescentes y de cara inferior escabrosa ó tomentosa, un poco cartáceas. Cabezuelas amarillas dispuestas en corimbos apanojados, discoídeas y homógamas; invólucro imbricado, cuyas escamas interiores son coloridas; receptáculo algo plano y pajoso; brazos del estilo cónicos por el ápice. Aquenio rollizo, cortamente estipitado, cuyo vilano peludo es áspero: neuroloena, F. 59, T. II, S.-T. VIII.

791. Todos los aquenios conformes, lampiños ó pubescentes, 792. - Aquenios no conformes, de tal suerte que los del disco, ob-comprimidos, están encerrados entre las escamas interiores y las pajitas esteriores, mientras los de la circunferencia son sub-trígonos, todos de base aguzadita ó adelgazada, sub-pubescentes. Sub-arbusto de como 6' de altura y muy ramoso, de hojas simples, cortamente peciolaras, esparcidas ó espiralmente alternas, aovado-lanceoladas, acuñadas por la base y aguzadas por el ápice, aserraditas, peninervias y pelierizaditas. Fllores arnarillas en grupos poco fornidos, cuyos pedúnculos, saliendo de la dicotomía, llevan una sola cabezuela sin brácteas, sub-globosa, con el invólucro lampiño y formando panojas flojas, cuyas cabezuelas heterógamas tienen el invólucro hemisférico 
con 5 brácteas dispuestas espiralmente y en 2 séries, ovales y mucronaditas; receptáculo convexo con pajitas ó paleas membranosas muy angostas, cuyas esteriores son mayores. Flores radiadas con pocas lígulas ó semi-florones en una série única, escondidas entre las escamas del invólucro y las pajitas derechas esternas y mayores del receptáculo. Florones del disco tubuloso-5-dentados; estilo corto incluso. Vilano de los aquenios formado de paleas variadas; en efecto, las de la circunferencia son cerdosas y pequeñas, mientras las 5 del disco, ovales, derechas, aserrado-pestañosas y agudas son 3 veces mas largas que la corola : vargasia, F. 59, T. II, S.-T. X.

792. Plantas herbáceas ó matas mas ó menos ramosas, pubescentes ó alampiñadas, con hojas opuestas, simples, escabroso-pubescentes, triplinervias, pecioladas, aovadas ó aovado-lanceoladas, puntiagudas ó aguzadas, aserradas ó sub-aserradas, enteras ó subenteras, de cara superior escabroso-pubescente, mientras la inferior es pubescente ó alampiñada y glandulosa, redondeadas ó cuneiformes por la base, largas de $2^{\prime \prime}-3^{\prime \prime}-1^{\prime \prime}$. Cabezuelas discoídeas ó radiadas, con los radios femeninos, dispuestas en corimbos terminales ó axilares, con flores purpúreas ó amarillas; invólucro imbricado, con las escamas aovadas ó aovado-oblongas y obtusas ú oblongo-lanceoladas, aguzadas y obtusas por el ápice; lóbulos de la corola sin venas entre las nervaduras marjinales; brazos del estilo sub-troncados ó con un apéndice cónico diminuto. Receptáculo cónico y pajoso. Aquenios lampiños ó pubescentes, lijeramente angulosos; penacho formado de $20,10,5$ escamas cerdosas, uninervias, pinatífido-estriadas y aserraditas : calea, F. 59, T. II, S.-T. X.

793. Planta herbácea, lampiña y verde mar, de tallo derecho muy ramoso superiormente, tieso y que se eleva á $2^{\prime}-3^{\prime} y$ hasta $4^{\prime}$ : todas sus partes exhalan un olor fuerte muy desagradable, debido á la presencia de una esencia contenida en las muchísimas glandulitas transparentes que se ven en sus hojas y lemas órganos. Hojas simples, ordinariamente alternas, glaucas, largamente pecioladas, oblongo-lanceoladas ú oblongas, puntiagudas ú obtusitas, festoneadas ó enteras, largas de $11_{[} 2^{\prime \prime}$, sin el peciolo que lo es otro tanto, $y$ anchas de 1". Cabezuelas cilíndrico-cónicas, largas de 10 á $12^{\prime \prime \prime}$ y anchas de 4 " largamente pedunculadas, purpúreas y formando como una cima terminal abierta ó floja; invólucro uniseriado con 5̋ escamas oblongo-lineares, valvadas, al principio concavas y por fin distintas, membranosas por los bordes y de ápice calloso; brazos del estigma con apéndices pelierizaditos. Aquenio elongado, aguzado superiormente, linear, comprimido y pelierizadito; penacho peludo y formado de pelo suave : por॰phillum, F. 59, T. II, S.-T. IX.

794. Disco las mas veces hermafrodito ; receptáculo peludo; aquenio desnudo ; hojas alternas, 797. - Disco siempre hermafrodito; receptáculo paleáceo; aquenios coronados; hojas de ordinario opuestas, 795.

795. Cabezuelas radiadas ó discoídeas, 796. - Siempre mas ó menos radiadas y nunca discoídeas, 800 .

796. Radiadas ó discoídeas, eon las flores de los radios estériles; invölucro 2-seriado; receptáculo llanito; aquenio de pajitas decíluas 
cuando se desprende, 798. - Discoídeas ó cortamente radiadas, con las flores de los radios femeninas; invólucro 1, 2-seriado; receptáculo cilíndrico ó cónico; aquenios del disco comprimidos, frecuentemente con la márjen pestañuda, mientras los de los radios son comprimido-angulosos, todos desnudos ó coronados por 2, 3, 1 aristas ó cerdas, 799.

797. Plantas herbáceas ó matas bisanuales, sub-leñosas ó pereniales, de tallo derecho, ramosísimo, pubescente-blanquecino, alto de $3^{\prime}$ á $4^{\prime}$; hojas alternas cuyas radicales bi ó tripinatisectas, con los lóbulos algo obtusos, mientras las caulinares y ramales son pinatífidas; con las divisiones mas ó menos largas y lanceoladas, pecioladas todas, las florales al contrario sentadas, son mucho mas pequeñas; todas tienen la cara inferior pubescente, blanquecina, y la superior lampiña y verde. Calátides globosas ó sub-globosas, heterógamas, pendientes y pedunculadas, en espigas simples y axilares, cuya reunion forma panojas bastante grandes, flojas y piramidales; invólucro imbricado de hojuelas obtusas, pubescentes, con la márjen membranosa; flores de la circunferencia ó de los radios femeninas, mientras las del disco son hermafroditas y todas fértiles, aquenio obaovado : absinthium, F. 59, T. II, S.-T. antemídeas.

798. Plantas herbáceas, lampiñas ó alampiñadas, con tallo derecho y tetrágono ó cilíndrico y trepador; hojas opuestas, simples, aserradas ó mas ó menos profundamente partidas, pinatisectas, 1, 3yugas, rarísimas veces enteras, de segmentos aovado-lanceolados ó aovados, oblongo-lanceolados ó cuneiforme-oblongos y larceolados, aguzados. Cabezuelas dispuestas en corimbos ó largamente pedunculadas; flores de la circunferencia ó radios estériles, blancas ó amarillas; invólucro 2-seriado, con las escamas de la série esterior apretadas, lanceoladas y pestañudas ó pubescentitas, ó abiertas, lineares y desparramadas. Brazos agudos; receptáculo algo llano y pajoso; aquenios comprimidos ó tetrágonos, lampiños ó pelierizaditos superiormente, 2, 4-aristados, de aristas diverjentes esteriormente, erguidas y mas largas por el centro: bidens, F. 59, T. II, S.-T. XI.

799. Yerbas anuales ó vivaces, de tallos desparramados, membreados ó enderezados desde la base arraigante, alampiñadas ó escabroso-pubescentitas, con hojas opuestas, simples, pecioladas ó subsesiles, aovado-lanceoladas, lanceoladas ó aovadas, festoneadorepandas, triplinervias, contraidas ó aguzadas por la base, otras veces lanceoladas ó lineares, bien enteras, aguzadas hácia la base. Cabezuelas largamente pedunculadas, solitarias ó casi así, ovoídeas y por tin cónicas, radiadas ó cónico-discoídeas y raras veces radiadas sub-globo:as, y por último oblícuamente cónicas y discoídeas; invólucro de 5,6 escamas ó con 5 solamente, otras veces cuyas escamas 6,7 son dispuestas en dos séries ; receptáculo cilíndrico ó conico-cilíndrico: spilanthes, F. 59, T. II, S.-T. XI, G. I.

800. Muy cortamente radiadas; flores de los radios femeninas é inclusas; corola de los florones del disco 4-dentadas, 801. - Radios mas ó menos cortos y femeninos. pero nunca inclusos; corola de los flósculos del disco 5́-dentada, 802. 
801. Yerba anual, escabrosa, desparramada ó derecha y alta de $1^{\prime}$ á $2^{\prime}$, muy ramosa, alampiñada, con hojas simples, opuestas, lanceoladas ó elíptico-lanceoladas, aserradas is sub-enteras, triplinervias $y$ con las venas arqueadas, subsesiles y largas de 3 á 4". Cabezuelas axilares ó terminales y como apanojadas, pedunculadas, solitario-ternadas y blancas; invólucro 2-seriado. Brazos del estilo obtusitos y peludos; aquenios del disco comprimidos, desnudos ó apenas coronados y los de la circunferencia sub-tetrágonos, tuberculados, coronados por dientes diminutos ó pelo, otras veces desnudos ó sub-troncados. Receptáculo pajoso y cuyas pajitas son lineares: eclipta, F. 59, T. II, S.-T. XI.

802. Brazos del estilo sub-cilíndrico-obtusitos, peludos desde el vértice casi hasta la base; aquenios del disco comprimidos y 4-gonos, cortamente coronados y 4-lentados, 803. - Brazos del estilo cortamente cónicos y pelierizaditos. Aquenios de la circunferencia comprimido-callosos, 3-asurcados de cada lado, mientras los del disco, comprimidos, están provistos de alas estrechas, dentado-pestañudas, ó todos comprimidos, desnudos, 804.

803. Arbustos ó matas marítimas, muy ramosos, plateado-sedosos ó alampiñados, altos de $1^{\prime}$ á $4^{\prime}$, con hojas simples, opuestas, sentadas, bastante espesas y algo carnoso-suculentas, espatuladas ó lanceoladas, mucronaditas, bien enteras, como sub-conadas por la base, en la cual se halla una especie de lígula ó membranita triangular. Cabezuelas solitarias, pedunculadas y terminales bastante grandes y anilloșas, con los radies femeninos y cortos. ligulados y uniseriados, con los semiflósculos de divisiones obaovadas ú oblongas, siendo los flósculos del disco hermafroditas y 5 -fidos; invólucro hemisférico, imbricado, con las escamas de la série esterior de ordinario foliáceas, aovadas ú oblongas y agudas, un poco abiertas, tan largas ó mas cortas que las interiores, obtusísimas y membranosas por la márjen. Receptáculo casi plano con pajitas lanceoladas : borichia, F. 59, T. II, S.-T. XI.

804. Yerba anual desparramada y lampiña, echada, ramosa y con hojas simples, alternas, cuyas inferiores son arrosetadas, cuneiformes, aserradas ó cortadas, las superiores solas pecioladas. Cabezuelas pequeñas, amarillas y pedunculadas, solitarias; invólucro 2, 1-seriado. Flores de los radios de 10 á 12, mientras las del disco son pocas. Aquenios de la circunferencia cilíndricos, y los del disco comprimidos; receptáculo plano y pajizo: chrysanthellum, F. 59, T. II, S.-T. XI.

805. Cabezuelas paucífloras, discoídeas, pequeñas, reunidas en grupos, con invólucro doble, cuyo especial es dístico y comprimido, con escamas alternativamente conduplicadas; corolas desigualmente 5-fidas, 806. - Cabezuelas pluri ó 1-floras, discoídeas; invólucro único imbricado, con las escamas superiores mas largas; corola 5fida, de segmentos iguales; hojas frecuentemente glandulosas, 807.

806. Yerbas vivaces de tallo simple ó ramoso, tieso, derecho, hojoso, con hojas simples, bastantes veces arrosetadas, alternas, espatulado-festoneadas, de cara inferior con pelo largo y sedoso, supe- 
riores, lanceoladas, y las florales acorazonado-deltoídeas ú obaovadooblonqaas ó elípticas, aserrado-festoneadas, velludas inferiormente, las superiores oblongo-lanceoladas y las florales acorazonado-deltoídeas y peludas, en fin lanceolado-oblongas, pubescentes ó alampiñadas. Glomérulos formados de algunas cabezuelas, largos de $4^{\prime \prime \prime}-6^{\prime \prime \prime}-10^{\prime \prime \prime}$ y cónicos, sostenidos por un invólucro general, pedunculados, distantes $\mathrm{y}$ dispuestos en corimbos ó panojas delgadas, ó sentados y en espigas interrumpidas, cuyas flores son morado-purpúreas ó á veces blancas. Aquenios claviformes, costilludos, con el vilano uniseriado y formado de 5 cerdas ó 1, 2-seriado y con algunas cerdas dilatadas por la base. Receptáculo desnudo: elephantopus, F. 59, T. II, S.-T. V.

807. Arbustos pequeños, matas ó plantas herbáceas anuales, mas ó menos ramosos, aterciopelados, pubescentes, velludos ó alampiñados, altos de $2^{\prime}-4^{\prime}$ hasta $8^{\prime}$, con hojas simples, alternas, obaovadoredondeaditas ó lanceoladas, elípticas, aovadas ó aovado-oblongas, aovado-lanceoladas, elíptico-oblongas, ovales ó lanceolado-oblongas, lanceoladas, enteras ó repando-dentaditas, mucronadas, puntiagudas, aguzadas ú obtusas, de base aguda, obtusa ó redondeada, membranáceas ó cartáceas, pecioladas, de cara superior lampiña ó alampiñarla, bastantes veces lustrosa y no raras veces escabrosa, mientras la inferior es pubescente, velluda ó pelierizado-escabrosa. Cabezuelas solitarias y sentadas por el ápice de las ramitas hojosas, o en cimas sca dicótomas y sin hojas, sea escorpioídeas y tambien áfilas $\dot{o}$ en fin escorpioídeas y hojosas. Aquenios cilíndricos o claviformes, con vilano ordinariamente doble, de manera que la série interior es peluda, mientras la esterior es de ordinario formada de escamas diminutas; receptáculo desnudo : vernonia, F.59, T. II, S.-T. V.

808. Vejetales de corola polipétala, 809 .

809. Ovario libre ó súpero, 810. - Ovario ínfero ó adherente, 1036.

810. Estambres hipojínicos, es decir, insertos en derredor del disco y por debajo del ovario, que en tal caso está siempre libre. 811. - Estambres perijínicos ó insertos en el cáliz, cualquiera que sea por otra parte la posicion relativa del ovario, 978 .

811. Estambres siempre libres, 812. - Estambres raramente libres, pero soldados entre sí y formando uno solo ó algunos andróforos, 901 .

812. Esłambres siempre en número definido y fijo, mas ó menos constante, 813. - Estambres siempre en número indefinido, 868.

813. Cinco estambres ó menos, 814. - Seis estambres ó mas, 821.

814. Cuatro estambres, 815 . - Cinco estambres, 816.

815. Vejetales sarmentosos de tallos y ramos delgados y larguísimos, á veces algo nudosos, bastante blandos y casi herbáceos ó subleñosos, conteniendo en ciertas especies una savia abundante y potable; no rara vez echan raices adventivas muy largas. Hojas alternas, sencillas ó compuestas, y entónces de tres en rama, enteras, mas ó menos crandes, enteras ó mas ó menos dentadas; las simples son - de ordinario anchas, redondeadas y hastante dobles, enteras y acorazonadas por la base; zarcillos simples, nunca enrollados en espiral 
y opuestos á las hojas. Flores muchas, pequeñas, blancas ó verdosoamarillentas, á veces coloradas, en racimos ó en cimas axilares ó terminales, con los brazos bastante largos y ramificados, pediceladas y de cáliz monosépalo pequeño y 4-dentado; corola de 4 pétalos estendidos y caducos, distintos; estambres enderezados y opuestos á los pétalos, saliendo de un disco 4 ó 5̆-lobo. Ovario único, bilocular, con 2 huevecillos en cada celda, de cuyo ápice sale un estilo simple, cortísimo y á veces nulo; estigma algo bilobulado. Baya prieta ó morada, pisiforme, con 1 ó 2 semillas por causa del aborto de algunos óvulos: cissus, F. 122.

816. Siempre 5 estambres, 817. - Estambres 4, 5, 3 ó 2, 821.

817. Vejetales sarmentosos, provistos de zarcillos ramosos, rollados en espiral y opuestos á las hojas, 818. - Vejètales nunca jamás sarmentosos, mas ó menos herbáceos, ó matas y frutices; fruto capsular, 819.

818. Tallos leñosos, mas ó menos delgados, larguísimos y ramosísimos, con hojas simples, alternas, largamente pecioladas, mas ó menos lobuladas y undulosas á la par, con 2 estípulas caducas acompañando á la insercion del peciolo. Flores pequeñas, muchas, verdoso-amarillentas, en racimos ó umbelas opuestos á las hojas y que ocupan el lugar de los żarcillos, que á veces las llevan, de cáliz muy pequeño, corto, sub-entero ó apenas 5 -lobo; corola de 5 pétalos adlierentes ror el ápice, despegándose pues por la base y carendo de una sola pieza á manera de gorro empujado por los estambres opuestos á ellos é insertos en la parte esterior del ảisco 5-lobo. Ovario único bilocular con 2 óvulos en cada celda, esférico, y de cuyo ápice sale un estigma grueso, sentado y un poco cuadrílobo. Baya bilocular, suculenta, con 2 ó 4 semillas, de forma, color y tamaño muy variados : vitis, F. 122.

819. Estilo único, terminado en un estigma mas ó menos cabezudo, 819 bis. - Estilos 3, apincelado-multifidos por el vértice. Plantas herbáceas, matas ó frutices, mas ó menos ramosos, de $6^{\prime \prime}$ hasta 18-24" de alto y á veces algo mas $3^{\prime}$, velludos, pelierizados ó pubescentes, de hojas alternas, simples, pecioladas, mas ó menos festoneadas, aserradas ó inciso-aserradas, oblongas, aovadas, lanceoladas ú oblongo-lanceoladas, aguzadas ú obtusas, con dos glándulas amarillas situadas por la base.ó sin ellas, estipuladas. Flores solitarias, axilares, bastante grandes y amarillas, con los pedícelos frecuentemente acrescentes hácia el peciolo, de donde sale bastantes veces, $y$ bracteado, otras veces están sentadas en el vértice del peciolo, pero siempre acompañadas de brácteas ; cáliz 5-fido ó 5-partido; corola con 5 pétalos de ordinario mas grandes que el cáliz, en cuya garganta se insertan; estambres 5, de anteras alargadas y er-. guidas. Ovario sentado, con 3 placeritas parietales plurioruladas. Cápsula 3-valve por el vértice y medianícida, con semillas hoyosas: turnera, F. 145.

819 bis. Corola simétrica; 5 escamas petaliformes opuestas á los pétalos y separadas de ellos por un verticilo de filamentos estériles dilatados por el ápice; anteras sin conectivos, abriéndose por una rajadura lateral, 820 . - Corola no simétrica, formada de 5 pétalos, 
cuyo anterior, mayor y labeliforme, está provisto de una uña cóncava ó cortamente gibosa; anteras conniventes cujas 2 anteriores tienen una glándula situada por la base, mientras el vértice está con frecuencia adornado con un apéndice, que es una prolongacion del conectivo. Plantas herbáceas ó matas leñosas, ramosas, de tallos derechos ó tendidos, masó menos ramosos y desparramados, de raiz ordinariamente perpendicular, mas ó menos ramosa, lampiños, pubescentes ó tomentosos. Hojas simples, alternas, pero cuyas inferiores son no rara vez opuestas, bastante estrechas, sentadas ó muy cortamente pecioladas, dentaditas ó aserradas, lampiñas, pubescentes ó tomentosas, acompañadas de 2 estípulas membranosas, lineares, mas ó menos ovales y aguzadas. Flores á veces bastante grandes y blancas ó pequeñas y moraduscas, solitarias, axilares, cuyo pedícelo bastante largo está articulado por encima de su parte media, de cáliz con 5 sépalos; corola de 5 pétalos asimétricos. Orario globoso, algo trígono, unilocular, con muchos huevecillos insertos en 3 placentas parietales, de cuyo ápice sale un estilo simple terminado por un estigma cabezudo algo lateral. Cápsula frecuentemente acompañada de las envolturas florales marcescentes, unilocular, polisperma, de dehiscencia medianícida, cuyas 3 valvas llevan consigo las placentas pegadas lonjitudinalmente por su medio, semillas mas ó menos globosas, tiradas con elasticidad al abrirse las cajitas: jonidium, F. 86.

820. Arbustillos, matas sub-leñosas ó plantas herbáceas, de tallos derechos, mas ó menos ramosos y lampiños; de hojas simples, alternas, mas ó menos aserradas, mas ó menos pecioladas ó subsesiles, oblongo-lanceoladas, elíptico-lanceoladas ó lanceoladas, aguzadas ó puntiagudas, acompañadas de estípulas fimbriadas ó franjeadas. Flores blanco-rosaditas, muy bonitas, en racimos terminales, axilares, solitarias ó fasciculadas, curo pedícelo bastante largo y filiforme es articularlo por encima de la base, de cáliz persistente con 5 sépalos, curo ápice se termina por una ó algunas cerdas. Estambres alternos con las escamas y de anteras oblongas. Ovario trilocular con algunos óvulos anátropos, de cuyo vértice sale un estilo simple terminado por un estigma pequeño algo cabezudo. Cápsula trilocular, polisperma, marjenícida, con 3 placentas, trivalve, cuyas semillas tienen el embrion axil y cilíndrico : sauragesia, F. 85.

821. Fruto capsular; corola siempre polipétala lejítima; 822. Fruto drupáceo; corola seudo-monopétala ó las mas veces polipétala. Arboles bastante grandes, altos de $30^{\prime}$ á $40^{\prime}$ ó mas bajitos, muy ramosos, de hojas simples, alternas, pecioladas, coriáceas, bien enteras, festoneadas ó aserradas y lampiñas. Flores de ordinario fasciculadas ó en curimbos, frecuentemente polígamo-dioicas ó hermafroditas, pedunculadas y blancas, pequeñas, y de cáliz pequeño, aorzado, 4-dentado, mas rara vez 5, 6-dentado y persistente; corola hipojínica enrodada 4, 5, 6-partida, ó con los pétalos sub-distintos, ó lijeramente reunidos por los filamentos, de estivacion imbricada; estambres en número igual á los pétalos ó segmentos de la corola seudo-gamopétala, alternos con ellos é insertos en su parte mas inferior, cuyos filamentos filifoimes llevan anteras introrsas, bilocu- 
lares y lonjitudinalmente deliscentes. Ovario sentado 4-locular, con los óvulos solitarios en las celdas ó á veces mellizos, colaterales, pendientes del ápice del ángulo interno, anátropos. Drupa abayada, sub-globosa, coronada por el estigma subsesil, con tantos lóbulos cuantas celdas hay, con 4 pirenas ó huesecitos, monospermos y venosos, con la semilla inversa, tríquetra, de testa delgadísima y membranácea ;"embrion situado por el ápice de un endospermo carnoso, pequeño, lonjitudinalmente partido por un surco ; raicilla súpera: Ilex, F. 83.

822. Plantas herbáceas anuales, de tallo delgado enderezado ó tendido por el suelo, muy ramoso, altas de 8 a $16^{\prime \prime}$, con hojas simples, opuestas, cortamente pecioladas ó sentadas, linear-lanceoladas ú orbiculares, sub-acorazonadas por la base, pequeñas y lampiñas. Flores pequeñas, blancas y en panojas terminales flojas, de cáliz con 5 sépalos, abiertos, mas cortos que los pétalos, aovado-lanceolados; aguzados, lampiños ó pubescentitos y largos de $11_{[} 2^{\prime \prime \prime}$; corola de 5 pétalos con el ápice bífido, inclusos; estambres 3 ó 2 á veces 5 opuestos á los sépalos. Ovario oval unilocular con algunos huevecillos; de cuyo ápice salen 3 estilos. Cápsula oval igualando al cáliz, conteniendo 8 ó 2 semillas pequeñas y abriéndose por 3 val ras : drymaria, F. 148. 834 .

823. En número fijo y constante, 824. - En número variable,

824. Seis estambres, 825. - Mas de 6 estambres, 839.

825. Siempre tetradinámicos; corola de 4 pétalos unguiculados y dispuestos á manera de cruz; una silicna ó silícula, 826. - Nunca tetradinámicos; corola con 4 pétalos nunca dispuestos en cruz; cápsula silicuiforme sostenida por un podójino largo. Plantas herbáceas ó matas, de tallo de ordinario derecho, mas ó menos ramoso, algunas veces aguijonoso, desparramado 'y mas ó menos tendido, lampiñas ó pubescentes y bastantes veces glandulosas; hojas de ordinario palmatisectas y largamente pecioladas, acompañadas de estípulas con bastante frecuencia aguijonosas, así como los peciolos. Flores de ordinario blancas ó rosadas, bastante grandes en racimos terminales saliendo ordinariamente de la axila de una hoja floral, de cáliz con 4 sépalos; corola de 4 pétalos, cuya estivacion es abierta ó imbricativa; estambres insertos sobre el ginóforo filiforme, ó en un disco cónico y por debajo del ginóforo filiforme ó del ovario, con anteras largas y alabardadas. Ovario único, cilíndrico, elongado, mas ó menos fusiforme y sostenido por un podójino mas ó menos largo y filiforme, unilocular, poliovulado, cy̨yo vértice lleva un estigma sentado y cabezudo. Cápsula bivalve, cuyas vęntallas están separadas de la placenta intervalvular y parietal : cleome, F. 88, T. I.

826. Una silicua, 82\%. - Una silícula, 833.

827. Con 4 glándulas situadas en el disco que sostiene el ovario, de las cuales dos están entre los estambres menores y el pistilo, mientras las dos otras se hallan entre las mas largas y el cáliz, 828: - Con dos glándulas en el disco ó sin ninguna, 831.

828. Silicua dehiscente, ni toruloะa, ni articulada tampoco, 829 . 
- Silicua indehiscente, torulosa, algo avejigada, cónica y casi como articulada; plantas herbáceas anuales ó bisanuales, de raiz napiforme, perpendicular mas ó menos gruesa, cuyo color, tamaño y forma varian mucho, siempre carnuda, de la cual sale un tallo derecho poco ramoso, cilíndrico, con algunos pelos tiesos, alto de $2^{\prime}$ á $3^{\prime}$, con hojas alternas, pecioladas, simples, mas ó menos enteras, ondulosas y pelierizaditas. Flores blancas ó rosadas en espigas terminales, de cáliz con 4 sépalos conniventes y casi cerrado, enderezados, algo cerdosos, cuva base es un poco con figura de saco. Las dos glándulas correspondientes á los estambres mayores son casi ovales, algo deprimidas ó de ápice achatado, mientras las que corresponden á los menores son irregularmente cuadradas y con dos depresiones en el vértice. Estigma casi oval, onduloso por la circunferencia, con un surco mediano y cabezudo. Silicua que parece como bilocular por causa de un estrechamiento y cuyas semillas estín envueltas en una sustancia blanca y como esponjosa: raphanus, $F$. 89 , T. II.

829. Silicua cuyo ápice se termina en pico corto, cónico, rollizo ó comprimido, estéril ó monospermo, con las valvas siempre convexas, 3, 5-nervias, 830. - Silicua sin pico, con las.valvas mas frecuentemente convexas y sin nervios. Plantas herbáceas anuales ó bisanuales, cuyos repollos son frecuentemente muy desarrollados y comestibles, de tallo lampiño y verde mar, alto de 3 ó $5^{\prime}$, de ordinario muy poco ramoso; hojas grandes, simples, alternas, pecioladas, enteras, ondulosas por la márjen, lampiñąs y glaucas. Flores blancas ó amarillas en espigas largas y flojas o apanojadas, terminales, y de cáliz con 4 sépalos enderezados, conniventes y cerrados por el vértice, iguales y gibosos por la base, caducos, tan largos como las uñas de los pétalos. Las glándulas que corresponden á los estambres mayores son pequeñas, erguidas, mientras las correspondientes á los menores,son anchas, achatadas, casi con figura de herradura, algo petágonas y con dos depresiones en su ángulo esterno ó inferior. Estigma hemisférico glanduloso, con una depresion transversal por el centro. Silicua cilíndrica, alargada, algo comprimida ó tetrágona, algo torulosa, con el tabique elevado y las semillas esféricas: Zıassica, F. 89, T. II.

830. Planta herbácea anual, lampiña, de tallo derecho poco ramoso y alto de $\mathcal{Z}^{\prime}$ á $3^{\prime}$, con hojas rajadas por la base ó no partidas, dentadas, ondulosas por la márjen, cuyas inferiores bastante grandes y cortamente pecioladas son obaovadas, mientras las superiores casi sentadas son lanceoladas, simples y alternas todas. Flores amarillas en espiga terminal á veces apanojadas, cuyos pétalos igualan al cáliz abierto. Las glándulas correspondiendo á los estambres mayores son algo salientes, ovales, de ápice redondeado y casi llanas inferiormente, mientras las que corresponden á los menores son mucho mas anchas, menos pronunciadas y de ápice con una depresion irregular. Estigma cabezudo, casi hexágono y glanduloso. Silicua cilíndrica, torulosa, uninervia y con venas proeminentes, cortamente picuda, algo derecha sobre el pedícelo estendido, pico filiforme y sin semillas : sinapis, F. 89, T. II. 
831. Planta herbácea perennal, acuática, ó de los lugares húmedos, lampiña, de tallos largos, ramosos, tendidos y de ápice erguido, con hojas alternas simples pinatisectas, con los segmentos aovados y ondulosos, desiguales y cuyo terminal es de ordinario mayor. Flores blancas en espigas terminales, de cáliz cerrado; corola abierta cuyos pétalos tienen las uñas cortas dos veces mas largos que el cáliz; 4 glándulas hipojínicas. Silicua estendida igualando el pedícelo que la lleva, oblongo-linear, con las valvas convexas y casi sin renas; semillas dispuestas en dos séries con los cotiledones acumbentes : nasturtium, F. 89, T. II.

832. Silícula comprimida lateralmente, con las valvas aquilladas y de ordinario aladas; semillas una en cada celda; seis glándulas hipojínicas, 833. - Silícula lomentácea, separándose transversalmente en 2 artejos indehiscentes, monospermos; 4 glándulas hipojínicas. Planta herbácea anual que se halla en las orillas del mar, de tallo como de 10 á $12^{\prime \prime}$ de alto, algo mas ó menos, lampiña; hojas simples, alternas, lanceoladas, sub-enteras, algo pecioladas. Flores blanquecinas algo teñidas de rojizo, en espigas terminales, de cáliz con los sépalos erguidos, cuyos laterales son gibosos por la base, y casi cerrados por el ápice. Estilo simple o nulo terminándose por un eśtigma obtuso á reces sentado. Silícula lanceolada algo tetrágona, provista de dos dientes por su parte media, formada de dos artejos, cuyo superior ó pico lanceolado-ensiforme terminado por el estilo, contiene una semilla erguida, tres veces tan largo como el inferior cuneiforme con una semilla colgante: ambos son de igual anchura: cakile, F. 81, T. I.

833. Plantas herbáceas anuales, lampiñas, de tallo recto mas o menos ramoso superiormente, alto de 1, 2 y hasta $3^{\prime}$; lıojas inferiores pecioladas, simples, alternas, lanceoladas, mas ó menos aserradas. Flores blancas, pequeñas, cuyos pétalos faltan algunas veces, en espigas largas y delgadas, cuya reunion forma panojas ó cimas terminales, de cáliz pequeño entreabierto; corola de pétalos iguales espatulados y con uñas largas; estambres casi icuales; las 6 glandulitas están sentadas en el disco : lepidium, F. 89, T. III.

834. Estambres en número variado, 834 bis. - Siempre 5 estanbres; vejetales polígamos, 229 .

834 bis. De 4 hasta 8 estambres, 835. - De 5 hasta 10 estambres y mas, 836 .

835. Arbustos ó árbolẻs bajitos, mas ó menos ramosos, aguijonosos, curos aguijones son estipulares; hojas alternas, compuestas, imparipinadas, con hojuelas sentadas, cuya terminal ó impar está raras veces abortiva; raquis alado. Flores pequeñas en grupos axilares ó cimas, de cáliz 4 ó 5 -lobo, persistente y monosépalo; corola con 4 ó 5 pétalos insertos en el fundo del cáliz; tantos estambres mas largos que los pétalos y cuyas anteras amarillentas son esertas. Ovario formado de 2 á 3 carpidios distiritos; estilo único terminado por dos estigmas puntiagudos. Folículos 2, 3, 1 abriéndose por fin en 2 valvas, monospermos: fagara, F. 114, G. I.

836. Fruto formado de jo ó á veces 4 carpidios mas ó menos sepa- 
rados y secos, 837.-Fruto mas ó menos drupáceo ó cuyos carpidios son casi drupas al principio, 840 .

837. De 8 á 10 estambres, de los cuales algunos abortan; 5 ovarios cuya base está reunida al favor del disco; 5 estilos ginobásicos distintos ó reunidos por la base, 838. - De 5 hasta 8-10 estambres sin abortar ninguno, 839.

838. Arbol alto de como $20^{\prime}$ á $30^{\prime}$, recto, cuyo tronco no pasa de 4 á $6^{\prime \prime}$ de diámetro, con la corteza color ceniciento, ramoso superiormente, cuyos ramos derechos están algo desparramados, terminándose por ramitas cilíndricas pubescentes y como empolroradas á la par, con dos estrías lineares, verticales, bastante pronunciadas y opuestas, saliendo de la base de la insercion de los peciolos. Hojas alternas compuestas, de tres en rama, con el raquis largo como de 6 á $7^{\prime \prime}$ comprimido por la insercion $y$ de base algo triangular, rugoso y del color de las ramitas, casí cilíndrico, con la cara superior achatadita y acanalada, como empolvorada, mientras la inferior ó esterna es convexa y escamosa; vértice dilatándose sensiblemente para volverse el ápice un triángulo aplanado anteriormente, cuyos lados laterales dan insercion á una hojuela grande y sentada, y en el ápice troncado se halla la tercera. Tales hojuelas, que forman la hoja trifoliolada de ese vejetal, son un poco desiguales, de tal suerte que la del medio es algo mayor que las laterales óvalo-lanceoladas con el ápice terminado en punta y la base aguzada, enteras, un poco ondulosas por la márjen y algo inequilaterales por la base, de manera que el lado ó mitad interna es mas estrecha de como $1_{[} 2^{\prime \prime}$ que la esterna, son largas de 8 á $10^{\prime \prime}$ y anchas de $31_{[} 2^{\prime \prime}-4^{\prime \prime}-41_{[} 2^{\prime \prime}$, con la márjen algo revuelta; la hojuela mayor ó impar casi oboval puntiaguda por el ápice y aguzada por la base, es tambien inequilateral, larga de 10 á $12^{\prime \prime}$ y anchas de 4 á $41{ }_{1} 2^{\prime \prime}$; son coriáceas con la cara superior de un hermoso color verde manzana, lustrosa y casi alampiñada, porque con el lente se la ve muy finamente pubescente, $\mathrm{y}$ con muchas papulitas que corresponden á glándulas transparentes; la costilla y nervaduras son visibles por causa de su color mas pálido y amarillento á la par, mientras la inferior de color verde amarillento algo aceitunado con la costilla, nervaduras y venas bastante pronunciadas, pubescente, como empolvorada y papulosa; tienen muchos puntitos transparentes visibles solo con el lente; se hallan en la base de la hojuela mayor algunos pelos negros; raquis casi derecho y formando con la ramita un ángulo agudo, mientras las hojuelas son casi horizontales, ó algo inclinadas hácia abajo, tiernas son blanquecinas, enteramente pubescentes, escamositas, las ramitas que las llevan entónces herbáceas son oval-estriaditas y tambien pubescentes y escamosas á la par. Las hojas de las ramitas floríferas son de ordinario mas pequeñas que las demas. Flores blancas en racimos especiformes' y terminales, cuyo pedúnculo pubescente leproso y derecho es largo de 10,12 ", cilíndrico inferiormente y oval-anguloso superiormente, terminándose por un racimo largo de 6 á $8^{\prime \prime}$, con brazos laterales esparcidos é irregularmente dispuestos, de manera que los unos son opuestos y los otros alternos pero sin simetría ninguna, largos solamente de 6 á $8^{\prime \prime \prime}$ con una brac- 
teita foliácea rerde, lanceolada, saliendo de la cara inferior en donde se ruelven dicótomos, del inedio de la horquilla sale una flor sentada $y$ solitaria, y cada brazo secundario, tan largo como el principal, se termina por tres flores, cura mediana es sub-sentada, mientras las dos laterales son pediceladas, con una bracteita en la insercion del pedícelo y otra como á $l^{\prime \prime \prime}$ del cáliz; los grupos florales ocupando el vértice del racimo, son simplemente pedunculados, trífloros y con las dos bracteitas caducas ya señaladas; los pedúnculos, pedícelos y cálices son pubescentes, empolrorados y de color çris algo pardusco. Cáliz monosépalo algo campanudo, con 5 divisiones profundas, ovales, tomentosas y cuyo pelo está dispuesto por grupitos, leproso y mucho mas corto que la corola formada de 5 pétalos iguales, blanco-amarillentos, bastantes veces soldados por la base, de manera que la corola parece monopétala, asaz espesos y quebradizos, como aterciopelados esteriormente, con glandulitas transparentes, verdoso-amarillentas, de ápice como mucronadito, al principio derechos, se doblan mas luego hácia fuera, largos de $18^{\prime \prime \prime}$, mientras el cáliz persistente lo es solamente de 4 á $5^{\prime \prime \prime}$. Estambres 7, 6, 5, derechos y esertos, pero dos solos son de ordinario fértiles y anteríferos, con el filamento ancho petaliforme ó estrecho, lameliforme y triangular, alargado y cuyo ápice puntiagudo está pegado en la base de la antera, larga como la mitad de él y de cara franjeada; los estériles ó estaminodios son generalmente mas largos, tambien petaloídeos y parecen á primera vista otras tantas divisiones de la corola, pero su ápice algo mas estrecho se termina por un cuerpecillo glanduloso, redondo y amarillo, que no es otra cosa sino la antera abortarla, cuyos $2[3$ inferiores son finamente lanudos, mientras el 1 [3 superior es lampiño; prefioracion de la corola semi-imbricada. Todo el fundo de la flor está ocupado por un disco hipojínico muy desarrollado, pero que no adhiere al fundo del cáliz y envuelve enteramente el ovario que aparece en el centro como 5 funtitos rojizos, es con figura de corona y con 12 estrías que lo hacen parecer como lobadito, amarillo y largo de como $12^{2 \prime \prime}$, de 5 carpelos muy pequeños, de ápice rojizo hoyoso y rugosito, mientras la base es lisa y amarillo-pálida ; del centro y base sale un estilo único filiforme, cilíndrico, blanco, tan largo como la corola y terminado por un estigma grueso, amarillento, cabezudo, oval, cóncavo y 5 -iobo. Fruto formado de j̇ carpidios ó cajitas dispuestos á manera de estrella, adheridos solamente por una parte de la base, oval-comprimidos y á la vez irregularmente cuadrang̨ulares, pubescentes, cuyo pelo está en grupitos : blanco sucio ó blanquecino, con muchas glandulitas transparentes; se aluren superiormente por el ángulo obtuso ó interno hasta el ápice; entónces sus paredes se despegan en dos partes, una interna blanca y como apergaminada, mientras la esterior verde $y$ mas espesa se abre la primera; contienen dos semillas casi esféricas, negras, lustrosas y pegadas junto en la parte media del ángulo interno, del tamaño de un grano de mijo : bonplandia ó galipea, F. 111, T. I.

839. Matas ramosísimas de como vara y media de alto, con hojas alternas compuestas y hasta descompuestas, pecioladas, pero cuyas 
superiores están casi sentadas, lustrosas, lampiñas y de olor fuerte y fétido, con muchas glandulitas transparentes. Flores amarillas y bastante grandes en cimas ó panojas terminales, de cáliz monosépalo, plano, abierto y decíduo, con 4 ó 5 divisiones lanceoladas; corola de 4 á 5 pétalos cóncavos, acucharados, undulosos por la márjen, denticulados o pestañosos, abiertos y algo estendidos, unguiculados y mucho mayores que el cáliz; estambres derechos, diverjentes, esertos é insertos por la base y en derredor de un disco hipojínico amarillo y de ordinario mas ancho que el ovario, con tantas glándulas redondas cuantos estambres hay. Pistiló formado de 4 á 5 carpidios, rugositos y reunidos entre sí á favor del disco en que está pegada su base; el ovario es pues compuesto y ginobásico; de entre ellos salen 4 á 5 estilos distintos inferịormente, cada uno correspondiendo al ángulo interno de un carpelo. pero reunidos entre sí superiormente y volviéndose un estilo único cuyo ápice se termina en un estigma con 4 ó 5 surcos; dos óvulos colaterales hay en cada carpidio. Fruto formado de 4 ó 5 carpelos ó cajitas, separadas inferiormente y reunidos por el vértice $y$ formando así una especie de cápsula : rutu, F. 112.

840. Estambres ocho, 841.-Estambres diez ó mas, 856.

841. Hojas simples siempre y sin zarcillos, fruto drupáceo, 842. - Hojas compuestas, con ó sin zarcillos, fruto capsular, abayado ó drupáceo, 814.

842. Plantas herbáceas, de hojas abroqueladas, y cuyo fruto como algo drupáceo es formado de 3 carpelos monospermos, 843. - Arbustos ó árboles bajitos, espinosos ordinariamente, ramosos, con hojas simples, alternas, elípticas ú oval-oblongas, enteras, obtusas, como de $1^{\prime \prime}$ de ancho sobre ?" de largo, lustrosas, verdes por ambas caras, lampiñas del todo y ápenas pecioladas, coriáceas y ordinariamente acompanadas de una espina, corta y derecha, situada por la base. Flores en racimos, corimbos ó grupos axilares, reunidas 6 á 8 en el vértice de un pedúnculo comun espinoso, pediceladas, pequeñas, blancas y embalsamando el aire de un olor como de gerofle; de cáliz monosépalo, corto, lampiño, con 4 divisiones poco profundas y puntiagudas; corola con 4 y á veces 5 pétalos distintos, oblongos, verduscos por afuera, mientras su cara interna está cubierta de un vello blanco, sedoso, de uñas muy cortas que se insertan entre las divisiones del cáliz, de ápice obtuso y algo doblado hácia fuera. Estambres de filamentos cortos, con anteras dorsi y basifijas á la par, biloculares. Ovario oblongo, redondeadito, 4-locular, á veces 3,5 locular, con un huevecillo colgante de una placenta central en cada celda, del ápice sale un estilo corto que se termina por un estigma puntiagudo. Drupa amarilla, carnosa, oval ú oblonga, á veces globosa, del tamaño de una ciruela y conteniendo un hueso monospermo: ximenia, F. 116.

843. Tallos largos como volubles ó trepadores, lampiños, con hojas alternas, largamente pecioladas, discoídeas, bastante dobles, lampiñas y lustrosas. Primorosas flores axilares y de ordinario solitarias, cuyos pedúnculos largos se enrollan á manera de hélice y así sirven á sostener las ramas; de cáliz monosépalo, con 5 divisiones 
desiguales, cuya superior se alarga en espolon; corola con 5 pétalos largamente unguiculados, pegados en el fundo del cáliz, desiguales, mas ó menos franjeados ó barbudos, cuyas dos superiores son mayores. Ovario trílobo, trilocular, de cuyo vértice y de entre los lóbulos sale un estilo único terminándose por tres estigmas. Fruto formado de una especie de drupa con tres lóbulos ó carpidios convexos, apenas carnudos, algo arriñonado-triangulares, asurcados, monospermos y desprendiéndose los unos de los otros: tropcolum. F. 109.

844. Plantas abejucadas, provistas de zarcillos; corola cuyos pétalos son provistos de apéndices; disco formado de glándulas distintas sentadas entre los pétalos; fruto seco capsular, formado de carpidios á veces samaroídeos, 845. - Arboles ó arbustos sin zarcillos; corola cuyos pétalos nunca están apendiculados ó sin escamas, pero algunas veces glandulosos ó barbudos por la base é interiormente ; disco anular ó formado de glándulas soldadas entre sí y dispuestas á manera de anillo. Fruto drupáceo ó abayado, otras veces capsular, 850 .

845. Fruto formado de 3 sámaras pegadas en el eje y por fin separándose las unas de las otras, 846. - Fruto capsular, 848.

846. Ala ciñendo el carpelo ó celda ; semillas crustáceas con arillo bastante pronunciado; cotiledones espesos y derechitos, 847. - Ala basilar, escurrida á lo largo del carpóforo, celdillas velludas interiormente; semillas crustáceas, cuyo arilo es de ordinario diminuto; cotiledones encorvados. Arbustos sarmentosos ó bejucos sosteniéndose por medio de zarcillos pedunculares ó axilares, cuyas ramitas lampiñas, alampiñadas ó pubescentes llevan hojas alternas biternadas, ordinariamente punteadas, con las hojuelas aovadas ó elípticas aserrarlas ó sub-enteras, á veces con algunos festones hácia el vértice, lampiñas, con la cara superior mas ó menos lustrosa; raquis desnudo y triangular ó provisto de una márjen estrecha, otras veces tiene una ala estrecha, acompañada de estípulas. Flores pequeñas, blanquecinas, en racimos simples ó compuestos y entónces apanojados, pediceladas y saliendo de la axila de una bráctea; de cáliz con 5 sépalos obtusos y pubescentes; corola de 4 pétalos cada uno con una escama; estambres 8, acompañados de 4 ó 2 glándulas situadas esteriormente á ellos. Ovario triangular, trilocular, de cuyo ápice salen tres estilos ó quizás un estilo único tripartido, terminado cada uno por su estigma correspondiente : serjania, F. 121, T. II, G. I.

847. Bejucos muy ramosos cuyas ramitas son pubescentes ó alampiñadas, con hojas ternadas, alternas, estipuladas, pubescentes ó alampiñadas, con las hojuelas aovadas, aserradas ó incisas, cuneiformes desde el medio hasta la base. Flores pequenas blancuzcas en racimos justa-axilares, cuyo pedúnculo está provisto de dos zarcillos fuertes enrollados en espiral y situados por el ápice; pedícelos fasciculados y articulados hácia la parte media ; cáliz con 5 sépalos; corola de 5 pétalos provistos de escamas; estambres 8 situados mas interiormente que las 4 ó 2 glándulas que les acompañan, y cuando son dos, solamente una es inferior y la otra superior y ambas escotadas. Ovario triangular, trilocular $y$ formado de 3 carpelos, de 
cuyo ápice salen 3 estilos ó 1 único muy profundamente 3-partido, cada cual con su correspondiente estigma: urvillea, F. 121, T. II, G. II.

818. Disco redondeadito ó cilíndrico glanduloso; cápsula vesicular é hinchada á la par, por fin loculícida, con semillas globosas, crustáceas, provistas de un arilo y con el embrion enroscado, 849 . - Disco reemplazado por 2 ó 4 glándulas mas esteriores que los estambres; cápsula nunca avejigada, 3-locular ó 1-locular por causa de aborto, septícida, con semillas crustáceas y provistas de un arilo. Arbustos samentosos ó bejucos sosteniéndose á favor de los pedúnculos ó por medio de zarcillos axilares, muy largos y ramosísimos, con hojas alternas, estipuladas, biternadas, imparipinadas, con las divisiones mas inferiores, ternadas ó simplemente imparipinadas, puntearlas ó no ; raquis desnudo, marjinado ó alado. Flores blanquecinas, pequeñas, en racimos axilares ó justa-axilares y á veces apanojados, pediceladas $y$ saliendó de la axila de una bráctea; de cáliz con 5 sépalos aovados, distintos, ó de los cuales. 2 están reunidos; corola de 4 pétalos cuya base lleva inferiormente una escamita. Ovario ạgo escéntrico, trígono, trilocular, de cuyo ápice sale un estilo único inferiormente, $y$ de vértice tripartido, terminándose por unos tantos estigmas. Cápsula de forma variada enteramente desnuda ó algunas veces provista de tres alas situadas hácia el eje y por la base, otras veres por el ápice, ordinariamente pubescente interiormente : paullinia, F. 121, 空. II, G. II.

849. Plantas herbáceas anuales y abejucadas ó perennales subleñosas y trepadoras, pubescentes, velludas, alampiñadas ó lampiñas, de tallos mas ó menos largos, delgados y muy ramosos; hojas biternadamente compuestas, alternas, sin estípulas y de hojuelas biternado-incisas y obtusamente aserradas ó solamente biternadas, aovadas y dos veces aserradas. Flores pequeñas blancas, en corimbos axilares pedunculados, cuyos pedúnculos tienen dos zarcillos situados hácia el ápice, pedícelos articulados hácia la parte media; cáliz con 4 sépalos, cuyos dos interiores son mayores; corola de 4 pétalos asimétricos provistos de escamas, largos de $1-11{ }_{1} 2^{\prime \prime}, 2-3^{\prime \prime \prime}$, $6^{\prime \prime \prime}$; glándulas formando el disco, redondeaditas ó cilíndricas, de las cuales 2 están opuestas á los pétalos superiores mas cortos que el superior. Cápsula sub-globosa, larga de 1", turbinado-redondeadita y larga de $4^{\prime \prime \prime}$ o por fin eliptical-angulosa y larga de $3^{\prime \prime}$ : cardiospermum, F. 121, T. II, G. IV.

850. Fruto capsular, 851.-Fruto abayado ó drupáceo, 853.

85̃. Pétalos sin escamas, estambres ordinariamente 8 , pero algunas veces 10 , cápsula seca 3 o 1-locular, loculícida, con las semillas crustáceas y ariladas, 852. - Pétalos provistos de escamas; siempre 8 estambres; cápsula de pericarpio algo carnudo, dehiscente, 3-locular, con las semillas bastante gruesas, negras, lustrosas, crustáceas y envueltas en un arilo blanco, carnudo, muy desarrollado y comestible. Arbol bastante alto, ramoso, de hojas alternas, pinadas, formadas de 3 á 4 pares de hojuelas obaovadooblongas, bien enteras y largas de $3^{\prime \prime}$. Flores blanquecinas, pubescentes, pediceladas en racimos axilares, y de cáliz con 5 sépalos im- 
bricativos; corola con 5 pétalos, oblongos, con las escamas grrandes y bílobas; estambres esertos, peludos inferiormente é insertos en un disco entero. Estilo 3-fido. Fruto rojo, lustroso, obaovado-oblongo, obtusamente trígono, largo como de unas $4^{\prime \prime}$, obtuso por ambos estremos : blighia, F. 121, T. I, G. III.

852. Arboles o arbustos con hojas alternas, pinadas y compuestas de $2,4,5,6,8$ pares de hojuelas; flores blanquecinas, pequenas, pediceladas y en racimos axilares; de cáliz con 5 sépalos imbricativos; corola de 5 pétalos redondeados ó acogullado-cuneiformes, desnudos; estambres esertos; estilo mas ó menos cortamente trífido. Cápsula lampiña ó tomentosa, trígono-turbinada ó sub-globosa mas ó menos obtusamente 3-aquillada, semillas globosas, sub-comprimidas ú ovoídeo-globosas, mas ó menos envueltas por el arilo amarillento, brunas ó negras y lustrosas : cupania, F. 121, T. I, G. IV.

853. Fruto drupáceo, 854. - Fruto como abayado ó mejor formado de 3 carpidios, con el pericarpio carnudo, conteniendo una semilla globosa, gruesa, prieta, huesosa, no llenando enteramente la celda que contiene un poco de líquido hácia la madurez; entónces el pericarpio mas ó menos amarillento es semi-transparente, conteniendo una sustancia como mucilajinosa, mas luego se vuelve seco, arrugado esteriormente, bruno, lustroso y color como acanelado interiormente. Arboles bastante altos, coposos y asaz corpulentos, lampiños, de hojas alternas paripinadas y con 5-4, 5-3 ó 1 pares de hojuelas oblongo-lanceoladas, mas ó menos aguzadas, lampiñas ó de cara inferior pubescente, cuyo raquis está anchamente alado, ó solamente marjinado y hasta desnudo. Flores blanquecinas, pequeñas, en racimos apanojados, pediceladas, y de cáliz con 5 ó 4 sépalos imbricativos; corola con tantos pétalos cuantos sépalos hay, pestañosos y con una escamita diminuta; estambres de ordinario 8 , pero á veces 4 y hasta 10 : sapindus, F. 121, T. I, G. I.

854. Baya corticosa de un hermoso color ponceau cuando madura, tuberculosa y monosperma, 85̌.--Baya verde amarillenta, larga de 1 á 11 [2", esférica, 2, 1-esperma. Arbol muy ramoso que se eleva á 40 y $50^{\prime}$ de altura, bastante corpulento, con hojas paripinadas, cuyas hojuelas biyugadas son elípticas ó elíptico-lanceoladas, bien enteras y lampiñas, alternas y con raquis algo alado. Flores pequeñas, blancas algo verdositas en racimos ramosos terminales, de cáliz monosépalo, 5-partido, con segmentos imbricativos; corola de 4 pétalos desnudos. Ovario globoso bilocular, con un óvulo enderezado en cada celda; del ápice sale un estigma sub-sentady y abroquelado. Drupa globosa del tamaño de un huevo de paloma, conteniendo una pulpa que parece como miel y es comestible : melicocca, F. 121, T. I, G. II.

855. Arbol alto de como 25 á $30^{\prime}$, con ramos largos y estendidos horizontalmente, de corteza pintadita; hojas alternas paripinadas y formadas de 2 á 3 pares de hojuelas lanceoladas, lampiñas, lisas y algo lustrosas, marcadas de un surco lonjitudinal. cortamente pecioladas y puntiagudas por ambos estremos. Flores pequeñas en panojas axilares ó terminales, aterciopeladas esteriormente, así como los pedícelos que las llevan; de cáliz monosépalo como troncado, con 
5 divisiones muy cortas ó dientes; corola de 5 pétalos refiejos y algo velludos interiormente; estambres 7 ; ovario globoso unilocular y uniovulado, en cuyo ápice hay un estigma bífido: euphoria, F. 121, T. I, G. VII.

856. Diez estambres, 857. - De 10 hasta 30 y raras veces solamente 5 estambres; fruto aqueniforme agarabatado, 867 . 862.

857. Fruto siempre seco, 858. - Fruto drupáceo ó algo carnudo,

858. Fruto formado de 5, 10 y hasta $12-\operatorname{cocos}$, cuyos carpidins indehiscentes son tuberculados ó espinosos 861. - Fruto no formado de carpidios, 859 .

859. Fruto capsular, 860.-Una legumbre ó vaina. Bejucos grandes, muy altos, muy ramosos, de tallo bastante grueso que parece una cadena chata, de ramitas lampiñas ó alampiñadas, con ó sin zarcillos; hojas alternas, pecioladas, simples, acorazonado-redondeaditas algo bílobas por el ápice, anchas de 5, 4, 3" y largas de 6 $1_{[2-4} 1_{\{} 2-3^{\prime \prime}$, palmatinervias y con 9 á 11 nervaduras ó formadas de dos hojuelas distintas, semi-aovadas, aguzadas*ó puntiagudas, subsemi-acorazonadas por la base, paralelas, 3, 4-nervias, anchas de 8-4", con peciolo largo de 6-3-2-1", y acompañado de dos estípulas muy pronto cadueas. Flores blancas en racimos terminales, pedunculadas y cuyos pedúnculos bastante largos salen de la axila de una bráctea; de cáliz monosépalo cuyo tuho es campanudo y el limbo bilabiado y á la par 5-fido; corola de 5 pétalos insertos junto con los estambres hácia la base del tubo calizinal. Ovario sentado, terminándose en un estigma cabezudo y ordinariamente oblícuo. Legumbre bivalve ó abriéndose tardíamente, llano-comprimida : schnella, F. 130, S.-F. 2, T. IV, G. II.

860. Plantas herháceas ó árboles altos, frondosos y corpulentos. con hojas alternas, compuestas y paripinadas, acompañadas de estípulas. Flores solitarias ó en grupos axilares y á veces terminales; de cáliz monosépalo, 5-partido, con las divisiones casi iguales ; corola de 5 pétalos iguales al cáliz y con uñas; estambres algo desiguales y de ordinario tan largos como los pétalos. Ovario 5-locular, con dos óvulos en cada cẹlda, pentágono, colocado por encima de un disco corto, cóncavo ó convexo y envuelto por las escamitas de los filamentos estaminales; del ápice sale un estilo simple terminado por un estigma muy pequeño. Cápsula pentágona ó con 5 alas é indehiscente, 5-locular y ordinariamente de dehiscencia loculícida: zygophyllum, F. 113, T. II, G. II.

861. Plantas herbáceas, de tallos ramosos, desparrados y tendidos por el suelo, con hojas alternas ó á veces opuestas, paripinadas, formadas de 8-3 ó de 3-4 pares de hojuelas, cortamente oblongas, oblícuamente oblongas ú ovales, de cara inferior sedosa ó peluda; con dos estípulas bastante largas, enderezadas y lanceoladas. Flores hastante grandes, solitarias, axilares y pedunculadas; de cáliz con 5 á 6 divisiones profundas ó sépalos abiertas y lanceoladas, decíduo ó persistente ; corola con 5 pétalos mas ó menos grandes y con uñas cortas; estambres insertos en el disco. Ovario pentágono ó con 10 á 12 estrías y con tantas celdas uniovuladas: estigma sentado y $\breve{v}-$ 
fido. Carpidios 5, divididos interiormente por un seto transverso, formando así celdillas monospermas, ó 10 á 12 carpidios monospermos y separándose del eje central : tribulus, F. 113, T. I.

862. Fruto drupáceo, 863. - Pericarpio un poco carnudo, 5, 2locular, de dehiscencia tardía y septícida, comprimido y aquillado, con las celdas monospermas por causa de aborto. Arboles de mediana altura, cuyo tronco recto está cubierto de una corteza pardusca, curas muchas grietas dan salida á una resina verdusca; hojas opuestas, paripinadas, coriáceas, lampiñas, lustrosas, con 2, 5,4 pares de hojuelas obaovadas ú ovales, otras veces oblícuamente lanceolado-elípticas, obtusas ó puntiagudas. Primorosas flores azules, pedunculadas, en grupitos axilares en la sumidad de las ramitas; de cáliz con 5 sépalos ovales, pubescentes ó lampiños y mas cortos que los pétalos; corola de כ́ pétalos espatulados ú obaovados, largos de 6"' y azules; estambres con las anteras corvas y de base bífida; ovario estipitado comprimido, con 2 ó 5 ángulos, 5 ó 2-locular, con 8,10 huevecillos colgantes en cada celda; del ápice sale un estilo simple corto, terminado por un estigma cabezudito. El fruto es una especie de cápsula de pericarpio algo carnudo, lampiña, lustrosa y amarillenta, con 2, 3 o 5 celdas formando tantos ángulos, monospermas por causa de aborto, con semillas casi globosas cuyo embrion está encerrado en un endospermo agrietado : guajacum, F. 113, T. II, G. I.

863. Fruto drupáceo lejítimo, proviniendo de un ovario único, 86.5. - Fruto formado de carpidios drupáceos, proviniendo de un ovario multiple, 864 .

864. Flores carmesí con los pétalos torcidos y derechos, estam bres 10 , siempre esertos y procediendo cada uno de una escama basilar, 865.-Flores nunca carmesí, pero de un color blanquecino sucio, con 4 ó 5 pétalos no torcidos pero sí derechos; estambres 8 á 10 inclusos y procediendo cada uno de una escama larga y escotada. Arboles de mediana altura, ramosos hácia el vértice, con hojas alternas pinadas ó ternadas, de ordinario grandes, con las hojuelas bien enteras, lampiñas y coriáceas. Flores en panojas terminales, de brazos muy largos y horizontales, ó en racimos; de cáliz monosépalo pe-

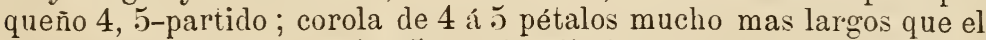
cáliz y ambos decíduos; 4 á 5 ovarios distintos, uniovulados, insertos en un ginóforo; estilo único y comun. Carpidios sub-drupáceos, cuya semilla tiene un embrion derecho y sin endospermo : simaba, F. 110, G. III.

865. Arbol bajito, lampiño, ramoso, con hojas alternas imparipinadas, de raquis alado y formado como de dos piezas o artejos, cuyo inferior es largo de $3 i_{[} 2,3,2 l_{[} 2^{\prime \prime}$, y el segundo ó superior de 20 ó $15^{\prime \prime \prime}$, anchos de como $4^{\prime \prime \prime}$. en la parte superior ó mas ancha, separados por un estrechamiento ó mejor por un trecho en donde el raquis está desnudo y de donde salen las dos hojuelas inferiores opuestas y sub-sentadas, ó muy cortamente pecioladas, mientras las tres otras salen del ápice, la impar que sigue al raquis tiene el peciolo algo mas larguito, son elíptico-lanceoladas, con una punta obtusa bastante larga, y aguzadas por la base, bien enteras pero undulosas por 
los bordes, largas de $3^{\prime \prime}-2^{\prime \prime}$ y anchas de 14 á $15^{\prime \prime \prime}$. Flores bastante grandes $y$ primorosas, en espigas terminales, pedunculadas y saliendo de la axila de una bracteita; de cáliz monosépalo 5-partido y pequeño, largo de $1^{\prime \prime \prime}$; corola de כ́ pétalos largos de 16"'; estambres tan largos como la corola ó lijeramente esertos. Cinco ovarios distintos, uniovulados; estilo simple. filiforme, mucho mas largo que los estambres y terminado por un estigma apenas distinto y muy pequeũo. Drupitas biangulares y ovoídeas á la par, largas de 4-6"', negras y con una mancha mas pálida situada por la base; endocarpio crustáceo:quassia, F. 110, G. 4.

866. Arbusto muy ramoso siempre verde que se eleva á 10 ó $15^{\prime}$ de altura, cuyo tronco y ramas son cubiertos de una corteza bastante rugosa y agrietada color blanco sucio ó ceniciento, mientras las ramitas son de un hermoso verde lustroso, enteramente lampinas. Hojas alternas imparipinadas, formadas de 7 hojuelas ovales, obovales ú óralo-lanceoladas, enteras, algo desiguales, con el ápice redondo, obtuso ó un poco puntiagudo, pecioladas, alternas y largas de 1 á 1 I $2^{\prime \prime}$, la impar es siempre mayor y un poco espatuliforme, lustrosas, coriáceas y con muchos puntitos transparentes; la hoja entera tiene como 3 á $31_{[} 2^{\prime \prime}$ de largo. Flores blancas, con olor de azahar, en racimos axilares ó terminales, pedúnculos pubescentes provistos de una escamita por la base; cáliz muy pequeño campanudo, monosépalo 5-partido y persistente; corola de 5 pétalos obóvalo-lanceolados, sin uña, doblados hácia fuera y algo enrollados, largos de 8-10"t ó algo mas, insertos en la parte esterior de un disco que ocupa todo el fundo del cáliz; prefloracion un poco imbricada; estambres desiguales de los cuales 5 son mayores y 5 menores alternativamente, derechos, blancos con las anteras como dídimas y de un color amarillento verdoso sucio. Ovario poco pronunciado amarillento verdoso, con algunas glándulas que parecen tuberculitos, saliendo del centro del disco, y que parece continuarse en un estilo grueso, cilíndrico, blanco-amarillento, largo de como 4 á $5^{\prime \prime \prime}$ y terminándose por un estigma cabezudo, grande, oval, glanduloso y amarillo. Drupa roja, oval, del tamaño de un guisante, con glandulitas, conteniendo un hueso oval puntiagudo, de color acanelado claro, no muy duro y con un surco lateral: murvaya, F. 115, T. III.

$86 \%$. Matas o arbustillos muy ramosos, raras veces plantas herbáceas, aterciopelados, pubescentes, peludos y á veces cerdosos, cuyo pelo está de ordinario dispuesto á manera de estrella; hojas alternas, pecioladas, simples, aserradas, festoneadas ó lohadas, rarísimas veces sub-enteras; dos estípulas pronto caducas, lanceoladas y colgantes acompañan á la insercion del peciolo. Flores pequeñas, amarillas, pediceladas opuestas á las hojas ó en racimos terminales; de cáliz con 5 sépalos caducos y.ordinariamente con un apéndice situado por debajo del ápice; corola de 5 pétalos opuestos á unas tantas glándulas hipostémones, ó á veces nula; estambres de base ceñida por una cúpula corta. Ovario único, esférico, pelierizado, 2, 5-locular con Las celdas biovuladas y divididas por un tabique falso: del ápice sale un estilo simple algo mas largo que los estambres, terminado por un estigma cuyas divisiones ó lóbulos son 
diminutos ó apenas visibles. El fruto es un aquenio agarabatado; embrion rectito de cotiledones foliáceos: triumfetta, F. 99, T. I, G. I.

868. Un pistilo único, 869. - Algunos pistilos en la misma flor y por consiguiente algunos ovarios y un fruto compuesto, 840 .

869. Vejetales con suco propio, sea lechoso sea resinoso, 870. Vejetales sin suco propio alguno, 878.

870. Fruto capsular, 871. - Fruto drupáceo ó abayado ; vejetales polígamos ó no, 875 .

871. Planta herbácea, espinosa, con suco lechoso amarillo, cápsula seca unilocular; hojas alternas, 872. - Arboles 6 arbustos, á veces parásitos, ć́psula algo carnosa 4, 5, 12-locular; suco resinoso rojizo; hojas opuestas; flores polígamas, 874 .

873. Yerba anual que se eleva á como unos $3^{\prime}$ de altura, de tallo derecho y poco ramoso; hojas simples, sentadas y un poco abrazantes, irregularmente sinuosas $y$ lobuladas, con aguijones por sus bordes, glaucas y con manchas blancas largas de $6,5,4,3^{\prime \prime}$ sobre $21,2,3^{\prime \prime}$ de ancho. Flores grandes amarillas cuyos pedúndulos axilares y unífloros forman una especie de panoja terminal; de cáliz con 2 á 3 sépalos, cóncavos, oval-puntiagudos y pronto decíduos; corola de 4, 6 pétalos anchos, de vértice obțuso y redondeado, algo cóncavos y con uñas muy cortas ; ovario único, ovoídeo, oblongo y algo cónico, anguloso y con puas, cuyo ápice está coronado por 4, 6 estigmas sentados, dispuestos á manera de los radios de una rueda y opuestos á las placentas. Cápsula espinosa, unilocular, membranosa, algo pentágona, aovada, polisperma, dehiscente por el vértice á favor de 5 ó 6 valvas pequeñas; placentas intervalvulares no salientes interiormente y reunidos por el ápice; semillas esféricas, pequeñas, prietas, rugosas y con muchos hoyuelitos é insertas en placentas lineares, verticales y parietales, con embrion axil en un endospermo oleajinoso : arjémone, F. 90.

874. Arboles mas ó menos bajitos que á veces se elevan hasta 30 ó $40^{\prime}$ de altura, muy ramosos, ó arbustos con hojas simplemente pecioladas, coriáceas, enteras, con las nervaduras lineares y paralelas, ó peninervias, ob-ạovado-cuneiformes. Flores bastante grandes, solitarias y axilares ó en cimas terminales; de cáliz con 4 hasta 16 sépalos dispuestos ordinariamente en 2 verticilos foliáceos, cuyn esterior es sucesivamente mas pequeño; corola de 4 á 8 pétalos imbricativos; estambres muchos ó algunas veces en número definido en las flores hermafroditas, con anteras lineares y estrorsas. Orario globoso, 4, 5, 12-locular, de celdillas poliovuladas, de ápice con estigmas, deprimidos, sentados y en igual número que las celdas. Cápsula cuyo pericarpio es algo carnudo, dehiscente en tantas valvas cuantas celdas tiene, con muchas semillas ariladas, cuyo embrion pequeño tiene los cotiledones plano-convexos y distintos : clusia, F. 96. T. I.

875. Anteras introrsas ó reventándose lateralmente; orario 4locular, con las celdillas multi-ovuladas, con un estigma deprimido, sentado y 4-lobo; drupa á veces muy gruesa, de carne anarilla y comestible: sale por las cortaduras hechas en su corteza una espe- 
cie de goma-resina no aromática, 876. - Anteras introrsas pero nunca reventándose lateralmente; ovario 1, 2-locular con un solo huevecillo erguido en cada celda; estilo distinto terminado por un estigma abroquelado y lobado; drupa globosa verdusca y de como 1" de diámetro: por las grietas ó heridas de la corteza sale una resina aromática, 877 .

876. Primoroso árbol que se eleva á 50 ó $60^{\prime}$ de altura, muy coposo y bastante corpulento, enteramente lampiño; hojas opuestas, simples, pecioladas, coriáceas, obaovado-oblongas, redondeadas por el ápice, muy enteras, lustrosas, con venitas proeminentes por ambas caras, largas de $8-4^{\prime \prime}$ sobre $5-3^{\prime \prime}$ de ancho. Flores pedunculadas, solitarias ó fasciculadas, blancas teñidas de color de rosa, saliendo del tronco ó de las ramas gruesas ó en grupos axilares, de como $1^{\prime \prime}$ de diámetro y de olor muy agradable; de cáliz con $2 \dot{0} 4$ sépalos, muy pronto decíduos, iguales, cóncavos y bastante grandes, alcanzando hasta la mitad de los pétalos, corola de 4, 6 pétalos imhricativos, obaovados, un poco cóncavos, redondeados, obtusos, casi iguales y larges de 6-8"' : mammea, F. 96, T. III.

87\%. Primorosísimo árbol, muy coposo y bastante corpulento, que se eleva á una altura de $50^{\prime}$ á $70^{\prime}$, resinoso, cuyas ramitas lampiñas y parduscas son tetrágonas; hojas peninervias, opuestas, simples, coriáceas, eliptical-oblongas ú oblongas, obtusitas ó escctadas, cuya base se aguza hasta el peciolo, de tamaño muy variado y largas por consiguiente de $3^{\prime \prime}$ hasta $10^{\prime \prime}$ sobre 1 á $3^{\prime \prime}$ de ancho; con venas delicadas, densamente aproximadas, derechitas y visibles, especialmente por la cara inferior, lustrosas y cortamente pecioladas. Flores pequeĩas, blancas, algo rosadas y con olor agradable, en cimas arracimadas ó apanojadas axilares y mas cortas que las hojas; de cáliz con 2,4 sépalos decíduos; corola con tantos pétalos, largoos de $3^{\prime \prime \prime}$, ovales, cóncavos, abiertos y cuyos esteriores son algo menores; estambres algunas raras veces en número definido: calophyllum, F. 96 , T. II, G. I.

878. Estambres ordinariamente en número indefinido ó á veces y á la par definido, 879. - Estambres siempre en número definido, 892 .

879. Estambres en número definido ó indefinido, 880. - Estambres siempre muchos y por consiguiente en número indefinido, 884 .

880. Estambres muchos ó definidos, 881. - Siempre en número definido, 20,6. Arboles bajitos ó bastante grandes, ramosos y cuyas ramitas son escamosas; hojas alternas, simples, lampiñas, coriáceas, enteras, lustrosas, obłongas ó elípticas, concolores ó discolores, largas de $4-6^{\prime \prime}$ o de $3-2^{\prime \prime}$, pecioladas. Flores en corimbos paucífloros y cortamente pedunculados, formadas de un cáliz cerrado en el capullo ovoídeo y monófilo, reventándose, y entónces bífido ó 4-fido; corola de 4 pétalos blancos, escamosos esteriormente y peludos interiormente. Ovario estipitado, 4-locular á favor de tabiques falsos, estriado lonjitudinalmente, estrechado por debajo del estigma grande, redondo y umbilicado. Baya globosa del tamaño de una naranja pequeña : morinsonia, F. 88, T. II, G. III.

881. Corola de estivacion abierta ; baya estipitada y siempre glo- 
bosa; hojas ternatisectas, 882.-Corola de prefloracion imbricativa; fruto sostenido por un ginóforo mas ó menos largo, casi siempre silicuiforme y raras veces ovoídeo; hojas siempre enteras, 883.

882. Arboles bajitos que no alcanzan mas de $20^{\prime}$ á $30^{\prime}$ de altura; hojas alternas, simples, pecioladas, con los segmentos aovados, puntiagudos ó aguzados. Flores en racimos terminales, frecuentemente polígamas, de cáliz con 4 sépalos muy pronto decíduos; corola de 4 pétalos; estambres de 20 á 24 ó de 8 á 16, mas largos que la corola é insertos en un disco cónico. Ovario casi globoso, sostenido por un ginóforo delgado tan largo como los estambres, cuyo ápice lleva un estigma sentado y cabezudo: cratceva, F. 88, T. II, G. I.

883. Arbustos ó árboles bajitos que se elevan lo masá $30^{\prime}$ de altura, muy ramosos y no muy corpulentos; hojas alternas, pecioladas, mas ó menos coriáceas, lanceoladas, lanceolado-oblongas, elípticas, oblongo-lanceoladas, aguzadas, puntiagudas, escotadas ú obtusas por el ápice, de base redonda ó á veces acorazonadita, lampiñas por la cara superior, mientras que la inferior es con bastante frecuencia pubescente ó escamosa, ó con glándulas axilares ; estípulas caducas. Flores blancas de ordinario bastante grandes, en grupos paucífloros, axilares ó en racimos terminales: de cáliz con 4 sépalos cóncavos y pronto decíduos, ó 4-partido ó 4-fido, con los segmentos valvares, otras veces imbricados: en el fundo tiene 4 glándulas opuestas á los sépalos; corola de 4 pétalos muy pronto decíduos; estambres muchos ó á veces 8 , de ordinario muchísimo mas largos que la corola y de filamentos capilares derechos; ovario largo, cilíndrico, unilocular poliovulado, sostenido por un ginóforo filiforme muy largo: del ápice sale un estilo simple cortísimo, terminándose en un estigma cabezudo. Fruto á veces ovoídeo y abayado, pero de ordinario es silicuiforme, alguna que otra vez seco y reventándose, y con mayor frecuencia abayado y tambien reventándose, con dos placentas y conteniendo muchas semillas: capparis, F. 88, T. II, G. II.

884. Cáliz con 3 sépalos; estambres muchísimos dispuestos en algunas séries, curas anteras ovales, sentadas y grandes se abren por poros situados en la rarte mediana de ambas caras; baya corticosa muy gruesa, unilocular, con muchísimas semillas horizontales, semillas aromáticas bastante gruesas y de endospermo ruminado, 885 . - Cáliz con 5, 7 sépalos; estambres muchos nunca dispuestos por séries, cuyas anteras no sesiles se abren por una grieta; baya globusa, roja, pequeña y solo con 6-8"' de diámetro, plurilocular, polisperma. Arbol que se eleva á como unos $30^{\prime}$, ó arbusto de solo $10^{\prime}$ de altura, muy ramoso y de ramitas velludas o glandulosas; hojas simples, alternas, pecioladas, enteras, oblongas ú oblongo-lanceoladas, aguzadas por el vértice y de base semi-acorazonada, algo inequilaterales, de cara superior aterciopelada, mientras la inferior es peludu-tomentosa, largas de $6-2^{\prime \prime}$ sobre $3^{\prime} 1 / 2^{\prime \prime}$ de ancho, con el peciolo largo de 3-1"' é igualando casi las estípulas lineares que lo acompañan. Flores blancas bastante grandes, cuyos pedícelos axilares en la sumidad de las ramitas son solitarios o fasciculados, largos de 1-1 $1_{1} 2^{\prime \prime}$ y de ápice dilatado á manera de disco, y de eáliz con 
5, 7 sépalos; corola de 5, 7 pétalos obaovados, largos de $6^{\prime \prime \prime}$ y escediendo un poco la punta filiforme de los sépalos lanceolados; disco peludo sosteniendo un ovario 5, 4,6-locular y multiovulado, de cuyo ápice sale un estigma sentado, piramidal y con algunos ángulos. Bara polisperma, cuyas semillas muy diminutas y ovoídeas están insertas en unas placentas lameliformes que dividen las celdas; embrion cilíndrico axil con cotiledones casi igualando la radícula: muntingia, F. 99, T. I, G. III.

885. Arbol no muy grande, pero que se eleva hasta 30 ' de altura, muy ramoso y de tronco bastante grueso; hojas simples, alternas, enteras, oblongas, coriáceas, muy enteras, lustrosas y cortamente pecioladas, lampiñas. Flores solitarias, grandes, blanquecinas, olorosas, cuyos pedúnculos laterales ó casi opuestos á las hojas, largos de como 4-6" é inclinados, llevan dos brácteas situadas hácia su parte media; cáliz con 3 sépalos; corola con 6 pétalos, cuyos esteriores oblongos, undulosos, amarillos y disciplinados, de manchas purpúreas, son como mitad mas cortos que los interiores, tomentoso-pestañozos y blanquecinos esteriormente, acorazonados, coherentes por la base y conniventes. Estambres inclusos y dispuestos en 10 á 12 séries sobre el disco. Ovario esférico unilocular con muchos huevecillos, de cuyo ápice sale un estigma sesil y aplanado. Baya esférica muy gruesa, como de unas 5 á $6^{\prime \prime}$ de diámetro, lampiña, corticosa, cuya única celda contiene muchas semillas ovales ú oblongas, largas como de $l^{\prime \prime}$ engastadas en pulpa poco abundante : monodora, F. 95, T. II, G. III.

886. Cápsula esférica, erizada, cuyas celdas contienen alguna pulpa, 887.-Cápsula lejítima ó siempre sin tripa alguna, 888 .

887. Arbol muy ramoso superiormente, de tronco bastante grueso y que se eleva hasta 25 á $30^{\prime}$ de altura; hojas simples, alternas, pecioladas, situadas hácia la sumidad de las ramitas cilíndricas y cubiertas de una peluza aleonada que las hace parecer como sedosas, oblongo-ovales, un poco aguzadas por el vértice, mientras la base es algo acorazonada, finamente aserraditas, de cara superior aterciopelada y lustrosa, de color amarillento-verdoso, mientras la inferior, algo mas pálida, con reflejo dorado y sedoso á la par, es tomentoso-sedosa, con la costilla, nervaduras, nervios y venas bastante pronunciados y cubiertos de pelo sedoso-aleonado; el vello está dispuesto á manera de estrella; largas de $6,8,12$ y hasta $15^{\prime \prime} \mathrm{y}$ anchas de $41_{[} 2,6$ y hasta $8^{\prime \prime}$; peciolo bastante grueso, largo de 1 $1_{\Gamma} 2$ á $2 l_{[} 2^{\prime \prime}$, cuya insercion está acompañada de dos estípulas triangulares largas de como $4^{\prime \prime \prime} y$ anchas de $2^{\prime \prime \prime}$, muy pronto caducas. Primorosas flores color de oro muy olorosas, en racimos paucífloros, cuyo eje ó pedúnculo es lateral ú opuesto á la hoja correspondiente, muy pelierizado, así como los brazos, los pedícelos y cálices, con dos brácteas situadas por su insercion y otras á lo largo de los brazos cada vez que de ellos sale un pedícelo, muy pronto decíduas ; cáliz monosépalo profundamente 5,4-partido, cuyas divisiones son como mitad mas largas que los pétalos, lanceoladas, abiertas, lampiñas interiormente $y$ largas de $6-8^{\prime \prime}$ sobre $2^{\prime \prime}$ de ancho, de prefloracion valvar; corola con 5 pétalos ó á veces 4 , obovales, derechos y al- 
ternando con las divisiones calizinales; estambres dispuestos en muchas séries, cuyas anteras son pegadas en el ápice de un filamento blanco, tan largo como ellas y velludo : tienen el ápice adornado de un apéndice membranoso entero ó escotadito, tan largo como la mitad de las celdas que principian por abrirse por el ápice adberido y por fin por una rajadura lonjitudinal, oblongas é introrsas. Ovario 8 ó plurilocular y pluriovulado, de cuyo ápice sale un estilo eserto simple y terminándose en un estigma ensanchado y encorvado : apeiba, F. 99, T. II, G. II.

888. Silicuiforme, 891. - Nunca silicuiforme, 889.

889. Cápsula erizada rojo-moradusca; muchas semillas pegadas de dos placentas parietales y con arilo suministrando tinte amarillo rojizo; flores color de rosa,890. - Cápsula pubescente, ovoídea y del tamaño de un huevo de gallina, cuyas semillas sin arilo pero con pelo blanco y sedoso están pegarlas de 5 placentas parietales; flores grandes y amarillas. Arbol alto de 20 á 30', de tronco derecho y de 6 á 8" de diámetro, con ramos derechos; hojas grandes alternas ó quizas mejor esparcidas, largamente pecioladas, simples, de base acorazonada y 5 -lobas, con los dos lobulos de la base menores, y todos ovales, puntiagudas, lampiñas por ambas caras, y lustrosas por la superior, undulosas, anchas de 4-5" sobre 5-6" de largo, sin contar con el peciolo que lo es de $6^{\prime \prime}$ y cuya insercion está acompaniada de dos estipulitas, subulado-triangulares, pronto caducas y pubescentes por la cara esterior, derechas y casi aplicadas al tallo; muy tiernas las hojas están pubescentes y moraduscas. Flores primorosas, grandes, en panojas terminales saliendo antes que las hojas y floreándose sucesivamente principiando la florescencia por las mas inferiores, los brazos que las llevan son largos como de $6^{\prime \prime} \mathrm{y}$ tanto mas pubescentes cuanto mas tiernos, pedúnculos bastante gruesos pubescentes, moraduscos superiormente é inclinados, salen de la axila de una bráctea caduca y llevan una flor que se desprende con mayor facilidad, y de cáliz monosépalo, profundamente 5-fido, cuyos segmentos dispuestos como en dos séries parecen casi imbricados; la série esterior es formada de dos mas pequeños, mas cortos, oval-lanceolados, puntiagudos, largos de como 10"' y anchos de $4^{\prime \prime \prime}$ por la base, son opuestos; los tres interiores, mucho mayores, son casi petaloídeos, ovales, redondeados y obtusos por el ápice, amarillentos, valvar-torcidos y largos de $14-16^{\prime \prime \prime}$ sobre $10^{\prime \prime \prime}$ de ancho; todas las divisiones son pubescentes esteriormente y tambien interiormente $\mathrm{y}$ como plateadas $\mathrm{y}$ con manchitas rojas, que nos han parecido glandulitas llenas de un tinte análogo al onoto, cuyo olor tiene, de bordes pestañosos y algo membranosos; limbo marcescente, mientras la base del cáliz se vuelve como una cúpula que envuelve la base de la cápsula: el ápice del pedúnculo participa tambien un poco de ese desarrollo; corola de como 3-4" de diámetro, de 5 pétalos ob-acorazonados, undulosos, un poco cuneiformes por la base, largos de como $21_{[} 2^{\prime \prime}$ y anchos de $2^{\prime \prime}$ por el vértice y de $11_{[} 2^{\prime \prime}$ por la parte media, con manchitas rojas, especialmente por la cara interna y hácia la base, marcescentes; estambres de filamentos al principio arqueados y mas luego derechos, largos de 10 á $12^{\prime \prime \prime}$, con 
anteras basifijas, enderezadas, de un color amarillo mas subido que ellos, casi cónicos, largas de como $111_{1} 2^{\prime \prime \prime}$, con un surco lonjitudinal situado por la parte media de la cara, pero abriéndose por dos poros situados por el ápice. Del centro de un disco que llena todo el fundo del cáliz y que da insercion á los estambres y pétalos, sale el ovario ovoídeo, cubierto de pelo sedoso y como plateado, unilocular, poliovulado, de cuyo ápice sale un estilo filiforme, cilíndrico, largo de $15^{\prime \prime \prime}$, arqueado, con el vértice doblado por arriba y terminándoze en un estigma lateral con forma de boca algo franjeada. Cápsula oroídea ó casi redonda, como membranosa, algo pentágona, pubescente y de un color sea moradusco, sea aleonado y algunas veces gris amarillento : se abre por los ángulos en 5 valvas en cuyo medio se hallan las placentas verticales, membranosas y bastante desarrolladas, de manera que simulan tabiques; su parte interna y libre, mas des.arrollada y como esponjosa, lleva muchas semillas dispuestas en cios séries laterales $\mathrm{y}$ pegadas por medio de un podospermo bastante pronunciado que ocupa la parte mas delgada y mas derecha de la semilla cilíndrica, arqueada, prieta por la parte convexa cubierta de pelo blanco, suave y bastante largo, mientras la parte cóncava es color blanquecino amarillento y lampiña; no todavía maduras contienen el tinte ya señalado, que se halla tambien en la parte intcrior de la cápsula todavía verde : coclospermum, F. 87, T. II, G. II.

890. Primorosos árboles que se elevan de $15,25^{\prime}$ y hasta $30^{\prime}$ de altura, ó que se quedan arbustos de 8 á $10^{\prime}$ de alto, muy ramosos, lampiños, con hojas simples, alternas, pecioladas, aovadas, acorazonadas por la base, en donde hay un punto morado oscuro correspondiente al ángulo y al ápice del crecido del peciolo, y de vértice con una punta bastante larga, lisas, lustrosas, de color verde 0 scuro algo teñido de morado, enteras, con puntitos, lampiñas, anchas de $3^{\prime \prime}$ y largas de $4^{\prime \prime}$, sin el peciolo, que lo es de $2^{\prime \prime}$. Flores primorosas bastante grandes, color de rosa pálido ó blancas, en corimbos terminales, cuyos pedícelos ob-conicos, largos de $6^{\prime \prime \prime}$, están acompanados por la insercion de dos brácteas opuestas, cóncavas, ovallanceoladas, caducas, cuya base persistente se vuelve un tubercullito, achocolatadas, los pedúnculos y pedícelos son aterciopelados; cáliz con 5 sépalos, distintos, imbricados, caducos y alternando con otras tantas glándulas esteriores; corola de 5 pétalos obovales, cóncavos, abiertos, de vértice undulos o y obtuso, cuyos bordes no tardar á doblarse hácia dentro, con uña muy corta; estambres mas cortos que los pétalos, de filamertos flexuosos, con anteras basifijas color de lila, acuñadas y abriéndo:e por dos poros ó rajaduras muy cortitas situadas por el ápice de las celdas, insertos por la superficie de un disco pentágono bastante desarrollado, color dé carne con puntitos rosados, de cuyo centro deprimido sale un ovario oblongo, pelierizado, algo comprimido y de cuyo ápice nace un estilo de base cilindrica, mientras el vértice es mucho mas ancho, comprimido $\mathrm{y}$ como espatuliforme, terminándose por un estigma en forma de boca oval, glaudulosa, con dos labios redondeaditos; el estılo, doblado al principio y escondido entre los estambres, se endereza mas tarde y es mas largo que ellos. Cápsula colorada ó algunas veces verduzea, 
oval-comprimida, algo puntiaguda por el vértice y acorazonada por la base, cubierta de puas, unilocular, abriéndose por dos valvas cargando con las placentas situadas verticalmente en su parte media, llevando muchas semillas apeonzadas y casi enteramente cubiertas por el arilo: bixa, F. 87, T. II, G. I.

891. Plantas anuales sub-frutescentes ó matas leñosas, á veces arbustos, ramosísimos, de tallo derecho ó á veces desparramado, mas ó menos pubescentes, peludos ó lampiños, de hojas simples, alternas, pecioladas, aovado-oblongas ó aovadas, oblongas, aguzadas ú obtusas por el ápice, ó con una punta, aserradas ó festoneadas. Flores amarillas solitarias ó en grupos cuyos pedúnculos cortos uni ó paucífloros son opuestos á las hojas, de cáliz con 5,4 sépalos caducos; corola de 5, 4 pétalos espatulados ó á veces obaovadooblongos igualando al cáliz ó algo mas cortitos quc él; estambres hipójinos ó insertos en el ápice de un ginóforo corto y ceñidos por una cúpula undulosa situada por la base. Ovario clongado, cilíndrico 2,5-locular, con muchos huevecillos, de cuyo ápice sale un estilo simple terminándose en un estigma algo dentado ó trífido. Cápsula loculícida de ordinario elongada ó silicuiforme, lampiña ó pubescente, cuyo ápice es raras veces entero, pero que se termina por 5, 3 cuernecillos, 5, 3-locular, con muchas semillas, cuyo embrion encorvado tiene los cotiledones foliáceos : corchorus, F. 99, T. I, G. II.

892. Vejetales nunca acuáticos, frutices, arbustos ó matas, 892 bis. - Vejetales herbáceos y siempre acuáticos, 415 .

892 bis. Fruto mas ó menos seco, 893. - Fruto carnudo, 899.

893. Del todo y siempre seco, 894.- Fruto formado de carpidios abayados y por fin secos y dehiscentes, 898 bis.

894. Cuyos muchos carpelos 1, 2-espermos dispuestos en espiga y por fin coherentes forman un estróbilo; 894 bis. - Carpidios, cajitas ó carpelos nunca dispuestos en estróbilo, 896.

894 bis. Arbol grande y coposo que se eleva con frecuencia hasta $80^{\prime}$ de altura, con hojas alternas, pecioladas, simples, enteras, coriáceas, lustrosas, del todo lampiñas, con puntitos transparentes, redondeadas ó cuneiformes por la base, cuyo tamaño es bastante variado y largas de 5-3-6", acompañadas de estípulas caducas y envainadoras. Flores grandes y primorosas, blancas y muy fragantes, terminales y solitarias, de cáliz con 5 sépalos coloridos y decíduos: corola de 6, 12 pétalos; muchísimos estambres. Estróbilo abriéndose por medio de la rotura irregular de los carpelos que lo forman: talauma, F. 94, T. II.

895. Fruto formado de carpidios ó carpelos mas ó menos numerosos, foliculares ó no, 895 bis. - Muchísimos aquenios agrupados en cabezuela redonda ó mas o menos conica, 898 .

895 bis. Carpelos estrellados, no foliculares, abriéndose por la cara superior, siempre monospermos y muy aromáticos, 896. Carpelos nunca estrellados, siempre foliculares, con una sola ó algunas semillas ariladas, 895 bis.

896. Arbol que se eleva á 15-25' de altura, muy ramoso y bastante copudo, con hojas simples, alternas, del todo lampiñas, agru- 
padas ó como apiñadas hácia el vértice de las ramitas, cortamente pecioladas, elípticas, alargadas y de ápice aguzado en punta, coriáceas, largas de 2 à $21 / 2$ sobre $11 / 2$ de ancho, con 2 estípulas caducas. Flores amarillentas, solitarias, cuyos pedúnculos largos salen de la axila de las hojas superiores; cáliz decíduo de 3,4 sépalos escamosos y desiguales; corola con 16, 20 pétalos dispuestos en 3 séries, cuyos mas interiores, lineares y obtusos, son erguidos, mientras los mas esteriores, estendidos y mas anchos, son doblados hácia fuera y abajo á la par: estambres de filamentos cortos insertos en un disco hipojínico bastante desarrollado, con las anteras pegadas al filamento por su cara interna. Ovarios 8,16 , uniloculares y monospermos; estilo lateral corto saliendo de la cara esterna del carpelo correspondiente y terminándose por un estigma asurcado situado en su cara interna : illicium, F. 94, T. I.

896 bis. Arilo completo; los 2 sépalos interiores máximos, concavos, volviéndose endurecidos despues de la florescencia y encerrando el fruto ruptil, 897. - Arilo no enteramente completo y lacerado; todos los sépalos iguales y ninguno de ellos se vuelve endurecido despues de la florescencia; carpelos dehiscentes. Arbustos abejucados y trepadores, muy ramosos y largos, con hojas simples, peninervias, alternas, rugosas, pecioladas, obaovadas ú obaovado-oblongas, aserradas ó enteras, con los dientes apartados, terminándose por 8,16 ó 12 venas equidistantes adelgazándose hácia la base de la hoja, mas ó menos proeminentes inferiormente. Flores á veces polígamas en panojas terminales ó laterales, flojas, con los brazos mas ó menos cortos $\mathrm{Y}$ arracimados; cáliz con 5 sépalos abiertos, de los cuales uno es esterior, dos internos, sub-valvados, pero que no son mas largos que los demas, obaovados y sedosos por la cara interna; corola de 4, 6 pétalos y algunas raras veces menos; estambres indefinidos, cuyas celdillas de las anteras diminutas son diverjentes. Carpelos 3, 5, mas rara vez 1, 2, aguzados, dehiscentes por la parte interna, con muchos huevecillos dispuestos en dos séries: tetracera, F. 95 , G. I.

897. Arbustos abejucados y trepadores, muy ramosos y bastante largos, con hojas simples, alternas, ásperas, aovado-oblongas, subenteras ó serpeadas, peninervias y con las venas dispuestas por el estilo de las de la tetracera, de peciolo marjinado por el ápice. Flores amarillas suaveolientes, en panojas terminales ó mas veces axilares y paucífloras, saliendo en especial sobre los ramos del año anterior; cáliz con 5 sépalos desiguales, de los cuales 2 son esteriores y 2 interiores, sub-valvados; corola con 1 á 6 pétalos; estambres indefinidos cuyas celdillas de las anteras son diminutas y diverjentes. Carpelo 1, 3; estigma abroquelado. Folículo solitario ruptil, monospermo por causa de aborto del otro óvulo: davilla, F. 95, G. II.

897 bis. Flores hermafroditas ó polígamas; aquenios lonjitudinalmente ribeteados ó encrestados; hojas simples, siempre enteras, 898. - Flores siempre hermafroditas y de ordinario amarillas; aquenios lisos, estriados ó tuberculados; hojas de ordinario multífidas y algunas reces enteras, siempre simples. Plantas herbáceas 
anuales ó vivaces, bastantes veces con la raiz fasciculada; hojas radicales y algunas solamente caulinares, alternas y correspondiendo á la insercion de los pedúnculos ó salida de los ramos. Flores á veces bastante grandes $y$ ristosas, algunas veces blancas, amarillas, terminales y solitarias ó apanojadas y raras veces sentadas en la bifurcacion de los ramos; cáliz con 3 , 5 sépalos caducos, foliáceos y de estivacion imbricada; corola de 5 á 15 pétalos hipojínicos, cuya base presenta por su parte interna un hovito nectarífero ó está provista de una escamita; estambres mas cortos que los sépalos y pétalos, ordinariamente muchísimos, pero no rara vez son pocos en las flores pequeñas. Ovarios muchos, libres, uniloculares, con un solo óvulo erguido y ascendente de la base de la celda; carpelos muchísimos volviéndose aquenios en cabezuelas ó espigas, sub-comprimidos, cuyo ápice se termina en un cuernecillo ó rejon, de semilla erguida : vanunculus, F.

898. Plantas herbáceas de los lugares anegadizos y pantanosos, con hojas simples, radicales, largamente pecioladas, de limbo entero, erguidas ó nadantes, acorizonado-redondeaditas, con 9, 5 nervaduras, que saliendo de la base alcanzan al vértice, ó alabardadoovales, con las orejitas á veces puntiagudas. Flores blancas siempre, hermafroditas ó á veces polígamas, en umbelas ó verticilos en el vértice de un bojordo mas ó menos alto, de 6 " hasta 12 " ; cáliz con 3 sépalos policostilludos, algo mas cortos que la corola, de tantos pétalos blancos é imbricados; estambres de ordinario definidos y entónces 6, 12. Aquenios formando cabezuela, muchos, picudos ó no, monospermos, distintos ó adheridos un poco por la base; semilla sin endospermo, de embrion ordinariamente encorvado, con la raicilla delgada: echinodorus, F. 30.

898 bis. Arboles bajitos de 20,25 o $30^{\prime}$ de altura, con los ramos largos y de ordinario horizontales, ó arbustos con hojas simples, alternas, dísticas, cortamente pecioladas, coriáceas, lanceolado-lineares, oblongo-lanceoladas ó lanceoladas, aguzadas en punta por el vértice, obtusas por la base, de cara superior lustrosa y lampiña, mientras la inferior está á veces pubescente ó alampiñada, enteras. Flores axilares, solitarias ó fasciculadas, de ordinario sedosas, cortamente pedunculadas, con brácteas cuya superior envuelve mas ó menos al tubo calizinal cupuliforme, trílobo ó tridentado; corola de 5 pétalqs lineares, espesos, esteriores, cóncavos, mientras los interiores, algo mas cortos, son aquillados por la cara interna; estambres insertos en un disco amarillo encerrando los ovarios, con anteras de conectivo truncado. Ovarios 2 ó muchos, distintos, con 2, 6 huevecillos suturales; estilos conniventes y formando un cuerpo cónico : xylopia, F. 95, T. II, G. I.

899. Baya lejítima y sincárpica, 900. - Carpidios abayados estipitados, con semillas hoyosas. Arbol alto, ramoso, de hojas simples. alternas, membranosas, alampiñadas, pecioladas, oblongas, cuyo vértice se termina en punta; flores grandes, pecioladas, fasciculadas y axilares, de cáliz con 3 ó á veces 4 segmentos reunidos por la base y puntiagudos; corola de 6 pétalos dispuestos en 2 séries, cura interior es mas cortita; estambres con un conectivo que se prolonga 
mas allá del ápice de las celdillas de las anteras estrorsas en apéndice aovado y puntiagudo; muchos ovarios insertos en un disco acubileteado, distintos, algo comprimidos, con muchos huevecillos dispuestos en dos séries, terminados por un estigma agudo: cananga, F. 95, T. II, G. II.

900. Arboles bajitos, mas ó menos frondosos y altos de 25 á 30', ó arbustos de ordinario lampiños, con hojas simples, alternas, mas ó menos punteadas, cortamente pecioladas, coriáceas, enteras, oblongas, elípticas, lanceolado-oblongas ú oblongo-lanceoladas, de vértice puntiagudo ú obtuso, lampiñas, pubescentitas y por fin lampiñas, ó de cara inferior peluda ó aterciopelada, cara superior de ordinario lustrosa. Flores solitarias, terminales ó laterales y opuestas á las hojas, ordinariamente bastante grandes y de cáliz pequeño monosépalo, con 3 divisiones; corola con 6 pétalos distintos en 2 séries, cuyos 3 esteriores mayores, son espesos, mientras los 3 interiores son de ordinario mas pequeños y mas delgados; estambres de filamento muy corto, con un conectivo que se prolonga mas allá de las celdas de las anteras, largas y estrorsas. Muchísimos ovarios uniloculares y uniovulados, terminados por un estigma sesil y obtuso. Baya mas ó menos gruesa, de forma variada, lisa, rugosa, escamosa o tuberculada, formada de muchísimos carpidios reunidos en un sincarpio carnudo; semillas de epispermo como crustáceo, con un endospermo ruminado, conteniendo un embrion pequeño situado for el ápice: anona, F. 95, T. I.

901. Estambres monadelfos ó diadelfos, 902. - Estambres poliadelfos, 977 .

902. Siempre monadelfos, 903. - Diadelfos siempre, 973.

903. En número siempre definido, 858. - En número indefinido, mas ó menos numerosos, 951 .

904. De 3 hasta 5, 905. - De 5 hasta 12, 20 ó muchos, 912.

905. Tres estambres, 906. - Cinco estambres, 907.

906. Arbustos sarmentosos ó bejucos, mas ó menos altos y ramosos, con hojas simples, opuestas, pecioladas, lampiñas, elípticas, oblongas, eliptical-oblongas ú oval-oblongas, aserraditas ó enteras y acompañadas de dos estípulas. Flores en panojas ó en cimas dicótomas, pedunculadas, de cáliz 5-fido persistente y pequeño; corola con 5 pétalos; estambres transversalmente dehiscentes y de celdillas confluentes, insertos en la parte interna de un disco grande, á veces cupuliforme. Ovario trígono, trilocular, con óvulos ascendentes y definidos, de cuyo ápice sale un estilo trífido terminado por tantos estigmas cabezudos. Fruto formado de carpidios estriados, coriáceos, navicular-comprimidos, medianícido-bivalvés, con 4,6 semillas pegadas por la base ordinariamente á favor de un ala. Hippocratea.

907. Columna ó andróforo pegado por su parte superior á los pétalos por medio de glándulas; anteras solitarias insertas entre los lóbulos de la columna, 908.-Columna ó andróforo de vértice libre, pentandro y sin lóbulos estériles, anteras opuestas á los pétalos, 909.

908. Arbustos sarmentosos ramosísimos, que se elevan hasta $20^{\prime}$ 
y mas de altura, aguijonosos y algunas veces inermes, con el tallo y las ramitas angulosos ó cilíndricos; hojas simples, alternas, pecioladlas, mas ó menos tiesas, lineares, lanceolado-lineares, ó asaz grandes y acorazonado-aovadas, mucronadas ó con una punta, enteras ó con algunos dientes. Flor'es pequeñas, en grupos axilares ó laterales hácia el vértice de las ramitas y de ordinario colgantes, te-

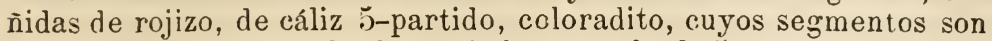
mas largos que la corola, lanceolados; corola de 5 pétalos subsesiles ó cortamente ungüiculados y de cuyo ápice sale un ápendice estrecho, pegados á los lóbulos estériles de la columna por la márjen del limbo; columna 5-loba, anteras subsesiles en los senos entre los lóbulos. Ovario 5-locular, mas ó menos esférico y erizadito ó glanduloso, con 2 huevecillos en cada celda, cuyo superior es ascendente, mientras el inferior está colgante; estilo simple terminado por un estigma de 5 lóbulos globosos. Cápsula pentácoca, erizada, cuyos carpidios monospermos se abren á lo largo del lado interno; embrion derecho contenido en un endospermo; cotiledones convolutos, foliáceos y bílobos : buettneria, F. 104, T. II.

909. Cáliz provisto de un invólucro lateral formado de 3 hojuelitas caducas : ovario formado de un carpelo solitario, con un estilo simple, lijeramente lateral y terminado por un estigma de ordinario apincelado, caja ó carpidio bivalvado y monospermo, 910 . - Cáliz sin invólucro alguno ó á veces con uno que acompaña á las flores y es de 3 hojuelas persistentes; cápsula 5-locular con 5, 10 semillas: hojas peninervias, 911 .

910. Arbustillo ó mata de como 4 á 5 ' de altura, derecho, no muy ramoso, aterciopelado-tomentoso y blanquecino, ó alampiñado, con hojas aovadas, oblongas ó lanceolado-oblongas, plegadas, festoneadas ó dentadas, largas de $2 "$ " 5 " sobre $5-7$ "' de ancho, pero cuya figura varia mucho, así como la disposicion y tamaño de los grupos florales estipulados. Flores fasciculadas en grupos de ordinario axilares, pedunculados ó sentados, amarillas ó blanquecinas y de cáliz Ј-fido, lanudo o lampiño, con los lóbulos subulados; corola con 5 pétalos derechos é iguales; columna adherente á la base de las uñas de los pétalos, entera ó dividida en 5 filamentos: waltheria, F. 104, T. III.

911. Arbustitos, matas ó plantas herbáceas que se elevan á 4-5' de altura lo mas, mas ó menos ramosos y derechos, lampiños, pubescentes, peludos ó tomentosos, con hojas simples, alternas, pecioladas, estipuladas, oblongo-lanceoladas, oval-redondeadas, aovadas, aovado-oblongas, festoneado-aserradas, aserradas ó festoneadas solamente, á veces aserradas dos veces, de ápice obtuso ó terminado por una punta, lampiñas, tomentosas, peludas ó velludo-lanudas Flores fasciculadas sin invólucro alguno, axilares o terminales, otras veces en grupos espiciformes y ceñidas por un invólucro de 3 hojuelas; cáliz .j-fido, ordinariamente mas corto que la corola, con los lóbulos lanceolado-aguzados, ovales con una punta, deltoídeos con una punta ó lanceolado-puntiagudos; corola de 5 pétalos cuyas uñas están reunidas con la base de la columna dividida superiormente en . filamentos ó entera, con anteras biloculares; estilos 5 , distintos ó 
reunidos por la base. Cápsula loculícida, con los tabiques coherentes, pero que por fin se separan del eje filiforme, ó septícida y loculícida; en fin otras veces está formada de 5 cocos: melochia, F. 104, T. III.

912. En número variable, 913.-En número fijo y constante, 937.

913. Filamentos reunidos en una columna mas ó menos larga, 914. - Nunca formando columna, 924.

914. Columna muy larga y reunida con el carpóforo que contiene y que tiene el ovario casi junto á su ápice, terminado por 106 por muchos estambres, cuyos filamentos son monánteros, $y$ cuyos esteriores son estériles, con anteras biloculares cuyas celdas están reunidas por los estremos. Carpidios foliculares, ordinariamente torcidos en hélice y formando una especie de cápsula cónica, 915. - Columna no muy larga, atravesada por el estilo solamente, 916.

915. Arbustos que se elevan de 4-8-10-12 y hasta $15^{\prime}$ de altura, bastante ramosos, furfuráceo-tomentosos o tomentosos solamente, raras veces lampiños ó alampiñados, con hojas alternas, simples, mas ó menos pecioladas, acorazonadas, aovadas ó acorazonadoredondeaditås, con ó sin punta, festoneadas, aserradas, sinuadodentadas ó á veces algo lobadas, de cara superior lampiña ó alampiñada, mientras la inferior es aterciopelado-peluda ó peludotomentosa: acompañada la insercion del peciolo por dos estípulas. Flores blancas ó rojizas, ordinariamente fasciculadas y axilares ó en corimbos terminales; en el primer caso son mellizas en el ápice de un pedúnculo comun, con el pedícelo envuelto por la base en una estípula envainadora caduca, de cáliz 5 -fido, de ordinario bilabiado y campanudo; corola con 5 pétalos enderezados y casi aplicados al andróforo, mas largos que el cáliz y de base orejuda ó desnuda, ordinariamente asimétricos. Ovario que aparece en el ápice de la columna y de base envuelta en los filamentos, 5-locular, oval ú ovoídeo, con algunos óvulus en cada celda, mas ó menos pubescente y de cuyo ápice sale un estilo quinque-partido con estigmas sub-cabezudos. Frutoformado de 5 carpidios torcidos en espiraló á veces rectos, por fin distintos, foliculares, abriéndose á lo largo de una línea ventral, polispermos y cuyas semillas son lampiñas : helicteres, F. 103, T. II.

916. Anteras uniloculares, 917. - Anteras biloculares, 920.

917. Columna dividida en 5 filamentos, cuyo ápice de cada uno lleva 2, 3 anteras; cáliz sin invólucro; hojas palmeadas, 918. Columna tubulosa cuya parte superior está cubierta esteriormente por las anteras lineares, "adnadas, contiguas y dispues tasen espiral, de ápice 5, 10-fido; cáliz acompañado de un invólucro caduco y trífilo, 919 .

918. Arbol muy grande y muy corpulento, que se eleva á mas de $60^{\prime}$ de altura, de tronco con aguijones cuando tierno, los cuales desaparecen con la edad; con ramas gruesas estendidas horizontalmente y dispuestas casi por grados, dándole un semblante particular y característico. Hojas grandes, alternas, compuestas de 5, 7 hojuelas lanceoladas ú oblongo-lanceoladas, enteras ó dentaditas lácia la punta, pecioladas ó subsesiles, de tamaño bastante variable, 
saliendo del ápice de un pedúnculo comun muy largo. Flores en grupos saliendo primero que las hojas, en las ramitas tiernas, de una especie de tubérculo, en número de 10 á 15, cuyos pedúnculos, largos de 10 á $12^{\prime \prime \prime}$, se van ensanchando por el ápice hasta desaparecer confundidos con la base del cáliz, algo grandecitas, tomentosas y amarillentas ó rosaditas esteriormente, de cáliz cortamente 5 -lobo, y á la vez unduloso, algo campanudo y largo de $68^{\prime \prime \prime}$; corola de 5 pétalos obaovados, lampiños interiormente, largos de como $20^{\prime \prime \prime}$, igualando á los órganos sexuales y abriéndose las anteras desde la parte mediana, anfractuosas y sostenidas por filamentos de vértice subulado; estilo terminado por 5, 6 divisiones, cada una con su estigma correspondiente, algo cabezudo y ensanchado. Cápsula 5-locular, loculícida, bastante gruesa, ovoídea ó casi globosa, del tamaño de un huevo de pava á lo mas, con muchas semillas algodonosas : eriodendron, F. 103, T. I, G. II.

919. Arbol alto de 30 á 50', no muy corpulento, bastante ramoso superiormente, con hojas grandes, alternas, simples, acorazonadas por la base $y$ aguzadas por el vértice, redondeadas, angulosas ó apenas 5, 7-lobas, sub enteras o dentadas, de cara superior lustrosa y lampiña, mientras la inferior es pubescentita, largas de 10 á $12^{\prime \prime}$, sin el peciolo, que lo es de 6 á 8" sobre 9 á $11^{\prime \prime}$ de ancho, con dos estípulas caducaspor su insercion. Flores solitarias, grandes, terminales en las ramitas nuevas, derechas, amarillentas, y como acampanadas, de cáliz cortamente 5-lobo, de cuyos lóbulos desiguales dos son puntiagudos é imbricativos por la base, mientras los tres otros, redondeados y bastante grandes, son induplicativos, largo de $21_{\text {[ }} 2$ á $3^{\prime \prime}$, pubescente interiormente, como sedoso y amarillento; corola de 5 pétalos largos de $4-5^{\prime \prime}-6^{\prime \prime}$ y anchos de $15-20^{\prime \prime \prime}$, con uñas oblongo-lineares é iguales al cáliz, un poco mas larga que la columna, de cuyo ápice salen 5 estigmas lineares torcidos en espiral y formando así un cuerpo cilíndrico. Cápsula 5-locular, polisperma, loculícida, cuyas muchas semillas, pequeñas, ovoídeas, lustrosas y prietas, están envueltas en un algodon de color algo aleonado oscuro, larga de 8-10 y hasta $12^{\prime \prime}$ sobre como $2^{\prime \prime}$ de ancho por la base, es cilíndrico-pentágona, y cónica : ochroma, F. 103, T. I, G. III.

920. Columna libre de los pétalos, 10 fida, de cuyas divisiones las unas son estériles y las demas fértiles, 921. - Columna soldada con la base de los pétalos, filiforme, apenas 5 -loba por el ápice, con $10-$ 15 anteras sentadas en el dorso, cuyas celdillas ovoídeas están unidas por los estremos. Arbol de 25-35' y hasta $50^{\prime}$ de altura, cuyos ramos ó vástagos son muy derechos, con hojas simples, alternas, cortamente pecioladas, enteras, lampiñas y con 2 estípulas muy pequeñas. Flores en racimillos cortos, axilares ó laterales, pedunculados, pedícelos 1-floros casi del largo de los peciolos; cáliz dentado ú operculado, ovoídeo y por fin apeonzado, reventándose irregularmente, de manera que el tubo se queda partido en algunos lóbulos desiguales, casi tan largos como los órganos sexuales; corola con 5 pétalos oblongo-espatulados, mas largos que el cáliz, blancos y lijeramente estriados á la derechia. Ovario sentado, 2, 3-locular, cuyas celdillas son biovuladas, de cuyo ápice sale un estilo filiforme, bífi- 
do, terminándose por estigmas sub-cabezudos. Pericarpio ó fruto leñoso y como coriáceo á la par, indehiscente, de ordinario unilocular y monospermo : myrodia, F. 103, T. I, G. IV.

921. Cáliz 3, 2, 4-partido; lóbulos fértiles de la columna, con 3 anteras; especie de nuez tuberculosa, 5-locular y de celdas polispermas, 922. - Cáliz siempre 5-partido y colorido; lóbulos fértiles de la columna bianteríferos. Baya grande, corticosa, 5 -locular, pulposa y polisperma, 923 .

922. Arboles bastante frondosos, que se elevan á 25-40 y hasta $50^{\prime}$ de altura, ramitas pubescentes, con vello dispuesto en estrella ó pulverulento-rojizas y alampiñadas; hojas simples, alternas ó dísticas, pecioladas, aserradas, ordinariamente de base oblícua, oblongo-lanceoladas ó aovadas, aguzadas ó con una punta, de base semiacorazonada, ásperas ó alampiñadas y otras veces lampiñas por la cara superior, mientras la inferior es pubescente y de ordinario blanca ó pulverulenta cuando tiernas. Flores pequeñas amarillentas, fragrantes, en corimbos ordinariamente axilares en el vértice de las ramitas nuevas; de corola con 5 pétalos largos de 11 [ $2^{\prime \prime \prime}$, de limbo cuculif orme, con un apéndice terminal, linear, bífido y tan largo como él. Ovario mas ó menos globoso, j-locular, con muchos óvulos en cada celda, de cuyo ápice salen 5 estilos contiguos, cada cual con su correspondiente estigma, un poco cabezudo. Fruto sub-drupáceo, purpúreo-negrusco, largo de 12-8" sobre 9-6" de diámetro, ó globoso y con 5 surcos lonjitudinales, cuyas semillaś contienen un embrion encorvado en un endospermo delgado: guazuma, F. 104, T. I, G. I.

923. Arbol de 25 á $30^{\prime}$ de altura, bastante ramoso, con hojas simples, alternas, pecioladas, muy grandes, enteras, oblongas, aguzadas, lampiñas, largas de $6,8^{\prime \prime}, 10^{\prime \prime}$ sobre 3 à $4^{\prime \prime}$ de ancho. Flores pequenas fasciculadas ó solitarias, caulinares ó rameales, otras veces laterales, pediceladas y de cáliz 5-partido coloradito ó rosadito, con los segmentos lanceolados, aguzados y un poco mas largos que la colora amarillenta; corola de 5 pétalos, cuyo limbo acogollado se termina por un apéndice espatulado; lóbulos fértiles de la columna opuestos á los pétalos y cargando con dos anteras cada uno. Ovario único oval, כ-locular, cuyas celdas eontienen muchos huevecillos y de cuyo ápice sale un estilo simple 5-fido, con tantos estigmas cabezuditos. Fruto abayado bastante grande, indehiscente, amarillo ó rojo-moradusco, coriáceo oval-oblongo, ó quizás mejor como fusiforme, de superficie desigual abollada, con 10 surcos lonjitudinales, cuyas 5 celdas contienen muchas semillas y pulpa, largo de 6-8-10" sobre como 3 á 4 " de diámetro por la parte media; embrion sin endospermo, con los cotiledones gruesos, mantecosos y arrugados: theobroma, F. 104, T. I, G. II.

924. Pero sí reunidos en tubo los filamentos, 925. - Nunca formando tubo y mas ó menos soldados por la base; una legumbre, 933.

925. Fruto abayado, 926. - Fruto capsular, 928.

926. Sépalos 7, de los cuales 2 son esteriores y menores; tubo estaminal desnudo, 927. - Sépalos 3, distintos, imbricativos y per- 
sistentes, igiales; tubo estaminal cerrado esteriormente por 5 escamas petaloídeas alternando con los pétalos, 936 .

927. Arbol bajito, de 10 á 15' de altura, con hojas esparcidas, enteras, coriáceas, cortamente pecioladas, eliptical-oblongas, redondeadas por la base, y de ápice puntiagudo ú obtuso, largas de 2$3^{\prime \prime}$ sobre 1-1 2 de ancho, con el peciolo ensanchado por el ápice. Flores en corimbos axilares, ó por fin laterales, encojidos, apenas mas largos que el peciolo, de cáliz con 3 sépalos distintos, imbricativos, persistentes, largos de $1^{\prime \prime \prime}$, anchamente redondeados, diminutamente pestañosos, mitad mas cortos que los pétalos derechos, obaovado-oblongos, carnudos, $\overline{5}$ ó 4 é imbricativos; tubo estaminal algo mas cortito que la corola, ceñido esteriormente por joscamas petaloídeas, hipojínicas y alternas con los pétalos; 10, 20 anteras contiguas, abriéndose por dos rajaduras lonjitudinales y situadas en la parte esterior y superior del tubo. Ovario unilocular con 4, 5 placentas parietales y lonjitudinales, llevando muchos huevecillos horizontales, campilótropos, provistos de dos tegumentos y dispuestos en algunas séries: del ápice sale un estilo corto, terminándose en $4, j$ estigmas globulosos y contiguos. Baya globoso-ovoídea, llena por las placentas que por fin envuelven enteramente las semillas ovoídeas, brunas. lustrosas, largas de $1^{\prime \prime \prime}$, muchas, de testa crustácea, con endospermo carnudo y aceitoso, 3 veces mas larco que el embrion ; larga de 3-6" sobre 4- 6 "' de diámetro, sostenida por el cáliz abierto y coronada por los estigmas persistentes: cinnamodendron, F. canelláceas.

928. Cápsula muy gruesa, de pericarpio algo carnudo, pero que se vuelve seco y al fin se abre por 4, 5 valvas; semillas gruesăs $\mathrm{y}$ sin arilo alguno, 929. - Cápsula nunca de pericarpio carnoso, pequeña, loculícida y cuyas semillas están cubiertas de un arilo pulposo, 930 .

929. Primoroso árbol que se eleva á 45-50' y mas de altura, muy frondoso y corpulento, con hojas pinadas, largas de 18 á $24^{\prime \prime}$, compuestas de 8, 10, 6 pares de hojuelas coriáceas, elíptico-lanceoladas, con una puntita, lampiñas, opuestas, cortamente pecioladas, un poco desiguales, las inferiores siendo algo menores, largas de 3-4 1, 2-69-11" sobre 2-3-3 $1\left[2^{\prime \prime}\right.$ de ancho, con el raquis grueso, cilíndrico $y$ largo de 15" ; peciolos gruesos de 3 á 4 "' de largo. Flores pequeñas, blanquecinas, en panojas arracimadas, axilares ó terminales, en grupos paucífloros, pedunculados ó cimas pequeñas esparcidas á lo largo de los brazos, largos de 8 a $1.5^{\prime \prime}$; cáliz con 4,5 sépalos distintos, cóncavos y mas cortos que la corola, con 4 hasta 15 pétalos coriáceos, aovado-oblongos, torcidos $y$ abiertos; tubo estaminal 8 , 10-festoneado, con tantas anteras sentadas interiormente $y$ alternando con los festones. Ovario 4,5 -locular, con 4 óvulos biseriados en cada celda, sentado en un disco bastante espeso y llevando en el ápice un estilo corto terminado por un estigma ancho, discoídeo ó troncado y asurcado por la circunferencia. Cápsula globosa, de vértice algo puntiagudo, cuyo diámetro es de 3 á $5^{\prime \prime}$, como corticosa, algunas veces con gotas de goma blanquecina en su superficie lam- 
piña y de un color gris algo sucio; semillas gruesas, angulosas y oleajinosas : carapa, F. 117, T. II, G. IV.

930. Curola de pétalos aovado-oblongos é imbricativos; tubo estaminal 10,8-partido, cuyos segmentos subulado-oblongos y obtusos llevan cada cual una antera terminal y ovoídea, 931. - Corola de pétalos valvares adheridos por la base ó distintos; tubo estaminal entero, con 8, 10 dientes y filamentos muy cortos insertos entre los dientes, con anteras terminales subuladas y lampiñas, 932.

931. Arluoles bajitos que se elevan á $20-25$ ' de altura, muy ramosos, con hojas ordinariamente imparipinadas, formadas de $5,10,7$ pares de hojuelas bien enteras, elípticas, oblonga-lanceoladas ú aovado-oblongas, lampiñas, desiguales y cuyas inferiores son menores. Flores en panojas arracimadas, axilares, peduncularlas, pubescentitas, 2, 4 veces mas cortas que la hoja, con pocas divisiones ó brazos 10-paucífloros ó con 11, 3 flores, de cáliz 5, 4-fido; corola de pétalos blanquecinos ó verdoso-amarillos, lampiños y largos de 1-2"'; tubo estaminal corto y peludo, interiormente. Capsula subglobosa con 5-6"' de diámetro, curas semillas ovoídeas están cubiertas de un arilo rojo: triclitia, F. 117, T. II, G. I.

932. Arbol bajito que alcanza á $20-30^{\prime}$ de altura, á veces bastante corpulento, muy fragrante y resinoso, bastante ramoso y coposo, con hojas pinadas formadas de 9,3 hojuelas eliptical-oblongas, bien enteras, largas de 4-3" y anchas de 2-1", sea alternas con la terminal á veces abortiva, ó en el mismo raquis opuestas é imparipinadas, lampiñas. Flores en panojas axilares, flojas, racemiformes, pubescentitas, con las divisiones acorimbadas y cortamente pedunculadas; cáliz 4,5-dentado; corola de pétalos amarillento-blancos. Ovario 3-locular, de celdillas con 2 óvulos colaterales. Cápsula globosa: moschoxylum, F. 117, T. II, G. III.

933. Cáliz encerrado en una vaina bracteolar de ordinario bífida; legumbre comprimida polisperma y estipitada, 934. - Cáliz enteramente desnudo; leg̨umbre leñoso-coriácea, oblonga, monosperma por causa de aborto, 935 .

934. Arboles de ordinario bajitos, que se elevan á 25 ó $30^{\prime}$ de altura, pero algunos alcanzan hasta 45 y $50^{\prime}$, muy ramosos y copozos, no muy corpulentos, de hojas alternas, paripinadas y compuestas de $2,4,6$ y mas pares de hojuelas elípticas, eliptical-oblongas ó lanceolado-oblongas, cuspidadas, de base redondeada, sub-acorazonada ósub-aguzada, lustrosas, lampiñas y como papiráceas. Flores grandes, ordinariamente color carmesí, fạsciculadas ó en racimos grandes y colgantes, mas ó menos pediceladas, con brácteas grandes y caducas, de cáliz colorido 4,5-fiło; corola con 5 pétalos iguales mas cortos ó mas larguitos que los estambres en número de 11, 10 y á veces 15 , insertos en el vértice del tubo calizinal. Ovario estipitado Y cuyo ginóforo está adherido con el tubo del cáliz: brounea, F. I30, S.-F. 2 T. IV, G. III.

ys. Arbol que se eleva hasta 50' ó 60' de altura, bastante coposo y asaz corpulento, con hojas paripinadas, alternas, compuestas de 4, 3 pares de hojuelas oblongas, lampiñas, largas de 8-5" y obtusas. Flores en espigas densas y elongadas, compuestas por la base y 
como arracimadas, largas de $6-10^{\prime \prime}$ y formadas de grupos de flores, cujo cíliz campanudo es 5, 6-dentado: corola con 5, 6 pétalo ignales, obaovarlos, pestañosos, largos de $2^{\prime \prime \prime}$, dos veces mas que el cíliz; estambres 10, 12, alternativamente estériles y cubiertos de vello decíduo, esertos: mora, F. 130, S.-F. 2, T. V, G. IV.

936. Arbol grande que se eleva á $90^{\prime}-100^{\prime}$ de altura, muy coposo y bastante corpulento, con hojas simples alternas, cortamente pecioladas, lanceoladas ó lanceolado-elípticas, peninervias y con venas delicadas, de vértice con una punta obtusa y aguzalias por la base, lampiñas, de forma y tamaño muy valiados; yema globosa. Flores color de escarlata, en cimas umbeliformes, ordinariamente 3, 9-fioras, pedícelos delgados y tan largos como las flores, de cáliz con 7 sépalos; corola de 5 pétalos torcidos; estambres 15,20 , de tubo 5, 3 -fido, con los lóbulos anteríferos rectos, anteras lineares estrorsas. Ovario sin líneas espirales, 5-locular, con dos ó algunos óvulos en cada celdilla; estilo cilíndrico con 5 estigmas lanceolados y recorvados: moronobea, F. 96, T. IV.

937. Cuyos filamentos son soldados en tubo, 938. - Filamentos reunidos mas ó menos por la base, pero no formando tubo nunca, 944 .

938. Fruto abayado ó drupáceo, 939. - Fruto capsular, 942.

939. Baya llena de pulpa jelatinosa; cáliz con 3 sépalos distintos, imbricativos; vejetal muy aromático; hojas simples, 940. - Drupa pequeña amarillenta; cáliz อ̄-partido; vejetal no aromático, hojas bipinadas, 941.

940. Arbol de 50 de altura, ó arbolito de 10-15', con hojas siempre verdes esparcidas, coriáceas, enteras, lampinas y lustrosas, espatuladas, rudondeadas por el ápice y de base aguzada hasta volverse peciolo corto, de cara inferior mas pílida, largas de $2 \cdot 3^{\prime \prime} \mathrm{y}$ anchas de $1^{\prime \prime}$. Flores en corimbos terminales, cuyos pedícelos son mucho mas largos que ellas, moradas $y$ con las anteras amarillas, de cáliz persistente, con los sépalos largos de $l^{\prime \prime \prime}$, anchamente redondos, diminutamente pestañosos; corola con 5,4 pétalos carnudos, imbricativos, erguidos, obaovado-ablongos y mitad mas largos que el cáliz; tubo estaminal sin escamas esteriores, con 10 anteras contiguas en la parte superior y esterior, abriéndose por dos rajaduras lonjitudinales desde su ápice y alcanzando liasta la parte media: iguala al estilo incluso y es un poco mas corto que la corola. Ovario con 2 ó 3 placentas parietales, puntitormes, situadas debajo del medio de la pared, llevando cada una dos óvulos colaterales, campilótropos y ascendentes, aunque sostenidos por un funículo colgante; estilo corto terminándose en 2,3 estigmas globulosos y contiguos. Baya negra, globosa, con $4^{\prime \prime \prime}$ de diámetro, conteniendo pocas semillas, de testa crustácea, negras, lustrosas, orbiculares, anchas de $2^{\prime \prime \prime}$ y convexas por ambos lados, cuyo tegumento interior adhiere á un enilospermo carnudo mitad mas largo que el embrion que contiene y cuya radícula corta es inferior : canella, F. canelláceas.

941. Arbol bajito que se eleva á $25^{\prime}$ de altura, no muy ramoso. de ramos largos y medio desnudos, cuyo tronco tiene como 4 á $6^{\prime \prime}$ 
de diámetro lo mas, muy primoroso cuando es todavía arbusto; hojas alternas bipinadas bastante grandes, lampiñas y de un hermoso verde oscuro, con hojuelas aovado-lanceoladas ó lanceoladas, aguzadas, profundamente aserradas por debajo de lia punta. Primorosas flores azules disciplinadas, en cimas apanojadas axilares ó terminales, de cáliz 5-partido; corola de 5 pétalos oblongo-lineares, convolutivo-imbricativos; tubo estaminal 20,30 -dentado y con 10 anteras sentadas en su garganta. Ovario 5-locular, con óvulos sobrepuestos, inferior, fértil. Drupa amarilla globosa, muy poco carnuda, largamente pedunculada, larga.de $4-6^{\prime \prime \prime}$ sobre $4^{\prime \prime \prime}$ de ancho: melia, F. 117 , T. I.

942. Tubo estaminal entero, 10-dentado, con las anteras insertas interiormente entre los dientes; cápsula abriéndose desde la base, 943. - Tubo estaminal enteramente confundido con el ginóforo, de cuyo ápice salen 5 filamentos largos y fértiles. Arbol alto que se eleva á 50 ó 70' y mas de altura, muy coposo y muy corpulento, con hojas alternas, imparipinadas y compuestas de 8,5 pares de hojuelas oblongas, oblícuas por la base, muy variables, tan pronto mas anchas como mas estrechas, corta ó largamente pecioladas, enteras, lampiñas. Flores en panojas grandes pendientes, con frecuencia largas de como I', pediceladas, amarillo-pálidas y de cáliz 5-lobo; corola de 5 pétalos imbricativos, oblongos, pubescentes, cuya costilla está por la cara interna provista de un pliegue que adhiere con el ginóforo. Ovario 5-locular, y cada celda contiene 8, 12 ơvulos. Cápsula ovoídeo-sub-costilluda; semillas con un ala terminal y conteniendo un endospermo delgado: cedrela, F. 118, G. II.

943. Arbol alto de $50^{\prime}$ á $70^{\prime}$, muy frondoso y corpulento, con hojas alternas paripinadas, lampiñas, compuestas de 6,10 hojuelas, inequilaterales, aovadas ó aovado-lanceoladas, con una punta, de ordinario largas de $2^{\prime \prime}$ sobre $1-11_{1} 2$ de ancho. Flores en panojas axilares, cuyos pedúnculos llevan cimas acorimbadas, de cáliz 5fido; corola de 5 pétalos torcidos; ovario 5-locular, cuyas celdas contienen cada una como unos 12 óvulos. Cápsula leñosa larga de $3-4^{\prime \prime}$, cuyas valvas se abren por la base, quedándose pegadas por el vértice, de semillas con endospermo y provistas esteriormente de un ala terminal oblonga: sweitenia, F. 118, G. I.

944. Fruto seco, capsular ó leguminoso, 945. - Fruto carnudo abayado ó drupáceo, 947.

945. Una cápsula, 946. - Una legumbre. Arbustos ó árboles bajitos muy ramosos, con mayor frecuencia aguijonosos, á veces inermes, de ramitas alampiñadas, tomentosas ó pubescentitas, con hojas simples alternas, pecioladas ó quizás mejor compuestas de dos hojuelas ordinariamente reunidas por la márjen interna y formando una hoja bíloba de cara superior lampina y lustrosa, mientras la inferior es alampiñada sobre las nervaduras, aterciopelada ó pubescentita, con 9, 7, 11 nervaduras, bien pronunciadas. Flores en racimos ó solitarias y opuestas á las hojaś, bastante grandes, blancas, á reces teñidas de color de rosa, de cáliz monosépalo, con el tubo cilíndrico y el limbo ligulado-espatiforme, raramente 5-partido, pero de ordinario entero; corola de 5 pétalos bastantes veces un- 
güiculados y mas largos que el cáliz; estambres 10, á veces distintos, todos fértiles, de los cuales algunos son estériles, insertos junto con los pétalos en el ápice del tubo calizinal. Ovario estipitado cuyo ginóforo es libre del cáliz, terminado por un estigma infundibularlamelado ó cónico. Legumbre bivalve ó indehiscente : baußinia, F. 130, S.-F. 2, T. IV, G. I.

946. Bonitas plantas herbáceas, de ordinario anuales, á veces vivaces y con la raiz tuberculosa, $\mathrm{y}$ alguna que otra vez vejetales frutescentes, de hojas compuestas de 3 hojuelas saliendo horizontales del ápice de un pedúnculo largo, sesiles ó algo pecioladas, alternas, lampiñas ó pubescentitas y con dos estípulas situadas en la insercion del peciolo comun. Flores amarillas ó rosadas en cimas umbeliformes ó en racimos terminales paucífloros, de cáliz persistente 5 -partido ó con 5 sépalos distintos; corola torcida y de 5 pétalos; estambres 10, algo desiguales. Ovario ovoídeo, mas ó menos eónico ó alargado, con 5 celdillas pluriovuladas, de cuyo ápice salen 5 estilos terminardos cada uno por un estigma cabezudo ó apincelardo. Cápsula 5-locular, loculícida, con 5 ángulos, polisperma, cuyas semillas pequeñas, cubiertas de una testa carnosita ó especie de arilo, que se separa del tegumento interior ó lejítímo, contienen un embrion derecho, de cotiledones foliáceos y un endospermo delgado: oxalis, F. 262, G. I.

947. Fruto drupáceo, 948. - Baya redonda ó alargada y como fusiforme, pentágona, polisperma, 5-locular y muy ácida. Árboles bajitos, muy ramosos superiormente, lampiños, con hojas alternas. imparipinadas, bastante grandes y de hojuelas opuestas, ovales. Flores caulinares ó ramales, en racimitos axilares ó en grupos, pedunculadas, rojizas y de cáliz monosépalo pequeño y 5-fido, con los segmentos un poco desiguales, lanceolados ú óvalo-lanceolados, obtusos ó puntiagudos; corola mucho mas grande que el cáliz, de 5 pétalos desiguales mas ó menos abiertos; estambres 10, desiguales, alternativamente mas largos y mas cortos. Ovario redondo ú oval, 5 -locular, pluriovulado, de cuyo ápice salen 5 estilos de estigma oblícuo y como espatulado. Semillas negras, lustrosas, pequeñas $\mathrm{y}$ como lentiformes : arer»hoa, F. 108, G. II.

948. Drupa con un hueso único, 949. - Drupa con 3 pirenas ó huesecitos encrestados por el dorso, muy rara vez con uno solo; arbustos ó raramente árbol bajito, muy ramosos, con hojas simples, opuestas, mas ó menos pecioladas, aovadas, elípticas, oblongeas, lanceoladas ó aovado-lancęoladas, linear-lanceoladas, obtusas ó con una punta, mas ó menos coriáceas, enteramente lampiñas, ó de cara superior lampiña y lustrosa, mientras la inferior está provista de pelo en forma de huso, pegado por su medio $y$ por consiguiente bicuspidarlo, muy punzante y cura picadura abrasa, bien enteras ó dentadas: dos estípulas caducas acompañan á la insercion del peciolo. Flores de ordinario rosadas, en umbelas ó corimbos axilares y mas rara vez solitarias ó mellizas, Jargamente pediceladas, de cáliz 5 -fido con 10, 6 glándulas situadas esteriormente por la base y correspondiendo mas ó menos con las divisiones; corola de 5 pétalos largamente ungüiculados. Ovario casi esférico, de cuyo ápice salen 
3 estilos de ápice ganchudo y troncado: malpighia, F. 1₹0, T. I, G. II.

949. Cáliz sin glándula situada esteriormente y por la base. Arboles bastante grandes, de los cuales algunos se elevan hasta $40^{\prime}$ y mas de altura, ó arbustos, con hojas opuestas, simples, mas ó menos pecioladas, obaovadas, ovales, elíptico-lanceoladas, mas ó menos coriaceass, enteramente lampiñas, del todo tomentosas ó de cara superior lampiña $y$ lustrosa, mientras la inferior es alampiñada, pubescente o tomentosa; cos estípulas persistentes. Flores las mas veces amarillas, en racimosterminales, y de cáliz .̌-partido: corola con 5 pétalos de ordinario ungüiculados; estambres 10 , con las anteras adlieridas. Ovario con 3 celdas 1-ovuladas, 3 estilos distintos puntiagudos. Drupa de hueso 3-locular, ordinariamente amarilla: byrsonima, F. 120, T. I, G. I.

950. Arbolitos, arbustos ó frutices muy ramosos, algunas veces espinosos, cuyas ramitas lampiñas ó provistas de escamitas llevan hojas simples, alternas, de ordinario membranáceas, algo coriáccas, caducas, lampiñas, mas ó menos pecioladas, bien enteras, ohaovadas, ovales, elípticas ú obaovado-oblongas, largas de 1 á $3^{\prime \prime}$, de ápice redondo-entero, escotado ó con una punta; estípulas persistentes. Flores pequeñas blancas ó blanquecinas, mellizas ó amanojadas, axilares y precoces, raras veces solitarias, de cúliz à-partido, persistente ; corola de 5 pétalos iguales, interiormente provistos de una escama doble, de estivacion imbricada; estambres 10 , con anteras introrsas. Ovario 3, 1-locular por cansa de aborto, de óvulo soitario colgante; 3 estilos distintos ó unidos por la base. Drupa pequeña, ordinariamente roja y lustrosa, cuya semilla está formarla de un embrion recto en el eje de un endospermo cartilajinoso : $\bullet r^{\prime} y t h r^{*} x y-$ lum, F. 119.

951. Filamentos reunidos formando una columna en el centro de la flor, 952.-Filamentos nunca reunidos en columna, pero formando un tubo dividido superiormente en muchos filamentos, con las anteras uniloculares é incumbentes. Arboles bajitos ó bastante altos y que se elevan algunos hasta $40^{\prime}-50^{\prime}$ de altura, muy ramosos y asaz corpulentos, de hojas alternas, compuestas, palmeadas y con $5,9,7$ hojuelas eliptical-oblongas, obaovado-oblongas ó elíptico-lanceoladas, subsesiles, en el ápice de jeciolo largo. Flores primorosas, grandes, blanquecinas ó rojas, solitarias, axilares y de cáliz troncado ó sinuoso, pequeño y aterciopelado, campanudo; corola muy grande de 5 pétalos libres, caducos, lineares, largos de 6 á $8^{\prime \prime}$ y anchos de 6 á 8"', tomentosos. Ovario ovoídeo, aterciopelado, כ́-locular, polispermo, de cuyo ápice sale un estilo muy largo filiforme, terminado por un estigna 5-lobo. Cápsula gruesa, redonda ú ovoídea, 5-lccular, loculícida, con muchas senillas lampiñas y gruesas : pachira, F. 103, T. I, G. V.

952. Fruto abayado, 953. - Fruto cajsular seco, 956.

953. Hojas compuestas y dijitadas, baya corticosa muy gruesa, 954. - Hojas simples y punteadas; baya colorada y no gruesa, 955.

954. Hojas siempre compuestas; fruto que parece capsular, pero indehiscente y lleno de una pulpa farinácea. Arbol mas grande, mas 
corpulento y mas frondoso que los demas vejetales conocidos, no muy alto sin embar.go, con ramas muy gruesas, muy largas y horizontalmente estendirlas. Hojas alternas con jó 7 hojuelas elípticas, algo aguzadas, lampiñas y en la punta de un peciolo bastante largo, cilindrico y pubescente. Flores solitarias, axilares, colgantes, blancas, con las anteras purpúreas, cuyo pedúnculo, largo de 4-6" y pubescente, está provisto de 2 brácteas lineares, y de cáliz ancho y con tigura de copa, decíduo y de 5 divisiones; corola de jo pétalos reunidos entre sí casi hasta la parte media y seudo-monopétala, dob'ałos hácia arriba; muchísimos estambres en el ápice de un andróforo muy largo. Ovario oval, 10-locular, con estilo filiforme mas largo que los estambres y terminado por 10 estigmas estrellados. Fruto grueso con 10 celdas polispermas, cuyas semillas, huesosas, son arriñonadas y desnudas en la pulpa: adansonia, F. 103, T. I, G. I:

9\%. Arbustos ó arbolitos de hojas alternas, palmatinervias, estipuladas, pecioladas, acorazonadas, mas largas que anchas, festoneadas ó sub-enteras, algunas veces algo 3-lobas, con una punta por el ápice, alampiñadas, del todo lampiñas, ó de cara superior lampiña, mientras la inferior tiene vello agrupado en las axilas de las venas; peciolo peludo, velludo ó pubescente. Flores pediceladas, axilares, rojas, y de cáliz $\check{5}$ fido, ceñido por la base de un invólucro con 7,12 hojuelas lineares, enderezadas ó sub-derechas y casi igualando al cáliz, otras veces pestañudas abiertas ó reflejas por el ápice; corola de pétalos convolutos por la base y orejudos de un larlo; columna dos veces tan larga como la corola. Baya amarilla : malvaviscus, F. 100, T. III, G. IV.

956. Fruto formado de algunas cajitas ó carpelos agrupados circularmente en la base persistente del estilo ó del lecho, 957. - Una cápsula única; columna J-dentada por el ápice, 968.

957. Base del cáliz envuelta en un calículo, 958. - Base del cáliz sin involícelo alguno, 964 .

953. Tantos carpidios cuantos estigmas cabezudos hay, ordinariamente separándose por fin del eje central; columna anterífera por el ápice, 959.-Carpidios monospermos mitad menos numerosos que los estigmas; columna de ordinario 5-dentada por el ápice, 961 .

959. Carpidios dehiscentes, 960. - Carpidios indehiscentes, 20, J, monospermos, corvos, cinendo al lecho central y por fin separándose de él. Vejetales sub-leñosos, pubescentes, blanquecinos ó algo pinchudos, con hojas deltoírleas ó aovadas, aovado-lanceoladas ó romboídeo-lanceoladas, aserradas ó festoneado-aserradas por arriba de la base, estipuladas. Flores en espigas oblongas terminales ó axilares y reducidas, otras veces fascicularlas o solitarias-axilares, cortamente pediceladas; invólucro con 3 hojuelas lanceoladas ó lineares igualando al cáliz, ó por fin mas cortas que él ú obsoletas; cáliz de lóbulos aovados ó aovado-lanceolados, puntiagudos, tan largos como el tubo ó un poco mas largos que él; pétalos color anaranjado ó amarillos obacorazonados y un poco esertos. Carpidios sin arista, lampiños y pubescentes por el ápice inclinado, llanos por el 
dorso ó tricuspidados, pelierizados por arriba y con el dorso estriado: malvastrum, F. 100, T. II, G. I.

960. Planta herbácea anual, pelierizada, de tallo delgado, ramosísimo, desparramado ó tendido por el suelo, con hojas alternas, pecioladas, palmatífidas y dentadas, estipuladas. Flores axilares, rojas, de pedícelos mas largos que los peciolos. Pétalos largos de $3^{\prime \prime \prime}$; carpidios 20,14, bispermos, separándose los unos de los otros y del lecho central, pelierizados, con dos picos y abriéndose entre ellos; semillas separadas por un tabique transversal; estambres 10, 20; invólucro de 3 hojuelas y persistente : modiola, F. 100, T. II.

961. Carpidios siempre indehiscentes, agarabatados y por fin separándose los unos de los otros; invólucro 5-partido; hojas ordinariamente provistas de 3 glándulas elípticas y rajadas situadas por la cara inferior en la base de las nervaduras, 962. - Carpidios dehiscentes á lo largo de una línea dorsal ó indehiscentes, nunca å̃arabatados y por fin separándose los unos de los otros: involúcelo de 5-15 hojuelas distintas ó reunidas; hojas sin glándula alguna, 963.

962. Vejetales sub-leñosos ó arbustillos muy ramosos, altos de 3 á 5', con las ramas delgadas, largas y algo estendidas, de hojas alternas, pecioladas, palmatinervias tan pronto trífidas como algo lohadas ó enteras, otras veces 5, 3-lobas, color verde mar y pubescentes á la par por la cara inferior; lóbulos aovados ú oblongos, diminutamente aserrados, otras veces romboídeos, contraidos por la base y desigualmente aserrados, con estípulas lineares y pronto caducas. Flores sub-solitarias, axilares rosadas hastante grandes; corola de pétalos tres reces mas largos que el cáliz y de 6-8"'. Segmentos del involúcelo igualando al cáliz mas ó menos ó exactamente. Carpidios pubescentes, tomentosos ó pelierizados: urena, F. 100, T. III, G. I.

963. Arbustos ó vejetales sub-leñosos, mur ramosos, de liojas alternas, pecioladas, acorazonado-redondeadas, oblongo-elípticas, elíptico-lanceoladas, acorazonadas, sub-cordiformes ú orales, mas ó menos aserradas ó festoneado-aserradas, lampiñas del todo ó solamente por la cara superior, ó con vello esparcido y estrellado, punteadas ó no, estipuladas. Flores aglomeradas ó fasciculadas y cuyos glomérulos ó fascículos axilares son acompañados de un invólucro, ó en fin racimosas ó corimbosas, peduncularlas y de ordinario amarillas; cáliz de ordinario mas corto que el inrolúcelo $\mathrm{y}$ raras veces igualándole; corola seudo-monopétala, con 5 pétalos mas ó menos grandes y por consiguiente mucho mas largos que el cáliz. Carpidios lampiños aristados ó espinosos por el vértice ó sin aristas ni espinas tampoco : paronia, F. 100, T. II, G. III.

964. Sin involúcelo ni invólucro comun tampoco, 965. - Sin involúcelo acompañando á la base del cáliz, pero con un inrólucro de 3 hojuelas acorazonadas ó alesnadas, de ordinario con una mancha blanca por la base y situadas en el pedúnculo corto de los glomérulos paucífloros. Plantas herbáceas ó sub-leñosas, muy ramosas, de las cuales algunas se elevan hasta 5 y $6^{\prime}$ de altura, pero por lo comun de 2 á $3^{\prime}$ solamente, de ordinario pelierizadas, cuyo pelo blanco y tieso es á veces punzante; hojas alternas, pecioladas. punteadas, 
frecuentemente palmatílobas, redondeaditas, lobuladas ó enteras, aovadas obtusitas y aserrado-dentadas, otras veces 3 -fidas de los lóbulos oblongos y puntiagudos con estípulas cerdáceas. Flores amarillas, blancas á veces teñidas de purpúreo, en glomérulos axilares, paucifloros, pedunculados, pediceladas ó sub-sentadas, y de cáliz 5fido ó 5-partido, y dos á 3 veces mas corto que la corola, estilo $10-$ fido; carpidios 5 por fin separados los unos de los otros, alampinados, lampiños, pubescentitos ó velludos, mas cortos, mas largos que el cáliz ó igualándole : malachra, F. 100, T. III, G. II.

965. Carpidios monospermos, 966.-Carpidios con 3, 9 semillas, dehiscentes superiormente por la sutura ventral ó á la par por la línea dorsal, por encima de la hase ó por ella. Arbustitos, arbustos ó vejetales sub-leñosos, pubescentes, alampiñados, aterciopeladotomentosos ó aterciopelados solamente, con hojas cordiformes, acorazonado-redondeaditas ó redondeadas, bien enteras, festoneadas ó rara vez desigualmente dentadas ó sub-trílobas, del todo pubescentes, ó alampiñadas, de ordinario con una punta, pecioladas $y$ estipuladas. Flores de ordinario amarillas y algunas raras veces rosadas ó blancas, en panojas terminales, en racimos ó corimbos axilares, otras reces sub-solitarias, de pedícelo articulado hácia el ápice ó por debajo de él; otra vez hácia la parte media mas ó menos largo; cáliz 5 -fido ó 5 -partido, de ordinario dos veces mas corto que los pétalos; estigmas 5 ; carpidios 5 , biarticulados y estrechados por un anillo calloso ó un tabique incompleto, no inflados : 5 ó 10 ni inflados ni contraidos tampoco, con dos picos, y 2, 3 semillas, dehiscentes entre los picos y segun la línea dorsal, ó 12, 30 membranáceos, inflados, redondeados por el ápice, separándose tarde y bivalves por la base, con 4,5 ó 1 semilla por causa de aborto: abutilon, F. 100, T. I, G. II.

966. Dehiscentes hácia el ápice ó indehiscentes, separándose tarde del lecho central, en número de 5, 15, 967. - Siempre indehiscentes, deprimidos, con el pico ó el ápice puntiagudo por la parte interna. Planta herbácea anual peluda ó alampiñada, muy ramosa, con los ramos inferiores estendidos por la base y de vértice ascendente, con hojas alternas, pecioladas largamente, alabardadas ó lobadas por la base, largas de 2 l 2 -3 l /2", estípulas bastante grandes. Flores morado-azuladitas, axilares, solitarias, cuyos pedícelos son largos de 3-4:" ; cáliz profundamente 5-fido, con los segnentos aovados y puntiagudos, tres veces mas corto que la corola bastante grande : anoda, F. 100, T. II, G. II.

967. Arbustillos ó vejetales de ordinario sub-leñosos y raras veces herbáceos, derechos, ramosos, pubescentes, alampiñados, peludos, tomentosos y muy rara vez lampiños; hojas alternas, pecioladas, elíptico-lanceoladas, lanceoladas, oblongas, aovadas, romboídeo-lanceoladas, cordiformes, acorazonado-triangulares ó aovadas, mas ó menos aserradas, festoneado-aserradas, con una punta en el rértice, á veces aguzadas, pubescentes ó tomentosas y aterciopeladas con estípulas. Flores de ordinario amarillas sub-solitarias ó fasciculadas, axilares, apanojadas ó racemosas, terminales ó axilares, con el pedícelo tan pronto articulado como sin articulacion; cáliz 
5-fido ó 5-dentado, de tubo de ordinario anguloso, con 5 ó 10 ángulos, á reces cilındıico ó sub-cilíndrico, por lo comun mas corto que la col ola; carpidios biarrejonados ó bipicudos, raras veces obtusos ó desprovistos de aristas y de pico : sida, F. 100, T. I, G. I.

968. Involúcelo mas ó menos caduco, 969. - Involúcelo siempre persistente, 971.

969. Caduco ó sub-persistente; cápsula loculícida, 970. - Siempre caduco y de 3 hojuelas lanceoladas, ignalando al cáliz; cápsula indeliscente y coriácea. Arboles altos de 25 a $30^{\prime}$, pero que algunas veces alcanzan hasta 50', bastante corpulentos entonces, muy frondosos, lampiños; hojas alternas, largamente pecioladas, coriáceas, acorazonadas, enteras, con una punta por el vértice, con dos estípulas pronto caducas, lampinas y lustrosas. Flores solitarias axilares, mas ó menos largamente pedunculadas, amarillas algo teñidas de púrpura ó purpúreas grandes y primorosas, derechas o colgantes, de cáliz campanudo con 5 rejones y troncado; corola campanuda grande, seudo-monopétala y 5-pétala. Cápsula globosa, con 5 celdas plurispermas, cuyas semillas largas de $4^{\prime \prime \prime}$, trigonal-obaovadas, estriadas y alampinadas, pero velludas por la base y los ángulos: thespesia, F. 100, T. IV, F. V.

970. Vejetales herbáceos y sub-leñosos, pelierizados ó peludos, con hojas alternas, pecioladas, alabardadas é irregularmente dentadas ó 5-lobas é irregularmente a=erradas. Flores solitarias, axilares, grandes, pedunculadas, de cáliz espatiformes, cuya base está acompañada de un involúcelo con $6,10,9,22$ divisiones mas cortas que el cáliz y lineares; corola amarilla dos ó tres veces mas larga que el cáliz. Cápsula alargada 5-locular, loculícida, cuyas celdillas contienen michas semillas lampinas $\mathrm{y}$ estriadas ó peludo-sub-estriadas : abetmoschus, F. 100, T. IV, G. I.

971. Cáliz 5-fido ceñido por un involúcelo con 7 á 12 divisiones mas ó menos lineares, 972.-Cáliz cortamente 5-dentado, mas corto que el involúcelo tripartido y cuyas divisiones foliáceas acorazonadas y muy grandes, aguzadas, undulosas por los bordes que se juntan, hacen parecer el cáliz como triangular y alcanzan hasta la mitad de la corola. Arbustos ó plantas herbáceas alguna vez, con hojas alternas, pecioladas, grandes, acorazonadas, 3 á 5-lobuladas, con estípulas caducas, lanceolado-alesnarlas, largas de $1^{\prime \prime}$. Flores amarillas ó volviéndose algo purpurinas, en racimos ó cimas paucifloros en el rértice de ramitas axilares, pedunculadas, de cáliz campanudo 5-dentado y abierto; corola grande. Cápsula 3, 5-locular, loculícida por el ápice, cuyas semillas, bastante gruesas y verduscas, llevan algodon: gossypium, F. 100, T. IV, G. III.

972. Cáliz siempre 5-fido, cuyo invólucro es 8,10 -fido ú 8, 10dentado, 972 bis. - Cáliz 5-fido ó 5-dentado, cuyo invólucro es formado de hojuelas distintas, simples, ensanchadas ó no por el ápice. Arbustos ordinariamente, ó á veces arbolitos y plantas herbáceas, pubescentes, aterciopelados, escabrosos, aguijonosos y lampiños, muy ramosos, de hojas simples, alternas, largamente pecioladas, acorazonadas, mas ó menos lobuladas y á la par festoneadas. aserradas o ni el uno ni el otro. Flores bastante grandes y de ordi- 
nario hermosas coloradas, rosadas, amarillas, color carmesí, etc., axilares, pedunculadas, solitarias y de cáliz mas ó menos aplicado á la cápisula, algunas reces rentrudo y hasta carnudo; corola seudomonopétala giande, con J pétalos iguales. Cápsula 5-locular, loculícida, con las celdillas conteniendo algunas semillas lanıpinas, á reces pubescentes y hasta algo algodonozas: hiliscus, F. 100, T. IV, G. III.

972 tis. Arboles bajitos que se elevan á 15-25', ó arbustos crandes, con hojas alternas, pecioladas, bastante grandes, acorazonadoredondeadas, mas ó menos cuspidadas, bien enteras ó apenas festoneadas, de cara superior lampiña y lustrosa, mientras la inferior es pubezcente, con 1 ó 3 de las nerraduras glandulosas por la base; estípulas anchas y decíduas. Flores amarillas y cuyo color es cambiante $y$ que varia del amarillo pálido al anaranjaco $y$ hasta al rojo bastante subido, ter minales y axilares cuyos pedúnculos son 1. 3foros; cáliz 5-fido, envuelta la base por un invclúcelo 8,10 -fido ú 8, 10-dentado, largo de 6 á 12"', mientras el cáliz lo es de 10, 18, $24^{\prime \prime \prime}$; corola grande con los pétalos largeos de $2-212^{\prime \prime}-4^{\prime \prime}$. Estilo grueso y pubescente por el rértice, cortamente 5 -fido, con los estigmas dilatados. Cápsula 5-locular, loculícida, cuyas celdas plurispermas, son divididas lonjitudinalmente por tabiques falsos, incompletos y que se separan en dos membranas cuando se abre: pasitium, $F$. 100, T. IV, G. IV.

973. Estambres siempre diadelfos; cápsula comprimida, bilocular, loculícida, con semillas carunculadas, 974. - Estambres tan pronto diadelfos como monadelfos, 975 .

974. Plantas herbáceas ó sub-leñosas, muy ramosas, derechas, estendidas ó desparramalas, altas de 6 á $122^{\prime \prime}$ alcanzando á reces hasta $3^{\prime}$; hojas simples, alternas, sub-sentadas ó cortísimamente pecioladas, enteras y de ordinario lineares. Flores bonitas, pequeñas, rosadas ó blancas, en racimos ó espigas terminales, cuycs pedícelos ordinariamente articulados llevan 3 bracteitas por ó hácia la ba:e, irregulares, casi amariposadas y de cáliz con 5 sépalos. cuyos 2 laterales y mayores son colorados; corola de 3 pétalos por causa de aborto, en parte adheridos, cuyo anterior ó quilla es diforme ó encrestado ó sin cresta, y en ese último caso adhiere con los estam bres y con el pétalo superior por la base ; estambres 8,6 , adherentes con la corola, de anteras uniloculares abriéndose por un poro terminal. Orasio pequeño oroídeo, 2-locular, de curo ápice sale un estilo simple mas ó menos largo, terminándose por un estigma hueco y bílobo, cuyo labio superior acogullado es barbudo jor el ápice encorvallo, otras veces es papiliforme. Semillas con una carúncula bipartida de segmentos aplicados á la testa, diminuta o distinta de las semillas, tríloba y galeiforme; endospermo abundante : polygala, F. 107, G. I.

975. Estambres 8; fruto samaroídeo, 976. - Estambres 4; fruto globoso erizado, especie de nuececita; arbusto formado de muchos tallos derechos, saliendo de una especie de cepa, pero que no tadan en doblarse por el rértice que lleva muchas ramitas que son ascendentes y erguidas, largos de 1 l 12 á 2 ', pubescentes, así como 
las ramitas cuando tiernos. Hojas simples, alternas ó esparcidas, elíptico-lanceoladas, arrejonadas, largas de 4-7-10"', sin el peciolo tan largo como el limbo, y anchas de 11 [ $2-2^{\prime \prime \prime}$, espesitas, pubescentes por ambas caras, algo tiesas y tanto mas pequeñas cuanto se acercan mas del vértice de las ramitas en donde se vuelven bracteiformes para acompañar á las flores, algo purpúreas, axilares ó arracimadas, solitarias en el ápice de un pedúnculo casi horizontal, moradusco, largo de $1-11_{[} 2^{\prime \prime \prime}$, con dos bracteitas opuestas situadas hácia su parte media, casi sesiles, lanceoladas, moraditas por la base: cáliz de 4 sépalos petaloídeos, convexos, pubescentes esteriormente, moraduscos, casi iguales, óvalo-lanceolados, poco puntiagudos $\mathrm{y}$ de base casi redondita; corola de 5 pétalos mucho menores que los sépalos, desiguales, no simétricos, cuyos tres posteriores son ordinariamente reunidos por las uñas; estambres posteriores, de anteras adheridas al ápice del filamento y apenas distintas de él, abriéndose por dos poros. Ovario unilocular con dos óvulos mellizos colgantes de la parte superior y algo lateral de la celdilla, horizontal en el ápice del pedúnculo, algo ovoídeo, velludo; estilo alesnado enderezándose pronto para llegar á la altura de los dos estambres mayores que le acompañan; se dobla un poco por el vértice y se termina por un estigma bílobo y algo enderezado. Fruto globoso del tamaño de un guisante, moradusco, con muchas puas delgaditas, diverjentes y con la punta agarabatada: krameria. F. 107, G. III.

976. Arbustos ó vejetales sarmentosos, á veces bastante altos, lampiños, con hojas simples, alternas, cortamente pecioladas, coriáceas, pequeñas, lampiñas $\mathrm{y}$ lustrosas por la cara superior, mientras la inferior es pubescentita ó alampiñada, aovado-lanceoladas, aovadas ú oblongas, redondeaditas ú ovales, enteras, articuladas por la base y provistas de dos glándulas estipulares. Flores primorosas rosadas ó moraditas en racimos ó panojas axilares y terminales, de cáliz con 5 sépalos decíduos. cuyos dos laterales mayores y petaloídeos forman alas; corola de J́ pétalos, cuyos dos laterales son escamiformes, el anterior ó quilla bilobado, con un apéndice que se dobla $\mathrm{y}$ se estiende por el dorso junto y entre los lóbulos. Anteras biloculares abriéndose por dos poros introrsos. Orario unilocular por causa de aborto del carpelo anterior, oval, comprimido, cuyo ápice se prolonga un poco á manera de cresta muy poco desarrollada: en el lado opuesto á ella se percibe una línea poco marcada que parece el principio del estilo que sigue elevándose $\mathrm{y}$ se termina en un estigma crestado $y$ verde : la parte opuesta al estilo se prolonga despues de la fecundacion con la cresta para formar un ala. Samara con una semilla sin carúncula ni endospermo tampoco: securidaca, F. 107 , G. II.

977. Arboles bajitos ó arbustos muy ramosos, espinosos frecuentemente, con hojas alternas, coriáceas, lampiñas, lustrosas, compuestas y ordinariamente unifolioladas, cuya hojuela grande se articula con el ápice del peciolo desnudo, marjinado ó alado, con puntitos ó glandulitas transparentes. Flores precicsas blancas, mas ó menos teñidas de rosado ó de púrpura, en grupos axilares o terminales paucífloros; de cíliz acubileteado 5, 3-fido, con los lóbulos 
deciduos; corola con 5,8 pétalos, mucho mas largos que el cáliz, derechos ó algo doblados hácia fuera; bastante espesos y casi carnudos, sin uñas, con glandulitas amarillentas transparentes, prefloracion algo imbricada; estambres muchos, de 20 á 60 , insertos en un disco hipojínico bastante desarrollado, de anteras oblongas, terminales y basifijas. Ovario aovado ó esférico, plurilocular, con óvulos biseriados, de cuyo ápice sale un estilo bastante grueso, cilíndrico, corto y terminándose en un estigma espeso, algo deprimido y esférico : el fruto es una liesperidia ó naranja mas ó menos gruesa, de forma variando entre el esférico y el óvalo: de color mas ó menos amarillo, cuya concha contiene muchísimas glandulitas llenas de esencia, con 7, 9 celdas mono ó paucispermas, de paredes membranosas: citrus, F. 115, T. I.

978. Cáliz no adherente y ovario súpero, 979. - Cáliz mas ó menos arlierente y ovario mas ó menos ínfero, 1086.

979. Estambres libres, 980. - Estambres nunca libres pero sí mono, di ó poliadelfos, 1025.

980. En número definido mas ó menos constante, 981. - Indefinidos y muchos, 1023.

981. Cinco estambres ó menos, 982. - Mas de 5 estambres, 991.

982. Menos de 5) estambres, 983.-Cinco estambres, 986.

883. Siempre 4 estambres, 985. - De 3 á 4 estambres, 984.

984. De 3 estambres y algunas veces de 4 ; vejetales lechosos; fruto drupáceo, 275. - Siempre 3 estambres; vejetales nunca lechosos, fruto seco. Arbustos ó bejucos muy ramosos y á veces bastante altos: hojas simples, opuestas, pecioladas, lampiñas, elípticas, eliptical-oblongas, oblongas ú oval-oblongas, bien enteras ó aserraditas, estipuladas. Flores amarillentas mas ó mencs verduscas, en cimas ó pañojas axilares mas cortas, iguales ó mas larguitas que las hojas, de brazos con bastante frecuencia dicotomos, lierrumbrosopuinosos ó aterciopelados, otras veces peludo-aterciopelados ó lampiños cargando á veces con pedícelos estériles mas ó menos numerosos y entremezclados con las flores pediceladas, de caliz 5 -fido; corola con 5 pétalos; estambres insertos por adentro de un disco grande cuyas anteras, transversalmente dehiscentes, tienen las celdillas confluentes. Ovario 3-Jocular, cuyos estilos son coherentes inferiormente, de óvulos definidos, ascendentes, cuyo embrion no tiene endospermo. Fruto formado de carpidios estriados, coriáceos, que por fin se separan, aquillado-comprimidos, medianícido-bivalves, con las semillas pegadas por su base, ordinariamente por medio de un ala inferior y alargada: hippocratea, F. 12:3.

985. Arbustos bajitos, ramosos y con las ramitas tetrágonas, lampiñas y de hojas simples, opuestas ó verticiladas, cortamente pecioladas, obaovadas, ovales, oval-oblongas ó espatuladas mas ó menos aserradas, del todo lampiñas ó de cara inferior pubescentita, coriáceas y estipuladas. Flores en cimas axilares, pedunculadas y mas cortas que las hojas; cáliz 4-partido; corola de 4 pétalos redondeados, planos y abiertos; estambres insertos por la mairjen del disco en que está anidado el ovario, de 4 celdillas uniovuladas, de cuyo ápice sale un estilo corto terminado por un estigma 4-denta- 
do ; a veces está coronado el ovario por 4 estigmas sesiles. Drupa colorada, pequeña, pisiforme, nonosperma; semilla enderezada, de testa membranosa y provista de un arilo diminuto: mygenda, F. 83, G. II.

986. Fruto drupáceo, 987.-Fruto capsular, 942.

987. Hojas compuestas, 983. - Hojas simples, 989.

988. Arbol de $15-40^{\prime}$ de altura, ramoso, con hojas compuestas de 2, 3, 1 pares de hojuelas, oval-redondeaditas, de ápice escotado ó redondo, bien enteras, larģaménte pecioladas, lampiñas y largas de 1-1 1 [2". Flores pequeñas, apanojadas, axilares, y de cáliz jo partido ó J-lobo; corola con 5 pétalos; ovario unilocular, cuyo óvulo cuelga de un cordoncito central y ascendente: 3 eitigrmas subsesiles. Drupa ovoídeo-oblonga encarnada: 1’hus, F. 128, G. I.

989. Flores nunca polígamas; todos los estambres fértiles; árbol bajito, de ramas tortuosas y estendidas ó arbusto de hojas alternas, pecioladas, trinervias, aovado-sub-redondas, algo aserradas, con la cara inferior tomentosc-blanquecina, así como los peciolos, ramitas y flores; espinas estipulares mellizas, cuya esterior está encorvarla. Flores en corimbos axilares, de cíliz abierto, 5-fido, circunciso hácia la parte media del tubo despues de la florescencia, y la parte que queda es sub-adherente con la base del fruto; disco glanduloso adherilo al cáliz que lleva 5 pétalos insertos en él ; así como los estambres, pero mas interiormente. Estilos simples 2, 3. Drupa subglobosa, lampiña, de hueso sin valvas, bilocular, 2-espermo, mas rara vez 1, 3 locular, y entónces 1, 3-espermo, con semillas sulorbiculares, comprimidas, no asurcadas $\mathrm{y}$ sin endospermo: zizyphus, F. 124, G. I.

990. Primorosos árboles que se elevan á 40-ふ̌ $0^{\prime}$ de altura, etc., 272

991. En número de 8 ó de 10. Fruto capsular ó legumínoso, 992. - En número variable de 6 á 10. Fruto drupáceo, 994.

992. Siempre 8 estambres. Fruto capsular, 993. - Siempre 10 estambres, alguna rara vez menos por causa de aborto. Fruto leguminoso ó capsular, 999.

993. Arbusto lampiño y ramoso, quo se eleva á como $15^{\prime}$ de altura lo mas, pero de ordinario de $\frac{1}{2}$ á $5^{\prime}$ nada mas, con hojas alternas simples, algunas reces opuestas, pecioladas, elíptico-lanceoladas, con una punta, enteras ó á reces dentaditas, largáa de $2-21,2^{\prime \prime}$ sobra 10-1-1"' de ancho. Flores blanco-amarillentas, en colimbos terminales, multífloros, muy olorosas, pequeñas, y de caliz 4 -partido sin apéndices; corola de 4 pétalos ungüiculados, aovados, abiertos y mucho mas largos que las divisiones calizinales, insertos junto con los estambres salientes y dispuestos en 4 pares, de anteras redondeaditas. Ovario 4, 3-locular oroídeo, poliovulado, de cuyo vértice sale un estilo simple y alesnado. Cáp:ula de 4 celdas conteniendo muchas semillas diminutas, glohosa y con el estilo persistente: lawsonia, F. 13 כ.

994. Ovario 5, 1-locular, cuyas coldas contienen '2 óvulos cada una, 995. - Ovario 5, 1-locular con un solu huevecillo en cada celda. El fruto es una especie de nuez coriácea, indehiscente, de 
color gris oscuro, arrinonada, larga de 12 á $15^{\prime \prime \prime}$ sobre 7 á $9^{\prime \prime \prime}$ de ancho situada en el vértice del pelúnculo carnıdo piriforme y que parece una pera bastante gruesa, roja ó amarilla, lustrosa. V́éase 27\%.

995. Flores polígamas, de 6 a 10 estambres con las anteras oblongas, 274. - Flores nunca polígamas, 995.

996. Cáliz 4, 5-fido ó 4, 5-dentado; corola 4, 5-fida ó con 4, „) pétalos, 997. - Cáliz dininuto siempre 4-fido; eorola con 4 prítalos imbricados. Arbustos ó árboles bajitos, resinosos, lampiños, con hojas alternas ú opuestas á la par, provistas de puntitos transparentes imparipinadas ó 1 folioladas, formadas de 3, 5, 7 pares de ho. juelas aovadas ó deltoídeo-redondeaditas, aovaro-oblongas, aoradolanceoladas ó elípticas, enteras o mas ó menos festoneaditas $y$ lampiñas. Flores en corimbos apanojados, blancas y pequeñas; estambres hipójinos 8 . Ovario unilocular, con 2 óvulos colgantes ; estioma sentado y cabezudo. Drupa pequeña de $4^{\prime \prime \prime}$ de diámetro á lo mas y ordinariamente de 2 solamente : amyris, F. 127.

99\%. Corola de 4, 5 pétalos valvados, 998.-Corola 4, 5-fida. Arbol grande, corpulento, frondoso, de corteza blanquecina que deja chorrear ura resina líquida que no tarda en volverse sólida, de olor muy agradable, se eleva hasta $60^{\prime}$ y mas de altura. Hojas alternas, comprestas, imparipinadas, bastante grandes, largas rle 6-8", formarlas de 3, 4 pares de hojuelas elíptico-lanceolarlas, con una punta, bien enteras, lampiñas, casi sentadas, inequilaterales, el lado superior siendo mayor, opuestas, algo undulosas por los bordes, algo desiguales y largas de $4-41 \Omega^{\prime \prime}$ sobre $20-21^{\prime \prime \prime}$ de ancho. Flores pequeñas blanquecinas, pedunculadas, en racimos terminales, y de cáliz 4, 5dentado ; estambres 8, 10, con anteras oblongas. Ovario 4, J-loc rlar con un estilo simple, de ápice 4, 5-lobo. Drupa globosa, coriácsa, abriéndose tarde, con 5, 1 huesecitos, con un surco á lo largo de la línea por donde debe abrirse, lampiña: hedwigia, F. 125, G. III.

998. Arboles resinosos bastante grandes, lampiños, con hojas alternas, compuestas, imparipinadas ó trifolioladas, con 5, 7 hojuelas bien enteras, ordinariamente coriáceas, pecioladitas, elíptico-lanceoladas, aguzadas, langas de $4-2^{\prime \prime}$ sobre $12^{\prime \prime}-6^{\prime \prime \prime}$ de ancho. Flores en racimos ó corimbos axilares, 2 á 3 veces mas cortos que la parte desnuda del raquis, de ordinario ternadas y cuyo pedícelo es dos veces tan largo como ellas; de cáliz 4, 5-dentado ; corola con $\frac{1}{x}, 5$ pétalos valvalos, revueltos por el ápice y pubsscentes por la márjen; estambres 8,10 , con anteras oblongas. Ovario 4, 5-locular, con un estilo de ápice 4, 5-lobo. Dirupa coriácea, abriéndose tarde y con 51 huesecito : icica, F. 125, G. I.

999. Una lęumbre lejítima, 1002. - Una cápsula, 1000.

1000. Cápsula muy larga, con las semillas huesosas y ala las, 1001. -Cápsula no muy larga ni con semillas huesosas ni aladis, 1020.

1001. Cípsula como silicuitorme, medianícida, 3-valve y larga de 8 á $11^{\prime \prime}$. Arbol bajito, hastante coposo y bonito, que se eleva solo á 15-25' de altura, con primorosas hojas alternas, descompuestopinatisectas, tres veces pinatisectas, largas de 18 a $2 t^{\prime \prime}$, con los segmentos u hojuelas espatulados ó elípticos, obtusos, con glándulas 
estipitadas, pubescentitas, muy caducas y situadas por la cara superior del raquis comun, de los raquises secundarios y tambien de los terceros entre la insercion de los de cada par de hojas compuestas ó en la de los peciolulos de las hojuelas, verde subido y lampiñas 6 alampiñadas cuando adultas y algo glaucas, pero de cara inferior pubescente cuando tiernas; de cada lado de la insercion del raquis hay un tuberculito que parece reemplazar á las estípulas que faltan. Flores preciosas, blancas, olorosas, en grandes panojas axilares en el vértice de las ramitas, derechas, de brazos pubescentes con una bracteita aterciopelada por la insercion, de cáliz con 5 segmentos desiguales, petaloídeos, lanceolado-estrechos, casi tan largos como los pétalos; corola con 5 pétalos desiguales, sentados, un poco espatulados; 10 estambres insertos junto con los pétalos en la garganta del cáliz, de filamentos alesnados, pubescentes, de los cuaies 5 son estériles, desiguales. Ovario fusitorme, pubescente, estriado y algo hexágono, verdoso y sostenido por un podójino, unilocular, poliovulado y de cuyo ápice sale un estilo blanco, simple, arqueadito, alesnado, pubescente, tan largo como los estambres, terminándose por un estigma pequeño, glanduloso y puntiforme. Cápsula tríquetra, colgante, larga de 8 á 12", con semillas como huesosas, prietas, con tres ángulos poco marcados, turbinadas y con tres alas membranosas saliendo de los ángulos, pegadas por un podospermo muy corto en una especie de celdilla como corchosa: moringa, F. 130, S.-F. 2, T. V, G. III.

1002. Legumbre indehiscente, 1003. - Legumbre dehiscente.

1003. Llena de pulpa mas ó menos abundante, 1004. - Sin tripa ó pulpa alguna, 1007 .

1004. Legumbre cilíndrica ordinariamente muy larga, con tabiques membranosos transversales que la separan en celdas monospermas, 1005.- Legumbre gruesa como romboídeo-redondeada, de cáscara leñosa, unilocular, conteniendo una sustancia como farinácea en lugar de tripa lejítima, 1006.

1005. Arboles bajitos ó á reces bastante grandes y asaz corpulentos, muy ramosos, con hojas alternas, compuestas, estipuladas, paripinadas, cuyo raquis es ó no glandulífero, formadas de $4,8,10$, 20 pares de hojuelas, opuestas, pecioladas, algo coriáceas, aovadas, oblongas ó aovado-oblongas. Flores en racimos colgantes, amarillas ó rosadas, pediceladas, y de cáliz con 5 sépalos sub-distintos y decíduos; corola de 5 pétalos, algo ungüiculados, abiertos, un poco desiguales, redondos, obtusos, cóncavos y algo undulosos por los bordes; estambres 10, todos fértiles ó de los cuales 3 abortan y son diformes, con anteras largas, aovado-oblongas, reventándose superiormente por rajaduras incompletas ó hácia la base por poros. Ovario largo, cilíndrico, sostenido por un podójino, y de cuyo ápice sale un estilo simple, arqueado, terminado yor un estigma glandular puntiforme : cathartocarpus, F. 130, S.-F. 2, T. V, G. II.

1006. Arbol muy grande y muy corpulento, frondosísimo, que se eleva ¿ mas de 50' y $60^{\prime}$ de altura, resinoso; hojas alternas compuestas de dos hojuelas coriáceas, lustrosas y lampiñas, subsesiles, largas de $3^{\prime \prime}-1$ [ 4 sobre $18-20^{\prime \prime \prime}$ de ancho, inequilaterales, oblícua- 
mente oblongo-lanceoladas, enteras, obtusas; hay dos estípulas. Flores blanquecinas en cimas terminales, con pedícelos cortos cura base está acompañada de dos brácteas membranosas y decíduas, de cáliz 4, 5-partido, pubescente, de limbo decíduo, mientras el tubo casi leñoso es persistente, acompañado de dos bracteitas; corola con 5 pétalos mas largos que el cáliz, algo desiguales, ovales, ungüiculados, puntiagudos, abiertos, con puntitos transparentes; estamıres 10 , cuyos filamentos, blancos, alesnados, largos de $15^{\prime \prime \prime}$ y filiformes, son arqueados por la parte media algo crecida y llevan anteras oblongas y esertas; se insertan junto con los pétalos en el vértice del tubo del cáliz. Ovario estipitado, unilocular, con alģunos óvulos comprimidos ; estilo simple, filiforme, mucho mas largo que los estambres, arqueado y terminado por un estigma cabezudo: hymenea, F. 130, S.-F. 2, T. III, G. II.

1007. Samaroídea ó con un ala, 1008. - Nunca samaroídea y siempre sin ala, 1009.

1008. Arboles resinosos grandes, coposos y corpulentos, que se elevan á 40 y $50^{\prime}$ de altura, con hojas alternas compuestas é imparipinadas, de hojuelas membranosas, pecioladas, alternas, oblongas ú ovales, obtusas y con muchas glandulitas transparentes. Flores blancas ó rosaditas, en racimos axilares en el vértice de las ramitas, mas largos que las hojas, pediceladas, y de cáliz troncado apenas 5dentado, campanudo; corola amariposada mayor que el cáliz; 10 estambres estendidos y algo inclinados, mas cortos que los pétalos y con anteras arrejonadas. Ovario estipitado, estrecho, delgado, arqueado, oblongo, mas largo que los estambres, terminado por un estigma comprimido y apenas distinto. Legumbre samariforme, membranosa con 1 o 2 semillas arriñonadas ocupando el vértice, envueltas en un líquido balsámico amarillento, que mas tarde se vuelve resina, ó sin ese líquido, que se halla en el pericarpio, colgante del pedícelo y pegada por el ala, larga como de $21_{1} 2-2^{\prime \prime} y$ ancha de $5^{\prime \prime \prime}$ : myrospermum, F. 130, S.-F. 1, T. II.

1009. Legumbre erizada ó espinosa, 1010. - Legumbre nunca erizarla ni espinosa, 1011.

1010. Arbustos sarmentosos de las orillas del mar, muy ramosos, de tallos larguísimos y aguijonosos, con hojas alternas, grandes, con estípulas grandes y pinatífidas, paripinadas y formadas de 5,8 pares de hojuelas pubescentes ó alampiñadas, ovales, oval-oblongas ó aovadas, arrejonadas y con puntitos transparentes; raquises primarios y secundarios, pubescentitos y con aguijones corvos. Flores amarillas en racimos axilares en el vértice de un pedúnculo comun largo y aguijonoso, con pedícelos cortos que salen de la axila de una bráctea lanceolada, decídua y mas larra que la flor; de cáliz 5 -partido, campanudo; corola de 5 pétalos casi iguales, cóncavos, lanceolados; 10 estambres inclusos, de filamentos peludos inferiormente y con anteras mediifijas. Ovario larguito y oval, cuyo ápice lleva un estilo simple mas largo que los estambres, terminado por un estigma algo cabezudo. Legumbre anchamente aovalo-oblonga, convexo-comprimida, bivalve, con pocas ó l sola semilla, cortamente estipitada; semillas grandes, huesosas, lustrosas, blancas ó 
amarillentas, sub-comprimido-globosas : guilandina, F. 130, T. II, G. II.

1011. Legumbre como torulosa y linear, 1012. - Lequmbre nunca torulosa ni linear, pero mas ó menos comprimịda, 1013.

1012. Arbol bajito, bastante fronảoso y de ramas alco estendidas, que se eleva á 15 ó $20^{\prime}$ de altura, con hojas alternas, bipinadas con las pínulas apiñadas; peciolos primarios abortivos, mientras los secundarios, alargados, alados y linear-aguzarlos, son paripinados, con hojuelas diminutas, oblongas o aovadas, obtusas, desiguales, las inferiores mayores y largas de $2^{\prime \prime \prime}$ sobre $]_{[} 2^{\prime \prime \prime}$ de ancho: las superiores suelen abortar, son muy numerosas $y$ hay de 8 hasta 28 pares de ellas en las pínulas de los individuos jovenes, mientras que en las de los adultos hemos contado hasta 80 . Flores amarillas en racimos axilares ó terminales, pedunculadas, y de cáliz 5-partido, cuyos segmentos lanceolados se doblan por abajo aplicándose al pedícelo, caducos y amarillentos, pero de base persistente y verde. Corola de 5 pétalos algo desiguales, ungüiculados, ovales, abiertos, con el superior ó estandarte mas ancho que los demas, con una mancha rojiza, pero no tarda en tomar ese matiz, unduloso por los bordes, algo pubescente interiormente; 10 estambres salientes, algo corvos, pero sin embargo enderezados, con anteras rojizas enderezadas, ovales y mediifijas, de filamentos peludos por la mitad inferior é interna. Ovario elongado, comprinido. moradito y con puntitos blancos, algo cuadrangular; estilo bien distinto casi alesnado, cilíndrico, larguito y arqueado, terminado por un estigma poco distinto, oblícuo, algo franjeado por los bordes y con una boca ó abertura central. Legumbre linear, larga de 4 á 5", casi cilíndrica, pero comprimida entre las sernillas, puntiaguda, bivalve, con algunas 0 pocas semillas oblongo-cilindricas, de color aceitunado, con manchitas irregulares mas pálidas, lustrosas y muy duras, con una línea mas oscura saliendo del estremo ombilical y que se esticnde á lo largo de la cara y divide la semilla en dos partes iguales : parkinsonia, F. 130, S.-F. 2, T. II.

1013. Nuy comprimida, aguzada por ambos estremos, membranáceos sin ventallas, pero que se revienta lonjitudinalmente, segun el surco que se ve á lo largo de sus caras chatas, con 2 semilas solamente, 1014 -Nas ó menos comprimida y de dehiscencia bivalve, polisperma, 1015 .

1014. Artol de tronco tortuoso y anfractuoso, bastante corpulento. poco largo, pero con ramas gruesas y derechas mas largas que ćl : se eleva á 30-40' de altura, ba:tante frondoso, de ramitas con frecuencia espinosas; hojas alternas, paripinalas y compuestas de 3,4 pares de hojuelas obaovadas, remalladas y lampiñas; base del raquis con una espina estipular. Flores amarillas en racimos axilares erguidos casi tan largos como las hojas y de 2 a $211^{2} 2^{\prime \prime}$, pediceladas, y de caliz 5-partido, con los segmentos reflejos, desiguales, memìranáceos, algo purpúreos y decíduos, mientras persiste el tubo corto, campanudo y verde ; corola con 5 pétalos, casi iguales, dos veces mas largos que el cáliz, abiertos, obovales y un poco puntiagudos; estambres 10 , salientes, de filamentos alternativa- 
mente desiguales, con pelo por la base, de anteras orales, insertos junto con los pétalos en la parte superior del tubo del cáliz. Ovario lanceolado, comprimido y con un surco lonjitudinal en cada cara, 3-ovulado, cortamente estipitado, con estilo capilar, recto y algo mas corto que los estambres, terminado por un estigma cahezudo. Legumbre larga de $20,2 \cdot 2 " \prime$, sin el pedícelo, que lo es de $21_{[} 2-3^{\prime \prime \prime}$, y ancha de $5^{\prime \prime \prime}$ : hematoxylon, F. 130, S.-F. 2, T. II, G. I.

1015. Siempre 10 estambres, cuyas anteras no se abren por dos poros en su ápice, 1016.- Estambres 10, pero de los cuales 3 abortan siempre $y$ son mas ó menos diformes; anteras abrićndose por dos poros ó grietas incompletas por el ápice; legumbre comprimida ó cilíndrica, seca ó á veces con alğuna pulpa, con frecuencia plurilocular por causa de seudo-tabiques membranosos, 1019.

1016. Legumbre siempre comprimida, 1017. - Legumbre comprimida, oblonga, seca y bivalve ó como abayada, indehiscente é hinclıado comprimida; estigma cóncavo, diminutamente pestañoso ; árbolcs bajitos ó arbustos orlinariamente aguijonosus, lampiños ó pubescentes, con hojas paripinadas, alternas, estipuladas, compuestas de $2,3,6,10,4,-4,5,1$ pares de pínulas, con $2,1-8,12-5$, 3,9 pares de hojuelas lampiñas, alampiñadas ó pubescentes. Flores amarillas ó blancas, en racimos axilares ó terminales, de pedícelos sin brácteas y articulados, de cáliz apeonzado persistente, de limbo colorido 5-partido, cuyo segmento inferior mayor está abovedado; corola con 5 pétalos desiguales, ungüiculados; 10 estambres de filamentos lanudos por la base, arqueados y ascendentes. Ovario oblongo con estilo filiforme, terminado por un estigma concaro y diminutamente pestañoso : cosalpinia, F. 130, S.-F. 2, T. IV, G. I.

1017. Lequmbre ancliamente oblonga, lateralmente encorvada, llano comprimida, convexa por el lado estęrior y cóncava por el interior, con alounas semillas separadas las unas de las otras por un tejido celular, 1018. - Legumbre plano-comprimida, oblícuamente redondeadita por el ápice, estipitada, prieto-lustrosa, a!go torulosa por causa de las semillas, separadas por tejido celular, larca de 4-5" sobre 8-10-12"' de ancho y $2^{\prime \prime \prime}$ de diámetro. Primoroso arbusto de 10 á $15^{\prime}$ o árbol de hasta 25 á $30^{\prime}$ de altura, muy ramoso y aguijonnso, lampiño, con hojas alternas, paribipinadas, largas de 18 á 20-25", compuestas de 9,3 pares de pínulas con 10,5 pares de hojuelas tan pronto opuestas como alternas, larras de 8 á $10^{\prime \prime \prime}$ y anchas de $3^{\prime \prime \prime}$, cuyos peciolulos son acompanados de dos estipulitas aguijonosas y pronto caducas, oblongas o espatulado-oblongas, redondeadas ó sub-trancadas por el ápice arrejonado; dos estípulas muy pequeñas, triangulares y muy pronto caducas acompañan á la insercion del raq̣uis, cuya base crecida está acompañada de 3 aguijones conicos, de los cuales 2 son laterales y el tercero situado en la cara superior. Flores en racimos apanojados, piramidales y terminales, largamente pedunculadas, bastante grandes, preciosas, amarillas ó rojizo-anaranjadas, con pedícelos muy largos y articulados hácia el ápice, de cáliz 5 -fido con 5 divisiones desigguales y cari petaloídeas, caducas y cuya inferior es mayor y obaovado-aquillada; corola con 5 pétalos ungüiculados mucho mas largos que el cáliz, 
unduloso-festoneados por los bordes y larcos de 1"; estambres 10 inclinados y mucho mas largos que la corola, de filamentos encarnados lanuditos por la base, con anteras mediifijas. Ovario verde comprimido mas ó menos estipitado, con estilo filiforme tan largo como los estambres, terminado por un estigma discoídeo, cóncavo y pestañosito. Semillas obovales, comprimidas, de ápice acorazonado, mientras la base mas estrecha y oval tiene una cicatriz correspondiendo con el podospermo triangular $\mathrm{y}$ bastante desarrollado : poinciana, F. 130, S.-F. 2, T. II, G. III.

1018. Arbol bastante grande que se eleva á 30 ó $40^{\prime}$ de altura, inerme y lampiño, muy ramoso y coposo, de tronco corto asaz corpulento, que se termina por ramas muy gruesas cuyas inferiores son estendidas. Hojas bipinadas, compuestas de 15, 5, 9 pares de pínulas imparipinadas, un poco desigliales, las superiores siendo mas largas, formadas de 24, 20, 16 pares de hojuelas oblongo-lineares, ó quizas mejor elípticas, opuestas, sentadas, obtusas, del todo lampiñas, de cara inferior mas pálida y provista de puntitos negros dispuestos en dos séries paralelas y lonjitudinales á lo largo de la parte mediana de cada mitad; raquis principal y los raquises secundarios cilíndrico-velludos, parte tierna de las ramitas tinamente pubescente. Flores pequeñas blanco-amarillentas, en racimos compuestos contraidos, cuyos brazos cargan con 8, 12 flores, estriados y pubescentes, pedícelos filiformes cortos, saliendo de una depresion correspondiente, sin brácteas y articulados por el ápice, solitarios y con una sola flor, de cáliz con el tubo persistente y apeonzado, de limbo 5 -partido, cujas divisiones casi iguales son valvares; corola de J pétalos un poco espatulados, cóncavos y rizados por los bordes, iguales á las divisiones del cáliz, largos de 2"'; estamıbres 10 . Ovario comprimido color rojizo-morado, así como el estilo grueso -que se termina en un estigma verde pálido, cabezudito, cóncavo y lampiño. Legumbre larga de 2-1 $1_{[} 2^{\prime \prime}$, ancha de $9-10^{\prime \prime \prime}$ y espesa de 3 á $4^{\prime \prime \prime}$ redondeada por el ápice y con 8,6 semillas: lebidibia, F. 130, S.F. 2, T. II, G. IV.

1019. Plantas herbáceas anuales, matas sub-leñosas y leñosas ó arbustos, mas ó menos ramosos, lampiños, alampiñados, pubescentes ó velludos: hojas alternas, estipuladas, compuestas, paripinadas y de hojuelas opuestas ; raquis con ó sin glándulas vasculares situadas por su cara superior sea por encima de la base, sea entre las hojuelas. Flores ordinariamente amarillas, axilares, supra-axilares o terminales, en racimos, cimas y panojas, á veces solitarias ó mellizas, pedicelarlas, y de cáliz con j̇ sépalos sub-distintos y decíduos, mas ó menos desiguales y bastantes veces algo petaloíleos; corola de 5 pétalos algo desiguales, redondeados, undulosos por los bordes, obtusos y con unas muy cortas, abicrtos y por lo comun bastante grandes; estawbres 10 , cuyos 3 superiores abortan con frecuencia, con anteras oblongas, biporosas por el ápice, otras veces son 5,10 , todos fértiles, de anteras lineares, reventándose por el ápice á favor de dos rajaduras cortas, pubescentitas á lo larga de un áurco lonjitudinal que presentan; los 3 estambres inferiores son de ordinario mucho mas largos que los demas, con los filamentos ar- 
queados, las anteras enderezadas é inclinados, mientras los 4 del centro son derechos y de filamentos cortos. Ovario mas ó menos estipitado, mas ó menos comprimido, largo con un estilo mas ó menos largo y arqueado, terminado por un estigma discoídeo, glanduloso y oblícuo en el ápice algo crecido. Legumbre de forma y tamaño muy variados, sea cilíndrica ó casi así, leñosa ó coriácea, plurilocular, á veces llena de pulpa, con semillas comprimidas y paralelas á los tabiques, sea plano-comprimida, bivalve, con semillas comprimidas paralelas á las valvas y cuyo diámetro mas largo está transverso á ellas, sea membranácea, comprimida, por fin bicónvexa ó sub-cilíndrica, biralve, plurilocular, seca y con senillas comprimidas y por fin paralelas á los tabiques, algunas veces comprimidotetrágona y linear, con semillas comprimidas paralelas á las valvas, cuyo diámetro mas largo está igualmente paralelo á ellas, otras raras veces llano-comprimida, indehiscente, crecida en las partes correspondientes á las semillas obacorazonadas, mas cortas que el podospermo, comprimidas, paralelas á las valvas, y cuyo diámetro mas largo está transverso á ellas; en fin llana, comprimida, bivalve, con semillas comprimidas, paralelas á las valvas y con podospermo deltoídeo: cassia, F. 130, S.-F.2, T. II, G.

1020. Estambres 10, cuyas anteras, provistas de un apéndice con forma de espolon cónico, posterior y situado por la base, se abren por 1,2 poros terminales; hojas con tres nervaduras principales, reunidas por un sinnúmero de venas transversales, 971. - Estambres 12, 13 ó mas; cáliz tubular con 12 estrías, giboso ó espolonado por la base; ovario desigualmente bilocular con una glándula en su lado superior, 1022.

1021. Arbusto ó árbol de $25,30^{\prime}$ de altura, bastante ramosos, con hojas simples, opuestas, pecioladas, coriáceas, lustro:as, lampiñas, con ó sin tumorcitos por la base, elípticas ó aovado-lanceoladas con una purita mas ó menos larga, con ó sin dientecitos glandulosos por los bordes, largas de 5 á $6^{\prime \prime}$ sobre 3 á $4^{\prime \prime}$ de ancho. Flores blancas con la base de los pétalos carmesí ó rosada, ó rosado-purpúrea, bastante grandes y primorosas, en cimas terminales ó solitarias, sostenidas por 2, 4 brícteas algo distantes del cáliz, con limbo abierto, 5 -lobo, de lóbulos saliendo por debajo de la márjen ondeada. Ovario siempre libre 5-locular cuyas semillas muchas no están acaracoladas: meriana, F. 136, T. III.

1022. Plantas herbáceas anuales ó matas sub-leñosas, con hojas simples, opuestas, mas ó menos cortamente pecioladas ó subsesiles, enteras, lampiñas ó algo pubescentes, aovadas, aovado-lanceoladas, oblongo-lanceoladas ú oblongas. Flores pequeñas, rosadas, alternas, pediceladas, solitarias, axilares, estra-axilares ó interaxilares, otras veces opuestas y en racimos terminales; de cíliz monosépalo tubuloso; corola con 5 pétalos desiguales. Estilo simple con estigma algo bífido. Cápsula membranosa cubierta por el cáliz marcescente, reventándose lateralmente, de dos celdas con muchas semillas pequeñas y lentiformes : cuphea, F. 135, G. I.

1023. Estambres muchos ó á veces 10,20; drupa mas ó menos carnuda, de hueso liso; hojas sin estípulas, 1024. - Estambres mu- 
chos, de los cuales como 20 son fértiles, unilaterales; estilo basilar. Fruto drupáceo-carnudo, pero volviéndose por fin seco y separándose en valvas; hojas con estípulas. Arbustos muy ramosos, de $6^{\prime}$ á $15^{\prime}$ de alto, muy ramosos, lampiños, con hojas simples, coriáceas, alternas, pecioladas, lampiñas del todo, ovales ú oval-redondeadas, obaovadas ú ohaovado-redonditas, de base redondeada ó algo aguzada. Flores pequeñas en cimas corimbiformes, axilares, mas cortas que las hojas y pubescentes, pediceladas, y de cáliz campanudo 5-fido, cuyos segmentos un poco dublados hácia fuera son decíduos : la base sola persiste; eorola con 5 pétalos pequeños enderezados, espatulados é insertos en la garganta del cáliz; estambres desiguales, velludos, con anteras dorsifijas. Ovario sostenido por un ginóforo muy corto adherido al tubo calizinal, oval, lampiño inferiormente y pubescente por la mitad superior, unilocular con $26 \mathrm{vu-}$ los colaterales, basilares y anátropos; estilo mucho mas largo que los estambres. Drupa oval ú obaovara costilluda, del tamaño de como una ciruela, cuvo color varia bastante, blanco-amarillenta, morada, etc. : chrysob̈alanus, F. 131.

1024. Arboles altos ó bajitos, siempre verdes y lampiños, de hojas bien enteras, conduplicadas en el boton, alternas, pecioladas, oblongas ó aovado-oblongas, elípticas ó eliptical-oblongas, lustrosas superiormente y provistas inferiormente de dos puntos giandulares situados por la base, ó un poco distantes de ella y marjinales, los cuales faltan en ciertas especies. Flores en racimos axilares o laterales, pedunculadas, y de un cáliz 5, 4-fido ; corola con 5, 4 pétalos, rosácea ; ovario ovoídeo unilocular, con dos óvulos colaterales; estilo terminal. Drupa monosperma ovoídea ó globosa, arrejonadita ó trcncada por el ápice; almendra y corteza con olor prúsico ó que huelen á almendras amargas : prunus, F. 132, grupo IV.

1025. Estambres monadelfos ó diadelfos, 1026. - Estanubres poliadelfos.

1026. Siempre monadelfos ó siempre diadelfos, 1027.-Monadelfos o diadelfos, 1078 .

1027. Monadelfos, 1028.-Diadelfos, 1053.

1028. Fruto seco ó una legumbre, 1029. - Fruto carnudo abayado, 1085 .

1029. Corola papilionácea ó amariposada, 1030. - Corola no amariposada, 1046 .

1030. Legumbre indehiscente, 1031. - Legumbre dehiscente ó á veces indehiscente, 1040 .

1031. Samaroídea ó con un ala, 1032.-Nunca samaroídea, 1035.

1032. Legumbre de ordinario muy dura, comprimida, redondcada, adelgazada por ambos estremos, ó con un ala estreclia, llevando las semillas en la parte media, 1033.- Sámara muy grande, erizada en toda la parte inferior en donde se hallan las semillas, 1034 .

1033. Arboles de 25 á $30^{\prime}$ de altura, lampiños, con hojas alternas, estipuladas, imparipinadas y compuestas de 7, 5, 9 hojuelas alternas, reticuladas, oblongas, obtusitas ó con una punta, lustroso-lampiñas. Flores amarillas, en racimos ordinariamente compuestos, con pedícelo provisto de dos bracteitas, y de cáliz desigualmente 5-den- 
tado, con la base apeonzada, lampiño ó tomentoso y mas largo que el pedícelo; tubo de los estambres abierto por ambos lados o por el superior solamente. Ovario con algunos ó un óvulo solo, sostenido por un ponjino: pterocarpus, F. 1:30, S.-F. l, T. I, G. I.

1034. Arboles bastante grandes y corpulentos, asaz coposos, que se elevan á 40-50' de altura, pubescentes; hojas alternas ó esparcidas, grandes, imparipinarlas y de raquis velludo ó bozosn, algo colgantes y compuestas de $7,9,11$ y raras veces de solo 3 hojuelas sub-coriáceas, peninervias, pecioladas, opuestas y alternas en la misma hoja, desiguales, las de la base siendo siempre mucho menores, todas aovado-oblongas, redondas por la base $y$ un poco aguzadas por el ápice, largas de 6-5" las mayores, y anchas de 3-2 $1_{[} 4$, y las menores de $4-3$ 1 $2^{\prime \prime}$ de largo sobre 2 1 $2-2$ " de ancho, de cara superior convexa alampinada, mientras la inferior ahovedada es bozosa ó velluda, con ó sin escamitas discoídeas color de oro; las hojas enteras, largas de 12-14" están acompañadas por la insercion del raquis de dos estípulas bastante grandes, palmatinervias. Flores amarillas y olorosas en racimos tirsoídeos terminales, de brazos acompañados de brácteas, cuyos pedícelos, largos de $18^{\prime \prime \prime}$ y aterciopelados, salen de la axila de una bráctea espatiforme; cáliz campanudo, como bilabiado y 5 -fido á la vez, con los segmentos superiores mayores; corola pequena apenas eserta, con el estandarte orbicular, las alas oblongas y mas largas que la quilla dipétala; estambres monadelfos ó á reces diadelfos en las flores del mismo racimo; filamentos desiguales y con anteras ovoídeas, dorifijas é introrsas. Ovario comprimido, irregularmente cuadrilátero, cortamente estipitado al principio, peludo, con 2 celdas uniovuladas; estilo lateral con estigma terminal muy pequeño. El ovario, vuelto fruto, es ovoídeo, ancho de $2^{\prime \prime}$ con las puas y de $15^{\prime \prime \prime}$ sin ellas, y parece una castaña ó bola erizada de puas fuertes, punzantes, aterciopelado-escamosas, color bruno achocolatado, largos de 8-10"', con una espina mas fuerte en el vértice y al larlo del ala, proviniendo del estilo, ala larga de $5-6^{\prime \prime}$ y ancha de $21,2-3^{\prime \prime}$, undulosa por la base que sale del vértice del fruto y prolongándose hasta la base, pero de un solo lado, membranosa y estriado-venosa, la cual, en lugar de hacer cuerpo con el pericarpio, sale de adentro de él, despues de haber formado en su interior una especie de saco fibroso de dos celdas con una ó dos semillas pequeñas y lentiformes: nos parece pues una prolongacion aliforme de la placenta : centrolobium, F. 130, S.-F. 1, T. I.

1035. Como drupácea, 1036. - Nunca drupácea, pero con ó sin pulpa, 1038.

1036. Como drupáceo-ovoídea, redondeadita, monosperma y sin carne ó con alguna pulpa esteriormente; semillas sin olor. 1037. Drupácea, ovoíteo-oblonga, de color como aceitunado, lisa, lijeramente comprimilá, cortamente peduncularla, con semilla muy aromática; epicarpio como coriáceo, quebrádizo, fácilmente separable de una poea pulpa contenila en un tejido esponjoso que sale del hueso á que está muy adherido. Arbol grande corpulento y coposo, lampiño, con hojas alternas, compuestas de 4 hojuelas alternas, co- 
riáceas, óvalo-lanceuladas, algo puntiagudas por el ápice y redondeadas por la base un poco inequilateral, enteras y algo undulosas por la márjen, largas de $4^{\prime \prime} \mathrm{y}$ anchas de 18 á $22^{\prime \prime \prime}$, de cara superior lustrosa y lisa, peciolo muy corto, situado y contenido en una especie de cavidad á propósito en los lados del raquis, largo de $4^{\prime \prime}$, deprimido, como alado y ancho de 1"'; esa especie de ala estrecha está arrollada hácia abajo, formando así como un ribete interrumpido en el lugar correspondiente con la insercion de la hojuela y despues de haber echado un apéndice que tapa la foseta de insercion, se estiende un poco sobre la cara superior y desaparece, la altima hojuela parece situada en el ápice del raquis, cuya ala lateral se va prolongando como de $1_{1} l^{2 \prime \prime}$, terminándose en lengüeta ensiforne. Flores rosado-moraduscas en racimos terminales, pero cuyo brazo mas inferior sale de ordinario de la axila de la última hoja, de pedúnculo y brazos finamente aterciopelarlos y de color acanelado; pedícelo de las flores saliendo de un hoyo de insercion, acompañado de una bráctea decídua, y con dos bracteitas acompañando á la articulacion, pronto caducas y que envuelven al capullo. Cáliz un poco comprimido, algo carnoso, con 5 divisiones muy desiguales, cuyas 2 superiores, mayores, son petaloídeas y moraduscas; estandarte sin uña, cuyas dos mitades están casi aplicadas la una á la otra ; quilla cuyos dos pétalos están soldados entre sí hácia el $l_{[} 3$ superior; estambres con anteras basifijas, pequeñas, globosas é inclusas. Ovario algo estipitado, comprimido, lampiño, con figura de $\Omega$, de podójino morado, con un estilo blanco algo alesnado, terminado por un estigma cabezudo y glandu]oso. Fruto largo de 2 l $1_{2}-2$ " y $1_{[} 2^{\prime \prime}$ de diámetro: cumaruna, F. 130, S.-F. 1, T. I, G. VII.

103\%. Arboles de hojas imparipinadas; flores purpuráceas, apanojadas, de cáliz cortamente 5-dentado ó troncado; pétalos de la quilla distintos, 1082.

1038. Con pulpa siempre. Corola no lejítimamente papilionácea por causa de aborto, 1039.- Siempre sin pulpa alguna, 1040.

1039. Primoroso árbol bastante corpulento y muy coposo, que se eleva á 45 ó $50^{\prime}$ de altura, lampiño, con hojas alternas paripinadas, largas de 5 á $6^{\prime \prime}$, estipuladas y formadas de $10,15,18$ pares de hojuelas opue:tas, casi sesiles, oblongas, retusas ó redondeadas por el ápice, decíduas, lampiñas, de base inequilateral y un poco desiguales. Flores amarillento verduscas, disciplinadas, en racimos axilares, pendientes, paucífloros; pedícelos saliendo de la axila de una bráctea oboval algo coloradita y decídua; cáliz 4-partido, bilabiado y apeonzado por la base, decíduo; corola con 3 pétalos undulosos, enderezados, muy ungüiculados y desiguales, de estandarte oblongo con la márjen en rollado-rizada: los dos pétalos de la quilla faltan siempre, pero están reemplazados por dos apéndices subulados que se hallan por debajo de los estambres, que son 3 , inclinados, con los rudimentos de 4 mas. Ovario estipitado, con el ginoforo adherido al tubo del cáliz, alargado, velludo, arqueado, de estilo poco distinto, terminado por un estigma cabezudo. Legumbre morena, rugosa, algo corva, como torulosa, de cáscara seca y frájil, semi-cilíndrica y con 3 líneas salientes y lonjitudinales, larga de $4-5$ sobre $1 \quad l_{[} 2$ 
de ancho; 6 á 12 semillas negras, lustrosas, irregularmente trapeciformes : tamarindus, F. 130, S.-F. 2, T. III, G. I.

1040. Con 4 alas anchas, membranáceas y lonjitudinales, 1041. - Sin ala alguna, 1042.

1041. Arbol ramoso, lampiño, que se elera á 25,30 de altura, con hojas alternas imparipinadas, estipuladas, compuestas de 5, 4, 3 pares de hojuelas opuestas, pubescentas ó alampiñadas, oblongas ó elípticas, ú óvalo-larceoladas, pecioluladas cuya impar mayor que las demas es casi espatulada, puntiagudas, largas de 2 á 3 " sobre 1 , I $1_{[} 2$ de ancho. Flores precoces blanco-rosadas ó purpuráceas, en racimos laterales o terminales compuestos; pedícelos unífloros, pubescentes y articulados superiormente; cáliz campanudo, corta y anchamente 5 -dentado, pubescente; corola cuyas alas adlieren con la quilla falciforme; estandarte adherido, con la columna estaminal por encima de la hase. Ovario con 4 lados, alargadito, pluriovulado, con estilo alesnado terminado en un estigma puntiagudo. Legumbre linear, larga de 2-4" y ancha de $4^{\prime \prime \prime}$, pubescentita, sostenida por un podojino largo de $5-2^{\prime \prime \prime}$ y de ordinario 3 veces mas que el cáliz, cuyas 4 alas anchas y membranáceas están á lo largo de ambas márjenes, dos por cada una y transversalmente estriadas, laceradas ó undulosas y anchas de 8-6"'. Semillas 6, 8, transversalmente oblongas, negras, sub-comprimidas y largas de $3 l_{[} 2^{\prime \prime \prime}$ : piscidia, F. 130, S.-F. 1, T. I, G. III.

1042. Subterránea, plantas herbáceas, 1043. - Nunca subterránea, 1044.

1043. Yerba anual, de tallos muy ramosos y desparramados, ascendientes por el vértice, lampiña o velluda, de raiz con algunos tuberculitos pisiformes; hojas paripinadas, alternas, estipuladas, inequilaterales, lanceoladas y adheridas á la base del raquis, falciformes y largas de 8-10"' sobre 1"' de ancho por la base, compuestas de dos pares de hojuelas oblongo-ovales, opuestas, lampiñas y lustrosas, pero pestaniosas, largas de 10-15-20" sobre 5-8-12"' de ancho, con el raquis largo de $3^{\prime \prime}$, llevando las hojuelas opuestas y cortamente pecioladas, el primero par á $10^{\prime \prime \prime}$ del ápice que carga con el segundo. Flores amarillas, con pedúnculos muy largos, axilares, paucífloros, y de cáliz de tubo alargado y filiforme, de limbo con 4 segmentos, 3 superiores y 1 inferior; corola de estandarte redondito aplicado á las alas que no están estendidas. Ovario con pocos óvulos de estilo filiforme larguísino, con el estigma eserto. Legumbre ovoídeo-cilíndrica, un poco torulosa, de cáscara como apergaminada, de superficie rugosa y como reticulada, terminada por un pico, y con 2, 3 semillas : arachis, F. 130, S.-F. 1, T. IV, G. II.

1014. Legumbre mas ó menos oblonga, como avejigadita, apergaminada y en que las semillas hacen ruido cuando madura, nunca rojas; 10 estambres, 1045 . - Legumbre oblonga, sub-troncada por anubos estremos y dividida por tabiques falsos, semillas globosas, coloradas con una mancha negra, lustrosas 9 estambres. Nata abejucada, de tallos ramosísimos, muy largos, delgados, alampiñados ó lampiños, con hojas paripinadas, alternas, con una punta termi- 
nando el raquis, estipuladas, compuestas de 11 á 15 pares de hojuelas oblongas ó quizas mejor elípticas, obtusas, arrejonaditas por el ápice, de cara superior verle oscuro lustrosa y lampiña, mientras la inferior, mas pálida, tiene pelo esparcido ó es alampiñada, largas de 4-5"' y anchas de $11_{[} 2$, alternas ú opuestas en la misma hoja, larga de $2 l_{l} 2^{\prime \prime}$, con el raquis y peciolos pubescentes. Flores rosaditas en racimos axilares 6 terminales y fasciculadas en los brazos, de cáliz troncado y unduloso; corola de estandarte casi liorizontal, no mas largo que los otros pétalos, alas mas cortas que la quilla, cuyos pétalos están soldados entre sí; andróforo abierto por la parte correspondiente al estandarte con que está algo pegado por la uña. Legumbre desigualmente 4-lateral, oblonga, de color aceitunado y pubescente, larga de 15 á $18^{\prime \prime \prime}$ y ancha de $8^{\prime \prime \prime}$, algo crecida en los lugares correspondientes á la semillas rojas ordinariamente 4 , á veces color de carne, siempre lustrosas y con la mancha negra: abrus, F. 130, S.-F. I, T. III, G. III.

1045. Plantas herbáceas anuales, matas sub-leñosas ó arbustillos, algunas veces desprovistos de hojas reemplazadas por un filodio simulando una hoja simple, con estípulas mas ó menos desarrolladas y í veces e:curridas á lo largo del tallo, ú hojas imparipinadas alternas, estipuladas y compuestas de 3,5 hojuelas largamente pecioladas. Flores de ordinario amarillas ó amarillentaz, en racimos terminales, y de cáliz campanudo, con 5 divisiones profundas, como bilabiado; corola de estandarte grande, quilla falciforme y libre; estamhres alternativamente desiguales: crotalaria, F. 130, S.-F. 1, T. V, S.-T. III, G. I.

1046. Legumbre con pulpa y mas ó menos indehiscente, 1047. Legumbre sin pulpa, 1048 .

1047. Corola con 3 pétalos; pulpa hallándose en el mesocarpio. Legumbre enteramente indehiscente; estambres 3, 2-fértiles, 1039. - Legumbre indehiscente ó reventándose por las márjenes espesas y ensanchadas, cumprimida ó sub-prismática; semillas encerradas en la pulpa que las tiene envueltas á manera de arilo. Arboles altos y coposos, lampiños ó pubescentes, ásperos ó lisos, inermes; hojas alteruas, estipuladas, pinadas, cuyo raquis está de ordinario provisto de glándulas situadas entre los pares, compuestas de 2,1-2,3$1,4-4,5-4,3$ pares de hojuelas mas ó meros grandes, pubescentes ó lampiñas, coriáceas ó membranáceas. Flores blancas en'cabezas, umbelas, espiças ó racimos axilares ó terminales, sentadas ó subsesiles, de cáliz 5-dentado; corola tubulosa 5, 4, 2-dentada y pequeña, algo mas larga que el cáliz; estambres muchos y muy largos, de filamentos filiformes muy esertos: inga, F. 130, S.-F. 3, T, II, G. VI.

1048. Corola de 5 pétalos mucho mas grandes que el cáliz, ungüiculados, blanca ó roja; estambres definidos y apenas esertos, 1049. - Corola 5-fida apenas eserta y muy pequeña; estambres muchísimos ordinariamente y de filamentos muy largos y esertos, 1050 .

1049. Cáliz 4, 5-fido encerrado en una especie de vaina bracteolar de ordinario bífida; corola roja : ginoforo adherido al tubo cali- 
zinal, legnmbre siempre dehiscente; hojas paripinadas, 9.34. - Cáliz desnudo de tubo cilíndrico, con el limbo ligulalo-espatáceo, raras veces 5-partido; corola grande abierta y blanca; ginoforo no arherido con el cáliz y libre; legumbre bivalve ó indehiscente. Hojas simples bífidas, o quizás mejor formadas de dos hojuelas grandes soldadas por el lado interno, 945 ,

1050. Estambres muchísimos ó 10, 1051. - Estambres siempre muchísimos; legumbre acaracolado, o torcido en espiral con las semillas ariladas o sin arilo: Arboles grandes ó arbustos armados 6 inermes, lampiños ó pubescentes, con hojas bipinadas, alternas, de raquis con glándulas situadas entre las pínılas, y compuestas de un par de pínulas con un solo par de liojuelas, otras veces hay $2,4,-4$, $8,8,16$ pares de pínulas con $2,8-3,12-12-20,30$ pares de hojuelas. Flores en cabezuelas ó en expigas sesiles ó sub-sentaras, y de cáliz 5-partido; corola 5, 6-dentada: pithecolobium, F. 130, S.-F. 3, T. $2, \mathrm{G} . \mathrm{V}$.

1051. Legumbre dehiscente con elasticidar, ordinariamente comprimida y mas espesa por las márjenes, 1052. - Legumbre indehiscente, algo pulposa, ancha, casi con figura de oreja humana, comprimida, hinchada en los lugares correspondiendo con lassemillas, con tabiques falsos, coriácea y lustroso-bruna. Arbol primoroso muy alto, muy frondoso y muy corpulento, lampiño y con hojas grandes alternas, cuyo raquis lleva las glándulas situadas entre el primero ó el último par de pínulas 4, 9-yugadas; con 20, 30 pares de hojuelas, inequilaterales, oblongas, con una punta, verde mar por la cara inferior, del todo lampiñas y lustrosas por la superior, largas de $6^{\prime \prime \prime}$. Flores subsesiles blanco-rerduscas en cabezuelas anchas de $6^{\prime \prime \prime}$, con el pedúnculo largo de $1112^{\prime \prime}$, cáliz pubescentito. 5-fido ; corola 5-deutada, raras veces 5, 3-fiúa; éstambres muchí:imos y blancos. Legumbre undulosa formando un arco entero, cuyo ápice llega hasta á tocar la base tambien redonda, ancha de 1 1 [2-1 " $3 / 4^{\prime \prime}$ y el fruto entero tiene $3-4^{\text {"N }}$ de diámetro : enterolotium, F. 130, S.-F. 3, T. II, G. VI.

1052. Arbustos inermes ó armados, algunas raras veces árboles bajitos ó muy grandes, bastantes veces polígamos, 297.

1053. Legumbre cubierta de pelo tieso, cuja picadura abrasa muchísimo, 1054. - Legumbre desnuda, 1055.

1054. Plantas herbáceas ó matas volubies de tallo larguísimo, muy ramoso, con hojas alternas, estipuladas, de tres en rama, curas hojuelas, ordinariamente bastante grandes y desiguales, están del todo lampiñas ó sedo:as por la cara inferior. Flores grandes fasciculado-racemosas ó amanojadas, amarillas, purpúreas o a\%nl-oscuras, etc.; de cáliz cortamente camranudo 4-fido ó 4-dentado; corola de estandarte conduplicado-aovado, aovado-lanceolado ó aovadooblongo, mitad de lo largo o casi tan largo como las alais y orejudo por la base; quilla de ordinario cartilajinosa por el ápice lijeramente eserto: estambres de anteras alternativamente desiguales. Estigma terminal. Legumbre gruesa, coriácea, oblungo-linear y sin erestas, ó comprimido-oblonga y con crestas transversales convexas: mucuna, F. 130, S.-F. 1, 'T. VI, S.-T. III, G. V. 
1015. Legumbre lomentácea, 1056. - Legumbre nunca lomentácea, 1057.

1056. Comprimida y formada de unos artejos ó de solamente 2, monospermos, separándose y desprendiéndose cuando maduros. indehiscentes ó deliscentes. Plantas herbáceas tendidas y volubles, ó matas volubles de tallo derecho muy largo y muy ramoso; hojas alternas, estipuladas, ordinariamente de tres en rama. que á veces están unifolioladas por causa de aborto. Flores amarillas, rosadas, blancas ó morado-azuladitas, fasciculado-racimosas, terminales ó axilares, raras veces simplemente fasciculadas, pediceladas, $y$ de cáliz tubulado, cortamente campanudo, como bilabiado y cuya base está acompañada de dos brácteas; corola de estandarte obaovado, con las alas adheridas á la quilla biorejuda; estambre correspondiente al estandarte adherido á la columna ó á veces libre : desmodium, F. 130, S.-F. 1, T. IV, G. I.

1057. Legumbre linear, 1058. - Legumbre nunca jamás linear, 1061 .

1058. Algo comprimida, larga hasta de 1 ', estipitada, tumida por ambas márjenes; flores muy grandes de quilla obtusamente falciforme, 1059. - No comprimida, tetrágona, alargada ó mas ó menos cilíndrica, mas ó menos encorvada, pequeña, no estipitada; flores pequeñas, de quilla con un espolon por cada lado, 1060 .

1059. Arbol bajito, con pocos ramos bastante largos y estendidos, que se eleva á $15^{\circ}$ ó $20^{\prime}$ de altura, con hojas alternas, paripinadas, largas de $10^{\prime \prime}$ y formadas de muchos pares de hojuelas pubescentes ó alampiñadas, desiguales, cuyas superiores é inferiores son mas pequeñas, cortamente pecioladas, alternas escepto las 4 del ápice, que están opuestas, obovales ó casi elípticas, obtusas y enteras, largas, las mayores, de $14^{\prime \prime \prime}$ y anchas de $5-51\left[2^{\prime \prime \prime}\right.$. Flores muy grandes, largas de $31_{1} 2^{\prime \prime}$, blancas ó moraditas, pendientes y en racimos paucífloros axilares, pediceladas, y de cáliz campanudo, undulosodentadito; corola con estandarte oval-ohlongo mas corto que las alas libres y que la quilla cuyos pétalos no están soldados entre sí. Semillas separadas por tabiques falsos: agati, F. 130, S.-F. 1, T. galégeas, H., G. III.

1060. Plantas herbáceas anuales ó matas sub-leñosas, á veces arbustillos, de tallo derecho y ramoso, mas ó menos pubescentes ó con pelo frecuentemente pegado por la parte media; hojas imparipinadas, alternas, estipuladas, compuestas de $2,3,1-2,5-6-4,3,1,7$ pares de hojuelas opuestas, ovales, obaorado-oblongas, elipticaloblongas y en fin espatulado-oblongas. Flores disciplinado-purpuráceas en racimos axilares derechos mas cortos que las hojas, pedunculadas, y de cáliz 5-fido, con los segmentos abiertos; corola de estandarte redondeadito; estambres 10, siempre diadelfos, con anteras apiculadas. Legumbre bivalve, arqueadita, larga como de 12 á $18^{\prime \prime \prime}$, con las semillas troncadas y separadas por tabiques falsos: indignfera, F. 130, S.-F. 1, T. galégeas, H., G. I.

1061. Mas ó menos comprimida, 1062. - Sub-cilíndrica y subcomprimida á la par, 1074. 
1062. Unicamente comprimida, 1063. - Sub-comprimida solamente.

1063. Cáliz nunca acompañado de brácteas, 1064.-Cáliz siempre con brácteas, disco vainifero, 1067.

1064. Cáliz 4-fido, con el lóbulo superior bidentado; estandarte redondeadito y orejudo; estambres siempre diadelfos: lecumbre contraida entre las semillas muchas, 1065. - Cáliz desigualmente 5 -fido ó 4, 5 partido; estandarte sin orejas; estambres mas veces diadelfos; legumbre no contraida entre las semillas 1 ó $2,1066$.

1065. Arbusto de 6 á $12^{\prime}$ de altura, bastante ramoso y lampiño, con hojas alternas, estipuladas, largamente pecioladas y trifolioladas, cuyas hojuelas coriáceas, cortamente pecioluladas, lanceoladooblongas, puntiagudas y blanquecino-sub-tomentosas inferiormente, son largas de $2^{\prime \prime}-21\left[2^{\prime \prime}\right.$ sobre $15-18^{\prime \prime \prime}$ de ancho. Flores amarillas en racimos axilares paucífloros, pediceladas, y de corola cuyo estandarte está á veces con manchas anaranjadas. Ovario pluriovulado. Legumbre continua larga de $11_{1} 2$ á $2^{\prime \prime}$, con algunas semillas lenticulares : cajanus, F. 130, S.-F. 1, T. IV, G. II.

1066. Vejetales sub-leñosos ó mas ó menos herbáceos, volubles, de tallo mas ó menos largo y ramoso, anguloso ó sub-cilíndrico, tomentosos ó alampiñados, con frecuencia provistos de glandulitas amarillas; hojas alternas, estipuladas, compuestas de 3,1 hojuclas, aovado-romhoídeas, ó aovadas, con una punta ó sin ella. Flores pequeñas, ordinariamente amarillentas, las mas veces en racimos axilares, pauci ó plurífloros, mas ó menos pediceladas, de cáliz 5-fido, con el lóbulo inferior mas largo. ó 4-partido, casi tan largo como la corola y con el segmento superior bífido; corola de estandarte con venitas ó estrías purpuráceas. Legumbre larga de 6-10" ó de 1012 "' sobre 3-4" de ancho, cuyas semillas reniformes ó redondeaditas con un rafe mas ó menos pronunciado tienen 1-2-2 $1\left[2^{\prime \prime \prime}\right.$ de diámetro: rhinchosia, F. 130, S.-F. 1, T. VI, S.-T. I, G. I.

1067. Estandarte orejudo por la base y bicalloso por el medio, 1068.-Estandarte orejudo y sin callos, 1071.

1068. Callo de la base semi-lunar ó falciforme agudo; quilla recta, torcida, encorvada ó sub picuda; estambre del estandarte espolonado por la base, 1069. - Estandarte acanalado y con 4 callos, de los cuales 2 son superiores y proeminentes; quilla falciforme encorvada á ángulo recto ó torcida; estambre del estandarte sin espolon y contenido en el canal formado por los callos, 1070 .

1069. Plantas herbáceas anuales ó vivaces alg'!nas veces, de tallos muy ramosos, delgados, volubles, mas ó menos largos, lampiñas, alampiñadas ó pubescentes; hojas alternas, estipuladas, compuestas de 3 hojuelas con estipulitas. Flores racimoso-fasciculadas, blancas, amarillas ó purpúreas, pediceladas, de cáliz campanudo cortamente 4, 5-fido; estilo cartilajinoso rollizu ó acanalado algo adelgazado por el vértice y terminado por un estigma terminal cabezudo y pelierizadito. Legumbre con las valvas convexas ó planas, y cuyas semillas, separadas por tabiques falsos y delgados, son comprimidas ó aovado-sub-reniformes, con la estrófila pequeña: dolichos, F. 130, S.-F. 1, T. VI, S.-T. III, G. II. 
1070. Plantas anuales herbáceas, de tallo larguísimo muy ramoso y voluble, con hojas alternas, estipuladas, compuestas de 3 hojuelas bastante grandes, pecioladitas y estipuladitas por la insercion. Flores blancas ó á veces purpuráceas, en racimos pedunculados acompañados de una hojuela única ó quizís mejor opuestos á un ramo abortado foliáceo; pedícelos semi-verticilados; cáliz campanudotubuloso y 4-fido, con la lacinia sliperior ancha y obtusa, mientras las 3 inferiores son agudas; corola de estandarte abierto ó estendido. Ovario estipitado pluriovulado, terminado por un estilo comprimido con el vértice sub-barbudo y el estigma terminal troncado y lampiño. Legumbre llano-comprimida, acinaciforme y hácia ambas suturas tuberculado-arrejonada, sub-tetrasperma; semillas separadas por tabiques falsos y celulosos, algo comprimidas, ovales y blancas ú oval-redondeaditas, negras ó purpuráceas, con un callo blanco: lablab, F. 130, S.-F.1, T. VI, S.-T. III, G. IV.

1071. Biorejudo y obaovado; cáliz campanudo y como bilavado, 1072. - Uniorejudo y redondeadito; cáliz campanudo 4, 5-fido, 1073.

1072. Planta herbácea ó sub-leñosa, vivaz, de raiz tuberoso-feculenta, bastante gruesa, de tallo muy largo, ramosísimo y voluble, lampiña, con hojas alternas, estipuladas, compuestas de tres hojuelas ordinariamente sinuoso-angulosas, deltoídeo-aovadas, de cara inferior pulescente ó alampiñada, largas de $3 l_{[} 4^{\prime \prime}$ o $4 \quad l_{\mid} 2^{\prime \prime}$ y anchas de $4,3 "$, con estipulitas por la insercion. Flores azules teñidas de morado, en racimos espiguiformes, pedicelarlas y agrupadas por ả 3 ó por á 4 , de cáliz campanudo ó quizás mejor aorzado, pubescente, bilabiado, con el labio superior mayor algo escotado y obtuso, mientras el inferior, trílobo, es calloso pqr los senos; corola con el estandarte obaovado, de ápice escotado, alas oblongas, largamente ungüiculadas y orejudas ó dentadas, quilla de pétalos adheridos por la márjen. Ovario un poco alargado, estipitado y cuya base está envuelta en una vainita membranosa saliendo del disco; estilo grueso, comprimido transversalmente, peludo y con un estigma terminal. Legumbre recta, alampiñada, sub-flexuosa por la márjen, larga de $5-6^{\prime \prime}$ solure 10 á $12^{\prime \prime \prime}$ de ancho, con 7,8 semillas comprimido-redondeadas, algo arriñonadas, coloradas o parduscas: pachyırrizus, F. 130, S.-F. 1, T. VI, S.-T. III.

1073. Vejetales anuales de tallo mas ó menos largo, ramoso, voluble o postrado, con hojas alternas, estipuladas y compuestas de 3 hojuelas aovadas ó aovado-lanceoladas, lampiñas, alampiñadas ó peludas por la cara inferior, con estipulitas en la insercion. Flores amarillas á veces disciplinadas de color púrpureo, cuyos pedúnculos axilares llevan cabezuelas umbeliformes ó racimitos, pediceladas. Estilo cartilajinoso y peludo por el vértice, con estigma lateral: vigna, F. 130, S.-F. 1, T. VI, S.-T. III. G. VI.

1074. Cáiiz siempre acompañado de dos bracteitas, 1075 .

1075. Estandarte grande, espolonoso por arriba de la base; legumbre costilluda hácia ambas márjenes, 1076. - Estandarte sin espolon, ni giboso; quilla torcida en espira; legumbre no costilluda, $107 \%$. 
1076. Plantas hlerbáceas ó de tallo sub-leñoso por la base, volubles, muy ramosas, con hojas alternas, estipuladas, compuestas de 3 hojuelas de tamaño y forma variando un poco, segun las especies, cuya insercion lleva una estipulita situada esteriormente, mientras la impar estí con dos. Flores primorosas, grandes, inversas, azules, blancas, disciplinadas de purpúreo $\mathrm{y}$ de amarillo, axilares y mellizas ó en racimitos paucífloros y tambien axilares, pedicelarlas y de cáliz infundibuliforme, ordinariamente 5-fido y como bilabiado; corola inversa, de manera que el estandarte, muy ancho y redondeado, está pendiente, mienträs la quilla, de una sola pieza, cuyos dos pétalos estín soldados, se ha vuelto superior y es muy saliente. Ovario larguito, comprimído, algo arqueado, con dos surcos laterales y pubescente, cuyo estilo dilatado hácia el ápice lleva un estigma espatulado y pestañoso. Legumbre sentada, comprimida, mas ó menos linear y cilindrácea, con falsos tabiques celulosos entre las semillas troncadas : centrosema, F. 130, S.-F. 1, T. VI, S.-T. II.

1077. Plantas herbáceas, de ordinario anuales, de tallo mas o menos largo, delgado, ramoso y voluble, lampiñas, alampiñadas, pubescentes ó sedosas; hojas alternas, estipciladas, compuestas de tres hojuelas, cuyas laterales son de ordinario oblícuas y provistas de estipulitas por la insercion de su peciolo muy corto y como articulado. Flores blancas, amarillas ó purpuráce $ı$ s, fasciculado-racemosas, pedunculadas y de cáliz campanudo 4, 5 fido o 4, 5-dentario; corola de estandarte redondito; estilo cartilajinoso por el vértice y con un estigma oblicuo ó lateral. Samillas comprimidas mas ó menos arriñonadas, blancas ó coloradas: phaseolus, F.130, S.-F.1, T. VI, S.-T. III, G. I.

1078. Estambres mona lelfos ó diadelfos, 1079.-Estambres nunca monadelfos, pero sí diadelfos ó triadelfos; legumbre como discoídea, llano-comprimida y monosperma, 1084.

1079. Cáliz acampanado de dos brácteas, 1080. - Cáliz sin brácteas, 1082 .

10S0. Cáliz campanudo, bilabiado; estandarte redondeadito; estambre del estandarte arlherido á la columna por encima de la base; legumbre bastante grande, tumida-sub-comprimida, llena de tejido celular y cnn las valvas frecuentemente costilludas á lo largo de las suturas, 1081. - Cáliz campanudo ó espatiforme, nunca bilabiado; estandarte conduplicado muy largo y mucho mas que las alas contenidas con frecuencia en el cáliz; estambres monadelfos por la base, pero cuyo filamento del que corresponde al estandarte está frecuentemente libre por encima de ella. Arboles de ordinario bastante altos y corpulentos, muy coposis y que se elevan á 40-50' de altura, aguijonosos ó inermes, lampiños ó aterciopelados; hojas alternas estipuladas y compuestas de 3 hojuelas pecioladas, aovado-romboidales algo desiguales, siendo la impar siempre mayor. Flores de ordinario de color de escarlata, mas ó menos largas, precoces, fasciculaclo-racimosas, de cíliz campanudo-troncado, con dientecitos obsoletos ó espatiforme, con J́ dientes diminutos por el ápice y cuya rajadura llega casi hasta la base; corola con los pétalos de la quilla pequeños y distintos; legumbre torulosa, linear, falsiforme, llena de 
tejido celular, á veces folicular ó indehiscente; semillas casi glohosas, encarnadas y de ordinario con una mancha negra, muy lustrosas y bonitas: erythrina, F. 130, S.-F. 1, T. VI, S.-T. III, G. VII.

1081. Vejetales de tallo largo, sub leñoso inferiormente, voluble, muy ramoso, alampiñados ó lampiños; hojas alternas, estipuladas, compuestas de 3 hojuelas bastante grandes. Flores purpuráceas en racimos axilares, pediceladas $y$ de cáliz con el labio superior entero ó bílobo, mientras el inferior es trífido ó entero; corola de quilla encorvada y obtusa. Legumbre siempre dehiscente, larga de 6-910-3" y ancha de 12-10-15"', con semillas blancas ó bruno-oscuras, ovoídeo-oblongas ó redondeaditas, algo comprimidas: canavalia, F. 130, S.-F. 1, T. VI, S.-T. II, G. III.

1082. Legumbre dehiscente, blanco-comprimida, plurisperma, 1083. - Legumbre indehiscente, como drupácea, ovoídeo-redondeadita y monosperma; árboles bastante grandes y coposos, que se elevan á 40'-50' de altura, asaz corpulentos; hojas alternas, imparipinadas, compuestas de 4, 8, 3, 4 pares de hojuelas opuestas, lanceolado-oblongas ú oblongas, aguzadas, con una punta ó retusas, del todo lampiñas o de cara superior lampiña, mientras la inferior es herrumbroso-pubescente. Flores purpúreas en panojas terminales bastante grandes, pediceladas; cáliz cortamente 5-dentado ó troncado; corola con los pétalos de la quilla distintos; estambres monadelfos ó con el filamento del estandarte á veces libre. Ovario estipitado, pauci ó uniovulado, con un estilo corto encorvado, terminado por un estigma diminuto. Semilla pendiente, de raicilla muy corta, recta y súpera : andira, F. 130, S.-F. 1, T. I, G. II.

1083. Vejetales sub-leñosos ó matas leñosas y á veces anuales, que se vuelven por fin sub-leñosas, pubescentes, tomentosos ó aterciopelados, de tallo ordinariamente derecho, ramoso ó algunas veces desparramado, con hojas alternas, estipuladas, imparipinadas y compuestas de 4, 7, 9, 11, 20 pares de hojuelas, raras veces son 3 , 1-folioladas. Flores purpúreo-azulitas ó blancas, racimosas y terminales ó á veces fasciculadas y hasta solitarias, pediceladas y de cáliz 5 -fido, con los segmentos mas ó menos desiguales; corola de estandarte rerlondito y sedoso esteriormente, con las alas transversalmente rugositas y de ordinario adheridas á la quilla obtusa; estambre del estandarte adherido á la columna por encima de la base ó raras veces distinto. Ovario inserto oblícuamente, larguito, pubescente ó lampiño, terminado por un estigma cabezudo, lampiño ó pestañoso. Legumbre llano-comprimida, sentada, algo coriácea, arqueada y pubescente, con algunas semillas arriñonado-comprimidas, adornadas de manchitas blancas y negras : tephrosia, F. 130, S.-F. 1, 'T. galégeas, H, G. II.

1084. Arbustos ds las orillas del mar, muy ramosos, con hojas alternas, estipuladas, imparipinadas o 1 -folioladas y compuestas de $3,5,2$ hojuelas alternas, aovadas ú ovales, puntiagudas y lampiñas, ó de una sola aovada $\dot{o}$ aovado-oblonga y pubescente inferiormente. Flores pequeñas, blancas, en racimos cortos, de ordinario corimbosos y axilares; cáliz corto y desigualmente dentado; estambres 10 , 9 , de anteras bífido-didínamas. Ovario largamente estipitado y con 
dos óvulos. Legumbre coriácea, oblícua y casi discoídea, lisa y pubescente, de podójino tan largo como el cáliz ó lijeramente asimétrica, oval-orbicular, lisa y lampiña, de podójino mas largo que el cáliz: hecatophyllum, F. 130, S.-F. 1, T. I, G. VI.

1085. Plantas herbáceas ó mas frecuentemente matas ó arbustillos abejucados, muy ramosos, sarmentosos y sosteniéndose por medio de zarcillos axilares, de tallos delgados y muy largos ordinariamente, pubescentes ó lampiños. Hojas simples, alternas, largamente pecioladas, mas ó menos profundamente lobuladas, partidas ó dijitadas, cuyo peciolo tiene bastantes veces una ó algunas glándulas situadas por su cara superior, y de insercion con dos estípulas foliáceas mas ó menos grandes, de forma y tamaño muy rariados. Flores solitarias, ordinariamente grandes y primorosas, $\dot{o}$ pequeñas, pedunculadas, y de cáliz monosépalo 5, 4-partido ó profundamente lobulado, cuyo tubo está adornado por una corona, de ordinario compuesta de apéndices filiformes pintados de los mas hermosos colores, mas ó menos numerosos y dispuestos en algunas séries: bastantes veces el cáliz está sostenido por un invólucro ancho formado de 3 hojuelas ó 3-fido; la corola suele faltar bastante á menudo y cuando existe tiene 5 pétalos; estambres 5 y á veces 4 , insertos en la parte superior del ginóforo, de filamentos achatados, con las anteras movibles y pegadas por la parte media del dorso á favor de un apéndice, oblongas y bastante grandes, las cuales en el acto de la fecundacion dan una vuelta para presentar su cara al estigma. Ovario sostenido por un podójino larguísimo, que suele faltar algunas veces, y que pasa por dentro del andróforo y que lo tiene por encima de los estambres, unilocular, con 3 placentas poliovuladas: del ápice salen 3 estilos bastante largos, gruesos, obcónicos, diverjentes, casi horizontales y algo inclinados hácia abajo, con un estigma cabezudo ó con forma de boca, pero sin estar hueco, redondo y de circunferencia sinuosa. Baya á veces muy gruesa, de forma, color y tamaño muy variados, con muchas semillas hoyosas: passiflor'a, F. 144.

1086. Ovario enteramente ínfero, 108\%. - Ovario semi-ínfero o cáliz semi-adherente.

1087. Estambres perijínicos, 1088. - Estambres epijínicos.

1088. En número definido, 1089. - Mruchos é indefinidos, 1094.

1089. Fruto carnudo, abayado, 1090. - Fruto seco capsular ó no, 1091.

1090. Matas leñosas de $2-4^{\prime}$ de altura $\delta$ arbustos de $10^{\prime}$, muy ramosos, de ordinario pelierizados, con hojas simples, opuestas, pecioladas, enteras, aserradas ó festoneadas, tripli-5-nervias ó con las nervaduras principales encorvadas y alcanzando al ápice, y las venas y nervios formando con ellas una redecilla: lo que es característico, aovado-oblongas ó aovadas. Flores en cimas subsesiles, axilares, corimbiformes di ligualesá los peciolos, blancas o rosadas y de cáliz campanudo ó semi-globoso, con 5, 4, 6 lóbulos alesnados y ordinariamente abiertos; corola con 5,4 pétalos torcidos; estamlıres 8,10 , 12 , inclinados en la estivacion, es decir doblados por abajo hácia el ovario ó el fondo del cáliz, y al abrirse las flores se enderezan $Y$ ise 
vuelven ascendentes, de anteras anteriores y adheridas al conectivo, reventándose ordinariamente por 1 ó 2 poros terminales y lineares: algunas veces son mas gruesas, tuberculadas por el lado posterior ó la base, con las celdas reunidas. Ovario casi libre en el capullo y adherido solamente por algunas líneas lonjitudinales, pero por fin enteramente pegado con el cáliz, de ápice prolongado en pico largo, cilíndrico y asurcado. Baya azul pelierizada, con semillas ovales ó á veces piramidales : clidemia, F. 136, T. I, G. II.

1091. Cápsula lejítima y sin alas, 1092. - Cápsula formada de 3 cocos y de ordinario alada; arbustos sarmentosos ó trepadores, provistos á veces de zarcillos terminales, 1093.

1092. Plantas herbáceas, algunas veces acuáticas y nadantes, pero casi siempre enteramente terrestres y de los lugares húmedos y hasta pantanosos, matas sub-leñosas $\sigma$ arbustillos, de tallo de ordinario derecho y muy ramoso, desparramado ó tendido, lampiñas, pubescentes ó velludas; hojas simples, alternas, subsesiles ó cortamente pecioladas, enteras ú ondulosas por los bordes, alguna que otra vez aserraditas. Flores bastante grandes amarillas y alguna vez blancas, solitarias y axilares, en el vértice de las ramitas, de manera que su disposicion simula bastantes veces espigas apanojadas, habiéndose vuelto las hojas muy pequeñas, de pedúnculo mas ó menos corto, cuyo ápice lleva dos bracteitas; cáliz de tubo obtuso-anguloso ó prismatical-obaovado, tan largo como el ovario con que adhiere, con limbo 4, 5, 6-partido; de segmentos mas ó menos largos, mas ó menos ovales ó lanceolados, puntiagudos, lampiños, pubescentes ó peludos, abiertos y decíduos ; corola con 4, 5, 6 pétalos anchos, mas ó menos redondos y enteros, cóncavos y ungüiculados; estambres en número doble de los pétalos con que los unos alternan, mientras los otros están opuestos á ellos, de filamentos derechos, bastante largos, cuyo ápice alesnado lleva una antera grande, estrorsa y abriéndose por una grieta lonjitudinal; la insercion de los filamentos opuestos á los pétalos está acompañada de pelo blanco dispuesto como en semi-luna. Ovario muy largo con 4 ángulos, 4, 5 celdas poliovuladas : del centro de su ápice troncado y cubierto por el disco sale un estilo anguloso terminado por un estigma ancho $y$. como hipocrateriforme, cuyo centro está ocupado por un cuerpo glanduloso y oval. Cápsula 4, 6-locular, con muchísimas semillas diminutísimas y brunas, 8, 12-costilludito y abriéndose por la destruccion del pericarpio: jussica, F. 138.

1093. Mas ó menos altos, muy ramosos, con algunas ramitas volviéndose zarzillos, hojas alternas, simples, estipuladas, pecioladas, peninervias, elípticas, aovadas ó aovado-oblongas, aserradas ó festoneado-aserradas, lampiñas, alampiñadas ó de cara inferior tomentosa ó pubescente. Flores pequeñas, amarillentas, en grupos esparramados á lo largo de pedúnculos pubescentes ó velludo-tomentosos, axilares ó terminales y arracimadas; cáliz de tubo persistente y adherido con el ovario, apeonzado, 5 -partido; corola con 5 pétalos convoluto-espatulados; estambres insertos junto con los pétalos á un dísco 5-lobo, cuyos lóbulos libres están opuestos á los segmentos del cáliz, con anteras redondas. Ovario redondeado, 3-locular, con 3 
estilos. Al madurarse la cápsule los cocos indehiscentes que la forman se desprenden, dividiendo así cada ala en dos, cuya mitad.llevan consigo, monospermos: gouania, F. 124, G. III.

1091. Cáliz de muchísimas divisiones, cuyas interiores se confunden á veces con los muchos pétalos que forma la corola y están dispuestos por séries; estambres y estilo de ordinario muy largos, 1095. - Cáliz de 5 divisiones siempre, corola siempre de 5 pétalos. 1105.

1095. Vejetales carnosos mas ó menos ramosos, cuya altura y tamaño varian muchísimo, casi siempre con aguijones mas ó menos numerosos, y que parecen agujas y son muy punzantes, mas ó menos largos, fasciculados y blancos, reemplazados á veces por un pelo tieso y tambien muy punzante, sin hojas lejítimas ó de ninguna clase, 1096. - Arboles bajitos, con aguijones que parecen agujas fuertes en grupos esparcidos y diverjentes ; con hojas lejítimas carnosas, 1104 .

1096. Parásitas ordinariamente, de tallo cilíndrico ramosísimo, delgado, colgante y que no pasa de 2 ' re largo, 1100.-- Raras reces y casi nunca parásitas, cuyos tallos anguloso-comprimidos y á veces cilíndricos son mas ó menos derechos, estendidos ó trepadores, mas ó menos largos y mas ó menos ramosos, 1101.

1100. Tallos cilíndricos con ramos tambien cilíndricos ó comprimidos y simulando así alas foliáceas, articulados, alternos, opuestos ó verticilados. Flores pequeñas blanquecinas, sentadas entre los festones de los ramos comprimidos ó laterales en los cilíndricos, de cáliz tubular corto igualando al ovario desnudo, sépalos, pétalos y estambres indefinidos y reunidos entre sí por la base. Ovario inferior unilocular, poliovulado; estigmas distintos. Baya cilíndrica, pisiforme, algo prieta ó blanca: rhipsalis, F. 146, G. III.

1101. Tallo mas ó menos articulado, con ángulos mas ó menos proeminentes, en número variado segun las especies, derecho ó tendido por el suelo, mas ó menos ramoso, alguna vez que otra trepador ó rastrero, 1102. - Tallo articulado ó quizás mejor formado de artejos ó piezas mas ó menos grandes, pero que no se separan, comprimidas y provistas de una especie de puas carnudas caducas que son tenidas por hojas abortadas, acompañadas de pelo blanco y de espinitas situadas encima de tubérculos mas ó menos pronunciados, de los cuales salen flores sentadas mas ó menos grandes y situadas por el vértice y circunferencia de las piezas figurando con frecuencia hojas grandes y muy espesas, 1103.

1102. Superficie ordinariamente dispuesta en redecilla $y$ con areolas desnudas, con pelo ó espinitas mas ó menos largas y numerosas, diverjentes; flores con frecuencia muy grandes y primorosísimas sentadas hácia el vértice de los tallos ó ramos y sobre los ángulos ó laterales, color de rosa ó blancas, algunas reces muy olorosas, de cáliz que se va dilatando por arriba mas allá del ovario y entónces tubuloso, con sépalos esteriores adheridos que lo hacen parecer como escamoso; sépalos, pétalos y estambres muy ramosos, cuyos últimos están dispuestos en muchas séries sobre el tubo del cáliz con que está soldada la corola, cuyos pétalos están tambien 
por séries. Ovario mas ó menos grueso, espinoso, ovoídeo ó redondeado, unilocular, poliovulado: del centro del ápice troncado sale un estilo único filiforme mas largo que los estambres, los cuales esceden la corola, ó igualándoles, que lo tienen como prisionero en su centro, terminado por tres estigmas distintos ó por un estigma único y trílobo. Baya mas ó menos gruesa, con muchísimas semillas casi sin endospermo, de embrion cuyos cotiledones, de ordinario encorvados, se dirijen hácia el hilo : cereus, F. 146, G. I:

1103. Flores solitarias sesiles y laterales, amarillentas, mas ó menos rojizas ó rosadas, de cáliz cuyo tubo iguala el ovario, escamoso y con los sépalos esteriores y caducos; sépalos, pétalos y estambres indefinidos y reunidos entre sí por la base; ovario unilocular poliovulado: del centro de su ápice sale un estilo filiforme igualando casi á los estambres, de ordinario mas cortos que la corola, ó mas corto que ellos, entonces esertos y terminado por 3 estigmas distintos. Baya mas ó menos gruesa, desnuda ó provista de espinitas ó de pelo punzante muy fino, cuyas muchísimas semillas, pequeñas $\mathrm{y}$ comprimidas, contienen un embrion cuyos cotiledones están enroscados á manera de espiral en derredor de un endospermo escaso : opuntia, F. 146, G. II.

1104. Arbustos ó árboles de 12 a $20^{\prime}$ de altura, cuyo tronco, largo de 8 á 12 , echa pronto ramos largos y estendidos ó á veces rectos, con hojas simples, alternas, oblongo-elípticas ó algo espatuladas: sub-sentadas, y cuya base del peciolo está acompañada de pelo blanco corto y á la par de 1, 2 espinas cortas, encorvadas ó rectas. Flores sentadas, precoces, espar'cidas á lo largo de las ramitas y en especial hácia el vértice, blancas, purpúreas ó amarillas, solitarias o en cimas racemosas, de cáliz tubulado, cuyo tubo no se prolonga mas allá del orario, foliáceo porque se queda con los sépalos mas esteriores que simulan hojas y persisten, mientras los interiores, dispuestos por séries, se marchitan y desprenden; corola cuyos muchos pétalos, pluriseriados, se insertan en la parte superior é interior del tubo, calizinal, mientras los estambres lo están por la inferior. Ovario unilocular, poliovulado, con hojas, de cuyo ápice troncado sale un estilo cilíndrico, filiforme, tan largo como los estambres y terminado por un estigma trílobo y glanduloso. Baya redondeada, desnuda solamente por el vértice ombilicado, mientras la mitad inferior está con hojitas esparcidas pequeñas; muchas semillas de endospermo escaso y cuyo embrion tiene los cotiledones foliáceos: periescia, 146, G. IV.

1105. Fruto bastante grueso, que no es ni baya ni drupa, de corteza ó concha corticosa, polilocular, con las semillas envueltas en un arilo carnudo y rosado, coronado por el limbo persistente del cáliz, ó una balausta, 1106. - Fruto abayado, 1107.

1106. Arboles bajitos ó arbustos ramosísimos, con frecuencia espinosos; hojas simples, opuestas ó fasciculadas, sin puntitos transparentes, cortamente pecioladas, lanceolado-oblongas ó linear-lanceoladas, por ambos estremos aguzadas, algo coriáceas, lampiñas y lustrosas, un poco undulosas por los bordes, y especialmente agrupadas hácia el vértice de los ramos largos, delgados, en varita, Y 
terminándose por un grupo de algunas flores encarnadas ó amarillentas muy bonitas. Cáliz infundibuliforme de tuho apeonzado, con el limbo espeso, casi coriáceo y 5, 7-lobo, cuyos segmentos lanceolados se terminan por un tuberculito carnudo y puntiagudo, de estivacion valvar; corola con 5, 7-pétalos insertos en la parte superior del tubo calizinal en una depresion ó surquito que se halla en la parte interna de carla seno que separa las divisiones del cáliz, con que alternan, sesiles, redondeados, enteros, derechos y algo undulosos; muchos estambres libres desiguales, de filamentos encarnados, filiformes, derechos, con el spice doblado hácia dentro y provisto de una antera amarillenta y dorsifija, insertos en un disco que forra todo el interior del tubo calizinal. Ovario redondeado ó casi esférico, cuyo ápice en forma de cono y saliente en la garganta del cáliz lleva un estilo simple bastante grueso, cilíndrico ó casi con figura de botella, terminado por un estigma díscoídeo, glanduloso, con una depresion por el centro y verdusco. Fruto bastante grueso, esférico, manzaniforme, coronado por el tubo calizinal, de cáscara coriácea, colorada ó amarillenta, cuyas muchas celdas irregulares están dispuestas en 2, 3 séries, cuya inferior es 2,4 -locular y la superior 4, 9-locular, conteniendo muchas semillas de embrion oblongo con la raicilla corta, basilar y puntiaguda, los cotiledones foliáceos y enroscados á manera de espiral : punica, F. 134.

1107. Cáliz de limbo enteramente cerrado y sin division alguna, pero que se revienta en la estacion de la florescencia, 1108. - Cáliz de limbo ordinariamente con 5 divisiones valvares, 1111.

1108. Limbo calizinal abriéndose circularmente hácia la parte media y á lo largo de la línea de insercion, mucho por encima del ovario: la corola suele faltar con frecuencia, 1109. - Cáliz reventándose por el vértice en 2,3 lóbulos irregulares y desiguales, uno de los cuales se lleva frecuentemente el ápice separado á manera de gorra, á veces la corola suele faltar, 1110.

1109. Arboles mas ó menos grandes ó arbustos ramosísimos, cuyas ramitas cilíndricas ó comprimidas y como de dos filos, tienen puntos interpeciolares, lampiñas, pubescentes, herrumbroso-sedosa: ó velludas; hojas simples, opuestas, mas ó menos pecioladas, de ordinario lampiñas, lustrosas, ordinariamente con muchos puntos transparentes, elípticas, elíptico-lanceoladas ó eliptical-oblongas ú oblongo-lanceoladas, aguzadas y terminandose por una punta obtusa, lampiñas por ambas' caras ó por la inferior pubescentitas, alampiñadas ó sedosas. Flores blancas situadas lácia el rértice de las ramitas, en donde forman racimos compuestos $\dot{o}$ simples, otras reces están en grupos axilares, cuyos pedícelos lampiños, pubescentes, tomentosos ó sedosos. mas ó menos cortos, son $2,3,5$-cótomos ó ahorquillados; cáliz de limbo cerrado y adherente; corola con 2 , 5 pétalos mas ó menos abortados y que faltan las mas veces; estambres muchísimos y distintos. Taya de ordinario pequeña, monosperma ó con algunas semillas de testa cartilajinosa, de embrion con los cotiledones espesitos, foliáceos, arrugados ó torcido-plegados, y la raicilla casi tan largá como estos é inflexa: calypliantlies, F. 133 , T. I, G. I. 
1110. Arboles bajitos ó arbustos mas ó menos ramosos, cuyas ramitas lampiñas ó herrumbroso-tomentosas llevan hojas simples, opuestas, cortamente pecioladas, mas ó menos coriáceas, óvalo-lan. ceoladas, aguzadas por la base y de vértice obtuso y redondo, ó elípticas y obtusamente puntiagudas, enteras ó festoneaditas, con muchos puntitos transparentes, de cara superior lustrosa, lampiña y rugosita, mientras la inferior, mas pálida y tambien rugosita, tiene las costillas y nervaduras pubescentes $\mathrm{y}$ bastante pronunciadas, otras reces sin puntos transparentes, lustrosas y lampiñas por la cara superior, mientras la inferior es herrumbroso-pubescente ó tomentosa á lo largo de la costilla, y cuyas nervaduras asaz proeminentes se van reuniendo hácia la márjen, en donde forman un arco continuo y flexuoso. Flores blancas, bastante grandes, solitarias, axilares y largamente pedunculadas, ó en cimas tricótomas, de pedúnculos herrumbroso-tomentosos; corola de 5,8 pétalos ó nula; estambres muchísimos. Ovario con 2,3 celdas conteniendo 2 ó algunos óvulos, de estilo alesnado mas largo que los estambres y terminado por un estigma cabezudo. Baya globosa mas ó menos gruesa, coronada por los restos del limbo calizinal y aromática: marliera, F. 133, T. I.

1111. Cáliz de ordinario cerrado en el capullo ó diminutamente 4, 5-dentado, y por fin reventándose en tantos lóbulos simétricos; pétalos 4, 5: ovario 5, 2, 7-locular poliovulado; embrion anular, de semilla alargada y cuyos cotiledones son muy cortos, 1112. - Cáliz nunca jamás cerrado en el boton, pero con los̀ lóbulos ó divisiones bien marcados y separados; prefloracion valvar, 1113.

1112. Arboles bajitos ó arbustos muy ramosos, cuyas ramitas tetrágonas, comprimido-cilíndricas, son lampiñas, pubescentes ó alampiñadas y llevan hojas opuestas, simples, pecioladas, situadas hácia el vértice, cartáceas ó coriáceas, oblongas ó eliptical-oblongas, lanceolado-oblongas, oval-oblongas ó aovadas. Flores blancas bastante grandes, con pedúnculos axilares pauci ó raras veces multífloros; estilo mas largo que los estambres, alesnado, derecho, decíduo, saliendo del centro del disco que forra todo el fondo del cáliz y en que se insertan los estambres, muchos y desiguales. Baya mas ó menos gruesa, glolosa, oval, piriforme, de pulpa rosada ó blanca, umbilicada, con muchas semillas de testa muy aguda ó huesecitos muy pequeños, de un olor particular característico. Hojas aromáticas: psidium, F. 133, T. I, G. VI.

1113. Tubo calizinal bastante desarrollado y bien pronunciado, cilíndrico ó apeonzado, 1114. - Tubo del cáliz poco desarrollado ó apenas pronunciado, $106 \%$.

1114. Cilíndrico, cuyo fondo está lleno de una especie de tejido; ovario 2-locular, poliovulado; cotiledones semi-ovoídeos, sinuosos, abroquelados y encerrando en parte la raicilla alargada y derecha, 1115. - Apeonzado mas ó menos desarrollado, 1116.

1115. Arbol bajito, frondoso y de copa piramidal, con hojas simples, opuestas, coriáceas, elíptico-oblongas ú óvalo--lanceoladas, de limbo algo escurrido en el peciolo, que tiene hasta $2^{\prime \prime}$ de largo, crecido y como articulado por la base, enteras, lampiñas y lustrosas, 
con los nervios laterales numerosos saliendo en ángulo recto de la costilla. Flores blancas teñidas de rosado, muy olorosas, en racimos sinuosos, terminales, tricótomos, con los pedícelos cortos y bastante espesos, articulados y provistos de 2 bracteitas; cáliz de limbo con 4 segmentos colorados y persistentes; corola con 4 pétalos, coherentes, redondeados, sentados, algo cóncavos, derechos, abiertos y decíduos; muchos estambres mas largos que los pétalos, que á primera vista parecen libres, pero que están en 4 haces ó grupos situados en una especie de hoyo cuadrangular hácia la base de los dientes del cáliz, con los filamentos amarillos, de anteras oval-acorazonadas y de igual color. Ovario oblongo algo cilíndrico, con 2 celdas conteniendo como 20 óvulos, de los cuales uno ó dos solamente no ahortan; estilo filiforme, corto y algo alesnado, saliendo del ápice del ovario y del centro de una especie de disco ó glándula cuadrangular, sin adherir con ella, terminándose por un estigma pequeño y cabezudo. Baya ovoídea coronada por el cáliz, larguita, algo claviforme, con una ó pocas semillas cilíndricas ó casi ovales, oleajinosas y muy aromáticas, cuyo embrion elíptico, grande, espeso, verdusco, con los cotiledones espesos, carnudos, semi-ovoídeos, abroquelados, desiguales, encerrando la raicilla corta y superior: caryophyllus, F. 133, T. I, G. VIII.

1116. Muy desarrollado; embrion nunca enroscado en espira, 1117. - Menos desarrollado; embrion enroscado á manera de espiral, 1120.

1117. Mas largo que el ovario y sin ninguna especie de tejido en el fondo, 1118. - No mas largo que el ovario y provisto de una especie de tejido que llena su parte inferior; embrion globoso ú ovoídeo, ordinariamente indiviso y de raicilla corta, 1119.

1118. Arbol lampiño, de hojas coriáceas, ovales ú oboral-oblongas, pecioladas $\mathrm{y}$ sin puntitos transparentes, Jargas de $4-3^{\prime \prime}$ sobre 2-2 1 [ 2 " de ancho, sin el peciolo, que es largo de 10 á $6^{\prime \prime \prime}$, redondeadas por el ápice. Cimas laterales tricótomas, con flores blancas dispuestas en racimitos, de cáliz tubuloso, cuyo limbo es onduloso ó troncado; corola con 4, 5 pétalos coherentes, y sin embargo decíduos. Ovario con dos celdas multiovuladas. Baya con una ó pocas semillas, de embrion con los cotiledones semi-globosos, distintos y abroquelados, encerrando la raicilla corta : syzygium, F. 133, T. I, G. IX.

1119. Arboles bastantę grandes y coposos que se elevan á 30 ó 40' de altura, con hojas simples, opuestas, cortamente pecioladas, coriáceas, lustrosas, lampiñas, oblongas, lanceolado-oblongas, obaovado-oblongas ó lanceoladas, mas ó menos aguzadas, largas de 5-8." y anchas de 2 a $3^{\prime \prime}$, enteras, con muchísimos puntitos transparentes. Flores bastante grandes, primorosas, blancas ó purpúreas, en cimas laterales y terminales á la par, paucífloras, simples y mucho mas cortas que las hojas, de pedúnculos sin brácteas y casi articuladas con el cáliz, de base adelgazada y con el limbo 4-lobo, segmentos obtusos y profundos; corola con 4 pétalos ảispuestos á manera de rosa, blancos ó purpúreos, anchos, cóncavos y obtusos, mucho mas cortos que los estambres libres. Ovario 2, 3-locular, con muchos 
óvulos, de los cuales uno solo ó dos no abortan; estilo simple, filiforme, alesnado y casi tan largo como los estambres. Baya esférica ó pisiforme, amarillenta ó purpurácea, con una ó dos semillas mas ó menos libres dentro del fruto: jambosa, F. 133, T. I, G. III.

1120. Cáliz con 4,5 y hasta 6 segmentos, pétalos en igual número; ovario 4 ó multilocular, algo coronado, de celdillas multiovuladas; baya con pocas semillas, de testa membranácea, cuyo embrion tiene la raicilla alargada y los cotiledones cortos, 1121. - Cáliz con 4,5 divisiones, pétalos en igual número; ovario cuyas 2 celdas contienen 2 ó algunos óvulos; baya como drupácea con 1, 2 semillas, de testa membranácea, de embrion en espiral ó inclinado, con la raicilla alargada y los cotiledones cortos, 1122.

1121. Arbol bajito muy aromático, ramoso, cujas ramitas pubescentes y comprimido-cilíndricas, llevan hojas rugositas, simples, opuestas, pecioladas, membranáceas, elípticas, apiculadas, alampiñadas, opacas, largas de $3-2^{\prime \prime}$, sobre $2-11_{1} 2^{\prime \prime}$ de ancho, con el peciolo de $4^{\prime \prime \prime}$; renas primarias pareciendo costillas, arqueadas, distantes y cuya impresion aparece por la cara superior, mientras están algo espesas y bastante pronunciadas por la inferior, con los nervios transversales y mas delgaditos. Primorosas flores blancas, axilares, con pedúnculos solitarios ó fasciculados, algo distantes y largos de 4-12"', están acompañados de 2 brácteas largas de $3-2^{\prime \prime \prime}$ y llevan brácteitas de $11_{[} 2^{\prime \prime \prime}$; corola de pétalos obaovados largos de $3^{\prime \prime \prime} \mathrm{y}$ dos veces mas que los segmentos del cáliz. Baya globosa y blanca, pequeña como de $3^{\prime \prime \prime}$ de diámetro: campomanesia, F. 133, T. I, G. VII.

1122. Arboles de copa piramidal bastante corpulentos y que se elevan hasta $45-50$ de altura, con las ramitas comprimido-subtetrágonas, alampiñadas ó lampiñas, que llevan hojas simples, alternas ú upuestas, coriáceas, bien enteras, pecioladas, oblongas ó lanceoladooblongas, obaovadas, ovales ú obaovado-redondeaditas, lampiñas, lustrosas y con puntitos negros por la cara inferior, en donde las venas y nervios son bastante pronunciados. Flores blancas en cimas terminales ó axilares, tricótomas y plurífloras, mas largas ó mas cortas que las hojas; pimenta, F. 133, T. I, G. V.

1123. Cáliz 5, 4-lobado; pétalos 5, 2; ovario 2, 4-locular, cuyas celdillas contienen 2 órulos nada mas; embrion de cotiledones espesito-foliáceos, arrugados ó torcido-plegados, casi tan largos como la raicilla inclinada, 1124 . - Cáliz 4, 5-lobo; pétalos 4, 5; ovario con 2, 3 celdas multi ó 2-ovuladas; embrion globoso ú ovoídeo, ordinariamente indiviso, con la raicilla corta, 1125.

1124. Arbustos, árboles bajitos ó á veces arboles grandes y coposoś, cuyas ramitas alampiñadas, pubescentes ó herrumbroso-tomentosas, llevan hojas opuestas, simples, enteras, pecioladas, coriáceas, opacas ó con puntitos transparentes, de cara superior lustrosa y lampiña, mientras la inferior, mas pálida, está algunas veces alampiñada, con las venas en redecilla ó diminutamente areoladas, obovales, eliptical-oblongas ó elíptico-lanceoladas, obtusas, escotadas ó con una punta, de tamaño variando entre 1 y 4 " de largo sobre 1-2" de ancho; sin embargo, las hay hasta de 10-12" de largo. Flo- 
res en cimas de ordinario mas largas que las hojas, cuyo tubo calizinal se prolonga algo mas allá del ovario ó apenas está tan largo como él; baya con una ó pocas senillas de testa cartilajinosa, con el ápice cóncavo ó llano, pero siempre mas ó menos coronado: myrcia, F. 133, T. I, G. II.

1125. Arbustos, árboles bajitos ó á veces bastante grandes, cuyas ramitas lampinas, alampiñadas, pubescentes, tomentoso ó sedosoherrumbrosas, llevan hojas simples, opuestas, enteras, corícceas ó papiráceas, pecioladas, del todo lampiñas, con puntitos transparentes y a!gunas veces opacas, ovales, cuneiforme-elípticas, elípticolanceoladas. óvalo-lanceoladas, elípticas ú oboval-oblongas, mas ó menos aguzadas ú obtusas, con las venas mas ó menos delgadas y pronunciadas por la cara inferior y juntándose para formar un arco mas ó menos continuo, flexuoso, alguna vez que otra doble y mas ó menos distante de la márjen. Flores blancas axilares, solitarias ó fasciculadas, racimosas ó corimbosas, cuyos pedícelos mas ó menos cortos están provistos de bracteitas o sin ellas. Ovario casi tan largo como el tubo del cáliz ó mas corto que él. Baya con una ó algunas semillas, ovoídea ó globosa, de tamaño y color muy variados 5 algunas reces comestible : eugenia, F. 133, T. I, G. IV.

1120. Estambres 8, 20, semi-epijínicos, 1127. - Estambres enteramente epijínicos, 1128 .

112\%. Plantas herbáceas, carnudas, de tallos desparramados y tendidos ó derechitos, en especial por el vértice, largos de 6 á $12^{\prime \prime}$, cilíndricos, mas ó menos moraditos, lampiños, con hojas simples, alternas ú opuestas, subsesiles ó algo pecioladas, esesas y carnudas, espatuladas ó sub-cilíndricas, pequeñas, lampiñas, entejérrimas, de ordinario arrosetadas por debajo de las flores, á las cuales forman así una especie de invólucro. Flores amarillas ó rosadas, terminales y agrupadas, sub-sentadas, de cáliz 2-partido, con el tubo adherido, y cuyo limbo es decíduo; corola con 4,6 pétalos mucho mas grandes que las divisiones del cáliz, semi-epiínicos, abiertos y delicados. Ovario esférico, semi-ínfero, unilocular, poliovulado, con un estilo 3, 8-partido. Pixidio envuelto por el cáliz persistente, con muchas semillas muy pequeñas, negras y diminutamente granujientas : portulaca, F. 148, T. II, G. II.

1128. Estambres muchos é indefinidos; fruto capsular, 1129. Estambres 5 : el fruto es un diaquenio, 1130.

1129. Planta herbácea, cuya parte inferior del tallo es sub-leñosa, ramosísimo, largo, delgado, como articulado, con pelo blanco y asperidades, como sarmentoso y saliendo de una raiz fusiforme del tamaño del dedo pulgar. Hojas simples, alternas, pecioladas, hastado-trílobas, desigualmente aserradas, pubescentes y larsas de $2^{\prime \prime}$, sin el peciolo, que lo es de l'", sobre 15-18"' de ancho. Flores amarillas axilares, solitares y situadas hácia el vértice de los ramos, de 8-10" de diámetro ; cáliz de tubo cilíndrico ó claviforme, con pelo agarabatado, glanduloso y muy pegadoso, cuyo limbo 5-fido, decíduo, se desprende despues de verificada la fecundacion de una sola pieza y lleva consigo la garganta $y$ los organos en ella insertos; corola con 5 pétalos ovales algo esertos, algo espatulados y pubes- 
centes esteriormente; estambres de 20 á 30 , mitad tan largos como la corola, cuyos 10 mas esteriores tienen los filamentos espatulados, siendo todos mas cortos que la corola, con anteras elípticas basifijas. Ovario oblongo como claviforme, unilocular, con muchos óvulos, de cuyo ápice sale un estilo filiforme bastante largo, derecho y terminado por un estigma algo cabezudo. Cápsula claviforme y cilíndrica á la par, cubierta de mucho pelo glanduloso, claviforme, muy pegadoso y transparente, unilocular polisperma, abriéndose en 3 valvas por el ápice y se desprende del pedúnculo como si fuera articulada: mentzetia, F. 142.

1130. Flores siempre en umbela simple ó compuesta, 1132.-Flores nunca en umbela pero en cabeza involucrada, 1131.

1131. Planta herbácea bisanual, lampiña, de tallo dicotómicodesparramadito alto como de $\mathrm{I}^{\prime}$; hojas alternas simples espinosas, coriáceas, cuyas inferiores espatulado-lanceoladas, aserradas, con los dientes puntiagudos y punzantes, largas de $4,4 I_{l} 2,5^{\prime \prime}$, anchas de $11,15,20^{\prime \prime \prime}$, son envainadoras por la base del limbo, mientras las superiores son mucho mas pequeñas, lanceoladas y palmatipartidas, sin vaina por la base. Flores blanquecinas, pequeñas, sesiles y agrupadas sobre un receptáculo cilíndrico-cónico, cubierto de pajuelas espinosas separando las flores, cuyo conjunto forma una cabezuela ovoídeo-oblonga, cortamente pedunculada, cuya base está envuelta por un invólucro de hojuelas espinosas mas largas que la cabezuela, lanceolado-palmatipartidas y de ordinario profundamente aserradas; cáliz de limbo 5-partido, persistente, de tubo corto áspero y con vejiguitas; corola con 5 pétalos, de ápice algo escotado, derechos, converjentes, oblongos ú obovales; 5 estambres cuyos filamentos, arqueados al principio, no tardan en enderezarse. Ovario ovoídeo, algo comprimido, de cuyo centro del vértice salen dos estilos diverjentes. Fruto rollizo ú ovoídeo-oblongo, tuberculado ó escamoso, coronado por el limbo calizinal vuelto espinoso, formado de dos carpidios ó aquenios sin fajas ni costilludo tampoco, enteramente adheridos al carpóforo ó columna : eryngium, F. 149, S.-Or. I, T. III.

1132. Umbelas simples ó prolíferas; hojas larguísimamente pecioladas, abroqueladas ó acorazonadas, mas ó menos festoneadas y nunca pinatisectas, 1133. - Umbelas siempre compuestas; hojas siempre pinatisectas, 1134

1133. Plantas herbáceas de los lugares húmedos y hasta pantanosos, de tallo delgado, mas ó menos largo y arraigante, lampiñas, con hojas alternas, simples, de peciolo largo de 6 á $8^{\prime \prime}$ mas ó menos, segun el lugar cn donde se cria la planta, cilíndrico, derecho, sosteniendo un limbo orbicular, festoneado ó acorazonado-redondeadito ó cordiforme-aovado con un seno abierto y festoneado-dentado, dentado solamente ó unduloso, lampiño ó alampiñado, de 18 á $24^{\prime \prime \prime}$ de diámetro, mas ó menos doble y carnoso. Flores en umbela abierta ó recojida con algunas ó pocas flores pediceladas, acompañada por la base $y$ en el vértice del pedúnculo largo de 4 á $6^{\prime \prime}$ y mas de un invólucro de 4 á 5 hojuelas; cáliz de limbo entero y apenas notable; corola con 5 pétalos aovado-agudos, enteros, iguales y blancos; es- 
tambres 5. Diaquenio lateralmente comprimido, cuyos carpidios sin fajas, con 5 ó 9 costillas, son filiformes: hydrocotyle, F. 149, S.Or. I, T. I.

1134. Fruto ovoídeo, oval ó globoso, mas ó menos comprimido, con ó sin puas, mas ó menos estriado, 1136.-Fruto cilíndrico, bastante largo, estriado y mas ó menos picudo, 1135.

1135. Planta herbácea anual, de tallo derecho, lampiño, lustroso, alto de como $2^{\prime}$ algo mas ó menos; hojas bastante grandes, alternas, envainadoras por la base, cuyas inferiores largamente pecioladas son 3-pinatisectas, mientras las del tallo y ramos van volviéndose mas simples á medida que se acercan del vértice. Flores pequeñas blancas en umbelas terminales y laterales á la par, compuestas de 4 ó 5 radios sin invólucro alguno; cáliz entero; corola con 5 pétalos de ápice cordiforme y desiguales, ligulados y algo ungüiculados; estambres 5 salientes y enderezados; ovario fusiforme terminado por dos estigmas diverjentes: chcrophyllum, F. 149, S.-Or. II, T. III.

1136. Diaquenio pelierizado, cuyo pelo tieso parece puas y con crestas membranosas, 1137.-Diaquenio nunca erizado, 1138.

1137. Planta herbácea bisanual, cuyo tallo derecho, mas ó menos ramoso, estriado y peludo sale de una raiz carnuda, perpendicular, mas ó menos gruesa, alto de 2 á $3^{\prime}$; hojas alternas, envainadoras por la base, cuyas inferiores son 2,3 veces pinatisectas, con los segmentos pinatífidos, cuyos lóbulos oblongo-lineares son cuspidados, mientras se vuelven mas simples á medida que se hacen mas superiores, de manera que las últimas se han puesto laciniadas y casi sentadas : todas son velludas. Flores blancas en umbela compuesta ó algo teñidas de color purpúreo por el centro de las umbelas en donde son estériles, mientras las de la circunferencia algo mas grandes son todas fértiles; hojuelas del invólucro foliáceas y multífidas, casi tan larga como la umbela, que por fin se vuelve recojida, mientras las de los involúcelos son muchas, enteras ó trífidas; cáliz de limbo 5-dentado; corola con 5 pétalos, inclinados, de ápice acorazonado ó escotado, mayores por la circunferencia que en el centro y pareciendo como radiados. Ovario ovoídeo, con dos estilos diverjentes. Fruto lijeramente comprimido por el dorso, cuyos carpidios con 4 fajas simples; costillas secundarias aguijonosas y aladas, cuyas puas en una série son casi tan largas como el diámetro del fruto oval-oblongo; costillas primarias 5, cerdosas; daucus, F. 149. S.Or. I, T. IX.

1138. Umbela sin invóluero alguno, 1139. - Umbela con invólucro, 1144 .

1139. Raiz carnosa bastante gruesa, amarillenta interiormente, feculenta y comestible, 1140.-Raiz poco carnosa, no gruesa, blanca ni feculenta ni comestible tampoco, 1141.

1140. Planta herbácea vivaz, con hojas 1, 3-pinatisectas, cuyos segmentos inferiores están partidos en lóbulos aovado-aguzados y aserrados. Flores blancas en umbelas compuestas, de cáliz cuyo limbo es obsoleto ó apenas notable; corola con 5 pétalos aovados ó lanceolados, enteros pero con una punta inclinada. Fruto aovado- 
oblongo sub-comprimido; carpidios con 5 costillitas iguales, enteras, obtusas; endospermo asurcado por el lado comisural : arvacucha, F. 149, S.-Or. II, T. IV.

1141. Pétalos redondealos, enrollados hácia dentro y con un lóbulo escamoso y obtuso, 1142.-Pétalos sub-redondos, de ápice inflexo ó involuto y sin lóbulo alguno, 1143.

1142. Planta vivaz de tallo derecho, poco ramoso y lampiño, liso, estriado y con hojas alternas, cuyo peciolo, tanto mas corto cuanto mas superior está la hoja, es envainador por la base, bipínati ó 3pinatisectas, con muchísimos segmentos capilares, de un olor particular característico. Flores amarillas en umbelas compuestas bien fornidas, iguales, de cáliz algo hinchado con el limbo entero y muy poco pronunciado ; corola con 5 pétalos içuales y enteros; 5 estambres salientes, enderezados y algo diverjentes. Ovario oval, de cuyo ápice salen dos estilos diverjentes. Diaruenio casi oval, de carpidios o mericarpios con 5 costillas salientes obtusas, cuyas laterales, mas gruesas que las demas, están por los bordes: foniculum, F. 149, S.-Or. I, T. II.

1143. Plantas herbáceas bisanuales, de raiz á veces hastante gruesa y comestible, pero siempre blanca, de tallo bastante grueso, lampiño, estriado; hojas radicales con largos peciolos estriados esteriormente y con un canal grande y unido por la cara inferior, de base algo envainadora, al principio derechas y mas luego tendidas, pinatisectas, con los segmentos algo cuneiformes, y de ápice dentado ó trífido, alternas en el tallo y ramos, en donde se han vuelto laciniadas y mucho mas pequeñas, de un olor particular característico cuando estrujadas; flores amarillentas en umbelas compuestas; cáliz de limbo obsoleto; disco corto, cónico y á la par escotado; diaquenio oval, contraido lateralmente, algo dídimo, de carpidios con 5 costillás iguales y filiformes : apium, F. 149, S.-Or. II, T. I.

1144. Un invólucro y un involúcelo, 1145. - Un invólucro solamente ; planta herbácea anual, de tallo ramoso y lampiño, con hojas alternas, cuyas inferiores son bipinatisectas y con segmentos anchos $\mathrm{y}$ dentaditos, mientras las ramales son finamente partidas. Flores blancas en umbelas 3,5 -radiadas, desiguales, las de la circunferencia siendo mayores; cáliz con 5 dientes desiguales, agudos y persistentes; corola de 5 pétalos obaovados, bífidos por el ápice doblado, cuyos interiores son mas pequeños; estambres 5 . Ovario globoso coronado por los dientes calizinales y de cuyo ápice salen dos estilos diverjentes. Diaquenio globoso, 10-costilludo, apenas bipartible ; mericarpios con 5 lomas primarias deprimido-flexuosas, las secundarias, en número de 4 , están cerca de la márjen, mas proeminentes y aquilladas; vallecillos sin fajas; comisura con dos fajas, olor particular : coriandrum, F. 149, S.-Or. III, T. I.

1145. Planta herbácea bisanual, de tallo mas ó menos ramoso, estriado, lampiño y alto de $2^{\prime}$ á 3 , dereclıo, saliendo de una raiz perpendicular poco carnuda y del tamaño como del dedo pulgar; hojas radicales largamente pecioladas, 3-pinatisectas, con los segmentos superiores lanceolados ó trífidos, alternas en el tallo y ramas y volviéndose menos partidas á medida que se hacen mas suje- 
riores, de manera que las últimas son lanceolado-trífidas solamente. Flores blanco-amarillentas en umbelas compuestas de invólucro oligófilo, mientras el involúcelo es al contrario polífilo, las del centro estériles y solas fértiles las de la circunferencia; cáliz de limbo obsoleto; corola de 5 pétalos sub-redondos, estrechados en lacinia encorvada; estambres 5, mas largos que la corola; estilos 2, diverientes: fruto lateralmente comprimido, aovado, sub-dídimo, de mericarpios 5-yugados ó costilludos, cuyas lomas filiformes iguales son laterales y marjinales; vallecillos con una faja, mientras la comisura tiene dos; carpóforo bipartido : petroselinum, F. 149, S.-Or. II, T. I.

1146. Ovario semi-ínfero, 1147.-Ovarios parietales; estambres libres insertos en un disco espesito situado en el ápice del tubo calizinal, que se vuelve por fin carnudo y como abayado, conteniendo muchos aquenios huesosos, 1149 .

1147. Estambres muchos y poliadelfos insertos por adentro de la garganta del cáliz, con cuyos segmentos alternan, 1148. - Estambres libres y en número definido, 1149.

1148. Arbusto ó árbol bajito, con hojas simples, alternas, aserradas ó sub-enteras, pecioladas, lampiñas, papiráceas, elipticaloblongas, largas de $5-3^{\prime \prime}$ sin el peciolo, que lo es de $2^{\prime \prime}$, solre 20 22-25"' de ancho, estipuladas, con dos estipulitas lineares y caducas. Flores verdoso-amarillentas en racimos espiciformes, terminales, mas ó menos pediceladas y anchas de como $8^{\prime \prime \prime}$; cáliz de tubo apeonzado, cuyo limbo es 6, 7-partido, cuyos segmentos llevan una glándula por la base ; corola con 6,7 pétalos sesiles, cóncavos, obtusos, rerlondeados y estendidos; de 18 á 24 estambres en 8 andróforos cubiertos de pelo sedoso opuestos á los pétalos y alternando con otras tantas glándulas, llevando 3, 4 anteras cada uno. Estilos 3; placentas 3. Cápsula unilocular polisperma de dehiscencia medianícida 3-valve por el ápice : homalium, F. 132, páj. 323.

1149. Siempre 5 estambres; 3 estilos y ovario 3 -locular; base del fruto nunca acompanada y envuelta en el limbo calizinal persistente, 1150.-De 8 á 12 estambres; estilo único; fruto envuelto por encima de la base por el limbo calizinal persistente, cuya semilla germina en su interior, estando todavía colgando del árbol, y cuya radícula lo agujera para salir afuera. Arbol de las orillas del mar, lampiño, con raices adventivas que se vuelven troncos, alto de $1 \breve{\jmath}$ á $25^{\prime}$ y á veces $30^{\prime}$ de altura, muy ramoso; hojas opuestas, simples, pecioladas, coriáceas, bien enteras, obaovadas, ovales ú obaovadolanccoladas, obtusas, largas de $5,4,3^{\prime \prime}$ sobre $3,21_{[} 2,2^{\prime \prime}$ de ancho, con estípulas intrapeciolares. Flores axilares pedunculadas y casi

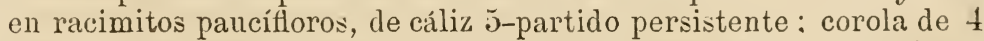
pétalos lacerado-lanudos por la márjen y mas cortos que el limbo calizinal. Estambres 8 insertos por adentro del cáliz valvar. Ovario bilocular, cuyas celdas contienen dos óvulos colgantes. Fruto monospermo por causa de aborto de los demas óvulos: rhizophora, F. 137.

1150. Árbustos ó árboles bajitos, muy ramosos, de ramitas pubescentes ó tomentosas, con hojas simples, alternas, pecioladas, es- 
tipuladas, aovadas ú oblongas, elípticas ó elíptico-lanceoladas, enteras ó aserraditas, del todo lampiñas ó de cara inferior alampiñada ó tomentosa. Flores en glomérulos formando cimitas axilares apenas tan largas como los peciolos, de cáliz adherido por la base persistente, cuyo limbo abierto y de 5 lóbulos aquillados por la cara interior es por fin circonciso; corola con 5 pétalos espatulados y ungüiculados ; estambres 5, saliendo afuera antes de la antesis completa. Ovario mas ó menos globoso ó cónico 3-locular, anidado en el disco llano, con 3 estilos libres ó reunidos por la base. Fruto capsulár formado de tres cocos ó cajitas abriéndose por el lado interno, cada uno con una sola semilla, lustrosa, negra y bien pulida: colubrina, F. 124, G. II.

1151. Primorosos arbustos de tallo largo, derecho, cilíndrico, mas ó menos aguijonoso, de hojas altèrnas, compuestas, con estípulas soldadas á la base del raquis, imparipinadas con tres ó mas hojuelas, cortamente pecioladas mas ó menos ovales, aserradas, cuya impar es de ordinario mas grande que las laterales, raquis y costilla no rara vez aguijonosos, cara superior lustrosa y lampiña, mientras la inferior, no lustrosa, es con frecuencia pubescente. Preciosas flores olorosas terminales, tan pronto solitarias como en especies de cimas; cáliz de tubo apeonzado ó urceolado, con limbo partido en 5 segmentos largos, lanceolados, decduos, de los cuales 2 solos están enteros, mientras los demas son laciniados; corola con 5 pétalos obtusos, redondeados, cóncavos, ob-cordiformes algunas veces, de color muy variado y á veces numerosísimos; muchos estambres dispuestos en algunas séries, desiguales, de filamentos alesnados, derechos y con anteras basifijas. Ovarios muchos, uniloculares, pegados en la pared interna del cáliz, mas ó menos ovales y pequeños, peludo-sedosos, terminados por un estilo simple, peludo, un poco lateral, largo y un poco eserto, terminado por un êstigma discoídeo algo cabezudo. Aquenios huesosos mas ó menos numerosos, pequeños, sedosos, á veces triangulares y distintos, contenidos en el cáliz vuelto ahayado: rosa, F. 132, grupo II. 


\section{FÉ DE ERRATAS}

Pájina vir, lín. 34, en lugar de historia natural; de d'Orbigny, léase historia natural de d'Orbigny.

viIr, lín. 1, en lugar de knuth, léase kunth.

$\mathrm{xI}$, lín. ultima, léase de los rudimentos de las rocas calcíreas y con la incesante accion de los vejetales; hasta que, y quitarla pues de la páj. VII, línea última tambien.

xxix, lín. 16, en lugar de en que nace, léase que nace.

xxxir, lín. 14, en lugar de los que se debe, léase lo que se debe.

xxxv, lín. 9, en lugar de hacen, léase hacer.

xxxviI, lín. 14, en lugar de pectórico, léase pectósico.

xLvi, lín. 17, en lugar de quelastomáceas, léase melastomáceas.

83, lín. 7, en lugar de retinervias, léase rectinervias.

84, lín. 11, en lugar de albejaca, léase albajaca.

92, lín. 11, en lugar de asoldadas, léase ó soldadas.

106, lín. 33, en lugar de umbelical, léase umbilical.

109, última línea, en lugar de con mas îrecuencia, léase con mas fiecuencia.

116, lín. 44, en lugar de cupiliforme, léase cupuliforme.

129, lín. 46, en lugar de endoplema, léase endopleura.

131, lín 43, en lugar de y la iguala, léase y les iguala.

134, lín. 33, en lugar de que se esperimentando en la, léase que se va esperimentando la.

153, lín. 8, en lugar de con los cuales, léase con que.

Id., lín. 38, en lugar de auguria, léase anguria.

Id., lín. 42, en lugar de roehmeria, léase boehmeria.

157, lín. 23, en lugar de asparijineas, léase asparajineas.

Id., lín. 36, en lugar de superovaridos, léase superovariados.

162, lín. 12, en lugar de oacao, léase cacao.

181, lín. 15, en lugar de é.interna, del cual se las halla formadas, etc., léase é interna del cual se las halla, formadas, etc.

184, lín. 21, en lugar de forman, léase formar.

191, lín. 46, en lugar de carnúcula, léase caríncula.

199, lín. 35, en lugar de mas ó menos, 5 lobadas, léase mas ó menos 5 lobadas.

202, lín. 9, en lugar de í fuera de, léase á fuera.

206, lín. 46, en lugar de 5 senta; dos son, léase J-sentados son.

209 , lín. 15, en lugar de $116^{\prime \prime}$, léase $16^{\prime \prime}$.

215, lín. 9, en lugar de amento ó estrobiliforme, léase amento estrobiliforme. 
226, lín. 30, en lugar de carpidios, drupéceos, léase carpidios drupriceos.

238, lín. 7, en lugar de son espiguitas, léase son en espiguitas.

241, lín. 44, en lugar de periantie, léase periantio.

246, lín. 11, en lugar de acompaíadas, léase acompañadas.

250, lín. 44, en lugar de caroliforme, léase coroliforme.

251, lín. 42, en lugar de terminada, léase terminado.

260, lín. 41,. en lugar de cebollota, léase cebolleta.

265, lín. 31, en lugar de tienen al aspecto, léase tienen el aspecto.

292, lín. 22, en lugar de cípsula, léase chípula.

302 , lín. 12 , en lugar de $y$ de dos cuales 2 , etc., léase $y$ de los cuales dos, etc.

307, lín. 8, en lugar de aureiitas, léase orejitas.

308, lín. 20, en lugar de aguzacitas, léase aguzaditas.

310, lín. 12, en lugar de envueltas, léase envueltos.

Id., lín. 14, en lugar de ravio, léase varia.

Id., lín. 24, en lugar de esterieres, léase esteriores.

314, lín. 3, en lugar de adheridas, léase adheridos.

324, lín. 23, en lugar de apendice, léase ápice.

325, lín, 24, en lugar de pirenas, obtusamente, léase pirenas obtusamente.

329, lín. 23, en lugar de especiformes, léase espiciformes.

344, lín. 32, en lugar de petúgonas, léase pentágonas.

346, lín. 45, en lugar de especiformes, léase espiciformes.

35̃2, lín. 42, en lugar de desparvadas, léase desparramadas.

366, lín. 41, en lugar de dispues tusen, léase dispucstas en

368, lín. 33, en lugar de colora, léase corola. 


\section{INDICE GENERAL DEL TONO I.}

A

Abreviaturas.

\begin{tabular}{r|ll} 
& & \\
Pay. & Cariópside (del). & Pag. \\
$x$ & Carúncula (de la). & 143 \\
Cinarrodon (del). & 129 \\
93 & Clasificacion de los frutos. & 143
\end{tabular}

pag.

143

129

Absorcion, respiracion, etc. 93

Aguijones (de los).

Albúmen (delt).

78

127

Andróforo (del).

Anfisarca (de la).

Antigüedad del reino vejetal.

Antera (de la).

Anteridios (de los).

Aquenio (del).

Arilo (del).

Arquegonios (de los).

Astil (del).

116

145

- de los vejetales.

150

Conectivo (del).

Consideraciones sobre la nutricion de los vejetales.

Corola (de la).

XI

114

127

143

129

148

72

B

Baya (de la).

Bellota (de la'.

Brácteas (de las).

Bulbo ó cebolla del).

\section{G}

Caja.

Calículo (del)

Cáliz (del).

- súpero, semi-ínfero, ín:: fero.

Caña (rie la).

Cápsula de la).

Carcérulo (del).

Embrion (del).

- monopétala.

- polipétala.

- catapétala.

Cotiledones (de los).

\section{I.}

Datos históricos sacados de la botánica.

Definicion de la botánica. $\quad 60$

Dehiscencia de los frutos. $1-2$

- septícida, loculícida, septífraga.

- valvar.

Disco (del).

Discurso preliminar.

Documentos.

Drupa (de la).

\section{E}

Elaterio (del). 
antítropo $y$ heterótropo. $\quad \begin{aligned} & \text { Pag. } \\ & 131\end{aligned}$ Endospermo (del .

127

Envenenamiento de los vejetales (del). $\operatorname{XxxIX}$ Envoltura suberosa (de la).

- herbácea.

Epidermis (de la). Escreciones (de las).

Espata (de la).

Espinas (de las'.

Esporanjios de los .

95

92

78

148

Esporos (de los).

Estambre del).

- monadelfos, diadelfos, poliadelfos, didínamos, tetradínamos.

Estaminodios (de los).

E.tigma (del).

Estilo (del).

Estípulas de las).

Estivacion (de la).

Estróbilo (del).

Eterio (del:.

Evaporacion (de la).

\section{F}

148

111

117

115

111

109

90

102

145

144

95

Herbarios (de la preparacion de los).

Herborizaciones de las.

Hesperidio (del).

Hnjas de las!

- simples.

- comprestas.

Huevecillos (de los).

\section{I}

Inflorescencia (de la).

- axilar.

- terminal, mista, anómala.

Insercion de los estambres (de la).

- hipojínica, perijínica.

rag.

L

45

81

84

88

105

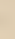

Fecundacion (de la).

Filamento (del).

Fillodio (del).

Flor (de la).

- hermafrodita, masculina, femenina, monoica, dioica.

- monandra, diandra, poliandra, isostemone, dipostemone ó polistémone. - ginandra.

Frutos (de los).

14.3

116

93

97

98

117

116

137

\section{G}

Generacion (de la).

Geografía botánica.

Germinacion (de la). xxvir-134

Ginostemo del!.

Glándulas (de las).

Gluma de la).
96

$\mathrm{XL}$

116

80

93
- epijínica.

- hipoperijínica

Invólucro (del). (T)

\section{J}

Jaleas vejetales (de las). Xxxvi

\section{L}

Legumbre (de la!.

Lentejillas (de las).

Ley de las analojías botánicas.

\section{M}

Madera de la).

71

Maduracion de los frutos. $\mathrm{xxxv}$

Médula (de la).

71

Melónida (de la).

145

Método natural de A. L. de Jussieu.

- analítico y dicotómico. 165

\section{$\mathbf{N}$}

Nectarios (de los.

Nuculanio (del). 
Nuez (de la).

\section{rag.}

\section{$\mathrm{O}$}

Odrecillo del'.

Organografía.

Orgános reproductores de los rejetales criptógamos.

- de la nutricion y de la vejetacion de los criptógamos.

Ovario (del).

- libre ó súpero, adherente ó ínfero, parietal.

\section{$\mathrm{P}$}

Paralelo entre los vejetales

y los animales.

Peciolo (del).

Pedúnculo (del).

Pelos (de los).

Peponida (de la).

Periantio ó perigonio del.

Pericarpio (del).

Periclinio ó periforantio.

Perispermo (del).

Plantas parásitas (de las) tocante á la agricultura.

Piña de la .

Pistilo (deli.

61

81

Pixidio (del).

Polaquenio del:

Pólen (del).

102

79

145

119

139

92

127

Prefloracion de la .

XXXVIII

Prefoliacion (de la).

Prólogo.

Propagacion artificial de los vejetales.

- por estaca, esquejos ó cogollos.

- por magullo ó acorlo.

- por injerto.

XXXII

XXXIII

XXXII

XXXII

\section{li:}

Raiz (de la).

Resúmen de botánica elemental.

Rizoma ó cepa.

Pag.

66

59

73

\section{S}

Sámara de la).

Samaridio (del).

Semilla (de la).

153

144

- madura.

Sicono (del).

Silícula (de la).

Silicua de la).

Sincarpio (del).

Sistema de Linneo.

Sorosis (del).

126

128

146

145

144

144

150

146

\section{$\mathrm{T}$}

Tallito (del).

Tallo (del).

133

- lejítimo.

Taxonomia.

Tronco (del).

\section{U}

Utilidar de los veistales para la existencia de los animales.

XXII

\section{V}

Vejetales acotiledóneos, cotiledóneos, monorotiledóneos, dicotiledoneos.

Y

Yemas, bulbos y tubéreulos.

Yemecita ó plumilla de la). $13: 3$

Zarcillos ide los. 



\section{INDICE DE LOS GÉNEROS}

\section{Ex $\mathrm{n}$ \\ MÉTODO DIGOTOMICO}

\begin{tabular}{|c|c|c|c|c|c|}
\hline A & & & Pag. & & Pag. \\
\hline & & Alpinia. & 474 & Areca. & 100 \\
\hline & Fag. & Alternanthera & 377 & Argemone. & 872 \\
\hline Abelmoschus. & 970 & Amaranthus. & 197 & Aristolochia. & 420 \\
\hline Abies. & 104 & Amarillis. & 455 & Artante. & 315 \\
\hline Abrus. & 1044 & Amblogine. & 198 & Artocarpus. & 113 \\
\hline Absinthium. & 774 & Amomum. & 473 & Arundo. & 332 \\
\hline Abutilon. & 965 & Amyris. & 996 & Asclepias. & 664 \\
\hline calypha. & 152 & Anacardium. & 277 & Asophila. & 246 \\
\hline cacia. & 298 & Anda. & 128 & Aspidium. & 76 \\
\hline Aceutobium. & 223 & Andira. & 1082 & Avena. & 329 \\
\hline Achyrantes. & 378 & Andrographis. & 496 & Averrhoa. & 566 \\
\hline Acnistus. & 627 & Andropogon. & 2.58 & Aydendron. & 357 \\
\hline Acroclidium. & 358 & Angræcum. & 439 & & \\
\hline crocomia. & 95 & Aneimia. & 81 & $\mathbf{B}$ & \\
\hline Acrosticum. & 57 & Angelonia. & 541 & & \\
\hline Adansonia. & 954 & A nguria. & 239 & Bactris. & 102 \\
\hline Adenanthera. & 284 & Anona. & 900 & Bambusa. & 324 \\
\hline Adhatoda. & 496 & Anóda. & 966 & Basella. & 390 bis \\
\hline Adianthum. & 66 & Anredera. & 405 & Batis. & 244 \\
\hline Agaricus. & 22 & Anthurium. & 309 & Bauhinia. & 945 \\
\hline Agati. & 1059 & Antidesma. & 219 bis & Befaria. & 692 \\
\hline Agave. & 460 & Apeiba. & 897 & Begonia. & 528 \\
\hline Agrostis. & 328 & Apium. & 1143 & Beurreria. & 608 \\
\hline Alectra. & 544 & Arceutobium. & 233 & Bidens. & 795 \\
\hline Aleurites. & 120 & Arachis. & 1043 & Bignonia. & 177 \\
\hline Allamanda. & 580 & Arrhostoxy- & & Bixa. & 890 \\
\hline Allium. & $\begin{array}{l}414 \\
173\end{array}$ & lum. & 233 bis & Blettia. & 433. \\
\hline Aloe. & 413 & Arracacha. & 1140 & Blechnum. & 535 \\
\hline
\end{tabular}


INDICE DF IOS GENEROS

\begin{tabular}{|c|c|c|c|c|}
\hline & Pag. & Pag. & & Pay. \\
\hline Blighia. & 8.51 & Casearia. & Cococipselum. & 708 \\
\hline Bocconia. & 375 & Cassia. & Cocculus. & 241 \\
\hline Bœrhaavia. & 386 & Casuarina. & Coffea. & 738 \\
\hline Bchmeria. & 196 & Cathartocarpus. 1005 & Colocasia. & 159 bis \\
\hline Boletus. & 24 & Catasetum. $\quad 444$ & Colubrina. & 1150 \\
\hline Bonplandia. & 838 & Catalpa. & Commelina. & \\
\hline Bontia. & 551 & Cattleya. & Comocladia. & \\
\hline Borrago. & 672 & Cecropia. & ferva. & \\
\hline Borreria. & 704 & Cedrela. & carpus. & \\
\hline Borrichia. & 803 & Celosia." & volvulus. & \\
\hline Brassica. & 829 & Celtis. & aifera. & \\
\hline aelia. & 462 & Ceramium. & & \\
\hline Brosimum. & 114 & 1102 & prus. & \\
\hline Brownea. & 934 & olobium. & Coriandrum. & \\
\hline Brunsfelsia. & 553 & olium. & & \\
\hline Bryophyllum. & 677 & 695 & & \\
\hline & 89 bis & 1076 & & \\
\hline Bumelia. & 641 & 187 & aria. & \\
\hline Bur & 274 & 626 & & \\
\hline ima. & 949 & 34 & tia. & \\
\hline Byt & 908 & odium. & & \\
\hline & & 769 & arrya. & \\
\hline C & & 737 & Cri & \\
\hline & & Clileianthes. & aria. & \\
\hline Cæphælis. & 741 & Crysanthellum. 804 & Crot & \\
\hline nia. & 1016 & nus. 1023 & Cub & \\
\hline Caj & 1015 & phyllum. & $\mathrm{Cuc}$ & \\
\hline Cakile. & 832 & 150 & ita. & \\
\hline Caladium. & 161 & 719 & & \\
\hline Calea. & 792 & momum. $\quad 353$ & Curcuma. & \\
\hline ndra. & 297 & endron. 927 & Cup & \\
\hline pis. & 663 & . $\quad 192$ & Cus & \\
\hline llum. & 877 & 190 & & \\
\hline ranthes. & 1119 & 467 & $\mathrm{Cy}$ & \\
\hline Cameraria. & 650 & 341 & Cyn & \\
\hline lora. & 360 & pelos. & $\mathrm{Cy}$ & \\
\hline & 899 & 815 & exyllum. & \\
\hline Canella. & 940 & 185 & Cyrthopodium. & \\
\hline Canna. & 481 & 977 & & \\
\hline anavalia. & 1081 & Cladonia. & $\mathrm{D}$ & \\
\hline nanesía. & 1121 & 25 & & \\
\hline Capparis. & 883 & 417 & & \\
\hline Capraria. & 570 & Cleome. & & \\
\hline apsicum. & 620 & Clerodendron. & Daphnopsis. & \\
\hline & 929 & Clidemia. & & \\
\hline ospermum & 1. 849 & 874 & & \\
\hline & 204 & Cochlospermum. 889 & odium. & \\
\hline & 950 & Coccoloba. $\quad 887$ & & \\
\hline b-ullu & 1115 & Coccos. & Devenischia. & \\
\hline
\end{tabular}


EN EL MÉTODO DHCOTÓMICO.

\begin{tabular}{|c|c|c|c|c|c|}
\hline & Pag. & & Pag. & & Pag. \\
\hline Digitaria. & 25.5 & Fucus. & 16 & Hygrophylla. & 533 \\
\hline Dieffenbachia. & 156 & & & & \\
\hline Dipholis. & 640 & $\mathrm{G}$ & & I & \\
\hline Dianthera. & 497 & & & & \\
\hline Dicksonia. & 63 & Gaulteria. & 679 & Ibatia. & 66 \\
\hline Dioscorea. & 243 & Genipa. & 728 & Ichthyothere. & \\
\hline Diospiros. & 301 & Geophylla. & 744 & Icica. & \\
\hline Diplazium. & 79 & Gerardia. & 543 & Ilex: & \\
\hline Dolichos. & 1069 & Gnaphalium. & 789 & Illicium. & \\
\hline Dodonea. & 278 & Gonolobus. & 666 & Indigofera. & \\
\hline Dorstenia. & 167 & Gossipi & 931 & Inga. & \\
\hline Diodia. & 702 & Gomphrena. & 404 & Ionidium. & \\
\hline Doyerea. & 183 & Gouania. & 1093 & Inopsis. & \\
\hline Dracontium. & 307 & Gramnitis. & 61 & Ipomea. & \\
\hline Drymaria. & 822 & Guachamaca. & $\begin{array}{l}611 \\
0.0 .\end{array}$ & Isotoma. & \\
\hline $\mathrm{E}$ & & $\begin{array}{l}\text { Guazuma. } \\
\text { Guayacum. }\end{array}$ & 863 & Iriartea. & \\
\hline & & Guetarda. & 7.51 & & \\
\hline Echinodorus. & 889 & Guilandina. & 1010 & $J$ & \\
\hline Echit & 654 & Guilelmia. & 101 & & \\
\hline Eclipta. & 801 & Gymnogramme. & 61 & Jacaranda. & \\
\hline Elais. & .96 & & & Jacquinia. & \\
\hline Elephantopus. & $\begin{array}{l}806 \\
317\end{array}$ & $\mathrm{H}$ & & bosa. & \\
\hline & $\begin{array}{r}317 \\
1051\end{array}$ & Habenaria. & & Janipha & \\
\hline Enterolobium. & $\begin{array}{r}10.01 \\
283\end{array}$ & Hamelia. & $\begin{array}{l}429 \\
732\end{array}$ & Jarilla. & \\
\hline & $\begin{array}{l}200 \\
424\end{array}$ & Hecatophyllum. & 1084 & $\begin{array}{l}\text { Jasminium. } \\
\text { Jatropha. }\end{array}$ & \\
\hline $\begin{array}{l}\text { Epipactis. } \\
\text { Equisetum. }\end{array}$ & 41 & Hediosmum. & $\begin{array}{r}104 \\
139\end{array}$ & Juglans. & \\
\hline $\begin{array}{l}\text { Equisetum. } \\
\text { Eriodendron. }\end{array}$ & 918 & Hedwigia. & 997 & Juniperus. & \\
\hline Erithrina. & 1080 & $\mathrm{Hel}$ & 447 & Jussiea. & 109 \\
\hline Ery & 1131 & Helicteres. & 915 & Justicia. & \\
\hline Erythalis. & 753 & Heliotropium. & 671 & & \\
\hline xylum. & 950 & Helosis. & 165 & K & \\
\hline Eugenia. & 1125 & Hematoxyllum. & 1014 & & \\
\hline Eupatorium. & 777 & Hemitelia. & 52 & Krameria. & \\
\hline orbia. & 133 & $\mathrm{Her}$ & 59 & Kœmpferia. & \\
\hline Euphoria. & 855 & Hernandia. & 142 & Kyllingia. & \\
\hline & 594 & Herp & 539 & 1 & \\
\hline & 199 & Hibi: & $\begin{array}{r}272 \\
23\end{array}$ & & \\
\hline Exostemma. & $\begin{array}{r}719 \\
35\end{array}$ & Hidnum. & $\begin{array}{r}23 \\
984\end{array}$ & & 107 \\
\hline Evernia. & & $\begin{array}{l}\text { Hippocratea. } \\
\text { Hippomane. }\end{array}$ & $\begin{array}{l}984 \\
123\end{array}$ & Lactuca. & \\
\hline$F$ & & & 563 & Lagetta. & \\
\hline & & & & I C & \\
\hline & 835 & Homalium. & 1149 & Laguncularia. & \\
\hline & & & & & \\
\hline $\mathrm{m}$. & 1142 & & 1006 & & \\
\hline Ficus. & 111 & Hypoxis. & 464 & Leonurus. & \\
\hline
\end{tabular}




\begin{tabular}{|c|c|c|c|c|c|}
\hline & $P x g$. & & $P(i \boldsymbol{\alpha}$. & & Pug. \\
\hline Leopoldina. & 93 & Mickania. & 780 & Ocymun. & 516 \\
\hline Leria. & 765 & Micromeria. & 519 & Oldenlandia. & 707 \\
\hline Lepidium. & 833 & Mimosa. & 288 & Olea. & 489 \\
\hline Leucas. & 522 & Mimusops. & 638 & Omphalea. & 121 \\
\hline Leucæna. & 289 & Mirabilis. & 397 & Oncidium. & 440 \\
\hline Libidibia. & 1018 & Mollugo. & 382 & Ophyoglossum & 82 \\
\hline Limnanthemur & m. 588 & Momordica. & 180 & Opuntia. & 1113 \\
\hline Lippia. & 510 & Modiola. & 960 & Orchis. & 430 \\
\hline Lindsæa & 70 & Monodora. & 858 & Oriza. & 321 \\
\hline Lisianthus. & 600 & Mongorium. & 491 & Oreodoxa. & 99 \\
\hline Lobelia. & 689 & Monniera. & 669 & Oreodaphne. & 225 \\
\hline Lonchitis. & 67 & Monstera. & 253 & Osmunda. & \\
\hline Lucuma. & 634 & Montrichardia. & 158 & Ottonia. & 318 \\
\hline Luffa. & 179 & Mora. & 935 & Oxalis. & 83 \\
\hline Lycoperdon. & 26 & Morinda. & 742 & & \\
\hline Lycopersicum. & 624 & Moringa. & 1001 & $\mathbf{P}$ & \\
\hline Lycopodium. & 47 & Morinsonia. & 880 & & \\
\hline Lygodium. & 80 & Moronobea. & 938 & Pachyphyllum. & \\
\hline & & $100 \mathrm{Tt}$ & 136 & Pach & $10^{r}$ \\
\hline M & & Moschoxyllum. & 932 & Pali & 747 \\
\hline & & & 1054 & ium. & \\
\hline $\begin{array}{l}\text { Maclura. } \\
\text { Macrocnemum }\end{array}$ & 220 & Muntingia. & 884 & Pandanus. & $20 t$ \\
\hline Macrocnemum & 708 & Murraya & 866 & Panic & 337 \\
\hline chra. & 964 & Mus & 448 & Pari & 972 bis \\
\hline Mal & 463 & Mygenda. & 985 & isonia. & 1012 \\
\hline ghia. & 948 & Myr & 214 & & \\
\hline trum. & 959 & istica. & 215 & nium. & $78 \%$ \\
\hline iscus. & 955 & dia. & 920 & & 108 \\
\hline Mammea. & 876 & IIyrospermum. & 1008 & Paullin & 858 \\
\hline & 720 & & & & \\
\hline & 480 & $\mathbf{N}$ & & nthus. & 13 \\
\hline & 273 & & & & 42 \\
\hline Mar & 83 & Nasturtium. & 830 & Pel & \\
\hline avia. & 683 & Necta & 359 & lethra. & 28 \\
\hline intia. & 40 & & 415 & & 31 \\
\hline & 661 & dium. & 75 & Per & 1104 \\
\hline & 546 & lepis. & 75 & & 224 \\
\hline Mas & 49 & Nerium. & 656 & Pet & 385 \\
\hline Mau & 204 & Neurolæna. & 790 & elinum. & 1145 \\
\hline & 441 & & 599 & um. & \\
\hline iliana. & 92 & Nim & 416 & Pha & \\
\hline Mel & 941 & Nonatelia. & 733 & Pha & 171 \\
\hline Melicoca. & 854 & Nostoc. & 14 & Phaseolus. & 1077 \\
\hline & 911 & Nothoclena. & 58 & Philocorine. & 16 \\
\hline & 193 bis & Notylia. & 435 & endron. & $158 b i$ \\
\hline & & & & & \\
\hline Mentha. & 564 & $\mathrm{O}$ & & Phœnix. & 205 \\
\hline Mentzelia. & 1129 & & & Phoradendror & 233 bis \\
\hline Meriana. & 1021 & Ochroma. & 919 & Phy: & \\
\hline
\end{tabular}




\begin{tabular}{|c|c|c|c|c|c|}
\hline & Pag. & & Pag. & & Pas \\
\hline Phyllanthus. & 149 & Ranunculus. & 897 bis & Sida. & $!$ \\
\hline & 361 & Rauwolfia. & 644 & Sideroxyllon. & \\
\hline Phyloxerus. & 403 & Remirea. & 325 & Simaba. & \\
\hline Picrœna. & 272 & Rinchosia. & 1066 & Simaru & \\
\hline Picrœmnia. & 227 & Rhizophora. & 1149 & rorium. & \\
\hline Pilea. & 196 & Rhus. & 988 & & \\
\hline Pimenta. & 1122 & Richard & 700 & Sipho & \\
\hline Pinus. & 105 & Ricinus. & 144 & chinus. & \\
\hline Piper. & 310 & Rivina. & 362 & Sle & \\
\hline Piptadenia. & 281 & Poccella. & 3.5 & Sloanea. & \\
\hline Piscidia. & 1041 & Rosa. & 11.51 & $\mathrm{Sm}$ & \\
\hline & 302 & Rosniarinus. & 560 & Sola & \\
\hline Pist & 154 & Ron & 717 & & \\
\hline Pithecolobiun. & 10.50 & Ruell & 534 & So & \\
\hline Plantago. & 567 & umex. & 247 & yllum. & \\
\hline alis. & 431 & Ruta. & 839 & ce. & \\
\hline & 17 & & & dia. & \\
\hline Plu & 782 & $S$ & & & \\
\hline ago. & 570 & & & Sp & \\
\hline Plu & $\begin{array}{r}653 \\
1017\end{array}$ & Sace & 320 & & \\
\hline a. & $\begin{array}{r}1017 \\
975\end{array}$ & Sagi & $\begin{array}{ll}1 & 4 \\
21 & 3\end{array}$ & $\begin{array}{l}\text { Stac } \\
\text { Ster }\end{array}$ & \\
\hline um. & 384 & Salv & 501 & $\begin{array}{l}\text { Stel } \\
\text { Stru }\end{array}$ & \\
\hline & 62 & Sar & 734 & Stry & \\
\hline um. & 798 & Sapi & 853 & Sweiteinia. & \\
\hline & 722 & Sal & 125 & & \\
\hline Port & 1127 & a) & $63 \tilde{5}$ & & \\
\hline eria. & 412 bis & temnia. & 6.58 & & \\
\hline & 680 & m. & 16 & & \\
\hline Potamogeton. & 306 & Sasa & 223 & Tabernæmonta & \\
\hline & 316 & ia. & 820 & & \\
\hline & 393 & Scr & 719 & Taen & \\
\hline Prosopis. & 280 & a. & 319 & Tala & $4 b i$ \\
\hline & 1024 & & 82 & rindus. & 103 \\
\hline ria. & 746 & & 267 & cium. & \\
\hline & 1112 & & 575 & & \\
\hline & 71 & & 413 & & \\
\hline arpus. & 1033 & s & 342 & ialia. & 27 \\
\hline Punica. & 1106 & ndrium. & 73 & sia. & 96 \\
\hline Q & & Scutellaria. & $\begin{array}{l}5 \% 2 \\
515\end{array}$ & $\begin{array}{l}\text { Tetracera. } \\
\text { Teucrium. }\end{array}$ & $\begin{array}{c}896 \text { bis } \\
51\end{array}$ \\
\hline & & & 859 & oma. & \\
\hline Quassia. & 865 & Schœnus. & 340 & hrasta. & \\
\hline & & & 184 & & \\
\hline & & Secudiraca. & 976 & Tila & \\
\hline & $24:$ & & & & \\
\hline & 729 & & 380 & & \\
\hline & 828 & wicana. & 18.5 & Trianthema. & \\
\hline
\end{tabular}


ÍNDICE DE LOS GÉNEROS EN EL MÉTODO DICOTÓMICO.

\begin{tabular}{|c|c|c|c|c|c|}
\hline & Paly. & & Pag. & & Pag. \\
\hline Tribulus. & 861 & Urvilea. & 847 & Warszeuwiezia. & 723 \\
\hline Trichilia. & 931 & Usnea. & 33 & & \\
\hline Trichomanes. & $\begin{array}{r}77 \\
100\end{array}$ & \multicolumn{2}{|l|}{$\mathrm{V}$} & \multicolumn{2}{|c|}{$\mathrm{X} \quad 1$} \\
\hline Triumphetta. & 867 & Vachelia. & 296 & Xanthosoma. & 160 \\
\hline Trophis. & 221 & Valeriana. & 694 & Xilopia. 89 & $98 \mathrm{bis.}$ \\
\hline Tropæolum. & 843 & Vanilla. & 422 & Ximenia. & 842 \\
\hline Tuber. & 27 & Vargasia. & 791 & & \\
\hline Tupa. & 690 & Veratrum. & 418 & \multirow{2}{*}{\multicolumn{2}{|c|}{ Z }} \\
\hline Turnera. & 819 & Verbena. & 418 & & \\
\hline Typha. & 163 & Vernonia. & 807 & Zamia. & 231 \\
\hline & & Veronica. & 495 & Zanthoxyllum. & 229 \\
\hline \multirow[t]{2}{*}{$\mathrm{U}$} & & Vigna. & 1073 & Zea. & 172 \\
\hline & & Vinea. & 648 & Zingiber. & 477 \\
\hline Ulantha. & 427 & Vitis. & 818 & Ziziphus. & 989 \\
\hline Ulva. & 13 & Vittaria. & 73 & Zygophyllum. & 860 \\
\hline Urena. & 962 & & & & \\
\hline $\begin{array}{l}\text { Urera. } \\
\text { Uretion }\end{array}$ & 249 & & & & \\
\hline Urtica. & 250 & Waltheria. & 910 & & \\
\hline
\end{tabular}




\section{EL MÉDICO BOTÁNICO GRIOLLO}

\section{PARTE PRIMERA}

HLORA MÉDIGA I ÚTII. DE LAS AXTILLAS 
far - Ineprenta de Poupart-Daryl y Ca, calle du bac, 30. 


\section{El.}

\section{MÉDICO BOTÁNICO \\ G R I OL L O}

POR

\section{Renato de GROSOURDY}

DOCTOR EN MEDICINA DE LA FACULTAD DE MEUICINA DE PARIS

rX-PEPETIDOR DE QCINHCA EN LA MISMA FACULTAD, EX-PROFESOR PAKTICLLAL DE QUimica Y Botávica Médicas EN LA MISMa CIUDAD

SOCIO CORRESPONSAL DE VARIAS CORPORACIONES CIENTIFICAS FRANCEGAS

Y ESTRANJERAS

\section{PARTE PRIMERA}

\section{FLORA MÉDICA Y ÚTIL DE LAS ANTILLAS}

Y DE LA PARTE CORRESPONDIENTE DEL CONTINENTE AMBRICANO

\section{TOMO II}

Conteniendo las familias y terminando por dos apéndices, uno sobre las maderas útiles de esos faises y otro sobre la agricultura apropiada á ellos.

Las plantas de un grénero tionen igguales propiedacies, las qure están en un órden muy natural se asemejan tambien por las propiedades; las que se hallan en una clase ò familia natural se corresponden igualmente de este modo por sus virtudes.

\section{I.Nve, Filosofa hofanicu.}

\section{'TOMO' II (de la obra)}

PARIS

LIBRERIA DE FRANCISCO BRACHET

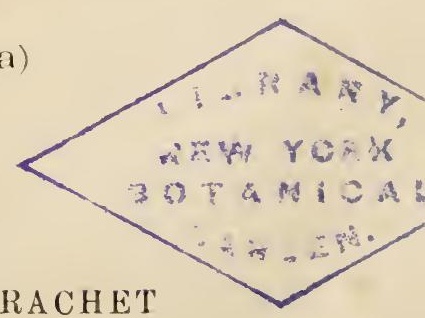

8, Calle de l'abBaye, 8 


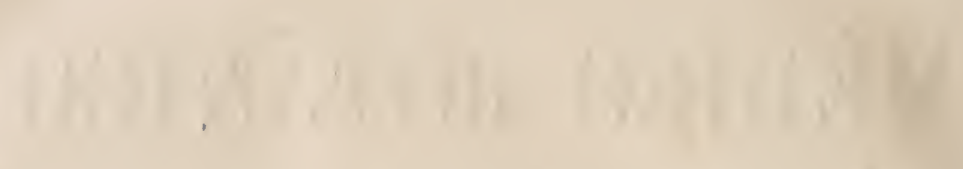




\section{DIVISION PRIMERA}

\section{VEJETALES AGAMIOS GRIPTÓGAMOS}

ó AGOTILEDÓNEOS

SEGGION I

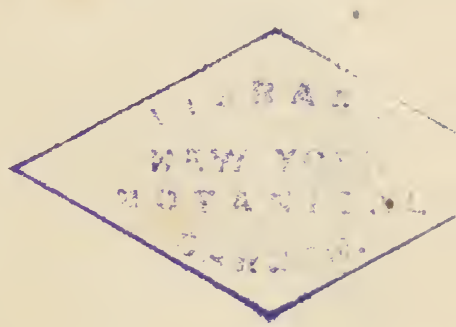

CLASE I. - ALGAS

F'amilia la. - ALGAS, THALASÚPHITAS ó FÍCEAS. -

Se han dado esos varios nombres á unos vejetales celulares desprovistos de flores y que se alimentan por absorcion, la cual se verifica por toda su superficie y á espensas del medio ó centro en que viven, que es ordinariamente el agua, tan pronto dulce como salada; algunas se han hallado en las aguas termales y una sola clase nace en ciertos líquidos fermentados. Algunas veces se encuentran en la superficie del suelo húmedo y en ese caso viven en el aire. Se presentan con forma sea de cuerpecillos microscópicos provistos de una envoltura silicea ó sin ella, sea de filamentos sencillos ó membranosos mas ó menos desarrollados; por último, su forma se acerca mas de la de los demas vejetales; tienen ramos y como hojas. Su color ordinariamente es bruno, aceitunado ó verde, otras reces varía entre el rosado mas pálido y el morado subido. Esos rejetales no tienen raices lejítimas, ni tallos, ni hojas propiamente dichas, porque todos estos órganos están confundidos en uno solo de tamaño $\mathrm{y}$ de forma muy variados por supuesto, llamado fronde ó talluelo. El principal carácter con que se diferencian de lus demas vejetales agamos consiste en la presencia en ellos de órganos reproductores yemaceos, llamados gonodias, los cuales son compuestos de una vesiculita membranosa llena de una mucosidad organizable verde ó de color bruno. Tales plantas son vivíparas ó se propagan : $1^{\circ}$ por medio de esporos desarrollados por su superficie, á veces nacidos en su capa cortical, otras veces están contenidos en su interior y en conceptáculos cuya forma y posicion son muy variadas; $2^{\circ}$ al favor 
de zoosporos libres ó agrupados que en ese último caso comunican á la ramita que los lleva una forma particular. Los órganos reproductores de esas plantas se reducen en último análisis á una ó algunas celdillas privilejiadas cuyo endócromo, dotado de un color mas vivo ó diferente del de la celdilla, toma un desarrollo relativamente mayor, y llegada ya la madurez se desprenden espontáneamente de la celdilla vecina para irse á germinar y á reproducir por consiguiente un individuo enteramente igual á la planta madre. Se propagan ademàs estos vejetales por propágulas ó remas; en las confervas, en efecto, cada endocromo puede considerarse como una yema capaz de vejetar por sí sola, dando nacimiento á una planta semejante á la de que ha salido; la facultad de reproduccion por division se halla muy desarrollada en las vauquerias, cuyos fragmentos se vuelven con prontitud individuos distintos y perfectos; se multiplican tambien por prolificacion, es decir, que en lugar de sacar su orijen del desarrollo de una celdilla única, como las yemas,

- proviene de la concentracion de la accion orgánica hácia uno ó algunos puntos del vejetal, de tal manera, que mucho se acerca á la ramificacion ; pur último, la propagacion es fiscípara ó por separacion y division de los cuerpecillos, como sucede para las algas mas inferiores, las diatomeas por ejemplo. Hemos dicho mas arriba que esas plantas son vivíparas, en efecto, los zoosporos, llegada la madurez ó la sazon de la reproduccion, principian por moverse dentro de la celdilla que los contiene ó despues de salidos de ella y siguen moviénciose con velocidad en el agua durante algun tiempo, hasta que se peguen en uno de los cuerpos inmediatos, y entónces no tardan en germinar, desarrollarse y volverse una planta igual y semejante á la de que se han desprendido. La pequeñita alga llamada Protococcus plurialis, produce un zoosporo que toma la forma de un infusorio, Anustasia nivalis, que á su vez da nacimiento á una alga; tales seres son pues el punto de transicion del reino vejetal al reino animal, y tomando en mayor cuenta y consideracion los hermosos trabajos del señor Herschberg y las consideraciones del célebre profesor Nees d'Esembeck sobre los movimientos fitonómi$\cos$, se admitiriá un reino de infusorios partidos en dos órdenes, es decir en Microfitos y en Microzoarios, y así se acabaria con las dudas sobre la transformacion de las plantas en animales y de los animales en plantas, que todavía tienen á los sabios divididos ne dos campos.

Ordinariamente estos vejetales son vivaces, aunque bastantes tengan una vida muy corta y efémera, y bien que secos desde ya tiempo vuelven á aparecer vivos al mojarlos. Tales seres crecen generalmente con bastante prontitud, y ciertas algas de las aguas dulces, las vauquerias y las oscilatorias por ejemplo, se desarrollan con mucha rapidez, puesto que con el microscopio se puede presenciar su desarrollo, que es maravilloso en las oscilatorias de las aguas termales, y casi siempre en relacion con la velocidad de sus movimientos.

El tamaño de las algas es muy variado y se halla entre los dos estremos siguientes: 1/300 de milímetro para el protococcus atlanti- 
cus, mientras que el mucrocystis pirifera tiene 500 metros de largo, Se hallan en las temperaturas mas estremas y hasta opuestas, y sin embargo pueden vivir y propagarse en los lugares que ocupan; en efecto, se las halla en medio de las nieves perpetuas de los polos y de las montañas mas elevadas del globo, hemetaccus nivalis, como en las fuentes termales cuya agua tiene de $+40^{\circ} a ́+90^{\circ}$ termométricos de calor, anabcna thermalis; se crian sin embargo con mayor abundancia en los paises templados y hasta frios que en los cálidos. Habitan las aguas dulces y saladas, y ninguna puede vivir largo tiempo fuera de dichas aguas; pero el mar, los lagos y los rios no son los únicos lugares que las contienen; en efecto, en todas partes en donde haya durante algun tiempo agua ó humedad está uno seguro de hallar alguna alga.

Segun el señor Payen, los Thalassiofitos contienen cantidades mas ó menos considerables de inulina, sustancia que contribuye á darles bastante consistencia conservándoles á la vez mucha flexibilidad. La materia orgánica forma los 0,835 de su parte seca ó los 0,208 del peso total del fucus en su estado normal ó recien sacado del agua. Su parte inorgánica se compone de oxalato de cal, de sulfato y fosfato de la misma base, de silice, de cloruro de sodio y de potasio, de sulfato de potasa, de yoduro y de bromuro de potasio y de magnesio; mientras que su parte orgánica es formada de celulosa que constituye la trama de las celdillas y se presenta bajo varios estados diferentes; la forma mucilajinosa se llama gelin, del cual se diferencia la fucina solo porque al aire se vuelve bruna; $2^{\circ}$ de inulina; $3^{\circ}$ algunos cuerpos grasos azoados en proporcion de 12 á $24 / 100$ del peso de la sustancia orgánica; $4^{\circ}$ de materia azucarada manito ó glucosis; $5^{\circ}$ de otras sustancias grasas; $6^{\circ}$ de un aceite esencial ; 70 por fin, de uno ó dos principios colorantes.

Análisis dicotimico de ese grupo natural que comprende algunas sub-familias y hasta familias distintas.

1. Cuerpecillos ó cuerpos mas ó menos vesiculosos angulosos o no, 2. - Cuerpos celulares ó tubulares nunca jamás vesiculosos ni angulosos, 4.

2. Cuerpos angulosos cristalinos, fragmentarios con ó sin envoltura silicea, provistos de celdas y propagándose por separacion espontánea, 3. - Cuerpos vesiculares filamentosos ó membranosos, multiplicándose por zoosporos engendrados en su interior y á espensas de la sustancia verde; Confervíceas.

3 . Individuos bien libres angulosos, provistos de una coraza silicea ó sin ella, ó encerrados en tubitos calizos. Dratómeas. - Individuos cilíndricos sin coraza silícea ninguna. Desimidieas.

4. Celulares ó tubulares nunca simétricos, 5. - Siempre tubulares y simétricamente ramosos, multiplicándose por medio de un núcleo espiral lleno de una sustancia como sebácea. Charáceas.

5. Propagándose por esposos simples formados en su superficie. Fucáceas. - Propagándose por tetrasporos. Ceramieas. 
Sub-familia la. - Diatomáceas, Agh.; Chaodíneas y FragilLARIEAS, Endl. - Consisten en cuerpecillos ordinariamente prismáticos y rectangulares, desnudos ó contenidos en un tubo gelatinoso simple ó ramoso, aislados ó agrupados y reunidos en filamentos libres ó pegados de los cuerpos vecinos, sesiles ó pediculados, provistos de una envoltura silícea diáfana, quebradiza, pero que no se deforma por la desecacion y contiene una sustancia mucosa de color aleonado amarillento ó rojizo; son seres acuáticos que tienen en las especies libres un movimiento rastrero que se efectua en el sentido de su eje lonjitudinal. Se reproducen por medio de esposos ó por separacion lonjitudinal ó deduplicacion de los artejos; en cierta época de su vida esos cuerpecillos presentan pues el fenómeno de su division espontánea lonjitudinal, la cual da nacimiento á dos individuos al principio mas delgados, pero que no tardan en tener el tamaño y la forma del corpúsculo de donde han salido. Esta deduplicacion se manifiesta por una línea ó estría lonjitudinal que aparece sobre la parte media de la entoltura por donde se separan las dos mitades. Estos seres viven en los mares y las aguas dulces, y las mismas especies se hallan á la vez en las comarcas del mundo mas lejanas y apartadas las unas de las otras, y necesitan muy poco tiempo para desarrollarse y multiplicarse en cantidad espantosa en las aguas en que aparecen y se establecen. Su coraza ó envoltura silícea constituye en ciertos lugares de Europa depósitos fosiles que se esplotan y que suministran la sustancia que se conoce en el comercio con el nombre de Tripoli y que aprovechan las artes para el pulimento de los metales.

Tribu 1. - Frustulieas. - Individuos nunca inclusos en tubos. Diatoma tenue, Agh. Cba.

Tribú 2. - Hydrolineas. Individuos inclusos en tubos.

Sub-familia 2. - Dismidieas. - Algas microscópicas con forma de cuerpecillos formados de dos semi-esporos opuestos reunidos por la base y de figura muy variada; los unos son aislados, ovales ó redondos, enteros ó lobados, múticos ó provistos de apéndices espinosos; los otros, reunidos por series en forma de filamentós, tienen una envoltura membranosa que se deforma con la desecacion y está llena de un endocromo verde, de figura de estrellitas con muchos brazos, cuya superficie lleva granitos redondos á veces bastante gruesos, esparcidos por ella, contenidas estas estrellitas en una capa de mucus mas ó menos espesa. Se propagan á favor de un esporo redondo, liso ó espinoso, formado por la concentracion del endócromo resultando de la reunion de dos cuerpecillos; esta especie de copulacion se verifica en el punto de soldadura de los hemisomates mellízos; se propagan además por reduplicacion de cada hemisomate; se llama así á los dos lóbulos ó celdillas que constituyen un cuerpecillo ó uno de esos vejetales. En la base de cada hemisomate desprendido y separado se presenta un pezoncito redondo, que, desarrollándose sucesivamente, se trasforma, al cabo de algun tiempo, en un nuevo hemisomate igual á aquel en que estaba pegado antes de su separacion, y ya está el individuo nuevo completo y perfecto. Viven en las aguas vivas y quietas de los estanques y de los panta- 
nos, siempre sumerjidos se hallan agrupados en el vértice de los vejetales acuáticos, y con frecuencia ocupan el centro de unas masas mucosas que provienen de la concentracion del mucus que envuelve á cada uno de ellos, y parecen huevecillos de ranas.

Tribu 1. - Mrcrosterreas. - Individuos libres. Ruddulphia australis, Gray. Parásitas sobre las fucoideas del puerto de la Habana, Cha.

Tribu 2. - Equirelleas. - Individuos en número determinado contenidos en una mucosidad comun á todos ó encerrados en tubos. G. T. Desmidia.

Sub-familia III. - CONFERVÁCEAS, Endl. Srxsporéas y Zoosperiseas, Dene. Zoospermeas, J. Agh. - Vejetales ordinariamente verdes, alguna vez que otra color aceitunado y muy rara vez rojos ó morados, en los cuales se observan dos clases de fructificacion, frecuentemente reunidas sobre el mismo individuo. Uno de estos modos de propagacion proviene de la metamórfosis de los granos clorofílicos contenidos en las celdillas, que toman formas regulares y se mueven con mucha velocidad, han recibido varios nombres y son las Esporidias de J. Agh., las Gonidias de Kutz., los Esporozoideas de Derb. y los Zoospermos de Dene.; en efecto, á cierta época determinada de la vida de estos vejetales, la sustancia verde ó clorofilar contenida en los endocromos de los filamentos, en las celdillas ó en los tubos que los constituyen, sufre una modificacion orgánica profunda, á favor de la cual se trasforman en cuerpecillos movibles globosos ú ovoideos y provistos de un apéndice con figura de pico; principian por moverse en el interior de la celdilla y de los tubos dando con el pico en el mismo punto, de suerte que á un momento dado, escitado sin duda por esos golpecitos continuamente repetidos, se abre para darles salida; entónces vueltos libres se ajitan y se entregan á movimientos muy rápidos dirijidos siempre hácia la luz, que parecen instintivos y como voluntarios, duran como un cuarto de hora y cesan desde el momento que se haa pegado de los cuerpos que están á su alcance; no tardan en germinar y en desarrollarse en filamentos semejantes á la planta madre. El otro modo de propagacion es esterior y proviene de la metamórfosis de una celdilla ó de una ramita trasformada, y contiene en un perisporo hyalino muchísimos granitos de sustancia verde, los cuales se condensan en un esporo simple ó cuaterno. Los esporos simples están contenidos en las celdillas de las ulvas, en los endocromos de las conferveas y de las zynemeas; su tamaño es generalmente mayor que el de los zoosporos, y provistos con frecuencia de un episporo simple ó doble. En la sazon de la madurez se quedan simples ó se separan en otros cuatro, cuyo cada uno es tal cual las divisiones de un tetraspermo ó de un esporo cuaternario; puede germinar y por consiguiente propagar la planta madre. Su forma es redonda ú ovoidea, y como los zoospermos se van adelgazando en pico, y se vuelven entónces apeonzados; tal pico está adornado de cerdas en número variado, las cuales constituyen su órgano locomotor; se mueven ordinariamente con el pico dirigido por delante y giran en el líquido á favor de un movimiento de trepidacion; tales esporos 
tienen un puntito rojo que les hace tan semejantes al infusorio llamado microglena Monadina, que no se puede diferenciarles de él. En la tribu de las Zinemeas se ha observado un acercamiento, una especie de copulacion, es decir, que dos filamentos que antes del acto de la fecundacion no llevan ningun indicio del papel que van á desempeñar, se acercan segun su diámetro lonjitudinŁl y al tocarse emiten de cada endocromo un tubito de juncion por el cual pasan del uno al otro que parece tener el papel de hembra, todos los granitos que contiene.

Tales rejetales son formados de frondes membranosas mas ó menos grándes, compuestas de celdillas justapuestas en el mismo plan ó en tubos continuos ó tabicados, simples ó ramosos, á veces dispuestos en derredor de un eje filamentoso de donde echan radios ó brazos hácia la periferie de una fronde compuesta, cilindrácea, tubulosa ó globosa, etc. Se crian con mayor frecuencia en las aguas dulces, mas rara vez en las del mar, y algunas veces en ambas á la par.

\section{Análisis dicotómica de las varias tribus.}

1. Celdillas aisladas ó reunidas, ó filamentos simples ó ramosos, 2. - Frondes muy variados tanto por su forma y finura como por su consistencia y disposicion, 10.

2. Siempre celdillas, 3. - Filamentos siempre, 6 .

3. Juntas por el cabo adelgazado ó igual las unas con las otras, contenidas en una redecilla polígana, raras veces ligadas entre sí por medio de un tejido membranoso, y conteniendo gonidias diversamente conformadas. T. I. Hrdonodicteas, G. T. Hydrodicthon, Roth. - Siempre globosas ó elípticas, nunca pegadas entre sí por el estremo y libres las unas de las otras, 4.

4. Mas ó menos distintas ó ligadas por medio de una ganga ó sustancia mucilajinosa. T. II. Palmelleas, Dene., 5. - Agrupadas por serie filiformesimple ó ramosa y contenida dentro de una masa mucilajinosa di versamente conformada. T.III. Nostociness, Harr., G. T. Nostoc, Vanch. Chlorococcum murorum, Grev., sobre la tierra húmeda en la Habana.

5. Ganga ó sustancia mucilajinosa nula ó poco aparente. T. IV. Protococcideas, Menegh. Chlorococcum Montagnei, Cba.-Ganga bien manifiesta. T. IV. Coccochloreas, Endl. G. T., coccochloris, Spreng.

6. Tubulosos simples ó raras veces con alguna ramificacion, dotados de movimiento ó sin ninguno, \%. - Ramosos ó sencillos sin ningun movimiento propio, 10.

7. Con movimiento propio, tubulosos y cilíndricos y estendidos en membranas ó en laminas y conteniendo endocromos disciformes que los hacen parecer como provistos de tabique.T. VI. OscillatnRINEas, Bory. Oscillatoria chitonoplastes, Lyngl. Cba. O. calida, $\mathrm{Agh}$. en las aguas termales americanas. - Sin movimiento alguno propio, 8.

8. Siempre tubulosos y continuos, simples ó mellizos, 9. - Nunca 
tubulosos pero siempre articulados y sencillos, quedándose aislados ó acercándose los unos á los otros en la sazon de la reproduccion, y echando artejos ó tubos de union por donde las gonidias de un filamento pasan al otro; esporos simples ó cuadriyugados. T. VI. ZYGNEMeas, Duby., G. T. Zynema, en las aguas quietas de Europa $y$ de América.

9. Llenos de endocromos confluyentes ó no distintos. T. VIII. LEPтотнRICEAs, Kg., G. T. Leplothrix. - Flagelliformes con endocromos distintos naciendo solitarios ó mellizos de un glóbulo trasparente $\mathrm{y}$ echando radios ó brazos hácia todos los puntos de un segmento de esfera; ganga mucilajinosa. T. IX. Rivularieas. Harr., G. T. Rivularia.

10. Simples ó ramosos y nunca jelatinosos, articulados; gonidias verdes, color de aceituna ó brunas; esporos simples nacidos de la concentracion de las gonidias, de un solo endocromo, o de la mezcla de los de dos endocromos vecinos. T. X. Conferteas, J. Agh. Confej'ca fascicularis, Agh. puerto de la Habana, etc. - Siempre ramosos $y$ jelatinosos, cilíndricos y articulados, terminados por una celda mayor hialina y con figura de cerda; gonidias dispuestas por zonas transtersales; reproduccion por zoosporos, por yemas cuaternas ó por esporos esternos. T. XI. Draparvaldieas, C. Montg. G. T. Draparnaldia, Bory.

11. Frondes mono ó polisifonieas, 12. - Frondes apenas sifonieas, cilíndricas tubulosas, continuas, torulosas, las cuales se vuelven todas como un receptáculo de esporos. T. XII. Lemaxieas, Dne. G. T. Lemania, Bry.

12. Nonosifornieas, 13. - Polisifonieas y formadas de un tejido frecuentemente anastomosado y mas ó menos denso, compuesto de tubos ramosos, continuos ó articulados, desnudos ó incrustados de sustancias calizas. T. XIII. Halmedeas, Dne. - Halimeda incrassuta. Limx. en el mar de las Antillas.

13. Formadas de fitras mas ó menos ramosas y nunca membranosas, 14. - Nunca formadas de fibras, pero de una ó de algunas capas de celdillas justapuestas, llanas ó tuberculosas, membranosas verdes ó purpurinas; esporos con major frecuencia cuarternarios. T. AIII. Ulváceas, Agh. - Esporidias contenidas en vesiculitas. S. T. Sifoneas, G. T. Bryopsis ramulosa, Montge, en el puerto de la Habana. - Esporidias por la superficie de la fronde. S. T. Ulteas, G. T. Llva lactuca y latissima, Agh. U. palmata, Agh., C.T.V. 469 , etc.

14. Continuas y llenas de un tejido esponjoso formado de fibras dispuestas á manera de redecillas. T. XIV. Catlerpeas, Grev. G. T. Caulerpa fastigiata, Montg. Cba. C. ericifotia, Agh. Mar de las Antillas. - Articuladas y encrustadas ; ramos dispuestos á manera de radios ó por haces en el vértice de la fronde, separados ó soldados lateralmente. T. XV. Acetabularieas, Zunard. Acetabularia crenulata, Acelabulum caribcum, Lamx., en las Antillas. H. Monile, Lamx. Coralina monile, Ellis. en todas las Antillas, etc.

Sub-famitia IT. - FLORIDEAS, Lamx. CIIORISTOPOREAS, Dne. CERAMIACEAS, Lindl. - Estos vejetales están 
caracterizados por su color que presenta todos los matices, desde el rosado mas pálido hasta el bruno ó el morado y por sus dos clases de órganos reproductores que nunca jamas se hallan juntos sobre el mismo individuo; los unos están por la superficie de las frondas y consisten en espondias numerosas contenidas en una especie de pericarpio jelatinoso ó membranoso. Se ha darlo el nombre de esporidias á los esporos de las florideas, los cuales salen de la capa medular ó central de la fronda, son redondos ó planos, angulosos ó con mayor frecuencia piriformes, formándose muy á menudo en los artejos de los filamentos que se abren á manera de gavilla en el conceptáculo, cuyas formas muy variadas corresponden á las tribus. En tales conceptáculos hay que observar dos cosas particulares, la placenta y el pericarpio ó esporanjio. La placenta es axil, nula ó aparente, convexa ó emisférica, y en ese último caso celulosa ó fibrosa; otras veces es parietal : en esta circunstancia los filamentos esporígenos están dispuestos en hacecillos que salen de todos los puntos de su cavidad y converjen hácia el centro. El esporangio parece obliterado en las florideas cuyo fruto conceptacular está escondido en la fronde, pero las mas veces sobresalen esteriormente. El conceptáculo está cerrado ó provisto por su vértice de un poro mas ó menos visible, alguna que otravez con una boquita ó un pico; en las ceramieas los esporos son oblongos y contenidos en una membrana hialira y esférica; tal aparato es axilar ó terminal, desnudo ó involucrado, es decir acompañado por su base de algunas ramitas abortadas; se llama flavella ó flavellidia en las cryptonemeas, por causa del lugar diferente que ocupa. En las Peleserieas y las Plocarieas el conceptáculo se llama coccidia, es esférico ó hemisférico, conteniendo en un esporanjio celuloso, que en lugar de abrirse se revienta, esporos oblongos, aglomerados y pegados en una placenta central. Algunas veces el último endocromo solo se vuelre esporo, ó bien los endocromos siguientes participan de igual metamórfosis. Cuando los esporos están dispuestos por series de á 4 , se diferencian de los tetrasporos por la presencia del endofragma que les separa; sesiles ó pedicelados están revestidos de un episporo simple ó doble que se llama perisporo. Los otros órganos reproductores están con mayor frecuencia, pero no siempre, anidados en la fronde; formados de un esporo, al principio indiviso, encerrado en un perisporo, celuloso, pero que se va separando en cuatro á la sazon de la marlurez. Tales esporos se llaman entónces tetrasporos y nacen casi siempre en la capa cortical de las frondes, ordinariamente globulosos, raras veces oblongos o elipsoideos; los cuatro esporitos en que se parten están, al desprenderse, metidos en una celdilla matriz gelatinosa y trasparente llamada perisporo y mas tarde salen de ella, sea que se reviente ó se halle absorvida. El lugar de donde salen los tetrasporos es tan variado como su forma y el modo de que están reunidos entre sí; en efecto, se les halla aislados á lo largo de las ramitas ó agrupados, en número mayor ó menor, en un involucro llamado glœcocarpo, otras veces resultan de la metamórfosis de uno ó de algunos endocromos, comunicando entónces al ramo primitivamente cilíndrico en que han nacido una forma lan- 
ceolada, y en este caso toman el nombre de Estichidia. En el género sirospora ocupan el vértice de las ramitas en donde están dispuestos por series de á 3 ó de á 4 , á manera de las perlas de un collar. Se desarrollan además en las celdillas de la capa subepidérmica de los géneros cura fronde es continua, se les halla entónces esparcidosirregularmente ó agrupados en un espacio circonscrito de ella, ó por fin situados sobre apéndices foliáceos particulares llamados esporofilos; algunas veces están anidados entre los filamentos tabicados que irradian de un punto de la periferie de la fronde y constituyen así especies de verrugas hemisféricas llamadas Nemathecias. Llegada la sazon de la madurez, el tetrasporo se divide en 4 esporos de tres maneras diferentes; se efectua esa separacion triangularmente, cada parte parece entónces un tetraedro con una cara convexa, crucialmente ó por fin transversalmente, de manera que las dos divisiones de en medio son disciformes, mientras que las dos estremas son hemisféricas, pero pronto despues de la salida del tetrasporo fuera de la celdilla perispórica, cada division de él se vuelve perfectamente esférica; eso se observa en las formas oblongas y elípticas. Las frondes se presentan bajo dos formas diferentes principales : en el primer caso consisten en filamentos tabicados ó solamente articulados, los cuales ino son sino la celdilla madre que se va añadiendo á sí misma segun la longitud; otras veces la fronde es continua, corticosa, pegada á los cuerpos inmediatos por medio de garras dispuestas á manera de escudo ó filiformes. Todos los vejetales de esa subfamilia viven en las aguas del mar.

\section{Análisis dicotómica de las varias tribus.}

1. Frondas mas ó menos filamentosas, 2 ; - no filamentosas propiamente dichas, pero mas ó menos membranosas, celulosas, coriáceas, 8 . -

2. Fronda monosifoniea, articulada, raras veces celulosa; conceptáculos desnudos ó involucrados; tetrasporos ordinariamente salientes por la superficie. T. I. Ceranieas, J. Agh. G. T. Ceramium filamentosum, clariculatum, rubrum, etc. Agh., en las Antillas. - Frondas filamentosas lejítimas, 3.

3. Compuestas de filamentos anastomosados entre sí ó fieltrados por el centro y libres por la periferie. T. II. HaLOplegMeas, Montg. G. T. Haloplegma, Montg.-Celuloso-filamentosas; conceptáculos anidados y escondidos por adentro de la capa cortical, raras cepreces esertos; tetrasporos inclusos, T. III. Criptoneneas, J. Agh., 4.

4. De fronda gelatinosa, 5. Nunca gelatinosa, pero celulosa ó cornea, 6 .

5. Cilíndrica ó comprimida; filamentos periféricos radiados, moniliformes, libres ó poco adherentes entre sí; conceptáculos anidados entre los filamentos de.la periferie. T. IV. Gleocladeas, Harv. - Membranáceas, llanas ó cilíndricas; conceptáculos y te- 
trasporos anidados los unos y los otros adentro de la capa cortical. T. V. Gasterocarpeas.

6. Carnosas y membranosas, 7. - Corneas 'y membranosas; conceptáculos nacidos dentro de la capa cortical cuyos filamentos forman en su rededor una especie de pericarpio saliente ó incluso, pero que siempre se abre por medio de un poro; tetrasporos triangularmente divididos. T. VI. Coccocarpens, J. Agh. G. T. Gigartina ascicularis, Lmx. En las Antillas.

7. Filamentos radiados mas ó menos íntimamente soldados entre sí; conceptáculos anidados en la capa cortical, á veces abriéndose por un poro, otras veces escapándose los tetrasporos al llegar la madurez por una abertura formada por el apartarse las fibras ó filamentos corticales. T. VII. Nemastomeas, J. Agh. - Conceptáculos inmergidos en la sustancia de la fronde 6 anidados dentro de especies de verrugas; tetrasporos naciendo algunas veces entre los filamentos radiantes de las rerrugas, otras veces en los endocromos de los filamentos. T. VIII. Esponjrocarfeas. Grev. Chondrus spherococcus, Ag. Ch. multipartitus, Lamx. En las Antillas.

8. Celulosas continuas ó articuladas, 9. To celulosas, pero reticuladas y de forma variada, 15 .

9. Continuas, 10. - Areoladas ó articuladas y color rojo de sangre; conceptáculos esteriores; ó conceptáculos y pericarpios como en las lomentarieas; tetrasporos inclusos dispuestos por series sobre ramitas ó segmentos de la fronde transformadas en estrichidias. T. IX. Rodonieleas, J. Agh.

10. Compuestas de celdillas redondas ó poliedricas, 11. - Nunca formadas de celdillas redondas ni poliedricas tampoco, conceptáculos siempre esteriores, 14.

11. Placenta central, 12. - Placenta no central ordinariamente, 13.

12. Esporos nacidos en los endocromos de filamentos enderezados. T. X. Plocarieas, Montg. - Pericarpio celuloso contenido en los conceptáculos; esporas piriformes enderezadas y pecadas por el estremo mas delgado en la placenta. T. XI. Lonextarieas.

13. Conceptáculos anidados en verrugas; tetrasporos soriformes. T. XII. Rizofillineas, Montg.

14. Siempre de forma variada, placenta parietal; conceptáculos inmergidos ó mamilares; filamentos esporíjenos converjentes hácia el centro de los conceptáculos, como en los fucus. T. XIII. CheTAkgieas, Kg. - Simples ó compuestas, 15.

15. Siempre ccmpuestas, planas, reticuladas y provistas de una nervadura ramificada. T. XIV. Turétıeas, Montg. - Simples aereoladas ó sin aerolas ó alveolitas, 16.

16. Siempre en redecilla; tetrasporos desarrollados por dentro de las fibras formando la redecilla ó en las celdillas de la fronde. T. XV. Axomalofileas, Dne. - Nunca en redecillas, pero mas ó menos articuladas, 17.

17. Frondas comprimidas, pinadas, con eje articulado; conceptáculos esféricos, axilares y pedicelados; los de las esporas uniloculares, mientras los de los tetrasporos son poliloculares. T. XVI. 
Ecterodonteas, Montg. - Frondas cilindráceas comprimidas ó planas, continuas ó articuladas, cubiertas de una capa calcárea ; conceptáculos esteriores ó inmerjidos, abriéndose por un poro; esporos piriformes al madurar, partiéndose en 4 transversalmente. T. XVII. Coralineas, Lmx. Coralina.

Sub-familia V. - FICOIDEAS, Sprg. F'CCÁCEAS, Lindl. FICEAS, Endl. ASPLOSPOREAS, Dne. - Las algas que forman esa gran sub-familia viven casi todas en los mares, casi todas son viváceas y entre ellas se liallan las especies gigánteas. De frondas coriáceas, con ó sin nervaduras, membranosas ó filamentosas, continuas ó articuladas, y en ese último caso mono ó polisifonieas, de color rerde aceitunado ó bruno y volviéndose negras al aire; planas, filiformes y cilindráceas; compuestas de celdillas cuya forma es muy rariada; raras vecestán reducidas á una celda única, pero en el mas alto grado de su desarrollo toman formas tales, que en ellas se ven tallos, hojas pecioladas, vesículas aéreas y receptáculos distintos. La fructificacion consiste : $1^{\circ}$ en esporas verdes ó parduscas, formadas de un núcleo simple ó multiple, envueltas en un perisporo suministrado por la celdilla matriz y provisto de un episporo ó membrana propia. Cuando los esporos están desnudos ó esteriores, el alga se !lama gimnosperma y angiosperma al contrario, cuando están contenidos en un conceptáculo con una placenta y un periscarpio ó forangio: tal conceptáculo se forma en la capa cortical de la fronde y no está separado de la médula sino por una ó por algunas capas de celdillas; sobresale muy poco de la superficie del vejetal y tiene en el vértice un poro por donde han de salir, á la sazon de la madurez, las esporas nacidas de sus paredes interiores y que converjen hácia el centro de la celda. Estos conceptáculos están tan pronto esparcidos por la superficie de la fronde como reunidos por el vértice, formando por su reunion un órgano llamado receptáculo, casi confundido con la fronde ó enteramente distinto de ella. Los esporos son unos cuerpecillos esféricos ovoideos ó piriformes, los cuales se forman siempre en una celdilla periférica ó superficial, sea que pertenezca á la capa cortical de la fronde ó á la pared del conceptáculo; la celdilla crece con su núcleo y viene á ser su envoltura ó perisporo. Las esporas son continuas $\sigma$ se dividen antes ó despues de su salida del conceptáculo en 2,4 ú 8 , cuyas partes ó divisiones constituyen otras tantas esporas capaces de germinar. Por la madurez, las esporas inclusas se desprenden de la pared del conceptáculo, caen en su cavidad y salen por el poro situado en su vértice con un mucílago abundante que facilita su salida; no tienen movimiento, aunque con frecuencia están provistas de cerdas. Algunos zoosporos han sido observados en rejetales de esa sub-familia, y el señor Thuret los ha visto reproducir las laminarias. El segundo órden de órganos reproductores se compone de los acrospermos ó anteridias y de las espermatodias. Los primeros consisten en filamentos ramosos, cuyos últimos endocromos, ordinariamente mas gruesos y elípticos, están llenos de un núcleo gonímico ó de granulos que se hallan contenidos, sea en el mismo conceptáculo con las esporas, sea en conceptáculos diferentes sobre el mismo in- 
dividuo ó sobre dos individuos distintos; desagregándose en ciertas épocas dan nacimiento á cuerpecillos dotados de una gran movilidad. Se ha dado el nombre de parafises á unos filamentos confervoideos, ordinariamente simples, que acompañan algunas veces á las esporas esteriores, y que se hallan inclusos con las esporas, sea solos sea con los acrospermas tambien, y naciendo como estos últimos de las paredes, y converjiendo hácia el centro del conceptáculo, en la boquita poriforme del cual se les vé con frecuencia presentarse; en fin, las espermatodias consisten en filamentos sentados ó estipitados, simples, bi ó cuadrífidos por el vé tice, lanceolados, ovoideos ó aguzados, etc., con numerosas gonidias verdes dispuestas por series lineares longitudinales y transversales que los forman enteramente. Se llama endócromo á las celdillas que contienen, en las algas filamentosas y articuladas, la materia colorante de cada artejo ó segmento, ha recibido tambien los nombres de esporangios, gonidias y de cromatidias.

\section{Análisis dicotómica de las varias tribus.}

1. Fronda vesiculosa ó tubulosa y filamentosa, 2. - Frondani vesiculosa ó tubulosa, ni filamentosa tampoco, 6 .

2. Vesiculosa ó tubulosa; tubos continuos, simples ó ramosos; esporas laterales, frecuentemente involucradas ó terminales; reproduccion por zoosporos. T. I. Vaucherieas, Dne. Bryopsis pennata, Lmx., Antillas. - Tubulosa ó filamentosa, 3.

3. Tubulosa, 4. Filamentosa, 5 .

4. Tubos continuos flojamente reunidos, con figura de fronde, esporas laterales ó terminales. T. II. Espongodieas, Lamx.-Fronde principal monosifoniea continua ó articulada, desnuda ó incrustada de sustancia caliza, frecuentemente casi cornea; ramitas articuladas, membranosas, verticiladas á lo largo del tallo ó reunidas por haces terminales. T. III. Actixocladeas, Dne.

5. Filamentos ramosos, articulados y confervoideos; esporas laterales cortamente pediceladas; espermatodieas. T. IV. ECTOCARPEAS, Agh. - Filamentos ramosos con tabiques celulosos, frecuentemente terminados por una cerda ó una especie de pestaña, y reunidos en una fronde diversamente conformada por medio de una sustancia gelatinosa; esporas esteriores. T. IV. Chetoforeas, Dne.

6. Fronde gelatinosa, 7. - Fronde nunca gelatinosa, 8.-

7. Desnuda ó incrustada de sustancia caliza y polisifonea; esporas laterales ó terminales y agregadas. T. VI. Bratacospernieas, Dne. Liagora pulverulenta, Agh. Galaxaura rugosa, Lmx. Dicotoma fragilis, Lmx. D.cylindrica, etc. En la mar de las Antillas. - Polisifoniada, eje filamentoso echando ramitos horizontales no adherentes y en cuya base se hallan esporas ó espermatodias. T. VII. CHORDARIEAS, J. Agh.

8. Con figura de aceituna, articulada, ramosa, polisifoniada, fructificacion monoica, esporas solitarias y laterales. T. VIII. Esfacilarieas, J. Agh. - Nunca jamás con figura de aceituna, pero 
mas ó menos estensa, simple ó compuesta, continua ó de forma muy variada, 9 .

9. Provistas mas ó menos de acrocistos, 10. - Siempre sin acrocistos, 12.

10. Fronda de forma muy variada; acrocistos dispuestos á manera de cadena en su interior ó distintos y pedicelados; receptáculos distintos simples ó ramosos, solitarios ó agrupados, axilares ó terminales, T. IX. Crstosireas, Endl. Sargassum vulgare, Agh. Fucus natans, Turn. S. Cymosum, Agh. S. Esperii, Agh. S. lendigerus, Agh. S. turbinatus, agh. Fucus turbinatus, L. Turbinaria denudata, Bory. S. platicarpum, Montg. C. T. V., 468. - Todas esas especies se hallan en el mar de las Antillas, y el vulgare constituye especialmente las uvas del trópico; no pasan del 40 grado en ambos hemisferios. - Fronda siempre continua, acrocistas nunca dispues tas á manera de cadena en el interior de ella, 11.

11. 'Fronda estipitada coriácea, en cuyos segmentos se desarrollan, alguna vez que otra, las acrocistas; esporas anfígenas, enderezadas, agregadas en soros mas ó menos estendidos; zoosporcs. T. X. LAMINARIEAs, Bory. - Fronda celulo-filamentosa de color aceitunado, frecuentemente provista de areocistas innatas; conceptáculos esparcidos ó agregados en el vértice de las ramas, pero nunca jamás reunidos en un receptáculo distinto de la fronda. T. XI, FuCEAs, Mengh. Fucus vesiculosus, L. F. compressus, Agh. F. pigmeus, Her. $F$. serratus, L. C. T. V., 470. Se hallan en el mar de las Antillas.

12. Fronda continua, membranosa, plana, unas veces flabelliforme; esporas esteriores esparcidas ó agregadas en soros, acompañadas ó no de paraspermos. T. XII. Dictroteas, Lamx. Dictiota ciliata, Lmx. D. polipodioides, Lmx. D. dentata, Lmx., etc. Todas se hallan en el mar de las Antillas. - Fronda continua membranosa, cartilajinosa, filiforme, comprimida ó plana, sólida ó hueca, con ramificaciones distintas ó irregulares; receptáculos con figura de cabeza, coronados por filamentos caducos. T. XIII. EsporocNeas, Grev.

\section{CLASE II. - FUNGÁCEAS.}

Familia 2. - HONGOS, AGARICÁCEAS, Ldly. - Vejetales siempre terrestres ó parásitos sobre los demas y hasta sobre los animales, cuyas formas y cuyos coloresvarian tarto como su consistencia y su tamaño; en efecto, son tan pronto carnudos, mucilajinosos y membranosos, como coriáceos, cartilajinosos y hasta casi leñosos. Al hablar detenidamente de las varias tribus que unos autores miran, con razon sin duda, como otras tantas familias, estudiaremos sus numerosas formas: diremos solamente de paso que en los mas superiores se distingue un piececito, un sombrero mas ó menos grande, cuya cara inferior es cubierta por laminitas, tubitos ó poros, mientras que los mas inferiores consisten en unas masas globosas ovoideas ú oblongas. Las fructificaciones consisten en semillitas desnudas ó no desnudas, ó esporitos visibles solamente con el 
microscopio, que se presentan bajo la forma de un polvo muy sutil mas ó menos prieto, ya esparcido por la superficie de la planta, ya contenido en receptáculos capilares ó conceptáculos carnosos, duros ó leñosos.

\section{Análisis dicotómica de las sub-familias establecidas en ese grupo ó familia.}

1. Esporas cubiertas de mucosidad o contenidas en celdillas prolongadas, cilíndricas ó claviformes. Hipoxileas. - Esporas nunca jamás envueltas en mucosidad, 2 .

2. Agrupadas por á 4; 3. - Esporas y esporangios solitarios, 4.

3. Himenio encerrado en un peridio. Licoperdíceas.

4. Esporas no encerradas ó desnudas, 5. - Esporas siempre encerradas, 6 .

5. Talluelo apenas notable. Uredineas. - Talluelo vedijoso; esporas frecuentemente por á 7. - Botriticeas.

6. Contenidas en sacos ú odres Helvelláceas. - Contenidas en esporangios desnudos ó cubiertos por un velo vesicular. Mucoráceas.

Sub-familia 1. - HIPOXILEAS. - Vejetales muy pequeños, casi siempre negros, ordinariamente parásitos, y en este caso salen del tejido celular de las plantas fanerógamas vivas, rompiendo su epidermis; algunas especies nacen sobre la madera muerta y aun en la tierra. Tienen fructificaciones análogas á las de los líquenes y que forman toda la planta; sus receptáculos son solitarios, agregados y aun soldados entre sí por la base, de forma globulosa, de consistencia coriácea, cerrados al principio y se van abriendo despues por un agujero ó por una hendidura, y contienen una especie de núcleo distinto, blando, delicuescente, el cual está formado de esporos cubiertos de mucosidad ó contenidos en celdillas prolongadas, cilíndricas ó claviformes. Constituye ese grupo la familia de los hipóxi los de Decandolle, y corresponde á los pirenomicetas de Fries; su principal género es la sphaeria ó esferia que ha dado lugar á muchas divisiones y otros géneros. Ninguna de las especies, que son muchas, tiene aplicacion alguna, sea á la economía doméstica, sea á las artes.

Sub-familia 2. - HONGOS LEJÍTIMOS, AGARICÁCEAS, Ldly. HIMENOMICETOS, Fes. - Los vejetales agrupados en esta division son tan pronto jelatinosos como carnosos y coriáceos, y nacen sobre los restos de materias vejetales ó animales; otros salen de la tierra y mas raras veces se encuentran en los vejetales vivos, cuya presencia en ellos indica que están enfermos. Empiezan á crecer debajo de la tierra, ó en su superficie, en el estado de fllamentos entrecruzados, de los cuales nacen cuando las circunstancias se vuelven favorables. Tales vejetales tienen esporas ó esporangios esteriores, situados en una membrana mas ó menos distinta del receptáculo general, y el conjunto de estos dos órganos forma ya una masa jelatinosa, como se vé en las trémulas y otros géneros, ya un disco ó una copa, ya un cuerpo cilíndrico y ramificado, tales 
son las clavarias; lo mas generalmente, sin embargo, aparecen con figura de un cuerpo abultado ó estendido en su parte superior, algunas veces sinuoso, lleno de cavidades y de bultos, como en las morchellas, pero ordinariamente con forma de sombrero, como se vé en los agáricos, bolestos y otros géneros. El himenio se va estendiendo á la superficie inferior del sombrerillo bajo forma de láminas mas ó menos desiguales dirijidas del centro á la circunferencia y llamadas hojillas, tales se las observa en los agáricos; otras veces se halla en forma de filamentos verticales semejantes á las cerdas de un cepillo; los hidnos están en ese caso; en fin, consiste en un tejido esponjoso y poroso, como en los boletos. Las esporas ó esporongios están colocados en gran número en los pliegues de las hojillas, en los puntos ó en los poros de esta membrana. Algunas veces el sombrerillo, al salir del receptáculo rompe una membrana ó envoltura que se llama rolva $y$ cuyas señales se encuentran en la base; otras veces el crecimiento se verifica sin ruptura en la base, pero los bordes del sombrero están unidos al estremo del pedúnculo por una membrana que se rompe y cuyas señales se ven en la parte superior del piececito en forma de collar, y á veces en el sombrerillo mismo.

Contiene ese grupo mucho mayor número de géneros y de especies que los demas juntos, y en él se hallan la mayor parte de las especies comestibles y tambien muchas venenosas, algunas utilizadas por las artes, y en fin, el mayor número cuya utilidad y provecho nos son todavía desconocidos. Se hallan en él los géneros boletus, agaricus, tremella, hidnum, clavaria, etc. Se come en las Antillas el agaricus niveus, L. A. edulis, Bull., etc: C. T. V., 171.

Sub-familia 3. - LICOPERDACEAS. - Se presentan esos vejetales generalmente en figura de masa redonda ó de bola mas ó menos gruesa, ora en la superficie del suelo, ora en su interior, ora parásitas sobre otros vejetales. Su receptáculo fibroso contrene las esporas en su interior, mas ó menos redondo y compuesto de dos capas concéntricas mas ó menos distintas, la primera de las cuales, mas coriácea, está cubierta de asperezas que se forman á medida que va avanzando la edad del vejetal; la segunda, mas filamentosa ó carnosa, da nacimiento á los esporos, casi siempre encerrados en celdillas. Tales hongos principian por ser fuertes, coriáceos y cerrados por todas partes; despues se abren mas ó menos por el vértice y muchas veces los esporos se diseminan bajo la forma de polvo sutil con los restos del tejido interior filamentoso. Se halla en esa division la trufa ó criadilla de tierra, una de cuyas especies, el tuber cinereum, C. T. V., 172, se encuentra en las Antillas; el pedo de lobo coronado ó lycoperdon coronatum, 52. En fin, entre las parásitas citaremos la spermoedia maydis, que constituye el maiz atizonado, C. T. V. 183, y el sclerotium clavum, tizon o centeno cornudo.

Sub-familia 4. - UREDINEAS. - Los vejetales conıprendidos en este órden son muy pequeños, todos parásitos, $\mathrm{Y}$ salen de las demas hojas vivas, de los demas vejetales, rompiendo su epidermis. Se consideran como esporangios que contienen muchos esporos y que no están rodeados de ningına envoltura comun. Se presentan con la mayor frecuencia bajo la forma de manchas amarillas, pardas 
ó negruzcas en la superficie de los órganos foliáceos de los vejetales. Tales parásitas son muy temibles por el cultivo principalmente de las cereales. En efecto, á ellos pertenece el tizon del trigo, uredo carbo y U.vera, el uredo maydis ó maiz con bubas: no son peligrosos para los animales ni para el hombre, que comen sin peligro los cereales atacados por ellos.

Sub-familia 5. - MUCEDINEAS. - Tales son las vejetaciones, llamadas vulgarmente enmohecimiento, que se ven diariamente desarrollarse sobre todas las materias orgánicas en descomposicion ó que principian á descomponerse con ciertas condiciones de temperatura, de oscuridad, etc. Se presentan ordinariamente con forma de filamentos delgaditos, cilíndricos ó abultados en forma de cabeza, simples ó ramosos, divididos ó no por tabiques, por lo regular de color blanco; producen esporos, ya esteriores y aislados, ya in. teriores y aglomerados en ciertas celdillas. En esta division se encuentra el oidio, que fué tan fatal á los viñedos, que era quizás solo el síntoma aparente de una enfermedad contajiosa y desconocida de esos vejetales, así como el de las papas. El pan enmohecido, por ejemplo, no se debe comer, porque no solo es malsano, sino que puede determinar accidentes de gravedad. Así será para todas las sustancias alimenticias que presenten enmohecimiento.

Muchísimas veces se pregunta á los médicos y á los boticarios y tambien á las personas aficionadas á la botánica, qué hongos ó setas son las que se pueden comer, porque se supone general y vulgarmente que hay reglas fijas para poderlos escojer; pero eso no es exacto. Los botánicos han reconocido solamente ciertas categorías de órganos como nocivos; pero no conocen carácter ninguno que sea comun, especial y único á las especies comestibles, lo que es causa de las desgracias que cada año suceden con esos vejetales. Se suele tener por peligrosos, como lo son en rerdad : $1^{\circ}$ los hongos ó setas que cambian pronto de color cuando se les corta, y hay, por ejemplo, algunos cuya cortadura se vuelve azul de una manera muy notable; $2^{\circ}$ los que son lechosos ó que contienen un suco que parece leche y por lo regular es mas ó menos acre y hasta cáustico; $3^{\circ}$ en fln, los que al enrejecer se convierten en una especie de agua negra. No es posible establecer una linea divisoria terminante entre los inocentes ó buenos para comer y los que son venenosos, puesto que es digno de observacion que hasta los que se comen impunemente en ciertas circunstancias, se hacen venenosos en otras. Falta aclarar no solo cuales hongos son verdaderamente ponzoñosos, sino los que suelen ser inocentes y dejan de serlo cuando no han llegado ó han pasado de su sazon. Puede pues creerse que demasiado maduros, y sobre todo secos, se hacen mas dañosos que antes de alcanzar toda su madurez. Los principales hongos venenosos pueden reducirse á los del género amanita y del género agárico : distínguense los primeros en que salen de una especie de bolsa $\sigma$ bulbo, en que su sombrerillo está guarnecido de hojillas ó laminillas radiantes por debajo y sostenido por un pedúnculo mas ó menos hinchado en la base; mientras los del género agárico no tienen por la base del pedúnculo bolsa alguna y las hojillas del sombrerillo son 
ordinariamente sencillas y mas cortas. No solamente reina cierta vaguedad en la accion de los hongos sobre la economía, sino que hasta los mismos venenosos ofrecen en esta parte tal variedad, que es imposible comprender los síntomas producidos por ellos en un solo cuadro; en efecto, hay los que obran realmente como nerviosoinflamatorios, puesto que inflaman los órganos y causan estupor al mismo tiempo: otros solo irritan el sistema dijestivo : otros causan unicamente estupor, aplanamiento; otros en fin, segun afirma Orfila, obran á la manera de los sépticos. Estando en las Antillas poco vulgarizado el uso de los hongos como alimento, y siendo además esos vejetales muclıo mas escasos en los paises cálidos que en los templados, no describiremos aquí los síntomas particulares á esas intoxicaciones, diremos solamente de paso, que los dolores de estómago, cólicos y sudores frios, indicios de la intoxicacion, no se presentan sino algunas horas despuếs de comidos los hongos. La accion mortífera de los que son venenosos parece ser debida á ciertos principios que entran en su composicion, puesto que privándolos, por medio de cocimientos, de dichos principios pueden ser comidos impunemente. Los principios que se consideran mas activos son uno acre, muy fugaz y poco conocido, otro muy deletéreo que Lepeletier ha encontrado unido á sales de potasa y sosa, muy soluble en el agua : se llaman fungina y amanita. Segun los esperimentos de Orfila, el vinagre dado mientras los hongos están todavía en el estomago ó los intestinos, activa su accion porque hace mas solubles sus principios venenosos, y por consiguiente es muy perjudiciål: cuando ya han sido espulsados, entónces su empleo es muy favorable; de la sal comun hay que decir otro tanto. El éter sulfúrico, el mas empleado en estos últimos tiempos contra esa intoxicacion, es el mas conducente y eficaz. La cura debe empezarse siempre por hacer arrojar la sustancia tósiga por los vómitos y cámaras, como lo tenemos señalado al hablar de los venenos en la parte correspondiente del Compendio, porque si el envenenado no arroja los hongos comidos, se muere siempre: si se consigue que los arroje hay grande esperanza de salvarle. Muchas especies son venenosas cuando se comen crudas y no lo son cuando se preparan con sal ó se cuecen. Los rusos comen cualquiera clase de hongos ó setas, pero tienen la precaucion de cocinarlos con agua y mucha sal de comer: despues de sancochados así, botan el caldo y hasta los esprimen en una tela y entónces los guisan : de esa manera no sucede ninguna desgracia. Si se quisiese ensayar una especie que se ha visto usar otra vez, es preciso asegurarse primero de la identidad perfecta de la especie y de su pais, con la que se juzga comestible, exámen difícil, que no debe hacerse sino con individuos en buen estado y de diferentes edades ó por medio de láminas y descriciones detenidas : despues es necesario aderezar un plato á la manera del pais en que se usa. Si es un ensayo enteramente nuevo el que se quiere hacer, conviene no comer la primera vez mas que uno o dos bocados y otro dia mayor cantidad, si el primer ensayo ha salido bien: en el caso de creerse envenenado escitar cuanto antes el vómito $y$ las deposiciones y despues tomar éter sulfúrico. En las Antillas y en los demas 
paises cálidos aunque húmedos, hay muy pocas especies de hongos en comparacion de los que abundan en los paises frios y templados. Por lo general, las setas constituyen un alimento fuerte, reparador y bien nutritivo, pero indijesto, de que deben abstenerse los estómagos débiles.

\section{CLASE III. - LIQUÉNEAS.}

Familia 3. - LIQUENÁCEAS. - Plantas terrestres que duran mucho tiempo, rara vez verdes, pero á veces adornadas de los mas primorosos colores; mas todas se vuelven verdes cuando están húmedas ó mojadas y su tejido seco, quebradizo ó coriáceo se hace blando y flexible. Se crian, ora en el suelo, ora en las cortezas de los demas vejetales, ya vivos ó ya muertos, pero nunca en putrefaccion, y tambien sobre los peñascos mas desnudos y estériles. Se presentan en forma de espansiones membranosas, ramosas ó filamentosas, tan pronto foliáceas coıno dendróideas, cuya figura, tamaño y consistencia varian muchísimo. En efecto, muchas veces no son sino una especie de polvo fino sin forma determinada, otras veces costras mas ó menos regulares y un poco mas consistentes, etc. Se compone el tejido de esos vejetales de tres clases de celdillas; las unas cortitas, cuyas paredes espesas están íntimamente pegadas entrie sí; las otras, alargadas en filamentos flojamente feltrados forman la capa medular de los líquenes mas perfectos, cuya corteza corresponde á las primeras, mientras las terceras globosas, esparcidas y sin adhesion entre sí, se llaman gonidias y pueden desarrollarse y reproducir el vejetal de donde han salido, constituyen su parte mediana ó gonidal. Tales gonídeas están á veces esparcidas por grupitos en medio del tejido medular. Unos saquitos mas ó menos larguitos, llamados teques, contienen los esporos en número de dos, cuatro, seis y ocho ordinariamente, agrupados en la sustancia del talluelo que constituye el receptáculo; otras veces están en una sustancia propia é intermedia llamada hipotecio. Tal receptáculo forma en derredor de los grupos un ribete saliente á espensas, sea del talluelo, sea de la sustancia propia ó hipotecio, sea de ambas á la par, y constituye así una marjencita ó una cavidad cerrada, conteniendo las teques, la cual toma el nombre de peretechio. Con los teques se entremezclan unos filamentos estériles llamados parafises, los cuales son mas largos y cujo vértice está ligado por una sustancia viscosa que segregan, forman una masa ó núcleo, la cual con su receptáculo se llama apotecio. Se da el nombre de espermatias á otros órganos mucho mas pequeños y con frecuencia zambullidos en la sustancia del talluelo, cuya superficie está cubierta de filamentos celulares ordinariamente tabicados, cuyas estremidades, ora ovoideas, ora filiformes, acaban por desarticularse y, libres en la cavidad que jes ha producido, salen por fin á favor de un poro situado por el vértice y su presencia casi constante en las cercanías de los apotecios hace suponer que sirven para la fecundacion. El esporo wa maduro y sólido fuera de las teques germina á manera de los 
hongos, es decir, que se alarga por uno ó por algunos puntos en filamentos ramosos, que multiplicánłose, no tardan en entrelazarse sea entre sí, sea con los dos esporos vecinos y forman una especie de redecilla de donde salen, en los lugares donde está el fieltro mas espeso, pequeñas masas celulosas que van dilatándose poco á poco, forman el talluelo y ya el líquen ha nacido.

\section{Análisis dicotimica de las varias tribus.}

1. Receptáculo suministrado por el talluelo mismo, 2. - Receptáculo formado al contrario por una sustancia propia, 3 .

2. Apotesias abiertas con el núcleo deshecho en esporos desnudos. T. I. Coniotálasios. Pulveraria chlorida, Ach. Se halla en las grietas de la corteza de los árboles y de las piedras. - A potesias primitivamente cerradas $y$ por fin abiertas, espulsadores de un núcleo jelatinoso, compuesto de esporas desnudas. 'T. II. Idiotálamos. Umbilicaria rellea, Ach. Sobre las rocas.

3. Provistos de peritecio cerrado, apotesias cerradas ó abiertas, mediante un escípulo taloideo irregularmente hendible; núcleo incluso, ascigero y deliquescente ó rajable. T. III. Gasterotálanos. Variolaria amara, Ach. V. discoidea, Pers. Lichen discoideus, L., - provistos de un peritecio abierto; a potesias abiertas; núcleo disciforme, persistente y ascigero. T. IV. Himexotíla mos. Cladonia sanguinea, Mart. C. T. V.53. - Cenomice vermicularis, Ach. Cla. vermicularis', Hook. Lichen vermicularis, L. - Parmelia parietina, Ach. Lichen parietinus, L. : F23. - Evernia pumastri, Hook. Lichen pumastri, L. - Peltidea aphthosa, Hook. Lichen aphthosus, L. - Usnea plicata, Ach. Lichen plicatus, L. : C. T. V., 415.

\section{SEGGION II}

\section{CLASE IV. - MUSCÍNEAS.}

Familia 4. - HEPÁTICAS. - Yerbecitas terrestres verdes y con estomates por la superficie, que se crian en los lugares umbrosos y húmedos, alguna vez que otra parásitas, con forma de espansiones membranosas ó foliázeas, algunas veces provistas de tallitos con hojuelitas empizarradảs ó dísticas, monoicas ó dioicas, pero á veces enteramente desprovistas de hojitas no son sino una espansion herbácea llamada fronde. Tienen dos clases de órganos reproductores: las anteridias, que consisten en unos saquitos perfectamente cerrados al principio, pero que despues, á cierta época, se abren por un punto de su superficie, por donde sale la materia que contienen. la cual es formada de un montoncito de corpúsculos ordinariamente ligados entre sí por un líquido mucilajinoso; y los archegonios ó esporangios, especies de capsulitas pediceladas con muchas ventallitas y sin tapa, llenas de esporas pegadas en ellas por medio de filamentos elásticos en forma de espira; otras veces hun- 
didas en el tejido de la espansion y entónces se hallan desprovistas de ventallitas y las esporas que contienen están sin los filamentos elásticos mencionados.

\section{Análisis dicotómica de las tritus de esa familia.}

1. Esporos triangulares, piramidales ó semiredondos y sin elaterio. RicCí́cEAS. - Esporos siempre provistos de un elaterio ó filamento espiral entremezclado con ellos, 2.

2. Esporangios pediculados, dehiscentes por dientes ó circuncisos, rarísimas veces cuadrífidos. Plantitas membranosas con talluelo lobado, frecuentemente provisto de estomas ; anteridios sumerjidos en el talluelo ó en receptáculos disciformes sentados y á veces abroquelados ó pediculados. Marchaxciáceas. Marchantia androgina, L. : C. T. V. 339. - M. chenopoda, L. 567. Esporangios ó cajitas pedicelados, cuadrivalves, rarísimas veces univalves y sin opérculo. JUNGERMANIÁCEAS.

\section{CLASE V. - FELICÍNEAS.}

Familia 5. - HELECHOS. - Plantas herbáceas ó leñosas que se crian ya en la tierra, ya en los peñascos ó en las paredes antiguas y tambien á veces falsas parásitas, viven pegadas á la corteza de los árboles, rarísimas veces son trepadoras; de tallo ó rizoma ordinariamente progresivo, es decir, que mientras se alarga y crece por el estremo por donde salen las hojas, se va destruyendo por el otro estremo que lleva las raices; otras veces parecen árboles y simulan los astiles de las palmeras y son mas ó menos altos; por último y rarísimas veces, consisten en un bejuquito mas ó menos largo y muy delgado, mas ó menos fuerte, con hojas simples ó compuestas y alternas. Las hojas ó frondas, á veces muy grandes y siempre muy elegantes, antes de su desarrollo completo están siempre arrolladas á manera de báculo de obispo y hácia adentro, no solamente el limbo general sobre el peciolo comun, sino tambien todas sus divisiones ó lóbulos, llamadas pinulas sobre los peciolos parciales, de tal manera que cuando son tiernas, la cara inferior está siempre escondida; provistas de pelos escamosos ó membranosos abundantemente esparcidos por la superficie y ordinariamente mas ó menos aleonados ó brunos. Los órganos reproductores ó esporas son siempre contenidos en saquitos celulosos, esporanjios ó capsulitas, siempre situados por la cara inferior de las hojas, que entónces conservan su forma ó se vuelven muy diferentes de las no fructíferas, pierden en este caro la mayor parte ó todo el parenquima, quedándose solamente las nervaduras cubiertas de capsulitas. Tales esporanjios presentan generalmente en su pared celulosa una hilera de celdillas mucho mayores y mas espesas que las demas, dispuestas cabo á cabo y á manera de anillo que rodea mas ó menos la capsulitas, cuya posicion varía bastante: á veces es incompleto y falta con frecuencia; parece tener por papel determi- 
nar la ruptura de la capsulita y facilitar por sus movimientos higrométricos la salida de los esporos. Las capsulitas no nacen esparcidas ni aisladas tampoco por la superficie de la cara inferior de las hojas, sino por grupos que se llaman soros, cuya forma variada suministra, así como el anillo, muy buenos caracteres diferenciales : su posicion relativa varía tambien, de tal manera que están esparcidos con mayor ó menor regularidad, sea por la superficie, sea por lo largo de los bordes, sea en las nervaduras de las hojas. Algunas veces se presentan desnudos en la superficie de la fronde, pero con mayor frecuencia una membrana delgadita que parece un pliegue de la epidermis les cubre y toma entónces el nombre de indusio, que forma como una cápsula cercando el soro, pero las mas veces le cubre á manera de una tapa con goznes; otras veces está pegado por un punto único ó segun una línea prolongada; todos los caracteres sacados de la forma de los soros, de la del indusio, de su adherencia, figura y direccion sirven para diferenciar los géneros entre sí. Las capsulitas consideradas aparte, son sentadas ó mas ó menos pediculadas; los esporos se forman en su interior cuatro por cuatro en las celdillas madres, las cuales al principio están soldadas entre sí, formando un tejido continuo que, reabsorviéndose mas adelante, deja los esporos libres en la cavidad de la capsulita.

\section{Análisis dicotímica de las varias tribus.}

1. Esporanjios situados sobre las hojas, 2. - Esporanjios no situados sobre las frondas, 4.

2. Ceñidos por un anillo, 3. - No ceñidos por anillo alguno, 7.

3. Capsulitas provistas de un anillo vertical ó escéntrico, sentadas ó pediculadas y transversalmente dehiscentes; frondas simples ó compuestas. T. I. Polipodiáceas. Polypodium suspensum, P.-P. cataguala. - A splenium serratum, L. - Adiantum trapeziforme, L. - Pteris pedata, L. - Capsulitas situadas en un receptáculo formado por una vena prolongada mas allá de la márjen de la fronda, sentadas, ceñidas por un anillo completo escéntrico, transversal respectivamente al punto de insercion horizontal ú oblícuo, irregularmente dehiscente. Esporas convexas ó tetraedras apiramidades; indusio con la textura de la fronda. Tallo rastrero cuyas frondas, ordinariamente tiernísimas y casi transparentes, son destituidas de estomas. T. II. Himeneofíleas. Martenzia dichotoma, Sw.

4. Anillo completo, 5. - Anillo incompleto, ancho, dorsal, dehiscente por el vértice; esporas oblongas ó casi globosas; indusio variado; frondas bipiñadas; esporangios epifilos ó situados de todos lados en frondas contraidas, estipitadas ó tenuísimamente membranosas. T. III. Osuundáceas. Osmonda lancea. C. T. V., 312.

5. Esporanjios sin receptáculo, 6. - Esporarijios situados sobre un receptáculo frecuentemente mas ó menos elevado, sentados; anillo ancho y escéntrico; esporas triquetras ó trilobas. T. IV. Cratheáceas. Cyathea speciosa. C. T. V., 702.

6. Esporanjios sub-globosos; anillo vertical; esporas sub-globo- 
sas ù oblongas. T. V. Polrpodeas. - Esporanjios hipofilos tenuísimamente membranosos; anillo incompleto, ancho, aproximado por la base á veces á penas cercada. 'T. VI. PARkerIEAs.

7. Sentados, libres ó entresoldados, abiertos por el ápice ó lateralmente; esporas elipsoideas; indusio nulo, superficial ó unido á los esporanjios; frondas simples, pinadas ó triplo-pinadas. T. VII. Maratiáceas. Marattica alata, Senth. - Esporanjios sin anillo alguno, sentados uniloculares ó casi biloculares con un tabique transversal incompleto, libres ó entresoldados, semi-bivalves; esporas farináceas. Frondas fuera del tallo rizomatoideo, apareadas, bi-formes apretadas en la vernacion; las estériles estendidas, simples ó compuestas, mientras las fértiles son reducidas al raquis ó peciolo comun, llevando los esporanjios dispuestos en espiga terminal, dística, articulada, uniloculares, y abriéndose transversalmente. T. VIII. Ofiogloseas. Ophyoglossum reticulatum; C.T.V., 799; Zotrichium cicutarium, Sw.

F amilia 6. - LICOPODIA CEAS. - Primorosos y elegantísimos vejetales mas ó menos herbáceos, intermedios entre los musgos y los helechos por su semblante, cuyo tallo derecho, mas ó menos largo y rastrero, simple ó ramoso está vestido de muchísimas hojuelitas mas ó menos empizarradas, dísticas ó esparcidas, vivaces. Fructificaciones axilares ó terminales, cuyos órganos reproductores son los unos cajitas, ó saquitos globulosos ó reniformes y uniloculares, conteniendo un infinidad de granitos ó esporitos, mientras los otros consisten en cápsulas ó sacos mayores que se abren por dos ó tres ventallas y contienen solamente tres ó cuatro esporos mas gruesos. En el primer período, estas dos clases de sacos presentan igual apariencia é igual modo de desarrollarse; en el interior de una envoltura celulosa se organiza un tejido celular, cada cual de sus celdillas está llena de una masa granulosa, la cual mas adelante se parte en cuatro masas secundarias. En la mayor parte de los sa cos ó cajitas, á cierta época de su vida, las paredes de las celdas madres están reabsorbidas y los granos formados por grupos de á cuatro, es decir las esporas pequeñas se aislan, se vuelven libres en la cavidad comun y luego se huyen por una hendidura; en un pequeño número de saquitos situados mas inferiormente todas las celdas madres abortan con sus granitos, escepto una, la cual toma un desarrollo considerable y acaba por formar las cuatro esporas gruesas, llenendo el saco ensanchado, moldado sobre ellas y que se abre á la sazon para dejarlas salir. Las pequeñas esporas sembradas á lo largo se modifican, y al cabo de unos cuatro ó cinco meses su interior se halla lleno de un tejido celular mur fino; cada una de cuyas celdillas contiene un cuerpecito filiforme, arrollado en arco ó en espira que es un anterozoïde y la espora no es otra cosa sino una anteridia que revienta al fin por uno de sus estremos para dejar salir las utriculas, las cuales agujerean las anterozoïdes que se mueven como suelen hacerlo. Las esporas mayores, despues de un tiempo mas largo, producen por su vértice una capa celulosa en la cual se forman algunos archegonos. En una celda, al centro de uno de ellos, se desarrolla, se presenta y crece un cuerpecito celuloso que 
es casi un embrion lejítimo. Lycopodium cernum, L. L. linifolium; L. flabellatum. C. T. V., t. 2,701.

Familia 7. - EQUISETACEAS. - Vejetales herbáceos vivaces y que se crian en los terrenos húmedos, cuyos tallos ó especies de cañas son huecos interiormente, con tabiques que corresponden á las articulaciones y cuya parte sólida, casi enteramente celulosa, presenta vacíos ó claros mucho mas pequeños y dispuestos en uno ó dos arcos, acompañados de algunos vasos anulares. De las articulaciones salen ramitas mas ó menos numerosas y verticiladas : entre ellas y pegara al tallo se halla una vaina membranosa que sale tambien del nudo, mas ó menos larga y terminada por cierto número de lacinias ó dientes, que ha de considerarse como una hoja única amplexicante, en el espesor de la base de la cual nacen las ramitas adventivas que la agujerean para salir. Ese tallo se termina por una especie de cono ó piña formado por la reunion de muchas escamas claviformes y perpendiculares al eje. Por debajo de la cabeza de

- cada uno de esos clavos nacen saquitos, cápsulas ó esporanjios dispuestos en arco, los cuales á su madurez se agrietan lonjitudinalmente y dejan salir un sin número de esporas, cada una de las cuales se presenta bajo la forma de una masa celulosa, de cuya parte inferior salen cuatro hilos clásticos ó claterios, cuyos movimientos farorecen la diseminacion. Al principio el saco estaba lleno por un tejido celular continuo y despues en esas celdillas, segun la ley comun, se han formado cuatro utrículas, las cuales rueltas libres mas adelante dan nacimiento en su interior á otra utrícula adherente á la primera por un punto único; esta última constituye la espora y la primera los elateros. Equisetum giganteum. C. T. V., 54. 


\section{DIVISION SEGUNDA}

\section{VEJETALES FANERÓGANIOS Ó COTILEDÓNEOS}

SUB-DIVISION T. - MONOCOTILEDÓNEOS.

SEGGION I. - ALBUMINADOS.

ÓRDEN $1 \%$.

Vejetales de periantio nulo, simple, mas ó menos petaloideo ó que no parece corola de ninguna manera y cuyas semillas están provistas de albumen ó endospermo farináceo.

\section{SUB-ÓRDEN 1\%. - APERIANTEOS.}

Vejetales de flores sin periantio alguno, el cual está á veces reemplazado por unas escamas que acompañan á las flores, pero que no constituyen una envoltura floral lejítima.

\section{CLASE IV. - AROÍDEAS.}

Familia 8. - ARÁCEAS. - Vejetales ordinariamente herbáceos, sin tallo lejítimo; sin embargo algunos tienen uno que es una especie de caña sólida un poco análoga á la de azúcar; algunos son trepadores, y entónces los tallos mas ó menos ramosos son muy largos: raices fibrosas saliendo casi siempre de una rizoma mas ó menos desarrollada y feculenta, de la cual nacen á veces muchos tuberculitos ó hijos. Hojas sencillas, radicales en las especies desprovistas de tallo, cuyo largo peciolo es envainador por la base, alternas, de limbo á veces muy grande, frecuentísimamente con figura de flecha ó de alabarda, entero ó lobado raras veces, alguna rara vez agujereado, arrolladas en la yema. Flores en espádice terminal en el vértice de un bohordo mas ó menos largo en las especies 
sin tallo, pedunculado y axilar en las otras, ceñido por una espata las mas veces coroliforme ó foliácea, mas ó menos grande, con figura de cartucho, libre ó mas ó menos soldada con la parte inferior del espádice, persistente 6 caduca. Tales flores son ordinariamente monoicas y raras veces hermafroditas; las femeninas ocupan la parte inferior del espádice, mientras que las masculinas están mas superiores ó cubren su vértice, y separadas las unas de las otras por nectarios glandulosos de forma variada; raras veces las femeninas y las masculinas están entremezcladas las unas con las otras; el vértice del espádice está casi siempre desnudo; su forma, tamaño y color son muy variados. Flores enteramente desnudas ó ceñidas por escamitas en número variable de cuatro á seis y que parecen desempeñar las funciones de cáliz; estambres y pistilos en número definido ó indefinido; estambres hipojinos de anteras 1, 2 ó poliloculares ovales $y$ estrorsas. El fruto consiste en una baya redonda, unilocular ordinariamente ó plurilocular monosperma por aborto, cuyas semillas tienen un embrion cilíndrico, derecho y axil.

\section{Análisis dicotómica de las tribus y subtritus.}

1. Flores monoicas siempre enteramente desnudas, con los pistilos situados siempre por la base del espádice y los estambres en la parte superior, separados los unos de los otros por organos sexuales rudimentarios formando un anillo mas ó menos grande; bayas las mas veces uniloculares monospermas; embrion axil, antitropo ó anatropo. Espata envolvente y persistente. T. I. Aríceas, 2. Flores hermafroditas y algunas veces monoicas entremezcladas con cuatro ó seis escamas calicinales acompañando á otros tantos estambres; espádice enteramente cubierto de flores y cilíndrico; espata pequeña caduca envolvente; estambres hịpójinos ó períjinos en número de 1,4 y 8 , cuyas anteras, siempre biloculares, se abren lonjitudinal ó transversalmente. El fruto es una baya de dos celdas monospermas, ó una cápsula ya unilocular y monosperma, ya trilocular ó polilocular. Ovulos semireflexos; embrion axil. T. II. OronCIÁCEAS, 5 .

2. Ovario plurilocular, estambres distantes de muchos pistilos verticilados situados cerca de la base del espádice, S.T. I. CRIPTOCORINEas. - Ovario unilocular. Flores femeninas separadas de las masculinas por órganos sexuales rudimentarios interpuestos, 3.

3. Espádice si zmpre libre y sin adherencia con la espata, 4. Espádice raras veces libre, pero mas ó menos soldado con la espata, estambres y pistilos numerosos contiguos con los órganos sexuales rudimentarios comunmente mezclados con los pistilos; espádice raras veces desnudo por el vértice. Anteras cuyas celdillas están hundidas en el conectivo muy grueso y abroquelado. S.-T. II. ANapoREAS. Dieffenbachia seguina, Schott. C. T. V., 4.

4. Anteras cuyas celdillas están hundidas en el conectivo muy grueso y abroquelado; estambres y pistilos numerosos contiguos ó separados por interposicion de órganos sexuales rudimentarios ; vér- 
tice del espádice frecuentemente desnudo. S.-T. III. Caladieas. Colocasia esculenta, Schott. Caladium bicolor, Schott. Xanthosoma edule. Schott. X. sagittafolia, Schott. Syngorium auritum, Schott. Philodendion hederaceum, Schott. C. T. V., 173-1-2. - Anteras no hundidas en el conectivo por ser mayores que él; estambres y pistilos ó flores muchas con órganos sexuales rudimentarios interpuestos; vértice del espádice siempre desnudo. S.-T. IV. Dracunculineas. Arum arborescens. C. T. V., $17 \%$.

5. Flores enteramente desnudas. S.-T. I. Caleas. Monstera cannafolia, Schott. C. T.V., 221. - Flores provistas de escamas, reemplazando el perigonio, 6.

6. Hojas planas enteras ó palmatisectas. S.-T. II. Oroncieas. Pothos scandens, Lin. Dracontium polyphyllum, L. : C. T. V., 178. - Hojas ensiformes abrazadoras en la estivacion. S.-T. III. AcoROIDEAS.

Familia 9. - TYFACEAS. - Plantas herbáceas vivaces, de raiz algo carnosa, que se crian en los lugares algo pantanosos; con hojas simples, muy largas, estrechas, derechas, lanceoladas, envainadoras por la base y alternas. Flores numerosísimas unisexuales y monoicas, dispuestas en espádice terminal formando especies de amentos gruesos y cilíndricos, de los cuales el masculino ocupa la parte superior y el femenino la inferior, separarlos por un trocito desnudo del eje, ordinariamente provisto de una espata foliácea, estrechay, caduca. Las flores masculinas son formadas de un cáliz trifilo ó reemplazado por escamitas ó por pelos y de tres estambres; las femeninas se componen de un cáliz igual ó formado de seis escamitas, de un ovario súpero simple unilocular con un solo ovalo pendiente terminado por un estilo único con un estigma dilatado, como membranoso y marcado de un surco lonjitudinal. Fruto indeniscente, aquenio, cuya semilla es formada de un endosperma farinoso conteniendo en su centro un embrion axil y cilíndrico de radicula superior. Typha angustifolia, L. : C. T. V , 703.

\section{SUB-ÓRDEN 2.}

Periantio reemplazado por escamas ó brácteas escamosas que desempeñan sus funciones.

\section{CLASE V. - GLUMÁCEAS.}

Familia 10.-GRAMINEAS. - Plantas ordinariamente herbáceas anuales ó viváceas, algunas de las cuales se vuelven casi arbolitos en los paises tropicales, de raices fibrosas y capilares, saliendo á veces de un rizoma; caña mas ó menos gruesa herbácea ó leñosa, ordinariamente hueca y atabicada, pero á vecès tambien sólida y mas ó menos suculenta, siempre cilíndrica, con hojas alternas ó dísticas, simples, lanceoladas mas ó menos estrechas, provistas de una vaina bastante larga, cuya insercion abraza el nudo y es abierta; de su parte posterior y opuesta á su hendidura sale el lim- 
bo mas ó menos largo y siempre estrecho, separado ordinariamente de ella por una especie de estrechamiento provisto interiormente sea de una membranita truncada, aguda, entera ó laciniada, á veces reemplazada por pelos, que se llama lígula. Flores ordinariamente hermatroditas, raras veces unisexuales, monoicas ó polígamas, dispuestas en espigas ó en panojas, formadas por la reunion de espiguitas, terminales ó axilares, sencillas ó compuestas y siempre glumáceas, es decir que su envoltura floreal se compone de dos brácteas mas interiores y de cuya axila salen los estambres; se llanıan paleas y están opuestas dos por dos; ordinariamente se hallan además por fuera del estambre mas esterior dos escamitas llamadas paleolas; las escamas de la gluma se terminan con bastante frecuencia por una arista mas ó menos desarrollada y de forma variada situada por el vértice que otras veces es mútico, entero ó recortado. Estambres hipójinos ordinariamente en número de tres, son algunas raras veces 6,2 ó 1 , de filamentos capilares y largos sosteniendo anteras grandes esertas, biloculares, hasifijas y bífidas por ambos, estremos, el pistilo se compone de un ovario único súpero, unilocular, monospermo, terminado por dos estilos, bastantes veces soldados entre sí y formando uno solo con estigma mas ó menos largo, erizado ó plumoso. El fruto es una cariópside rarísimas veces un aquenio, de forma y tamaño bastante rariados, desnuda ó envuelta en las rentallas de la gluma que se desprende con ella, cuyo embrion discoideo está aplicado á la parte inferior y lateral del endospermo farinoso y ordinariamente bastante grueso.

\section{Análisis dicotómica de las tribus que constituyen esa grande familia.}

1. Ordinariamente 6 estambres. Espiguitas uniflores, que suelen con frecuencia carecer de gluma por causa de aborto, otras veces bi ó triflores; tienen una ó dos flores inferiores neutras y con una sola pajita, flor terminal fértil; pajita tiesa; flores con frecuencia declines. T. I. Orizeas. Oriza sativa, L. Pharus lapulaceus. C.T. V., ]84-675. - Nuncajamás seis estambres, 2.

2. Espiguitas hermafroditas, polígamas ó monoicas; las mas veces con una sola flor, con ó sin rudimento de otra flor superior; otras veces son biflores, cuyas dos flores son hermafroditas ó masculinas; en fin tienen tambien.dos ó tres fleres cuya terminal es fértil y las otras incompletas; glumas las mas veces iguales; pajitas frecuentemente lustrosas y endurecidas con el fruto; estilo y estigma casi siempre elongados. T. II. Falarideas. - Zea mais, L. Andropogon citratum, L. A. squarrosum, L. A. insulare, L. : C. T. V., 182219-220-340. - Espiguitas siempre hermafroditas, 3.

3. Bifloras ó unifloras, -4 . Multifloras, 12 .

4. Solamente bifloras ó multifloras á la vez, 5. - Unifloras ủnicamente, ó á la jar uni y multifloras, 8.

5 . Solamente bifloras, cuya flor inferior es incompleta; las glumas, cuya inferior $y$ tambien ambas suelen abortar, son mas delga- 
ditas que las pajitas que con frecuencia son mas ó menos coriáceas y las mas veces múticas; la inferior cóncava; cariopside, comprimida paralelamente con el embrion. T. III. Paníceas. - Panicum italicum, L. P. miliaceum.-Bifloras, unifloras y multifloras á la vez, 6 .

6. Bifloras, uni ó trifloras, 7. - Bifloras ó multifloras, cuya terminal está las mas veces achaparrada, tienen dos glumas y dos pajitas membranosas y herbáceas; la pajita inferior está las mas veces provista de una arista dorsal y torcida. T. IV. Avenícens. Avena sativa, L.

7. Bifloras ó unifloras situadas sobre un eje articulado, de las cuales flores una es sentada, mientras la otra es pediculada, cuando mellizas; pajitas membranosas nunca en forma de quila, cuya inferior está frecuentemente provista de una arista; hay dos estilos. Flores dispuestas en panojas mas ó menos flojas, las dos ventallas de la gluma llevan pegado por fuera una especie de penacho de pelos largos y sedosos; ambas ventallas de la gluma inferior son lam-piñas. 'T. V. Sacaríneas. Saccharum officinale, L. : C. T. V., 420. - Bifloras, uni ó trifloras colocadas en las escavaciones del eje, ya solitarias, ya apareadas con una pedicelada frecuentemente desecada; una flor de cada espiguita inferior ó superior con frecuencia incompleta. Gluma de una ó de dos valvas, casi siempre coriáceas, algunas veces enteramente deficientes. Pajitas membranosas muchas ó raras veces cortísimas ó nulas. T. VI. Rotboeliáceas.

8. Unifloras solamente con ó sin otra flor rudimentaria, 9. Multifloras siempre ó multi y paucifloras á la par, 10.

9. Siempre unifloras, sin rudimento alguno de otra flor, con pajitas enrolladas, provistas de una arista en su ápice y las mas veces endurecida con el fruto; tal arista es simple ó trifida, muy á menudo torcida y articulada por su base; ovario estipitado y las mas veces con escamitas. T. VII. Estipáceas. - Unifloras raras veces con otra flor rudimentaria subulada y superior; hay dos glumas y dos pajitas membranosas y herbáceas cuya inferior tiene bastantes veces una arista; estigmas las mas veces sentados. T. VIII. Agrostídeas.

10. Unifloras con ó sin el pedículo de otra flor superior ó multifloras, las mas veces cubiertas de pelos suaves ó cuya sola base está envuelta por ellos; dos glumas y dos pajitas membranosas y herbáceas; tales glumas son á menudo iguales con las flores ó mas largas que ellas; pajita inferior aristada ó mutica. T. IX. ARUndinácens. Arundo donax, L. : C.T. V., 621.-Uni ó multifloras, sin estar nunca cubiertas de pelos, 11 .

11. Cuya reunion forma espigas unilaterales de flores superiores achaparradas; dos glumas y dos pajitas membranosas y herbáceas las últimas de las cuales son músticas y con aristas á la par; glumas persistentes en el eje de la espiga, la superior de las cuales mira á fuera. Espigas digitadas ó apanojadas. Muy raras veces solitarias y de eje nunca articulado. T.X. Chrorídeas. Cynodon dactylon.-Con frecuencia provistas las flores de una arista; la superior de estas es achaparrada; hay dos glumas y dos pajitas herbáceas, las primeras faltan raras veces. Estigmas sentados en el vértice de un ovario pro- 
visto de pelos; inflorescencia en espiga. T. XI. Hordeáceas. Hordeum vulgare, L. Triticum sativum, L.

12. Multifloras y raras veces paucifloras ; dos glumas y dos pajitas membranosas $\mathrm{y}$ herbáceas, rara vez coriáceas; pajita inferior las mas veces provista de una arista no torcida; inflorescencia casi siempre apanojada. T. XII. Festucáceas. Bambusa gandua, L. C. T. V., 419. - Bromus. - Dos espiguitas multifloras siempre, cuyas flores superiores están apanachadas; tienen dos glumas, dos pajitas membranosas y herbáceas ; cura pajita inferior es tri ó multifida con sus divisiones subuladas y terminadas á manera de arista. T. XIII. Papoforeas.

Familia 11. - CIPERACEAS. - Plantas herbáceas que se crian ordinariamente en los suelos húmedos, cuyas raices fibrosas y capilares salen con bastante frecuencia de un rizoma mas ó menos desarroilado, de tallo sólido, raras veces nudoso, casi siempre triangular, con hojas simples, estrechas y largas ó lanceoladas, enteras, muchísimas reces cortantes y ásperas, cuyo limbo sale de una vaina cerrada, alternas o trísticas; las superiores no tienen vaina. Flores hermafroditas ó unisexuales, en espigas terminales ó espiguitas agrupadas de varios modos. Tales flores se componen de una escamita que tiene lugar de cáliz, de tres estambres ordinariamente, pero cuyo número puede variar de 1 á 12 , cuyo filamento delgado y capilar mas ó menos largo sostiene una antera de vértice puntiagudo y de base bifida, basifija y bilocular, son hipójinos; de un pistilo formado de un ovario súpero con un huevecillo derecho, cuyo vértice lleva un estilo bi ó trífido con estigmas filiformes y velludos; al esterior del ovario se hallan algunas veces cerdas ó escamitas en número variado y que no son otra cosa sino estambres abortados; algunas veces en las flores femeninas el ovario está escondido tras una envoltura particular ó utrícula que se abre para dejar salir el estilo y cuya abertura ó boquita está provista de dos dientecitos. El fruto es un aquenio corneo ó membranoso, globoso ó comprimido, triangular ú ovoideo, cuya semilla tiene el embrion con forma de trompo situado en su parte mas inferior, esterior y lateral sobre un endospermo farinoso.

\section{Análisis dicotomica de las varias tribus.}

1. Espiga ó espiguitas diclines, 2. - Espigas nunca unisexuales pero siempre hermafroditas, 5 .

2. Diclines ó andrójinas á la par, 4. - Andrójinas ó diclines solamente y nunca á la vez, 3 .

3. Solamente andrójinas monocárpicas con pajas numerosas insertas en muchas series sobre el eje discoideo, deprimido y apretadamente empizarradas, cuyas internas están incluidas en las esternas mayores y monandras, algunas de las inferiores están vacías; flor hermafrodita terminal con las pajas íntimas de 3 á 12 , monandras y como ceñidas de un perigonio paleáceo y poliandro ; perigonio propio y disco nulo; estilo bi ó quinquefido; cariopside crustácea, 
globosa, arrugada y con el vértice desnudo. T. I. Crisitriqueas. - Solamente diclines, cuyas masculinas tienen las pajitas dísticas ó empizarradas en muchas series; las ínfimas algunas veces están vacías; estambres tan pronto 1 como 3 y raras veces 5 . Espiguillas femeninas unifloras, con muchas glumas empizarradas en muchas séries y algunas veces nulas; dos paleas ó pajitas opuestas ó casi opuestas; perigonio siempre nulo; disco mas ó menos manifiesto: cariopside como huesosa, hoyosa ó cancelada. T. II. Esclerieas. Scleria flagellum, Sw.

4. Diclines, andrójinas y rarísimas veces dioicas, con involucro foliáceo ó espatiforme, cuyas masculinas simples son multífloras, con las flores empizarradas por todas partes, unipaliáceas; sin perigonio alguno; ordinariamente tienen tres estambres y rara vez solo dos. Espigas femeninas simples ó compuestas con espiguillas empizarradas por todas partes; andrójinas, casi siempre unifloras por aborto; se componen de dos glumas cuya delantera es plana y la trasera bicarenada, juntas por las márjenes desde la base hasta el ápice en un odrecillo ó utrícula bidentada, persistente, conteniendo un ovario con un pedicelo estéril, setiforme, rarísima vez fértil y masculifloro; pajas y perigonio nulos; estilo bi ó trifido. Cariopside lateralmente comprimida ó trigona con el ángulo dirigido al eje. T. III. Caríceas. Killingia odorata, Kth. C. T. V., 286.-Monodiclines con espiguillas unifloras, unisexuales, bi ó plurifloras, andrójinas, cuyas masculinas son algunas veces reducidas al solo pedicelo; gluma única y delantera; pajas dos paralelas al eje; binas en las flores unisexuales, cuya trasera inferior y mayor es abrazadora, mientras la delantera superior y menor es deficiente en las espiguillas andrójinas; perigonio nulo ó multisetoso, con las cerdas muy lisas, blandas y mas cortas que las pajas; estambres siempre tres ; cariopside trígona casi siempre picuda, por persistencia de la base del estilo. T. IV. Elineas. Hypoporum hivtellum, Nees.

5. Hermafroditas ó polígamas, 6. - Solo hermafroditas, 7.

6. Con frecuencia polígamas paucífloras ó unifloras con las pajas dísticas ó empizarradas en muchas series; las ínfimas y las supremas algunas veces vacías; perigonio formado de cerdas ásperas, pestañosas ó plumosas, libres ó entresoldadas por la base, algunas veces tambien unidas al disco frecuentemente desvanecido, raras veces son desvanecidas; estambres 3 ; cariopside cartilajinosa ó crustácea, separada por la base del estilo y variamente ensanchada. T. V. Rincusporeas. Ramivea maritima, Aubl. C. T. V., 344.'-Rarísimas veces polígamas, multifloras, rara vez uni ó trifloras, con pajas ditísticas ó empizarradas en muchas series; perigonio nulo, algunas veces cerdoso ó membranáceo; 2 ó 3 estambres fértiles; disco mas ó menos distinto, membranoso, acubileteado, truncado ó lobado. Algunas veces desplegado en estaminodios separados en torno del estipite cariopseo y pegado á él con la márjen libre y arrimado á la base del fruto; estilo bi ó trifido, rarísimamente simple y tridentado en el ápice; cariopside crustácea ó cartilajinosa trigona y ceñida del disco. T. VI. Fuireneas.

7. Siempre unifloras, 10. - Uni-trifloras ó multifloras, 8. 
8. Uni ó trifloras con pajas empizarradas en muchas series, cuyas inferiores están siempre vacías mientras las del estremo son solamente floríferas; perigonio nulo; los estambres varian de 2 á 12 y muchas veces de 3 á 6 y casi siempre prolongados despues de la floracion, transversalmente pegados y adherentes á la cariopside; disco nulo; estilo bífido, con los brazos frecuentemente bífidos tambien; raras veces bulboso por la base, y con mayor frecuencia enteramente caedizo; cariopside huesosa, gruesa, durísima, frecuentemente engrosada por el ápice, desnuda ó coronada por la base tenue del estilo ; algunas veces drupácea con cáscara frágil, separable del endoscarpio crustáceo, rarísimamente crustácea, ventruda y coronada del bulbo del estilo. T. VII. Cladieas. - Multifloras, 9.

9. Multifloras siempre y embricadas con las pajas por todos lados ó raras veces dísticas empizarradas, todas conformes, cuyas ínfimas son estériles; perigonio nulo ó cerdoso con las cerdas capilares, escabrosas hácia atras, otras veces muy lisas, prolongadas despues de la florescencia, raramente comprimidas y lineares; disco nulo; estilo bi ó trífido con la base frecuentemente bulboso-engrosada y persistente; cariopside crustácea comprimidita, desnuda en el ápice ó arrejonadita y rarísimas veces cuspidada. T. VIII. Escirpeas. Scirpus palustris, L. : C.T.V., 56.-Multifloras, raras veces uni ó trifloras, con pajas ó escamitas dísticamente empizarradas, todas conformes y casi siempre con las márjenes escurridas por los ángulos del eje. Perigonio raras veces existente y cerdoso con las cerdas erizadas hácia atras; disco nulo; estilo bi ó trífido, rarísimamente bulboso por la base y caedizo; cariopside crustácea, comprimidita, desnuda en el ápice ó arrejonadita y rarísimamente cuspidata. T. IX. Cipereas. Ciperus articulatus, L. C. hydra, L. C. odorata, L. C. elegans, L. C.T.V., 55-185-222.

10. Pajas 204 , algunas reces solitarias; perigonio y disco nulos, estambres de 2 á 3 , ó de 3 á 8 ; estilo bifido, cariopside comprimida, desnuda en el ápice ó acorchado-engrosada, algunas veces picuda por la persistencia de la base del estilo. T. X. Hipolitreas.

\section{SUB-ÓRDEN $3^{\circ}$.}

Periantio escamoso ó petaloídeo; semillas con embrion antitropo estrario.

\section{CLASE VI. - JONCINEAS.}

Familia 12. - COMELÍNEAS. - Plantas herbíceas, ordinariamente vivaces, de tallo herbíceo carnudo, algo nudoso, con hojas simples, estrechas y bastante largas ó lanceoladas, envainadoras por la base, alternas y dísticas. Flores hermafroditas dispuestas por grupos axilares ó terminales, á veces como apanojadas, contenidas en brácteas foliáceas y como espatiformes; se componen de un periantio de seis divisiones cuyas tres esteriores son verdes y como foliáceas, mientras las tres interiores son petaloideas; estambres de 
3 á 6 ; cuando son 3 están acompañados entonces por tres filamentos estériles, todos con glandulitas ó pelos articulados, de anteras, introrsas y biloculares; pistilo compuesto de un ovario súpero, trilocular, dispermo, cuyo vértice lleva un estilo único con estigma sencillo. Cápsula bilocular con dos semillas peltadas en cada celda, abriéndose por 3 ventallas, placenta axil; endospermo duro y carnoso, conteniendo alojado, en una cavidad opuesta al hilo, el embrion con forma de trompo. Commelina communis, L. Tradescantia discolor. C. T. V., 626-625-132.

\section{ÓRDEN $2^{\circ}$.}

Vejetales sin periantio ó que tienen este órgano doble, sepaloideo ó petaloideo; semilla raras veces con endospermo farinoso.

SUB-ÓRDEN $1^{\circ}$. - APERIANTEOS.

CLASE VII. - PANDANOIDEAS.

Familia 13. - PANDANÁCEAS o PANDÁNEAS. - Vejetales mas ó menos grandes, que á primera vista parecen palmeras, de hojas algunas veces grandes, alternas, simples ó compuestas, y entónces pinadas ó palmeadas y en forma de abanico. Flores monoicas ó dioicas dispuestas en espádice con una espata corta y caduca, cuyas masculinas se componen de un solo estambre, con antera sentada, sin perigonio ordinariamente y las femeninas están formadas de un ovario monospermo unilocular ó plurilocular, de placenta parietal, con un estigma sentado; embrion corto y axil.

Hojas simples, árboles que no parecen palmeras, pero casi bromeliáceas gigánteas; perigonio nulo. Pandaneas. Pandanus candelabrum. C. T. V., 188. - Frondes ordinariamente grandes en abanico ó pinadas, á primera vista parecen palmeras; flores ordinariamente provistas de un perigonio. Ciclanteas. Cardulovica palmata. Palmito de sombreros, se halla en Puerto Rico y en Cuba; en el Perú se llama jipajapa y sus hojas sirven tambien para sombreros de Panamá. Phitelephas maciocarpa, H. B. K.; marfil vejetal.

SUB-ÓRDEN 2. - PERIANTEOS.

GRUPO $1^{\circ}$. - ESPADIGIFLOROS.

CLASE VIII. - FENOCOÍDEAS.

Familia 14.-PALMERAS.- Primorosos vejetales cuyo tallo es un astil ó estipe mas ó menos grueso, ó mas ó menos delgado, cuyos entrenudos son ora muy cortos, ora separados los unos de los otros por trozos largos, lisos y lustrosos; otras veces su superficie está vestida con la base persistente de las hojas, y, despues de des- 
prendidas estas, se queda desigual, rugosa y agrietada; algunas veces provistas de espinas derechas mas ó menos largas y fuertes; otras veces, aunque raras, el tallo está reemplazado por un rizoma; raices fibrosas, de las que muchas son adventivas $y$ forman por la base un cono mas ó menos grueso. Frondes ú hojas que en ciertas especies alcanzan mas de $25^{\prime}$ de largo, están dispuestas á manera de corona en el vértice del astil, ó alternas en las especies de tallo pequeño y larguísimo y como sarmentoso; radicales cuando falta el tallo; simples ó compuestas y provistas de peciolos largos y muy fuertes; tienen figura de abanico son palmatisectas ó pinatisectas ó pinadas, de prefoliacion plicada; una vaina mas ó menos grande y leñosa se halla siempre en las bases del peciolo, la cual se revienta por los progresos de la rejetacion ó al desprenderse la fronde. En las axilas de las frondes, cualquiera que sea su posicion, nacen las flores dispuestas en espádices simples ó frecuentemente ramosos, envueltas por una espata mas ó menos espesa, dura, leñosa, de forma y tamaño muy valiados, única ó multiple, completa ó incompleta, que suele faltar algunas raras veces; la cual se abre á la sazon para dejar salir el espádice á fuera y rerificarse la floracion; tales flores son hermafroditas ó polígamas, monoicas ó dioicas y formadas de un periantio compuesto de dos verticilos de hojuelas coriáceas, cuyas tres interiores no tienen siempre la misma forma y la misma lonjitud que las esteriores y bastante á menudo se sueldan entre sí; estambres ordinariamente seis, raras reces tres solamente, algunas veces mas numerosas en las flores diclines, cuyos filamentos son libres ó monadelfos, con anteras bastante grandes y biloculares: el pistilo se compone de 3 ovarios distintos ó soldados, así como los estilos son 3 ó 1 , segun la disposicion del ovario correspondiente, con estigma mas ó menos prolongado. El fruto consiste en una especie de drupa mas ó menos gruesa, curo hueso mas ó menos duro, mas ó menos grueso ordinariamente unilocular está contenido en una envoltura fibrosa muy espesa, carnosa ó como crustácea mas ó menos delgada. La semilla que llena el hueso con que se suelda y se confunde algunas veces, se forma de un perispermo espeso, generalmente muy duro, corneo ó cartilajinoso, frecuentemente ruminado, sólido ó hueco, y en ese caso mas ó menos lleno de agua, por la base y por los lados del cual se halla una cavidad en donde está anidado un embrion pequeño que mira sea al hilo, sea por otro lado cualquiera: al germinar la parte inferior del embrion se desarrolla la primera, penetra en el interior del ẹndospermo, vive á sus espensas, cuya sustancia modifica, bajo la infiuencia de su presencia y la vuelve el alimento necesario para el desarrollo de las otras partes del embrion que entónces pueden salir á fuera; véase lo que decimos sobre el particular al hablar de la germinacion.

\section{Análisis dicotómica de las trib́us.}

1. Estambres hipójinos ó períjinos, muchas espatas mas ó menos incompletas y raras veces una sola completa, 2. - Estambres siempre y solamente hipojinos, 3 . 
2. Flores casi siempre unisexuales, monoicas ó dioicas, sentadas; frecuentemente cercadas por todas partes de brácteas y de bracteillas perfoliadas, espataceo-unidas y como amentíceas, dispuestas en espádices ramosos; ovario compuesto de 3 carpillos, raras veces de dos, primitivamente entresoldados y tribilocular; huevecillo único en cada celdilla $\mathrm{y}$ derecho: fruto casi siempre monospermo por causa de aborto, abayado, cuadriculado-corticado, con escamas primeramente derechas y despues rolteadas empizarradas, corneas. Frondes pinadas ó palmado-flebelliformes ó con figura de abanico, con alas reduplicadas. T. I. LepidocaníNe.s. Mauritia flexunsa. C. T. V., 185.-Flores casi siempre hermaíroditas ó polígamas, dioicas, sentadas, sin estar acompañadas de bracteas; er espádices ramosos, á veces con figura de escoba ó como de abanico; ovario compuesto de 3 carpillos primitivamente separados y por fin separados ó unidos en uno solo, todos ó algunos solamente desenvueltos, rarísima vez un carpelo único; cuyos huevecillos, solitarios en las celdillas y derechos, scn laterales ó volteados, fruto abayado, triple, profundamente trílobo, simple o doble por aborto, escluidos los carpillos abortados por la formacion del desenvuelto, rarísimas veces solitario. Frondes casi siempre palmado-flebelliformes, rarísimamente pinadas, con alas reduplicadas y coronando estirpes inermes. T. II. ConIFINEAs. Phonix dactilifera, L. Copernicia tectorum, Mart. Chamoerops humilis, L. - C. T. V., 622.

3. Muchas espatas ó mas rara rez una sola ; flores monoicas; alas de las hojas reduplicadas, 4. - Algunas espatas y nunca una sola; flores dioicas; alas de las frondes induplicadas; flores masculinas de textura como glumácea, sumerjidas en los hoyuelos del espádice, formados por la reunion de las escamas salientes en la florescencia, como amentáceas; espatas incompletas, articulado-envainadoras ó raras veces completas y del todo cubridoras de los espádices. Ovario compuesto casi siempre de 3 carpillos, raras veces de 2 ó de. 4 , primitivamente entresoldados; tri ó raramente bicuadrilocular, con huevecillo solitario en las celdillas, ascendente ó rolteado: fruto drupaceo ó raras veces abayado, indiviso ó lobado; frondes palmado-flabelliformes ó pinadas. T. III. BorAsíxzAs.

4. Flores primeramente reclusas dentro de una espata solitaria completa ó de muchas, de las cuales la mas íntima está entónces completa y bracteada, sentadas ó sumerjidas en hoyuelos trabados, á manera de alveolos, con las brácteas amarillo-blanquecinas; filamentos de los estambres confluyentes por la base; ovario compuesto de 3 carpillos, raras veces de 2 , cuaternos ó senos primitivamente unidos, trilocular ó raras veces bi-cuadri-sexlocular, cuyos huevecillos, solitarios en cada celdilla, son derechos ó volteados. Fruto drupáceo, monopireneo, trilocular ó frecuentísimamente unilocular, con las celdillas abortadas, inclusas en la cáscara ó en el endocarpio huesoso ó lapideo de la fértil; núcleo oleoso mas ó menos coherente con un endocarpio craso por los vasos reticulados de la testa. Frondes grandes y pinadas. T. IV. Cocoíneas. Coccos nucifera, L. Elais occidentalis. C. T. V., 568-624. - Flores sentadas en un raquis liso ú hoyoso; las espatas faltan algunas raras veces; ovario 
compuesto de tres carpillos, raras veces de dos, primitivamente entresoldados, y tribilocular, rarísimas veces con un solo carpillo unilocular; huevecillos solitarios en las celdillas, rarísimas veces son dos, derechos o laterales, suspendidos y con frecuencia en una ú otra celdilla faltos del todo. Fruto trilocular profundamente tri]obo: $\dot{0}$ con mayor frecuencia uni-bilocular por aborto de las celdillas; abayado o lijeramente drupíceo con el endocarpio de cada carpillo separado ó escluido de los abortados por formacion del fértil. T. T. Arecíxens. Oréodoma regia, H. B. I. O. olevacea, Mart. Euterpe edulis, Mart. Iriariea andicola spreng. etc. C.T.V., 623-623-625.

\section{GRUPO II-ASPADIGIFLOROS.}

\section{CLASE IX. - LIRIOÍDEAS.}

SUB-CLASE Ia.-STPEROVARIEOS.

\section{Famitia 15. - MELANTÁCEAS ó COLCHICÉCEAS. -} Plantas vivaces herbáceas que salen de una cebolla sólida ó de rai ces fibrosas; hojas ordinariamente radicales, sencillas, con las nervaduras paralelas, pecioladas, con la base del peciolo envainadora, alternas en los tallos. Flores radicales hermafroditas 6 en panojas, terminales, polígamas $\mathrm{y}$ sostenidas por un tallo herbáceo derecho, tan pronto hermafroditas como unisexuales ó polígamas y que constan de un periantio á veces largamente tubulado ó no, regular, petaloideo, monófilo y con seis divisiones mas o menos profundas, de cura base salen seis estambres opuestos á ellas, cuyos filamentos libres llevan anteras biloculares, estrorsas; pistilo formado de uno hasta seis ovarios con estilo simple ó trífido, que suele faltar raras veces, con estiunma glanduloso. Cápsula trilocular abriéndose por tres ventallas, polisperma, ó el fruto se compone de tres ó mayor número de caysulitas agrupadas uniloculares, abriéndose por la cara interna y hácia el vértice, polispermas; semillas formadas, además del tegumento propio memiranoso ó reticular, sobrecargado algunas reces hácia el hilo por un tubérculo mas ó menos voluminoso, de un endospermo carnoso que contiene un embrion cilíndrico situado hacia el punto opuesto al hilo.

Raices ordinariamente fibrosas sin cebolla, perigonio de hojuelas libres ó sentadas, ó algunas veces ungüiculadas ó coherentes por la hase en un tubo cortísimo; flores polígamas apanojadas. TeráTREis. Teratrum sabadilla. C. T. V., 461-801. - Una cebolla sólida; perigonio de hojuelas petaloideas larguísimamente ungüiculadas, de las que algunas soldadas ordinariamente forman un tubo largo; flores hermafroditas. Corr'HícEss. C'olchicum autuminale, L.

Familia 16. - LILIACEAS. - Tejetales herbáceos vivaces, ordinariamente provistos de un bulbo ó de un rizoma ó leñosos, entónces arbustos $y$ hasta árboles bastante grandes; hojas radicales alargadas, estrechas y envainadoras por la base, mas ó menos sen- 
tadas, alternas y cuyas nervaduras son paralelas, algunas veces muy carnosas. Flores hermafroditas ordinariamente, raras veces polígamas y unisexuales, dispuestas en espigas, en cimas ó en especies de cabezas esféricas ó en panojas, situadas en el vértice de un bohordo mas ó menos largo, con frecuencia acompañadas de brácteas parciales, y de una especie de espata membranosa general alguna rara vez, otras veces axilares solitarias ó en grupos; constan de un periantio petaloideo con seis divisiones dispuestas en dos séries concéntricas, conformes, tan pronto distintas como soldadas en tubo por la base; seis estambres opuestos á las divisiones y dispuestos tambien en dos verticilos concéntricos, libres ó soldados con el tubo del periantio, hipójinos, cuyos filamentos llevan una antera bilocular. Pistilo único cuyo ovario se forma de tres carpelos correspondiendo con los tres estambres mas interiores y soldados en uno único, libre, trilocular, algo trigono polispermo, cuyos huevecillos están pegados en el ángulo interno segun una ó dos séries verticales, de cuyo vértice sale un estilo único triangular, terininado por un estigma trílobo ó por tres estilos distintos; fruto capsular ó abayado; cápsula trilocular, loculícida, con tres ventallas cuyos tabiques resultan de la duplicatura de las ventallas que son septiferas por en medio de su cara interna, con algunas semillas un poco planas y situadas en su ángulo interno, cuyo perispermo es carnudo ó cartilajinoso y contiene un embrion cilíndrico cuya radícula está vuelta liácia el hilo, alguna vez que otra retorcido; de tegumento propio crustáceo ó membranoso : cuando es una baya tiene tres, cuatro ó una sola celdilla por causa del aborto de las demas, con una ó dos semillas.

\section{Análisis dicotomica de las tribus de esa familia.}

1. Plantas bulbosas ó cuya raiz es mas ó menos tuberosa, 2. Plantas nunca jamas bulbosas, ni tuberosas tampoco, 4 .

2. Siempre bulbosas y herbáceas, cuyo perigonio tiene sus hojuelas libres o coherentes en lo mas bajo de la base y con frecuencia nectaríferas; estambres insertos en el receptáculo ó en la base del perigonio ; fruto capsular cuyas semillas anátropas son comunmente comprimidas con tegumento moreno-verdusco, esponjoso ó duro; tienen el embrion diminuto, recto ó encorvado, situado en la base del albumen. T. I. Tulipáceas. Lilium. - Bulbosas ó con raices amanojado-fibrosas y algunas veces tuberosas, herbáceas, cuyo perigonio tubuloso es sexpartido y lleva algunas reces los estambres pegados en su tubo, otras veces están insertos en el receptáculo. Ovario trilocular con muchos huevecillos ó en número casi definido, anátropos ó anfítropos, que se vuelve cápsula ó especie de baya, cuyas semillas anátropas ó anfítropas son globosas ó angulosas, con tegumento crustáceo negro y frágil y tienen un embrion recto ó inversamente encorvado con la raicilla dirijida al hilo, 3 .

3. Plantas herbáceas siempre bulbosas, cuyo periantio tubuloso y sexpartido lleva los estambres insertos en su tubo, otras veces lo 
son en el receptáculo; fruto capsular. T. II. Jacinteas. Scilla Peruviana. Allium sativum, etc. L. : C. T.V., 346-422-848.- Yerbas con raiz fibrosa o tuberosa, cuyo perigonio es patente; huevecillos por lo comun anfítropos y fruto eapsular. T. III. Anteríceas.

4. Nunca bulbosas, pero cuya raiz es tuberosa ó fibrosa; yerbas perennes cuyo perigonio tubuloso con limbo sexfido lleva los estambres insertos en el tubo; fruto capsular con semillas anátropas, comprimidas, cuyo tegumento membranáceo es frecuentemente pálido; embrion axil. Agrpínteas. Polyanthes tuberosa, L. - Nunca bulbosa, ni tuberosa tampoco, 5 .

5. De raices fibro-amanojadas ó solamente fibrosas; plantas herbáceas crasas, algunas veces frutescentes ó árbores; perigonio tubuloso sexfido o sexdentado y algunas veces sexpartido; estambres insertos en el receptáculo ó en el tubo perigonial; ovario trilocular con los huevecillos anátropos; fruto capsular ó abayado con semillas comprimidas angulosas ó aladas, de tegumento membranáceo pálido ó negro y con embrion ortotropo. T. IV. Aloíneas. Aloe spicata, L. - C. 'T. V., 525. - Iucca aloefolia. Raices siempre fibrosas saliendo con frecuencia de un rizoma; plantas ordinariamente herbáceas; flores hermafroditas, polígamas ó unisexuales raras veces; de perigonio con cuatro, seis y hasta ocho divisiones, cuya base adhiere con los estambres libres ó rarísimamente monadelfos; ovario de dos ó tres celdas con uno ó con dos huevecillos; baya tri ó cuadri locular, ó unilocular por aborto. 'T. V. Asparagíneas. $A s-$ parragus of.ticinalis, L. - C. T. V., 345.

Familia 17. - ESMILACEAS. - Vejetales sarmentosos y leñosos o especies de bejucos, cuyos tallos larguísimos muy fuertes, mas ó menos ramosos están ordinariamente provistos de ąuijones muy fuertes, raras veces inermes; hojas simples alternas cuyas nervaduras son anastomasadas, pecioladas y acompañadas por dos zarcillos muy fuertes que salen de su axila; otras veces plantas herbáceas cuyos tallos como los de los bejucos salen de un rizoma mas ó menos desarrollado. Flores dioicas en especies de umbelas ó cimas axilares cuyo periantio único y monosepalo tiene seis divisiones iguales, profundas $y$ abiertas; en las masculinas liay seis estambres, de anteras introrsas ó vueltas hácia el centro; las femeninas tienen el periantio conforme, pero consistente, conteniendo un pistilo formado de un ovario libre $\mathrm{y}$ globoso, trilocular, con un huevecillo único en cada celdilla, cuyo rértice llera tres estilos ó un estilo tripartido con sus correspondientes estigmas. El fruto consiste en una baya globosa con tres celdas monospermas ; embrion homotropo intrario. Smilax salsaparilla, L. S. antisifilitica. S. pseudo china. C. T. V., 386-387.

Familia 18. - TILANDSIEAS. - Plantas herbíceas vivaces y casi siempre parásitas sobre los árboles rivos, algunas raras veces terrestres, cuyas hojas simples, estrechas, ensiformes ó con forma de cinta, son sentadas, dispuestas en roseta, del centro de la cual sale un bohordo mas ó menos largo y á veces provisto de algunas hojas mas pequeñas ó escaniformes y alternas; flores hermafroditas en espicas ó panojas terminales formadas de un periantio monófilo, 
cuyas tres divisiones esternas son mas ó menos verdes ó grisáceas, mientras las tres internas son siempre petaloídeas; estambres seis insertos en el tubo perigoneal; pistilo único formado de un ovario trilocular polispermo con la placenta axil, llerando en su vértice un estilo único terminado por un estigma algo trílobo. El fruto consiste en una cápsula linear, oblonga, trilocular, abrićndose por tres ventallas y conteniendo en una placenta axil muchas semillas alargadas y peludas, con el embrion antitropo extrario. Tillandsia usneoides. T. Recuriata. C. T. Y., 683.

\section{SUB - CLASE II. - INFEROVARIEOS.}

\section{GRUPO $1^{n}$. DICLINES.}

Famitia 19. - DIOSCÓREACEAS.-Plantas vivaces cuyos tallos trepadores, semileñosos ó herbáceos muy largos y ramosos, á reces como alados ó desnudos y cilíndricos salen ordinariamente de una raiz mas ó menos gruesa, perpendicular, carnosa ó feculenta, especie de rizoma bastantes veces; hojas simples, alternas, pecioladas, frecuentemente acorazonadas, cuyas nervaduras son ramificadas. Flores en racimos ó espiguitas axilares, cuya reunion forma algunas veces panojas terminales, pequeñas y blancuzcas; constan de un periantio regular con seis divisiones profundas, en las mascuiinas hay seis estambres libres ó como monadelfos y perijinos, cuyas anteras biloculares son intorsas; las femeninas se componen además del perigonio señalado, de un pistilo único formado de un ovario ínfero trilocular, con uno, dos ó mas huevecillos, ascendentes ó inclinados en cada celda, y cuyo vértice lleva tres estilos distintos ó un estilo trífido con los correspondientes estigmas. El fruto consiste en una cápsula samariforme ó provista de una ala membranosa que suele faltar bastantes reces con tres celdas conteniendo algunas se, millas membranosas, ó unilocular monosperma por causa de aborto; otras veces es una baya trilocular con dos ó tres semillas globosas que contienen, como las otras, en el interior de un endospermo casi córneo un embrion colocalo hácia el hilo. Dioscorea alata, L. D. tuberculifera. D. satica, C. T. V., 189-190-191.

\section{GRUFO 2. - HERMAFRÓDITOS.}

\section{Familia 20. - IRIDÁCEAS ó IRÍDEAS. - Plantas herbá-} ceas vivaces, ordinariamente provistas de un rizoma ó bulbosas, con raices capilares ó fibrosas; hojas sencillas, mas ó menos estrechas, largas y bastantes veces ensiformes, enrainadoras por la base, sesiles, radicales ó algunas veces alternas sobre el bohordo, simulando un tallo lejítimo. Flores hermafroditas solitarias en el vértice de un bohordo mas ó menos largo ó en grupos axilares en la parte superior de una especie de tallo algo nudoso, mas ó menos ramoso, cilíndrico ó comprimido, en donde están como apanojadas o en especies de cimas paucilloras; con mucha frecuencia envueltas antes de 
la floracion en una espata membranosa, delgada y como apergaminada ó escamosa; tales flores se componen de un periantio tubuloso con seis divisiones profundas, mas ó menos desiguales, irregulares y siempre petaloídeas, en dos séries y cuyas tres esternas corresponden con los tres estambres insertos en la garganta del perigonio, y cuyos filamentos, á veces soldados con el tubo periconeal, llevan una antera bastante grande, bilocular estrorsa ó que se abre hácia afuera; pistilo formado de un ovario ínfero, único, trilocular polispermo, cuyo vértice lleva un estilo terminado por tres estigmas opuestos á las anteras, petaloideos ó laciniados y huecos. El fruto es una cápsula con tres celdas polispermas y cuya dehiscencia es loculícida; las semillas están formadas de un tegumento propio y de un embrion cilíndrico y homótropo contenido en un endospermo carnoso ó córneo. Cypura ILartinicensis. Sisyrinchium Palmifolium. C. T. V., $425-316$.

\section{Familia 21. -}

Plantas herbáceas viváceas, ordinariamente bulbosas: el bulbo sin embargo suele faltar algunas veces. El tallo está casi siempre reemplazado por un bohordo que alguna vez que otra es muy crande y simula un tallo lejítimo; hojas ordinariamente radicales simples, lanceoladas, mas ó menos largas, dispuestas á manera de roseta, estendidas en el suelo ó derechas, de consistencia blanda ó bastante duras y fibrosas, las mas veces envainadoras por la base, alternas. Flores hermafroditas dispuestas en cimas terminales ó en cimas ó en grupos laterales á lo largo del bohordo, ordinariamente envueltas en una espata membranosa antes de la floracion; se componen de un periantio tubuloso, monosepalo, con seis divisiones mas ó menos profundas, iquales, equitantes, derechas ó dobladas hácia afuera, algunas veces las tres esteriores son algo mas cortas que las tres interiores, á veces provisto de seis escamitas situadas en la garganta; seis estambres insertos en el tubo perigoneal ó en el fondo del perigonio cuando no es tubuloso, de filamentos libres ó reunidos entre sí por una membrana petaloidea que sale de la garçanta, con anteras grandes, biloculares é introrsas; pistilo formado de un ovario único infero con tres celdas que contienen muchos huevecillos y cuyo vértice lleva un estilo simple mas 0 menos largo terminado por un estigma sencillo ó trífido. El fruto es una cápsula polisperma, trilccular, abriéndose por tres ventallas septíferas, y por consiguiente de dehiscencia loculícida; algunas veces es una baya, unilocular por causa de aborto, con tres semillas que presentan, como las de la cápsula frecuentemente una carúncula celulosa y contienen en un endospermo carnoso un embrion cilíndrico y homótropo, con la raicilla cerca del hilo no estrofiolado.

\section{Ancilisis dicotimica de las tribus.}

1. Vejetales siempre bulbosos, 2. - Vejetales nunca bulbosos, 3.

2. Sin corona alguna ó de estambres libres. T. I. Amarileas. Amarillis punicea, L. A. equestris, L. Crinum anericanum. C. 
T. V., 287-678-677. - Estambres acompañados de apéndices alternando con ellos ó reunidos por una corona petaloídea. T. II. NARcíseas. Pancratium Caribaum, L. -C. T. V., 288-6\%6.

3. Raices fibrosas á veces con tubérculos feculentos; vertícilo esterior diferente del anterior. T. III. Alstronmérieas. Alstroemeria edulis, Tuss.-Raices fibrosas, nunca tuberculosas; hojas muy grandes, muy tiesas, muy espesas, fibrosas, con figura de espada, terminadas por una pua muy punzante; los dos vertícilos de la flor conformes; bohordo muy grande. T. IV. Agáreas. Agave americana. A. vivipara. A. fetida. A. Cubensis, L. - C. T. Y., 388.

Familia 22. - IIIPOXIDEAS. - Plantas herbáceas, vivaces, con una especie de rizoma con raices fibrosas; hojas todas radicales, sesiles, larguitas y estrechas, envainadoras por la base; flores siempre hermafroditas dispuestas en especie de umbela en la sumidad de un bohordito y contenidas en una espata bivalva antes de la floracion; se componen de un periantio monófilo con seis divisiones equitantes, profundas, aguzadas y casi iguales, un poco tubuloso $\mathrm{y}$ que lleva los seis estambres insertos en su garganta, de anteras introrsas; pistilo formado de un ovario ínfero, turbinado, cuyo ápice lleva un estilo simple terminado por un estigma sencillo. Fruto seco, coronado é indehiscente, algunas veces abayado, trilocular polispermo; semilla cuya testa es crustácea y lustrosa, con el embrion intrario ó interior, cuya raicilla está remota del hilo estrofiolado. Hypoxis scor: zonerefolia, L. - C.T. V., 315.

\section{Ó RDEN $\not$ I T.}

Vejetales de periantio doble cuyo interior es siempre petaloídeo, y á veces ambos simulan una corola; endospermo farináceo.

$$
\text { S UB-ÓRDEX } 1^{\circ} \text {. }
$$

Periantio interior solo petaloídeo y simulando una corola.

\section{CLASE X. - BROMELÍNEAS.}

Familia 23. - BROMELIÁCEAS. - Plantas herbáceas vivaces, terrestres ó falsas parásitas con hojas sencillas alternas, largas, derechas, tiesas, coriáceas, estrechas, puntiagudas y punzantes, con las nervaduras lonjitudinales, cuyos bordes están con mucha frecuencia provistos de aguijones muy fuertes, dispuestas ordinariamente en forma de roseta; frecuentemente estos rejetales están enteramente cubiertos de bozo blanco; del centro de las hojas mas interiores, que frecuentemente se han vuelto de un primoroso color encarnado, sale un bohordo mas ó menos largo terminado por una piña, una espiga $\delta$ una panoja de flores siempre hermafroditas, que se componen de un periantio monosépalo mas ó menos tubuloso, con seis divisiones mas ó menos profundas, cuyas tres esteriores. 
nunca petaloideas y mas estrechas, simulan un cáliz lejítimo, mientras las tres interiores, mas grandes, petaloideas y adornadas con primorosos colores, parecen una corola; hay seis estambres insertos en la garganta perigoneal, cuyos filamentos, nunca petaloideos y libres, llevan anteras biloculares é introrsas; pistilo formado de un ovario ínfero trilocular polispermo, de cuyo vértice sale un estilo simple terminado por tres estigmas planos ó subulados. Fruto trilocular abayado ó capsular polispermo; bayas sueltas ó muchas soldadas entre sí y formando una piña, las semillas lustrosas, negras, mas ó menos comprimidas, se componen de un endospermo farinoso en cuya parte inferior se aloja esteriormente un embrion prolongado y retorcido. Bromelia ananas, L. Malla anthelmintica, R. de G. Y. M. karatas, etc. C. T. V., 573-824.

SUB-ÓRDEN 2 .

Ambos periantios petaloídeos, cuyo esterior algunas veces es glumáceo.

\section{CLASE XI. - ESCITAMÍNEAS.}

Familia 24. - MUSÁCEAS. - Vejetales herbáceos vivaces que á veces bastante grandes parecen arbolitos, pero cuyo tronco bastante grueso, está formado por la reunion de las vainas de las hojas, y de poca consistencia; otras veces es un bohordo que simula un tallo, y que salen ordinariamente uno $y$ otro de un rizoma mas ó menos desarrollado; hojas regulares ó grandísimas cuyas nervaduras son transversales, limbo enrollado en la prefoliacion, simples, enteras, largamente pecioladas, con la base del peciolo envainadora; son alternas; flores dispuestas en racimos, en espigas ó en panojas, enderezadas ó inclinadas y hasta colgantes, están envueltas antes de la florescencia en una ó en dos espatas, una de ellas general y la otra parcial, caducas; tales flores se componen de un periantio monófilo irregular con cinco ó con seis divisiones desiguales, todas petaloideas, dispuestas en dos séries, á veces como bilabiado, de tal suerte que, en esa circunstancia, la série esterna tiene cinco divisiones, mientras que la interna é inferior á la rez presenta solamente una. Estambres cinco á seis de filamentos mas ó menos cortos, libres, con anteras bastante grandes, biloculares é introrsas y ornadas por el vértice de una especie de cresta petaloidea; pistilo formado de un ovario ínfero, cuya forma y tamaño varian bastante, trilocular, polispermo y raras veces monospermo, de cuyo vértice sale un estilo simple terminado por un estigma simple y cóncaro ơ formado de tres lóbulos ó de tres lacinias. El fruto es una baya á veces bastante grande y gruesa, mas ó menos carnosa y larga, con tres celdas polispermas; otras reces consiste en una cápsula trilocular tambien y polisperma, que se abre por tres rentailas septíferas y cura dehiscencia es por consiguiente 
loculícida. Las semillas están á veces pegadas por medio de un podospermo y rodeadas de pelo horizontal, y se componen de un tegumento propio crustáceo y de un endospermo que contiene un embrion prolongado y derecho.

Semillas solitarias en las celdas de la cápsula cuya dehiscencia es septicida. T. I. Helicoxín.s. Heliconia bijai, L. H. psittaconnm, L., etc. C. T. V., 347. - Muchas semillas en cada celdilla del fruto, que es tan pronto carnudo y abayado como capsular, y en ese último caso de dehiscencia loculicida. T. II. URAxíEas. Musa paradisiaca, L. M. sapientum, L : C. T. V., 193-194-195-196.

F'amilia 25. - ZINJIBERACEAS. - Plantas herbáceas, vivaces, provistas ordinariamente de un rizoma mas ó menos desarrollado y ramoso; de donde sale un bohordo lejítimo ó talliforme, sencillo, desnudo ó mas ó menos provisto de hojas ó de escamas; hojas ordinariamente radicales, simples, enteras, cuyas nervaduras son transversales y el limbo de prefoliacion enrollada, con peciolo mas ó menos largo, separado frecuentemente del limbo por una ligula y de base envainadora. Flores siempre hermafroditas, dispuestas en especies de mazorcas ó espigas terminales, densas, mas ó menos gruesas, escamosas, ovales ó con figura casi de cono; tales flores, solitarias, mellizas ó en número de tres, salen de la axila de una escama grande ó bráctea, libre ó soldada con las vecinas y formando así una especie de involucro, envueltas además cuando muy tiernas, y por consiguiente antes de la floracion por una espata membranosa muy delgada y blanca, y se componen de un periantio doble, cuyo esterior tiene tres divisiones persistentes que parecen un cáliz lejítimo, mientras el interior, formado de 4 ó de $\breve{5}$ divisiones desiguales reunidas en tubo por la base y petaloideas, simula una corola monopétala; un solo estambre fértil de filamento ordinariamente petaloideo que lleva una antera bilocular, cuyas celdas están con frecuencia situadas en sus bordes; filamentos estériles petaloídeos ó abortados; pistilo cuyo ovario ínfero, trilocular. y polispermo, lleva en su vértice un estilo petaloideo con un estigma cóncavo ó con figura de copa. El fruto es una cápsula trilocular que se abre por tres ventallas septiferas cuya placenta es axil ; muchas de sus semillas tienen un perispermo doble y el embrion esterior, y algunas de ellas están provistas de un arilo, mientras falta en las otras. Zingiber officinalis, L. Z. Zevumbert, Borb. Curcuma longa, L. Kcenpferia rotunda.C. T. V., 182-23-22\%-726.

F́milia 26. - CANNACEAS ó MARANTACEAS. - Plantas herbáceas vivaces no aromáticas, con rizoma ó tubérculos; de hojas simples, mas ó menos pecioladas, enteras, enrolladas á manera de cartucho en la prefoliacion, cuya base del pecíolo, mas ó menos largo, es envainadora y con una ligula que separa su vértice de la base del limbo, que suele faltar con bastante frecuencia, radicales ó alternas en un tallo que es una especie de caña mas ó menos ramosa y algo nudosa. Flores siempre hermafroditas dispuestas en espizas mas ó menos flojas ó en panojas formadas las unas y las otras de grupos paucifloros, envueltos antes de la floracion en una bractea espatiforme que suele faltar bastantes veces; tales flores constan 
de un periantio doble cuyo esterno de tres dirisiones glumáceas, delgadas, vercies, membranosas ó coriáceas, reemplaza el cáliz lejítimo, mientras el interior, petaloídeo, de 4 á 6 divisiones desiguales, mas ó menos tubuloso, representa la corola; un estambre único cuyo filamento, mas ó menos petaloídeo, tiene una antera unilocular situada por su borde; pistilo formado de un ovario ínfero trilocular polispermo de cuyo vértice sale un estilo petaloideo á veces unido con el filamento y de estigma lateral. Eì fruto es una cápsula trilocular ó bilocular por causa de aljorto, y entónces con una sola semilla; las semillas no tienen nunca arilo y se componen de un endospermo farinoso simple $\mathrm{y}$ de un embrion cilíndrico, homotropo $\mathrm{y}$ alojado en él; placentacion axil.

\section{Análisis dicotómica de las varias tribus.}

1. Tejetales rizocarpios ó provistos de un rizoma cuya inflorescencia terminal es flojamente apanojada, racimosa ó espigada. T. I. Globeas. Globba wiformis, L. - Vejetales nunca jamas rizocarpios, 2.

2. Pero con raices tuberosas, amanojarlas ó frecuentemente rastreras, leñosas y cuya inflorescencia, por lo comun radical, espigada ó terminal, está densamente provista de brácteas. T. II. Aromess. Maranta arundinacea. C. T. T., 198. - Vejetales de raices nunca jamas tuberosas pero siempre fibrosas, 3 .

3. Inflorescencia terminal ocupando el vértice del tallo ó del bohordo y con frecuencia flojamente apanojada ó racimosa. T. III. Alpivieas. Alpinia spicata, L. - C. T. V., 225. - Vaina de las hojas tubulosa; inflorescencia terminal-densamente espigada. T. IV. Costeas. Costus spicains, Sw. C. T. T., 225-317.

\section{- CLASE XII. - ORQUIOÍDEAS.}

Famitia 2\%.-ORQUÍDEAS ú ORQUIDEÁCEAS. - Vejetales herbáceos, raras veces fructicosos, pero siempre vivaces, terrestres ó epifitos y entónces seudo-parásitas; de raices fibrosas, faciculadas ó arnanojadas, con ó sin tubérculos cuando son terrestres, siempre fibrosas, mucho mas gruesas, mas fuertes y larguísimas cuando epifitos, y formando una especie de redecilla que tiene envueltas las ramas de los árboles sobre los cuales viven. Los tubérculos en las clases que les tienen son en número de dos ovoideos ó casi globosos y otras veces mas ó menos comprimidos y palmeados, el uno, que es del año anterior, se gasta para suministrar á la vejetacion principiante del vejetal $y$ sin duda tambien á la formacion del otro que ha de tener igual papel el año venidero y reemplazar al otro que ya no sirve $\mathrm{y}$ se ha arrugado; y las raices lejítimas salen un poco mas arriba que ellos. En esa familia el tallo es muy variado y con mucha frecuencia está reemplazado por un bohordo: en las especies terrestres hay un rizoma muy corto de donde sale todos 
los años un tallo herbáceo, con un número variable de hojas modi ficadas y alternas, especie de bohordo cuyas hojas están algunas veces reemplazadas por brácteas, terminándose siempre por una espiga $\dot{0}$ un racimo de flores; las especies trepadoras tienen un tallo verde carnoso, ordinariamente cilíndrico y larguísimo, generalmente simple y pocas reces ramoso, provisto de hojas alternas bastante dobles y hasta carnosas ; echa bastantes veces raices abventivas larguísimas y muy fuertes. Muchas epifitas están provistas de un tallo lejítimo ordinariamente poco largo, como de media vara $y$ raras veces mas, con hojas alternas y dísticas; en fin la mayor parte de las seudo-parásitas tienen en lugar de tallo un seudo-bulbo, especie de rizoma aéreo y superficial, mas ó menos grueso, mas ó menos largo, algunas veces lo hemos hallado hasta como de una vara, pero ordinariamente no pasa de 2" hasta 8" á 10", segun las clases, generalmente ovoideo, fusiforme, comprimido y acorazonado o no, de seccion transversal cilíndrica, ovoidea, oval, elíptica ó angulosa, pero siempre la misma en los mismos géneros, terminado por hojas en número variando de 1 hasta 10 , pero constante para cada especie. Hojas siempre simples, blandas ó coriáceas, á veces hastante dobles y hasta carnudas, otras veces graminoideas, alternas o dísticas en el vértice del seudo-bulbo, aunque sus vainas persistentes, que se han vuelto una membrana blanca muy delgada, salgan alteinas de las especies de zonas que existen en la superficie de los seudo abulbos; las especies terrestres las tienen con frecuencia radicales; tales hojas tienen siempre todas las nervaduras lonjitudinales y no ramificadás, su tamaño varia mucho, pero no es así de su figura; en efecto, en general son mas ó menos ovales, oval-lanceoladas ó lanceoladas, otras veces casi redondas ó elípticas ; en algunas especies, particularmente en las trepadoras, el limbo está como articulado en el vírtice de la vaina de la cual se desprende; hemos observado en algunas seudo-bulbosas hojas articuladas de un modo muy particular; en efecto, las tres nervaduras principales se separan hácia el vértice de la vaina, de suerte que la parte de ellas que queda presenta tres espinas, siendo la mediana mayor que las otras dos, que son laterales, de manera que la parte superior de la vaina que correspondia al limbo separado presenta una superficie oblicuamente cortada que corresponde con otra que se halla tambien en la base del limbo, pero en la cara opuesta formando cada una la mitad del espesor de la hoja en ese lugar y tambien con tres espinas, este último está un poco mas hondo, las costillas se han separado pues oblicuamente, segun su diámetro transversal y algo lonjitudinal á la vez y constituyen así las espinas ; es una articulacion escamosa. En tal circunstancia, desprendidas las hojas, el vértice del seudo-bulbo está armado de puas fuertes y muy punzantes.

Las flores de las orquideas son muy interesantes tanto por su hermosura, que proviene de sus caprichosas y maravillosas formas, como por los hermosos colores que las adornan y por su tamaño; son solitarias en el vértice de un pedúnculo que sale del rizoma ó del seudo-bulbo, otras veces de la axila de una de las escamas mas ó 
menos grandes, mas ó menos foliáceas que acompañan á la base de ese órgano, pero las mas veces están en espigas, racimos ó primorosas panojas aguirnaldadas, mas ó menos furnidas: á veces largas de mas de una vara, cuyos grupos o racimitos que las forman están dispuestos en espiral ó algunas otras veces dísticos, así es tambien la disposicion de las flores sobre los ejes que las sostienen y salen siempre de la axila de una bráctea mas ó menos grande, mas ó menos membranosa y á reces espatiforme; son sesiles ó cortamente pedunculadas; ordinariamente ántes de abrirse la flor, su ovario, que se hallaba recto, se tuerce segun el eje lonjitudinal ficticio que pasa por su centro de tal manera que la posicion relativa de las varias partes de la flor abierta con el eje que la sostiene se halla enteramente intervertida, volviéndose inferiores las partes que al principio eran superiores y vice-versa; se componen de un periantio adherente con el ovario sentado que, situado por su vértice, se parte en seis divisiones, siendo las tres inferiores semejantes ó conformes entre sí; generalmente las tres primeras y dos de las segundas se enderezan por encima del eje de la inflorescencia, la sesta, al contrario, se vuelve hácia abajo y de esa manera el periantio se hace como bilabiado, cuyo labio superior está formado por cinco divisiones afectando bastantes veces la forma de un yelmo, á veces por tres solamente, dos quedándose estendidas, laterales y simulando así como unas alas, mientras la inferior, llamada labelo, que al principio se hallaba en la parte superior, constituye el otro labio: esa última principalmente por sus formas caprichosas, su tamaño á veces muy grande y sus primorosos colores da á esas flores el aspecto tan pronto de una mariposa ó de un insecto, como de otro objeto natural; la base del labelo entero, las mas veces trilobado, derecho ó doblado hácia abajo, convexo ó cóncavo y de circunferencia ondulosa, etc., es bastantes veces callosa ó abrazadora, otras veces tiene un hueco que alguna vez que otra se va prolongando en espolon mas ó menos largo; las divisiones esteriores se sueldan á veces entre sí, otras veces la mas superior se suelda sola con las dos laterales de la serie interna, en fin esa soldadura se hace alguna vez que otra con la columna ó ginostemo, que resulta de la reunion de los órganos reproductores de ambos sexos sale del vértice del ovario y se eleva en el centro de la flor, corta y trunca oblicuamente, de manera que la superficie plana ó lijeramente cóncava que la termina mire hácia afuera; tal superficie, cubierta de una sustancia viscosa, no es sino el estigma. Los estambrés son tres, opuestos á las divisiones perigonales esteriores, pero rarísimas veces se les halla, y dos solamente son perfectos, el tercero mas superior estando estéril, y casi siempre hay uno solo que es el superior, mientras los otros dos abortos están representados en el fondo de la flor ó hácia la base del ginostemo por dos tuberculitos y corresponden á las divisiones laterales de la serie perigonial interna. La antera se inserta sobre el estigma mismo, sea un poco mas abajo quedándose paralela con él, sea un poco mas arriba, y toda su lonjitud pasa mas allí que él, y en esa circunstancia se la dice terminal, otras veces está enderezada ó recostada sobre la superficie estigmática; tiene una ó dos celdillas, 
otras veces cuatro y hasta ocho, sentada ó estipitada á causa de un piquito que se halla en el vértice de la columna, conteniendo un polen cuyos granitos están mas ó menos agrupados y aglomerados ligados flojamente entre sí por otra sustancia, y siempre separables los unos de los otros: cuando esos granitos están agrupados por cuatro, formando así grupitos muy numerosos que forman dos ó á veces cuatro masas polínicas bastante grandes, fácilmente separables, se llama pulverulento; tales grupitos de granitos con forma de cuña están unidos á un eje elástico, llamado retinaclo, por un hililo tambien elástico que es la caudícula ó colita, de manera que apartando los unos de los otros con suavidad forman como una especie de racimo; por último los granitos polínicos están aglutinados á manera de un tejido sólido, compacto, con aspecto y consistencia de cera y pareciendo como una masa de tejido celular muy fino: es el polen llamado ceráceo. En esos varios casos está contenido en las dos, cuatro ú ocho celdillas membranosas de la antera y formando tantas masas polínicas, llamadas polinias, como celdillas hay; las polinias son libres ú ordinariamente pegadas á una glandulita estigmática, sea inmediatamente, sea, por lo regular, á faror de la caudícula. La parte de la columna que mira hácia el labelo está formada por el estilo, soldado y confundido con el filamento estaminal, y la superficie pegadiza que ocupa su estremo y que bastantes veces representa una boquita que comunica con el canal que se halla al interior de la columna que recorre lonjitudinalmente y abre en el ovario, constituye el estigma trílobo, cuyos lobulos mas ó menos confluyentes, y por consiguiente muy poco visibles, son en alcunos muy distintos, y á veces dos de ellos parecen provistos de un estilo muy largo; tal boca se halla á la sazon de la fecundacion llena de un líquido viscoso bastante abundante que coje los granitos ó masas polínicas al desprenderse de la antera que á veces se separa de él, pero que con mayor frecuencia se queda en su lugar hasta despues de verificada la fecundacion; ovario ínfero siempre torcido, mas ó menos largo y ordinariamente claviforme ó con figura de maza, mas ó menos anguloso ó á reces triangular, unilocular, cuyas tres placentas parietales, bíndas, prolongadas y lonjitudinales están opuestas á las divisiones internas del periantio y cargan con un sin número de huevecillos. El fruto es una cápsula mas ó menos gruesa, mas ó menos larga y cuya figura es ordinariamente fusiforme y ovoidea á la vez, marcada de tres ángulos mas ó menos pronunciados, unilocular y conteniendo muchísimas semillitas muy finitas pegadas á lo largo de las placentas persistentes correspondiendo á los tres ángulos señalados saliendo del pedúnculo y terminándose á la base del periantio, mientras las ventallas intermedias se desprenden y caen, su casco ó testa, flojo y reticulado, contiene un embrion carnudo, sólido y sin endospermo: raras veces como leñoso é indehiscente; bastantes veces de pericarpio harto espeso y como carnuclo, pero que acaba por volverse seco. Tal cápsula se abre por tres ventallas que se separan, los ángulos que llevan las placentas quedándose reunidas y conservando así, durante bastante tiempo, la forma del fruto ; a reces el podospermo de las semillas está bastante 
desarrollado $\mathrm{y}$ carnoso, lo que ha enganado á algunos observadores, de manera que han dicho y hasta escrito que alģunas veces la cápsula de las orquideas contenia pulpa.

\section{Análisis dicotómica de las tribus y tambien de las sub-tribus.}

1. Dos estambres fértiles laterales mientras el superior abortado está reemplazado por un apéndice nectariforme; polen granuloso volviéndose por fin una sustancia como pultácea; estilo semi-libre; estigma partido en tres areolas opuestas á los estambres: plantas herbáceas terrestres. T. I. CIPripedíEas. Cypripedium, L.-Un solo estambre fértil, 2.

2. Polinias ó masas polínicas ceráceas ó que parecen como cera, en número definido ó indefinido, 3. - Pólen pulverulento ó aglomerado en lobulitos elásticamente coherentes, 29.

3. Polinias en número definido siempre, 4. - Polinias nunca en número definido pero muchísimas, 21.

4. Sin tejido celular superfluo é intermedio alguno; antera terminal opercular. Plantas epifitas ó terrestres herbáceas, estando con mucha frecuencia espesada la base de las hojas ó de los tallos. T. II. Malaxídeas, 5. - Reunidas por un tejido celular intermedio que á reces falta, pero entónces lo son por las colitas, 10.

5. Columna derecha, muy poco prolongada por la base, 6. - Columna recostada sobre el ovario, y mas prolongada por la base, 9 .

6. Polinias doz. S.-T. I. Pieurotalideas. Plenrothallis triangularis, R. Br. Pl. sagittifer a, H. B. K. - Mias de dos polinias, 7.

7. Polinias cuatro, 8. - Polinias orho. S.-T. II. Nefelatíleds. Niphelaphylum.

8. Sea colaterales sea sobrepucstas ó dispuestas de tal cual manera. S.-T. III. LrparídeAs. Liparis, Rich., Malaxis, Ștz.

9. Polinias cuatro, por pares colaterales ó no: antera bilocular; labelo articulado con el pié de la columna ó conado, sentado ó ungüiculado, entero ó lobado. S.-T. IV. Dexdrobieas. Dendrotiun, Sw. - No por pares dispuestas, globosas, libres ó un poco adherentes con el piquito ó glándula del estigma; antera bilabiada, bilocular, abriéndose por tres ventallas. S.-T. V. Corallorizideas. Corallov'hiza, Hall.

10. Aglutinadas al abrirse las flores con una colita y á la vez pegadas con la glándula estigmática, 11. - No aglutinadas al abrirse las flores, pero reunidas por una membrana celulosa colerente por medio de colitas pulverulentas y las mas veces redobladas, 25.

11. Antera terminal, raras veces dorsal, opercular. Plantas herbáceas epifitas ó terrestres, las primeras con un seudo-bulbo provisto de pocas hojas, las otras caulecentes. T. III. VArdeas, 12.

- 12. Polinias dos, enteras, asurcadas ó profundamente bilobas, á veces son cuatro, 13.

13. Flores provistas de espolon, cuernecillos ó de un saquito, situados por la base del labelo que alargan mas ó menos, 14.-Flores sin espolon ni saquito en la base del labelo, 15. 
14. Polinias dos siempre mas ó menos partidas; labelo con espolon; antera bilocular. S.-T. I. SarCantídeas. Angrœcum, Thus.Labelo libre sentado ó sub-sentado ó algo conado con la columna, con un saquito ó un espoloncito; antera unilocular. Polinias dos posteriormente asurcadas ó escarbadas. S.-T. II. Inopsídeas. Inopsis, H. R. Rodriguera.

15. Labelo libre sentado ó algo sentadito, 16. - Labelo libre, pero articulado, con la base prolongada de la columna, otras veces largamente ungüiculado, 20.

16. Columna sin alas, ni orejitas ó petaloidea, 17. - Columna con alas orejitas ó cuyo vértice está provisto de cerdas, 19.

17. Siempre desnuda y aptera, sin ser nunca petaloidea, 18. Siempre petaloidea. S.-T. III. Pachifileas. Pachyphyllum.

18. Columna aguzada, hendidura del estigma vertical; antera dorsal unilocular; polinias dos enteras; glándula diminuta; labelo calloso por en medio, conado con las dos divisiones perigoniales laterales. S.-T. IV. Notilideas. Notylia, Lndl.

19. Columna alada ú orejada con la cual está continuo el labelo tuberculoso ó crestado por la base ; antera unilocular ó semi-bilocular, con ó sin piquito ó rostela; polinias dos posteriormente asurcadas; colitas mas ó menos cortas; glándula espesa ú oblonga. S.-T. V.Brasideas. Oncidium, Swtz.-Columna con dos cerdas por el vértice, derecha y libre; antera sub-hilocular anteriormente tronca; polinias dos, posteriormente bilobadas ó asurcadas ; colita máxima, glándula cartilajinosa sub-cuadrada. S. T. VI. CAtasetídeas. Catasetum maculatum, H. B. K. Cyrtopodium glutiniferum, Br. C. Adansonii. C. puntatum, Wild. C. T. V., 421.

20. Polinias ordinariamente dos, pero algunas veces cuatro colaterales ó incumbentes la una sobre la otra y como apareadas; periantio connivente ó abierto : columna aptera. S.-T. VII. MaxilaRIDEAs. Maxilaria.

21. Sin glándula diáfana ninguna; antera terminal opercular, yerbas epifitas ordinariamente y con seudo-bulbo, algunas veces terrestres y provistas de un tallo lejítimo, rara vez con raices lobadas ó carnosas. T. IV. Epidendreas, 22.

22. Polinias cuatro, 23. - Polinias ocho, 24.

23. Labelo mas ó menos trabado, con las márjenes de la columna ó libre de ellas, con ó sin espolon; antera bi ó cuadrilocular o solamente cuadri locular. S.-T. I. LeLIAdEas. Epidendrum, Cattleya moyses, Lndl. - Labelo siempre libre sin espolon ninguno, ungüiculado, articulado con la columna, adornado con dos cuernecillos, antera siempre cuadri-locular, S.-T. II. Isochilddeas. Isochylus, R. $\mathrm{Br}$.

24. Labelo con ó sin espolon, que está reemplazado por un saquito o por nada, sentado ó ungüiculado; antera dos, cuatro, seis, ocho locular. S.-T. III. Bletideas. Bletia verecunda, R. P.: C. T. V., 133.

25. Polinias reunidas por un eje aracnoideo elástico que las tiene atadas con la glándula estigmática ; antera terminal erguida ó volteada, persistente del todo y de celdillas completas. Plantas herbáceas siempre terrestres, con hojas suculentas planas, cuyas radicales 
son siempre mayores que las demas, volviéndose gradualmente envainadoras y caulinares y por fin transformándose en brácteas Flores ordinariamente con figura de yelmo. T. T. Ofrídeas, 26. Polinias aglomeraditas en lobulitos por medio de una materia elástica, 34.

26. Celdillas de la antera contiguas y paralelas, cuya base no es nunca alargada ni divaricada tampoco, 27. - Celdillas de la antera separaditas y diverjentes por la base, con frecuencia prolongada, 28.

2\%. Glándulas encerradas en el cartucho simple ó doble de la estigma con ó sin espolon, las cinco divisiones superiores del periantio ordinariamente formando yelmo. S.-T. I. Serapiadeas, Orchis. Lin. Serapias, L. - Glándulas enteramente desnudas ó semi c cesnudas, divisiones superiores del periantio dispuestas á manera de yelmo, base de las anteras trunca ó dilatada en un cartucho falso. S.-T. II. Giunadenideas. Gymnadenia, R. Br.

28. Glándulas encerradas en los cartuchos del estigma, los cuales están desnudos, mas ó menos diminutos, con una ó con dos ventallas ó cubiertas por el lóbulo valvar de la antera; labelo con espolon infundibular ó avejigado. S.-T. III. Holotrichide as. Holotrix, Rich.Glándulas enteramente desnudas, labelo libre ó mas ó menos adnado con las márjenes de la columna ó con ella misma, otras veces connivente con los pétalos, con ó sin espolon, sentado ó ungüiculado; antera erguida, volteada ú horizontal, sentada ó estipitada: S.-T. IV. Satiriadeas. Satyrium, Sivtz.

29. Antera terminal opercular persistente ó decidua. Plantas herbáceas las mas veces terrestres, algunas epifitas, de aspecto y de semblante muy variado; unas son afilas y parásitas sobre las raices de ciertas clases de vejetales, rojizas y parecen orobanches; de hojas membranosas y graminoideas, á veces reticuladas, otras veces plicadas, alguna que otra vez carnosas, rarísimamente duras, desprovistas de vaina y articuladas con el tallo; flores casi siempre membranosas, grandes y primorosas, raras veces pequeñitas y herbáceas. T. Vi. Aretuseas, 30.

30. Pólen sectil, con lobulitos elásticamente coherentes ; estigma situado hácia la base de la columna. S.T-. I. GAstrodieas. Gastrodia. - Pólen granuloso ó pulverulento; estigma situado hácia el vértice de la columna. S.-T. II. Euaretuseas, 31.

31. Dos polinias solamente, 32. - Polinias cuatro ú ocho, 33.

32. No asurcadas por la base y enteras; periantio con figura de yelma ó no, labelo espolonado y de limbo articulado. S.-T. III. LimoDorideas. Epipactis, feuill. Ĺtimodorum, Tuss. - Asurcadas por la base ; labelo sin callos, pero con laminitas, crestitas ó vello, mas ó menos sentado; antera estipitada bilocular. S.-T. IV. Pogonideas. Pogonia, Juss.

33. Polinias cuatro comprimidas; de base plicada por atras; antera terminal persistente, de celdillas aproximadas, semi-cuadrilocular; yerbas terrestres. S.-T. V. Epistefieas. Epistephyum.-Polinias ocho ó cuatro bipartidas; labelo con dos callos por la base; 
antera terminal recostada, bilocular.S.-T. VI. Acrantídeas. Acianthus. R. Br.

34. Estigma las mas reces prolongado en piquito ó rostela fiscile; antera dorsal persistente $y$ casi paralela con el estigma ó con la cara de la columna; yerbas todas terrestres con raices amanojadas, algunas raras veces y casualmente epifitas; unas especies afilas son parásitas sobre las raices de otros vejetales y rojizas; de hojas membranosas, ensiformes ó pecicladas, mas á menudo envainadoras, raras veces duras, plicadas ó arundináceas ; flores espigadas, raramente apanojarlas, y con frecuencia provistas de vello glanduloso, la mayor parte pequeñas y semi-herbáceas. T. VII. Neottínas, 35.

35. Columna petaloídea ó adornada con apéndices petaloídeos; labelo diforme bicarinado por la base: antera mútica de celdillas aproximadas; polinias dos, bilobas. S.-T. I. Diurídeas. Diuris, Smith. - Columna nunca petaloídea y siempre aptera, algunas raras veces con apéndices por la base, 36 .

36. Derecha carnosa y cilíndrica, entera ó bifida, - 37. Prolongada en especie de pié, no derecha, carnosa y cilíndrica; labelo diforme anterior, paralelo con la columna, acanalado á veces con un espolon escondido por debajo de las bases de los sepalos. S. T. II. EspiRAXthideas. Spiranthes, Rich. Stenorhynchus.

37. Siempre bifida, mas ó menos carnosa, cilíndrica; labelo conforme por la direccion $y$ forma de las demas divisiones perigoniales petaloídeas. S.-T'. III. Telinírrudeas. Thelymitva, Forst. De ápice entero ó indiviso, labelo siempre diforme, 38.

38. Labelo siempre sin espolon posterior ó anterior, 39.-Labelo anterior con espolon ó sin él, $y$ entonces las mas veces ventricoso, otras veces cóncavo ó plano por la base; espolon un poco mas largo que los pétalos; flores boquiabiertas; polinias ocho, dos ó cuatro. S.-T. IV. Tisuríneas. Plexaure, Endl.

39. Labelo posterior cóncavo recostado sobre la columna enana o alargadita que tiene escondida; sepalos ó divisiones esteriores perigoniales abiertas ó revolutas; rostela trunca; rarísima vez se halla la columna bipartida. S.-T. V. Cravichideas. Cranichis, Swtz.- - Labelo anterior y estendido; sepalos ó divisiones esteriores perigoniales estendidas ó reflejas, alguna rara vez volviéndose como barba. S.-T. VI. Listerideas. Listeria, R. Br.

Familia 28. - VANILLACEAS. - Plantas viváceas sarmentosas que trepan por encima de los árboles y demas vejetales; y á primera vista parecen parásitas, pero no lo son puesto que tienen sus raices en el suelo, y sus tallos larguísimos y ramosísimos casi herbáceos y carnosos, contienen una savia como mucilajinosa á veces muy acre y conteniendo muchas agujitas muy finas ó prismas blancos y sedosos; sepáradas accidentalmente de la raiz echan raices adventivas muy largas, cilíndricas, bastante fuertes, de un color blanco sucio algo amarillento, que se van alargando hasta haber alcanzado el suelo, donde penetran y echan raices; mas ó menos cilíndricos ó elípticos, con cuatro ó cinco surcos verticales opuestos ; provistos de especies de zarcillos opuestos á las hojas, ó sin ellos cuando no son trepadores; con hojas sencillas, sentadas, bastante 
dobles, ovales y alternas, sin vaina, articuladas con el tallo, mas veces reticuladas, lampiñas, duras y plicadas: flores siempre hermafroditas y ginandras, dispuestas en racimos ó en espigas axilares $\mathrm{y}$ formadas de un periantio monofilo con seis divisiones desiguales y de las cuales la inferior ó labelo es cóncava en forma de capuz y con su limbo dilatado en lámina, undoso por los bordes, conado ó no con la columna, con ó sin barba ó pelo hácia la base. Antera terminal opercular en el género vainilla, polinias dos bilobuladas y granulosas, pero ordinariamente el pólen es pulverulento, granuloso ó en masa pulposa, concreto; estigma situado hácia el vértice de la columna; todas lás divisiones perigoniales son petaloídeas y bastante grandes, subiguales conformes y libres por la base. El fruto es una cápsula siliciforme, indehiscente, mas ó menos larga, mas ó menos delgada, unilocular, con muchísimas semillas insertas en tres placentas parietales, por medio de un podospermo carnoso bastante desarrollado y formando una especie de arilo que envuelve la base de la semillita cuyo embrion cilíndrico y homótropo está alojado en un endospermo farinoso; el podospermo ha sido considerado, por equivocacion, como pulpa, y constituye la parte aromática de la vainilla del comercio.

1. Flores en espiga axilar pauciflora y color carmesí, hojas aorado-oblongas, con las nervaduras bien risibles y bastante pronunciadas, sepalos ondulosos, labelo puntiagudo, cápsula cilindrácea, delgada, muy larga, no aromática; ella no produce pues la vainilla del comercio, y su nombre proviene sin duda de una equirocacion y por haber confundido las especies. Vanilla aromática, L. - C. T.V.228.-Flores en espiga ó en racimito axilar paucifloro y nunca color carmesí, pero mas ó menos blancas ó amarillentas.

2. Cápsula con olor aromático y constituyendo la vainilla del comercio, 3. - Cápsula sin olor ó con un olor apenas pronunciado, 4.

3. Hojas oblongo-lanceoladas, planas, finamente estriadas, flores de color verde amarillento, con el labelo amarillo púlido por la cara superior y remellado; tallo muy largo, del tamaño del dedo meñique y muy ramoso, con hojas puntiagudas, cortamente pecioladas, de un color verde mar, bastante distantes y largas de 5-9" ; espigas enderezadas, bastante densas ó furnidas, sub-sesiles y multiflores, racemiformes y cuyo raquis, casi tan grueso como el tallo, es largo de como 6"; brácteas pequeñas y verdes; sépalos lustrosos, lanceolado-oblongos, sub-obtusos y cuyos estirones son largos de como 15", mientras los interiores están algo mas cortos y sin embargo un poco mas largos que el labelo, cuyo limbo desplegado es reflejo $\mathrm{y}$ pubescente inferiormente; ginostemo cóncavo y pubescente anteriormente. $V$. planifolia, Hort. Kew. Myrobroma fiagrans, Salisb. C. T. V. 228 se cria muy bien en las Antillas y suministra la rainilla del comercio. - Hojas elípticas oblongas aguzadas; flores blanquecinas, con los sépalos revueltos por el ápice; labelo puntiagudo; cápsula triedra ó trilateral; tallo muy ramoso del tamaño del dedo meñique y largo de $30-40^{\circ}$, con frecuencia colgante de los árboles y pasando de unos á otros; con hojas sesiles y mas grandes que los entrenudos, largas de 6-8" y anchas de 3", de un color 
verde oscuro; pedúnculos con $5-15$ flores saliendo de la axila y cuyos sépalos esteriores, lanceolados, sub-aguzados y un poco ondulosos, son largos de $21 / 2-3$ ", mientras los laterales son conformes ó mas estrechos y mas ondulosos; labelo mas corto que los sépalos, con el limbo aovado y algo rizado por los bordes; ginostemo lampiño, de ápice algo espesito ; antera cortamente bicorne por el ápice ; cápsula larga de 6-8" derecho ó sub-falciforme, delgada, de un color pardo moreno cuando madura; muy aromática. $V$. Guianensis, Splitgerber. Se halla en el comercio. C. T. T., 228.

4. Flores blancas con los bordes del limbo de las divisiones morados, tallos como de cuatro caras convexas, separados por surcos lonjitudinales bastante hondos, que contienen muchos cristalitos blancos, hojas largas como de 8" á 10" y anchas como de 3"; flores en racimos axilares, situados hácia la sumidad de los tallos cuyo raquis parece como articulado, llevando cada articulacion una flor de pedúnculo cortito, derecho y saliendo de la axila de una bráctea; fruto del tamaño del dedo meñique y largo como de 5", maduro huele un poco á vainilla. $V$. inodora. C. T. V., 825.- Flores enteramente blancas; tallos con unas cinco caras pronunciadas y conrexas, separadas por surcos que les dan un aspecto como acanaladito; hojas largas como de 2" á 3", lanceoladas, acuminadas. lecorvadas hácia el vértice y de bordes algo membranosos; flores grandes casi sentadas y dispuestas en espiga axilar, cuyo eje es espeso y flexuoso; labelo con pelo, pestañoso, asurcado, cuyos bordes son ondulosos y la punta enrollada y obtusa; frutos bastante largos, oblongos y de base cónica y lisa, sin olor alguno. $V$. claviculata.

\section{CLASE XIII. - FLUVIALES.}

\section{SUB-CLASE 1 ${ }^{\mathrm{a}}$. - EXALBUMINADOS Y ASPADICIFLOROS.}

Framilia 1a. - POTA'MEAS ó NÁYADEAS. - Plantas herbáceas que se crian siempre en las aguas dulces de los rios ó de las lagunas en donde viven mas ó menos sumerjidas, cuyos tallos, mas $\dot{o}$ menos delgados y hasta filiformes, bastante largos de ramos cilíndricos ó comprimidos, llevan hojas simples, opuestas ó alternas, sentadas ó mas ó menos pecioladas, enteras y de bordes ondulosos ó como rizados. Flores hermafroditas ó monoicas, apétalas ó desnudas, dispuestas en espigas ó espádices que salen fuera del agua para que se verifique la fecundacion ó que se quedan siempre sumerjidas, $y$ se componen de un periantio con cuatro sépalos ó enteramente nulo; de cuatro ó seis estambres insertos sobre una especie de receptáculo o de brazo, é hipojinos con el pólen globoso; de un pistilo formado de cuatro ovarios libres y distintos con un solo huevecillo, cada uno con su estigma correspondiente y las mas reces sentado. Frutos aqueniformes, cuya semilla sin endospermo tiene un embrion homótropo y macropodo.

РоталIgeton. Tallo cilíndrico prolífero con hojas papiráceas largamente pecioladas oblongas, ó lancelado-oblongas, aguzadas por la base y cuyo peciolo es convexo por el rértice, las sulmmersas per- 
sistentes y mas estrechas son alternas; estipulas libres no aquiladas; espigas cilíndricas cuyo pedúnculo es tan grueso como ellas; aquenios aquilados. P. fluiíans, Rth. - Tallo cilíndrico ramoso, con hojas membranosas cortamente pecioladas, lanceolado-oblongas u ovales cuando superiores; estípulas libres y nunca aquiladas; espigas cilíndricas con los pedúnculos tan gruesos como ellas; aguenios apenas aquiladitos. $P$. plantaginea, Dr. Var. Jamacensis.

Familia 30. - ALISMACEAS. - Plantas herbáceas, que se crian en los lugares luúmedos, de hojas simples, pecioladas, de base envainadora, á veces dispuestas en roseta, ovales, lanceoladas ó asaetadas, ordinariamente radicales, alternas y saliendo de una especie de rizoma. Flores hermafroditas ó monoicas dispuestas en espigas ó en panojas terminales sostenidas por un bohorclo mas ó menos corto y que a veces está provisto de algunas hojas y simula un tallo; constan de un periantio con seis divisiones de las cuales las tres interiores son mayores y petaloideas, mientras que las tres esteriores, mas pequeñas, son verduzcas; estambres de seis á veinte y hasta 30 ; en las femininas muchos pístilos agrupados en cabecita ocupan el centro de la flor, son formados de un ovario, sea libre sea soldado con los que están á su lado, unilocular con uno ó algunos huevecillos, derechos ó inclinados y adheridos en su lado interno, cuyo vértice lleva un estigma á veces sentado; fruto seco capsular, unilocular, mono ó polispermo, indehiscente ó cuya dehiscencia se hace por su lado interno y reunidos muchos como en cabeza sobre una especie de receptáculo mas ó menos desarrollado y mas ó menos cónico; las semillas son ascendentes ó inversas y compuestas de un tegmento propio que cubre inmediatamente un embrion grueso derecho ó encorvado á manera de herradura.

Perigonio con las divisiones internas y esternas conformes, de limbo abortado ó nulo; anteras estrorsas; huevecillos solitarios ó apareados, colaterales y anátropos; embrion recto. T. I. JuxCAGíNEAS. - Perigonio de divisiones internas petaloideas, mayores y cuyo limbo es nervioso; anteras introrsas en las flores hermafroditos; huevecillos solitarjos ó apareados, sobrepuestos y campilotropos: embrion agarabatado, T. II. Alisunas. G. I. Echinodorus cordifolius, Gr. C. T. V. 17.

G.II.SAGITTARIA. Hojas asaetadas, con lasnerraduras inferiores recorvadas, de peciolo blando y como esponjoso pordentro; bohordo como de unas 6" á 8", blando y como esponjoso interiormente, con los vertícilos de flores distantes, cuyos pedicelos son casi iguales; filamentos de los estambres mas largos que las anteras; capsulitas cortamente mucronadas; enteramente ceñidas por una ala. S. acutifolia, L.: C. 'T. V., 15. - Hojas ovales bastante grandes y largamente pecioladas, tiesas duritas y fuertes, de base un poco escurrida tan pronto oval-oblongas como elíptico-lanceoladas, con todas las nervaduras ascendentes; bohordo muy largo, fuerte, tieso y bastante duro; verticilos de las flores paucifloros y distantes; pedícelos de los mas superiores mas cortos; anteras mas largas que los filamentos; capsulitas mucronarlas provistas de una alita dorsal y esponjosa. S. lancifotia, L. : C. T. T., 16. 


\section{SUB-CLASE 2a. - ALBUMINADOS Y ESPADICIFLOROS.}

Familia 31. - LEMNÁCEAS. - Yerbitas que se presentan á la superficie de las aguas estancadas especialmente, en donde forman una especie de alfombra verde algo rojizo y que consisten en una ó algunas hojitas casi discoideas ó lentiformes, espesitas ordinariamente, sin tallito ninguno, de la cara inferior de las cuales salen unas raicitas. Flores monoicas en número de uno ó dos, envueltas en una espata antes de la floracion, de las cuales las masculinas constan de un solo estambre sin periantio ninguno, de antera unilocular, mientras las femeninas, tambien envueltas por una espata persistente $y$ sin ningun perigonio, son formadas de un ovario unilocular biovulado, terminado por un estilo único con su correspondiente estigma. Capsulita unilocular y con dos semillas, cuyo embrion axil, antitropo ó anátropo, es macrópodo y acanalado interiormente. Lemna polirrhiza, L. L. gibbosa, L. L. minor, etc.

Familia 32. - PISTIACEAS. - Plantas herbáceas, anuales, nadantes, flagelíferas, que con frecuencia se hallan terrestres en el fango medio desecado de las lagunas, de raices con divisiones simples cubiertas, cuyo tallo es cortísimo, algo grueso, separándose mas inferiormente, en partes planas; hojas pecioladas, algunas veces sentadas, dispuestas en roseta, acuñadas ú obovales, elípticas ó sub-orbiculares, con bozo como pulverulento por la base de su cara inferior, de nervaduras paralelas, cuyos nervios de la parte superior é inferior están separados por celdillas medulares máximas ; vainas hialinas finamente membranosas y caducas; espatas solitarias, axilares, sentadas ó pecioladas, mas largas que los espádices yal principio ceñidas por una bráctea hialinea vainal caduca. Flores monoicas en número de dos superpuestas y situadas en la parte inferior de una espata tubulosa, persistente y mas ó menos coloreada, cuya superior es masculina y caduca, inserta por la base del espádice anterífero muy diminuto y soldado con el perigonio verde, pequeño y escuteliforme; tal espádice cilíndrico, sub-claviforme, semi-libre, lleva en el ápice ó por debajo de él dos á ocho anteras dispuestas en una serie y verticiladas; estas anteras sentadas ó cortísimamente estipitadas, dorsofijas y cuadriloculares, se abren esteriormente por cuatro poros sobrepuestos dos en dos, cuyos granitos polínicos son ovales y lonjitudinalmente estriados; ovario unilocular inserto al perigonio escamiforme verde $\mathrm{y}$ deciduo colocado oblicuamente, $\mathrm{y}$ espádice adherido lateralmente en el fondo de la espata, con pocos ó con muchos huevecillos parietales derechos y ortotropos; estilo terminal, corto, algo encorvàdito, con un estigma obtuso y glandulífero. Baya unilocular, mucilajinosa interiormente oligo-polisperma, cuyas semillas oblongas ó de forma variada, lisas ó rugositas, colocadas sobre un podospermo de base cóncava y de ápice truncado, asurcadas radiantemente, con el estremo micropilar cerrado ó abierto; de tegumento doble, cuyo esterior es suberoso engrosado, mientras el interior es membranáceo; embrion minuto, de cotiledon obovalo y situado en el ápice del endospermo. Pistia occidentalis, Klotzsch. C. T. V., párr. 577. 


\title{
SUB-DIVISION II. - VEJETALES FANEROGGAMOS DICOTILEDÓNEOS.
}

\author{
SECCION 1. - APÉTALOS.
}

\section{ÓRDEN I. - GINNOSPERMOS.}

\section{CLASE XIV. - COXÍFERAS.}

Familia 33. - ABIETINEAS. - Árboles elevados y mas raras veces arbustos desparramados, ramosísimos con hojas casi siempre perennes, estrechamente lineares, ríjidas, esparcidas ó amanojadas y los manojillos ordinariamente de base metida dentro de una vaina membranosa. Flores unisexuales amentáceas, con escamas ovulíferas, verdaderos carpillos abiertos empizarrados al rededor de un eje comun y con figura de cono ó estrobilo, mientras los amentos formados por las flores masculinas, son terminales ó laterales, solitarios, amontonados, ó espigados, con muchos estambres desbracteados insertos en el eje por todos lados y mas ó menos apretados; de filamentos cortísimos, gruesecillos; superiormente prolongados en un conectivo escamiforme, derecho ó encorvado, que lleva anteras las mas veces biloculares, con las celdillas aovado-oblongas, separadas por un estrecho conectivo $y$ separadas por el mismo prolongado, lonjitudinalmente dehiscentes ó con menor frecuencia rotas al traves, otras veces tres ó multiloculares, con las celdillas cilíndricas, pendientes del conectivo prolongado sobre ellas, lonjitudinalmente abiertas y cuyo pólen es globoso. Las flores femeninas constan de carpillos numerosísimos escamiformes insertos por todos lados en el eje mas ó menos prolongado, empizarrados, engrosados en el ápice ó iguales, algunas veces aguzados ó arrejonados debajo del ápice, rarísimas veces desnudos, casi siempre provistos de una bráctea libre ó pegada, persistente ó al fin desvanecida, con huerecillos apareados en cada carpillo, raras reces ternados ó solitarios é inversos, ortótropos, abiertos por el ápice, prolongado en cuello y pronto cerrados, alados. El fruto es una piña ó cono formado de las hojas carpelares, linescentes ó coriáceas engrosado-areoladas en el ápice, raras veces atenuadas, persistentes ó al fin sueltas por la base, con brácteas desvanecidas ó persistentes entre las hojas carpelares, con semillas segun el número de luevecillos binados o ternados debajo de las hojas carpelares escavadas, rarísimas veces solitarias y pegadas, inversas, con tegumento coriáceo ó leñoso, prolongado en una ala membranosa persistente y caediza con la semilla ó algunas reces mas pertinazmente adherida al carpillo y se- 
parada de la semilla en la madurez; endospermo carnoso-oleoso; embrion frecuentemente multíplice, inverso, cuyos cotiledones oblongo-lineares, agudos ú obtusos, son en número de tres hasta quince, y raras veces de dos, y cuya raicilla, cilíndrica y dirijida al vértice de la semilla, es ínfera respecto del ápice del carpillo. Pinus Bahamensis, Gr. Ábies balsama, L. C. T. V. párr. 349. P. cccidentatis.

Fanilia 34. - CUPRESINEAS. - Árboles y raras veces arbustos, ramosísimos, con hojas opuestas, verticiladas ó esparcidas, ordinariamente pequeñas, ríjidas, perennes y con frecuencia empizarradas por series. Flores unisexuales, amentáceas, desbracteadas, empizarradas y de amentos terminales ó laterales, solitarios ó amontonados, algunas veces espigados con los estambres y las escamillas ovulíferas, insertos en un eje comun. Las masculinas se componen de estambres numerosos, desnudos, insertos en el eje casi horizontalmente por un filamento cortísimo grueso, prolongado en un conectivo escamiforme, escéntricamente abroquelado con la márjen superior del conectivo mas angosta, mientras la inferior, anterífera por debajo, lleva anteras con vario número de celdillas paralelas, separadas, pegadas, aovadas ú oblongas y lonjitudinalmente dehiscentes, con pólen gluboso. Las flores femeninas son formadas de carpillos en corto número, desbracteados, abiertos, verticilados, abroquelados é insertos al rededor de un eje acortado, o en el mismo eje prolongado, con huevecillos solitarios, apareados ó indefinidos en la base del carpillo o cerca de su estípite, sentados, derechos, ortótropos, abiertos en el ápice y comummente prolongados en un cuello estiliforme y cerrado despues de la fecundacion. El fruto es un sincarpio drupáceo ó apiñado, con los carpillos, carnoso-engrosados ó leñosos, endurecidos, estrechamente aproximados, algunas reces unidos por las márjerıes y al fin de nuero separados. Semillas derechas desde la base del carpillo, solitarias, apareadas ó numerosas con tegumento membranáceo. leñoso ó huesoso, angulado ó alado, con endospermo carnoso y embrion inverso, cuyos cotiledones son dos, raras veces mas, y entónces tres y hasta nueve, son oblongos, obtusos, y su raicilla cilíndrica se dirije al vértice de la semilla y es súpera respecto del carpillo. Juniperus Barbadensis, L. C. T. V., párr. 350 .

\section{CLASE XV. - CICADOÍDEAS.}

Familia 35. - CICÁDEAS. Árboles mas ó menos altos, cuyo tronco es un astil, ó plantas vivaces sin ningun tallo visible ó aparente en la superficie del suelo, pero que, sin embargo, siempre existe subterráneo perpendicular mas ó menos grueso, simulando una raiz perpendicular, de cuyo vértice salen algunas hojas pinatisectas derechas, grandes y dispuestas á manera de corona, alternas y enrolladas á manera de báculo ántes de su entero desarrollo; de divisiones ú hojuelas mas ó menos grandes y estrechas opuestas ó alternas, mas ó menos pronto caducas. Flores dioicas en espigas 
amentiformeś ó que parecen conos, terminales, bastante gruesos, derechos, pedunculados, ordinariamente sencillos, solitarios ó en número de tres ó de cinco, cuyos masculinos son mas largos, mas delgados y mas puntiagudos, y formados de escamas mas ó menos carnosas, espatuladas que llevan muchos estambres jegados por su cara inferior mas ó menos cubierta con ellos, y cuyo cada uno constituye una flor masculina. Los conos femeninos son mas gruesos, mas cortos, como truncos por el vértice, y compuestos de escamas mas espesas, mas densamente apretadas y abroqueladas con dos flores femeninas inversas ó trastornadas, situadas hácia la axila y pegadas en la cara inferior, las cuales se componen de una especie de cáliz globoso con un pequeño horado en su vértice y aplicado al ovario, al cual está en parte adherido por la base; ese ovario es unilocular $y$ de su vértice sale un estigma con forma de pezon. El fruto es una especie de nuez ó de drupa como esponjosa por causa del cáliz que á veces se vuelve carnudo y simula así un pericarpio; con una semilla compuesta de un endospermo que tiene alojado un embrion de dos cotiledones desiguales, coherentes entre sí y cuya raicilla cstá soldada con el endospermo.

Z A MIrA. 1. Hojuelas linear-oblongas sub-falcadas, con figura de cuña, redondeado-obtusas por el vértice aserradito. - Z . integrifolia, Ait., C. T. V., párr. 205. - Hojuelas lanceolado-lineares, nunca sub-falcadas ni con figura de cuña por la base, raquis inerme, 2.

2. Hojuelas alargadas, estrechamente lineares, enteras, con algunas pocas nervaduras; dos veces escotadas y obtusas á la rez con callos en el vértice. $Z$. angustifotia, Jacq. - Hojuelas obtusas, planas, aserradas por debajo de la punta ; raquis comprimido, liso y triquetro. Z. media, parr. 205.

\section{ORDEN II. - ANJIÓSPERIOS.}

SUB-ÓRDEN 10. - APÉTALOS.

\section{SERIE la. - APERIANTEOS.}

Vienen á agruparse en esa division las familias cuyos vejetales tienen sus flores desprovistas de periantio y por consiguiente enteramente desnudas, ó cuyo periantio está ấ veces reemplazado por una ó por algunas escamas.

GRUPO 1․ - HIPÓJINos.

CLASE XVI. - PIPERÍNEAS.

I'anilia 36. - CLORANTÁCEAS. - Arbustos ó matas, raras veces plantas herbáceas y anuales, con olor aromático muy pronun- 
ciado, cuyas hojas simples y opuestas tienen el peciolo envainador, trabado $\mathrm{y}$ acompañado de estípulas. Flores hermafroditas ó unisexuales, diminutas terminales ó raras reces axilares, cuyas hermafroditas y masculinas están dispuestas en espigas, mientras que las femeninas están apanojadas; todas están desnudas; las masculinas se componen de muchos estambres, ó de uno solo, insertos en un eje comun formando así una espiguita amentácea, apretados y empizarrados, sin bráctea ninguna; cuando el estambre es único está acompañado de una bráctea en cuya base se encuentra pegado; filamentos cortísimos que llevan una antera bilocular, cuyas celdas lineares y marjenales, con respecto al conectivo, son lonjitudinalmente dehiscentes. En las flores hermafroditas los estambres, en número de uno á dos ó cuatro están pegados en el dorso del ovario por filamentos aquillados, entresoldados por la base, desiguales y cuyos laterales, mas cortos, tienen sus anteras uniloculares. Ovario simple, sentado, trígono y casi globoso unilocular, cuyo único huevecillo, suspendido del vértice de la celdilla, es ortótropo; estigma terminal sesil, obtuso ó deprimido, escotado por un surco ó casi lobado y caduco. El fruto consiste en una especie de drupa abayada, monosperma, con el cuesco tenue y frájil, cuya semilla pendiente y con tegumento tenuísimamente membranáceo tiene un endospermo carnoso, conteniendo un embrion inverso diminuto y situado jor su vértice, cuyos cotiledones cortísimos están apretados y con raicilla ínfera

Hediosarum Swtz. 1. Hojas lanceolado-lineares, 2. - Hojas elíptico-lanceoladas, 3.

2. Arbusto de hojas aguzadas, aserradas por la base, lampiñas, largas de 5"-3" y anchas de 10"' á 12"”, de peciolo tan largo como la raina ó de 3 ", ; amentos o espiguitas masculinas ovoideo-oblongos, obtusos y nudosos, mientras las flores femeninas se hallan alternas á lo largo de ramitas anguladas, y forman así corimbitos tri ó pluriramosos. H. Nútans, Swtz.

3. Arbusto como de unos $12^{\prime}$ á $16^{\prime}$ de altura, con hojas glabras, aserradas hasta en medio ó solamente por la base, largas de 4 " -2 " $y$ anchas de $18^{\prime \prime \prime}-8^{\prime \prime \prime}$, cuyo peciolo, largo de $8^{\prime \prime \prime}$ á $4^{\prime \prime \prime}$, tiene una vaina tan larga como él. Flores femeninas en racimos formados de espiguitas trífidas cuyas dos laterales son mas cortas que la de en medio. H. arborescens, Swtz. C. T. V., 230.

Familia 37. - PIPERACEAS. - Plantas herbáceas anuales ó perennes, ordinariamente terrestres, algunas veces parásitas y comunmente suculento-carnosas: otras veces, y con frecuencia, matas ó arbustos, cuyos tallos nudosos parecen como articulados, algunas veces sarmentosos ó trepadores, con ramos axilares y solitarios ú opositifolios; hojas simples opuestas ó verticiladas y algunas veces alternas por causa de aborto, integérrimas, y de peciolo mas ó menos envainador por la base, sin estípulas, palmatinervias mas ó menos lisas ó ásperas, pubescentes ó lampiñas, carnosas y lobles ó delgadas y coriáceas ó membranosas, con ó sin puntitos transparentes. Flores hermafroditas ó unisexuales por causa de aborto, sentadas en espádices, ordinariamente carnosas, ó casi sumerjidasó anidadas en las brácteas, que son abroqueladas ó pegado-escurridas, 
raras veces pediceladas; se componen de una bráctea, cuya figura y tamaño son bastante variados, la cual acompaña á cada flor y reemplaza así al perigonio que siempre falta; de estambres en número variado: en efecto, unas veces son dos, situados uno de cada lado del ovario, otras veces tres, de los cuales uno es posterior, ó cuatro, cinco, seis y por fin, en número indefinido, pero soliendo abortar algunos de ellos; sus filamentos, cortísimos y lineares, están adheridos al ovario por la base y llevan anteras estrorsas aovadas y pegadas, las cuales, ordinariamente biloculares, con ó sin conectivo, y raras reces uniloculares, se abren lonjitudinalmente. El pistilo está formado de un orario simple, sentado, casi globoso, unilocular y monospermo, cuyo huevecillo único es basilar y erguido, de estigma terminal casi oblícuo ó un poco lateral, corto, alesnado ú orbicular, indiriso, tri ó cuadrílobo, lampiño ó pelierizado. El fruto es una baya monosperma, parcialmente carnosa, pequeña y cuyo pericarpio es á reces muy delgado, ovoidea ó mas ó menos globosa, con una semilla derecha, lisa ó asurcada, casi globosa, cuyo tegumento cartilajinoso $\mathrm{y}$ tenue contiene un endospermo doble casi cartilajinoso y comunmente ahuecado por el centro y un embrion diminuto y antítropo, apeonzado ó lenticular, con dos cotiledones cortísimos y gruesecitos y una raicilla súpera.

G. I. Prperaromaticum, L.: C. T. V., pár. 19.

G. II. Potoniorphe, Miq. 1. - Hojas peltadas ó abroqueladas, de base un poco acorazonada y cerrada siempre, 2. - Hojas nunca abroqueladas, de base acorazonada abierta ó bífida, 3 .

2. Nata fruticosa de como unos $4^{\prime}$ á $6^{\prime}$ de altura, algo mas ó menos, cuyo tallo, mas ó menos ramoso, derecho y nudoso, es lampiño $y$ verde con las partes mas tiernas glaucas, lampiño. Hojas muy grandes, de limbo casi orbicular, acorazonado $\mathrm{y}$ con una puntita por el vértice, de como $8^{\prime \prime}$ á $10^{\prime \prime}$ de diámetro, con 13 nervaduras, de las cuales dos pares salen por debajo de la costilla, de cara superior verde oscuro y lustrosa, mientras la inferior es de un color verde mucho mas pálido y un poco amarillento; algo undulosas $\mathrm{y}$ enteras, con peciolo largo de $2^{\prime \prime}$ á $3^{\prime \prime}$, cilíndrico, estriado $\mathrm{J}$ glauco, cuya base es envainadora; al desprenderselas hojas, se queda en la parte correspondiente del tallo ó de los ramos una cicatriz anular. Pedúnculos axilares erguidos, cilíndricos, de como 1" 1 [2 á 2 " de largo y cuyo vértice carga con 5 á 12 espádices amentiformes que salen sucesiramente de una bráctea espatiforme que tiene envuelta la base de los pedícelos largos, de como 4" y que sostienen los espádices largos de como 3" á 4 ", delgados, cilíndricos y formando una especie de umbela; la espata es lanceolada, caduca, y tiene como unas $2 "$ " de largo. P. peltatı, Miq.: C. T. V., pár. 35.j.

3. Nata fruticosa de como unos 3' á 8 ' de alto, cuyo tallo, derecho y erguido, mas ó menos ramoso, estriado y rojizo, es algo pubescente, especialmente en sus partes mas tiernas. Hojas grandes acorazonadas, enteras y con una punta deltoidea por el vértice, de nervaduras en número de 11 á 13 , de las cuales un par sale por debajo de la base de la costilla, 6" a 10 " de diámetro tiene el limbo; peciolo de como 6" a 8 " de largo, y cuya base membranosa 
abraza el tallo y contiene los espádices amentáceos; antes de la florescencia es peludo. Pedúnculos axilares, largos de comounas 6" á 8", llevando en su vértice tres, cinco ó seis espádices amentáceos, largos como 2 " a 4 ", cuyos pedícelos, largos de 5" á 6", salen de la axila de una bráctea escamosa, redonda y un poco pestañosa. $P$. umbellata, Miq.: C. T. V., pár. 20.

G.III. Peperomia, R.P., 1.-Hojas alternas y rarísima vez opuestas, 2. - Hojas siempre opuestas ó verticiladas; estigma terminal, 43.

2. Siempre alternas y de nervaduras palmeadas, 3. - Alternas, pero algunas veces parcialmente opuestas, de costilla bien pronunciada y achatada ; estigma diminuto, subulado $y$ picudo y anteriormente lateral, 28.

3. Estigma sentado en el vértice del ovario, 4. - Estigma diminuto situado en el lado anterior del ovario subulado y picudo, 28.

4. Yerbas delicadas, rastreras y arraigantes; frutas subsesiles, sin pico ninguno, 5.- Plantas herbáceas cuyo tallito poco elevado es simple ó mas ó menos ramoso; fruto estipitado, sentado ó subsesil, 14.

5. Tallo siempre lampiño, 6. - Tallo tan pronto pubescentito como lampiño, 11 .

6. Hojas orbiculares, planas y membranoso-pestañadas; fruto ovoideo subsesil, 7. - Hojas obcordadas ó arriñonadas, nunca pestañosas, 8.

7. Tallitos filiformes, difusos ó esparcidos, flexuosos, largos de algunas pulgadas, lampiños, con las ramitas amentíferas tan largas como los espádices que llevan; hojas lampiñas con pestañas largas y distantes, cuyas tres nervaduras son apenas visibles, anchas de como 3 "', transparentes y sin puntitos negros ; filamentos de los estambres distintos; estigma diminuto, amentos de 6" á 4" ; fruto ovoideo subsesil. P. exilis, Gr. Acrocarpidium exile, Niq.

8. Obcordadas y plano-cóncavas; fruto ovoideo subsesil, 9. Ariñonado-redondas cun una puntita obtusa; fruto oval, puntiagudo y sentado, 10.

9. Tallo filiforme mas ó menos largo, lampiño, hojas glabritas con tres nervaduras apenas notables, largas como de 7 " 4 :" $\mathrm{y}$ anchas de 5" á 4"', retusas por el vértice y anchamente acuñadas ó redondas por la base; anteras subsesiles; amentos largos de 8" "á 10 " y cortamente pedunculados; parásita ó que se lialla sobre las piedras, P. cordifolia, Dietr. Piper cordifolia, Sw. Acrocarpidium cordifolium, Miq.

10. Hojas orbiculares ó discoideas, convexas superiormente y cóncavas inferiormente, carnoso-pestañosas, 12. - Hojas ovales; las inferiores son ovalo-redondas y planas, 13.

12. Tallos elongados cuyas ramitas amentíferas son largas de como 1" "á 1" $1 / 2$, filiformes, ramosos y largos de 6" á 12 ", algo mas ó menos, con pelo esparcido y arqueadito, negros y lustrosos; hojas con tres nervaduras ápenas notables, anchas de 3" á 4" ; anteras subsesiles; estigma diminuto, parásita ó terrestre á la vez. P. nummularifolia, Kth.: C. T. V.,párr. 290.

13. Se cria tan pronto parásita como sobre las rocas y entre el musgo, cuyos tallos elongados y filiformes tienen las ramitas amen- 
tíferas mas largas que en la especie anterior; hojas lampiñitas cuya cara inferior tiene puntitos rojizos, con tres nervaduras apenas pronunciadas, de 4" á 5" de largo por 3" á 4" de ancho, cuyas cerdas marjinales acaban por desaparecer; anteras sesiles; estigma diminuto, ovario ovoideo. P. rotundifolia, Kth. P. vicentina, Miq. Pipei rotundifolium, L. Sw.: C. T. V., pár. 290.

14. 'Tallo bajito, simple ó con algunas ramitas; fruto estipitado. 15. - Tallo no tan bajito y siempre ramoso; fruto sentado ó subsesil, 18.

15. Hojas ovaloblongas, obtusitas y lampiñas, pestañosas; fruto elíptico, 16. - Hojas redondas, recortadas por la base, algo peludas; fruto fusiforme, pelierizado y estipitado, 17 .

16. Parásita entre los musgos, cuyo tallo, largo de 2 " á 3", lampiñito, simple ó sencillamente dividido y ascendente, sale de una base sin hojas, filiforme y arraigante; hojas delicadas, pestañosas hácia ó por el vértice, planas, con tres nervaduras apenas notables, cortamente pecioladas y largas de unas 4" á 8"', sobre 2" ó 3"' de ancho; amentos terminales solitarios, cortamente pedunculados $y$ largos de 10" á 12" ; filamentos de los estambres distintos, estigma apincelado; fruto fusiforme, lampiño y constantemente estipitado. $P$. tenella, Dieter. Piper tenellus, Sw. Acrocarpidium tenellam, Miq.

17. Tallo lampiño, simplemente ramoso, suberguido y largo de 2 " á 3"; hojas con pelo esparcido por la cara superior, mientras que la inferior es lampiña; filamentos de los estambres muy cortos; fruto redondo. P. hispidula, Swtz. Piper hispidulus, Sw.

18. Yerba pubescentita y suculenta, 19.-Plantas herbáceas siempre lampiñas y mas ó menos suculentas, 20 .

19. De tallo alto como de 1', ascendente y ramoso, con hojas delgadas, ovales ó elípticas, puntiagudas ú obtusas, manifiestamente trinervias y cuya cara inferior está provista de puntitos negros y de pelo corto y ordinariamente encorvado, largas de 1" $1 / 2$ y anclia de 10 " á 6", con peciolo estrecho; estigma terminal; fruto subgloboso, sentado y obtuso; amentos pedunculados de como 4" á l" largos. P. hirteila, Miq.

20. Bastante suculentas, 21. - Nunca suculentas, pero membra noso-transparentes, $2 \cdot 2$.

21. Tallo delicado, ordinariamente espitámeo ó de 6", esparramado, con hojas sub-acorazonada-deltoideas, puntiagudas, tres á siete nervios, anchas de 10" a 14." y largamente pecioladas; amentos terminales ó axilares largos de 1" á 2 " y cortamente pedunculados, cuyas flores distantes están provistas de brácteas y decíduas: filamentos de los estambres distintos; estigma apincelado; fruto redondo ú ovoideo, obtuso y sentado. P. pellucida, Kth.: C. T. V., pár. 711.

22. De tallo trepador ó arraigante, 23. - De tallo ni trepador, ni arraigante, pero desparramado, 24.

23. Manchado con puntitos negros, bastante blandos y cuyas ramitas son esparıamadas ó diverjentes; hojas ovales ú ovalolanceoladas y puntiagudas ó aguzadas por el ápice, triple-nervias, con dos venas accesorias, provistas de puntitos negros por ambas caras, lar- 
gas como de 1" á 2 " sobre 6" á 12" de ancho; peciolo estrecho; amentos largos de 1" á 4" y cortamente pedunculados; estigma diminuto; fruto ovoideo y globoso con un piquito corto y oblícuo; parásita ó criándose en las paredes viejas. $P$. glabella, Dict. $P$. nigropunctata, Miq. Piper glabellum, Sw. P. dictachyon, Sieb.

24. Erguido, ramoso y con hojas elípticas, cuya cara inferior lleva puntitos negros, 25. - Desparramado con hojas ovalolanceoladas sin puntitos negros, 26.

25. Como de 8" á 10" de alto, cuyas hojas quinquenervias, puntiagudas con el ápice obtusito y ovales por la base, son largas de 1 "1/2 á 1" sobre 1" 1/2 á 1" de ancho; peciolo corto, acanalado y envainador; amentos cortaramente pedunculados y largos de 3" á 5"; estigma diminuto; fruto globoso y sentado, con un pico corto y derecho, P. acuminata, Miq. P. obliqua, R. P. P. haniltoniana, Miq. Piper acuminatum, Sw.

26. Se parece mucho al anterior, pero es parásita y con hojas elíptico-lanceoladas aguzadas, obtusitas por el ápice y de base estrechándose hasta rolverse peciolo, trinervias, con dos venas accesorias, largas de 1" $1 / 2$ á 4", sobre 1 2 á 1" 1 [2 de ancho; amentos cortamente pedunculados y largos de 18" hasta 4"; estigma diminuto; fruto globoso, sentado y con un piquito algo oblícuo. $P$. dendrophyla, Schlest. Piper tenuiflorum, H. K. B.

27. Yerba pubescentita y suculenta, cuyo tallo rastrero y arraicante echa ramitas cortitas y ascendentes con hojas delgadas deltoideo-redondas, obtusas, cinconervias, sin putitos negros, anchas de 4" "á 9"', de limbo casi tan largo como el peciolo y de cara inferior glabrita; amentos cortos casi tan largos como los pedúnculos; fruto oblongo; cilíndrico, subsesil, poco carnoso y con un piquito linear. P. repens, Kth. P. reniformis, Hook. Piper bracteatum, Thomp. Acroc. repens, Miq. Acroc. guildingianum, Niq.

28. Terba suculenta de tallo rastrero y arraigante con el vértice erguido, cuyas hojas delgadas son abroqueladas ó con el limbo distinto del peciolo, 29. - Plantas herbáceas suculentas y lampiñas cuyo tallo ascendente ó derecho lleva hojas cuya base se estrecha hasta volverse frecuentemente peciolo, 29 .

29. Siempre lampiñas, 31 . - Tan pronto glabras como pubescentitas, 30.

30. De hojas alternas, distantes, delgadas, ovales, con una puntita obtusita, cuya base es subcordada ó redonda, pestañosas, con siete nervaduras apenas notables, largas de 1" ó 2" sobre 6" â 18", de ancho; peciolo ordinariamente mas corto que el disco é inserto por la base; amentos generalmente mellizos, casi tan largos como los pedúnculos ó como de 1" á 2"; ovario picudo; fruto ovoideo, sentado y mas largo que su pico encorvado. $P$. distachya, Diet. Piper distachyum, L.

31. Hojas abroqueladas, ovales y cuspidadas; amentos solitarios mas cortos que el pedúnculo alongado, 32. - Hojảs elípticas, redondas por la base y subabroqueladas; amentos ordinariamente mellizos, 33 .

32. De tallo mas ó menos largo, cujos internudos son de 2" ó 3 " 
de largo, con hojas alternas distantes, delgadas, siete â nueve nerviositas, largas de 1" $1 / 2$ á 3" sobre 9" á 24 " de ancho; amentos largos de 1" ‘ 2"; ovario picudo; fruto ovoideo, sentado y tan largo como su pico. P. hernandifolia, Diet. - P. ponthieuei, Miq. - Piper hernandifolium, V.

33. Hojas alternas distantes, delgadas, constantemente cuspidadas, con una punta oblícua y nerviositas, largas de 3" á 2 "sobre 2" ó l" de ancho, papiráceas, opacas y cuya cara inferior tiene puntitos amarillos poco notables, de base redonda y escurrida de una línea sobre el peciolo, tan largo como el disco y que se inserta inmediatamente por encima de la base, algo acanalado y tan largo como los internudos; amentos largos de 1" á 1" $1 / 2$, ordinariamente mellizos, mas cortos que el pedúnculo, erguidos y axilares. Ovario picudo; fruto ovoideo y oblongo á la par, sentado y mas largo quo su pico encorvado. P. producta, Gr.

34. Carnosas y suculentas á la par, 36. - Solamente suculentas; amentos cortos y subsesiles, verticilados en la parte afila de las ramitas y dispuestos en panoja terminal, 35 .

35. Tallo como de l' de alto, derecho y erguido, cuya parte inferior es sin hojas, mientras el vértice las tiene alternas, papiráceas, elípticas, mucronadas por el ápice redondo, de base aguzada que se vuelve peciolo, largo de $1 / 2$ á 2 ', peninervias, largas de unas 3" ‘ 8 " sobre $11 / 4$ ó 3" $1 / 2$ de ancho; panojas largamente pedunculadas y tan largas como las hojas; amentos cortos subsesiles; largos como de 6 á 11" y en número de 4 á 8 por vertícilo; ovario picudo: fruto ovoideo con apéndice corto Yipico deciduo.P. Pernambucensis, Miq.

36. Tallos erguidos, 37. - Tallos ascendentes, 42.

37. Tan pronto ascendentes como erguidos, 38. - Ascendentes solamente y siempre, 39 .

38. De hojas inferiores opuestas, mientras las superiores son alternas, todas coriáceas, elíptico-redontitas, puntiagudas por ambos estremos, largas como 1 1/2 á 2 "sobre 10 " de ancho, cortamente pecioladas y peninervias; amentos solitarios y mas largos que las hojas; ovario picudo, P. alpina, Diet.

39. Hojas coriáceas anchamente ovales ó espatuladas y pecioladitas; fruto tan largo como su pico, que es tieso é inclinado, 40. Hojas coriáceas espatulado-lanceoladas, ó espatuladas sesiles ó subsesiles; fruto mas largo que el apéndice que lleva el pico deciduo, 41 .

40. Como de I' de alto, con hojas retusas ú obtusas, peninerrias, largas de 2"-3"-6". sobre $21 / 2$ á 3" de ancho, de peciolo acanalado largo, como de 4 á 12" ; amentos subterminales largos como de 20 . 6", ordinariamente mellizos, elongados y arqueados, cuyos pedúnculos son tan largos como las hojas; ovario picudo ; fruto ovoideo $\mathrm{y}$ sentado. P. obtusifolia, Dietr. Var. - P. cuneata, Miq. - P. papyracea. P. obtusifolium, L. - P. clusiifolium, Jacq.

41. Figura de las hojas muy variada, a veces obovales y obtusitas, obtusas ó retusas, peninervias; amentos largos de 4 á $6^{\prime \prime}$, ordinariamente mellizos, elongados y cuyo pedícelo tiene 1"; ovario 
picudo, fruto ovoideo, sentado y de pico filiforme. Piper cuneifolium, Jacq. - P. magnolifolium, Jacq.-Pemia suartiana. P. amplexicaulis, Diet.

42. Como de 1' de altura, con hojas elípticas ó elíptico-oblongas, obtusitas, estrechándose hasta volverse peciolo corto, acanalado y largo, como de 4" á 8", peninervias y cuyas venas son muy poco visibles, largas de 3" á 5 ", sobre $21 / 2$ á $11 / 4$ " de ancho; amentos ordinariamente mellizos; elongados y largos como de 4" ; ovario picudo. P. talinifolia, Kth.

43. Eje del amento unido y liso; fruto sin apéndice, 44. - Eje del amento con hoyitos ó facetas, fruto picudo, 61 .

44. Hojas delgadas y con puntitos, 45. - Hojas tiesas y opacas, 58.

4.5. Tallo rastrero filiforme mas ó menos largo, arraigante y de cuatro caras, 46. - Tallo erguido ó ascendente, 47.

46. Cuyas ramitas cortas son ascendentes, con hojas obovales, ovales ó espatulado-obtusas, ó recortadas, trinervias, lampiñas, pestañosas y provistas de algunos puntitos grandes y trasparentes, y dispuestas en verticilos de á 4 ó de á 6 ú opuestas, largas de 3 ó 2 "' sobre 20 1" de ancho; amentos largos de 4 ó 2"', terminales, solitarios y pedunculados, con las flores aproximadas. P. swatziana, Miq. - P. tenerrisna, Schl. - P. filiforme, Sw.

47. Siempre erguido, 49. - Erguido ó ascendente; hojas ovalolanceoladas, lampiñas y con puntitos transparentes, 48 .

48. Planta como de l', cuyo tallo ramoso y subcilíndrico lleva hojas verticiladas por á 3 , á 4 ó á 5 , aguzadas y con una punta obtusa, trinervias y largas de 12 " á 16 "' sobre 3 "'á 6" de ancho, y cuyo peciolo es largo de 2 á 1 "'; flores distantes en amentos firiformes, derechos, cortamente pedunculados y largos de 3 ó de 2"; fruto sentado $\mathrm{y}$ obtaso. P. stellata, Dietr. - Piper stellatum, Sw.

49. Lampiñito, ramoso y subcilíndrico, 50. - Mas ó menos pubescente ó peludo, 51 .

50. Planta cespedosa como de 4" á 8" de alto, cuyas hojas, verticiladas por á 4 ú opuestas', son lanceoladas ó elíptico-lanceoladas, aguzadas con una punta obtusa, apenas trinervias, glabras y cuyos puntitos transparentes son muy poco notables, largas de 4 "", 14 "' ó 18"', sobre 3" o 4"' de ancho; flores aproximadas entre sí, pero distantes á lo largo de los amentos, largos de 4"' á 12"'. P. mirtillus, Miq.

51. Nas ó menos cilíndrico, mé menos pubescente ó peludo y siempre ramoso, 53. - Solamente abescente, cuyo vello es muy cortito, estriado, simple ó ramoso, 52.

52. Yerba como de 1' de altura, con hojas opacas y suculentas, largas de 1" ó 2 ", sobre 4" ó 15"' de ancho, verticiladas por á 3 ú opuestas, elípticas, elíptico-redondas ó elíptico-lanceoladas, puntiagudas ú obtusas por ambos estremos, uni-trinervias, pubescentitas y con puntitos negros densamente agrupados en ellas, y con peciolo largo de 2,4 "'; amentos largos de $11{ }^{2}$ ó 5", terminales, 
cortamente pedunculados, flores distantes en el eje elongado; fruto ovoideo sentado y obtuso. P. ciliata, Kth.

53. Pubescentito ó pubescente, 55. - Densamente velludo y estriado, pelo tan largo como ancho y articulado, 54.

54. Planta cespedosa, alta como de unas 4 o 6", cuyas hojas, verticiladas por á 4 d 6 ú opuestas, son obovales ú ovales, obtusitas ú obtusas, suculentas, largas de 3"“ ó $\frac{1}{4} "$ ", solore ' 2 ó 3"” de ancho, cortamente pecioladas r trinervias, de cara superior, pubescentita $i$ alampiñada; mientras la inferior es siempre pubescente y tiene además algunos puntitos transparentes bastante grandes; amentos terminales cortamente pedunculados, de 6 ú 8 " largos y con las flores distantes. P. verticillata, 'Dietr. - Piper verticillatum, L.

55. Cilíndrico, pubescente y con algunos pelos mas largos que los demas; hojas alampiñadas ó pubescentes sin puntitos negros, 56 . - Solamente pubescentito y con pelo muy cortito, subcilíndrico, hojas lampiñitas con puntitos negros por la cara inferior, 57 .

56. Yerla cespedosa alta de 3" $\dot{4} 4$ ", con hojas verticiladas, por á 3 ó 4 , espatulado-oblongas, oblongas ó ovales, obtusas ú obtusitas, adelgazándose liasta volverse peciolo largo de $1 \eta^{2}$ ó 1"', apenas trinervias, largas de 4" o.".", sobre ?" de anchura, de cara superior alampiñada ó pubescentita, con puntitos transparentes apenas notables; amentos terminales cortamente pedunculados y largos de 3"” at 4 , con flores aproximadas. P. pulchella, J)ietr.

57. Yerba de $1^{\prime}$ de alto, cuyo tallo es tricotomo y fastigiado por el vértice, con hojas verticiladas por á $4 \dot{0} 6$ ú opuestas, obtusas, trinervias, lampiñitas. subsesiles, largas de 3 " á 4 "'. sobre $2[3$ " l"' de ancho; amentos filiformes, derechos, cortamente pedunculados y largos como de 6" á 15"', con flores distantes: fruto sentadn v obtuso. P, gallioides, Kth.

.58. Tallo erguido y subcilíndrico, 59. - Tallo rastrero y de cuatro caras, 60 .

59. Planta alta de $l^{\prime}$, cuyo tallo simple $\dot{o}$ algo ramoso y lampiño lleva hojas opuestas ó verticiladas por á 3 ó 4 , oralo-lanceoladas $o$ lanceoladas, aguzadas y mas puntiagudas que las demas, largas de 11 [ 2", 2" sobre 6", 8" de ancho, 5ó 7 nervias, lampiñas, coriáceas y de base que se estrecha hasta volverse peciolo largo de 2"-3"; amentos largos de 1". terminales, pedunculados y con flores aproximadas. P. septemneris, R. P.

60. Cespedoso y meduloso, simple ó algo ramoso y lampiño, cuyas hojas opıestas, ovales, obtusitas, redondas por la base y trinervias. tienen 1.2" de largo, sobre 18" de ancho, glabras y col'tamente pecioladas : amentos axilares; largos de 6 a 8 ", cortamente pedunculados y cuyas flores son aproximadas. P'. quadrangularis, Dietr's. - P. muscosa. L. -K. - P'iper quadrangulare, Thomp.

61. Tallo ascendente, ramoso y estriado, 62. - 'Tallo rastrero. subcilíndrico o cuadrangular, 63.

62. Planta lampiña cuyas ramitas erguidas son largas de 4" á 6"; hojas raras reces opuestas y ordinariamente verticiladas por á 4 . oborales, recortadas, acuñadas por la base que se termina en un pe-

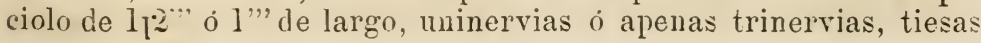


y suculentas á la par, largas de 4" o 6" " y auchas de 2 ó 3"”, con puntitos transparentes apenas notables; amentos terminales, largos de 1 " o $11_{[} 2$ ", pedunculados, con flores aproximadas; ovario picudo; fruto ovoideo cortamente picudo. P. quadrifolia, Klh. - Piper quadrifolium, L.

63. Subcilíndrico y cuyos ramos no son ni erguidos ni ascendentes tampoco, 67. - Tetrágono y de ramos ascendentales ó erguidos, 64 .

64. Peludo do ramitos ascendentes solamente, 66. - Glabrito con ramitos erguidos ó ascendentes, 65 .

65. Como de 2 " a 6 " de alto, simples ó sencillamente dicótomos, y lampiñitas las ramitas; hojas verticiladas por á 3 á 4 ó á 6 , romboideoélipticas, obtusas, de base subsesil y acuñada, uninervias ó apenas trinervias, lampiñas, tiesas y suculentas í la par, largas de 4" 6 6"', sobre 3 o 5" de ancho, oscuramente pelucido puntaditas; eje dos veces hoyoso y pubescente, cuyos amentos, largos de 6 á 8 "' y obtusos por el ápice, son largos como el pedúnculo y llevan flores aproximadas; ovario picudito; fruto oval y con pico muy corto. $\mathrm{Pa}-$ rásita. P. reflexa, Dietr. - P. fliformis, P. P.

66. Como de $2 "$ ó t" de alto con hojas verticiladas por á 3 ó á 4 u opuestas, ovales ú obovales, mochas ó recortarlas por el ápice, largas de $6 "$ " 8 ", sobre 6" á 8 " de ancho, trinervias. pestañosas, lampiñitas ú con pelo esparcido por la cara superior, suculentas y oscuramente pelucido puntadas, cuyo peciolo tiene 1" o 2 "' de lar"go ; amentos terminales, solitarios ó ternados, largos de 2 " ó 3 ". cuyo eje glabro lleva flores aproximadas: ovario picudo, fruto globoso, cuyo pico es casi tan ancho como largo. P. trifolia, Dietr. P. ovalifolia, Hook. - Piper trifolium, I.

67. Planta deá 8" 4" , con hojas verticílidas por á 3 ó á 4 ú opuestas, ovalo-redondas yecortadas ó redondas por el ápice y tambien por la base, oscuramente trinervias, suculentas, pelucido puntadas, cuyo peciolo es largo de 1 o $2 "$ ", largas de 4 o $5^{\prime \prime}$, sobre 3 o 4 "' de ancho; amentos terminales, cortamente pedunculados, largos de I' o 11 [2" y cuyo eje glabro lleva flopes aproximarlas: ovario obtuso de estigma espeso. P. obversa, Dietr. - Piper obversum, V.

G. IV. ExnEA, Kth. - 1. Hojas tiesas, cuyas venas transversales son dispuestas á manera de redecilla, 2. - Hojas membranosas, 3 .

2. Arhusto bastante alto o arbolito, lampiño, cuyas ramitas llevan hojas papiráceas, grandes, ovales il ovaloblorgas, cortamente aguzadas, oblícuas, oscuramente pelucido-puntadas, lustrosas, largas le 8" á 10", sobre 5 ú 8" de ancho, cuyo peciolo es largo de 4" ó 5 ; amentos largos como los peciolos, cortamente pedunculados y con flores contiguas; bayas ovoideas. $E$. sinilacifuliu, $\mathrm{K}$ th. - Piper decumanuin, W.

3. Bayas aproximadas y lijeramente asurcadas; hojas ovales con puntitos transparentes, 4. - Bayas distantes á lo largo de los amentos y con surquitos bien marcados, 5 .

t. Arljusto lampiño con hojas membranosas diminutamente pelucido-puntalas, ovales y con una punta estrecha y obtusa, á veces 


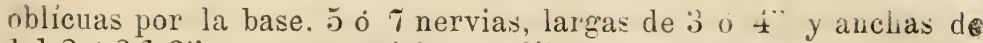
11 [ 2 o 21 [2", y cuyos peciolos son lijeramente pubescentes; amer. tos de 11 [ 2 ó 3" de largo; bayas ovales y obtusas. E. sieberi, Miq. -E. plantaginea, Kth. - Piper medium, Jacq. - P. discolor, Desc.: C. T. V.. pár. 389.

J. Hojas ovalo-lanceoladas ó hastado-subuladas y sin puntitos transparentes, 6. - Hojas ovales y con puntitos transparentes, 7.

6. Arbusto lampiño que se eleva como á 3' ó 10' de altura, de ramos dicótomos, cuyas hojas, con una punta estrecha y ordinariamente obtusa, son 5 nervias, y largas de $2 l_{[2}^{2}$ ", 3" o 4 ", sobre $6, \delta$ o 24 "' de ancho, tienen el peciolo y las costillas pubescentes; amen. tos largos de 3"; bayas ovales. E. amalago, Gr.-E. unguiculata y Glaucescens, Kth. - E. ceanothifolia, Miq. - E. cariifolia, Miq. Piper amalago, L. - P. glaucescens, Jacq. - P. unguiculatus, R. P.: C. T. V., pár. 390.

7. Arbusto lampiño cuyas hojas membranosas tienen una puritita estrecha y obtusa por el vértice, mientras la base es con frecuencia oblícua, redondeada, subacorazonada ó acunada, trinervias y además con 1 ó 2 pares de nervios suplementarios. largas de 3 á 6" , sobre 1 l [2 á $31_{[} 2$ " de ancho; amentos de $11_{[} 2$ " o 4 " de largo y dé eje lampiñito; bayas ovoideas y oblongas i la par, bruscamente picudas. E. Surartiz, Gr. - E. plantaginea, Miq. - Piper discolor, Sw.

G. V. Artanthe, Miq. - 1. Nervaduras principales de las hojas con puntitos transparentes, arqueadas y mas distantes del vértice que no lo son entre sí, 2. - Nervaduras principales de las hojas lisas ó provistas de ampollas, situadas á igual distancia las unas de las otras como del vértice de la hoja, 13.

2. Hojas lisas y raras veces ásperas, 3. - Hojas siempre ásperas $\mathrm{y}$ de base muy desigual, 10 .

3. De base mas ó menos desigual, 5. - De base igual : pedínculos mas cortos que el peciolo desnudo, 4 .

4. Ramitas densamente pelierizadas, cuyas hojas oblongas o elíptico-oblongas son puntiasudas, lisas ú ordinariamente ásperas y pustulosas, por la cara superior lampina, mientras la inferior tiene solamente sus nervaduras lampiñitas ó pelierizaditas, alğo coriáceas. largas de $21_{[} 2$ ", $31_{[} 2$ ", sobre $11_{[} 2$ " de ancho y cuyo peciolo tiene solamente 3 ó 6 " de largo; nervaduras principales 4 yugadas, cuyas superiores salen hácia la parte mediana de la costilla; amentos largos de 1" l[2. A.rugosa", Miq. - A. trichostachya, Miq. - Pipei rugosum, Lam.

5. Base desigual ó apenas desigual; pedúnculos mas cortos que el peciolo marjinado, 6. - Base muy desigual ó solamente algo des. izual; peciolos desnudos, 7 .

6. Arbusto de hojas ovales ó elípticas, lisas, papirciceas, largas como de 6 á 8 " y anchas de 3 á 5 ", con la cara superior lampiña. mientras la inferiol tiene sus nervios pubescentitos, nervadura: principales $\check{5}-7$ yugadas, casi equidistantes, cuyas superiores salen á alguna distancia del vértice de la hoja: peciolos largos de 8 á 12"': amentos derechos, largos como de unas 2 á 3". 4 . coruscans, Miq. 
7. Base muy desigual y redondeada á la par; hojas lisas, pedúncalos mas largos que los peciolos, 8. - Base desigual, hojas lisas ú ordinariamente pustuloso-ásperas, pedúnculos mas cortos que los peciolos, 9.

8. Arbusto como de $6^{\circ}$ de altura, con hojas ovaloblongas ú ovales; con una punta aguzada, de cara superioi lampina, mientras la inferior tiene pelos sobre su nervadura, papiráceas y largas de 3 o 5 " y de $11 l^{2}$ ó $21_{1} 2$ " de archo; lado esterior de la base prolongándose como de ?": nervaduras principales 4,5 yugadas alternas, euyas inferiores son aproximadas, mientras las superiores salen á alguna distancia del vértice de las hojas; peciolos largos de 1 á 2 "'; amentos de 1 á 3 " de largo, ordinariamente derechitos, cuyos pedúnculos son largos de 4"; cuatro estambres. A. Jamaicensis, Gr. - Piper nitida, sw.

9. Arbusto de hojas oblicuamente ovales, puntiaguảas, lampiñas. pero de nervaduras velludas, membranosas, largas de 4 , $\tau$ ", sobre 2 64 " de ancho, con frecuencia un poco lustrosas : nervaduras principales alternas $\mathrm{r}$ curas superiores salen hácia el medio de la costilla ; peciolo largo de 5 ó 12"'; amentos derechos como de 2 o 4" largos, con flores densamente aproximadas, curo pedúnculo tiene 4 "' de largo. P. bredemeyeri. P. macrophylla. P. ulmifolia, Miq. Piper unitum, Sieb. P. dilatatum, Rchb. P. Zredemeyeri, Jacq.

10. Ramitas espesas, pelierizaditas, con pelo largo $\mathrm{Y}$ deciduo: pedúnculos mas largos que el peciolo desnudo y corto; amentos arqueados, 11. - Ramitas ásperas, pelierizadas, pedúnculos tan largos ó mas cortos que los peciolos desnudos y sub-cilíndricos; amentos derechos, 12 .

11. Arbusto ranoso como de 11 , 2 hasta 2 varas de altura, cuyas hojas ovaloblongas, cpn una punta estrecha por el vértice, y de base muy desigual, son ásperas, papiráceas y largas de ‘) á 8 " sobre 4 o 5 " de ancho, con peciolo de 1 á $2 "$; nervaduras principales 6,7 yugadas, alternas y cuyas superiores salen hácia la parte mediana de

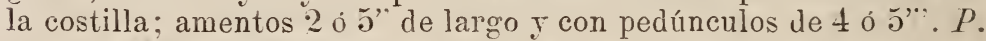

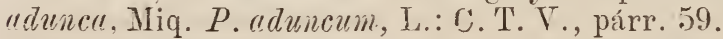

12. Arbusto que á veces se eleva hasta 3 varas de altura, de hojas ovaloblongas ú ovales, con una punta estrecha por el vértice y de base muy desigual, ásperas y papiráceas, largas de 4 o 10 ", sobre -2-3-4" de ancho; mucho mas pálidas y algo amarillentas ; de nervaduras principales, 5-6 yugadas, alternas $\mathrm{r}$ cuyas superiores salen del medio de la costilla; amentos largos de unas 2 ó 6 " con una punta mas ó menos larga y cuyo pedúnculo tiene 2 ó $5^{\prime \prime \prime}$. P. scabra, Miq.: C. 'T.V., párrr. 60. - Variedades; hojas sin pelo estendido; ramitas pelierizaditas cuyo pelo deflexo y deciduo es mas corto que el diámetro del eje. P. scabia y hirsuta, Miq.-Hojas y ramitas con pelo largo, estendido, articulado y persistente. P. hirsuta. Piper hirsutum, Sw.

13. Base de las hojas muy desigual, no se ve en ellas ningun puntito transparente, 14. - Base de las hojas igual, con ó sin puntitos transparentes; vejetales lisos y lampiños, 21 .

14. Peciolos y ramitas verrugosos; peciolos de márjen alada y 
mas cortos que los pedínculos, 15.- Peciolos y ramitas nunca verrugosos, pero al contrario lisos, lampiños ó peludos, 16 .

15. Arbolito cuya epidermis está cubierta de verruguitas blancas, deprimido-globosas; de hojas grandes oblongas ú oraloblongas, puntiagudas, de base sub-acorazonada y muy desigual, cuyo lado esterior se prolonga como de 5 á $10^{*}$ ", lisas, lampiñas y coriáceas, largas de 8", 12" y hasta 24 ", sobre 4" 3 " de ancho ; nervaduras principales equidistantes 10 á 12 yugadas; peciolo largo de 2 á 6 "'; amentos derechitos ó arqueados de 4 á 6 "largos, cuyo pedúnculo tiene solo 8 ó 12 ". P. rerrucosa, Gr. Piper rerrucosum, Șw.

16. Peciolos acanalados desnudos y tan largos como los pedúnculos, 17. - Peciolos nunca acanalados ni desnudos tampoco, mas cortos ó tan largos como los pedúnculos, 18.

17. Arbusto de tallo y ramos con nudos bastante pronunciados $y$ cuyas ramitas lisas y lampiñas llevan hojas oblongas ú oblongolanceoladas, aguzadas y rara vez obtusitas, de base muy desigual, lisas, glabras y papiráceas, largas de 8" ó 4 , sobre 21 [2" ó 11 [2 de ancho; nervaduras principales equidistantes 7 ó 12 yugadas: peciolo largo como de 3 á 5 " solamente; amentos de 3 á 5 " de largo. $P$. geniculata. P. xylopioides. P. xestophylla. P. staminea, Miq.

18. Peciolos alados por la márjen y tan largos como los pedúnculos, 19. - Peciolos alados y envainadores á la par y mas cortos que los pedúnculos, 20 .

19. Arbusto cuyo tallo se eleva como á 12 y hasta $20^{\circ}$ de altura, de ramitas lisas que llevan hojas grandes, ovaloblongas, de base redondeada ó subacorazonada y muy desigual, puesto que el lado es terior se dilata como de $10^{\circ}$ " o 5 mas que el otro, lisas, glabras y papiráceas, largas de 12 " í 8 " sobre 5 " o 4 " de ancho, de nervaduras principales 10 ó 12 yugadas, equidistantes ó cuyas inferiores están aproximadas las urias de las otras; peciolo largo de unas 4 ó 6 ": amentos derechos de como 6" de largo. P. macrophylla, Gr. P. Tassertiana. P. macrophylla, Miq. Piper macrophyllum, Sw. P. incequale, H. B. K.

20. Arbusto cuyo tallo y ramos tienen nudos bastante pronunciados, de ramitas lisas, peludas ó lampiñas que llevan hoias oblon @as ú oraloblongas, con una punta obtusita $\mathrm{y}$ de base muy desigual con asperidades por la cara superior que parece como verrugosita, mientras la inferior, lisa, es pubescentita en los nervios, papiráceas y largas de 5 " o 4 ", , soble 2 ", $111^{\circ} 2^{\prime \prime}$, raras veces 21 [2" de ancho; nervaduras principales equidistantes 8 á 10 yugadas: peciolo largo de 1 á $2 "$ y ancho de 2" : amentos largos de 3 a 4 " y con perínculo de 4 á 6 . P. tuberculata, Miq. Piper tuberculatuir, Ktk. I. rerrucosuin, Sieb.

21. Hojas nunca elípticas, de peciolo acanalado, desnudo, tan largo ó mas corto que los pedúnculos, 22. - Hojas mas ó menos elípticas, de peciolo acanalado desnudo, tan largo ó dos reces mayor que los pedúnculos, 2:3.

22. Arbusto cuyas liojas aguzadas y estrechas por la base igual, son papiráceas, inequilaterales, larcas de 5" ó 3" sobre ?" ó 1 de ancho $y$ con puntitos transparentes diminutos; de nerraduras princi- 
pales 4 o 6 yugadas, sub-equidistantes, de las que las mas inferiores están aproximadas las unas de las otras: peciolos largos de 3 á 4" : amentos de 2" ó l" largos mientras su pedúnculo lo es de 6" o 4". P. Xilostoides, Miq.

23. Hojas solamente elípticas: peciolo tan largo como los pedúnculos, 24. - Hojas tan pronto elípticas como ovales: peciolo dos reces mas largo que los pedúnculos, 25 .

24. Arbusto cuyas hojas, largas de 7" ó 5" sobre 3" ó 21 [2" de ancho, inequilaterales, pero de base igual, papiráceas y enteramente opacas, se terminan por una punta estrecha: principales nervaduras equidistantes 6 a 10 yugadas; peciolo largo de 6 is 8 mientras los amentos lo son de 2". P. equalis, Mia.

25. Arbustillo de hojas terminadas por una punta estrecha $y$ de base igual, papiráceas, con puntitos transparentes, frecuentemente nequilaterales, largas de " 7 " $\dot{4} 4$ ", sobre 4 " o 2 " de ancho y con peciolos de unas 12"' nervaduras principales ò á 6 yugadas equidistantes ó de las cuales las mas inferiores están aproximadas las unas de las otras; amentos largos de $3 " a ́ 1$, mientras sus pedúneulos lo son de 6" á 4 solamente. P. martiana, Miq. P. srharhii. Miq. C V. Schilleria candate, Klh.: C. T. T., pár. 62.

\section{CLASE XTII. - TRTICÍNEAS.}

Familia 38. - ANTIDESHEAS. - Arboles ó arbustos inermes ó aguijonosos, algunas veces trepadores, con hojas alternas simples, pecioladas, coriáceas, cuyas estípulas están apartadas de la base del peciolo $\because$ caedizas. Flores en espigas amentiformes y bracteadas, unisexuales y cuyas masculinas se componen de un perigonio calicinal di, tri ó quinquepartido, con la estivacion empizarrada; los estambres son 5 insertos en lo mas bajo del perigonio ó iguales en número con sus divisiones y opuestos ó alternos con ellas, cuyos filamentos filiformes libres ó unidos en la base con un disco central glanduloso y mínimo, son mas largos que el perigonio y se terminan por una antera introrsa, bilocular, cuyas celdillas, que están separadas ó pegadas en un conectivo horizontal, se abren por una grieta vertical; además hay un pistilo rudimentario sentado en el centro de la flor; las femeninas constan de un periantio calicinal 3 ó 5 partido y caduco, de un pistilo formado de un ovario libre, ceñido por la base de un disco anular, unilocular y cuyos dos huevecillos, colateralmente colgantes del vértice de la celdilla, son anátropos ; estigma terminal sentado y deprimido, arrayonado, 3 ó כ lobo. El fruto consiste en una drupa abayada, coronada por el estigma, monosperma por causa de aborto de uno de los huevecillos, cuyo cuesco huesoso esteriormente hoyoso ó punteado echa interormente apéndices que penetran en la semilla inversa y de tegumento membranáceo; endospermo carnoso ₹ copioso; embrion ortotropo con cotiledones grandes $\mathrm{y}$ foliáceos y de raicilla corta y supera. Antidesma alexitaria. C. T. T., párr. 619.

Fanilia 39. - LRTICACEAS. - Plantas herbáceas anuales 
ó vivaces, maias enredaderas ó arbustos, de hojas simples, opuestas $\delta$ alternas, pecioladas, enteras ó dentadas, festoneadas ó mas ó menos profundamente lobadas, con pelos punzantes o sin ellos y hasta glabras algunas reces. con dos estípulas caducas situadas hácia la insercion del peciolo que acompañan. Flores monoicas, dioicas $y$ tambien polígamas, rarisimamente hermafroditas, solitarias o agrupadas de varios modos y axilares, ó bien en especie de espigas í de racimos terminales, siempre muy pequeñas y constan de un perigoniu monotilo euyo limbo es mas ó menos profundamente 4 o j partido: hay tantos estambres cuantas divisiones perigoniales y con los cuales alternan ó son opuestos y en cuyo fundo se insertan; de filamentos doblados durante la estivacion y al abrirse la flor, saliendo por fuera con elasticidad: las femeninas son formadas de un periantio con 2 ó 4 sépalos, que algunas reces están reemplazados por una escama en cuya axila está situado el pistilo, que se compone de un orario único, súpero, cuyo estilo simple ó bífido y frecuentemente lateral suele faltar bastantes veces: estigma ordinariamente con figura de pincel ó bífido, sentado algunas veces, pero las mas terminando el estilo ó sus divisiones. Fruto seco aqueniforme, á veces contenido en un cáliz que vuelto carnoso lo hace aparecer abayado; de cuesco crustáceo y quebradizo; embrion derecho y encerrado por lo comun en el interior de un endospermo mas ó menos delgado.

\section{Anúlisis dicotómica de las tribus con la de las especies.}

1. Vejetales proristos de pelo muy punzante y cuya picadura abrasa mucho; hojas opuestas ó alternas, 2. - Perigonio de las flores femeninas contraido por el rértice 2,4 dentado 6 entero y que á reces suele faltar; pelo nunca punzante; tallos siempre leñosos. T. I. Boenueriets, G. IV.

2. Divisiones calicinales de las flores femeninas desiguales; algunas veces vejetales lampiños; de hojas opuestas. T. II. UREREas. G. I. - Flores femeninas cuyo periantio es ordinariamente 3 partido ; estigma apincelado; ordinariamente plantas herbáceas siempre mas ó menos punzantes; de hojas opuestas. T. III. Procrideas. G. I. UrtibacA, de Gy. Urera, Gaud., 1. - Cimas cuyos pedúnculos son dos ó tres veces dicótomos; rafidias ó venas visibles por la cara superior de las hojas ó nulas, 2.-Cimas cuyas flores aproximadas forman una especie de espigas ramosas ó simples, hojas con muchas rafidias ó venas lineares visibles por la cara superior, 7 .

2. Aquenio saliendo por afuera de la baya calicinal, 3. - Aquenio enteramente encerrado en la baya calicinal, 4.

3. Arbusto como de 6' hasta 12 ' de altura, muy aguijonoso, mas ó menos ramoso y erguido ó derecho, con hojas grandes ovales ó redondeaditas, sinuoso-dentadas, laryas como de 6 á 12 ", con puas largas, rojizas, las cuales se hallan tambien en los peciolos, pedúnculos, pedicelos y ramitas, largamente pecioladas; cimas laterales las mas veces tricótomas y abiertas cuyas flores son pediceladas. 
$U$. baccifera, de Gy. U. baccifera, Gaud. Urtica baccifera, L.: C. T. V., párr. 21.

4. Hojas festoneado-aserradas y pubescentes; cimas las mas veces esparramado-dicótomas, cuyas flores femeninas son pediceladas, 5. - Hojas festoneadas, raras veces sinuoso-sub-enteras, lampiñas, cimas á veces esparramado-dicótomas, cuyos últimos brazos de las femeninas son filiformes y cargan con 3 á 7 flores sentadas, 6 .

5. Arbusto ó arbolito con hojas anchamente ovales, ordinariamente un poco acorazonadas por la base, sin puas, cuyas superiores tienen como 3 á $4^{\prime \prime}$ de largo y casi un tanto de ancho, mientras las inferiores son frecuentemente largas de mas de $1^{\prime}$, ' con las nervaduras principales 6 á 8 yugadas: cimas axilares ó laterales. $U$. caracasana, Gand. U. Jacquini, Wedd. Urtica caracasana, Jacq. U. aestuans, Sieb.

6. Arbolito bajito que se eleva á unos 15 ó $20^{\prime}$ de altura ó menos, de hojas ovales ó aovaloblongas, con una punta, recortadas por la base como de unas 4 á $6^{\prime \prime}$ de largo, sobre 2 á $3^{\prime \prime}$ de ancho: cimas axilares ó laterales. $U$. elata, Gr. $U$. sinuata. Wedd. Urtica elata, Swtz.

7. Hojas triplinervias, espicas femeninas ramosas y mas cortas que el peciolo, 8. - Hojas trinervias; aquenio saliendo por fuera de la baya calicinal, 9 .

8. Mata con hojas ovalo-redondas, obtusitas, festoneadas ó subenteras y de base redondeada, glabras ó alampiñadas por la cara inferior; flores en racimos axilares. U. crassifolia, Wedd.

9 . Flores de ambos sexos en espigas ramosas mas largas que los peciolos, 10. - Espigas simples apenas tan largas como los peciolos, 11.

10. Arbusto ó arbolito de hojas elíptico-oblongas con una punta obtusa por el ápice, redondeadas o acuñadas por la base. festoneadas ó sub-enteras con las nervaduras de la cara inferior glabras ó alampínadas, largas de $4^{\prime \prime}$ á $3^{\prime \prime}$ sobre $2^{\prime \prime}$ ó $112^{\prime \prime}$ de ancho, membranáceas. U. microcarpa, Wedd.

11. Mata con hojas oblongas ó elíptico-oblongas, obtusas y sin embargo con una punta. recortadas por la base, repando enteras $y$ lampiñas, de como $5^{\prime \prime}$ ó $2^{\prime \prime}$ largas sobre $2^{\prime \prime}$ á $1112^{\prime \prime}$ de ancho, papiráceas ; peciolo corto; flores en racimos axilares, sub-sesiles. U. spicata, Wedd.

G. II. PrleA, Lindl, 1. - Hojas pequeñas numerosas ; ta lo desparramado y blandito; flores andrójinas, 2. - Hojas de tamaño regular ó á reces bastante grandes, 3 ó 5 nervias, 5 .

2. Hojas obovaloredondas, entegerrimas, de cara superior, con venas lineares y mas veces transrersales, 3.- Hojas acuñadas ó lanceoladas, cuyas mas largas son aserradas mientras las menores son ordinariamente enteras; de nervios oblicuos y lineares, visibles jor ambas caras, 4.

3. Tallo ramoso anual ó sofruticoso, á veces suculento, con hojas apareadas, cuyas menores parecen una estípula grande; cimas contraidas, mas cortas que las hojas y ordinariamente andrójinas. $P$. microphylla, Lieb.: C. T. V., párr. 354.

4. Planta herbácea bastante varialle, delicada y á veces sofruti- 
cosa, glabra ó alampiñada, con hojas heteromorfas: cimas diminutas, contraidas, pedunculadas, mas veces andrójinas, cuyo pedúnculo es casi tan largo como las hojas. P. lucida, Bl.P. Cutensis, Wedd. Lrtica Tucida. U. cuneifolia. U. serratulata, Swtz. C. T. V. 354.

5. Bien enteras: cimas mas cortas que ellas; tallo derecho simple ó algo ramoso, un poco estrechado ó contraido hácia los nudos; vejetales por lo comun lampiños, 6. - Hojas siempre mas ó menos aserradas, 11 .

6. Hojas linear-lanceoladas ó solamente lanceoladas con venitas desparramadas por ambas caras y lineares; flores dioicas, 7. - Hojas elípticas ó elíptico-lanceoladas, ovales ú ovalo-lanceoladas, 8.

7. Tallo derecho y erguido como de 1 á $2^{\prime}$ de alto, con hojas aguzadas, 3 nervias y perfectamente enteras, cortamente pecioladas, largas de $11_{[}^{2}$ a $21_{[} 2^{\prime \prime}$; cimas masculinas contraidas y cuyos pedúnculos son 2 á 3 veces mas largos que las hojas; mientras que las flores femeninas se hallan en espigas interrumpidas, subsesiles y tan largas como los peciolos. P. nudicantis, Wedd. Urtica nudicantis, Swtz. U. lanceolata, Poir.

8. Elíptico lanceoladas ó elípticas, enteras ó repandas, cuyas venitas se presentan por la cara superior bajo forma de puntitos; flores dioicas, 9. - Ovales ú oralolanceoladas: venitas lineares visibles solamente por la cara inferior; flores andrójinas ó unisexuales, 10 .

9. Matita de tallo de 2 á 6 ' de altura, sofruticoso y ramoso desde la parte inferior, con liojas cortamente aguzadas, acuñadas ó redondeadas por la base, trinervias, ordinariamente glabras por la cara superior, mientras la inferior es pubescente ó lampiña en las nervaduras, apareadas y desiguales; la menor es oval, las mayores tienen como 2" ó 1" de largo, sobre 8" á 5" de ancho, mientras las menores son largas solo de 6" a 4" ; cimas masculinas contraidas, diminutas, cortamente pedunculadas y urdinariamente mas cortas que el peciolo delgadito de las hojas; las femeninas al contrario son desparramado-abiertas, subsesiles $y$ tan largas como los peciolos. P. parietaria, Bl. P. riveria. Wedd. Urtica parietaria, L. : C. T. V., pár. 3533.

10. Yerba con hojas aguzadas trinervias, de cara superior peluda, mientras la inferior es pestañosa y pubescente á la par, á veces lampiña por los nervios, largas de $111^{2} 2$ ó 5", sobre 11 [ 2 i 2 " de ancho: cimas estendidas, pedunculadas y casi tan largas cumo el peciolo alargado de las hojas. P. citiaris, Wedd.

11. Tallo mas ó menos fruticoso y rara vez herbáceo, derecho y uunca jamas rastrelo ni desparramado al suelo tampoco, 12. Tallo blando y las mas veces herbáceo, ordinariamente rastrero, cun los ramos herbáceos y ascendentes, 25 .

12. Erguido, simple ó ramoso inferiormente; hojas lampiñas $y$ casi iguales, 14. - Erouido, siempre ramoso y sofruticoso; hojas desiguales pelitiesas, 13 .

13. Matita como de 1'de alto, cuyas ramitas pelitiesas son de color mohoso; hojas elipticas ó elíptico-lanceoladas, con una punta, de dientes como cortantes, larcas como de $18^{\prime \prime \prime}$ a $8^{\prime \prime \prime}$, sobre $8^{\prime \prime \prime}$ a 4 "' de 
ancho; las menores al contrario tienen solamente 40 ?" de largo, con pelo tieso y esparcido, triplinervias, con venas lineares mas pronunciadas $\mathrm{y}$ mas gruesas por la cara.superior que por la inferior: estípulas como redondas, abiertas, membranáceas, de color mohoso y persistente; cimas andrójinas, espigadas y apenas mas largas que las estípulas. P. rufu, Wedd. Urtica rufa, Swtz.

14. Cimas cortamente pedunculadas y contraidas, 15. - Cimas largamente pedunculadas, desparramadas y esertas, 18.

15. Flores dioicas; hujas lijeramente aserradas hasta cerca del vértice y cuyos dientes son truncos: venitas lineares $\mathrm{y}$ visibles por ambas caras, 16. - - Flores monoicas; hojas aserradas hasta mas allá de la parte mediana y cuyos dientes son puntiagudos: venitas lineares visibles, especialmente por la cara superinr, 17 .

16. Terba como de 1', glabra y con hojas lanceolado-oblongas. puntiagudas, algo redondeadas por la base, largas de 2 á 3 " y anchas de 12 a 18 "'; triplinervias y cortamente pecioladas ; cimas contraidas y dos veces mas cortas que el peciolo de las hojas, el cual es delgado y de 4 á 8" de largo: las flores masculinas están en corimbos ramosos y las femeninas en espigas, de pedúnculos cortos en ambas clases. P. reticulata, Wedd.

17. Yerba como de 1', un poco áspera, cuyas hojas inferiores son alternas, mientras las superiores son opuestas, lanceolado-elípticas con una punta, acuñadas por la base, trinervias, algo espesitas, largas de 2 á 3", sobre 18 á 10 "' de ancho, cuyo peciolo tiene 1" á 1 " $1_{1} 2$ de largo; cimas contraidas, diminutas $y$ cuatro reces mas cortas que el peciolo delgado y algo dilatado por el rértice, subsesiles é inferiores, mientras las masculinas, caulinares ó axilares son superiores: en el fondo del perigonio hay un nectario ciatiforme. P. sessiliflora, WVedd, Urtica sessiflora, Swtz. U. variegata, Sprg.

18. Tallo subfruticoso; cimas abiertas y estendidas, 19. - Tallo subfrutico:o mas ó menos suculento y herbáceo; cimas abiertas y estendidas, vejetales lampiños, 22 .

19. Flores siempre dioicas y en espigas interrumpidas; hojas gruesamente festoneadas, enteras por la base, con venitas pequeñas visibles por ambas caras, 20. - Flores dioicas y raras veces monojcas, casi espigadas; hojas gruesamente festoneadas, cuyas venitas son visibles por ambas caras, 21.

20. Nata de como 3 á 4' de altura, lampiña, cuyas hojas oblongolanceoladas, lanceoladas ó elípticas, aguzadas y 3 ó 5 nervias, son largas de $5^{\prime \prime}$ á $2^{\prime \prime}$, sobre 24 " á $8^{\prime \prime \prime}$ de ancho, redondeadas ó algo acorazonadas por la base, con dientes agudos; estípulas oblongo-lanceoladas, largas de 4" ; cimas tan largas ó mas que los peciolos, formadas de espiguitas del tamaño de un guisante y hasta menor. P. - densiflora, Kth.

21. Vejetal de unos piés de altura, lampiño y con hojas grandes ovales provistas de una puntita, ordinariamente algo acorazonadas por la base, triplinervias ó trinervias, cuyos dientes son obtusos, largas de 6" y anchas de 3", con peciolo de 2"; estípulas ovaloblongas y largas de 10"'; cimas mas largas que los peciolos y mas cortas que las hojas. P. grandis, Wedd. Urtica grandifolia, L. 
22 . Flores dioicas en cimas estendidas; hojas diminutamente repando-aserradas hasta mas allá del medio, con venitas visibles por la sola cara superior, 23. - Flores monoicas, cuyas masculinas son como en especie de cabecita; hojas repando-aserradas, con la base entera y cuyos dientes son obtusos y estendidos: venitas lineares visibles por la cara superior, 24 .

23. Yerba de 1" con hojas lanceoladas, cuyas inferiores menores son elípticas, todas aguzadas, triplinervias, largas de 3 á 4 ", sobre 20 "' á 8 de ancho, callosas por la márjen; cimas largamente pedunculadas, casi tan largas como las hojas, de las cuales las femeninas tienen muchos brazos filiformes. P. semidentata, Wedd. Urtica semidentata, Poir.

24. Yerba como de 1', cuyas hojas oval-oblongas y con puntitos

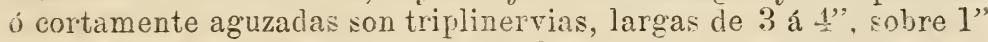
á 1 " 1 [2 de ancho, redondeadas y algo acorazonadas por la base, cuyo peciolo es dos reces mas larono que las estípulas oblongas, decíduas y largas de 2 á 3"'; cimas largamente pedunculadas y casi tan largas como las hojas, cuyas musculinas contraidas están partidas, mientras las femeninas tienen muchos hrazos. $P$. gondotiana, Wedd. P.elegans, Wedd.

25. Cimas recojidas, 26. - Cimas estendidas y desparramadas, 41 .

26. Subsesiles, 27. - Algo ramosas y pedunculadas, 34 .

2\%. Flores dioicas, 28. - Flores andrójinas, 29.

28. Yerba cuyo tallo de 3 á 4" de largo, rastrero y arraigante, algo anguloso y estriado, lampiño y suculento, con ramitas cortitas y escondiditas en los céspedes, lleva hojas opuestas acuñadas y orbiculares á la par. festoneadas por debajo de la parte media, trinervias, glabras, dobles, algo suculentas y de como 4" de ancho, moreno-verduscas, estípulas ovales persistentes, situadas entre las hojas y semi-abrazadoras, pequeñas y blanquecinas: venitas lineares situadas por debajo y cerca de la márjen de la cara superior. cuyas marjinales son diminutas y puntiformes; flores terminales y saliendo de entre las hojas. P. depressa, Bl. Urtica depressa, Sivtz.

29. Tallo rastrero, arraigante y peludo, 30. - Tallo trepador, arraigante ó á veces rastrero por la base y ascendente, 31 .

30. Yerba de tallo bastante largo, filiforme y estriadito, ramosito y con hojas orbiculares, festoneadas como hasta en medio, nervosovenosas por ambas caras, largas de 6"" á 4"', sobre 6" "á $3^{\prime \prime \prime}$ de ancho, cuyo peciolo es casi tan largo como ellos; las ramitas son opuestas $y$ se terminan por un verticilo de 4 hojas que contiene las flores; estípulas opuestas, pequeñas y blanquecinas; en las flores femeninas cuyas divisiones perigoniales son pestañosas hay en el fondo un nectario ciatiforme diminuto. P. nimmularifolia, Wedd. Urtica nummularifolia, Swtz. : C. T. Y., pár. 352.

31. Tallo trepador o arraigante cuyos ramos no son nunca ascendentes, 32. - Tallo no trepador, pero de base rastrera, arraigante y cuyos ramos son ascendentes, 33 .

32. Yerba cuyo tallo elongado, glabro, cilíndrico y algo suculento 
tiene ramas opuestas que cargan, con hojas ovales ú oval-oblongas, obtusas, acuñadas por la base entera, obtusamente aserradas, lisas y lustrosas, con solo 3 á 4 dientes por cada márjen, triplinervias, largas de $6^{\prime \prime}$ á $4^{\prime \prime \prime}$, sobre 3 "' ó $2^{\prime \prime \prime}$ de ancho y cortamente pe. cioladas; venitas lineares en la cara superior, mientras las de la cara inferior son puntiformes y apenas visibles; estípulas diminutas; flores subsesiles y pocas. P. radicans, Wedd. Urtica radicans, Swtz.

33. Yerba alampiñada con tallo elongado de como 6" de largo, cuyos ramos opuestos $y$ subdivididos cargan con hojas opuestas, ovales con una punta, dentado-aserradas, de base acuñada y entera, trinervias, con pelo esparcido por los nervios, cuyas venitas poco notables y por fin lineares, son visibles por ambas caras ó puntiformes por la superior, largas de 18" á 8', sobre 2 á 4" 'de ancho, pestañosas y cuyo peciolo delgadito y pubescente tiene 4 á 8 "' de largo; estípulas mínimas, conadas, amplexicaules y supra-axilares; divisiones perigoniales pestañosas en las flores masculinas. P. Swartzii, WVedd. U. ciliata, Swtz.

34. Tallo rastrero arraigante, 35. - Tallo nunca rastrero ni arraigante tampoco, 38 .

35. Peludo ó lampiñito; hojas ovalo-redondas, festoneado-aserradas, con la base entera y trinervias, 36. - Lampiñito cuya base sola estio rastrera y arraigante, mientras la parte superior es ascendente; hojas ovalo-redondeadas y obtusamente aserraditas hasta mas allá de en medio, 37.

36. Yerba raras veces alampinada, alta de como unas 6 á 8", cuyas hojas largas de 10 "' á 6"' y de 8"' á 4"' de ancho, con frecuencia tan largas como anchas, con pelo especialmente en los nervios de la cara inferior, raras veces alampiñadas, nervios laterales arqueándose por debajo del medio del limbo; estípulas anchamente oblongas, estendidas y persistentes, cimas andrójinas y raras veces unisexuales contraidas ó con algunos brazos, cuyos pedúnculos igualan al peciolo ó á las hojas mismas. P. nummularia, Gr. P. repens, Wedd. U. repeins, Swtz.

37. Yerba de tallo desnudo inferiormente, simple, corto, delicado $\mathrm{y}$ con hojas trinervias, de cara inferior lampiña y verdemar, mientras la superior tiene pelo transparente y poco, ó es alampiñada, membranosas, con tres dientes por cada márjeñ, venitas lineares visibles, especialmente por la cara inferior, agrupadas cerca de la márjen y desapareciendo en medio del disco; peciolo largo de $6^{\prime \prime \prime}$ á $1^{\prime \prime \prime}$; estípulas redondeadas, pequeñas y persistentes; cimas unisexuales, con pedúnculo igual al peciolo ó á las hojas mismas; las masculinas son glomeruliformes y peludas. P. rotundata, Gr.

38. Flores andrójinas en cimas contraidas ó poco ramosas, 39.Flores dioicas, cuyas cimas masculinas son contraidas y las femeninas estendidas y con pocos brazos, 40 .

39. Yerba de tallo corto $\mathrm{y}$ desnudo inferiormente y cuya parte superior ó ascendente, larga de 2 á $6^{\prime \prime}$, peluda ó alampiñada, carga con hojas ovales provistas de una punta, gruesamente festoneadoaserraditas, de base entera. trinervias, lampiñas ó con algun pelo 
transparente, y largas de $12^{\prime \prime}$ ó $1^{\prime \prime} 1_{1} 2$, sobre $4^{\prime \prime \prime}$ á $14^{\prime \prime \prime}$ de ancho; venitas lineares visibles por ambas caras, con peciolo largo de 10 á $12^{\prime \prime \prime}$; estípulas ovales, obtusas y per'sistentes, largas de 1 "'; cimas axilares en las hojas superiores é iguales con los pedúnculos. $P$. incequalis, Wedd.

40. Planta herbácea alampiñada, cuyo tallo de 5" á $1\left[2^{\prime \prime}\right.$ de alto. es ramoso inferiormente, lampiño y ascendente por el vértice, con hojas ovales con una punta, grosera y agudamente aserradas, de base entera, trinervias y largas de 3 á $1_{[} 2^{\prime \prime}$, sobre 24 á $3^{\prime \prime \prime}$ de ancho, opuestas y pecioladas; venitas lineares visibles por la cara superior; estípulas anchamente oblongas y persistentes; pedúnculo de la cima largo é igualando al peciolo ó á las mismas hojas terminales y de cuya axila sale. P. laxa, Wedd. Trtica laxa, Swtz.

41. Pedunculadas y andrójinas, 43. - Sesiles y tambien andrójinas, 12 .

42. Terba de tallo largo de 12 á $4^{\prime \prime}$, lampiño, erguido, con hojas oval-redondas con una punta ú obtusas, aser'radas, con la base entera, trinervias, lampiñas ó con algun pelo transparente y situado por su cara superior; largas como de $1^{\prime \prime \prime} \mathrm{y}$ frecuentemente mas cortas que el peciolo; venitas lineares visibles por ambas caras; estípulas mínimas; cimas formando rertícilos sentados y mas cortos que los peciolos; aquenio diminuto, oval y obtuso. P. hyalina, Fzl. Urtica pumila, Euph. C. T. T. 354.

43. Tallo sofruticoso y leñoso dicótomo, 44. - Tallo mas ó menos herbáceo r nunca leñoso, 45 .

44. Mata lampiña cuyos ramoż desparramados, largos de como ' 2 poco mas ó menos y herbáceos, cargan con hojas orales provistas de una punta ú obtusas, aserradas y de base entera, alampinadas ó pubescentitas á lo largo de los nervios de la cara inferior, opuestas, largas de 12 á $18^{\prime \prime \prime} \mathrm{y}$ pecioladas; estípulas estraxilares, semiabrazadoras, bífidas y de márjen arrollada hácia afuera, venitas lineares visibles por ambas caras; cimas ombeliformes, cuyos pedúnculos son ordinariamente tan largos ó algo mas que las hojas superiores, de cuya axila salen. P. diffusa, Wedd. Urtica diffusa. Siv.

45. T'allo peludo, rastrero y arraigante por la base, desnudo, de vértice ascendente y con hojas, 46. - Tallo peludo ó alampiñado no arraigante, cuyos ramos son ascendentes y herbáceos, 47.

46. Ovales de vértice redondo, obtusamente aserradas y de base entera, 3 ó 5 nervias, con la cara inferior lampiña, mientras la superior tiene pelo esparcido y transparente, membranosas, largas de 16 á 12"', sobre 12 á $6^{\prime \prime \prime}$ de ancho, pestañosas, 3 á $ّ$ nervias; venitas por la cara inferior; estípulas anchamente oblongas, obtusas y persistentes; cimas piramidales cortamente pedunculadas, cuyos pedúnculos son casi tan largos como los peciolos; aquenio diminuto oblícuamente oval redondeado. $F$. ovalis, Gr.

47. De hojas grandes ovales con una punta ú obtusas, largas de 3 á $2^{\prime \prime}$, gruesamente aserradas y enteras por la base sub-acorazonada ó anchamente acuñada, 3 nervias con renitas chiquitas lineares y visibles por ambas caras; estípulas largás de 4 á $2^{\prime \prime \prime}$, estendi- 
das o persistentes; cimas corimbiformes y apanojadas á la par, anchamente pedunculadas y ordinariamente igualando á las hojas. P. pubescens, Lieb. P. diffusa, Gr. P. furcata, Lieb. P. acuminata, Lieb. P. grossecienata, Miq. Urtica involucrata, Sims. U. graidifolia, Swtz.

G. III. Urtica, L. - 1. Flores dioicas, 2. - Flores monoicas 0 andrójinas, 5 .

2. Alguna vez que otia sin tallo, 3. - Siempre con un tallo erguido, 4 .

3. Yerba cuyo tallo, cuando existe, es cortito, de hojas ordinariamente radicales, anchamente pecioladas, erguiditas, ohlongas, aguzadas, un poco aserradas, nervioso-venosas, alguna vez que otra ásperas, pubescentes; estolones cauliformes rastreros, cilíndricos, simples, saliendo de la raiz del lado de las hojas y que llevan hojas opuestas, sub-redondas, oblongas, dentadas, nerriosas, veludo pubescentes y algo rizadas; estípulas situadas hácia la base de los peciolos, abrazadoras, oblongas, enteras y membranáceas; perúnculos saliendo del centro de las hojas radicales, mas largos que ellas, filiformes erguidos y lampiños; flores masculinas en cabecita contraida, mientras las femeninas son en cimas estendidas y formadas de flores diminutas; aquenio oblongo. U. stolonifera, Swtz.: C. T. V., pár. 352.

4. Planta herbúcea de hojas opuestas, aspadas, pecioladas, oblongas, angostadas por ambos estremos, obtusas aserradas, 3 nervias, con venas rugosas situadas hácia la márjen, alampiñadas y pelitiesas por los nervios y las renas, cuyos peciolos algo comprimidos son pelierizados; estípulas ovales situadas entie las hojas; flores masculinas apretadas, diminutísimas y dispuestas en racimitos terminales estendidos y mas cortos que las hojas, mientras las femeninas son en cabecitas. $U$. rugosa, Swtz.

う. Planta lampiña, 6. - Planta alguna vez que otra lampiña, pero con mayor frecuencia pubescente, $\boldsymbol{7}$.

6. Como de $1^{\prime}$ de alto, cuyo ramos amanojados, simples, cilíndricos y quebradizos están acompañados de estolones larguísimos, filiformes y saliendo de la base; hojas pecioladas, opuestas acorazonadas y redondeadas á la jar, aserradas, 3 nervias, venosas y lampiñas, de peciolo largo algo cilíndrico y lampiño, mientras las que salen de los estolones son cortamente pecioladas y orbiculares, con estípulas opuestas, oblongas, blanquecinas, enteras y situadas entre las hojas; flores en racimos pedunculados, terminales, casi apanojados, diminutísimos y blancuzcos, cuyos pedícelos y perigonios son de color rojizo. $L^{\prime}$. betulafolia, Swtz.

7. Yerba cuyos tallos desparramado y ramosos son cilíndricos, lampinos ó pubescentes, con rarno I ramitas estendidos, rastreros y pubescentes; hojas alternas pecioladas, las terminales son un poco verticiladas $\mathrm{por}$ á tres ovales, tan anchas como largas y de $1\left[2^{\prime \prime}\right.$ de diámetro, algo mas anchas por la base, integérrimas y aguzadas, con el peciolo corto y pubescente; las de los ramos son blancas y velludas; estípulas laterales; flores diminutas apretadas en medio de las hojas terminales, cuyas masculinas en cimas piramidales, de 
perigonio con cuatro divisiones pestañosas y estrechitas, pelitirojizas, tienen en el fondo de aquel un nectario ciatiforme diminutísimo $\mathrm{y}$ con el rudimento del pistilo; mientras las femeninas en cabezas sentadas y verdes están acompaĩadas de dos brácteas mínimas membranosas y situadas por debajo del perigonio rentricoso que tiene solamente 2 á 3 divisiones valvares; estigma filiforme y deciduo. U. lapulacea, Swtz. Rousselia lapulacea, Gaud.

G. IV. Boehmeria, Jacq. 1. Flores dioicas, 2. - Flores monoicas ó andrójinas, 3.

2. Arbusto de $3^{\prime}$ hasta $10^{\prime}$ de altura, cuyo tallo derecho, simple ó alģo ramoso, cilíndrico, estriado y verrugoso hácia el vértice que corresponde con las hojas desprendidas y es pelitieso; hojas agrupadas hácia la sumidad de los tallos y de las ramas opuestas, grandes, ovales ó lanceoladas, estendidas, aguzadas, nervicso-venosas, festoneado-aserradas, de cara inferior pelierizada, mientras la superior es áspera, largas de 10 á 6", largamente pecioladas; estípulas distintas; flores en espigas axilares, laterales y situadas algo por debajo de las hojas, terminales, larguísimas, colgantes y for-. madas de grupitos algo redondos y alternatívamente interrumpidos por brácteas lanceoladas, membranáceas aleonadas y decíduas; tale: espigas son tan largas ó mas largas que las hojas; flores femeninas desnudas; aquenio sub-redondo y comprimido á la par. B. cuudatu, Swtz.: C. T. V. 69.

3. Hojas opuestas, 4. - Hojas alternas, 5.

4. Planta herbácea ó sofruticosa, alta de 2' á 3' algo mas ó menos, de tallo derecho y erguido, estriado, alguna vez que otra ramoso; con cuatro caras, acanalado y lampiño, cuyos ramos opuestos, erguidos y estriados lleran hojas raras veces alternas, ovales ú oblongo-lanceoladas, aguzadas, festoneado-aserradas, aspadas, pecioladas 3 nervio-venosas, alampiñadas y lustrosas por la car'a superior; estipulas distantes. Flores en espigas axilares, ordinariamente simples, frecuentemente con brácteas hasta el vértice, andrójinas y formadas de grupos unisexuales, cuyos masculinos son paucifloros y casi sentados, mientras los femeninos multifloros é imbricados se hallan hácia la base de la hoja floral. B. cylindrica, Wedd. B. littoralis, Swtz. Critica cylindrica, L. U. reticulata, Swtz.

כ. Nata sofruticosa ó herbácea; estigna deciduo, 6. - Arbustillo; estigma persistente, $\%$.

6. Pubescente de unos 2', algo mas ó menos, de altura. cuyo tallo, erguido, cilíndrico, estriado, pelitieso y ramoso, lleva hojas ovales aguzadas, dentado-aserradas, nervioso-renosas, ásperas y pelierizadas por la cara superior, mientras la inferior es pelitiesa solamente, cun peciolos larguitos, inclinados, estriados y pubescentes; estípulas laterales. Flores femeninas desnudas, aqueirio diminuto, cónico y negro. B. hirta, Swtz. B urticifolia, Pers. Phenaix urticifolia. Ph. larigata. Ph. Haitensis, Wedd.

7. Arbustillo cuyo tallo liso se eleva á unos $5^{\prime}$ ó $\tau^{\prime}$ de altura, con ramos alternos poco ramosos, cilíndricos y en varita, estendidos $y$ reclinados, pubescentes y estriados; hojas oblícuamente aovadooblongas ó lanceolado-oblongas, aguzadas por el vértice y festo- 
neado-aserradas por la base, ásperas, algo pubescentes ó alampinadas, desiguales de tal suerte que las unas son largas de 3 "á $12^{\prime \prime}$, mientras las otras lo son solamente de $1^{\prime \prime}$ á $5^{\prime \prime}, 3$ nerrias y venosas. con peciolo cuya lonjitud varia mucho, cilíndrico y pubescente. Flores monoicas en racimitos laterales ó axilares, cuyas masculinas interiores salen de la axila de las hojas inferiores ó se hallan agrupadas en las ramitas desprovistas de hojas, cortamente pediceladas ? 3 andras, mientras las femeninas desnudas y acompañadas de brácteas son mas ó menos numerosas y superiores; aquenio oral comprimido y marjinado. B. ramiflor

Familia 39. - ARTOCARPACEAS. - Arboles ó arbustos fiutices, ó matas las mas reces lechosos, de hojas simples alternas o dísticas, pecioladas, enteras, aserradas, pinatífidas, palmatilobas ó peltado-dicuitadas, con una ó con dos estípulas libres, axilares ó algo laterales y caducas. Flores monoicas ó dioicas, con los estambres erguidos en la yema, dispuestas en cimas apanojadas, en racimos, en espigas ó en especie de cabeza, y muchas, agrupadas en un l'eceptáculo concavo, cilíndrico ó plano, á veces vuelto una especie de involucro. Las masculinas constan de un perigonio de dos hasta seis dirisiones, cuya estivacion es empizarrada y rara vez valvar, casi nunca abiertas $\mathrm{y}$ de tantos estambres como divisiones perigoniales hay, alguna que otra vez se hallan en número menor, insertos por la base del perigonio y opuestos á sus divisiones, con filameñtos erguidos, libres, rara vez soldados entre sí, cuyas anteras, er@uidas ó inclinadas introrsas $\dot{0}$ estrorsas son biloculares $\mathrm{r}$ se abren por una grieta lonjitudinal, otras veces uniloculares peltadas y con dos laminitas sueltas que acompañan su abertura; las femeninas al contrario, se componen de un periantio tubuloso, entero, de base algo desviada, otras veces con tres á cinco divisiones que parecen raras: veces como liojuelitas mas ó menos reunidas entre sí: suelen faltar alguna vez que otra; pistilo formado de un estilo simple, terminal ó escéntrico. que se termina por un estigma filiforme expatularlo, peltado ó apincelado, otras veces dentado, bífido ó bidentado, y por fin rarísima rez tríficlo; ovario libre ó infero unilocular y casi nunca bilocular ó trilocular, de celdas monospermas con huerecillo basilar. y ortótropo ó parietal; otras veces colgante del vértice de la celda y entónces anátropo ó campilótropo. Fruto encerrado en el perigonio persistente pergamináceo ó drupáceo, otras veces agrupadas las semillas en un involucro carnoso, y en ese caso abayado: mas raras veces en cono capsular que se abre en dos ventallas; semilla única con testa membranácea, cuyo embrion, incluso en el eje del endospermo () con mayor frecuencia exalbuminado ó sin endospermo, es liomotropo, antítropo, ó por fin anfítropo; radícula superior.

\section{Anuilisis dicotomica de las tribus.}

1. Flores femeninas unchísimas agrupadas sobre un receptaculo, 2. - Flores femeninas pocas ó algunas solamente agrupadas juntas sobre un receptáculo apenas pronunciado, 3. 
2. Siempre muchísimas flores femeninas agrupadas densamente sobre un receptáculo globoso ú oblongo, algunas veces mezcladas con las masculinas, huerecillo péndulo ó colgante. T. I. Euarto('ÍRPEAS. - Muchas flores femeninas agrupadas sobre un receptáculo llano ó algo concavo y provisto esteriormente de escamas empizarradas, pero las mas reces solitarias: huerecillo colgante. T. II. Olmedíeas. Olmedin Cubensis. Castilloa elastica. Cav.

3. Flor femenina única, rarísima vez hay dos flores soldadas con el receptáculo ó con el involucro; huevecillo colgante. T. III. BroSInE. nidas, 4.

4. Huevecillo sublateral semianátropo; estigma discoideo y peltado á la rez; flores femeninas apanojado-cimosas y mas raramente agrupadas hácia el ápice de los pedúnculos segundarios. T. IT. Pourouneas. - Huerecillo único, erguido, inserto hácia la base de la celda; estilo corto cuyo estigma sencillo capitado y á la par apincelado es alguna rez que otra lateral ; flores femeninas en especies de amentos amanojados. T. V. Coxocefaleas.

T. I. Euartocárpeis. C. T. Artocarpus. - 1. Hojas mas ó menos pinatífidas, muy grandes, 2. - Hojas enteras no muy grandes, 3.

2. Árbol muy corpulento y grande, cuyos ramos, muy gruesos, muy largos y desnudos, se van ramificando hasta volverse ramitas cuyo rértice inclinado lleva hojas cortamente pecioladas, largas de como 1' 1 [2 ó menos, sobre $6^{\prime \prime}$ á $8^{\prime \prime}$ de ancho, sinuoso-pinatífidas y algo redondeadas, ásperas y cuyos lóbulos enteros y oblongos tienen una punta; hay dos estípulas lanceoladas, grandes, por afuera velludas y caedizas; perigonio masculino bífido: estilo bi ó tripartido; fruto formando una especie de sincarpio carnoso bastante grueso, con ó sin pepitas que parecen castañas. A. incisa, L.: C. T. V., pár. 201.

3. Arbol muy parecido al precedente del que difiere por sus ramos no tan estendidos, por sis hojas enteras oral oblongas ó elípticas con una punta y mucho mas pequeñas, de cara superior lisa, lustrosa y verde oscuro, mientras la inferior mas pálida lleva pelo; por sus ramitas y pedúnculos peludos y por el fruto largo y mucho mas grueso: perigonio masculino lipartido: estigma simple. A. integrifolia L.: C. T. V., pár. 202.

G. II. - Trophis americana, L.: C. T. V.. pár. 165.

T. III. Brosmens. G. III. Brosimum.-1. Arbol grandísimo cuyo tronco picado deja chorrear con abundancia una leche comestible y nutritiva. B. galactodendron, Kth.: C. T. V., pár.204. - Arboles no tan grandes y cuya leche no es tan abundante ni comestible tampoco, :2-

2. Hojas enteramente lampiñas con doce venas principales sa. liendo de cada lado de la costilla, 3. - Hojas de cara superior lustrosa, mientras la inferior es pubescentita y de color mohoso, con ocho venas principales saliendo de cada lado de la costilla. 3.

3. Arbol bastante alto y corpulento cuyas hojas oblongas ó elíptico-oblongas ticnen una punta ó una puntita largas de 3 á $6^{\prime \prime}$; pedícelos tan largos como el pecinlo y el diámetro de los amentos: que es 
de 2 a $3^{\prime \prime \prime}$; fruto globoso de 10 á $12^{\prime \prime \prime}$ de diámetro solamente. $B$. alicastum, Swtz.: C. T. V., pár. 203.

4. Arbol mas bajito; con hojas oblongas ú oboval-oblongas, con una puntita y largas de 2 á $3^{\prime \prime}$; amentos cortamente pedunculados é igualando casi los peciolos. $B$. aubletii, Pæp.

T. V. Conoceríleas. G. IV. Cecropia, L. 1. Hojas 7 ó 9 lobadas y partidas hasta el $1[3$ de su diámetro, 2. - Hojas 7-9-11 lobadas y partidas solamente hasta en medio, 3 .

2. De cara superior áspera y verde, mientras la inferior es blanco-tomentosa, con los nervios ordinariamente alampiñados; el limbo de como $l^{\prime}$ de diámetro, cuyos lóbulos ovales y con una punta son enteros y desiguales entre sí, largamente pecioladas; flores masculinas numerosas en los receptáculos y cortamente pediceladas, las femeninas al contrario son solamente 4 ó 2 y sesiles. C.peltata, L.: C. T. V., pár. 63.

3. Asperas y alampiñadas á la vez por la cara superior, mientras la inferior es blanco-tomentosa, con lóbulos oboval-oblongos y obtusos. C. palmata, IV.

Familia 40. - CELTIDEAS. - Árboles ó arbustos con ramos alternos, frecuentemente armados de espinas axilares, con hojas alternas, enterísimas ó aserradas, casi siempre trinervias y acompanadas de estípulas caedizas. Flores polígamas solitarias, cimosoapañojadas ó racimosas, con perigonio calicino pentafilo ó 5 partido, empizarrado en la estivacion, abierto en la florescencia, deciduo ó persistente; estambres 5 , insertos en lo bajo del perigonio y opuestos á sus segmentos ú hojuelas, de filamentos rollicitos, casi siempre cortos, encorvados en la estivacion, enderezándose elásticamente en la florescencia, con anteras biloculares, articuladas por el dorso en el ápice del filamen ${ }^{+} \rho$, de ordinario estrorsas en la yema y despues introrsas, lonjitudinalmente dehiscentes. Pistilo con ovario aovado, frecuentemente inequilateral, unilocular, con un solo huevecillo fijo en la pared cerca del ápice y anfítropo con micropilo superior, de cuyo ápice salen 2 estilos con estigmas aleznados. Drupa poco carnosa y monosperma, de semilla pendiente, arqueada hácia arriba, con tegumento tenue, membranoso ; endospermo carnoso, escaso ó desvanecido; embrion derecho, ganchudo, con cotiledones planos ó conduplicados é incumbentes, de raicilla larguita y súpera.

G. I. Celtis, L., 1. - Anteras prolongadas por la base; estilos lineares enteros, 2. - Anteras iguales por la base; estilos bífidos, 3.

2. Árbol sin espinas, son hojas aovadas, oblicuas poi la batse, cuspidadas, aserradas superiormente, alampinadas, con las nervaduras saliendo de la base y proeminentes inferiormente. C. (rini)via, Lam.-C. Jamaicensis.-C. Suartzii, Planch.

3. Arbusto sarmentoso, muy ramoso, con las espinas estipulares recorvadas; hojas aovado-oblongas, subtriplinervias y lijeramente oblicuas por la base, enteras y lampiñas. Flores cimosas; drupa aovada amarillenta, carnudita, cuyo pedícelo es tan largo como el peciolo. C. aculeata, Sw. - Rhannus iguaneus, L. - Ziziphus iguanea, L. - Mertensia aculeata, W. - M. lerigata, W. con dos ra- 
riedades, de las cuales una tiene las hojas aserradas superiormente. $C^{\prime}$. servata, y la otra las hojas y la inflorescencia pubescentes. $C$. pubescens. C. T. V., 674.

F́amilia 41. - MOREAS. - Írboles o ar rustos mas ó meno: lechosos y tambien yerbas acaules de hojas simples, radicales, mas (i menos lobadas y largamente pecioladas: cuando pertenecen á los írboles son, al contrario, siempre ramales enteras, alternas mas $\dot{0}$ menos pecioladas; estípulas frecuentemente enrolladas y conteniendo entónces la yema en la prefoliacion, persistentes ó caedizas y dejando casi siempre en pos de sí una cicatriz semi-anular; flores unisexuales, cuyas masculinas ordinariamente amentaces espigadas ó racimosas, ocupando á veces la parte superior ó los lados diel receptáculo, se componen de un perigonio 3 o 1 partido, cuyas divisiones son empizarradas durante la estivacion, y alguna vez suelen faltar enteramente; hay 3 á 4 estambres insertos en el fondo perigonial y opuestos á las divisiones, de filamentos filiformes ó subuladas, lisos ó arrugados por el través, al principio encorvados en la yema y por último estendidos y algo esertos que llevan una antera introrsa, bilocular aovada y casi globosa, dorsifija, derecha, recostada y lonjitudinalmente dehiscente; pístilo rudimentario y algunas veces enteramente borrado: las flores femeninas son, al contr.ario, mas densamente espigadas ó apretadas en receptáculos mas o menos globosos, algunas veces entremezcladas con las masculinas sobre un receptáculo plano y abierto, piriforme, cerrado y sin mas abertura que su ápice en donde se hallan las masculinas; están formadas de un perigonio tetráfilo o con 5 hojuelitas concavas y biseliadas, cuyas esteriores son mavores, pístilo cuyo ovario sentado $\dot{n}$ mas ó menos estipitadito, es unilocular ó rara vez bilocular con una celda menor y vacía, mientras se halla en la otra un huevecillo inserto en medio de la pared, anfítropo, encorvado y con el micrópilo superior, estilo terminal y bífido, o escéntrico y entero. El fruto consiste en un aquenio ó en utrículos monospermos inclusos cn un perigonio que se vuelve carnoso, libres o unidos entre sí para tormar un sincarpio, otras veces están contenidos en un receptáculo carnoso, raras veces se hallan sostenidos por un estipillo alojado, y parcialmente ceñidos por sus márjenes; semilla única y como ganchosa, de tegumento crustáceo y irrájil ó tenue y membranáceo, con al hilo ventral; endospermo carnoso y embrion derecho ganchoso. con cotiledones oblongos, planos é incumbentes ó lecostados y cuy laicilla nas o menos laiga es súpera.

G. I. Maclua, Nutt. - i. Arboles sicmpre espinosos: 2.Arboles inermes, $\because$.

2. Con hojas gruesamente aseliadas, oval-oblongas ú oblongas. con una puntita, redondeadas ósub-acorazonadas por la base que es algo desigual, lampinas: espigas masculinas cilíndricas; cahecitas femeninas globosas, cuyas flores tienen un estilo mas largo que st diámetro. M. xanthorilon, Endl. Broussonetia tinctoria, Klh. Mo ins werthoxilon, Jacq.

3. Arbol cuyas hojas sub-enteras oblongas, aguzadas y sub-troncadas por la base son alampiñadas ó pubescentes en los nervios de la 
cara inferior, blanquecinas; flores masculinas en espigas cilíndricas, mientras las femeninas son en cabecitas globosas, casi tan largas como los peciolos; estilos casi tan larges como el diámetro de las flores. M. tinctoria, Don.: C. T. V., pár. 459.

G. II. Morus nigia, L. Maral.

G. III. Ficus, L. - 1. Hojas palmeadas y 5 lobas; 3 estambres, 2. - Hojas nunca palmeadas ni lobadas tampoco, pero siempre enteras; 2 estambres, 3 .

2. Este vejetal, que en Europa se eleva de 20' hasta $25^{\prime}$ de altura, se queda en las Antillas y en el continente americano al estado de arbusto, de tallos poco ramosos y casi derechos, con hojas bastante grandes largamente pecioladas y acorazonadas por la base, de cara superior verde oscuro, lustrosa y áspera, mientras la inferior, de color mas pálido, es pelitiesa; frutos bastante gruesos, morados ó blanco-amarillentos. $F$. carica, L.: C. T. V., pár. 627.

3. Fruto mellizo las mas veces y cuyo diámetro transversal es de como 2 á $3^{\prime \prime \prime}$ solamente, 4. - Fruto siempre solitario, cuyo diámetro transversal es de $4^{\prime \prime \prime}$ hasta $12^{\prime \prime \prime}, 7$.

4. Hojas lanceolado-oblongas; fruto globoso casi tan largo como su pedúnculo pruinoso y aplanado por el vértice, 5. - Hojas ovaloblongas ú oblongas; fruto 3 ó 4 veces mas largo que el pedúnculo $\mathrm{y}$ á veces cóncavo por el ápice, 6 .

5. Árbol regular de hojas oblongas, obtusas, ó con una punta, redondeadas por la base, largas de 2 " 1 [ á 3 " sobre $3\left[4^{\prime \prime}\right.$ ó 1 " 1 [ 2 de ancho, con 8 á 14 nervaduritas apenas notables y cuyo peciolo es largo de unas 3 á $6^{\prime \prime \prime}$; frutos algunas veces provistos de callos al rededor de la parte chata, de abertura cerrada, de $2^{\prime \prime} 1_{1} 2$ de diámetro y cuyo pedúnculo es largo de $2^{\prime \prime \prime}$ solamente: involucro bilobo y diminuto. F. sumacheri, Gr.

6. Árbol que se eleva como á $20^{\prime}$ de altura, con hojas coriáceas, redondas por el vértice y obtusas por la base, largas de 1 ó $2^{\prime \prime}$ sobre 8 á $12^{\prime \prime \prime}$ de ancho, cuyo peciolo asperito es largo de 2 á $3^{\prime \prime \prime}$, con 8 á 10 nervios apenas visibles; fruto lampiño amarilloso y por último rojo, con bracteitas que tapan la abertura $\mathrm{y}$ donde forman un pezoncito obtuso y cónico; involucro bilobo y diminuto. $F$. pertusa, L. - F. Americana, Swtz. - Lrostigma pertusa, Miq.

7. Higos de como 8 á $12^{\prime \prime \prime}$ de diámetro, 8.-Higos cuyo diámetro es solamente de 4 á $8^{\prime \prime \prime}, 13$.

8. Hojas mas ó menos elípticas ; invólucro diminuto, 10.-Hojas nunca elípticas, pero ovalo-redondas por el vértice que tiene á veces una punta obtusa; invólucro bastante grande y tan largo como el mismo fruto, 9 .

9. Arbol de hojas largas de 5 á $9^{\prime \prime}$ sobre 3 á $6^{\prime \prime}$ de ancho, cuyo peciolo cortito tiene solamente 2 á $9^{\prime \prime \prime}$ y provistas de 79 nervaduras; fruto globoso, subsesil, aterciopelado, con bracteitas que tapan la abertura ceñida por una especie de anillo calloso y mamiliforme; invólucro bilobado y aterciopelado; fruto con 8 a $10^{\prime \prime \prime}$ de diámetro. $F$. crassinervia, Desf. - Urostigma cassinervia. - U. arderianum, Miq.-U. trigonatum, Gr.

10. Hojas elíptico-oblongas con una punta; higos globosos ape- 
luzados ó alampiñados 2 á 3 veces tan largos como el pedícelo que los lleva, 11. - Hojas elípticas obtusas; higo lampiño mucho mas largo que su pedícelo, 12.

11. Arbol grande, de hojas cuya base es acuñada ó redondeada, con puntitos blancos esparcidos por la cara inferior, largas de 6 á $8^{\prime \prime}$ sobre $2^{\prime \prime} 1$ [ á $3^{\prime \prime}$ de ancho, con 12 á 15 nervaduras; peciolo largo de $1^{\prime \prime}$ á $1^{\prime \prime} 1_{1} 2$; fruto cuyo vértice está provisto de bracteitas anchas y formando un pezoncito distinto, umbilicado y convexo á la par, y alsierto. Ir. lawifolia, Lam. - F'. virens, Ait.- $F$. Martinicensis, IV;- Trostigma laurifolia, Mir. C. 'I'. B. 628.

12. Hojas olitusas por ambos estremos, algo ásperas y con puntitos blancos esparcidos por sus ambas caras, largas de 4 " y anchas de $2^{\prime \prime}$, con 7 á 8 nervaduras y curo peciolo es largo solamente de 6 á 8"': higno allanado ó achatado por el vértice, abierto y cuyo diámetro es de 8 á 10": invóluero con 2 lóbulos redonditos. $F^{\prime}$. suffocans, H. F. B. Ir. citrifolia, Lam.

13. Hojas mas ó menos ovales ó aovadas, 14.- Hojas ni ovales ni aovadas tampoco, 21 .

14. Ovales; ligos gloljosos, 4 á 5 veces tan largos como su pedícelo ó subsentados, puhescentitos ó alampiñados; invólucro $1_{[} 4$ tan largo como él, 15. - Aovadas, aovadc-acorazonadas ó aovadooblongas, 16.

15. Hojas redondas por ambos estremos ó sub-acorazonadas por la base, con 6 á 8 nervaduras y cuya cara superior está provista de puntitos blancos, largas de 3 á $5^{\prime \prime}$ solre 2 á $3^{\prime \prime}$ de ancho y cuyo peciolo es largo de 4 á $10^{\prime \prime \prime}$; fruto de 5 á $8^{\prime \prime \prime}$ de diámetro y teniendo la abertura del vértice tapada por bracteitas formando un pezoncito obtusamente cónico; involucro bilobo y pubescentito. $F$. trigona, L.- Lrostigma trigona, Miq.

16. Aovadas solamente $y$ una puntita; higo globoso lampiño y 3 á 4 veces mas largo que el pedícelo; invólucro diminuto, 17.-Aovado-acorazonadas ó aovado-oblongas, 18.

17. Hojas redondeadas ó sub-acorazonadas por la base, largas de ¿ $7^{\prime \prime} 3^{\prime \prime}$ sobre á $4^{\prime \prime} 2^{\prime \prime}$ de ancho y cuyo peciolo tiene ó $2^{\prime \prime} 1^{\prime \prime}$ de largo; nervaduras 8 á 10; higo allanado por el vértice cerrado, rojo y cuyo diámetro es de 6 á 8". F. lentiginosa, V. - F. tinctoria, Tuss. Urostigma lentiginosa, Lieb.-U. laurifolium, Gr.

18. Aovado-acorazadas ó aovadas con una puntita; higo apeonzado tan largo como su pedícelo, inclinado hácia abajo y glabro ; invólucro diminuto, 19. - Aorado-oblongas, ordinariamente con una puntita obtusa; higo globoso, casi tan largo como el pedícelo y lam piño, 20 .

19. Hojas un poco ásperas y con puntitos blancos esparcidos por la cara superior, mientras la inferior es diminutamente reticuladovenosa, largas de $\left.3^{\prime \prime} 1{ }^{2}\right\rceil^{\prime \prime} 1\left[2\right.$ á sobre ó $2^{\prime \prime} 1\left[21^{\prime \prime}\right.$ de ancho, con peciolo largo de 8 á $18^{\prime \prime \prime}$; fruto lijeramente umbilicado por el vértice, agujereado y bracteado, verdoso y de $6^{\prime \prime \prime}$ de diámetro. $F$. levigata, V.-Urostigma larigata, Lieben.

20. Arlol grande y coposo, con hojas redondeadas ó acorazonadas por la base, largas de 2 a $3^{\prime \prime}$ sol)re $1^{\prime \prime}$ o $1^{\prime \prime} 1[2$ de ancho, cuyo 
peciolo tiene 8 á 15"' de largo con 6 á 8 nervaduras poco pronunciadas; fruto rojo morenuzco, con bracteitas tapando la abertura del vértice en donde forman un pezoncito obtusamente cónico; involucro diminuto cuyos dos glóbulos son redonditos. F. populnea, W.I'rostigma populnea, Miq.

21. Mas ó menos elípticas ú oblongas, pero nunca lanceoladas, 22. - Nunca elípticas pero sí lanceoladas, mas ó menos oblongas, 25 .

22. Solamente elípticas y obtusas por ambos estremos; higo glohoso subsesil y lampiño, 23. - Oblongas ó clíptico-oblongas, con una punta; higos globosos, glabros, amarillentos y mas largos que el pedícelo estriadito, 24 .

23. Hojas largas de á $4^{\prime \prime} 2^{\prime \prime}$ sobre á $2^{\prime \prime} 1^{\prime \prime}$ de ancho, de peciolo largo de 8 á $10^{\prime \prime \prime}$, y con $\delta$ á 10 nervaduras; fruto con bracteitas que tapan la abertura del vértice donde forman un pezoncito convexo y ceñido por un anillo ealloso; invólucro $]_{1} 2$ o 3$]^{-1}$ tan grande como el fruto, y con 4 lóbulos irregulares. deltoideos ó redondos, ordinariamente sub-dimidiados. $F$. dimidiata, Gr.

24. Árbol bastante grande, con hojas redondeadas ó cortamente aeuñadas por la base, largas de á $4^{\prime \prime} 2^{\prime \prime}$ sobre $1^{\prime \prime} 1\left[21^{\prime \prime}\right.$ ó de ancho, cuyo peciolo tiene 6 á $8^{\prime \prime \prime}$ de largo, con puntitos diminutos y blanquecinos por ambas caras, 8 a 12 nervaduras apenas visibles: higo amarillo pálido, profundamente cóncavo por el rértice y cuyo diámetro es de 5 á $6^{\prime \prime \prime}$, bracteitas tapando su abertura $y$ formando en el centro de ella un punto convexo; invólucro diminuto cuyos dos lóbulos estendidos y redondeados tienen apenas $1^{\prime \prime \prime}$ de largo. $F$. ochroleuca, Gr.-F. pertusa, Swtz. $-F$. Americana, Lam.

25. Lanceolado-olylongas ó elíptico-oblongas, con una punta obtusa; ligos globosos, glabros y rojizos, casi tan largos como el pedúnculo, 26. - Lanceolado-oblongas y obtusas, pero jamas elípticas; higo globoso, lampiño, rojizo y 3 á 4 reces mas largo que su pedúnculo, 27 .

26. Árbol grande, con hojas acuinadas ó redondeadas por la base, un poco ásperas por causa de los puntitos blaneos espareidos por su superficie, ordinariamente largas de $3^{\prime \prime}$ y anchas de $]^{\prime \prime} 1$ [2, cuyo peciolo es largo de 4 á $6^{\prime \prime \prime}$, y con 8 á 12 nervaduras poco pronuneiadas; fruto aplanado por el vértice, ó algo calloso al rededor de sut abertura tapada; pedícelo inclinado $\mathrm{y}$ ordinariamente mellizo de 4 ¿ $6^{\prime \prime \prime}$ de laroo ; invólucro lijeramente bilobo dos veces mas corto que el diámetro transversal del fruto, y cuyos 2 lóbulos son redondos. F. pedunculata, Ait. Trostigma pédunculata, Miq.

27. Árbol bastante grande de hojas acuñadas por la base obtusita, largas de 2 á $4^{\prime \prime}$ y anchas de $1^{\prime \prime}$ á $1^{\prime \prime} 1_{[} 3$, con peciolo de 3 á $8^{\prime \prime \prime}$, ý cuya cara superior tiene esparcidos puntitos blanquecinos diminutos. nervaduras 8 á 14, poco pronunciadas; bracteitas tapando la abertura del fruto $\mathrm{y}$ formando en el vértice in pezoncito chiquito $y$ convexo involucro diminuto y bilobo. $F$. pallida, $\mathrm{V}$.

G. IV. Dopstenia, L. - 1. Receptáculo siempie cuadrangular ó de 4 lados y mas ó menos onduloso por la circunferencia, 2. - 
Receptáculo nunca cuadrangular, pero mas ó menos discoideo ó ciatiforme $\mathrm{y}$ bastantes veces dentadito, 5 .

2. Hojas acorazonado-redondas, palmati-partidas ó palmatifidas, 3. - Hojas acorazonadas ó palmeadas, 4.

3. Yerba con rizoma ramosa, cuyas escamas estipulares son verdes $\mathrm{y}$ estendidas; de hojas ásperas y alampiñadas, cuyos lóbulos ovales ú oblongos, ordinariamente aguzados, son recortados, dentados, ó sub-dentados; limbo de 3 á 8 " de diámetro y situado en el vértice de un pociolo largo de 4 á $6^{\prime \prime}$ : receptáculo peltado de 6 á 8 "' de diámetro, cuya márjen es dentada ó lobada, y sostenido por un pedúnculo derecho, dilatado por el vértice y largo de ‘ $6^{\prime \prime} . D$. contrayerva, L. : C. T. T., pir. 458.

4. Se parece mucho í la anterior, de la cual difiere por sus hojas casi enteras ó algo angulosas y cuyos ángulos son aguzados $y$ por al receptáculo, son muy ondulosas. D. Houstoni.

5. Plantas con tallo, 6. - Plantas sin tallo ninguno, 7 .

6. Terba que se cria en las orillas de los arroyuelos y de las quebradas, con tallitos colorados y escamosos, cuyạs hojas de peciolo largo y erguido, que sale de la axila de las brácteas escamiformes, son ovales, dentadas y erguidas, 5 nervias y de color verde oscuro; de los pedúnculos laterales y rojizos, los unos se terminan por un receptáculo discoideo y globoso á la par, con flores masculinas y sesiles, mientras los otros lo llevan aplanado, anguloso ó laciniado y con fiores femeninas y fértiles. D. caulescens.

7. Hojas acorazonadas, repando-enteras, 8. - Hojas espatuladooblongas; receptáculo ciatiforme, 9.

8. Hojas alampiñadas, largas de á $3^{\prime \prime} 1^{\prime \prime}$ y anchas de á $1^{\prime \prime} 1\left[21^{\prime \prime}\right.$ algo mas corto el limbo que el peciolo, obtusitas; receptáculo orbicular dentadito y peltado, cuyo diámetro es de $4^{\prime \prime \prime}$, apenas convexo interiormente $\mathrm{y}$ sostenido por un pedúnculo pubescente no tan largo como los peciolos, que tienen de á $4^{\prime \prime} 2^{\prime \prime}$. D. cordifolia, Lam.

9. Hojas peluditas o alampiñadas, largas de á $\left.2^{\prime \prime} 1_{[} 21^{\prime \prime}\right]_{[} 2$ y anchas solamente de à $12^{\prime \prime \prime} 6^{\prime \prime \prime}$, obtusas, sub-acorazonadas por la base, festoneaulas y de limbo mas largo que el peciolo, que tiene como 1"; receptáculo un poco con figura de trompo, peltado, subentero o dentadito, pubescente por debajo, cuyo diámetro es de 3 a $6^{\prime \prime \prime}$, coin el pedúnculo mas corto que los peciolos. D. tubicina, R.P.

\section{ÓRDEN 2. - PERÍJIYOOS.}

\section{CLASE XVIII. - AMENTÁCEAS.}

\section{SUB-ÓRDEN 10. - EXALBUMINADOs.}

\section{Familia 42. - JUGLANDÁCEAS ó JUGLÁNDEAS. - Ár-} boles generalmente bastante grandes, corpulentos y coposos, cuyas hojas alternas, compuestas y pinadas ó solamente de 3 en rama, sin glándulas, pero sin embargo aromáticas, no están acompañadas de 
estípulas; flores monoicas, amentáceas y apétalas cuando masculinas y formadas de un perigonio cuyo limbo está partido en 2 á 6 lacinias desiguales, pegado por la base con una bráctea simple ó tríloba, conteniendo estambres en número igual ó doble del de sus divisiones y algunas veces hasta indefinidos, insertos en un torus o disco y cuyas anteras tienen las dos celdillas situadas en los lados de un conectivo que á reces se vuelve espeso y se prolonga por encima de ellas; las flores femeninas, al contrario, tienen su perigonio adherente con el ovario que encierra y cuyo limbo se divide por encima de él en 4 lóbulos que alterinan alguna rara vez con la de una especie de corola muy pequeña y caduca que suele faltar: tal ovario uni ó 4 ovulado tiene una celda úmica, pero partida en 4 celdillas falsas por medio de 4 tabiques falsos o incompletos, otras veces bilocular y con dos huevecillos colaterales y colgantes del vértice de las celdas; estigma grande, papiloso, discoideo, 4 lobo $\mathrm{r}$ sentado: ordinariamente sin embargo hay un estilo muy corto terminado por dos ó cuatro estigmas largos, sub-cilíndricos y arrollados hácia afuera. El fruto es una drupa ó mejor una nuez conteniendo una semilla única formada de un embrion sin endospermo, oleajinosa y cubierta de un episperma membranoso, cuyos cotiledones, muy gruesos, carnudos y anfractuoso-sinuados, son 4 lobos raicilla superior y yemita con dos hojitas pinadas.

Juglaxs, L. - 1. Arbol grande de hojas con 15 hojuelas, 2. Arbolito cuyas hojas son de 3 en rama, 3 .

2. Muy corpulento, frondosísimo y cuya corteza tiene un color ceniciento; hojas muy grandes, cuyas hojuelas, de 2 á 3" cle largo y con la base desigual y redondeada, son aserradas y pubescentes, así como sus peciolos cortitos; flores saliendo antes que las hojas, cuyas masculinas en amentos están formadas de escamas oblongas $y$ tridentadas ó profundamente partidas por ambos lados ó bordes y llevando unas 8 á 10 anteras oblongas casi sentadas, mientras que las femeninas, provistas de escamas bracteiformes 4 dentadas. son mas ó menos solitarias, cuyo ovario oblongo se termina por un estilo que lleva dos estigmas divaricados y muy largos. Nuez amarillenta, oblongo-oval, con una puntita en el vértice, velluda y como pegadiza á la vez, de cuesco muy duro y leīoso. J. cinerea, L. : C. T. V.. pár. 412.

3. Como de unos $20^{\prime}$ de altura, hojas de hojuelas lanceoladooblongas ó elíptico-oblongas, relondeadas por la base y obtusas por el vértice, pecioladas, cuya márjen está arrollada por afuera y de cara inferior pubescente ó alampiñada, y cuyo pelo persiste ordinariamente en las costillas; son largas de $2^{\prime \prime}$ á $3^{\prime \prime} 1$ [ 2 y casi tanto como el raquis que las lleva; amentos masculinos pedunculados y axilares: flores femeninas solitarias, de perigonio libre y 5 partidos, sostenidas por un pedículo delgado, pubescente; brazos del estilo con estigma papiloso, 3 á 4 veces mas largos que las divisiones perigoniales, lineares y obtusas: ovario bilocular; drupa unilocular por causa de aborto, ovoideo-globosa y amarillo-anaranjada. J. baccata, L. Picordendion juglans, Gr. P. arboreum, Pl. Rhus arborea. Macf. Schmidelia macrocarpa, Rich., fl. Cba. 
Familin 43. - SALÍCINEAS, SALICICEAS. - Arbustos o árboles ramosísimos, de hojas simples, coriáceas, mas ó menos estrechas y siempre lanceoladas, lustrosas, mas ó menos pecioladas ó sesiles, enteras, y cuya base está acompañada de estípulas caducas; son alternas o esparcidas; fiores amentáceas, monorcas ó dioicas, muy pequeñas y desnudas, cuyas masculinas constan de 2 hasta 20 estambres, situados en la base de una escama que reemplaza al cáliz o insertos por su cara superior, mientras que las femeninas se componen de un yistilo formado de un ovario fusiforme, terminado por dos estiomas bipartidos, $y$ situado tambien en la axila de una escama igual á la de las masculinas; algunas raras veces está acompañado de un involucro á manera de cúpula, simulando el perigonio: tal ovario uni ó bilocular con uno ó con muchos huevecillos derechos, asidos al fondo de las celdas y por la base de dos tropospermos parietales. El fruto es una cápsula pequeña y oblonga y sus muchas semillas son con pelo blanco y sedoso ó desnudas, cuyo embrion derecho, homótropo y sin endospermo está envuelto en el epispermo.

Salix, L. - 1. Árbol frondoso cuyas ramitas larguísimas y delgadas se doblan hácia abajo y alcanzan casi al suelo, 2. - Árbol mucho mas alto, piramidal, ramosísimo, con ramas erguidas y mas cortas, 3.

2. Casi con figura de paraguas, cuyas hojas lineares, lanceoladas y lampiñas son finamente aserraditas, á las cuales suceden despues de desprendidas amentos cilíndricos y delgaditos: brácteas, ovario y cápsulas lampiños. S. Zabilonica, L.

3. Hojas lineares aserradas y lampiñas, largas de á $2^{\prime \prime} 1_{[2} 1^{\prime \prime} 1_{[2} 2$ y anchas de á $4^{\prime \prime \prime} 3^{\prime \prime \prime}$; estípulas caedizas; amentos terminales saliendo con las hojas en la sumidad de las ramitas; brácteas peludas y decíduas, ordinariamente con 4 á 6 estambres; estigmas sentados; cápsulas glabras, oval-cónicas, cuyo pedículo es 3 á 4 veces mas largo que el disco. S. Humboldtiana, WV. : C. T. V., pár. 779.

Familia 44. - MIRIC'ACEAS. - Arbustos ó arbolitos ramosísimos cuya corteza trasuda resina ó cera aromática, de hojas sencillas, enteras, mas ó menos pecioladas, alternas ó esparcidas, con estípulas ó sin ellas, cuya cara inferior está provista de puntitos transparentes resinosos. Flores amentáceas, desnudas y muy pequeñas, monoicas ó las mas reces dioicas, cuyas masculinas constan de muchos estambres, ordinariamente agrupados en un andróforo ramoso $\mathrm{y}$ situado en la axila de una escama bracteiforme, otras veces son solamente 2, 6 í 8, cuyas anteras 2-4 loculares se abren lonjitudinalmente: las femeninas al contrario, ordinariamente solitarias $y$ sentadas tambien en la axila de una bráctea mayor que ellas y formando por su reunion amentitos globosos: se compone de un ovario lenticular, con un solo huevecillo basilar y átropo y de un estilo muy corto, que lleva dos estigmas largos, alesnados y glandulosos : tal ovario está acompañado hácia el lado esterior de dos ó de mayor número de escamas hipójinas y persistentes, las cuales á veces se sueldan con él, que se ha vuelto una especie de nuececita monosperma é indehiscente; otras veces membranácea y como aladita por los bordes, envuelta en una capa de cera, dispuesta por granitos, la 
cual suele faltar algunas reces; semilla derecha sin endospermo alguno, $\mathrm{y}$ cuyo embrion grueso sigue una direccion opuesta á la suya $y$ antitropo y está inmediatamente cubierto por el epispermo delgarlito.

Tribu 1a. - Mrrícens. - Arbustos cuyas hojas tienen puntitos ó glándulas resinosas; flores desnudas y amentáceas; estambres 2,6 í $\overleftarrow{8}$, óvulo simple, basilar átropo, estigma bipartido.

Mrrica L. - 1. Hojas oblongas ú oblongo-lanceoladas, 2. - Hoja espatuladas ó lanceoladas, 3 .

2. Oblongas solamente, estrechadas por la base y algo aserraditas hácia el vértice; amentos masculinos aguzados, bayas globosas con cera. M. ceirifera, L. - Oblongo lanceoladas, acuñadas y cónicas por la base, enteras, sensiblemente lisas y lustrosas, pero de costilla velluda. M. Mexicana, L.

3. Aserradas especialmente mas allá del medio ó sub-enteras, cuya cara superior es pubescente ó alampiñada, mientras la inferior tiene sus nervaduras solas pubescentitas; amentos dioicos, serótinos y subsolitarios y axilares, cuyos masculinos, cortamente cilindricos, tienen las fiores con brácteas cuneiformes, de 4 á 5 estambres con los filamentos reunidos hasta el medio, insertos en un andróforo filiforme peludo; mientras los femeninos ovoideos tienen sus flores con brácteas caducas; fruto drupáceo-ovoideo y cubierto de cera. $M$. microcarpa, Benth.: C. T. T., 283.

Tribu 2. - Cistaríneas. - Arboles bastante grandes, sin hojas, cuyas ramitas estriadas tienen sus nudos ceñidos por una vainita como foliácea; flores desĩudas amentáceas é involucradas, un solo estambre; ovario unilocular de huevecillo simple r colgante: estigma bipartido fasuarina equisetifolia, Fort.

\section{SÉRIE II. - PERIANTADOS.}

ÓRDEx 1' - EPIJNos.

STR-ÓRDEX 1\%. - GMANDROS.

\section{CLASE XIX. - ARISTOLOQUINEAS.}

Fumilia 45. - ARISTOLÓQUIACEAS ó ARISTOLÓQUIPAS. - Vejetales sofruticosos ó á veces arbustillos, cuyos tallos mas veces sarmentosos, mas ó menos largos, mas ó menos ramosos, trepan por encima de los rejetales vecinos, de corteza bastantes veces como corchosa: algunas reces son plantas herbáceas viraces. Hojas sencillas largamente pecioladas, alternas, enteras ó lobadas, mas ó menos anchas y grandes, frecuentemente acorazonadas por la base, lustrosas, coríceceas y lampiñas. sin estipulas. Flores hermafroditas solitarias ó á veces en especies de racimos paucifloros y siempre axilares, pedunculadas y cuyo pedúnculo está con frecuencia acompañado por una bráctea mas ó menos grande; regula- 
res é irregulares, formadas de un periantis tubuloso, petaloídeo y pintado con los colores mas variados y bastantes reces primorosísimo, cuya figura y tamaño varian mucho, con un lóbulo único v lingruiforme, llamado labio, mas ó menos grande, maś ó menos laræo, que suele faltar alpunas veces; otras reces son trílobas y de estivacion vulvar: 6 hasta 16 estambres hay insertos ordinarianente sobre cl ovario y pegados en derredor de la base del estilo, cuyas anteras sentadas son estrorsas y biloculares; otras veces, cuando falta el estilo, son casi sentadas y salen de un disco epijino. Pistilo formado de un orario único, libre, con 3 ó 6 celdillas, colierentes en el centro por medio de las placentas multispermas; los huevecillos están pegados en dos séries verticales en el inqulo interno, ascendentes ú horizontales; de un estilo terminal, corto y en forma de columna, coronado por un estioma arrayonado por a 3.1 o 6 radios; el estilo suele faltar algunas veces. Fruto ordinariamente capsular, de leliscencia loculícida, cuya cada celda contiene muchas semillas achatadas ó angulosas, pesentando hácia el ápice de un epispermo grueso carnudo ó algo córneo, un embrion pequeñito, derecho, cura raicilla, mas larga que los cotiledones, mira hácia cl hilo; raras veces el fruto está abayado.

Aristolochia, L. - 1. Hojas lobadas ú orejudas, 2. - Hojas siempre enteras, 7 .

2. Bi ó tríloluas, sin ó con orejita, con ó sin bráctea, acompañando á la insercion del pedúnculo unífloro, 4. - Siempre orejudas; brúctea abrazadora del tallo, ancha y acorazonada, acompañando á la insercion del pedúnculo, 3 .

3. Nata de talio voluble, cuyos ramos delgadísimos, lampiños ó pelitiesos, llevan hojas acorazonado-orejudas, oblongo-aguzadas,algo obtusas, pecioladas, Y cuyas orejitas son obtusitas: pedúnculos unifloros, mas cortos que el peciolo: perigonio, sedoso, tubuloso, algo inflado, largo como de unas $\%$ a $8^{\prime \prime \prime}$ y cuyo vértice es lingüiforme $y$ aguzarlo. A. pentandire, Jacq.

4. Bílobas ó las mas veces trílobas: pedínculo unifloro, saliendo de la axila de una bráctea grande, acorazonado-redonda y persisiente, J. - Orejudo-trílobas, pedúnculos unífloros sin bráctea alguna, 6.

5. Tallo largo del tamaño del dedo pulgar, algo nas ó menos pardusco, enredadero i cuyos muchos ramos muy larosos, casi volubles y algo alampiñados, llevan hojas truncadas o acorazonadas por la base, pedatinervias $\mathrm{y}$ de cara inferior pubescentita, de lóbulos estendidos, oblongos ú oval-oblongos, obtusos, bastantes veces truncadas por el medio, de manera que parecen terminarse en media luna. cuyas puntas les hacen bílobas, anchas le $?$ a $6^{\prime \prime}$ : limbo-perigonial doblado por adentro, con 6 estrias por la base linchada ó 6 espuelitas, cuya basilar obtusamente filiforme tiene lasta 20 : $3^{\prime \prime \prime}$, campanudo, cuya boca de golpe unilabiada y truncs tiene un labio redonleadito ú ovaloblongo, como de 8 a 10"' de diámetro y cuyo vértice - ra prolongando en una colita filitorme, larga desde l' liasta l'. 1. triloba, L. - A.biloba, L. - A. macima, Mart. - A. caudata, Hook. : C. T. V.. 318-708. 
6. Mata de tallo voluble ramosísimo, delgado, estriado y lampino, con hojas pecioladas acorazonadas y orejudo-trílobas, obtusas por el vértice y aguzadas á la par, cuyas orejitas obtusas son encorradas hácia afuera; pedúnculos unítloros é iguales con las flores largas de $1 " 1{ }^{2}$ y tubulosas, cuyo perigonio oroideo inflado por la base, algo arqueado y un poco dilatado por el rértice se va proloncando en una lengüiia orbicular, obtusísima, verde esteriormente, mientras que interiormente es aleonado-riolácea con pelos is barla bastante laroguita: cápsula wohosa del tamaño de la yema del dedo. A. Pasifloirefolia, Rich.. Fl. de Cba.

T. Limbo perigonial, grande y bilabiado, 8. - Limbo perigonial de tamaño variado no grande y unilabiado, 9.

8. Hata enredadera de tallo largo como de 1 " 1 [2 de diámetro. un noco corchoso esteriormente, muy lamoso, y cuyos ramos. larguísimos. lleran hojas grandes, larguísimamente pecioladas, arriñonadas, pedatinervias, como de 3 á $\zeta^{\prime \prime}$ de diamétro r cuyo seno hasilar es anchamente abierto, redondas; estípulas acorazonadoredondas y persistentes; tamario de las flores muy variado, curo perigonio, doblado por adentro, tiene la base obovoidea inflada y mas larga que el tubo estrechado; labio superior linear oblongo, doblado lonjitudinalmente, subsesil y como de $2^{\prime \prime}$ de largo. mientras el inferior, algo mas corto, redondeadito y estrechándose como en uña, es largo de $3^{\prime \prime}$, con la lámina espatulada, de 10 á $12^{\prime \prime \prime}$ y aun mas de diámetro. A. vingens, Vah. - A. grandizlora. Vah. C. T' V. 37.

10. Mata de tallo erguido, derecho y lampiño, cuyas ramas llevan hojas acorazonado-oblongas, obtusitas, pedatinervias, de cara inferior pubescentita, bastante grande y cuyo diámetro es de 3 á $4^{\prime \prime}$, con el seno basilar, estrecho y abierto á la par; estípulas nulas; limbo perigonial derecho y largo de $1^{\prime \prime}$, cuyo labio oral obtuso y sin apéndice terminal es pubescente esteriormente. A. obtusata, Sw.

11. Labio unilateral, 12. - Labio abroquelado, 17.

12. Hojas acorazonadas bastante grandes, 14. - Hojas elípticooblongas y pequeĩas, 13.

13. Mata formando maleza sobre las rocas, madrepóricas de la isla de Cuba, cuyo tallo tendido, delgado y lampiño echa muchos ramos que llevan hojas cortamente pecioladas, obtusas por ambos estremos y de cara inferior mas pálida; pedúnculos unífloros mas largos que las hojas, perigonio largo como de $1^{\prime \prime} 1[2$, color purpúreo moradusco y manchado de puntitos color rojo oscuro, inflado y giboso por la base, con una lengüita barbuda, obtusa, recortada y mas larga que el tubo que se abre por su cara interna y hácia su parte superior: cápsula oroidea y globosa, apiculada y del tamaño de la punta del dedo. A. tigrina, Rich., Fl. de Cba.

14. Tallo pequeño, enredadero, saliendo de una raiz con figura de maceta, como de $1^{\prime \prime}$ de diámetro lo mas, 15. - Tallo bajito poco enredadero ó no, saliendo de una raiz gruesa y carnosa, con suco ó leche amarillo aleonado, 16.

15. Mata muy ramosa, alampiñada, cuyos ramos delgados y bastante largos cargan con las hojas acorazonado-oblongas, obtusitas. pedatinervias, largas como de $3^{\prime \prime}$, de cara inferior pubescentita $y$ 
cuyo seno basilar es abierto; limbo perigonial, encorvado hácia adentro, embudado por arriba y cuya boca truncada se prolonga de golpe en un labio corto, redondo, estrechado por la base y sin apéndice terminal, interiormente con una manclia moren a como aterciopelada y peluda, situada hácia el medio. A. barbata, Jacq. : C. T. V., 320-710.

16. Tallo cilíndrico, largo, delgado, voluble, estriado y muy ramoso, lampiño; hojas distantes, aovado-aguzadas, acorazonadas, reticulado-renosas, un poco aflechadas, con el seno de la base abierto y profundo, enteras, lampiñas, largas de $4^{\prime}$ á $5^{\prime \prime}, 6^{\prime \prime}$, y anchas de 3"1 12 á 4"; peciolo pubescente por su cara superior y largo de 1" $1[2$; estípula grande entre acorazonada y redonda. amplexicaula. Flores solitarias y axilares de pedúnculos delgados, tanto ó mas largos que las flores, que tienen $]^{\prime \prime} 1_{[2} 2$ á $2^{\prime \prime} 1_{[} 2$ de largo, unífloro: periantio hinchado y globoso por la base y casi blanco, despues viene el tubo estrecho, pero no tarda en volverse infundibiliforme. manchadito y reticulado de color bruno, de boca dilatada y oblícua, con el labio inclinado mas largo que el tubo y gradualmente acuminado desde la base hasta el ápice obtuso y transversalmente diciplinado de bruno. A. anguicida. C. T. V., 319.

17. Ninguna estípula; una brảctea situada hácia el medio de los pedúnculos largos; labio anchamente oval, desigualmente unduloso y festoneado á la par, 18. - Una estípula oval y subpersistente; pedúnculos desnudos y sin bráctea; lábio acorazonado oblongo, ni ondeado ni festoneado tampoco, 19.

18. Nata ó arbustillo lampiño ó alampiñado enredadero, cuyos muchos ramos muy largos llevan hojas acorazonadas, puntiagudas,

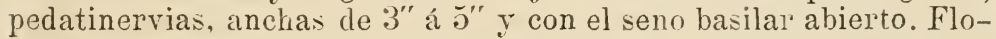
res de tamaño muy variado, abigarradas de purpúreo, cuyo limbo perigonial, doblado por dentro, muy grande y de tubo oblícuo, es 6 costado y 6 giboso por la base; labio entero por la base, largo de 4 ú $8^{\prime \prime}$ y dos veces tan largo como la parte inflada y derecha del tubo, $\dot{y}$ cuyo vértice va prolongándose en una cola filiforme y larga de mas de 1'. A. grandiflora, Sw.-A.arborescens, Desc. - A.gigas. A. footens, Lindl.

19. Mata de raiz fusiforme, larga como de 6 ", espesa y color verde moreno de la cual sale un tallo lampiño enredadero, cuyos ramos llevan hojas acorazonadas, puntiagudas. pedatinervias, largas de 4

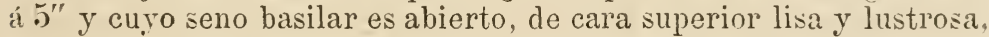
mientras la inferior, mas"pálida, es pubescente. Pedúnculos axilares como 4 tantos mas cortos como los peciolos, con 1, 2 o 3 flores, cuyo limbo doblado por dentro es como de unas (j"' de diámetro. mientras la parte hinchada ó avejigosa de la base lo ticne de 6 á $\&^{\prime \prime \prime}$, con la parte contraila del tuho muy corta; lahio mas largo que el tubo y uo $1^{\prime \prime \prime} 1_{[}^{2} 2$ á $2^{\prime \prime \prime} 1$ [2 largo y arrejonado. 1 . odoratissime. $\mathrm{L},-A$. gluecescens, Kth. 


\section{OKRDEN II.-PLIRIJNOS.}

SLB-ÓRDEX I0. - ALBTMIXIDOS.

\section{CLASE MX. - BALATOFORIAEAS.}

Funilia 46. - BATANOFÓREIS. - Plantas herbáceas vivaces y parásitas en las raices de los árboles, nunca verdes, cuyo tallo mas ó menos carnoso tiene $1^{\prime \prime}$ hasta $l^{\prime}$ de altura, es simple y sale de un rizoma ramoso ó tuberoso, sin hojas, que suelen reemplazar muchas escamas, derecho y erguido. Flores agruparlas en un espádice terminal, con frecuencia separadas por escamas filiformes, monoicas y apétalas, curas masculinas constan de un perigonio valvar. tubuloso y tríloluc, curas dirisiones profundas, iguales y abiertas estín algunas veces reemplazadas por una escama simple que entónces tiene el lugar del perigonio fallo; hat tres estambres, raras veces en mayor ó menor número, soldados á la par por los filamentos Y por las anteras. formando así una columna ancroforica, cuyos tres hrazos cargan con 3 á 6 estambres y tienen pues 6 á 12 celdas introrsas é insertus ell la garganta del perigonio. Las flores femeninas se componen de un orario libre ó inferior unilocular, con un huevecillo inverso, coronado por el limbo perionial entero ó partido en ' 2 ó en 1 lacinias desiguales: y curo rértice lleva uno ó do: estilos filiformes, terminarlos por otros tantos estigmas seneillos. El fruto es una carionside glohosa y umbilicarla, cura semilla se forma re un embrioncito rlohoso y alojado en una fosita superficial re un endosperno copidso. Itelosis Giuianensis, Pich. - Cynomorium Cayennense.S\%.-Phyllocorine Jamaicensis, J. Hook. : C. T. V. .58.

\section{(LASE AXI. - SANTALIXEAS.}

Familia 4\%. - LORAYTICEAS. - Vejetales vivaces sofruticosos ó matas parásitas ramosísimas, de lojas simples, opuestas ó á veces alternas, enteras, sentadas ó pecioladas, mas ó meno espesas y carnositas, sin venas; suelen faltar algunas raras veces y entonces los vejetales son afíleos. Flores hermafroditas o dioicas solitarias y axilares ó espigadas, arracimadas axilares ó terminales, ordinariamente pequeñitas y formadas de un perigonio superior que suele faltar algunas veces, con mayor frecuencia saliendo del borde de la espansiorr cupuliforme y carnosá del pedúnculo y ordinariamente ceñido por algunas lurácteas situadas por la base, compuesto de 3-4 á 8 sépalos, frecuentemente reunidos en un tubo y de estivacion valvar, en ese último caso algunos botánicos lo tienen por una corola seudomonopétala; tantos estambres hay cuantos lóbulos perigoniales, á los cuales son opuestos, de anteras 1 ó biloculares, reventándose algunas veces por arriba en muchas cavidades; pistilo único, compuesto de un ovario adherer 'e ó ínfero cuyo vértice coronado 
jor un disco epijino y anular lleva un estilo largo y delgado que se termina por un estigma sencillo, algunas veces sentado por faltar el estilo. El fruto es una baya unilocular cuya semilla única, invertida y adheridla á la pulpa del pericarpio viscoso y bastante copioso, contiene, además de su tegumento propio, alojado en un endospermo carnoso, un embrion cilíndrico cuya radícula está vuelta hácia el hilo.

T. I. Loranteas. Vejetales siempre parásitas, de hojas opuestas o alternas ; flores siempre hermafioditas, con un cáliz y una corola frecuentemente muy notables, pero en realidad cuyo perigonio es único; anteras entrorsas bílobas, basifijas ó pegadas y erguidas, á veces recostadas $\mathrm{y}$ vacilantes, abriéndose por dos grietas lonjitudinales; ovario unilocular monospermo, de estilo filiforme con un estigma simple $\mathrm{Y}$ cabezudo; fruto carnoso drupáceo, coronado por una ciçatriz anular ó por la márjen persistente del perigonio y anidado por parte solamente en una cúpula bracteiformo.

Loraxthus, L.:- - Flores grandecitas ordinariamentecorímbosas, sostenidaspor una bráctea cartuchiforme, divisiones perigoníales reunidas eutubo delgado; filamentos delos estambreslargos é insertos en la garganta de la corola con anteras oblongas ordinariamente recortadas por el dorso; estilo filiforme con estigma cabezudo, 2. Flores siempre pequeñas, 3 .

2. Ramitas cilíndricas bastante largas y colgantes, con hojas bastante variadas, pero ordinariamente aovadas ú ovales, obscuramente venosas y cuyas nervaduras salen por debajo del medio de la costilla; flores corimbosas de pedícelos ternados y tres veces mas largos que el periantio, cuyas divisiones interiores ó la corola estáu dobladas hácia afuera $r$ un poco mas largas qua las anteras recortadas, sostenidas por filamentos tan largos como ellas y tambien como el estilo. L. Americanus, Jacq. - L. Jacquini. D. C. - L. Plumieri. Cham. C. T. T. 688.

3. Espigadas y anidadas en las escavaciones del raquis con tres bracteitas diminutas enteras, escondidas en su fondo ó abortadas. Pétalos distintos; estambres alternativamente desiguales, insertos por debajo del medio de los pétalos; filamentos estaminales mas largos que las anteras, ahuecados por la márjen yor debajo de las anteras estériles, porque 3 solas son fértiles acorazonadas, 4. Nunca jamas anidadas, arracimadas ó espigadas, 5 .

4. Ramitas cilindricas y furfuráceas, con hojas ovales, obtusas, peninervias por la base, largas de 3 á $I^{\prime \prime}$ cuyos peciolos cortos se doblan sobre sí. Espigas axilares, tetrásticas, frecuentemente mellizoternadas, constantemente pedunculadas, ordinariamente tres vece:s mas cortas que las hojas, cuyas flores aproximadas están provistas de 3 bracteitas redonditas, persistentes y enteramente escondidas en la escavacion raquidiana ; corola purpúrea constantemente oblonga cuyas 6 divisiones son lanceoladas. Anteras fértiles redondas y arrejonadas. Bara ovoidea oblonga y morada. L. occidentalis, L.L. immersus, Benth. - L. spicatus, H. B. K.

5 . Racemosas y dispuestas en los pedícelos por vertícilos de á 3 y sostenidas por una bracteita subulada; pétalos distintos; filamentos estaminales anchos, insertos por clebajo de los pétalos, con anteras 
erguidas y recostadas por el dol'so; estilo obtusito, 6. - Racemosas ó subespigadas, solitarias en cada pedícelo ; tubo perigonial envuelto por una bracteita cupuliforme 3 dentada ó 3 fida; pétalos distintos; estambres alternativamente desiguales é insertos por debajo del medio de los pétalos, cuyos filamentos mas largos están ahuecados por la márjen y debajo de las anteras estériles; 3 anteras fértiles solamente acorazonadas y erguidas; estilo obtusito, $\%$.

6. Ramitas cilíndricas, con los internudos de las mas tiernas tetragonos; hojas largas de $1^{\prime \prime} 1_{[} 2$ á $3^{\prime \prime}$, mientras los pedícelos tienen solamente $1^{\prime \prime \prime}$ de largo; racimos axilares ó terminales y compuestos de grupos de flores subsesiles ó cuyas inferiores están pediceladas; flores de un color verde blancuzco en verticilos de á tres y sesiles, de cáliz subtrunco, tan largo como la bracteita oval y puntiaguda; corola oraloblonga en la rema, cuyos 6 pétalos lanceolado-lineares tienen 1 á $1^{\prime \prime \prime} 1_{[}^{2} 2$ de largo; los filamentos mas largos son dilatados por el vértice; anteras erguidas y subuladas; estilo un poco con figura de maceta; baya oval. L. aricularis, Mart.: C. T. T. 689.

7. Ramitas sub-comprimido-cilíndricas, 8. - Comprimidas y por fin cilíndricas, 9 .

8. Hojas espatuladas, lanceoladas ú ovales, de base adelgazada hasta volverse peciolo, largas de 1" á $16^{\prime \prime \prime}$ y anchas de 3 á $9^{\prime \prime \prime}$ y ohtusas; racimos axilares, simples y con 3 á 9 flores; dos veces mas cortos que las hojas, herrumbroso fulfuráceas, pedículos casi tan largos como las flores, cuya corola tiene 6 pétalos lineares y largos de 1 "' 1 2 . Bracteitas cupuliformes iguales, anchamente 3 fidas con lóbulos deltoideos. Bara oroideoblonga. L. parriflorıs, Jacq. - L. montanus, Maf.

9. Hojas obovales ó espatuladas, acuñadas por la base, redondeadas ó escotadas p $0^{\prime}$ el vértice, largas de $1^{\prime \prime} 1$ [2 á $2^{\prime \prime}$ y anchas de 6 á $12^{\prime \prime \prime}$. Racimos axilares simples y desprovistos de escamas por debajo, con 6 ó con algunas flores, tan largos como las hojas ; pedícelos: distantes y tan largos como las flores cuya cornla rojiza oblonga e. obtusita en la rema; bracteitas oblicuamente cupuliformes, anchamente trífidas y cuyos dos lobos son mas cortos; baya oblonga. $L$. uniflor us, Jacq.-L L. parriflorus, Lam.-Tiscum purpurcum, L.

T. 2. Visceas. Hojas siempre opuestas que suelen faltar algunas veces; flores dioicas ó monoicas, ordinariamente anidadas en el eje carnoso de las espiguitas axilares y opuestas ; corola y cáliz confundidos en un perigonio único formarlo de 3 á 5 lóbulos carnosos cuya estivacion ralvar es deprimida; disco epijino rennido con cl perigonio carnoso y de figura de copa ; hay tantos estamlires cuantas divisiones perigoniales, é insertos por afuera del disco entre los sépalos; ovario unilocular con tres huevecillos suspendidos. Baya adrupada monosperma, de pericarpio membranoso y con mucosidad. G. I. Phoradendrox, Nutt. - 1. Hojas anchas y hastante grandes, largas de 2 á $6^{\prime \prime}$. -2 . Hojas pequeñas y mucho menos largas, 3.

2. Ramitas cilíndricas, así como los tallos, cuyo color es amarillento-morenito, de hojas elípticas ó elíptico-lanceoladas, sul-aguzadas por ambos estremos, sin nerraduras o con nervios distantes $y$ apenas pronunciados á lo largeo de la costilla; largas de 3 á 5" y an- 
chas de 1 á $2^{\prime \prime}$, con peciolo cortísimo y bastante dobles. Espigas 3 ó 1 , á veces mellizas axilares y 2 á 3 veces mas cortas que las hojas y tormadas de 4 á 6 atrejos; Hores femeninas trífidas; baya ovoidea globosa.Ph. latifolium, Gr. - Tiscum latifolium, Sw. - V. tereticaule, Dc.-V. flavescens, Macf.-V. Cubense, Rich. C. T. V. 309.

3 . Hojas estrechas y largas de 1 á $2^{\prime \prime} 1_{l} 2,4$. - Hojas obovales, pequeñas y largas de 2 á $6^{\prime \prime \prime}, 5$.

4. Ramas y ramitas tetrágonas y opuestas, cuyas hojas lanceoladas, linear-lanceoladas ó elíptico-lanceoladas, obtusitas y largas de 1 á $2^{\prime \prime} 1{ }^{2}$ sobre 3 á $8^{\prime \prime \prime}$ de ancho, tienen 2 o 4 venas delgaditas y situadas por ó cerca de la base de la costilla; 1 á 2 espigas axilares tan largas como las hojas ó mitad mas cortas que ellas, con $40 j 5$ artejos distintos y cuyos surcos son tetrásticos; bayas ovoideo-globosas y rojas. Ph. vubrum, Gr. - Tiscum rubrum, L.-V. tetragonum, Pœpp.-V. Kunthianum, Dc.-Loranthus viscifolius, Kth.

5. Ramitas tetrágonas que por fin se vuelven estriado-cilíndricas, de hojas obovadas, espatuladas ó elíptico-lanceoladas, obtusas, sin venas ó con 3 á 5 nervios muy poco pronunciados, largas de 6 á $12^{\prime \prime \prime}$, sobre 3 á $6^{\prime \prime \prime}$ de ancho; espigas axilares solitarias, diminutas y mucho mas cortas que las hojas, con 1 ó con 2 artejos cuyos surcos son tetrasticos. Baya sub-globosa. Ph. myrtilloides, Gr. - Viscum tetragonum, Dc.-V.mucronatum, Dc. $-V$.myrtilloides, Wll.

G. III. Arceuthobium, M. B. - 1. Artejos ó piezas de lase spigas con dos flores. - 2. Flores dispuestas por séries marjinales en las piezas comprimidas de las espigas, 3 .

2. Ramitas estriado-cilíndricas y frájiles con los internudos del tallo dos veces mas largos que los artejos de las espigas; escamas con una punta, conniventes y formando una vaina trunca, abierta é igual con la de las espigas axilares, cortamente pedunculadas con 2 o 6 artejos cuyas flores son aspadas; flores femeninas de limbo perigonial 3 lobo. A.cupressoides, Gr.-Viscum cupressoides, Macf.

3. Tallo erguido de 1 á $2^{\prime}$ de altura, cuyas ramitas ascendentes tienen los internudos ordinariamente largos de 1 ó $1^{\prime \prime} 1$ [2 y anchos de 3 á $6^{\prime \prime \prime}$; escamas apenas notables y caedizas. Espigas laterales constantemente pedunculadas, cuyas masculinas, largas de 4 á $8^{\prime \prime \prime}$, con tres ó dos artejos, tienen piezas espatuladas con algunas flores dispuestas en una série por cada márjen, acompañadas de un invólucro subtruncado y estendido, mientras las espigas femeninas, mas largas, cilíndricas, con 3 ó 4 artejos, tienen piezas con 2 á 4 flores dísticas cuyo limbo perigonial tan largo como el tubo es trílobo como en las masculinas. A. opuntioides. Gr. - Viscum opuntioides L: C. 'T. V. 308.

SUb-ÓRdex 2. - exalbuminados.

CLASE XXI bis. - DAFNOIDÍNEAS.

Familia 46. - LAURÁCEAS ó LAURÍNEAS. - Arbustos ó primorosos árboles mas ó menos altos y corpulentos, de hojas per- 
sistentes y alternas, rarísimas veces opuestas, simples coriáceas, como barnizadas y lustrosas, mas ó menos pecioladas, de tamaño muy rariable, pero ordinariamente no muy grandes, enteras y ordinariamente provistas de muchísimas glandulitas transparentes y regularmente mur olorosas. Flores apétalas hermafroditas, monoicas ó polígamas, dispuestas en grupos axilares, en racimos of en panojas terminales, y que constan de un periantio persistente con 4 o 6 divisiones profundas y empizarradas por los bordes en la estivacion, conteniendo pegados en su base de 3 hasta 12 y mayor número de estambres, dispuestos en 2 ó 3 séries, de los cuales algunos suelen abortar y se quedan representados por sus solos filamentos estériles, mas ó menos deformados; mientras los fértiles llevan anteras que se abren por valvas en número de 2 ó de 4 que se levantan de abajo para arriba, ó de la base hácia el ápice. Pistilo único, compuesto de un ovario superior cryo vértice lleva un estilo único y simple que se termina en un estilo sencillo. Fruto abayado ó drupáceo, desnudo ó cubíerto, monospermo, frecuentemente situado en el ápice engrosado y crecido del pedúnculo, que vuelto una especie de cúpula acompaña á su base; semilla única que contiene por debajo de su epispermo un embrion muy grueso inverso como ella misma y homotropo; sin endospermo alguno, cuyos cotiledones gruesos y carnosos son mas ó menos oleojinosos y siempre feculentos.

\section{Anúlisis dicotónica de las tribus.}

1. Flores hermafroditas ó polígamas, 2. - Flores dioicas ó poligamas, 8.

2. Hermafroditas solamente, 3. - Hermafroditas y polígamas á la vez, 7.

3. De limbo perigonial, articulado y caduco, 4. - De limbo perigonial persistente, 5 .

4. Cuyas divisiones son anchas; glándulas con forma de dientes, y estambres fértiles con anteras de 4 celdillas dispuestas á manera de media luna inferiormente, las anteras de la série interior son estrorsas. Baya pegada por encima de una cúpula profunda y trunca á la vez; vemas de las ramitas incompletas. T. I. Nectandreas. G. II. Curas divisiones no son anchas, glándulas estaminiformes; cel dillas de las anteras nunca dispuestas en media luna; anteras de la série esterior estaminal saliendo un poco por afuera. Yemas de las ramitas completas. T. II. CAMforeas. - Camphora officinalis. Law'us camphora, L.: C. T. V., 289 bis.

5. Siempre persistente; glándulas estiminiformes; anteras bi ó 4 loculares curas interiores son entrorsas; yemas de las ramitas incompletas. T. IlI. Faibas. - Phobe montana, Gr.-Laurus montana, Sw. - Cinnamomum inontanum, Ns. C. T. V. 223. - Persistente ó caduco 6.

6. Caduco por desarticularse; con ó sin glándulas estaminiformes; anteras cuyas interiores estrorsas tienen dos ó 4 celdillas; fruto seco ó carnado y encerrado en el tubo perigonial vuelto carzoso ó endurecido; yema de las ramitas incompleta. T. IV. Crip- 
ToCarieas. - Cryptocarrya pretiosa, Mart. - A gatophyllum aromaticum, Gaertn. - Raveilsar aromalica, Son. - Persistente ó caduco, tan pronto con glándulas á manera de dientes, como sin ellas; anteras cuyas internas son introrsas y con dos celdillas abriéndose por el ápice á favor de poros. Baya al principio envuelta por el perigonio que mas luego se vuelve cúpula espesa, la cual ticne su base ceñida. T. V. Acrodiclidieas. - Acrodiclidium Jamaicensis, Ns. - Laurus triandra, Sw. - Laurus parviflora, Pœpp.: C. T. V.66. - Aydendron argenteum, Gr. - Oreodaphne argentea, Plan. 68.

7. Hermafroditas y polígamas de limbo perigonial articulado y caduco que tiene glándulas estaminiformes; anteras con 4 celdas de las cuales las de la série estaminal esterior son entrorsas; yemas incompletas. T. VI. Cinanomeas. - Cinnamomum aromaticum, Dc. C. T. V., 231. Hermafroditas y las mas veces diclines unisexuales, de limbo perigonial, tan pronto persistente como caduco por desarticulado; glándulas estaminiformes ; anteras bi ó 4 loculares, cuyas interiores son entrorsas; pedículos sosteniendo los frutos espesos y á veces algo carnosos; yemas de las ramitas completas. T. VII. Perseas. - Persea gratissima, Gr.: C. T. V., 321.

8. Dioicas solamente, 9. - Dioicas ó polígamas, 10.

9. Cuyas divisiones perigoniales son diminutas ó faltan enteramente; 9 hasta 18 estambres cuyas anteras de 2 á 4 celdillas son ordinariamente todas inclusas en la flor; bara situada en el tubo perigunial estendido; rema de las ramitas incompleta. T. VIII. TETRANTHEREAS. - Laurus notilis, L. - Cuyas divisiones perigoniales son iguales y caducas; 9 hasta 10 estambres todos fértiles, cuyas anteras con $\dot{2}$ o 4 celdillas son todas contenidas por dentro de la flor. Baya sostenida por un pedícelo desnudo ó por el tubo perigonial discoideo; yemas completas. T. IX. Dafridieas. - Daphnidium.

10. Con 9 estambres fértiles sin ester: es ningunos, cuyas antera: de 2 á 4 celdillas son todas introrsas; perigonio enrodado, delgado y amarillo. Bava sostenida por un pedícelo desnudo, alguna vez que otra espeso; yemas completas. T. X. Flavifloreas. - Sassafras officinalis. - Laurus sassafías, L. - Mas ó menos de 9 estambres, anteras siempre con 4 celdillas, 11 .

11 Abriéndose por cuatro poros; las flores masculinas suelen faltar de las glándulas estaminales, mientras las glándulas de las femeninas son caliciformes : 3 á 6 anteras interiores y sentadas; yemas incompletas. T.XI. Dicipelreas. - Dicyphylium caryophyllatum, Ns. - Sobrepuestas y abriéndose por ventallas y apareadas; perigonio persistente campanudo ó enrodado y con divisiones estrechas; á veces ciñe á manera de cúpula la base de la baya; yemas incompletas. T. XII. OreonafNeas. G. I.

G. I. Oreoda phxw, Ns. 1. Ramos lampiños, pulverulento-pubescentitos hácia la sumidad algo colorida; estigma ancho; cúpula con figura de escudo, 2. - Ramitas y panojas estendidas, estrigoso pubescentitas; estigma diminuto; cúpula con figura de copa, 3 .

2. Arbol mediano de hojas papiráceas, oblong̨as ó elípticas, ordi- 
nariamente aguzadas, obtusitas, de cara superior lisa y algo reticuladita, mientras en la inferior las venas principales parecen como costillas delicadamente reticuladas, largas de 3 á $10^{\prime \prime}$ y anchas de 1. 1 2 á $3 "$. Panojas pulverulento-pubescentitas, alampiñadas, subcontraidas o estendidas por la base ; pedícelos con verruguitas, verdes y tan largos como las flores y estendidos; lóbulos perigoniales aovados ú oblongados y obtusos; anteras cuadradas de filamentos cortos, cuyos 3 interiores son biglandulosos; ningun estambre estéril; cupula algo cóncava en $1[2$ de la lonjitud de la baya que es ovoideo globosa, con una puntita.-O. Leucoxylon, Gr. - Laurus leucoxyln, Sw.-Phobe membranacea, Macf.

3. Árbol grande, corpulento y coposo, de hojas tiesas y papiráceas, elípticas, aovadas, ordinariamente redondeadas por el vértice, lampiñas y venoso-reticuladas; venas simulando costillas y dispuestas en redecilla visible por ambas caras, ordinariamente con pelo situado en la axila de las venas de la cara inferior; largas de $4^{\prime \prime}$ ú $8^{\prime \prime}$, solıre $2^{\prime \prime}$ o $3^{\prime \prime}$ de ancho; pedícelos mas largos que las flores y estendidos: perigonio pubescentito y con lóbulos redonditos; cúpula $1 / 5$ le lonjitud de la baya. ovoideo-oblonga ú oblonga y distinta del pedícelo espesado y rugosito. O. coriacea. Ts.

G. II. Nectandra, Rottb. - 1. Anteras redondeadas dispuestas á manera de semiluna, 3. - Anteras oval-oblongas mucho mas largas que el tubo perigonial, cuyas 6 esteriores tienen sus celdas apareadas y sobrepuestas, 2 .

2. Árbol grande, corpulento y coposo, de ramitas verdes y alampiñadas, con hojas subcoriáceas oblongas, lampiñas, reticuladovenosas, de venas mas proeminentes por la cara inferior; panojas pequeñas pubescentitas. flojas, abiertas, pedunculadas, infraterminales; pedícelos nas cortos que las flores, cuyas divisiones perigoniales, aovado-oblongas, ohtusas y pubescentitas, son tan largas como los estambres; anteras sentadas iguales y pubescentes, cuyas 3 interiores tienen 2 glándulas; hay 3 estambres interiores estériles, díminutos, subcilíndricos y sin glándulas. N. staminea, Gr.

3. Hojas lustrosas reticulado-venosas, curas venitas están dispuestas á manera de redecilla por ambas caras, 4. - Cara superior mucho mas lisa; venas principales pareciendo costillas distantes y. proeminentes por la cara inferior $y$ formando arcos oblongados, mientras las secundarias son transversales, 9.

4. De ramitas purpúreas. 5. - De ramitas nunca purpúreas, pero sí parduscas ó verdes, 8 .

5. Pubescentitas, árbol grande, corpulento, coposo, y que se eleva como á 15 ó 20 varas de altura; hojas papiráceas, lanceolado-oblongas o elíptico-oblongas con una punta obtusa, lampiñas ó alampiñadas, largas de 2 á $6^{\prime \prime}$, sobre 1 á $2^{\prime \prime} 1[2$ de ancho; panojas estendidas pubescentitas; perigonio tan largo como los pedícelos y cuyas divisiones oblongas y obtusas son pubescentes; anteras iguales sentadas, obovalo-redondeaditas: 3 estambres estériles í con figura de maceta ; cúpula corta ciatiforme, 5 veces mas corta que la haya ovoidea ó aovado-globosa. N. sanguinea, Rossb. - Laurus Borbonia, H. B. K. - N. concimn. Ns. - T. Martinicensis, Jacq. C. T. V. 64.- 
Árbol como de unos $30^{\prime}$ de altura con hojas coriáceas elíptico-oblongas, con una punta obtusa, lampiñas, largas de 3 o $6^{\prime \prime}$ y anchas de 1 á $2^{\prime \prime}$ $1_{[} 2$, venas proeminentes formando redecilla visible por ambas caras: panojas axilares arracimadas é inclinadas hácia alıajo, pubescentitas y mas cortas que las hojas; perigonio tan largo como los pedícelos y cuyos lóbulos oblongos y obtusos son pubescentes por dentro; 6 estambres esteriores subsesiles, hay además 3 interiores esertos espatulados y con un filamento biglandular, todos fértiles, mientras los otros 3 , èstériles y diminutos, son con figura de maceta. $N$. coriacea, Gr. - Lauris coriacea, Sw. C. T. V. 65.

6. Parduscas, sulısedosas ó grises y lampiñas, 7. - Verdosas y lampiñas, 8 .

7. Árbol grande, corpulento y coposo, de hojas papiráceas, lanceolado-oblongas ó elípticas, obtusas, lampiñas ó barbudas en la áxila de las venas de la cara inferior, largas de 3 á 4"; panojas estendidas y subsedosas, perigonio tan largo como el pedículo, curos lóbulos aovado-oblongros $y$ obtusos son subsedoso-pubescentes; anteras iguales; 3 estambres interiores con figura de maceta; cúpula aorzada. N. exaltata, Gr. - Laurus exaltuta, Sw. - Oreodaphne exaltata, Ns. C. T. V. 67.

8. Árbol grande, corpulento y coposo, cuyas hojas oblongas, de base aguzada, de vértice obtusito, con una punta pequeña y delgada, tienen la cara superior lustrosa y lampina, mientras que la inferior provista de una redecilla proeminente es pubescente; semilla ovoidea bastante gruesa y muy aromática. $N$. pichury. Laurus pichurin, L. : C. T. V. 232.

9. Ramitas purpúreas, 10. - Ramitas nunca purpúreas, pero parduscas, 13.

10. Ramitas purpúreas alampiñadas, 11. - Ramitas purpúreas, alampiñadas ó pubescentitas, 12 .

11. Árbol mediano, de hojas subcoriáceas, lanceolado-olılongas i aovado oblongas, ordinariamente aguzadas, lampiñas desde tiernas, lisas y de cara superior no lustrosa, venas primarias, color anhumbroso. en número de 5 ú 8 en cada lado de la costilla, largas de 4 á $9^{\prime \prime}$, sobre 1 o $3^{\prime \prime}$ de ancho. Panojas acorimbadas desparramadas, pubescentitas y de pedicelos tan largos como las flores, cuyo perigonio blanquecino tiene las divisiones ovales y tomentosas interiormente; cúpula corta en forma de escudo, distinta de la parte espesada del pedúnculo y estendida por la base de la hava globosa, tres veces

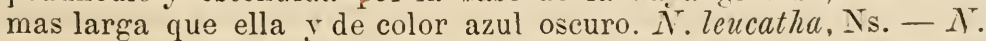
pallida. N. Pisi, Miq. - Laurus Borbonia, Sw. C. T. Y. 64.

12. Árbol muy grande, corpulento Y coposo, de hojas papiríceas aovado-oblongas ó elípticas, cortamente aguzadas, lampiñas, lustrosas y lisas por la cara superior, por donde aparecen las impresiones de las venas primarias en núméro de 4 o 6 de cada lado de la costilla, mientras que son proeminentes por la inferior, con venas secundarias delgaditas; panojas axilares puhescentitas y mas cortas que las hojas; anteras iguales sentadas, redondeaditas, cuyas interiores son biglandulosas; hay estaminodes. N. membranacea, Gr. - Lauris membranacea, Sw. 
13. Árbol primoroso y grande cuyas ramas y ramitas lampiñas llevan hojas pecioladas, elíptico-oblongas, aguzadas, coriáceas lampiñas, de cara superior lustrosa y peninervia, con venitas dispuestas en redecilla, racimos terminales algo acorimbados, mas cortos que las hojas; flores pediceladas con lacinias perigoniales algo desiguales, todas obovaloblongas y obtusas, esteriormente pubescentes é interiormente glanduloso-velluclas, cuyas esteriores son algo mayores; 6 estambres esteriores menores y de anteras entrorsas y 3 interiores estrorsas; 3 filamentos de cada série tienen por la base una glándula globosa; hay 3 estaminodios alesnados pelitiesos. $N$. cigua, A. Rich., Fl. Cuba.

Familia 48. - HERNANDIACEAS. - Árboles bastante altos, densamente ramosos, con las ramitas algo rollizas, con muchas hojas simples, alternas, pecioladas, subabroqueladas, entegérrimas y sin estípulas. Flores acsilares acorimbadas, hermafroditas, solitarias, envueltas en un calículo tubuloso, bífido y deciduo, ó monóicas ternadas adentro de un invólucro tetráfilo, cuyas laterales masculinas son cortamente pediceladas y desnudas, mientras la del medio, sentada y caliculada, es femenina. Las masculinas constan de un perigonio coroliforme bipartido, cuyas lacinias son en dos séries, las interiores estando mayores: 3 estambres opuestos á los segmentos esteriores, de filamentos cortos, erguidos, con la base dilatada, acompanados de una glándula pediculada y sub-coherenté; anteras biloculares, con las celdas situadas por la márjen del conectivo, lonjitudinalmente dehiscentes. Las femeninas se componen de un periantio tubuloso ceñido por un calículo muy corto, aorzado y caduco, de tubo ventrudo, con la garganta estrechada y colierente con el estilo, cuyo limb3 8 partido con las lacinias biseriadas; 4 estambres rudimentarios, glanduliformes insertos en las fauces y formando un anillo adherido con el estilo; ovario sentado, libre y unilocular, con un óvulo único, colgante del ajpice de la celda y anátropo; estilo terminal, simple, elongado, coherente con las fauces del perigonio, claviforme por el vértice $y$ terminado por un estigma infundibuliforme, franjeado y 4 lobo. Drupa monosperma 8 costilluda, encerrada en el tubo del cáliz hinchado, ventrudo y esponjoso interiormente, semilla inversa subglobosa, de testa crustácea, con el rafe anular, embrion sin endospermo ortótropo, con los cotiledones maximos lobados y torulosos; raicilla corta y superior. Hernandia sonora, L: C. T. V. 502 .

Familia 49.- TIMELEACEAS ó TIMÉLEAS. - Arbustos ó árboles de mediana altura, con hojas simples, cnteras, alternas, $y$ alguna vez que otra opuestas, coriáceas y pecioladas ; fiores apétalas, ordinariamente hermafroditas, pero sin embargo bastantes veces unisexuales por causa de aborto y frecuentemente provistas de un invólucro, dispuestas en grupos axilares que salen antes de las hojas $y$ algunas veces en especie de cimas terminales. Están formadas de un perigonio coroliforme, colorido, monófilo y tubuloso, cuyo limbo con 4 á 8 divisiones mas ó menos profundas, dispuestas en dos séries y siempre de estivacion empizar'rada, está algeunas veces 4 dentado y provisto alguna vez que otra de 4 escamas petaloideas. 
situadas por la base de los lobulos ó en la garganta perigonial ; 4 á 8 estambres hay pegados por el interior del tubo; pistilo compuesto de un ovario único y súpero, ordinariamente solitario lateralmente pegado y terminado por un estigma subsesil. Fruto abayado ó drupáceo monospermo; semilla invertida, así como el embrion contenido en un endospermo delgado que suele faltar bastantes veces, derecho y cuyos cotiledones plano-convexos son á veces lobados y como ganchosos, de raicilla corta y superior.

G. I. LA GetT Tinteavia, Lamk.-Daphnelagetta, Sm. : C. T. V.39.

G. II. Daphnorsis, Mart. - 1. Arbustos de ramitas puljescentitas que llevan hojas de dos colores, 2. - Arbolitos como de unos 20 á $30^{\prime}$ de altura, cuyas ramitas lampiñas tienen hojas de un solo color siempre, 3 .

2. Papiráceas, lanceolado-oblongas, de cara superior glabra, mientras la inferior es pubescentita, largas de 3 ó $4^{\prime \prime}$, sobre 10 á $18^{\prime \prime \prime}$ de ancho, cuya base va adelgazándose en peciolo corto, mientras el vértice es tan pronto puntiagudo como obtuso; pedúnculos simples de 1 á 1 " 1 [2 largos, llevando flores cortamente pediceladas, sedosas, blanquecinas, de tubo perigonial tres veces mas largo que el limbo, cuyos lóbulos lanceolados y puntiagudos son encorvados; baya ovoidea. D. Suartzii, Meisn. - Daphne occidentalis, Sw. Haragasseria Suartzii, Gr.

3. Flores masculinas de tubo perigonial, con figura de maceta y 3 ó 4 veces mas largo que el limbo, 4. - Flores masculinas cuyo tubo perigonial, ni filiforme ni en maceta tampoco, es solamente 2 veces mas largo que el limbo, $\check{5}$.

4. Hojas papiráceas ó subcoriáceas, lanceolado-oblongas, elípticolanceoladas ó elípticas, ordinariamente puntiagudas, largas de 3 á 4" y cortamente pecioladas; flores cimosas y en cabeza á la par, blanco-seríceas, cuyos pedúnculos son bi ó tricótomos, sentarlas, cuyas femeninas están por la periferie, mientras las del centro, cualquiera que sea su sexo, están siempre menos desarrolladas; perigonio de las femeninas infundibuliforme, y por último campanudo, con anteras ahortadas $y$ el estigma algo eserto; baya elipsoidea, larga de $4^{\prime \prime \prime}$, puntiaguda y tan larga como el perlícelo que la lleva. $D$. $t i$ nifotia, Gr. - Daphne tinifolia, Sw. - Nordmannia tinifolia, Tisch. - Hargasseria tinifulia, Endl. C. T. T. 40.

J. Hojas subcoriáceas, lanceolado-oblong̨as y lampinias, venosas, ordinariamente mas estrechas que en la especie anterior; flores cimosas carnoso-pubescentes, sentadas ó cuyas femeninas son subsesiles, las del centro menos desarrolladas que las de la circunferencia; perigonio de las femeninas embudado y por fin campanudo, con los lóbulos ol,tusitos y doblados hácia adentro; pedúnculos á veces dicótomos; bara elipsoidea, puntiaguda y mas larga que su muy cortito pedícelo. D. Caribca, Gr. - D. tinifolia, Meisn. C. T. V. 40.

\section{CLASE XXII. - POLIGOXOÍDEAS.}

Familia 50. - POLIGON ÍCEAS ó POLIGÓNEAS. - Plantas herbúceas con raiz perpendicular malo ó menos grtuesa y carnosa 
ó bastantes veces fibrosa, ó arbustos y hasta árboles algunas veces bastante grandes, con hojas sencillas enteras, mas ó menos palmeadas ó lobadas, le figura y de tamaño muy variados, siempre alternas, cuyo peciolo mas ó menos largo está provisto por la base de una especie de vaina membranácea estipular que ciñe al tallo y á los ramos, por encima de cuyos nudos ó especies de coyunturas mas. ó menos crecidos está situada y que se llama ocrea, de prefoliacion arrollada hácia afuera; flores apétales, ordinariamente bastante pequeñas y dispuestas en grupos axilares, en espigas y ó en panojas terminales, que constan cle un perigonio comunmente coroliforme, monófilo, cuyo limbo partido en 4 ó 6 lacinias o lóbulos mas ó menos profundos, y alguna vez que otra dispuestos en dos séries, cuyos esteriores están al cunas veces provistos de un tuberculito glandular situado por en medio de la base esteriormente, de estivacion imbricada. De 4 hasta 9 y 10 estambres insertos en el fondo perigonial y hácia la base de las divisiones á las cuales están opuestos, y en dos séries, cuya interior es incompleta, con las anteras estrorsas, mientras la série esterior las tiene introrsas, biloculares y que se abren lonjitudinalmente. Pístilo compuesto de un ovario único, libre, unilocular, cor un huevecillo único y basilar anátropo, cuyo vértice lleva 2, 3 ó 4 estilos libres ó soldados entre sí, á veces muy cortos, terminados por estigmas simples ó plumosos. El fruto es una cariopside ó un aquenio triangular ú oral mas ó menos encerrado en el perigorio persistente, que algunas veces vuelto carnoso simula una drupita, cuya semilla derecha contiene un endospermo farináceo, frecuentemente delgado y de un embrion derecho ó arqueado situado lateralmente en él, con la raicilla vuelta hácia arriba.

\section{Ancilisis dicotómica de las sub-órdenes, tribus y sub-tribus.}

1. Flores hermafroditas ó polígamas, 2. - Flores dioicas poliandras cuyo perigonio femenino es 6 partido, con los lóbulos interiores conados en tubo triquetro piramidal, adherente con el ovario incluso en él; ocrea lejítima ninguna. Sub-órden I. Srmmerieas.

2 . Siempre hermafroditas y sin invólucro; perigonio 3 partido cuyo fructífero es seco; estambres 8; ovario libre y triquetro, de óvulo colgante, con el funículo basilar, libre y larguito, por último erguido; ocreas lejítimas nulas ó apenas pronunciadas; tallos las mas veces fruticosos y zarcillosos. Sub-órden II. Brunnichieas. Hermafroditas ó polígamas con ó sin invólucro, 3 .

3. Con invólucro; ocrea lejítima apenas pronunciada; el invólucro tubulado y gamofilo o raras veces prolífilo envuelve á una ó algunas flores; perigonio 6 partido; estambres 9 , ovario libre, huevecillo basilar sentado y ortótropo, con la semilla derecha, embrion inverso con la raicilla superior y encerrado en un endospermo muy poco desarrollado. S.-órd. III. Eriogoneas. - Hojas sin invólucro, variamente ocreadas; estambres 1-9, frecuentemente $6-8$ y rarísimamente 12-17; ovario libre ó mas rara vez adherid por su base con el perigonio; óvulo basilar erguido. S.-órd. IV. Poligoneas, 5. 
5. Aquenio 2-4 angular cuyos ángulos están dilatados en ala ó en cresta; embrion axil; flores casi siempre hermafroditas. T. I. PLERIGOCARPEAs, 6. - Aquenios con los ángulos sin alas ó rarísimamente provistos de una: embrion lateral $y$ mas rara rez axil: estam-bres definidos en número de 6-9, rarísimamente 1-5. T. II. Apterocarpeas. 7.

6. Ovario 4 gono; estigmas 4 cabezudos: aquenios triquestros con los ángulos alados ó dentado-crestados, erizados ó dilatados en una membrana avejigada: perigonio 5 partido marcescente 0 acrescente; estambres 12-17. Sub-tribu I. Galrlgoneas. - Ovario 2-3 gono; estigmas 2 ó 3; aquenio lenticular ceñido por una ala ó triquetro 3 alado, cuvas alas son entegérrimas y desnudas; perigonio 4-6 partido; estambres 6-8-9. Sub-tribu II. Ríbarbareas.

7. Flores hermafroditas ó polígamo-dioicas, 8. - Flores monóicas ó dioicas, 9 .

8. Flores sola y únicamente hermafroditas, de perigonio 3-5 partido, con lóbulos sub-iguales y conniventes por encima del fruto. conformes ó cuyos tres esteriores son á reces aquillados ó alados ; aquenio libre lenticular ó triquetro 1 locular encerrado en el perigonio seco, mas raras veces eserto. Eupoligoneas. S.-T. III. - G. I. Hermafroditas ó polígamo-dioicas, 9 .

9. Perigonio marcescente con ó sin callos ó tuberculitos, $4-6$ partido, cuyos 2 ó 3 lóbulos interiores acrescientes erguido-coniventes encierran el fruto, mientras los esteriores apenas agudos son llanos y reflexos; aquenio triquetro raramente lenticular. RumiEss, S.-T. IV. G. III. - Perigonio carnudo y formando una especie de drupa, pero por fin volviéndose marcescente al desecarse, 5 partido y por último cerrado; aquenio incluso frecuentemente adherido con la base perigonial trigono ó sub-globoso, semi-trilocular; semilla asurcada, 3-6 loba, de endospermo las mas veces ruminado. Subtribu V. Coccolobeas. G. II.

10. Flores monoicas de perigonio femenino 6 fido, cuyos 3 lóbulos esteriores conados en tubo triquetro, de ápice 3 dentado, encierran el fruto, los dientes del vértice se vuelven espinitas ó salen del centro de la quilla, mientras los interiores son mucho menores derechos. Sub-tribu. VI. Ceratogeneas. - Flores dioicas mas raramente hermafro ditas: perigonio fructífero seco, 6 ó mas raras veces 3 par tido, con los 3 lóbulos esteriores crecidos y aliformes, erguidos y membranosos, mientras que los anteriores menores están subinclusos ó alguna rara vez son nulos; aquenio libre incluso ó subeserto, triquetro ó azurcado, trílobo, l semi-trilocular, de endospermo ruminado. Sub-tribu. VII. Triplarideas.

G. I. Polig onų, L. - 1. Hojas conpuntitos transparentes; cáliz provisto de glándulas, 2. - Hojas sin puntitos transparentes y perigonio sin glándulas, 3 .

2. Yerba de tallo lampiño, con hojas lanceoladas, aguzadas, pestañositas, ocrea tubular pestañosa: flores en racimos erguidos, delgados é inferiormente interrumpidos; pedícelos por fin esertos; estambres 8 ; estilos 3 ; aquenio triangular, lustroso. $P$. acre, Kth. : C. T. V., 27. 
3. De tallo pubescente ó alampiñado ; ocrea cerdosa y con pestañas largas, 4. - Yerba enteramente lampiña; ocrea sin cerdas ni pestañas tampoco, 5 .

4. Hojas lanceoladas ú oblongo-lanceoladas, aguzadas por la base, elongadas é insertas por arriba de la base de la ocrea tubular $y$ apretada, cuyas franjas tiesas son largas de 6 á $8^{\prime \prime \prime}$; flores rosadas en racimos erguidos filiformes o delgaditos; estambres 6 y á veces 8 ó 5 estilos, 2 reunidos por la base; aquenio biconvexo ylustroso. $P$. acuminatum, Kth. - P. barbatum, Mey.

5. Yerbas de hojas lanceoladas ú oblongo-lanceoladas, aguzadas y pecioladas, cuyo peciolo sale por arriba de la base de la ocrea tubular; flores color de rosa en racimos erguidos filiformes; estambres $6-8$; estilos 2 ó 3 ; aquenio bi-convexo ó triangular y lustroso. P. glabratum, WT.

G. II. Coccoloba, Jacq. - 1. - Aquenio saliendo un poco por afuera del limbo perigonial carnudo; hojas papiráceomembranosasy pegadas en la base de la ocrea,2. - Aquenio enteramente encerrado en el perigonio vuelto carnoso, hojas coriáceas insertas en el dorso de la ocrea, 3.

2. Arbolito de 20 á $25^{\prime}$ de altura algo mas ó menos, muy ramoso, con hojas papiráceas, elípticas ó elíptico-oblongas aguzado acuminadas por ambos estremos, ó algo redonditas por la base, largas de 7 á 4" sobre 21 l 2 ó 2 de ancho; nervaduras cuyos surquitos son visibles por la cara superior, mientras que son proeminentes por la inferior, algunos nervios algo salientes se ven por ambas caras; flores amarillentitas en espigas simples, largas de 3 á $4^{\prime \prime \prime}$ en forma de varita, ordinariamente algo mas gruesas por el vértice en donde están aglomeradas las flores; base del perigonio 5 partido envuelta por brácteas; estambres esertos; baya blanca ovoidea larga de $2^{\prime \prime \prime}$

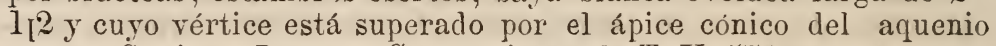
negro. $\dot{C}$. nivea, Jacq. - C. excoriata : C. T. V. 574.

3. Pedícelos de las flores mas largos que las brácteas y con un nudo ó una articulacion por debajo del ápice, 5. - Pedícelos de las flores un poco mas largos que las brácteas diminutas y con un nudo en el ápice, 4.

4. Arbol grande, de madera jaspeada, con hojas anchamente elípticas, obtusitas ó con una puntita, redondeadas ó algo recortaditas por la base, lampiñas, de cara superior pulida y lustrosa, largas de 8 á $5^{\prime \prime}$ sobre 5 á $3^{\prime \prime}$ de ancho, cuyo peciolo tiene 12 á 18"', con la ocrea aplicada, estriada y larga de 6 á $8^{\prime \prime \prime}$, cara inferior con las nervaduras algo proeminentes; racimos simples, flojos, subsentados, largos de 4 á $2^{\prime \prime} 1_{[} 2$, con los pedícelos simples, distantes, estendidos ó cabizbajo de $2^{\prime \prime \prime}$ le largo; tubo perigonial oval-semi-globoso, ancho de $2^{\prime \prime \prime}$ y mas largo que los lóbulos pubescentitos; estambres sub-iclusos y cortos; estilos esertos; baya aovado-conica larga de $8^{\prime \prime \prime}$ sobre $6^{\prime \prime \prime}$ de ancho; aquenio fibroso. C. zebra, Gr.

5. Hojas acorazonado-orbiculares , 6. - Hojas redondeaditas, lampiñas, cuyas nervaduras y venas aparecen en la cara superior por los surquitos que forman, mientras que son proeminentes por la inferior; cortamente pecioladas y anchas de 24 á $8^{\prime \prime \prime}$; ocrea hendida 
Y redondeada; racimos compuestos cuyos pedícelos son casi tan jargos como las flores y articulados hácia en medio, perigonio largo de $1^{\prime \prime \prime}$; bara ovoidea larga de $3^{\prime \prime}$. Arbol bastante grande y alto. $C$. latifolia, Lam.

6. Hojas frecuentemente mas anchas que lareas, lampiñas, pulidas con las nervaduras algo proeminentes por ambas caras, largas de 6-3" sobre $7-3^{\prime \prime}$ de ancho, cortamente pecioladas y cuyos nervios no son proeminentes; ocrea alampiñada; racimos simples filiformes largos de 8 á $6^{\prime \prime}$, con pedícelos amanojados articulados hácia el medio y mas largos que las flores, blanquecinas y de $1^{\prime \prime \prime} 1{ }^{2} 2$ de diámetro; bara ovojdea larga de $8-6^{\prime \prime \prime}$ r de color moreno azuladito. Arbol mediano ó bastante grande y muy ramoso. C. urifera, Jacq.: C. T. T., 70 .

Arbol bastante alto y poco ramoso, de hojas subsesiles, alampiñadas y ásperas por la cara superior en los lugares correspondientes con los surquitos de las renas, arrumbroso-pubescentes inferiormente $y$ en especial anchas de $6-2^{\prime \prime}$ con peciolo espeso, largo de 2 á $3^{\prime \prime \prime}$, y àdherido á la ocrea estendid a corta y arrumbroso-velluda; racimos simples con pedícelos amanojados mas largos que las flores pequeñas y verduscas; bara ovoido-oblonga $C$. pubescens, L.

G. III. Rumex. 1. Flores de perigonjo arejigado ó como vesiculoso, 2. - De perigonio nunca jamas avejicado, 3.

2. Planta herbácea de tallo como de $6^{\prime \prime}$ algo mas ó menos, con hojas sub-carnosas pecioladas aovadas ó sub-deltoideas, obtusas ó ąuzaditas y acuñaditas á la vez por la base acorazonada y sub-hastada, curas superiores son mas estrechas y casi sentadas; racimos simples ó apanojados $y$ afilos, con $2 \dot{0} 3$ grupitos de 2 á 5 flores, apartados; pedícelos unifloros ó con dos llores conaulas por el dorso Y situadas en su ápice: valvas mayores del perigonio tenuamente reticuladas, sub-orbiculares, desiguales, con ó sin callos, de márjen entera, acorazonadas: flores hermafroditas pocas, mezcladas con las masculinas. R. vesicarius, L.-Lapathum resicarium, Iœnch.: C. T. V. 575 .

3. Tallo estriado como de $l^{\prime}$ de largo, saliendo de una rajz perpendicular, carnuda, del tamaño del dedo pul rar, poco ramoso; hojas radicales largamente pecioladas, mientras las caulinares lo son mur poco. ovales sub-acuminadas, llanas, redondeadas por la base y con la márjen dobladita hácia afuera y unduloso-festoneaditas, de cara superior lampiña, mientras la inferior es finamente pubescentita, peninervias y bastante grandes: las del tallo casi lanceoladas Y pequeñas; flores en racimos apanojados, afilos y mas cortos que las hojas, formadas de verticilios sub-confluyentes densamente multifioros; de pedícelos 2 á 3 veces mas largos que el perigronio, bastante grandes y con lobulos oval-obtusos, cuyos interiores dos veces mayores que los esteriores peninervios intererrimos son sin callos. R. latifolium, Inth.: C. T. V. 804. - Yerba vivaz de raizcarnuda, derpendicular y del tamaño del dedo, cuyo tallo derecho se eleva como á 1' 1 [ 2 ó a 2 ' de altura : lojas radicales elongadas, undulosorizadas, lareramente pecioladas atruza pas por ambos estremos, puntiagudas, oblongas, ? hastonte ancies, mientras las caulinares 
lanceoladas y poco pecioladas son lineares en la parte superior ó en los ramos; flores en panojas foliosas por la base y por fin densas y sub-afilas, y formadas de verticilos aproximados ; divisiones perigoniales no muy grandes, anchamente ovales, sub-acorazonadas, obtusas con redecilla proeminente, entegerrimas ó apenas dentaditas por la base y todas callíferas. $R$. crispus, L. - Lapathum crispum, Lan.: C. T. V., 804.

\section{CLASE XXIII. - QUENOPODÍNEAS.}

\section{Familia 51.- QUENOPODIÁCEAS, SALSOLÁCEAS,} ATRIPLICEAS y QUENOPODIEAS. - Plantas herbáceas frutices y raras veces arbustos lampiños pubescentes o lanados; de tallo cilíndrico o anguloso, continuo y foliáceo ó articulado y frecuentemente afíleo; hojas simples alternas y raras veces opuestas, sentadas o pecioladas, las mas veces membranáceas y dilatadas, otras veces carnudas, suculentas, semi-cilíndricas ó cilíndricas; en el primer caso son entejérrimas dentadas incisas, picadas ó sinuadas, mas ó menos venosas, lampiñas, claucas y mas ó menos pubescentes sin estípulas; flores diminutísimas, regulares y hermafroditas, alguna vez que otra polígamas, y rarísimamente declines ó unisexuales por causa de aborto, sentadas ó pedunculadas, solitarias ó agrupadas, tan pronto axilares como apanojadas, espigadas, arracimadas y terminales; acompañadas de 2 brácteas ó de 2 bracteitas, raramente contiguas, frecuentemente con forma de quilla, cóncavas, ordinariamente foliáceas y raras veces deciduas, suelen faltar algunas veces. Perigonio con 5 y rara vez $4-3$ y hasta 2 sépalos mas ó menos reunidos entre sí por la base, ordinariamente iguales, lampiños ó velludos, herbáceos, verduzcos, los cuales despues de la fecundacion se quedan secos ó se vuelven carnudos con ó sin puas, de estivacion imbricada; estambres 5 , raras veces en número menor por causa de aborto, insertos con mayor frecuencia en el fondo del perigonio, ordinariamente toros fértiles y opuestos á las divisiones perigoniales y cuyos filamentos son raras veces mas largos que ellas, subalados y filiformes; libres ó algunas veces reunidos por la base en una especie de cúpula corta, con anteras biloculares erguidas ovales ú oblongas, introrsas, abriéndose por una grieta lonjitudinal, y pegadas por la base de su dorso ó por el ápice; de celdas opuestas y trabadas á veces por la base, mas rara vez separadas por la base y el vértice á la par; conectivo angosto, no rara vez terminado en un apéndice erguido mas ó menos dilatado, petaloideo ó con figura de cartucho ó avejigado ; granitos polínicos, globosos y ovales á la par; los estaminodios ó estambres absortos que se observan en algunos pocos géneros son diminutos, situados entre los filamentos y alternan con las divisiones perigoniales; se halla ordinariamente un nectario situado entre los estambres y el pistilo, el cual es tan pronto semi-anular y gruesecito, como ciatiforme carnosito ó membranáceo, pero que suele faltar frecuentemente; ovario único ovaloblongo ó deprimido y globoso á la vez, mas frecuen- 
temente libre que soldado con el tubo perigonial y siempre unilocular, huevecillo único tan pronto sesil y sentado en el fondo de la celda, como sostenido por un funículo corto, horizontal o colgante y anfitropo, cuyo micrópilo mira hácia la base, la periferie ó el vértice del ovario; hay comunmente dos estilos, raras veces son tres, terminales y tan pronto larguitos como cortos, subulados, filiformes, mas o menos aproximados por la base y divergentes por el ápice, cuya superficie esterior lleva el estigma; algunos géneros tienen un estilo único que se termina por 2-3 y rara vez 4 estigmas lanceolados, comprimidos ó semi-cilíndricos. Fruto monospermo envuelto en el perigonio, indehiscente mútico ó apiculado; de pericarpio membranáceo utriculado y perteneciendo á un aquenio, otras veces á una cariopside y rarísimamente á una baya; semilla horizontal ó vertical erguida $\dot{\alpha}$ inversa, lenticular ó reniforme, de tegumento tan pronto doble y con testa, crustáceo ó coriáceo y endospleura membranácea, como simple, delgado y membranáceo. Endospermo copioso, poco ó nulo, ordinariamente farináceo ó rara vez sub-carnoso; embrion homotropo, las mas veces encorvado $\dot{o}$ anular, periférico y ceñiendo al endospermo mas ó menos perfecta y completamente, otras veces es plano ó en forma de espiral; raicilla situada cerca del ombligo; plumula inconspicua ; cotiledones planos y convexos á la rez, angulosos.

\section{Análisis dicotómica de las tribus y sub-tribus.}

1. Embrion anular S. Ord. I Ciclobeas, 2.- Embrion dispuesto en espiral S. Ord. II. Espirolubeas. II.

2. Tallo articulado y frecuentemente desprovisto de hojas, mas ó menos carnudo y suculento; flores hermafroditas todas conformes $\because$ alojadas en cavidades que se hallan en el raquis ó en los artejos sencillos ó dobles. Tr. I. Salicornieas. - Tallos continuos y siempre provistos de liojas, 3.

3. Flores hermafroditas y raras veces polígamas, todas conformes ó con la misma forma, 6. - Flores diclines, es decir, unisexuales o polígamas, 4 .

4. Cuyas masculinas tienen formas diferentes de las femeninas 0 son dimorfas, cuyo perigonio se halla frecuentemente reducido á 2 ventallas ó divisiones; pericarpio libre, $\dot{o}$ algunas veces adherente, comprimido, cuyas semillas tienen el tegumento doble ó simple, en el primer caso la testa es crustícea. Hojas membranosits llanas, mas ó menos triangulares y hastadas. Tr. II. EsprNa('IEAs, כ.

5. Semilla con tegumento doble. S. Tr. I. Atripliceas. Atriples. Spinacia. - Semillas de tegumento simple ó único. S. 'T'. II. Eurutineas.

6. Hermafroditas ó polígamas, 7. - Siempre polígamas, 8.

7. Hojas llanas i lineares membranciceas, raras veces carnuditas remi-cilíndricas; pericarpio libre; semilla de tegumento sencillo. Tr. III. Canforosmeas. 8.

S. Hojas llanas membranosas mas ó menos triangulares y romboideas; fruto ordinariamente libre, de semilla con tegumento io - 
ble cuyo esterior es por lo regular crustáceo. Tr. IV. Quenopodieas ó Axserineas, 9. - Hojas coriáceas, llanas y lineares; fruto adherente curo pericarpio es adherente y confundido con el tegumento simple de la semilla. - Tr. V. Corisfermeas, 10.

9. De semilla horizontal. S. Tr. V. Beteas. Chenopodium. - De semilla vertical. S. Tr. II. Bliteas. Blitum.

10. De semilla vertical. S. T. I. Panderieas. - De semilla horizontal. S. 'Tr. II. Kínhieas.

11. Tallo continuo con hojas suculentas y rermiculares; flores hermafroditas todas conformes $y$ con bracteitas; pericarpio libre y raras veces adherente; semilla con dos tegumentos cuyo esterior es crustáceo, embrion enrollado en espiral sobre un mismo plano. T. VI. Suadeas ó Scedineas, 12. - Tallo continuo ó articulado con hojas suculentas semi-cilindricas ó cilíndricas; flores hermafroditas conformes; pericarpio delgado $y$ apenas libre; semilla de tegumento sencillo y membranoso ; cuyo embrion está enrollado en espiral encima de unos planos, de manera que figura un cono.T. VII. SALSoLEAS, 13.

12. De semilla vertical. S. T. I. Eschanguneas. - De semilla horizontal. S. T. II. EsCHOBERICEAS.

13. De semilla horizontal. S. T.I. Sodcas. Salsola. - De semilla vertical. S. T. II. Axabasquas.

S.-T. Beteas. Chenopodium, L. 1. Embrion incompletamente anular; hojas con glandulitas, 3. - Embrion completamente anular; hojas sin glándulas, 2.

2. Deltoideo-aovadas con dientes algo desiguales; espigas axilares ó terminales abiertas ó flojas; perigonio un poco aquillado y que no encierra enteramente el fruto, de semilla orlada y opaca. C. murale, $\mathrm{L}$.

3. Yerba anual de tallo asurcado, ramosísimo, alto de $1^{\prime} 1_{l} 2$ hasta 2 , derecho y erguido, cuyos ramos estendidos llevan hojas algo pecioladas, derechas lanceolado-oblongas, ó espatuladas, sinuoso-dentadas cuyas superiores son enteras y casi sentadas y lineares, de un color verde bastante subido; flores en racimos axilares, derechos, largos de unas $2^{\prime \prime}$ y foliosos ; perigonio fructífero apretado contra el fruto y nunca con figura de quilla; semilla redondeada lisa, lustrosa y negra. C. ambrosioides, L. C. spatulatum, Sieb.: C. T. V., 826. Planta herbácea perenne, de tallo cuya base es algo leñosita, derecho ramosísimo y que se eleva á 2 ó $3^{\prime}$ de altura, anguloso, cuyos ramos mas ó menos rojizos y lampiños llevan hojas pecioladas, derechas y erguidas, lanceoladas y oblongas á la vez ó elíptico-oblongas, cuyas inferiores son sinuadas, aguzadas por ambos estremos. Flores en racimos largos axilares ó terminales, delgados densifloros, cuyo perigonio fructífero está aplicado al fruto perfectamente, nunca con figura de quilla estilo trífido, semilla redondeada lisa $y$ lustrosa. C. anthetminticum, L.: C. T. V., 827.

Familia 52. - BATIDEAS. - Vejetales fruticosos que se crian en los sanitrales y lugares anegados de cuando en cuando por las aguas del mar, de tallo derecho, ramoso, que se eleva á 2 ó $3^{\prime}$ de altura lo mas, con hojas opuestas suculentas, y muy dobles, sin es- 
típulas, sentadas ó apenas pecioladas; flores dioicas amentáceas desnudas, en amentos o especie de conos oblongo-cilíndricos apanojados ó no, axilares ó terminales. Las masculinas constan de 4 estambres que alternan con algunas escamas membranosas, las cuales están inclusas en un invólucro delicado y bífido é insertas por la base de una bráctea orbicular reunida por los bordes con las vecinas $y$ formando así los conos y cuyo ápice estí doblado por afuera, son esertos $\mathrm{y}$ de filamentos aplanados que llevan anteras bi-loculares lonjitudinalmente dehiscentes; los amentos femeninos están formados de flores compuestas de una simple bráctea que sostiene el pistilo semianidado en el eje carnudo del cono un poco 4 seriado, y sin invólucro; ovario 4 locular, coronado por el estigma bi-lobo, con un huevecillo basilar $y$ anátropo en cada celdilla; fruto suculento abayado, de endocarpio coriáceo, cuya semilla de testa membranosa contiene un embrion simplemente arqueado, con cotiledones carnosos y grandes, y una raicilla corta, cónica y apropiada á la forma simétrica de la semilla, endospermo nulo.

Batis maritima, L.: C. T. V., 472.

Familia 53. - BASELEAS ó BASELACEAS. - Plantas herbáceas ó algunas veces matas de tallos ordinariamente trepadores, volubles frecuentemente por la derecha, larguísimos, mas ó menos delgados y ramosísimos, con hojas simples mas ó menos pecioladas, bastante dobles y á veces carnosas, sin estípulas, ordinariamente alternas, y alguna vez que otra opuestas, lampiñas comunmente verdes, pero alguna rara vez rojas, mas ó menos grandes y de forma variada, enteras; flores pequeñas pediceladas o sentadas, solitarias ó en espigas axilares simples ó ramosas, delgadas y fiojas, que constan de un perigonio doble, carnoso ó membranoso, lampiño comunraente colorado, coroliforme y persistente, cuyo esterior mas ó menos soldado por la base con el interior es bi-partido de divisiones ó sépalos casi opuestos, iguales derechos ó abiertos y estendidos, y por fin secos ó abayados con una ala ó quilla en el dorso ó sin ella; mientras que el interior mas ó menos envuelto por el primero es quinquefido ó 5 partido, cuyas lacinias profundas simulan á veces sépalos iguales ó desiguales, derechos y raras veces abiertos ó estendidos, y de estivacion empizarrada ; los estambres son 5, períjinos y salen de la base, ó del centro de la parte interior del perigonio, ó mas bien hipójinos é inferiormente soldados entre sí y con el perigonio á la vez, á cuyos lóbulos están opuestos, inclusos ó poco salientes, con filamentos alesnados y filiformes, mientras su parte inferior es ensanchada, de anteras biloculares, aovadas o asaetadas, introrsas $\mathrm{y}$ algunas veces recostadas o estrorsas y lonjitudinalmente dehiscentes. Pistilo con ovario unico aovado o casi trígono, libre, unilocular, uniovulado, curo huevecillo fijo en el fondo de la celdilla es anfítropo; lleva en su vértice un estilo simple, cortito, raras veces prolongado y terminándose por tres estigmas algo separados, engrosados hácia è ápice, obtusos ó bífidos, algunas veces hay un solo estigma trílobo ó casi trílobo y cabezudo, mas rara vez simple; fruto monospermo aqueniforme envuelto por el perigonio ya seco bialado ó sin alas, ya vuelto carnudo y abayado; pericarpio crustá- 
ceo, cartilajinoso ó membranoso, evalvo ó sin ventallas, algunas veces adherente á la parte interior perigonial; semilla vertical aovada $\dot{o}$ casi giobosa, con testa membranosa, cuyo endospermo abundante o escaso estí dividido en dos masas aplicadas al centro de la espira, otras veces es anular ó cuya figura es intermedia entre la ganchosa y la de semi-lunar, gruesecito $y$ periférico; embrion de cotiledones plano-convexos y algunas veces casi foliáceos cuya raicilla descendente se dirige hácia la base cárpica.

S.-örd. 1a. Baseleas. Endospermo casi nulo, escéntrico ; embrion en espiral. - Basella rubra. B. cordifolia : C. T. V. 680-681.

S.-órd. 2. Anrederas. Endospermo manifiesto y regular, central; embrion anular. Anrederas scandens. Devenischia hemostatica: C. T. V. 129.

Familia 54. - FITOLACACEAS. - Vejetales herbáceos ó sofruticosos, las mas veces lampiños, cuyos tallos cilíndricos ó irrezularmente angulosos, derechos ó inclinados son continuos, foliosos y llevan hojas simples alternas, rarísima vez sub-opuestas, sentadas ó pecioladas, de limbo cuya base se va dilatando y aguzando en peciolo, membranosas ó dobles y como carnudas, anchas ó angostitas. mas frecuentemente entegérrimas, raras veces envainadoras, denticuladas y peninervias, sin estípulas ó con dos estípulas libres y situadas en la base de los peciolos, subuladas ó aguijonosas, deciduas 6 persistentes. Flores regulares ó sub-irregulares, hermafroditas ó raras veces dioicas, pediceladas ó alguna vez que otra sentadas Y dispuestas en espigas, en racimos ó en corimbos axilares ó terminales $y^{\prime}$ opuestos á las hojas; las flores están acompañadas por tres brácteas ó bracteitas, raras veces dos, persistentes ó caducas, cura inferior es con bastante frecuencia mayor que las laterales aproximadas, de las cuales á veces está un poco apartada. Perigonio formado de 4 á 5 sépalos, mas ó menos reunidos entre si por la base, ordinariamente iguales, pero alguna vez que otra desiguales, las mas veces lampiños, herbáceos, de márjen frecuentemente membranosa, á veces colorados por la cara interior, quedándose en el mismo estado despues de la florescencia que antes de ella. La corola suele faltar con bastante frecuencia y cuando existe se inserta en la parte inferior de la base calicinal, cuyos pétalos, en igual ó en menor número que los lóbulos calicinales, alternan con ellos, son libres, diminutos y angostamente unguiculados ; estambres sub-hipójinos insertos en un disco hipójino que ocupa el fondo del cáliz ó pegados en la base de un carpóforo diminuto, su número es tan pronto igual al de los sépalos, con los cuales alternan entónces, como muchos cuyos interiores están en ese caso opuestos á ellos y los interiores alternos, raras veces están en haces ó andróforos alternos, mas rara vez aun se hallan en número indefinido y sin orden ninguno; filamentos filiformes subulados y de base oval ú oval-triangular, libres $\dot{0}$ soldados entre sí inferiormente y formando así una especie de cúpula o de nectario fimbriado ó entero, $y$ se terminan por anteras biloculares erguidas ó inclinadas, ovales, oval-asaetadas ú oblongolineares, introrsas, abriéndose pour una grieta lonjitudinal y pegadas por el dorso ó por la base; de celdas opuestas, trabadas por la 
base, raras veces distintas ó apartadas á la vez por la base y por el ápice; granitos polínicos globosos, ovales ó esféricos y rarísima vez sub-trílobos. Ovario tan pronto simple y algo escéntrico, como compuesto y formado entónces de algunos carpelos distintos, mas ó menos conados ó reunidos y verticilados; otras veces es unilocular aunque compuesto, porque tiene una columna ovulífera; cada celdilla contiene un huevecillo único y cuando hay muchos están pegados en la columna central; el óvulo inserto por la base es canfilótropo y rara vez anfítropo ó anátropo; los estilos laterales salen del ángulo central ó interno de las cajitas, son distintos ordinariamente y rara vez están reunidos por la base, recorvados á manera de gancho y con los estigmas correspondientes situados en la cara interna. Fruto envuelto en la base del cáliz que se ha quedado tal cual sin crecer, á veces estipitado y tan pronto formado de muchas cajitas, como de dos solamente, utricular, cocciforme, nuciforme ó por fin samariforme. Testa de la semilla membranosa ó crustácea, las mas veces lustrosa y quebradiza, cuya endopleura es membranosa; endospermo farinoso, rarísima vez carnoso, tan pronto copioso ó escaso, central y situado entre los cotiledones, como nulo: embrion anular, rara vez homótropo, arqueado, periférico ó rarísimamente erguido.

\section{Análisis dicotomica de las sub-órdenes y tribus.}

1. Fruto siempre simple formado de un carpelo único; cotiledones convolutos ó arrollados. - Sub.-órd. I. Petriverieas. - 2. Fruto compuesto ó raras veces simple, 3 .

2. Un aquenio; endospermo nulo ó escaso; embrion recto ó encorvado. T. I. Seguierieas. Petiveria alliacea, L. : C. T. V.,.291. - Baya ó aquenio coriáceo endospermo copioso; embrion anular. T. II. Rivineas.

3. Fruto compuesto, que es una cápsula tan pronto unilocular con una columna central, como bi ó multilocular, cuyas cajitas están pegadas en la columna; cotiledones nunca convolutos. Suborden II. Giromerieas. 4. - Fruto las mas veces compuesto y rarísimas veces simple, y formado de dos ó mayor número de cajitas distintas ó reunidas y sin columna central ninguna; cotiledones nunca convolutos; testa crustácea. Sub-órden III. FitolaCACEAs. 6.

4. Flores hermafroditas; frutos uniculares; sernillas pegadas en la columna central. T. I. Estegnospermeas. - Flores dioicas siempre, 5 .

5. Frutos bi ó multi-loculares formados de cajitas pegadas al rededor de una columna central, y sin embargo libres entre sí $y$ dehiscentes; testa de la semilla crustácea. T. II. Girostemoneas. - Frutos siempre multiloculares, cuyos carpelos están pegados al rededor de una columna central, un poco reunidos é indehiscentes entre sí; testa membranosa. T. III. Tersonieas.

6. Fruto monocarpio y que consiste en un aquenio papiráceo; semilla de testa crustácea. T. I. Microteas. - Fruto bi o policarpio, 7 . 
7. Fruto dicarpio, rara vez policarpio, cuyos carpelos son cocciformes; semilla de testa membranosa. T. II. Limeas. - Fruto siempre policarpio; carpelos abayados sin jugo ó utriculados; testa crustácea. T. III. Gieseriess.

Petiverieas. T. II. Rivineas. Rivina, L. - 1. Estambres 4 , alternos con las divisiones calicinales, de anteras ovales é introrsas; estilo con un estigma cabezudo, pedicelos provistos por la base de una bráctea decídua, 2. - Estambres 8-12, con anteras asactadas y estrorsas; estigma sentado y apincelado; pedícelos provistos de una bráctea situada por encima de la base, 3 .

2. Planta fruticosa de tallo derecho largo de 6 á 8', pero mas veces solo de una vara, muy ramoso hácia la sumidad $y$ cuyos ramos herbúceos llevan hojas ovales, pecioladas, aguzadas por el vértice, casi enteras. Flores pequeñas, blancas y teñidas de color de rosa, en espigas axilares; lacinias del perigonio oblongas ú obovales, obtusas, aplicadas á la base del fruto, que es una baya globosa, roja y lustrosa, piriforme y tan larga como el pedúnculo que la sostiene. R. Tovis, L. - R. humilis, L. - R. purpurescens, Schrd.: C. T. V. 76.

3. Arbustillo de unos 15 á $20^{\prime}$ de altura, pero las mas reces mucho mas bajo, trepador ó sarmentoso, cuyos largos ramos llevan hojas elípticas ó elíptico-lanceoladas, por el vértice aguzadas, lampiñas, algo festoneaditas. Flores en racimos flojos, ordinariamente mas largos que las hojas, mas grandes que las del precedente y blanquecina ; cuyas lacinias perigoniales, ovales y redondeaditas por fin son reflejas y venoso-riticuladas. Baya mas larga que su pedícelo, de color negro teñido de purpúreo. $R$. octandra, L. - Trichostigme rivinoides, A. Rich., Cba. : C. T. V. 76.

Ficotalacáceas. T. Il. Limeas. Phytolacca, L.-1. Tallo asurcado; estamlires 8; carpelos 8 à 10; 2. - Tallo estriadito, estambres $10-20$; carpelos $10-20 ; 3$.

2. Mata herbácea cuyo tallo saliendo de una raiz carnosa bastante gruesa se eleva á rara y media de alto, algo mas ó menos, ramosa superiormente, color moradusco así como los ramos y peciolos, de hojas elípticas ó elíptico-lanceoladas, puntiagudas, zrandes y pecioladas; flores en racimos espigados, erguidos, cuyos pedícelos son mas cortos que las flores, amarillento blanquecinas, bayas negras bastante gruesas, cuyos carpelos tienen el dorso convexo y proeminente. P. oclandra, L. - P. decandra, Desc. : C. T. V., 489.

3. Vejetal sofruticoso de como dos varas de alto, de tallo ramoso por el vértice, con hojas orales ú óvalo-lanceoladas, cortamente aguzadas, pecioladas, enteras y bastante grandes; flores rojizoblanquecinas en racimos filiformes ó delgaditos, de ápice colgante ó inclinado, mas largos que las hojus: baya negra y los carpelos que la forman convexos por el dorso, son muy poco proeminentes, $P$. icosandra, L. 
ÓRDEN II. - HIPÚJINOS.

\section{CLASE XAIV. - AMARANTÍNEAS.}

\section{Familia 55.-AMARÁNTEASO AMARANTÁCEAS.-Plan-} tas ordinariamente herbíceas y raras veces fruticosas, con hojas simples, enteras, mas ó menos pecioladas ó sentadas, aiternas esparcidas y algunas veces opuestas, ordinariamente sin estípulas y comunmente enteras; flores apétalas hermafroditas ó unisexuales $y$ muy pequeñas, dispuestas en espigas terminales, simples ó ramosas, á veces globosas ó axilares y en grupos ó espiguitas, las cuales constan de un periantio escarioso persistente, coroliforme y de color, monófilo con 3 á 5 lacinias, cuya base está acompañada con frecuencia de escamas ó bracteitas escariosas: 5 estanilures hipójinos tan pronto libres, distintos ó interruptos por otras tantas escamitas ó estamínodes, como monadelfos y reunidos por la base que forma una especie de cilindro ó de tubo membranoso, cuvo vértice lobulado lleva las anteras pegadas por su cara interior; pistilo formado de un ovario único, simple, súpero unilocular, monospermo ó polispermo y de placentacion basilar, cuyo ápice lleva de uno hasta tres estilos, que se terminan en un estigma cabezudito 5 suelen faltar algunas veces; el fruto, ordinariamente ceñido por el periantio, consiste en una cápsula unilocular mono ó polisperma que se revienta perpendicularmente desde el vértice, o se abre transversalmente y es un pixidio; en fin á reces es indehiscente y monospermo: embrion escéntrico, cilíndrico, oblongo torcido al rededor del endospermo harinoso.

\section{Análisis dicolómica de las tribus.}

1. Anteras uniloculares, estambres monadelfos; ovario unilocular monospermo; hojas opuestas. T. I. Gomréveas. Irisine celosioides, L.: C. T. T. 362. - Philoxerns rermiculatus, R. Br. : C. T. V. 362. - Alternanthera achyrantha, R. Br. : C. T. V. - 322. Anteras biloculares, 2 .

2. Estambres reunidos por la base, orario multi-orularlo. T. II. Cerosieas. - Celosia argentea. L. : C. T. T. 74. - Achyranthes aspera, L.: - Estambres distintos, de anteras ordinariamente biloculare; ovario uni-ovulado; hojas alternas. T. III. Amaranteas ó Aquinanteas. - Amblogyne polygonoides, Raf.

G. I. Euxulus, Raf. - Yerba lampiña de tallo derecho, estriadito. ramoso, con hojas ovales ó romboídeas, ordinarianıente retusas, pecioladas; flores en racimos axilares sub-globosos, cuyas superiores forman espigas terminales, verduscas, con brácteas la mitad menos largas que el periqonio; utrículos ó frutos redondeados y ovales á la vez, de ápice un poco aguzado y rugoso. E. riridis, Moq. : C. T. V., 629. - Yerba lampiña de tallo derecho, anguloso o estriadito y 
ramoso, con hojas largamente pecioladas, ovales, obtusas, aguzadas por ambos estremos; flores en espigas bastante largas, algo flexuosas y delgadas, verdes y formando panojas terminales, cuyas flores, bastante densas y cortamente jediculadas, están acompañadas de brácteas tres veces mas cortas que el cáliz, utrículos ó frutos rugosos, casi globosos y de vértice agudito. $E$. caudatus, Moq. - Chenopodium caudatum, Jacq.

G. II. Amarantus, L. - 1. Flores monoicas; fruto reventándose transversalmente, pero incompletamente y por encima de la base, 2. Fruto abriéndose transversalmente por en medio ; flores polígamas, 3 .

2. Planta herbácea, lampiña, de tallo derecho muy ramoso que se eleva á 2 y 3 ' de altura y algunas veces mas, segun el terreno en que se cria, con hojas romboidas ó romboido-lanceoladas, con dos espinas axilares largas de 4 á $5^{\prime \prime \prime}$, muy punzantes y escediendo el peciolo. A.spinosus, L. : C. T. V., 630.

3. Yerba glabra, de hojas romboidal-ovales, obtusas y comunmente retusas ; flores en racimos apanojados, verduscas, cuyas espiguitas superiores cilíndricas son continuas y flexuosas, mientras que las inferiores están interrumpidas por la base ó reducidas á grupos axilares; 5 sépalos oblongo-mucronados, pálidos, con una quilla verdusca, casi iguales, con las brácteas espinositas y con el fruto. A.tristis, L. - Yerba pubescente con hojas ovales ó romboido-oblongas; flores en racimitos apanojados, apurpuraditos, rojas ó verciuscas, cuyas espiguitas cilíndricas están apretalas y estendidas; 5 sépalos oblongo-mucronados, casi la mitad mas cortos que las brácteas espinositas; fruto saliendo un poco fuera del cáliz. $A$. paniculatus, L.

Familia 55. - NICTAJINEAS. - Plantas herbáceas ó arbustos sarmentosos y algunas veces arbolitos, de hojas simples, enteras, opuestas ordinariamente, y raras veces alternas; entre las yerbas algunas tienen la raiz gruesa, el tallo como nudoso y las hojas desiguales en la misma pareja. Flores hermafroditas ordinariamente ó polígamas y hasta dioicas por causa de aborto, dispuestas en grupos axilares, en especies de racimos, panojas ó cimas, acompañadas por la base de una ó algunas bracteitas ó sin ellas, contenidas ó no en un invólucro mono ó polífloro que suele faltar algunas veces, y que constan de un perigonio coroliforme, ordinariamente simple, mas ó menos grande, tubulado y cuya base persistente y volviéndose mucho mas dura envuelve al fruto y lo tiene encerrado; estambres 5 ó 1-3-4 ó 6-8 y hasta 10, cuyos filamentos libres, glandulosos ó escamosos por la base, se insertan al rededor del borde superior de un disco hipójino cupuliforme, anteras biloculares; pistilo único formado de un ovario simple unilocular y monospermo, de huevecillo solitario, basilar y erguido, cuyo ápice lleva un estilo sencillo yá veces torcido, terminado por un estigma cabezudo, algunas raras veces multífido; el fruto consiste en una especie de coriópside contenida en la base persistente del perigonio que la hace casi parecerse á un aquenio, algunas veces parece abayado por haberse vuelto canosa la basa perigonial; la semilla está formada de un endospermo central harionso ycopioso, al rededor del cual está rollada la rai- 
cilla que mira por abajo hácia el punto por donde está pegada la semilla; en lugar de ser arqueado el embrion, es á veces derecho ó conduplicado.

\section{Ancilisis dicotomica de las tribus.}

1. Invólucro nulo; una o tres bracteitas, tan pronto decíduas como persistentes, acompañan á las flores, las cuales son liermafroditas ó polígamas, $\mathrm{y}$ algunas veces dioicas por aborto: embrion conduplicado, derecho ó convoluto. T. I. Boerhanvieas. - Pisonia subcordata, $\mathrm{Sw}$. - Sieinpre un invólucro, 2.

2. Invólucro caliciforme, mono ó polífilo; estambres 5; embrion encorvado; Yerbas de raiz mas ó menos carnosa y gruesa; tallos herbáceos como nudosos y crecidos en los lugares correspondientes y como articulados. T. II. Mira bíleas. - Mirabilis jalappa, L., y sus variedades. - M. dichotoma, Desc. : C. T. V., 531. Invólucro bracteiforme, cuyas brácteas mayores y dilatadas están con frecuencia pintadas y simulan una corola; estambres 8 ; vejetales sarmentosos y trepadores. T. III. Bougalnvilieas.

BoérhaAvieas. - Boerhaavia, L. - 1. Vejetales sofruticosos, trepadores ó enredaderos, 2. - Plantas herbáceas, nunca de tallo trepador, 3.

2. Tallos desparramados, muy ramosos, no muy largos, lampiños con hojas lisas, glabras, cortamente pecioladas, acorazonado-redondeaditas ó aguzaditas, á veces algo repandas, de cara inferior con algunos tuberculitos; fiores amarillento-blancuzcas, dispuestas en umbelas terminales de á 6 ó á 7 , cuyo pedúnculo comun es algo mas largo que las hojas; tubo calicinal elipsoídeo y por fin en forma de maceta, sub-trunco y glanduloso por el vértice, de color oscuro y tan largo como el limbo estendido. B. scandens, L.: C. T. V., 782.

3. Lampiñas; flores rojas ó rojizas, 5. - Pủescentes; flores color de sangre, 4.

4. Yerba de tallo ascendente, ramoso, que se eleva á $1_{1}^{\prime} l_{1} 2$ de alto, con hojas ovales, de vértice redondeado, sub-sinuosas y undulosas, pecioladas, concolores ó de cara inferior mas blanquecina; flores dispuestas en panojas cortas, desparramadas y flojas ó en corimbitos axilares, pediceladas; tubo perigonial por fin con figura de maceta y cilíndrico á la par, redondeado por el vértice, con estrias densamente glandulosas. B. hirsuta, W.-B. caribcea, Jacq.: C. T. V. 292.

5. Flores de color rojo pálido y á veces casi blancas, un poco teñidas de rojo, vértice del tubo calicinal obtusamente mucronado, 6 . - Flores rojas siempre, vértice del tubo perigonial nunca mucronado, pero redondeado y entero, 7 .

6. Yerba cuyo tallo, alto de 2 á 3 , es muy ramoso por el vértice, derecho, algunas veces alampiñado, con hojas ovales ú oval-lanceoladas, de vértice aquazadito y puntiagudas, cortamente pecioladas, undulosas por los bordes, de cara inferior mas blanquecina que la superior. Flores en panojas bastante grandes, flojas, erguidas y de pedícelos muy largos; tubo calicinal por fin aclavado, 5 angu- 
loso y trunco, con estrias proeminentes sin glándulas; 2-3 estambres. B. erecta, L. : C. T. V. 292.

7. Tallo de hase estendida por el suelo, desparramado y cuyo vértice muy ramoso es ascendente y como de $l^{\prime} l_{[} 2$ ó algo mas de alto, de hojas ovales redonditas por el vértice, algo pestañosas por la márjen y bastante dobles, un poco ásperas y de cara inferior mas blanquecina. Flores en janojas flojas, elongadas y abiertas ó estendidas, con pedúnculos filiformes trílloros; tubo perigonial por último con figura de maceta, 5 anguloso, con estrias finas y glandulosas. B. paniculala, Rich. - B. diffusa, Sw. : C. T. V. 242.

\section{SUE-Division 2. - Gamopétalos ó eumonopétalos.}

\section{SEGGION I. - PERIJINOS. \\ CLASE XXV. - CAMPANULINEAS.}

Familia 57. - LOBELIÁCEAS. - Plantas ordinariamente herbáceas anuales, bisanuales ó vivaces, comunmente con savia lechosa, ó algunas reces arbustos ó frutices trepadores, de hojas simples mas ó menos sentadas y á veces escurridas ó decurrentes, raramente enteras, pero sí dentadas, festoneadas ó algo lobuladas y alternas. Flores siempre hermafroditas, de prefloracion valvar, solitarias y axilares, ó en espigas ó panojas flojas y terminales, las cuales constan de un cáliz monosépalo, semi-adherente y con 5 dientes ó lacinias tiesecitas mas ó menos larguitas; corola monopétala bi ó monolabiada, labios desiguales, cuyo superior es bi-partido, mientras el inferior mayor es trilobado, marce insertos en el cáliz con anteras bi-loculares, soldadas entre sí y formando así un tubo por donde pasa el estilo y terminado por el estigma, y de los cuales algunos tienen el ápice barbudo. Pistilo compuesto de un ovario semi-ínfero, bi ó 3 locular polispermo ó á veces 5 locular, cuyo vértice, prolongado á manera de pico, se termina en un estilo simple largo y filiforme que lleva un estigma bilabiado y bastantes veces velludo, cuyos huevecillos están pegados en placentas gruesas. El fruto es una cápsula con dos ó tres celdas, y se abre por el vértice á favor de algunas ventallas que se quedan soldadas por sus lados, otras veces por medio de poros cuyo número corresponde con el de las celdillas, por donde salen semillas pequeñitas de endospermo carnudo; algunas raras veces abayado é indehiscente.

\section{Análisis dicotómica de las tritus.}

1. Fruto indehiscente seco ó abayado; en algunos géneros el tubo de la corola está hendido hasta la base, y en los demas la base se queda cerrada. Tallos comunmente leñosos; pedúnculos frecuentemente axilares y multíforos. Inflorescencia thirsoídea ó anómala. T. I. Delissaneas. Centropogon Surinamensis, Prl. - Fruto siempre capsular, 2. 
2. Cápsula unilocular, 3. - Cípsula bilocular; con dos ventallas medio septíferas y abriéndose por el ápice ó mas rara vez por medio de dos poros. Plantas herbáceas. - T.II. Lobrifis. - Isotoma longiflora,Prl.: C. T. V.,399. - Tupa assurgens. A. D. C.: C. T. V. 400.

3. Cápsula unilocular prismática y elongada, con tres ventallas lateralmente dehiscentes, curas dos son medio placentariadas. - T. III. Cuntonikas. - Sub-bilocular de tatique incompleto y abrienlose á favor de un opérculo ó tapa convexo situado en el ápice. - T. IV. LISOPOMEAS.

Familia 58. - GOODENOVIACEAS. - Vejetales fructicosos o plantas herbáceas no lechosas, con pelo ó lampiños, cuyas hojas simples, mas ó menos espesas, de forma y tamaño muy varios, son esparcidas, dentadas y algunas reces incisas, sin estipulas. Flores distintas axilares formadas de un cáliz monosépalo cuyo tubo está mas ó menos pegado ó adnado con el ovario, de limbo con 3 ó con 5 lóbulos, á veces entero y vagamente persistente; corola monopétala mas ó menos regular, de tubo henrido lonjitudinalmente por la cara suparior y raras veces 5 partible, con el limbo 5 partido con dos labios y raras veces con uno solo, inserta en un disco llano y lanceolado, de lobulos laterales; estambres 5 concretos con la corola con cuyos lóbulos alternan, de filamentos distintos, cuyas anteras concretas ó mas veces libres, verticalmente pegadas por la base y hiloculares, son lonjitudinalmente deliscentes. Polen simple ó compuesto. Ovario bilocular y raras veces 1 ó 4 lccular, cuyo ápice lleva un estilo simple y rarísimamente doble, terminado por un estigma carnudo, entero ó bílobo con la boca pestañosa y raras veces desnuda, provisto de un endusio submembranoso o ciatiforme. Fruto tan pronto polispermo y capsular con los tabiques paralelos á las ventallas, ó mas rara vez contrarios á ellas, como drupáceo ó nuciforme; semillas indefinidas las mas reces provistas de un endospermo carnudo, de embrion erguido con los cotiledones ordinariamente foliáceos y de plumula apenas notable.

Tribu la. Escevoleas. - Semillas en número definido; ordinariamente una ó dos en cada celdilla; el fruto consiste en una especie de drupa ó de nuez adherente con el cáliz cuyo limbo ordinariamente la coroua. - Sccrola Plumieri, I.: C. T. V. 401. - Tribu $2^{a}$. Gondenieas. - Semillas en número indefinido en la celdilla de la capsula.

\section{SEGGION II. - EPIGINOS.}

ÓRDEX 10. - SINAITÉRE.IS.

\section{CLASE XXVI. - ASTEROÍDEAS.}

Familia 59. - COMPUESTAS ó SYNANTÉREAS. - Plantas herbáceas anuales ó bisanuales, matas, frutices y arbustos algunas veces, de hojas compuestas, algunas veces simples, enteras, dentadás, lobadas, laciniadas, siıuadas ó roncinadas, ordinaria- 
mente alternas y algunas raras veces opuestas, sentadas ó pecioladas, lampiñas ó velludas, lisas ó ásperas. Flores pequeñas agrupadas en número muy variado en el vértice de un pedúnculo mas ó menos crecido y desarrollado y formando así calátides ó cabecitas cercadas por un invólucro formado de una ó de algunas séries de hojuelas, cuya forma, tamaño y consistencia varian muchísimo y presentan por esa disposicion particular el aspecto de una flor única cuyo invólucro hace el papel de cáliz, de tal suerte que otras veces se llamaba cáliz comun. Estas florecitas son de dos clases ; las unas regulares, de corola infundibuliforme y tubulosa con el limbo 5 dentado o 5 lobado, las otras irregulares cuyo limbo hendido en toda su lonjitud se prolonga por afuera conforma de una lengüitamas ó menos larga terminada por 5 dientes. Esas fiores se llaman semiflósculos ó lígulas y las primeras flósculos; tales flores son ya hermafroditas, ya solamente masculinas ó femeninas y otras veces neutras, y pueden presentarse las unas y las otras en la misma cabecita ó calátide, ó en calátides diferentes que están dispuestas en espigas, en racimos o en panojas terminales mas ó menos fornidas, algunas veces solitarias y axilares. El ápice del pedúnculo crecido que lleva las flores se llama receptáculo, foranto ó clinanto, es llano ó cóncavo, otras veces convexo ó cónico; las flores salen de su superficie lisa ó están mas ó menos anidadas en su sustancia, $\mathrm{y}$ formando así areolas mas ó menos profundas en la superficie, cuyos bordes al levantarse en derredor de la base de cada ovario ó de cada aquenio se vuelven escamitas enteras ó laciniadas, membranas irregulares ó regulares. cerdas ó pelos. Ese conjunto de flores mas ó menos grueso está cercado y ceñido por un invólucro formado de hojuelas ó de brácteas de forma, tamaño y consistencia muy variados, frecuentemente reducidas á escamas, algunas veces terminadas por una pua y dispuestas circularmente en una série ó en dos y entónces forman asícomo dos arcos concéntricos. En ese caso son poco nurnerosas y àlgunas veces las esteriores, mas pequeñas, no parecen las de la série interior: en el caso de ser numerosas, lo que sucede ordinariamente, son empizarradas y dispuestas en espiral; comunmente libres y algunas veces soldadas entre sí por la base; cada florecita puede estar acompañada de una bracteita propia, que sale con ella del receptáculo y que se presenta con el aspecto de una escama blancuzca ó de una membranita, que se llaman pajitas o bracteitas, cuando faltan, lo que suele suceder con bastante frecuencia, el receptáculo se dice desnudo. cuando el invólucro contiene flores hermafroditas solamente, la calátide se dice homógama. y se llama al contrario heterógama si hay juntas flores hermafroditas y unisexuales; en este último caso las flores neutras ó femeninas se hallan por la circunferencia, mientras que las hermafroditas ó las masculinas ocupan el centro; cuando las cabezas están formadas las unas de flores masculinas solamente $\mathrm{y}$ las otras de femeninas, pero hallándose sobre la misma planta, se dicen heterocéfalas $y$ monoicas cuando contienen á la vez flores femeninas y masculinas; las calátides pueden tener á la vez flores flosculosas ó discoídeas, ó flores semi-flosculosas ó liguladas ó ambas á la vez. y las calátides se llaman radiadas; las flores 
pueden ser todas bilabiadas y las cabezas se dicen falso-discoídeas; otras veces las de la circunferencia son liguladas y las del centro labiadas, las calátides son entónces radiatiformes ó falso-radiadas ; algunas veces en las cabezas flosculosas ó falso-discoídeas las flores esteriores conservan la forma de las interiores, pero se vuelven mucho mayores, y las calátides se llaman entónces coronadas. Tales flores son formadas de un cáliz adherente con el ovario, de tal manera que no tiene limbo alguno; otras veces se dilata un poco por encima del ovario, en donde forma una coronita; con mayor frecuencia se rresenta con forma de algunas divisiones, raras reces foliáceas, pero frecuentemente con la de pajitas ó de escamitas; mas generalmente constituyen un penacho ó pappo del ovario y saliendo del ápice sentado ó estipado; se dice el penacho plumoso cuando los radios que le forman llevan pelo visible, simple ó peliforme cuando glabro parece un pelo largo y liso; cubierto de dientecitos, se llama denticulado. La corola es regular, infundibiliforme, tubulosa y 5 dentada en los flósculos, unilabiada y un poco tubular en los semiflóscalos, y otras veces bilabiada, con uno de los labios vuelto hácia el centro y es entero ó partido, mientras el otro que mira hácia afuera es con 3 o 4 divisiones: tales corolas tienen 5 nervaduras principales que alternan con los lóbulos, de prefloracion valvar. Estambres 5 llevados por el tubo corolar, tienen los filamentos libres ó soluados entre sí; pero las anteras son siempre soldadas entre sí por los bordes y forman así un tubo, de tal manera que el vértice, ordinariamente prolongado en un apéndice mas ó menos largo, es solo distinto; algunas reces su base se dilata y se alarga en una colita que suele faltar otras veces. Pistilo formado de un ovario unilocular con un huevecillo único y erguido, ínfero terminado por un estilo largo, filiforme simple en las flores masculinas, pero siempre en las femeninas y en las hermafroditas partido en dos brazos terminales, de las que una parte de su superficie está cubierta de pelos colectores y con los bordes de la cara interna provistos de dos fajitas glandulosas tenidas por los estigmas lejítimos, aunque se llame cStigmas ordinariamente á los brazos que las llevan; la forma, tamaño $\mathrm{y}$ disposicion de los brazos son muy variados; el fruto es un aquenio coronado por el penacho ó sin él; embrion hemítropo sin endospermo ninguno y de raicilla corta $y$ vuelta hasta el punto por donde se pega la semilla.

\section{Análisis dicotómica de las tribus y sub-tribus.}

1. Calátides homógamas y flores todas liguladas; plantas herbáceas lechosas y de hojas alternas simples, mas ó menos roncinadas. Estilo cubierto de pelo esteriormente y cuyos brazos largos y vueltos por afuera son enrollados y con la cara superior llana. - T. I. Liguliflores. - Calátides heterógamas, 2.

2. Corolas tubulares ó á veces liguladas, solamente las de la circunferencia ó periferie están en ese último caso. - T. II. Tubuliflores ó Corimbíferas, 3. - Bilabiadas ó las de las circunferen- 
cias liguladas: estilo con figura de baston y de vértice un poco en maceta, con los brazos muy cortos y olıtusos, esteriormente pelierizados ó quizá mejor sin brazos, pero cuyo vértice simula una boca con los dos labios óvales derechos, oltusos y peludos por los bordes. - T. III. Labiatiflores. - Leria nutans, De.: C. T. V., 687.

3. Un crecido ó especie de nudo situado inmediatamente por debajo del punto en donde principian los brazos, cubierto ordinariamente de pelo: fajitas estigmáticas tan largas como los brazos cortos, derechos y frecuentemente formando como una boca y confluyen por el vértice de ellos. - S.-T. I. Cardú́ceas. - Ningun crecido ó nudo por deluajo del orijen de los brazos del estilo, 4 .

4. Brazos lineares siguiendo iguales hasta el vértice provisto de pelos, llanos esteriormente $y$ con pelo muy fino, fajas estigmáticas llegando solamente hasta la parte velluda del vértice; penacho peludo; hojas alternas.-- S.-T. II. Asteroídeas. G. II. - Brazos del estilo nunca lincares é iguales á la vez, ni llanos, ni peludos tampoco esteriormente, 5 .

5. Estilo perfectamente cilíndrico, de lurazos troncos por el vé tice, coronado con pelos dispuestos á manera de pincel, pero que despues ra prolongándose en cono ó en apéndice. - S.-T. III. SeNEcióEas, 7. - Vértice de los brazos nunea prolongado en cono ó en apéndice tampoco, 6 .

6. Brazos largos, cubiertos de pelo por afuera y de vértice dilatado á manera de maceta ; fajas estigmáticas llegando a penas al medio de la lonjitud del brazo. punto en donde principian á ser peludos esteriormente; cabezas homócamas y discoídeas: hojas ordinariamente opuestas. - S.-T. IV. Eupatoríeas. G. III.-IV.-V. - Brazos alargados y subulados, ó cortos y obtusos, delgados y cilíndricos, pelierizaditos esteriormente, cuyo pelo es largo é igual; fajas estigmáticas marjinales que no alcanzan al medio de su lonjitud; cabezas discoídeas y homógamas; hojas ordinariamente alternas. S.-T. V. Vernonífas. - Vernonia arborescens, Sw. - Ellephantopus scaber, L.: C. T. V., 84.

7. Flores unisexuales, de penacho no peludo; hojas ordinariamente opuestas. S.-T. VI. Melanpodíneas. - Clibadium Radieri, Gr. - C. terebinthaceum, Dc. G. VI. - Venenoso para las reses $\mathrm{J}$ sus ramas sirven para pescar embarbascado. - Parthenium histerophurus, L. : C. T. V., 148. - Ambrosia artemisifolia, L. . C. T. V. 8:31. - Flores nunca unisexuales, 8.

8. Cabezas siempre discoídeas; anteras de base provista de una colita ó apéndice; estilo de brazos truncos y con pelo apincelado; hojas alternas, enteras ordinariamente, muy peludas y blancas. S.T, VII. Grafalíeas. - Gnaphalium Domingense, Lam.: C. T. V., 403. - Cabezas algunas reces solamente discoídeas, radiadas ó no, 9.

9. Flores del disco siempre hermafroditas, 10. - Flores del disco ordinariamente pero no siempre herniafroditas; aquenio desnudo ó coronado; hojas alternas. Axtemídeas. Egletes Domingensis, Cass.

10. Cabezas discoídeas homógamas ó heterógamas, algunas veces radiadas; anteras sin apéndice por la base; unos géneros tienen el vértice de los brazos provisto de un apéndice cónico corto; ginoxys, 
por ejemplo, y algunas especies del género senecio; penacho no peludo; hojas ordinariamente alternas. S.-T. VIII. SExEcioídeas.Neurolena lobata, B. Br. C. T. V., 151-257. - Senecio discolor, Dc.:

11. Receptáculo desnudo y achatado ó llano; hojas con oflándulas transparentes bastante grandes y numerosas. S.-T. IX. TAGETíNEAS. - Porop; hyllum ruderale, R. Br.: C. T. V., 296. - Receptáculo paleáceo nunca llano. 12.

12. Cónico; cabezas discoídeas o radiadas cuyos radios son ordinariamente femeninos; penacho formado de escamas distintas; hojas ordinai iamente alternas, pero opuestas en las de las Antillas. S.-T. X. Heleníeas. - Calea Jumaicensis, L.: C. T. V. 152. - Receptáculo de formas variadas, las mas veces convexo, con bastante frecuencia cónico, algunas veces llanito y otras veces muy pequeño y cilíndrico; aquenio coronado, cerdoso ó desnudo; lojas ordinariamente opuestas ; cahezas discoídeo-homógamas ó heterógamas y radiadas. S.-T. XI. Helínteas. - Eclipta alba, Hassk : C. T. V., 131. - Borrichic arborescens, Dc.: C. T. V.,259. - Bidens leucanthus, W.: C.T.V., 327. Chysanthellum procumlens, Rich.: C. T. V., 328.

G. I. SpILanthes, Jacq. 1. Yerba vivaz alampiñada de tallos estendidos y echandoraices, mientras los ramos son ascendentes y llevan hojas lanceoladas ó lineares, enteras, aguzadas por la base sub-sentada; cabezas blancas de 4"' de dićmetro, solitarias, sulb-globosas y por último obtuso-cónicas y discoídeas; receptículo cónico cilíndrico; escamas del involucro en número de 6 á 7 y dispuestas en dos séries; aquenio con dos aristas desiguales de las que la mas larga es pelitiesita y pestañosa. S. urens, Jacq.: C. T. V., 458. - Yerbas anuales, 2.

2. Desparramada, alampiñada, muy ramosa y cuyos ramos estendidos por el suelo llevan hojas óvalo-lanceoladas, lanceoladas ú ovales. festoneadito-ondeadas, triplinervias, de base anģostada ó agruzada hasta el peciolo; cabezas ovoídeas y por fin cónicas, con los radios blar cos; receptáculo cilíndrico; invólucro de 56 escamas, encerrando casi las lígulas; aquenio desnudo ó con dos cerdas diminutas, pestañoso, neģro y con la márjen blanca. S. uliginosa, Sw. - S'.tene'la y debilis, Kth. - S. Salzmanni, Dc. C. T. V. 458. De tallo en varita, áspero, pubescentito ó ala mpiñado, con hojasovales ó lanceoladas, festoneadas ú ondeadas, triplinervias, angostadas y de base aguzándose en peciolo; cabezas cónicas, discoídeas y raramente radiadas; receptáculo cilíndrico; invólucro de 5 escamas; aquenio con dos aristas, pestañoso y largo de l"'. S'. exasperata, Jacq.

(x. II. Pr.urhea, Cass. - Arbustillo ramoso que se eleva á 4 o 6 ' de altura, cuyos ramos herrumbroso-tomentosos llevan hojas oblongas ó elíptico-oblongas, puntiagudas, bien enteras ó dentaditas, ondeadas, de cara superior glanduloso-pube:centita, mientras la inferior es blanca, pubescente ó tomentosa; cabezas pediceladas, hemisféricas corno de 4"' de diámetro y dispuestas en corimbos amanojados tomentosos, cuyas escamas del invólucro ovales ú ovaloblongas son obtusas y tomentosas, mientras las de la série interior son oblongo-lineares, aguzadas y escariosas. P. odorata, Cass. : C. T. V., 149. - Mata sofruticosa, de tallo derecho, ramoso superior- 
mente y que se eleva á 3 ó $4^{\prime}$ de altura, cuyos ramos pubescentes ó alampiñados llevan hojas oblongo-lanceoladas ó lanceoladas, desigualmente aserradas, ondeadas, algo pubescentitas, sul,-tomentosas ó alampiñadas y pecioladas; cabezas purpúreas de 2 á $3^{\prime \prime \prime}$ de diámetro, pediceladas y sub-globosas, formando corimbos terminales sub-amanojodas, de escamas herrumbroso-pubescentes y abiertas ó estendidas, cuyas esteriores ovales y obtusitas se vuelven gradualmente oval-lanceoladas y puntiagudas para formar la série interior. P. purpurescens, Dc.: C. T. V., 150-2566.

G. III. - Eupatorium. L. 1. Receptáculo cilíndrico corto y prolongado entre las escanas del involucro; convexo ó achatado porencima de ellas; invólucro formado de escamas apretadas, alampiñadas y dispuestas en algunas séries, 2. - Receptáculo deprimido y ordinariamente diminuto; invólucro abierto formado de 1 á 3 sćries de escamas cuyas esteriores son frecuentemente mas cortas, las de la série principal estando sub-iguales, 3.

2. Arbustito velludo que se eleva como á unos $6^{\prime}$ de altura, con ramos cilíndricos, tiesos, estendidos y que llevan hojas opuestas, pecioladas, ovales ú óvalo-lanceoladas, aguzadas, frecuentemente acuñadas por la base, triplinervias, velludo-pubescentes y con glándulas diminutas esparcidas por la cara inferior, gruesamente aserradas, con algunos dientes por encima de la base sub-entera, largas de $3^{\prime \prime}$, sobre 1' 144 de ancho; cabezas con 20 á 25 flores azul-pálidas ó blanquecinas y olorosas, pediceladas y dispuestas en corimbos tricótomós y densos ; receptáculo llano; invólucro large de $4^{\prime \prime \prime}$, con escamas estriadas, cuyas interiores oblongo-lanceoladas son aguzadas, mientras las esteriores aorado-oblongas son obtusas; aquenio áspero por los angulos. E. odoratum, L. - E. brachiatum, Wirkstz.C. T. V. 152.

3. Arbustillo que se eleva á como unos $4^{\prime}$ á $6^{\prime}$ de altura, cuyos ramos cilíndricos y aterciopelado-herrumbrosos llevan hojas opuestas, pecioladas, deltoídeas, obtusas ú obtusitas, sinuosas, oscuramente aserradas ó sub-enteras, 3 nervias, de cara superior pubescentita, mientras la inferior es aterciopelado-herrumbrosa y glandulosa, ordinariamente largas de $11_{[} 2$ á $3^{\prime \prime}$, sobre 1 á $2^{\prime \prime}$ de ancho y cuyo peciolo tiene solamente 3 ó $4^{\prime \prime \prime}$ de largo. Corimbos amanojadoredonditos formados de cabezas pediculadas y con 8 á 15 flores; receptáculo diminuto, de invólucro cuyas escamas lanceoladas, obtusas, estriadas, son herrumbroso-pubescentes y mas veces sub-iguales; corola gradualmente cónica como de $1^{\prime \prime \prime}$ de largo; aquenio linear algo áspero y tan largo como la corola y el invólucro. $E$. villosum, Sw. - Mata de tallo sufruticoso ó casi leñoso, delgado, largo como de $1^{\prime} l_{[} 2$, ramosísimo y estendido en el suelo, cuya sumidad herbácea es ascendente y carga con hojas casi sentadas, opuestas. lanceoladas, 3 nervias, aguzadas, enteras $y$ lampiñas, frecuentemente moraduscas, así como los ramos. Flores en corimbo flojo; oligocéfalo, cabezas pediceladas formadas de 1-2 flores; invólucro con una série ó algo mas de escamas lineares, acuminadas, desiguales y pubescentes por el dorso, E. ayapana, C. T. V. 719.

G. IV. Critonia, P. Br. - 1. Arbusto ramoso superiormente, derecho y que se eleva á 8 ó 10' de altura, lampiño, muy oloroso, y con 
hojas ianceoladas ó elíptico-lanceoladas, aguzadas por ambos estremos, aserradas y cuyos dientes pequeños son frecuentemente distantes los unos de los otros, un poco lustrosas y largas de 4 ó 6", sobre 2 á $3^{\prime \prime}$ de ancho, cuyo peciolo tiene 4 á $5^{\prime \prime \prime}$ de largo; panojas algo amanojadas y formadas de cabezas en grupos de á 3 ó de á 5 , sentadas ó subsesiles y con 3-4-5 flores; de invólucro largo de 3 á 4"', con escamas dispuestas en 3 ó en 4 séries, estriadas, obtusas, cuyas interiores son oblongas, las del medio gradualmente mas cortas y ovales, mientras que las esteriores son muy cortitas; aquenio pelierizadito. C. dalea, Dc. : C. T.V. 258. - Arbusto alto de 10 á $16^{\prime \prime}$, no aromático, con ramos y peciolos pubescentes, de hojas ovales, elípticas ó cuyas superiores son elíptico-lanceoladas, puntiagudas, aserradas y con los dientes aproximados y frecuentemente mucronados. no lustrosas, largas de $8^{\prime \prime}$, sobre $4^{\prime \prime}$ de ancho; las superiores de 3 á $4^{\prime \prime}$, sobre 1 á $2^{\prime \prime}$, con el peciolo de 4 á $12^{\prime \prime \prime}$; panojas grandes piramidales, formadas de cabezas sentadas agrupadas por á 3 ó á 7 , formadas de 2-3-4 flores, cuyo invólucro, largo de $2^{\prime \prime \prime}$. es formado de escamas sub-estriadas, obtusas y dispuestas en 3 o 4 séries, con las interiores oblongas $\mathrm{y}$ las del medio bruscamente acortadas y ovales, mientras las esteriores son muy cortitas; aquenio algo pelierizado ó alampiñadito. C. parviflora, Ḋc. - Eup. parviflora, Sw.

G. V. Mrkania. WV. - Cabezas dispuestas en espigas oblongadas y compuestas ó en racimos, 2. - Cabezas terminales sostenidas por ramitas acorimbalas, pediceladas ó con las del centro solamente sentadas, cuyo involucro está con brácteas situadas por la base ó sin ellas, 3 .

2. Mata abejucada, de tallos largos, ramosos, delgados, cilíndricos, pubescentes ó alampiñados, con hojas membranosas, alabardadodeltoídeas, cortamente aguzadas, dentado-ondearlas ó sub-enteras. 3 nervias, anchas de $3^{\prime \prime}$; cabezas subsesiles dispuestas en espigas compuestas y delgadas, con brácteas mucho mas largas que el pedícelo rudimatario; de invólucro largo de $1^{\prime \prime \prime} 1[2$ y formado de escamas oblongas y obtusas; flores blancas olorosas, de corola, con el limbo 5 fido; aquenio espeso y pubescentito. M. hastata, W.-Eup. hastatum, L.

3. Mata abejucada como voluble ó mejor enredadera, de tallo largo muy ramoso, bastante delgado, anguloso y puliescente, con hojas deltoídeas, anchamente acorazonadas ó sibcordadas por la base. 5 nervias, irregularmente dentadas ó sulb-enteras, de cara inferior pubescente ó alampiñada, cuyas inferiores son tan largas como el peciolo y tienen 2 ó $4^{\prime \prime}$ de ancho, mientras las superiores son frecuentemente aovadas; cabezas en corimbos apanojados, cuyos parciales son contraidos; pedúnculos velludo-pulescentes; pedícelos ternados mucho mas cortos que las cabezas; bracteitas lanceoladas. ó elíptico-lanceoladas, aguzadas y mitad tan largas como el invólıcro, que tiene $3^{\prime \prime \prime}$ de largo y cuyas escamas oblongas, sub-estriadas, obtusitas ó puntiagudas son puhescente:; limbo de la corola 5 fido, campanulado y tan largo como el tubo; aquenio lampiño con penacho color herrumbroso pálido. M. gonoclada, Dc. - M. guaco, Desc. : (. T. V., 717. Mata enredadera de tallos largos, alampiñada, 
cuyos ramos estriado-cilíndricos algo angulares por su parte superior llevan hojas membranosas, acorazonadas, profundamente sinuarlas, puntiagudas ó aguzadas, 5 nervias, dentadas ó subcimoso ondeadas, alampiñadas; corimbos parciales comunmente umbelados, con pedúnculos angulares, a $a^{\prime}$ co alados por la base, alampiñados, cuyos pedícelos en grupos de 3 o de 5 , son ordinariamente mas cortos ó mucho mas cortos que las cabezas; bracteitas lanceoladas como una mitad menos largas que el invólucro, cuyas escamas oblongas ó oblongo-elípticas, obtusas ó mucronadas, son alampiñadas y estriadas; limbo de la corola campanulado, casi tan largo como el tubo, con 5 dientes deltoídeos; aquenio glanduloso.M. Orinocensis, Kth.M. umbellifera, Gard. - M. sieberiana, Dc.-M. suaveolens, Kth. : C. T. V. 718.

Liguliflores. - Lactuca, L. - Hojas mas ó menos cóncavas, mas ó menos estrechas por la base, bastante grandes, undulosas ó rizadas por los bordes, ó no rizadas, enteras ó sinuadas, con la costilla en forma de quilla lisa y lampiña ó algo alampiñada; tallo con algunas hojas acorazonado-entejérrimas; tallo apanojado superiormente. L. sativa, L. : C. T. V., 560. - Tallo derecho, hojas lanceolado-ensiformes, amplexicaulas y dentadas; flores en racimo terminal compuesto. L. Canadensis, L. - Sonchus pallidus, IVild. Malgedium integrifolium, Cass. - Lactuca Canadensis, altisima angustifolia flor pálido-sulfurea, Tuss. : C. T. V. 561.

\section{ÓRDEX II. - ESTAMBRES LIBRES.}

\section{CLASE XXVII. - LONICEROÍDEAS.}

\section{Familia, 60.- TALERAINÁCEAS o TALERIANEAS.-} Plantas herbíceas, anuales, bisanuales ó vivaces, frecuentemente provistas de un rizoma; hojas simples enteras, lobadas ó partidas de tal suerte que ś veces parecen compuestas, pero son solamente pinatífidas, opuestas, mas ó menos pecioladas. Flores pequeñas siempre bermafroditas, dispuestas en corimbos ó cimas terminales y en panojas algunas veces, acompainadas á veces de hojas florales que simulan un invólucro y constan de un cáliz monosépalo y adherente con el ovario, cuyn limbo dentado tiene con frecuencia sus divisiones rolladas hácia dentro, acrescentes y volviéndose un penacho plumoso ó membranoso; corola monopétala de limbo con 5 lóbulos, mas veces desiguales, y alguna vez provista de un espoloncito, de prefloracion valvar; estambres 5 ó 3 períjinos pegados al interior del tubo de la corola y alternando con sus lóbulos. Pístilo único formado de un ovario ínfero 1 ó 3 locular monospermo, cuyo vértice lleva un estilo simple terminado por 1 o por 3 estigmas; el fruto es una cápsula indeliscente $\dot{0}$ un aquenio con 1 hasta 3 celdas monospermas, de las cuales, dos ordinariamente suelen abortar; coronado por un penacho ó vilano plumoso ó membranoso; embrion sin endospermo.

G. Valeriana, L. - 1. Hojas todas enteras ó un poco partidas, 2. 
Hojas inferiores ó radicales enteras, mientras las caulinares son siempre tripartidas ó pinatílobas, 3 .

2. Yerba de tallo derecho, simple y estriado que se eleva á $I^{\prime} I_{\lceil} 2$ $\delta 2^{\prime}$ de altura, muy poco ramoso y con hojas angostamente lancenladas, aguzalas por la base, dentaditas y pestañosas: flores agrupadas en vertícilos que forman por su reunion espigas oblongadas y algo interrumpilas. $V$. coarctata, C. T. V., 297.

3. Yerba velluda de tallos ramo:os, estriados ó asurcados, cuyas hojas radicales son enteras, acorazonadas ó acorazonado-festoneadas y aguzadas, mientras las caulinares son pinatisectas, con 3 o 5 divisiones ovales, dentaditas, aguzadas, con una impar grande; la base del peciolo es color rosado. Flores en espigas desparramadas; corola de base gihosa, estambres tan largos como ella; penacho formado de 10 rádios ó divisiones. V. paniculata, C. T. V., 297.

Familia 61. - CAPRIFOLIACEAS. - Arbolitos ó arbustos de hojas simples ó compuestas é imparipinadas, cuyas hojuelas son desiguales y ordinariamente dentaditas ó enteras, opuestas, pecioladas y sin estipulas. Flores hermafroditas dispuestas en corimbos, cimas ó racimos terminales, que constan de un cáliz monosépalo adherente, de limbo 5 partido y chra base está acompañada de brácteas; corola monopétala enrodada ó raras veces de otra forma, mas ó menos infundibiliforme, con 5 dirisiones jguales y cuyo tubo, mas ó menos corto, lleva 5 estambres esertos, raramente epíjinos, pero sí períjinos y alternos, con lóbulos del limbo corolar; prefloracion empizarrada; pistilo unien formado de un ovario ínfero cuvo ápice lleva un estilo simple terminado por 1 ó por 3 estigmas; el fruto es un nuculanio, unicular y con tres huesecitos ó una drupita monosperma; embrion pequeño contenido en un endospermo córneo ó carnudo.

Tribu 1a. - SAMBCcíveas. - Corola regular enrodada ó formada de 5 pétalos iguales soldados por la base solamente, raras veces tubulosa, estilo nulo y por consiguiente los 3 estigmas son sentados. Sumbucus Virojiniana. C. T. T., 402. - Tribu 2. - Lonicértas.Corola tubulosa frecuentemente irregular y no enrodada; estilo filiforme terminado por 3 estigmas libres ó reunidos en uno solo.

\section{CLASE XXVIII. - COFFÍNEAS.}

Familia 62. - RUBLÍCEAS. - Plantas herbiceas anuales ó vivaces, matas. fructices, arbustos, arbolitos y hasta árboles muy grandes y corpulentos, de lioj zs simples, enteras, cuya figura, consistencia y tamaño varian muchísimo, pero por lo comun mas ó menos lanceoladas y coriáceas, lampiñas ó pubescentes, lustrosas ó no, pecioladas ó mas raras veces sentadas, opuestas ó verticilalas, acompañadas de dos ó mas estípulas situadas entre la insercion de los peciolos con cuya base están frecuentemente soldałos, de manera que las hojas se hallan trabadas; otras veces forman así una especie de vainita que abraza el ramo, ó libres, de ficrura y tamaño muy variados: suelen faltar. algunas raras veces. Flores siempre hermafroditas, cuya inflorescencia varía mucho; en efecto, están 
tan pronto en grupos axilares como solitarias; espigadas como arracimadas, en cabezas como en cimas ó en panojas, y se componen de un cáliz adherente, cuyo limbo, raras veces entero, es ordinariamente partido en 4 , ó mas raras veces en 5 lóbulos mas ó menos profundos, reemplazados á veces por igual número de dientecitos; corola regular mas ó menos grande, cuya figura y tamaño varían muchísimo, de limbo dividido en 4 ó 5 lóbulos mas ó menos profundos de prefloracion torcida ó valvar. Estambres perijinos 4 ó 5 soldados con el tubo de la corola y raras veces libres de ella, inclusos ó esertos, alternando con las divisiones de la corola y de anteras biloculares que se abren por una grieta lonjitudinal. Pistilo único formado de un ovario ínfero, raras veces libre, por encima de la base, y algunas veces coronado por un disco carnudo atravesado por el estilo, bilocular, mono ó polispermo, cuyo vértice lleva un estilo simple, pero cuyo ápice está bastantes veces partido en tantas divisiones cuantas celdillas hay, terminándose por un estigma ordinariamente cabezudo. El fruto varía tanto por su clase como por su forma, tamaño y consistencia : en efecto, es tan pronto seco y formado de dos carpelos ó aquenios aplicados el uno al otro y separables, ó capsular como carnudo, abayado ó drupáceo, con dos ó con algunas celdillas, con una ó con muchas semillas; tales frutos, cualquiera que sea su clase, son siempre coronados por el limbo calicinal persistente; semillas algunas raras veces provistas de un ala membranosa, pero ordinariamente desnudas y formadas, además de su tegumento propio ó epispermo, de un embrion central y derecho alojado en un endospermo córneo ó carnudo; otras veces está situado transversalmente respecto de] hilo.

\section{Análisis dicotómica de los órdenes y tribus.}

1. Celdillas con uno y raras reces corı dos huevecillos, 2. - Celdillas polispermas ó con muchos huevecillos, 10 .

2. Arboles ó arbustos, á veces matas y hasta plantas herbáceas, con hojas opuestas casi siempre, eor estípulas enterpeciolares, caducas ó persistentes, libres ó trabadas con la base de los peciolos, otras raras veces verticiladas. Frutos drupáceos mas ó menos carnudos, cuyas dos celdas contienen una nuececita mas ó menos dura, huesosa ó córnea, cuya semilla es ordinariamente allanada y asurcada por la cara interna, mientras la esterior es convexa; á veces por casualidad ó por causa de aborto, la nuececita es única y entónces las dos semillas contenicriston las celdillas son erguidas, deprimidas ó lateralmente adberentes; endospermo córneo mas ó menos desarrollado; otras veces el fruto es seco y formado de dos capelos que al madurar se separan el uno del otro ó se quedan pegados. O. $1{ }^{\circ}$. CoFfé́ceas, 3.

3. Hojas opuestas y con estípulas entrepeciolares, 4. - Hojas verticiladas $\mathrm{y}$ sin estípulas; plantas herbáceas anuales o vivaces: fruto seco ó abayado, cuyas semillas son provistas de un endospermo córneo que contiene un enibrion de raicilla inferior; huevecillos 
lateralmente pegados. T. I. Estreli.idas ó Gallíeas. Que constituye la familia de las galliáceas de Lindley. Rubia tinctorum, L. comun en los páramos de Mérirla.

4. De fruto carnudo, 5. - De fruto seco, 9.

5 . Semillas sin endospermo, ordinariamente cilíndricas, cubiertas por el funículo vuelto grandecito; embrion de raicilla larga y con cotiledones cortos; fruto drupáceo; huevecillos colgantes; inflorescencia ordinariamente axilar; árboles ó arbustos de hoja opuestas ordinariamente, pero algunas veces verticiladas por 3 o 4 , con estípulas entrepeciolares. T. II. Guetrárdeas. - Strumpfia maritima, Jacq. : C. T. V., 284. - Semillas provistas siempre de endospermo, 6 .

6. Huevecillos colgantes, 7. - Huevecillos nunca colgantes, pero laterales ó derechos, 8.

7. Corola de prefloracion empizarrada, embrion pequeño, arbolitos, arbustos ó bejucos de estípulas reunidas con los peciolos y formando una vajinita persistente; inflorescencia axilar en cimas amanojadas ó arracimadas; fruto drupáceo ó abayado. T. III. CHiocócCEAS. A. - Corola de estivacion valvar; embrion pequeñito incluso en el endospermo; estípulas caedizas; infiorescencia axilar en panojas tricótomas; arbustos ó bejucos; fruto siempre drupáceo. T. IV. VANGuteríEas.

8. Laterales; corola torcida; embrion regular inclusu en el endospermo, arqueado ó derecho, de radícula inferior y cotiledones foliáceos; estípulas persistentes apiculadas; arbolitos o arbustos. T. V. Ixóreas ó Cóffeas. - Cofféa Arabica, L. : C. 'T. V., 260.Erguidos y derechos raras veces, pegados por encima de la base de la celdilla, corola de lóbulos valvares; embrion regular incluso en el endospermo carnudo ó cartilajinoso; estípulas enteramente persistentes ó cuya parte superior es caediza ó marcescentes, coniventes por la base y formando una vajinita ó libres; flores de inflorescencia axilar ó terminal, en corimbos u ómbelas, en panojas ó racimos, algunas veces en cabezuelas; plantas herbáceas, matas, arbustos ? hasta álboles. T. VI. Psichotrieas. B.

9. Raicilla superior del embrion inclusa en un endospermo carnoso; lóbulos de la corola de prefloracion empizarrada; arbustos frecuentemente espinosos ó matas; flores en cimas acorimbadas terminales ó en cabezas; fruto formado de dos carpelos mas ó menos prismáticos, situados en un carpóforo. T. VII. Cefalásteas. Cephalanthus. - Huevecillos lateralmente pegados; embrion regular contenido en un endospermo cartilajinoso y de raicilla inferior: lóbulos de la corola de estivacion valvar; estípulas cerdosas persistentes, cuya base forma vajinita; inflorescencia axilar o terminal, en grupos, en cimas ó en cahezuelassolitarias ó apanojadas; fruto capsular ó formado de dos carpelos indehiscentes. T. VIII. EspermaCÓr:Eas. E.

10. Arboles, arbustos, frutices, matas y á veces plantas herbáceas, con hojas opuestas ó verticiladas algunas veces; estípula. interpeciolares, libres ó las mas veces trabadas; fruto capsular, abayado ó drupáceo, con semillas aladas ó no en el primer caso y uunca 
aladas en el segundo, bilocular ó multilocular. Ór. 11. Cinchon ÁCEAS.

11. Fruto carnudo, 12. - Fruto capsular, 14.

12. Placentas ó trofospermos parietales con algunas semillas; lobulos de la corola de estivacion torcida ó empizarrada; estípulas interpeciolares persistentes ó raras veces caedizas; inflorescencia terminal, acorimbada ó aracimada, á veces solitaria; baya con dos celdillas conteniendo algunas semillas; arbustos ó árboles bastante grandes. T. I. GardexíEas, F. - Placentas ó trofospermos centrales, 13.

13. Con muchos huevecillos ó 2 solamente, engastados ó unidos en él; prefloracion de los lobulos de la corola empizarrada ó torcida; flores corimbosas, arracimadas o solitarias y dispuestas en ca.bezas involucradas terminales; fruto abayado ordinariamente bilocular, algunas reces bi- $-\frac{1}{4}$ y $4-5$ locular, con algunas semillas y rara vez una sola; arbustos ó árboles con estípulas interpeciolares. T. II. RavdíEas, H. - Huevecillos superficiales, 14.

14. Lóbulos de la corola de prefloracion empizarrada; muchos huevecillos situados por la periferie del placenta; fruto con dos celdas ó con 4-5 ó 6 de semillas pequeñas; sarcocarpio espesito; flores ordinariamente en cimas terminales, en panojas ó en racimos, á veces con algunos brazos escorpioídeos, es decir, rollados; arbustos ordinariamente, raras veces árboles; estípulas interpeciolares. T. III. Hamelíeas. I. - Lóbulos de la corola de estivacion valvar; muchos huevecillos sobre la superficie placentaria; baya bi 4-5 locular polisperma; poco carnoso el sarcocarpio; flores axilares amanojadas ó agrupadas; arbustos abejucados ó yerbas rastreras; estípulas enterpeciolares. T.IV.-SA BIcíEas. Coccocypselum repens, Sw.

15. Estípulas enterpeciolares libres, 16. - Estípulas trabadas ó reunidas con los peciolos y con cerdas, 17.

16. Corola de estivacion valvar; cápsula bilocular con muchas semillas comprimidas y provistas de una membranita marjinal, á veces prolongada en colita por ambos estremos; loculícida ó septícida; inflorescencia ordinariamente corimbosa; arbustos ó árboles cuyas estípulas entrepeciolares son caedizas. T. V. Crxcóxeas, J.Corola de prefloracion valvar, cápsula bilocular polisperma, septícida ó loculícida, con semillas provistas de un ala ó sin ella y raras veces con una colita; inflorescencia terminal o axilar, acorimbada, arracimada, apanojarla, ó flores solitarias en los pedúnculos; arbustos ó árboles y rara vez plantas herbáceas de estípulas enterpeciolares. T. VI. RondeletíEas. K.

17. Cápsula loculícida por el vértice, un poco espesa, bi-locular y con muchas semillas; flores axilares solitarias y mas ó menos pedunculadas; plantas herbáceas. T'. VII. Hediotídeas. L.

Oldenlendia. L. K.-G.-I. - Yerba anual lampiña ó alampiñada cuyo tallo delgado y ramoso se eleva como á l' $]_{[} 2$ de alto y lleva hojas lanceoladas ó lineares sentadas, 1 nervias y terminándose inferiormente en vaina, largas de 1" ; estípulas formadas de 3 cerdas; flores blancas en úmbelas ó corimbos, con 2 ó 5 pedícelos filiformes, ordinariamente mas cortos que los pedúnculos; de corola de $1^{\prime \prime \prime}$, cuyos 
lóbulos son tan largos como el tubo; anteras ovoídeas; cápsula trunca, sub-globosas, aguzada y con un diente lanceolado. O. corymbosa, L.: C.T. V.834. - Yerba anual lampiña de tallo delgado, délill, alto como de $\mathrm{l}^{\prime}$, no ramoso y con hojas lanceoladas ó linear-lanceoladas, aguzadas, uninervias, largas de $I$ á $2^{\prime \prime}$; estípulas con algunas cerdas $\delta$ reducidas; flores de pedícelos sub-solitarias y largas como de $8^{\prime \prime \prime}$, filiformes ordinariamente escediendo las hojas; de corola mitad tan larga como el tubo; anteras ovoídeas, cápsula glolosa, estrechada hácia las comisuras, diente lanceolado y aguzado. O. herbacea, Dc. - O. tenuifolia, Forst. - Hedyotis Heynii, Br.

A. - G. II. - Erithalis, P. Br. Arbusto ó arbolito ramoso, de hojas obovales ó espatulado-lanceoladas, obtusas ú obtusitas, largas de 3 á 4", lustrosas, cortamente pecioladas; flores de limbo calizinal ondeado sub-trunco, de corola con las divisiones oblongo-lineares ó larceolado-oblongas y largas de 4"" ; carpidios 6 10-20. - E. fructicosa, L. - E. odorifera, Jacq.: C. T. V. 367. Arbusto de hojas elíptico-lanceoladas ó lanceoladas, aguzadas por ambos estremos, largas de $3-4^{\prime \prime}$ sobre $1^{\prime \prime}$ de anchọ; flores cuyo cáliz tiene el limbo con 5 dientes, deltoídeas y de corola con divisiones óvalo-lanceoladas; carpidios $5-6$. E . angustifolia, Dc.

G. III. Chroccoca.-P. Br. Arbusto de tallo muy ramoso, sarmentoso, alto de $4^{\prime}$ á $10^{\prime}$ con hojas como apergaminadas elípticas ú ovallanceoladas, cortamente acuñadas por la base, de vẻrtice mas ó menos acuminado-obtusito ó algo puntiagudo; estípulas cuyo mucro ó punta es mas corta que su vainita ó tan larga como ella; flores blancas pequeñas, en racimos oblongos tan largos como las lojas, ordinariamente compuestos, con 2 brácteas bi-dentadas, situarlas por la base, de cáliz con dientes deltoídeos, de corola 5-loba ó 5 -fida cuyas divisiones son óvalo-lanceoladas; anteras lanudas é inclusas en el tubo de la corola ; baya orbicular blanca con $2-3^{\prime \prime \prime}$ de diámetro. C'. racemosa, Jacq. : C. T. V., 368. - Bejuco largo y bastante alto, de ramos larguísimos y horizontales que llevan hojas pequeñas ovales ú ovaloblongas, cortamente acuñadas por la base y cuyo vértice se termina en una punta obtusita ; largas de 8 "' á 1" ; estípulas alesnadas y mas largas que su vaina; flores blancas pequeñas, en racimos flojos, simples, mas cortos que las hojas, provistas de dos brácteas dentarlas situadas por la base; dientes calizinales deltoídeo-ovales $y$ obtusitas; corola con 5 lóbulos larceolados ú óralo-lanceolados y cuyo tubo está superado por los ápices puntiagudos de las anteras; baya blanca orbicular y de $2^{\prime \prime \prime}$ de diámetro. C. parvifolia, Vallschl. - C. racemosa, Var. Si. - C. racemosa, Sieb.: C. T. V., 368.

B. Psichotríeas. - Flores sin invólucro alguno. S.-T. I. PsiCotríeas lejítimas ó Eupsicotríeas. C. - Flores dispuestas en cabezas ó en grupos terminales provistos de un involucro. S.-T. II. Cefaelídeas. D.

C. - G. IV. Psichotria, L. - 1. Huesitos ó pirenas de la baya separables los unos de los otros segun el eje, lijeramente encorvados por la comisura, apenas 5 crestados, ó 4 -asurcados, ó lisos por el dorso, endospermo sin surcos por el lado cóncavo ó allanado de la comisura; arbustos á veces abejucados, con estípulas sub-cartilajinosas, 
ianudas ó de vaina marcescente ; flores en panojas o cimas terminales 2. - Huesitos ó pirenas de la baya no separables, 3.

2. Arbustillo lampiño de hojas membranosas, lanceoladas ó espatulado-lanceoladas, obtusitas, con venas arqueadas, largas de 24" y aguzándose gradualmente por la base hasta volverse peciolo; estípulas pequeñas, curtilajinosas, deltoídeas, 2 por cada lado, ó una sola, pero reventándose en 2 divisiones; cimas con tres brazos paucífloros; flores en racimitos con bracteitas; limbo calizinal dilatado, subentero y mas largo que el tubo; lóbulos de la corola l[ 3 mas largos que el tubo; baya globosa, cahizbaja y de $2^{\prime \prime \prime}$ de diámetro, cuyos pirenas son lisas o lijeramente 5-crestaditas. $P$. nutans, Sw. - Frútice ó mata leñosa lampiña que se eleva á 1 ó $4^{\prime}$ de altura, de ramos estendidos que llevan hojas membranosas, elípticas ó elípticooblongas, puntiagudas, con venas arqueadas, largas de $111^{2} 2$ á $3^{\prime \prime}$, de cara inferior, con pelo en la axila de las nervaduras; estípulas redondeaditas, dentaditas, una por cada lado, marcescentes, con los dientes decíduos, y por fin volviẻndose cartilajinosas; cimas 2 veces con 3 brazos paucíloros, con las flores en racimitos, de limbo calizinal dilatado, finamente dentadito y mas largo que el tubo; corola hipocrateriforme, transversalmente aplicada en la garganta, lampiña, de tubo largo de $2^{\prime \prime \prime} 1_{[} 2$ y $1_{[} 3$ mas corto que los lóbulos de ella; baya oval-globo:a, por último casi lisa, erguida y de $2^{\prime \prime \prime}$ de diámetro. $P$. horizontalis, Sw.

3. Involutas ó rolladas á manera de espiral por las comisuras, 4. - Nunca jamas rolladas ó involutas, 9.

4. Estípulas decíduas, con la base corta persistente; endospermo camfilótropo y penetrando en la parte rollada de las pirenas; flores en panojas terminales, formadas de racimitos distantes, con luracteitas pequeñitas y terminales, de brazos estendidos, 5. - Estípulas persistentes mellizas ó bífidas; la espiral de la márjen de los huesecitos formada por causa de un surco grande situado en la comisura ; endospermo como en el precedente; panojas terminales cuyas flores son aracimarlas, 6 .

5. Arbustillo lampiño, jaspeado y glauco, cuyas ramas cilíndricas y lisas llevan hojasapergaminadas, oval-oblongas, redondeadas por la base y obtusitas por el vértice, con venas costilludas $\mathrm{y}$ distantes, largas de 8-3" sohre $4^{\prime \prime}-11{ }^{\prime \prime} 2^{\prime \prime}$ de ancho, lustrosasy de cara inferior abigarrada con puntitos negros, de peciolos largosde $2^{\prime \prime}-1[2$; panojas flojas, tan largas como las hojas, formadas de racimitos compuestos de algunas flores, ordinariamente distantes re 6-12"' las unas de las otras, y de brazos verticilados por á 5 ó á 3; flores de limbo salizinal 5 -dentado y por fin 5-fido ; corola larga de $1^{\prime \prime \prime} 1_{[} 2$, cuyos lóbulos son dos veces mas cortos que el tubo; anteras oblongas; baya oblongaelipsoídea larga de $3^{\prime \prime \prime}$, lisa y coronada por el limbo calizinal. $P$. $f(e-$ tida, Gr. - P. feetens, Sw. - P. Browei, $\mathrm{Hb}$.

6. Brácteas grandes y escediendo el cáliz, 7. - Bracteitas pequeñas ó apenas notables, 8 .

7. Arbusto de unos 6 á $8^{\prime}$ de altura, lampiño, cuyos ramos, lijeramente tetrágonos, llevan hojas apergaminadas eliptical-oblongas ó tanceolado-oblongas, puntiagudas, largas de 5-4", con peciolos de 3 
á 6 "' de largo y cuyas venas son arqueadas; estípulas reunidas por la hase cortamente bifidas y persistentes, largas de $3^{\prime \prime \prime}$; panojas pedunculadas, peludas, cuyos brazos estendidos llevan por el vértice racimitos ternados é involucrados, cuyas bracteitas ovales son un poco mas largas que el cáliz; flores de color a marillo prálido, de corola larça de $2^{\prime \prime \prime} 1_{1} 2$, alampiñada interiormente, cuyos lóbulos pubeseentitos son mas cortos que el tubo infundibuliforme; anteras oblongas é inclusas, baya ovoídea, de color de añil y coronada por el limbo calizinal sub-entero: pirenas ó huesecitos con 5 crestitas. P. brachiata, $\mathrm{Sw}$ - P. capitata, Dc.

8. Arbustito lampiño de ramos cilíndricos y un poco estrechados, que llevan hojas apergaminadas eliptical-oblongas ó elípticas, puntiagudas, largas de 4-3", con las venas arqueadas; estípulas 2 de cada lado, lineares y aguzadas, mucho mas largas que la vainita que forman por la reunion de su hase y persistentes, largas de 1 á ' 2 '", panojas largamente pedunculadas corimbiformes, de lirazos coloridos y terminados por cimas escorpiódeas y flores sentadas, acompañadas de bracteitas lanceolado-lineares tan largas cono el cáliz ó escediéndole un poquito; corola blanca, glabra en la garganta, larga de $2^{\prime \prime \prime}$ y cuyos lóbulos son la mitad tan largos como el tubo, con figura de maceta; anteras lineares; baya redondeadita, negra, de 1-2"' de diámetro, contraida en las comisuras, transversalmente rugosita, con huesecitos 5 angulosos. P. patens, $\mathrm{Sw}$.

9. Huesecitos ó pirenas comprimidos por el dorso y con 3 crestas, cuyas laterales son contiguas con los ángulos de las comisuras; endospermo plano-comprimido y sin surcos, tallos herbáceos con hojas grandes, estípulas solitarias cuya parte superior es caediza mientras la base persistente forma vaina, 10. - Huesecitos ó pirenas semicilíndricos con 5-3 crestas equidistantes; endospermo asurcado por debajo de las crestas, llanito y con dos surquitos situados en el lado comisural ó sin ellos; estípulas solitarias decíduas desde la base o cerca de ella ; panojas terminales con flores diminutamente bracteoladas, 11.

10. Yerba sofrutecente ó mata de 2 a 3 ' de alto, glabra ó alampiñada y algo suculenta; de hojas obovales ó elípticas, ordinariamente puntiaguditas, costilludo-venosas, largamente pecioladas, largas de 10-6" y con peciolos de $2^{\prime \prime}$; estípulas puntiagudas, panojas axilares tricótomas, de pedúnculos mas ó menos larg̨os, lampiños 6 pubescentitos, formados de flores arracimaditas de color rojo pálido y pequeñas, de limbo cảlizinal 5-dentado, y de corola cuya garganta es velluda; anteras lineares; baya de color carmesí, oval y por fin algo lisa. P. uliginosa, $\mathrm{Sw} .-\mathrm{P}$. leeris, Dc.: C. T. V., 4:35-476.

11. Estípulas distintas, 12. - Estípulas reunidas y formando una vainita, frecuentemente diminutas, 13.

12. Mata fruticosa de 3 á $4^{\prime}$ de alto, ramosa lampiña y de hojas algo coriáceas ó apergaminadas, elípticas ú oblongas, obtusas ó puntiagudas por ambos estremos, largas de 3 á $7^{\prime \prime}$, con venas costilludas, de cara inferior frecuentemente con grupos de pelo en la axila de las venas; estípulas anchas, lifidas, largas de 5 á $4^{\prime \prime \prime}$, con divisiones subuladas y decíduas, con los pelos de la base persistentes; 
panojas tricótomas, cortamente pedunculadas ó subsesiles, formadas de flores arracimaditas, cuyo limbo calizinal es 5-fido, corola larga de $1^{\prime \prime \prime}$, cuyos lóbulos son tan largos como el tubo; baya elipsoídea larga de 3 á $4^{\prime \prime \prime}$, de huesecitos blancos, cuyo endospermo tiene dos surcos por la comisura. P. tenuifolia, Sw. - P. glabra, Sieb.

13. Arbustillo cuya parte superior es herrumbroso-pubescente, con ramos que llevan hojas apergaminadas, lanceolado-elípticas, aguzadas largas de $4^{\prime \prime}$ á $2^{\prime \prime} 1_{1} 2$, sobre $1^{\prime \prime} 1_{1} 2$ de ancho, acostilladovenosas, de cara superior alampiñada, mientras la inferior es algo pelitiesa ó alampiñada entre los nervios; estípulas conadas ó ruptiles, con una vainita diminuta, obovales, frecuentemente puntiagudas, bífidas, membranoso-herrumbrosas, decíduas, con la base corta marcescente, largas de 6 á $3^{\prime \prime \prime}$; panojos sesiles y tricótomas, mas cortas que las hojas, formadas de flores en racimitos, cuyo limbo calizinal es diminutamente 5-dentadito, corola larga de $2^{\prime \prime \prime}$, cuyas divisiones son mas cortas que el tubo; baya elipsoídea larga de $3^{\prime \prime \prime}$ y ancha de $1^{\prime \prime \prime} 1{ }^{2}$, de pirenas llanos con endospermo bi-asurcado por la comisura. P. rufescens, Kth. - P. Portoricensis, Dc.

G. V. Palicourea, Aubl. -- 1. Estípulas persistentes, dos de cada lado, ó reunidas por la base en una vaina; flores perliceladas, 2. Estípulas decíduas bi-dentadas; flores ternadamente arracimadas, 3.

2. Arbustillo rarnoso, de unos 6 á $8^{\prime}$ de altura, lampiño; base de los ramos cilíndrica, mientras el vértice es sub-tetrágono; hojas apergaminadas elípticas, ó lanceolado-oblongas, puntiagudas, pecioladas, á veces lanceolado-elípticas; de nervaduras regularmente arqueadas; estípulas lineares aguzadas, mas largas que la vaina, muy cortas y largas de 1 á $2^{\prime \prime \prime}$; panojas piramidales, raramente corimbosas, con brazos de color anaranjado, flores del mismo color, corola lampiña larga de 4 á $6^{\prime \prime \prime}$, cuyo tubo es cilíndrico y con figura de maceta á la vez; estambres y estilo esertos: baya oval-redondeadita, lateralmente sub-comprimida. P. crocea, Dc. - P. croceoides, Ham.: C. T. V., 482.

3. Mata fruticosa, lampiña, que se eleva á unos 5 ó $6^{r}$ de altura, lisa y con los entrenudos cilindricos; hojas membranosas lanceolado-oblongas ó elíptico-oblongas, puntiagudas, pecioladas, de nervaduras arqueadas y distantes; estípulas diminutas, sub-distintas y de divisiones deltoídeas; panojas acorimbadas, de flores blancas olorosas y ternadas, subsesiles hácia el ápice de los brazos, de corola lampiña, hipocrateriforme, cuyo tubo, largo de $6^{\prime \prime \prime}$, filiforme y con figura de maceta á la vez, es algo arqueado, lóbulos desiguales oblongo-lanceolados $I_{[} 3$ tan largos como el tubo; baya sub-globosa, lateralmente sub-comprimida. P. pavetta, Dc. - Psychotria pavetta, Sw. - Paretta pentandra, Sw:

D. - G VI. Cephaters, Sw. - Bayas casi lisas; pirenas y epispermo planos, ó lijeramente encorrados por la comisura; brácteas involucrales reunidas por la base, abiertas y coloridas, 2. - Pirenas obtusamente 5-estriadas y enrolladas por la comisura; endospermo campilótropo, penetrando un poco en la parte rollada; brácteas in- 
rolucrales distintas ó casi distintas, tan largas ó mas cortas que las filores, 3 .

2. Arbusto lampiño de 12 á 15 ' de alto, de entrenudos tetrágonos, cuyos ramos llevan hojas eliptical-oblongas, con una punta corta y obtusita, largas de 6 á $3^{\prime \prime}$; estípulas tan largas como su vaina, axilares, redondas, obtusamente 2 -lobadas, abiertas y largas de $2^{\prime \prime \prime}$; flores en cabezas terminales, largamente pedunculadas, de 8 á $6^{\prime \prime \prime}$ de diámetro ; invólucro purpúreo cuyas dos divisiones grandes, anchamente orales y obtusitas, son mucho mas largas que las flores. C. punicea, V. - C. elata, Sw.

3. Arbusto que se eleva hasta $15^{\prime}$ de altura, lampiño, de ramos cuyos entrenudos son cilíndricos, mientras la sumidad sub-tetragonal lleva hojas cortamente pecioladas, lanceolado-oblongas, aguzadas y largas de 4 á $3^{\prime \prime}$; vaina estipular trunca, abierta y provista de algunas aristas tiesas y decíduas; cabezas florales terminales y subsesiles, de brácteas azul pálido, cuadradas así como las pajitas y cortadas por el vértice; flores blancas y bayas azules. C. muscosa, Sw. - Vlorinda muscosa, Jacq.: C. T. V., 434. - Arbustillo lampiño de entrenudos obtusamente sub-tetrágonos, cuyos ramitos llevan hojas largamente pecioladas, lanceolado-oblongas ó elípticas, largas de 5 á $3^{\prime \prime}$, con el peciolo de 12"', puntiagudas; estípulas tan largas como su vaina, ovales, 2-lobas y sin aristas; cabezas florales ordinariamente axilares, sentadas y de 10 á 6 "' de diámetro, cuyas brácteas, involucrales redondeadas, son mas cortitas que las flores; pajitas obóvales de vértice laciniado ó pestañoso; baya sub-globosa con surcos. C. axillaris, $\mathrm{Sw}$.

G. V. II. Moninda, L. - Mata fruticosa de como 1' de alto, lampiña o alampiñada, cuyos ramos cilíndricos llevan hojas lanceolado-oblongas, puntiagudas y largas de 3-2"; estípulas subuladas; cabezasflorales pequeñas, solitarias en las axilasó terminal'es mas largas que su pedúnculo, que tiene solamente 1 ó $3^{\prime \prime \prime}$ de largo, formadas de flores blancas y olorosas; frutos globosos de 4 á $6^{\prime \prime \prime}$ de diámetro. M. 100yoc, L. : C. T. V., 510.

Vejetal arborecente, glabro, de ramitas tetrágonas que llevan hojas ğrandes, elípticas, puntiagudas ú obtusas, largas de 6 á $8^{\prime \prime}$; estípulas redondeaditas: oabezas florales opuestas á las hojas ó axilares, casi tan largas como su pedúnculo que tiene solo 6 á $8^{\prime \prime \prime}$ de largo; fruto sub-globoso de $\mathbf{l}^{\prime \prime}$ de diámetro. $M$. citrifolia, L. - $M$. macrophylla, Desf.

G. VIII. Geophila reniformis, Don.: C. T. V., 483.

G. IX. Richardsonia, Kith. - Planta herbácea anual, de tallo derecho y erguido, de como 2 ' de alto, tricótomo y ramoso, con pelo tieso y de hojas elíptico-lanceoladas, puntiagudas y atenuadas por la base que se vuelve peciolo, pelitiesas; estípulas truncas con cerdas tiesas; cabezas florales, cuyo invólucro consta de 2 ó 3 hojas ó brácteas foliáceas ovales y sesiles; fruto formado de 3 cajitas tuberculoso-punteaditas; limbo calicinal 6-partido y cerdoso. R. Cubensis, Rich. - Tallo peludo con hojas lanceolado-oblongas ó elípticas; cerdas estipulares tan largas como su corta vaina; cabezas florales con algunas flores blancas, de cáliz con 6 divisiones foliáceas ovalo- 
deltoídeas, tan largo como el fruto truncado-obval, erizado y formado de 3 á 4 carpelos ; corola con 6 lóbulos de estambres esertos. R. scabra, L. : C. T. V. 483.

E.-G.X.Speriacoce tenuior, Lam. - S. stricta, L.C, T. V.484.

G. XI. Drodia, L. 1. Hojas sentadas y sin venas, 2. - Hojas cortamente pecioladas, áspero-venosas, 3 .

2. Yerba anual pinchuda, de tallo delgado, como de 6", con hojas lineares de márjen revoluta; cerlas estipulares setáceas, mas largas que su vaina; flores axilares blancas ó teñidas de púrpura, sub-solitarias, de cáliz con 4 lobos deltoídeo-lanceolados y mas cortos que los carpelos, sin estrias laterales; tubo de la corola delgado y oboval; fruto sub-globoso, lijeramente aquilado, áspero y erizado. $D$. prostata, Sw. - Spermacoce strigosa. L.

3. Vejetal casi leñoso, algo trepador, muy ramoso, de tallo y ramos obtusamente tetrágonos, ásperos por los ángulos, ordinariamente peludo ó alampiñado, con hojas oblongo-lanceoladas, puntiagudas, á-pero-venosas, con 4-5 pares de venas arqueadas, ásperas; cerdas estipulares peludo-setáceas; flores axilares en grupos de 5 , de cáliz con 4 lobos lanceolados, 1 [2 o 1 1 3 tan largos como los carpelos : corola blanca de tubo corto casi tan largo comolas divisiones calizinales; fruto ovoídeo-oblongo, sin estrias, alampiñado y áspero. D.savmentosa, $\mathrm{Sw}_{\mathrm{w}}$ - Spermacrice spinosa, Løe. - Borrera perrotettii, Dc.

G. XII. Borrera, Miq.1. Cápsula septícida por arriba del centro, con los carpelos persistentes por debajo de él. 2. - Cápsula septícida hasta la base y cuyos carpelos se desprenden, 3 .

2. Planta herbácea ó sofrutescente alampiñada, cuyo tallo sub-cilíndrico ó lijeramente anguloso, tiene hojas elíptico-lanceoladas ó lanceoladas, aguzadas, con 5 ó 1 pares de renas; cerdas estipulares setáceas, lampiñas mas cortas que su vaina, prolongadas ó tan largas como ella; flores en vertícilos, ó cabecitas, formados de algunas flores. con cáliz de 4 dientes diminutos, iguales, orales, obtusitos y mucho mas cortos que el fruto obovalgloboso, cuyas semillas oblongas son estriado-asurcadas transversalmente. B. lavis, Gr. Spermacre laris, Lam. - S. tenuior, Sw. - B. virgata, Cham.

3. Yerba anual alampiñada, cuyo tallo tetrágono, largo como de $1^{\prime}$ y ramoso, lleva hojas oblongo-lanceoladas ó elípticas, obtusas ó puntiagudas, muy variahles, subsesiles ó cortamente pecioladas, con 5 pares de venas; cerdas estipulares setáceas y mas largas que su vaina; vertícilos ó cabezas formados de algunas flores de cáliz con 4 dientes lanceolado-subulados, casi tan largos como el fruto oboval, cuyas semillas diminutas son oblongas y escrobiculadas, es decir que parecen pólvora. B. parriflora, Miq. - Yerba vivaz sofruticosa alampinada, cuyo tallo tetrág̨ono se eleva de $1^{\prime}$ á $4^{\prime}$ de altura: bojas linear-lanceoladas, cortamente aguzadas, largas de 1" 1 [2 á 1" sobre 3 ó $2^{\prime \prime \prime}$ de ancho, sentadas con venas distantes y sub-biyugadas; cerdas estipulares setriceas, tan largas ó mas cortas que su raina; cabezas florales y vertícilos accesorios globosos y de $6^{\prime \prime \prime}$ de diámetro, provistos de un invólucro formaro de 2 hojas; flores blancas de cáliz con 2 á 4 dientes lanceolados y obtusitos, la mitad tan largos como el 
fruto ovaloblongo, curas semillas oblongo-lineares son redondeaditas. B. verticillata, Mer. - Sperm. verticillata, Sw.

F. - G. XIII. Gexipa. L. - 1. Árboles bastante grandes, ramosos y coposos, 2. - Arbusto de hojas obovales, lampiñas y subtruncas por el vértice, largas de 4 á $2^{\prime \prime}$; flores en corimbos cortamente pedunculados, cuyos pedícelos son tan largos como el cáliz, de limbo 5-fido, con los lobulos lineares y distantes; corola lampiña. de tubo eserto largo de $6^{\prime \prime}$ y casi tanto como los lóbulos del limbo; anteras semi-esertas ; estigma bífido, de divisiones lanceolado-setáceas; baya ovoídea. G. clusiifolia, Gr.

2. Hojas lanceolado-oblongas, glabras y largas de 5 á 10 " solure $3-2$ " de ancho, algo aguzadas por ambos estremos, peciolarlas; flores amarillentas en corimbos cortamente pedunculados, con pedícelos mas cortos que el cáliz trunco; corola sedosa y pelierizada por la garganta, de tubo cortamente eserto y tan largos como sus lóbulos estendidos; anteras esertas; estigma con figura de maceta; bara ovoídea, un poco fusiforme, larga de 4 á $5^{\prime \prime}$ sobre 2 " de diámetro transversal. G. Americana, L.: C. T. V., 87. - Hojas obovales, largas de 6 a $8^{\prime \prime}$ sobre $31{ }^{2}$ o $2^{\prime \prime}$ de ancho, alampiñadas ó de cara inferior pubescente; flores en corimbos cortamente pedunculados, cuyos pedícelos son tan largos como el cáliz trunco ondeado ó dentado; corola pinchudo-tomentosa esterior é interiormente, de tubo cortamente eserto, tan largos como los lobulos; anteras esertas, estioma claviforme; baya ovaloblonga. G. caruto, Kth.: C.T.V , 87.

H. G. XIV. RAndia, L. 1. Limbo de la corola torcido por la izquierda y de tubo cilíndrico ó gradualmente ensanchado, 2. - Corola de limbo con estivacion torcido-empizarrada, cuyo tubo largo y cilíndrico está bruscamente dilatado por la garganta, 3 .

2. Arbusto alto de 10 á 15', ramosísimo, cuyos ramos estendidos y dispuestos ordinariamente á manera de pirámide, son espinosos ó inermes, de espinas opuestas y supra-axilares; hojas obovales ó elípticas, por fin coriáceas, lampiñas y largas de 1 á $3^{\prime \prime}$; flores de olor muy agradable y suave análogo al del azahar, axilares, ternadas, subsesiles ó laterales, cuyo limbo calizinal, cortamente acampanado, tiene dientes lanceolados, obtusitos y encorvados, de corola cuyo tubo sub-cilíndrico y largo de 2 á 4 "', velludo interiormente, tiene la misma lonjitud ó es dos veces mas largo que los lóbulos ovaloblongos ú ovales; anteras lineares; luaya globosa ú ovoídea. $R$. aculeata, L - R. mitis, Lam.; C. T. V., 85. -- Arbustos cuyas ramitas llevan por debajo de su vértice espinas en vertícilo de á 4 ; lıojas ovales ó elípticas, puntiag̣udas membranosas. alampiñadas, largas de 3 á $2^{\prime \prime}$, con la cara inferior pubescentita sobre las nervaduras; flores blancas en grupos terminales, cuyo limbo calizinal largo de 3 á $6^{\prime \prime \prime}$ es 5-partido. con los lobos lineares y abiertos; tubo de la corola larģo de $12^{\prime \prime \prime}$, cilíndrico-lampiño por la garganta, y cuatro veces mas largo que los lobulos ovalo-lanceolados del limbo subuliforme en la estivacion; bava ovoídeo-redondita. $R$. armati, De. - Gardenia armata, Sw. - Muscenda spinosa. Jacq.

3. Arbusto inerme de hojas lanceolado-elípticas ó lanceoladas, largas de 1 á 3 "', membranosas y de cara inferior pubescente ; flores 
solitarias en el ápice reducido de las ramitas, sentadas, cuyo limbo calizinal de $2^{\prime \prime \prime}$ y 5 -fido tiene sus lóbulos distantes, subulado-setáceos y erguidos; tubo de la corola largo de 2 á $3^{\prime \prime \prime}$, esteriormente pubescente y velludo por la garganta y 2 á 4 veces tan largo como los lóbulos ovales y puntiagudos del limbo; baya larga de una línea alampiñarla y ovoídea. R. Mousscende, Dc. - Mousscenda formosa, Jacq. C. T. V. 86.

I. Hamelíeas. G. XV. Hajielia, Jacq. Arbusto de unos 6 ú $8^{\prime}$ de altura, ramoso, cuyos ramos pubescentitos y cilíndricos llevan hojas verticiladas por á 3-4-5, ú opuestas, elípticas, puntiagudas, largas de 3 á $2^{\prime \prime}$ sobre $11_{\text {l }} 2$ á $1^{\prime \prime}$ de ancho, acunadas por la base, de cara superior alampiñadita, mientras la inferior es pubescente ó alampiñada; flores en cimas de 3 á 4 brazos, frecuentemente dicótomos, cuya flor del centro es sub-sentada, de color carmesí; tubo calizinal oval mucho mas largo que su muy corto pedícelo, corola larga de $12^{\prime \prime \prime}$ á $6^{\prime \prime \prime}$, de tubo pubescentito ó alampiñado, tubuloso, sub-cilíndrico y mucho mas largo que los lóbulos dentiformes y algo erguidos del limbo; baya ovoídea. H. patens, Jacq : C. T. V., \&8 Planta ó arbustillo de 3 á $4^{\prime}$ de alto, muy ramoso y lampiño, de hojas opuestas, elípticas, puntiagudas y glabras por ambas caras, lustrosas, un poco venosas, pecioladitas; flores amarilias en cima 3-cótoma inferiormente, cuyo tubo calizinal acampanado es mucho mas corto que los pedícelos, y de limbo con lóbulos lineares obtusos y abiertos; corola larga de $6^{\prime \prime \prime}$, cuyo tubo lampiño es campanudo tubuloso por encima de la base cilíndrica y 6 reces mas largo que los lóbulos suberguidos; baya ovoídea. II. lutea, Rohr. - H. chryantha, Jacq. H. axillaris, $\mathrm{Sw}$.

J. G. XVI. Macrconemum Jamaicense, L. C. T. V. 159.

G. XVII. Cixchoxa.Árbol cuyo tronco derecho se eleva á 8 ó 15 varas de altura, coposo y de hojas oblongas, por ambos estremos acuminadas, lampiñas, de cara superior lustrosa, mientras la inferior es glandulosa hácia las axilas de las nervaduras; limbo del cáliz campanado $y$ con dientes triangulares; limbo de la corola rosado-lanudo con los lóbulos color de nieve superiormente; cápsula oval 2 veces mas larga que ancha; ala de la semilla dentada. Al picarle la corteza sale un suco amarillo. C. Condaminea, K. B.-Árbol alto de 10 á 15 metros y cuyo tronco derecho lleva una copa grande y frondosa; hojas elípticas ú oblongo-obovales obtusas acuñadas por la base, acuminadas, de cara superior lampiña ó alampiñada, mientras la inferior es pubescente; dientes del cáliz triangulares; filamentos de los estambres iguales; lóbulos del estigma lineares. $C$. Boliviana, Wedd. C. T. V. 736.

K. Roxdoletieas. G. XVIII. Cutarea speciosa, Aubl.: C.T. V.158. L. G. XIX. Exosterima, Dc. - 1. Árboles mas ó menos grandes; cápsu las ovales ó lanceolado-oblongus; pedícelos iguales al tubo calizinal ó mas largos que él, 2. - Arbustos de 10 á $25^{\prime}$ de altura ; cápsulas obovales ú oboval-oblongas; pedícelos tan largos ó mas largos que el tubo calizinal, 3.

2. Pedícelos tan largos como el tube calizinal cilíndrico, cápsula lanceolado-oblonga y lisa, larga de $6^{\prime \prime \prime}$. Arrbol alto ramoso y coposo, 
lampiño, cuyas hojas elípticas ú oblongas son largas de 4 á $6^{\prime \prime}$; flcres de color rojo pálido en panojas corimbosas cuyos pedícelos tienen $4^{\prime \prime \prime}$ de largo ; tubo de la corola de 14 á $6^{\prime \prime \prime}$ y casi tan largo como los lóbulos del limbo. E. floribundum, R. S.: C.T. V., 155. - Árbol bajito, glabro, ramoso y de hojas obovales ó elípticas y largas de 3 á $6^{\prime \prime \prime}$; Hores de color rojc pálido, acorimbadas y cuyos pedícelos ternados ó verticilados por á 3 , son mas largos que el tubo calizinal oval y largo de $2^{\prime \prime \prime}$; tubo de la corola de 2 a $1^{\prime \prime \prime} y$ dos reces mas largo que los lóbulos del limbo; cápsula oval con 10 costillas ó estrias pronunciadas y larga de $8^{\prime \prime \prime}$. E. brachicarpum, R. S.: C. T. V., pár. 156-736.

3. Flores acorimbadas de pedícelos ternados tan largos ó cuyo inferior es mas largo que el tubo calizinal cilíndrico; arbusto lampiño de hojas lanceolado-oblongas, largas de 3 á $2^{\prime \prime}$, curos peciolos tienen solo $3^{\prime \prime \prime}$ de largo; tubo de la corola largo de $8^{\prime \prime \prime}$ y casi tanto como los lóbulos del limbo; cápsula oboval. E. triflorum, G. Don.: C.T. V. 738. - Flores axilares muy fragantes, de pedícelos axilares tan largos como el tubo calizinal cilíndrico y que lo son de $3^{\prime \prime \prime}$; tubo de la corola largo de 12 á 16"' y casi tanto como los lobúlos del limbo; ar busto ramoso y derecho, glabro y con hojas elípticas ó lanceolado-elípticas, largas de 2, 3, 1", largamente pecioladas y sub-complicadas; cápsula ovoídeo-oblonga y lisa. E. Caribcum, R. S. : C. T. V., 735.

G. XX. Warszewiczia coccinea, Kl. - Macronemum coccineum, V. - Calycophyllum coccineum, De. - Scomburghiana, Kl. C. T. V. 741 .

G. XI. Portlandia, P. Br. 1. Lóbulos calizinales, foliáceos, elíptico-lanceolados; cápsulaelíptica 5-costilluda, 2. - Divisiones calizinales lineares ó lanceolado-aguzadas; cápsula oblonga ó elíptica y lisa, 3.

2. Arbusto de 10 á $15^{\prime}$ de alto, de hojas elípticas ó elíptico-oblongas, puntiagudas, coriáceas, lustrosas y venosas; estípulas deltoídeas ú ovales, flores blanquecinas, olorosas, cuya corola, larça de 8 á $3^{\prime \prime}$, lo es á veces tanto como las hojas de la axila de las cuales salen, cortamente pedunculadas, con el tubo gradualmente cónico, sostiene un limbo de lobulos redondearlo-deltoídeos; anteras largas de 14 á $6^{\prime \prime \prime}$ y de $1_{[} 4$ ó de $1_{1} 2$ menos que los filamentos. P. grandiflora, L. : C.T. V., 158.

3. Estípulas alesuado-redondeatitas, divisiones calizinales linearaguzadas; arbusto del tamaño del precedente, de hojas oblongas, puntiagudas, coriáceas, de cara superior lustrosa, con nervaduras arqueadas y venas apenas notables; corola larga de 7 a 8 ", tanto como las hojas que las llevan en su axila, de tubo gradualmente cónico y de lobulos del limbo redondeado-deltoídeos: anteras largas de $2^{\prime \prime}$ y la mitad menos que los filamentos; cápsula oblonga y aguzada por la base. P. gypsophylla, Nacf. - P. palantha, Hook.Arbusto de 2 á $3^{\prime}$ de alto solamente, de hojas ovales o elepticaloblongas, puntiagudas, coriáceas, lustrosas, renosas y largas de 5 á $3^{\prime \prime}$; estípulas deltoídeas; lóbulos calizinales lanceolado-aguzados; corola de color carmesí, larga de $2^{\prime \prime}$, la mitad de la lonjitud de las 
hojas; de tubo aguzado gradualmente cilíndrico, con 5 estrias por la base; limbo de lóbulos deltoídeos y de $4^{\prime \prime \prime}$ de ancho; anteras largas de $8^{\prime \prime \prime}$ y mitad menos que los filamentos; cápsula elíptica. $P$. coccinea, Sw. - Coutarea speciosa, Aubl. : C.T. V., 158.

G. AXII. Manettia, L. - 1. Limbo calizinal con 8 lóbulos lanceoladolineares y sub-ignales, 2. - Limbo calizinal con 4 ó 5 divisiones, 3.

2. Arbusto lampiño de hojas ovales, acuminadas y cortamente agruzadas por la base y membranosas ; estípulas sub-truncas, dentaditas; flores en corimbos pauicífloros axilares, esertos ó reducidos á una solitaria, largamente pedicelados, de corola cuyo tubo subcilíndrico es peludo interiormente y barbudo por la garganta; anteras largas de 4 "' y cuya mitad está eserta ; semilla ceñida por una ala recortada. $M$. coccinea, W. C. T. V. 742 .

3. Lóbulos calizinales 4 , lanceolado lineares y alternando con 4 dientecitos ; arbusto de hojas ovales, puntiagudas tiesas, reticuladovenosas, de cara inferior, cuya costilla solo es pubescentita; estípulas cortamente subuladas; flores en cimas paucífloras; de corola color de añil, larga de $6 "$ ", cuyo tubo cilíndrico tiene pelo esparcido por su interior; anteras oblongo-lineares, cuva mitad son esertas y de filamentos cortos; cápsula azul, pero septícida y seca, con semillas ceñidas por una ala estrecha y entera. M. lygislrum, Sw. Petesia lygistrum, L. - Lygistrum axillare, Lam. - Lóbulos calizinales 4-5 ovales ú óvalo-lanceolados, puntiagudos, pero sin dientecitos alternando con ellos; arbusto de tallo algo pelierizadito por los ángulos ó alampiñado, de hojas ovales, acuminadas ó puntiagudas, apergaminadas, de cara inferior glabra ó pelitiesita por la costilla; estípulas deltoídeas y dentaditas; fiores rojas en cimas poci ó plurífloras, sub-sentadas, cuyos pedícelos son mas largos que los peciolos ó por último elongados; de corola cuyo tubo cilíndrico y de vértice claviforme algo peludo interior y esteriormente, sostiene un limbo de divisiones ovales y puntiagudas; anteras oblongo-lineares inclusas; semillas ceñidas por una ala ancha y dentadita, $M$. caly$\cos a, \mathrm{Gr}$.

\section{SEGGION III. - HIPOJINOS.}

\section{CLASE XXVIII. - ASCLEPIADÍNEAS.}

Familia 61. - LOGANIÁCEAS. - Arbustos ó arbustillos y raras veces plantas herbáceas, de hojas simples, opuestas, enteras y ordinariamente acompanadas de estípulas interpeciolares, cuya base reunida forma una vaina. Flores racimosas ó corimbosas, terminales ó axilares, mas rara vez solitarias, compuestas de un cáliz libre 4-5 lobo; de una corola regular y menos frecuentemente, irregular, con 5 y raras veces 4 ó algunas divisiones y de estivacion valvar, torcida ó empizarrada; estambres en número variable insertos en el tubo de la corola, con cuyos lóbulos no se hallan siempre simétricos, de anteras biloculares y lonjitudinalmente dehiscentes; pistilo cuyo ovario libre bi y rarísimamente trilocular ó unicular tiene sus huevecillos anfítropos o raras veces anátropos, y lleva en 
su ápice un estilo simple, terminándose en un estigma simple $\dot{0}$ bílobo. Fruto capsular, con las valvas dobladas adentro por la márjen y placentíferas, ó drupáceo-abayado, cuyas semillas, ordinariamente abroqueladas y raras veces derechas desde la base, son algunas veces aladas $\mathrm{y}$ están formadas de un endospermo carno $=0$ cartilajinoso y de un embrion recto, de cotiledones foliáceos y cuya raicilla mira al hilo.

\section{Análisis dicotómica de las órdenes y tribus, etc.}

1. Plantas herbáceas ó matas, 2. - Siempre árboles, arbolitos 0 arbustos, 5 .

2. Yerbas con estípulas ordinariamente o sin ellas; corola de estivacion valvar ; caja ó cápsula dídima y polisperma, cuyas semillas sin alas tienen un embrion diminuto con cotiledones apenas visibles. O. I. Espigelieas. Spigelia anthelmia, L. : C. T. V., 828. - Matas ó yerbas á veces sin estípulas, de flores iromeras cuya corola tiene la estivacion convolutiva ó empizarrada quincuncial ó con dos lóbulos interiores y dos esteriores. O. II. Logonieas, 3.

3. Fruto capsular, 4. - Fruto abayado, 5.

4. Caja bilocular polisperma y septícida, con las valvas ó ventallas aquiladas, comprimidas y bífidas por el ápice y cuyas semillas comprimidas no tienen alas. T. I. Gersemeas. - Cápsula bilocular septícida y polisperma cuyas semillas abroqueladas no tienen alas. T. II. Euluganieas.

5. Corola de estivacion valvar; embrion regular; árboles, arbustos ó bejucos. O. III; Estricneas, 6. - Flores anisomeras, de corola con estivacion torcida ó empizarrała; baya bilocular, de celdillas polispermas; semillas peltadas y apteras. O. IV. Potalieas. - Polalia amara, Lam. : C. T. V. $75 \%$.

6. De fruto capsular, 7. - De fruto abayado ó drupáceo, 9.

7. Cápsula bilocular, 8. - Caja trilocular polisperma de semillas sin ala's. T. I. LABORDIEAS.

8. Cápsula bipartible con las celdillas dobladas hácia adentro por la márjen y dehiscentes desde el ápice, cuyas semillas, en número de 1 ó 2 por celdilla, son abroqueladas y aladas. T. II. AytoniEas. - Cápsula bilocular, bipartible y polisperma, cuyas semillas son abroqueladas y aladas; flores irregulares con un estambre único. T. III. Usterieas.

9. Baya bilocular y disperma, cuyas semillas abroquelałas no tienen alas. T. IV. Gardverieas. - Baya ó drupa bilocular, polisperma, algunas veces unilocular por causa de aborto; semillas siri alas. T. V. Eunstricieas.

G. Strychyos, L. - 1. Ramos sin zarcillos, 2. - Ramos provistos sienipre de zarcillos, 3.

2. Arbusto sarmentoso ó cuyas ramitas abejucadas y de color. herrumbroso son tomentosas y'llevan hojas óvalo-lanceoladas, aguzaditas, sub-coriace $ı$, lustrosas, cortamente pecioladas y largas de $4^{\prime r}$; flores en racimos compuestos, elongados, axilares ó terminales, 
con los pedúnculos horizontales; cálices y frutos tomentosos; fruto globoso, 1-locular polispermo. S. scandens.

3. Arbusto tortuoso de ramas sarmentosas cubiertas de pelos estendidos, largos y aleonados; de hojas sentadas oval-oblongas, aguzadas membranosas, trinervias, aleonado-pelierizadas por ambas caras, con pelo largo y largas de 3 á 4"; bayas, flores color de fuego; baya globosa, lampiña, del tamaño de una manzana regular, con 10 á 20 semillas oblícuamente arrinonadas, discoídeas y anchas de 1". S. toxicaria. Routhamon curare, Aub. : C. T. V. 854. - Arbusto abejucado cuyas ramitas, densamente pubescentitas, llevan hojas coriáceas, ovales ó eliptical-oblongas, con una punta obtusita, complicadoredondeadas por la base, triplinervias, con un par de nervaduras accesorias supra-basilares y de venas dispuestas en redecilla bastante proeminente, lampiño-lustrosas y largas de 4 á $3^{\prime \prime}$, sobre 2 ó $11\left[2^{\prime \prime}\right.$ de ancho, con el peciolo de $3^{\prime \prime \prime}$ solamente; flores en cimas tricótomas, axilares y subsesiles, de pedícelos ternados y cortos, de cáliz con 4 lóbulos lanceolados y puntiagudos, corola pubescentita, cuyas divisiones lanceoladas y muy barbudas por la base, son $1_{[} 3$ tan largas como el tubo filiforme y largo de $3^{\prime \prime \prime}$; anteras y estilo un poco esertos; estigma emarjinado piriforme. S. Trinitensis, Gr.

Familia 62. - ASCLEPIADACEAS. - Plantas herbáceas anuales ó perennes, matas, sofrutices, bejucos y raras veces arbustos ó árboles, cuya savia es casi siempre lechosa ; de hojas opuestas, por casualidad verticiladas por á 3,4 y 5 ; á veces alternas, simples intejérrimas, mas ó menos pecioladas, alguna vez que otra glandulíferas; estípulas apenas pronunciadas y con frecuencia reducidas á la presencia de una hilera de pelo transversalmente situada. Inflorescencia estra-axilar y mas rara vez axilar, indefinida ó en racimos, corimbos y ordinariamente en especie de umbela ó cima, cuyos pedúnculos y pedícelos están provistos de brácteas situadas por la base; de flores rojas, anaranjadas, amarillas, blancas y raras veces azules, cuyo olor es ordinariamente agradable, que constan de un cáliz monosépalo 5-partido, cuyas divisiones son alguna vez subconadas por la base, con 5 ó 10 glándulas aguzadas y situadas interiormente en la parte mas inferior de la base, persistentes y algunas raras veces acrescientes; prefloracion quincuncial; corola monopétala hipojina, decídua, regular, tan pronto enrodada, como campanuda, infundibuliforme como hipocrateriforme y por fin algunas raras veces urceolada, de glándulas o de apéndices situados hácia su seno é insertos mas ó menos alto en el interior del tubo; prefloracion valvar torcida raramente hácia la izquierda y ordinariamente por la derecha; los estambres son 5 , insertos en la parte mas inferior de la corola con cuyos lóbulos alternan, de filamentos formando un tubo que contiene el pistilo, raras veces libres; con anteras erguidas é introrsas y de 4 celdillas incompletas, porque los tabiques que las separan son semi-completos, perpendiculares ó transver'sa'les; tales celdillas se hallan siempre prolongadas por fuera en un apéndice cartilajinoso, cuyo ápice es simple ó trunco, otras veces están reunidas por un conectivo incrasado ó aguzado que se dilata en membrana delgada y blanca; polen hácia la adherencia de las 
anteras en masas correspondientes á las celdillas, otras raras veces tales masas polínicas parecen confluyentes, mellizas ó solitarias, pegadas por medio de prolongamientos filiformes al estigma y respecto del cual se hallan horizontales ó colgantes. Pistilo formado de un ovario único, pero compuesto por 2 carpelos aplicados el uno contra el otro por la sutura placentaria, uniloculares y con muchos huevecillos, regularmente dispuestos por séries é imbricados, tan pronto ascendentes como colgantes, anátropos, lenticulares ó vermiformes, algunas veces sub-peltados y provistos de una membrana celulosa, de micrópilo algo anchito y situado jor su ápice; no hay disco ninguno; hay dos estilos, los cuales se hallan mas ó menos aproximados y conectos por el ápice que se termina por un estigma único, carnoso ordinariamente, pentágono y situado hácia los ángulos de unos cuerpecitos lustrosos que alternan con las anteras, deprimido ó plano, con un pezoncito central bilobado, cónico ó provisto de un pico entero mas ó menos bífido ó coronado con 2 á 7 cerdas filiformes; las mas veces se dilata hasta formar una especie de cúpula irregular y sinuosa. Fruto formado de 2 folículos, de los cuales uno suele abortar algunas veces, lisos, pelierizados ó con puas carnositas, apergaminados ó raras veces carnositos cuando maduros, con muchas semillas comprimidas, las mas reces provistas de una márjen, de testa lisa ó asperita, aleonada, opaca ó corchosita, frecuentemente provistas de cerdas situadas hácia el micrópilo carnosito y formando un penacho mas ó menos fornido $\mathrm{r}$ mirando hácia el vértice del folículo, raras veces hácia la base; con endospermo delgado, carnoso ó córneo y opaco, de embrion recto, cuyos cotiledones son foliáceos y de raicilla corta, con la plúmula apenas notable.

\section{Análisis dicotómica de las tribus y sub-tribus.}

1. Filamentos de los estambres enteramente libres ó solamente por el vértice; masas polínicas 5 á 20 , granulosas y cuyos granitos, en número de 4 por cada una, están dispuestos crucialmente ó por séries ó solitarios, de ápice dilatado, plano ó con figura de cartucho cuaternadamente aplicados á los cuerpecillos estigmáticos; anteras cuyo dorso raras veces tiene pelo; folículos muy divaricados. T. I. Periplóceas. - Filamentos de los estambres siempre conados ó reunidos, 2.

2. Anteras 4 loculares $y$ lampiñas, conteniendo 20 masas polínicas, diminutas, erguidas y pegadas con los cuerpecitos asurcados y carnosos del estigma. T. II. SECAMónieas. - Anteras siempre biloculares, 3.

3. Ordinariamente terminadas por una membrana, masas polínicas 10 , dispuestas por pares ascendentes y reunidas por medio de los prolongamientos estigmáticos, erguidas y opacas ó raras veces transparentes por su parte superior o lateralmente y casi operculadas; yerbas carnosas ó frútices volubles. T. III. Estapélieas, 5. Sin membrana terminal ninguna, 4 . 
4. Masas polínicas 10 , apareadas, pegadas con los prolongamientos del e:tigma por el surco lonjitudinal que las hace parecer bipartidas, colgantes. T. IV. Asclepí́deas. B. 7. - Anteras de dehiscencia transversal, conteniendo 10 masas polínicas apareadas y reunidas por medio de los prolongamientos del estigma, lonjitudinalmente partidas por un surco, horizontales, bastantes veces transparentes hácia el ápice ú ocultadas por debajo del estigma comprimido, pentágono o dispuesto ó manera deestrella; yerbas viváceas ó frutices volubles. T. V. Govolóbeas. D.

5. Masas polínicas enteramente opacas. S.-T. I. Pergulárieas. A. - Masas polínicas no enteramente opacas, 6 .

6. Corona estaminal nula; tubo de la corola ordinariamente peludo interiormente, con la garganta desnuda, ó algunas raras veces provista de 5 escamitas situadas por debajo de los senos. S.-T II. Grunismeas. - Masas polínicas con pelo situado hácia su ápice i lateralmente. S.-T. III. Ceropegieas.

A. - Pergulyrieas. G. I. - Marsdenta, R. Br. - Mata fruticosa abejucada superiormente, curas ramas tienen pelo dispuesto en dos séries, de hojas lanceolado-oblongas, lanceoladas ó espatuladas, con una punta obtusita y aguzadas por la base, lampiñas y largas de 1 "á 2 1/2". Cimas cuyos pedúnculos son casi tan largos como los peciolos; lóbulos calizinales, orbiculares y pestañosos; corola larga de $2^{\prime \prime \prime}$, cortamente infundibuliforme, cuyas divisiones ovales son dos veces tan largas como el tubo, y barbuda por encima de la garganta; hojitas de la corona carno itas. M. clausa, R. Br. - M . affinis, Rich.: C.T. V. 487.-Bejuco leñoso lampiño, de hojas ovales o anchamente oval-oblongas, algo acorazonadas por la base y largas de 8 á $4^{\prime \prime}$; cimas umbeliformes, sub-sentadas; divisiones calizinales redondeaditas y pestañosas; corola larga de $3^{\prime \prime \prime}$, enrodadoinfundibuliforme, cuyos lóbulos oval-oblongos son obtusos y pestañosos, interiormente lampiños y 3 veces mas largos que el tubo; hojitas de la corona lanceoladas, estigma convexo y cónico á la par. 1. maculata, Hook.

7. Corona estaminal nula, 8. - Siempre una corona estaminal simple, doble ó triple, 9 .

8. Garganta de la corola sin escamitas. S.-T. I. Astefáneas. Gargantid de la corola provista de escamitas algo carnosas. S.-T. II. Microlómeas.

9. Corona estaminal simple, 10. - Corona estaminal doble ó triple, 13.

10. Garganta de la corola desnuda, 12. - Garganta de la corola no desnuda, 11 .

11. Hojue!as de la corona estaminal ó divisiones simples, enteras y esertas hácia la base del ginostejio, mas o menos profundamente bífidas. S.-T. III. Haplostemmeis. - Corona estaminal adherida, con el tubo de la corola tubulosa, formada de 5 hojuelas simples y provistas interiormente de un dientecito; masas polínicas reunidas por un prolongamiento geniculado y algo anchito; corpúsculos estigmáticos lineares raras veces sostenidos por un cuernecito ó un pedícelo subulado: estigma elongado-dilatado por el ápice, trunco 
ó mas frecuentemente 2-7-fido; yerbas vivaces sofruticosas ó fruticosas volubles. S.-T. IV. Oxypetáleas.

12. Las 5 hojuelas de la corona estaminal mas ó menos cóncavas ó con figura de cartucho, raras veces insertas en el vértice del gi nostejio, pero ordinariamente por acientro de una lígula ó apéndice, son agudas ó desnudas, un poco engrosadas, y en ese caso de márjen unidentada. S. -T. V. EUasclepiádeas. - Corona ciatiforme ó tubulosa, de boca sub-entera ó lobada. S.-T. VI. Cynoctóneas.

13. Corona estaminal siempre doble, 14. - Corona estaminal doble ó triple, campanuda, cuyas hojuelas mas ó menos reunidas inferiormente, opuestas ó alternas $y$ terminadas en un apéndice linear, ciñen el ginostejio sesil ó estipitado. S.-T. VII. Eustegreas.

14. Corona frecuentemente, pero no siempre doble, cuya série esterior es sinuado-lobada, mientras la interior es formada de 5 hojuelas carnositas ó liguladas y mas ó menos redondamente tumidas. S.-T. VIII. Sarcostemmeas. - Sarcostemma Brownei, Miq. : C. T. V., 487. - Calotropis procera, R. Br. : C. T. V., 488. - Corona compuesta de hojuelas dispuestas en dos séries, opuestas, lineares, iguales ó cuyas est eriores, ovales y agudas, tienen un dientecito diminuto situado por su parte interna; frutices de flores pequeñas cuyo interior está provisto de papillas blancas. S.-T. IX. DistárSEAS.

C. Eusclípadieas. - Asclepras, L. - Mata de base fruticosa, cuyo tallo derecho, poco ramoso, se eleva como á una ó vara y media de alto, algo pubescente y rojizo, de hojas membranosas opuestas, oblongo-lanceoladas ó lanceoladas, aguzadas por ambos estremos, pecioladas y alampiñadas; flores carmesí, de interior anaranjado, dispuestas en especie de corimbo ó umbela terminal, cuyos pedícelos son largos de 3 á 4" y llevan una solitaria en el vértice; divisiones de la corola elípticas y puntiagudas; columna ó ginostejio bruscamente estipitada; apéndices de los cartuchitos anaranjados, lanceolado-falcados, ovales, oblongos y cortamente esertos, folículos, oblongo-lanceolados y lisos, de semillas numerosas y con un penacho plumoso. A. Curasarica, L. : C. T. V., 394. - Mata de tallo derecho algo ramoso, sofruticoso inferiormente, que se eleva a 2 ó 3 ' de altura, cuando mas, nunca teñido de rojizo, pero verde bastante subido y pubescente, con hojas oblongo-lanceoladas, un poco mas dobles y mas grandes que las del anterior, mas pubescentes, algo undulosas por los bordes, de cara superior verde pálido, con manchitas verde-amarillentas, alampinada, mientras la inferior, mas pálida, es pubescente; flores blancas algo verduscas en umbelas estra-axilares ó terminales, de pedúnculos mas cortos que las hojas, cuyos pedícelos, largos de 2 á $3^{\prime \prime}$ y erguidos, son unífloros, con una bracteita pubescente situada en su insercion y muy decídua; divisiones calizinales de color verde pálido y amarillento por la puntita moradusca y dobladas hácia abajo ; corola blanca, de lóbulos elípticos y obtusitos; apéndice de los cartuchos lineares falcados, blanco y teñido de color de rosa, ovales, oblongos y esertos; folículos lanceolados y lisos. A. nivea, L.

D. Gonolobeas. Gonolobus, Much. - Mata fruticosa de tallo de- 
recho, alto de 3 á $5^{\prime}$, de ramos volubles, peludos, que llevan hojas ovaloblongas, acorazonadas, pecioladas, puntiagudas y largas de 4 á $2^{\prime \prime} 1,2$; redúnculos axilares, 4-5 floros; flores en corimbitos paucífioros, de pedícelos delgaditos, cuyo cáliz lijeramente peludo, de lobulos ovales y puntiagudos, es $1_{\mid} 3$ ó $l_{[} 4$ tan largo como la corola, que tiene $1^{\prime \prime \prime}$ de diámetro, es 5-partida, lijeramente peluda y con divisiones lanceolado-acuminadas. Ordinariamente un solo folículo á causa del aborto del otro, del tamaño del puño, como fusiforme irregularmente con la parte media mas crecida, de vértice agudo y cuyo dorso está provisto de 3 alas, de las cuales 2 son laterales, y la de en merlio situara en la sutura, membranosas, van del vértice hasta la base y son anchas de 4 á $5^{\prime \prime \prime}$; lampiño. G. rostratus, R. Br.: Pág. 302. - Bejuco cuyos ramos peludos alampiñados llevan hojas anchamente acorazonadas, ovaloblongas por encima de la base, puntiagudas y largas de 4"; flores en corimbos ombeliformes axilares, pedunculados y de pedícelos delgados, cuyo cáliz de segmentos lanceolado-acuminados es $1_{[} 3$ o $l_{[} 4$ tan largo como la corola 5-partiła, cuyas divisiones lanceolado-aguzadas son glabras; corona corta lampiña undılosa sub-entera. G. Martinicensis, Decs.Ibatia muricata, Gr.: C. T. V., 493.

Familia 63. - APOCINEAS ó APOCINACEAS. - Plantas herbáceas ó matas fruticosas, de tallos volubles ordinariamente 0 árboles mas ó menos grandes. arbustos y frutices, cuya savia es comunmente lechosa : sin embargo, bastantes vejetales de esa familia no la tienen así; de hojas simples comunmente enteras, opuestas, verticiladas y raras veces alternas, mas ó menos lanceoladas, coriáceas y barnizadas, pecioladas y raras veces acompañadas de estípulas, que están con frecuencia reemplazadas por glándulas axilares solitarias ó amanojaditas; flores ordinariamente dispuestas en cimas $y$ otras veces en racimos, regulares y hermosas, axilares ó terminales, algunas veces solitarias y alguna vez apanojadas, formadas de un cáliz monosépalo 5 -lobo, ó con 5 ó raras veces 4 sépalos mas ó menos libres por la baso y persistentes, de estivacion quincuncial, provisto de unas glándulas escamiformes situadas en la parte mas inferior de la base; corola monopétala infundibuliforme ó hipocrateriforme, raras veces acampanada ó enrodada, de tabo ensanchado y velludo hácia el oríjen de los estambres y cuya garganta está desnuda ó adornada de 5 lacinias dispuestas á manera de corona, y que lleva un limbo 5̆-4 lobo, cuyas divisiones oblícuamente obovales tienen estivacion torcida ó imbricada. Estambres 5 y rarísimas veces 4 , insertos en el tubo de la corola y alternos con los lóbulos, de filamentos ordinariamente cortos y á veces nulos, libres ó rara vez un poco reunidos entre sí, terminados por anteras introrsas comunmente inclusas, á veces esertas. frecuentemente asaetadas y cuyos lobulos de la base adhieren y están pegados con el centro del estigma; polen granuloso, elipscídeo y que se aplica inmediatamente al estigma; nectario carnoso que ciñe la base del ovario, formado de 5 glándulas alternas con los lóbulos calizinales, de las cuales una suele abortar y las que quedan se hallan conadas en grupos de 2 ó 3 , otras veces tres glándulas abortan y las dos existentes alternan 
con los ovarios; por fin bastantes veces no hay nectario ninguno. Pistilo formado de 2 ovarios súperos, libres o reunidos entre sí en uno único uni ó bilocular, cuyo ángulo interno está ocupado por la placenta, cuya posicion es otras veces marjinal, ordinariamente con muchos huevecillos anfítropos ó casi anátropos; dos estilos reunidos en uno solo que sale del vértice de los ovarios terminado por un estigma crya base está dilatada en anillo o en membrana, campanudo, glanduloso por el centro y de ápice bífido ó simple. Fruto tan pronto folicular como capsular, folicular-carnoso, como drupáceo ó abayado; semillas ordinariamente colgantes ó mas raras veces ascendentes, calvas ó cabelludas y algunas veces aladas, con un endospermo que suele faltar algunas veces; de embrion erguido cuya radícula es mas frecuentemente súpera, y de cotiledones planos ordinariamente y rarísimas veces convolutos.

\section{Análisis dicotómica de las tribus y sub-tribus.}

1. Ovario único, 2. - Dos ovarios distintos, 7.

2. Bilocular, 3. - Unilocular con dos placentas parietales que llevan muchos huevecillos anfítropos, semillas siempre calvas; cáliz sin glándulas. T. I. Willugbeieas. 4.-

3. Bilocular y formarlo de dos ovarios mas ó menos reunidos por la base con óvulos anfítropos pegados en las ventallas: fruto abayado ó drupáceo y á veces capsular, cuyas semillas son siempre calvas; cáliz ordinariamente sin glándulas. T. II. CARISSEAS. 5. - Bilocular cuyas semillas son caljelludas por la parte superior. T. III. Parsonsíeas.

4. De fruto capsular cuyas semillas son aladas por la márjen. S. T. I. Allainandeas. Allamanda cathartica, Sieb.: C. T. V., 537. - Baya indehiscente, de semillas nunca aladas. S. T. II. WILLIGHBEIEAS lejítimas.

5. Frutos capsulares cuyo disepimiento placentario gordo se separa de las paredes á favor de la dehiscencia ó al abrirse la cápsula; semillas aladas por la márjen; raicilla súpera. - S.-T. I. CraSPIDospermeas. - De fruto abayado ó drupáceo, 6.

6. Baya ó drupa, las mas veces bilocinlar, y algunas raras veces unilocular por causa de aborto durante la maduracion, cuyas semillas no tienen ala ninguna; raicilla súpera. S.-T. II. EưdA RISSE as, B. - Siempre una drupa bilocular cuyas celdillas están divididas por un tabique falso, de semillas lateralmente aladas, raicilla escéntrica respecto del fruto horizontal y mirando hácia el ala. S.-T. III. Thevecieas. Theretia neriifolia, Juss.: C. T. V., 731.

7. De semillas calvas, 8. - De semillas siempre provistas de una cabellera, 10 .

8. Ángulo interno de los ovarios ovulífero; muchos huevecillos anfítropos; frutos abayados drupáceos ó foliculares y mas ó menos carnosos; conectivo no prolongado por debajo de las celdillas de las anteras; corola toreida por la izquierda. T. IV. Plunerieas, 9.

9. Endospermo ruminado y provisto de una especie de costillitas 
ó nervios formados por los pliegues del epispermo; radícula ínfera. S.-T. I. Alixieas. - Endospermo carnudo nunca ruminado y que suele faltar alguna vez; raicilla ínfera; cáliz frecuentemente provisto de glándulas situadas por su interior y á veces con un nectario; óvulos pocos ó muchos; semillas con ó sin alas; otras veces angulosas. S.-T. Il. Euplumierieas ó Ta Bernemontaneas. A.

10. Por ambos estremos; huevecillos anfítropos. T. V. AlstoIIEas. - Uno de los estremos solo provisto de cabellera, 11.

11. Situada inferiormente; cotiledones convolutos. T. VI. WRGHTIEAS. - Carnosas superiormente las semillas; óvulos anfítropos ó casi anátropos; conectivo dilatado $\mathrm{y}$ prolongado por debajo de las celdillas de las anteras; cáliz 5-partido; estigma indusiado ó provisto de un indusio ; folículos elongados; hojas opuestas ó verticiladas; ordinariamente bejucos. T. VII. Echrteas. C.

A. Euplumierieas. G. I. Plumieria, L. 1. Flores coloradas, 2. - Flores blancas, 3.

2. Flores cuyo color rojo es casi uniforme $\mathrm{y}$ saliendo antes de las hojas $\in \mathrm{n}$ umbelas terminales pedunculadas; arbolito de unos $15^{\prime}$ de alto, de tronco del tamaño del muslo, ramoso superiormente, de hojas ollongas ú oboval-oblongas, puntiagudas, lampiñas, pecioladas y largas de 8-5", sohre 2 á $3^{\prime \prime}$ de ancho, de cara superior lustrosa, mientras la inferior es un poco pubescente, cuyo peciolo lleva dos glándulas hácia la base; pedúnculos pubescentes bastante largos, de pedícelos dicótomos y como articulados; lóbulos calizinales sub-truncos; corola de dirisiones anchamente ovales y algo mas largas que el tubo algo encorvado y que lleva los estambres insertos hácia su base; folículos oblongos, corvados, acuminados y tuberculosos. P. rubra, L. : C. T. V., 427. - Flores coloradas pero con la mitad de la superficie de las divisiones de la corola mucho mas pálida que la otra y casi rosada : árbol del tamaño y aspecto general ó semblante del anterior, de hojas grandes, oblongas, acuminadas por ambos estremos, algo puntiagudas, lampiñas y largas de 8 á $12^{\prime \prime}$ sobre 3 á $4^{\prime \prime}$ de ancho, cuyo peciolo largo no tiene glándulas; flores en cimas glabras un poco contraidas, con pedúnculos largos de 6 á $8^{\prime \prime}$, pubescentes y algo rojizos; lóbulos calizinales redonditos, divisiones de la corola oboval-oblongas ú obovales, largas de 10 á $12^{\prime \prime \prime}$ y dos veces tan largas como el tubo que lleva los estambres insertos hácia su base; folículos como de $8^{\prime \prime}$ de largo, sobre $18^{\prime \prime}$ de ancho. P. tenorii, Gasparr.: C. T. V., 427.

3. Árbol cuyo tronco alcanza á $15^{\prime \prime}$ y mas de diámetro y se eleva bastante derecho como á 35' y mas de alto, ramoso superiormente, con hojas espatulado-oblongas ú oblongas, ú oblongo-lineares, redondas ó mucronadas por el vértice, lampiñas, pecioladas y largas de 8 á 3" sobre 4 á 3 " de ancho, de nervaduras oblícuamente transversas y reunidas por una redecilla no saliente; fiores en cimas lampiñas, contraidas, largamente pedunculadas, lóbulos calizinales redonditos $\delta$ mucronado-truncos; divisiones de la corola largas de 10 á 12 ó 6 á 8"', espatulado-lineares ú oblongo-lineares, son ordinariamente mas largas que el tubo que lleva los estambres pegados por debajo de su parte media, folículos lineares aguzados conniven- 
tes por el ápice, como de $7^{\prime \prime}$ de largo, solre 6 á $8^{\prime \prime \prime}$ de ancho. P.obtusa, L. - Arbol algo mas pequeño que el anterior, de hojas bastante variables, oblongo-lineares o lineares, redondas ó aguzadas por el vértice, de márjen como ribeteada y doblada hácia abajo ó rolladi ta, de cara inferior tomentosa con las nervaduras rectangulamente transversas y reunidas por una redecilla algo pronunciada; flores en cimas largamente pedunculadas y de pedícelos cortos y amanojados unífloros, lóbulos calizinales anchamente redondos; divisiones de la corola largas de 8 á $12^{\prime \prime \prime}$ y obovales, son tan largas como el tubo que lleva los estambres pegados por encima de su base; folículos lisos un poco obtusos, oblongos, un poco arqueados por su cara superior y parduscos. $P$. alba, L.: C. T. V., 785.

G. II. CAMERARIA, L. - Árbol grande, de hojas elípticas, puntiaguras, cuyas nervaduras acostilladas y aproximadas se reunen en una arcada marjinal continua, largas de $1^{\prime \prime} 1_{1} 2$, pecioladas; tubo de la corola largo de 4"', con las divisiones del limbo casi tan largas como él; anteras oblongas tan largas como su apéndice; samaras largas de $2^{\prime \prime}$ con el carpelo de $8^{\prime \prime \prime}$. C. Tatifolia, L.: C. T. V., 538. - Arbusto de $8^{\prime}$ de altura, algo mas ó menos, de hojas lanceoladas oblongo-lineares, obtusas, recortarlas por el vértice, largas de 10 á $12^{\prime \prime \prime}$ sobre 4 á $2^{\prime \prime \prime}$ de ancho, cortamente pecioladas, nervaduras delicadas dispuestas en redecilla floja; tubo de la corola de $4^{\prime \prime \prime}$ y los lóbulos de $2^{\prime \prime \prime}$ solamente de largo; anteras ovales y algo mas cortas que su apéndice. C. angustifolia, L.

G. III. Tabernemontana, L. - Arbusto grande de hojas oblongas ú oblongo-lanceoladas, puntiagudas ó de punta obtusita, de base aguzada hasta confundirse con el peciolo, largas de 7-4". de nervaduras distantes y arqueadas; flores en cimas cortas, de pedúnculo apenas largo como el peciolo, blancas y de cáliz 5-partido, con lóbulos ovales y obtusos, corola de limbo oval y puntiagudo en la yema, cuyas divisiones oblicuamente espatuladas son casi tan largas como el tubo de $4^{\prime \prime \prime}$ sub-cilíndrico y de vértice sub-campanudo; anteras de punta eserta; estigma 5-anguloso con indusio ancho; folículos ovales ú oblongo-cilíndricos, encorvados, puntiagudos y acostillados. T. citrifulia, Jacq. : C. T. V., 730. - Árbol muy alto y bastante corpulento, de hojas oblongas, undulosas, obtusitas, cortamente aguzadas hasta el peciolo, largas de 8 á 4 " sobre 4 á $2^{\prime \prime}$ de ancho, de nervaduras distantes, derechitas y reunidas hácia la márjen; cimas subsesiles y con algunas flores de cáliz 5-partido con los lóbulos ovales ú oval-lanceolados y de ápice recorvado y obtusito ; corola de limbo oval-obtusito en la yema, con las divisiones oblícuamente obovales ú oboval-oblongas peludas hácia la garganta, undulosas y tan largas como el tubo de 4"', cilíndrico por arriba de la base de ella. T.psychotriifolia, Kth.

B. Eucarisseas. G. IV. Rauwolfia, L. - Arbolito de 15 á 20' de altura, ramoso, lampiño y de hojas apergaminadas opuestas ó verticiladas por á 4, elípticas ó lanceolado-oblongas, largas de 2 á 5 " sobre $1^{\prime \prime}$ $1 / 2$ de ancho, de cara superior lustrosa, con nervaduras delicadas por la cara inferior. Cimas formadas de algunas flores blancas de cáliz 5-fido con los lóbulos ovales y redondos á la par, una vez tan 
largo como el pedícelo y $1_{[} 3$ ó $1_{\Gamma_{4}}$ tan large como el tubo cilíndrico de la corola barbuda por la garganta, cuyas divisiones son tan largas como el tubo, que lo es de $2-3$ "' ; la punta del estigma sale mas allá del endusio; drupa recortada, de carpelos semi-ovoídeo-redonditos y larga de 4"'. R. nitida, L.: C. T. V., 809. - Arbusto de 3 á $8^{\prime}$ de alto, ramoso, pubescente ó alampiñado, de hojas membranosas en verticilos de á 3 o 4 , eliptical-oblongas, puntiagudas, cortamente pecioladas, largas de 3 á $2^{\prime \prime}$, con venas delicadas y acostilladas; flores blancas teñidas de rosado en cimas paucíforas, de cáliz 5-fido, con lóbulos ovales, obtusos, la mitad tan largos como los pedícelos y como el tubo de la corola, que lo es de $1^{\prime \prime \prime} 1$ [2; corola peluda de divisiones pequeñas redonditas 1 l 3 tan laręas como el tubo; drupa redondeadita, cuyos carpelos están reunidos hácia el vértice. $R$. canescens, L. : C. T. T., 809.

C. Echiteas. G. V. Echites, L. - 1. Semillas cuyo vértice lleva una cabellera sentada en él, 2. - Semilla cuyo rértice se prolonga en un pico filiforme o delgado, 6 .

2. Tubo de la corola infundibuliforme por encima de la base, peludo interiormente y por debajo de los estambres, cuyas anteras obtusitas son acorazonadas por la base; folículos reunidos hácia el vértice; bejuco de ramos pubescentes y con hojas oblongas, mucronadas de Ј á $2^{\prime \prime}$ de largo, acorazonadas, de cara inferior pubescente ó casi lampiña y con nervaduras arqueadas; flores en cimas espigaditas cuyos pedícelos alternos están escedidos por las brácteas lanceoladas; de cáliz cuyos lóbulos subulados son mucho mas cortos que la parte estrecha de la corola amarilla, cuyo tubo ensanchado desde en medio ó desde mas arriba es largo de $1^{\prime \prime} 1$ 1 2 á $2^{\prime \prime}$; anteras acorazonadas, oblongas y glabras; folículos torrulosos. E. symphytocarpa, Mey. - E. Brachystachya y rugosa, Benth. - E. versicritor, J. Mull. - E. tenvicantis, Stadelm. - Tubo de la corola sub-cilíndrico, raicilla tan larga como los cotiledones estrechos; arbustitos derechos ó trepadores y bejucos, 3 .

3. Anteras oblongas obtusas y con una puntita inelinada, 4. Anteras tiesas acuminadas por el ápice y aguzadas por la base alabardada 0 acorazonada, 5 .

4. De base con dos cuernecillos; planta sofruticulosa algo abejucada; lampiña, mas ó menos ramosa y de hojas óvalo-lanceoladas y acuminadas; flores amarillas en cimas corimbiformes, con pocos pedícelos mellizos, de cáliz cuyos segmentos glandulosos, desprovistos de escamitas interiormente, son ovalo-lanceolados, acuminados y 1 [ 4 de la lonjitud del tubo de la corola cilíndrico, bruscamente ensanchado por en medio, largo de $6^{\prime \prime \prime}$ y como una mitad mas que los lóbulos, que lo son de $4^{\prime \prime \prime}$, anteras lampiñas; folículos torrulosos. $E$. torosa, Jacq.: C. T. V., 495. - De base acorazonada ó sub-acorazonada; planta lampiña, de hojas oral-oblongas ú oblonęo-lanceoladas, mucronadas y largas de 4 á $2^{\prime \prime}$ : flores verdosas en cimas axilares contraidas y mas cortas que las hojas, cuyos pedícelos son como apareados ó truncos, cáliz cuyos segmentos orales, obtusos y provistos interiormente de escamitas, son $1_{1} 6$ de la lonjitud del tubo de a corola, cilíndrico, bruscamente ensanchado mas arriba de la parte 
media y dos veces tan largo como los lóbulos obovales del limbo; anteras obtusitas de base sub-acorazonada, oblongo-lanceoladas y lampiñas; folículos cilíndricos. E. trifida, Jacq. - Mesechites trifida, J. Nill.

5. Flores rosadas, folículos torulosos; planta lampiña trepadora ó estendida por el suelo, con hojas lanceoladas ú oblongo-lanceoladas, aguzadas, simplemente aryueado-renosas, cuyos arcos están situados hácia la márjen y son largas de $1^{\prime \prime}$ a $33^{\prime \prime}$; cimas paucífloras con pedícelos mellizos; segmentos caliiznales glandulosos y desprovistos de excamas óvalo-lanceolados, larós de $1^{\prime \prime \prime}$, puntiagudos y $1_{1} 8$ ó $1_{1} 10$ de la lonjitud del tubo de la corola cilíndrico, ensanchado bruscamente arriba del medio y dos ó tres veces tan largo como los lóbulos deltoídeos al reves; anteras aguzadas desde la base alabardada y lampiñas. E. repens, Jacq. - Flores verdoso-blanquecinas; folículos comprimido-cilíndricos; planta fruticulosa y glabra, de hojas ovales ú oval-redonditas, mucronadas, cuyas venas arqueadas son reticuladas. con las arcadas situadas cerca de la márjen, y largas de $1^{\prime \prime} 1_{1} 2$ a 4 "; cimas axilares umbeliformes y pedunculadas; segmentos calizinales glandulosos sin escamita interior, subulados, largos de $1^{\prime \prime \prime} 1_{1} 2$ y $1_{[} 8$ ó $1_{[} 12$ de la lonjitud del tubo de la corola que tiene 14"' á 18"', es cilíndrico, ensanchado por debajo del medio y aguzado por arriba y tres veces mas largo que los estambres y tres ó cuatro veces tan largo como los lóbulos oblicuamente obovales; disco 5-lobo; anteras lampiñas, acuminadas desde la base alabardada, de apéndice y punta algo obtusitos. $E$. umbellata, Jacq.

6. Semillas terminadas en un pico largo lonjitudinalmente cabelludo por la base, cotiledones semi-cilíndricos y casi tan largos como la raicilla delgadita; arbustos sarmentosos ó trepadores, 7. Semillas terminadas por un pico largo y filiforme, lijeramente involutas por dentro de una escama placentaria; anteras corneas, alabardadas con orejitas estrechas $y$ obtusitas, aguzadas desde la base, contenidas en la parte mas baja de la porcion campanuda de la corola ó provistas de un apéndice terminal largo y membranoso; cotiledones lineares arrollados por la márien y tan largos como la raicilla delgarla; bejucos cuyo peciolo es articulado hácia la base, 8 .

7. Bejuco leñoso muy laręo, lampiño y muy ramoso, con hojas ovales ú oboval-oblongas, obtusas, mucronaditas, con venas delicadas acostilladas y largas de $2^{\prime \prime} 1{ }^{2} 2$ á $1^{\prime \prime \prime} 1_{[} 2$; cimas pedunculadas 2 floras, á reces 3 o 1 -floras; segmentos calizinales sin glándulas $\mathrm{y}$ sin escama interior, ovales, puntiagudos, $1_{1} 861_{1} 5$ de la lonjitud del tubo de la corola blanca que tiene $1^{\prime \prime} 12^{2}$ y ellos $1^{\prime \prime}$ á $1^{\prime \prime \prime} 1 \Gamma^{2}$ de largo v cuya parte campanuda es casi tan larga como la base cilíndrica y como los lóbulos anchos; anteras oblongo-lanceoladas, obtusitas, de base redondo-acorazonada, y pelierizadas por la parte superior del dorso; folículos cilíndricos. E. biflora, Jacq.: C. 'T. V., 43.

8. Arbustillo trepador o hejuco ranoso pubescente o alampinado, con hojas oval-oblongas ú oblongas, obtusitas ú obtusas, y largas de $2^{\prime \prime} 1_{[} 2$ á 1" 1 [2: cimas corinbiformes; segmentos calizinales glandulosos, pero sin escama interior, lineares acuminados y tan 
largos como la parte estrecha del tubo de la corola amarilla, cuya parte campanuda del tubo es tres veces mas larga que la base cilíndrica y algo mas que los lóbulos anchamente ovales; anteras sin apéndice terminal y de dorso lijeramente peludo ó alampiñado; folículos encorvadus y estriados; semillas mucho mas largas que la parte desnuda de su pico. E'. suberecta, Jacq. C. T. V. 365-395.

9. Folículos solitarios ó mellizos no carnositos cilíndricos y puntiagudos, con manchitas purpúreas oblongas, largas de $4^{\prime \prime}$ y anchas de $15^{\prime \prime \prime}$ á 16" : planta trepadora de ramos verrugosos que llevan hojas oblongas, sub-acorazonadas ú obtuso-mucroneas largas de 4"; lóbulos calizinales óvalo-agudos; corola 5-partida, de segmentos elípticos sub-agudos y abiertos ó estendidos; semillas obovales aguzadas y comprimido-cóncavas, cuya cabellera es 4 veces mas larga que ellas. E. maculata.C.T.V.493.-Frutoelipsoídeo-carnoso, parecido á un limon elongado, áspero, giboso por acá y acullá y solitario, de color citrino; planta abejucada, glabra, cuyos ramos volubles llevan hojas anchamente acorazonadas, óvalo-elípticas, acorazonado-agudas, largas de $2^{\prime \prime}$ y anchas de $1 "$. Flores purpúreaestrelladas, de corola 5-fida con sus divisiones abiertas; hay un nectario doble en el fondo de la flor. E. citrina, A. D. C.: C. T. V. 494.

Familia 64. - GENCIANEAS ó GENCIANACEAS.-Plantas herbáceas anuales, bisanuales ó vivaces, cuya raiz es algunas veces bastante gruesa y perpendicular, pero las mas veces fibrosa; hojas simples, ordinariamente opuestas, á veces verticiladas, sesiles $\mathrm{y}$ envainadoras por la base, enteras y algunas veces dentaditas; lampiñas sin estípulas y frecuentemente palmatinervias; flores siempre hermafroditas, solitarias ó apanojadas, ó espigadas y terminales, las cuales constan de un cáliz monosépalo, persistente con 4 ó 5 dirisiones mas ó menos profundas; de una corola regular monopétala, ordinariamente marcescente, con 5 lobos, de estivacion torcida por la derecha y rarísimas veces induplicativa ó empizarrada, campanuda ó infundibuliforme, cuyo tubo mas ó menos largo lleva 5 estambres inclusos, pegados en su interior y alternos con sus lóbulos. Pistilo formado de un ovario único, súpero, fusiforme sentaro sobre un disco hipójino, bilocular y con muchos huevecillos situados en dos placentas axiles, cuyo vértice lleva un estilo á veces bipartido y que suele faltar alguna rara vez, terminado por un estigma entero ó bílobo. El fruto consiste en una cápsula con una ó con dos celdas formadas por el borde de las ventallas que penetra en el interior, de dehiscencia septícida, conteniendo muchas semillas pequeñas cuyo embrion recto se halla alojado en el centro de un endospermo carnudo.

\section{Análisis dicotómica de las tribus y sub-tribus.}

1. Estivacion de la corola induplicativa; epidermis de la testa leñosa; vainas de las hojas radicales alternantes; yerbas acuáticas o de los lugares anegadizos. T. I. Meníntheas. - Limnanthemum Humboldtianum, Gr. : C. T. V., 141.-Estivacion de la corola tor- 
cida por la derecha; testa membranosa; hojas opuestas enteras, entejérrimas y raras veces alternas; yerbas terrestres y rarísimas veces frutices. T. II. Eugenciáneas, 2.

2. Estilo persistente, 3. - Estilo siempre decíduo, 4.

3. Anteras provistas de un conectivo; estilo distinto del estigma, doble ó simple. S.-T. I. Lisiánteas. - Anteras con conectivo; estigma persistente sentado ó llevado por un estilo persistente, cuyo vértice se confunde con los brazos estigmatíferos. S.-T. II. SwerTíeas. - Voyria uniflora, Lam.: C. T. V., 143. - Anteras con un conectivo, estilo distinto del estigma doble ó sencillo. S.-T. III. Lisiántheas. A, 5.

4. Celdillas de las anteras erguidas y opuestas al conectivo. dehiscentes por medio de una grieta lateral abreviada, poriformes, las mas veces contiguas por arriba. S.-T. IV. CHı́óneas. - Eustoma exaltata, Gr.: C. T. V.141. - Slevogtia occidentalis, Gr. : C. T. V. 142 .

5. Anteras con un conectivo; estilo distinto, decíduo. S.-T. V. Chloráceas. - Anteras sin conectivo, 6.

6. Por fin callosa-recorvadas. S.-T. VI. Sabáttreas.-Torcidas en espiral. S.-T. VII. Erithreáceas. - Coutoubea densiflora, Mart.: C. T. V. 145-326.

A. Lisantheas, G. I. - Lisanthus, Aubl. - 1. Corola marcescente de tubo contraido, sosteniendo un limbo frecuentemente oblícuo y abierto; hojas de nervaduras arqueadas, 2. - Corola decídua, cuyo tubo va ensanchándose gradualmente y se transforma casi en el limbo: hojas de nervaduras arqueadas, 3.

2. Yerba anual, de tallo casi cilíndrico y simple que se eleva á 3 o $4^{\prime}$ de altura y lleva hojas ovales ó elípticas, cuyas superiores son sesiles; brazos de las cimas racimiformes con flores unilaterales, de cáliz 5-fido, con los lobulos obtusos; corola verdusca ensanchada por la garganta, larga de 1", cuyas divisiones oblongas y obtusas son iguales con los estambres ó algo mas larguitas; lóbulos de la estigma obovales. L. chelonoides, L.

3. Planta herbácea anual cuyo tallo tetrágono por la parte superior se eleva á 2 ó $4^{\prime}$ de altura y lleva hojas elípticas, elipticalobloneas, cuyas superiores son sentadas, frecuentemente ovalolanceoladas; brazos de las cimas flojos y arracimados; de flores cabizbajas con cáliz 5-filo de lóbulos redondos; corola blanca ó azul, larga casi de 1", de tubo comprimido por encima del cáliz y 4 veces tan largo como las divisiones redondeaditas; estambres que no esceden el limbo; divisiones del estigma oblongo-lineares; cápsula ovoídea tres veces tan larga como el cáliz. L. uliginosus, Gr.

G. II.Schultesia, Mart. - Yerba de hojas oblongas lanceoladas $\delta$ lineares; cimas dicótomas cuyas flores laterales están acompañadas de dos bracteitas que faltan á las del centro, cortamente pediculadas, de cáliz con 4 alas transversalmente venosas, semi-ovales ó semilanceoladas; corola de color rosado moradusco 4-fida, cuyas divisiones son sub-truncas; filamentos con 2 dientecitos por la base. $S$. stenophylla, Mart. - Planta herbácea cuyo tallo, largo de como 6", simple inferiormente, lleva hojas lanceolado-lineares; cimas uni ó 
paucífloras, de flores acompañadas de dos bracteitas elongadas, cuyas centrales son subsesiles; de cáliz con 4 alas estrechas transversalmente venosas, semi-lanceolado-lineares; corola grande, de $1 " 1 / 2$ á 2 " de largo, rosada y 4 divisiones profundas ovales y mucronaditas; filamentos sentaditos ó subulados por la base. S. heterophylla, Miq.

\section{CLASE XXIX. - CONVOLVULÍNEAS.}

Familia 65. - CONVOLVULÁCEAS. - Plantas herbáceas anuales ó vivaces, de raices frecuentemente tuberculosas; otras veces matas y raramente frutices, de tallos larguísimos ordinariamente delgados y volubles, mas ó menos ramosos y de savia lechosa. Hojas siempre simples, enteras, acorazonadas, dentadas, lobadas y hasta dijitadas, pecioladas, alternas y ordinariamente sin estípulas. Flores mas ó menos grandes, solitarias ó cimosas, ordinariamente axilares y á veces terminales y que constan de un cáliz de 5 sépalos ordinariamente distintos ó soldados por la base, algunas raras veces de 4 solamente, foliáceos, persistentes, acompañados frecuentemente de dos brácteas foliáceas situadas en su base, pero que suelen faltar bastantes veces; de una corola monopétala mas ó menos grande, infundibuliforme ordinariamente, cuyo limbo 5 -lobo tiene á veces 5 ángulos mas ó menos runtiagudos, de prefloracion torcida; estambres 5 insertos en el tubo de la corola, desiguales, ordinariamente inclusos y alternos con sus divisiones, cuyas anteras biloculares $\mathrm{y}$ asaetadas son derechas. Pistilo formado de un ovario único, con dos carpelos reunidos, ó 2 á 4 separados, 1, 2, 3 ó 4-locular, con uno ó dos huevecillos erguidos en cada celda; estilo único ó algunos estilos con sus correspondientes estigmas, largo filiforme, cuyo estigma en cabecita ó globoso, es entero, bílobo ó hasta 4-lobo. El fruto es capsular ó al gunas raras veces algo carnudo, 2, 3, 4-locular, con 1 ó 2 semillas erguidas en cada celda, casi lıuesosas, ombligadas por la base y pegadas por la base de una placenta central, la cápsula se abre por tantas ventallas cuantas celdas tiene, raras veces indehiscente ; las semillas ordinariamente desnudas ó glabras y mas ó menos lisas están á veces cubiertas de pelo; con ó sin endospermo y de embrion con los cotiledones arrayados ó nulos, alojado en el centro del endospermo blando, cuando existe.

\section{Análisis dicotómica de las tribus y sub-tribus.}

1. Embrion espiral sin endospermo y acotiledóneo ó sin cotiledones, dos estilos distintos frecuentemente desiguales y estigma cabezudo; un pixidio; plantas herbáceas afileas y parásitas. T. I. CusCUTÁCEAS. A. - Embrion con ó sin endospermo y de cotiledunes bien visibles y arrugados; vejetales con hojas y no parásitas, 2.

2. Endospermo nulo; ovario formado de 2 ó 4 carpelos separados y distintos; 2 estilos basilares; 2 ó 4 aquenios: semillas erguidas. T. II. I)ICHóndreas. - Con ó sin endospermo 3.

3. Endospermo carnudo ó nulo, fruto indehiscente, seco $\sigma$ á veces 
algo carneso ; ovario 4-locular de celdas 1-ovuladas, estigma eabezudo y bíloho; bejucos. T. III. Argrrieas. - Endospermo espeso ó nulo; cípsula dehiscente 1, 2. 3, 4-locular, con 2 ó con 1 huevecillo en cada celda. T. IV. Covvolvúleas. 4.

4. Estilo único. S.-T. I. Eucontolvúleas, 5.- Estilo dividido o algunos estilos. S.-T. II. Evolvúleas, 6.

5. Ovario 1-locular ó cuando tiernecito bilocular. S.-T. III. CALISTEfí́EAs. - Ovario nunca unilocular, 6.

6. Ovario 3 ó 4-locular. S.-T' IV. Batáteas. B. - Ovario bilocular, 4 ó 6-ovulado. S.-T. V. Ipomeas. C.

A. Cuscúteas. - Cuscuta. I. - 1. Flores en racimitos densos, escamitas de la corola inclusas, 2. - Flores amanojadas, escamitas de la corola proeminentes, 3 .

2. Flores verdoso-amarillentas cuyos pedícelos son mas cortos que ellas, de cáliz ventricoso, cuyos lóbulos son cortos y redondos, apenas escedidos por la corola campanuda, con 5 dientes redonditos, obtusos y erguidos, escamitas inclusas; cápsula globosa, irreg̣ularmente circuncisible. C. Americana, C. T. V., 507.

3. Pedícelos ordinariamente mas largos que las flores, de cáliz anchamente campanudo, igual al tuho de la corola ó escediêndole, con lóbulos deltoídeos; corola enrodada 5 -fida, de divisiones estrechanente lanceoladas y agudas, cápsula globosa circuncisible ó irregularmente ruptible. C. umbellata, Kth. - Pedícelos casi tan largos como las flores, 4 .

4. Tallo de color anaranjado; flores blancas de cáliz con lóbulos obtusamente deltoídeos y tan largos como el tubo de la corola cam panudo-enro lada, frecuentemente provista de glándulas y cuyas divisiones ovales y obtusas son casi tan largas como el tubo y reflejas; cápsula deprimido-globosa, eserta y abayadita. C. obtusifnnra, Kth. - Cáliz de lobulos deltoídeos y algo mas cortitos que el tuho de la corola espesa y campanuda, cuyas divisiones deltoídeas, derechas ó abiertas están inclinadas por la punta aguda ; cápsula cónica encerrada en la corola y abayadita. C. indecora, Chois. - C. decora; Engelms.

B. Batáteas. - G. I. Batatas, Rumph. - 1. Ovario bilocular por el vértice, semillas lampiñas, 2. - Ovario 4-locular por el vértice y bilocular por debajo de él, semillas velludas, 5 .

2. Raiz tuberculífera mas ó menos gruesa, de la cual salen tallos herbáceos estendidos por el suelo, con el vértice ó ramos ascendentes, ó derechito, mas ó meros largo, mas ó menos voluble. cuyas ramitas, son algunas veces pelierizaditas y llevan hojas acorazonadas, ondeado-enteras ó sinuadas, 3 ó 7-lobas, bastante grandes y pecioladas; flores ordinariamente rosadas $\sigma$ blancas mas ó menos teñidas de color de rosa, en cimas pedunculadas, ordinariamente paucífloras, axilares y cuyo pedúnculo es tan largo como el peciolo ó algo mas cortito, de cáliz con sépalos ovales 11 oblongo-mueronados, cuyos dos esteriores son mas cortos, y $1_{[} 5$ ó $]_{[} 4$ de la lonjitud de la corola larga de "2" ó de 1" 1 22; semillas lampiñas y con algunas líneas pubescentitas. B. edulis, Chois. : C. T. V., 200. - Variedades, 3.

3. Sépalos largamente pestanosos; ovario pelierizado; hojas aco- 
razonado-deltoídeas; repandas o sinuosas; flores blancas; tubérculos de como 2 libras ó libra 12 , maduros á los tres meses de sembrados, color como de púrpura ó moradusco esteriormente y de carne mas ó menos amarilla y á menudo con fragancia de rosa. $B$. porphyrorhi$z a$. - Sépalos y ovario lampiños, 4.

4. El primer sépalo oval; hojas acorazonado-deltoídeas, ondeadas ó sinuadas por las orejitas; flores rosadas; tubérculos color de ladrillo esteriormente, $\mathrm{y}$ de carne verdoso-amarillenta. $B$. edulis, March.-El primer sépalo oblongo; hojas 5, 7, 3-lobadas por arriba del medio, cuyos lóbulos oval-lanceolados, aguzados y diverjentes, tienen su parte media mas ancha; flores disciplinadas de blanco y de rosado; tubérculos elongados blancos. B. leucorrhiza, March.

5. Plantás lampînas de hojas palmatífidas, con 5, 7, ú 8 lóbulos ohlongo-lanceolados, raramente ovales, enteros; flores rosadas en cimas pluri ó paucífloras, cuyos pedúnculos son mas largos que los peciolos, de cáliz cuyos sépalos ovales, obtusos y cóncavos son casi 1 [6 de la lonjitud de la corola, qne tiene $2^{\prime \prime}$ ó $1^{\prime \prime} 1$ [2 de largo. Cápsula cuyas sernillas están provistas de pelo algodonoso ó de lana, dispuesto por series ó terminal, con trechos lampiños entre ellas; raiz tuberífera. $B$. digitata, Chois. : C. T. V., 210. - Planta de ramitas pubéscentes ó alampiñadas, que llevan hojas acorazonadoredorditas, enteras ó á veces sinuado-lobadas, de cara superior pubescentita, mientras la inferior es tomentosa; flores rosadasó blancas, solitarias ó ternadas en el vértice de un pedúnculo axilar, de cáliz cuyos sépalos largos de $4^{\prime \prime \prime}$, ovales y obtusos, son $1_{\mid} 9$ ó $1_{[} 12$ de la lonjitud de la corola, que tiene 4 ó $3^{\prime \prime}$ de largo; semillas provistas de lana larga estendida á lo largo de la márjen; raiz tuberculosa. $B$. jalapa, Chois. : C. T. V., 533.

G. II. Pharbitis, Chois. - Disco cupuliforme $1_{[} 2$ o $1_{[} 3$ de la !onjitud del ovario, 2. - Disco campanudo que encierra el ovario, 3.

2. Planta herbácea de ramos peludos ó alampiñados, con hojas acorazonado 3-lobas, cuyos lóbulos son deltoídeo-ovales y enteros; flores pocas ó 1 en el vértice del pedúnculo, de caliz con sépalos largos de $1^{\prime \prime}$, lanceolado-lineares, aplicados, pubescentitos ó alampiñados y frecuentemente pelierizado-pestañosos por la base, son 1 [ 2 del tubo de la corola largo de $2^{\prime \prime}$, la cual cs azul interiormente y se va ensanchando gradualmente por arriba de la base cilíndrica, disco $1 / 2$ de la loniitud del ovario 3-locular, 6-ovulado. P. acuminata, Chois.

3. Vejetal lampiño, de tallo muy ramoso, con hojas acorazonadotrílobas ó mas rara vez acorazonado-redonditas, cuyos lóbulos enteros, ondeados, puntiagudos son lateralmente ovales, mientras el de en medio es oblongo; flores azuladas ó carmesí, ó con esos dos colores mezclados y matizándose, pocas ó 1 en el vértice de los pedúnculos; de cáliz con sépalos largos de 8 á 10"', ovalo-lanceolados, largamente aguzados, sub-derechos, lampiños y $l_{[} 2$ del tubo de la corola largo de 8 a $10^{\prime \prime \prime}$, la cual va ensanchándose gradualmente desde la base; ovario con tres celdas y 6 huesecillos. $P$. cathartica, Chois.: C. T. V. 535.

C. Ipomaras. - G. I. Iponcea, L. - 1. Sépalos membranosos y 
por último coriáceos, 3. - Sépalos grandes y escariosos y por últino cartilajinosos; corola grande, infundibuliforme ó campanuda, de tubo ancho y dilatado desde la base; anteras inclusas y por fin subtorcidas ; ovario bilocular 4-ovulado, sin disco cupuliforme; cápsula reventándose transversalmente hácia el medio, 2.

2. Tallo pubescente ó alampiñado, con hojas acorazonado-redonditas, mucronado-apiculadas, pedunculos pauci ó l-floros y por último vueltos espesos y acompañados de brácteas oblongas y decíduas; flores amarillento-blancuzcas, de cáliz con sépalos ovales redondos y $1 / 3$ ó $1 / 4$ de la lonjitud de la corola, larga de 2 " $1 / 2$ á $3^{\prime \prime}$, infundibuliforme y cuyo tubo es campanado, los cuales al fin llegan á $3^{\prime \prime}$ de largo; cápsula globosa, grande de como l" de diámetro, delgadita arriba de la parte media y encerrada por los sépalos acrescentes y conniventes; semillas diminutamente pubescentitas. J. ventricosa, Chois. - Convolvulus ventricosus, Bert. - C. grandiflorus, Jacq. - Enredadera muy larga que trepa á una altura bastante grande por encima de los vejetales inmediatos á ella, lampiña, saliendo de un tubérculo del tamaño de la cabeza y no comestible, de hojas palmatífidas, cuyos lóbulos 7 elíptico-lanceolados y puntiagudos, son enteros y salen de una base de 6 á $8^{\prime \prime \prime}$ de diámetro; flo-res amarillas pocas en el vértice de un pedúnculo que por fin se vuelve espeso superiormente, de cáliz con sépalos ovales redondos $1 / 2$ de la lonjitud de la corola campanudo-infundibuliforme y larga de a 2 " ; cápsula globosa grande y de $1 " 1] 2$ á 2 " de diámetro, apergaminada y envuelta por los sépalos crecidos y conniventes: semillas pubescentes. J. tuberosa, L. : C. T. V. 534.

3. Ovario pegado sobre un disco cupuliforme ó anular, 10. Ovario sin disco ninguno, 4.

4. Con dós celdas y 4 huevecillos; corola grande hipocrateriforme y de tubo cilíndrico; cápsula reventándose por la base y abriéndose superiormente en valvas irregulares, 5. - Con 2 celdas ó cun 4 por el vértice solamente y conteniendo 4 huevecillos; corola ordinariamente grande, campanudo-infundibuliforme; anteras inclusas; cápsula abriéndose en 2 ó 4 ventallas por la base, 6 .

5. Enredadera de tallos muy largos y lampiños con hojas grandes acorazonado-redondas, con una punta, enteras ó sinuoso-dentadas hácia las orejitas, á veces trílobas; flores blancas de olor muy suave 1 á 3 en el vértice de los pedúnculos apenas largos como el peciolo, de cáliz con sépalos desiguales, cuyos dos interiores ovales y oblongos son obtusos, mientras los 3 esteriores, óvalo-lanceolados. se terminan por un ápendice filiforme, $1\left[41_{1} 5\right.$ de la lonjitud del tubo de la corola, largo de 3 á 4 " y ancho de $3^{\prime \prime \prime}$ ó $2^{\prime \prime \prime}$, la cual tiene el limbo abierto y ancho de 4 " a $5^{\prime \prime}$ de diámetro; estambres cortamente esertos; cápsula oblonga con semillas lampiñas. J. Bonanox, L. C. T. V. 684.

6. Semillas no algodonosas, tallos ordinariamente rastreros, 7.Semillas algodonosas, tallos volubles ó trepadores, 9.

7. Hojas provistas de dos glándulas por la base; yerba lampiña de hojas linear-oblongas, acorazonadas ó redondas por la base, enteras ú ondeadas; pedúnculos unífloros casi tan largos como los pe- 
ciolos, de cuya axila salen; flores blancas, de cáliz con sépalos ovaloblongos mucronadito-obtusos, cuyos dos esteriores son algo mas cortos que los demas, $1_{[4}$ ó $l_{[} 5$ de la lonjitud de la corola, terminándose gradualmente en punta por la base. J. acetosifolia, R. S. : C. T. V. 508 .

8. yerba rastrera lampiña cuyo tallo larguísimo y delgado alcanza á mas de $100^{\prime}$ de largo, no muy ramoso, lleva hojas redonditas, recortadas, acuñadas ó truncas por la base glandulosa y con venas pinadas; pedúnculos comunmente casi tan largos como los peciolos con pocaz flores purpúreas, de caliz con sépalos ovaloblongos, obtusos mucronados y cuyos mas largos tienen $5^{\prime \prime \prime}$ y los 2 mas cortos y esteriores $4^{\prime \prime \prime}$ de largo, y son $1_{1} 5$ de la corola larga de $2^{\prime \prime}$ y aguzándose gradualmente hasta la base; ovario con un disco anular, cápsula bilocular con semillas aleonado-pubescentes. $J$. pescapre, Sw. - J. maritima, R. Br. - Convolvulus pescapre, L. - Yerba rastrera de tallos bastante largos y ramosos, lampiñas y de hojas arriñonadas, acorazonadas ó sub-truncas por la base glandulosa, cuyas nervaduras inferiores son palmadas; pedúnculos casi tan largos como los peciolos y con pocas flores ro:adas, de cáliz con sépalos mucronaditos, cuyos tres interiores son oblongos y obtusos, mientras los dos esteriores, redonditos, son la mitad ian largos; los mas largos $1_{\text {[ }} 6$ ó $1_{\text {[ }} 8$ de la corola, que se va estrechando gradualmente hasta la base y es larga de $3^{\prime \prime}$; cápsula bilocular de semillas lijeramente pubescertes. J. asarifolia, R. S. - J. ulica, Chois.: C. T. V. 509.

9. Planta lampiña de tallo sofruticoso y trepador, cuyos ramos llevan hojas.3, 5, 7-partidas de divisiones elípticas ó elipticaloblongas, apendiculadas, pecioladas, enteras ú ondeadas y de tamaño muy variable; cimas flojas, pedunculadas, dicótomas y formadas de algunas flores blancas ó purpúreas, o una sola, de cáliz con sépalos redondos, cuyos 3 interiores, redonditos, son $l_{[} 6$ ó $l_{I} 7$ de la lonjitud de la corola larga de $3 "$ o $2^{\prime \prime}$ y lijeramente ventricosa por arriba de la base, mientras los dos esteriores, oval-redonditos, son un poco mas cortos y de 4 "' solamente los otros, teniendo $5^{\prime \prime \prime}$ de largo; cápsula bilocular globosa escediendo al cáliz aplicado á ella, con semillas velludas largamente lanudas por la márjen, y cuya lana color de moho está estendida á manera de franja. J. macrorı tiza, R. S.: C. T. V. 534.

10. Disco anular y corto, corola tubulosa é hipocrateriforme y de tubo cilíndrico; anteras esertas durante la espansion del limbo; ovario con 4 huerecillos, bi o t-locular por el rértice; cápsula abriéndose por 4 y rara ve' 6 ventallas, 11. - Disco siempre cupuliforme, mas o menos grande, 12.

11. Planta lampiña cuyo tallo sale de una raiz provista ge tubérculos pequeños comestibles y lleva hojas acorazonado-aguzadas, enteras ú ondeadas; cimas formadas de algunas flores carmesí, de cáliz con sépalos oval-redonditos ó redondos, coloridos cuyos dos esteriores son mas cortitos, todos $1_{[} 4$ ó $l_{[} 6$ de la lonjitud de la corola, cuyo tubo es casi 4 veces tan largo como el limbo 5 -partido, con las divisiones oblongo-lanceoladas; semillas lampiñas en las 
earas, mientras la márjen es ribeteada ó franjeada. J. repanda, Jacq. - Exrgonium repandum, Chois.

12. Ovario 2-4-locular con 4 huevecillos; corola blanca campanudo-infundibuliforme; anteras inclusas y por último recorvadas y torcidas á la par; cápsula abriéndose á favor de ventallas irregulares, 13.-Ovario con dos celdas solamente ó con 4 por el vértice, 16.

13. Ovario con dos celdas, cuyos tabiques por fin son apenas notables, 14. - Ovario con 4 celdas de tabiques persistentes, 15.

14. Planta herbácea de tallos bastante grandes y muy ramosos, trepadora, peluda, de hojas profundamente palmatifidas, con 5-7 segmentos elíptico-lanceolados, pinatifidos ó sinuoso-dentados, alampiñados; estrujadas huelen á almendras amargas; flores blancas solitarias ó 2 en el vértice del pedúnculo axilar, de cáliz con sépalos lampiños, oblongos, obtusitos, largos de $8^{\prime \prime \prime}$ á $10^{\prime \prime \prime}$, conniventes al rededor de la cípsula, mas largos que la mitad de la corola que tiene 1 " $11^{2}$ de largo; ovario bilocular; semillas lampiñas. $J$. dissecta, Pursh. : C. T. V., 686.

15. Planta trepadora de ramos peludos que llevan hojas 5-partidas de lóbulos elípticos ó lanceolado-elípticos, con una puntita, enteros; flores blancas en cimas flojas y pedunculadas, de cáliz con sépalos oval-oblongos, obtusitos, desiguales, cuyos 3 esteriores de $8^{\prime \prime \prime}$ á $10^{\prime \prime \prime}$, son mas largos que los demas, y densamente pelierizados inferiormente, mas largos que la mitad de la corola que tiene $15^{\prime \prime \prime}$ de lonjitud, y conniventes al rededor de la cápsula 4-locular y conteniendo semillas lampiñas. J. pentaphylla, Jacq. - Convoloulus pentaphyllus, L. - Balatas pentaphylla, Chois.

16. Solamente dos celdas y 4 huevecillos; corola obcónica, cilíndrica por arriba del cáliz y por fin de base ovoídea; anteras subinclusas y por último algo torcidas; cápsula abriéndose á favor de 4 ventallas iguales. Enredadera lampiña ó pubescentita, de tallos bastante largos y ramosos, que llevan hojas acorazonado-deltoídeas, bastante variables y aguzadas, no muy grandes; flores amarillas en cimas umbeliformes, pauci j plurífloras y pedunculadas, cuyos pedúnculos son ordinariamente mas largos que los peciolos, de cáliz con sépalos ovales, obtusos, sub-iguales, connivente-empizarrados, y largo de 3 á $4^{\prime \prime \prime}, 1_{[} 3$ ó $1_{[} 4$ de la lonjitud de la corola, que tiene de largo $1^{\prime \prime}$; cápsula sub-globosa con 4 semillas bruno-aterciopeladas, y cortamente velludas por la márjen. J. umbellata, Mey. : C. T. V. 636.

G. II. Quanochtr vulgaris, Chois.: C. T. V. 462.

G. III. Cosvolvulus, L. - I. Estigmas en forma de maceta y oblongos á la vez; ovario sin disco cupuliforme, 2. - Estigma filiforme, ovario pegado en un disco cupuliforme. $\check{J}$.

2. - Flores en cimas contraidas y pedunculadas, 3. - Flores amanojadas, pediceladas y de pedúnculo corto ó nulo, 4 .

3. Planta herbícea voluble, lampiña o rara vez pubescente, de hojas acorazonado-ovales con una punta, enteras ú ondeadas; flores violáceas en cimas pedunculadas y hracteadas, de cáliz herbáceo, mitad de la lonjitud de la corola, peludo ó alampiñado, sin cerdas y cuyos 3-2 sépalos esteriores mas largos son ovales y con una punta, 
mientras los 2-3 interiores óvalo-lanceolado, son aguzados; cápsula con 4 ventallas y de semillas lampiñas. $C$. pentanthus, Jacq. $-C$. riolaceus, V.

4. Yerba voluble y alampiñada, de hojas lanceolado-lineares ú oblongo-lanceoladas, obtusamente mucronadas, enteras, cortamente pecioladas; pedúnculo ordinariamente escediendo el peciolo lleva flores pediceldas y amanojadas, blancas ó purpúreo-pálidas, de cáliz con sépalos pequeños, membranosos, $1_{1} 4$ de la lonjitud de la corola, y con una punta, cuyos esteriores son óvalo-lanceolados, mientras los tres interiores son redonditos; limbo de la corola largo de 6"", quinquefido; cápsula con 4-8 ventallas, de semillas enteramente ásperas y con una ala estreclıa por la márjen. C. Jamaicensis, Jacq.

5. Planta herbácea pubescente ó tomentosa, de hojas ovales, mucroradas, ondeadas ó enteras; flores blancas amanojadas, pediceladas en el vértice de un pedúnculo corto, de cáliz con sépalos pequeños, membranosos, oval-redonditos y obtusos, sub-iguales, $1_{1} 6$ de la corola larga de $6^{\prime \prime \prime}$ y de limbo ondeado, cápsula con 4-8 valvas, cuyas semillas lampinas y asperitas están provistas de una ala marjinal. estrecha. C. nodiflorus, Desc.

\section{CLASE XXX. - ASPERIFOLIAS.}

Familia 66. - BORRA.JÍNEAS. - Plantas herbáceas anuales, bisanuales $y$ vivaces, matas, frutices, arbustos, arbolillos $y$ hasta árboles hastante grandes, de hojas simples, enteras, mas ó menos pecioladas, á veces sentadas, ordinariamente pelitiesas, ásperas $Y$ alternas. Flores siempre hermafroditas en grupos axilares, en espigas ó en panojas terminales ordinariamente con los brazos de prefloracion escorpioídea ó de vértice rollado á manera de báculo de olispó ántes de la floracion, compuestas de un cáliz monosépalo persistente, con 5 divisiones mas ó menos profundas é iguales, casi siempre pelierizadas, o peludas y ásperas ; corola monopétala ordinariamente regular, con 5 lóbulos mas ó menos profundos, de figura o forma muy variada, de tal suerte que es tan pronto enrodada $\dot{0}$ hipocrateriforme como infundibuliforme ó campanuda, cuyo tubo mas ó menos corto, lleva 5 estambres, mientras que su garganta es tan pronto desnuda como adornada de 5 apéndices de forma variada. abovedados, huecos, con una abertura situada en la parte interna de la base y alternos con los estambres. Pistilo formado de un ovario súpero, simple ó compuesto de 4 lobos, ó 4 ovarios distintos uniloculares monospermos de huevecillo colgante, con un estilo simple ginobósico, terminado por un estigma entero ó lobado; en caso de ser sencillo el ovario, el estilo sale de su vértice, es entero ó mas ó menos partido. El fruto consiste en un tetraquenio contenido en el cáliz, otras veces es una especie de drupa mas ó menos abayada, 4-locular monosperma, cuyo hueso es frecuentemente unilocular por causa de aborto; semillas de embrion inverso con la raicilla súpera, alojado en un endospermo carnoso delgado que ordinariamente suele faltar. 


\section{Análisis dicotómica de las tribus y sub-tribus.}

1. Fruto carnoso, abayado ó drupáceo, 2. - Fruto seco indehiscente aqueniforme, 3 .

2. Embrion de cotiledones lonjitudinalmente plegados y sin endospermo; árboles, arbustos ó frutices de pistilo formado de un ovario 4-locular indiviso, cuyo estilo terminal es ordinariamente dos reces bifurcado ó dicótomo por el vértice y por consiguiente con 4 estigmas, raras veces nulo. Huesecito de los frutos de 4 celdillas monospermas. T. I. Condíceas. A. - Embrion de cotiledones planos y con endospermo tenue y carnoso ; arbustos, matas, frutices y raras veces yerbas de ovario ordinariamente indiviso ó raras veces lobado, plurilocular ó mas bien 4-locular, con adicion de cavernas. Estilo comunmente bílobo por el vértice y raras veces simple; fruto abayado, con muy poca carne y 4 huesecitos. T. II. Ehretíeas. B.

3. Ovario formado de dos carpillos indivisos, 4. - Ovario compuesto de algunos carpillos y con estilo terminal simple; fruto partible de semillas con endospermo escaso ó sin él; matas ó plantas herbáceas anuales. T. III. Heliotropíeas. C.

4. Pegados al estilo y uniloculares, semillas sin endospermo. plantas siempre herbáceas. T. IV. Roquelíeas. - Biloculares y frecuentemente partidos en 2 nuececillas uniloculares; el estilo simple $\sigma$ bífido sale de la base del ginobasio entre los segmentos del ovario; fruto rarísimas veces algo carnosito; bi ó cuadripartible mas frecuentemente, con los segmentos ó aquenios dispermos en el primer caso y monospermos en el segundo; semillas sin endospermo; plantas ordinariamente herbáceas y raras veces frutices ó arbustos. T. V. Rorageas, 5.

5. Garganta de la corola desnuda, 7. - Garganta de la corola provista de 5 apéndices abovedados, 6 .

6. Situados en frente de los lóbulos de la corola y por consiguiente alternos con los estambres ; 4 núculos por fin circuncisos por arriba de la base y por consiguiente agujereados. S.-T. I. Archusess: Borrayo officinalis, L.: C. T. V. 632. - 4 núculos siempre cerrados por la base. S.-T. II. CyNogloseas.

7. Corola siempre regular, 8. - Corola mas ó menos irregular; 4 núculos cerrados por la base. S.-T. III. Echieas.

8. 4 núculos, 9. - 2 carpilios biloculares. S.-T. IV. Cérinteas.

9. Cerrados por la base. S.-T. V. Litospermeas. - Circuncisos por arriba de la base y por consiguiente agujereados. S.-T. VI. Craniosperieas.

A. Corntíceas. Cordia, L. 1. Cáliz con surcos, 2. - Cáliz no asurcado, 7.

2. En número de 10 y 365 dentado; corola marcescente torcida por la derecha con la márjen interior plegada, 3. - Eñ número de 10 á 12 é irregularmente circuncisible por debajo del ápice cerrado; corola plegada y empizarrada á la par, decídua, 4 .

3. Arbusto ó árbol que se eleva á 15 ó $25^{\prime}$ de altura, poco corpu- 
lento y muy ramoso, de hojas oblongo-lanceoladas ú oval-oblongas, enteras, lampiñas y largas de $3^{\prime \prime}$ á $8^{\prime \prime}$; panojas plurifloras cuyas últimas flores son amanojado-agrupadas; de cáliz largo de 4 á $5^{\prime \prime \prime}$, eampanudo, cilíndrico-pubescente, pelierizado ó herrumbroso-pubescente ó alampinado, con 3-5 dientes desiguales y deltoídeos; corola blanca infundibuliforme, lar za de $8^{\prime \prime \prime}$ á $10^{\prime \prime \prime}$, quinquefida, pequeña por debajo de la parte eserta de su tubo y cuyos lóbulos obovales y sub-retusos son largos de 3 a $4^{\prime \prime \prime}$; estambres cortamente esertos é insertos por debajo del medio del tubo de la corola. C. Gerascantoides, Klh.: C. T. V., 255. - Árbol de unos 30' de altura, poco corpulento y ramoso, con pelito finito y á veces dispuesto á manera de estrella, de hojas oblongo-lanceoladas ó eliptico-oblongas, con una punta entera alampiñada ó estrellado-pubescente por la cara inferior ; panojas estendidas, cuyas últimas flores son agrupadas, de cáliz claviforme y cilíndrico, peludo tomentoso con pelo estrellado, cuyos 5 dientes pequeños son iguales y largo de $2^{\prime \prime \prime}$ á $4^{\prime \prime \prime}$; corola blanca hipncrateriforme de limbo 5-fido tan largo como el tubo, cuyos lóbulos espatulado-oblongos son largos de $1^{\prime \prime \prime} 1$ [2 á $3^{\prime \prime \prime}$; estambres largamente esertos é insertos cerca de la garganta. $C$. Gerascanthus, Jacq.: C. T. V., 255.

4. Drupa nunca acompañada por la base persistente de! cáliz, 5 . - Drupa acompañada siempre por la base persistente del cáliz, 6 .

5. Árbol de 30 á $45^{\prime}$, bastante corpulento, áspero y alampiñado, con hojas elíptico-redonditas, dentado-repandas, de color uniforme y largas de 2 a 4"; panojas corimbiformes cuyas últimas fores son subsesiles, de corola blanca, infundibaliforme, cortamente 5 -loba, tres reces mas larga que el cáliz turbinado y de 6"' con los lóbulos recortado-redonditos; drupa blanca, elipsoídea y larga de $5^{\prime \prime}$ á $8^{\prime \prime \prime}$. C. alba, Ps.: C. T. V., 633 .

6. Arbusto como de 8 á 12 de altura, áspero y con hojas ovales, sub-enteras y largas de 5 á 8"; cimas corimbiformes de flores pediceladas con el cáliz cilíndrico herrumbroso-áspero, desigualmente 3, 5-dentado, casi mitad de la lonjitud del tubo cilíndrico de la corola encarnado-oscura, hipocrateriforme, cuyo limbo 6 y á veces 5 , 8-fido tiene $1^{\prime \prime \prime}$ á $2^{\prime \prime \prime}$ de diámetro y con los lóbulos óvalo-redonditos; rupa blanca oval-sub-globosa, con una punta obtusa y de 8 á $12^{\prime \prime \prime}$ de diámetro. C. sebestana, Jacq.: C. T. V., 426. - Ovario sub-estipitado; drupa blanca, semi-transparente oval-ceñida por la base persistente del cáliz, con una sola semilla por causa del aborto de las otras. Arbolito de 15 á $20^{\prime}$ de altura, con muchos ramos alternos cilíndricos, blanquecinos y lampiños, cuyas ramitas cargan con hojas óvalo-elípticas, agudas por ambos estremos, dentaditas, membranosas, reticulado-venosas, largas de 2 á $3^{\prime \prime}$, de cara superior glabra y áspera, mientras la inferior es pubescente; peciolo largo de $12^{\prime \prime}$ y algo cilíndrico, apenas pubescente y verrugoso; flores blancas en corimbos terminales de brazos dicótomos y de pedúnculos estriadopubescentes, desparramados, con las flores agrupadas y sesiles, tienen como $3^{\prime \prime \prime}$ de diámetro ; cáliz campanudo, estriado-asurcado, pubescente y con 4 dientecitos obtusitos; corola infundibuliforme de limbo 5-fido y abierto, con la garganta peluda, su tubo es tan largo 
como el cáliz; estambres apenas esertos. - C. dentata, Kth.: C. T. V., 426 .

7. Cáliz liso, reventándose por el ápice cerrado, ensanchado y frecuentemente espeso en derredor de la drupa; corola grande, empizarrada y decídua con el tubo eserto, 8. - Cáliz no liso y reventándose por el ápice cerrado ó regularmente 4, 5-dentado : corola empizarrada y decídua, cuyo tubo iguala ordinariamente el cáliz, 9.

8. Flores en cimas ó en panojas corimbiformes, 8. - Flores dispuestas en grupos, espigas y cabezas, 10.

9. Arbolito ó arbusto que se eleva de 15 á $25^{\prime}$ de altura, con las hojas oboval-oblongas ó elípticas, ondeado-enteras, de cara superior lampina y lustrosa, mientras la inferior es pubescentita, membranosas y por fin coriáceas, decíduas al aparecer las flores, ordinariamente aguzadas por la base y largas de 2 á $6^{\prime \prime}$; cimas acorimbadas herumbroso-pubescentes, con flores subsesiles y cortamente pedicela das por la base contraida del cáliz globoso, pubescente, liso y por fin 3,5-dentado y largo de 1 ó $1^{\prime \prime \prime} 1$ [2 ; corola blanca cuyos lóbulos elípticos casi tan largos como el tubo son relejos; drupa encarnadoglobosa y de 3 á 4"' de diámetro. C. collococca, L. C. T. V., 803.

10. Arbusto de 6 á $10^{\prime}$ de altura, pelierizado y ramoso, de hojas ovales ú oval-lanceoladas, obtusitas, aserradas y cuyos dientes son obtusos y largos de 1 á $2^{\prime \prime \prime}$; flores blancas en cabezas glohosas pedunculadas, de cáliz 5-fido con lóbulos subulado-filiformes, flexuosos, pelierizados y tan largos como el tubo estrigoso de la corola infundibuliforme, largo de $2^{\prime \prime}$ y dos veces mas que el cáliz con los lóbulos muy cortos; drupa oval-obtusa, colorada, larga de 2 "' y cortamente eserta. C. globosa, Kth. - C. bullata, Dc. - Varronia globosa, L. - V. Gullata, Sw. - V. humilis, Jacq.

B. Ehretíeas. G. I. Beureeria, P. Br. 1. Estambres insertos por debajo de la garganta de la corola; drupa globosa ú ovoídea, con 4 huesecitos o pirenas que se separan bastante tarde $y$ sin ningun carpóforo distinto, 2. - Estambres insertos en la parte mas inferior del tubo de la corola, pelierizado por debajo de ellos; fruto seco formado de 4 nuececitas que se separan del carpóforo bipartido y filiforme, 3 .

2. Árbol pequeño ó arbusto de 5 á $15^{\prime}$ de altura, lampiño con hojas oboval-oblongas, oblongas ú oboval-redonditas, pecioladas y largas de 2 á $5^{\prime \prime}$; flores en cimas estendidas, ordinariamente apanojadas ; tubo de la corola largo de $3^{\prime \prime \prime}$ y tanto como los lóbulos obovales y algo mas que el cáliz lampiño, que tiene 2 á $3^{\prime \prime \prime}$ de largo; drupa amarilla, globosa ó por fin obtusamente 4 -angulosa, 2 ó 3 veces mas larga que el cáliz y con 3 á $6^{\prime \prime \prime}$ de diámetro. B. succulenta, Jacq. E. boureria, L.

3. Arbolito como de unos $15^{\prime}$ de altura, cuyas ramitas pelierizaditas llevan hojas elípticas ó lanceolado-oblongas, puntiagudas ú obtusitas, aguzándose hasta volverse peciolo corto, lampiñas ó alampiñadas, con las nervaduras arqueadas y largas de 3 á $2^{\prime \prime}$; flores en cimas corimbiformes, pelierizaditas, de cáliz pubescentito, mucronado en la yema y por fin 2,3 -dentado, tubo de la corola de $8^{\prime \prime \prime}$ y dos reces tan largo como los lóbulos oval-redonditos y como el cá- 
liz; fruto subulado piramidal largo y ancho de 6 "' de huesecitos, esponjosos y cóncavos por el dorso. B. exsucca. Jacq. - Ehretia exsucca, $\mathrm{L}$.

G.II.Tournefortia, L. 1. Drupa seca, ahuecada por la base, entera por el ápice y con dos huesecitos cuyo tabique de cada uno es sólido; semillas con endospermo de embrion recto, 2. - Drupa no seca y mas ó menos carnosa, 3.

2. Arbusto alto de 2 á $6^{\prime}$, enteramente sedoso-tomentoso y con muchas hojas espatulado-lineares, obtusas, sesiles y largas de $1^{\prime \prime} 1_{1} 2$ á $2^{\prime \prime} 1[2$; flores blancas en espigas cortas formando corimbos con pocos brazos; tubo de la corola velludo, cuyos lóbulos son ovales y obtusos; drupa ovoídeo-cónica. T. gnaphaloides, R. Br. - Heliotropium gnaphaloides, Jacq.

3. Drupa entera con dos huesecitos biloculares, campilospermo: por causa de los tabiques ahuecados; embrion recto, 4.-Drupa con 4 huesecitos ó raras veces 1 solo, dividido en algunos lóbulos monospermos; embrion encorvado; anteras coniventes con la punta coherente; drupas cortamente pediceladas y apartaditas, 5 .

4. Arbusto abejucado ó samentoso algo trepador pelierizado ó pelierizadito, muy lamoso, de hojas elípticas, puntiagudas, pecioladas y largas de 3 a $5 "$, cuyas nervaduras son 6,9 -yugadas; flores blancas, en espigas contraidas y formando corimbos, de corola curo tubo es estriado por arriba de la base, cilíndrico, largo de $2^{\prime \prime}$ y tres veces como el cáliz, sosteniendo lobulos deltoídeo-ovales; drupa subglobosa peluda y blanca. T. hirsutissima, L.: C. T. V. 363.-Vejetal sofruticoso ó frutice, de hojas grandes, lampiñas eliptical-oblongas, obtusitas, aguzándose hasta volverse peciolo, largas de 12 á 8"; flores blancas en espigas corimboso-apanojadas, cuyo tubo de la corola es pelierizado, cilíndrico, largo de $2^{\prime \prime \prime}$ y tres veces tanto como el cáliz, sosteniendo lóbulos ovales y obtusitos; drupa sub-globosa y lampiña. T. fcetidissima. W.: C. T. V. 392-802.

5. Planta herbácea voluble, con hojas lampiñas ó alampiñadas y por fin de cara inferior con puntitos rugositos, ovales o elípticas. puntiagudas, pecioladas $y$ largas de 3 á $1^{\prime \prime}$ : flores en espigas desparramadas y acorimbadas, cuyo tubo de la corola largo de 2 á $3^{\prime \prime \prime}$ delgado, pubescentito o pubescente, es 3,4 y raramente 6 veces tan largo como el cáliz, llevando un limbo de lóbulos subulados; anteras oblongas con su punta conivente é insertas por debajo de la garganta de la corola; drupa 2.4 ó á veces 1-loba y lampiña. T. laurifolia, Vent. - T. syringifolia, V.

C. Heliotropieas. Helyotropiem, L. 1. Fruto bílobo ó dídimo, 2. - Fruto separándose en cuatro nuececitas. 5.

2. Fruto bílobo de nuececitas cónicas, costilludas y apareadas: corvla contraida por su garganta lampiña; anteras distintas ; estigma peltado hemisférico tan largo como el estilo; espigas sin brácteas, 3. - Fruto dídimo cuyas nuececitas sub-globosas son apareaìas, 4.

3. Yerba anual alta de 1 á 2 , poco ramosa, derecha y pelierizada, con hojas grandes ovales ó sub-acorazonadas, cuya base se estrecha en peciolo muy largo, festoneado-ondeadas peludas, de un 
color verde blanquecino; flores moraduscas en espigas elongadas y simples; anteras insertas por debajo del medio del tubo de la corola; fruto lampiño cuyos lóbulos diverjentes son 2-dentados, con los carpidios provistos de una cavidad superficial á lo largo de la comisura. H. indicum, L. : C. T. V., 683.

4. Planta herbácea o sofruticosa peluda y que se eleva á 1 ó $2^{\prime}$ de altura, de hojas frecuentemente opuestas, ovalo-lanceoladas, ovales ó lanceolado-oblongas, puntiagudas, pecioladas y cuya cara superior tiene pelo esparcido por su superficie, mientras la inferior lo tiene limitado á las venas; flores blancas en espigas simples y ordinariamente bipartidas ó mellizas en el vértice de un pedúnculo único; anteras oblongas provistas de una punta, insertas por debajo del medio del tubo de la corola corta y eserta; estigma convexo, sesil y pubescentito; fruto áspero, alampiñado, cortamente 4lobo, de carpidios paralelos y apareados. H. par'viflorum, I.- Heliophytum parviflorum, Dc. $-H$. fatidum, Dc. $-H$. humile, Pœpp.

5. Espigas sin bráctea, corola comunmente glabra en la garganta; anteras ordinariamente distintas, 6. - Espigas bracteadas ó simples, cuyas flores son laterales; corola pubescentita en la garganta: anteras subuladas y coherentes por medio de su punta pubescentita é insertas hácia el medio del tubo de la corola; estilo corto, 7.

6. Planta anual ó fruticulosa cubierta de pelo denso y blancuzco; ordinariamente estendida por el suelo y cuyos tallos largos de 1 á $2^{\prime}$ llevan hojas espatuladas ú ovaloblongas en espigas termina?es filiformes 3 ó 4 ó mas raras veces 2-partidas; corola cortamente eserta, con pelo distinto por encima de los estambres, cuyas anteras distintas y mucronadas se insertan por arriba de la base de la corola ; estigma cónico alampiñado y sentado; nuececitas pequeñas, subglobosas y pubescentitas por el dorso. $H$. innudatum, Sw. $-H$. cinereum, canescens y procumbens, Ktk. - H. ovalifolium, Forsk.

7. Frutice hojoso, estriadito ó pelierizado-velludo, de $1^{\prime}$ á $5^{\prime}$ de alto, cuyas hojas son lanceolado-aguzadas ó lineares, sub-sentadas, arrolladas por los bordes y largas de $16^{\prime \prime \prime}$ á $4^{\prime \prime \prime}$; flores blancas en espigas cortas, densas y corvas, por fin cortamente pediceladas; tubo de la corola largo de $2^{\prime \prime \prime}$ y casi tanto como el cáliz y cerrado por pliegues decurrentes y pubescentes y con lóbulos ovales; estigma cónico tan largo como el estilo y pubescentito por el ápice bidentado; nuececitas sub-globosas, pubescentitas y con un hueco por cada lado. H. fruticosum, L. - H. ternatum, V. - H. demisum, R. S. -- H. hirtum, Lehm.

\section{CLASE XXXI. - SOLANÍNEAS.}

Familia 67. - SOLÁNEAS ó SOLANÁCEAS. - Plantas herbáceas anuales, bisanuales $y$ vivaces, cuya raiz, algunas raras veces, lleva tubérculos, matas ó vejetales fruticosos ó frutices lampiños, pubescentes, velludos, inermes ó aguijonosos, algunas veces arbustos y mas raras veces hasta arbolitos, con hojas sencillas alternas a olitirias ordinariamente. pero bastantes reces mellizas, ente- 
ras, dentadas, festoneadas, lobuladas y á veces mas o menos partidas hasta parecer como compuestas, peciolarlas, inermes ơ aguijonosas, lampiñas, pubescentes, velludas ó aterciopeladas, sin estípulas. Flores hermafroditas solitarias ó mellizas, axilares ó en grupos racemiformes axilares ó extra-axilares pedunculados con las flores pediceladas, otras veces en racimos, en espigas ó en panojas terminales; las cuales constan de un cáliz monosépalo ordinariamente persistente y algunas no raras veces acreciente, otras veces la mitad superior se desprende despues de la fecundacion $y^{\prime}$ la parte inferior persiste y acrecenta, cuyo limbo es con 5 divisiones mas ó menos profundas y casi siempre iguales. Corola monopétala regular, cuya forma y tamaño varian muchísimo, de limbo con 5 lóbulos mas ó menos profundos, los cuales están á veces reemplazados por' igual número de ángulos puntiagudos, cuyo tubo mas ó menos largo lleva 5 estambres pegarlos en su interior y alternos con las divisiones del limbo; estivacion torcida; los estambres son esertos ó inclusos, ordinariamente con filamentos mas ó menos largos, cuyas anteras biloculares y ordinariamente bastante grandes y basifijas se abren á favor de poros situados por el ápice ó de grietas lonjitudinales; pistilo formado de un ovario único, súpero, sentado en un disco hipójino que da tambien insercion por su alrededor á la corola y por consiguiente á los estambres; con 2,3 y raras veces 4 celdas polispermas $y$ con dos placentas axiles, de cuyo vértice sale un estilo simple mas ó menos largo y terminado por un estigma cabezudo entero ó bílobo. El fruto consiste en una baya mas ó menos gruesa, cuyo tamaño, color y forma varian bastante; ordinariamente lampiña, pero algunas veces mas ó menos pubescente, 2-3-locular y polisperma; otras veces es una cápsula con 2 ó 4 celdas y que se abre por 2 ó 4 ventallas y cuya dehiscencia es septícida; semillas ordinariamente ásperas, pequeñas, frecúentemente arriñonadas y comprimidas, formadas de un epispermo algo áspero, de un embrion mas ó menos arqueado ó recto alojado en un endospermo carnoso.

\section{Análisis dicotínica de las.tribus y sub-tribus.}

1. Embrion siempre encorvado en derredor del endospermo, arq keado, semi-arqueado ó en espiral. Algunos ovarios 1-5-6-loculares dos biloculares y reunidos en uno único. T. I. Nolaníneas, 2. - Embrion corvo mas ó menos recto; ovario único bilocular, mas rara vez 1-3-4-locular, de celdas polispermas; fruto indehiscente membranoso, abayado capsular 2 y mas raras veces 1-3-4-locular; cuyos muchas semillas están mas ó menos comprimidas, arriñonadas $\delta$ romboídeo-redondas y mas rara vez trígonas, con el hilo submarjinal. T. II. SolaxíNeAs, 3 .

2. Corola regular; un estilo único central y basilar; algunos ovarios libres 1-5-6 loculares, cuyas celdas son monospermas; drupas distintas carnosas 1-6 loculare. S. T. I. Nolunineas: - Corola regular; 2 ovarios 2-3-loculares reunidos en uno único 2-partido ó 4-locular, cuyas celdas son monospermas. S.-T. II. Grabowskítas.

3. Corola irregular, campanudo-sub-bilabiada; fliamentos de los estambres membranosos y reunidos por la base, fruto no carnoso. 
sub-globoso, membranoso, indehiscente 2-4-locular y sin ventallas; placentas centrales reunidas: cotiledones del embrion semicilíndricos y vueltos en espiral. S. -T. I. Triguereas. - Corola regular. 4

4. Embrion mas ó menos encorvado, 5. - Embrion mas ó menos recto, 7 .

5. Fruto abavado siempre; embrion mas ó menos arqueado, enteramente arqueado ó en espiral, 6. - Fruto capsular y raras veces abayado, incompletamente 4-locular, cotiledones del embrion mas ó menos arqueados y cilíndricos. S. T. II. Datureas. C.

6. Corola enrodada, globosa ó anchamente campanura, cuyo tubo es cortísimo; anteras grandes erguidas igualando los filamentos, biporosas por el ápice ó lonjitudinalmente debiscentes por la parte interior; ó con los filamentos mas cortos que las anteras y lonjitudinalmente dehiscentes por grietas. S.-T. III. Eusoláneas. A. Corola campanuda, tubulosa é infundibuliforme, de estivacion valvar plegada; ovario globoso ú oval, cáliz ordinariamente 5-partido y mas rara vez 5-fido. S.-T. IV. Atrofíneas. B.

7. Embrion siempre enteramente recto, 8. - Embrion casi recto ó lijeramente arqueado, 9 .

8. Cápsula con pocas semillas; estigma obtuso. S.-T. V. RESTíEAS. - Cápsula bilocular, con valvas semi-agrietadas ó hendidas; semillas pocas y tríquetras con hilo basilar y pegado en la parte mas inferior del tabique. S.-T. VI. Metemichíeas.

9. Casi recto ó lijeramente arqueado y sub-cilíndrico de cotiledones mas cortos y claviformes; cápsula bilocular cuyas valvas se separan por último del tabique; ovario sentado, las mas veces una glándula hipójina ciñe su base; estigma cabezudo y bílobo. S.-T. VII. HIOScí́.MEAS. - Embrion casi recto y nunca lijeramente arqueado, 10.

10. Sub-cilíndrico de cotiledones sub-comprimidos; cápsula bilocular cuyas valvas se separan por último del tabique, ovario estipitado pluri ó polispermo; estigma bilaminado. S.-T. VIII. FabIáNEAS. - Sub-cilíndrico, de cotiledones pequeños ovales y comprimidos, fruto abayado siempre, con semillas pocas y angulosas, cuyo hilo ventral está colgante de la parte media del tabique; ovario estipitado; baya bilocular. S.-T. IX. Cestreas. D.

A. Eusolíneas. G. I. Solanum, L. 1. - Anteras mas ó menos oblongas, 15. - Anteras nunca oblongas, delgadas y aguzadas por el vértice provisto de poros diminutos terminales ó estrorso-termi nales, 2.

2. Nunca jamas formando grietas, 3. - Siempre formando grietas transversales, 14.

3. Hojas inermes ó aguijonosas solamente por la costilla, 4. Hojas siempre armadas de aguijones fuertes, rectos y situados sobre las nervaduras y sobre las costillas, 10.

4. Tallos provistos de aguijones delgaditos y rectos ó inermes, 5 . Tallos nunca inermes, 6.

5. Arbusto inerme estrellado pubescente y por último alampiña. do, como de 3 a $4^{\prime}$ de altura, con hojas oblongo-lanceoladas, acuminadas, enteras ú ondeadas, pecioladas y largas de 6 a $2^{\prime \prime}$; flores 
blancas en cimas laterales, simplemente racemiformes, pedunculadas y cuyos pedícelos son cabizbajos por último; de cáliz largo de $5^{\prime \prime \prime}$ con 5 dientes y mucho mas corto que la corola 5 -partida y larga de 10 á $12^{\prime \prime \prime}$, cuyos lóbulos lanceolados y puntiagudos son casi tan largos como los estambres elongados casi encerrando el estilo filiforme y largos de $3^{\prime \prime \prime} 1_{1} 2$; estigma diminuto; baya globosa roja de $4^{\prime \prime \prime}$ de diámetro. S. racemosum, L.: C. T. V., 5.51. - Arbusto de 3 á $4^{\prime}$ de alto, muy ramoso, estrellado pubescente y aguijonoso, cuyo pelo y aguijones finitos comprimido-cónicos por la base y rectos son largos de 3 ó 1"' y de color amarillo aleonadito ; hojas oblongo-lanceoladas, muy aguzadas, enteras ú ondeadas, largas de 6 á '2", pecioladas y aguijonosas por la costilla ó inermes. Por ambas caras y especialmente por la inferior velludas; flores blancas á veces algo teñidas de púrpura en racimos simples, delgados, flojos y lateriflol'os, largamente pedunculados, con pedícelos col cantes; cáliz 5-dentado mucho mas corto que la corola larga de $8^{\prime \prime \prime}$ á 10"', 5 partida, cuyos lóbulos lineares y obtusitos son mitad mas largos que los estambres, cuvas anteras lineares tienen $2^{\prime \prime \prime} 1[2$ de largo; estilo espeso por la parte eserta de su punta. Baya pisiforme roja.- $S$. igneum, L.

6. Tallos provistos de aguijones recorvados, corola 5-partida, 7. - Tallos con aguijones rectos ó muy rara vez algo recorvados; corola 5 -fida y plegada por la base. Arbustos tomentosos y aguijonosos á lo largo de los ramos, 9 .

7. Arbustos abejucados ó de tallos sarmentosos ó como volubles, escabrosos y aguijonosos sobre las ramas, peciolos y costillas de las hojas, todos los aguijones cortos y recorvados y á la vez estrelladopubescentes, 8. - Tallos nunca ni sarmentosos ni rolubles tampoco, arbustos escabrosos, con aguijones cortos y recorvados sobre las ramas, peciolos $\mathrm{Y}$ costillas $₫$ a la vez estrellado-pubescentes; hojas eliptical-oblongas, puntiagudas, enteras y un poco aguzadas en peciolo largo, de cara superior verde oscuro y alampinada, mientras la inferior es velludo-aterciopelada y largas de 6 á $2^{\prime \prime} 1_{[} 2$; flores en cimas laterales corimbiformes, cortamente pedunculadas, cuyos pedícelos inermes son velludo-aterciopelados, así como el cáliz 5-fido, casi un 1 [ 3 de la lonjitud de la corola que tiene $5^{\prime \prime \prime}$ y es 5-partido, con lóbulos lanceolado-lineares, mientras los segmentos de la corola son subulados, casi dos veces mas largos que los estambres desiguales; baya globosa amarilla. S. micrantha, Lam. - S. olscurum, Sieb.

8. Vello raro, diminuto $y$ nulo en las partes verdes, hojas oblongolanceoladas ú óvalo-lanceoladas, largamente aguzadas, ondeadoenteras ó lijeramente ondulosas, largamente pecioladas, membranosas y largas de 5 á 4" ; flores blancas disciplinadas, en cimas laterales flojas, paucífloras, cuyos pedícelos son inermes, así como el cáli\% 5-fido, cuyos lóbulos subulados son provistos de un apéndice largo, casi 1 [ 4 de la lonjitud de la corola 5-partida, cuyas divisiones lineares y puntiagudas esceden un poco los estambres, cuyas anteras son largas de $4^{\prime \prime \prime}$; baya amarilla. S. lancifolium, Jacq. - S. crotonoides, Sieb. - S. incquale, Prl. - S. preslei y clavifactum, Dun. Aguijones de base comprimida; hojas elípticas ú óvalo-lanceoladas, 
sinuoso-angulosas, pecioladas, concóloras y de color verde oscuro y largas de 5" á 4"; flores azulitas en cimas laterales desparramadoracemiformes ó acorimbadas, de cáliz aguijonoso, 5-fido, cuyos lóbulos subulados tienen una punta corta, y son $1_{[} 3$ mas cortos que la corola, larga de 6 "', tomentosa esteriormente y 5 -partida, cuyas divisiones oblongo-lanceuladas esceden un poco á las anteras; baya globosas. S. scabrum. V. - S. volubile, Sw. C. T. V., 393.

9. Algunas raras veces inerme, aguijones apartaditos, rectos y sub-comprimidos; vello estrellado; hojas ovales, sinuoso-angulosas ó sub-enteras, puntiagudas, sub-acorazonadas ó truncas por la base, largamente pecioladas, largas de 8 á $2^{\prime \prime}$, con las costillas y los peciolos aguijonosos, de cara superior escabrosa, mientras la inferior es velludo-aterciopelada; flores blancas en cimas laterales, ordinariamente bífidas, escorpioídeo-corimbiformes, con pedícelos glandulosos, de cáliz inerme, 5-fido y por último 5-partido, cuyos lóbulos ovales son mucronado-agudos, 3 [4 mas corto que la corola estrellada 5-fida, con las divisiones óvalo-lanceoladas y largas de 5 á $7^{\prime \prime \prime}$; estilo encorvado por el ápice. S. torvum. Sw. : C. T. V., 552.Nunca inerme, aguijones distantes, delgados y rectos, vello-estrellado; hojas ovales ú oval-oblongas, ondeado-enteras ó lijeramente sinuosas, obtusitas, de cara superior escabrosa, mientras la inferior es velludo-tomentosa, raras veces con algunos aguijones por la costilla; de peciolo inerme y largas de 2 á 3 "; flores azuladas en cimas laterales, paucífloras, de cáliz aguijonoso por la base ó inerme, 5-fido, con lóbulos ovales ú óvalo-lanceolados y obtusitos, $2[3$ mas corto que la corola 5-fida, larga de á 6"' y cuyas divisiones óvalo-lanceoladas son dos veces tan largas como las anteras de $2^{\prime \prime}$; baya achatado globosa; roja y ceñida por el cáliz acrecente y foliáceo. $S$. inclusum, Gr. - S. tomentosum americanum, Grisb. - S. tomentosum, Hort-Germ. - S. hybridum, Dun.

10. Arbustillos, 11. - Matas sofruticosas, 12.

11. De tallo ceniciento, ramoso y que se eleva á $3^{\prime}$ ó $5^{\prime}$ de altura, tomentoso, con pelo estrellado, aguijonoso en las ramas y costillas de las hojas, cuyos aguijones amarillos y largos de 2 á $8^{\prime \prime \prime}$, fuertes, rectos, son comprimidos ó recorvos, raras veces inermes, con hojas anchamente ovales, anguloso-pinatífidas, de cara superior escabrosa, mientras la inferior es peludo-tomentosa, con los lóbulos deltoídeos y estendidos, largas de 8 á 3 " y pecioladas; flores azules en cimas laterales sub-sentadas, escorpioídeo-contraidas, de cáliz inerme, 5-festoneado, con los dientes redondeaditos ó mucronados, y 3 veces mas cortos que la corola 5 -partida, esteriormente tomentosa, larga de 3 á 6"', con los segmentos óvalo-lanceolados; anteras uvalo-lanceoladas, encorvadas y largas de 2 á $3^{\prime \prime \prime}$; baya amarilla, ancha de 6"'. S. stramonifolium, Jacq. - S. toxicavium, Rich. S'. demerarense, Dun. C. T. V., 552.

12. Baya amarilla grande, cónica y larga de $2^{\prime \prime}$ á $3^{\prime \prime}$, sobre $11_{[} 2$ á $2^{\prime \prime}$ de ancho, lustrosa y colgante, 13. - Baya globosa encarnada, lampiña, de 6 á 8 "' de diámetro, sostenida por el cáliz pequeño; vejetal sofruticoso de $2^{\prime}$ á $4^{\prime}$ de altura, muy aguijonoso y con pelo simple, articulado y por fin alampiniado, aguijones delgados y rec- 
tos; largos de $3^{\prime \prime \prime}$ y amarillos; hojas ovales, pinatífidas, raramente ondeado-enteras, cuyos lóbulos son oval-oblongos ó frecuentemente sinuoso-dentados, largas de 6 á 4", largamente pecioladas, con las costillas muy aguijonosas y pestañosas por la márjen; flores blancas en cimas laterales paucífloras, de cáliz frecuentemente armado y 5-fido, con lóbulos óvalo-lanceolados y aguzados, $2[3$ mas corto que la corola larga de $4^{\prime \prime \prime}$ á $5^{\prime \prime \prime}$, alampiñada, 5-fida, cuyos segmentos son oblongo-lanceolados; anteras óvalo-lanceoladas. S. aculeatissimum, Jacq. - S. ciliatum, Lam. - S. Myriacanthum, Dun.

13. De base enteramente desprovista de tubérculos con figura de pezon, pero cuyo vértice se termina á manera de pezon: planta herbácea ó subfruticosa, ramosísima, de $2^{\prime}$ á $4^{\prime}$ de alto, aguijonosa, con vello simple, articulado, blanco y denso, aguijones amarillentos, fuertes y comprimidos, largos de 4 á $10^{\prime \prime \prime}$, con hojas grandes óvalo-angulosas, sinuosas, pecioladas, con las costillas y nervaduras aguijonosas, largas de 4 á $6^{\prime \prime}$, sobre $3^{\prime \prime}$ á $3^{\prime \prime} 1 l^{2}$ de ancho; flores azuladas ó azul-moraduscas, en cimas laterales, paucífloras y contraidas, de cáliz 5-partido, con segmentos subulados y 3 veces mas corto que la corola, larga de 6 á $8^{\prime \prime \prime}$, peluda, 5-partida, con divisiones lanceoladas, anteras oblongo-lanceoladas, aguzándose desde el medio y largas de $5^{\prime \prime \prime}$. S. mammosum, L. - S. pectinatum, Dun. : C.T. V., 553. - Baya del mismo tamaño y color que la anterior, pero cuya base está ádornada por su circunferencia de 3 á 5 pezones largos de 6 á 10"' y anchos de 2 á $3^{\prime \prime \prime}$; vejetal algo mas bajito que el precedente, con el cual tiene mayor analojía y todo el semblante. S. mamosissimum, R. de G-y. C. T. V., 553.

14. Planta herbácea ó sofruticosa, pubescente ó tomentosa con pelo estrellado, aguijonosa ó inerme, cuyos aguijones distantes, rectitos ó recorvados y cortos están comprimidos, alta de 3 á $4^{\prime}$ y ordinariamente poco ramosa, con hojas ovales ó oval-oblongas, ondeadas ó sinuosas, largamente pecioladas; flores azuladas en cimas laterales, ovales y puntiagudas; corola. larga de 5 á $8^{\prime \prime \prime}$ y 5-9-fida y con segmentos deltoídeos, que llera 5-9-estambres, cuyas anteras largas de 2 á $3^{\prime \prime \prime}$ son oblongo-lanceoladas; baya grande, ovoídea, sub-globosa ó elíptica, larga de 2 á $6^{\prime \prime}$, sobre 2 y hasta $3^{\prime \prime}$ de diámetro, blanca ó morada, lisa y lustrosa, sostenida por el cáliz un poco acreciente ó crecido. S. melongena, L. : C. T. V., 551.

15. Anteras oblongas solamente, obtusitas, con poros diminutos situados en su ápice trunco, 21. - Anteras oval-oblongas ú oblongas, 16.

16. Obtusas, poros grandes, introrsos $\mathrm{y}$ terminales, frecuentemente volviéndose grietas lonjitudinales; tallos inermes, flores cimosas, 17. - Poros diminutos situados en su vértice obtusito; no volviéndose nunca grietas; tallos inermes, flores en cimas laterales simplemente ombeliformes ó corimbiformes, á veces solitarias, 21.

17. Tallos herbáceos, 18. - Tallos leñosos, 19.

18. Yerba anual, alampiñada mas ó menos ramosa y alta de $1^{\prime} 1 \Gamma^{2}$ á $3^{\prime}$, con hojas ovales, acuneadas por la base peciolada, enteras ó sinuoso-dentadas; flores blancas, pequeñas y en cimas laterales ombeliformes, pedunculadas, de corola 5 -fida, dos reces tan largas como 
el cáliz 5-fido; filamentos lampiños con anteras cortamente oblongas y por fin lonjitudinalmente dehiscentes; baya globosa, amarillentoblancuzcas, acompañada del cáliz reflejo. S. nodiflorum, Jacq. : C. T. V., 5.51. - Con las dos variedades siguientes: de baya colorada y con las hojas sinuoso-dentadas. $S$. erythrocarpum, con las hojas tan sinuoso-dentadas que parecen compuestas. S. chenopodioides. Desc.; hojas sinuoso-dentadas con la baya negra. S. oleraceum, hojas enteras y baya negra. S. caribeum. C. T. T., 551 .

19. Hojas lampiñas ó alampiñadas, 20. - Hojas lepidotas ó cubiertas de un polvo escamoso. - Arbolito ó arbusto que se eleva á 15 ó á veces á $25^{\prime}$, pero siempre de tronco delgado, ramosísimo en su parte superior, de corteza color ceniciento y cuyas ramitas son densamente escamosas, amarillentas, llevan hojas elípticas ú ovales, puntiagudas, pecioladas, enteras ú ondeadas, de cara superior provista de escamitas diminutas, mientras la inferior es de ordinario mas densamente lepidota, y largas de 6 á $4^{\prime \prime}$, con el peciolo te $6^{\prime \prime \prime}$ á $8^{\prime \prime \prime}$; flores blancas en cimas terminales ó laterales, largamente pedunculadas, con los pedícelos amanojados, largos de 4 á $5^{\prime \prime \prime}$, estendidos ó cabizbajos, de vértice espeso y escamosos, así como el cáliz, 4-lobo, de lóbulos redondito-deltoídeos y mucho mas cortos que la corola 4-partida, con los segmentos oval-oblongos y obtusitos; anteras oblongas y largas de $2^{\prime \prime}$ : baya ovoídea. S. puntulatum. Dun.

20. Arbusto lampiño alto de 4 á $6^{\prime}$ ó algo mas, muy ramoso, lampiño, con hojas eliptical-oblongas ú oblongo-lanceoladas. puntiagudas, enteras, pecioladas, ordinariamente mellizas, con una mas pequeña, de cara inferior, con la axila de las venas peluda ó alampiñada. largas de 5 á $3^{\prime \prime}$, con el peciolo de 8 á $2^{\prime \prime \prime}$; flores blancas en cimas pedunculadas. laterales, formadas de racimitos enrollados, cuyos pedícelıs mas largos tienen $6^{\prime \prime \prime}$; de cáliz pequeño, 5-fido, con corola -f-fida, de segmentos oval-oblongos y puntiagudos, $\mathrm{y}$ largos solamente de 4 á 6"'; anteras ovoídeo-oblongas la mitad tien largas como los segmentos de la corola; baya amarilla, globosa y de 4 á $6^{\prime \prime \prime}$ de diámetro. S. triste, Jac. : C. T. V., 554 .

21. Cáliz trunco cuyas 10 nervaduras se dilatan en apéndices inframarjinales, 22. - Cáliz con 5 divisiones; arbusto alto de 4 ó $\tau$, ramosísimo, lampiño y de hojas lanceolado-oblongas ó elipticaloblongas, obtusitas, aguzándose por la base hasta volverse peciolo, enteras y largas de 4 á 11 [ $2^{\prime \prime}$; cimas corimbiformes ordinariamente. con pocas flores, que á veces son solitarias, de cáliz 5 fido, con los se omentos oblongoos, obtusos y á veces mellizos, 1 [2 ó 1 [ 6 mas corto que la corola 5-fida, cuyos lóbulos arriñonado-redonditos son mucronados y mas cortos que el tubo chatito y estendido; anteras oral-oblongas; estilo rectito; baya ovoídea negro-azulada y larga de 8 á 6 "'. S. havanense, Jacq. - S. coriaceum, Hook. - S. hookerianum. Spreng. - S. vaccinifolium, Dun.

22. Arbusto alampiñado, pero cuya parte superior es pubescentita con el pelo estrellado; hojas ovales ú oval-oblongas, puntiagudas, pecioladas, enteras, mellizas, cuvas mayores son largas de 6 á $4^{\prime \prime}$, mientras las menores lo son de $2^{\prime \prime}$ solamente, con el peciolo de 6 á $8^{\prime \prime \prime}$, de cara superior lampiña, mientras la inforior es pubescentita ó 
alampiñada; flores blancas en cimas ombeliformes sentadas, con los pedícelos largos de 8 á $4^{\prime \prime \prime}$, de cáliz largo de $2^{\prime \prime \prime}$, con los apéndices situados esteriormente y por debajo de la márjen del limbo trunco, oblongos, obtusos, estendidos ó recorvados, casi la mitad mas cortos que el tubo, suelen faltar raras veces; corola lampiña larga de $8^{\prime \prime \prime}$ á $10^{\prime \prime \prime}$, con el limbo sinuoso y 5-anguloso; antel'as oblongas cuyo quinto filamento es mas largo que los demas; estilo rectito; estigma claviforme; baya globosa, con $8^{\prime \prime \prime}$ de diámetro. S. neglectum, Dun.

23. Arbusto abejucado, aguijonoso ó inerme, cuyos aguijones de las ramas tomentosas y de las hojas son delgados y rectos, el pelo es estrellado, de hojas lanceolado-oblongas, obtusitas, ondeado-enteras, cortamente pecioladas y largas de 3 á $2^{\prime \prime}$, con la cara superior escabroso-pubescente; flores blancas en cimas laterales, pauci ó l-floras y sentadas, de cáliz profundamente 4-5-fido, cuyos lóbulos oblongos y obtusos son la mitad mas cortos que la corola 4-5-partida y larga de $2^{\prime \prime \prime}$, cuyos segmentos oval-oblongos y obtusitos son dos veces tan largos como las anteras que tienen 1"' de largo; baya globosa de $3^{\prime \prime \prime}$ de diámetro. S. polygamum, V.

G. II. Physalis, L. - Yerbas anuales, 2.- Yerba vivaz velludopubescente, con hojas acorazonadas ú ovales, puntiagudas, con algunos dientes ó enteras; segmentos calizinales lanceolado-aguzados, estrias de la vejiga calizinal apenas notables; corola amarilla larsa de 6 á $8^{\prime \prime \prime}$ y con puntitos morados interiormente; anteras moradas. P. perutiana, L. - P. pubescens, R. Br. - P. edulis, Sims. C. T. V., 360.

2. Pubescentes, 3. - Alampiñadas, 6. te, 5 .

3. De tallo solamente pubescente, 4. - Enteramente pubescen-

4. 'Tallo pubescente, ramoso y de hojas ovales ó sub-acorazonadas puntiagudas, dentado-sinuosas ó sub-enteras; lóbulos calizinales lanceolado-aguzados; vejiga 5́-angulosa; corola amarillenta, larga de 3 á $4^{\prime \prime \prime}$ y con puntitos purpúreos interiormente, anteras moradas. P.pubescens, L. - P. barbadensis, Jacq. - P. hirsuta, Dun. : C. T. V., 360.

5. Viscoso pubescente, desparramado por el suelo, muy ramoso y con hojas deltoídeo-ovales, anguloso-dentadas; lóbulos calizinales lanceolado-aguzados, con los ángulos de la vejiga estrechos y por fin apenas notables; corola amarillenta larga de $4^{\prime \prime \prime}$, con el limbo abierto; anteras moradas. $P$. foetens, Poir. - De hojas sub-acorazonadas ú ovales, con una puntita, sub-enteras ó dentadas; segmentos calizinales lanceolado-aguzados; vejiga 5-angulosa; corola larga de $2^{\prime \prime \prime}$, amarillenta; anteras amarillas. P. minima, L. $-P$. pruinosa, L.

6. Hojas ovales, puntiagudas, aserradas, con dientes apretados ó con dientes apartados; segmentos calizinales lanceolado-acuminados, estrias de la vejiga apenas notables ó nulas; corola larga de $4^{\prime \prime \prime}$, amarillenta, pálida ó lijeramente coloradita por la garganta, anteras moradas. P. linkiana, Ns. - Hojas ovales ú oval-oblongas, puntiagudas, sinuoso-dentadas ó sub-enteras; lóbulos calizinales deltoídeos, vejiga con 5 ángulos pronunciados; corola enteramente 
pálida, larga de $4^{\prime \prime \prime}$, anteras moradas. P. angulata, L. - P. capsicifolia, Dun.

B. G. III. Capsicua, L. - 1. De frutos mas ó menos erguidos y nunca colgantes, 2. - Frutos siempre colgantes o cabizbajos, 7.

2. Vejetales herbáceos $y$ anuales, 3. - Vejetales fruticosos ó sub-fruticosos y por consiguiente vivaces y raras veces bisanuales, 4 .

3. Planta herbácea, bastante ramosa, alta como de unos $3^{\prime}$; con hojas solitarias pecioladas, elípticas ú ovales, aguzadas, enteras y lampiñas; frutos á veces bastante gruesos, pero ordinariamente como de 4 á 6"' de diámetro, sobre 1" de largo; lisos, cónico-oblongos, oblongos y asperitos, angulosos, ovoídeos, globosos y por fin con forma de aceituna, segun la variedad á que pertenecen, acompañados de la base crecida del cáliz. E. annuum, L. : C. T. V., 454. Yerba de tallo ramosísimo, flexuoso, tuberculadito, lampiño y alto como de 3 á 4', con hojas de peciolos pubescentes, solitarias, ovales, aguzadas, enteras, de cara inferior asperita y pubescentita en las venas; cálices lampiños y con dientes cortísimos. C. conicum. Mey.

4. Tallos y ramos fruticosos, 5. - Tallos y ramos sub-fruticosos, 6 .

5. Arbustillo alto de 3 á 6 , algo mas ó menos, muy ramoso, lampiño, cuyos ramos flexuosos y cilíndricos se terminan por ramitas algo angulosas, alampiñaditas, que llevan hojas solitarias o mellizas, ovales, puntiagudas, enteras, pecioladas y lampiñas; cáliz por fin trunco 10-nervioso, aguzándose en pedícelo espeso; baya roja ó amarilla, larga de 6 á $12^{\prime \prime \prime}$. C. frutescens, L.: C. T. V., 454. Arbustito que parece mucho el precedente alampiñado, de ramos divaricados, cuyas ramitas angulosas, estriaditas y lampiñas llevan hojas pequeñas oblongas, óvalo-acuminadas ó lanceolado-ovales, enteras, alampiñadas, á veces mellizas, puntiagudas y enteras; flores blancas pequeñas, en grupos axilares, de cáliz 5-dentado, cuya base se vuelve bruscamente pedícelo, delgado y erguido; baya roja globosa, ovoídeo-globosa, de 3 á $4^{\prime \prime \prime}$ de diámetro. B. baccatum, L. - C. laurifolium, Dun. : C. T. V., 454.

6. Mata ramosa como de $3^{\prime}$ de alto, con hojas ovales, aguzadas $y$ pubescentes; cáliz 5-anguloso, peludo y cuyas divisiones bastante profundas son algo subuladas y estendidas; baya pisiforme, globosa ó algo óvala, roja, lustrosa y acompañada por la base del cáliz. $C$. microcarpum, Dc. - Mata ramosísima como de $3^{\prime}$ de altura, algo mas ó menos, cuyos ramos. verdes hácia el vértice pubescente y dividiéndose en muchas ramitas divaricadas, son por la base blanquecino-acanelados; hojas pequeñas, solitarias $\dot{0}$ mellizas $\mathrm{y}$ desiguales, ovales, aguzadas. obtusitas y de base casi redonda, de cara superior verde lustrosa y lampiña, mientras la inferior, mas pálida, es peluda en las nervaduras, pecioladas. C. microphyllum, L.

7. Planta herbácea cuya base del tallo es leñosita, fuerte $y$ bastante gruesa, asurcado, ramosísimo por el vértice y alto como de 4 ' á 5' o algo menos, con hojas bastante grandes, ovales, casi enteras, algo ásperas, cuya base desigual se aguza en peciolo, de cara inferior con las nervaduras muy pronunciadas y mas pálida que la sunerior lustrosa, lampiñisina: flores solitarias, cuyos pedícelos de 
las fructíferas son recorvados, leñositos y gruesos; baya gruesa y hasta muy gruesa, globosa ú óval y hasta como elíptica, torrulosa ó asurcada, lisa, lustrosa, encarnada. C. dulce, L. - C . longum. De. - Mata sub-fruticosa, derecha, alta como de unos $3^{\prime}$ ó 4', muy ramosa superiormente, lampiña y con hojas ovales, oblongas, aguzadas, de un color verde teñido de amarillento; flores solitarias ó mellizas de cáliz oblícuo algo 5 -anguloso, cuyo limbo algo dilatado es trunco y tiene 5 o 6 dientecitos erguidos y obtusitos; baya agnzada por ambos estremos, color rojo subido, larga de I" á ' 2 ", colgante y acompañada por la base calizinal. C. pendulum, Wild.

G. IV. Lycopersicum, T. - 1. Bayas á veces bastante grandes y gruesas, algo chatas, irregularmente discoídeas, como asurcadas, 2 . - Bayas mas pequeñas, globosas ó piriformes, 3 .

2. Planta anual herbácea, blancuzco-velluda, viscosa, de tallos delgados, cuyos numerosos ramos muy largos, angulosos, son flexuosos casi trepadores, carnosos y llevan hojas bastante grandes. desiguales, pinatífidas, cuyas divisiones son partidas ó dentadas, muy velludo-tomentosas: flores amarillas en racimos paucifloros axilares, cuyos pedícelos son uníforos, de cáliz que pasa de la mitad de la corola; baya lustrosa encarnada de $2^{\prime \prime}$ á $3^{\prime \prime}$ de diámetro vertical. L. esculentum, L. : C. T. V., 553.

3. Baya globosa siempre, 4. - Baya siempre piriforme, 5.

4. Yerba peluda, de hojas pinadas con interrupcion, pinatisectas, cuyos segmentos mas largos son inciso-aserrados, con una punta deltoídea; pedícelos sin bracteitas : cáliz la mitad mas corto que la corola; baya colorada de $3^{\prime \prime \prime}$ á $6^{\prime \prime \prime}$ de diámetro. L. Humboldtii, Dun. - Yerba anual ramosísima, de tallo y ramos largos, delgados y casi abejucados, velludo-tomentosa, con hojas interrupto-pinadas. cuyas flores en racimos paucífloros, con los pedícelos bastante largos, de cáliz casi igual á la corola; bayas rojas, ó mejor encarnadas. lampiñas, lustrosas y del tamaño de una cereza. I. cerasiforme, Dun.

5. Yerba que se parece mucho á la precedente, de hojas penatipartidas con interrupcion de segmentos partido-dentados, y de cara inferior alampiñada; flores en racimos flojos con los pedícelos larguitos y sin brácteas; lacinias del cáliz casi iguales á la corola: baya colorada, lustrosa, lampiña y del tamaño de una pera de las mas pequeñas. L. pyriforme, Dun.

G. V. Acristus aiborescens, Schlecht. C. T. V., 555.

C. Datúreas. G.VI. Datura, L. 1. Plantas her báceasa nuales, 2.Arbusto cuyo tallo bastante ramoso superiormente y de corteza cenicienta se eleva á unos $\mathrm{S}^{\prime}$ á $20^{\prime}$ de altura, con las ramitas y hojas pubescentes ó alampiñadas bastante grandes, pecioladas ovales ú ovaloblongas, enteras aguzadas por ambos estremos; primorosísimas flores blancas, grandes, como colgantes, de cáliz ventricoso, tukuloso, anguloso y con 5 dientes, largo como el tubo de la corola muy grande, campanuda superiormente $y$ de limbo con 5 dientecitos correspondiendo con otros tantos ángulos muy visibles en el tubo largo, tiene como 4" á 5" de largo sobre $3^{\prime \prime}$ de ancho superiormente: anteras coherentes y lineares, biloculares; cápsula inerme; fiorp: de olor muy suave. D. suareolens, N. B.: C. T. V., 558. 
2. Alampiñadas, 3. - Pubescente de como $3^{\prime}$ de altura, muy ramosa y cuyos ramos estendidos son dicótomos y algo rojizos así como los peciolos, con hojas ovales, pecioladas, bastante grandes, de base inequilateral y de vértice aguzado, enteras ó con algunos pocos dientes, velludas por ambas caras, muy suaves, blanquecino-verdes; flores bastante grandes, blancas, rectas, pero el pedúnculo no tarda en doblarse despues de la fecundacion, de manera que el ovario se vuelve colgante, de cáliz flojo 5-dentado y casi la mitad mas corto que la corola grande y larga de $6^{\prime \prime}$, cuyo limbo ahierto es cortamente 5-dentado y con el tubo sub-cilíndrico; anteras distintas oblongas $y$ larcas de $4^{\prime \prime \prime}$ á $5^{\prime \prime \prime}$; cápsula colgante y cabizbaja, casi globosa, aguijonosa, con aguijones subulados y largos de como 6" á 8"'. D. Metel, L.: C. T. V., 557.

3. Cápsula erguida, 4. - Cápsula colgante ó cabizbaja; hojas ovales, ondeadas, con algunos pocos dientes grandes, bastante grandes, pecioladas, de cara superior lampiña, mientras la inferior es algo alampiñada: cáliz 5-dentado, 1 ? 3 mas corto que la corola, blanca ó á veces teñida de morado, larga de $6^{\prime \prime}$ á $7^{\prime \prime}$, frecuentemente doble, abierta y aguzándose gradualmente hasta transformarse en el tubo sub-cilíndrico, con los 5 dientes largamente subulados; anteras linear-oblongas y lareas de $6^{\prime \prime \prime}$; cápsula muricada curos aguijones cortos y tuberculiformes tienen como $2^{\prime \prime \prime}$ de largo. D. fastuosa, L.

4. Tallo, ramos y peciolos de las hojas morados, de como $2^{\prime} l^{2} 2$ a 3 de alto, con hojas ovales, sinuoso-dentadas verde-moradusco, pecioladas; flores violadas de cáliz 5-dentado la mitad mas corto que la corola larga de $3^{\prime \prime}$ á $4^{\prime \prime}$, cuyo limbo 5-dentado y abierto se va estrechando gradualmente hasta formar el tubo cilíndrico, sus dientes son subuladofiliformes; anteras distintas, oblongas y largas de $2^{\prime \prime \prime}$ 1 [2; cápsula erizada de aguijones iguales, subuliformes y largos de $4^{\prime \prime \prime}$. D. tutula, L. - Tallo verde, bastante ramoso superiormente, alto de como $3^{\prime}$, algo mas ó menos, cuyos ramos divaricados llevan hojas ovales, bastante grandes, sinuoso-dentadas, pecioladas, verdeoscuras, lustrosas; flores blancas ó teñidas de rosado, de cáliz 5dentado, la mitad mas corto que la corola, larga de $2^{\prime \prime} 1_{[} 2$ á $3^{\prime \prime}$ y cuyo limbo abierto y con 5 dientes subulado-filiformes se va estrechando gradualmente hasta formar el tubo cilíndrico; anteras distintas, oblongas y largas de $2^{\prime \prime \prime}$; cápsula elipsoïdea cubierta de aguijones cuyos superiores son dos veces mas largos que los inferiores. D. stramonium, L.: C. .T. V., 556 .

G.II.V.Nicotiana, L. Planta herbácea alta de 1'a a 2 ", de hojaslanceoladas ó lanceolado-lineares, sentadas, cuyas inferiores mas grandes son elípticas y aguzadas por la base; flores en cimas racimiformes, verduzco-amarillentas, de cáliz j-fido con lóbulos iguales y lanceolado-lineares, $1_{[} 3$ mas corto que la corola infundibuliforme, de tubo filiforme y claviforme estrechado, contraido por debajo de los segmentos cortos y lanceolado-aguzados; cápsulas por último cortamente eserta. N. pusilla, L. $-N$. angustifolia, R. P. Yerba alta de $3^{\prime}$ á $4^{\prime}$ y mas, de tallo bastante grueso, recto y muy poco ramoso con hojas oblongo-lanceoladas, muy largas, y á veces bastante anchas, las hemos visto, no raras veces, largas de $2^{\prime} 1$ [ 2 y 
anchas de 6 " á 10" en el medio, por ambośs estremos aguzaditas, casi sentadas, puntiagudas, cuyas inferiores son decurrentes: flores rosaditas en cimas apanojadas algo corimbiformes, de cáliz 5-fido con los segmentos óvalo-lanceolados y sub-iguales, $l_{[} 3$ mas corto que la corola infundibuliforme de tubo claviforme y no estrechado, curos lóbulos son subulado-deltoídeos y abiertos; cápsula cortamente eserta. $N$. tabacum, L.: C. T. V., 559.

D. G. VIII. Cestrum. L. 1. Filamentos muy cortos é insertos en la garganta de la corola, 2. - Filamentos mucho mas largos que las anteras insertos en la parte media ó por arriba del medio del tubo de la corola, 3 .

2. Flores amarillo-pálidas pediceladas y en cimas racimiformes ó paucífloras; arbusto lampiño de hojas apergaminado-membranosas oblongas o elípticas, con una punta obtusita, delicadamente venosas y largas de $5^{\prime \prime}$ á $1^{\prime \prime} 1_{[} 2$; pedícelos largos de $1^{\prime \prime \prime}$; cáliz con 5 dientes ovales y obtusos, tubo de la corola largo de $6^{\prime \prime \prime}$ á $8^{\prime \prime \prime}$, claviforme ensanchándose gradualmente hasta formar la garganta; segmentos ovales, obtusos y por fin reflejos, con el estilo eserto ; estambres inclusos é insertos por dentro de la garganta, cuyos filamentos son tan largos como las anteras enteras; baya ovoídea azul, larga de $3^{\prime \prime \prime}$ y cortamente aguzada por la base. C. pallidum, Lam. - C. tinctorium, Jacq. - Flores blancas sub-sesiles en cimas contraidas paucífloras y sub-sentadas; arbusto cuyas ramitas pubescentitas llevan hojas apergaminado-membranosas, óvalo-lanceoladas, ó elipticaloblongas, obtusitas, alampiñadas con venas finitas y largas de $2^{\prime \prime}$ á $4^{\prime \prime}$. pecioladas; cáliz con 5 dientes subulado-deltoídeos; tubo de la corola largo de $8^{\prime \prime \prime}$ á $12^{\prime \prime \prime}$, filiforme, lampiño, bruscamente hinchado por la garganta; lóbulos oblongo-lineares; estambres inclusos é insertos por dentro de la garganta; filamentos tan largos como las anteras enteras; baya ovoidea azul y cortamente aguzada por la base. C. vespertinum, L.: C. T. V., 85ั2.

3. Vejetales no lampiños, 4. - Arbustos lampiños, 5.

4. De ramitas pubescentes con hojas membranosas, ovales, puntiagudas, largas de $6^{\prime \prime \prime}$ á $5^{\prime \prime \prime}$, alampiñadas, finamente venosas y pecioladas; cimas contraidas sub-sesiles, cuyas flores sub-sentadas tienen el cáliz cortamente 5 -fido de segmentos deltoídeo-subulados; la corola larga de $12^{\prime \prime \prime}$ á $10^{\prime \prime \prime}$, cuyo tubo filiforme, claviforme $\mathrm{y}$ lampiño se va ensanchando gradualmente, y de lóbulos lanceoladolineares, estambres inclusos, insertos por encima del medio del tubo de la corola y cuyos filamentos son enteros; baya oblonga. C. latifolium, Lam. - C. chorantum, Dun. - Ramitas velludas con pelo dentadito ó pelierizadas; hojas apergaminadas oval-oblongas ú óvalolanceoladas, obtusitas por el vértice, y sub-acorazonadas ó redonditas por la base, arqueado-venosas, de cara inferior con las nervaduras proeminentes y con pelo persistente sobre la costilla, largas de $5^{\prime \prime}$ á $2^{\prime \prime}$ y pecioladas; cimas contraidas sub-sesiles formadas de flores sub-sentadas y verdoso-blanquecinas, de cáliz largo de $11_{1} 2^{\prime \prime \prime}$ ؛ $2^{\prime \prime \prime}$ y con dientes deltoídeas: corola larga de $6^{\prime \prime \prime}$ á $8^{\prime \prime \prime}$, cuyo tubo olaviforme y estrechándose gradualmente sostiene lobulos ovales y obtusitos, llevando los estambres inclusos en él y pegados por su 
medio; filamentos pubescentes por debajo del diente; baya ovoídea negra y larga de $6^{\prime \prime \prime}$. C. hirtum, Sw. - C. hir sutum, Jacq.

5. Cimas sub-sesiles contraidas cuyo eje es pubescente, 6. - Cimas pedunculadas de eje lampiño, 7 .

6. Hojas apergaminadas, grandes, oblongas ú oblongo-lanceoladas, aguzadas, arqueado-venosas, cuyas nervaduras proeminentes por la cara inferior por fin se hacen visibles por la superior y son largas de $8^{\prime \prime}$ á $4^{\prime \prime}$; flores sub-sesiles amarillentas y cambiando de color, de cáliz largo de $1^{\prime \prime \prime}$ á $2^{\prime \prime \prime}$, con 5 dientes deltoídeos ó diminutos, de corola larga de $6^{\prime \prime \prime}$ á $8^{\prime \prime \prime}$, cuyo tubo claviforme y gradualmente aguzado es glabro y con lóbulos óvalo-lanceolados, ú ovaloblongos; estambres inclusos é insertos casi por el medio del tubo de la corola, cuyos filamentos pubescentitos son enteros ó provistos de un dientecito situado por encima de la parte pubescente; baya ovoídea. C. macrophyllum, Vent. - C. megalophyllum, Dun. $-C$. bellasombra, Dun. - C. vespertinum, Sieb. - C. Schotii, Seudtn.C. conglomeratum, R. P. - Hojas coriáceas, lustrosas elípticas, obovales ú oblongas, obtusitas ú obtusas con venas apenas notables ó delgaditas, pecioladas y largas de 4 " $1_{[} 2$ á $2^{\prime \prime}$; flores verdosoamarillentas, cambiando de color y cortamente pediceladas; de cáliz con 5 dientes diminutos ó deltoídeos; corola larga de $8^{\prime \prime \prime}$ á $6^{\prime \prime \prime}$ con el tubo claviforme lampiño y gradualmente aguzado, de lóbulos óvalo-redondeaditos ú ovales; estambres inclusos é insertos por arriba del medio del tubo de la corola, cuyos filamentos pubescentitos inferiormente son enteros ó están provistos de un dientecito situado por arriba de su base; baya ovoídea larga de $6^{\prime \prime \prime}$ á $5^{\prime \prime \prime}$. C. laurifolium, Cher. - C. alaternoides, Desf. - C. subtriflorum, Dun.

7. Flores sub-sesiles blancas y muy fragrantes; filamentos lampiños y siempre enteros ; arbusto ramoso de $6^{\prime}$ á $8^{\prime}$ de alto, con hojas apergaminado-coriáceas ovaloblongas, obtusitas, delicado-venosas, pecioladas y largas de $4^{\prime \prime}$ á $3^{\prime \prime}$; cimas pedunculadas y contraidas; cáliz con 5 dientes diminutos ó deltoídeos; tubo de la corola largo de 6 "' a 8 "', claviforme, lampiño y aguzándose gradualmente; estambres inclusos é insertos por debajo de la garganta, cuyos filamentos son casi tres veces mas largos que las anteras; baya sub-globosa de $3^{\prime \prime \prime}$ á $4^{\prime \prime \prime}$ de diámetro. C. diurnum, L.: C. T. V., 853 3 . Flores pediceladas verdoso-amarillas, de flamentos pubescentitos inferiormente, tan pronto enteros como provistos de un dientecito situado por arriba de la base; arbusto ramoso, de como $6^{\prime}$ á $8^{\prime}$ de alto $y$ con hojas apergaminado-coriáceas, ovales ú oval-oblongas, con una punta obtusita y largas de $4^{\prime \prime}$ á $2^{\prime \prime} 1_{[} 2$, delgado-venosas; cimas racimiformes mas largas que los peciolos, con los pedícelos inferiores frecuentemente tan largos como el cáliz, que lo es de $2^{\prime \prime \prime}$ á $3^{\prime \prime \prime}$, con 5 dientes oval-redondeaditos ó deltoídeos y casi ${ }_{[} 3$ mas corto que el tubo de la corola, que es largo de $8^{\prime \prime \prime}$ á $9^{\prime \prime \prime}$, cuyo tubo claviforme y lampiñ se va estrechando gradualmente, sostiene los lóbulos orales y obtısos y contiene los estambres inclusos y pegades por arriba de su medio. C'. nocturnum, L.: C. T. V., 853. 


\section{CLASE XXXII. - PERSONADAS.}

Familia 68. - ESCROF ULARIÁCEAS. - Vejetales ordinariamente hérbaceos, subfruticosos, raras veces leñosos, de hojas simples, pecioladas ó sentadas, enteras ó frecuentemente festoneadas, dentadas $\mathrm{y}$ hasta lobadas algunas reces, opuestas ordinariamente o verticiladas y alguna vez que otra alternas, comunmente sin estípulas; flores hermafroditas en grupos axilares, en espigas terminales, sencillas ó ramosas y en este caso racimosas, bastantes veces solitarias en la axila de las hojas, formadas de un cáliz monosépalo persistente 3 o 4 y ordinariamente $\bar{J}$-fido, cuyos segmentos, mas ó menos largos, son desigualitos; corola irregular monopétala. personada ó enmascarada, ordinariamente bilabiada, cuyo tubo lleva pegados en él dos estambres didínamos y rarísimamente 4 ó 5 perfectos y siempre desiguales; pistilo cornpuesto de un ovario único súpero, simple, bilocular, con la placenta axil, polispermo, sostenido por un disco hipójino y cuyo vértice lleva un estilo sencillo mas $\delta$ menos largo, ordinariamente filiforme, terminado por un estigma simple, caljezudo ó á veces bílobo; cápsula cuya dehiscencia es loculícida ó septícida, otras veces se efectua por medio de poros que se hallan hácia el vértice; rarísimas veces el fruto es una baya; semillas con un endospermo carnoso; embrion pequeñisimo, derecho y de raicilla vuelta hícia el hilo ú opuesta á su punto de insercion.

\section{Análisis dicotímica de las sub-órdenes y de las tribus.}

1. Corola bilabiada, cuya estivacion es plegada o empizarrada: labio superior las mas veces plegado segun los senos; inflorescencia centrífuga desde el prinćipio. S.-órd. I. SALriglosídeas.A.1.Corola rnas ó menos bilabiada, de estivacion siempre imbricada, 2 .

2. Labio posterior esterno, inflorescencia centrípeta ó compuesta. cuya parcial está en cima centrífuga, mientras la general está en tirso centrípeto. S.-órd. II. Axtirrhinídeas, 3. - Labio posterior nunca jamás esterno; inflorescencia centrípeta ó compuesta, pero rarísimas veces centrífuga. S.-órd. III. RINaxthídeas, 9.

3. Corola siempre bilabiada, mas ó menos enmascarada, tubulada y frecuentemente espolonífera; cápsula abriéndose por medio de poros; inflorescencia centrípeta uniforme; hojas opuestas ó verticiladas. T. I. Eunntirnhíseas. - Antirrinum. - Corola mas ó menos bilabiada, 4.

4. No bilabiada, pero con dos lóbulos enteros y cóncavos, cáliz. con 4 divisiones que parecen valtas, inflorescencia compuesta; hojas opuestas ó verticiladas. 'T. II. Calceoráriess. - Calceolaria. IIas ó menos bilabiada, tubulada ó no, 5 .

5. No tubulada, enrodada, cuyos lóbulos planos tienen una foseta. o bilabiada; estambres declinados; inflorescencia centrípeta uniforme, hojas alternas. T. III. Terbísceis. - Veibossum. - Mas ó menos tubulada, 6 . 
6. Corola enrodada y raras veces tubulosa, bilahiada, con una foseta ó espolonada; cápsula con dos ventallas; inflorescencia centrípeta; hojas inferiores opuestas. T. IV. Hemimerídeas. B. Corola siempre tubulosa, 7 .

7. Cápsula siempre con dos ralvas, 8. - Cápsulas con 2 ó con 4 ventallas, algunas raras veses una baya indehiscente; estivacion de los segmentos calizinales empizarrada; inflorescencia compuesta. T. V. Quilóseas. Escrofularia.

8. Cáliz ancho, de estivacion valvar; inflorescencia completa. pedúnculos con brácteas opuestas. T. VI. Escobedieas. - Alectra Brasilensis, Benth.; Matacana, Prco.; Cane-killer, Antillas inglesas. - Corola rarísimas veces sub-redondeadas; cápsula algunas raras veces indehiscente, estivacion de los lóbulos calizinales imbricada ; inflorescencia centrípeta, uniforme, rarísima vez irregularmente compuesta. T. VII. Gracióleas. C.

9 Hojas mas ó menos opuestas, 10. - Hojas siempre alternas, 14.

10. Siempre opuestas, convexas, atravesadas por una membrana linear: flores cimosas o mas rara vez solitarias y axilares. T. I. Buddleieas. Buddleia. - Cuyas inferiores solas son mas ó menos opuestas, 11.

- 11. Estambres dispuestos por pares aproximados y de anteras biloculares, cuyas celdas son con frecuencia mucronadas y las mayores iguales. T. II. Gerardieas. Gerardic hispidula, Mart. Estambres nunca por pares dispuestos, 12.

12. Labio posterior de la corola yelmiforme ó cóncavo y erguido; inflorescencia centrípeta racimosa. T. III. Eufrasieas. Eufrasia. - Labio posterior nunca con figura de yelmo; inflorescencia centrípeta racimosa, 13.

13. Hojas inferiores algunas veces solamente opuestas, estambres distintos de anteras bi ó uniculares. T. IV. Veroníceas.-Veronica serpyllifolia, L. - Hojas inferiores á veces opuestas; estambres no dispuestos por pares, pero aproximados, de anteras diminutas $\mathrm{y}$ uniloculares. T'. V. Buchiereas. Buchnera.

11. Fasciculadas hácia los nudos ó rarísimas veces opuestas y nunca jamás conjuntas y cuyas florales están conformes con las superiores ó decurrentes; flores superiores solitarias ó fasciculadas y axilares, mas raras veces cimosas. T. VI. Sibthorbieas. D. Inflorescencia centrípeta y racimosa, hojas pecioladas y apretadas por la base. T. VII. Digrtáleas.-Digitalis purpuvea.

A. Salpiglosídeas. - Brupsfelsia, Sw.-1. Fruto seco y capsular; arbusto alampiñado de hojas elípticas cortamente pecioladas y largas de 1" 1 2 á $2^{\prime \prime}$; cáliz tubuloso lijeramente dilatado y mas largo que el pedícelo, con los dientes oblongo-lanceolados y obtusitos; corola azul cuyo tubo es un poco mas largo que el cíliz, que lo es de $7^{\prime \prime \prime}$ á $8^{\prime \prime \prime}$. B. hopeana, Benth. - Fruto carnoso, indehiscente i abriéndose muy tarde, 2 .

2. Arbolito que se eleva a $10^{\prime}$ óa $15^{\prime}$ de altura y cuyas hojas elípticas, eliptical-cblongas ú obovales, pecioladas, venosas y largas de $1^{\prime \prime} 1,2$ á $3^{\prime \prime}$, con caliz campanudo כ-dentado tan largo como el pedícelo solitario, con dientes redondos; corola amarillo pálida, la ${ }^{\natural} g a$ 
de $2^{\prime \prime}$ á 2 " $1 / 2$ y cuyo tubo es 8 á 10 veces tan largo como el cáliz y 3 veces como el limbo, con frecuencia lijeramente arqueado hácia arriba, de lóbulos redondos y enteros; baya amarilla, globosa y con $8^{\prime \prime \prime}$ de diámetro. B. Americana, Sw. - B.pubescens, Desc.: C. T. V., n॰ 72. - Árbol que alcanza hasta $20^{\prime}$ y mas de altura, lampiño o con hojas clípticas ó eliptical-oblongas, obtusitas, cortamente pecioladas, venosas, apergaminadas y largas de $3^{\prime \prime}$ á $3^{\prime \prime} 1 / 2$; cáliz campaniforme, 5 -dentado $l_{[} 3$ o $1_{[} 4$ tan largo como el pedícelo solitario y cuyos dientes son redondos; corola amarilla, de tubo largo de $3^{\prime \prime}$ á $2^{\prime \prime}{ }_{[}[2$, y 10-12 veces mas que el limbo, rectito y con los lóbulos enteros. B. fallax, Duchass.

B. Hemimerídeas. - Angelonia, Bonpl. - Yerba viscosopubescente anual y derecha, bastante ramosa y alta de $l^{\prime}$ á $l^{\prime} 1[2$, con hojas oblongo-lineares, puntiagudas, asserraditas, sentadas y de base redonda, largas de $1^{\prime \prime}$ á $3^{\prime \prime}$; primorosas flores moradas en racimos terminales flojos, corola de $6^{\prime \prime \prime}$ á $8^{\prime \prime \prime}$ de diámetro, cuyos lóbulos inferiores son oblongos y obtusos, apéndice de la garganta corto; cápsula globosa y loculícida por la base. A salicarifolia, H. B.Planta herbácea pareciéndose mucho á la precedente, de la cual difiere por ser lampiña, tener las hojas lanceoladas ó linear-lanceoladas, puntiagudas, aguzadas por la base, mientras el vértice es entero ó con alłunos dientes apartados; lóbulos inferiores de la corola obovales. A. angustifolia, Benth. - A. salicarifolia, Var. - A. Jamaicensis, Benth.: C. T. V., n 429.

C. Gracióleas. - Herpestrs, Gr. - 1. Tallos rastreros solamente, ó rastreros y á la vez echando raices, 2 . - Tallos derechos ó difusos y nunca rastreros, 3 .

2. Yerbecita vivaz de tallo blando, largo de $3^{\prime \prime}$ á $4^{\prime \prime}$, estendido por el suelo, en donde echa raices, pubescentito y con hojas ovales enteras, palmatinervias, sentadas, largas de $2^{\prime \prime \prime}$ á $4^{\prime \prime \prime}$ y á veces 8 "', alampiñadas, tan largas ó mas que el pedícelo bracteado y que sale de su axila; los lóbulos mas anchos del cáliz son ovales, mientras los laterales son lanceolados; corola blanquecina cortamente eserta y de labio superior escotado; celdillas de las anteras oblongas y paralelas; estigma bífido, cápsula 4-valvar. H. repens, Cham. y Schl. - Yerbecita de tallos difusos, rastreros y cuya parte inferior echa raices en el suelo, largos de $4^{\prime \prime}$ á $6^{\prime \prime}$, ramosos y lampiños, con hojas espatuladas ú obovales, subsesiles, sub-enteras, algo suculentas y largas de $3^{\prime \prime \prime}$ á $6^{\prime \prime \prime}$, cuyos nervios son apénas visibles; pedícelos ordinariamente esertos y de vértice bibracteado; segmentos calizinales mas anchos, ovales, mientras los laterales son lanceolados; corola azulita, larga de 6 "' y dos veces mas que el cáliz, cuyos lóbulos son sub-iguales, con el labio superior profundamente bífido; celdillas de las anteras oblongas y paralelas; estigma cabezudo; cápsula 4-valvar. H. Monniera, Kth. : C. T. V., no 532.

3. Planta herbácea de tallo derecho, lampiño, largo de $8^{\prime \prime}$ á 12 ", anual y con hojas lanceolado-lineares, aguzadas por ambos estremos, largas de $12^{\prime \prime \prime}$ á $8^{\prime \prime \prime}$, uninervias y subsesiles y aserraditas por el. vértice; flores subsesiles blanquecinas, segmentos mayores del cáliz ovales ú óvalo-largos, mientras los laterales son lanceolados; 
corola cortísima eserta, larga de $2^{\prime \prime \prime}$ y cuyo labio superior es escotado; anteras redondeaditas y de celdillas paralelas; estigma obtuso; cápsula 4-valvar. H. sessilifolia, Benth. - Yerbecita anual, difusa y acostada sobre el suelo, cuyos tallos ramosos y largos de $3^{\prime \prime}$ á $8^{\prime \prime}$, son lampiños y llevan hojas ovales, obtusitas, aserraditas, uninervias, cortamente pecioladas y largas de $4^{\prime \prime \prime}$ á $10^{\prime \prime \prime}$, frecuentemente mas cortas que el pedícelo filiforme abracteolado y largo de $3^{\prime \prime \prime}$ á $8^{\prime \prime \prime}$; segmentos calizinales mayores, ovales ú oval-oblongos, mientras los laterales son lanceolados; corola amarilla, cortamente eserta, larga de 4"' y cuyo labio superior es escotado; celdas de las anteras redondeaditas y divaricadas; estigma obtuso, cápsula bivalvar. $H$. chamadryoides, Kth. - H. chrysantha, Cham. - $H$. Culiensis, Popp. - Lindernia dianthera, Sw.

I. Sirthorbieas. - Capraria, L. - Arbustillo de tallo recto, ramoso y alto de $2^{\prime}$ á $4^{\prime}$, alampiñado, mas ó menos peludo ó pubescente, de hojas elíptico-lanceoladas ó eliptical-oblongas, densamente aserradas por arriba de la base; flores blancas cuya corola de 4"' á $5^{\prime \prime \prime}$ de largo lleva 4 estambres y es ordinariamente 2 veces mas larga que el cáliz; cápsula óvalo-subglobosa, igualando al cáliz. C. biflora, L. : C. T. V., no 24l. - Mata leñosa de $3^{\prime}$ á $4^{\prime}$, de tallo y ramos delgados, lampiña y raramente pubescente, con hojas lanceoladas, aguzadas, aserraditas por arriba del medio ó sub-enteras; flores blancas, de corola larga de $4^{\prime \prime \prime}$ á $5^{\prime \prime \prime}$, que lleva 5 estambres, cuyas anteras son frecuentemente la mitad mas cortas que los filamentos; cápsula ovoideo-oblonga, igualando al cáliz. C. Mexicana, Moric.

Scoparia dulcis, L. : C. T. V., 71-670. - S. tenuifolia, Var.

Familia 69 - CRESCENCIEAS. - Arboles mas ó menos grandes, pero ordinariamente medianos ó raras veces arbustos trepadores, con hojas simples, alternas ó fasciculadas, sin estípulas, alguna rara vez compuestas, bi ó 3 -folioladas; flores siempre hermafroditas, solitarias ó mellizas y saliendo del tronco y de los ramos, otras veces corimbosas, formadas de un cáliz inferior monosépalo, al principio muy entero y formando un saco cerrado al rededor de la corola y que por último se revienta desde la base en 2 ó 3 segmentos casi iguales o cerrado en las yemas, se queda siempre mas ó menos trunco, pero sin partirse; corola grande campaniforme irregular, un poco bilabiada, de estivacion imbricara ó infundibuliforme, con el tubo elongado, la cual lleva 4 estambres didínamos, con el rudimento del $5^{\circ}$ estambre situado entre el par superior, que es el mas largo, ó sin él; anteras bílobas, cuyos lóbulos diverjentes son uniloculares y se revientan lonjitudinal é interiormente, de pólen blanco y globoso. Pistilo compuesto de un ovario superior, sentado en un disco amarillo y anular, unilocular y con 4 placentas parietales carnosas, grandes y polispermas, cuyos óvulos son horizontales; otras veces es bilocular, su vẻrtice lleva un estilo mas ó menos largo, filiforme y terminado por un estigma bilamelado. Baya mas ó menos gruesa, de casco leñoso, bastante duro y muy resistente, de forma y tamaño inuy variados, pulposa, cuyas placentas se han soldado entre sí y tienen las semillas anidadas sin simetría nilıguna, las cuales están comprimidas, achatadas y mas ó menos 
redondeadas, de testa coriácea y lisa, sin endospermo y cuyo embrion recto tiene cotiledones espesos, redondearlitos y acorazonados y la raicilla espesa $y$ situada cerca del hilo.

Tribu 1a. - Crecencieas. A. - Fruto carnoso, leñoso, ovalgloboso y unilocular; hojas alternas mas ó menos fasciculadas $Y$ simples.

Tribu 2. - Tanecieas. B. - Fruto carnoso silicuiforme, biplurilocular; hojas opuestas, mas raramente verticiladas y compuestas.

A. Crescentia, L. - 1. Hojas fasciculadas, 2. - Hojas ordinariamente no amanojadas, 3.

2. Árbol que se eleva de $15^{\prime}$ á $20^{\prime}$ ó á $30^{\prime}$ de altura, cuyo tronco recto, poco largo y de corteza de color ceniciento lleva muchos ramos largos en forma de varita y mas ó menos horizontales, con hojas espatuladas, subsesiles apergaminadas, largas de $8^{\prime \prime}$ á $4^{\prime \prime \prime}$, lampiñas y lustrosas; flores bastante grandes colgando de un pedúnculo ecrto doblado hácia abajo, y bastante grueso, con el cáliz 2-partido, de corola larga de $3^{\prime \prime}$ á $2^{\prime \prime}$ y de $1^{\prime \prime}$ á $1^{\prime \prime} 1_{1} 2$ de ancho superiormente, de base plegada transversalmente, color amarillento muy pálido y matizada del mismo color, pero mas subido, con lóbulos dentadoundulosos, fruto mas ó menos grueso, globoso, oval, elíptico, casi piriforme, etc., de $1^{\prime}$ á $2^{\prime \prime}$ de diámetro, con el casco leñoso, muy resistente. $C$. cujete, L.: C. T. V., 75.-Arbol que se parece mucho al precedente, pero no tan coposo y cuyos ramos menos largos y menos horizontales llevan hojas oboval-oblongas ú oval-oblongas, cortamente pecioladas ó subsesiles, tiesas y esparcidas, largas de 10 á $3^{\prime \prime}$, cáliz bipartido; corola desigualmente 5-loba larga de $2^{\prime \prime} 1_{[} 2$ y matizada de mas oscuro; fruto ovoídeo con una punta obtusa larga de $3^{\prime \prime}$ y cuyo casco es quebradizo. C. cucurbitina, L.

3. Arbol mucho mas grande y mas corpulento que los precedentes, cuyo tronco derecho alcanza á $1^{\prime}$ ó $2^{\prime}$ de diámetro, muy frondoso y cuya corteza es algo teñida de rojizo, y cuyos ramos y ramitas derechos y no horizontales llevan hojas ovales lampiñas, alternas, cortamente pecioladas, largas de $6^{\prime \prime}$, sobre $3^{\prime \prime}$ de ancho, un poco aguzadas por ambos estremos; flores blancuzcas cuyos estambres algo esertos ó salientes, tienen las anteras amarillas y con el estilo mas largo que ellos; frutos pequeños y simulando como limones, de casco delgado, algo flexible y quebradizo, cuya tripa muy amarga contiene semillas parduscas acorazonado-trílobas. C. latifolia, C. T. V., 858.

B. Tanceciun, Sw. - Arbusto sarmentoso ó trepador con la médula de los ramos cilíndrica; hojuelas membranoso-apergaminadas, ovales ó elípticas, con una punta obtusita, lampiñas y largas de $5^{\prime \prime}$ á $3^{\prime \prime}$; flores blancas en corimbos axilares, paucífloros, de cáliz tubular-campaniforme, sub-tronco, cuya corola enteramente pubescente y larga de $6 "$ á 8 ", tiene los lóbulos orales, obtusitos y undulosos, con 2 anteras esertas $y$ el estilo tan largo como el tubo; fruto semejante á una totumita, solamente mas pequeño, oblongo y largo de 1'. T. jaroba, Sw. - T. albiflorum, Dc.: C. T. V., 635. - Arbusto no sarmentoso cuyos ramos tienen la médula oblícua; lojuelas coriá- 
ceas, ovales, lampiñas y largas de $3^{\prime \prime}$ á 4 "; flores en racimos paucífloros axilares y terminales, de cáliz tubular-campaniforme, subtronco; corola enteramente pubescentita, larga de 6" á $7^{\prime \prime}$, con los lóbulos deltoídeos, puntiagudos y undulosos; 2 anteras esertas; estilo tan largo como el tubo. T. crucigerum, Seem. Bignonia crucigera, L.

Familia 70. - BIGNONIÁCEAS. - Vejetales fruticosos mas o menos trepadores y sarmentosos, provistos con frecuencia de zarcillos que salen del vértice del raquis; Arbustos y árboies muy grandes y corpulentos, muy raras veces plantas herbáceas, algunas veces matas; de hojas frecuentemente compuestas, ordinariamente opuestas, verticiladas y rarísimas veces alternas, sin estípulas. Flores primorosas, siempre hermafroditas, solitarias, en grupos axilares ó en racimos y panojas terminales, que constan de un cáliz monosépalo, persistente, con 5 divisiones mas ó menos profundas; corola monopétala, ordinariamente campaniforme, de limbo irregular, bastantes veces como bilabiado y otras veces con 5-lóbulos mas ó menos profundos y desiguales, cuyo tubo ordinariamente corto lleva 4 estambres didínamos insertos en su interior, donde se repara un apéndice que es el rudimento del $5^{\circ}$ estambre abortado; algunas raras veces hay tres filamentos estériles; anteras cuyas celdillas, ordinariamente distintas son contiguas por la base. Pistilo único formado de un ovario simple, superior $y$ sentado sobre un disco hipójino, bilocular con muchos óvulos distantes del eje é insertos á lo largo de cada márjen de un tabique central placentario: su vértice lieva un estilo simple mas ó menos largo, filiforme y terminado por un estigma bílobo ó bilamelado. El fruto consiste en una cápsula de forma y tamaño variados, con dos celdas y que se abre por dos valras opuestas á los tabiques, conteniendo muchas semillas ordinariamente aladas, comprimidas, sin endospermo y cuyo embrion es recto, con cotileiones grandes, foliáceos $y$ ordinariamente escotados.

\section{Anilisis dicotomica de las tribus y sub-tribus.}

1. Cápsulas siempre biloculares, 2. - Cápsulas ordinariamente uniloculares y á veces biloculares, 5 .

2. En las cápsulas maduras el tabique es paralelo, con las valvas llanas ó convexas; dehiscencia hacıéndose á lo larģo de las márjenes ó marjinícida. T. I. Evbróóvieas. A. 3. - En las cápsulas maduras el tabique estí opuesto á las valvas llanas ó mas frecuentemente convexas y septíferas, especialmente cuando tiernas y por esa razon la dehiscencia es loculícida. T. II. Catálpeas. B. 4.

3. Semillas dispuestas en una sola série por cada lado del tabique. S.-T. I. Movostictídes. - Semillas dispuestas en 2-3-4 séries de cada lado del tahique. S.-T. II. Plesostredes. - Cybistrax antisifilitica, Mart.-Biginonia antisifilitica, Mart.-B. revidiflora Lood. C. T. T., 783. 
4. Semillas dispuestas en algunas séries de cada lado del tabique. S.-T. I. Pleostictídes. - Semillas dispuestas segun una sola série, por ambos lados deb disepimento. S.-T. II. Monostictídes.

5. Cápsula bilocular ó unilocular, cuyas celdas se abren lonjitudinalmente por el medio; semillas colgantes, aladas ó carnosas por ambos lados; raicilla superior. T. III. Incarvílleas. - Cápsula siempre unilocular, cuyas dos valvas llevan las placentas situadas en su medio. T. IV. ECCREMOCÁRPEAS.

A. Monostictídes. - Bignonia, L. - i. Cáliz cerrado en la yema y por fin tronco ó dentadito, inflorescencia terminal, 2. - Lóbulos del cáliz desiguales, inflorescencia axilar, 3 .

2. Bejucos de tallo muy largo y ramoso, ordinariamente tetrágono ó por último anguloso, sub-cilíndrico, lampiño y con las ramitas angulosas; hojuelas 2.3 oval-oblongas ú ovales, aguzadas ó puntiagudas, enteras y largas de $6^{\prime \prime}$ á $3^{\prime \prime}$; flores grandes rosadas, con estrias ó listas, corimbosas, de cáliz trunco, corola campaniforme por arriba de la base, larga de $2^{\prime \prime}$ á $3^{\prime \prime}$ y asperita; celdas de las anteras oblongas y rectitas, cápsula larga de $8^{\prime \prime}$ á $\mathbf{1} 2^{\prime \prime}$, anchamente linear y obtusa por las márjenes, con las valvas lijeramente estriadas, y cuyas semillas anchamente redondeadas por los estremos tienen una ala opaca casi tan ancha como la mitad de ellas, que lo son de $1^{\prime \prime} 1$ [2. B. equinoctialis, L. : C. T. V., 77.

3. Bejuco delgado larguísimo y ramosísimo, lampiño, con las ramitas angulosas y por fin cilindricas, que llevan hojas estipuladas, cuyas dos hojuelas lustrosas son elípticas ó elíptico-lanceoladas, festoneado-sub-enteras, puntiaguditas, con los nervios dispuestos en redecilla y de raquis dilatándose en un zarcillo terminal trífido ó con tres ganchitos. Primorosas flores amarillas fasciculadas y axilares, de cáliz anchamente campanudo, liso, oblícuamente 5-festoneado, con los lóbulos anchos $y^{\prime}$ largos de $6^{\prime \prime \prime}$ a $8^{\prime \prime \prime}$, corola lampiña campaniforme, de tubo sub-cilíndrico y larga de $1^{\prime \prime} 1_{[} 2$ á $3^{\prime \prime}$, celdillas de las anteras oblongas y encorvadas ; cápsula larga de $18^{\prime \prime}$ á $12^{\prime \prime}$, casi linear, obtusa por los bordes, lijeramente estriada, cuyas semillas numerosísimas, linear-oblongas, largas de $2^{\prime \prime \prime}$, sobre $12^{\prime \prime \prime}$ á $15^{\prime \prime \prime}$ de ancho, tienen una ala transparente por los estremos, mucho mas anchos que su parte media. $B$. unguis. L.

B. G. 1. Tecoma, Juss. I. Limbo calizinal desigual; tubo de la corola gradualmente dilatado; cápsula de valvas enteras; hojas dijitadas ó simples, 3, - Limbo calizinal con 5 dientes iguales; tubo de la corola ventricoso por encima de la base; valvas de la cápsula por fil bipartidas; hojas imparipinadas opuestas, 2.

2. Arbusto de $4^{\prime}$ á $10^{\prime}$ de altura, muy ramoso, lampiño, de hojas imparipinadas, con 2 á 5 pares de hojuelas oblongo-lanceoladas, aguzadas, aserradas y cuya anchura varia mucho; primorosas flores amarillas racimosas, de cáliz la mitad mas corto que la parte estrecha del tubo campanudo de la corola larga de $2^{\prime \prime}$ á $1^{\prime \prime} l_{[} 2$; estambres inclusos con las celdillas de las anteras lanceoladas y rectas; cápsila linear, aguzada sub-comprimida y larga de $8^{\prime \prime}$ á 4". T. stans, Ju-.. C. T. V., 364.

¿. Hojas escamosas cuyas escamitas están ordinariamente dis- 
tantes; flores rosadas ó blancas, 5. - Hojas sin escamas; flores amarillas, 4 .

4. Árbol grande, frondoso y bastante corpulento, de tronco recto y que se eleva á $40^{\prime}$ ó $50^{\prime}$ de altura y aun mas, lampiño y de hojas apergaminadas formadas de 4, 5 ó 6 hojuelas oblongo-lanceoladas, aguzadas, aserradas por encima de la base, todas pecioladas, cuyas terminales son largas de $8^{\prime \prime}$ á $6^{\prime \prime}$ con el peciolulo de $20^{\prime \prime \prime}$ á $10^{\prime \prime \prime}$, mientras las inferiores lo son solamente de $3^{\prime \prime}$ á $2^{\prime \prime}$, con el pecioiulo de $6^{\prime \prime \prime}$ á 4 "'; flores en corimbos umbeliformes y saliendo ántes que las hojas, de cáliz campanudo polvoriento $1_{[} 4$ o $1_{[} 7$ mas corto que la corola larga de $2^{\prime \prime}$ á $2^{\prime \prime} 1_{[} 2$ y lampiña, cortamente 5-loba con los lóbulos desiguales y deltoídeos; estambres profundamente inclusos con las celdas de las anteras oblongas y encorvadas por el ápice, $T$. serratifolia, Don. - Bignonia serratifolia, V.

5. Arbol grande bastante frondoso y corpulento, de madera y corteza blancuzcas, con hojas tiesas frecuentemente de cara inferior blanquecina, formadas de 3-5-8 hojuelas lanceolado-oblongas ó linear-oblongas, obtusitas, enteras todas pecioluladas, largas de $3^{\prime \prime}$ á $1^{\prime \prime}$ y con peciolulos de $6^{\prime \prime \prime}$ á $2^{\prime \prime \prime}$; flores amarillentas en corimbos paucífloros dispuestas, de cáliz campanudo, escamoso, con los lábios mucronados, cuyo superior es frecuentemente mas largo que el inferior bífido, $1_{[} 4$ ó $1_{[} 6$ mas corto que la corola lampina esteriormente y pubescentita interiormente, larga de $2^{\prime \prime} 1_{[} 2$ á $2^{\prime \prime}$, con los estambres profundamente inclusos y cuyas celdillas de las anteras oblongo-lineares son rectas; cápsula linear sub-comprimida y larga de $6^{\prime \prime}$ á $8^{\prime \prime}$, con las valvas lisas y sin estrias y conteniendo muchas semillas tan anchas como su ala oblonga, larga de $4^{\prime \prime \prime}$. T . leucoxyllon, Mart.: C. T. V., 716. - Árbol bastante alto y grande, corpulento y frondoso, pero no tanto como el anterior, lampiño y de corteza blancuzca, con hojas tiesas diminutamente escamosas, formadas de 3-5-7 hojuelas eliptical-oblongas, elípticas ó elíptico-lanceoladas, obtusitas enteras y todas pecioluladas largas de $3^{\prime \prime \prime}$ á $6^{\prime \prime \prime}$ y cuyos peciolulos de las del medio lo son de $12^{\prime \prime \prime}$ a $20^{\prime \prime \prime}$, mientras los de las inferiores de $3^{\prime \prime \prime}$ á $6^{\prime \prime \prime}$ solamente; flores blancas ó rosado algo moraduzcas en corimbos paucífloros, de cáliz campanudo, escamoso, con los lábios redondeados cuyo inferior es bífido, $1_{1} 2$ ó $1_{1} 7$ mas corto que la corola larga de $3^{\prime \prime}$ á $2^{\prime \prime} 1[2$, lampiña esteriormente $y$ pubescentita interiormente con los estambres profundamente inclusos, cuyas celdas de las anteras son oblongo-lineares y rectitas; cápsula linear, elongada, "sub-cilíndrica y larga de.11" á 8", nosotros la hemos hallado algo comprimida, aguzada por ambos estremos, algo ventricosa y convexa en la parte media, larga de $2^{\prime \prime}$ á $3^{\prime \prime}$ sobre $1^{\prime \prime}$ de ancho por el medio, con las valvas provistas de 3 estrias salientes, conteniendo muchas semillas tan anchas como su ala oblonga y larga de $5^{\prime \prime \prime}$. T. pentaphylla, C. T. V., 727.

G. II. Catalpa longisiliqua; Cham.: C. T. V., 78.

G. III. Jacaranda corvulea, Gr. - Bignonia corulea, L. - B. Bahamensis, Dc.

Familia 71. - PEDALIACEAS, PEDALINEAS O SESA$M E A S$. - Plantas herbáceas anuales ó perennes, algunas veces 
con raiz perpendicular carnosa y bastante gruesa, frecuentemente polvorientas, mas ó menos glaucas ó velludas y mas ó menos vi=cosas, ramosas, con hojas simples mas ó menos grandes y pecioladas, lampiñas ó las mas veces velludas ó pubescentes, sin estípulas, opuestas ó las superiores alternas; flores completas hermafroditas, mas frecuentemente axilares y solitarias y raras veces en espigas ó racimos axilares o terminales, que constan de un cáliz monosépalo con 5 divisiones mas ó menos profundas, iguales; corola mas ó menos grande, monopétala, hipójina, irregular, con el tubo mas o menos largo, cilíndrico ó giboso y de garganta ventruda con el limbo 5-lobo, frecuentemente bilabiado, cuyos lóbulos casi redondos son algunas veces valvados en la estivacion, sostenida por un disco hipójino, carnoso y glanduloso, y cuyo tubo lleva 4 estambres didínamos, cuyas anteras biloculares y grandes están pegadas en un conectivo articulado sobre el filamento y prolongado mas allá de ellas; siempre el $5^{\circ}$ estambre es estéril ó rudimentario; pistilo único formado de un ovario ceñido de un disco glanduloso hipójino, con 1,8 y ordinariamente 2 ó 4 celdillas, con pocos ó con muchos óvulos, que lleva en su vértice un estilo único que se termina por un estigma dividido en 2 ó 4 lóbulos ó bilamelado; fruto capsular y dehiscente polispermo, ó drupáceo-nucamentoso indehiscente ó casi indehiscente, compuesto de 5 carpelillos en el estado normal y por causa de aborto reducidos ordinariamente á dos, tres ó cuatro, muchas veces con valvas encorvadas hácia adentro y por consiguiente con las verdaderas celdillas bipartidas, cuyas semillas, en número variado y uniseriadas, tienen alas ó están sin ellas, sin endospormo y cuyo embrion recto tiene los cotiledones planos ó plano-convexos y la raicilla mas corta que ellos.

Tribu la. Eusesíneas. Plantas siempre anuales, de fruto capsular dehiscente y de consistencia membranosa, cuyas semillas numerosísimas y oleosas son frecuentemente aladas ó están desprovistas de ellas. - Sesamum orientale, L.: C.T.V., 637. - T. II. EuredaLínEas. Plantas anuales ó perennes, cuyo fruto indehiscente ú oscuramente dehiscente por el ápice y nuncamentoso-drupáceo se termina frecuentemente por un ápice ganchoso, bífido, muy punzante y muy fuerte; semillas solitarias ó escasas en las celdas, nunça aladas, poco ó nada oleosas. - Martynia diandra, Glox.: C. T. V., 638. - Craniolaria annua, L.: C. T. V., 506.

Familia 72. - ACANTACEAS. - Plantas herbáceas anuales ó perennes. matas, arbustos y raras veces arbolitos, cuyas raices son raramente tuberculosas, con hojas simples, enteras, mas ó menos festoneadas $\mathrm{y}$ ondeadas, mas ó menos dentadas $\mathrm{y}$ hasta lobadas algunas raras veces, pecioladas y opuestas, cuyo par es frecuentemente desigual ; las partes herbáceas están ordinariamente provistas de líneas de pelo adnato; sin estípulas; flores ordinariamente sostenidas por una bráctea, ó mejor saliendo de su axila, solitarias mellizas, en espigas ó en panojas terminales y compuestas de un cáliz monosépalo persistente con 4 ó con 5 divisiones desiguales reemplazadas $\{$ reces por igual número de dientes ; corola monopétala, comunmente irregular, que parene mas ú menos bilabiada $y$ 
cuyo limbo está dividido en 4 ó en 5 lóbulos, de tubo mas ó menos largo, que lleva 2 ó 4 estambres didínamos insertos en su interior é inserta ella en un disco hipójino; el pistilo único se compone de un ovario simple mas 6 menos larguito fusiforme, con 4 caras poco pronunsiadas, superior, bilocular, con óvulos ordinariamente en número definido, dispuestos á lo largo del eje y ascendentes, cuyo vértice lleva un estilo sencillo mas ó menos largo terminado por dos estigmas simples ó por uno bílobo. El fruto consiste en una cápsula de forma muy variada, mas ó menos larga, pero ordinariamente fusiforme y con 4 caras mas ó menos pronunciadas, elásticamente loculícida; se abre pues á favor de 2 valvas septíferas y lonjitudinalmente desde el vértice hasta la base; los tabiques están formados por sus propios bordes y por consiguiente son bipartidos, frecuentemente con apéndices ganchosos á lo largo de la márjen; contiene algunas semillas pegadas por los apéndices ó retináculos, destituidas de endospermo y cuyo embrion dirije la radícula hácia el hilo.

\section{Análisis dicotómica de los úrdenes y de las trilus.}

1. Semillas no sostenidas por retináculos. Ord. Io. AnechitácEas. 2. -- Semillas sostenidas por retináculos ganchosos, disepimiento de las cápsulas bipartido. Ord. II. EcMatacánteas, 3.

2. Plantas trepadoras cuya cápsula contiene pocas semillas gruesas, con una especie de cúpula pegada por su base en lugar de los retináculos; placenta coherente en el eje. T. I. Tumbergieas. Tumbergia fragrans, Roxb. - Cápsula con muchas semillas pequeñas nacidas sobre un cordoncillo en forma de pezoncito. T. II. NelsoNIFAS.

3. Cáliz quinquefido ó 5-partido, 5. - Cáliz 4-partido, 4.

4. Con lacinias desiguales ó bilabiado; corola infundibuliforme ó bilabiada, de tubo cortísimo y con las fauces ordinariamente prolongarlas; estambres 4 insertos en el ápice del tubo, didínamos, de los que un par es cortísimo, o por ahorto dos solos, de anteras con las celdillas paralelas; cápsula tetrasperma por la base. T. I. BARLErieas. Barleria lutea, L.: C. T. V., 361. - Con las lacinias desiguales pero no bilabiado; corola unilabiada con el tubo cartilajinoso; 4 estambres didínamos con anteras uniloculares; cápsula tetrasperma por la base. T. II. Acívteas. A canthus.

5. Quinque fido, 7. - Siempre 5-partido, 6.

6. Regular, corola bilabiada ó hoquiabierta, pocas reces casi regular ó embudada; estambres 4 casi iguales y con anteras estrechas y uniloculares; cápsula tetrasperma desle la base ó en el medio, pocas veces en el medio di-hexasperma. T. III. Afelándreas. Profundamente 4 partido y regular; corola bilahiała con los lábios de igual forma; estambres raras veces 4-didínamos $y$ de ordinario dos solamente, con anteras comunmente biloculares y de celdillas paralelas o algunas veces uniloculares, y entonces de celdas sobrepuestas; cápsula tetrasperma en el merlio con el tabique en algunos casos separal!le de las valvas I elásticamente levantado. T. IV. DI'IITTEREAS'. 
7. Cáliz no siempre quinque fido, pero alguna vez por peqqueĩez ó falta de la lacinia dorsal cuadrífido ó casi cuadrífido, 8. - Cáliz siempre mas ó menos profundamente 5-fido, 10.

8. Corola bilabiada ó boquiabierta, raras veces emluudada con el limbo 4-fido casi igual; estambres nacidos de la base del tubo, pocas veces 4 -didínamos y ordinariamente dos solamente, con anteras biloculares cuyas celdillas paralelas ó mas frecuentemente separadas por el conectivo, son mochas ó espolonadas por la base, despues se vuelven uniloculares por causa de aborto; cápsula mas estrecha comprimida y estéril desde la base hasta casi el medio, y desde el medio dipleisperma. T. V. Gandarúseas. A. - Corola mas ó menos bilabiada, 9 .

9. Corola nunca bilabiada, pero boquiabierta; estambres 4-didínamos y raras veces dos fértiles solamente, con anteras de celdillas paralelas; cápsula estrecha; polisperma desde la base, en un solo género oligosperma desde el medio, aunque sin la base contraida. T. VI. Higrofíleas. - Hygrophylla hispida. C. T. V., 500.

10. Corola bien bilabiada, 11. - Corola casi regular no manifiestamente bilabiada, tubulosa, infundibuliforme ó casi campaniforme, con tubo mas ó menos pronunciado; estambres 4-didínamos $y$ sin embargo casi iguales, á veces 2 solamente, con anteras de celdillas paralelas; cápsula di-tetra-polisperma, casi siempre estéril y mas angosta en algun espacio por la base. T. VII. RuELíEAs. B.

11. Casi bilabiada con lábio superior estrecho $y$ tubo largo ó casi asalvillada con limbo regular; estambres 2 perfectos é insertos en el ápice del tubo, con anteras biloculares de celdas paralelas: cápsula desde la base hasta el medio ó mas allá estrecha, deprimida $F$ estéril. T. VIII. Erantédeas. - Justicia eustachiana. - Bilabiada ó boquiabierta; estambres dos con anteras biloculares cuya celdilla inferior es barbuda ó lanosa y despues obliterada por la lana; cápsula deprimida y polisperma desde la hase. T. IX. AxdroGrafíDEas. Andrographis paniculata, Nees.: C. T. V., 254 lis.

A. Gandarúseas. - Dianthera, As. Gr. 1. Tubo de la corola elongado; labios aproximados; el superior es sub-entero ó escotado, mientras el inferior es 3-festoneado; celdillas de las anteras separadas por el conectivo ancho; plantas herbáceas, cuyas flores color carmesi están en racimos terminales compuestas de brazos racemiformes ó contraidos; brácteas pequeñas. D. segunda, Gr. - Lábio inferior de la corola estendido y anchamente 3-lobo; flores espigadas ó axilares con brácteas pequeñas; plantas herbáceas ó sufruticosas bajitas, 2 .

2. Tallo delgado alto de $1^{\prime}$ á 2 ', herbáceo ó sub-frutecente, lampiño, frecuentemente con una línea de pelo, pubescentito por la sumidad; hojas lanceolado aguzadas, ú oblongo-lanceoladas, largas de $4^{\prime \prime}$ á $1^{\prime \prime}$, sesiles; flores rosaditas con la garganta de la corola pintadita o azulitas, distantes en espigas ramosas, elongadas y ordinariamente unilaterales y terminales, de cáliz con 5 segmentos pequeños, linear-aguzados $1_{[} 4$ o $1_{[} 6$ mas cortos que la corola larga de $4-5^{\prime \prime \prime}$, bilabiada hasta el 102 de su lonjitud, cuyo labio superior oval y entero escede los estambres, cuyas celdillas de las anteras 
ovoídeas y oblícuas son separadas por el conectivo contraido ó pequeño. D. pectoralis, Mar.: C. T. V., 428. - Yerba alampiñada de tallo rastrero y delgadito largo de $6^{\prime \prime}$ algo mas ó menos, con hojas del toídeo-ovales, puntiagudas ú obtusitas y largas de 6 á $3^{\prime \prime}$; flores pocas distantes en una espiga simple y filiforme, unilateral, de cáliz con los segmentos linear-aguzados $l_{1} 4$ mas corto que la corola larga de 3-4"' blanca con pintas rojas en la boca, bilabiada hasta el 1 1 4 y cuyo lábio superior es escotado; celdillas de las anteras ovoídeas y oblicuamente diverjentes, de las cuales una está mas alta. D. reptans, Gr. - Rytinoglosa reptans, Nees.

Adhatoda justicia, C. T. V., 294.

B. Ruelieas. Ruellia, L. 1. Cáliz profundamente 5-fido, 2. Cáliz 5-partido; cápsula sub-cilíndrica con 6-24 semillas situadas desde casi la base; retináculos obtusitos por el vértice; flores laterales acompañadas de dos brácteas en la base y dispuestas en cimas laterales ó axilares, 4.

2. Cápsula comprimida con 4 á 8 semillas situadas por arriba de la base sólida, con retináculos dentaditos por el vértice; flores axilarés, sentadas y sin brácteas, 3.-Cápsula sub-comprimida con 16-4 ó raras veces 2 semillas, de retináculos subulados; cimas abiertas, axilares y cuyas flores laterales están acompañadas de dos brácteas por la base ; planta fruticosa como de $3^{\prime \prime}$ á $5^{\prime \prime}$ de alto y de ramos abejucados, glandulosa; con hojas óvalo-lanceoladas, acuñadas y pecioladas; flores azules en cimas apanojadas, de cáliz con segmentos linear-filiformes acompañado de brácteas lanceoladas; tubo de la corola largo de $1^{\prime \prime}$, hinchado por el medio; cápsula oblongo-linear, lateralmente sub-comprimida, con 8-12 semillas lisas situadas por arriba de la base. $R$. paniculata, L.: C. T. V., 500 .

3 . Planta herbácea ó sufruticosa, alta de $1^{\prime}$ á $2^{\prime}$ peluda ó alampiñada y de tallo derecho ó poco ramoso, con hojas lanceolado-oblongas, lanceoladas ú ovales, subsesiles; flores purpúreas 1 ó 2 y axilares; de cáliz largo de 4-5"', con los segmentos linear-aguzados; corola larga de $1^{\prime \prime}$ á $11 l^{2} 2^{\prime \prime}$ con tubo ensanchado por el medio; cápsula ovoídea, pubescente, con 4 semillas por arriba de la base. $R$. geminiflora, Kth.: C. T. V., 476-786. - Variedades: Hojas lanceoladas y largas de 1" á $1 " 1$ 1 2 ; pelo estendido. Depteracanthus angustifolius, Ns. - Vellito corto, hojas oblongo-lanceoladas y largas de 1". Dipt. conesceins.

4. Planta herbácea, de raiz amanojado-tuberculosa, alta de $l^{\prime}$ á $2^{\prime}$, cuyo tallo es mas ó menos recto y á veces algo estendido por el suelo, con la sumidad ascendente, ramoso, alampiñado y glanduloso superiormente; con hojas elípticas, obtusitas, acuñadas por la base y pecioladas. Flores azuladas en cimas dicótomas, y frecuentemente en panojas abiertas, de cáliz largo de $5 \cdot \mathbf{8}^{\prime \prime \prime}$, con los segmentos linear-filiformes y mucho mas largos que las brácteas lineares; corola larga como de $2^{\prime \prime}$ a $2^{\prime \prime} 1[2$, de tubo ensanchado por debajo del medio, parte estrecha de la corela mas corta que el cáliz; cápsula lanceolado-oblonga, pubescente, larga de $6-12^{\prime \prime}$ y con 10 á 12 semillas. R. tuberosa, L.: C. T. V., 474 . 


\section{CLASE XXXIII. - SELAJINOÍDEAS.}

Familia 73. - MIOPORÁCEAS.-Matas, frutices, arbustos y raras veces arbolitos con hojas alternas $r$ á reces opuestas, simples, enteras ó dentalas, casi siempre sembradas de glandulitas resinosas, sin estípulas; flores axilares solitarias hlancas 0 amarillas, á veces rojas, formadas de un cáliz persistente 5-partido ó raramente 5-fido. con los lóbulos á reces imbricados por la lase y de estivacion quincuncial ; corola monopétala 5 -loba, casi regular ó variamente bilabiada, con un lóbulo siempre delantero, colocado por dentro en liz estivacion; estambres 4 ordinariamente salientes, didínamos, sin restijios del quinto superior, cuyos dos inferiores son mas largos todos insertos en la hase de la corola, de anteras semi-lunadas y oscilantes, cuyas dos celdillas, confundidas en una, se abren por una sola hendidura. Pistilo con ovario sentado sobre un receptáculo cainoso, sin nectario alguno, libre, bi ó multilocular, con las celdillas frecuentemente sub-divididas por la márjen de las hojas carpilares, y con dos huevecillos pendientes y anátropos, terminado por un estilo simple ó rara vez bífido. Drupa pequeña abayada ó casi sin jugo. con el hueso ordinariamente bilocular, muchas veces completa $\dot{0}$ incompletamente 4-locular y 8-4-2-espermo, cuyas semillas inversas y oblongas están provistas de un endospermo carnoso, con el embrion rollizo, cuyos cotiledones son plano-convexos y la raicilia súpera. - Bontia daphnoides, L.: C. T. V., 634.

Familia 74. - JAZMINEAS. - Arbustos y á veces árboles bastante grandes y corpulentos; pero mas á menudo pequeños, de hojas simples y algunas veces tan lobuladas y tan partidas que á primera vista parecen completas, como lo son realmente algunas raras veces, pecioladas, onuestas de ordinario y alguna que otra vez alternas; cuyas flores casi siempre hermafroditas y bastantes veces polígamas están dispuestas en grupos axilares en racimos y en tirsos terminales, constan de un cáliz monosépalo persistente con la base turbinada y raras veces formado de 4 sépalos; corola monopétala, regular ó irregular, cuyo tubo lleva pegados dos estambres y rarísimente 4 ; algunas veces está compuesta de 2 o de 4 pétalos, otras veces suele faltar enteramente; pistilo formado de un ovario único, súpero bilocular, monospermo, cuyo vértice sobrelleva un estilo simple $y$ raras veces bífido, terminado por un estigma bílobo. El fruto consiste en una cápsula que se abre por dos valvas, otras veces en una baya ó una drupa con una ó dos celdas conteniendo de 1 á 4 semillas ó huesecitos con un endospermo carnoso ó duro que contiene el embrion. Jasminum officinalis, L. - Mongorium samzac, L.: C. T.V., 430 .

\section{CLASE XXYTY. - VERBEXINEAS.}

Familia 75. - VERBENÁCEAS'. - Plantas herbáceas, matas, frutices, arbustos y algunas raras reces árboles bastante gran- 
des, cuyas hojas, ordinariamente simples y alguna rara vez compuestas, enteras, festoneadas ó dentadas y pecioladas, son opuestas $o$ verticiladas, sin estípulas. Flores siempre hermafroditas, de inflorescencia centrípeta y en espigas, racimos, cimas ó cabezas axilares ó terminales, las cuales constan de un cáliz monosépalo, tubulado, mas veces persistente 4-5-dentado ó lobulado; corola monopétala mas ó menos irregular con 4-5 lóbulos iguales ó desiguales, cuyo tubo lleva 4 estambres didínamos pegados en su interior, rarísimas veces son dos y mas rara vez todavía 6 ; de limbo ordinariamente bilabiado y de estivacion imbricada; pistilo único formado de un ovario simple, súpero, 8-4-2 y rara vez l-locular, con 1-2 óvulos en cada celdilla y cuyo ápice lleva un estilo sencillo mas ó menos largo y filiforme que se termina en un estigma simple ó bílobo. El fruto consiste en una baya ó en una drupa mas ó menos seca, y en ese último caso reventándose ordinariamente en nuececitas ó huesecitos en número de 2 ó de 4 , conteniendo cada uno una semilla erguida; otras veces es un pericarpio á veces bi ó trílobo simulando así aquenios ó semillas desnudas cubiertas por el cáliz persistente; semillas sin endospermo y de embrion recto.

\section{Análisis dicotómica de las tribus y sub-tribus.}

1. Óvulos erguidos y derechos desde la base de la celdilla y anátropos; inflorescencia indefinida simple y centrípeta. T. I. VERBENEAS, 3. - Huevecillos pendientes desde el ápice del eje, anfítropos y apareados en cada celdiila. Cápsula coriácea indehiscente y al fin quebrantándose en la germinacion ó druputa mas ó menos carnosita, 2 .

2 . Inflorescencia centrípeta en cabezuela ó espiga. Flores con brácteas ó bracteillas hermaneadas, escamiformes y empizarradas; cáliz 5-fido; corola casi regular 4-fida. T. II. AriceníEas. E. Huevecillos insertos sobre la base de la celdilla en el ángulo central, pendientes, anfítropos ó casi anátropos; fruto drupáceo; inflorescencia definida di-tricótomo-cimosa. T. III. Viteas. D.

3. Fruto drupáceo mas ó menos carnosito, 4. - Fruto capsular, 8.

4. Flores nunca en capitulos ó cabezuelas, 5. - Flores en capitulos ó en espigas mas ó menos bracteadas, de cáliz cortamente tubuloso membranáceo, de corola tubulosa sub-hipocrateriforme, de limbo oblícuo sub-bilabiado; drupa dipirinácea, de la que cada hue:o es unilocular; frutices. S.-T. I. Lavíneas. B.

5. Fruto drupáceo bi o 4 pirenáceo ó con 2 ó 4 huesecitos, 6. Fruto drupáceo sub-carnoso, 7.

6. Flores en racimos flojos de cíliz tubuloso, ciatiforme, cuyo fructífero es acrescente, de corola campanuda ó hipocrateriforme ; fruto cuyos huesecitos ó pirenas son biloculares; frutices o arbustos. S. T II. Derínteas. C.

7. Flores en racimos flojos de cáliz sub-bilabiado y de corola unilabiada. S.-T. III. Mosochíless. - Flores en racimos axilares, paucífloros, de cáliz tubuloso y de corola infundibuliforme; yerbas y frutices tropicales. S.-T. I V. CaSsELÍEAS. 
8. Flores en racimos flojos de cáliz ciatiforme 5-dentado y pequeño, envuelto en otro cáliz mayor, esterior 5-partido, colorido y acrecente; aquenio 2 ó 1-locular, monospermo por aborto. S.-T. V. PÉtReas. - Fruto separable por último en carpelos encerrados en el cáliz persistente ; flores en cabezuelas, en espigas ó racimos, de cáliz campanudo, con la corola hipocrateriforme, tubulosa, cuyo limbo oblícuo es sub-bilabiado ó hendido. T. VI. Euverbéneas. A.

A. Stachytarpha V. - Vejetales anuales sufruticósos, 2. Vejetales perennes casi leñosos ó arbustillos, 3 .

2. Alampiñado y cuyo tallo mas ó menos ramoso se eleva á 2 y hasta $4^{\prime}$ de altura, con hojas ovales, bien aserradas, aguzadas en peciolo, de cara superior verde oscuro, lampiña y lustrosa y algo áspera, mientras la inferior, mas pálida, tiene algunas nervaduras peluditas; flores azules en espigas cilíndricas delgadas, largas de 8 á $10^{\prime \prime}$ y con surcos menos hondos que el diámetro del eje espeso de $2^{\prime \prime \prime}$ por la base ; cáliz largo de 2-3"' , comprimido y bífido, contenido en cavidades correspondientes del eje; acompañado por brácteas oblongo-lanceoladas, aguzado-aristadas y estriadas; corola de tubo bastante largo y arqueado, con el limbo como de $4^{\prime \prime \prime}$ de diámetro. S. Jamaicensis, V.: C. T. V., 492. - Velludo y alto de $1^{\prime}$ á $2^{\prime}$, ramoso y con hojas ovales, ú ovaloblongas, aserradas ó festoneadas, acuñadas por la base y casi sentadas; flores azules en espigas elongadas, cilíndricas, casi sesiles, un poco mas cortas que las del anterior y de vértice arqueado, con los surcos mas estrechos que el eje; brácteas todas herbáceas y membranosas, lanceolado-oblongas, aguzado-aristadas, estriadas é iguales con el cáliz 4-dentado, peludo y comprimido; corola algo mas corta que en la anterior especie. S. strigosa, V.

3. Mata ó arbustillo de tallos dicótomos y como de 3 á 4' de alto, bastante ramosos, lanudoś ó pubescentes y blanquecinos, con hojas ovales, obtusas, aguzadas y aserradas, de base entera que va estrechándose hasta volverse peciolo muy corto, alampiñadas, lanudas ó pubescentes; flores en espigas delgadas, rectas, densífloras, algo lanudas, con brácteas linear-aguzadas, subulado-setáceas, de márjen escariosa inferiormente, iguales al cáliz ó mas cortas que él, cuya lonjitud es de $2^{\prime \prime \prime}$, comprimido con 4 nérvios y 4 dientes. $S$. Cayennensis, V.

B. G. I. Lippia, L. 1. Plantas anuales ó sufruticosas, 2.-Vejetales fruticosos ó arbustillos derechos ó difusos y con glándulas aromáticas, 4 .

2. Yerba desparramada con los pedúnculos cortos, 3. - Planta herbácea $\delta$ sufruticosa y arraigante, pubescente, y con hojas espatuladas, aserradas por el vértice, alampiñadas ; cabezuelas ovoídeas y por fin oblongas; pedúnculos axilares, simples, de ordinario mas largos que las hojas; brácteas óvalo-redonditas acuñadas por la base, mucronadas ú obtusas, un poco mas cortas que la corola blanca; cáliz bífido superiormente y bipartido inferiormente, un poco mas corto que el tubo de la corola. L. nodiflora, Rich.

3. Desparramada y tendida, sin glándulas, pubescente, con hojas romboideo-ovales, bien aserradas, largas de $1^{\prime \prime}$ á $\left.1^{\prime \prime}\right]_{[2}$; pedúnculos 
axilares, fasciculados ó solitarios, casi tan largos como la cabezuela cónico-oblonga y obtusa, ordinariamente mas cortos que el peciolo; brácteas cuneiformes y cuspidadas, cuya arista escede algo la corola pequeña y rosada; cáliz diminuto 2 -dentado, casi 1 -2 de la corola. L. betulifolia, Kth.

4. Hojas orales ú ovalo-oblongas sobre ramas con forma de varita y pelierizadito-pubescentes, aserraditas, ásperas, escabroso-pelierizaditas por la cara superior, mientras que la inferior es ordinariamente peludo-tomentosa, con dientes de ordinario obtusitos; flores en cabezas de $6^{\prime \prime \prime}$ de diámetro, sub-globosas y por último cortamente oblongas, cuyos pedúnculos 1 ó 2 axilares son tan largos como el peciolo ó mas cortos que las hojas, con brácteas ovales, puntiaguditas ó puntiagudas, un poco mas cortas que la corola morada, cáliz pequeño bífido $l_{[} 3$ mas corto que el tubo de la corola, el cual tiene $4^{\prime \prime \prime}$ de largo. L. geminata, Kth. : C. T. V., 244. - Con las dos variedades siguientes : 1 . Hojas puntiagudas largas de 2 á 3"; pedúnculos largos de 6 á $12^{\prime \prime \prime}$ y ordinariamente mucho mas largos que los peciolos; brácteas puntiagudas. L. lockartii. Lantana lockartii, Don. - 2. Hojas obtusas largas de 6 á 12"'; pedúnculos mas largos que los peciolos y largos de 6 á 10"' : brácteas anchas y mucronadas. L. microphylla, Targ. Lantana lippioides, H. A. - Arbusto de 5 á $6^{\prime}$ de alto, estrigoso y con las ramas en forma de varitas y con hojas lanceolado-lineares, aserradas, rugosas ó plegaditas segun sus venas principales, peludo-pubescentes interiormente, con los dientes mucronados y largas de $2^{\prime \prime} 1$ [2 á $1^{\prime \prime}$; flores azuladitas ó rosadas, en capitulos globosos y por fin oblongos y de 4 "' de diámetro, con los pedúnculos largos, axilares y casi iguales á las hojas; cuyas brácteas redondito-mucronadas son mas cortas que la corola larga de $2^{\prime \prime \prime}$; cáliz comprimido, bidentado y mitad mas corto que el tubo de la corola. L. stcchadifolia, Kth. Terbencu strechadifolia, L. Zapania stechadifolia, Pers.

G. II. Lavtana, L. - 1. Celdillas del huesecito apartadas y con una cavidad entre ellas ó intermedia; arbustos de ordinario aguijo nosos, 2. - Celdillas del hueso contiguas: arbustitos inermes, 3 .

2. Arbusto muy ramoso que se eleva como de 6 a $10^{\prime}$ de altura, con hojas ovales ú oral-oblongas, puntiagudas, aserradas, de cara superior pelierizada, mientras la inferior es pubescente o alampiñada, largas de 2 á $4^{\prime \prime}$ y çasi tanto como los pedúnculos, pecioladas; flores amarillas cuyo color se ruelre rojizo, en capitulos un poco achatados y sin invólucro, pero cuyas brácteas lanceoladas son mitad mas cortas que el tubo de la corola, largo de $3^{\prime \prime \prime}$; drupas lustrosas y negras de 3 a $2^{\prime \prime \prime}$ de diámetro. L. camara, L. : C. T. T., 242. - Arbusto que parece mucho al anterior pero algo mas bajito, de hojas ovales, puntiagudas, aserradas, largas de $I^{\prime \prime}$ á $3^{\prime \prime} 1_{[} 2$, pecioladas y de cara superior pelitiesa, mientras la inferior es pubescente ó alampiñada, ordinariamente mas corta que los pedúnculos largos; flores amarillas cuyo color se vuelve por último anaranjado, en cabezas achataditas y sin invólucro, pcro sí con brácteas linear-aguzadas, de ordinario 1 [3 del tubo de la corola, que es larga de 4"; 
drupa lustrosa, negra y de $2^{\prime \prime}$ de diámetro. L. crocea, Jacq. : C. T. V., 243.

3. Capitulos sub-globosos ó achataditos, 4. - Cabezuelas por fin mas largas que anchas, 6 .

4. Cabezuelas sub-globosas con las drupitas de 1 "' de diámetro, 5 . - Capitulos al principio achataditos, con las brácteas del invólucro anchamente óvalo-deltoídeas y mas cortas que el tubo de la corola. largo de 3 á $2^{\prime \prime \prime}$. Hojas ovales obtusitas, festoneadas, pubescentes y ordinariamente mas cortas que los pedúnculos, largas de 1 á $2^{\prime \prime}$ y pecioladas. L. reticulata, Pers.

5. Brácteas esteriores del invólucro anchamente ovales y tan largas como las flores, de color lila, con la garganta de la corola amarilla, mientras las interiores óvalo-redonditas son $1[2$ del tubo de la corola, el cual tiene 1 l 2 á $2^{\prime \prime \prime}$ de largo. Hojas pequeñas ovales, obtusas, festoneadas, pubescentes, tan largas ó mas cortas que los pedúnculos y que tienen solamente $12^{\prime \prime \prime}$ á $6^{\prime \prime \prime}$ y hasta $3^{\prime \prime \prime}$ de largo. L. involucrata, L. : C. T. V., 242. - Brácteas esteriores del invólucro óvalo-lanceoladas, tan largas como las flores, de color lila pálido, mientras las interiores aovadas son la mitad del tubo de la corola, el cual es largo do $2^{\prime \prime \prime}$. L. odorata, L. L. recta, Ait. L. peduncularis, Anders.

6. Hojas mas ó menos ovales ó aovadas, 7. - Hojas elípticas ó eliptical-oblongas, puntiagudas, de base acuñada y aguzada, festoneadas, de cara inferior pelierizadita ó peludo-pubescente, frecuentemente verticiladas, tan ú ordinariamente mas largas que los pedúnculos y de 5 á $2^{\prime \prime}$ de largo; cabezas ovoídeo-globosas y por fin oblongas, sin invólucro, pero sí con brácteas subuladas mas cortas que el tubo de la corola rosada, teñida de lila ó blanca, con las fauces amarillas ó iguales con él; drupa de $1^{\prime \prime \prime} 1[2$ de diámetro. L. trifoliata, L. L. annua, L.

7. Hojas ovales ú oval-redonditas, obtusas, redondeadas por arriba de la base acuñada, festoneadas, peludas inferiormente, largas como los pedúnculos ó mas cortas que ellos, largas de 1 á $2^{\prime \prime}$; capitulos sub-globosos, y por último cortamente oblongas, sin invólucro y cuyas brácteas aovadas ó aovado-redonditas, mucronadas ó cuspidadas son mas cortas que el tubo de la corola rosada ó raras veces blanca y larga de $2^{\prime \prime}$. L. radula, Sw.

C. Citarexylum, L. - 1. Flores subsesiles, 2. - Flores cuyos pedícelos son mas largos ó tanto como las brácteas. 3 .

2. Árbol de 20 á $60^{\prime}$ de altura, muy ramoso, de tronco bastante recto, cuya epidermis espesa se desprende en lacinias, color ceniciento, de ramitas siempre con 4 caras, cuyas hojas apergaminadas y por fin tiesas, lustrosas, eliptical-oblongas ó elípticas, ordinariamente obtusitas, de cara inferior lampiña ó alampiñada, con las venas por fin formando redecilla por ambas caras, son largas de 7 á 2 ", con el peciolo corto y color amarillo-rojizo; flores blancas en espigas racemosas, elongadas, flojas y colgantes, ordinariamente largas de 6 á $12^{\prime \prime}$, de cáliz subsentado o cortamente pedicelado, largo de 1 ", sub-trunco y de la mitad del tubo de la corola sostenido por pedícelos mas cortos que las brácteas, de cuyas axilàs salen; estambres 
fërtiles 4, drupa globosa, pisiforme y negra. C. quadrangulare, Jacq.: C. T. V., 325. - Arbol que se elevaá 15 ó $20^{\prime}$ de altura y cuyas ramitas tetrágonas se vuelven por último estriado-cilíndricas, con hojas apergaminadas y por fin tiesas, eliptical-oblongas, lanceoladooblongas ó elípticas, ordinariamente obtusas, de cara inferior lampiña ó alampiñada, largas de 6 á $2^{\prime \prime}$, y cuya redecilla formada por' las venas se vuelve por fin bastante proeminente por ambas caras; flores blancas en racimos espigados elongados y tlojos, de ordinario largos de $6^{\prime \prime}$ á $10^{\prime \prime}$; de cáliz subsesil, largo de 1 " $1_{[2} 2$, cuyo vértice es desigualmente lobado y mitad del tubo de la corola; estambres fértiles 4 y á veces 5 ; drupa sub-globosa, al principio roja y por último negra. C. cinereum, L.

3. Arbusto de 10 á $12^{\prime}$ de altura, cuyas ramitas apenas tetrágonas y mas luego estriado-cilíndricas, llevan hojas apergaminosas, por último coriáceas, eliptical-oblongas, obtusitas, lampiñas, de cara superior pálida y lustrosa, mientras la inferior tiene sus nervaduras arqueadas, largas de 8 á $5^{\prime \prime}$ y pecioladas; racimos frecuenternente compuestos por la base, tiesos y erguidos, largos de 8 á $4^{\prime \prime}$, cuyos pedícelos aproximados y estendidos son mas cortos que el cáliz campanudo, sub-trunco, largo de $1^{\prime \prime} 1[2$ y 1 [2 á $2[3$ mas corto que el tubo de la corola; estambres 4 , drupa oroídeo-oblonga, negra y larga de $4^{\prime \prime \prime}$. C. caudatum, L.

D. Clenodendron aculeatum, Gr. - Volkameria aculenta, L. - Cl. fragrans, W. - Volk, japonica, Jacq.

E. Aviceníeas. - Avicennia, L. - Arbolito muy ramoso que se eleva á como 16 ó $25^{\prime}$ de altura, de hojas ovales, algo acorazonadas por la base, enteras, pecioladas, apergaminado-tiesas, de cara superior blanca y lustrosa, mientras la inferior es tomentosa. Flores blancas en especies de racimos axilares, cuya corola tiene los lóbulos estendidos, lampiñas superiormente y sedosas esteriormente; estigmas subsesiles. A. tomentosa, Jacq.: C. T. V., 112.-A Arbol algo mas bajito que el anterior, con muchas ramas largas, rectas y en forma de varita, delgadas, blancas y que llevan hojas lanceoladas o lanceolado-elípticas, aguzadas ú obtusitas, lustrosas y lampiñas por ambas caras, cuya inferior es blanquecina. Flores de corola pubescente por ambos lados y cuyos lóbulos están doblados hácia afuera; estambres esertos iguales, con el estilo. A. nitida, Jacq. :

Familia 76. - LABIADAS', LABIATAS ó LAMIACEAS. - Plántas herbáceas anuales ó perennes, sofruticosas ó frutices y raras veces arbustos de tallos y ramos de ordinario tetrágonos, hojas simples, enteras, festoneadas, dentadas o lobadas, pubescentes ó velludas, mas rara vez lampiñas ó alampiñadas, pecioladas, opuestas ó verticiladas. Flores siempre hermafroditas en grupos axilares, tan furnidas que simulan vertícilos lejítimos y cuya reunion forma espigas simples ó apanojadas mas ó menos flojas, mas ó menos largas y terminales, con brácteas y hojas florales, mas ó menos coloridas, formadas de un cáliz tubuloso, monosépalo, persistente, ordinariamente bilabiado y con 4-5 divisiones ó dientes, que á veces son punzantes, casi siempre estriado; corola monopétala irregular, de ordinario bilabiada, cuyo labio superior, muchas veces con figura 
de yelmo, tiene los estambres escondidos, los cuales insertos en su garganta son 4 y didínamos, y algunas raras veces 2 solamente, por causa del aborto de las demas, pistilo único con un ovario 4-lobo ó 4 ovarios distintos sentados sobre un disco hipójino, uniloculares y monospermos, estilo ginobásico único, largo, filiforme y terminado por un estigma bífido. El fruto consiste en un tetraquenio ó 4 aquenios contenidos en el fondo del cáliz acresciente bastantes veces $J$ ocultados por él, con una semilla recta ordinariamente sin endospermo.

\section{Análisis dicotómica de las tribus y de las sub-tribus establecidas en esta familia.}

1. Estambres 4, y rarísimas veces dos, 2. - Estambres 2, siempre rectos y ascendientes, con las celdillas de las anteras oblongolineares, solitarias o separadas por un conectivo mas ó menos largo, filiforme y estrecho, rarísimas veces aproximadas; cáliz de divisiones iguales, cuyas superiores están mas ó menos reunidas y ordinariamente bilabiado; corola siempre bilabiada. T. I. Moná rdeas. A.

2. Siempre 4 estambres, $3 .-4$ ó á veces dos estambres distantes, rectos, divaricados ó conniventes por debajo del labio superior', con anteras biloculares de conectivo filiforme; lóbulos de la corola planos y abiertos; cáliz con estrias paralelas en número igual ó doble de sus dientes, ó 13 reunidas por pares. T. II. Menthoídeas, 7.

3. Ascendentes ó divaricados, 4. - Siempre los inferiores mas largos y declinados ó inclinarlos en el lóbulo inferior de la corola, 10 .

4. Cuyos posteriores mas largos son ascendentes ó diverjentes; caliz igual ú oblícuo, con 15 estrias paralelas y lonjitudinales ó subbilabiado; corola inclusa ó eserta y cuyas fauces son ordinariamente ensanchadas con el labio superior abovedado y el inferior abierto. T. III. Nepéteas. - Ascendientes y paralelas, 5.

5. Corola cuyo labio superior es con forma de yelmo, 6.-Corola sin labio superior ó que no es nunca con figura de yelmo y cortísimo, mientras el inferior es elongado; algunas veces la corola es subjgual. Estambres inferiores mas largos; raramente los estambres son paralelamente ascendientes $\mathrm{y}$ ordinariamente esertos; estilo decíduo. T. IV. Ajtgoídeas. D.

6. Estambres mas largos, ascendientes paralelamente por debajo del yelmo, que es ordinariamente cóncavo; lábio superior de la corola mas frecuentemente cóncavo ó en forma de nave; aquenios lisos tuberculados, rectos y libres desde la base T. V. Estaquídeas, 13. - Cáliz sub-igual, corola bilabiada, estambres ascendientes paralelamente por debajo del yelmo, cuyos inferiores son mas largos; nuececitas carnosas ó sub-abayadas, ordinariamente sub-conadas por la base ú oblícuamente pegadas. T. VI. PrasíEAs.

7. Corola siempre mas ó menos bilabiada, 8. - Corola no bilabiada, pero sub-igual, con los estambres distantes y no connirentes. S.-T. I. Mentheas. - Mentha rubra, L. : C. T. V., 25I-293.

8 Siempre con 4 estambres, 9.-Con 2 ó 4 estambres ascendien- 
tes por la base, mientras que el vértice es diverjente, ó conniventes $y$ ascendentes paralelamente por debajo dellabio superior de la corola arqueado, cuyo tubo está desnudo por adentro; anteras biloculares. S.-T. II. Melíseas.

9. Celdillas de las anteras confluyentes, despues de la fecundacion óvalo-arriñonadas ú orbiculares. S.-T. III. Pogostómeas. - Pogostomea pachuli. - Labios de la corola á veces oscuros ó muy poco pronunciados, con el tubo desnudo por adentro; estambres distantes. y diverjentes ó divaricarlos, no conniventes, de anteras biloculares. S.-T. IV. ThYMeas. B.

10. De cáliz las mas veces posterior, la corola estando mas tirada por delante, con el diente superior mas largo que los demás; corola tambien inclinada por delante ó declinada; anteras tiernas subbiloculares y despues de la fundacion uniloculares por haberse vuelto confluyentes las celdillas y entónces óvalo-arriñonadas ú orbicularmente abiertas. T. VII. OcImoÍdeas, 11.

11. Corola bien bilabiada, cuyo labio superior es bífido, mientras que el inferior es trífido, con la lacinia mas inferior contraida por la base, y por fin de repente inclinada hácia abajo. S.-T. I. HipıríDEas ó Lavandúleas C. - Curola mas ó menos labiada, 12.

12. Corola con la lacinia inferior elongada y cóncava. S.-T. II. Plectranteas. - Lacinias de la corola sub-iguales, cuyas superiores son mas ó menos conadas en labio, mientras la inferior mas angosta y declinada, es plana ó lijeramente cóncava. S.-T. III. MosCHÓSMEAS.

13. Cáliz siempre manifiestamente bilabiado y nunca hinchado, cuyos labios se quedan cerrados sobre el fruto. S.-T. I. EscuteláRIEAs. Scutellaria purpuranscens, Sw. : C. T. V., 140 -Cáliz no brlabiado ó rarísimas veces bilabiado, 14 .

14. Nunca bilabiado, con 2 ó con 4 lóbulos, cálices fructíferos hinchados. S.-T. II. Melíteas. - Rarísimas reces manifiestamente bilabiado, pero ordinariamente tubuloso, campanudo á infundibuliforme, con 5 ó 10 dientes iguales ú oblícuos. S.-T. III. Lameas.-Leueas Martinicensis, R. Br. C. T. V., 138-254-Leovitis nepetcefolia, R. Br.: C. T. V., 139.

A. Monárdeas. - Salvia, L. 1. Vertícilos florales mas ó menos distantes, 2. - Vertícilos florales aproximados; corolas cortamente esertas. Planta anual, alta de $1^{\prime}$ á $2^{\prime \prime}$, recta, tiesa y pubescente, con hojas ovales, puntiagudas, aserradas, largamente pecioladas y largas de 2 á $4^{\prime \prime}$, cuyas flores ovales son algo mas largas que los pedícelos; flores azules en espigas, cuyos vertícilos son poco furnidos, de cáliz campanudo, velludo, pubescente, con el labio superior oral y puntiagudo, mientras el inferior es bidentarlo, óvalo-lanceolado y aguzado, corola cortamente eserta, lampiña, conteniendo los estambres inclusos y largos de 4 á $5^{\prime \prime \prime}$. S'. hispanica, L.

2. Corola pequeña, vertícilos distantes, 3. - Corola superiormente como de $12^{2}$ " de largo, vertícilos por último distantes, 4 .

3. Yerba anual, difusa de hojas ovales puntiagudas por el vértice y acuñadas por la base, aserradas, alampiñadas ó á veces con pelo esparcido y largas de $1^{\prime \prime} l_{[} 2$ á l", cuyas florales son subuladas; flores 
azules, cuyos vertícilos de 2 á 6 flores son arracimados, de cáliz glanduloso, mitad mas corto que la corola y largo de $3^{\prime \prime \prime}$, con el labio superior entero y obtuso, mientras el inferior es bipartido, con los segmentos deltoídeos, obtusitos ó mucronados. S. occidentalis, Sw. - S. obscura, Bth. C. T. V., 252. - Planta sub-fruticosa muy ramosa, alta de' 2 á $3^{\prime}$, un poco peluda y con hojas deltoídeas, obtusas, truncas ó sub-acorazonadas por la base, festoneadas, lijeramente pubescentes y largas de 12 á $6^{\prime \prime \prime}$, cuyas florales mas pequeñas son lanceoladas: vertícilos de 2 á 6 flores arracimadas, cáliz glanduloso de labio superior entero, conforme al inferior que tiene 2 dientes deltoídeos y que pasa un poco mas allá de la mitad de la corola azul ó blanca $\dot{y}$ larga de $3^{\prime \prime \prime}$. S. serotina, L. - S. dominica, Sw. C. T. V., 253.

4. Planta herbácea, recta, poco ramosa, de hojas acorazonadoovales ú aovadas, festoneadas, largas de 1 á $2^{\prime \prime}$, á reces con la cara inferior peludo-pubescente, cuyas florales decíduas son óvalo-lanceoladas; flores color grana, dispuestas en vertícilos distantes y con 6 á 10 flores, de cáliz pubescentito con 3 dientes óvalo-deltoídeos, corola pubescentita 2 ó 3 veces mas larga que el cáliz, con los estambres esertos y largos de 8 á 10"'. S. coccinea, L. - Planta subfruticosa derecha, ramosa, lijeramente pubescente, $y$ con hojas ovales, puntiagudas, aserradas, alampiñadas y largas de 5 á $4^{\prime \prime \prime}$, cuyas florales decíduas son óvalo-subuladas ; flores azules en rertícilos arracimados 6-10 floros, de cáliz alampiñado entre las estrias pubescentitas, con 3 dientes conformes y subulados, como dos reces mas corto que la corola larga de $10^{\prime \prime \prime}$ y conteniendo los estambres inclusos. S. Taurifolia, Jacq.

Rosmarines officinalis, L. :

B. Micromeria, Berth. - Arbustillo difuso muy ramoso, alto de 1 á $10^{\prime}$, tuberculado-pubescente, de hojas pequeñas, largas solamente de 3 á $5^{\prime \prime \prime}$, obovales ú orales redondeaditas, con la márjen arrollada, enteras y de cara inferior peluda. Flores blancas 2-4 por vertícilo, de cáliz sub-dentado, con los dientes cortos, subuladolanceolados y obtusitos; corola de $3^{\prime \prime \prime}$ y mitad mas larga que el cáliz, con los estambres inclusos y cuyas celdas son paralelas; estilo eserto. M. obovata, Benth. : C. T. V., 245. - Planta herbácea delicada é inclinada, lampiña ó alampiñada, con hojas deltoídeo-redonditas, con algunos dientes obtusos, aserrados, y cuyo peciolo mas ó menos largo es pestañoso; flores purpúreo-blanquecinas, dos por vertícilo, sin brácteas y de cáliz pedicelado, peludo por los fauces, con los dientes deltoídeo-obtusitos y dos veces mas cortos que la corola larga de 4 á $5^{\prime \prime \prime}$, con las anteras de celdillas paralelas inclusas. $M$. Brownei, Benth.

C. G. I. Hyptis, Jacq. - 1. Flores en capitulos ó cahezuelas, 2. Flores cuyos vertícilos están dispuestos en espigas ó en cimas concontraidas, 4 .

2. Sesiles y capitulos axilares, 3 . - Sesiles y cabezuelas dispuestas en racimos; planta herbácea fuerte, alta de 2 á 3 ', no muy ramosa, derecha, alampiñada, con hojas ovales, puntiagudas, desigualmente aserradas, pecioladas y largas de 1 á $3^{\prime \prime}$; capitulos 
ordinariamente paucífloros y dispuestos en racimos simples ó compuestos, interrumpidos de cáliz igual, trunco y con el tubo cilíndrico y ventrudo por la base, cuyos dientes cortamente setáceos y erguidos son mucho mas cortos que el tubo, corola eserta. H. spicata, Poir. : C. T. V., 137.

3. Frutice ramoso, alto de 2 á $\boldsymbol{7}^{\prime}$, delgado, alampiñado y con pocas ramas larguitas y estendidas que llevan hojas ovaloblongas, puntiagudas, igual y densamente aserradas, largas de 2-5", cuyas florales oblongo-lineares y por último reflejas son mas cortas que los capitulos glohosos, axilares y mas cortos que sus pedúnculos largos de $2^{\prime \prime}-1^{\prime \prime}$; cáliz igual con dientes subulado-setáceos, erguidos y por fin $1_{[} 3$ del tubo; cabezas fructíferas, anchas de 10 á $12^{\prime \prime \prime} H$. capitata, Jacq.: C. T. V., 248. - Planta herbácea cuyo tallo procumbente ó ascendente echa raices por la luase y es peludo por el vértice, bastante ramosa, alta de $1^{\prime}$ á $2^{\prime} 1 l^{2}$, algo teñida de rojizo y con hojas pecioladas, cortamente ovaloblongas ú ovales, obtusamente aserradas y largas de $1^{\prime \prime}$, cuyas florales ovales aplicadas á las cabezas y casi tan largas como ellas, las cuales son globoso-hemisféricas tan largas como sus pedícelos ó mitad mas cortas que ellos y tienen 4-6"" de diámetro, de cáliz igual, trunco y con los dientes setáceos, erguidos, pelierizaditos y por último mas cortos que el tubo. $H$. atrorubens, Poit.

4. Flores sesiles en espigas verticiladas ó formadas de verticilos, 5 - Verticilos en cimas contraidas, subsesiles ó pedicelados, 6.

5. Planta herbácea fuerte, de tallo bastante grueso inferiormente, algo ramoso y que se eleva á $6^{\prime}$ ó $3^{\prime}$ de altura, muy pelierizada, con hojas pecioladas, óvalo-lanceoladas, aguzadas, aserradas y cuyas florales son lineares; espigas cilíndricas, terminales y largas de $3^{\prime \prime}$ á $1^{\prime \prime}$, con frecuencia como apanojadas, de flores blancas cuyo cáliz igual tiene los dientes subulados y mas cortos que su tubo. H. spicigera, Lam.: C. T. V., 137.

6. Hojas mas ó menos pecioladas, simplemente festoneado-aserradas ó aserradas, 7.- Hojas largamente pecioladas, dos veces aserradas ó sub-sinuosas; planta fuerte peluda, alta de $3^{\prime}$ á $5^{\prime}$, ramosa $\mathbf{y}$ con hojas ovales, las inferiores siendo acorazonadas y cuyas florales son diminutas $\mathrm{y}$ setáceas; capitulos formados de pocas flores 5 á 2 azuladitas y axilares, de cáliz subsesil ó muy cortamente pedicelado y largo por fin de 5 á $2^{\prime \prime \prime}$, con 10 estrias y cuyos dientes subulado-setáceos, tiesos, y abierto-erguidos son por último mas cortos que su tubo, corola cortamente eserta. H. suaveolens, Poit.: C. T. V., 249.

7. Planta herbácea cuya parte inferior del tallo delgado es sufruticosa, con frecuencia tendida en el suelo y de vértice ascendente, mas ó menos ramosa, alta de $2^{\prime}$ ó sostenida por las malezas alcanza hasta 4 y $5^{\prime}$, pubescentita ó alampiñada y blancuzca, con hojas pecioladas ovales, desigualmente festoneado-aserradas ó á veces solamente aserradas, de cara inferior peludo-pubescente ó alampiñada, cuyas florales son setáceas ; flores blancas y pintaditas unilaterales y dispuestas en cimas contraidas, cortas espirales y recorvadas, racimosas ó apanojadas y cuyo diámetro es $2-4^{\prime \prime \prime}$, de cáliz cortamente 
pedicelado, con 10 estrias y sub-igual, que tiene el tubo cortamente campanudo y densamente velludo por la boca trunca y cuyos dientes setáceos y sub-erguidos son mas cortos que el tubo largo de $1^{\prime \prime \prime}$ solamente. H. pectinata, Poit. C. T. V., 250. - Mata bisanual de tallo en forma de varita, con ramos apanojados, que se eleva á $6^{\prime}$ ó $\mathrm{l}^{\prime}$ de altura, ordinariamente alampiñada y de hojas cortamente pecioladas, oblongo-lanceoladas, ó lanceoladas, aserradas, cuyas florales son setáceas ó abortadas. Flores pequeñas blanquecinas en verticilos sesiles dispuestos en racimos interrumpidos y cuyo inferior es axilar, de cáliz igual y pedicelado con tubo cortamente campanudo y glabro, y cuyos dientes óvalo-lanceolados y erguidos son mas cortos que el tubo. H. verticillata, Jacq.: C. T. V., 247-223.

G. II. OcInum, L. 1. De estambres cuyos filamentos superiores son apendiculados ó llevan un diente por la base, 2. - De estambres cuyos filamentos no llevan diente alguno, 3.

2. Planta herbácea, derecha, ramosa, como leñosa por la base, alta de $1^{\prime}$ á $1^{\prime} 1$ [2, pubescente y con hojas pecioladas, ovales, aguzadas por ambos estremos, denticuladas ó enteras, de cara inferior blanquecina y con los peciolos pestañosos; flores en espigas terminales formadas de muchos verticilos aproximados, cuyo cáliz pequeño y algo cilíndrico es mitad mas corto ó tan largo como la corola. O. americanum, L. C. T. V., 246.

3. Planta muy lampiña, erguida, de tallo simple ó muy poco ramoso y alta de $8^{\prime \prime}$ á $1^{\prime}$, con hojas pecioladas, anchamente ovales, puntiagudas, gruesamente aserradas y de base cuneiforme, cuyas florales son sesiles, decíduas y mas cortas que los cálices; fiores en racimos sencillos, con cálices fructíferos ovales, recorvados, muy lampiños, cuyo diente superior oval, obtuso y cóncavo alcanza la mitad de los laterales mucronados, algo mas cortos y parecen alas, mientras los inferiores son ovales y casi tan largos todos como la corola. O. sellovii, Benth. - Planta herbácea anual de tallo derecho, ramoso, alto de $1^{\prime}$ á $l^{\prime} l_{[} 2$, alampiñada, con hojas pecioladas, ovales, puntiagudas, aserraditas, de base cuneiforme ó redondita, alampiñadas, cuyas florales son bracteiformes y decíduas; flores cuyo cáliz fructífero recorvado es oblongo y ensanchadito en derredor de los frutos, con el diente superior obtuso, cóncavo y decurrente hasta la base del tubo, mientras los 4 inferiores óvalo-lanceolados son subulados, y de ellos 2 son laterales muy aguzados y simulan como alas; corola inclusa. O. micranthum, IV.

D. Teucrium, L. Planta herbácea cuyo tallo simple, derecho, se eleva á $1^{\prime}-1^{\prime} l_{[} 2$ de altura, lampiña y con hojas cuneiformes elípticas, pinatífido-aserradas, de lóbulos ó dientes oblongos y obtusos; vertícilos bífloros y axilares; pedícelos de las flores dos veces mas largos que el cáliz profundamente 5-fido; corola azulito-blanquecina casi dos reces tan larga como el cáliz. T. cubense, L.: C. T. V., 136. - Yerba velluda y pubescerte ó alampiñada, cuyo tallo derecho y ramoso se eleva como á 2-3' de altura, con hojas pecioladas ovales, ú óvalo-lanceoladas, fuertemente aserradas; verticilos aproximados y formando una espiga delgada; flores de cáliz subsesil, ventrudo, oblícuo, desigualmente כ̆-dentado por su vértice contraido y cuyo 
diente superior es mas ancho; corola dos veces tan larga como el cáliz. T. inflatum, Sw.

Familia 77. - PLANTAJINEAS. - Plantas herbáceas anuales ó vivaces, de hojas simples, basinervias, pecioladas, radicales y ordinariamente dispuestas á manera de roseta; de flores hermafroditas de ordinario, ó á veces monoicas que son muy pequeñas y salen de la axila de una bráctea, mas ó menos desarrollada y escariosa. dispuestas en espigas simples, cilíndricas, largas ó globosas y terminales en el vértice de un pedúnculo axilar mas ó menos largo y simulando un bohordo; se componen de un periantio doble y persistente, cuyo esterior 4-partido reemplaza al cáliz lejítimo, mientras que el interior tubuloso, escarioso y 4-fido hace papel de corola y lleva 4 estambres pegados en su tubo, alternos con sus divisiones $\mathrm{y}$ de filamentos largos, derechos y esertos. Pistilo único formado de un ovario libre superior 1-2 ó 4-locular polispermo, cuyo vértice lleva un estilo simple terminado por un estigma simple ó á veces bífido $y$ provisto de pelos colectores. Fruto capsular ordinariamente ó un pixidio, con 2 ó 4 celdillas conteniendo pocas ó muchas semillas pequeñas, pegadas en una placenta axil; otras raras veces consiste el fruto en una cápsula dehiscente monosperma; embrion cilíndrico, escéntrico y homótropo contenido en un endospermo carnoso. Plantago major, L. Var. - P. m. tropica, C. T. V., 73.

\section{CLASE XXXV. - PRIMULÍNEAS.}

Familia 78. - PLUMBAJÍNEAS. - Plantas herbáceas ó fruticosas y algunas veces arbustos sarmentosos; de hojas simples, enteras, lanceoladas, cortamente pecioladas, alternas, á veces envainadoras por la base y agrupadas en el pié del tallo, cuyas flores hermafroditas están en espigas simples mas o menos globosas, situadas en el ápice de un bohordo ó de un pedúnculo mas ó menos largo que lo simula, otras veces en racimos ó en panojas terminales. y constan de un cáliz tubuloso 5-dentado, provisto de glándulas estipitadas y 5-estriado, otras veces escarioso y entero, de una corola asalvillada, 5-partida, la cual suele faltar á veces y está reemplazada por apéndices petaloídeos ordinariamente distintos; estambres 5 , hipójinos, provistos por arriba de su base de un apéndice dorsal petaloídeo, ó ceñidos por los lóbulos opuestos de la corola que se inserta con ellos sobre un disco; pistilo único formado de un ovario simple unilocular con un solo óvulo, colgando de un funículo central, curo ápice lleva un estilo simple ó 5 -partido, con un estigma subulado. El fruto es una cápsula monosperma envuelta por el cáliz cuya semilla contiene un endospermo cal'noso en cuyo centro estí alojado un embrion axil.

Tribu 1a. Estatíceas. Cáliz escarioso ó coriáceo, corola formada de 5 pétalos ó apéndices petaloídeos estaminíferos; estilos subdistintos; pericarpio membranáceo indehiscente $y$ ruptible por el vértice circularmente. Statice Bahamensis, Gr. - T. 2. EuruumBAJÍNEAS. Cáliz herbáceo; corola monopétala que carga con los estambres: estilos soldados entre sí por la hase : pericarpio capsular. 
Plumbago, L. Arbusto sarmentoso cuyas ramas delgadas, largas de algunas varas y lampiñas llevan hojas ovales ú oblongo-lanceoladas, aguzadas ó puntiagudas, y cuya base se vuelve peciolo muy corto, pero sin orejitas; flores blancas en racimos cuyo tubo lleva glándulas sobre sus ángulos convexos; con brácteas oblongas aguzadas, cuya inferior es algo mas larguita, pero todas mas cortas que el cáliz cilíndrico y cónico á la par por la base, la mitad mas corto que el tubo filiforme de la corola, largo de 8 á 10" y cuya corola tiene los lóbulos mucronados. P. scandens, L.: C. T. V., 38. - Flores azules en racimos apanojados; vejetal fruticoso mucho mas pequeño que el anterior, con muchos ramos divaricados y nunca, sarmentosos, lampiños, de hojas ovales, oblongas, algo romboídeas, aguzadas por ambos estremos y de base que se continúa con el peciolo casi alado $y$ orejado ; flores con brácteas glandulosas, ovales aguzadas y curas laterales son menores, las esteriores tres veces mas largas y la inferior tres veces mas corta que el cáliz 5fido, con la base trunca $y$ cuyos dientes son lanceolados, lampiño inferiormente y glanduloso superiormente; los cálices fructíferos son tubulosos, cónicos, endurecidos "y apenas asurcados; tubo de la corola la mitad mas largo que el cáliz y dilatado hácia el vértice : las lacinias del limbo ovales y aguzadas $P$. corulea, Kth.

Familia 79. - MIRSINEAS. MIRCINACEAS. - Arbustos ó árboles de hojas alternas rarísimas veces opuestas, ó ternadas, enteras ó dentadas, mas ó menos grandes; flores ordinariamente hermafroditas, pero algunas veces unisexuales y dispuestas en racimos, en cimas ó simplemente en grupos tan pronto axilares como terminales; se componen de un cáliz persistente, con 4 ó 5 lacinias, de una corola monopétala regular, con 4 ó 5 divisiones profundas, en cuya base están insertos otros tantos estambres que les son opuestos y cuyos filamentos cortos sostienen anteras asaetadas; pistilo formado de un ovario libre unilocular, con algunos óvulos pegados en una placenta central, en la cual están mas ó menos profundamente anidados y cuyo vértice lleva un estilo sencillo que se termina por un estigma que suele ser bílobo. El fruto es una drupa seca, ordinariamente globosa y pequeña; otras veces consíste en una baya con 1 hasta 4 semillas abroquelaclas, de hilo cóncavo $y$ cuyo tegumento simple cubre un endospermo carnoso ó córneo, en el cual se aloja un embrion cilíndrico algo encorvado y transversal al hilo.

Sub-órden 1a. Meseas. Corola monopétala; ovario adherido al cáliz é ínfero, con huevecillos en número indefinido y anidados en los alvéolos de la placenta central, nunca cubiertos por encima, y rolviéndose semillas apeonado-angulosas y aplanadas, cuyo embrion no transverso respecto al fruto es cilindráceo, con la comisura de los cotiledones dirijida al flilo. Massea. - Sub-órden 2 y tribu lá á la vez Eumirsíneas. Corola poli ó monopétala, ovario súpero con óvulos solitarios ó en número indefinido en los alvéolos profundos del trofospermo central, $y$ al fin mas ó menos cubiertos por membranas procedentes de los alvéolos ; semilla única revestida de membranas placentarias resiníferas, casi globosa, comunmente escavada en la base. con embrion transverso respecto al fruto, linear $y$ frecuente- 
mente arqueado, con la comisura de sus cotiledones dirijida á los lados re la semilla. - Myrsine floribunda, R. Br.

Tribu 2. Eniberíens. Corola polipétala; huevecillos pocos ó uno solo; semilla vestida. - Embelia. - Tribu 3. Ardisieas. Corola monopétala; óvulos pocos ó muchos y en número indefinido; semilla restida. - Avdisia caribcea, Miq. - A. cubana, A. Dc.

Familia 80. - TEOFRASTEAS. - Árboles pequeños, arbustos ó frutices, nunca jamas lechosos, pero á veces algo resinosos, con hojas simples opuestas ó sub-verticiladas, coriáceas y sin estípulas. Inflorescencia indefinida y racimosa, cuyas flores las mas veces hermafroditas, carnosas y cartilajinosas á la vez, son ordinariamente de color anaranjado, pero sin embargo tan pronto blancas como rosadas y constan de un cáliz 5-partido ó 5-fido, cuyos lóbulos son pestañosos y de estivacion quincuncial; corola monopétala campaniforme 5-fida ó de limbo 5-lobo, de igual estivacion que el cáliz; con 5 apéndices alternos con sus lóbulos é insertos en la base $o ́$ en el ápice de su tubo, de estiracion distinta, otras veces hay otros tantos menores que están opuestos á los lóbulos de la corola; estambres fértiles 5, pegados en la base de la corola y opuestos á los lóbulos; de filamentos ligulados ordinariamente libres ó raras veces reunidos, con anteras erguidas, lanceoledas $\mathrm{y}$ biloculares, cuyas celdas están reunidas por un conectivo que se dilata por encima de ellas en un apéndice trunco y mucronadito, estrorsas y lonjitudinalmente dehiscentes. Ovario libre unilocular, de placenta central ovoídea, globosa y cortísimamente estipitada, mas rara vez no hay placenta, polispermo y de cuyo ápice sale un estilo único terminado por un estigma cabezudo oscuramente 2 ó 5-lobulado. Fruto globoso, crustáceo ó cartilajinoso, seco ó carnosito, indehiscente ó reventándose irregularmente despues de seco, con semillas elipsoídeas, las mas veces lateralmente sub-comprimidas y cubiertas por la pulpa placentaria, que algunas veces se ha vuelto membranosa; ombligo lateral, central ó situado hácia la base, redondo $J$ elongado: endospermo copioso con el embrion casi escéntrico ó central, tan largo como la semilla, casi paralelo con la placenta y reeto; de raicilla ínfera mirando al estremo inferior, un poco cóncava, no perforada y cilíndrica; cotiledones aplicados el uno al otro por la cara. ovales ú oval-agudos, foliáceos y mas cortos que la raicilla.

Tribu 1a. Clavíseas ó Téofrásteas. - Frutos no pequeños, cuyas semillas están cubièrtas de una membrana placentaria coriácea y comun; comisura de los cotiledones opuesta á la semilla lateral.Theophrasta Jussiei, Lind. C. T. V., 208. - T. 2. JaquiníEas. Frutos pequeños con las semillas anidadas ó alojadas en una placenta mucilajinosa y casi cubiertas por ella; comisura de los cotiledones mirando al hilo.

JAQUinia, L. 1. Hojas anguloso-espinosas, 2. - Hojas nunca anguloso-espinosas, mucronadas ú obtusas por el vértice, 3 .

2. Arbusto muy ramoso que se eleva á 3 ú $8^{\prime}$ de altura, de hojas verticiladas, lanceoladas y cortamente pecioladas y de márjen un poco arrollada; flores solitarias en el ápice de las ramitas ó en um- 
belas poco furnidas, cuyos pedícelos, como 4 veces mas cortos que las hojas, son inclinados ó colgantes. J. ruscifolia, Jacq.

3. Hojas aproximadas ó sub-verticiladas y provistas de puntitos transparentes, 4. - Hojas esparcidas ó sub-verticiladas, sin puntitos transparentes, lampiñas, cuyo vértice aguzado se termina en una arista ó espinita, mientras la base contraida es sub-sentada y de márjen arrollada y largas de $2 " 1_{[} 2$ á $1^{\prime \prime} 1_{[} 2$ sobre $6^{\prime \prime \prime}$ á $10^{\prime \prime \prime}$ de ancho; arbusto de ramos cilíndricos y lampiños, cuyas flores de color anaranjado están dispuestas en racimos terminales, flojos, lijeramente pubescentes; de pedícelos casi 4 veces mas cortos que las hojas sosteniendo 3 flores erguidas un poco mas largas que ellos, de corola cuyo tubo campanudo y largo de 3 "' escede un poco al cáliz. - J. aristata, Jacq. - J. umbellatn, A. Dc.-J. aurantiaca, Ait. - .J. Caracasana, Ktl.

4. Ramitas verticiladas un poco mas gruesas ó crecidas hácia la insercion de las hojas, 5 . - Ramitas cilíndricas no verticiladas ni crecidas tampoco hácia la insercion de las hojas; árbol que se eleva hasta $30^{\prime}$ de altura, pero á veces se queda arbusto ó arbolillo, con hojas obovales ó espatuladas y provistas de muchas glandulitas transparentes, cuya cara inferior es mas ó menos venosa; flores en racimos terminales formados de grupos tan largos como las hojas y con brácteas ovales agudas y diminutas. J. arborea, V.C. T. V., 856.

5. Arbusto bajito, ramoso y lampiño, con hojas acuñado-espatuladas ú obovales, lampiñas, coriáceas, de márjen arrollada y con glandulitas, subsesiles, obtusas ó mucronadas y largas de 4" 1 [2 á 1"! 1 [2 sobre 1" 1 $2-6^{\prime \prime \prime}$ de ancho; flores blancas en racimos terminales flojos tan largos como las hojas, cuyo tubo de la corola infundibuliforme es dos veces mas largo que el cáliz y de $3^{\prime \prime \prime}$; baya pisiforme anaranjada. J. arimillaris, Jacq. C. T. V., 856.

\section{CLASE XXXVI. - ERICOIDDEAS.}

Familia 81.-ERICÍNEAS ó ERICÁCEAS. - Matas, plantas fruticosas, arbustos y hasta arbolitos con hojas alternas y bastantes veces opuestas ó verticiladas $\mathrm{y}$ sin estípulas, cuyo tamaño y forma varian muchísimo, pecioladas ó sesiles, peludas, pubescentes ó lampiñas; flores de inflorescencia muy variada, que constan de un cáliz 4 ó 5-partido, libre, persistente y cuyos lóbulos son casi iguales; corola monopétala 4 ó 5 -partida ó formada de 4 ó 5 pétalos, regular ó bastantes veces irregular; de estivacion empizarrada; estambres poco ó nada soldados con la corola, ordinariamente hipójinos, definidos y en número igual á los pétalos ó á las divisiones de la corola y á veces el doble de ella, con filamentos libres ó raras veces sosteniendo anteras biloculares, cuyas celdillas duras, secas y separadas en el ápice ó por la base, son frecuentemente apendiculadas y se abren por un poro terminal; pistilo compuesto de un ovario libre plurilocular polispermo, cuya base está algunas veces rodeada de un disco nectarífero hipójino, mientras que el vértice lleva un estilo único y iieso terminado por un estigma indiviso, dentado ó trílobo. Cápsula polisperma plurilocular y cuya dehiscencia es tan 
pronto septícida como loculícida, ó á veces el fruto consiste en una baya; semillas pequeñas indefinidas, insertas en placentas centrales y de testa muy adherente, con endospermo carnoso; embrion rollizo con cotiledones cortos y raicilla próxima al hilo.

\section{Ancilisis dicotómica de las tribus.}

1. Fruto capsular, 2. - Fruto abayado é indehiscente; corola decídua. Arbustos siempre verdes. T. I. Arbuteas. Arbutus pun gens, Kth. - A. guayaba, Mco.

2. Loculícido dehiscente ó con valvas septíferas; corola caduca; arbustos siempre verdes ó de hojas caedizas. T. II. ANDronédEAs. Gaulteria odorata, Kth. Pejoa, Ccas. - Dehiscencia septícida; valvas dobladas hácia dentro por las márjenes y por otros tantos tabiques bi-lamelados; arbustos de corola bastante grande y caediza; disco hipójino glanduloso y frecuentemente escamoso. T. III. RODEREAS, 3.

3. Corola monopétala. S.-T. I. Rodereas Corola poliépetala. S.T. II. Ledeas. - Bejaria ó Befaria urens.

\section{CLASE XXXVII. - DIOSPIROİDEAS.}

\section{Familia 82. - DIOSPÍREAS ó EBENÁCEAS. - Arbustos} ó árboles de hojas simples, enteras, coriáceas, pecioladas y alternas, cuyas flores, ordinariamente dioico-polígamas ó hermafroditas y pequeñas, están en grupos axilares y se componen de un cáliz monosépalo ó á reces formado de 5 sépalos sueltos; en el primer caso es persistente y con 4-5-6-7 divisiones mas ó menos profundas, las cuales están algunas veces reemplazadas por igual número de dientes; corola monopétala campanuda con 5 o 6 segmentos mas ó menos profundos y torcidos por la derecha, inserta en la base ó en la garganta calizinal ; estambres 3-8 y hasta 20 hipójinos, insertos en la base de la corola con cuyos lóbulos alternan y ordinariamente dispuestos en dos seiries; de anteras grandes erguidas, lineares lanceoladas y biloculares. Pistilo formado de un ovario súpero con 3 á 12 celdillas conteniendo cada una 102 óvulos colgantes, y cuyo vértice lleva un estilo simple $\delta$ כ-partido, terminacio por un estigma entero o bífido. Fruto abayado ó drupáceo uni ó poli-locular con una sola semilla comprimida en cada celda, cuyo embrion alojado en el centro de un endospermo cartilajinoso tiene igual direccion que su radicilla delgada y súpera. - Diospiros Virginiana. - D. Tetrasper$m a, \mathrm{~S} w$.

Familia 83.-AQUIFOLIACEAS o ILICINEAS.-Arbustos $\dot{0}$ arbolillos y árboles bajitos de hojas simples coriáceas, lampiñas, dentadas, angulosas, aguijonosas, undulosas, raras veces enteras, pecioladas, alternas ú opuestas; flores siempre hermafroditas solitarias ó en grupos axilares y compuestos de un cáliz con 4 ó 6 sépalos pequeños é imbricados; corola con tantos pétalos cuantos sépalos tiene el cáliz, soldados entre sí por la hase y formando una 
corola seudo-monopétala, la cual lleva tantos estambres cuantas divisiones hay y con las cuales alternan. Pistilo cuyo ovario único superior y trunco tiene 2 o 6 celdillas contenienrlo cada una un solo óvulo colgante y lleva en su ápice un estigma ordinariamente sentado y lobulado. El fruto carnoso es abayado ó drupáceo, contiene tantas nuececitas indehiscentes ó huesecitos leñosos, fibrosos y monospermos, cuantas celdas tenia el ovario cuya placenta es axil ; semillas con embrion diminuto, homótropo y situado en el vértice de un endospermo carnoso

G. I. Ilex, L. - Flores mas ó menos polígamas y de corola enrodada, 2. - Flores nunca polígamas, 3.

2. Árbol de mediano tamaño, cuyas hojas elíptico-obovales ú ovales, pecioladas y largas de $4^{\prime \prime}$ á $2^{\prime \prime}$, son redondeadas por la base, bien enteras ó aserrado-ondeadas, con los dientes bastante apartados, de cara superior lustrosa, con venas delicarlas proeminentes por ambas caras; peciolo largo de 4"' á 8"' y de cara superior acanalada. Flores en corimbos tan largos como los peciolos, amanojados y provistos de pedícelos accesorios; corola ancha de 3 á $4^{\prime \prime \prime}$, con 4 ó 5 divisiones, así como el cáliz; 40 j estambres, de anteras ovales obtusas y de base sub-acorazonada; baya globosa, lisa, pisiforme y ordinariamente con 5 huesecitos lisos. J. dioica, Gr. - Prinos dioica, V.

3. Corola enrodada, 4. - Corola no enrodada y dividida casi hasta la base, 5 .

4. Arbolito de como $30^{\prime}$ de alto ó arbusto de 2 ', cuyos muchos ramos son fastigiados ó dispuestos á manera de pirámide, angulosos y cuyos ángulos escurridos simulan estípulas, muy hojosos y llevan hojas pequeñas obotales ó espatuladas emarjinado-mucronaditas y de base aguzada en peciolo corto, largas de $4^{\prime \prime \prime}$ a $12^{\prime \prime \prime}$, bien enteras y de cara superior sin venas y lustrosa; flores en corimbos 3-floros un poco mas largos que los peciolos y sub-solitarios; cáliz y corola con 4 divisiones y 4 estambres, de anteras ovales oblongas. $J$. obcordata, Sw.: C. T. V., 498.

5. Arbol de $30^{\prime}$ á $40^{\prime}$ de altura, con hojas elípticas ú óvalo-lanceoladas, aguzadas ú obtusitas, sub-agudas por la base, por arriba de la cual son bien aserraditas ó enteras, con la cara inferior venosa, largas de $1^{\prime \prime} 1_{1} 2$ á $3^{\prime \prime} 1_{[} 2$, con un peciolo de 4 á $10^{\prime \prime \prime}$ de largo; flores ordinariamente perfectas, en. corimbos solitarios algo mas largos que los peciolos; corola dividida casi hasta la base en 4, 6 y hasta 8 lacinias: otras tantas divisiones tiene el cáliz y hay otros tantos estambres con las anteras ovales; baya globosa y asurcada, de $2^{\prime \prime \prime}$ de diámetro y de huesecitos con surcos. J. montana, Gr. Prinos montana, Sw. - Variedades : hojas pequeñas largas de 1", óvalo-lanceoladas y aguzadas. $J$. lanceolata. J. multiflora, Rich. Prinos lanceolata, Macf. - J. Macfadieni, Wprs. - Hojas grandes y largas de $3^{\prime \prime}$ á $3^{\prime \prime} 1_{1} 2$, ovales, largamente aguzadas y con el peciolo tan largo como el pedúnculo comun. J.ovata. C. T. V., 747.

G.II. Mrgenda, Jacq. 1. Drupas ovoídeo-oblongas, hojas elípticas, 2. - Drupas ovales, hojas mas ó menos ovales, 3.

2. Espatuladas coriáceas, lampiñas, estrechándose en peciolo, largas de $2^{\prime \prime}$ á $1^{\prime \prime}$, aserradas y con los dientes diminutos muy 
distantes ó nulos; flores blancas en cimas pedunculadas, divaricado-dicótomas, paucífloras, dos ó cuatro veces mas cortas que las hojas; estigmas 4-sentados y coronando la drupa ovoídeo-oblonga, larga de $2^{\prime \prime \prime}$ sobre $1^{\prime \prime \prime}$ de ancho. M. latifolia, Sw.

3. U obovales. de cara inferior lampiña ó pubescente, aserradas, subsesiles, largas de $8^{\prime \prime \prime}$ á $12^{\prime \prime \prime}$, ordinariamente redondeadas por el vértice y con las venas distantes; flores en cimas pedunculadas paucífloras, casi tan largas como las hojas; estilo distinto con ùn estigma 4-dentado, drupa oboval larga de $2^{\prime \prime \prime} M$. rhacoma, Sw. $M$. Uragoga, Rich. C. T. V., 384. - Obovales ú ovaloblongas, aserradas, con los dientes apartados ú ondeadas, lampiñas, cortamente pecioladas, largas de $1^{\prime \prime}$ o 2 " sobre 1 [ 2 ó $1^{\prime \prime}$ de ancho, flores coloradas en cimas pedunculadas dos veces dicótomas, paucifloras, dos ó tres veces mas cortas que las hojas; estilo distinto cuyo estigma es 4-dentado; drupa oboval roja, M. pallens, Sw.

Familia 84. - SAPOTACEAS ó SAPOTEAS. - Arbolillos o árboles altos corpulentos y coposos, ordinariamente lactescentes, de hojas simples, coriáceas, persistentes, pecioladas, alternas ó esparcidas, de ordinario sin estípulas, algunas veces de 2 colores, pero ordinariamente concóloras; cuyas flores, siempre hermafroditas y pequeñas, están dispuestas en grupos axilares mas ó menos furnidos y constan de un cáliz monosépalo persistente con 5 ó 6 divisiones mas ó menos profundas; corola monopétala, mas á menudo dobles y con 10 o 12 divisiones profundas, cuyas interiores están alguna vez que otra reemplazadas por escamas en número igual; estambres fértiles 5 ó 6 insertos en la base de la corola á cuyos lóbulos son opuestos, mientras los estériles alternan con ellos; pistilo formado de un ovario simple, súpero plurilocular, con la placenta axil y cada una de sus celdillas contiene un solo óvulo ascendiente, de vértice llevando un estilo simple terminado por un estigma 5-fido ó 5-lobo. El fruto es una baya mas ó menos gruesa, globosa ó mas ó menos ovala, con 4-12 ó raramente 2 celdas y por consiguiente otras tantas semillas, pero de las cuales siempre suelen abortar algunas, mas ó menos gruesas, duras, lustrosas, ordinariamente comprimidas, con el ombligo blanco y que ocupa casi un lado entero; testa fuerte y bien dura, sin endospermo: en ese caso el embrion es grande $\mathrm{y}$ oleoso ó con un endospermo, entónces el embrion menor tiene los cotiledones foliáceos, siempre de raicilla corta y ordinariamente inferior.

G. I. Chrysophyliux, L.- - 1. Nervaduras de las hojas pronunciadas en la cara inferior y casi perpendiculares respecto á la costilla, 2. - Cara inferior con nervaduras mas ó menos pronunciadas y oblícuas respecto á la costilla, 3 .

2. Fruto grueso y globoso; árbol grande bastante corpulento y coposo, cuyas hojas, como sedoso-doradas por la cara inferior, son ovales ú oblongas, puntiagudas, bastante grandes y pecioladas ; flores purpúreo-blanquecinas pequeñas, cuyos pedícelos fasciculados son mas cortos que los peciolos, de corola campanudo-infundibuliforme, con el tubo dos veces mas largo que el cáliz; anteras ovoídeas; estigma 8 ó 10-festoneado; baya verdosita, purpúrea ó azu- 
lita. C. caimito, L.: C. T. V., 81.-Baya ovoídeo-oblonga y pequeña, azul oscuro o negra; árbol menos grande que el precedente, cuyas hojas ovales, obtusitas ó mucronadas son dorado-sedosas ó doradotomentosas inferiormente, pecioladas, largas de $3^{\prime \prime}$ á $1^{\prime \prime} 1{ }^{2} 2$ sobre 2 " de ancho; flores blanquecinas cuyos pedícelos amanojados son mas cortos que los peciolos, corola campanudo-infundibuliforme, anteras ovoídeas; estigma 5-festoneado; baya con una sola semilla por aborto, larga de $8^{\prime \prime \prime}$. C. oliviforme, Lam. - C. monpyreneum, Sw.: C. T. V., 82.

3. Arbusto de hojas dorado-sedosas, inferiormente lanceoladooblongas ó eliptical-oblongas, con una puntita obtusa, con venas delicadas, largas de $3^{\prime \prime}$ á $1^{\prime \prime} 1$ 2 sobre $8^{\prime \prime \prime}$ á $10^{\prime \prime \prime}$ de ancho; flores coll pedícelos fasciculados tan largos como los peciolos ; tubo de la corola eserto ; anteras ovoídeas; ovario 5-locular, baya larga de 6"' ovoídeo-oblonga y con una sola semilla. C. microphyllum, Jacq. - Árbol bastante grande, cuyas hojas eliptical-oblongas ú oblongas con una punta obtusa son largas de $5^{\prime \prime}$ á $2^{\prime \prime}$, pecioladas y no tienen la cara inferior sedoso-dorada, pero lijeramente sedosa y por fin alampiñada; flores con pedícelos amanojados, mas cortos que los peciolos, de corola campanuda sedosa, cuyo tubo es dos veces mas largo que el cáliz; anteras ovoídeas; estigma 5-6-festoneado; baya azul oscuro larga de $6^{\prime \prime \prime}$ á $8^{\prime \prime \prime}$ y ovoídea ú obovoídea. C. glabrum, Jacq. C. microcarpum, Sw. C'. argenteum, Sieb.

G. II. Sa POta, Plum, 1. Cáliz 5-partido, anteras ovoídeas ó deltoí. deas, lateralmente dehiscentes; apéndices de la corola diminutos, lineares y encorvados; ombligo tan largo como la semilla; hojas lustrosas, estriadas á causa de unas venas delicadas y transversas, 2. - Cáliz con 6 hojuelas dispuestas en 2 séries; anteras asaetadolanceoladas, lateralmente dehiscentes, mas cortas que los apéndice. de la corola; ombligo mas corto que la semilla; hojas estriadas á causa de venas distantes, transversas y apenas notables, pedícelos solitarios y axilares, 3 .

2. Árbol cuyas ramitas y pedícelos son lijeramente sedosos, con hojas pulidas oblongas ó elípticas, de vertice con una punta corta y obtusita, largas de 5 á $6^{\prime \prime}$, de peciolo largo de 6 á $8^{\prime \prime \prime}$; pedícelos fasciculados y axilares; cáliz sedoso con los segmentos ovales y obtusitos, corola 5-fida cortamente eserta, cuyos apéndices igualan las anteras ovoídeas; baya globosa, dura, áspera, con 4 celdas $y$ ancha de 1". S. v'ugosa, Gr.

3. Arbol bastante grande, corpulento, muy ramoso y cuyas ramitas, pedícelos y peciolos son pubescentes y color de orin á la rez, con hojas lanceolado-ovales, puntiagudas por ambos estremos, concóloras, lampiñas, largas de $3^{\prime \prime}$ á $4^{\prime \prime}$ con peciolo de $8^{\prime \prime \prime}$ á $12^{\prime \prime \prime}$; flores blancuzcas, solitarias, cuyos pedícelos son tan largos como los peciolos; sépalos ovales, obtusitos, pubescentes y color de orin, con los 3 interiores coloreados; corola larga de $5^{\prime \prime \prime}$ y lijeramente eserta; baya de $3^{\prime \prime}$ de diámetro y mas ó á veces menos, de color bruno algo teñido de amarillo, con cáscara bastante dura, globosa ú ovoídea, con 8-10 y hasta 12 celdas; de carne blanquecina ó achocolatada, semlilas largas de 8 a 10"'. S' achras. Mil.: C. T. V.. 79-365. - Arbol mas 
grande todavía y mas corpulento, cuyas ramitas, pedícelos y peciolos son lijeramente verduzco-pubescentitos, con hojas oblongas ó lanceolado-oblongas, obtusas ú obtusitas por los dos estremos, de cara superior lampiña, mientras la inferior mas pálida es alampinada y plateado-pubescentita cuando son tiernas las hojas, largas de $6^{\prime \prime}$ a $4^{\prime \prime}$ y hasta $8^{\prime \prime}$; pedícelos tan largos como los peciolos ; cáliz largo de $3^{\prime \prime \prime}$, con los sépalos ovales, obtusitos y pubescentitos; baya dura, pequeña, globosa 6-locular, ancha de $6^{\prime \prime \prime}$ y mucronada, con las semillas largas de $3^{\prime \prime \prime}$ á 4 "'. S. sideroxylon, Gr.

G. III. Lucuma, Juss. Cáliz con 4 sépalos en 2 séries, baya globosa y pequeña; árbol bastante grande, cuyas ramitas color de orin, sedosas y alampiñadas, llevan hojas papiráceas, oboval-oblongas ú obovales, obtusas, lampiñas, con las nervaduras pronunciadas y distantes, delicadamente reticuladas, largas de $8^{\prime \prime}$ á $4^{\prime \prime}$ y hasta $2^{\prime \prime}$, pecioladas; flores bastante grandes, de pedícelos fasciculados ó solitarios, axilares y ordinariamente mas cortos que los peciolos; cáliz de sépalos redondeaditos, abiertos, sedosos y de color de orin, la mitad mas cortos que la corola 6-loba; anteras óvalo-lanceoladas, lateralmente dehiscentes é iguales con los apéndices aquillados; ovario 4-locular. L. multiflora, A. D. C. - Cáliz con 9-10 sépalos dispuestos en algunas séries imbricadas; baya ovoídeo-oblonga y grande, de carne amarilla ó colorada; árbol grande cuyas ramitas velludas $\mathrm{y}$ color de orin llevan hojas apergaminadas, oboval-oblongas ó espatuladas, de base largamente cuneiforme, mientras el vértice, ancho y redondeado, es mucronado, largas de $8^{\prime \prime}$ á $6^{\prime \prime}$ sobre $3^{\prime \prime}$ á $2^{\prime \prime}$ de ancho superiormente, de cara superior lampiña, mientras la inferior es alampiñada con las venas pronunciadas y distantes, con redecilla delicada, flores de pedícelos laterales sub-solitarios, pero aproximados y mas cortos que el cáliz, con sépalos redondeaditos, conniventes, sedosos, cuyos interiores son la mitad mas cortos que la corola 5-fida y sedosa, cuyos apéndices aquillados y subulados son iguales á las anteras lanceoladas; ovario 5-locular; baya áspera color bruno, larga de $6^{\prime \prime}$, con $2^{\prime \prime} 1{ }^{2}$ de diámetro, ordinariamente con una semilla fusiforme, ventruda, lustrosa, larga de $2^{\prime \prime} 1_{1} 2$, con la cicatriz ombilical muy grande. I. mammosa, G.: C. T. V., 6.

G. IV. Dipholis salicifolia, A.I). C. Achras salicifolia, L. Bumelia salicifolia, Sw. B. negra, Bert. B. pentagona, Sw. D. negra, Gr. - Bumelia nigra, Sw. - Sideroxylon nigrum, Gœrtn. D. montana, Gr. Bumelia retusa, Sw.

G. V. Mrausops globosa, Gœrtn. M. bidentata, A. D. C:M. balata, Crucg 
SUB-SECCION III. - POLIPÉTALOS Ó IIALIPÉTALOS.

1a DIVISION.-HIPÓJINOS.

ÓRDEN 1a. - PLEUROS PERMEOS.

('LASE XXXVIII.-VIOLÍNEAS.

Familia 85. - SAUVAGESIEAS. - Plantas herbáceas ó fruticosas, de hojas simples, enteras ó dentadas alternas ó verticiladas, sentadas ó cortamente pecioladas con dos estípulas fimbriadas, cuyas flores siempre hermafroditas son solitarias y axilares ó racimosas, con el pedícelo mas ó menos articulado por arriba de la base, que está acompañada de ordinario de una bráctea foliácea y constan de un cáliz con 5 pétalos persistentes y comunmente soldados por la base y formando un cáliz seudo-monosépalo, de una corola con 5 pétalos iguales ó desiguales entre sí ; bastantes veces contiene además otra corola interior formada de 5 escamas petaloídeas opuestas á los pétalos, de los cuales están separadas por un vertícilo de filamentos claviformes; estambres 5 , otras veces 8 y raras veces en número indefinido, libres, cuyas anteras biloculares é inclinadas hácia afuera se abren por una grieta lonjitudinal por cada celda ó por medio de un poro. Pistilo único compuesto de un ovario simple unilocular, con muchos óvulos anátropos pegados en 3 placentas parietales y cuyo vértice lleva un estilo simple, delgado y terminado por un estigma pequeñísimo. El fruto es una cápsula cubierta por el cáliz persistente ó por la corola interior marcescente, cuya celda única se abre por 3 valvas cuyos bordes, lijeramente proeminentes por adentro forman 3 tabiques incompletos placentíferos, de dehiscencia marjenicida, cuyas semillas pequeñas y numerosas contienen en el centro de un endospermo carnoso un embrioncito axil casi tan largo como él y cilíndrico.

Sauvagesia, L. 1. Plantas fruticosas ó fruticulosas y por consiguiente perennes, 2.- Planta herbácea y anual cuyo tallo, de como $6^{\prime \prime}$ de alto, mas ó menos ramoso, derecho ó inclinado, lleva hojas elíptico-lanceoladas, aserraditas, puntiagudas, cuya base se va estrechando hasta volverse peciolo, corto, largas de $1^{\prime \prime}$ á $1^{\prime \prime} 1_{1} 2$; estípulas óvalo-lanceoladas, con largas franjas ; pedícelos axilares, filiformes, con una sola flor de pétalos blancos y escamas petaloídeas rosadas, curo cúliz tiene los sépalos iguales, lanceolados, aguzados, largos de $2^{\prime \prime \prime}$ y casi iguales á la corola y á la cápsula, curas semillas son ovoídeas; filamentos estériles numerosos. S. erecta, L.: C. T. V., 452 .

2. Arbustillo de hojas oblongo-lanceoladas ó lanceoladas, aserradito-ondeadas, aguzadas por ambos estremos, largas de $3^{\prime \prime \prime}$ á $4^{\prime \prime \prime} y$ cuya anchura es variable, cortamente pecioladas, estípulas lanceolado-aguzaras, erguidas, mas largas que el peciolo y con franjas 
muy largas; flores en racimos terminales, las cuales ordinariamente fasciculadas tienen un cáliz con sépalos iguales eliptical-oblongos, obtusitos y de $3^{\prime \prime \prime}$ mas largos que la corola y mas cortitos que las cápsulas, cuyas semillas son globosas; filamentos estériles muchos. S. elata, Benth. - Vejetal fruticuloso, cuyo tallo delgado, unduloso, alto de $6^{\prime \prime}$ á $2^{\prime}$ y poco ramoso lleva hojas diminutas, aproximadas, lanceoladas, sub-enteras ó algo aserraditas con los dientes apartados, sub-sesiles y largas de $2^{\prime \prime \prime}-3^{\prime \prime \prime}$; estípulas lineares volviéndose franjas; flores en racimos terminales, de cáliz con los sépalos desiguales, óvalo-lanceolados, marjinados, obtusos, callosos por la base, cuyos interiores son largos de $2^{\prime \prime \prime}$, mientras los esteriores tienen $1^{\prime \prime \prime}$ solamente $\mathrm{y}$ todos mas cortos que la corola; filamentos estériles muchos. S. sprengelii, St-Hil. S. serpilifolia, Mart.

Familia 86. - VIOLARIEAS o VIOLARIACEAS.-Plantas herbáceas ó fruticulosas; con hojas ordinariamente alternas y á veces opuestas, simples y de prefoliacion enrollada, estipuladas y mas ó menos pecioladas, enteras, dentadas ó lobadas, lampiñas o tomentosas y hasta velludas; flores de ordinario solitarias y axilares, derechas ó cabizbajas, curos pedúnculos bi-bracteados, simples ó ramosos, llevan pedícelos saliendo de la axila de una bracteita, solitarios, con una sola flor formada de un cáliz con 5 sépalos persistentes iguales ó desiguales, de márjen ordinariamente membranácea, libres o algo reunidos por la base, mas veces prolongándose por debajo, cuya estivacion es imbricada y por eso se hallan en 2 séries : corola con 5 pétalos hipojinos alternos con los sépalos é insertos sobre un disco, frecuentemente marcescentes, de estivacion oblicuamente convoluta, tan pronto iguales entre sí como desiguales, el inferior mas grande y dispuesto á manera de labillo, á veces de base prolongada en espolon; estambres 5-insertos en el disco y alternando con los pétalos, de anteras biloculares abriéndose interiormente por una grieta doble y lonjitudinal, aplicadas al ovario ó libres, filamentos ordinariamente dilatados en lígula cuyo ápice forma, por encima de las anteras, un apéndice membranoso de color y forma variados; ovario unilocular polispermo y con 3 placentas parietales, cuyo vértice lleva un estilo único, hueco y terminado por un estigma lateral; cápsula con tres valvas y abriéndose con elasticidad desde el vértice hasta la base tirando las semillas, cuyo hilo engrosado parece como una caruncula; endospermo carnoso, pero con mayor frecuencia muy escaso; embrion recto, axil y tan largo como él; de raicilla mirando hácia el hilo, plumula apenas notable y cotiledones mas á menudo llanitos.

Jonidiun, Vent. 1. Flores pequeñas, nunca blancas, rejetales alampiñados ó lampiños, 2.-Flores blancas, de labillo muy grande, vejetal muy velludo y blanquecino, cuyos tallos, mas ó menos tendidos por el suelo, divaricados y largos de 8 a $15^{\prime \prime}$, son ramosos y ascendientes por el vértice, llevan hojas simples, alternas, subsesiles, ovales ú óvalo-lanceoladas, aguzadas por ambos estremos, aserraditas con los dientes terminados por un tuberculito verde pestañoso, velludas por ambas caras, largas de $2^{\prime \prime}$ á $2^{\prime \prime} 1_{\lceil} 2$ sobre 6 á $9^{\prime \prime \prime}$ de ancho; estípulas lineares, derechas y casi aplicadas al tallo, 
membranosas por los bordes, con una costilla, velludas y pestañosa:, largas de $2^{\prime \prime \prime}-33^{\prime \prime \prime}$, persistentes. Flores solitarias axilares, cuyo pedunculo, largo de como $1^{\prime \prime \prime}$, se dobla como al nivel de su articulacion, provista de dos lurácteas que se parecen á las estípulas, es muy velludo; sépalos iguales triangulares ú óvalo-lanceolados y cuyo rértice se termina por una punta, largos de como $6^{\prime \prime \prime} \mathrm{y}$ anchos de como $112^{\prime \prime \prime}$, teniendo por cada uno de sus lados como 6 á 11 lacinias verdes obtusas, cilíndricas por la base y á la par claviformes, largas de como $1^{\prime \prime \prime} \mathrm{y}$ todas vueltas hácia afuera, lo que hace el cáliz como erizado, y terminadas por un tubérculo amarillento-verdoso ; cáliz acreciente y muy velludo; labillo blanco, de limbo ancho de como $1^{\prime \prime}$, con figura de una pala, algo acorazonado y mucronaditu, con una manchita amarilla triangular en el oríjen de la uña larga de $3^{\prime \prime \prime}$, amarilla, con un tuberculito de cada lado; cápsula ovoídea con tres ángulos poco pronunciados, pubescentes, semillas piriforme: parduscas, con manchitas mas pálidas. J. tomentosum. C. T. V., 479.

2. Tallos lampiños ó alampiñados, nunca viscosos, labillo mas o menos moradito ó con estrias moradas, mas ó menos redondo, 3. Tallo lampiño cuyas ramitas moraduscas son muy viscosas; labillo blanco con una manchita amarilla rodeada por una lista rosada, acorazonada, escutiforme y mucronadito: frútice muy ramoso superiormente ó casi simple, alto de $1^{\prime} 1{ }^{2} 2$ á $2^{\prime} 1[2$, con hojas lanceoladas, las superiores son con frecuencia alternas y mas pequeñas que las inferiores opuestas y largas de $2^{\prime \prime}, 3^{\prime \prime}$ á $4^{\prime \prime}$, sobre 6 á $10^{\prime \prime \prime}$ de ancho, aguzaditas por el rértice y redondeaditas por la base, subsesiles ó con peciolo muy corto, horizontales, aserradas y además con muchas asperidades por la circunferencia; estípulas lineares un poco dobladas hácia afuera, lanceoladas, puntiagudas, moraditas y largas de como 1"', no pronto caduca. Pedúnculo morado filiforme, largo de como 10 á $15^{\prime \prime \prime}$, horizontal y algo doblado por arriba de la articulacion; labillo ancho de $2^{\prime \prime \prime}$, sépalos moraduscos esteriormente y con dos surcos pronunciados y laterales; cápsula globosa algo trígona, con el estilo persistente, de semillas pequeñas prietas, algo piriformes, con estrias laterales mas pálidas. J. viscosum.

3. Planta herbácea ó fruticulosa anual, de tallos difusos largos de 6 á $8^{\prime \prime}$, alampiñada, cuyas hojas inferiores son opuestas, ob-lanceolado-aserradas, mientras las superiores alternas, algo mas pequenas, son lanceolado-lineares, obtusitas y ordinariamente enteras; estípulas diminutas, subuladas y algo tiesas; pedúnculos tan largos como las hojas, sépalos óvalo-lanceolados, puntiagudos y largos de $1^{\prime \prime \prime}$, lampiños y 3 veces mas cortos que el labillo, cuyo limbo es redondo; cápsulas con pocas semillas, lampiñas, globosas y de color amarillento blanquecino. J. strictum, Vent., C. T. V., 478.

Familia 87. - BIXINEAS ó BIXINACEAS. - Árboles mas ó menos grandes ó arbolillos, de hojas alternas simples, enteras, con bastante frecuencia provistas de glandulitas transparentes, cuyo peciolo tiene la base acompañada de dos estípulas que suelen faltar no raras veces. Flores hermafroditas y alguna vez que otra unisexuales por aborto, axilares, en racimos ó en panojas terminales, cuyos pedícclos llevan brácteas, compuestas de un cáliz con 4 hasta 7 sépa- 
los enteros, tan pronto libres y distintos, como soldados entre sí por la base, de prefloracion imbricada, corola con tantos pétalos cuantos sépalos hay, con los cuales alternan: algunas veces suelen faltar; estambres muchos y en número indefinido, cuyos filamentos libres salen de un disco ancho, ocupando todo el fondo del cáliz, y llevan anteras biloculares; pistilo formado de un ovaric libre, unilocular y con muchos óvulos pegados sobre 4 y hasta 7 placentas parietales, cuyo vértice lleva un estilo simple mas ó menos largo y á veces 2 o 4-partido por el vértice. Fruto capsular ó carnudo cuya única celda contiene muchas semillas situadas solıre trofospermos parietales, lineares y no muy proeminentes, siempre lonjitudinales, envueltas mas ó menos en una especie de pulpa ó arilo, cuyo embrion homótropo está alojado en el centro de un endospermo carnoso, de cotiledones foliáceos y con la raicilla dirijida hácia el hilo.

\section{Anrilisis dicotómica de las tribus.}

1. Fruto dehiscente, seco ó mas ó menos carnoso, 2.-Fruto siempre indehiscente y carnoso; estambres insertos en un disco piríjino. T. I. Prokieas. Trilix crucis, Gr. Prokia crucis, L. - Guacimilla de costa, Cba. Lcetia apetala, Jacq. Majagua macho, Cba.

2. Fruto capsular seco, cuyas valvas llevan por su medio las placentas lineares; estambres hipójinos indefinidos. T. II. BIxeAs. A. - Fruto mas ó menos carnoso, 3.

3. Estambres períjinos; pedícelos articulados por la base ó por arriba de ella. T. Ill. Sanrdeas. Thiodia lotioides, Gr. Lotia guidonia, Sw. - Estambres insertos sobre un disco libre. - T. IV. Flacolrtieas. - Flacourtia ramonchii. C. T. V.. 520.

A. G. I. Brxa, L.-Hojas bastante grandes, acorazonadas, no coriáceas, muy undulosas, tanto por la circunferencia como por la superficie, verdes por ambas caras, con muchísimas glandulitas coloradas, especialmente por la cara inferior y visibles solamente con la lente; flores bastante grandes, mas ó menos rosadas y í veces casi blancas, cuyos pétalos obtusos y redondos por el vértice son largos de cumo $16^{\prime \prime \prime}$ y anchos de $5^{\prime \prime \prime}$; cápsula rojiza ó de un color blanco amarillento, oval y algo comprimida, de base mas o menos acorazonada y de vértice aguzadito, cubierta de muchas puas largas de $1^{\prime \prime}$ a $l^{\prime \prime \prime} 1_{1} 2 y$ de su color; larga de $1^{\prime \prime} 12_{2}$ á $2^{\prime \prime}$ sobro 12 á $14^{\prime \prime \prime}$ de ancho; cada una de sus placentaslleva 20 á 30 semillas bastante gruesecitas y que la tienen casi llena. Cara interior de la corteza del árbol, que se eleva á $10^{\prime}$ o $15^{\prime}$ de altıra, siempre verde pálido interiormente. B. orellana, I. B, platicarpa, R. P. : C. T. V., 16-1. - Árbol mucho mas grande y corpulento, ordinariamente alto de 20 á $30^{\prime}$. muy ramoso y con la corteza de un color mas oscuro y cuya cara interior es roja $y$ suelta un tinte que tiñe los dedos de rojo amarillento; de hojns nunca acorazonadas; algo coriáceas, undulosas por la márjen solamente, de cara superior verde manzana y lustrosa, mientras la infurior es fusca ó como acanelada, color debido á la presencia en ella he un bozo muy cortito y fino y á las glandulitas rojas, pero poeo nu- 
merosas, con la costilla y las nervaduras de igual color, algo mas subido. Flores como la mitad mas pequeñas que las del anterior $y$ mas pálidas. Sépalos del cáliz ovales, algo puntiagudos, largos como $1^{\prime \prime \prime} 1_{[} 2$ sobre $12^{\prime \prime \prime}$ de ancho; pétalos blancos algo rosaditos y de color sucio esteriormente, obovales y de cara superior cóncava y dispuesta á manera de cuchara, largós de como $10^{\prime \prime \prime}$ sobre $2^{\prime \prime \prime}$ de ancho. Cápsula verde oscuro con puas cortitas largas de $l_{[} 4^{\prime \prime \prime}$, casi globosa, un poco comprimida y con dos surcos laterales, principiando por la base y juntándose por el vértice obtuso y mas desarrollado que la hase, la cual es algo aguzada $y$ con surquitos saliendo de ella Y prolongándose como hácia la mitad de ambas caras, apenas del tamaño de una arellana, larga de 12 á $13^{\prime \prime \prime} \mathrm{y}$ ancha de 7"', $^{\prime \prime}$ segun el diámetro entero posterior y $10^{\prime \prime \prime}$ por el bilateral; como '7 á 12 semillas sobre cada placenta, dos ó tres veces mas pequeñas que las del precedente, de manera que la cápsula no está nunca llena. $B$. upatensis, R. de Gr. B. spherocarpa. T. Onitillo ú onoto de los Indios caribes.

G. II. Coclhospermum Gossipifolium. C. T. T., 65.).

\section{CLASE XXXIX. - CRUCIFERINEAS.}

\section{Familia 88. - CAPARIDEAS o CAPARIDACEAS. - Plan-}

tas herbáceas anuales, bisanuales ó vivaces, matas, frútices y hasta árboles, de hojas sencillas, mas ó menos coriáceas, lustrosas, lampiñas, alampiñadas ó polvorientas, otras reces compuestas y dijitadas, mas ó menos pubescentes ó lampiñas, pecioladas $J$ siempre alternas, acompañadas de dos estípulas mas ó menos foliáceas, persistentes ó caedizas. Flores siempre hermafroditas, solitarias ó en grupos axilares, otras veces dispuestas en racimos, en cimas ó en panojas terminales, cuyo pedúnculo sale de la axila de una bráctea que sin embargo suele faltar bastantes reces, constan de un cáliz con 4 sépalos mas ó menos caducos, raras veces soldados entre sí por la base; corola con 4 pétalos y raramente con 5 , abiertos, caducos, mas ó menos grandes y ungüiculados, ordinariamente alternos con los sépalos; estambres en número definido 4,6 y hasta 20 , otras veces en número indefinido y entónces muchos insertos al rededor de un disco hipójino. Pistilo único formado de un ovario siempre unilocular polispermo y sostenido por un podójino mas ó menos largo y filiforme, cuyo vértice lleva un estilo simple, el cual suele faltar algunas veces : entónces el estigma sencillo y cabezudo está sentado. El fruto es una cápsula siliciforme, pedicelada, unilocular, polisperma, cuyas placentas laminiformes constituren tabiques falsos en que están pegadas las semillas: se abre en dos valvas; otras veces es una baya unilocular con muchas semillas parietales ó esparcidas en la pulpa, frecuentemente reniformes, sin endospermo.

Tribu 1a. - Cleoseas. - Fruto capsular dehiscente; estambres ordinariamente definidos; hojas compuestas.

Crecine L.-Siempre 6 estambres, 2. - Estambres en número indefinido; disco hipójino reducido á un anillo de glándulas; pétalos cortamente ungüiculados. Planta glandulosa, cuyas hojas tienen 3-5 
hojuelas obovalolanceoladas iguales á los peciolos; flores amarillas con pétalos obovales, estambres como 20 igualando la corola; estilo corto; cápsula sentada, áspera y con pelos glandulosos, cuyas ralvas son convexas y estriadas. C. viscosa, L. Polanisia viscosa, Dc. P. icosandra, W. $\dot{A}$.

2. Insertos sobre el ginoforo filiforme, 3.-Insertos sobre un disco cónico situado por debajo del ginóforo ó del ovario, 5.

3. Estivacion de la corola abierta, 4. - Estivacion de la corola imbricada; segmentos de las hojas 7-5-lanceólados y bastante largos; flores grandes rosadas cuyos pétalos como 10 veces mas largos que el cáliz son espatulados; estambres insertos por encima de la base del ginóforo, cuya articulacion superior escede mucho la corola y es un poco mas corta que los estambres. $C$. speciosa, Kth.

4. Hojuelas 5-3 y á veces 7 obóválo-lanceoladas ó elíptico-lanceoladas; flores blaneas cuyos pétalos obovales son 4 veces mas largos que el cáliz; estambres insertos en el medio del ginóforo; cuya articulacion inferior iguala los pétalos; cápsula linear de $2^{\prime \prime}$ á 3 " de largo é igual al ginóforo ó mas larga que él. C. pentaphylla. L.gynandropsis pentaphylla, Dc. G. triphylla, De: G.palmipes, De: : C. T. V., 44 .

5. Hojas siempre palmeadas ó trifoliadas, 6. - Hojas indivisas; planta lampiña, difusa, ordinariamente de como $6^{\prime \prime}$ á $8^{\prime \prime}$ de alto é inclinada, cuyas hojas largas de como 6"' y lanceoladas, son bien enteras; bracteas conformes casi tan largas como los pedícelos distantes; estambres iguales á la corola amarilla, cuyos pétalos son largos de 2", cápsula subsesil, larga de $8^{\prime \prime \prime}$, terminada por el estilo y persistente, con las valvas convexas. C. procumbens, Jacq.

6. Hojas siempre trifoliadas, 7. - Hojas con mas de 3 hojuelas o con 3 raras veces. 8 .

7. Planta lampiña; segmentos de las hojas óvalo-lanceolados ó lanceolados, enteros ó aserraditos; flores blancas curos estambres salen un poco fuera de la corola; cápsula subsesil aguzada por la base. C. polygama, L. C. serrata, L. C. triphylla, Dese.: C. T. V., 45.-Yerba glandulosa pubescente anual y difusa, cuyas estípulas son aguijonosas; divisiones de las hojas elípticas cuneiformes por la base y sub-enteras; flores pequeñas axilares, blancas, teñidas de rosado con los estambres inclusos, cápsula subsesil, lampiña y larga de $1^{\prime \prime \prime} 1\left[2\right.$ á $2^{\prime \prime \prime}$, con las semillas muricadas. C. aculeata, L.

8. Flores blancas; planta pubescente frecuentemente glandulosa, con las estípulas aguijonosas; $5-\tau$ hojuelas lanceoladas; brácteas acorazonadas ú aovadas; estambres largamente esertos; ovario mucho mas corto que el ginóforo, pero cápsula madura dos vecés mas larga que él que tiene 2 á $3^{\prime \prime}$, lampiña ó glandulosa. C. pungens, IV. C. heptaphylla, Sw. C. spinosa, Macf. C. swartziana, Wild. C. spinosa, Sw. Flores purpúreas, planta glandulosa pubescente con estípulas y peciolos aguijonosos y cuyas hojas son con 3 o 5 segmentos elíptico-lanceolados; brácteas ovales; estambres lijeramente esertos; ovario cortamente estipitado y cápsula $6-12$ veces mas larga que el ginóforo que lo es de $2-4^{\prime \prime \prime}$ solamente. $C$. houstoni, R. Br. C. heptaphylla. Mey. C. cubensis. Rich. 
Tribu 2. Capparídeas. - Fruto abayado; estambres siempre muy numerosos; hojas ordinariamente indivisas ; árboles, arbustos 6 frutices.

G. I. Crateva, L. - Baya ovoídeo-globosa, obtusamente mucronada, del tamaño de un huevo de paloma y sostenida por un ginóforo muy largo. Árbol que se eleva á 15 ó 25' de altura; mas ó menos corpulento y bastante coposo; hojas lampiñas con los segmentos aovados y puntiagudos; estambres 20-24 insertos sobre un disco cilíndrico en las flores fértiles y cónico en las masculinas y tres veces mas largo que los pétalos blanquecinos y largos de 6-8"'. C. ginandra, L.: C. T. V., 46.-Bayaglobosa no mucronada y del tamaño de una naranja pequeña; árbol de 25 á 30' de altura, muy coposo, cuyas hojas tienen los segmentos anchamente aovados y aguzados; estambres 8-16. C. tapia, L.: C. T. V., 753.

G. II. CAyparis, L. - 1. Fruto abayado siliciforme, 2. - Baya ovoídea; caliz 4-partido, con los segmentos valvados, de ordinario 8 estambres insertos sobre un disco corto y columnario. Árbol de 12 á 25 ' de altura ó arbusto ramosísimo, cuyas ramas y los pedúnculos son leproso-tomentosos, con vello apretado; hojas lanceoladas, largas de $34^{\prime \prime}$, cortamente pecioladas, cuya cara superior es lampiña, mientras la inferior pulverulento-pubescente tiene el vello estrellado; flores blancas en corimbos pequeños pedunculados y axilares por el vértice de las ramitas, de cáliz con segmentos subuladosobtusos por el ápice y largos como de $1^{\prime \prime \prime}$; corola de pétalos ovaloblongos, cortamente ungüiculados, largos de $3^{\prime \prime \prime}$ é igualando los estambres, baya ovoídeo-globosa velluda, dos veces mas larga que el ginóforo y ancha de 8-6"'. C. ferrugina, L. C. octandra, Jacq.

2. Cáliz 4-partido ó 4-fido, 3. - Cáliz con sépalos distintos, valvados, yema tretágona un poco arrollada por las márjenes; fruto seco ó reventándose; arbusto ó árbol bajito que se eleva á 6-10' de altura, cuyas ramas é inflorescencia son densamente escamosas, con hojas lanceolado-oblongas ó elípticas, largas de $21_{1} 2$ á $4^{\prime \prime}$, pecioladas y de cara superior lustrosa y lampiña, mientras la inferior, leprosa, es plateada ó color de orin pálido; flores blancas y por fin teñidas de púrpura, grandes, en orimbos axilares ó terminales paucífloros, de cáliz con sépalos aovados largos de 6 "', ó á veces puntiagudos, pero de ordinario elípticos y obtusos esteriormente, casi mitad mas cortos que la corola, cuyos pétalos son leprosos esteriormente, mientras tienen la cara interior lampiña; estambres 16 á 32 esertos; fruto de 3 á $12^{\prime \prime}$ de largo, sostenido por un ginóforo largo de $6^{\prime \prime \prime}$ á $2^{\prime \prime}$ y con valvas continuas ó toruloso. C. jamaicensis, Jacq.-Variedades: de hojas lanceolado-oblongas, recortadas ó redondeadas por el vértice. C. emarginata, Rich. - De hojas elípticas ó elíptico-lanceoladas, con una punta; fruto continuo ó toruloso. C. siliquosa, L. C. torrulosa, Sw. C. breynia, L. C. intermedia, Kth.

3. Cáliz 4-partido ó 4-fido, con los segmentos valvados; arbusto ó árbol pequeño de 8 á $15^{\prime}$ de altura, cuyas ramitas ó inflorescencia están cubiertas de escamitas blancuzco-rufas; con hojas lanceoladooblongas, largas de 3 á 4", pecioladas y de cara superior lampiña, mientras la inferior es leprosa; flores blancas en corimbos pedun- 
culados y axilares hácia el vértice de las ramitas; de cáliz largo de $1^{\prime \prime \prime}-1^{\prime \prime \prime} 1_{[} 2$, con los lóbulos lanceolados, obtusos, convexos y leprosos por el dorso, 4 veces mas corto que la corola velluda, cuyos pétalos son ovales, cortamente ungüiculados y largos como de $6^{\prime \prime \prime}$, tomentosos, especialmente por el dorso, mientras el cáliz está solamente escamoso; 16 estambres esertos ; fruto largo de 9-10" sobre 3 " de diámetro, algo toruloso, color de orin leproso, 6 veces mas largo que el ginóforo. C. amygdalina, Lam. C. breynia, L.:C.T. V. :305.

4. Cáliz 4 partido, estambres de ordinario mucho mas largos que la corola, 5. - Cáliz 4-lobo, estambres iguales á la corola verdosito-purpurina; arbusto de $77^{\prime}$, ó árbol de 20 á $25^{\prime}$ de altura, muy ramoso, y cuyas hojas coriáceas, oblongas ordinariamente con una punta y largamente pecioladas, son largas de 10 a $3^{\prime \prime}$, ordinariamente algo acorazonadas, con las venas proeminentes por ambas caras, glándula axilar diminuta ó nula y las del cáliz mucho menos desarrolladas que en las demas especies; flores en corimbos terminales sub-contraidos, cuyo cáliz largo de $l^{\prime \prime \prime}$ tiene los lóbulos redondeaditos, pequeños y casi 4 veces mas cortos que la corola lampiña; fruto corto y largo de 1 á $2^{\prime \prime}$, sobre 4 á $6^{\prime \prime \prime}$ de ancho, y sin embargo casi dos veces mas largo que el ginóforo. C. frondosa, Jacq. C. commutata, Spr. C. cuneata, Dc.

5. Fruto linear, largo de 3 á 7", 6. - Fruto oblongo, tuberculado, igualando el ginóforo y largo solamente de 1-2" sobre 6 á 10" de diámetro; arbusto de 8 á $12^{\prime}$ de altura, con hojas coriáceas oblongas, aguzadas hácia el vértice y de base sub-acorazonada, cortamente pecioladas y largas de 3 á $4^{\prime \prime}$; glándula axilar ovoídea ó abortada; pedúnculos con pocas flores blancas, cuyo cáliz largo de 4 á 6" tiene sus segmentos redonditos y grandes, con los esteriores largos de $4^{\prime \prime \prime}$ y los interiores de 6"', pero todos de igrual anchura; corola con pétalos obovales, lampiños, dos veces mas largos que los sépalos y mucho mas cortos que los estambres sub-indefinidos. C. verrucosi, Jacq. C'. amplissima, Lam. C'. baducca americana, L.

6. Flores rosadas cựos pétalos oblongos y lampiños son tres veces mas largos que el cáliz y dos veces mas cortos que los estambres sub-indefinidos ; arbusto de 8 á 15' de alto, mas ó menos ramoso y de hojas coriáceas, lampiñas, oblongas ú oblongo-lanceoladas, aguzadas, cortamente pecioladas y largas de 3 á 4", provistas de una glándula axilar ohovoídea; pedúnculos con pocas flores, cuyo cáliz largo de $3^{\prime \prime \prime}$ tiene sus segmentos redondeaditos, de como 20 á 24 estambres; fruto largo de $4^{\prime \prime}$ é igualando el ginóforo. C. eustachiana, Jacq. C. cynophallophoi attenuata, Gr.-Flores grandes blancas ó teñidas de color de rosa, cuyos pétalos grandes obovales son tres veces mas largos que el cáliz y mas de un tanto mas cortos que los estambres indefinidos; arbusto de 8 á $10^{\prime}$ ó árbol de 15 á $25^{\prime}$ de altura, cuyos ramos largos y flexuesos parecen á veces como sarmentosos, son lampiños y sin escamas; hojas coriáceas, lampiñas oblongas, heteromorfas y cuya forma está entre oblonga, orbicular y linear, de cara superior lustrosa, mientras la inferior es opaca; obtusas y cortamente pecioladas, largas de 2-3", con una glándula axilar oblonga: pedínculos con pocas flores, cuyo cáliz largo $4^{\prime \prime \prime}$ es 
con segmentos redonditos, dividido casi hasta la base y con los dos sépalos esteriores mas pequeños ; fruto mas largo que el ginóforo ó igualándole; largo de 3 a $7^{\prime \prime}$ sobre $4-8$ "' de ancho, con valvas continuas ó torulosas y ahriéndose gradualmente por uno ó por ambos lados, colorado interiormente. C'. cynophallophora, L. C'. Alexuosa, I. : C. T..V., 329. - Tariedades: con hojas oblongas, oblongo-elípticas ú oblongo-lanceoladas, obtusas ó recortadas, glándula axilar oblonga ý sub-trunca; fruto toruloso. C. lavigata, Mart. - 2. Hojas redondeaditas, glándula axilar diminuta ó aborta. C. latifitia. - 3 . Hojas lineares ó lanceolado-lineares, de cara-inferior á veces leprosa. C. saligna, Valh. C. ionyifolic, Sw. C. hastata; L.

G. III. Morinsonid anericana, L. : C. T. V., 690.

Familia 89. - CRUCIFERAS. - Plantas herbáceas ordinariamente anuales, bisanuales ó vivaces y fruticulosas, cuya raiz es á reces carnosa, bastante gruesa, suculenta y comestible, perpendicular, de forma y tamaño rariados; hojas simples, enteras ordinariamente, pero á veces lobadas, sinuosas ó dentadas, lampiñas, mas o menos glaucas, pubescentes ó peludas, mas ó menos pecioladas y siempre alternas. Flores siempre hermafroditas en espigas; corimhos ó panojas terminales, las cuales constan de un cáliz con 4 sépalos caducos, casi iguales y bastante espesos, dos de ellos suelen presentar bastante á menudo un hueco por la base; cornla con 4 pétalos dispuestos á manera de cruz y ungüiculados; 6 estambres tetradínamos, cuya insercion de todos los filamentos ó solamente de dos ó de dos pares de ellos está acompanada por una glandulita situada entre ellos y los pétalos, la cual suele faltar bastantes veces. Pistilo único formado de un ovario simple súpero, mas ó menos alargado, bilncular, con algunos óvulos, terminado por un estilo mas ó menos largo, á veces persistente, pero que suele faltar no rara vez, estigma simple ó bíloho. El fruto es una silicua ó una silícula con dos celdas poli ó paucispermas y abriéndose por dos valvas. las cuales no se desprenden algunas raras veces $\mathrm{y}$ el fruto parece indehiscente $y$ es monospermo: por fin otras veces está formado de artejos que se separan sin abrirse; las semillas están asilas por cada lado del diafragma que constiture el tabique placentario falso, el cual divide las dos celdas; embrion diversamente encorrado $r$ sin endospermo, con una raicilla corva.

Una silicua, 2. - Una silícula, 3.

2. Silicua separándose transversalmente en artejos ó piezas uniloculares y unispermas. T. I. Lonentíceas.-Cakile aqualis, L'her.: C. T. V:, 274. - Silicua bastante larga y con dos valvas. T. II. SIr.rovosas. - Nastu'tium officinale, R. Br. : C. T. T., 276. - Sinapis brassicata, L. : C. T. V., 29-273-457. - Brassica oleracea, I. : C. T. V., 27\%. - Raphan: ;raphanistrum, L.: C. T, Y.,694.

3. Fruto redondeadito mas u menos comprimido, corto, ile tabique linear, silícula. T. III. Siliculosas. - Lepidium, L. - Terba mas ó menos ramosa, de tallo derecho y alta de $l^{\prime}$ á $1^{\prime} 1_{[} 2$, lampiña y con hojas lanceoladas, ordinariamente aserradas; flores en racimos terminales, elongados, diandras; silículas casi orbiculares, sin alas y recortadas: cotiledones acumbentes. L. rirginianum, I. : 
C. T. V., 275. - Yerba cuyo tallo derecho 'se eleva hasta 2 ' $2^{\prime} 1[2$, lampiña, cuyas hojas inferiores son pinatisectas pecioladas. Flores en racimos elongados ó casi en cimas siempre tetradínamas: silículas casi orbiculares, aladas y recortadas por el vértice, semillas oblongas y cotiledo nesincumbentes. L. satixum, L. : C. T. V., 275.

\section{CLASE XL. - PAPAVERINEAS.}

Familia 90. - PAPAVERÁCEAS. - Plantas herbáceas anuales ó bisanuales, matas ó raras veces arbustos, cuya savia lechosa es blanca ó amarilla, algunas veces acuosa solamente, con hojas simples mas ó menos lobadas ó sinuadas, sesiles ó pecioladas, lampiñas ó pubescentes, siempre alternas. Flores bastantes veces muy grandes y pintadas de los mas hermosos colores y siempre hermafroditas; solitarias en el ápice de largos pedúnculos terminales; se componen de un cáliz con dos y rarísimas veces tres sépalos caducos y cóncavos; corola con 4 ó 6 pétalos planos ó algo cóncavos, plegados ó mejor ajados antes de desplegarse, los cuales suelen ialtar alguna vez que otra; estambres hipójinos indefinidos y muchos insertos en derredor de un disco amarillo que sostiene el orario; algunas veces son solamente 4-8-10. Pistilo único formado de un ovario simple, súpero y libre, con una ó algunas celdas polispermas, cuyo ápice está coronado por un estigma escutiforme y asurcado ó con radios, otras ve-ces un estilo mas ó menos corto sale de él y se termina por un es. tigma partido ó lobado. El fruto es una cápsula silicuiforme, con una $\dot{o}$ algunas celdas lejítimas ó falsas, polisperma y abriéndose por poros situados por debajo del estigma; otras reces su dehiscencia se hace por medio de 2 o 3 ventallas; semillas pequeñas pegadas en unas placentas laterales que forman los tabiques falsos y verticales y cuyo embrion pequeño y axil está alojado en el vértice de un endospermo carnoso. Argemone mexicana, L. : C. T. Y., 477-565. - Bocconia. frutescens, L. : C. T. T., 82\%.

ÓRDEX II. - r'IAMTIOBLÁSTEAS.

\section{CLASE NLI. - NINFEINEAS.}

Familia 91. - NINFEACEAS. - Primorosas plantas herbáceas, acuáticas, vivaces, cuyas grandes hojas son simples, enteras, dentaditas ó sinuosas, ordinariamente discoídeas, acorazonadas y un poco abruqueladas, con peciolos muv largos que salen alternos del rizuma que echa sus raices en el fondo de los rios o de las lagunas; Hores primorosas y mas ó menos grandes, cuyas varias partes son distintas las unas de las otras, ó en parte reunidas por causa del desarrollo del torus ó disco, solitarias en el ápice de un pedúnculo muy largo y estra-axilar, nadantes siempre, así como las hojas, en la superficie del agua y formadas de un cáliz con 4-6 sépalos foliáceos, á veces persistentes, corola con muchos pétalos dispue tos en algunas séries, muchísimos estambres libres, cuyas anteras lineares y bilo- 
culares son introrsas. Pistilo formado de algunos carpelos mas ó menos envueltos en una prolongacion del tálamo, los cuales son otros tantos ovarios libres, cuyo ápice se termina en un estilo simple ó soldados todos entre sí, constituyendo así un ovario único coronado jor tantos estigmas dispuestos á manera de radios cuantas celdas hay. Fruto capsular conteniendo muchas semillas pegadas en sus paredes y laterales, carnoso é indehiscente; esas semillas están compuestas de un tegumento propio, epispermo, grueso y algunas veces en redecilla, de un endospermo grueso, persistente, harinoso y quê contiene en su vértice un embrion irregularmente globoso ó napiforme, contenido en el saco embrionario, con la raicilla vuelta hácia el hilo y los cotiledones espesos.

NrypheEa, L. - 1. Ápice de las anteras prolongado por un apéndice largo del conectivo; estípulas diminutas y distintas, flores abriéndose de dia, 2. - Conectivo prolongándose muy poco por encima del ápice de las celdas de las anteras de los estambres esteriores; estípulas reunidas en la vaina peciolar; flores abriéndose de noche. Planta de hojas acorazonadas algo abroqueladas, sinuosodentadas, ó á veces enteras, de cara inferior con los nerrios algo acanalados; flores blaneas ó amarillo-pálidas, con los sépalos sin nervaduras proeminentes, conectiro de ápice obtuso; apéndices de los estigmas claviformes y por fin circularmente inclinados. $N$. vudgeana, Mey., N. blanda, Planch. : C. T. V. 310. - Variedad: peciolo con un anillo de pelos ciñendo el vértice; celdas de las anteras estrechamente lineares y cuya anchura es igual á la de la márjen del conectivo llano; hojas enteras. N. amazonum, Mart.

2. Hojas grandes acorazonadas, un poco abroqueladas, sinuosodentadas, con las venas formando redecilla en la cara inferior, ordinariamente purpúrea, lampiñas y lustrosas; flore blancas cuyos sépalos no tienen nervaduras proeminentes, pero sí algunas líneas purpúreas; estambres esteriores mucho mas largos que los interiores; apéndices de los estigmas cortos, cónicos y puntiagudos. $N$. ampla, Dc. : C. T. T., 310.-- Variedades: hojas con los dientes puntiagudos. $N$. plumieri, Plan. - Sépalos y pétalos oblongos un poco puntiagudos, como de l" de largo, apéndıces de las anteras esteriores largos de $2^{\prime \prime \prime}$ y del ancho de la antera. $N$. parviflora.

Famitia 92. - NELOMBONEAS. - Plantas acuáticas herbáceas, cuyos peciolos y pedúnculos salen de un rizoma mas ó menos grueso que se halla en el fondo de las lagunas ó riachuelos; hojas abroqueladas, anchas, orbiculares, enteras, emersas, de prefolia. cion enrollada; flores grandes, solitarias en el ápice de un pedúnculo largo y que sale bastante por fuera del agua, blancas, rosadas ó amarillas, cuyo cáliz tiene sus sépalos libres y colgantes; corola formada de muchos pétalos oblongos, estendidos y dispuestos en algunas séries. Muchísimos estambres, cuyos filamentos van prolongándose por encima de la antera y forman un apéndice pequeño. Ifuchos pistilos hay alojados en los alveolos de un receptáculo bastante desarrollado, compuestos cada cual de un ovario libre unilocular, con 1 ó con 2 óvulos colgantes y cuyo vértice llera un estilo corto terminado por un estigma escutiforme. El fruto es una espe- 
cie de nuez monosperma pequeña y alojada en el alveolo correspondiente; embrion sin endospermo, cuyos cotiledones espesos ciñen la plúmula. N'elumbium luteum, W.

ÓRDEN III. - AXOSPÉRMEAs.

\section{CLASE XLII. - BERBERIDINEAS.}

\section{Familia 93. - MENISPÉRMEAS' MENISPERMÁCEAS.}

- Plantas fruticosas trepadoras ó enredaderas, ó arbustos mas 0 menos tomentosos y frutices, de hojas simples mas o menos lobadas o enteras. pecioladas, lampiñas, pubescentes, tomentosas y velludas, ordinariamente palmatinervias, sin estípulas. Flores siempre unisexuales, de ordinario dioicas, en racimos ó espigas axilares ó terminales bracteadas, formadas de un cáliz de prefloracion imbricada, con muchos sépalos dispuestos por séries de á tres, lo que sucede tambien para los pétalos, que suelen faltar alguna vez que otra. Hay muchos estambres monadelfos, otras veces son libres y en número determinado igual al de los pétalos, ó duplo y hasta triple de él. Iuchos pistilos libres ó soldados entre sí por el lado interno, con los ovarios distintos uniculares y contiendo un ovulo único y lateral, con un estilo corto terminado por un estigma simple. Fruto drupáceo monospermo cuyas semillas reniformes contienen un embrion ordinariamente alojado en un endospermo.

Tribu $1^{\text {a }}$. - Coculeas. 3 hasta 12 carpelos campilótropos; emhrion contenido en un endospermo con figura de herradura; raicilla dirijida hácia el rudimento supra-basilario del estilo, cotiledones lineares y contiguos. Coculus, Dc.- Anteras al principio 4-loculares, despues bílobas y abriéndose por una grieta confluyente, oblí-. cuamente lateral y á la par vertical; estilos cilíndricos y ganchosos; mata de hojas oblongas ó elíptico-lanceoladas, lampiñas, cuyas venitas están en redecilla muy fina y las dos nervaduras principales algo distantes de la base, enteras, coriáceas y largas de $1-8^{\prime \prime}$, pecioladas; pétalos diminutos, escamiformes, opuestos al cáliz y á los estambres interiores que igualan; anteras globosas tan largas como el filamento espeso; drupas ovales redondeaditas, largas y anchas de $5^{\prime \prime \prime}$. C. domingensis, Dc. - Anteras biloculares cuyas celdas distantes se abren por una grieta lateral; estilos foliáceos é inclinados; mata de hojas acorazonado-triangulares, 5-7-nervias, membranáceas y ordinariamente largas de $111^{2} 2$ á $2^{\prime \prime}$, lampiñas ó diminutamente pubescentes, largamente pecioladas; flores distantes en racimos delgados, simples, mas largos que el peciolo y cuyos pétalos, tan largos como los sépalos interiores, son obovales; celdas de las anteras lineares distantes y separadas por un conectivo archo; 3 ovarios. C. tamoides, Dc. C. pauper, Gr.

Tribu 2.-Cisanpelídeas. Carpel solitario; embrionalojadoen un endospermo espeso y en forma de herradura, de cotiledones linearesy contiguos. Cisampelos planta fruticulosa enredadera, cuyos ramos delgados son largos de 1 o 2 varas y hasta mas, pubescentes, con 
hojas acorazonado-redondas, ó como arriñonadas, casi discoideas, algo abroqueladas, de cara superior lustrosa y verde-amarillenta, mientras la inferior es tomentosa, largamente pecioladas: flores masculinas en corimbos compuestos y pedunculados, mientras. que las femeninas están en racimos ó espigas y en fascículos saliendo de la axila de una bráctea, redondeadita y mas larga que ellas. Drupa sub-globosa roja y peludita. C. pareira, L.: C.'T. T.,369-720.-Tariedades: 1 . Hojas abroqueladas pubescentes por ambas caras. $C$. parei$r a$, L. - 2. De hojas abroqueladas, alampiñadas por la cara superior, mientras la inferior es tomentosa. C. microcarpa, Dc. - 3. De hojas cuyo peciolo sale de la base pubescente, en especial inferiormente, ó lampiñas. C. caapeba, L. - Mata ó frutice de tallo derecho, casi nunca ramoso, muy tomentoso en todas sus partes y alto de $1^{\prime} 1{ }^{2} 2$ á $3^{\prime}$; algunos tallos salen á veces de la misma raiz; de un color blanco sucio ó aleonado. El individuo femenino es ordinariamente algo mas alto que el masculino, de hojas ovales redondeadas, algo ondeado-sinuosas por la circunferencia, apenas escotadas por el vértice, con un rejon poco pronunciado, de cara superior mas verde que la inferior, blanquecino-aleonada, largas de 21 [2 á $2^{\prime \prime}$ y anchas de 21 [ 4 á 11 [2, sin contar el peciolo que tiene 4 á $5^{\prime \prime \prime}$, con las nervaduras bien pronunciaras por la cara inferior, todas saliendo de la base y dispuestas á manera de abanico, muy poco ramificadas, y visibles tambien por la cara superior, porque las partes que corresponden á ellas están mas pálidas; las del masculino difieren de aquellas par ser mucho menores, elípticas, mas ó menos ovales, largas de $21_{[} 2$ á $2^{\prime \prime}$, sin el peciolo que tiene 8 á $10^{\prime \prime \prime}$, y anchas de $\left.12_{[} 3,11_{[} 2,1\right]_{1} 4^{\prime \prime}$. Flores femeninas en espigas axilares, ordinariamente mellizas, largas de $12_{[} 3$ á $11 l_{\Gamma} 2^{\prime \prime}$, cuyo eje en zigzag lleva en cada ángulo saliente una bráctea foliácea, oval-acorazonada, ancha como de 3 á $4^{\prime \prime \prime}$, que tiene en su axila un grupo de 6 á 8 flores casisentadas, mientras las masculinas son en pequeñas cimas, mas o menos umbeliformes ó apanojadas, situadas en el ápice de un pedúnculo filiforme largo de $\tau^{2}$ á $9^{\prime \prime \prime}$, axilares y en número de 6 ordinariamente en cada axila de las hojas. C. vestita, H. M. C. pannosa, Benth.

\section{CLASE XLIII. - MAGNOLINEAS.}

Familia 94.-MIRISTÍCEAS ò MIRISTICÁCEAS'-Arbustos ó árboles ramosísimos, con hojas sencillas, coriáceas, pecioladas, sin estípulas, enteras, mas ó menos oblongas ó elípticas, lustrosas y lampiñas, cuyas flores apétalas siempre dioicas, axilares o terminales, solitarias ó agrupadas, se componen de un cáliz monosépalo con tres divisiones valvaries, tanto las masculinas como las femeninas; en las primeras hay desde 3 hasta 12 estambres, monadelfos con las anteras reunidas y á veces soldados entre sí, abriéndose por un surco lonjitudinal, mientras que las segundas contienen un ovario libre, unilocular, con un solo óvulo derecho y que lleva por el ápice un estilo muy corto terminado por un estiçma lobado. Fruto drupáceo 
farticular cuya parte carnosa se aljre en dos valvas cuando está maduro para dar salida á una especie de hueso cubierto de una concha crustácea adornada por un arillo dividido en muchas lacinias y que parece como cera de color rojizo anaranjado; semilla gruesa cuyo embrion pequeño, recto y homótropo está alojado en el vértice de un endospermo zrueso, duro, marmóreo y ruminado.

MrristicA, L. - Anteras 9-12 lineares sostenidas por una columna cilíndrica cortamente estipitada; pocas flores axilares ó una sola. Árbol muy ramoso como de 30 á $40^{\prime}$ piés de altura, de hojas eliptical-oblongas, cuspidadas, lampiñas, lustrosas, largamente pecioladas, con 8 á 10 pares de venas primarias; flores cabizbajas cuyas masculinas son corimbosas, mientras las femeninas son solitarias; cáliz ovoídeo y trífido; drupa globosa con una punta en el vértice, de color y tamaño de un albaricoque pequeño, colgante. $M$. moschata, Thumb. : C. T. V., 2:35. - De ordinario tres anteras solamente, cuya columna es cilíndrica y estipitada; flores fasciculadas en panojas paucifloras. Ábol grande que se eleva á $60^{\prime}$ de altura, cuyas hojas son lineares, oblongas, alampinadas, de base redondeada ó aguzada y de vértice cuspidado, pecioladas, largas de 4 á 8" sobre $8^{\prime \prime}$ á $2^{\prime \prime}$ de ancho, cuya cara inferior es color de orin, con 24 ó 30 pares de venas primarias. Los hacecillos de flores en número de 5 á 15 , son envueltos antes de la floracion en una bráctea grande, pero cada flor está sin bráctea alguna especial; cáliz infundibuliforme, trífido, velludo esteriormente y lampiño interiormente; baya globosa, lonjitudinalmente aquillada y de 6 á $8^{\prime \prime \prime}$ de diámetro. $\mathcal{I}$. surinamensis, Rol. - M. fatua, Sw.

Familia 95. - $A N O N A C E A S$ - Arbustos ó árboles mas ó menos grandes, pero de ordinario no muy corpulentos ni muy altos tampoco, pero sí muy ramosos y bastante copudos, con hojas sencillas, mas ó menos lanceoladas, oblongas, ovales, elípticas, enteras, mas ó menos coriáceas, pecioladas, lustrosas, lampiñas, alampiñadas ó pubescentes, sin estípulas. Flores siempre hermafroditas, telminales ó laterales y opuestas á las hojas ó axilares, las cuales se componen de un cáliz persistente con 3 sépalos ó 3 segmentos profundos y pequeños; de una corola con 6 pétalos dispuestos en 2 séries y algunas veces reducida á 3. Muchos estambros hipojinos insertos en derredor de un disco, cuyos filamentos cortísimos llevan anteras casi sentadas con las celdas laterales ó estrorsas; pistilo compuesto y. formado de muchos ovarios pegados en derredor de un eje central, súperos, uniloculares, müzospermos y cuyo vértice lleva un estigma sentado. Fruto compuesto, á veces bastante grueso, formado por muchas bayas uniloculares y monospermas, reunidas y soldadas entre sí, y sostenidas por un eje que no es otra cosa sino una prolongacion algo carnosa y cónica del pedúnculo, es lisu, escamoso ó áspero; las semillas cuyo tegumento propio es crustáceo, lustroso y formado de dos láminas, contienen un embrion pequeño alojado hácia el vértice de un endospermo grueso y ruminado, cs decir, con muchisimos surcos profundos y en que penetra el epispermo.

Tribu 1".- Axóxess. - Carpelos por fin soldados entre sí $y$ 
formando un sincarpio de forma y tamano variados; en bastantes especies el pólen está en masas coherentes y forma así polinias dispuestas á manera de rosario.

Axova, L. - 1. Corola con 6 pétalos bastante grandes, cuyos 3 interiores son bien notables; vejetales de hojas siempre verdes y persistentes, 2. - Corola con 3 pétalos solamente, la série interior estando reducida á 3 escamitas diminutas ó faltando enteramente, de ordinario carnosas; rejetales no siempre verdes y cuyas hojas son en mayor parte decíduas, 6 .

2. Pétalos esteriores anchamente aovados, con una punta y apenas mas largos que los interiores redondos, 3. - Pétalos esteriores, obtusos y bastante mas largos que los interiores, 5 .

3. Sub-acorazonados por la base y lampiños, 4. - No acorazonados y tomentosos; árbol bajito que se eleva á 15 o $20^{\prime}$ de altura, con hojas oblongas y por fin lampiñas, cuyas flores tienen los pétalos esteriores verdosos y largos de 1", mientras los interiores son amarillos; fruto globoso, aerolado y con $4-5$ " de diámetro, cuyas areolas se prolongan en puas diminutas y carnosas. A. montana, Macf. 1. muricata, Variedad Dun.

4. Fruto á veces muy grueso, irregularmente cónico, obtuso, areolado y cuyas areolas se prolongan en puas carnosas y encorvadas. Arbol frondoso que se eleva á $15-25^{\prime}$ de altura, con hojas oblongas, pecioladas, lustrosas y por fin lampiñas; flores bastante grandes cuyos pétalos esteriores, largos de 1 á $2^{\prime \prime}$, son amarillentos $\dot{o}$ verdositos, mientras los interiores son amarillos $\dot{0}$ rojos. Fruto de 6 á $10^{\prime \prime}$ de largo sobre 3 á 5 de ancho por la base, con la carne blanca y las semillas negras y lustrosas. A. muricata, L. : C. T. V., 91-576.- Fruto cónico, obtuso, liso y sin puas; árbol pequeño de 10 á $12^{\prime}$ de altura, ramoso y de hojas lanceolado-oblongas y lampiñas; pétalos esteriores largos de 1" $\mathrm{y}$ verduscos esteriormente. A. laurifolia, Dun.

5 . Pétalos esterior'es aovados, obtusitos, largos de $1 l^{2} 2^{\prime \prime}$, amarillentos esteriormente y un poco ásperos, lisos interiormente, blancos y con una mancha roja por la base, mientras los interiores son mucho mas estrechos, algo mas cortitos y de cara interior mas ó menos roja y la esterior blanca. Árbol fiondoso de 10 á $15^{\prime}$ de altura, con hojas oblongas ó elípticas con una punta, lampiñas, con un peciolo bastante grueso y corio, con los dos lados de la base dobladitos por afuera en la parte que corresponde al peciolo. Fruto aovado, globoso, liso y lijeramente areolado, amarillento y como de $2^{\prime \prime}$ de diámetro ú mas, con la carne amarillo subido y las semillas amarillentas. C. palustris, L.: C. T. V., 436. - Pétalos esteriores oblongos, obtusos y verduzcos, largos de $1_{1} 2-1^{\prime \prime}$, é interiores rojizos, dos veces mas cortos y redondos; árbol de 8 á $12^{\prime}$ de alto, bastante ramoso y de hojas oblongas, lampiñas $\mathrm{y}$ aguzadas por el vértice; fruto sub-globoso, tuberculado, verduzco, como de $4^{\prime \prime}$ de diámetro y con las semillas negras. A. mucosa, Jacq. - A. obtusifolia, Tuss.

6. Fruto tuberculado y globoso, 7. - Fruto no tuberculado pero sí areolado, liso y como en forma de corazon, amarillento, un poco teñido de rojo, con la carne blanco-amarillenta y las semillas ne- 
gras. Árbol muy frondoso, de copa redonda, alto de 15 á $25^{\prime}$ con hojas oblongas ú oblongo-lanceoladas, largas de 5 á $7 "$ sobre $1^{\prime \prime}$ á $I^{\prime \prime} 1 l_{1} 2$ de ancho, ásperas ó por fin lisas, no lustrosas y de un color verde amarillento. A. reticulata, L.: C. T. V., 92.

7. Fruto ovoídeo-globoso ó globoso como de 3 á $4^{\prime \prime}$ de diámetro, amarillento-verdoso y blanco, con tubérculos distintos, proeminentes, espesos. redondos y de $2-5^{\prime \prime \prime}$ de diámetro, con la carne blanca ó algo amarillenta y las semillas bruno-oscuro. Árbol no muy coposo, de ramas bastante apartadas las unas de las otras y alto de $15 a^{\prime} 20^{\prime}$, con hojas lanceolado-oblongas, glaucas y de cara inferior pubescente ó alampiñada; pétalos largos de 8 á $12^{\prime \prime \prime}$ sobre 1-2" de ancho, verduzcos, con un hueco purpúreo por la base interiormente. A. squanimosa, L. - A. cherimolia, Mill. C. T. V.. 93.

Tribu 2. Xylopieas. Fruto con carpelos distintos y pétalos valvados.

G. I. Xrlopia, L. 1. Bráctea superior envolviendo por parte el tubo calizinal, 2. - Brácteas decíduas y un poco apartadas del cáliz cupuliforme, sedoso y alampiñado, cuyos 3 lóbulos llegando hasta el medio son redondos, obtusos y 4 veces mas cortos que la corola sedosa, y cuyos pétalos esteriores son largos de 4-6"' . Arbol como de 12 á $15^{\prime}$ de altura, con ramas largas y no muchas, de hojas lanceoladas aguzadas en punta obtusita ó á veces recortadas y largas de 2-3" sobre 1 " de ancho, de cara inferior densamente peluda, en especial cuando son tiernas, cortamente pecioladas. $X$. glabra, L.

2. Cáliz cupuliforme, pubescente, cuyos 3 lóbulos, redondos y obtusitos llegan hasta el medio y son 4 veces mas cortos que la corola sedosa cuyos pétalos esteriores son largos de 4"'. Árbol como de 15 á $25^{\prime}$ de altura, con ramas largas horizontales bastante apartadas las unas de las otras, cuyas hojas como dísticas y horizontales son lanceolado-lineares, aguzadas por el vértice y redondeado-acorazonaditas por la base y largas de 3 á $5^{\prime \prime}$ sobre 1 " á $1_{[} 2$ de ancho, de cara superior lampiña, mientras la inferior es pubescente ó alampiñada, cortamente pecioladas; carpidios 2, comprimido-ovoídeos, sentados con 4-5 semillas ó 5 á 10 carpidios obovales y estipitados, mucho mas pequeños y solamente con 2 semillas. $X$. Jamaicensis, Griesb. X. muricata, L. X. salicifolia, Kth. X. frutescens, Aub.: C. T. V., 271. - Cáliz cortamente campanudo, 3 dentado ó á veces 3 -fido, con los dientes juntiagudos y 4 á 6 veces mas cortos que la corola, cuyos pétalos esteriores tienen 8 á $16^{\prime \prime \prime}$ de largo; árbol pequeño, de hojas oblongo-lanceoladas, con una punta, largas de 3 á 6 " sobre 1-2" de añcho; flores sedosas; carpidios estipitados, encorvado-oblongos, sub-cilíndricos, largos de $8^{\prime \prime \prime}$ y anchos de $3^{\prime \prime \prime}$, obtusos, redondeados por la base hácia el ginoforo, largo de $2^{\prime \prime \prime}$ y con 2 ó 4 semillas. $X$. grandiflora, Aub. X. longifolia, A. D. C. X. Cubensis, Rich. Unona acutifolia, Dun. U. xylipioides, Dun.: C. T. V., $27 \%$.

G. II. CAnaxga odorata, J. Hook. Xylopia aromatica, Mart.Unona odorata y leptopetala, 1) un. U. zelanica, Aub.: C. T. V. 456.

G. III. Monodora myiristica, Dun. Unona myristica, Dun. Xglopia undulata, P. R. Habzelia myristica, A. Dc.: C. T. V., 270. 
Familia 94. - MAGNOLIACEAS. - Arbustos ó árboles mas ó menos grandes, pero de ordinario bajitos, con hojas simples, coriáceas, enteras, persistentes, bastante grandes, lustrosas, pecioladas y con estípulas acompañando á la insercion del pecioloy decíduas, mas ó menos envainadoras; flores siempre hermafroditas axilares ó terminales solitarias o dispuestas en racimos mas ó menos furnidos, las cuales constan de un cáliz con 3 ó 5 sépalos caducos y mas cortos que la corola algunas veces muy grande, formada de 9 hasta 27 pétalos dispuestos en algunas séries; muchos estambres libres é hipojinos, cuyos filamentos cortos llevan á veces la antera pegada por su borde é insertos en derredor de un receptáculo comun á los pétalos; pistilo compuesto, cuyos ovarios muchos uniloculares, súperos y agrupados en derredor de un eje central y corto, especie de receptáculo, llevan en el ápice un estilo corto con su correspondiente estigma. El fruto es un cono formado de muchas cajitas comprimidas, libres, uniloculares, monospermas, abriéndose por dos valvas, cuyas semillas provistas de un arillo están pegadas en el ángulo interno de la celda y cuelgan de un funículo; otras veces se compone de algunas pocas cápsulas ó carpidios agrupados circularmente y en forma de estrella ó dispuestos en capitulo mas ó menos oblongo; en fin, algunas raras veces consiste en unas bayas dispuestas circularmente y soldadas entre sí; embrion diminuto y alojado hácia el vértice de un endospermo carnoso.

Tribu $1^{a}$. - Iliceas ó Winteraceas. Cárpelos dispuestos en verticilo, rarísima vez solitarios por causa de aborto, hojas con puntitos transparentes. Illicium anistum, L.: C. T. V., 268.

Tribu 2. Magnolieas. Carpelos dispuestos á lo largo del eje á manera de espiga; hojas sin puntos transparentes. Talauma Plumieri, Dc. Magnolia Plumieri, Sw.: C. T. V., 90.

\section{CLASE XLIV. - RENUNCULÍNEAS.}

Fanilia 95. - DILLENIÁCEAS. - Árboles, frutices, ó subfrutices mas ó menos sarmentosos ó abejucados con hojas siempre alternas, muy rara vez opuestas, simples, peninervias, enteras ó dentadas, mas veces coriáceas ó papiráceas, persistentes, ora pecioladás, ora sentadas, de base angostada y persistente, á veces abrazadora, y cuya mitad superior es bastantes reces caediza; flores solitarias ó en racimos y en panojas terminales, las cuales constan de un cáliz con 5 sépalos persistentes, cuyos dos son esteriores, mientras los tres otros son interiores, de cstiracion imbricada, así como la corola cuyos pétalos son 5 , decíduos, hipójinos y dispuestos en una sola série. Muchos estambres insertos en el disco, cuyos filamentos de base plana y de ápice dilatado son iibres ó poliadelfos y simétricamente dispuestos en derredor de los carpidios ú otras veces unilaterales, llevan anteras adheridas abriéndose de ordinario por una grieta lonjitudinal, introrias ó laterales, pero jamas estrorsas. Ovario formado de $2-5$ carpelos que suelen volverse un ovario único, sea por aborto, sea por haberse soldado entre sí, uniloculares y terminados por un estilo simple con su estigma entero. 
El fruto es bacciforme ó capsular con 2 valvas libres ó reunidas y aguzadas por causa del estilo persistente; semillas ovales dispuestas en dos séries y situadas en el ángulo interno de las cajitas ó de las celdas, son algunas ó dos solamente y hasta solitarias por aborto, tan pronto desnudas como vestidas de un arillo pulposo, de epispermo bastante duro, con un embrion diminuto, erguido, alojado por la base de un endospermo carnoso ó sub-cartilajinoso.

G. I. Tetracera volubilis, L. Trigarea aspeira, Desc., etc.: C. T. V., 408. G. II. Datilla rugosa, Poir. G. Iil. Curatella Americana, L. Chaparro.

Familia 96. - RENUNCULACEAS. - Plantas herbáceas anuales, bisanuales ó vivaces, cuyas raices ordinariamente fibrosas están algunas reces tuberculadas y fasciculadas, y matas ó frutices samentosos ó trepadores, rarísimas veces arbustos, con hojas simples mas ó menos lobadas ó enteras y mas ó menos pecioladas, radicales o caulinares, otras veces compuestas y hasta descompuestas, alternas de ordinario y sin embargo á veces opuestas. Flores siempre hermafroditas, cuya inflorescencia varia mucho: en efecto son solitarias y axilares o terminales, otras veces en espigas racimos ó panojas y se componen frecuertemente de un cáliz petaloídeo, polisćpalo, que á veces está solo ó acompañado de un invólucro foliáceo mas ó menos apartado de él; corola con 5 ó mas pétalos regulares ó con frecuencia irregulares, con forma y figura muy variadas y muy estrañas, $y$ á veces se cuentan hasta 20 de ellos, cuando son regulares 5 solamente, son unguiculados y llevan algunas veces un hoyo ó una laminita en su base ; otras veces suelen faltar enteramente y el cáliz se ha vuelto entónces petaloídeo. Hay muchos estambres libres, insertos en derredor de un disco hipojino, cuyos filamentos llevan anteras pegadas por su cara interna y adheridas con celdillas estrorsas ó laterales. Pistilo compuesto formado de alounos ó de muchos ovarios libres ó agrupados sobre un receptáculo falso; uniloculares y monospermos, con un estilo simple á veces lateral, que se termina por un estigma sencillo y de forma variada; algunas veces hay solamente 5 ovarios uniloculares polispermos y mas raramente uno único por haberse soldado algunos. El fruto muy variado consiste ora en una cápsula polisperma y unilocular, que se abre iateral y lonjitudinalmente por una grieta vertical, ora en muchosaquenios agrupados en cabeza, cuyo vértice se prolonga algunas veces en penacho plumoso mas ó menos largo, otra vez son 3 á 5 carpidios polispermos; en fin rarísima vez es una baya unilocular polisperma; las semillas contienen un embrion diminuto alojado hácia el vértice de un endospermo córneo y con igual direccion que él.

Tribu 1a. Clematídeas. Cáliz colorido de prefoliacion valvar; los pétalos suelen faltar alguna vez que otra ó son nias cortos que él; aquenios monospermos cuyo estilo muy largo es con figura de penacho y persistente, con semillas colgantes: vejetales leñosos, sarmentosos ó abejucados y con hojas opuestas.-Cukatis, L.-Bejuco de tallos delgados muy largos y muy ramosos, pubescente ó alampiñado con las hoias dirididas jor á 3 , curos segmentos aova- 
dos v enteros son largos de $1^{\prime \prime} 1_{[2}$ á 2 ". Flores en panojas polígamas, con cáliz blanquecino, de sépalos cuneiforme-ohlongos, abiertos, peludos y largos de 4-6"'; carpelos elipsoídeos, alargándose el véc' tice en penacho plumoso-largo, son largos de $3^{\prime \prime \prime}$ y anchos de $2^{\prime \prime \prime}$. C. dioica, L. C. Americana, Mill. C. Haranensis, Kth., etc.: C. T. V., 26. - Bejuco alampiñado que parece muchísimo al anterior, del cual difiere por tener las hojas pinatisectas ó con las divisiones del peciolo partidas por á tres y pinatisectas, cuyos segmentos, de ordinario 5, son aovados, enteros y lampiños; panojas dioicas, pubescentitas, con los sépalos oblongo-pubescentes; carpelos elipsoídeos ó elíptico-lanceolados. C. curipensis, Kth.

Tribu 2. Rayuncúleas. Cáliz verde y de prefloracion empizarrada; pétalos de los cuales uno lleva una escama pegada por su parte interna y hácia la base; aquenio de semilla erguida ; flores solitarias y terminales, sin invólucro; yerbas de hojas radicales ó alternas y envainadoras por la base del peciolo.- R R Runculus, L.Yerba perenne, cuyo tallo estriado por el vértice y ramoso se eleva á $1^{\prime}$ ó $I^{\prime} l_{[} 2$, de hojas tripartidas, con los segmentos cuneiformes, profundamente dentados; cáliz abierto ó recorvado; carpelos redondeados, lampiños y marjinados, terminados por un pico corvo ó recto formado por el estilo; pétalos amarillos. $R$. repens, L. Variedades : Cáliz recorvado; pétalos 5- 10 ; pico de los carpelos derechito. $R$. tropicus. $R$. pramorsus y Bomplandinus, Kth.: C. T. V., 24. - Yerba un poco inclinada, velluda, un poco mas bajita y de hojas redondeaditas, 3-5 lobas, cuyo cáliz se vuelve por fin recorvado é iguala á los pétalos; carpelos redonditos, marjinados, tuberculados, con un pico corto y ordinariamente ganchoso; de márjen aguda. $R$. parviflorus, L. C. T. V., 25.

\section{CLASE XLV. - GUTIFERINEAS.}

Familia 96. - GUTÍFERAS ó CLUSIÍCEAS. - Arbustos parásitos algunas veces, ó que principian por ser parásitos falsos y se vuelven despues terrestres cuando sus larguísimas raices adventivas han alcanzado el suelo en que penetran y se vuelven así troncos bastante gruesos y muy largos, otras veces son árboles de altura y tamaño regulares, cuyas hojas siempre simples y enteras, de ordinario coriáceas, algo dobles, lustrosas, lampiñas, cortamente pecioladas y articuladas por la base, son opuestas, á veces verticiladas y muy raramente alternas, con ó sin estípulas. Flores tan pronto hermafroditas como unisexuales, polígamas, axilares y solitarias ó en grupos y racimos, otras veces terminales, las cuales constan de un cáliz con dos sépalos caducos, otras raras reces con 4 y hasta con 6 persistentes, de estivacion imbricada; corola con 4 y hasta con 10 pétalos apenas unguiculados, dispuestos en 2 o 3 vertícilos ; estambres indefinidos insertos al rededor de un disco hipojjino, raras veces definidos y entónces 4 , de anteras adheridas. Pistilo único formado de un ovario simple superior unilocular polispermo, cuyo ápice lleva un estilocorto que suele faltar frecuentemente; estigma cabezudo ó 
con dos radios é igual número de lóbulos. Fruto tan pronto una cápsula mas ó menos globosa, uni ó plurilocular, polisperma, abriéndose por 4 hasta 12 valvas, cuyos bordes son generalmente proeminentes por adentro y pegados con las placentas, muchas, gruesas y axiles, como una drupa mas ó menos gruesa, unilocular, con 3 ó 4 huesos mas ó menos desarrollados; embrion homćtropo, ordinariamente sin endospermo, recto, con los cotiledones grandes, espesos y frecuentemente soldados entre sí y rectos. Los vejetales que forman esta familia contienen ordinariamente una savia lechosa amarilla ó resinosa.

\section{Análisis dicotomica de las tribus.}

1. Fruto capsular ó raras veces drupáceo, 2. - Fruto siempre drupáceo, mas ó menos carnudo, 3 .

2. Siempre una cápsula; ovario con algunas celdas conteniendo uno ó algunos óvulos. T. I. ClusieAs. A. - Tan pronto una cápsula como una drupa; ovario de dos celdas con 2 óvulos ó unilocular con uno hasta tres huevecillos. T. II. Calofyleas. Caxeleas ó Symfonieas. - G. I. Calophrllum calaba, Jacq.: C. T. V., 440. G. II. Rhedia laterifolia, L.: C. T. V., 282. - G. III. CANella alba, Murr. - G. IV. Cinvanodendron corticosum, Miers.

3. Ovario de alguras celdas que contienen cada una un solo óvulo. T. III. Garcinieas. - Mammea Americana, L.:C. T. V., 817.Garcinia mangostona. - Ovario con algunas celdas conteniendo cada una muchos óvulos. T. IV. Moronobeas. Moronobea coccinea, Aubl. C. T. V., 121.

A. Clusia, L. - 1. Flores blancas ó amarillentas, 2. - Flores rosadas mas ó menos pálidas; árbol muy ramoso y bastante coposo que se eleva comoá 25 ó $30^{\prime}$ de altura, muchas veces naciendo parásito en los árboles mas altos, y desde allí echando raices que con el tiempo se vuelven troncos, con hojas tiesas sub-recortadas, obovales coriáceas, de un primoroso color verde, de cara superior lustrosa, mientras la inferior opaca tiene muchas venitas un poco proeminentes y derechitas, lampiñas, largas de 5 á $6^{\prime \prime}$ y anchas de 3 á $4^{\prime \prime}$, con un peciolo corto, espeso, estriado y largo de $6^{\prime \prime \prime}$, hay 1 o 2 flores en el vértice de un pedúnculo corto, primorosas y grandes, de cáliz con 6 sépalos, corola con 6 á 8 pétalos largos de como 1' 1 2 , obovales ú obcordatos, estigmas 8 de ordinario o 7-9; fruto globoso de $20^{\prime \prime \prime}$ de diámetro. C. rosea, L.: C. T. V., 441.

2. Flores siempre blancas, 3. - Flores amarillo pálido; árbol de hojas redondeadas ó sub-truncas por el vértice, pecioladas largas de $2^{\prime \prime} 1_{[} 2$ a $2^{\prime \prime}$ sobre $1^{\prime \prime}$ á $1^{\prime \prime} 1_{[} 2$ de ancho, de cara superior estriadita, mientras en la superior se ven muchas venitas apenas notables, ó un poco proeminentes; pedúnculos con 2 ó 3 flores cuyo cáliz tiene 8 á 16 sépalos, y la corola 4 pétalos largos de $10^{\prime \prime \prime}-8^{\prime \prime \prime}$; como 12 estigmas; fruto sub-globoso. C. flara, $\mathrm{L}$.

3. Hojas subsesiles un poco abrazadoras por la base, venosas por sus ambas caras: árbol que se eleva como á $30^{\prime}$ de altura con hojas redondeadas ó sub-truncas por el vértice, largas de $3-4^{\prime \prime}$ sobre $2-3^{\prime \prime}$ 
de ancho, con las venas primarias numerosas, rectitas y algo proeminentes, cortamente pecioladas; pedúnculos 3 á 5 -floros, cáliz con 6 ó raras veces 4 á 8 sépalos; corola de 4 pétalos largos de como $9^{\prime \prime \prime}$; estigma 4-5. C. renosa, Jacq. - Hojas pecioladas de cara inferior sola venosa; árbol que se parece mucho al cupey ó clusia rosea, cuyas hojas redondeadas por el vértice son largas de $3-7^{\prime \prime}$ sobre $3-4^{\prime \prime}$ de ancho, con las venas primarias numerosas, de las cuales muchas son rectas; peciolo largo de 6 "' y espeso; pedúnculo con 1 o 3 -flores, con 6 á 9 sépalos y 5 pétalos largos de como $1^{\prime \prime}$; estigmas 5 , fruto colorado ovoídeo y largo de $3^{\prime \prime}$. C. alba, L.- Tovomira Plumieri, Gr. T. havetioides, Gr.

Familia 98. - MARCGRAVIEAS ó MARCGRAVIACEAS. - Vejetales fruticosos sarmentosos y trepadores ó bejucos leñosos mas ó menos largos, provistos de garras con las cuales se tienen pegados á los árboles; de hojas simples siendo las del tallo pegado diferentes de las de las ramas, alternas enteras, poco pecioladas. Flores siempre hermafroditas dispuestas en especies de umbelas terminales y entremezcladas con apéndices particulares casi con figura de cornetin y que son quizas brácteas; tales flores constan de un cáliz con 4, 5 ó 7 sépalos, cortos, empizarrados, persistentes y dispuestos en vertícilos de 2 o de 3 hojuelas; corola formada de 5 pétalos sentados, otras veces como monopétala, entera y desprendiéndose á manera de una caperuza; de ordinario muchos estambres, con anteras estrorsas, y raras veces solo unos 5 . Pistilo único formado de un ovario simple, globoso, plurilocular, polispermo, con los tabiques incompletos y las placentas multi-ovuladas, cuyo ápice está coronado por un estigma sentado con figura de estrella ó rayado. Fruto carnoso y dehiscente, cuya dehiscencia se verifica des̃de la base hasta el vértice, llerándose cada valva irregular de dicha indehiscencia un trofospermo situado por el centro de su cara interior; semillas muchísimas, pequeñitas, cuyo embrion sin endospermo es recto y cilíndrico, con la raicilla corta, pero mas larga que los cotiledones distintos, rectos y pequeños. - Mar.cgravia umbellata, L.: C. T. V., 373.

\section{CLASE XLVI. - MALVDIDEAS.}

Familia 99. - TILIÁCEAS. - Plantas herbáceas, matas, frutices, arluustos y árboles grandes y corpulentos, con hojas simples, pecioladas, enteras, festoneadas ó dentadas, lampiñas, pubescentes ó velludas, alternas y acompañada la base de su peciolo de dos estípulas caducas cuya forma y tamaño varian mucho; flores siempre hermafroditas, solitarias y axilares, ó en grupos racimosos ó apanojados y terminales, las cuales se componen de un cáliz con muchos sépalos o segmentos valvares y ordinariamente deciduos, pero las mas veces son 4 ó 5 ; corola de 4 á 5 pétalos con frecuencia glandulíferos por la base, suele faltar algunas veces; estambres muchos hipójinos de ordinario distintos, cuyas anteras biloculares son inclusas, abriéndose por grietas lonjitudinales. Pistilo simple 
formado de un ovario único, superior $\mathrm{y}$ plurilocular polispermo, de cuyo ápice sale un estilo sencillo ó á veces algunos y que suele faltar algunas raras veces ; estigma simple y entero. El fruto es una baya ó una cápsula plurilocular polisperma, ó muchos aquenios agrupados en cabeza; embrion recto o corvo alojado en un endospermo carnoso.

Tribu 12a. - Gremieds. - Flores con sépalos distintos y con pétalos que raras veces faltan; anteras ovoídeas ó redondeaditas abriéndose por una grieta lonjitudinal; conectivo no prolongado.

G. I. Triunfett. L. - Flores con pétalos siempre, 2. - Flores apétalas; vejetal fruticoso, ramoso y alto de 2 á $5^{\prime}$, aterciopelado y cuyos pelitos están dispuestos á manera de estrella, con hojas redonditas ó lobadas, desigualmente dentadas, cuyos dientes mas inferiores se vuelven glándulas obtusas, pecioladas y largas de $2^{\prime \prime}$ á 2 " 1 2; flores racimosas cuyos pedícelos igualan al fruto; sépalos peludos y provistos de un apéndice, amarillentos y largos de $1^{\prime \prime \prime} 1_{[} 2$; estambres 10; estigma bífido, aquenios globosos biloculares, lampiños, cuyo ganchito peludo iguala su diámetro, que es de $2^{\prime \prime \prime}$. T. lappula, L. : C. T. V., 96.

2. Dientes mas inferiores de las hojas semejantes á los demas ú homomorfos, 3. - Dientes mas inferiores de las hojas diferentes de los demas y transformándose en una glándula obtusa, ó heteromorfos; vejetal fruticuloso, ramoso, de como 3 á J' de alto, aterciopelado, con pelitos estrellados, cuyas hojas aovado-redonditas con una punta, desigualmente dentadas y pecioladas, son anchas de $3^{\prime \prime}$ á $5^{\prime \prime}$; flores cortamente pediceladas, cuyos pedícelos son mas cortos que los cálices, largos de $3^{\prime \prime \prime}$ é iguales á los pétalos oblongos; sépalos pubescentes y con un apéndice ó piquito; estambres 15; estigma 4-fido; ovario 4-locular. T. macrophylla, Vahl.

3. Sépalos nunca jamás con ápice glanduloso, 4. - Sépalos algunas veces con el ápice glanduloso; aquenios ovoídeo-globosos 3-4loculares, lampiños y con los ganchitos peludos é igualando á su diámetro que es de $\left.1^{\prime \prime \prime}\right]_{1} 2$ y largos de $2^{\prime \prime \prime}$; planta fruticulosa aterciopelado-peluda, cuyo pelo es estrellado, con hojas redondeaditas ó lobadas, desigualmente dentadas, cuyos dientes superiores son lanceolados; flores racimosas, cuyos pedicelos igualan al fruto, de cáliz largo de $2^{\prime \prime \prime} 1_{[2} 2$, con sépalos peludos provistos de un pico, igualando los pétalos oblongos; estambres 10; estigma apenas dentado. T. altheoides, Lam.

4. Aquenios ovoídeo-globosos 2 ó 3-loculares y lampiños, así como los ganchitos, 5. - Aquenios 3 ó 5-loculares, 7 .

5. Siempre biloculares, ordinariamente 4-spermos, 6. - Bi ó iriloculares; vejetal fruticuloso con pelo esparcido y ordinariamente simple, de hojas aovadas enteras ó cortamente 8-lobas, desigualmente aserradas, cuyos dientes superiores son oblongo-lanceolados, peciolados y largos de 2- $3^{\prime \prime}$ sobre $1^{\prime \prime} 1_{[} 4$ a $2^{\prime \prime}$ de ancho; flores fasciculadas distantes, cuyos pedícelos igualan las flores, de cáliz largo de $2^{\prime \prime}$ á $3^{\prime \prime \prime}$ é igualando los pétalos oblongos, con sépalos peludos y picudos; estambres 20 , rara rez 10 ; estigma diminuto y sub-entero. T. grossularifolia, Rich. 
6. Frutice muy ramoso y que se eleva como á 4 ó 6 ' de altura. pubescente, con pelo estrellado, raramente aterciopelado, algunas veces con la cara superior de las hojas alampiñada, de hojas redondeaditas, 3-5-lobas ó sub-enteras, desigualmente dentadas y cuyos dientes superiores son lanceolados; flores en racimos interrumpidos, cuyos pedícelos igualan el fruto, cáliz de $3^{\prime \prime \prime}$ de largo é igualando los pétalos espatulados y cuyos sépalos son peludos y picudos; estambres 15; estigma apenas dentado. T. semitriloba, L. : C. T.V., 97.

7. 3 á 5-loculares peludo-tomentosos, con los ganchitos lampiños y la mitad de su diámetro que es de $1^{\prime \prime \prime}$ ] [2; frutice de 3 á 4 ' de altura, cuyos ramos escabrosos y con cerdas pequeñas y estrelladas llevan hojas redondeaditas, desigualmente dentadas, ordinariamente angulosas, con una punta, de cara superior alampiñada, mientras la inferior es pubescente, las superiores son oblongas; flores en haces distantes, cuyos pedícelos igualan el fruto ; cáliz largo como de 3"', con sépalos peludos y picudos; pétalos espatulados; estambres 15: estigma 8-5-fido. T. rhomboidea, Jacq. - T. rhomboidea, Sw. Siempre 5-loculares, globosos y lampiños, con los ganchitos lampiños; frutice ó mata fruticulosa, alto de '3 á 4 ' y cuyos ramos velludos con pelo flexuoso llevan hojas anchamente aovadas, con una punta, y desigualmente festoneadas, cubiertas de pelo simple y esparcido ó alampiñadas y cuyas superiores son lanceoladas; flores en hacecillos distantes, cuyos pedícelos son mucho mas largos que los frutos, de cáliz con sépalos lampiños picudos, lanceolado-lineares largos de $8^{\prime \prime \prime}$ y mas que los pétalos obovales, que tienen solo $6^{\prime \prime \prime}$; estambres 10; estigma 5-fido. T. grandiflora, Vahl.

G. II. Corchorus, L. - 1. Estambres hipójinos; cúpula ninguna: plantas herbáceas aruales ó fruticulosas, 2. - Estambres insertos en el vértice de un ginóforo corto cuya base está ceñida por una cúpula ondeada; frutice bastante ramoso y tomentoso alto de 3 á 5', con hojas aovado-lanceoladas ú oblongas y obtusas, festoneadas, largas de $1^{\prime \prime}$ á $2^{\prime \prime}$, pecioladas, y de cara inferior lijeramente peluda; 2-8 pedícelos dispuestos como en umbela, casi tan largos como los pedúnculos; flores de cáliz con sépalos tomentosos, largos de como $3^{\prime \prime \prime}$ é iguales á los pétalos oboval-oblongos; estambres indefinidos; cápsula furfuráceo-lanuda, oblonga, obtusa, corva, 4-locular, larga de $6^{\prime \prime \prime}$ y ancha de 2 á $3^{\prime \prime \prime}$. C. hirsutus, L.

2. Vejetales mas ó menos lampiños, 3. - Vejetales munca lampiños, pero siempre mas ó menos peludos, 5 .

3. Enteramente lampiños, 4. - Lampiños, pero cuyo tallo está adornado de una línea pubescente y la cápsula pubescentita, 3-locular, linear, rectita y con tres dientes bífidos en el ápice, hojas aovadas, aguzadas, aserradas, cuyos dos dientes inferiores llevan una punta por el dorso y se terminan por una cerda corta; flores fasciculadas. C. astuans, L.

4. Enteramente lampiño, de tallo herbáceo ramoso que se eleva á 3 ó $6^{\prime}$ de altura, con hojas aovado-oblongas ó aovadas, largas de $5^{\prime \prime}$ ó mas pequeñas, pecioladas, con una punta, aserradas y cuyos dos dientes mas inferiores llevan una punta por el dorso y se terminan por una cerda larga; flores sub-solitarias, de corola con pétalos es- 
patulados largos de 3 á 4" é iguales á los sépalos; estambres indefinidos; cápsula lampiña, linear-rectita, sub-cilínárico-torulosa, larga de $2^{\prime \prime}$ sobre $2^{\prime \prime \prime}$ de diámetro, terminada por 5 puas cortitas, 5 -locular y con falsos tabiques transversos y completos. C'. olitorius, L. : - Enteramente lampiño seria, á no ser pubescentita la cápsula á lo largo de sus suturas, y á no tener de ordinario el tallo una sola línea muy finamente pubescente; frutice ramosísimo, alto de 2 á $4^{\prime}$, con los ramos derechos y dispuestos como á manera de escoba, de hojas aovadas, aguzadas, oblongo-lanceoladas y largas de $1^{\prime \prime} 1_{[2} 2$ á $3^{\prime \prime}$, pero ordinariamente mucho mas pequeñas, pecioladas, aserradas y con los dientes iguales y sin cerdas; flores fasciculadas porª́ 4 ó solitarias, con los pétalos obóvales ó espatulados, largos como de $2^{\prime \prime \prime} y$ sin embargo ordinariamente algo mas cortos que los sépalos estrechos; estambres muchos ó 4; cápsula linear, recta. sub-comprimida, larga de $1\left[2^{\prime \prime}\right.$ á $2^{\prime \prime} 1_{1} 2$ sobre $1^{\prime \prime \prime}$ de ancho, bilocular y con dos dientes bífidos en el ápice. C. siliquosus, L.

5. Cápsula lampiña oblongo-linear, larga de $8^{\prime \prime \prime}$ sobre $2^{\prime \prime \prime}$ de ancho, con 6 ángulos, de los cuales dos ó tres son alados, rectos, con 3 puas enteras ó bífidas por el ápice, 3-locular y con falsos tabiques transversos é incompletos; hojas aovadas con una punta, alampiñadas, aserradas, con los dientes iguales, flores sub-fasciculadas ordinariamente, 2 ó 1. C. acutangulus, L. - Cápsula peluda, linear. corva por la base, larga de $1^{\prime \prime}$ á $1^{\prime \prime} 1_{[} 4$ sobre $\left.1^{\prime \prime \prime}\right]_{[2}$ de ancho, subtorulosa, aguzada con el vértice, provisto de una punta entera, 2locular; yerba fruticulosa con pelo esparcido, y de hojas aovadolanceoladas ú oblongas, alampiñadas, festoneado-dentadas, con los dientes iguales y largas de $1^{\prime}$ á $2^{\prime \prime}$; flores fasciculadas por grupos de 3 ó solitarias, cuyos pétalos largos de como 2-3"', son espatulados: estambres indefinidos. C. hirsutus, L. C. tortipes. St. Hil.

G. 1II. Muntingia calabura, L. : C. T. V., 300.

Tribu 2. - Sló́neas. - Sépalos reunidos por la base ó libres en el vertícilo interior, anteras oblongas ó lineares, con el conectivo prolongándose mas allá de las celdas. - G. I. SloáneA, L. - Flores solitarias y cabizbajas, đe cáliz aterciopelado en 2 séries, cuya esterior 4-partida tiene los segmentos aovados y con una punta, mientras la interior es 4-fila, con los sépalos largos de $4^{\prime \prime \prime}$ á $5^{\prime \prime \prime}$ y la mitad tan achos, algunas veces mas cortos, trifidos ó sub-enteros; árbol que se eleva desde $60^{\prime}$ hasta $100^{\prime}$ de altura, muy ramoso y cuyo tronco alcanza un diámetro de $4^{\prime}$, con hojas oblongo-aguzadas, sub-enteras y lampiñas; estípulas pequeñas y caducas; estambres pubescentes mas cortos que la série esterior calizinal, larga de 6 "'. cuyos filamentos muy cortos llevan anteras oblongo-lineares, largas de $2^{\prime \prime \prime}$, sub-acorazonadas por la base y aguzándose por el vértice. con el dorso adornardo de un apéndice corto, abriéndose por poros situados por debajo del ápice; cápsula 4-locular globosa, erizada, con cerdas rectas, de 3-4" de diámetro y cuyas senillas están envueltas en un arillo encarnado. S. Jamaicensis, Hook. - Flores en racimos pubescentes mucho mas cortos que las hojas del cáliz formado de una sola série 5-6-partida, cuyos segmentos oblongo-lanceolados son aguzados; árbol muy alto, pero algo menos que el anterior, mas tan 
corpulento, con hojas ovales redondeadas por el vértice, sub-enteras ó apenas dentaditas, alampinadas, ordinariamente largas de 8 á $12^{\prime \prime}$, con el peciolo pubescente; estípulas lineares, elongadas y largas de 6"'. Estambres pubescentes, largos de $4^{\prime \prime \prime}$ y saliendo fuera del cáliz, euyos filamentos lineares son tan largos como las anteras subuladolineares, abriéndose por un poro oval que por fin se vuelve una grieta lateral, con un apéndice filiforme del largo de la celda, estilo eserto 5-4-fido, con los brazos lineares terminados por un estimma diminuto; cápsula 4-locular sub-globosa, S. Massoni, Sw. C. T. V., 98.

G. II. Apeiba tibourbou, Aubl.: C. T. V., 299.

Familia 100. - MALVACEAS. - Plantas herbáceas anuales, bisanuales y vivaces, matas, frutices, arbustos y hasta árboles, mas ó menos grandes, con hojas simples enteras, dentadas, angulosas, mas ó menos lobadas y á veces dijitadas, palminervias y siempre alternas, ordinariamente con pelo dispuesto á manera de estreila, pecioladas y acompañadas de 2 estípulas situadas por la base del peciolo, libres, caducas, de forma y tamaño muy variados. Flores primorosas siempre hermafroditas, solitarias y axilares, en espigas ó panojas terminales, cuyo pedícelo sale siempre de la axila de una hojuela floral y se componen de un cáliz monosépalo campanudo, con divisiones nuas ó menos profundas, ordinariamente de estivacion valvar, que están algunas veces reemplazadas por igual número de dientes; con frecuencia su base está ceñida ó envuelta por un calíeulo ó invólucro calizinal monófilo, cuyas divisiones mas ó menos estrechas varían entre 3 y 15 y cuya forma y tamaño varian mucho: raras veces está entero; corola de 5 pétalos distintos y ungüiculados, cuya base ó cuyas uñas están reunidas y soldadas entre sí por medio del andróforo, y entónces se ha vuelto corola seudo-monopétala que se desprende $\mathrm{y}$ ie cae así entera, llevando consigo el andróforo que contiene en su interior el estilo; es hipojjina, sus pétalos son iguales, de forma y tamaño muy variados $y$ de prefloracion torcida; hay muchísimos estambres monodelfos, rarísimas veces 10 , cuyas anteras sostenidas por filamentos ó andróforos secundarios que se sepazan del andróforo principal, dispuesto á manera de columna en el centro de las flores, son ordinariamente reniformes y uniloculares, con el pólen globoso y pelierizado; pistilo simple formado de un ovario superior compuesto y cuyas celdas separadas constituyen otros tantos ovarios agrupados circularmente al rededor de un eje central, cuyo vértice lleva un estilo filiforme, largo, sencillo, pero que no tarda en dividirse hácia su $]_{[} 3$ superior en 5 á 20 divisiones, cada cual con su estigma correspondiente cabezudo ó con figura de un hisopo mas ó menos velludo ó aterciopelado y que salen fuera por la abertura que se halla en el ápice del andróforo, donde diverjen; cuando el ovario es único, lo que sucede bastantes veces, es 5-locular y polispermo, mientras que en el caso precedente cada ovario parcial es unilocular, mono ó 2-spermo. El fruto consiste en 5 hasta 20 carpelos ó cajitas monospermas, de forma y tamaño muy variados, uniloculares y agrupados circularmente como ya lo tenemos señalado para los ovarios: algunas veces con 2 y mas semillas; otras veces es una cápsula única mas ó menos gruesa, ordinaria- 
mente 5-locular, abriéndose por 3 o 5 valvas; semillas arriñonadas, globosas y á veces triangulares, lisas ó ásperas, desnudas ó peludas, con un embrion corvo sin endospermo y cuyos cotiledones foliáceos están doblados sobre la raicilla.

\section{Análisis dicotómica de las tribus.}

1. Flores siempre con un calículo, 2. - Flores de cáliz sencillo y nunca acompañado de calículo ninguno; carpelos verticilados dehi:centes que se desprenden del eje en tantas de cajitas o en tentas valvas septíferas, monospermas, y cuyo número correspondeal de las estigmas; columna ó andróforo anterífero solamente por el vértice. T. I. Sineas. A.

2. Fruto nunca capsular, 3. - Fruto siempre capsular, con tantas celdas cuantos estigmas hay, ordinariamente loculícido, abriéndose por 3-5-10 valvas septíferas, alguna vez que otra indebiscente, androforo 5-dentado por el vértice. T. IV. HiBISCEAs. D.

3. Tantos carpelos cuantos estigmas hay, verticilados, distintos y ordinariamente acabando por desprenderse del eje central en otras tantas cajitas monospermas; andróforo anterífero solamente por el vértice. T. II. Málveas. B. - Carpelos en número la mitad menor que el de los estigmas, uni-orulados y por fin separándose los unos de los otros y desprendiéndose del eje, las mas veces armados; andróforo de ordinario 5-dentado por el vértice. T. III. Unéveas. C.

A. G. I. SıDA, L.-1. Cáliz siempre 5-fido, de tuho mas ó menos cilíndrico, hojas siempre enteras, 2. - Cáliz siempre 5-fido ó 5dentado, con el tubo de ordinario anguloso; carpidios con dos picos ó dos puntas en el ápice por dorde se abren, 3.

2. Tubo del cáliz sub-cilíndrico; carpidios obtusitos é indehiscentes; flores en corimbos terminales; vejetal fruticuloso, de tallo recto, con forma de varita y ramoso por el vértice, pelierizado o alampiñado, con pelo simple, cuyas hojas lineares, elongadas, bien enteras, son largas de 2-3" sobre 2-3"' de ancho, y acompañadas de estípulas setáceas é iguales al peciolo; corimbos con pocas flores, cuyo cáliz, largo de 2 á $3^{\prime \prime \prime}$, con figura de cúpula y por fin connivente y encerrando los 5 á 8 carpidios lampiños, tiene sus lóbulos deltoídeos y mas cortos que los pétalos blancos. S. linifolia, Juss. - Tubo del cáliz cilíndrico; carpidios separándose de su pico bífido y dehiscente á favor de un anillo transverso y calloso; semillas pubescentes; panojas flojas y terminales. Mata fruticulosa cuyo tallo se eleva derecho á 3 ó $4^{\prime}$ de altura, pubescente y con pelo estrellado y lleva hojas acorazonadas, aguzadas, de cara superior lampiña, mientras la inferior es tomentosa, cortamente pecioladas, algo aguzadas por la base y de vértice obtusito, 2 ó 3 reces mas anchas que largas; panojas aljiertas, con brazos distantes, paucífloras y con pedícelos racimosos, filiformes y cabizbajos, cáliz largo de $1^{\prime \prime \prime}$, con los lobulos aovados y puntiagudos, 2 reces mas cortos que los pétalos amarilios; 5 carpidios, cuyas semillas angulosas superiormente son pubescentes en los ángulos. S. divergens, Benth. S. periplocifolin. Macf. 
3. Hojas aguzadas ó redondeadas por la base, 4. -- Hojas acorazonadas por la base, 7 .

4. Flores cortamente pediceladas ó subsesiles, pedícelos no articulados por encima del medio, 5. - Flores pediceladas, cuyos pedícelos son articulados por encima del medio, 6 .

5. Mata fruticulosa cuyo tallo ramoso se eleva á 3 ó $5^{\prime}$ de altura, con hojas elíptico-lanceoladas, aserradas por encima de la base, romboídeo-lanceoladas, aguzadas ú obtusitas, de cara inferior lampiña, estrellado-pubescente ó estrigosa sobre las nervaduras, pecioladas; estípulas lineares ó setáceas tan largas como los peciolos y los pedícelos; flores axilares de ordinario fasciculadas ó solitarias, cortamente pediceladas, cuyo cáliz 5 -fido es mas corto que los pétalos amarillos; carpidios 8 á 10, reticulados, con dos picos ó dos puntas, lampiños ó pubescentes por el dorso y sobre el pico, recto ó por fin corvo y largo de $1_{1} 2^{\prime \prime}$ á $1^{\prime \prime \prime}$. S. carpinifolia, L. S. stipulata, Cav. S. acuta, Burm.

6. Frutice ó mata fruticulosa de tallo ramoso que se cleva á 2 ó $3^{\prime}$ de altura, pubescente ó alampiñado y con hojas romboídeo-lanceoladas ó lanceoladas, aserradas por encima de la base, óvalo-lanceoladas ó elíptico-lanceoladas, cara inferior pálida y pubescente; flores axilares y solitarias, de pedícelos elongados, casi tan largos como

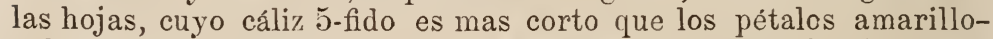
pálidos, con una mancha roja por la base; carpidios 8 á 10, raras veces 5, con dos picos, dos dientes ó un pico nada mas, lampiños y peludos en el pico. S. rhombifolia, L. S. retusa, S. alba, Cav.

7. Tubo calizinal 5-10-anguloso, 8. - Tubo calizinal cilíndrico, 11 .

8. Lóbulos calizinales subulados y tubo con 5 ángulos, 9. - Tubo 5-10-anguloso, lóbulos calizinales grandes y deltoídeos, 10.

9. Planta herbácea, peluda ó alampiñada, de tallos inclinados y difusos, con pelo ordinariamente simple, cuyas hojas acorazonadotriangulares ó acorazonado-aovadas, agudas y obtusas por el vértice, son bien lampiñas y con el peciolo casi tan largo como el limbo; pedícelos filiformes de ordinario, solitarios, articulados, tan largos ó mas que el peciolo; cáliz largo de $2^{\prime \prime \prime}$, 5-fido, mas corto que los pétalos amarillos; carpidios 5 , con dos picos peludos y tan largos como ellos. S. supina, l'Her. S. pilosa, Cav. S. procumbens, Sw. S. dombeyana, Dc.

10. Vejetal fruticuloso de 2 á $4^{\prime}$ de alto, muy ramoso, aterciopelado, tomentoso, con el pelo estrellado y cuyas hojas sub-acorazonadas ó cordiformes, con una punta ú obtusas y festoneado-aserradas, largamente pecioladas; flores de ordinario axilares, cuyos pedícelos solitarios son casi tan largos como el peciolo, de ordinario con un ramo floral accesorio ó con todas las flores agrupadas en la axila, cáliz tomentoso 5-fido, de tubo con 5 ángulos y con los lóbulos por fin conniventes; pétalos esertos de color amarillo teñido de bruno; carpidios 10-12-truncos y peludos por el vértice ó bi-aristados ó bidentados. S. cordifolia, L. S. althcifolia, Sw. S. multiflora, Micans. S. rotundifolia herbacea, y Cav. 
11. Mata fruticulosa alampiñada, con pelo diminuto y estrellado, de tallo delgado, ramoso y que se eleva hasta 4 y 5 ', de hojas acorazonadas, con una punta, festoneado-aserradas, lampiñas, grandes y largas de 3-4" sobre $3^{\prime \prime}$ de ancho, cuyo peciolo iguala casi el limbo; flores apanojadas, con los brazos primarios estendidos y racimosos, en parte axilares, mientras los secundarios son corimbosos, con 3 á 7 flores de pedúnculo articulado y cuyo cáliz, largo de $2^{\prime \prime \prime}, 5$-fido y pubescentito, tiene lóbulos cortamente subulados y es la mitad mas corto que los pétalos amarillos y por fin abierto; carpidios 5-6 cortamente bi-dentados y pubescentes. S. pyramidata, Cav.

G. II. Abutiron, T.-1. Carpidios 5 ó mas, 2.-Carpidios siempre en número mayor de 5 y de 12 á 20 , membranáceos, hinchados, redondeados por el vértice, muy tardíos para separarse y bivalvares por la base, 4-5 spermos ó monospermos por causa de aborto. Mata fruticulosa, ramosa, aterciopelada y de hojas acorazonado-redondeaditas, con una punta, festoneadas, pecioladas las inferiores, y sesiles las superiores; pedícelos axilares solitarios articulados por debajo del ápice, casi iguales á las hojas; cáliz largo de $2^{\prime \prime \prime}$, profundamente 5-fido y con los lóbulos aovados y puntiagudos, mas cortos que los pétalos blancos y largos de 3-4"' ; carpidios pulidos, apenas pubescentitos y largos de 4 á $6^{\prime \prime \prime}$. A. crispum, G. Don. Sida crispum, L. Bastardia crispa, St.-Hil.

2. Carpidios 5 á 10, 12 ó muchos, 3. - Carpidios siempre 5, biarticulados y estrechados por un anillo calloso transversal ó tabique incompleto, no hinchados, dehiscentes superiormente, cura parte superior contiene dos semillas y la inferior una; frutice ó mata fruticulosa de $4^{\prime}$ á $6^{\prime}$ y hasta $10^{\prime}$ de altura, bastante ramoso, pubescente ó alampiñado y de hojas cordiformes con una punta $o$ aguzadas, bien enteras ó apenas festoneadas, ordinariamente de cara superior alampiñada, mientras la inferior blanca está provista de pelito estrellado; flores apanojadas, con los brazos apartados, abiertos, terminadas las panojas por corimbos paucífloros ó unífloros, cuyos pedícelos elongados son articulados por debajo del ápice, cáliz pequeño largo de $1^{\prime \prime \prime}$ á $2^{\prime \prime \prime}$, diverjente, 5 -fido y con lobulos deltoídeos 2 a 3 veces mas cortos que los pétalos amarillos; carpidios diverjentes, ovoídeos, estrechados por debajo del medio, puntiagudos ó mucronados y 3 á 4 veces mas largos que el cáliz; semillas pubescentes. A. periplocifolium, G. Don. Sida periplocifolium, L. S. excelsior, Cav. S'. hernandioides, L'Her.

3. Carpidios 5 ó muchos, 4. - Carpidios de ó á 10 ó doce, 5.

4. Coriáceos, comprimidos, con una punta ó un pico ú obtusos. diverjentes por el ápice, dehiscentes á lo largo de una sutura ventral; y por fin segun una línea dorsal; arbusto o mata fruticulosa, que se eleva desde $2^{\prime}$ hasta $10^{\prime}$ de altura, aterciopelado-tomentoso, ordinariamente con el tallo pelıdo, de hojas acolazonado-redondeadas, con una punta, desigualmente dentadas, de cara inferior blanca y aterciopelada; pedícelos axilares sub-solitarios, articulados por rlebajo del ápice. casi iguales al peciolo; cáliz largo de $4^{\prime \prime \prime}$ á 5"', 丂̆fido, con los lóbulos aovados puntiagudos y el tubo no plegado, dos veces mas cortos que los pétalos amarillo-anaranjados, con una 
mancha mas oscura por la base; carpidios de 12 á 30, mucronados, iguales al cáliz acresciente ó un poco mas largos que él, con 3 á 9 semillas verrugosas y lampiñas. A. Indicum-A siaticum-livosutum, G. Don. A. graveolens, W. Arn. Sidla Indica-Americana-Asiatica, L. S. populnifolia é hivta, Lam. S. pubescens, Cav. S. abutiloides, Macf.

5. De 5 á 10 , ni hinchados ni estrechados, pero sí con 2 picos, 2 ó 3 semillas y dehiscentes entre el pico y la línea dorsal. Frutice ó mata fruticulosa, derecha, ramosa, escabra ó pubescente con pelito muy diminuto, de hojas acorazonado-redondeadas, con una puntita, festoneadas y un poco trílobas; pedícelos articulados hácia el vértice, dispuestos en corimbos ó en umbelas, sostenidos por pedúnculos axilares ó racimosos á lo largo del tallo ó de las ramas herbáceas; cáliz peludo 5-fido, por fin globoso y ancho de $4^{\prime \prime \prime}$, dos veces mas corto que los pétalos amarillos y con los lóbulos subulados; carpidios 5 , aovados, pelierizados, casi iguales con el cáliz aplicado á ellos ó cortamente esertos, dos veces mas largos que su pico aristado, con semillas muricadas y lampiñas. A. umbellatum, $\mathrm{S}_{\mathrm{w}}$. - De 5 á 12, membranáceos, sub-hinchados, con dos picos y bivalvares por la base; hojas de ordinario 3-5-fidas; arbusto lampiño con bojas 3fidas, aserradas por encima de la base acorazonada con los lóbulos puntiagudos; pedícelos axilares solitarios no articulados, casi igualando las hojas; cáliz profundamente 5-fido, largo de 8' aovado-lanceolados, aguzados, dos veces mas larcos que el tubo $\mathrm{y}$ dos veces mas cortos que los pétalos anaranjado-amarillos estriado: de colorado y un poco mas cortos que los estilos; carpidios 8. $A$. striatum.

B. G.I. Malvaz̃trum, As. Gr. Como 15 carpidios sin arista, lampiños y pubescentes por el vértice inclinado, liso sobre el pico; flores espigadas; mata fruticulosa como de 2 á 3 ', derecha y ramosa ó frutice que se eleva de 5 á $6^{\prime}$ de altura, pubescente ó blanquecino, con hojas deltoídeas ó aovadas con una punta, festoneado-aserradas por encima de la base, de cara inferior ordinariamente de color verde pálido ó lijeramente blanquecina y cuyo pelito es suave; espigas de las flores oblongas, cuyas algunas reducidas son axilares; calículos con 3 dirisiones lanceoladas igualando el cáliz, cuyos lobos aovados ó aovado-lanceolados son puntiagudos y tan largos como el tubo ó un poco mas; pétalos anaranjados ob-cordados y cortamente esertos. M. spicatum, Gr. Malva spicata, L. M. Americana, A. Rich. M. polystachia, Cav. - Carpidios 10 ó mas, tricuspidados, con la parte superior pelierizada á la vez que estriada sobre el pico; flores axilares fasciculadas ó solitarias; mata fruticulosa alta de 1 á 2 ', sub-estrigosa y cuyo pelo está aplicado al tallo, con hojas aovadolanceoladas ó romboídeo-lanceoladas, aserradas; flores superiores algunas veces aproximadas y algo espigadas, cortamente pedunculadas con el calículo, cuyos tres segmentos lineares son por fin mas cortos que el cáliz ú obsoletos. M. tricuspidatum, As. Gr. - Malva Americana, L. M. Coromandelina, Sw. M. Dominigensis, Spr. C. T. V., 446.

G. II. Anoda hastata, Cav.: C. T. V., 451. 
C. G. I. URena, L. - Hojas sea trífidas por arriba del medio ó con lóluulos apenas pronunciados y enteros, de cara inferior glauco-pubescente, y con lóbulos aovados ú oblongos y aserraditos, de ordinario con una ó á reces con tres glándulas ovales hendidas y situadas en la base de las nervaduras; mata fruticulosa o frutice, que se eleva á 2-3 y 5 ' de altura, bastante ramoso y cuyos ramos largos son en varita y moradusco-lampiños; flores axilares sub-solitarias bastante grandes y color de rosa subido, cuyos pétalos, de 6 á $8^{\prime \prime \prime}$, son tres veces mas largos que el cáliz. U. lobata, L.- Variedades: segmentos del invólucro escediendo mas ó menos el cáliz; carpidios pubescentes. $U$. Americanc, L. $U$. reticulata, Macf. $U$. viminea, Cav. U. Sicartzii, A. Rich. U. microcarpa, De. Divisiones del calículo bien iguales con el cáliz; carpidios tomentosos. U. Suartzii, Dc. U. sinuata, Sw. U. Americana y U. riberia, Sm.: C. T. V., 642. - Hojas cuyos 3 ó 5 lóbulos principan mas abajo que el medio, son romboídeos, estrechaditos por la base, desigualmente aserrados y con 3 glándulas hendidas y elípticas; cara inferior glauco-pubescente. Mata fruticulosa ramosa y qie se eleva á $2^{\prime}$ o $3^{\prime}$ de altura y se parece mucho á la anterior; seg̨mentos del invólucro ig̣alando el cáliz; flores bastante grandes, de color rosado, cuyos pétalos son largos de $6^{\prime \prime \prime}$ y 3 reces mas que el cáliz; carpidios pelierizados. U. sinuata, L. $L^{\prime}$. pavadoxa, Kth. U. Swartzii, Macf.: C. T. V., 612.

G. II. MAlachra, L. 1. Hojas muy raras veces lobadas, pero casi siempre enteras, 2. - Hojas de ordinario trífidas hasta el medio, cuyo lóbulo mediano es oblongo y puntiagudo ó aovało, así como las hojas superiores; mata fruticosa, muy ramosa, pelierizada y cuyo pelo largo y tieso es muy punzante, que se eleva á $5^{\prime}$ ó $6^{\prime}$ de altura, cuyos capitulos florales, ordinariamente pedunculados, están á veces acompañados de uno sesil y accesorio, con cáliz profundamente こ-fido, dos veces mas cortos que los pétalos de color purpúreo blanquecino y cuyos lóbulos son lanceolados; carpidios lampiños la mitad mas cortos que el cáliz. M. radiata, L.

2. Hojas redondeaditas, 3. - Hojas aovadas ol,tusitas, aserradodentadas, enteras; planta fruticulosa, alta de 3 á 5', ramosa, cuyos capitulos florales son sentados; cáliz profundamente 5 -fido, 2 veces mas corto que los pétalos purpuráceos y cuyos lóbulos son lanceolados ó aovadlo-lanceolados: carpidios velludos muy convexos por el dorso y mas cortos que el cáliz. M. urens, Poil. M. ciliala, Poir.

3. Algunas veces lobadas: mata ordinariamente pelierizada, alta de $1^{\prime} l_{1} 2$ á $3^{\prime}$, ramosa, cuyos capitulos florales son pedunculados; cáliz mas ó menos profundamente 5-fido, con lóbulos aovado-lanceolados, dos veces mas corto que los pétalos amarillos y casi igual á los carpidios lampiños y conniventes por encimá de ellos. M. palmata, Mch. M.trilozata, Desf. C. T. V.652. Enteras y muy raras veces lobadas; flores en capitulos peduncularos ó á veces subsesiles, con el cáliz 5-fido y por fin 5-partido, 2 á 3 veces mas corto que los pétalos blancos ó amarillos, y con lobulos subulados; carpidios alampiñados, la mitad mas cortos que el cáliz, de puas lineares y erguidas. Mf. capitata, L.: C. T. V., 6.5.5. 
G. IlI. Pavonia, Cav. 1. Invólucro con 5-15 segmentos, 2.-Calículo con 10 á 12 hojitas distantes las unas de las otras, filiformes y cuyo vértice se vuelve de repente un limbo pequeño; carpidios dehiscentes segun la línea dorsal; flores agrupadas, cuyos capitulos axilares son involucrados; hojas con puntitos. Frutice tomentoso, con hojas acorazonado-redondeaditas, irregularmente festoneadolanceoladas, de cara inferior blancuzca; invólucro de los capitulos pedunculados con hojuelas redondeaditas; segmentos del calículo casi igualando el cáliz, y terminados en un limbo diminuto oblongolanceolado y sub-peltado; carpidios lampiños obovales, corros por el ápice, convexos y estriados sobre el dorso y sin pico. P. bracteosa, Benth. Malachra trinervis. Prl.

2 . Invólucro 5 -15-fido, carpidios dehiscentes segun la línea ventral ó por fin segun la dorsal; hojas ásperas con puntos transparentes; flores fasciculadas cuyos hacecillos son involucrados; mata fruticulosa de 3 á $5^{\prime}$ de alto y bastante ramosa cuyas hojas oblongas son aserradas; hacecillos florales terminales ó axilares, con los pedúnculos distantes, cuyos inferiores son mas largos que los superiores, de pedícelos casi tan largos como el invólucro profundamente 5-8-fido, con los lóbulos lanceolados y aguzados, á veces mas largos que el cáliz; flores blancas; carpidios lampiños, convexos por el dorso, 3 aristados, cuya arista terminal está distante de las otras. P. typhalea, Cav. Urena typhalea, L. - Calículo con 5 á 15 hojuelas, carpidios indehiscentes; flores solitarias, racimosas ó corimbosas; frutice muy ramoso y de ramos largos, delgados y en varita que se eleva desde 3 hasta $9^{\prime}$ de altura, lampiños el tallo y ramos, mientras las hojas acorazonadas son provistas de pelo estrellado y esparcido por su superficie; pedúnculos axilares con una sola flor amarilla y bastante grande; las hojuelas del calículo distintas y en número de 6-8, son oblongo-lineares é igualan el cáliz 3 veces mas corto que los pétalos largos de $12^{\prime \prime \prime}$, y sin embargo mas cortos que la columna anterífera; carpidios lampiños con tres espinas tiesas, tan largas como ellos, diverjentes, una infraterminal y las otras dos situadas en el medio de la márjen. P. spinifex, Cav. Hibiscus spinifex, L. Paristata, Car. C. T. V.. 643.

G. IV. Malvariscus arboreus, Cav. M. mollis, Dc. Hibiscus malvariscus, $\mathrm{L}$.

D. Hibisceas. G. I. Abelnoschus, Med. - Mata fruticulosa muy ramosa, pelierizada, cuyos ramos largos y estendidos llevan hojas alabardadas é irregularmente dentadas, frecuentemente con lóbulos accesorios por la base; flores grandes solitarias amarillas, con la uña de los pétalos de color carmesí, con pedícelos axilares y casi igualando el peciolo; calículo con 6-10 hojuelas lineares sub-persistentes, tres veces mas cortas que el cáliz, cápsula oblongo-lanceolada, peluda, cuyas semillas lampiñas y estriadas huelen á almizcle. A. moschatus, Mch.: C. T. T., 298. - Planta herbácea anual cuyo tallo derecho, mas ó menos ramoso, se eleva desde 3 hasta $5^{\prime}$ de altura, peluda y con hojas 5-lobas irregularmente aserradas, undulosas, acorazonadas, velludas cuando tiernas y por fin volviéndose lampiñas $o$ á lo menos alampiñadas cuando adultas; flores axilares. 
solitarias, grandes, amarillas, con las uñas coloradas, cuyos pedícelos son mas cortos que el peciolo; calículo con 9 á 12 lacinias caducas y cuya base sola persiste, tres veces mas cortas que el cáliz 5 -dentado; pétalos largoos de $1^{\prime \prime} I_{[} 2$ á $2^{\prime \prime}$; cápsula oblongo-lanceolada, alampiñada, con 10 surcos y cerdas, cuyas semillas, á veces peluditas, son sub-estriadas $y$ sin olor particular. A. esculentus, IV. A.: C. T. V., 639 .

G. II. Hibiscus, L. 1. Semillas siempre lampiñas, 2. - Semillas lampiñas pubescentes ó algodonosas; hojuelas del involúcelo simples y distintas; cáliz aplicado sobre la cípsula, 3.

2. Hojuelas del calículo distintas, ensanchadas por el vértice: cáliz 5-fido y ventrudo ; frutice pubescentito con pelito denso, cuyas hojas acorazonadas y festoneadas son obtusitas; pedícelos axilares, articulados, casi tan largos como las hojas; divisiones del involúcelo 7-10 cilíndricas por la base, aovadas obtusitas, sin glándulas y cuyo vértice se ha vuelto limbo reniforme, dos veces mas cortas que el cáliz dos veces mas corto que la corola, cuyos pétalos rosados y abiertos tienen $12^{\prime \prime \prime}$ de largo; cápsula ovoídeo-globosa, peluda, contenida en el cáliz acreciente, con semillas algo muricaditas. $H$. sororius, L. - Hojitas del involúcelo distintas, de ordinario dilatadas en limbo bifurcado; cáliz 5-fido aplicado sobre la cápsula, cuyos segmentos llevan una glándula grande y situada sobre la parte esterior de la costilla; mata fruticosa ramosísima, como aguijonosa y áspera, cuyos ramos largos y en varita llevan hojas 3-5-lobas ó alabardadas, desigualmente aserradas, cuyos pedúnculos son mucronados; pedícelos axilares, articulados, mas cortos que el peciolo ó igualándole; segmentos del invólucro 10-12, muy ásperos, iguales ó mas largos que el cáliz pelierizado 4 á 6 veces mas corto que la corola, muy grande y color rosado con los lóbulos aovados, aguzados, 3-nervios y glandulíferos por el dorso; cápsula ovoídea, peluda, igualando el cáliz y larga de $10^{\prime \prime \prime}$ solamente; semillas apenas mucronaditas. H. bifurcatus, Cav. H. bicornis, Mey.

3. Semillas lampiñas ó pubescentes, 4. - Semillas nunca lampiñas, pero siempre como algodonosas; frutice como de $5^{\prime}$ de alto, lampiño, con hojas deltoídeas, aguzadas, bien festoneado-aserradas, algunas veces lijeramente lobadas; pedícelos axilares algo mas largos que las hojas y articulados hácia en medio; hojuelas del invólúcelo 9-10, lineares, iguales ó mas largas que el cáliz 5-fido de lóbulos aovados con una punta, dos veces mas corto que la corola, cuyos pétalos, largos de 6 á $8^{\prime \prime \prime}$ y abiertos, son de color morado-carmesí; cápsula ovoídeo-globosa, larga de $4^{\prime \prime \prime}$, peluda, igualando el cáliz, con semillas vestidas de pelo algodonoso-blancuzco. $H$. phoeniceus, Jacq. H. hirtus y unilateralis, Cav. H. Bancroftianus, Ham.

4. Arbustos ó frutices, 5. - Plantas anuales herbáceas y que se vuelven como fruticosas, pero no viven mas de un año, 6 .

5. Arbusto poco ramoso, pubescente y que se elevá á $10^{\prime}$ ó $12^{\prime}$ de altura y cuyas flores primorosas grandes, solitarias y axilares mudan su color blanco, tiñéndose de rosado que va subiendo poco á poco á medida que adelanta el dia hasta ponerse purpúreas por la 
tarde; con hojas acorazonadas, palmeadas ó 5 lobas, desigualmente dentadas, pubescentes y cuyo peciolo largo es algodonoso, así como las estípulas lineares; calículo de 7 á 9 divisiones; cápsula oval-redondeada y aterciopelada. H. mutabilis, L. - Frutice $O$ arbusto de 6 a $10^{\prime}$ de altura, aterciopelado, cuyas flores amarillo-rojizas no cambian de color; hojas acorazonadas, anguloso-sub-trílobas, algo dentaditas; pedicelos axilares infraterminales; calículo de 9 á 11 lacinias mas cortas que el cálíz 5-fido, con segmentos grandes folíiceos, aovados con una punta y 5 -nervios, casi dos veces mas corto que la corola, cuyos pétalos, largos de $2^{\prime \prime}$ á $2^{\prime \prime} 1$ [ 2 y aterciopelados esteriormente son abiertos, erguidos y en parte inclina-dos hácia afuera, un poco desiguales y oblongos ; cápsula redondeadita y trunca á la par, pelierizada, con las semillas lampiñas. $H$. clypeatus, L. : C. T. V.. 640.

6. Flores amarillas, 7. - Flores, cálices y peciolos color de rosa muy subido, cáliz acresciente y volviéndose como carnosito; mata ramosísima derecha como de 3 á $4^{\prime}$ de alto, cuyas hojas inferiores ovales y aserradas son sin lóbulos, mientras las superiores son 7-lobadas, algunas puas hay sobre la cara inferior del peciolo; hojas florales color de rosa y con una glándula por la base de su costilla, estípulas filiformes; flores solitarias y axilares con calículo de lacinias espesas y como carnosas; cáliz tuberculoso envolviendo la cápsula, sabor ácido. H. sabdariffa, L.: C. T. V., 580.

7. Flores enteramente amarillas; mata fruticulosa y ramosa, alta de 2 á 4', cuyos ramos estendidos, largos y no muchos son como algo aguijonosos, con las hojas inferiores enteras, velludas y aserradas, las del medio 3-lobas y por fin las superiores son palmeadas $y$ profundamente 5-lobas y aserradas; la costilla del segmento del centro tiene una glándula situada por la base de su cara inferior; peciolos tendidos, coloraditos y con aguijones rectos; primorosas flores ordinariamente amarillas, pero algunas veces purpúreas, casi sentadas, axilares y solitarias, de cáliz erizado y glanduloso; cápsula redondeada, velluda y cubierta por el cáliz; sabor ácido. $H$. cannabinus, L. - Mata herbácea al principio, pero que se vuelve semi-leñosa y que parece mucho al precedente en el semblante $y$ aspecto general, pero aterciopelada, con hojas acorazonado-redondas-angulosas, con 3 á 5 lóbulos cortos y aserrados; pedícelos axilares é infra-terminales, articulados, involúcelo con 10 á 12 lacinias filiformes, mas cortas que el cáliz 5-fido, segmentos aovados, con una purita y 5 nervios, son 3 á 4 veces mas cortos que la corola amarilla, con una gran mancha purpúrea interiormente y por la base ; cuyos pétalos, largos de $2^{\prime \prime} l_{[} 2$ y lampiños, son abiertos y obovales; cápsula globosa 5-alada, peluda y mas corta que el cáliz, que se ha vuelto mas grande, cuyas semillas apenas tuberculaditas tienen pelito diminuto y esparcido. H. vitifolius, L. : C. T. V., 581 .

G. III. Gossipium darbabense, L., y sus variedades. C. T. V., 644.

G. IV. Paritium, St-Hil. Corola amarillento-pálida por la madrugada, pero cuyo color se va subiendo á medida que adelanta el dia, de manera que despues de haberse vuelto anaranjado sigue hasta ponerse rojo oscuro ; cípsula aovado-globosa ó auvado-oblonga, ve- 
llúda y con semillas peludas; árbol bastante grrande y alto de 25 á $35^{\prime}$, con los ramos estendidos. cuyas ramitas llevan hojas acorazonado-redondeadas, grandes, cortamente cuspidadas, enteras, pecioladas, y cuya cara inferior es peluda; calículo por fin decíduo, al mismo tiempo que el ć́liz 8 á 10-dentado y dividido frecuentemente segun unas ó algunas suturas hasta el medio ó por debajo de él. $P$. elatum, G. Don. P. macrocarpum. P. abutiloides, G. Don. Hibiscus elatus, Macf. H. tiliaceus, Tus. H. abutiloides, W.Corola siempre amarilla sin cambiar de color, con pétalos obovales; cápsula ovoídeo-redondeadita y tomentosa, cuyas semillas son de ordinario lampiñas ó á veces con pelito diminuto y esparcido. Árłol ó arbusto como de 10 á $20^{\prime}$ de altura, bastante frondoso; con hojas acorazonado-redondeadas, ordinariamente cuspiladas, enteras ó apenas festoneaditas, grandes y cuya cara inferior es tomentosoblanquecina, siendo la superior lampiña y verde; calículo de ordinario 10 -fido y á veces 10-dentado ó profundamente 10-fido y persistente, con el cáliz algo mas largo que él. P. liliaceum, A. Juss. Hibiscus tiliaceus, L. H. arboreus, Desc. H. similis, BI. : C. T. V., 511 .

G. V. Thespesia, Corr. Flores color amarillo pálido, á veces algo teñidas ó pintaditas de purpúreo, derechas en la axila de las hojas superiores y muy cortamente pediceladas. Árbol que se vuelve á menudo bastante corpulento y se eleva hasta 45 y $50^{\prime}$ de altura, pero de ordinario su altura es de 20 á $25^{\prime}$. Ramoso y coposo, lampiño y escamoso, con hojas coriáceas acorazonadas, deltoídeas, con una punta, largamente pecioladas, lustrosas y de un color verde amarillento; pedícelos igualando los peciolos, largos de $5^{\prime \prime}-\tau^{\prime \prime}-3$ " ; hojas largas de 3-4-6", sobre 21 [2, 3 de ancho por la base; segmentos del involucro caducos al abrirse las flores, igualando al cáliz largo c̀e $6^{\prime \prime \prime}$, mucho mas corto que los pétalos oboval-oblongos y largos de $2^{\prime \prime}$ 1 2; fruto globoso, algo deprimido como de 15 "' de diŕmetro, con semillas largas de $4^{\prime \prime \prime}$, trigonal-obovales, estriadas, alampiñadas. pero velludas por la base y los ángulos; cortada al través la cápsula verde pero ya llegada á su tamaño, deja salir una especie de leche amarilla, que en las secas se concreta en una sustancia prieta que nos lia parecido resinosa. T. populnea, Corr. - Primorosas flores encarnadas, grandes y colgantes, axilares en la parte superior de las ramitas cuyo pedúnculo es largo como de 21$\rceil 2$ á $3^{\prime \prime}$. Árbol coposo y no muy corpulento, que se eleva como á $300^{\circ} 40^{\prime}$ de altura, con hojas aovadas ó casi redondeadjtas, obtusas ó con una punta, sub-acorazonadas, largas de 6 " á $3^{\prime \prime} 1[2$, y casi otro tanto de ancho, 5 " á 2 $1_{1} 2^{\prime \prime}$, con el peciolo largo de $6^{\prime \prime}-\delta^{\prime \prime}-3^{\prime \prime \prime}$; flores anchas de $4 "$, campanudas, con la columna larga de $2^{\prime \prime}$. T. grandiflora.-Hibiscus grandiflorus, I. : C. T. V., 6-18.

Familia 101. - BOMBACEAS. - Arbustos ó árboles muy grandes, muy corpulentos y muy coposos ó frondosos, de hojas simples ó compuestas y dijitadas, alternas y curos peciolos mas ó menos largos están acompañados por su insercion de dos estípulas persistentes; flores hermafroditas, solitarias y axilares ó agrupadas de varios modos axilares ó terminales y dispuestas en racimos, en ci- 
mas ó en panojas y se componen de un cáliz monosépalo con 5 lacinias de estivacion empizarrada $y$ algunas veces entero, cuya base suelen acompañar algunas brácteas que á veces simulan un calículo; corola de 5 pétalos regulares é iguales, libres ó reunidos entre sí por la base: algunas veces suele faltar; 5 hasta 15 estambres ó muchos monadelfos por la hase, mientras que el vértice de la columna está partido en 5 ó mas andróforos secundarios cargando cada cual con uno, con tres ó con muchos estambres, de anteras uniloculares cuando los estambres son indefinidos, y biloculares cuando definidos, con pólen liso y estriado. Pistilo formado de 5 ovarios distintos ó soldados entre sí y volviéndose asi un ovario único cuyo vértice lleva un estilo simple terminado por su correspondiente estigma mas ó menos lobado. El fruto es una cápsula mas ó menos gruesa y de forma variada, con 5 celdas polispermas, abriéndose por otras tantas valvas; otras veces contiene pulpa y se queda indehiscente; semillas con frecuencia peludas, bozosas ó algodonosas ó mas veces lampiñas; embrion sin endospermo, cuyos cotiledones foliáceos son doblados sobre la raicilla.

Tribu 1a.- A Dansonieas. Anteras uniloculares, alguna que otra vez mellizas; fruto sentado mas veces dehiscente y loculícido, pero sin embargo algunas veces indehiscente $y$ con tripa; semillas lampiñas ó bozosas.

G. I. Adansonia digitata, L. : C. T. V., 754.-G. II. Errodendron anfractuosum, Dc. : C. T. V., 371.-G. III. Oснвома lagopus, Sw. : C. T. V., 372. - G.IV. Mrrodra turbinata, Sw.: C. T. V., 473. G. V. PAChIra aquatica, Aubl, . T. V., 212,-P. insignis, Sav. 213.

Tribu 2. Helictéreas. Anteras biloculares; fruto sostenido por un podójino muy largo y filiforme, cuyas celdas largas están torcidos á manera de hélice $y$ por fin los carpidios foliculares que la forman se vuelven distintos y se abren segun una línea ventral; semillas lampiñas.

Helicteres, L. 1. Carpidios torcidos en espiral y formando una especie de cono leñoso ; anteras 6 ó diez, 2. - Carpidios rectos, anteras de 5 á 10 ; arbusto de 8 á $12^{\prime}$ de alto, muy ramoso, furfuráceo, con hojas acorazonado-redondeaditas ú aovadas, sinuoso-dentadas, á veces un poco 3-lobas y por fin de cara superior alampiñada, mientras la inferior es densamente peluda y largas de 1 á $3^{\prime \prime}$; flores blancas con el vértice de los pétalos rojizo, dispuestas en corimbos terminales y densos, cuyos pedícelos cortos y glandulosos por la base son ceñidos por dos brácteas lineares, cáliz campanudo, cortamente 5-lobo y largo de $3^{\prime \prime \prime}, 6$ veces mas corto que el ginóforo, los 4 segmentos inferiores son redondos $y$ el superior mas largo que ellos; pétalos mitad mas largos que el cáliz, no orejudos y de limbo oboval y corvo por afuera; celdas de las anteras oblongo-ovoídeas : fruto linear oblongo y largo de $1^{\prime \prime}$ á $1^{\prime \prime} 1_{[} 2$. H. semitriloba, Bertr. H. trapezifolia, A. Rich.

2. Arbustos furfuráceo-tomentosos con flores blancas, 3. - Arbusto no furfuráceo-tomentoso pero de tallos y ramos largos y en varita, alampiñados, curas flores son rojas, en grupos axilares formados de 5 pedúnculos que llevan cada uno dos flores mellizas, con 
dos brácteas por la base, rojo-moraduscas, grandes y dentaditas ; cáliz largo de $1^{\prime \prime}$, cónico y con 5 divisiones filiformes, ramositas, coloradas y con pelo blanco por el vértice, apretadito contra la corola; está todo cubierto con muchas puas pequeñas, carnositas y moraduscas y tambien con pelo blanco; pétalos largos lineares, espatulados y con el vértice rosado que solo se presenta por la abertura del cáliz; columna larga como de $1^{\prime \prime} 1[2$ por afuera del cáliz; con 6 estambres unilaterales; 5 hojitas verde pálido, derechas, lanceoladas y puntiagudas, hipójinas acompañan al ovario que tapan, el cual es ovoídeo, pubescente, terminado con 5 estilos largos y filiformes, cuyos estigmas subulados son amarillentos y transparentes; arbusto muy ramoso como de 10 á $20^{\prime}$ de alto, cuyos ramos ó vástagos largos llevan hojas grandes algo acorazonadas, sub-aovadas, inequilaterales, aserraditas, de cara superior alampiñada y cuyo pelo tiesito es estrellado por el vértice, mientras la inferior, mas pálida, es mas peluda, así como las ramitas. G. guasumaffolia.

3. Celdillas de las anteras oblongas ; fruto aovado-oblongo, largo de $1^{\prime \prime}$ á $1^{\prime \prime} 1_{1} 2$, tomentoso, de vértice redondeado ó á veces con una punta, pero de base redonda ó sub-trunca, formado como de 10 vueltas. Arbusto ó árbol bajito de 4 hasta $15^{\prime}$ de altura, ramoso y con hojas acorazonadas, con una punta, festoneadas y á veces al oo lobadas, largamente pecioladas y con la cara inferior aterciopelado-peluda; flores en hacecillos pedunculados ó terminales y axilares paucífloros; cáliz campanudo, bilabiado y 3 á 4 veces mas corto que el ginóforo, de lóbulos aovados con una punta y como dos veces mas corto que los pétalos no simétricos y orejudos por la base del limbo oblongo. H. Jamaicensis, Jacq. - H. isora, Desc. : C. T. V., 649. - Celdillas de las anteras lineares; fruto linear oblongo y largo de 1 " 1 [2 sobre 4 á 6"' de ancho, de ápice obtuso ó con una punta, formado de 5 vueltas; parte superior de los carpidios menos torcida; arbusto muy ramoso y como de $12^{\prime}$ de alto, con hojas acorazonadoredondeadas $\dot{0}$ acorazonado-oblongas, con una punta, aserradas y cuya cara superior acaba por ponerse alampinada, mientras la inferior es peludo-tomentosa; flores en hacecillos pedunculados terminales y axilares, pauci ó unífloros, de cáliz tubular-bilabiado, 2-4 veces mas corto que la columna, con segmentos lanceolado-aguzados, largo de $8^{\prime \prime \prime}$ y casi dos veces mas corto que los pétalos orejudos por la base del limbo linear é inclinado hácia afuera. H. baruensis, Jacp. HI. althaifolia, Lam.

Familia 102. - BUTNERIACEAS ó BITNERIACEAS.Plantas herbáceas, frutices, arbustos á veces sarmentosos y aguijonosos, ó en fin árboles mas ó menos grandes, con hojas simples, enteras, festoneadas ó dentadas, pecioladas y alternas, ordinariamente pubescentes ó peludas, cuyo pelo es de ordinario estrellado, con estipulas. Flores hermafroditas siempre caulinares ó en grupos axilares algunas veces, en racimos opuestos á las hojas ó terminales, que otras veces se componen de un cáliz monosépalo, acompañado con frecuencia de un calículo, y con 5 divisiones mas ó menos profunlas, estendidas y de estivacion valvar; corola con 5 pétalos planos torcidos en espiral antes de la florescencia, cóncavos á irrogulares: 
suele faltar algunas raras veces; estambres monadelfos en número igual, duplo ó multiple de los pétalos con que está soldado con frecuencia el andróforo, cuyas anteras bi o 3-loculares tienen pólen liso y globoso. Pistilo simple formado de un ovario compuesto de 35 carpelos soldados mas ó menos íntimamente entre sí, 1-3-5-locular poliovulado y cuyo vértice lleva tantos estilos libres ó soldados entre sí por la base cuantas celdas tiene el ovario. El fruto es una cápsula mas ó menos gruesa y de forma variada, pero las mas veces globosa, cuya base se queda frecuentemente acompañada del cáliz, con 3 á 5 celdas que se abren por tantas valvas septíferas, poli o plurispermas, cuyas semillas algunas raras veces están en pulpa de ordinario bastante escasa, con un embrion pequeño casi igual al endospermo que le tiene envuelto.

\section{Anúlisis dicotímica de las tribus.}

1. Columna $\delta$ andróforo mas ó menos pegado con los pétalos, 2 . - Columna siempre libre de los pétalos, partida en un número definido de filamentos fértiles y estériles. T. I. Theobrómeass. A.

2. Parte superior o vértice de la columna pegada con los pétalos por medio de glándulas; anteras solitarias insertas entre los lóbulos del andróforo. T. II. Bitnérieas. B.-Columna soldada por la base con las uñas de los pétalos, libre por el vértice que lleva 5 estambres, sin filamentos estériles, anteras opuestas á los pétalos. T. III. Heriánieas. C.

A. G. I. Gazuma, L. - Arbol muy ramoso, no muy corpulento, de ordinario de 15 á $20^{\prime}$ de alto, y ro raras veces se eleva hasta 40 y $50^{\prime}$, cuyas ramitas peludas con pelo estrellado llevan hojas oblongolanceoladas, aguzadas, semi-acorazonadas por la base, con la cara superior áspera y alampiñada, mientras la inferior es pubescente y de ordinario peluda; corimbos casi dos veces mas largos que los peciolos; pétalos amarillos largos de $12^{\prime \prime \prime}$, con el apéndice igual; fruto sub-drupáceo, ovoídeo-globoso, con 5 susquitos apenas notables por su parte superior, de color purpuráceo-negruzco. T. tomentosa, Kth., etc. - Árbol bastante coposo, menos corpulento y menos alto que el anterior y que se eleva solamente á 20 o $30^{\prime}$ de altura, cuyas ramitas alampiñadas, pulverulento-aleonaditas llevan hojas oblongolanceoladas ú aovarlas, con una puntita, oblícuas por la base, lampiñas y de cara inferior pulverulenta cuando tiernas; flores algo mas grandes que en el precedente y tambien en corimbos axilares y como dos veces mas cortos que los peciolos; fruto sub-drupáceo, negropurpuráceo, glohoso y con 5 surcos lonjitudinales. G. ulmifolia, Lam. : C. T. V., 93-651.

G. II. Theóbrama cacao, L. : C. T. V., 211-650.

B. Brittierta, L. - Arbusto sarmentoso, ramosísimo y que se eleva á favor de los vejetales vecinos hasta mas de '20' de altura, cuyo tallo inferiormente sin aguijones y como de $1^{\prime \prime}$ a $1^{\prime \prime} 1_{1} 2$ de diámetro es desigualmente cuadrangular, con la corteza cenicienta, mientras los ramos, ramitos, peciolos, etc.. son aguijonosos, las ra- 
mas angulosas por el rértice especialmente, lampiñas y en varita, llevan hojas tiesas, lineares ó lanceolado-lineares, enteras ó algo dentaditas y ásperas por la márjen, con el ápice mucronado, cortamente pecioladas, sub-alabardadas ó sub-acorazonaditas por la base, que otras veces es aoradita, cuyas inferiores bien alternas son largas de $4-5-3^{\prime \prime} 1_{1} 2$, y anchas de $2-1^{\prime \prime} 1 p^{2}$, mientras las superiores, unilaterales ó dísticas, son mucho mas pequeñas; peciolo como de $1_{[} 2$ " de largo; flores moraduscas pequeñas, cuyos pedúnculos axilares salen en número de 3 á 5 de la axila de las hojas superiores, largos como de $6^{\prime \prime \prime}$; llevan en su ápice algo mas grueso y provisto de algunas escamas bracteiformes 8-10 pedícelos largos como de $2^{\prime \prime \prime}$ y unífloros, formando una especie de umbela pequeña y colgante; segmentos calizinales, lanceolados y mucho mas largos que la columna $y$ de 1 á $2^{\prime \prime \prime}$, pétalos sentados, subsesiles fo ob-acorazonados, con los apéndices claviformes y lineares á la vez, pubescentitos y rojizos, tres veces mas largos que el limbo é igualando el cáliz; lóbulos de la columna cortos y redondeaditos; cápsula globosa ancha de 6 "' y con puas cortas. B. sabra, L. B. ramosissima y scalpellata. B. virgata, Phl. : C. T. V., 798. - Arbusto cuyo aspecto general parece mucho al del anterior, formando como él malezas impenetrables, pero no se eleva tanto y de ordinario no pasa de 8 á $12^{\prime}$ de altura, con las ramitas, pedúnculos $\mathrm{y}$ peciolos á la par que aguijonosos algo bozosos ó pubescentes, con hojas aovado-enteras, con una punta obtusa, pecioladas cortamente, largas como de 3 á $2^{\prime \prime} 1$ [2, sin contar el peciolo que tiene como 6 á $8^{\prime \prime \prime}$ sobre 2 á $1^{\prime \prime} 1_{1} 2$ de ancho, mientras las de las ramitas florales son óvalo-lanceoladas de 1" á 1 l 2 de largo, solvre 6 á 8 "' de diámetro, aguzadas y con una punta obtusa, lampiñas y con unos raros aguijones sobre la costilla y por la cara inferior; flores mas pálidas que en la especie anterior, en grupos axilares formados de algunos pedúnculos, de los que uno siempre mayor que los otros lleva en su vértice una especie de umbelita cuyos pedúnculos secundarios se terminan por pedícelos unífloros : casi siempre de la misma axila sale una ramita floral larga de 3 á 6"', curos grupos axilares tambien son menos furnidos; cápsula cubierta de muchas puas tiesas, punzantes, subuladas y largas de 4-6-7"', diver.jentes. B. Carthagenensis, Jacq., C. T. V., 798.

C. Melochia, L. - 1. Cápsula de dehiscencia loculícida ó septícida, 2. - Cápsula formada de כ̌ carpelos, columna う̌-fida ó casi entera; frutice alto de 2 a 7 , alampiñado y pubescente en las ramitas ú otras partes tiernas, de hojas aovadas, con una punta, aserradas, largas de $2-3^{\prime \prime}$, con los peciolos de las inferiores largos de $1^{\prime \prime}$ y los superiores muclio mas cortos que los peciolos, rojo-blanquecinas, de cáliz con los segmentos deltoídeos, con una punta larģa de 1 "' 1 [2, y mas corto que la corola, cuyos pétalos espatulados igualan casi la columna entera y los estilos distintos; cápsula sub-globosa, subcomprimida y de $2^{\prime \prime \prime}$ de diámetro, 5-angulosa, peluda, un poco mas larga que el cáliz y cuyos carpidios distintos acaban por fin por abrirse á lo largo de la línea rentral. M. nodiflora, Sw. Mongotia nodiflora, Kth. Reidleia nodiflora, Dc.

2. Cápsula siempre loculícida, con los tabiques adherontes al eje 
filiforme, del cual acaban por separarse; columna partida hasta la base adherida; flores en hacecillos axilares ó terminales, purpuráceas y desprovistas de invólucro, frutice alto de 2 á 5 , cuyas ramas están adornadas por una línea lonjitudinal pubescente y llevan hojas lampiñas, oblongo-lanceoladas, festoneado-aserraditas y largas de $1^{\prime}$ á $2^{\prime}$; hacecillos florales opuestos á las hojas y paucífioros, cuyo pedúnculo es casi del largo del pedícelo; cáliz con lóbulos lanceolados y aguzados, un poco mas cortos que la corola, amarillos; son obovales y largos de $3^{\prime \prime \prime}$, estilos sub-distintos, cápsula piramidal, 5angulosa, cuyos ángulos son aguijonosos por la base y esteriormente, largos de $3^{\prime \prime \prime}$ sobre 5 de ancho por la base. M. pyramidata, L. Cápsula loculícida ó septícida; columna dividida en fllamentos subulados, que están á veces coherentes por el vértice; grupos florales ceñidos por un invólucro de 3 hojuelas, estípulas estriadas, aovadolanceoladas, é igualando el peciolo corto; frutice de como 2 á $3^{\prime}$ de alto, ramoso, mas ó menos peludo, con hojas aovadas ó aovadooblongas, obtusitas, dos veces aserradas, frecuentemente sub-acorazonadas por la base y largas de 1" á 1" 1 [2 y cuyo pelo ocupa especialmente las venas; fiores en espigas interrumpidas terminales y axilares, de cáliz mitad mas corto que las hojitas lineares del invólucro y con segmentos lanceolados y aguzados; pétalos esertos, purpuráceos, con la uña amarilla, espatuladas, largas de 5 á $6^{\prime \prime \prime}$ y un poco mas largas que el invólucro; columna partida solamente por el medio, mas corta que los estilos reunidos inferiormente; cápsula velluda, globosa, encerrada en el cáliz, cuyas valvas son largas de I"' 1,2. M. serrata, Benth. M. hirsuta, A. Rich. Reidleia serrata, Vent.

Familia 103. - ESTERCULIACEAS. - Árboles grandes, corpulentos y frondosos, con hojas mas ó menos grandes alternas, ora simples, enteras ó lobadas, ora dijitadas, pecioladas, con estípulas peciolares mellizas; flores apétalas y de ordinario unisexuales por causa de ahorto, en racimos corimbos ó panojas, cuyos pedúnculos son axilares ó terminales, las cuales constan de un cáliz decíduo 5lobo, coroliforme, colorido y valvar; estambres definidos 5-10-15 o 20 , cortamente monadelfos por la base, de columna hipójina y á veces muy reducida, con anteras biloculares, cuyo pólen es liso y globoso; ovario que al principio parece único, pero formado de 5 carpelos que se separan despues, se vuelven distintos, estipitados, uniloculares, polispermos; fruto formado de 3 á 5 carpidios foliculares, cuyas semillas están provistas de un endospermo que contiene un embrion de cotiledones planos y foliáceos, con raicilla inferior aovada y corta.

Sterculia, L. - Primoroso árbol, corpulento, coposo y muy frondoso que se eleva á 40 ó $50^{\prime}$ de altura, con las ramitas, peciolos y estípulas muy pronto caducas, bozosos; de hojas alternas ó esparcidas, acorazonado-redondeadas, con 3-5 lóbulos profundos, enteros, ondulosos y grandes, oblongos y aguzado-obtusos, de cara superior lampiña, mientras la inferior es bozosa y cenicienta, largo el limbo de 13 á $15^{\prime \prime}$, sobre 8 á $10^{\prime \prime}$ de ancho; peciolo largeo de 6 á $8^{\prime \prime}$; flores en panojas axilares ó terminales de brazos delgados y diverjentes, 
de cáliz 5-fido liasta el medio, enteramente bozoso, anchamente aovado, con los segmentos sub-deltoídeos y algo dobladitos hácia afuera, coroliforme y de color amarillento, con puntitos purpúreos, largo de 6 á $8^{\prime \prime \prime}$ y ancho como de 10"" ; columna y estilo corvo, de modo que miran al fondo del cáliz; estambres 15 en 5 andróforos secundarios y dispuestos en dos séries en las flores masculinas; folículos lampiños, color aceitunado, aunque fuesen muy bozosos cuando tiernos, apenas pedicelados y largos como de 4 " á $4 l_{1} 2$ sobre $3^{\prime \prime}$ de ancho, irregularmente fusiformes, abiertos: su interior es de un primoroso color amarillo canario, sedoso por los muchos pelitos tieso: que le cubren, con 3 á 6 semillas jor causa de aborto, ovoídeas, negras, lustrosas, largas de 13 á $14^{\prime \prime \prime}$ sobre 5 á 6 "' de diámetro. $S$. Carthagenensis, Cav. : C. T.V., 654. - Árbol del tamaño del precedente, casi tan corpulento y tan frondoso como él, de hojas aovadooblongas, ordinariamente enteras, con una puntita, redondeada: por la base, de cara superior lampiña, mientras la inferior es pubescente, larcas de $\delta^{\prime \prime}$ á $6^{\prime \prime}$; cáliz profundamente 5 -fido, amarillento y largo de $4^{\prime \prime \prime}$, furfuráceo esteriormente, cuyos segmentos aovadolanceolados y abiertos son nectaríferos interiormente; columna con 10 estambres; carpidios semi-elípticos y por fin estipitados, largos de $1^{\prime \prime} 1_{[}^{2} 2$, cuyo carpóforo es casi tan largo como ellos. S. Caribcen, R. Br. S. ix $\iota$, Sw.

\section{SUB-DIVISION 11. - OLIGOSTÉMIONOS.}

GREPO I. - UNISEXUALES.

\section{CLASE XLVII. - CROTONÍNEAS.}

Familia 104. - EUFORBIÁCEAS. - Plantas herbáceas anuales ó vivaces, matas fruticulosas, frutices, arbustos, arbolitos y hasta árboles mas ó menos altos y no raras veces bastante corpulentos, cuya savia es ordinariamente lechosa; hojas simples, rarísimas veces compuestas, enteras, dentadas, festoneadas y mas ó menos lobadas, ordinariamente alternas, y sin embargo no rara vez opuestas, lampiñas, pubescentes y velludas, mas ó menos pecioladas, con dos estípulas situadas por la insercion del peciolo: suelen faltar algunas veces. Flores dioicas ó monoicas, cuya florescencia es muy variada, y compuestas de un cáliz monosépalo con 3-4-5) ó 6 segmentos mas ó menos profundos, acompanados interiormente de apéndices escamosos ó glandulosos, sin corola alguna; sin embargo, al parecer de algunos botánicos, tienen á veces una corola formada de pétalos sueltos ó reunidos entre sí, que los contrarios á esa opinion consideran como estambres abortos y estériles. Las flores masculinas contienen de ordinario muchos estambres, cuyo número muy variado está á veces definido y limitado, mientras que otras veces está indefinido, y con bastante frecuencia cada estambre puede considerarse como una flor masculina, mientras que en otras circunstancias los estambres 
son tan pronto libres como mono ó poliadelfos, cuyos filamentos ramosos ó articulados se insertan en un receptáculo o en el fondo del periántio; alguna vez que otra se hallan escamitas ó pajitas entremezcladas con ellos. Las flores femeninas tienen igual envoltura floral $y$ son formadas de un ovario único, las mas veces trígono, trilocular, libre, raramente sentado, pero de ordinario sostenido por un podójino mas ó menos largo, el cual le tiene bastantes veces por afuera de la flor, saliendo á veces de un disco hipójino, cuyas celdillas contienen 1 ó 2 óvulos colgantes del ángulo interno, con el tegumento interior espeso; de su ápice sale un estilo, ora único, trífido, con sus correspondientes estigmas bífidos y glandulosos, ora 3 estigmas sentados, oblongos y glandulosos. Fruto seco compuesto de tantas cajitas ó carpelos situados en derredor de una columna ó eje central, del cual se desprenden despues de maduros, abriéndose por el ángulo interno en dus valvas, con mayor ó menor elasticidad, cuantas celdillas tenia el ovario; contiene cada uno una semilla mas ó menos gruesa, de figura variada y que bastantes veces parece un insecto; frecuentemente con una carúncula carnosita, situada cerca de su punto de insercion ó sin ella, de cuesco crustáceo ó testa bastantes reces doble, con un embrion central y homótropo de cotiledones foliáceos, anchos y llanos, con la raicilla súpera, y alojado en un endospermo espeso, carnoso y oleoso. Otras veces el fruto es algo carnoso, indehiscente y parece una manzanita, pero contiene por el centro un hueso con 5 ó mas celdillas monospermas.

\section{Análisis dicotómica de las tribus y sub-tribus.}

1. Celdillas del ovario con dos óvulos, 2. - Celdillas del ovario con un solo huevecillo, $t$.

2. Cápsula loculícida, con los tabiques coherentes, semillas sin carúncula; flores ordinariamente sin pétalos, cuyo cáliz de estivacion imbricada contiene 4 ó 6 estambres insertos en derredor de un pistilo rudimentario. T. I. Buxeas. Tricera levigaia, Sw. T. citrifolia, WV. - Cápsula formada de cajitas ó carpidios, o fruto baciforme, con las semillas de ordinario sin carúncula; flores las mas veces sin corola, de cáliz cuya estivacion es valrar, 2 á 5 estambres y raras veces en número mayor é insertos en un disco central, libres ó soldados entre sí: tales flores son solitarias ó fasciculadas y axilares. T. II. Fillánteas, 3.

3. Estambres insertos en derredor de un pistilo rudimentario central. S.-T. I. Dripíteas. Drypetes crocea, Poit. - Estambres centrales. S.-T. II. Eufillánteas. A.

4. Flores con ó sin pétalos, de cáliz cuya prefoliacion es tan pronto valvar como empizarrada, fasciculadas, racinosas, espigadas o apanojadas; fruto cápsular partiéndose en carpelos ó cajitas dehiscentes, abayado ó drupáceo, de semillas con ó sin carúncula. T. III. Crotóneas, 5.

5. Inflorescencia centrífuga ó centrípeta, 6. - Inflorescencia ni centrípeta ni centrífuga, pero axilar ó terminal é involucrada, an- 
drojina, con flores apétalas ó desnudas, cuyos dos sexos, contenidos en un invólucro comun, figuran una flor única y se componen de una sola flor femenina, de ordinario eserta y cabizbaja, acompañada de algunas masculinas que constan de un estambre único; semillas con ó sin carúncula. S.-T'. I. Euforbieas. B.

6. Inflorescencia centrípeta, 7. - Inflorescencia centrífuga, androjina; flores pediceladas y cimosas, cuyas femeninas ocupan el centro; semillas con una carnúcula muy desarrollada. S.-T. III. JATRÓFEAS. C.

7. No androjjinas, 8. - Andrójinas, flores en racimos espiciformes, cuyo vértice está ocupado por la masculina; semillas con una carúncula grande. S.-T. IV. Ricíneas. Ricinus commurris, L.: C. T. V., 503.

8. Flores monoicas, espiciformes, brácteas masculinas, de ordinario plurífloras; flores apétalas ó desnudas, de cáliz imbricado ó nulo; estambres centrales $2-10$, semillas sea con una carúncula sea encerradas en un tegumento esterior que desaparece. S. T. V. HipPONÁNEAs. E. - Monoicas ó dioicas, racemosas, cuyas brácteas florales contienen una sola flor; en las monoicas las flores femeninas ocupan la parte inferior, 9. - Dioicas, ordinariamente en racimos ó espigas; flores masculinas, de ordinario agrupadas algunas en la axila de las brácteas florales; flores apétalas cuyas masculinas tienen el cáliz valvar; semillas globosas ú ovoídeas, con una carúncula apenas notable ó sin ella. S.-T'. VI. ACA Lífeas. G. I. A calyphacrspidata, Jacq. C. T. V. 3.57. - G. II. Tragia volubilis, L. : C. T. V., 23-397.

9. Semillas las mas veces provistas de una carnúcula. S.-T. VH. Eucrotóneas. E. - Estambres insertos en derredor del pistilo ahorto; semillas globosas sin carúncula. S.-T. VIII. Ditaxideas. - Ditaxis glabella, Gr. - D. fasciculata, V.

A. G. I. CICCA, L.-Flores monoicas entremezcladas las unas con las otras y fasciculadas, cuyos hacecillos laterales están dispuestos a lo largo de las ramitas ó raquices sin hojas, por haberse desprendido ellas; filamentos alternos con glándulas esteriores, ovario 3-4-locular, drupa amarillento-deprimida y globosa á la par, y con tantos ángulos cuantas semillas contiene; hojuelas dísticas aovadas, con una punta. C. distica, L. : C. T. V., 617. - Flores dioicas, de ordinario axilares, amanojadas, cuyos hacecillos m:sculinos son multífloros, mientras los femeninos al contrario contienen solamente 1 á 3 flores, de cáliz doblädo segun su lonjitud, filamentos ceñidos por el disco, ovario 3-5-locular, estilo con brazos ol,tusos, baya globosa; hojitas elíptico-lanceoladas ú obovolo-lanceoladas, obtusas. $C$. Antillana, Jacq. : C. T. V., 398-617.

G. II. Pyllantus, L - 1. Cáliz - t-partido en las flores masculinas, y 5-partido en las femeninas, 2. - Divisiones del cáliz en número igual para los dos sexos, 4.

2. Columna estaminal con dos anteras adheridas por el vértice, divaricadas $y$ con las celdillas distintas; estilos 3, ob-acorazonados, deprimidos y foliáceos; estípulas triangulares y persistentes; hacecillos androjinos dispuestos á lo largo de las ramitas afíleas y axila- 
res, 3. - Columna estaminal entera, con tres anteras adheridas y escurridas; estípulas y estilos como en la division precedente; hacecillos andrójinos situados lateralmente á lo largo de las ramitas afíleas; árbol como de 20', cuyas ramas simples llevan hojas aovadooblongas, con una punta, lampiñas, coriáceas, dísticas, apartadas y largas de 4 á 3 "; racimos situados lateralmente sobre el tallo, columna 3-angulosa superiormente por causa del ángulo interno y proeminente de las celdas de las anteras ovales. P. cauliflorus, Gr.

3. Frutice de 2 á $4^{\prime}$ de altura, con hojas aovado-lanceoladas, aguzadas, lisas, coriáceas, cortamente pecioladas y largas como de $3^{\prime \prime}$; racimos axilares largos de $3-1$, con los pedícelos de $2^{\prime \prime \prime}$; cáliz verdosoamarillento; anteras con las celdas oblongas. P. epistylium, Gr. Epistylium axillure, Sw.

4. Cáliz 5-6-partido, columna estaminal entera, con 3 anteras transversalmente dehiscentes; 3 estilos bífidos; pedícelos axilares, fasciculados ó solitarios y dispuestos á lo largo de las ramitas afíleas y de los cuales los masculinos son mas cortos; flores de ambos sexos entremezcladas y curas femeninas son mas largas, 5 .

5. Arbusto ramoso de 6 á 10' de altura, con hojas elípticas, membranáceas, con una punta, de base sub-acunada, lampiñas ó á veces pubescentitas y largas de 8 á $12^{\prime \prime \prime}$; estípulas subuladas y marcescentes; hacecillos axilares, cuyos pedícelos de las flores femeninas capilares y sub-solitarios son largos de 2 o $4^{\prime \prime \prime}$; segmentos calizinales 6, diminutos, aovado-oblongos; anteras sesiles en el ápice de la columna, globosas y contiguas, con las celdillas distintas; cápsula sub-globosa, contraida segun las líneas por donde ha de abrirse. $P$. conami, Sw. P. piscatorum, Kth. - Planta herbácea ó fruticulosa, anual, mas ó menos ramosa y alta como de $l^{\prime}$ á $I^{\prime} 1_{[} 2$, con hojas dísticas, subsesiles, ob-aovado-oblongas, otras veces lanceoladas, ovales ú obovadas, con el ápice redondeado ó mucronado, lampiñas y de cara inferior mas pálida, de ordinario largas de 3 á $4^{\prime \prime \prime}$; cstípulas setáceas persistentes; pedícelos axilares 1 á 3 y 3 á 6 veces mas cortosque las hojas; segmentos del cáliz 5 y aovados; anteras sesiles sobre el ápice de la columna, globosas y contiguas; estilos cortos é inclusos; cápsula diminuta, globosa y deprimida, con las semillas estriadas por el dorso llano. P. nuriri, L.: C. T. V., 357.

B. G. I. Euphorbia, L. - 1. Vejetales nunca carnosos y siempre provistos de hojas, 2. - Vejetales carnosos y sin hojas, mata inerme articulada y leñosa inferiormente, con los ramos opuestos 2-alados, con los entrenudos largos de 2 á $8^{\prime \prime}$ y anchos de $3^{\prime \prime \prime}$; flores en umbelas contraidas, laterales ó terminales, con dos brácteas y dos veces con 3 radios, las universales sentadas, mientras lis parciales son cortamente pediceladas, invólucro conteniendo pocas flores y provisto de 5 apéndices petaloídeos, franjeados y situados por el interior de los lóbulos. E. alata, Hook. C. T. V., 41.

2. Siempre arbustos ó frutices con las hojas opuestas ó verticiladas, 3. - Arbustos ó plantas herbáceas, 5 .

3. Largamente pecioladas, de base igual, bien enteras, cuyo peciolo es articulado hácia la base envainadora; estipulas glandulíferas y apenas notables, 4. - Cortamente pecioladas é insertas por el 
lado interior de una vaina estipular abierta: arbusto ramoso con las ramitas afíleas y provistas de vainas lobado-pestañosas densamente anulares y largas de $2^{\prime \prime \prime}$, cuyas hojas opuestas ó ternadas salen de las vainas superiores y son pequeñas, espesas, espatuladolineares, bien enteras, lampiñas y con algunos pelos sobre la costilla de la cara inferior y mas largas que los peciolos pubescentitos, largas de $2^{\prime \prime \prime}$ y anchas de $12^{\prime \prime \prime}$. sin venas, con el peciolo saliendo apenas de la vaina; pedunculos simples, cortos, terminales y casi enteramente contenidos por las vainas superiores, mientras los de las femeninas son esertos; invólucro con apéndices diminutos y redondeados; cápsula lampiña, semillas sin carnúcula. E. vaginuilata, Gr. C. T. V., 42-526.

4. Arbusto muy ramoso que se eleva de $6^{\prime}$ hasta $12^{\prime}$ de altura y á veces se vuelve un árbol pequeño, cuyas ramas cilíndricas, un poco mas espesas en los nudos llevan hojas opuestas ó ternadas, aovadas ó aovado-redondas, obtusitas, sub-acorazonadas por la base, lampiñas y de cara inferior glauca, largas de $2^{\prime \prime}-1^{\prime \prime}$, con el peciolo de $3^{\prime \prime}$ 1 " de largo; flores en cimas ó en panojas terminales pedunculadas y tricótomas: invólucro con 5 apéndices petaloídeos bien enteros $\mathrm{Y}$ amarillentos, y correspondiendo interiormente á la division de los lóbulos; cápsula lampiña, con las semillas sin carúncula, ovoídeas é irregularmente rugosas. $E$. cotinifolia, L. : C. T. V., 527.

5. Hojas opuestas, cortamente pecioladas, de ordinario oblícuas por la base ; estípulas entrepeciolares trabadas, 6. - Hojas cuyas inferiores son alternas y sin estipulas; invólucros dispuestos en grupos terminales, 10 .

6. Frutices ó yerbas perennes, 7. - Plantas herbáceas y anuales, 9 .

7. De tallos derechos y siempre fruticulosos, 8. - Planta fruticulosa ó herbácea postrada, lampiña, cuyos muchos tallos salen palmados de la raiz, largos como de 6 á 8", mas ó menos ramosos y formando cesped, con hojas óvalo-redondeaditas, oblicuas por la base, redondas por el vértice, bien enteras ó festoneadas, largas de $1_{1} 2$ á $\left.2^{\prime \prime \prime}\right]_{[} 2$, estípulas triangulares, ordinariamente laciniadas por la márjen, pedúnculos alados y axilares, simples, solitarios ó á veces ternados, invólucro con 4.5 glándulas que están de ordinario adornadas con una márjen petaloídea; cápsulas lampiñas con semilla sin carnúcula, sub-tetrágonas y lisas. E. serpens, Kth. E. centrunculoides, Kth. E. herniarioides, Nutt. C. T. V., 504.

8. Fruticuloso-lampiño, alto como de $l^{\prime}$ á $\left.1^{\prime}\right]_{[} 2$, con los ramos ascendentes, y en forma de varita, cuyas hojas aovadas con una punta y hien enteras son largas de 3 á $6^{\prime \prime \prime}$ y redondeadas ó sub-acorazonada por la base lijeramente oblícua ; estípulas 3 -angulares ! laciniadas por la márjen; invólucros con 4-5 apéndlices petaloídeos. redondeados y glandulosos; lóbulos fimbriados interiormente; cápsulas lampiñas, con semillas sin carnúcula, sub-glohosas y casi lisas. E. buxifolia, Lam. E. glabrata, V. Sw.

9. Yerbas cespedosas y estendidas por el suelo, 10. - Yerba difusa ó derecha, mas ó menos ramosa y de $1^{\prime}$ á $1^{\prime} l_{1} 2$ de alto, muy pclurla por todas sus partes y por eso como blanquecina, con hojas 
semi-aovadas ó aovado-lanceoladas, con una punta, oblícuas por la hase, aserradas y largas de 6-12"' ; flores en cimas globosas axilares $\mathrm{r}$ terminales, cuyos pedúnculos son mas largos que los peciolos y erguidos; invólucro de glándulas diminutas y redondeadas; cápsula peluda con semillas sin carúncula, pálidas, tetrágonas, transversalmente asperitas con 6 estrias, obtusas. $E$. pilulifera, L. E. hirta, L. - E. obliterata, Jacq.: C. T. V., 715.

10. Yerba pubescente, cespedosa y tendida por el suelo, cuyos tallos ó ramos son largos de 6 á 10", con hojas oblongas, obtusas, oblícuas por la base, aserraditas por el vértice y largas de $2.4^{\prime \prime \prime}$; invólucros dispuestos en grupos, cuyo pedúnculo es tan largo como el peciolo; apéndices petaloídeos diminutos, cápsula velluda con semillas sin carúncula, bien tetrágonas, transversalmente rugoso-estriadas, con 4 estrias obtusas y de ángulos enteros. E. maculata, L. E. burmanniana, Gay., C, T. T. 6.

G.II. Pedilanthus. tithimaloides, Poit. C. T. V., 473. - Hay 3 variedades de esa planta, que se diferencian por sus hojas. 1a De hojas aovado-redondas. Euphorbia tithymaloides, Jacq.; $2^{\text {a }}$ con hojas elípticas, de ordinario aguzadas por sus dos estremos $P$. padifolius, Poit. P. carinatus, Spr. P. tithimaloides y anacampseroides, Poit. Euph. carinata, B. M.; 3a cuyas hojas son espatulado lanceoladas. $P$. angustifolius, Poit.

C. G. I. Jatropha, L.1.Pètalos distintos ó un poco reunidos por la base, abiertos, 3. - Corola seudo-monopétala; estilos reunidos por la base ; estípulas decíduas, 2.

2. Arbusto de ramas rectas no muy ramosas y cuyas ramitas siguen la misma disposicion, alto como de 8 á 12 ', con la corteza cenicienta, de hojas aovado-oblongas, sub-panduriformes, con una punta 6 mucronadas, abroqueladas y sub-acorazonadas por la base, lampiñas y largas de 3 á $5^{\prime \prime}$, con peciolo largo de $1^{\prime \prime} 1_{[} 2$ á $3^{\prime \prime}$, é inserto con el limbo como a $2^{\prime \prime \prime}$ o $3^{\prime \prime \prime}$ de la base. Cimas dicótomas estendidas y flojas; corola 5-loba hasta el medio y tres veces mas larga que el cáliz 5-partido; estambres 10; estilos bífidos. J. hernandifotia, Vent. Curcas Partoricensis, Baill. - Arbusto de 6 á 12' de alto, muy ramoso y cuyos ramos son divaricados y de corteza verdosoamarillenta, con hojas sub-cordiformes y redondeaditas a la par, angulosas, ó con $3-5$ lóbulos apenas pronunciados, lampiñas ó alampiñadas y cuyo color es verde amarillento, de peciolo tan largo como el limbo que tiene como $3^{\prime \prime}$ á $4^{\prime \prime}$ de largo. Cimas pedunculadas y axilares terminales, cuyas cimas parcia'es pediceladas son contraidas, corola 5-partida, velluda interiormente, amarillento-pálida, larga de $3^{\prime \prime \prime}$ y dos veces mas que el cáliz 5-partido; estambres 10 á 15; estilos bífidos. J. curcas. L. Curcas purgans, Med.: C. T. V., 528 .

3. Flores en umbelas encarnadas terminales; arbusto muy poco ramoso, alto de 5 á $8^{\prime}$, con las hojas agrupadas todas hácia la sumidad, largamente pecioladas y de limbo grande 7-9-partido, algo abroquelado, lampiñas y sin glándulas, con los segmentos pinatífidos $y$ aguzados y los lóbulos bien enteros; estípulas multipartidas con segmentos setáceos; corola 3 veces mas larga que el cáliz 5-lobo; 
estambres 8-10, con las anteras amarillas; estigmas con dos brazos. J. multifida, L. : C. T. V., 530. - Frutice ó arbustito de 2 á 6 ' de alto, muy ramoso, de color verde ó moraduzco oscuro, con hojas 3 5 -partidas, pero de ordinario solamente lobadas, pestañosas y glandulíferas por la márjen, cuyas divisiones aovadas y con una punta son dentaditas ó enteras, lampiñas ó pubescentitas, lustrosas, largamente pecioladas y largas de $21 / 2$ á 3 " sobre 2 , de ancho; glándulas peciolares y estipulares á la vez, ramosas; cimas parciales contraidas; corola dos veces tan larga como el cúliz 5-partido y cuyos pétalos reunidos por la base son obovales y color purpúreo oscuro; estambres $8-12$, de anteras amarillas y á veces moraduzcas; estigma con dos brazos. J. gossipifolia, L. G. glandulifera, Roxb. $F$. elegans, Kth.: C. T. V., 356-5.25.

G. II. JANıPHA, Kth._Janiphamaniot, L. - Maniot aipi y utilissima, Pohl.: C. T. V., 206-20\%. - Este vejetal, tan importante para los paises intertropicales y tropicales, se subdivide en muchas variedades, cuyas dos mas importantes y que abrazan á las demas casi como especies, son conocidas con el nombre vulgar de yuca brava ó amarga, $y$ de yuca dulce, y á pesar de que haya tantas diferencias entre ellas que la primera constituye un veneno terrible, mientras que la otra es un alimento enteramente inofensivo; sin embargo, no hay calácteres botánicos bastante manifiestos y pronunciados para especificarlas $\mathrm{y}$ hacer de ellas dos especies bien caracterizadas; sin embargo, se puede llegar á diferenciarlas ýa reconocerlas, porque la yuca brava tiene sus ramitas tiernạs pentágonas ó á veces acanaladas, con los ángulos mas ó menos pronunciados, el tallo cilíndrico muy nudoso ó quizás mejor provisto de muchos tubérculos esparcidos sin ćrden y como aguijonosos, leñosos y punzantes, comprimidos hasta la base de color mas oscuro que el del tallo, que es ceniciento ó gris-parduzco, otras veces mas ó menos verde; peciolos de las hojas y las estípulas que acompañan á su base son color rojo-oscurro, mas subido por su insercion con el tallo; tal color se estiende por la cara superior de los lóbulos de las hojas que tiñe un poco quedándose mas pronunciado por las costillas, mientras que no existe en la cara inferior, que es verde mas ó menos oscuro $y$ de ordinario glauca; algunas veces hemos hallado variedades cuyos peciolos y hojas son enteramente verdes. La yuca dulce que a primera vista parece la brava tanto por su altura como por su aspecto y semblante general, se puede, sin embargo, con un poco de atencion distinguir con bastante facilidad porque su tallo es menos nudoso $r$ de color achocolatado, teñido de amarillento rojizo, cuyos tubérculos de ig̣ual color son mucho mas apartados los unos de los otros que en la brava, menos pronunciados, menos puntiagudos, romos y no tan comprimidos; además los peciolos son de color de rosa más subido hícia la axila $y$ el vértice que por la base, por su medio y por la cara inferior, cuyo color rosado sigue estendiéndose por las costillas y nervaduras de la cara superior que tine bastante con ese color y además la cara inferior está algo matizada de color de rosa; las ramitas tiernas no están nunca acanaladas ni pentígonas tampoco.

G. III. Areudites triloba, Forst.: C. T. V., 505. 
G. IV. Siphonra elastica, Pers. Hevea Guianensis, Aubl.

D. G. I. Sapium, Jacq. 1. Peciolo con glándulas situadas por debajo de su ápice, 2. - Peciolo sin glándulas; árbol bajito con hojas obaovadas ú oblongas, redondeadas y obtusas por el vértice y cuneiformes por la base, largas de 4 " sobre $2^{\prime \prime}$ de ancho, cuyo peciolo tiene $8^{\prime \prime \prime}$, sub-enteras por la márjen glandulosa, y al menos con dos glandulítas diminutas sentadas y situadas por arriba de la base, sin puntos transparentes y con las venas principales distantes y alternas con otras mas pequeñas; estípulas acorazonado-redondeaditas; racimos laterales, arqueado-filiformes, simples, muchos y largos de 2-3", cuyos grupos masculinos son algo distantes; estilo 2-3-fido. S. cuneatum, Gr.

2. Dos ó á veces 4 giándulas situadas por el vértice del peciolo ó por deluajo de él; árbol bastante alto y coposo, con hojas lanceoladooblongas, oblongas o elípticas, glanduloso-dentaditas ó sub-enteras con las principales nervaduras numerosas; estípulas triangulares $y$ redondeaditas á la vez; racimos filiformes terminales. $S$. aucuparium, Jacq. De ese vejetal hay dos variedades: $1^{2}$ de hojas con una punta y cortamente aguzadas por los dos estremos; racimos terminales sub-solitarios. Hippomane biglandulosa, Aubl. 2a De hojas con una puntita ú obtusas y redondeadas por ambos estremos ; racimos terminales ordinariamente agrupados por á 3. Hippomane, My. - Dos glándulas diminutas y sub-globosas situadas por debäjo del vértice del peciolo. Arbol de 20 á $50^{\prime}$ de altura, bastante coposo y corpulento, con hojas coriáceas, lustrosas, oblongas, redondeadas por ambos estremos con una punta obtusa, repando-enteras ó apenas festoneadas y provistas de puntos transparentes, con las principales venas numerosas; estípulas semi-acorazonadas; racimos filiformes, terminales, 3-5-partidos, S. laurifolium, Gr. S. Brownei, Bks. Stillingia laurifolia, A. Rich. Hippomane biglandulosa, Sw.: C. T. V., 851 .

G. II. Hippomane, L. Hojas espinosas y cuyo peciolo no lleva glándulas ; árbol pequeño, bastante frondoso, cuyas hojas ovalesparecen las del acebo; fruto amarillo, redondeado y con 4 surcos que lo hacen 4-lobo. H. espinosa, L. - Hojas sin espinas y cuyo peciolo lleva unas glándulas situadas por arriba de la base; árbol de mediana altura y tamaño, cuyos ramos estendidos y desnudos tienen por la sumidad hojas elípticas, aserraditas ó festoneadas. lustrosas, tan largo el limbo como el peciolo ó dos veces mayor; racimos terminales; drupa sub-globosa como de $1^{\prime \prime} 1[2$ de diámetro, no lobulada, coronada y de color amarillento-verdoso. H. mancinella, L.: C. T. V., 850 .

G. III. Omphalea, L. Tres estambres; árbol bastante grande y frondoso, pero cuya altura y tamaño varian bastante, con hojas obloncas, ovales ó cordiformes, lampiñas, con dos glándulas situadas por encima de la base; drupas amarillas, globosas, asurcadas, cuyodiámetroes de $1^{\prime \prime} 1_{[} 2$. O. triandra, L.: C. T. V., 431.-Dos estambres nada mas; arbusto sarmentoso y pubescente, cuyas hojas ovales, oblongas y acorazonadas son pubescentes por la cara inferior y tienen dos 
glándulas situadas por encima de la base.O. diandra, L.: C. T.V.432

IV. Huю crepitans, L.: C. T. V., 490.

E. Croton, L. 1. Racimos cuyas flores femeninas ocupan la parte inferior ó son abortas, 2. - Racimos con las flores de ambos sexos entremezcladas en sus divisiones.

2. Estambres de 10 á 20. - 3. Estambres de 20 á 50 ; estilo 24partido con los brazos simples; semillas lisas. Arbustos ó frutices de hojas glandulíferas por la márjen y por la base, lampiñas ó con pelo estrellado; estípulas glandulosas ó apenas notables, racimos ordinariamente terminales. Frutice de 1 á 2 ' de alto, cuyas ramitas peludas llevan hojas aovadas ó aovado-lanceoladas, de ordinario con una punta, ondeado-enteras.o dentaditas, largas de 1 á $3^{\prime \prime}$ y proristas de puntitos transparentes, con la cara superior áspera, mientras que la inferior es blanco-tomentosa ó blanco-pubescente, cuya márjen lleva glándulas distantes y dos por la base, las cuales diminutas y globosas son estipitadas o subsesiles; estípulas diminutas. glandulíferas y caducas; estambres muchos, pétalos blancos; estilo 4-partido; semillas ovales apenas estriadas y con una depresion en derredor de la carúncula. C. humilis, L. Var. - C. origanifolius, Lam., C. T. V., 239-396.

3. De 10 á 20 , ó de 15 á 20 v mas estambres, 4. - De 10 á 15 o menor número de estambres, 12.

4. De 10 á 20 estambres, 6 . - De 15 á 20 ó de 15 á muchos, 5 .

5. De 15 á 20 , estilos profundamente 8 -fidos y con brazos simples, semillas aovado-oblongas, lampiñas pero con puntitos: arbustos tomentosos, con pelo estrelliforme; hojas dentaditas ú ondeado-enteras: estípulas decíduas; racimos terminales; frutice de 1 á $5^{\prime}$ de alto, con hojas aovadas con una punta, cordiformes por la base, de cara superior tomentosa y áspera, mientras la inferior es peludotomentosa y suare, sin glándulas basilares; segmentos del cáliz de las flores femeninas un poco estriados esteriormente. $C$. astroites, Ait. C. phlomoides, Pers. Lasiogyne astroites, Griesb. - 15 o muchos estambres; estilo bi-partido, con los brazos simples; árboles pequeños ó arbustos, tomentosos y cuyo pelo es estrelliforme ; flores: de ambos sexos entremezcladas, cuyas femeninas en cimitas especiales ocupan el centro de los racimos terminales. Arbol como de $15^{\prime}$ de alto, cuyas ramitas son tomentosas y llevan hojas acorazonado-trífidas, de cara superior estrellado-pubescente, mientras la inferior tomentoso-pubescente tiene 2 glándulas por la base; lobulos aovados con una punta y bien enteros. C. gossipifolius, $\mathrm{V}$.

6. Estilos bipartidos ó bífidos, con los bra\%os simples; semillas lisas y pequeñas ; arbustos ó frutices aromáticos cuyas hojas, vestidas de pelo estrellado, son provistas de ordinario de dos glándulas: estípulas ordinariamente caducas, 7. - Cáliz de las flores femeninas valvar y de ordinario coroliforme; estilos bipartidos con brazos 2 -fidos ó 4-partidos, con las divisiones simples ó bífidas; semillas lisas; arbustos ó frutices aromáticos y escamosos, con hojas bien enteras ú ondeadas y sin gláridulas, estipuladas; racimos axilares 0 terminales, 11. 
7. Hojas de dos colores, bien enteras ó dentaditas, 10 - hojas concóloras, 8.

8. Dentadas, alampiñadas ó lampiñas por la cara superior, 9. -

Hojas peludo-tomentosas por sus dos caras; frutice muy ramoso de 2 á $3^{\prime}$ de alto, cuyas ramitas un poco espesas y con el pelo amarillento $\mathrm{y}$ estrellado llevan hojas aovadas, aorado-lanceoladas, ó elípticas, de ordinario acorazonadas por la base, obtusitas, mucronaditas, con dos glándulas por la base, concóloras, por causa del pelo, ondeado-enteras, raramente dentaditas y largamente pecioladas; las glándulas son diminutas estipitadas; racimos terminales, estambres como 12, semillas sub-tetrágono-ovoídeas, largas de $1^{\prime \prime \prime}$ y con los ángulos obtusos. C. flavens, L. C. Richardi, W. : C. T. V., 239-396.

9. Arbusto cuyas ramitas, peludo-tomentosas, con pelo denso, llevan hojas aovadas, ó aovado-oblongas, obtusitas, profundamente dentadas $\mathrm{y}$ con los dientes glandulosos, papiráceas, pelucido-punteadas, largeas de 8-3", de cara superiór alampiñada, mientras la inferior peluda, es por fin verduzco-pálida con algun pelo esparcido y con 2 glándulas escuteliformes, sostenidas por un pedícelo espeso, y situadas por el vértice del peciolo largo de 1 á $2^{\prime \prime}$; racimos terminales largos; cáliz de las flores masculinas valvar, mientras el de las femeninas es 5 -fido; estambres 12; estilos bífidos. C. corylifolius, Lam. C. montanus, Geis.

10. Arbusto de 4 á $8^{\prime}$ de alto, muy ramoso, blanco-tomentoso, con hojas lanceoladas, oblongas ó lineares, obtusas mucronaditas, de cara superior verde y áspera, mientras la inferior es blanco-tomentosa, bien enteras y con 2-3 glándulas cilíndricas por la base, largas de 2-2" 1 [2 sobre $2-6$ "' de ancho ; racimos terminales : pétalos blancos y como 15 estambres; semillas sub-cilíndricas, largas de $1^{\prime \prime \prime} 1[2$, lustrosas y con puntitos. C. cascarilla, L.: C. T. V. 237. Variedad con las hojas lineares y las flores á veces dioicas. C. linearis, Jacq.-Frutice de 3 á $4^{\prime}$ de alto, cuyas ramitas son amarillentopubescentes llevan hojas cuya figura y tamaño varian muchísimo, lanceoladas ó aovado-lanceoladas, acuminadas, de cara superior áspera, alampiñada con pelo estrellado y verde, mientras la inferior es peludo-amarillenta, bien enteras y con 2 glándulas cortamente cilínd ricas y situadas por la base, largas de $23\left[4,3,334^{\prime \prime} \mathrm{y}\right.$ anchas de 6 á $8^{\prime \prime \prime}$ y hasta $18^{\prime \prime \prime}$, con puntitos pelucidos, tres á cuatro reces tan largas como el peciolo que lo es de $6,12,15^{\prime \prime \prime}$; racimos terminales, pétalos blancos y como 15 estambres; semillas ovoídeas, largas de $1^{\prime \prime \prime} 1[2$, lustrosas, brunas y con ángulos apenas pronunciados por el dorso. C. balsamifer, L.: C. T. V. 239-396.

11. Hojas concóloras por fin y verduzcas ; estilos 2-partidos, con los brazos bífidos; arbusto de 8 á $20^{\prime}$ de altura; muy ramoso y cuyas ramitas color de orin y escamosas llevan hojas aovadas, enteras ú ondeadas, obtusas ó con una punta, lampiñas, color de orin ó plateado-pintadas, con escamas distintas, especialmente por la cara inferior, con puntitos transparentes, largas de 5-2" y cuyo peciolo lo es solamente de 12 á $2^{\prime \prime \prime}$; estípulas evanescentes; racimos simples ó compuestos, pétalos blancos y velludos por la márjen, estambres 10 
12 ; semillas oval-oblongas, no lustrosas, manchadas y convexas por ambos lados $C$. eleuteria, Sw. C. glabellus, L. C. nilens, W.: C. T. T., 238. - Hojas de dos colores, estilos 4-partidos con los brazos bífidos ó simples; arbusto de ramitas plateado-escamosas, con el centro de las escamas color de orin; hojas aovadas con una punta obtusita, algo acorazonadas por la base, ondeado-enteras, lampiñas y sin puntos transparentes, largas de 3 á $1^{\prime \prime} 1_{[} 2$, de cara superior verde y con escamas plateado-lustrosas esparcidas por ella, mientras la inferior blanca tiene las mismas escamas lustrosoplateadas conflurentes, con el peciolo largo de $12-2^{\prime \prime \prime}$; racimos simples de lo largo del peciolo: estambres 10 ; flores femeninas con una corola; estípulas espesitas, lineares y algo persistentes. C. pseudochina, Schl.

12. Estambres en número de 10, 12, quince, 13. - Estambres 8-10; estilos 2-firlos con los brazos simples; semillas lisas; plantas herluáceas y raras veces arbustos, peludas, con hojas aserradas y con glándulas estipitadas, escutiformes y situadas por el vértice dèl peciolo; estípulas setáceas persistentes; racimos cortos laterales ó terminales. Planta herbácea anual, peluda, cuyas hojas oblongas, obtusas, aserradas y alampiñadas son aproximadas á los racimos cortos y mas largos que ellas: segmentos del cáliz de las flores femeninas iguales, espatulado-oblongos, obtusos y casi tan largos como la cápsula aovado-oblonga, cuyas semillas oval-redondeaditas, lustrosas, brunas, largas de $1^{\prime \prime} 1_{[} 2$ y convexas por ambos lados están provistas de una carnúcula. C. glandulosus, L.

13. Estambres 10 doce, 14 . - Estambres 12-15; estilos 3-8-fidos, con los brazos simples; semillas rugosas y oblongas; plantas herbáceas ó fruticescon hojas de ordinario palmatílobas; estípulas persistentes; racimos largos con las flores femeninas fasciculadas. Planta herbácea anual ó mata fruticulosa, peludita, que se eleva de 2 á $3^{\prime}$ de alto, ramosa superiormente, $y$ cuyo pelo es simple, con hojas 3-5-partidas, de segmentos elípticos ó elíptico-lanceolados; aguzados, aserrados, largamente pecioladas y largas de 2 a $21 \mathrm{I}^{2} 2^{\prime \prime}$ sobre $11,2-2^{\prime \prime}$ de ancho; estambres 12 á 13 , cuyas séries interiores son formadas de 2 ó de 3 ; cápsula tan larga como el cáliz peludo cuyas semillas, largas de $2^{\prime \prime \prime}$, con verruga gruesa sobre los lados y estriados por el dorso y el rafe son apiculadas por detrás de la carúncula y de un color lijeramente bruno y no lustroso. C'. lobatus, L. Atrea lobatı, Kl.: C. T. V. 238.

14. Estambres 10-12. Cáliz de las flores femeninas frecuentemente glandulífero; estilo 4 ó á veces 6 -partido con los brazos simples; semillas lisas; arbustos ó plantas herbáceas, peludas con hojas ordinariamente aserradas; estípulas filiformes persistentes $y$ glandulíferas, 16. - Estambres 10-12 solamente; cáliz de las flores femeninas reduplicativo, valvar por la base; estilos 4 -partidos, con los brazos simples ó á veces bífidos; semillas lisas; arbustos aromáticos, con hojas bien enteras ú ondeadas, lampiñas, de cara inferior escamosa ó desnuda, estípulas sin glándulas, racimos de ordinario terminales, 15 .

15. Arbusto como de ja a $6^{\prime}$ de altura, sin escamitas y cuyas ra- 
mitas lampiñas o alampiñadas llevan hojas elípticas ó eliptical oblongas, con una punta, obtusas, con puntos transparentes, largas de $3-1^{\prime \prime}$, otras veces $6-5^{\prime \prime}$, con las venas no proeminentes; estípulas decíduas ; cáliz alampiñado, el de las flores femeninas tiene los segmentos oblongos, obtusos, reduplicativos por la márjen y un poco persistentes por la base, mientras que el de las masculinas imbricativo es mucho mas pequeño y mucho mas pubescente; semillas ovoídeo-oblongas, largas de $2^{\prime \prime \prime}$, lustrosas y convexas por el dorso. $C$. lucidus, L. Var. - Glandulifera, V.

16. Frutice difuso cuyas ramitas algo peludas llevan hojas ovales ú oblongas, obtusas, mucronaditas, bien enteras ó festoneadas hácia el vértice, de cara superior alampiñada, mientras la inferior es peluda, con pelo suave, estendido y estrellado, sin glándulas axilares, largas de 12-8'", con el peciolo 3-4; estípulas mas cortas que el peciolo y glandulíferas; racimos terminales cortos y simples, cáliz de las flores femeninas grande, cuyos segmentos son pestañosos y con glándulas estipitadas; semillas redondeadito-oblongas, largas de $1^{\prime \prime \prime}$, lustrosas y de color lijeramente bruno, convexas por el dorso. C. ovalifolius, Vest. C. difusus, Rich. Barhamia ovalifolia, Kl.: C. T. V. 240 .

\section{GRUPO II. - HERMAFRODITAS.}

\section{Clase XLVIII. - POLIGALINEAS.}

Familia 107. - POLIGÁLEAS ó POLIGALÁCEAS.-. Plantas herbáceas, matas fruticulosas, frutices y arbustos mas ó menos sarmentosos, con hojas simples, alternas, raras veces opuestas, cortamente pecioladas ó sesiles, enteras, lineares ó lanceoladas, lampiñas de ordinario $\mathrm{y}$ sin estípulas; flores no simétricas, solitarias y axilares, ó dispuestas en espigas, racimos ó panojas terminales, cuyo pedícelo sale casi siempre de la axila de una bráctea y compuestas de un cáliz de 4-5 sépalos, cuyos dos, ordinariamente mas interiores, son petaloídeos y coloridos, mientras los tres esteriores, menores y verdes, parecen glumáceos; estivacion empizarrada; corola con 3 á 5 pétalos, libres ó soldados entre sí á favor de los filamentos vueltos; andróforo abierto lateralmente, parece amariposada con mayor frecuencia y cuya quila está adornada á menudo de una cresta que sin embargo suele faltar no rara vez; estambres hipójinos, de ordinario diadelfos y en número de 8 , cuyo andróforo tubular se parte en dos desiguales y ascendentes, con anteras uniloculares que se abren por el ápice á favor de un poro; algunas raras veces son libres y entónces solamente $2-4$. Pistilo simple formado de un ovario único, súpero, á veces acompañado de ún disco hipójino unilateral, de ordinario bilocular, con 1-2 óvulos pendientes, cuyo tegumento esterior es como carnoso, algo comprimido y cuyo vértice lleva un estilo largo, mas $\dot{o}$ menos arqueado $\mathrm{y}$ terminado por un estigma hueco, bílobo ó unilateral; fruto capsular ó muciforme, bilocular o unilocular por aborto, con las valvas septíferas por el medio de su 
cara interna, con semillas solitarias ó $2-3$ en cada celda y pendientes, frecuentemente provistas de un arillo ó carúncula situada por la base, peludas ó comosas, embrion recto, plano y axil, en un endospermo que suele faltar algunas veces; otras veces consiste en una especie de nuez ó de cápsula indehiscente y erizada.

G. I. Polygala, L.- 1. Quila provista de una cresta; labio superior del estigma con figura de cartucho y barbudo por el ápice encorvado; carúncula bi-partida cuyos segmentos son aplicados á la testa ó diminuta, 2. - Quila sin cresta alguna y adherida por la base con los estambres $y$ demas pétalos; estigma papiliforme, carúncula distinta de la semilla, tríloba y escutiforme: los dos sépalos inferiores mas ó menos reunidos. Planta herbácea anual, delgada, ramosa, pubescentita y alta de 6 á 12", con hojas linear-lanceoladas, puntiagudas, cortamente pecioladas y alampiñadas, largas de 1 á $2^{\prime \prime}$ sobre $2-4^{\prime \prime \prime}$ de ancho; racimos elongados y por fin largos de $2^{\prime \prime}$, curos pedícelos cabizbajos y de ordinario unilaterales llevan cada uno una sola flor amarillento-purpurácea, con los sépalos inferiores unidos hasta el medio, cuya quila tiene las alas persistentes y obovales y es un poco mas larguita que los pétalos superiores; estilo inclinado y subulado, cuyo estigma es barbudo por debajo del ápice; cápsula oblonga, escotada, lampiña, larga de $2^{\prime \prime \prime}$ é igualando las alas, con semillas cilíndricas, oblongas y sedosas ó franjeadas por el ápice redondeado. P. augustifolia, Kth. P. brizoides, St., hil. C. T. V., 438.

2. Plantas herbáceas lampiñas, 3. - Yerba algo pubescente ó alampiñada, de tallo ascendente, de ordinario muy ramosa, filiforme y largo de 8 á $12^{\prime \prime}$, con hojas lineares, esparcidas, largas de 6 á " 8 "' y con puntos; racimos elcngados, cuyos pedícelos por fin cabizbajos llevan cada uno una flor purpurina ó blanca, con las alas oblongas, obtusas é igualando la corola; estilo corto igual al estigma, cuyo labio superior es redondeado y con figura de cartucho, mientras el inferior, proeminente, es algo mas corto ; cápsula elipticaloblonga, cortamente escotada, con semillas negras y redondeadas por ambos estremos y pubescentes, de carúncula bi-partida, cuyos segmentos llegan un poco mas allá del medio de la semilla y son decíduos. P. paniculata, L. - P. modesta, Miq. C. T. V., 438.

3. Alta de 8 á $12^{\prime \prime}$, de tallo delgado recto, filiforme, con algunas ramas fastigiadas, saliendo por encima del medio, con hojas lineares, esparcidas, distantes, largas de $6^{\prime \prime \prime}$, cuyas inferiores son mas cortas, pero mas anchas, con glándulas todas; flores purpurinas ó blanquecinas, en racimos terminales, capituliformes, con pedícelos igualando los sépalos inferiores, glandulíferos por la base, y todos membranosos; alas mucronadas, oblongas, 3 -nervias, y mas cortas que la corola, cuyo tubo es casi tubuloso y formado per los pétalos reunidos por arriba del medio; estilo delgado, dilatado por el vértice, labio superior del estigma grande y con figura de cartucho, mientras que el inferior, corto, es glanduloso; cápsula aovadooblonga, obtusita y cortamente escotada á la par y provista por cada lado de una série doble de glándulas amarillas y situarla sobre la sutura por donde se debe efectuar la dehiscencia, con semillas ob- 
cónicas, peludo-sedosas y franjeadas por el ápice, carúncula, diminuta, cubierta por el pelo. $P$. longicaulis, Kth. P. incarnata, Aubl. P. adenophora, Dc. P. stellera, Rich. P. adpressa, Stend.

G. II. SECURIDACa,L. - Arbusto recto que se eleva á 10 ó $15^{\prime}$ de altura y á veces muchísimo mas, sarmentoso, con hojas aovadolanceoladas, aovadas ú oblongas, coriáceas y de cara inferior pubesscentita, largas de $11_{1} 2$ á $3^{\prime \prime \prime}$, ordinariamente aguzadas por el vértice, con una punta ú obtuso y con las venas proeminentes por ambas caras; flores rosadas en racimos densos, y apanojadas, terminales ó axilares, con los sépalos inferiores aovado-oblongos y obtusitos, las alas orbiculares é iguales, con la quila cortamente bíloba, cuyo apéndice dentadito iguala sus lóbulos, pétalos posteriores espatulados y obtusos; samara aguzada por la base desde el vértice sub-tronco, rectilínea por la márjen superior; diámetro lonjitudinal del carpidio mayor que el ancho de la base de la ala. S. erecta, L. S. volubilis, L. - Arbusto sarmentoso que se eleva á 15 ó 25' de altura, cuyas ramas largas, delgadas y lampinas se terminan por muchas ramitas delicadas, racemiformes, largas como de $1^{\prime}$ y ordinariamente pendientes, hojas redondeaditas, lampiñas y lustrosas, redondeadas por ambos estremos ó sub-escotadas, largas de 8-10"', cuyas florales son mucho mas pequeñas; racimos terminales, filiformes, colgantes, cuyas flores distantes y pintadas, olorosas y largas de $4^{\prime \prime \prime}$, con las alas color de rosa esteriormente y blancas interiormente y la corola amarilla, de sépalos inferiores aovado-oblongos y obtusos, alas orbiculares igualando la quila cortamente bíloba, cuyo apéndice pestañoso-festoneado ó sub-entero iguala sus lóbulos; pétalos posteriores ob-aovados; samara rectilínea desde el vértice redondeado hasta el medio, por debajo del cual se va aguzando, hasta la base; diámetro lonjitudinal del carpidio, mayor que la anchura de la base de la ala. S. virgata, Sw. S. scandens, Tuss. : C. T. V., 439.

G. III. Krameria ixina, L. : C.T. V., 103.

\section{CLASE XLIX. - GERANIOÍDEAS.}

Familia 108. - OXALÍDEAS. - Plantas herbáceas á veces fruticosas y muy raras veces arbustos, las primeras tienen á veces las raices provistas de tubérculos feculentos comestibles; de hojas compuestas frecuentemente de tres en rama ó paripinadas, sin estípulas, que presentan á veces fenómenos de irritabilidad. Flores amarillas, blancas ó rosadas, axilares ó solitarias y en corimbos terminales, que constan de un cáliz con 5 sépalos mas ó menos soldados por la base ó distintos, corola de 5 pétalos alternos, con los sépalos y mas largos que ellos, con uñas cortas, algunas veces coherentes por la base, caducos y de prefloracion torcida. Estambres cuyos filamentos dilatados inferiormente son monadelfos, cuyos opuestos á los pétalos son mas cortos y frecuentemente estériles, con anteras oscilantes, bi-loculares y abriéndose por dos grietas lonjitudinales. 
Ovario sentado ó provisto de un ginóforo corto y compuesto de 5 carpelos opuestos á los pétalos y reunidos entre sí hácia el eje, conteniendo un solo óvulo colgante del ángulo interno ó algunos dispuestos en dos séries y anátropos; estilos 5 libres ó soldados entre sí por la base, con estigma cabezudo ó bílobo. Fruto capsular de dehiscencia loculícida con semillas frecuentemente provistas de un arillo; otras reces es una baya con tantas celdas polispermas; embrion recto alojado en el centro de un endospermo carnoso, con cotiledones foliáceos y raicilla corta y superior.

G. I. Oxalis, L. - 1. Planta de tallo con hojas, 2. - Planta herbácea sin tallo, cuyas hojas arrosetadas son todas radicales y con el peciolo largo de $1^{\prime \prime}$ y llevando en su ápice 3 hojuelas sentadas, anchamente ob-acorazonadas, con 'un seno estrecho, peludas, y de cara inferior glandulosa, acompañadas de estípulas y saliendo de una raiz formada de tubérculos agrupados; cimas umbelíferas en el vértice de un bohordo y formadas de flores moradas é inclinadas hácia el suelo, con sépalos bi-glandulosos por el ápice, obtusos y distintos; pétalos largos de 8 á 10"' ; estambres con pelo, cuyos mayores esceden á los estilos peludos. O. martiana, Zucc. O. bipunctata, Grah.

2. Herbáceas ó fruticosas, de hojas con 3 hojuelas, cuya mediana terminal está distante de las demas, 3. - Siempre herbácea, de hojas con 3 hojuelas sesiles y ob-cordadas. Anual, cuyo tallo es rastrero por la base y difuso, largo de 5 á 8 ", ramoso, estípulas peciolares; flores amarillas en cimas paucífloras ó solitarias en el vértice del pedícelo, que por fin se vuelve corvo; estambres mayores casi tan largos como los estilos; cápsula pubescente con algunas semillas. O. corniculata, L. O. stricta, Sw. : C. T. V., 578. - Variedades: I ${ }^{a}$ tallo bajito pariendo estolones que echan raices; hojuelas pequeñas pestañosas, con el seno abierto; pedúnculos 1 ó 2-floros. 0. microphylla, Poir. O. corniculata repens, Zucc. - 2. Tallo bastante largo y ascendente, con hojuelas pubescentes de seno estrecho, pedúnculos 2 -floros y pubescentes. O. jamaicensis, Macf.

3. Plantas herbáceas anuales ó fruticulosas, 4. - Frutice tortuoso cuyas ramitas herbáceas llevan muchas hojas pubescentes, con las hojuelas ovales, redondeadas ó escotadas por el vértice, acompañado el peciolo de estípulas; flores amarillas en cimas umbeliformes, paucífloras, no mas largas que las hojas, de sépalos distintos; estambres mayores y mas largos que los estilos; cápsula ovaloblonga, con 2-3 semillas tuberculosas en cada celda. O. frutescens, L. - O. Plumieri, Jacq.

4. Pubescente, alta como de $12^{\prime \prime}$, cuyas hojas de hojuelas variables, pubescentes ó lampiñas aovadas o aovado-lanceoladas, obtusas ó con una punta, largas de 8 á $13^{\prime \prime \prime}$ y de cara inferior glauca, son acompañadas de estípulas; flores purpurino-pálidas, pintaditas de amarillo por la base de los pétalos, en cimas corimbiformes y con pedúnculos bífidos, sépalos distintos; estambres mayores y del largo de los estilos; cápsula aovado-oblonga, con 2 ó 3 semillas transversalmente ásperas en cada celda. O. barrelieri, Jacq. - Lampiña y cuyo tallo, mas delgado que el de la anterior especie, se eleva á 6 ó 
$10^{\prime \prime}$, con hojas alampiñadas, cuyas hojuelas ovales ú óvalo-redondeaditas son redondeadas ó escotadas por el vértice, membranosas y de cara inferior glauca, con estípulas; flores amarillas en cimas corimbiformes y con los pedúnculos bífidos; sépalos distintos; estambres mayores y mas largos que los estilos; cápsula aovadooblonga, con 2-3 semillas transversalmente ásperas, en 4 celdas contenidas. O. sepium, A. St.-Hil. O. hedysaroides, Zucc. O. Plumieri, Sieb.

G. II. Averrhoa, L.-Árbol muy ramoso, alto como de 10' á 15', cuyo tronco y ramos son floríferos y fructíferos, de hojas cuyo raquis lärgo de 7 á $10^{\prime \prime}$ y pubescente, lleva hojuelas alternas, cortísiniamente pecioladas, aovado-lanceoladas ó lanceoladas, de base redondeada, un poco cordiforme y algo inequilateral, de cara superior lampiña, mientras la inferior es pubescente y como aterciopelada sobre la costilla, que es color aleonado, aguzadas y puntiagudas por el vértice, largas de 1 1 $2-2-3^{\prime \prime}$ y anchas de 6 á $8^{\prime \prime \prime}$, las de la base son las menores, las de la parte mediana de las hojas mayores y las del vértice algo menores que ellas; flores rosado-rojizas, en racimos simples ó por grupos saliendo de la corteza del tronco ó de los ramos, con los cálices pubescentes, limbo de los pétalos oval-oblongo, estambres 10; frutos un poco claviformes, con 5 ángulos obtusos y poco pronunciados, de color amarillo pálido teñido de anaranjado, lampiños y lustrosos, largos como de $21_{1} 2$ á $3^{\prime \prime}$, sobre $11_{[} 4$ á $1^{\prime \prime}$ de diámetro. A. bilimbi, L.: C. T. V., 579.-Arbol casi del mismo tamaño y altura que el anterior, pero de copa mas redonda y de aspecto mas bonito, con hojas cuyo raquis lampiño, largo de 4 á $5^{\prime \prime}$ lleva hojuelas alternas, muy cortamente pecioladas, desiguales entre sí, de base redondeada, inequilateral, curo lado superior mucho mas ancho es aigo dilatado en ángulo redondo, mientras que el inferior, apenas pronunciado, parece huirse, aovadas ó aovado algo lanceoladas, ú ovales, con una punta, lampiñas por ambas caras, con la costilla sin embargo un poco pubescente inferiormente, largas de $11_{[} 2$, $2,2^{\prime \prime} 1_{[} 2$ sobre $1^{\prime \prime} 1_{1} 2$ de ancho y casi aovadas, un pocotrianguares: las de la base son largas solamente de 8 á $6^{\prime \prime \prime}$; flores rosadas en racimos apanojaditos, axilares y terminales, con los cálices lampiños y el limbo de los pétalos sub-redondeado; 5 estambres; frutos del tamaño de un huevo pequeño de gallina, cuya forma tiene casi, amarillos y con 5 ángulos aguzaditos. A carambola, L.

Familia 109. - TROPCOLEAS. - Plantas herbáceas, difusas, volubles ó enredaderas, lampiñas y á veces glaucas, cuyas hojas simples y sin estípulas son alternas, largamente pecioladas, pectinervias y abroqueladas; flores axilares, solitarias, de ordinario largamente pedunculadas y formadas de un cáliz 5-partido colorido, cuya lacinia superior tiene la luase prolongada en espolon libre abierto por dentro de la flor ó á veces por fuera de los estambres, mientras los otros lóbulos son tan pronto libres como reunidos entre sí, de varios modos; corola de 5 pétalos insertos en la garganta del cáliz y con cuyos segmentos alternan, desiguales, irregulares $\mathrm{I}$ de los cuales dos son superiores, un poco apartados de los otros y situados en la boca ó fauce del espolon, mientras los tres inferiores 
ungüiculados son menores y hasta suelen abortar algunas raras veces: hay 8 estambres, cuyos filamentos libres son aplicados contra el ovario é insertos en el disco, con anteras terminales, oblongas, erguidas, bilosulares y abriéndose por una grieta doble. Pistilo simple formado de un ovario, con tres carpelos adheridos con la hase del estilo ó con el eje del fruto, uniloculares r monospermos: fruto formado de 3 carpelos algo carnositos reunidos hasta la madurez, porque entónces se separan, son indehiscentes y contienen una semilla única gruesa, sin endospermo y cuyo embrion mayor tiene cotiledones rectos, espesos, distintos, cuando tierno, mientras que mas tarde están reunidos entre sí; sin embargo, por la parte inferior quedan distintos, raicilla escondida entre ellos y con 4 tuberculitos.

Tropoelum, L. - Planta herbácea algo trepadora. de hojas bastante grandes, largamente pecioladas, abroqueladas, orbiculares, sub-5-lobas, cuyas nervaduras salen á manera de radios del punto de insercion del peciolo, algo lateral, cara superior lampiña y verde subido, mientras la inferior lijeramente pubescente es mas pálida. Flores grandes, hermosas y color de fuego, cuyos pedúnculos son largos de 4 á $6^{\prime \prime}$; los dos pétalos superiores, mayores, obovales y obtusos, se estrechan insensiblemente por la base, hasta volverse una uña, mientras los tres inferiores, mas largos, ovales, redondeados $\mathbf{y}$ enteros, tienen uñas mas estrechas, casi tan largas como el limbo, cuya parte inferior es pestañosa por los bordes. $T$. majus, L. Yerba enredadera de tallos largos, delgados, muy ramosos, lampiños y moraduscos, que llevan hojas largamente pecioladas, abroqueladas, truncado-orbiculares, con 5 lóbulos redondos ó quizás mejor 5-festoneados, con los dos superiores laterales y mas pequeños, con una puntita ó un punto amarillo por el vértice y correspondiendo con la nervadura; cara superior lampiña, algo glauca, así como la inferior, que además es mas pálida y con las nervaduras, nervios y venas muy pronunciados. Flores muy bonitas, ni pequeñas ni grandes tampoco, mas pálidas que las de la especie anterior, axilares ó en racimos terminales, paucífloros, largamente pedunculadas, limbo franjeado ó con muchas lacinias desiguales, cuyas inferiores son setiformes; la flor tiene como $10^{\prime \prime \prime}$ de diámetro. T. mauritzianum. - Cachipillo, Vzla.

\section{CLASE L. - RUTÍNEAS.}

\section{Familia 110. - SIMARÚBEAS ó SIMARUBÍCEAS'.-} Árboles mas ó menos pequeños, ó arbustos, con hojas compuestas y pinadas de ordinario con un impar: flores blancas, verdosas o rojizas, en racimos ó en cimas axilares ó terminales, hermafroditas, polígamas ó unisexuales y regulares, formadas de un cáliz con 4 ó con 5 divisiones mas ó menos profundas, corola con 5 pétalos de prefloracion torcida; estambres ordinariamente saliendo de una escama hipojina en número de 3-5-8-10, con anteras biloculares y muy rara vez 4-loculares. Pistilo compuesto formado de 2-3-4-气̄ ovarios distintos, uniloculares, con el óvulo pendiente, estilos distintos por la base y saliendo del vértice de los ovarios, algunas ve- 
ces uno solo, por estar soldados entre sí, terminado por un estigma 4-5-lobo; fruto compuesto de tantas drupitas cuantos ovarios habia, cuyas semillas, de tegumento membranoso, tienen un embrion sin endospermo, recto y con cotiledones espesos, de raicilla superior corta y escondida entre ellos.

G. I. Simaruba, Aubl.- Árbol alto de 40 á $50^{\prime}$, con las hojuelas oblongas ó lanceolado-oblongas, mucronadas, con una punta obtusita, bien enteras, lampiñas ó pubescentes inferiormente, largas $2,1_{[} 4,3,2^{\prime \prime}$ sobre $2,21_{[} 4,1^{\prime \prime}$ de ancho, con el peciolo de $1_{[} 2^{\prime \prime \prime}$, desiguales, verdes por ambas caras, panojas mas cortas que las hojas, pétalos abiertos. S. amara, Aubl. S. officinalis, Dc. : C. T. V., 162. Árbol como de 20 á $25^{\prime}$ de altura, con las hojas de hojuelas espatulado-oblongas ó lanceoladas, redondeadas por el vértice, lampiñas y de cara inferior pálida y glauca, largas de $2^{\prime \prime} l_{[4}$ por el vértice, $I^{\prime \prime} 2\left[3\right.$ por la base, anchas de $1^{\prime \prime} 1_{[} 4-11_{[} 2$, con el peciolo de 4 "'; flores amarillas en panojas, casi tan largas como las hojas, y de $2^{\prime \prime} 1$ 6-3, con los brazos inferiores de $1^{\prime \prime}$, de cáliz largo apenas de $1^{\prime \prime \prime}$, con los pétalos abiertos, largos de $3^{\prime \prime \prime}$, oblongos, obtusos y torcidos; drupas bi-anguloso-ovoídeas, purpurino-oscuras, secas, leñosas y largas de 8"'. S. glauca, Kth. S. officinalis, Macf. S. medicinalis, Endl. : C. T. V., 163.

G. II. Picraminia, Sw.-Hojas con 7-9 hojuelas aovado-lanceoladas ó lanceolado-elípticas, con una punta obtusa, de cara inferior lampiña ó pubescentita $\mathrm{y}$ alampiñada, con las principales venas proeminentes, largas de 4-2" y papiráceas; arbusto ramoso que se eleva como á 8-10' de alto, cuyas flores son dispuestas en racimos pubescentitos, filiformes, pendientes, dos veces ó mas largos que las hojas, formados de grupos algo distantes y largos de $1^{\prime \prime}-2^{\prime \prime}$, con tres pétalos blanco-verdosos, largos de $1^{\prime \prime \prime}$ y mas cortos que los estambres; bayas ovoídeas, por ambos estremos obtusas, largas de 4$5^{\prime \prime \prime}$ y anchas de $3^{\prime \prime \prime}$, encarnadas y por fin negras y lustrosas. $P$. antidesma, Sw. : C. T. V., 124. - Hojuelas 5-7 aovado-oblongas, con una puntita, lampiñas, papiráceas, lustrosas, largas de 2-3", con venas reticuladas por ambas caras; arbusto de 10 á 15' de alto, cuyas flores son dispuestas en racimos pendientes, frecuentemente divididos hasta la base y casi tan largos como las hojas, con pétalos 5-oblongos-lineares, mas cortos que los estambres y largos de $1^{\prime \prime \prime}$; bayas oblongo-ovoídeas ú ovoídeo-redondeadas por ambos estremos, largas de $5^{\prime \prime \prime}$ y anchas de $3{ }^{\prime \prime \prime}$, rojizas y por fin azul-oscuras ó negras y lustrosas. P. pentandra, Sw. P. micrantha, Tul. : C. T. V., 751 .

G. III. Sinaba, Aubl.-Árbol alto de 20 á $25^{\prime}$, de tronco delgado, recto y cuyos ramos dispuestos hácia la sumidad á manera de umbela llevan hojas largas de mas de 2 ', imparipinadas, con 15 ó 20 pares de. hojuelas desiguales, las de la base menores, las del medio mayores y las del vértice como intermedias, elíptico-lanceoladas, casi sentadas y alternas sobre el raquis bastante grueso y color aleonado, algo aguzadas por el ápice, terminado por una glándula redonda, hruna, lisa y lustrosa, de base redondeada y algo inequilaterales, enteras y con los bordes algo doblados hácia abajo, lam- 
piñas, largas de $8^{\prime \prime}$ las mayores y de 3 á $2^{\prime \prime}$ las menores y de 2-2 1 2 sobre $11_{[} 2$ de ancho. Flores largas como de $1^{\prime \prime}$, de color blanco un poco aleonadito ó verdoso-amarillentitas, sub-aterciopeladas, solitarias, un poco distantes y casi sesiles sobre los brazos largos que forman la panoja piramidal que termina los ramos, larga como de $3^{\prime} \mathrm{y}$ hasta mas; cáliz 5 -dentado, pétalos lineares, largos como de 1", esteriormente aterciopelados, cóncavos y con un dientecito en el borde interno; estambres 10 , de los cuales 5 son mayores y todos mas cortos como de $2^{\prime \prime \prime}$ que la corola; escamas estaminíferas casi tan largas como los filamentos, que se separan del $l_{[} 4$ superior de su cara superior y siguen libres, cargando una antera grande bi-locular y pegada en el ápice por el medio de su dorso, formando un tubo en el contro de la flor, separándose las unas de las otras solamente al desprenderse despues de la fecundacion, aterciopeiado-velludas; estilo mas largo que los estambres y sin embargo un poco mas corto que los pétalos, cuyo estigma puntiforme es poco notable. Fruto drupáceo del tamaño de un huevo de gallina y hasta mucho mas grueso, algo carnoso, oval-aterciopelado, monospermo y con olor desagradable. S. cedron, Planch . C. T. V., 749. - Arbol mediano cuyas hojas tienen 3-7 hojuelas espatulado-escotadas, apenas venosas, sub-coriáceas, largas de $3-5-6-1^{\prime \prime} 1_{[} 2$, y anchas de $21_{[} 2-3-11_{[} 2$, las inferiores siendo siempre menores que las superiores, subsesiles y de ordinario opuestas; flores en racimos solitarios formando panojas terminales, cuyos pedúnculos son polvorientos; pequeñas, solitarias ó agrupadas por á 3 , largas como de $2^{\prime \prime \prime}$, pelitiesas, cuyos pedícelos cortos salen de la axila de una bráctea decídua; cáliz mucho mas corto que los pétalos, filamentos mucho mas largos que las escamas oblongas, peludas y sueltas; ovarios tan largos como el ginóforo; estilo corto y simple; carpidio único por aborto, inequilateral, aovado, lampiño y largo de 10-12"'. S. orinocensis, Kth. S. guianensis, Planch. C. T. V., 750.

G. IV. Quassia amara, Lf. : C. T. V., 161. - G. V. Prcraena excelsa, Ludl. : C. T. V., 163.

Familia 11i. - DIOSMEAS ó CUSPARIEAS. - Plantas herbáceas, matas, arbustos y árboles mas ó menos altos, mas ó menos corpulentos y coposos de hojas alternas y compuestas, cuyas hojuelas opuestas ó pinadas, estan frecuentemente provistas de puntos glandulosos, sin estípulas; flores regulares ó irregulares, hermafroditas y dispuestas en corimbos ó en espigas ó panojas terminales ó axilares, blancas ó rojizas y que se componen de un cáliz con 4-5 segmentos mas ó menos profundos, de una corola con 4-5 pétalos, de ordinar.io libres ó á veces soldados entre sí, los cuales suelen faltar enteramente alguna vez que otra; de prefloracion imbricada ó valvar; estambres hipójinos $y$ algunas raras veces períjinos, en 1 o 2 séries y en número duplo de los pétalos ó igual, por causa de aborto parcial de algunos, cuyos filamentos carecen de apéndice; pistilo formado de carpelos en igual ó menor número que el de los pétalos libres ó soldados entre sí y volviéndose un ovario único plurilocular, cuyas celdas contienen de ordinario dos huevecillos sobrepuestos, con otros tantos estilos enteramente 
soldados entre sí ó libres hasta su parte superior, que está soldada sola y terminándose por un estigma, con tantos lóbulos cuantas celdas hay; fruto formado de carpidios ó cajitas 4-5, cuyo endocarpio al madurarse ellos se desprende con elasticidad y simula una valva leñosa, semillas con tegumento crustáceo, ora conteniendo en el eje the un endospermo carnoso un embrion cilíndrico ó con cotiledones anchos, otras veces está sin endospermo y el embrion tiene sus cotiledones tan pronto rectos y espesos, como delgados y ajados ó conduplicados, otras veces doblados de tal modo, que sus dos mitades abrazan en su pliegue la raicilla, que es siempre superior.

Tribu 1a. - PilocárPeas. - Flores regulares, polipétalas, isostémonas ó diplostémonas, con estambres hipójinos; el número de los ovarios iguala al de los pétalos, contienen dos óvalos y son distintos, así como los estilos, pero por la base sola, ó mas veces soldados entre sí; endospermo nulo; árboles ó arbustos de hojas simples ó compuestas. Evodia febrifuga, A. St.-Hil. - Árbol del Perú que contiene cinchonina.

Tribu 2a. - Eucuspárieas. - Flores regulares ó irregulares, frecuentemente seudo-monopétalas, de estambres hipójinos ó epipétalos en igual número que los pétalos, todos anteríferos, ó de los cuales, algunos deformados son estériles; ovarios en igual número tambien, bi-ovalados y distintos, así como los estilos, pero por la base sola; endospermo ninguno; embrion cuyos cotiledones doblados sobre la radícula son por lo comun conduplicados y ajados; árboles y arbustos de hojas compuestas. Bonplandia trifoliata, C. 'T. V., 756. - Monnere trifoliata, C. T. V. 532.

Familia 112. - RUTACEAS. - Plantas herbáceas, arbustos y á veces árboles, cuyas hojas, compuestas ó descompuestas, son alternas; flores regulares en cimas ó racimos terminales y compuestas de un cáliz, con 4-5 divisiones mas ó menos profundas, de una corola con otros tantos pétalos de prefloracion empizarrada. Estambres hipójinos en número duplo ó triple de los pétalos y cuyos filamentos son sin apéndices. Pistilo formado de 3.5 carpelos libres ó soldados entre sí hácia el eje, conteniendo 1-2 ó mayor número de óvulos, colgados del ángulo interno ó adheridos por su cara ventral : otros tantos estilos hay tan pronto soldados enteramente como distintos por la base, terminados por un estigma 3-5-lobado, en el primer caso, y entero en el segundo; fruto capsular ó formado de cajitas indehiscentes, cuyas semillas están colgantes ó adheridas, de embrion algo arqueado, con radícula superior y cotiledones achatados y envuelto en un endospermo carnoso. Ruta chalepensis, C. T. V., 28-331.

Familia 113. - ZIGOFÍLLEAS. - Plantas herbáceas, arbustos y árboles altos y corpulentos, cuyas hojas compuestas y pinadas son opuestas y acompañadas de estípulas, sin glandulitas transparentes; flores hermafroditas, solitarias y axilares, en racimos ó en panojas terminales, tan pronto blancas y azules, como rojizas $y$ amarillas, las cuales constan de un cáliz con 4-5 sépalos distintos, de prefloracion empizarrada; corola de 4-5 pétalos libres y ordinariamente imbricados y regulares; estambres en número duplo y 
raras veces igual con los pétalos, hipójinos dispuestos en 1 ó en 2 séries, distintos y cuyos filamentos tienen la base algo dilatada ó acompañada de un apéndice con que suele soldarse alguna que otra vez. El pistilo se compone de un ovario simple, situado sobre un disco glanduloso y acumpañado de tantas glándulas y tantos surcos cuantas celdas tiene interiormente, conteniendo cada una dos óvulos o mavor número, por lo regular colgados del ángulo interno, y su vértice lleva un estilo único simple, con un estigma 4-5-lobo: otras veces hay 4-.5 estilos distintos y cada uno terminado por su estigma correspondiente. Fruto carnoso ó capsular, que en este último caso se abre en otras tantas ventallas ó en otras tantas cajitas que se lesprenden y opuestas con los tabiques, cuyas semillas, de tegumento delgado y herbáceo, con epispermo cartilajinoso, que suele faltar bastantes veces, tienen el embrion verdusco, con cotiledones foliáceos y radícula superior.

Tribu $1^{a}$. - Tribúleas. - A. Carpelos ó cajitas ordinariamente subdivididas en celdillitas monospermas por medio de tabiques transversales; semillas sin endospermo. Tribulus, L. - Cáliz decíduo, carpidios 5, divididos interiormente en segmentos monospermos por tabiques transversos; yerba vivaz cuyos tallos divaricados, estendidos y largos como 6 á $12^{\prime \prime}$, llevan hojas largas de $4^{\prime \prime} 11^{2} 2,3$ ú 8 aparejadas, con hojuelas cortamente oblongas, desiguales, cuyas inferiores son menores y las superiores mayores, largas de $1^{\prime \prime}, 1^{\prime \prime} 1_{1} 2$ solvre 8 á 10"' de ancho, de cara inferior como sedosa. Pedúnculos largos como las hojas unífloras; cáliz de sépalos lanceolado-aguzados y mitad mas corto que los pétalos, largos de 8 á 10"', imbricalos, amarillos. ob-acorazonados y largos de $1^{\prime \prime} 1$ [2 sobre $1^{\prime \prime}$ de ancho. Estambres 10, carpidios 3-5-espermos, separándose del eje no. central, tuljerculados, con dos espinas diverjentes ó con 1 sola. $T$. cistoides, L. : C. T. V., 370. - Cáliz persistente, carpidios 10-12, separíndose del eje central, monospermos; yerba anual algo fruticulosa, de tallos ramosos divaricados, tendidos sobre el suelo y largos de 10 á $15^{\prime \prime}$ y hasta mas, con la sumidad ascendente á veces, de hojas con 2-3 ó 4 pares de hojuelas oblícuamente oblongas ú ovales, con la cara inferior peluda, largas de $1,1\left[2\right.$ " sobre $8,10^{\prime \prime \prime}$ de aucho, estípulas lanceolado-lineares; pedúnculos casi tan largos como las hojas, unífloros y erguidos, sépalos subulados y apenas mas cortos que los pétalos, de color blanco-amarillento sucio. 10-carpidios estriados, tuberculados é inermes. T. maximus, L. T. decolor, Macf.: C. T. V. 370.

Tribu $2^{a}$ - Euzigofílleas. - Celdas no partidas por tabiques ó indivisas, cuyas semillas están provistas de un endospermo. G. I. GuAracum, L.- Arbol mediano o bajito, ramosísimo y primoroso, de hojas con dos pares de hojuelas ob-ovales, obtusas, siempre verdes y lampiñas, largas de $12-6^{\prime \prime \prime}$; sépalos ovales persistentes y tres veces mas cortos que los pétalos espatulados azules y largos de 6"'; fruto aovado-redondeadito y retuso. G. officinale, L. : C. T. V., 404. - Arbol algo mas alto mas corpulento, de liojas con 4-5 pares de hojuelas oblícuamente lanceolado-clípticas ú ob-aovadas, con una punta ú obtusas, largas de 12-8"', sépalos ovales, lampiños, 
mitad mas cortos que los pétalos ob-aovados y largos de $6^{\prime \prime \prime}$; fruto ob-aovado redondeadizo y mucronado. S. sanctum, L. : C. T. V.404.

G. II. Zygofilium arboreum, L. : C. T. V. 407.

Familia 114. - ZANTOXILEAS ó ZANTOXILÁCEAS.Arbustos ó árboles mas ó menos altos, corpulentos y coposos, cuyas hojas opuestas ó alternas, son ordinariamente compuestas é imparipinadas, con puntitos glandulosos, transparentes y sin estípulas: flores unisexuales ó polígamas regulares, en racimos ó en panojas axilares, ó las mas veces terminales, que se componen de un cáliz, con 3-4-5 divisiones mas ó menos profundas, de una corola con 34-5 pétalos que algunas veces suelen faltar; las masculinas contienen tantos estambres hipójinos cuantos pétalos hay y á reces en número doble, con filamentos libres, tan pronto simples como provistos de un apéndice é insertos por debajo de un ovario rudimentario. En las femeninas se observan unas veces los rudimentos de los estambres acompañando á igual número de ovarios como pétalos hay, otras veces en menor número é insertos en un disco, distintos ó soldados entre sí y con dos óvulos cada uno: hay otros tantos estilos libres ó soldados mas ó menos completamente, los cuales suelen faltar algunas veces, con estigma simple ó lobulado. Fruto tan pronto simple, carnudo ó membranoso, como compuesto y formado de algunas cajitas ó carpelos, drupitas cuyo pericarpio leñoso en mayor parte se desprende al llegar la madurez, con semillas de tegumento lustroso, espeso y crustáceo, alguna rara vez aladas, formadas de un embrion recto ó arqueado, con radícula superior y los cotiledones ovados y aplanados, alojado en un endospermo carnoso.

G. I. FAGARA, Jacq.-1. Aguijones estipulares recorvados, hojas con 4-6 pares de hojuelas, 2. - Aguijones estipulares rectos, hojas con 1-3 pares de hojuelas ovales ó espatuladas, escotadas ú obtusas, bien enteras, lampiñas, coriáceas, largas de 6-3"', con dos tubérculos situados por la base de su cara inferior, de raquis inerme y con las articulaciones lanceoladas; flores en glomérulos cortos; carpidios 2-1-globosos, mucronados, subsesiles, con $1^{\prime \prime \prime} 1{ }^{4}$ de diámetro. Arbusto de 15 á $20^{\prime}$ de altura, tortuoso, con muchas hojas y ramoso, cuyos aguijones son largos de $1^{\prime \prime \prime} . F$. microphylla, Desf. F.pteiota, L. Zanthoxylum spinifix, Jacq. : C. T. V. 30-406.

2. Arbusto alto de $5^{\prime}$ á 8 ', ramoso, cuyas hojuelas espatuladas, obtusas, bien enteras, lampiñas y coriáceas, son largas de 6 á $3^{\prime \prime \prime}$; raquis provisto de un aguijon solitario, situado por la base de los pares de hojuelas y con los artejos espatulados; fiores en glomérulos. F. tragodes, Jacq. - Arbusto alto de $15^{\prime}$ á $20^{\prime}$, cuyas hojuelas ovales ú ob-aovadas, escotadas ú obtusas y festoneadas son lampiñas, con puntos transparentes, situados especialmente por debajo de los festones y con dos tubérculos por la base de su cara inferior y largas de 12-5"', cuyo raquis formado de artejos lanceolados es inerme; flores en glomérulos oblongas; carpidios 2-1 globosos, mucronados y tan largos como el carpóforo. $F$. lentiscifolia, W. $F$. pterota, L. - Zanthoxylum pterota, Kth. C. T. V. 31.

G. II. ZanthoxyuuI, L.-1. Estigma abroquelado por cohesion y subsesil, 2. - Estilo simple, distinto en las flores masculinas; hojas 
unifolioladas; árbol muy ramoso y curas ramas cargan muchas hojas elípticas bien enteras, lampiñas, con muchos puntitos transparentes, largas de 3-1" $1[2$, obtusitas y venenosas, cuyo peciolo articulado por debajo del ápice es largo de $10-4^{\prime \prime \prime}$; flores en panojas terminales, abiertas, casi tan largas como las hojas, lijeramente pubescentes, de cáliz diminuto y 5 -fido; pétalos apenas largos de $1^{\prime \prime \prime}$ é iguales con los 5 filamentos y el estilo; en las flores masculinas 3 ovarios coherentes y rudimentarios hay situados sobre un ginóforo mas corto que el estilo. $Z$. ocroleucum, Dc.

2. Hojas con 9-6 ó 6-2 pares de hojuelas mas ó menos festoneadas, 3. - Hojas con 5-10 pares de hojuelas bien enteras ó finamente aserraditas, lanceolado-oblongas, subsesiles, con una punta, cuyas inferiores son á veces elípticas, largas de como $111^{2} 2$ á 2 ; de cara superior lampiña, mientras la infe rior es pubescentita á lo large de las nervaduras ó alampiñada, provi ${ }^{\mathrm{s}}$ tas de puntos transparentes esparcidos, cuyo raquis pubescentito tiene aguijones cortos y rectos; panojas terminales ó axilares, pubescentes y de 2-4" de diámetro; ovarios 5 coherentes por el eje; carpidios 5 ó 2 erguidos, sentados, largeos de $3^{\prime \prime \prime}$ é insertos en un eje cónico y central, con el endocal'pio delgadito por la márjen. Arbol de 25 á 50 ' de alto, corpulento y coposo, cuyo tronco y ramas están armados de gruesos tubérculos cónicos terminados por un aguijon recto, fuerte, negro y muy punzante $y$ esparcidos sin órden por su superficie. Z. Clava herculis, L. Z. caribcum, Lam. Z. lanceolatum, Poir.: C. T. V., 94-405.

3. Arbol bastante grande y que parece mucho al anterior, de hojas con 9-6 pares de hojuelas, lanceoladas, festoneado-aserradas, sub-sesiles, largas de $2^{\prime \prime}$ y anchas de $8^{\prime \prime \prime}$ y con una punta, de cara superior lampiña, mientras la inferior es pubescente solamente sobre la costilla, provistas de muchos puntos transparentes y cuyo raquis es pubescentito é inerme; panojas terminales, pubescentes, abiertas y de 4-6" de diámetro; carpidios solitarios por causa de aborto, globosos, sentados, tarde dehiscentes, insertos en un torus ó lecho diminuto de 1 "' 1,2 de diámetro. Z. microcarpum, Gr. - Arbol como de $20^{\prime}$ de altura, con aguijones cortos y subulados o sin ellos, muy ramoso y de hojas con 6-2 pares de hojuelas, elípticas ú oblongas, festoneadas, con los festones anchamente truncos, pecioladas lampiñas $y$ con puntitos transparentes muchos por la ca ra inferior, de los cuales una série está entre los festones, largas de $11 l^{2} 2$ à $2^{\prime \prime}$ sobre 8 á 10 de ancho y cuyo raquis es lampiño; panojas terminales o axilares, lampiñas, verrugosas, abiertas y de 3 á $8^{\prime \prime}$ de diámetro; 5 ovarios coherentes en el eje, carpidios cabizbajos, y por fin mas cortos que los carpóforos, distintos, diverjentes, mas gruesos por el vértice y largos de 3-4"'; endocarpio adherente con las valvas. $Z$. aromaticum, W. Z. elephantiasis, Macf.

\section{CLASE LI. - HESPERIDÍNEAS.}

Familia 115. - AURANCIÁCEAS ó HESPERÍDEAS'. Arbustos ó árboles bajitos, con ó sin espinas, cuyas hojas aunque pa- 
rezcan simples, son siempre compuestas, sea formadas die un peciolo alado, llevando por su ápice una sola hojuela mas ó menos grande y articulada con él, sea que tenga tres ó mayor número de hojuelas coriáceas, lustrosas y siempre provistas de muchas glándulas vejiculares y transparentes. Flores siempre hermafroditas, en grupos axilares ó en racimos terminales, las cuales constan de un cáliz monosépalo persistente, con 5 ó 3 dientes, de una corola con 5 ó á veces 3 pétalos, cuya base alco dilatada se inserta en derredor y un poco por debajo de un disco hipójino y junto con los estambres, cuyo número varia desde 10 hasta 20 algunas veces mas, de filamentos libres, monadelfos ó poliadelfos : se observa alguna vez que otra un nectario en rededor de la base del orario. Pistilo único formarlo de un ovario simple mas ó menos globoso, súpero, sentado sobre el disco y plurilocular, mono ó polìspermo, cuyo vértice lleva un estilo único, mas ó menos corto, bastante grueso y terminado por un estigma grueso, simple, discoídeo y raras veces 3-5-lobo. El fruto es un hesperidio ó una baya, cuyas semillas, de epispermo membranoso, contienen un embrion recto, y sin endospermo, cuyos cotiledones rectos siguen el eje de la radícula.

\section{Análisis dicotómica de las trizus.}

1. Estambres siempre en número duplo de el de los pétalos, 2. Estambres en número duplo ó múltiple de el de los pétalos, un hesperidio; algunos huevecillos dispuestos en dos hileras. Hojas unifolioladas. T. I. Cítreas. A. - 2. Un huevecillo único ó dos colaterales, una baya, hojas trifoliadas. T. II. Lrmóxess. Limonia trifoliata. - Dos óvulos sobrepuestos, una baya; hojas imparipinadas. T. III. Clausénieas. Nur Vuya exotica, L. : C. T. V. 304.

A. Crtrus, L. - 1. De hojas enterarnente lampiñas, 2. - De hojas cuya cara inferior es pubescente, lijeramente provistas de glándulas; peciolo alado; fruto mayor oroídeo-globoso, deprimido por el ápice, largo como "de 5 á $7^{\prime \prime}$ y ancho de 2 á $3^{\prime \prime}$, de color amarillo. claro ó verdoso : los vástagos tiernos son pubescentes. $C$. decumana, L - Con las glándulas oleiferas, llanas ó cóncavas : de esa clase hay dos solas variedades: $1^{\mathrm{a}}$. CHADEO. C. cadeca mayor y $C$. cadeca menor, aue en Jamaica, Trinidad y las Antillas francesas se llama fruto prohibido.

2. Peciolo desnudo ó marjenado; fruto con un pezon, de sabor muy ácido y cuyo color es amarillo-pálido, llamado amarillo de limon. C. medica, L. : C. T. V., 301. - Hay bastantes variedades de esa especie, cuyas principales son : $1^{\mathrm{a}}$. La del fruto ovoídeo-oblongo, tuberculado y lijeramente ácido. $2^{\mathrm{a}}$. Fruto ovoídeo, casi redondo, rugoso y muy ácido. C. limonium, Riss. Barbadoro ó bigueta. C. T. V., 584. 3a. Fruto ob-ovoídeo, con el estilo ordinariamente persistente, lijeramente ácido. C. peretta, Riss. Peretta domingensis. Perita de Sto Domingo. 4a. Fruto bastante largo, ovoídeo-oblongo, tuberculado y con un pezon largo en el vértice, bien ácido. $C . M$. vulgaris. Limon francés. C. T. V., 583. - Peciolo alado; fruta glo- 
boso sin pezon alguno. C. aurantium, L. : C. T. V., 585. - De esa especie hay muchas variedades: $1^{\mathrm{a}}$. Frutos muy gruesos de color anaranjado, con las glándulas oleíferas convexas: sabor muy dulce. C. paradisi, Macf. - 2a. Fruto bastante grueso, color anaranjado mas pálido, rugosito y con las glándulas oleíferas cóncavas: sabor amargo ýácido á la par. C. bigaradia, Duh.: C. T. V. 302. 3a. Fruto mucho mas pequeño y como de 11 l 2 á 1 " de diámetro solamente, de color amarillo-pálido, liso y con las glándulas oleíferas cóncavas: de sabor mas ó menos dulce; arbusto espinoso, con las hojas festoneadas. C. espinosissima, Mley. C. Tima, Macf. 4. La naranja agria, cuya cáscara se llama de Curaça. C. A. vulgare. C. T. V., 58\%. $5^{2}$. Las naranjas de China ó dulces, cuyas flores son muy estimadas Y los frutos se confitan. C. sinensis. C. T. V., 588.

Familia 116. - OLACINEAS. - Arboles ó arbustos con ó sin espinas, lampiños, de hojas alternas simples, enteras y sin estípulas; flores pequeñas axilares, racimosas, corimbosas ó agrupadas, constando de un cáliz monosépalo, persistente y acrescente, mas ó menos trunco ó dentado; de una corola con 4-6 pétalos coriáceos. libres ó soldados entre sí por pares, con apéndices filiformes, de estivacion valvar, frecuentemente velludos interiormente; estambres hipójinos ó epipétalos desde 3 á 5 , de filamentos comprimidosubulados, con anteras acorazonado-oblongas, derechas y biloculares; ovario simple, ordinariamente súpero, unilocular ó dividido inferiormente por un tejido que se halla entre los óvulos pocos ó uno solo, desnudo y colgando de la placenta central libre ó del vértice de la celda; estilo único. Drupa unilocular, monosperma, frecuentemente ceñida la base por el cáliz crecido; semilla pendiente, con embrion basilar, ovoídeo, ordinariamente diminuto y situado en el ápice de un endospermo carnoso, con los cotiledones adherentes $\mathrm{y}$ de raicilla dirijida al hilo.

Xímexra americana, L. C. T. V., 514. - Ximenia montana. Tigrito, Ccas, cuyos frutos amarillos, esféricos, del tamaño de una ciruela pequeña, con poca carne, como línea y media de espesor, y una semilla tambien esférica y bastante gruesa, algo oleajinosa. Maduros y recien cojidos exhalan un olor prúsico muy fuerte y tienen el sabor de almendras amargas tan pronunciado que no se podria comer si no fuera muy peligroso hacerlo; despues de seca la pulpa $y$ á medida que se va pasando el olor va disminuyendo, hasta desaparecer del todo, hasta en la semilla. Ningun animal se lo come y es tenido con mucha razon como venenoso.

Famitia 117. - MELIACEAS ó TRIQUILIÁCEAS. - Arbustos ó árboles mas ó menos altos, corpulentos y frondosos. cuyas hojas son compuestas; pari ó imparipinadas y altcrnas, rarísimas veces simples; de flores siempre hermafroditas, ora en racimos, en espigas ó en panojas y tan pronto axilares como terminales, que constan de un cáliz monosépalo con 4-5 divisiones mas ó menos profundas y que á veces están remplazadas por igual número de dientes; de una corola con 4-5 pétalos valvares y mas veces abiertos; estambres 8-10 hipójinos y monadelfos, de modo que sus filamentos soldados entre sí forman un tubo cuyo vértice 8-10-fido lleva las 
anteras pecadas en él de varios modos, ora por su ápice, ora por su superficie interior y ordinariamente sentados. Pistilo formado de un ovario único sentado sobre el disco anular, de donde salen los estambres, con 3-4-5 celdillas, conteniendo de ordinario dos óvulos, á veces 1 y mas rara vez 4 ; en el primer caso son colaterales y sobrepuestos, de su vértice sale un estilo simple mas ó menos largo, terminado por un estigma cabezudito ó con 3 o mas dientecitos. El fruto consiste en una especie de cápsula con 3-5 celdas, abriéndose por tantas ventallas y con 3 semillas provistas de un arillo membranoso, alguna vez que otra es drupáceo y consiste en una especie de drupa ó de nuez, cuyo hueso asurcado tiene 5 celdas monospermas por causa de aborto; embrion de cotiledones rectos y segun el eje de la radícula sobresalientes y foliáceos, alojado en un endospermo delgado ó carnosito que suele faltar bastantes veces.

Tribu $1^{\text {a }}$. - Melieas. - Embrion provisto de un endospermo y cuyos cotiledones son foliáceos; ovario de celdillas bi-ovuladas. MClia sempervirens, Sw. : C. T. V., 333-836.

Tribu 2. - Triquílieas.- Embrion sin endospermo, cuyos cotiledones son espesos; ovario con 1-2 y raras veces hasta 4 óvulos.

G. I. Trichilia, L. - Hojas con 5 pares de hojuelas elípticas ú oblongo-lanceoladas, lampiñas, enteras, aguzadas por la base y de las cuales las mas inferiores sonmenores, largas de $21_{1} 2^{\prime \prime}, 3,4^{\prime \prime}$ sobre 11 [2á $2^{\prime \prime}$ de ancho, panojas pubescentitas $2-4$ veces mas cortas que las hojas, largas de cuyos brazos llevan pocas flores ó una sola, blancuzcas, con los pétalos lampiños y largos de $2^{\prime \prime \prime}$; estambres de 8 á $12^{\prime \prime \prime}$ con los filamentos reunidos por la base y formando así un tubo corto, peludo interiormente, anteras 10 y peludas; árbol bajito muy ramoso. T. hivta, L. T. spondioides, Jacq. - Hojas largas de 6 á 7 y con \%-10 pares de hojuelas aovado-oblongas, oblícuas por la base, redondeadas y con una punta obtusa por el vértice, lampiñas y largas de $31\left[2-4-4^{\prime \prime} 1_{[} 2\right.$ sobre 11 [2-2-2 $2^{\prime \prime} 1\left[2\right.$ de ancho, con el peciolo de $1^{\prime \prime \prime}$; inequiláteras por la base, cuyo lado superior redondeado es mayor que el inferior, que es aguzado y como huyente; las inferiores son menores; panojas pubescentitas 4 veces mas cortas que las hojas $y$ cuyos brazos llevan 3-11 flores verdoso-amarillas, con los pétalos largos de $1^{\prime \prime \prime}$; filamentos reunidos solamente por $1_{[} 3$ y por fin separados; anteras 10 y peludas; cápsula sub-globosa de 5-6" de diámetro, tomentosa y rugosa, cuyas semillas ovoídeas son envueltas en un arillo colorado. Arbol no muy ramoso, pero cuyos ramos son estendidos y bastante largos, que se eleva á 15-20'. T. spondioides, Sw., Jacq., A. Jus.

G. II. Gaurea, L. - Pétalos y ovarios lampiños; árbol bajito y ramoso, cuyas hojas largas de 4 á $7^{\prime \prime}$ tienen $2-8$ pares de hojuelas elípticas ó eliptical-oblongas, lampiñas, con 8-10 nervaduras pronunciadas por cada cara, cuyas axilas son barbudas en la inferior; flores blancas, de cáliz sub-entero, con dientecitos distantes, pétalos largos de $2^{\prime \prime} 1[2$; cápsula sub-globosa y asurcada. G. S'uartzii, Dc. G. vahtiana, Juss. - Pétalos y ovarios tomentosos; arbusto como de $15^{\prime}$ de altura, cuyas hojas largas de 8 á $12^{\prime \prime}$ tienen 4-12 hojuelas oblongas. lampiñas, con $12-15$ nervaduras, sobresalientes 
por ambas caras, cle axtlas lampiñas y largas de $6^{\prime \prime}-8^{\prime \prime}-91\left[2^{\prime \prime}\right.$ sobre $2,41[2$ de ancho, con una punta obtusa, casi alternas, con el peciolo largo de $1_{[} 2^{\prime \prime \prime}$; flores en espigas arracimadas, largas de $61_{[} 2-91_{[} 2-$ $16^{\prime \prime}$, formadas de espiguitas largas de $12-18^{\prime \prime \prime}$ o de grupitos y hasta de algunas solitarias, de cáliz sub-entero, 4-lobo y de pétalos largos de 2-3"'; cápsula piriforme y globosa á la par, sub-asurcada, aterciopeladita, larga como de $8^{\prime \prime \prime}$ sobre $6^{\prime \prime \prime}$ de ancho, cuyo pedúnculo largo de $12^{\prime \prime \prime}$, es tan grueso como su base aguzada. $G$. perottii, A. Juss. C. trichiloides, P1. C. T. V.. 496.

G. III. Moschroxylum Sreartzii, Juss., etc. : C. T. V., 763.

G. IV. Carapa guianensis, Aubl.: C. T. V., 808.

G. V. Pontesia ovata, Cav. Trichilia palida, Sw. T. odorata, Andr. T. moschata, Macf.

Familia 118. - CEDRELÁCEAS. - Se diferencia de la anterior, de la cual era una tribu, y con la que tiene mayor analojía, por estar sus estambres algunas veces distintos, pero mas ordinariamente monadelfos; por su ovario 4-locular con lo menos 4 ó muchos órulos en cada celda; fruto capsular de pericarpio leñoso, cuyas ventallas se desprenden de los tabiques, ora por el vértice, ora por la base, quedándose las semillas pegadas en dos séries en el eje persistente; tales semillas, ordinariamente empizarradas, son aladas, con ó sin endospermo. Arboles mayores muy corpulentos y muy frondosos, cuyas grandes r elegantes hojas pinadas son provistas de glándulas ó puntos transparentes.

G. I.Swertenra mahogoni,L.S.senegalensis, Desc.: C.T.V.102-762

G. II. Cedrela odorata, L. : C. T.V., 102.

Famitia 119. - ERITROTILEAS. - Arbustos ó árboles bajitos, muy ramosos, con hojas simples, opuestas ó alternas, pecioladas, ordinariamente pequeñas, lampiñas, lustrosas, bien enteras, pecioladas, de cara inferior areolada ó venosa, decíduas y acompañadas de estípulas pequeñas y agudas ; flores pequeñas blanquecinas ó amarillo-verdosas, apareadas ó amanojadas, raras veces solitarias y de ordinario axilares, las cuales se componen de un cáliz con 5 sépalos persistentes. los cuales, mas ó menos soldados entre sí, lo hacen redondo y monosépalo; de una corola con 5 pétalos de base algo mas anclia, iguales, provistos interiormente $y$ por la base de una escama doble, y cuya estivacion es empizarrada; estambres 10 monadelfos, con anteras introrsas, biloculares y lonjitudinalmente dehiscentes. Pistilo formado de un ovario simple 1-3-locular por causa de aborto, con un huevecillo único colgante, de cuyo vértice salen 3 estilos, á veces soldados entre sí por la base, estigma cabezudo. El fruto es una drupita monosperma, de semilla angulosa, cuyo embrion recto y alojado en el eje de un endospermo córneo tiene los cotiledones lineares, planos y foliáceos; de radícula superior.

Erythroxylum, L. - 1. Flores ó pedícelos de ordinario solitarios, 2. - Flores ó pedícelos nunca jamas solitario: 4.

2. Siempre solitarios; ramos siempre inermes, 3. - Mas veces solitarios, mellizos á veces; ramos siempre espinosos; arbusto ramosísimo como de 3 á $5^{\prime}$ de alto, cuyos ramos divaricados, alternos, cortos y de ápice espinoso, llevan hojas obovales, obtusas, cortísi- 
mamente pecioladas y de cara inferior mas pida que la superior $y$ reticulado-venosa; pedícelos 2 veces mas largos que las flores que llevan ; fruto trígono, con tres estrias mas pronunciadas que las demas. E. spinescens, A. Rich. - Arbusto de 4 á 6' de altura, con ramos alternos, frájiles, en forma de varita, rugositos, aleonaditolampiños, cuyos mas tiernos tienen las estípulas disticamente embricadas; hojas coltísimamente pecioladas, aproximadas, obaovado-elípticas, redondeadas por el ápice, algo mucronaditas, aguzadas por la base, entejérrimas, reticulado-venosas, membranosas, lampiñas y cuya cara inferior es un poco glauca, largas de 12-15"', $y$ anchas de 7-8"' $1_{[} 2$, con peciolo acanalado, apenas largo de 1 "', acompañado de estípulas axilares, solitarias, aovadas, agudas y casi igualando el peciolo. Flores solitarias, mellizas ó á veces algunas agrupadas juntamente, con los pétalos oblongos, obtusos, cuya base dilatada está provista por el centro é interiormente de una escama bíloba y derecha, lampiños, blancos y 3 veces mas largos que el cáliz; drupa aovada, cilíndrica y roja. $E$. hondense, Kth. E. coca, C. T. V., 261.

3. 'Arbusto muy ramoso como de 5 á 7 ' de altura, con hojas pequeñas, ob-aovadas, redondeadas ó escotadas por el vértice, membranosas, largas de 12 á $6^{\prime \prime \prime}$ sobre 8-4"' de ancho, y con el peciolo de 2-1"' 1 [ 2 y mucho mas largo que las estípulas, nunca reticuladovenosas y de cara inferior glauca y blanquecina; pedícelos apenas mas largos que las flores; drupa colorada, elipsoídeo-oblonga y del largo del pedícelo. E. brevipes, Dc.

4. Pedícelos fasciculados siempre, 5. - Pedícelos nunca fasciculados y en número de 2-3, mas cortos que el peciolo, de cuya axila salen; árbol bajito y mur ramoso, con hojas elípticas, lanceoladas, obtusamente aguzadas, $\dot{o}$ con una punta, coriciceas, largas de 31 12$2^{\prime \prime \prime} 1_{\rceil} 2$ sobre $1^{\prime \prime \prime} 1_{\lceil} 2$ de ancho y de cara inferior verde, cuyo peciolo largo de $3^{\prime \prime \prime}$ es acompañado "de estípulas aovadas; ramitas floríferas provistas de escamitas dísticas, cortitas, persistentes y bien distintas, con pedícelos mas largos que los peciolos y sosteniendo flores mayores que las demas especies, cuyos pétalos son largos de $3-2$ "'; fruto oblongo, obtusito por el vértice, sub-exágono y tan largo como el pedícelo. E. squamatum, V. E. havanense, Rich.

5. Hojas mas ó menos reticuladas, cuyas venas son conspícuas ó bien visibles $\mathrm{y}$ bastante pronunciadas, 6. - Hojas no areoladas y cuyas venas son casi inconspícuas; arbusto ramoso como de 8 á $10^{\prime}$ de alto, con hojas aovado-oblongas ú ob-aovadas, redondeadas ó sub-escotadas por el vértice, membranosas, tiesecitas y de cara inferior glauco-blancuzca, largas de 2-1" sobre 12-10"' de ancho y cuyo peciolo largo de 4-2" es acompañado de estípulas subuladas; pedícelos mas cortos que el peciolo; drupa oblonga, obtusa por ambos estremos, prismática y larga de 3 á $4^{\prime \prime \prime} . E$. obovatum, Macf. $E$. affine, Rich.

6. Venas conspícuas reticuladas por ambas caras, 7. - Areoladas solamente por la cara inferior, cuya redecilla es formada por un par de nervaduras que van juntándose mútuamente para encerrar espacios lanceolados en el centro de la superficie de la cara. Arbusto 
de 10 á 16’ de altura, volviéndose á veces árbol bajito, con hojas ob-aovadas ú ob-aovado-oblongas, redondeadas ó escotadas por el vértice, membranosas, de cara inferior un poco glauca, largas de 1" sobre 1" de ancho, cuyo peciolo, acompanado de estípulas triangulares, es largo de 2-3"i ; Hores blancas, fragrantes y precoces, cuyos pedícelos laterales son tan largos como el peciolo y el fruto que es oblongo, encarnado, obtuso por ambos estremos, desigualmente anguloso, y largo de 3-4"'. $E$. areolatum, L. : C. T. V. 261.

7. Arbusto de 10 á $15^{\prime}$ de altura, que bastantes veces se vuelve árbol bajito, con hojas ob-aovadas ú ovales, redondeadas por el vértice, membranosas y de cara inferior algo glauca, largas de $2-1^{\prime \prime} 1_{[} 2$ sobre $1^{\prime \prime}-8^{\prime \prime \prime}$ de ancho, á cuyo peciolo largo de $2-3^{\prime \prime \prime}$ acompañan estípulas subuladas; flores precoces cuyos pedícelos filiformes son mas largos que los peciolos y dos veces mas que el fruto elipsoídeooblongo, con ángulos desiguales y obtusos, largo de 3-2"'. E. obtusum, Dc. $E$. Havanense, Kth. E. areolatum, Pœpp. E. ovatum, Cav.

\section{CLASE LII. - ESCULÍNEAS.}

Familia 120. - MALPIJIÁCEAS. - Vejetales fruticosos ó frutices, sarmentosos, abejucados y leñosos, arbustos y árboles bastantes veces altos y corpulentos, con hojas simples, coriáceas, lampiñas ó pubescentes y cuya cara inferior está algunas veces provista de pelos, cuya picadura abrasa mucho, mas ó menos cortamente pecioladas, bien enteras $\mathrm{y}$ de ordinario opuestas; dos estípulas acompañan frecuentemente á la insercion del peciolo, frecuentemente caducas. Flores siempre hermafroditas y dispuestas en racimos ó en espigas, raras veces en panojas axilares ó terminales, cuyos pedícelos, ordinariamente articulados, llevan dos bracteitas situadas por su medio y unífloros; se componen de un cáliz monosépalo, con 5 divisiones mas ó menos profundas y de estivacion valvar, reemplazadas algunas veces por tantos dientes, de las cuales 4 llevan dos glándulas situadas esteriormente por la base. Corola con 5 pétalos mas ó menos ungüiculados, alternos con las divisiones calizinales, pero que algunas veces suelen faltar; estambres 10 ó menor número por aborto, libres $\mathrm{v}$ distintos ó cuyos filamentos están á veces reunidos por la base, de anteras adheridas. Pistilo formado de un ova rio único, súpero, con 2-3-5 celdas uniovuladas, con el óvulo licótropo ó ascendente, aunque sostenido por un funículo colgante; de su vértice salen 3 á 4 samaras soldadas entre sí por la base: otras veces es una drupa ó un noculanio, conteniendo tres huesecitos monospermos, cuyas semillas son formadas despues del tegumento propio de un embrion algo encorvado y sin endospermo.

\section{Análisis dicotómica de las tribus.}

1. Fruto seco formado de carpidios alados, 2. - Fruto siempre drupáceo, mas ó menos carnoso é indehiscente; estilos 3 , libres ó reunidos, estambres 10. T. I. MalpíjIeas. A. 
2. Estambres 10 o menos por aborto, estilos 3 ó tantos cuantos carpelos hay, libres; carpidios samaroídeos, secos é indehiscentes monospermos, con una ala ó cresta dorsal é insertos en un torus piramidal; hojas opuestas, raras veces verticiladas, frutices $\dot{0}$ arbustos sarmentosos ó abejucados. T. II. Banistérieas, - I. Stignaphyllon pe:iplocifolium, Juss. - II. Banisteria periplocifoTia. - III. Hepteropteris purpurea, Ith. B. purpurea, L. - Estambres de ordinario 10: estilos 3 reunidos ó uno único, carpillos secos formando el fruto, indehiscentes monospermos y cuyas alas principales son laterales, insertos ellos en un torus piramidal; frutices o arbustos de ordinario sarmentosos ó abejucados, con hojas opuestas ó verticiladas. T. III. HrReíceas. - I. Triopteris ovata, Catv. T. Janaicensis, Sw. Malpighia paniculate, Mill. - II. Hirea jussicana, Miq. - III. Teirapteris incqualis, Cav. T. citrifolia. Dc.IV. Hirca ridleyana, Juss.

A. G. I. Brosóxima, Rich.-1. Hojas de cara superior lampiña y lustrosa, mientras la inferior es mas ó menos tomentosa, 3. - $\mathrm{Ho-}$ jas enteramente lampiñas, 2 .

2. Arbol de 20 y $30^{\prime}$ y mas de altura, bastante coposo y corpulento, con hojas elípticas ó eliptical-oblongas, pecioladas; algunas veces las nervaduras de la cara inferior son alampinadas ó de color verde-pálido, largas de $4-3^{\prime \prime}$ y anchas de $1^{\prime \prime} 1[2$, de ordinario con una punta; brácteas aguzadas ó subuladas y sub-iguales; flores amarillo de oro en racimos, cuyos pedúnculos y brazos, así como los peciolos, son tomentosos y color de orin; celdillas de las anteras lampiñas é igualando el conectiro, ovario sedoso lanujinoso; drupa amarilla. B. coriacea, Dc. B. berteroana, Juss. Malpighia coriacea, Sw. : C. T. V., 100. - Arbusto ó árbol hajito, con hojas espatuladas, aguzándose por la base hasta volverse peciolo corto, de márjen arrollada, cuyas venas son inconspícuas, redondeadas ú obtusitas por el vértice, largas de 1 1 $2-1$ " sobre 8-5"' de ancho, de cara superior lustrosa, mientras la inferior se queda opaca. Flores al principio color de rosa y volviéndose mas tarde purpurinas, en racimos cortos pubescentitos ó lampiños, con brácteas lanceoladas y aguzadas, cuya inferior es dos veces mas larea que las laterales; celdillas de las anteras lampiñas y un poco mas cortas que el conectivo; ovario lampiño; drupa verdosa. B. lucida, Rich. Malpighia lucida. Mull.

3. Cara inferior tomentosa ó alampinada, 4. - Cara inferior siempre tomentosa: árbol mediano, de hojas eliptical-oblongas ó elípticas, acuñadas por la base, largamente pecioladas, largas de $4-3^{\prime \prime}$ y anchas de 2-1", pelo de la cara inferior persistente, aleonadopálido : flores amarillas en racimos largo-tomentosos, color de orin, con brácteas pequeñas, triangulares é iguales; celdillas de las anteras peludas é igualando el conectivo; ovario velludo. $B$. cinerea, Dc. $B$. crassifolia, Sun.

4. Opaca, y color de orin; árbol que se eleva como á 30 y $40^{\prime}$ de altura, bastante corpulento y coposo, con hojas elíptico-lanceoladas o lanceoladas, aguzándose por la base hasta volverse peciolo corto. largas de 5-2" y anchas de 21)-8"'; de vértice aguzado y con una 
punta obtusa; flores amarillas en espigas ó racimos simples, con bracteas lanceoladas, obtusas é iguales; celdillas de las anteras lampiñas, igualando el conectivo y cuyo ípice es separado y algo recorvado; ovario lampiño y drupa amarilla. B. spicata, Rich.: C.T.V.99. - Opaca pero jamás color de orin, pero con vellito aleonado; arbusto de 10 á $2 J^{\prime}$ de alto ó árbol bajito con hojas ovales ó elipticaloblongas, largamente pecioladas, largas de $5-3^{\prime \prime}$ y anchas de $1^{\prime \prime}-11_{[} 2$ con la cara superior venosa; flores amarillas en racimos, cuyas brácteas pequeñas son iguales y triangulares; pedícelos casi dos veces tan largos como las flores; celdillas de las anteras velludas $y$ un poco mas cortas que el conectivo; ovario lampiño: $B$. crasifotia, Kth. : C. T. V., 100.

G.II.Ma LPighia, L.-1. Hojas bien enteras; 2.-Hojas dentadas ; arbusto rastrero por la superficie del suelo, ramoso y con hojas redondeadito-oblongas ú ovales, sinuado-dentadas, lampiñas, cuyos dientes apartados son espinosos, redondeadas por ambos estremos, pero á veces escotadotricuspidadas, largas de $6^{\prime \prime \prime}$ y anchas de 5-4"'; umbelas con 1-2 flores sentadas y mas largas que las hojas; cáliz con 6 glándulas; drupas sub-globosas y con 3 surcos. M. coccigera, L.

2. Enteramente lampiñas porque se desprende temprano el poco pelo bi-cuspidado que tienen cuando tiernas, 3. - Con la cara inferior cubierta de pelo bi-cuspidado, persistente, 4 .

3. Arbol mediano con hojas aovadas, ordinariamente con una punta obtusita, ó de repente aguzadas, raramente obtusas, largas de $4-311_{1} 2-2$ " sobre $21_{[}^{2}-2-2$ " 1 [ 2 de ancho; flores purpurinas en umbelas 3-5-7-floras, pedunculadas, de cáliz con 6-8 glándulas, drupa sub-globosa apenas asurcada, con los huesecitos obtusamente 4-angulosos, cor estrias en el dorso, los lados y la cara interna, cuyos instersticios son transversalmente rugosos ó tuberculados. M. glab’a, L. M. nitida, Mill. M. undulata, Juss. C. T. V., 594. - Arbol pequeño que se eleva comóá unos 12 á $15^{\prime}$ de altura, muy coposo, con hojas elípticas, de ordinario obtusas, largas de $21_{[2} 2-2^{\prime \prime}$ y anchas de $12\left[3-1\right.$ " $1_{[} 4$, una ó dos flores rosadas axilares, con pedícelos largos de 1 1" 13 , o sentaditas, de cáliz con 6 glándulas; drupas sub-globosas, apenas asurcaditas. rojo-negruzcas cuando enteramente maduras, con los huesecitos 4-angulosos, transversalmente rugosos ó tuberculados por los lados. MI. punicifolia, L. : C. T. V. 593.

$\therefore$ Arbusto recto no muy ramoso, alto de 6 á $8^{\prime}$, con hojas elípticas ú oblongas, coriáceas, cortamente pecioladas, con una punta ú obtusitas, ordinariamente largas de 4 á $3^{\prime \prime \prime}$ y anchas como de $2^{\prime \prime}-$ $11_{[} 2-8^{\prime \prime \prime}$ : flores blancas teñidas de rosado, en umbelas 3-5-floras, pedunculadas ó subsesiles, de cáliz con 8-10 glándulas; drupa globosa, lisa ó algo asur'cada, purpurina y como de $6^{\prime \prime \prime}$ de diámetro. $M$. urens, L. : C. T. T., 582. - Con dos variedades : 1a. De hojas elípticas ú oblongas; cáliz con 10 glándulas. M. urens, Juss. : 2a . De hojas lanceoladas; cáliz con 8 glándulas, pétalos no simétricos. $M$. urens, Juss. M. Tanceolata, Gr.

Familia 121. - SAPINDACEAS. - Plantas herbáceas mas ó menos trepadoras, frutices ó bejucos, arbustos mas ó menos sarmentosos y árboles bastantes veces corpulentos; frondosos y muy altos, 
con hojas compuestas y alternas; flores poligamas ó á veces unisexuales por aborto, pero de ordinario hermafroditas, pequeñas, blanquecinas y dispuestas en racimos ó en panojas, se componen de un cáliz con 3-4-5 sépalos ordinariamente distintos ó algo soldados por la base y de prefloracion empizarrada, de una corola, con 4-5 pétalos, frecuentemente provistos en el interior de una escarna y separados de los estambres por el disco ó por glándulas, suelen faltar algunas veces; estambres ordinariamente 8 , ó en menor número por causa de aborto, comunmente escéntricos ó unilaterales, con filamentos filiformes, subulados, libres y distintos ó reunidos por la base y llevan anteras introrsas, biloculares y lonjitudinalmente dehiscentes. Pistilo simple formado de un ovario redondeado, 2-3-4locular, con celdas 1-2-3 ovuladas, cuyo óvulo solitario es ordinariamente erguido; del vértice sale un estilo simple 3 ó 4-bífido. Fruto abayado, como drupáceo ó capsular, dehiscente, bi-3-4-locular; otras veces es samaroídeo y con alas, casi siempre indehiscente; semillas globosas o comprimidas, ordinariamente solitarias en las celdas, derechas ó ascendentes y raras veces pendientes, por lo comun provistas de un arillo mas ó menos desarrollado, con un embrion corvo, de cotiledones incumbentes, cuya raicilla corta está de ordinario dirijida hácia el hilo sin endospermo.

\section{Análisis dicotómica de las tribus.}

1. Pétalos provistos de una escama ó apéndice petaloídeo situado en cada uña ó por la base, 2. - Pétalos harbudos interiormente, glandulosos ó desnudos pero sin apéndices lejítimos. Disco anular ó raras veces glándulas unidas. por la base y formando un anillo que se halla entre los pétalos y los estambres. Ovario solitario bi ó trilocular con celdas monospermas; árboles y arbustos no trepadores. T. I. Sapindeas. A.

2. Pétalos interiormente apendiculados con una lámina petaloídea en cada uña; glándulas separadas, situadas entre los pétalos y los estambres; ovario trilocular con celdas monospermas; yerbas ó arbustos trepadores y zarcillosos ó bejucos. T. II. Paulinieas. B. Pétalos algo escamosos por la base ó con mayor frecuencia nulos: ovario tri ó raras reces bilocular, con celdas que contienen dos óvulos cuyo superior es erguido, mientras el inferior es pendiente; estambres insertos en el disco hipójino; pericarpio vesicular ó samaroídeo; embrion espiralmente retorcido con los cotiledones incumbentes. Arbustos no trepadores con hojas simples ó compuestas. T. III. Dodoneáceas. C.

A.G. I. Sapindus, L. - Hojas con 4-5 pares de hojuelas desiguales, oblongo-lanceoladas ó elípticas, de cara inferior tomentosa, largas de $3-3^{\prime \prime} 1[2$ las superiores, mientras las inferiores lo son de $11_{[} 2$ a $2^{\prime \prime}$, anchas las unas y las otras de $11{ }^{2} 2$ á $2^{\prime \prime}$ y casi sentadas, con el raquis anchamente alado y largo de 9-10-11"; panojas pubescentes ; carpidio globoso amarillento sucio ó lijeramente pardusco. S. saponaria. C. T. V., 375. - Hojas con 1-3-5 pares de hojuelas, 
oblongo-lanceoladas, inequilaterales, con el lado superior redondeándose desde la base y algo arqueado, mientras el inferior, mas estrecho, es casi recto, aguzadas por el rértice ó cuyas mas inferiores son elípticas y lampiñas, desiguales y largas de $31_{\lceil} 2,41_{\lceil} 2$ $5-6 "$ y anchas de $11_{1} 2$ á $1^{\prime \prime}$, con el peciolo como de $1^{\prime \prime \prime}$; raquis marjenado ó desnudo y largo de 8-10-11", acanalado; panojas pubescentes, pétalos pestanosos, con una escamita diminuta, carpidio globoso, ordinariamente solitario por aborto, lustroso, blanco-amarillento sucio ó algo bruno, de $8^{\prime \prime \prime}$ de diámetro. $S$. incequalis, Dc. S. saponaria, Rich. S. forsythii, Dc.

G.II. Melicocca, L. Árbol alto de 40 á $50^{\prime}$, bien frondoso y bastante corpulento, de hojas con dos pares de hojuelas elípticas ó elíptico-lanceoladas, bien enteras y lampiñas, panojas terminales; baya casi globosa ú ovoídea. M. lijuga, L.: C. T. V., 596. - Árbol algo mas bajito que el precedente, muy frondoso, cuyos ramos cilíndricos y en ramitas, lisos y lampiños llevan hojas paripinadas y formadas de dos pares de hojuelas pecioladas opuestas, elípticas puntiagudas, y aguzadas por la base, integérrimas, reticuladovenosas, con las nervaduras $y$ las costillas muy proeminentes, coriáceas, lampiñas, algo glaucas, de cara superior lustrosita, mientras la inferior mas pálida es enteramente opaca, las superiores son largas de ()$^{\prime \prime}$ y anchas de $3^{\prime \prime}$, mientras las inferiores lo son solamente $4^{\prime \prime}-4 l_{l} 2$, con el raquis estriado, lampiño y largo de $21 l^{2-3} 3^{\prime \prime}$. Fruto elíptico-mucronado con el estilo persistente y largo de $9^{\prime \prime \prime}$; de semilla aovado-elíptica. M. oliveformis, Kth. C. T. V., 597.

G. III. Blighi sapida, Kœn. Akecsia africana, Tuss. Kth. Cupania sapida, Cumb. C. T. V., 218. - G. IV. Cupania glabra, Hook. C. T. V., 104.- G. V. Schmidelia cominia, Sw. - G. VI. Hipelate paniculata, Camb. Melicocca paniculata, Juss.- G. VII. Euphoria punicea. C. T. V, , 595.

B. G. I. SerJania, Kth. 1. Hojas biternadas provistas de líneas ó puntos transparentes, 2.-Hojas sin líneas ni puntos transparentes, biternadas, con hojuelas lineares, enteg'érrimas y agudas, con los peciolos alados. Flores muchas en racimos axilares, frecuentemente con 2 ó 3 brazos desnudos por la base, provistos los racimos de dos zarcillos opuestos situados en el punto en donde principian á ramificarse, alternas, pequeñas y poco pediceladas, blanquecinas; cápsula colorada tríloba, con tantas alas cuantos lóbulos hay y situadas por su base, membranosas y transparentes. S. angustifolia, IV.

2. Ramitas pubescentitas, hojuelas ovales, aserradas, lampiñas, de cara superior lustrosa, mientras la inferior opaca tiene pelo dispuesto por grupitos en la axila de las venas, largas de $1-2^{\prime \prime}$; raquis desnudo trígono; samaras pubescentitas superiormente, ala semiobaovado-oblonga, enteramente inferior y no estendiéndose sobre el dorso de la celdilla que es algo venosa; samara larga de $8^{\prime \prime \prime}$ y tan ancha por abajo, mientras que por el vértice lo es solamente de 4$5^{\prime \prime \prime}$. S. paniculata, Kth. S. equestris, Macf. - Ramitas pubescentitas ó alampiñadas; hojuelas elípticas, sub-enteras, lampiñas, largas de $3-6^{\prime \prime}$, algunas de ellas suelen abortar, cuyo raquis desnudo está á veces con una márjen estrecha; flores en racimos largos 
formando panojas flojas; ala semi-ob-acorazonada, enteramente inferior y no prolongándose sobre el dorso de la celdilla lisa, samara larga de 8 "' y ancha de $6-8^{\prime \prime \prime}$ por abajo y de $4^{\prime \prime \prime}$ por arriba. S. divaricata, Sw. Paullinia divaricata, Sw.

G. II. Paullinia, L. 1. Hojas de 3 en rama ó dos veces trifoliadas, 2. - Hojas imparipinadas, sin puntitos, con dos pares de hojuelas lampiñas, aovado-oblongas, ú oblongo-lanceoladas, con dientes distantes ó bien pronunciados, largas de 3-6" con el raquis alado por la base ; racimos del largo de las hojas ó mas corto que ellas; cápsula piriforme sin alas. P. pinnata, L. P. diverrifolia. P. Hostmani, Steud. C. T. V., 563.

2. Hojas dos veces de 3 en rama ó hiternadas, 3.-Hojas de 3 en rama, con las hojuelas sub-oblongas, sub-aguzadas, casi elípticas $y$ á veces como aovadas, festoneado-aserraditas por el vértice, lampiñas, cortamente pecioladas, reticulado-venosas, membranosas, largas de $2^{\prime \prime} 1_{[} 2-21_{[} 3^{\prime \prime}$ y anchas de 16-20"', la del medio aovadooblonga es cuneiforme por la base y larga de 2 1 [4-3", con el raquis lampiño, largo de $21_{1} 4$ á $3^{\prime \prime}$ y cuya ala integérrima es apenas ancha de $1^{\prime \prime \prime}$ y evanecente por la base. Cada racimo madura solamente 2 ó 3 frutos cortamente pedicelados, oblícuos, trígonos, largos de 8-9"", con 3 celdas monospermas por causa de aborto; racimos largos como de $2 "-2,1[2$ y cortamente pedicelados, simples y con muchas flores casi sesiles; ramitas angulosas, lampiñas y color aleonado. $P$. сисиюи. C. T. V., 564.

3. Provistas de puntitos transparentes dispuestos por séries, de hojuelas romboídeas ó eliptical-oblongas, con dientes distantes, grandes, obtusos y situados por arriba del medio, lampiñas, membranosas y largas de $11_{[} 2-4^{\prime \prime}$; raquis con una ala estrecha que falta por debajo de las divisiones; cápsula sin alas, piriforme, lampiña, cuya parte superior es sub-globosa, apenas 3-asurcada y aguzándose de repente para cojer el carpóforo, larga de 5-6"' y ancha de 4 "' superiormente, cilíndrica y de $1_{[} 2^{\prime \prime \prime}$ de diámetro por la base, con celdillas hemisférico-convexas, cuyas semillas globosas son cubiertas mas allá de la mitad por un arillo bruno y bi-partido. $P$. curasavica, Jacq. P. Jamaicensis, Macf.

G. III. Unvilea seriana, Gr.: C. T.V., 376.

G.IV. Cardiospermum, L. Pétalos superiores espatulados, 4 veces tan largos como los sépalos esteriores; cápsula sub-globosa, grande y redondeada por el vértice. Planta herbácea anual trepadora, muy ramosa, que se eleva á 5 ó 6' y mas de altura, pubescente ó alampinada, con las hojas bi-ternadas, partidas y obtusamente aserra $\rightarrow$ das, cuya terminal es con una punta; glándulas del disco redondeaditas ; pétalos largos de 2 á $3^{\prime \prime \prime}$, cápsulas largas de 1", pubescente ó ala mpiñada. C. halicacabum, L., etc.: C.T. V.379.- Pétalos superiores largos de $1 l_{[} 2-l^{\prime \prime \prime}$ ob-aovados y 3 veces tan largos como los sépalos esteriores; cápsula turbinado-redondeadita, pequeña, triangular, deprimida por el vértice y larga de $4^{\prime \prime \prime}$ y tan ancha. Planta herbácea anual trepadora, ramosísima y que se eleva á $6-8^{\prime}$ con hojuelas bi-ternadas, picadas y obtusamente aserradas, cuya termi- 
nal es aguzada; glándulas del disco redondeaditas. C. microcarpum, Kth. C. acuminatum, Miq.

C. Doponcea, Hojas ob-aovado-lanceoladas ú ob-lanceoladas, anchas de 2"-6" -18" y largas de 5"-4" 1 2-3", cápsula alada, redondeadita, mas larga que el pedícelo, de 10-12"" de diámetro, ceñida por la ala, cura anchura es casi igual por la base, y contigua por el vértice, con el seno terminal cerrado. D. riscosa, L. D. candolleana, Bl. D. arabica, Hook. - Hojas linear-lanceoladas, anchas de 8-5" y largas de 6-5-3"; cápsula alada redondeadita tan larga como el pedícelo y ancha de $5-6 "$ ", cuya ala ciñe la celda, mas ancha por arriba que hácia la base; seno terminal abierto, 3-angular. D. angustifoliu. Sw. D. bialata, Kth. B. Tinearis, E. Mey.

DIVISION II. - PERÍJINOS.

\section{SEGGION II. - PERIJINOS.}

\section{CLASE LIII. - CELASTROÍDEAS.}

Familia 122. - VINÍFERAS ó AMPELÍDEAS. - Plantas semi-leñosas ó bejucos, otras veces arbustos sarmentosos y provistos los unos y los otros de zarcillos opuestos á las hojas, que son sencillas, enteras, mas ó menos lobadas, á veces digitadas y por consiguiente compuestas ó pinadas, largamente pecioladas, alternas y con dos estípulas caducas acompañando la insercion del peciolo. Flores pequenas dispuestas en racimos y en cimas ó corimbos opuestos á las hojas, hermafroditás y formadas de un cáliz monosépalo entero ó con 4-5 dientecitos, de una corola con 4-5 pétalos insertos por el lado interior de un disco hipójino, caducos, ya libres y sueltos, ya adherentes entre sí por el vértice, formando asi una especie de bóveda que se desprende desde la base y se cae de una sola pieza á manera de caperuza; los estambres son 4-5 hipójinos, opuestos á los pétalos, cuyos filamentos libres ó soldados entre sí llevan anteras oscilantes. Pistilo simple formado de un ovario único, globoso, sentado sobre el disco anular, de contorno lobado que envuelve su base, 2-locular, con 1-2 óvulos en cada celda, y cuyo ápice sobrelleva un estilo corto, grueso, que suele faltar algunas veces $y$ que se termina por un estigma bílobo. Fruto abayado y globoso con 1-2 celdillas mono ó polispermas, con semillas huesosas pegadas á un eje central derecho, compuestas de un epispermo espeso, y de un embrion derecho $y$ situado hácia la base de un endospermo córneo.

G. I. Cissus, L. 1. Hojas compuestas y de tres en rama o trifoliadas, 2. - Hojas simples mas ó menos grandes, bastante dobles, acorazonado-oblongas, acorazonadas ó aovadas, lampiñas ó algunas veces pubescentitas, con los dientes aserrados, setáceas, distantes ó aproximadas, larcas de 2-3-4", sin contar el peciolo que lo es de 11" $1\left[2\right.$, sobre $11_{[2}, 2 l_{[} 2$ de ancho. Brazos de la umbela general simplemente bi ó tricotomos, de flores verduzco-amarillentas con 4 pétalos; estilo largo; bara sub-ğlobosa, negra, lustrosa con 1 se- 
milla y ancha de 4"'; bejuco alto y muy largo de tallo, sin fuerza, casi herbáceo y carnudo, trepador ó mejor sarmentoso y sosteniéndose por sus zarcillos, bastante grueso y casi cilíndrico, algo nudoso. C. sicyoides, L.: C T. V. 595-592.

2. Hojuelas aovadas lampiñas, aserradas lijeramente por arriba del medio ó sub-enteras, cuyas dos laterales son oblícuas, algunas veces acuñadas por la base, con los dientes acostados, distantes y setáceos. Brazos de las umbelas generales pubescentes y ordinariamente bífidos, con flores encarnadas, así como los pedícelos; estilo largo; baya purpúrea, ovoídeo-globosa, ancha de 2"'-3"” y monosperma. Bejuco bastante alto y muy largo, sosteniéndose á favor de sus zarcillos, de tallo y ramos algo angulosos. C. trifoliata, L. C. T. V., 590. - Hojuelas acuñado-ob-aovadas, redondeadas por el ápice, lampiñas, profundamente dentadas por arriba del medio, cuyos dientes, contiguos y abiertos, son anchos y con una punta, algo suculentas. Brazos de la umbela general simples, cuyas flores verdoso-amarillas tienen 4 pétalos; estilo largo; baya negra, globosa, monosperma y ancha de 2"'. C. acida, L., etc., C. T. V. 590.

G. II. Vitis, L. Flores siempre hermafroditas; hojas largamente pecioladas, mas ó menos profundamente lobadas, algo pubescentes, planas ú ondulosas, de color verde mas ó menos pálido, con los peciolos coloraditos; bayas de forma y tamaño muy variados, moradas, negras, blancas ó blanco-amarillentas, con ó sin semillas. $V$. vinifera, L.: C. T. V., 589. - Flores dioicas ó polígamas en racimos grandes y muy furnidos, amarillentas y pequeñitas; hojas anchamente acorazonadas, con una punta, de cara superior alampiñada, mientras la inferior es tomentoso-blanquecina ó aleonadita, cuyó pelo algunas veces persiste solamente en las nervaduras, dentadas, cuyos dientes están terminados por una glándula, algunas veces algo lobaditas y verdes por ambas caras en los vástagos tiernos, largas de $5 l_{[} 2,5$ " sin contar el peciolo, que lo es de $212-3$ ", y anchas de 4 á 4 l ${ }^{2}$ ". Bayas generalmente pequeñas, purpúreas, globosas, anchas de 2-3"', con semillas ob-aovadas, llanas por el vientre, convexas y estriadas por el dorso; arbusto sarmentoso, muy ramoso y bastante alto como de 10-15'. V. caribcea, Dc., etc.: C. T. V. 589.

Familia 123. - HIPOCRATEACEAS. - Arbustos ó frutices sarmentosos ó abejucados, con hojas opuestas, simples, coriáceas, enteras ó dentadas, acompañadas de estípulas, cuyas flores pequeñas, axilares y dispuestas en hacecillos ó en corimbus, se componen de un cáliz persistente 5 -fido, de una corola con 5 pétalos iguales, de 3-5 estambres reunidos por sus filamentos formando un antróforo tubuloso é insertos por el interior de un disco ancho; pístilo simple formado de un ovario único trígono, trilocular, con óvulos definidos y ascendentes, de cuyo vértice sale un estilo simple ó 3-fido con otros tantos estigmas; el fruto consiste en una cápsula membranosa de tres ángulos ó con tres alas, otras veces es abayado con tres celdas conteniendo cada una 4 semillas, sin endospermo y cuyo embrion es derecho.

Hifpocratea, L.-1. Hojas eliptical-oblongas aserraditas, cimas sin pedícelos, estériles y capilares, 2. - Hojas enteras oblongas 
largas de $4 "-6$ "; panojas lampiñas igualando las hojas y con un sin número de pedícelos estériles y capilares, color de orin, de 8"', los cuales son mucho mas largos que los fértiles entremezclados con ellos; flores de $1_{[} 2$ "' de diámetro, con pétalos de limbo aovado y obtuso; estambres muy cortos y contiguos; disco capiliforme y espeso; carpidios ob-aovados ú oblongos. C. comosa, Sw. : C. T. V., 437.

2. Hojas elípticas ú oblongas; cimas color de orin, mas largas que las hojas, con los brazos distantes, curas flores, verdoso-amarillas, tienen los pétalos ob-aovados y largeos de 1"' 1 [2; disco obtuso cónico; estambres de filamentos cortos; carpidios espatulado-oblongos, escotados por el vértice, largos de $1^{\prime \prime} 1\left[2-2^{\prime \prime} 1\left[2\right.\right.$ y anchos de $8^{\prime \prime}$, con 4-6 semillas. H. scundens, Jacq. : C. T. T., 437.-Hojas oblongas; panojas color de orin y aterciopeladas, ordinariamente mas largas que las hojas, cuyas cimas parciales que las forman están distantes, de flores con pétalos oblongos y largos de $1^{\prime \prime \prime}$, los filamentos cortos; carpidios ovales ú óvalo-redonditos, de vértice redondo, largos de $1^{\prime \prime} 1_{1} 2$ y anchos de $1^{\prime \prime}$, con 4 semillas. H. ovata, Lam. H. volubilis, Sw. L. lorigata, Rich. H. discolor, Mey.

\section{CLASE LIV. - RAMYOÍDEAS.}

\section{Familia 124. - RÁMNEAS o RAMNÁCEAS. - Arbus-} tos ó arbolitos con hojas simples, coriáceas, enteras, pecioladas, alternas y rarísimas veces opuestas, cura insercion está provista de dos estípulas ó foliáceas, caducas ó persistentes; flores pequeñas por lo comun, verdusco-amarillentas, tan pronto hermafroditas como unisexuales y polígamas, de inflorescencia muy variada; en efecto, ora están solitarias, ora er grupos, ora en corona ó en hacecillos axilares; otras veces en racimos ó en capitulos terminales, pero siempre constan de un cáliz monosépalo mas ó menos tubuloso, mas o menos adherente al ovario, con 4-5 lóbulos y valvar; de una corola con 4-5 pétalos, que suelen faltar algunas veces y bastante frecuentemente escamiformes y cóncavos, insertos en la parte superior del cáliz ú otras veces pegados en un disco situado en el fondo y alternando con sus divisiones, ungüiculados, sueltos ó á veces reunidos por la base y formando así una corola seudo-monopétala; estambres 4-5 alternos con los segmentos calizinales é insertos en la márjen del disco perijínico. Pistilo simple, formado de un ovario único, libre, semi-ínfero ó completamente ínfero, con 2 ó con 4 celdas monospermas, raras veces dispermas, de cuyo vértice salen tantos estilos como celdas tenga, terminándose cada uno por un estigma simple. El fruto es una baya, una drupita ó un nuculanio; otras veces es capsular, cuyas ventallas se llevan al desprenderse los troforpermos pegados en medio de su cara interior, cuyas semillas derechas no tienen azilo, pero sí un endospermo carnoso en que está alojado un embrion homotrojo de cotiledones largos y pequeños, $y$ cuya radícula es superior.

G.I. Zizyphus, L.- 1. Ramitas no angulosas, 2.-Ramitas con 5 ángulos, lampiñas, que se vuelven ramos tortuosos, flexuosos, con 
espinas estipulares rectas, y que llevan hojas algo redondeadas, ovales é inequilaterales ó un poco acorazonadas ó recortaditas, coriáceas y lampiñas; cáliz tomentoso, color de orin. Z . haranensis.

2. Ambos aguijones estipulares, corvos, hojas orales y algo redondeadas, aserraditas y con vello corto y suave hasta en el peciolo, las ramitas tiernas y las flores que son en corimbos axilares; fruto amarillo pálido, casi globoso y lampiño. Z. tomentos $\iota$, Poir. - Uno de los aguijones corvo, mientras el otro es recto; hojas dentadas; flores monoicas en racimos axilares, cuyos cálices no tubulosos son sin escamas petaloídeas; fiores femeninas con dos estilos, que se terminan por un estigma bífido: fruto amarillo pálido, con un hueso unilocular. Z. ignanea, C. T. V., 674.

G. II. Colubrina, Rich.-1. Vejetales mas ó menos pubescentes ó tomentosos, 2. - Arbusto lampiño, cuyas ramitas, lampiñas y cilindricas, llevan hojas aovadas, aserraditas, con las nervaduras arqueadas $I$ algunas veces triplo-nervias, largamente pecioladas $\mathrm{y}$ largas de $1^{\prime \prime} 1_{[} 2-2^{\prime \prime} 1_{[} 2$ sobre $1-1^{\prime \prime} 1_{1} 2$ de ancho; cimitas cortamente pedunculadas, mas cortas que el peciolo durante la floracion; cáliz lampiño; estilo cortamente $3-$ lobo; cápsula globosa, ob-aovada, tres veces tan larga como la cúpula adherida con ella, verdosa y de 4 "' de diámetro, con semillas redondeaditas, ovales, convexas por el dorso, algo angulosas por el lado interno, de embrion con cotiledones carnudos, llanos y tan espeso como el endospermo, que está partido en dos segmentos correspondientes á los lados de las semillas. C. asiatica, Brogn. Ceanothus asiatica, L. Rhamus asiatica, Lam.

2. Ramitas cuyo tomento es color de orin, ó alampiñadas, 3. Arbolito enteramente tomentoso, cuyas ramitas, color de orin, llevan hojas ovales ó eliptical-oblongas, obtusas ó aguzadas, enteras y con las dos caras densamente tomentosas, de nervaduras laterales, paralelas $\mathrm{y}$ aproximadas, haciendo parecer las hojas como plegaditas segun su direccion; estípulas largas y setáceas; flores pequeñas, muchas y axilares; ovario de vértice globoso, pero áspero. $C$. cubensis, Brogn. Ceanothus cubensis. Rich.

3. Arbol de $20^{\prime}-30^{\prime}$ de altura, curas ramas estendidas terminan por ramitas tomentosas color de orin y llevan hojas aovadas ú oblongas, bien enteras, obtusas ó con una punta por el vértice y subcordiformes ó redondeadas por la base, sin glándulas, con las nervaduras arqueadas, cuyas majores son largas de 4-3 1 [2-6" sobre 2 1[2-2-3 de ancho, de cara superior lustrosa y lampiña, mientras la inferior es color de orin, alampiñada ó tomentosa sobre las nervaduras escepcionalmente; cimitas umbeliformes, pedunculadas, ordinariamente mellizas ó ternadas, casi tan largas como los peciolos, que lo son de 8 á $10^{\prime \prime \prime}$; cáliz tomentoso, color de orin esteriormente, de $2^{\prime \prime \prime}$ de diámetro y cuyos lóbulos son tan largos como los pétalos; estilo 3-lobo por el ápice; cápsula sub-globosa, mas de dos veces mas larga que la cúpula y adherida á ella, negra $Y$ de $4^{\prime \prime \prime}$ de diámetro. C. ferv"uginosa, Brogn. Rhamus colubrinus, L. Ceanothus fervuginosa, Lam. - Arbusto ó árbol bajito; tiene las ramitas alampiñadas y con hojas elíptico-lanceoladas, bien enteras, de márjen glandulífera por arriba de la base, lampiñas ó lijeramente pu- 
bescentes ó alampinadas inferiormente, de ordinario con una punta y obtusas por el vértice, con las nervaduras arqueadas, largas de 4 $1{ }^{2} 2-4$ " y anchas de $11,2-13[4-2 "$, con el peciolo largo de 8-10""; cimitas contraidas, cáliz pubescentito esteriormente y de $1^{\prime \prime \prime} 1 \Gamma^{2}$ de diámetro; estilo profundamente 3-fido; cápsula globosa, tres veces tan larga como la cúpula adherida á ella, purpúrea y ancha de $2^{\prime \prime \prime}-$ $3^{\prime \prime \prime}$. C. reclinata, Brogn. Ceanothus reclinatus, L·Her. Rhamus elipticus, Sw. C. T. V., $16 \%$.

G. III.Gouania, L. - 1. Fruto con 3 alas, 2.-Fruto sin ó con alas, hojas festoneadas, ovales, sub-pubescentes ó alampinadas inferiormente, largas de $31{ }^{2} 2-4^{\prime \prime} 1\left[2\right.$, con el peciolo de como $4^{\prime \prime \prime}$ de largo, y anchas $21_{1} 4$ á $2^{\prime \prime} 1_{1} 2$, cuyas ramitas que las llevan se terminan ora en pedúnculos y otras veces en zarcillos; flores en racimos simples terminales, cuyos mas inferiores son axilares ó laterales. $G$. pubescens, Lam. G. martinicensis, Poir.

2. Ramitas pubescentes de hojas elípticas, eliptico-aguzadas, obtusas ó cordiformes por la base, aserradas, y cuyos dientes obtusos, distantes, son sin glándulas ó con glandulitas diminutas y á veces apenas visibles, con las venas terminales hácia la márjen, lampiñas ó alampiñadas, de ordinario largas de $11_{1} 2$ á $3^{\prime \prime}$ y anchas de $11_{[} 2-$ $2-1 "$, con el peciolo largo de 6 á $8^{\prime \prime \prime}$. Racimos pubescentes apenas mas largos que las hojas, cápsula lampiño-escotada, cuya ala es dos veces mas larga que la celda, larga de $3-44^{\prime \prime \prime}$ y ancha de $4-5^{\prime \prime \prime}$, con una escotadura profunda terminal. Gr. domingensis, L. G. glabrata, Jacq. : C. T. V., 168. Ramitas cubiertas de bozo color de orin, llevando hojas aovadas ó aovado-oblongas, sub-escotado-acorazonadas por la base, festoneado-aserradas, con las venas espesitas y tan largas como ellas, y terminándose en dientecitos glandulíferos, aserraditos, de cara inferior ordinariamente tomentosa ó pubescente y color de orin, algunas reces alampiñadas; de flores en racimos simples, axilares y mas largos que las hojas, distantes en ellos, velludo-tomentosos ; cápsula velluda, subtrunca, cuyas alas son dos veces tan anchas como la celda, redondeaditas y membranosas, pequeña, lijeramente escotada, larga de 2-3"' y ancha de $3-4^{\prime \prime \prime} . G$. tomentosa, Jacr.

\section{SECGION Il. - PERIJINOS LEJTTINOS.}

ÓRDEN 10. - AXOSPERIOS.

SUB-ÓRDEN $1^{\circ}$. EXALBUMINADOS.

\section{CLASE LV. - TEREBENTINEAS.}

Famitia 125. - BURSERÁCEAS. - Frutices, arbustos yárboles mas ó menos altos, corpulentos y frondosos que de ordinario son resinosos, con hojas alternas, compuestas é imparipinadas, algunas raras veces opuestas, con puntitos glandulosos transparentes, 
con $\dot{0}$ sin estípulas peciolares; Hores muy pequeñas, hermafroditas ó unisexuales, tan pronto monoicas ó dioicas como polígamas, dispuestas en espigas, en racimos $y$ en panojas axilares o frecuentemente terminales: se componen de un cáliz persistente monosépalo con 3-כ́ segmentos, de una corola cuyos pétalos 3-5 y alternos con los lóbulos del cáliz, son mas largos y se insertan por debajo de un disco libre ó que forra el fondo del cáliz, con estivacion valvar: suelen faltar alguna que otra vez; estambres 10-6, dispuestos en dos ó una sola série, insertos junto con los pétalos y mas cortos que ellos, cuyos filamentos tubulosos, libres ó monodelfos por la base llevan anteras introrsas, biloculares y lonjitudinalmente dehiscentes. Pistilo formado de un ovario único libre con $2-5$ celdas, de las cuales algunas suelen abortar, con 2 óvulos en cada una, colaterales y anátropos: de su vértice sale un estilo simple que falta algunas veces; estigma entero ó 2-5-lobo; fruto drupáceo conteniendo desde 1-5 huesos monospermos, otras veces consiste en una cápsula cuya dehiscencia es septícida y de endocarpio casi huesoso; semillas colgantes, redondeadas, angulosas ó comprimidas, á veces membranosa por los bordes, de embrion sin endospermo, con los cotiledones plegados y algunas veces tripartidos, y cuya radícula corta y derecha es superior.

G. I. ICıCA, Aubl.-Flores en corimbos axilares; hojas con 3-5-7 hojuelas, elíptico-lanceoladas, aguzadas, largas de $4-2$ " y anchas de $12-6^{\prime \prime \prime}$; corimbos dos o tres veces más cortos que la parte del raquis que no carga hojuelas, con pedícelos dos veces tan largos como las flores, ordinariamente ternadas, de cáliz diminuto, con dientes apenas pronunciados, dẽ 4 pétalos arrollados por el vértice. pubescentes por la márjen, largos de 1"' y conteniendo los estambres encerrados. J. heptapllylla, Aubl. Amyris ambrosiaca, Mey. J. copal, Rich. - Flores en panojas axilares, con hojas de 5 hojuelas elíptico-oblongas, sub-coriáceas, aguzadas, lustrosas, largas de $3-3^{\prime \prime} 1$ 12: á veces las hojas son paripinadas; flores en panojas axilares tres veces mas cortas que los raquises, con bracteitas diminutas. de brazos lijeramente blanquecino-tomentosos; 8 estambres algo. mas cortos que la corola, cuyos pétalos tienen la prefloracion valvar; anteras lineares-obtusas, algo dilatadas inferiormente, escotadas por la base, dorsifijas, biloculares, lampiñas, dehiscentes lonjitudinalmente por la parte interna y todas conformes; estilo recto, lampiño, igualando á los estambres y terminando por 4 estigmas cabezudos. J. tacamahaca. C. T. V., 449.

G. II. Bursera gummifera, L. B. acuminata, W. B. simplifolia, Dc. : C. T. V., 123-448-550.

G. III. Hedwigia balsamifera, Sw. Caproxylou hedurigii, Tuss. : C. T. V.447.

Familia 126. - ESPONDIACEAS. - Esta pequeña familia que formaba una tribu de la gran familia de las Anacardiáceas ó Terebintáceas se diferencia de ella por su fruto, que consiste en una drupa mas ó menos gruesa, de forma y tamaño muy variados y cuyo hueso está cubierto de hebras mas ó menos abundantes; tiene 5 celdas monospermas, de las cuales algunas suelen abortar, pero visi- 
bles en el ovario, cuyo vértice lleva tantos estilos cuantas celdas hay; flores pequeñas en panojas terminales y que de ordinario salen antes que aparezcan las hojas, con 5 pétalos insertos en un disco festoneado situado en derredor de la hase del ovario, de estivacion empizarrada; estambres 5-10; ovario 5-jocular, con uno ó dos ovulos; semillas sin endospermo, cuyo embrion tiene los cotiledones convexo-planos; árboles mas ó menos grandes, ordinariamente altos, frondosos y bastante corpulentos, resinosos y con hojas simples o compuestas.

G. I. Spondias, L. - Árbol alto como de $40^{\prime}-50^{\prime}$, con las ramas un poco distantes, de hojas largas de $8-9^{\prime \prime}$, cuyo raquis lo es de $5 l_{l} 2$ á 6 , con 3-8 pares de hojuelas desiguales, pecioladitas, aovadolanceoladas ó lanceoladas, aguzadas, sub-enteras ó aserraditas, de base inequilateral, largas de $4-33^{\prime \prime} 1_{[} 2$ y anchas de $2-11_{[} 3^{\prime \prime}$, con el peciolo de $1-1^{\prime \prime \prime} 1$ [ 2 de largo; flores pequenas amarillentas en racimos apanojados, frecuentemente largos de $6-12^{\prime \prime}$; drupa ovoídea larga de $2^{\prime \prime}$ y amarilla. S. lutea, L. S. moubin, Jacq. S. cytherea, 'Tuss. S'. graveolens, Macf. S'. myrobalanus, Mey.: C. T. V., 125.Arbol bajito de $15^{\prime}-20^{\prime}$ de alto lo mas, con los ramos estendidos, cuyas hojas están formadas de 8-10 pares de hojuelas cortamente pecioladas, eliptical-oblongas, obtusitas y de ordinario aserrarlas. Flores purpurinas en racimos simples, laterales, mas cortos que las hojas y paucífloros; drupa ob-ovoídea, larga de 1", moladusca. $S$. purpurea, L. S. myrobalanus, Jacq. S. cironella, Tuss. S. Lutea, Macf. : C. T.V., 126-616.

G. II. Mangífera indica, L.: C. T. V., 127.

Familia 127. - AMIRIDEAS o AMIRIDACEAS. - Arbustos ó árboles resinosos, con hojas imparipinadas ó de tres en rama, opuestas y con puntos glandulosos transparentes; flores hermafroditas en panojas axilares ó terminales, constando de un cáliz pequeño regular, persistente, con 2-5 segmentos; de una corola con 2-5 pétalos hipójinos, casi ungüiculados y de prefioracion imbricada; estambres libres $5-10$; pistilo simple formado de un ovario único libre, colocado sobre un receptaculito ó disco, unilocular y con dos huevecillos colgantes, cuyo vértice sobrelleva un estigma sentado $y$ cabezudo ; fruto drupáceo indehiscente, monospermo, de semilla sin endospermo y cuyo embrion tiene cotiledones espesos y carnosos, la radícula es cortísima y superior.

Amyris, L. - 1. Hojas con 3-5 hojuelas; anteras ovoídeooblongas, 2. - Hojas con 3-5-7 hojuelas aovado-lanceoladas ó elípticas, aguzadas, bien enteras ó apenas festoneaditas, verdes por ambas caras, de cara inferior mas pálicla, con venas reticuladas, lijeramente proeminentes por la superior, largas de 4-2" y anchas de 2-9"' ; panojas grandes mas largas que las hojas ó iguales á ellas; pétalos tan largos como los estambres o igualándoles; anteras redondeaditas; drupa ovoídea, larga de $3-4^{\prime \prime \prime}$ y ancha de $2^{\prime \prime \prime}$. A. balsamifera, L. A. toxifera, W. A. pinnata, Kth. A. sylvatica, Rich.

2. Arbusto de 5-15' de altura, con hojas de 3 ó 5 en rama, cuyas hojuelas aovadas ó deltoídeo-redondeaditas, con una punta, apenas festoneaditas $\dot{\delta}$ sub-enteras, son glaucas por ia cara inferior, largas 
de $1^{\prime \prime} 1$ 2 sobre $1^{\prime \prime \prime}$ de anclio $\mathrm{y}$ con los peciolos de $2^{\prime \prime}$, tienen sus venas dispuestas á manera de redecilla y visibles por ambas caras: panojas mas cortas que las liojas, pétalos ovales tan largos como los estambres; drupa globosa, pequeña, jurpurina y con $2^{\prime \prime \prime}$ de diámetro. A. sylvatica, Jacq. A. dyatripa, Spreng. A. floribunda, Nutt. A. cymosa, Rechb. - Arbusto del tamaño y altura del anterior, que parece mucho, pero con las hojas de tres en rama ó unifolioladas, largas de $21\left[2-1^{\prime \prime} 3\left[4\right.\right.$, con el raquis de $18^{\prime \prime \prime}$, cuyas hojuelas aovadas y con una punta obtusita, bien enteras ó apenas festoneaditas, verdes por ambas caras ó mas pálidas por la inferior, son largas de $2-1^{\prime \prime} 1$ [ 2 y anchas de 10 á $12^{\prime \prime \prime}$, con los peciolos de $3^{\prime \prime \prime}$; corimbos mas cortos que las hojas, pétalos ovales mas largos que los estambres, drupa globosa, negra, de $3^{\prime \prime \prime}$ de diámetro y pisiforme. A. maritima, Jacq. A. lunani, Spreng. C. T. V., 450.

Familia 128. - ZUMAQUINEAS. - Arbustos ó arbolitos de hojas alternas, siempre compuestas é imparipinadas ; flores pequeñas, hermafroditas, apanojadas ó racimosas, formadas de un cáliz pentasépalo, cuyos sépalos están soldados entre sí por la base é insertos con los 5 estambres en un disco calizinal; ovario unilocular, único y uni-ovulado; fruto drupáceo, con la semilla pendiente de un cordoncillo procedente de la base de la celda, sin endospermo, de embrion con cotiledones foliáceos y raicilla doblada sobre la juntura de ellos mismos.

G. I. RHus metopium, L. : C. T. V. 128.

G. II. Comocladia, S. Br.- 1. Hojas con hojuelas nunca espinosas, 2. - Arbusto de 4-8' de altura; hojas con unos 5-9-10 pares de hojuelas, de las cuales algunas 3-5 son espinosas, sentadas, lampiñas, aovado-deltoíleas y sub-acorazonadas por la base, largas de 8 á $9^{\prime \prime \prime}$ sobre como 7 á 8 de ancho, desiguales; panojas mas cortas que las hojas, largas de $51_{1} 2$ á $6^{\prime \prime}$, con el raquis de $41_{1} 2$ á $5^{\prime \prime} 1_{[} 2$; flores agrupadas en espigas largas de $6 "$; drupa oblonga roja. C'. ilicifolia, W.: C. T. V., 7.

2. Arbusto de 10-25' de alto, de hojas largas de 1-2', con 8-10 pares de hojuelas pecioladas, lampiñas ó alampiñadas por la cara inferior, bien enteras, oblongas, con una punta, sub-truncas por la base, las inferiores decrescentes, aoradas; panojas pubescentitas o alampiñadas, tan largas como las hojas, cuyas flores son fasciculadas y largas de $1_{[} 2^{\prime \prime \prime}$; drupa oblonga, negro-purpurina. $C$. integrifolia, Jacq.: C. T. V., 9. - Arbusto mas pequeño, cuyas hojas largas de $6^{\prime \prime}$, tienen 5 pares de hojuelas sesiles, alampiñadas por la cara superior, peludas y color de orin por la inferior, oblongas, obtusas, sub-truncas por la base, enteras, las infériores mas pequeñas; panojas peludas y color de orin, tan largas como las hojas; flores agrupadas. C. propinqua, Kth. C. T. V., 8.

Familia 129. - ANACARDIEAS ó ANACARDIACEAS. - Arboles de hojas alternas, simples ó compuestas ; flores pequeñas, apanojadas, hermafroditas ó polígamas, constando de un cáliz con 3-5 sépalos algunas raras veces adherentes un poco al ovario, mas ó menos soldados entre sí por la base; de estivacion empizarrada; de una corola con 4-5 pétalos; estambres 8-10 insertos, junto con 
los pétalos en un disco calizino en el fondo del cíliz mismó; ovario único unilocular, uniovulado; fruto drupáceo ó seco, cuya semilla está sostenida por un cordoncillo procedente del fondo de la celda 5 doblado por elápice, sin endospermo, y cuyo embrion tiene cotiledones gruesos y replegados sobre la radícula. Anacardium nccidentale. L. : C. T. V., 10.

\section{CLASE LVI. - LEGUMINOSAS.}

Familia 130. - FABÁCEAS ó LEGUMINOSAS. - Plantas herbáceas anuales ó vivaces y frecuentísimamente de tallos mas o menos largos y volubles; matas enredaderas ó bejucos, frutices, arhustos; arbolitos y árboles grandes, corpulentos y coposos, espinosos ó inermes ordinariamente, con hojas compuestas, descompuestas o sub-compuestas, cuya forma, tamaño y disposicion de la hojuelas que las forman varian tanto como su número y su consistencia, son sesiles ó pecioladas; las hojas son á veces simples por causa del aborto de las hojuelas, siempre alternas, cuyo raquis, á veces provisto de una ó algunas glándulas, está acompañado por su insercion de dos estípulas persistentes ó caducas, de figura y tamaño muy variados, y que algunas veces están reemplazadas por igual número de espinas ó de aguijones; bastantes veces una estipulita parcial acompaña los peciolos de las hojuelas y dos se hallan en la insercion de la hojuela impar; las glándulas del raquis, cuando existen, están situadas por la base sola ó por la base y por el vértice, otras veces las hay entre las dos hojuelas, formando los pares, sea entre algunas solamente ó rarísimas veces entre todos y siempre por la cara superior mas ó menos acanalada, este raquis se prolonga algunas veces en zarcillo o está terminada por una puntita mas ó menos caduca y bracteiforme, flores bastante grandes de ordinario y no rara vez muy hermosas, generalmente hermafroditas, otras reces, pero con mucha menos frecuencia, polígamas, de figura y de inflorescencia muy variada, pero que constan siempre de un cáliz monosépalo mas ó menos tubuloso, con 5 dientes ó lóbulos mas ó menos profundos y desiguales, de manera que algunas veces forman cumo dos labios : entónces el cáliz parece bilabiado, de base acompañada de brácteas que suelen faltar bastantes veces, y que cuando existen se vuelven no rara vez invólucro-monófilo; de una corola que falta algunas veces, pero que de ordinario es bastante grande y se compone de 5 pétalos mas ó menos unguiicukados, iguales ó casi iguales entre sí y forman una corola casi regular y mas ó menos abierta, otras vecés son desiguales, de figura y tamaño muy diferentes, y constituyen una corola irregular llamada amariposada ó papilionácea; 10 son los estambres, ya diadelfos, ya monadelfos y raras veces libres; sin embargo, suelen á veces esceder de ese número y son libres ó monadelfos y hasta poliadelfos; en ciertos géneros, algunos de los 10 estambres suelen abortar y están reemplazados por apéndices de figura y tamaño variados: son desiguales: anteras biloculares mas ó menos grandes abriéndose por una grieta lonjitudinal ó por poros 
situados en su ápice. El pistilo siempre simple, en forma de un ovario único comprimido, mas ó menos largo, algo oval y oblongo, lampiño ó pubescente, sostenido por un podójino mas ó menos larguito, unilateral, á veces algo arqueado, con los dos lados algo desiguales, unilocular, con pocos ó con muchos ovulos asidos en un trofospermo sutural con que están pegados á favor de un podospermo mas ó menos desarrollado y raras veces sesiles; el vértice del ovario se prolonga en un estilo un poco lateral y por lo comun bastan te largo, encorvado hácia arriba, terminándose por un estigma sencillo de forma muy variada, á veces bilamelado, con pelo ó lampiño. El fruto es siempre una legumbre ó vaina de figura y tamaño muy variados, algunas raras veces indehiscente, conteniendo pulpa ó no y partida en algunas celdillas monospermas por tabiques falsos, algunas otras veces está como articulada y se separa en algunas pie-zas monospermas, pero de ordinario es continua y se abre en dos ventallas que tienen las semillas pegadas en su borde interior por medio de podospermos mas ó menos largos; tales semillas de figura, de color y de tamaño muy variados, no tienen nunca endospermo y son formadas del tegumento propio ó epispermo, á veces casi córneo y muy duro, pero comunmente membranoso ó apergaminado, inmediatamente aplicado á un embrion de cotiledones muy gruesos; algunas raras veces la vaina es samariforme; ordinariamente lisa y lampiña, pero á veces pubescente y hasta cubierta de muchos pelos, cuya picadura causa escozor.

Sub-familia 1a. - PAPILIONACEAS O AMARIPOSADAS. - Sus flores se componen de un cáliz cuyas divisiones son iguales ó desiguales, y en este último caso bilabiado, el labio superior constando de 3 segmentos ó dientes y el inferior de 2 solamente; de una corola cuyos pétalos se insertan en un disco delgadísimo que forra el fondo del cáliz, y lo mas frecuentemente la parte interior del tubo hasta mayor ó menor altura y llevan nombres diferentes, de tal manera que el superior, ordinariamente mayor que los otros, envueltos mas ó menos en él en la estivacion y cuya figura, disposicion y tamaño varian muchísimo, se llama estandarte ó bandera, los lados laterales que á veces están provistos de una especie de diente $o$ apéndice por la base se denominan alas $\mathrm{y} \cdot$ varian tambien mucho, tanto por su figura como por su tamaño y color; en fin, los dos inferiores enteramente libres, pero aproximados uno á otro ó mas ó menos soldados entre sí jor su lado inferior, constituyen la quilla ó carena: los estambres son por lo comun en número doble de los pétalos, raras veces menor por causa de aborto, con anteras introrsas y biloculares, abriéndose las celdillas por una grieta lonjitudinal y cuyos filamentos son libres, monadelfos ó de ordinario diadelfos, en este último caso un estambre solo es libre y corresponde á la hendidura del andróforo y al estandarte. El pistilo se compone de un ovario liso ó pubescente, sentado ó estipitado, cuyos huevecillos están por lo comun dispuestos en dos séries. La vaina ó legumbre es algunas veces interrumpida interiormente, por cuya causa entónces cada celda monosperma se desprende cuando madura en tantas piezas indehiscentes; alguna rara vez es el fruto samaroí- 
deo ó como drupáceo; las semillas, de ordinario mas ó menos reniformes, son sostenidas por un podospermo mas o menos distinto, que á veces se vuelve como carúncula, de embrion comunmente corvo y raras veces recto; hojas primordiales opuestas.

\section{Análisis dicotómica de las tribus y sub-tribus.}

1. Embrion de radícula siempre encorvada, 2. - Embrion de radícula recta; 10 estambres monadelfos ó diadelfos, legumbre indehiscente samaroídea, ó frecuentemente interrumpida pors estrechamientos; cotiledones espesos y carnudos; radícula encorvada y raras veces recta; arbustos ó árboles bastante altos, corpulentos y coposos, de hojas imparipinadas con llas hojuelas frecuentemente alternas, rarísimas veces reducidas ú una sola. T. I. Dalbergieas. B.

2. Estambres 8-9-10 siempre libres; legumbre indehiscente samaroídea ó con dos ventallas; cotiledones foliáceos ó algo espesos; de ordinario árboles grandes y otras veces arbustos de hojas imparipinadas ó rara vez simples. T. II. Sofóreas. A. - Estambres muy rara vez libres. 3 .

3. Estambres monadelfos ó diadelfos, 4. - Estambres 10 siem-pre diadelfos, con los cuales adhiere frecuentemente el estandarte; legumbre con dos valvas y continua; hojas á menudo paripinadas, con zarcillo que va prolongando el raquis; yerbas anuales mas ó menos enredaderás. T. III. ViCieas. - G. I. Ervun lens, L. - G. II. Vicra sativa, L.-G. III. Abies precatorius, L.: C. T. V., 669.

4. Legumbre continua y bivalvar, 5. - Legumbre lomentácea ó transversalmente dividida en algunas piezas monospermas articuladas entre sí y desprendiéndose por la madurez, y raras veces reducida á una sola pieza indehiscente ; estambres 10 ; cotiledones foliáceos ; plantas herbáceas anuales ó vivaces, algunas veces arbustillos, de hojas con una sola ó con tres hojuelas ó imparipinadas, frecuentemente provistas de estípulas. T. IV. Hedisáreas. C.

5. Legumbre siempre continua; cotiledones foliáceos durante la germinacion; hojas con una, tres ó muchas hojuelas frecuenternente paripinadas. T. V. Lóteas, 6. - Legumbre continua ó con estrechamientos de trecho en treclio, pero que nunca se desprende en piezas despues de madura; cotiledones hipójeos ó epíjeos; plantas herbáceas anuales volubles de hojas las mas veces de tres en rama; rarisimamente pinadas y con frecuencia provistas de estipulitas acompañando las hojuelas, ó arbustos. T. VI. FAsEól.EAS, 8.

6. Estambres diadelfos ó raras veces monadelfos; legumbre de ordinario con dos valvas; hojas pinadas o 1 folioladas. S.-T. I. GALÉGEAS. - Estambres siempre diadelfos ó monadelfos sulamente, 7.

7. Diadelfos: hojas con 3-5 hojuelas, cuyas venas ordinariamente alcanzan la márjen. S.-T. II. 'T'rulolíEas. Trifolium repens, L. Monadelfos; alas con un alveolo; hojas palmadas ó sin hojuelas. S.-T. III. Genísteas.

8. Cáliz acompañado de dos bracteitas situadas por su base, 9. - 
Cáliz sin bracteitas, pedícelos solitarios ó mellizos. S.-T. I. RrxcosÍFAs. D.

9. Pedícelos desprovistos de bráctea comun por la base. S.-T'. II. Clitoríras. E. - Pedícelos fasciculados insertos sobre un nudo que sale del raquis. S.-T. III. Eufaseóleas. F.

A. Irrospermur, Jacq. Arhol grande y coposo, con hojas pinadas, largas de $61{ }^{2} 2$ a $7^{\prime \prime}$, con el raquis de $5^{\prime \prime}$, formadas de 2-5 pares de hojuelas ovalo-lanceoladas, aguzadas, coriáceas, frecuentemente emarjinadas ó ribeteadas por el vértice, con glándulas transparentes, de cara superior lustrosa y lampiña, mientras la inferior es alampiñada, largas de 5,41$\rceil 2^{\prime \prime}$ y anchas de $2 l_{1} 4$ á $2^{\prime \prime}$, alternas, desiguales, con una punta de 6 á $8^{\prime \prime \prime}$. Flores blancas en racimos axilares mas largos que las hojas, de cáliz campanudo, con jo dientes casi iguales cuyo impar es un poco apartado de los demás; estambres mas cortos que los pétalos $y$ de anteras puntiagudas; legumbre samaroídea larga de unos $2^{\prime \prime}$, de ápice oblícuamente redondeado, cuya celdilla contiene una semilla única, arriñonada, envuelta en un líquido halsámico que se vuelve resina. $M$. peruiferum, L. M. toluifemem, L.: C. T. V., 443. - Arbol que se eleva á 40' y $50^{\prime}$ de altura, bien corpulento y muy frondoso, con hojas formadas de 5-7 pares de hojuelas membranosas, oblongas ú ovalo-redondeaditas, retusas ú obtusas, lampiñas por ambas caras y algo glaucas, estriadas á causa de líneas transparentes, largas de 10-12"' ; flores blancas teñidas de color de rosa: legumbre tan ancha como su ala que se estrecha apenas por la base, algo arqueadita y çon algunas venas ; larga de $2-3^{\prime \prime}$ con el ala, la legumbre sola larga de 8-10"', cuya celda contiene una semilla casi cilíndrica, un poco comprimida por los estremos y arqueadita, sin líquido resinoso en su derredor, pero en las celdillas de las paredes de la celdilla se vuelve resinoso, larga de 8-0"' y ancha de 11 [2-2"'. M. frutescens, Jacq. M. emarginatum, Kl.: C. T. V., 279.

B. G. I. Pterocarpus, I. Hojas con 5-7-9 hojuelas oblongas obtusitas ó un poco puntiagudas, lampiñas y lustrosas, con bracteitas diminutas; cáliz lampiño mas largo que el pedícelo pubescentito, corola larga de $6{ }^{\prime \prime \prime}$; lesumbre lampiña estipitada, corchosa, áspera, con el eje oblícuo, ceñida por un ala estrecha, menos distinta por lado inferior, de $11_{[} 2-2^{\prime \prime}$ de diámetro, con el ala ancha ıle $3-4^{\prime \prime \prime}$ por ej lado superior. P. draco, L.: C. T. V., 110. - Hojas con 5-7-9 hojuelas eliptical-oblongas, lampiñas y lustrosas. Bracteitas lineares, frecuentemente casi tan largas como el cáliz tomentoso y de color de orin, mas largo que el pedícelo; ovario sentado y tomentoso; legumbre sesil, sub-membranosa, un poco mas espesa hácia su parte media. $P$. rohrii, Ney.

G. II. Andira, Lam. Hojas de raquis largo de 5, 6, 8", con 4-8 pares de hojuelas opuestas, lanceolado-oblongas ú oblongas, aguzadas ó con una punta obtusa, lampiñas, largàs de 4, 3, $31_{[} 2,21_{1} 2^{\prime \prime}$ y anchas de 1 l 2 á $2^{\prime \prime}$, algoo desiguales ó casi iguales: flores rosadomoraduzcas en panojas grandes terminales pubescentes y color de orin, de cáliz campanudo, con dientes triangulares y obtusos, casi tan largos como los pétalos lampiños: ovario lampiño, largamente 
estipitado, con pelo por su márjen anterior; legumbre ovoídea y como drupácea, larga de unos 2-2" $1_{[} 2$ sobre $1-1^{\prime \prime} 1_{[} 2$ de ancho, indehiscente. A. inermis, Kth.: C. T. Y., 765. Variedad con los pedícelos frecuentemente mitad tan largos como el cáliz, corola de 7-8"' de largo, con el estandarte ob-aovado, cuyo limbo es tres veces mas largo que el cáliz, A. sapindioides, Benth. Pterocarpus sapindioides, Dc. - Hojas de raquis larģo de á á 6", acanalado, con 3-4-6 pares de hojuelas opuestas ó lijeramente alternas, oblongas, retusas ó mucronaditas por el vértice, de cara superior lampiña, mientras la inferior es pubescente color de orin ó alampiñada, largas de 4, $\left.31_{[} 2,3,2\right]_{[} 2^{\prime \prime}$ bastante desiguales y anchas de $2,11\left[2^{\prime \prime}\right.$. cortamente pecioladas; flores moradas, largas de $\tau^{\prime \prime \prime}$ en racimos compuestos tan largos como las hojas, con los brazos distantes y pubescentes y color de orin, de cáliz campanudo, con los dientes triangulares, casi igual á los pétalos; ovario lampiño; legumbre drupácea muy grande, irregular $y$ corchosa. $A$. retusa, Al. A. aubletii, Beruh. Geoffroya pubescens, Rich.

G. III. Piscidia erythrina, L. : C. T. V., 566. G. IV. Platymiscrus Platystachium. Benth. G.V. Drepaxoc arpus lunatus, Mey. G. VJ. Hecastophyllux monetaria, Pers. Pterocarpus hecastophyllum, L.: C. T. V.. 385. G. VII. Coumaruna odorata. C. T. V., 409.

C.G. I. Desarodium, Dc. 1. Legumbre lomentácea nunca sinuosa, 2. - Legumbre lomentácea siempre sinuosa igualmente por ambas márjenes, con tabiques estrechos y centrales, y artejos reticulados é indehiscentes ; estípulas de ordinario orejudas y subuladas, fiores racimosas; yerba tendida, cuyo tallo anguloso echa raices por la base, estendido y ramoso, delgado y largo de 1-2 1 [?', de hojas con 3 hojuelas oval-oblongas ú oblongas; lomento subsesil, ganchoso, pubescente, lijeramente estrechado por los tabiques, no tortuoso y con 2-7 artejos óvalo-lineares algo truncos por ambos estremos $y$ cuyo terminal tiene punta; flores pequeñas, blanquecinas, pintaditas de color purpurino. D. scorpiurus, Desv. D. cincreum, Pœpp.

2. Legumbre Jomentácea de suturas continuas siempre, 3. - Legumbre lomentácea cuya sutura es continua ó lijeramente festoneada con los artejos reticulados, medio redondeados ó medio orales é indehiscentes: flores en racimos, 4.

3. Artejos reticulados, truncos pur los dos estremos, tarde dehisC.rices; flores fasciculadas opuestas a las hojas; segmentos calizinaLus tiesos y peludos; yerba tendida, difusa y peluda, de hojas con 3 hojuelas aovadas ú ob-acorazonadas; estípulas aguzadas y persistentes; flores pequeñas cuya corola color carmesí está encerrada en el cáliz pedicelado mellizas; lomento sentado, lijeramente arqueado, con 3-6 artejos sub-iguales, bien redondeados por la márjen dorsal. D. triflorum, Dc. Hedyearum triflorum, L. S'agotia triflora, Walp: Nicholsonia triflora, Gr. C. T. V., 812.

4. Yerba ascendente y difusa, con ramos cilíndricos que llevan hojas con 3 hojuelas ob-aovadas ú óvalo-redondeaditas, obtusas, raras veces sub-truncas; estípulas distintas; lomento sub-sentado, recto, ganchudo, pubescente, de sutura continua sinuosa por la parte media de la márjen dorsal, con 2-5 ariejos semi-ovales: flores pe- 
queñas purpurinas. D. ascendens, Dc. D. racemiferum, Dc. D.ellipticum, Macf. D. oboratum, Vog. Hedysarum adscendens, Sw.

G.II. Arachis hypogea, Dc.: C. T. V., 668. G. III. Brya ebenus, Dc. Aspalthus ebenus, L. Amerinum ebenus, Sw.

D.G. I.Rhynchosia, Lam. 1. Cáliz 5-fido con el lóbulo inferior mas largo, 2. - Cáliz 4-partido, casi tan largo como lá corola, de segmento superior bífido; mata tomentosa de tallo fruticuloso, trepador y anguloso, muy ramoso, de hojas con 3 hojuelas aovadas, con una punta, 3-nervias, de cara inferior reticulada y con las nervaduras proeminentitas, mientras la superior tomentosa es blanquecina ó verdosa y de tamaño muy variado; racimos formados de algunas flores cortamente pediceladas y por grupitos, de cáliz largo de 3-6"', turbinado con el tubo muy corto y los segmentos lanceolados ú oblongo-lanceolados, aguzados y abiertos, casi tan largos como la corola amarilla ó pintadita de color purpúreo; legumbre no estrechada, oblonga, pubescente ó alampiñada, larga de $10^{\prime \prime \prime}$ y ancha de $3^{\prime \prime \prime}$, con las semillas casi negras, arriñonado-redondeaditas de $2^{\prime \prime \prime}$ de diámetro. $R$. reticulata, Dc. $R$. latifolia, Nutt. $R$. macrophylla, Dc. $R$. longeramosa, Mart. R. aquinoxialis, Walp. Glycine reticulata, Sw.

2. Mata tomentosa ó alampiñada, de tallo como de $1^{\prime}$ de altura, trepador, obtusamente anguloso, bastante ramoso, cuyas hojas son con 3 hojuelas aovado-romboídeas y agúdas; flores racimosas distantes, de cáliz con lóbulos lanceolado-lineares, cuyo inferior es casi la mitad de lo largo de la corola amarilla, con el estandarte adornado de estrias purpurinas, largo de 3-4"' ; legumbre no estrechada, oblonga, aguzada por la base y larga de 6-10"', cuyas semillas negras y reniformes son anchas de $I^{\prime \prime \prime}$. $R$. minima. $R$. puntata, Dc. R. caribcea, Tow. Dotichos minima, L. - Bejucoalto, tomentoso o á lampiñado, de tallo fruticuloso, trepador, subcilíndrico y muy ramoso, de hojas con hojuelas aovadas ó aovadoromboídeas, con una punta, largas de $12\left[3,31_{[} 2,2\right.$, sobre $2445,31_{[} 5$, $14\left[5\right.$ de ancho. Racimos largos de 3 á $6^{\prime \prime}$, formados de algunas flores de cáliz con lóbulos aovado-lanceolados ó aovados, coli una punta, cuyo inferior es mitad de lo largo del estandarte estriado de color purpurino, corola larga de 5 á ' '"', amarilla; legumbre estrechada entre las dos semillas, tomentosa ó alampiñada, larga de 10 á $12^{\prime \prime \prime}$ sobre $4^{\prime \prime \prime}$ de ancho, de semillas negras con un anillo color escarlata amarillo al rededor del ombligo, redondeaditas y anchas de $2^{\prime \prime \prime}$ l $[2$. R. phaseoloides, precatoria, caribcea, Dc. Glycina pharseoloides, $\mathrm{Sw}$.

G. II. Cajanus indicus, Spr. : C. T. V., 445.

E. Centrosena virginianum, Benth. Clitoria virginiana, L. : C. T. V., 337.

F. G. I. Phaseolus. - 1. Tallo voluble, 2. Tallo derecho ó voluble por la parte superior, seríceo ó alampiñado, cuyas hojas tienen hojuelas aovadas ó lanceoladas; pedúnculos elongados mas $\dot{0}$ menos largos que las hojas, con pedícelos muy cortos, por fin recorvados; cáliz con 5 dientes aovado-lanceolados, con una punta. cuvo superior es algo mas corto; corola purpurina larga de 6 á $8^{\prime \prime \prime}$; 
legumbre sub-cilíndrica, serícea ó alampiñada, linear, aguzada y picuda, rectita o lijeramente arqueada, refleja, larga de 3 á $4^{\prime \prime}$ sobre $1^{\prime \prime \prime} 1_{1} 2$ de ancho. Ph. semierectus; Ph. lathyi'oides, L. Ph. crotolarioides, Mart.

2. Tallos ordinariamente volubles, con las hojuelas aovadas y con una punta, 3. - Tallo siempre voluble, densamente velludo y color de orin, con hojuelas aovadas, de cara inferior lijeramente velluda; pedúnculos mas largos que las hojas, con algunas flores amarillas, cuyo estandarte es largo de $12^{\prime \prime \prime}$ : cáliz velludo 4-fido, de segmentos tan largos como el tubo y cuyo superior es bi-dentado; legumbre sub-cilíndrica, muy velluda, derechita, colgante de un pedícelo muy corto, larga de $3^{\prime \prime}$ sobre $3^{\prime \prime \prime}$ de ancho. Ph. lariocarpus. Ph. hirsutus, Mart. Dolichos lignosus, Jacq. D. Jacquinini, Dc.

3. Cáliz 4-dentado, 4. - Cáliz 4 fido, cuyo lóbulo inferior lanceolado-linear es tan largo como el tubo, los laterales mas cortos falciformes, mientras que el superior es trunco; pedúnculos ordinariamente mas cortitos que las hojas, con pocas flores purpurinas pintaditas de blanco, con el estandarte largo de 10 á $12^{\prime \prime \prime}$, cuya corola grande es 3 ó 4 veces mas larga que el cáliz; legumbre linear comprimida, rectita ó corva. Ph. adenanthus, Mey. Ph.truxilensis y cirrhosus, Kth. Ph. rostratus, Wall. Ph. amcenus, Macf. Ph, surinamensis, Miq.

4. Cáliz mucho mas corto que las brácteas, con el diente inferior 3-angular y el superior trunco; pedúnculos mas cortos que las hojas ó iguales á ellas; flores ordinariamente verdosito-blancas, legumbre con figura de sable, comprimida, arqueado-picuda, larga de $1^{\prime \prime} 1$ l 2 á $3^{\prime \prime}$ sobre 5 á $8^{\prime \prime \prime}$ de ancho, con $3-4$ semillas sub-cuadradoredondeaditas, purpuríneas ó blancas. Ph. lunatus, L. Ph. bipunctalus, Jacq. Ph. inamcnus, L. Ph, saccharatus, fecundus y linearis, Macf. - Cáliz tan largo como las bracteitas, cuyo diente inferior es triangular y el superior sub-trunco; pedúnculos siempre mas cortos que las hojas; flores ordinariamente blancas, legumbre oblongolinear sub-comprimida, sub-torulosa, rectita, con pocas ó algunas semillas ovoídeo-oblongas, de color muy variado. $P h$. vulgaris. $P h$. nanus, L. Ph. gonospermus, Saw. Ph. compressus, Dc. Ph. dumosus, Macf. C. T. V., 696.

G. II. Dolichos, L.- 1. Raiz nunca tuberosa, 2.-Raiz siempre tuberosa, mas ó menos gruesa, de la cual salen tallos fruticulosos muy largos y volubles, con hojas de tres en rama, cuyas hojuelas rou sub-rotondo-aguzadas; racimos axilares, con pedúnculo aovadolanceolado, elongados; legumbres rectas, pendientes, comprimidas, torulosas, aleonado-relludas. D. tuberosus, L.: C. T. V., 217.

2. Tallo voluble $\operatorname{lan}_{\text {ino }}$, hojuelas anchamente aovadas; flores blancas en legumbre sub-ciliz irica, mucronado-ungüiculada por el apéndice y torulosa. D. sesquipedctlis, L. - Tallo derecho, ramoso, lampiño, no voluble, con hojuelas aovado-sub-agudas, pedúnculos elongados paucífloros; legumbre recta, cilíndrica, con semillas esféricas blancas, con el ojo negro. D. sperospermus, L.

G. III. Caxavalia, D. G.- Tallos rastreros ó escandentes, alampiñados, larguísimos y ramosísimos, hojuelas redondeaditas ú ob- 
aoradas, obtusas de $3-4^{\prime \prime}$ de diámetro; flores purpurinas de corola larga de una pulgada, con la quilla corva y obtusa, de cáliz cuyo labio superior, anchamente bílobo, es mucho mas corto que el tubo; legumbre oblonga, cortamente estipitada, larga, de 6 á 2 " sobre 14 á $10^{\prime \prime \prime}$ de ancho, con dos crestas esertas salientes juxta-marjinales, distantes de $1^{\prime \prime \prime}$ de la sutura que acompañan, con semillas de color castaño opaco, ovoídeas, sub-comprimidas y largas de 6 á $8^{\prime \prime \prime} . C . o b-$ tusifolia. C.rosea, Dc. Dotichos obtusifolius, Lam. D. roseus, Sw. Tallo siempre voluble y alampinado, con hojuelas aovado-oblongas ó aovadas, mucronadas, de tamaño variable, pero ordinariamente largas de 2 á 5"; flores purpurinas, de corola larga de 1", con la quilla corva y obtusa, de cáliz cuyo labio superior redondeado, recorvo y escotado es mas largo que el tubo; legumbre linear-oblonga, estipitada, cuyas crestas proeminerites y juxta-marjinales están distantes de 1-2"' de la sutura, con semillas rufo-brunas y lustrosas, ovoídeo-oblongas, sub-comprimidas y largas de $8^{\prime \prime \prime}$. C. gladiata, Dc. - Variedad de semillas blancas con e] rafe bruno. C. ensiformis, Dc. : C. T. Y., 698.

G. IV. Labla r vulgaris, Sw. Dolichos lablab, L. Cuyas variedades son $3: 1^{\text {a }}$. Flores blancas; legumbres de $2^{\prime \prime} 1_{[} 2$ delargo y $8^{\prime \prime \prime}$ de ancho, con semillas negras oval-redondeaditas y largas de $4^{\prime \prime \prime} . L$. leucarpus, $\mathrm{S}_{w}$. Dotichos albiflor $u s$, Dc. - 2a. Corola blanca; legumbre larga de 2 á $3^{\prime \prime}$ sobre 8 á $10^{\prime \prime \prime}$ de ancho, con semillas ovales, menos comprimidas, blancas y largas de $5^{\prime \prime \prime}$ L. perennans, Dc. Dolichos nankinicus, Saw. - 3a. Flores purpúreas; legumbre larga de $3^{\prime \prime}$ sobre 6 á $8^{\prime \prime \prime}$ de ancho, con las semillas oval-redondeaditas, purpurinas y largas de $4 " \prime \prime$. L. purpurea, Dotich. purpureus, Jacq. C. T. V., 697 .

G. V. Mucuna, Ad. - 1. Hojuelas de cara inferior mas ó menos sedosa, 2. - Hojuelas enteramente lampiñas, elípticas, con una punta; flores en racimos cortos, largamente pedunculados, de cáliz sedoso, 4-dentado, cuyos 3 dientes superiores son pequeños ó apenas notables y el inferior mas largo, con la corola larga de 18"', de estandarte aovado-lanceolado, casi tan largo como las alas, que son azules ó purpurinas, así como él; quilla de color verdoso-amarillento, provista de un pico cartilajinoso, obtusito, igualando las alas; legumbre larga de $6^{\prime \prime}$ sobre $1^{\prime \prime} 1 l^{2}$ de ancho con muchas líneas transversales, comprimida, espatulada, oblonga, callosa por la márjen y pelitiesa, color de orin, con semillas orbiculares, comprimidas, de 8 a $10^{\prime \prime \prime}$ de diámetro, brunas y casi enteramente cer̃idas por el rafe. M. altissima, Dc. Dolichos altissima, Jacq. : C. T. V., 381.

2. Legumbre sin crestas transversales, oblongo-linear, corva, cubierta de pelo cerdoso, denso y bruno muy incante; hojuela terminal mayor romboídea, las laterales oblícuamente deltoídeas; flores en racimos elongados, de cáliz 4-fido, cuyo lóbulo superior es anchamente deltoídeo, corola azul oscuro ó purpurina, larga de 15 á $18^{\prime \prime \prime}$, con el estandarte aovado, la mitad tan largo como las alas y algo mas pálido, y la quilla provista de un pico cartilajinoso y cortámente eserto. $M$. pruriens, Dc. Dotichos pruriens, L. : C. T. V., 34-380. Legumbre con muchas crestas transversas y foliaceas, com- 
primida y pelierizarla, larga de 4 á $5^{\prime \prime}$ y anclia de 11 á $2^{\prime \prime}$ : hojuela. terminal aovada, y las laterales oblícuas: flores fasciculadas, de cáliz cuyo lóbulo inferior lanceolado es tan largo como el tubo, mientras el superior es mas corto y deltoídeo, de corola amarilla, larga de $2^{\prime \prime}$, con el estandarte aovado-lanceolado, la mitad tan largo como las alas, y quilla con un pico cartilajinoso cortamente eserto. $M$. urens, De. Dolichos urens, L. Negretia urens, Tuss. : C. T. V:, 34.

G. VI. VIGA unguiculata, Walp. Dolichos unguiculatus, Jacq. : C. T. V., 699.

G. VII. Erytrhina, L. - 1. Cáliz campanudo-trunco; pétalos de la quilla distintos y contenidos en el cáliz. 2. - Cáliz espatiforme, pétalos de la quilla distintos y pequeños, 3 .

2. Arbol lampiño, aguijonoso, bastante grande, con hojuelas aovado-romboídeas, desiguales, cortamente pecioladas, con una bracteita acompañando á la base del peciolo, la mayor ó terminal larga de $33\left[5,31{ }^{2} 2^{\prime \prime}\right.$, $r$ anchas de $42\left[3,3^{\prime \prime} 3\ulcorner 5\right.$, mientras las laterales son largas de 2, 3, 3" 1 [2 sobre $2,24\left[5,134^{\prime \prime}\right.$ de ancho; las hojas enteras son largas de 6 á $10^{\prime \prime}$, y el raquis de $4,5,6^{\prime \prime}$. Dientecitos del cáliz largos de 4 á $6 "$ ", apenas notables, estandarte color de escarlata, erguido, linear-oblongo, obtuso y largo de $2^{\prime \prime}$ y 6 veces mas largo que las alas y la quilla, legumbre moniliforme, picudo-sub-comprida, lampiña, con algunas semillas color de escarlata, ordinariamente con una mancha negra. C. cortallodendron, L. E. speciosa, Ander. : C. T. V., 446.

3. Arbol grande aguijonoso, con aguijones cónicos, sub-angulosos, corpulento y coposo, con hojuelas aovado-romboídeas por el ápice, furfuráceo-tomentosas inferiormente y peluditas superiormente; inermes, largas de 4 " sobre $43{ }^{4} 4$ de ancho, cuya terminal es transversalmente elíptica, mientras las laterales son oblicuamente subredondeadas; cáliz hendido casi hasta la base y con 5 dientes diminutos, largo de 9 á $12^{\prime \prime \prime}$ y tomentoso; estandarte reflejo, orbicular, color de escarlata, ancho de 1 á $1 " 1_{1} 2$, alas y quilla casi tan largas como el cáliz; estambres mas largos que el estandarte, legumbre sinuosa, contraida inferiormente, aterciopelada y con algunas semillas. E. velutina, W. - Arbol grande aguijonoso, con aguijones corros, ó inerme algunas reces; hojuelas sub-aguzadas, truncas por la base y redondeadas, trinervias, lampiñísimas, inermes, cuya terminal es larga de $5-5)^{\prime \prime} 1_{[2}$ y ancha de 6 á 6 " $1_{[} 2$, mientras las laterales son deltoídeo-aovadas; flores en espigas sub-terminales, esparcidas, color grana y largas de $2^{\prime \prime} 1[2$, de cáliz unilabiado, entero y lampiño; estandarte larguísimo linear, cuneiforme, recto; legumbre torulosa larga de $8,10^{\prime \prime} \mathrm{y}$ polisperma. E. umbrosa, Kth.

G. Crotalaria, L. - Hojas sin hojuelas ó vueltas filodios, 2.Hojas largamente pecioladas y con 3 hojuelas. Planta sufruticosa anual, de tallo derecho, que se eleva á 2-3' de alto. pubescente, cuyas hojuelas ob-aovadas ú ovales, largas de 1 á $2^{\prime \prime}$, son de cara inferior peluła ó alampiñada; estípulas diminutas r decíduas : racimos opuestos á las hojas, con 5 ó algunas flores de cáliz profundamente 5 -fido, con lóbulos aorado-lanceolados, mas corto que la corola, verdoso-amarilla, larga de 5 á $6^{\prime \prime \prime}$, con la quilla barbuda por la már- 
jen y terminada por un pico horizontal; legumbre colgante, larga de $16^{\prime \prime \prime}$ sobre $5^{\prime \prime \prime}$ de ancho, oblonga, subsesil y con pelo estendido. C. incana, L. C', cubensis, Dc. Chrysocalyx schimperi, Hook.

2 . Planta fruticulosa anual, de tallo derecho y alto de 1 á 2 , pelierizado, pubescente, con hojas ó filodios ovales ó lanceolado-sentados; estípulas anchamente escurridas, con el vértice semilunar y encorvado; pedúnculos laterales elongados, con pocas flores amarillas, de cáliz profundamente 5-fido, ordinariamente tan largo como la corola, con los segmentos lanceolados; legumbre oblonga, lampiña, cortamente estipitada y larga de 1". C. stipularis. C. sagittalis, Des. - Del cual hay dos variedades, una cuyas hojas superiores, largas de $2^{\prime \prime}$, son oblongo-lanceoladas y obtusas. $C$. oblongata, y la otra sedosa-pubescente, con hojas lanceoladas, obtusas y largas de 1"', cuyas superiores mas pequeñas tienen solo $6^{\prime \prime \prime}$ de largo. C. espadilla, Kth. C. sericea.

H. G. I. Ixdigofera, L. - 1. Vejetales vivaces, sofruticosos, 2. Vejetales anuales y herbáceos ó fruticulosos, 4 .

2. Legumbre mas ó menos cilíndrica, 3. - Legumbre tetrágona, elongada, linear, larga de 1-2", con una punta refleja y con algunas semillas. Ramitas algo sarmentosas, pubescentitas, con pelo denso, de hojas con 1, 2, 3 pares de hojuelas opuestas, ovales, mucronadas. de cara inferior pálida y largas de 8-12""; estípulas largas; setáceas, racimos pedunculados, mas largos que las hojas, de flores distantes y largas de 2-3"', cuyos lóbulos calizinales son largos y subulados. J. subulata, U. J. scabra, Reth. J.mucronata, Spreng. J. flaccida, Roxb. J. lespedezoides, Hook. - Cilíndrica y torulosa ó no, 3. Algo comprimido-torulosa, arqueadita y de ordinario con 3 semillas, mata poco ramosa, derecha y alta de como 3 á 5', tomentoso-plateada, con hojas imparipinadas, cuyas hojuelas en número de 7-9 son obovales, obtusas, escotadas por el vértice, como sedoso-plateadas, con la impar mayor que las demas. Flores en espigas erguidas. J. argentea. C. T. T., 700.

3. Legumbre oblonga, linear, no tubulosa, mas espesa á lo largo de la línea dorsal, arqueado-refleja y con 3-6 semillas, larga de $5-6$ "' sobre $1_{[} 2^{\prime \prime \prime}$ de ancho; vejetal de tallo blanquecino pubescentito por los ramos y la cara inferior de las hojuelas opuestas y en número de 3-7 pares, espatulado-oblongas, largas de $10,11,14^{\prime \prime \prime}$, mucronadas y cortamente pecioladas: estípulas subuladas; racimos sentados, lóbulos del cáliz triangulares. J. anil, L. J. tinctoria, Dc. - Legumbre sub-comprimido-cilíndrica, lijeramente torulosa, un poco espesa á lo largo de las suturas, estendida é inclinada á la vez, rectita ó encorvada, con algunas semillas, larga de 16 á 14"' y ancha de $1^{\prime \prime \prime}$; mata lijeramente tomentosa, 6-4 pares de hojuelas opuestas, ovales ú ob-aovado-oblongas : estípulas subuladas, racimos sentados; lóbulos del cáliz triangulares. J.tinctoria, L. C.T. V., 766.

4. Legumbre tetrágona, linear, mucronada, con 4-6 semillas; tallo con pelo suave y estendido $; 2-5$ pares de hojuelas opuestas, obaovado-oblongas, de cara inferior lijeramente sedoso-pubescente; estípulas largas y setáceas; racimos pedunculados, ordinariamente mas largos que las hojas, lóbulos del cáliz subulados y casi tan lar- 
gos como la corola. J. hirsuta, L.-Legumbres cilíndricas, lineares, distantes, rectas y largas de 10-12"', con 6-12 semillas; ramitas, peciolo y legumbres glutinosos y con glándulas estipitadas ; 4-8 pares de hojuelas eliptical-oblongas, de cara inferior pubescente, con pelo denso: estípula: largas y setáceas; racimos pedunculados, de ordinario mas largos que las hojas; lỏbulos del cáliz subulados, casi tan largos como la corola. J. viscosa, Lam. J. inquinans, W.

G.II. Tephrosia, Pers.-1. Estandarte adherente conel estambre correspondiente; flor'es racimosas; hojas pinadas, 2. - Estandarte libre del estambre; legumbres hinchadas por ambas márjenes; flores axilares, fasciculadas o solitarias; hojas con 1-3 hojuelas; frutices de ramas en forma de varita, cilíndricas, sedoso-tomentosas que llevan hojas cortamente pecioladas, con 1-3 hojuelas linearlanceoladas, obtusas, de cara superior lampiña, mientras la inferior es sedoso-tomentosa y plateado-lustrosa, largas de 3-2" y anchas de 1-1 $1_{[} 2$ ", cortamente pecioladas, estriadas por muchas venas rectas, estípulas diminutas, setíceas; pedúnculos axilares 3-1, tan largos o mas cortos que el raquis, con pedícelos largos de $2-\mathrm{I}^{\prime \prime}$ y de vértice dilatado, lóbulos del cáliz lanceolados, cuyo inferior es mas largo ; estandarte sedoso, estilo lampiño, con un estigma pinceliforme. T. brevipes, Benth. Cytisus sessiliflorus, Poir. Rhinchosia brevipes, Dc. Erioseme breripes, Walp. C. T. V., 548.

2. Vejetales fruticulosos, perennes, 3.-Planta herbácea ó fruticuloso, anual, de tallo ascendente alto de $1-2^{\prime}$, pubescentito y anguluso superiormente, de hojas con 4-6 pares de hojuelas lanceoladas al revés ú ob-aovado-lanceolarlas, retusas, de ordinario mucronaditas, largas de 6-10"' y de car'a inferior pubescentita; estípulas lanceolado-setáceas; racimos terminales ú opuestos á las liojas, de flores $2-3$ juntas y por fin distantes, largas de $4^{\prime \prime \prime}$, con la corola purpurinopálida; lóbulos del cáliz subulados, sub-iguales. dos veces mas corto que el estandarte serloso, quilla horizontalmente encorvada; estilo lampiño, con estigma cabezudo, lampiño ó con algun pelo; legumbre continua pubescente, estendida y con $5-8$ semillas. $T$. leplostachia, Dc. T. ascendens, Macf.

3. Nata fruticosa de $4-5^{\prime}$ de alto, con tallo derecho, asurcado y aterciopelado, de hojas con 10-20 pares de hojuelas oblongo-lineares, pecioladas, sedoso-pubescentes, especialmente por la cara inferior, largas de 11 [ 2 a $2^{\prime \prime}$; estípulas subulado-sedosas; racimos terminales y axilares elongados, con algunas flores azules, de pedícelos fasciculados, de cáliz con lóbulos aovados, cuyos dos superiores son mas cortos; estandarte sedoso: estilo pubescente; legumbire continua pubescente, larga de $2^{\prime \prime}$. T. toxicaria, Pers. T. schiedeana. Schle. Galega toxicaria, Sw.: C. T. V., 410. - Mata fruticulosa, difusa, alta de $1^{\prime}$ á $\mathrm{I}^{\prime} \mathrm{l}_{\mathrm{I}} 2$ inclinada y peludo-pubescente, de hojas con 4-7 pares de liojuelas lanceoladas al revés y largas de $6-12^{\prime \prime \prime}$; estípulas subuladas ó lanceolado-cerdáceas, racimos opuestos á las hojas, de flores mellizas o solitarias, largas de $\breve{b}-6^{\prime \prime \prime}$, rosadas, de cáliz con lóbulos subulados, sub-iguales, tres veces mas corto que el cstandarte sedoso; estilo lampiño, con estigma largamente pestanoso; legumbre continua, pubescente, estendida y con $5-10$ semillas. 
T. cinerea, Pers. T. procumbens, Macf.-Var. T. littoralis, Pers.

C. T. V., 410.

G. III. Agati grandiflora, Desr.: C. T. V. 116.

Sub-familia 2. - CESALPINEAS. - Cáliz con ó divisiones, reunidas entre sí mas ó menos, de prefloracion empizarrada ó valvar, frecuentemente hendido hasta la base; corola con igual número de pétalos, algunas raras veces menos y que suelen faltar alguna vez que otra, de prefloracion empizarrada; flores no papilionáceas y cuyo pétalo reemplazando la quilla está en la parte interior del capullo; estambres frecuentemente no simétricos con las demas partes de la flor ó muy desiguales entre sí, ora muy numerosos, ora pocos por causa de aborto, raras veces regulares, con mayor frecuencia libres ó algo soldados por la base. Ovario sostenido por un ginóforo, ó por partes soldado con el cáliz. Legumbre con tabiques ó sin ellos, con pulpa en su interior ó sin ella, conteniendo cada celda una ó rlos semillas sin endospermo, cuyo embrion es de ordinario recto.

\section{Análisis dicotómica de las tribus.}

1. Cáliz campanudo ó tubuloso, 2. - Cáliz ni campanudo ni tubuloso, 8 .

2. Cáliz campanudo, 3.-Cáliz tubuloso-inferiormente y persistente, 4 .

3. Regular y con 5 dientes; corola de 5 pétalos casi iguales; 5 estambres fértiles, casi iguales, alternando con otros tantos estériles; hojas desnudas ó dos veces pinadas. T. I. Dimorfondreas. Ceratonia. - Por lo regular campanudo 5-fido; corola de 5 pétalos algo desiguales, inclinados ó diverjentes; sosten del ovario ó ginóforo libre. Hojas una sola vez pinadas con ó sin impar, cuyas hojuelas tienen tendencia á rolverse alternas. T. II. LEptolobieas. G. I. Hermatoxilon campechianum, L.: C. T. V., 112. G. II. Parkinsonia aculeata, L.: C. T. V., 768.

4. Con 4 ó 5 divisiones cóncavas, empizarradas, dobladas hácia dentro de la flor ó decíduas; 5 pétalos que á reces se quedan reducidos á uno solo; 10 estambres, á veces mas, otras veces menos, siendo algunos de ellos ó todos muy largos y doblados dentro del capullo ; ginóforo con mayor frecuencia soldado por un solo lado con el tubo calizinal; hojas pari o imparipinadas. T. III. Aunestreas.

G. I. Tanarindes indica, L.: C. T. V., 614-520. G. II. HimeNđA courbavil, L.: C. T. V., 444. - Divisiones calizinales tan pronto cortas y dentiformes como elongadas y valvares; 5 pétalos; 10 estambres por lo menos; ginóforo libre ó soldado; hojas compuestas de un solo par de hojuelas distintas ó soldadas entre sí por los bordes correspondientes y rarísima vez reducidos á una sola hojuela. T. IV. Bauhinieas. A.

5. Estambres siempre definidos, 6. - Estambres indefinidos mas ó menos numerosos, muy desiguales y que no se parecen entre sí, insertos junto con los pétalos en el disco ó distintos, y mas raca vez pegados en el cáliz, de dehiscencia valvar, rompiéndose irregular- 
mente o hendido hasta la base en 4 ó 5 lóbulos, casi iguales; pétalos 5 ó en número menor y á veces reducidos á uno único, otras veces faltan enteramente. T. V. Swartzieas. - Swartzia tomentosa, L.

6. Estambres 10, ó en número menor, 7. - Siempre 10 estambres fértiles apenas inclinados; ginóforo libre; cáliz 5-fido, ó mas á menudo 5-partido; corola de 5 pétalos algo desiguales; hojas pipinadas. T. VI. Eucesalpíneas. B.

7. Estambres 10 ó en número menor por causa de aborto de algunos que se quedan desformados o faltan enteramente, desiguales, cuyas anteras menores, oblongas y cuadrangulares se abren por poros situados en su ápice ó mas raras veces hácia la base; hojas pinadas sin impar ó mas rara vez cuyas hojuelas alternan un poco con la impar terminal. Legumbre con pulpa en su interior ó sin ella. T.V.CASIEAS,C.-Estambres 10 ó en número menor, iguales ó desiguales; ginó foro libre y muy corto ; ovario con un solo óvulo ó algunas veces con dos; legumbre indehiscente; cáliz con 4-5 divisiones profundas, empizarradas, reflejas durante la floracion; 4-5 pétalos casi iguales, los cuales faltan á veces; hojas con uno ó con algunos pares de hojuelas que tienden á volverse alternas, con impar ó sin él. T. VII. Cinonetreas. - Copaifera officinalis, Jacq.: C. T. V., 771.

A. G. I. Bauhinia, L. 1. Vejetales aguijonosos, 2.-Árbol bajito muy ramoso, inerme, cuyas ramas alampiñadas llevan en sus ramitas hojas sub-acorazonadas, redondeaditas, lobadas hasta el $1_{[} 3,9-$ nervias, lampiñas, con las nervaduras alampiñadas inferiormente, cuyos lóbulos anchamente a.ovados son redondeadito-obtusos y paralelos, anchas de כ̌ á $3^{\prime \prime} 1$ [2, con el peciolo de $1^{\prime \prime}-6^{\prime \prime \prime}$. Flores solitarias ó las superiores racimosas blancas, largas de 3 á 4", de ordinario opuestas á las hojas, con los pedícelos espesitos y de 4-6"' de largo; de cáliz largo, esteriormente tomentoso y color de orin, espatiforme, con el vértice entero, cuyo limbo es casi tan largo como los pétalos lineares y como los estambres distintos, de anteras elongadas y lineares; estigma infundibuliforme bi-lamelado, arovadooblongo y unilateral. B. megalandra, Gr.

2. Arbusto de como 10 á $15^{\prime}$ de alto, muy ramoso, con espinas estipulares y curas ramitas pubescentitas llevan hojas redondeaditosub-cuadradas, bílobas hasta el $1_{[} 3$ ó la $1_{[} 2$ de su lonjitud, sub-acorazonadas por la hase, 11-9-nervias, pubescentitas inferiormente, de lóbulos un poco diverjentes, aovado-deltoídeos y con una punta obtusita, anchos de 11 2-1" ; flores blancas mellizas ó solitarias, de cáliz pubescente esteriormente espatiforme, con el vértice entero, con el tubo largo de $4^{\prime \prime \prime}$ y el limbo de 9 á $10^{\prime \prime \prime}$; pétalos espatuladooblongos, retusos, aguzándose en uña corta, lampiños, largos de $1^{\prime \prime}$ 1 [2 á 2"; estambres todos fértiles, de los cuales 9 están reunidos por la base, con anteras lineares recorvadas ; estigma infundibuliforme lanceolado, desigualmente lobado y obtuso. $B$. vingula. $B$. aculeata, Jacq. B. pubescens, Dc. B. acuminata, Desc. - Arbusto del tamaño y altura del anterior, con estípulas espinosas pero no fuertes, ramitas pubescentitas con hojas redondeaditas, bílobas hasta el 1 [ 3 , truncas por la base, 9-nervias, puhescentitas inferior- 
mente, cuyos lóbulos anchamente aovados son redondeado-obtusos y paralelos, anchas de $2^{\prime \prime}$; pedúnculos bífidos con dos flores rosadoblancas, acompañadas de bracteitas lineares y persistentes, de cáliz pubescentito esteriormente, espatiforme ó entero, diminutamente denticulado por el vértice, pétalos anchamente ob-aovados, redondeados por el ápice, subsesiles, lampiños, tres veces tan largos como el limbo del cáliz: largeos de $1^{\prime \prime} 1_{[} 2$ á $2^{\prime \prime}$ sobre 15 á $18^{\prime \prime \prime}$ de ancho, teniendo uno de ellos una mancha purpurina por la hase; estambres 5-7 fértiles, sub-distintos por la base pestañosa, inclusos, de anteras oblongo-lineares recorvadas; estigma infundibuliforme lanceolado, desigualmente bílobo, labio mayor arriñonado: ginóforo mur corto. B. variegata, L.: C. T. V., 848.

G. II. Schnella, Radd. Arbusto sarmentoso con hojas cuyas dos hojuelas son distintas, semi-aovadas, aguzadas ó puntiagudas, subsemi-acorazonadas por la base, paralelas, 3-4-nervias, de cara superior lampiña y lustrosa, mientras la inferior pubescente es eomo sedoso-dorada, largas como de 8-4", con el peciolo de 6-3"; lóbulos dol cáliz obtusos, pétalos velludos esteriormente desiguales, curo mas largo es ob-aovado y dos veces mas largos que el cáliz; pedícelos largos de $1^{\prime \prime \prime}$, con flores de 5 á $6^{\prime \prime \prime}$. S. splendens, Benth. $B$. splendens, Kth. B. outimouton, Aubl. B. macrophylla, Poir. B. riparia, Split. - Arbusto cuyos tallos comprimidos larguísimos parecen una cadena, cuyas ramitas alampinadas están provistas de especies de zarcillos un poco color de orin, son pubescentitas cuando tiernas y llevan hojas acorazonado-redondeaditas un poco bílobas por el vértice, hasta el $1_{[} 3$ o $1_{[} 10$ solamente, 9-11-nervias, con los lóbulos paralelos, deltoídeos, aguzados, obtusitos, anchas de $4-3^{\prime \prime}$. coriáceas, de cara superior lampina, mientras la inferior color de orin es pubescentita sobre las nervaduras bastante proeminentes, con peciolo largo de 2-1"; flores blancas en racimos elongarlos. terminales, olorosas y largas de $66^{\prime \prime \prime}$, con el pedícelo de $2^{\prime \prime \prime}$, de cáliz cuyos lábios son diminutamente dentaditos; pétalos ob-aovadooblongos, velludos esteriormente $\mathrm{y}$ por fin alampiñados, escepto la parte mediana, dos veces tan largos como el cáliz. S. excisa, Gr.: C. T. V., 816.

G. III. Brow reA, Jacq. 1. Hojas con 6 ó menor número de pares de hojuelas; árboles bajitos de 20 á $25^{\prime}$ de altura, 2.-Hojas con 12 pares de hojuelas; árbol de como $60^{\prime}$ de altura, coposo y corpulento; lojuelas cortamente pecioladas, alternas, lanceolado-oblongas, largamente cuspidado-aguzadas, iguales, redondeaditas y apenas acorazonadas por la base, entejérrimas, membranosas, reticulado-venosas, lampiñas, mas pálidas y con las nervaduras proeminentes inferiormente, largas de $4^{\prime \prime} 1 \Upsilon^{2}$ sobre $14-16^{\prime \prime \prime}$ de ancho, las inferiores son menores y de $2^{\prime \prime} 1_{l} 2-3^{\prime \prime}$ de largo, con el raquis casi cilíndrico-tomentoso-aleonadito. Flores muy numerosísimas mas de 100 en espigas aovado-racimosas, largas de $2^{\prime \prime}$ y mas, con pedícelos de $1_{1} 2^{\prime \prime}$, pelierizados y bibracteados por el ápice, mientras la base está ceñida por brácteas; calículo turbinado, campanudo, cumprimido, tetrágono, pelierizado-tomentoso y aleonadito; cáliz de tubo elongado, anguloso, alampiñado esteriormente é interiormente pelieri- 
zadito, articulado y deciduo, de limho 4-partido. Pétalos espatulados, larguísimamente unguiculados; estambres 11, curos alternos mas largos esceden la corola. B. grandipes, Kth.

2. Estambres 11. cortamente esertos ó sul,-inclusos: calículo velludo tan largo como el tubo del cáliz, cuyos lóbulos son como mitad tan largos como el tubo y los pétalos, 3. - 10 estambres casi dos veces tan largos como los pétalos; hojas de 4-3 pares de hojuelas lanceolado-oblongas ó eliptical-oblongas, cuspidadas, sub-agudos por la base, largas de $4^{\prime \prime}-2^{\prime \prime}$ sobre $2-11\left[2^{\prime \prime}\right.$ de ancho; flores fasciculadas, calículo velludo y escediendo el tubo del cáliz cuyos lóbulos son 2-3 veces mas cortos que el tubo y que los pétalos, largas de $2^{\prime \prime}$, con pedícelos de $3^{\prime \prime \prime}$. B. speciosa, Rchb.

3. Estambres sub-inclusos ó 1-2"' mas largos que los pétalos, mucronados ó igualándoles; hojas con 6-2-1 pares de hojuelas elípticas ó eliptical-oblongas, cuspidadas, redondeadas ó sub-acorazonadas por la base, lustrosas, largas de 1-4" sobre 2 112-3" de ancho; flores fasciculadas, largas de $2^{\prime \prime}$, con los pedícelos de $3^{\prime \prime \prime}$. B. latifolia, Jacq. - Estambres cortamente esertos y 4"' mas largos que los pétalos; hojas con 2-4 pares de hojuelas eliptical-oblongas, cuspidadas, redondeadas por la base ; flores fasciculadas en la sumidad de las ramas y colgantes. B. rosa, Berg. B. coccinea, Lœfl.: C. T. V., 515.

B. G. I. Cacsalpivia, L. 1. Legumbre seca, con dos val zas y algunas semillas; flores en racimos simples, 2. - Legumbre como abayada, indehiscente, hinchado-comprimida, con pocas semillas : flores amarillas en racimos compuestos dispuestos; arbusto que se eleva á 15 ó $20^{\prime}$ de altura y se vuelve árbol bajito aguijonoso ó inerme algunas veces, lampiño con hojas 2-3 pinadas con 2-1 pares de hojuelas, al revés deltoídeo-redondeaditas ú oblicuamente romboídeas, lijeramente retusas, con puntos transparentes, largas de 12$9^{\prime \prime \prime}$ sobre 10 á $8^{\prime \prime \prime}$ de ancho; pedícelos articulados por debajo del ápice ; pétalos largos de $4-5^{\prime \prime \prime}$ y un poco mas que los segmentos mas cortos del cáliz $\mathrm{y}$ tanto como los órganos sexuales; filamentos $\mathrm{y}$ ovario velludos; estigma espesito; legumbre suculenta, negra, recta, sentada con las impresiones transversales de los falsos tabiques. hinchada por las márjenes, obtusita por el ápice, larga de 2 á $1^{\prime \prime}$ sobre $6^{\prime \prime \prime}$ de ancho y espesa de 3 á $2^{\prime \prime \prime}$, con 1-3 semillas lustrosas y brunas, comprimido-globosas y de $4^{\prime \prime \prime}$ de diámetro. C. bijuga, Sw. C. ventricosa, L. C. glandulosa, Bert. Poinciana bejuga, L. Acacia bancfortiana, Bert.: C. T. V., 49.

2. Arbusto de como 8 á $10^{\prime}$ de alto, con ramos difusos ó como sarmentosos, aguijonosos y pubescentes por la sumidad, de hojas 610-4-pinadas con 8-12 pares de hojuelas oblongo-redondeadas ó sub-truncas por el ápice, de cara inferior pubescentita ó alampiñada, largas de 6 á $5^{\prime \prime \prime}$ sobre $2^{\prime \prime \prime}$ de ancho; estípulas semi-asaetadas y decíduas; pedícelos muy largos articulados por debajo del ápice; pétalos de $6^{\prime \prime \prime}$ y mas largos que el cáliz; filamentos cortamente esertos, velludos por la base, estigma espesito, legumbre alampiñada oblícua y largamente cuspidada, sentada, comprimida y llana, por fin algo hinchada, redondeada por ambos estremos, larga de 2 
1 [2 á $2^{\prime \prime}$ sobre 10 á 8 " de ancho, con 6-8 semillas ovoídeas, pintadito-negras, largas de $4^{\prime \prime \prime}$. C. separia, Roxb. C. horrida, Rich.: C. T. V., 49. - Arbusto que se vuelve con frecuencia arbolito aguijonoso, lampiño, de hojas con 1-4-5 pares de pinulas, con 3-59 pares de hojuelas cada una, ob-aovadas ú oblongas, retusas ó redondeadas por el ápice, largas de 12-5-18"' sobre 5-2 1 [2-12"' de ancho; flores blancuzcas en racimos terminales, cuyos pedícelos largos son articulados por debajo del ápice, de cáliz cuyo segmento impar dos veces tan largo como los demas y reflejo es algo mas largo que el tubo, que lo es de $3^{\prime \prime \prime}$; pétalos mas cortos que el cáliz; órganos sexuales 2-3 veces tan largos como el cáliz que tiene $1^{\prime \prime \prime}$; filamentos escamosos inferiormente; estigma espesito; legumbre llana, comprimida, lampiña, oblícuamente aguzada y con figura de cimitarra por el vértice, continua interiormente, larga de '3" y ancha de $5^{\prime \prime \prime}$, cortamente estipitada, de $2^{\prime \prime \prime}$ nada mas, con 7-10 semillas sub-cuadradas, comprimidas y de 3 "' de diámetro. C. crista, L. C. bahamensis, Lam.: C. T. V., 49.

G.II. Guilandixa, L. Hojas pubescentitas ó alampiñadas con hojuelas ovales ó aovadas, obtusas, muy desiguales por la base, largas de 8 á $122^{\prime \prime \prime} \mathrm{y}$ anchas de 6 á $8^{\prime \prime \prime}$; estípulas abortivas; brácteas tan largas como el pedícelo; semillas amarillas. G. bonduc, L. G. microphylla, Dc.: C. T. T., 50. -- Hojuelas pubescentitas ó alampiñadas oval-oblongas, ovales ó aovadas, obtusas, sub-acorazonadas por la base casi igual, largas de 18"' y anchas de 8-10" ; estípulas partidas en segmentos grandes, brácteas recorvadas y mas largas que los pedícelos; semillas de color aplomado. G. bonducella, L. G. bonduc, And.: C. T. V., 111.

G. III. Poinciana pulchervima, L.: C. T. V., 337.G. IV. Libidibia coriaria, Schle.: C. T. V., 120.G. V. Peltophorum Linnci, Benth. Coesalpinia brasiliensis, L. C. jamaica, Sw.; C. T. V., 49.

C. G. I. CAsia. 1. Estambres 7 fértiles, mientras los demas abortados son estériles, 13. Estambres 5-10 todos fértiles, cuyas anteras lineares se revientan por el ápice á favor de dos grietas cortitas, pubescentitas á lo largo de un surco cerrado por debajo de ellas; legumbre plano-comprimida, bivalvar, con semillas comprimidas $y$ paralelas á las valvas, podospermo deltoídeo; pedícelos diminutos $\mathrm{y}$ con bracteitas diminutas, 2 .

2. De inflorescencia terminal; podospermo escamiforme, 3. De inflorescencia nunca terminal, pero cuyos pedúnculos son axilares ó supra-axilares; podospermo escamiforme, 4.

4. Mata fruticulosa y anual, de tallo derecho, cilíndrico, de ramitas con pelo glanduloso, que llevan hojas biyugadas, cuyas hojuelas son obovales, obtusísimas, alampiñadas, sin puntitos y largas de 12 á $8^{\prime \prime \prime}$; raquis con glandulitas situadas entre las pares; estípulas lanceoladas y cerdosas; racimos terminales, acompañados de flores accesorias y axilares, con pocas flores pediceladas, de sépalos largos de 2 "'; legumbre larga de 1", glanduloso-peluda, con líneas oblícuas correspondiendo á los tabiques. C. absus, L. C. viscosa, Macf.

4. Frutices ó matas fruticulosas, vivaces, 8. - Vejetales herbáceos ó fruticulosos anuales, 5 . 
5. Sub-frutices de hojas con un solo par de hojuelas, 6. - Hojas con 10 á 25 pares de hojuelas, 7 .

6. Lampiño, hojuelas oblícuamente semi-orbiculares ó semi-obaovadas, con las nervaduras dispuestas á manera de abanico y las venas escurridas, largas de 10 á $6^{\prime \prime \prime}$; estípulas acorazonado-subuladas mas largas que el raquis glanduloso ; pedúnculos solitarios unífloros y mas largos que las hojas; sépalos largos de $3^{\prime \prime \prime}$ estriados por algunas nervaduras y escariosos; legumbre con pelo largo, esparcido y densamente pubescente, larga de $11_{1} 2$ á $1^{\prime \prime}$, con semillas oblongas y oblícuas por la márjen. C. diphylla, L. - Peludo; hojuelas semi-ovales ú oblícuamente semi-orbiculares, reticulado-venosas y largas de 9-4"' ; estípulas oblícuamente acorazonado-subuladas tan largas ó mas largas que el raquis sin glándulas; pedúnculos solitarios unífloros y mas largos que las hojas; sépalos foliáceos, largos de $2^{\prime \prime \prime}$; legumbre pubescentita con pelo corto y larga de 12 á 8"'. C. rotundifolia, Pers. C. bifoliolata, Dc.

7. Planta herbácea ó fruticulosa, pubescente con pelo corvo, ó alampiñada, de hojas con 5-12-25 pares de hojuelas oblongo-lineares, mucronaditas, lijeramente oblícuas por la hase, peninervias, estriadas á causa de sus venas, y largas de à á $2^{\prime \prime \prime}$; raquis con una glándula estipitada situada por debajo del par mas inferior; estípulas aguzadas desde la base oblícuo-lanceolada y escediendo el punto de insercion de la glándula; pedúnculo con 1 ó á veces 3 flores, mucho mas cortas que las hojas; estambres 5-7-10; legumbre con pelo esparcido y corvo. C. nictitans, L. C. chamecrista, Sw. C. eschynomene, Dc. C. smaragdina, Macf.: C. T. V., 519.-Mata velludopubescente, alta de 1 á 2 , de hojas con $10-25$ pares de hojuelas oblongo-lineares, mucronaditas, oblícuas por la base, peninervias, estriadas á causa de sus venas largas de 5 á $3^{\prime \prime \prime}$; raquis con una glándula sesil y escutiforme, situada por debajo del par mas inferior; estípulas subuladas y escediendo la insercion de la glándula; pedúnculos largos de 4-3"', ordinariamente distantes de la axila, en número de 1-3, muy cortos y con 1-3 flores, con los pétalos inclusos y 7-8 estambres; legumbre larga de $1_{[} 2^{\prime \prime}$ á $1^{\prime \prime} 1_{l} 2$, velluda con pelo esparcido. C. patellaria, Dc.

8. Raquis con una ó con algunas glánàulas, 9.-Raquis sin glándula ninguna; mata peluda con hojas de 3 á 5 pares de hojuelas oblongas mucronadas, oblícuas por la base, alampiñado-pestañosas y largas de 8 á $4^{\prime \prime \prime}$; estípulas semi-subuladas; 1 -3 pedúnculos 1 flores casi tan largos como las hojas; legumbre pubescente larga de 18 á $10^{\prime \prime \prime}$. C. pilosa, L.

9. Una sola glándula situada por debajo del par mas inferior, 10. - Tantas glándulas situadas por deluajo de cada par cuantos pares de hojuelas hay ; frutice ó arbustillo cuyas ramas lijeramente pubescentitas llevan hojas con 8-4 pares de hojuelas, lampiñas, obaovado-oblongas, oblícuas por la base redondeada, largas de 12-4" y anchas de 4-2"', mucronadito-obtusas ó retuso-truncas por el ápice, peninervias, estriadas por causa de sus venas, glándulas peciolares subsesiles ó estipitadas; estípulas aguzadas desde la base lanceolada; 1-2 pedúnculos 1-floros y mas cortos que las hojas; 
estambres 10 ; legumbre con pelo esparciảo y corvo, larga de $1^{\prime \prime} 1_{[2} 2$ á $]^{\prime \prime}$. C. polyadena, Dc.

10. Pubescentes ó alampiñados, 11. - Tan pronto alampiñado como peludo, ese vejetal fruticoso ó fruticuloso es alto de 2-5-6'. cuyos ramos llevan hojas con 10-18-5 pares de hojuelas oblongolineares mucronaditas, lijeramente oblícuas por la base, peninervias, estriadas á causa de sus venas, largas de 3 á $10^{\prime \prime \prime}$ raquis con una glándula estipitada situada por debajo del par de hojuelas mas inferior y algunas veces tambien debajo de los pares superiores; estípulas cortas y subuladàs; $1-3$ pedúnculos con 1 sola flor é iguales ó dos veces mas largos que ella, mucho mas cortos que las hojas; estambres 10, con filamentos muy cortos; legumbre con pelo esparcido y corvo, larga de 1-2". C. glandulosa, L. C. chamachrista caribea, L. - De la cual hay dos variedades: la la de tallo con forma de varita, simple inferiormente y alampiñado; glándula peciolar solitaria, ó pocas, cortamente estipitada. C. stricta, Schrk., Y la $2^{2}$ de tallo difuso, cuyos ramos, peciolos y frecuentemente las hojuelas son peludos; glándulas peciolares largamente estipitadas. $C$. ramosa. C. viryata, Sw. C. Swartzii, Wickstr.

11. Siempre pubescentes, 12. - Alampiñado ó por fin lampiño ó lustroso el tallo fruticuloso y con forma de varita de esa mata alta de 2-3', lleva hojas con 20-30 pares de hojuelas oblongo-lineares, mucronadito-obtusas, inequilaterales, peninervias con venas distantes lampiñas y largas de 6-4"' ; raquis con una sola glándula turbinado-cilíndrica situada por debajo del par le hojuelas mas inferior; estípulas subuladas; pedunculos distantes de la axila muy cortos, de 3 á $4^{\prime \prime \prime}$ de largo solamente; legumbre alampiñada larga de $2^{\prime \prime}$ y con una ala estrecha situada por su márjen. C. pretexta, Vog.

12. Mata herbácea ó fruticulosa, de tallo delicado, pubescente, de hojas con 4-9 pares de hojuelas, inequilaterales, oblongo-lineares ú ob-aovado-lineares, mucronaditas, alampiñadas, largas de 3 á $1^{\prime \prime \prime}$ $1_{1} 2$, venosas inferiormente; raquis con una glándula estipitada situada por debajo de los pares; estípulas semi-subuladas; pedúnculos simples casi tan largos como las hojas, con una sola flor cuyos pétalos son largos de $4-5^{\prime \prime \prime}$; legumbre peluda con pelo esparcido y larga de 12-8"'. C. serpens, L. C. prostrata, Kth. C. pygmaa, Macf. C. diffusa, Salzm. - Arbusto de $8^{\prime}$ ó mata fruticulosa de $3^{\prime}$ de alto, pubescente con pelito corvo, de hojas con 6-2 pares de hojuelas inequilaterales ob-aovado-oblongas, redondeadas ó sub-truncas por el vértice, mucronadas, peninervias y de venas escurridas, de cara superior por fin alampiñada, largas de 5-3"' ; raquis con una glándula sesil y deprimida situada por debajo de los pares que une; estípulas aguzadas desde la base lanceolada; pedúnculos solitarios, casi tan largos como las hojas, con una sola flor cuyos pétalos son largos de $6^{\prime \prime \prime} ; 10$ estambres; legumbre pubescente con pelo esparcido y corvo, larga de 3-1". C. lineata, Sw. C. cuneata, Dc.

13. Legumbre sin alas siempre, 14. - Legumbre tetragonal con alas á lo largo de la parte mediana de las valvas, dehiscente y con algunas celdas, de semillas paralelas á los tabiques; estambres fér- 
tiles 7-6-5. Primoroso arbustito bastante ramoso que se eleva á 6$10^{\prime}$ de altura, cuyas hojas grandes están formadas de 6-14 pares de hojuelas desiguales grandes, oblongas, subsesiles por la base subtrunca, redondeadas ó retusas por el vértice, alampiñadas, par inferior cerrado por el nudo y distante del mas vecino, largas de 5-2" el par superior siendo mayor que los demas y el inferior el menor de todos; raquis triangular sin glándulas: flores amarillas en espiga terminal, larga de 6-8", con grandes brácteas amarillas y decíduas, cuyos pétalos grandes están lacerados por la márjen; legumbre mucronada con los bordes marjinales enteros y las alas festoneaditas, larga de 5". C. alata, L.: C. T. V., 383.

14. Cilíndrica mas ó menos ó casi así, leñosa ó coriácea, con algunas celdas, á veces llenas de pulpa, cuyas semillas comprimidas son paralelas á los tabiques ; anteras oblongas bi-porosas por el ápice; vejetales siempre leñosos, 15. - Nunca ó rara vez sub-cilíndrica, pero sí mas ó menos comprimida y plana, 19.

15. Has ó menos dehiscente y nunca verrugosa, 16. - Indehiscente, sub-comprimida y cilíndrica á la par, verrugosa, lampiña y con una punta. Arbolito alampiñado, de hojas con 2 pares de hojuelas semi-aovadas, con una punta, largas de 5-2" ; raquis con una glándula cónica situada entre el par mas inferior; racimos axilares ó formando corimbos flojos, cuyos pedícelos largos y abiertos no tienen brácteas, con pocas fiores de pétalos largos de 10"" ; legumbre larga de 8-10" y con semillas horizontales. C. bacillaris, L.

16. Vejetales rastreros ó sarmentosos, cuya legumbre coriácea y sub-cilíndrica se abre á lo largo de las suturas, 17. - Vejetales no sarmentosos; legumbre sub-cilíndrica y obtusa, coriácea y abriéndose tambien á lo largo de las suturas, 18.

17. Arbusto como trepador ó abejucado y bastante alto, alampiñado con hojas de 2 pares de hojuelas eliptical-oblongas lijeramente inequilaterales, con una punta, de cara superior lustrosa, largas de $3^{\prime \prime} 1_{1} 2$ á $2^{\prime \prime}$; raquis con una glándula cilíndrica entre los dos pares mas inferiores ó una sola y un tubérculo dorsal por la base; estípulas falciformes, cerdosas, sub-punzantes ó lanceoladas; racimos axilares corimbiformes, con brácteas decíduas; legumbre con un piquito, torulosa, transversalmente venosa, lampiña, larga de 46-2", con semillas horizontales. C. viminea, L. C. melanocarpa, Bert. C. undulata, Benth. - Arbustito algo rastrero no muy alto, lampiño, de hojas con 2-3-4 pares de hojuelas ob-aovadas ú ovalredondeadas, de ápice redondeado, largas de 16-10"'; raquis con una glándula entre el par mas inferior; racimos tan largos como las hojas, con pedícelos cortos y bracteolados, axilares y con pocas flores, cuyos sépalos son largos de 4 "' y los pétalcs de 6 "'; legumbre lampiña con un tabique lonjitudinal incompleto. larga de 8-3"', con semillas horizontales. C. bicapsularis, L.: C. T. V. 517.

18. Arbustito lampiño, de hojas con 3-4 pares de hojuelas aovado-oblongas ó aovado-lanceoladas, aguzadas y largas de 3 a $2^{\prime \prime}$; raquis con una glándula entre cada par; racimos axilares mas cortos que las hojas y terminales; brácteas decíluas; pedícelos tan largos como las flores, cuyos sépalos son largos de $4^{\prime \prime \prime}$ y los pétalos 
de 6-8"'; legumbre lampiña, transversalmente rugosita y larga de 3-2". C. larigata, W. - Arbustillo tomentoso-pubescente, de hojas con 6-8, á veces 2 pares de hojuelas oblongas ó lanceoladooblongas, redondeadas ú obtusitas por el ápice, de cara superior pubescente, mientras la inferior es tomentosa, y largas de 18-9"', raquis con glándulas entre todos ó solamente algunos pares; racimos axilares, cuyo terminal es corimbiforme, con flores cuyos sépalos son largos de 6 "' y los pétalos de 10-12"'; legumbre tomentosa y pubescente. C. tomentosa, L.

19. Siempre comprimida, 21.- Membranáceo-comprimida, pero por fin biconvexa ó subcilíndrica, bivalvar, sin pulpa y con algunas celdas, monospermas, cuya semilla comprimida es por fin paralela á los tabiques, 20.

20. Frutice ó mata fruticulosa pubescente, cuyas ramas obtusamente angulosas llevan hojas con 4-6 pares de hojuelas elípticas o eliptical-oblongas, aguzadas y largas de $1-2^{\prime \prime} 1_{[} 2$; raquis con una glándula cilíndrica por encima de la base; racimos cortos, con pocas flores, cuyos sépalos son largos de $3-4^{\prime \prime \prime}$ y los pétalos de $6-8^{\prime \prime \prime}$; legumbre linear-pubescente, no torulosa, por fin sub-comprimidobi-convexa, larga de $5^{\prime \prime}$, cuya última es arqueada ó rectita. C. hirsuta, L. C. caracasana, Jacq. C. venenifera, Rodrch. - Mata anual ó fruticulosa derecha, alta de $2^{\prime}$ á $4^{\prime}$, no.muy ramosa, alampiñada ó pubescentita, de hojas con 4-8 y á veces 12 pares de hojuelas aovado-lanceoladas, aguzadas, largas de $2-1^{\prime \prime}$ sobre $15-8^{\prime \prime \prime}$; raquis con una glándula ovoídea hácia la base; racimos cortos, de pedícelos bracteolados, con pocas flores amarillas, cuyos sépalos son largos de 2-3"' y los pétalos de $6^{\prime \prime \prime}$; legumbre lampiña, oblongo-linear, marjenada, comprimida, y por fin biconvexo-sub-cilíndrica, larga de 4-2", un poco arqueadita. C.occidentalis, L.: C. T. V., $30 \%$.

21. Llana y comprimida, pero sin ser tetrágona, 23. - Comprimida y tetrágona, linear, con semillas comprimidas y paralelas á las valvas y cuyo mas largo diámetro es tambien paralelo con ellas; estípulas largas, lineares y cerdosas, 22 .

22. Mata anual, alta de $1^{\prime}-2^{\prime \prime}$, fruticulosa y alampiñada, con hojas de 2-3 pares de hojuelas ob-aovadas, mucronadito-obtusas, cuneiformes por la base y largas de $12-6^{\prime \prime \prime}$; raquis con glándulas cilíndricas entre los 2 pares inferiores ó el mas inferior solamente; pedúnculos con pocas flores, cuyos sépalos son largos de $2-3^{\prime \prime \prime}$ y los pétalos de $6^{\prime \prime \prime}$; legumbre papirácea, lampiña, lisa, aguzada, con las márjenes crecidas, larga de 5-3" y cuya última es arqueada ó rectita. C. obtusifolia, L. C. tora, L. - Planta anual fruticulosa que se eleva de $6^{\prime \prime}$ á $3^{\prime}$ de altura, pelierizada y color de orin, cuyas cerdas son acostadas á lo largo de sus ramitas, peciolos y las márjenes; hojuelas 4-2 yugadas, ob-aovadas, mucronadito-obtusas, redondeadas por la base y sub-pelierizadas inferiormente, largas de 18-8"'; raquis con glándulas subuladas y estipitadas entre la mayor parte de los pares; pedúnculos cortos, axilares y paucífloros; legumbre papirácea, pelierizada y color de orin ó alampiñada, biconvexa, sub-tetrágona, profundamente estirada, transversalmente y segun los tabiques, con las márjenes filiformes enteras, lijeramente ar- 
queada y larga de 2-1", con semillas oblongas $y$ troncas. C. pericea, Sw. C. T. V., 519.

23. Bivalvar, con semillas comprimidas paralelas á las valvas, y cuyo mas largo diámetro es transverso á ellas, 24. - Indehiscente y con proeminencias correspondiendo á las semillas ob-acorazonadas, mas cortas que su podospermo, comprimidas, paralelas á las valvas y con su mas largo diámetro transverso á ellas ; mata fruticulosa, difusa, lampiña, de hojas con 4-7 pares de hojuelas ob-aovadas y largas de 8-12"' ; raquis sin glándulas; estípulas lanceoladas, aguzadas y persistentes; racimos axilares, paucífloros, con pedícelos sin brácteas; legumbre arqueada, anchamente oblonga, con una cresta correspondiente á las semillas, lampiña, larga de $1^{\prime \prime}$ 1,2 y ancha de $8 " \prime$. C. obovata, Coll. C. senna, Sw.: C. T. V., 518.

24. Raquis sin glándulas, árboles ó arbustos, 28. - Raquis con glándulas, 25 .

25. Situadas entre las hojuelas, 26. - Situada por encima de la base del raquis y oblonga; arbustillo alampiñado, de hojas con 5-8 pares de hojuelas lanceoladas ú oblongo-lanceoladas, aguzadas, inequilaterales, de ordinario pestañosas y largas de $21_{[} 2-1^{\prime \prime}$; racimos dispuestos en corimbos terminales, con flores cuyos sépalos son largos de $3 \cdot 4^{\prime \prime \prime}$, y los pétalos de 6-8"' ; legumbre membranosa, linear, lijeramente arqueada, lampiña subsesil y larga de 6-4". C. ligustrina, L. C. bahamensis, Mill.: C. T. V., 518.

26. Hojas con 4 hasta 10 pares de hojuelas, 27. - Hojas con 1024-30 pares de hojuelas oblongas, mucronadito-obtusas, alampiñadas inferiormente $y$ largas de 12-6"' ; raquis con una glándula cilíndrica entre el par mas inferior ; racimos terminales dispuestos en panojas corimbiformes, cuyas hermosas flores amarillas tienen sépalos largos de 3-4"' y pétalos de 4-8"' ; legumbre membranosa, anchamente oblongo-linear, rectita, lampiña, con líneas transversas, redondeada por la base, estipitada, larga de $4^{\prime \prime}$, con la última ancha de 10"'"; semillas oblongas. C. multijuga, Rich. C. calliantha, Mey. C. selloi, Don. C. magnifica, Mart. C. ampliflora, Steud. C. fulgens, Wall.

27. Arbusto ó árbol bajito, de hojas con 4-6 pares de hojuelas oval-oblongas ú ovales, con una punta obtusa, de cara inferior glauca y pubescentita ó alampiñada, largas de $3-1^{\prime \prime}$; raquis con una glándula ovoídea entre cada par de los mas inferiores; estípulas falciformes y lineares; racimos axilares corimbiformes pedunculados, cuyos pedícelos bracteolados llevan flores grandes, cuyos sépalos son largos de 3-4"' y los pétalos de 12-15"'; legumbre membranosa, oblongo-linear, recta, lampiña, transversalmente estriada segun los tabiques, de repente estipitada, larga de 5", con su ginóforo de $1^{\prime \prime}-1$ " 1r2, semillas oblongas. C. glauca, Lam. C. plumieri, Dc. C. planisiliqua, Lam. C. arborescens, V. C. sulfurea, Dc. C. discolor, Desv. - Frutice pubescentito ó alampiñado, de hojas con 4-8-10 pares de hojuelas ob-aovado-oblongas, mucronadito-obtusas, largas de 8-4"' ; raquis con una glándula cilíndrica entre el par mas inferior; pedúnculos con 2-4-6 flores cuyos sépalos son largos de $3-4^{\prime \prime \prime}$ y los pétalos de 6-8'" , legumbre membranosa, oblongo-linear 
ó linear, lijeramente arqueada, algo peluda, obtusa, redondeada por la base, estipitada y larga de 3-1" 1 [2. C. biflora, L. C. longissiliqua, L. hijo: C. T. V., 5l8. - Variedades : con las hojuelas escotadas. C. obcordata, Sw. La legumbre linear ancha de $2^{\prime \prime \prime}, C$. angustisiliqua, Lam.

28. Hojas con mas de 5 pares de hojuelas, 29. - Hojas con 5-32 pares de hojuelas oval-oblongas ó escotadas por el ápice y largas de 2-1" estípulas cerdosas, corimbos axilares pedunculados, mas cortos que las hojas, de flores con sépalos largos de 2-3"' y pétalos de 5-6"' ; legumbre coriácea, linear, recta, lampiña, hinchada por lás márjenes, mucronada, sub-sentada y larga de 3-5". C. emarginata, L.

29. Arbol de 30-50' de alto, de hojas con 6.5-4 pares de hojuelas oval-oblongas; redondeadas ó escotadas por el ápice, lampiñas, largas de 2-1" ; corimbos pubescentitos dispuestos en panojas grandes, con brácteas persistentes y de flores con sépalos largos de $4-3^{\prime \prime \prime}$ y de pétalos de 8-6"'; legumbre coriácea, pubescentita, linear, lijeramente arqueada, por fin recta y pendiente, hinchada por las márjenes, aguzada, cortamente estipitada y larga de 8-4". C. florida, V. C. gigantea, Bert. C. arborea, Macf. - Arbol de 25 á 30' de altura, de hojas con 10-12 pares de hojuelas oblongo-lanceoladas, cortamente aguzadas, de cara inferior algo pelierizada, largas de $1^{\prime \prime}$ $1\left[2\right.$ á $2^{\prime \prime} 1_{[} 2$; corimbos pubescentitos dispuestos en panojas grandes, oblongas y abiertas, con brácteas diminutas y decíduas; ovario lampiño. C. spectabilis, Dc. C. trinitatis, Rchb.

G. II. Cathartocapus. 1. Hojas con 10-20 pares de hojuelas, 2.Hojas con 4-8 pares de hojuelas aovado-oblongas, obtusitas, raramente aguzadas, alampiñadas, largas de 4-5" y anchas de 2-2" $I_{[} 2$; flores amarillas grandes, en racimos flojos, colgantes, con pedícelos largos sin bracteitas, cuyos sépalos son largos de $2-4^{\prime \prime \prime}$ y los pétalos de 8-12"' ; legumbre cilíndrica, lisa, lampiña y larga de 1-2'. Arbol de 15 á $25^{\prime}$ de altura, con las ramas estendidas y poco furnidas. $C$. fistula; casia fistula, L.: C. T. V., כ̌l5.

2. Legumbre cilíndrica, torulosa, lampiña, colgante; hojuelas inequilaterales, oval-oblongas, obtusas, pubescentitas, marjinadas y largas de $2^{\prime \prime}$; estípulas semi-asaetadas; racimos axilares mas cortos que las hojas, con pedícelos largos sostenidos por brácteas subuladas, flores con los sépalos largos de $3^{\prime \prime \prime}$ y los pétalos de $10^{\prime \prime \prime}$ y rojizos. C. marginata, Roxb. C. roxhurgii, Dc. C. javanica, Lin.Legumbre comprimido-cilíndrica, lampiña, transversalmente rugosa y larga de 3-1 1 2 y 4" rara vez; hojuelas oblongas, redondeadas por ambos estremos, de cara superior pubescentita, mientras la inferior pubescente es color de orin; racimos axilares, colgantes, pubescentes y color de orin, cuyos pedicelos, sin brácteas, llevan flores de sépalos largos de $3^{\prime \prime \prime}$, pétalos de $4-6^{\prime \prime \prime}$ y anteras peludas. $C$. grandis, L. C. brasiliana, Lam.

G. III. Moringa pterigorperma, Gœrtn : C. T. V., ว̆l.

G. IV. Mora excelsa, Benth.

Sub-familia 3. - MIMOSEAS. - Flores casi regulares, dispuestas en espigas con frecuencia amentiformes ó en capitulos ó ca 
bezuelas orbiculares, mas rara vez en panojas ó en corimbos, de cáliz con 4-5 divisiones mas $\dot{0}$ menos profundas, cuya prefloracion es con mayor frecuencia valvar, corola con otros tantos pétalos alternos con los segmentos del cáliz en cuya base se insertan ó en el receptáculo, libres y de prefloracion valvar, otras veces están soldados entre sí inferiormente y forman así un tubo mas ó menos largo, y en este caso, no muy comun, su vértice está imbricado en el capullo; estambres insertos junto con los pétalos, raras veces en igual número que ellos ó duplo. pero mas frecuentemente múltiple de él y hasta indefinidos, cuyos filamentos son libres ó reunidos entre sí en tubo; ovario único sentado ó estipitado, que se vuelve legumbre con dos ventallas ó lomentácea; semillas con el embrion recto, decotiledones grandes y carnudos por lo regular epígeos durante la germinacion; matas, frutices, arbustos y árboles inermes ó aguijonosos y espinosos, con hojas mas ó menos descompuestas y hasta sub-descompuestas y pinadas. Tribu 1. Prefloracion del cáliz y de la corola siempre empizarrada. PARQuieas. Pentachletra filamentosa, Benth.

Tribu 2. Acacieas. Prefloracion del cáliz y de la corola siempre valvar.

G. I. ExTADA, Ad. Hojas con 1-2 pares de pinulas, formadas de 2-5 pares de hojuelas oblongas ó eliptical-oblongas, de ordinario inequilaterales, lampiñas ó alampiñadas inferiormente, largas de 1-3"; racimos solitarios ó mellizos, largos de como $8^{\prime \prime}$, con muchas flores; legumbre sinuosa, larga de $2-8^{\prime}$ y ancha de como 2 á $3^{\prime \prime}$. E. scaniens, Benth.: C. T. V., 815. - Hojas con 4-6-2 pinulas formadas de 6-8 pares de hojuelas cada una, oblongas, redondeadas por el ápice, lampiñas ó pubescentitas inferiormente, largas como de 12 , $14,16^{\prime \prime \prime}$ y anchas de 6 á 8 "'; racimos en panojas terminales, largos de 9 á li", abiertos y bien furnidos. cuyo eje grueso llera muchos ejes secundarios saliendo mellizos, largos como de 4" y subulados, con muchas flores formando espiguitas amentiformes; legumbre oblonga, entera, casi recta, larga de 6-12" y ancha de 3" y hasta mas. E. polystachia, Dc.: C. T. V., 798.

G. II. Mrmosa. L. 1. Estambres en número doble del de los pétalos, 5. - Estambres de ordinario cuatro, 2.

2. Plantas inermes enteramente, 3.-- Plantas siempre mas ỏ menos aguijonosas, 4 .

3. Planta herbácea, de 6 á 12", tendida en el suelo, cuyo tallo filiforme y difuso echa raices por los nudos, inerme y alampinado; un solo par de pinulas, con 4 á 5 pares de hojuelas oblongas, ob-aovado-oblongas y largas de 2" ; pedúnculos largos de 1-2" y tanto como las hojas; flores en cabezuela; legumbre sub-cuadrada, peluda y con una semilla. 11. vira. L.

4. Nata fruticulosa, lampiña, cuyo tallo, alto de 1-2', tiene aguijones corvos así como los raquises, largos de 2-3"; un solo par de pinulas algo mas cortas que el raquis y con $3-4$ pares de hojuelas inequilaterales, oblongas ó semi-elípticas, con una punta, marjinadas y ordinariamente de cara inferior con cerdas que se liallan tambien esparcidas por la márjen, largáas de 8-12" ; pedúnculos casi 
tan largos como los capitulos florales y mucho mas cortos que los raquises; valvas de la legumbre articuladas, lampiñas y con aguijones en los bordes. M. casta, D. - Planta herbácea ó fruticulosa, peluda ó alampiñada, con aguijones infra-estipulares y esparcidos; 1-2 pares de pinulas casi tan largas como el raquis, con $15-25$ pares de hojuelas oblongo-lineares, con una punta, pestañosas, con cerdas aproximadas, alampiñadas y largas de 3-6"' ; capitulos florales ovoídeos; legumbre oblongo-sinuosa, con 2-5 semillas, cuyas valvas articuladas son lampiñas y aguijonosas por los bordes, con aguijones tendidos. M. pudica, L. Variedad: 1 solo par de pinulas. $M$. unijuga, Walp. M. irritabilis, Prl.

5. Legumbres con valvas articuladas, 6. - Legumbre con valvas continuas; frutice sarmentoso, cuyas ramas y peciolos están armados de aguijones pequeños y corvos; hojas con 3-5 pares de pínulas, con 3 pares de hojuelas muy inequilaterales, ob-anvadas y redonditas, anchas de 8-3"'; capitulos globosos, cuyos superiores están dispuestos á manera de racimo; corola 3 -fida; legumbre anchamente oblonga, entera, con 5-8 semillas, larga de 2-1" sobre 8"' de ancho, lampiña, inerme, pero cuyos bordes tienen aguijones corvos. $M$. ceratonia, Benth.

6. Arbustillo cuyo tallo y peciolos, pelierizados y color de orin, están armados de aguijones subulados y fuertes; hojas con 8-15 pares de pínulas, con 20-60 pares de hojuelas lineares oblícuamente puntiagudas, dø, cara superior lampiña, mientras la inferior es pubescentita y pestañosa, largas de $3-6^{\prime \prime \prime}$; raquis pelierizado; estípulas subuladas; capitulos florales globosos mas cortos que las hojas y cuyos superiores son racimosos; cáliz con cerdas terminales; legumbre oblonga, con 8-10 semillas, larga de 3-2" sobre 5 de ancho, cuyos artejos, transversalmente oblongos, están cubiertos por su superficie y bordes con cerdas largas, $\mathrm{y}$ amarillo teñido de color de orin. M. asperata, L.

G. II. LeuCera alauca, Benth., L. : C. T. V., 338.

G. III. ACACIA, W. - 1. Legumbre seca bivalvar y por consiguiente dehiscente y comprimida, 2. - Legumbre siempre indehiscente, 6 .

2. Raquises provistos de glándulas, 3. - Peciolos sin glándulas; arbusto inerme, cuyas ramitas y peciolos son velludo-pubescentes ó alampiñados; hojas de 5-8 pares de pínulas, con 10-20-25 pares de hojuelas oblongas, obtusitas, pubescentitas ó alampiñadas inferiormente, largas de $4 "$ "' flores blancas con las anteras amarillas, en racimos ovoídeo-oblongos ó sub-globosos, cuyos pedícelos son mas largos que el cáliz; estambres indefinidos y muchísimos; legumbre cortamente estipitada, oblonga, plano-comprimida, peluda, larga de $2^{\prime \prime}$ sobre $6^{\prime \prime \prime}$ de ancho, de valvas membranosas. A. villosa, W. A. lophantoides, Dc. A. valenzuela, Rich. Mimosa villosa, Sw.

3. Estambres indefinidos y muchísimos sub-distintos, 4. - Estambres definidos 10-20; flores en capitulos; estípulas grandes y foliáceas; frutice abejucadito, sarmentoso, lampiño, armado de aguijones corvos; ramitas tetrágonas que llevan hojas con 4-8 pares de pínulas distantes, formadas de 6-20 pares de hojuelas oblícuamente oblongas, mueronadas ú obtusas, largas de $3-4^{\prime \prime \prime}$; estípulas renifor- 
mes, decíduas $\mathrm{y}$ frecuentemente de $1^{\prime \prime \prime}$ de diámetro; raquis de ordinario con una glándula situada en la parte mediana del espacio que separa su base del par de pínulas mas inferior; capitulos florales blancos, arracimados y globosos; estambres 10 sub-distintos; legumbre llana, comprimida y lampiña. A. tamarindifolia, W. Mimosa tamarindifotia, L.

4. Flores en espig̣as, 5. - Flores en cabezuelas; bejuco leñoso muy alto, armado de pequeños aguijones ó á reces inerme, con las ramitas y peciolos pubescentitos ó alampiñados, cuyas hojas tienen de 6-12 pares de pínulas, con $15-20$ pares de hojuelas oblongolineares, muy inequilaterales, semi-acorazonadas por la base, obtusitas, alampiñadas y largas de 4-3"' ; glándula del raquis de ordinario diminuta; cabezuelas florales blancas, apanojadas ó en racimos axilares; legumbre estipitada, oblongo-linear, llano-comprimida, lampina, larga de 4 " y ancha de 10"', con el ginóforo largo de $4^{\prime \prime \prime}$, valvas membranosas. A. sarmentosa, Des. A. vestiana. A. guadalupensis. A. itsioides, Dc.

5. Árbol inerme ó con aguijones infra-estipulares, cuyas ramitas y los raquises son blanquecino-pubescentes: hojas de $10-30$ pares de pínulas, con 30-50 pares de hojuelas lineares, obtusitas, pestañosas, alampiñadas y largas de $2^{\prime \prime \prime}$; glándula peciolar escutiforme y situada en la parte media del espacio que separa la base del raquis del par de pínulas mas inferior; espigas amentiformes, elongadas, axilares y mas cortas que las hojas, con flores blancas; legumbre estipitada, anchamente linear, llano-comprimida, larga de 5-6" y ancha de $6-8^{\prime \prime \prime}$, con el ginóforo largo de 4-6"' ; valvas lijeramente reticuladas y venosas. A. catechu, W. : C. T. V., 113. - La acacia scleroxipla quizás no es sino una variedad de la catechu, de que difiere solamente por su legumbre sentada y la glándula peciolar situada inmediatamente por debajo del par de pínulas mas inferior. A. scleroxyla, Tus.: C. T. V. 113.

6. O abriéndose muy tarde, llano-comprimida; estambres de ordinario monadelfos; árboles inermes, 7. - Nunca dehiscente, hinchada, sub-cilíndrica ó algo espesa y comprimida á la rez, llena de pulpa; estípulas de ordinario espinosas y axilares; vejetales no aguijonosos; flores en cabezuelas, 8.

7. Ramitas pubescentes ó á reces alampiñadas, cuyas hojas están formadas de 7-12 pares de pínulas, con 20-40 pares de hojuelas oblícuamente oblongas, con una nervadura juxta-marjinal, puntiagudas, pestañosas y largas de $3-4^{\prime \prime \prime}$; raquis con una glándlula orbicular por encima de la base; cabezuelas florales globosas, arracimadas, blanquecinas: $10-15$ estambres reunidos por la base y 4 veces mas largos que la corola pubescentita; legumbre recta, moniliforme $\mathrm{J}$ sinuosa, aguzada por ambos estremos, lampina indehiscente, laręa de $4^{\prime \prime} \mathrm{y}$ ancha de $18^{\prime \prime \prime}$ en los trechos correspondiendo con las semillas; ralvas membranosas y coherentes. A. julibrissin, W. A. trichophylloides, Macf. A. augustiloba, De. Albizzia julibrissin, Boiv. - Ramitas alampiñadas, cuyas hojas se componen de 2-4 pares de pínulas, con 5-9 pares de hojuelas ob-aovado-oblongas, inequilaterales, redondeadas por el ápice, largas de $1-2^{\prime \prime}$; raquis con una glándula oval 
situada por encima de su base: flores pediceladas blancas, dispuestas en espiguitas largas y de corola dos veces mas larga que el cáliz; estambres muchos reunidos por la base, largos, amarillos y verduscos por el ápice; legumbre recta, oblongo-linear, puntiaguda por ambos estremos, sentada, llana é hinchada en las partes correspondientes con las semillas, lampiña, tarde dehiscente y larga de 6"12" sobre 1-2" de ancho. A. Lebbek. A. speciosa, W. A. propinqua, Rich. Allizzia Leblek, Benth.

8. Muchos estambres sub-distintos; estípulas espiniformes, 9.Estambres monadelfos definidos; 1-2 espinas situadas por encima de las estípulas membranosas ú obsoletas, 11 .

9. Pedúnculos sin bracteitas en su parte media; legumbre no moniliforme, 10. - Pedúnculos con brácteas en su parte media; legumbre moniliforme, sinuosa, estipitada, comprimida, lijeramente corva, tomentosa ó. alampiñada, larga de $4-6^{\prime \prime}$ y ancha de $8^{\prime \prime \prime}$, con el ginófloro de 6-8"'. Árbol de ramitas y raquises tomentoso-pubescentes ó alampiñados, cuyas hojas tienen de $4-1$ y á veces 9 pares de pínulas, con 10-20 pares de hojuelas oblongo-lineares, obtusas, $11_{[} 2-2$ " largas ; raquis ordinariamente glandulífero; flores en cabezuelas globosas. A. arabica, W.: C. T. V., 673.

10. Estipitada arqueada, tomentosa, con las valvas convexas y larga de 2 1 $2-2$ " sobre, 6-8"' de ancho; arbustoó árbol bajito, cuyas ramitas y raquises son tomentoso-pubescentes; hojas compuestas de 2- 6 y á veces 8 pares de pínulas, con 10-20 pares de hojuelas diminutas, oblongo-lineares, obtusas, alampiñadas, largas de $2^{\prime \prime}$; raquis con una glándula oblonga, deprimida, situada por encima de la base, y de ordinario otra entre el último par de pínulas; espinas estipulares fuertes, blanquecinas y largas de $6 "$ "' cabezuelas florales amarillas, solitarias y globosas. A. tortuosa, WV. Mimosa tortuosa, L. M. salinarum, V.: C. T. V., 114-671. Legumbre cortamente estipitada, corva ó rectita, lampiña, estriada, oblongo-linear y por fin cilíndrica, larga de 2-1" $1_{[2}$, ancha de 4-6"', con el ginóforo de 1-2"'; arbusto ó árbol bajito bastante frondoso, con las ramitas y los raquises alampiñados; hojas formadas de $4-8$ y á veces 2 pares de pínulas, con 10-20 pares de hojuelas diminutas, oblongo-lineares, obtusas, largas de 6 á $8^{\prime \prime \prime}$; raquis con una glándula escutiforme situada por encima de la base, $\mathrm{y}$ de ordinario con otra entre el último par de pínulas; espinas estipulares cerdosas; cabezuelas florales amarillentas, muy fragantes, globosas y fasciculadas. A. farnesiana, W., etc. : C. T.V., 116-672.

G. IV. Calliandra, Benth. - 1. Flores siempre en numero determinado ; 2. - Estambres 20 ó muchos mas; flores sesiles, de eáliz membranoso no estriado, y de corola 5-fida, cortamente reunida por la base; arbusto de unos $10^{\prime}$ de altura, inerme, cuyas ramitas y raquises son pubescentes ó alampiñados; hojas con 4-6 y á veces $2-8$ pares de pínulas de $12-25$ y hasta 40 pares de hojuelas oblongo-lineares, obtusitas, alampiñadas y largas de 4-5"'; flores blancas en cabezuelas fasciculadas, con 20-25 estambres tambien blancos; legumbre rectita, linear, aguzada por la base, larga de $3^{\prime \prime}$ 
y ancha de $3^{\prime \prime \prime}$, con las valvas papiráceas. C. portoricensis, Bepth. Mimosa portoricensis, M. caracasana, Jacq. Acacia portoricensis, W. A. ungulata, Desv. A. vespertina, Macf. A. littoralis, Rich.

2. Flores mas ó menos sentadas; legumbre sin pulpa, 3. - Flores pediceladas; legumbre llena de pulpa; cáliz tomentoso no estriado: corola 5-dentada; estambres reunidos en tubo incluso; árbol muy alto, muy corpulento y muy frondoso, inerme, con ramitas aterciopelado-pubescentes que llevan hojas con 4 ó á veces 6 pares de pínulas de 7, 2, 1 parés de hojuelas oblícuamente ob-aovadas ú obaovado-oblongas, obtusas, lampiñas y lustrosas por la cara superior. mientras la inferior es pubescente, largas de $3-8^{\prime \prime \prime}$; raquis con glándulas por la base y entre las pínulas; grupos florales con los pedúnculos largos de 5-2" y los pedícelos de 2-1"'; cáliz tomentoso subventrudo, escediendo un poco la parte media de la corola tomentosa amarillenta, y larga de $6^{\prime \prime \prime}$; estambres 20 de color carmesí; cortamente reunidos, y largos como de $2^{\prime \prime}$; legumbre rectita ó á veces corva, linear, subsesil, larga de 8-4" y ancha de 8-5"', con las valvas coriáceas y lampiñas, $\mathrm{y}$ las márjenes un poco espesas y pubescentes, sinuosas. C. saman, Gr. C. tubulosa, Benth. Mimosi suman, Jacq. Ingu saman, W. Pithecolobium saman, Benth.

3. Flores de ordinario sentadas; cáliz estriado; corola 5 dentada: estambres reunidos en tubo delgado, 4. - Flores siempre sesiles en cabezuelas florales, fasciculadas y laterales; corola estriada 5-dentada; estambres reunidos en tubo delgado eserto; legumbre llanocomprimida, abriéndose tarde y no con elasticidad; árbol de unos $25^{\prime}$ de altura, inerme y lampiño, de hojas con 1 par de pínulas formadas de $21_{[} 2-11_{\lceil} 2$ pares de hojuelas distantes, elípticas, con una punta, oblícuas por la base aguda, largas de 5-2", y cuyas inferiores son alternas ó solitarias; una glándula orbicular, á veces apenas notable, está situada entre el último par; cabezuelas florales color carmesí ó de rosa, sentadas ó cortamente pediceladas saliendo de las ramitas del año anterior, con corola tubulosa, larga de $4^{\prime \prime \prime}, \mathrm{y}$ mucho mas larga que el cáliz diminuto; estambres largos de como $l^{\prime \prime}$ y reunidos por su parte media; legumbre lijeramente corva, linear-oblonga, redondeada por la base, ondeada por la márjen, algo espesita, larga de 5-4" y ancha de $10-8^{\prime \prime \prime}$, con valvas coriáceas y lampiñas. C. Tatifolia, Gr. Mimosa latifotia, L. Jnga latifotia. W'. Pithecolobium latifolium, Benth.

4. Estambres de 20 á 40, 5. - Estambres de 10 á $20,7$.

5. De 20 á 40,6. - Siempre 20, de tubo delgado encerrado en la corola; arbusto inerme, con las ramitas y raquises lanudos, hojas formadas de 4-3 pares de pínulas, con 20 á 40 pares de hojuelas pequeñas, falciforme-lineares, aguzadas con una punta obtusa, largas de $2-1$ "' $1[2$, tiesas, pestañosas y alampiñadas; estípulas persisten tes, oblongo-lanceoladas, estriadas; cabezuelas florales globosas, sub-sentadas, axilares ó en espigas interrumpidas, de corola pelierizada, larga de $3^{\prime \prime \prime}$ y dos veces mas que el cáliz alampiñado y 2-3 veces mas corta que los estambres purpurinos y reunidos por el $l_{[} 3$. C. crucgerii, $\mathrm{Gr}$.

6. Arbusto inerme, lampiño y alto de $15-20^{\prime}$; hojas con 3-2 pares 
de pínulas de 18-8 pares de hojuelas oblongo-trapeziformes, anchamente truncas por la base, y oblícuas por el vértice, largas de 5- $6^{\prime \prime \prime}$ y anchas de 2-3"'; cabezuelas corimbosas, con flores sentadas, de corola 3-5-fida y larga de $3^{\prime \prime \prime}$; legumbre corva, lanceolado-linear, comprimida, lampiña, larga de $2-2$ " 1 [2 y ancha por el vértice de $3^{\prime \prime}$, mientras la base va aguzándose en ginóforo largo de $6^{\prime \prime \prime}$. C. comosa, Benth. Mimosa comosa, Sw. Jnga comosa, W. Pithecolobium comosum, Benth.

7. Estambres 10-15, cuyo tubo está encerrado en la corola; hojuelas pequeñas, con estípulas espinosas ó con una espina por su base, 8. - Estambres 10-20, cuyo tubo delgado está eserto; hojuelas anchas; arbusto inerme, alampinado, con hojas de 1 par de pínulas, con 3-7 pares de hojuelas eliptical-oblongas ú ob-aovadas, obtusitas, largas de 4-8"' y hasta $12^{\prime \prime}$; flores sesiles en las cabezuelas pedunculadas, de corola larga de 3 "' y á reces mas que el cáliz; estambres 10, largos de 12"', purpurinos y de tubo cortamente eserto; legumbre lijeramente corva, anchamente linear, largamente aguzada por la base, lampiña y larga de $3^{\prime \prime}$ sobre $4-5^{\prime \prime \prime}$ de ancho. $C$. purpureu, Benth. Mimosa purpurea, L. Jnga purpurea, IV.

8. Arbusto tortuoso, cuyas ramitas pubescentes ó alampiñadas están armadas de espinas infra-estipulares y llevan hojas de I solo par de pínulas, con 7-4 pares de hojuelas oblongas, obtusas, lampiñas, sub-pestañosas, y largas de 3-2"'; estípulas lanceoladas, estriadas y largas de $2^{\prime \prime}$; flores sentadas en cabezuelas pedunculadas, de corola larga de 2 "' y tres veces mas que el cáliz; estambres purpurinos, largos de 8-12"'; legumbre rectita, linear, aguzada por la base, velludo-pubescente, larga de $2^{\prime \prime} 1{ }^{2}$ sobre $3^{\prime \prime \prime}$ de ancho, con ventallas coriáceas. C. hamatomma, Benth.

G. V.Pithecolobiun, Mart.- - 1. Legumbre en figura de caracol, con las ventallas frecuentemente al fin torcidas, de semillas semicubiertas por un arilo carnoso; raquis con glándulas entre las pínulas, 2. - Legumbre torcida en espiral, con semillas sin arilo; raquises con glándulas entre las pínulas; árbol grande con ramitas y raquises pubescentes y color de orin; hojas con 4-8 pares de pínulas de 3-12 pares de hojuelas romboídeas, lampiñas ó alampiñadas inferiormente, largas de $6-10^{\prime \prime \prime}$ y anchas de $3-5^{\prime \prime \prime} ;$ flores subsesiles en cabezuelas largamente pedunculadas ó en espigas cortas; legumbre llano-comprimida, oblongo-linear, alampiñada, roja y ancha de $3^{\prime \prime \prime}$, y dando 3-5 vueltas contiguas. P. micradenium, Benth.

2. Arbusto de 10 á 15' de altura, armado de estípulas espinosas diminutas ó á reces inerme y lampiño; hojas uni-yugas, con un par de hojuelas oblícuamente ob-aovadas ú oblongas, obtusas y largas de $2-i^{\prime \prime}$; flores verdoso-amarillentas, sentadas en cabezuelas pedunculadas y arracimadas, de ordinario pubescentes; legumbre planocomprimida, anchamente linear, lampiña y dando poco mas de una vuelta, roja y ancha de 4-5"'. P. unguis cati, Benth. Mimosa unguis cati, etc.: C. T. V., 118 .

G. VI. JNGA, W. Mart.-1. Legumbre comprimida, 2.-Legumbre cuadrangular y con 4-costillas ó 4-angulosa, á veces sub-cilíndrica, 5. 
2. Flores en espigas, 3. - Flores en umbelas; arbusto lampiño de hojas con 1-4 pares de hojuelas elípticas o aovado-lanceoladas, de repente aguzadas, lustrosas, largas de $3-I^{\prime \prime}$; raquis desnudo, con una glándula pequeña y cilíndrica; nmbelas cortamente pedunculadas, con pedícelos tan largos como las flores, lampiñas, de cáliz diminuto y con el tubo estaminal largamente eserto; legumbre lampiña, oblonga, llano-comprimida, larga de $4^{\prime \prime}$, ancha de $I^{\prime \prime}$ y con las márjenes lijeramente espesas. J. heterophylla, IV. J. prostrata, Steud.

3. Flores en espigas alargadas ó en racimos espiciformes, 4. Flores siempre en espigas compactas y aovadas; árbol de ramitas espesas y pubescentitas, de color de orin; hojas con 2 pares de hojuelas elípticas, puntiagudas, frecuentemente lustrosas y por fin alampiñadas, con pelo esparcido, largas de $6-3^{\prime \prime}$, cuyas inferiores son mas pequeñas, todas con las venas primarias como 12-yugadas, y proeminentitas inferiormente; raquis: alado, con glándulas grandes y escudadas; flores sentadas en espigas cortas; aovado-oblongas, largas de 5-6"' con brácteas lineares y decíduas, de corola pinchuda, amarilla, larga de $6^{\prime \prime \prime}$ y dos veces mas que el cáliz estriado y encerrando el tubo estaminal; legumbre llano-comprimida, alampiñada y con las márjenes proeminentes. J. setifera, Dc. J. versicolor, Spruce. J. nitida, W.

4. Arbol grande, lampiño, de hojas con 2-1 pares de hojuelas elípticas o eliptical-oblongas, con una punta obtusita, lustrosas, largas de $4-3^{\prime \prime}$ y anchas de 11 [2á $2^{\prime \prime}$, cuyas inferiores sor menores; raquis desnudo, con glándulas diminutas escudadas; flores estendidas en racimos especiformes largos de 2-3", de pedícelos muy cortos y mas que el cáliz, de corola blanca lampiña, infundibuliforme, larga de $3^{\prime \prime \prime}$ y 4 veces mas que el cáliz, iguales al tubo estaminal; legumbre lampiña, oblonga, llano-comprimida, un poco hinchada en la parte correspondiente con las semillas, larga de 3-2" y hasta $5 "$ sobre 10-12"' de ancho. J. laurinea, W., etc. : C. T. V., 119.

5. Arbol grande cuyas ramitas ásperas, pubescentes ó alampiñadas llevan hojas de 4-5 pares de hojuelas elíptico-lanceoladas, cortamente aguzadas, largas de $4-2{ }^{\prime \prime}$, con los peciolos pubescentes y color de orin; raquis alado y con glándulas escudadas; flores en espigas cortas, paucifloras, sesiles o las inferiores cortamente pediceladas, cuyos pedícelos son mucho mas cortos que el cáliz tomentoso y no estriado, largo de 4-6"', de corola blanca, larga de 6-8 ${ }^{\prime \prime \prime}$, cerdosolanuda y conteniendo el tubo estaminal; legumbre tomentosa, subfalciforme, larga de $6^{\prime \prime}$ y ancha 6-12"'. J. vera, W. : C. T. V., 521. - Arbol grande cuyas ramitas ásperas, pubescentes ó alampiniadas llevan hojas con 4-3 pares de hojuelas elípticas ó elíptico-lanceoladas, puntiagudas y largas de $4-2^{\prime \prime}$ sobre $2-1^{\prime \prime} 1_{[} 2$ de ancho; raquis alado y con glándulas escudadas; flores en racimos cortos y paucífloros, cuyos pedúnculos, tomentosos y color de orin, llevan pedícelos tan largos como el cáliz tomentoso, campanudo y no estriado, que lo es de $2.3^{\prime \prime \prime}$, y sin embargo dos veces mas corto que la corola cerdoso-lanuda, conteniendo el tubo estaminal, y'larga de 5-6"'; legumbre tomentosa falciforme y larga de $4-6^{\prime \prime} . . J$. ingoides, W. 
G. VI. Enterolobium cyclocarpum, Gr. Mimosa cyclocarpa, Jacq. Iuga cyclocarpa, W. Pithecolobium cyclocarpum, Benth.

G. VII. Piptadexia peregrina, Benth. Mimosa piptadenia, L.

G. VIII. Adenanthera pavonina, L.

G. IX. Prosopis juliflora, De. P. dulcis, Var. P. domingensis, Benth. Mimosa juliflora, Sw. Algarobia juliflora, As. Gr.

\section{CLASE LVII. - ROSINEAS.}

Familia 131. - CRISOBALÁNEAS. - Arbustos ó árboles de hojas alternas, simples, enteras, coriáceas, acompañadas de estípulas; flores de cimas y racimos mas o menos apanojados, de cáliz abollado por la base, 5 -fido, raras veces 4 -fido ó dentado, de prefloracion imbricada; corola con 5 pétalos, pero que suelen faltar algunas reces; muchos estambres perijinos, frecuentemente mas desarrollados de un lado que del otro; ovario único, libre, unilocular, con dos huevecillos colaterales, basilares y anátropos, estilo suprabasilar y lateral; fruto drupáceo, cuya semilla única tiene su tegumento membranoso.

Chrysobalanus, L. - Drupa oval de color variado; arbusto muy ramoso, de 6-12' de alto, y que á veces se vuelve arbolito de unos $20^{\prime}$, con hojas ovales ú óvalo-redondeaditas, redondeadas ú obtusitas por el ápice, largas de 3", 2 "”, $1_{[} 621_{[} 2,2$ sobre $3,21_{[} 2$, 2 " de ancho, muy cortamente pecioladas ; cimas axilares, pubescentes, mas cortas que las hojas, con flores blancas, de estambres velludos; drupa carnosita, oval, tan pronto blanca como amarillenta $\mathrm{y}$ morada, del tamaño de una ciruela, con estrias obtusas, costilludas. C. icaco, L.: C. T. V., 108. - Drupa ob-óval, larga de 8"', puntiaguda por la base, mas pequeña que la del icaco, de pericarpio delgado, con las estrias menos obtusas ; arbusto de 6' de alto, ramosísimo, con hojas ob-aovadas ú ob-aovado-redondeaditas, puntiagudas ú obtusitas por la base, largas de $5 l_{[} 2,6$ " $1_{[} 4$ sobre $21_{[} 2,3$, $3 l_{1} 2$ de ancho; cimas axilares pubescentes $y$ mas cortas que las hojas; estambres velludos: C. pellocarpus, Mey. C. icaco, Dc. Variedad B.

Familia 132. - ROSACEAS. - Plantas herbáceas anuales ó vivaces, matas frutices, arbustos, arbolitos y árboles grandes, con hojas sencillas, enteras, festoneadas, dentadas, mas o menos lobadas, algunas veces compuestas, dijitadas ó pinadas, siempre alternas, cuyo peciolo mas ó menos largo está acompañado por dos estípulas de forma y tamaño variados, persistentes, ya sueltas, ya soldadas con su parte inferior; Hores de ordinario hermafroditas $y$ algunas veces polígamas, de inflorescencia tan pronto solitaria $y$ en grupos axilares mas ó menos furnidos, como racimosa, espigada y apanojada terminal; se componen de un cáliz monosépalo con 5 divisiones mas ó menos profundas, iguales ó desiguales, todas conformes ó algunas diferentes de las demás, alguna vez que otra acompañado por la base de un calículo ó invólucro soldado con él ó suelto. con tantos lóbulos como él: de una corola con 4-5 pétalos rosáceos 
insertos ell la garganta del cáliz, con cuyos segmentos alternan: suele faltar algunas veces; estambres muchos insertos, junto con los pétalos, pero un poco mas por abajo, perijínicos; pistilo único y simple ó compuesto y formado por la reunion de muchos carpelos agrupados sobre una especic de receptáculo mas ó menos pronunciado y de varias formas; á veces está formado de muchos carpelos libres esteriormente y distintos, colocados en el cáliz tubuloso; otras veces están soldados por su parte interna, mientras que por la esterna están pegados con el cáliz; algunas veces están reunidos sobre un receptáculo y forman capitulos; en fin, el ovario es único, mas ó menos globoso, libre ó soldado con el cáliz: tales ovarios son siempre uniloculares, con 1-2 ó muchos óvulos, suturales y anátropos, y de su ápice sale un estilo simple mas ó menos largo, algunas veces lateral, con estigma sencillo. El fruto es tambien muy variado, y consiste ya en una drupa mas ó menos gruesa y carnuda, ya en una melonida ó en un nuculanio; otras veces es uno ó algunos aquenios agrupados sobre un receptáculo carnudo ó seco; algunas veces prolongado el ápice; otras veces son cajitas; algunas veces son bayas ó drupas pequeñas soldadas entre sí y formadas por el cáliz que se ha vuelto carnudo; semillas de embrion homótropo y sin endospermo.

Grupo 1^. - Ponáceas. - Cáliz monosépalo tubuloso, de limbo 5 -partido con prefloracion imbricada; corola con 5 pétalos que faltan rarísima vez; estambres libres; ovario adherente ó ínfero, cuyo vértice lleva $2-5$ estilos distintos ó soldados entre sí hácia la base, terminado cada uno por un estigma simple, con 2-5 celdas conteniendo dos óvulos colaterales y ascendentes; fruto carnudo, grueso, coronado por el limbo calizinal persistente, con 2-5 celdas cartilajinosas ó reemplazadas por otros tantos huesecitos; es pues una melonida ó un nuculanio de semillas con tegumento coriáceo ó cartilajinoso. Malus vulgaris, L. Sidonia vulgaris. En Carácas esos árboles frutales se cultivan y dan frutos regulares, pero no tan b'xenos ni tan sabrosos como en Europa.

Grupo 2. Roseas. Cáliz cuyo tubo ventricoso está contraido hácia el vértice y semi-adherente, de limbo partido en 5 lacinias, de las cuales algunas están siempre pinatifidas; corola de 5 pétalos; muchísimos estambres; carpelos huesosos numerosos é insertos hácia el fondo del cáliz; con un estilo lateral muy largo y conteniendo un solo huevecillo colgado ; estilos y estigmas algunas veces soldados entre sí en haces y saliendo mas ó menos por fuera del tubo del cáliz, que se vuelve carnudo y simula así el fruto. Rosa lovigata, Mich., y muchas otras especies ó variedades que se cultivan para el adorno de los patios, y se aclimatan con bastante facilidad.

Grupo 3. Drídeas. Cáliz con 5 divisiones, rarísimas veces con 4 ó menor número, de prefloracion de ordinario valvar, cuya base está frecuentemente acompañada esteriormente de un calículo; corola con igual número de pétalos que suelen faltar alguna que otra vez; estambres indefinidos ó en número fijo y definido; frecuentemente muchos carpelos, algunas veces reducidos á un corto número, llevados por un receptáculo central mas ó menos desarrollado y saliente, libres; estilo terminal ó lateral conteniendo 1-2 óvulos, 
erguidos ó suspendidos; plantas herbáceas, matas, frutices y arbustos.

Tribu 1. Dalibárdeas. Cáliz sin calículo alguno, estambres indefinidos; muchos carpelos cuyo estilo es terminal y que se vuelven otras tantas drupitas; embrion de radícula superior; frutices sarmentosos y de ordinario aguijonosos.

Rubus, 1. Aguijones fuertes y corvos, 2. - Aguijones muy delgados, rectos y subulados, frutice no sarmentoso, alto de 4-5, no muy ramoso; frutos blancos ó rojos bastante desarrollados y muy sabrosos. R. idocus, L.

2. Hojas de 3-5 hojuelas eliptical-oblongas, puntiagudas, pubescentes superiormente y peludo-tomentosas inferiormente, desigualmente aserradas, con las venas primarias aproximadas, peciolo largo, aguijonoso inferiormente así como la costilla; racimos compuestos, velludos, pétalos ob-aovados tan largos como los segmentos del cáliz; fruto ovoídeo-redondeadito, largo de 4"', de color purpurino, dos veces tan largos como el cáliz estrechado, drupitas numerosas, decíduas. $R$. jamaicensis, Sw. R.ferrugineus, Wich.Alampiñado $\mathrm{y}$ de hojas con 3 hojuelas elípticas, puntiaguditas, lampiñas y concoloras, desiguales y profundamente aserradas, con las venas primarias aproximadas, largamente pecioladas, cara inferior de la costilla aguijonosa; pedícelos largos, fasciculados $\mathrm{y}$ formando racimos compuestos, cáliz pubescente apretado, mitad de lo largo del fruto aovado, redondo, largo de 3 " sobre 2 " $1\lceil 2$ de ancho, prieto purpurino. $R$. alpinus, Macf.

Tribu 2. Fragarieas. - Cáliz siempre con un calículo, y de prefloracion valvar; estambres muchos é indefinidos; muchísimos aquenios diminutos de estilo lateral, situados sobre un receptáculo carnudo; embrion de radícula superior. Frafaria resca, L.

Grupo 4. Amignáleas. Cáliz 5-fido, de prefloracion imbricada; corola de 5 pétalos; muchísimos estambres; ovario único libre, con un solo estilo enteramente ó casi terminal, unilocular y conteniendo dos óvulos colaterales y suspendidos; drupa mas ó menos carnuda, con un hueso duro conteniendo la semilla de tegumento membranoso; arbustos ó árboles mas ó menos grandes.

Prunus, L. 1. Dos manchas glandulosas situadas por la base ó un poco apartadas de ella y de la cara inferior de las hojas, 2. Hojas sin ninguna mancha glandulosa por su cara inferior; árbol bajito, con hojas elípticas ó eliptical-oblongas, redondeadas por la base y con una punta obtusa por el vértice, lustrosas superiormente, largas de $31\left[2^{\prime \prime}-21\left[2\right.\right.$ sobre $2^{\prime \prime}-1^{\prime \prime}$ de ancho; flores en racimos axilares; estambres 10-20; drupa globosa de $4^{\prime \prime \prime}$ de diámetro, sub-mucronada y de color purpurino. P. spharocarpa, Sw., etc.: C. T. V., 612 .

2. Situadas por la base; árbol alto de hojas oblongas ó aovadooblongas, redondeadas por la base y obtusitas por el ápice, largas de $6-4^{\prime \prime}$ sobre $21_{1} 2-2^{\prime \prime}$ de ancho; racimos laterales pubescentitos ó alampiñados; estambres muchos ó 20; drupa ovoídea, lijeramente mucronada, purpurina, larga de $10^{\prime \prime \prime}$ y ancha de $6 "$. . P.occidentalis, Sw. - Un poco apartada de la base; árbol de mediana altura, con 
hojas elípticas ó elíptico-oblongas mucronaditas, agudas por la base, lustrosas, largas de $4-3$ " y anchas de $2-1^{\prime \prime} 1_{[} 2$, con Jas glándulas distantes de $1^{\prime \prime \prime} 1_{1} 2$ de la base y cerca de la márjen; racimos axilares; estambres 20 ; drupa globosa, trunca por el ápice, casi negra y ancha de 6"". P. pleuradenia, Gr. C.T. V., 612.

Familia 132. - HOMALIEAS ú HOMALIACEAS. - Arbustos ó árboles con hojas simples, enteras, coriáceas, pecioladas, alternas, con estípulas caducas acompañando á la insercion del peciolo; flores hermafroditas en espigas, racimos ó panojas y compuestas de un cáliz monosépalo, cuyo tubo corto y cónico á la vez se termina en un limbo con 10-30 segmeritos, de los cuales son mayores y valvares los esteriores, mientras que los interiores son petaloídeos y tienen papel de corola que suele faltar, por la cara interior y hácia la base de ellos hay algunos apéndices glandulosos y sentados; estambres en número muy variado, ya igual al de los lóbulos esteriores del cáliz y opuestos á ellos, ya muchísimos y reunidos en hacecillos ó poliadelfos; ovario de ordinario semi-ínfero, unilocular, polispermo, cuyos muchos óvulos están asidos de 3 ó de 5 trofospermos parietales, con igual número de estilos saliendo de su vértice, cada uno con si correspondiente estigma sencillo. Fruto á veces seco y capsular, otras reces carnoso, con semillas cuyo embrion está alojado en un endospermo carnoso. Homalium racemosum, Jacq.: C. T. V. 795.

\section{CLASE LVIII. - MIRTOÍDEAS.}

Familia 133. - MIRTEAS ó MIRTÁCEAS. - Arbustos, arbolitos y árboles grandes y corpulentos, de hojas simples, coriáceas, lustrosas, cortamente pecioladas, persistentes, con muchas glándulas transparentes y aromáticas, opuestas, ordinariamente sin estípulas, enteras, con nervaduras marjinales ó justamarjinales y arqueadas; flores de ordinario blancas siempre hermafroditas, ora en grupos axilares ora en racimos ó en cimas terminales, compuestas de un cáliz monosépalo adherente, de limbo con 4-5-6 segmentos mas ó menos delgados y profundos; de una corola con tantos pétalos cuantas divisiones calizinales hay, con las cuales alternan y pegados en la parte superior ó garganta del cáliz; son muchísimos los estambres, libres ó algunas veces reunidos por medio de los filamentos diversamente soldados entre sí é insertos junto con los pétalos, pero un poco mas abajo de ellos, de anteras terminales y muy pequeñas. Pistilo formado de un ovario único é infero, rarísimas veces semi-ínfero, con 2-6 celdas conteniendo muchos óvulos, y de cuyo vértiee sale un estilo simple terminado por un estigma entero ó lobulado. El fruto ya es seco, ya carnudo y tan pronto una baya como una drupa; semillas sin endospermo, de embrion cuyos cotiledones no están nunca retorcidos mútuamente uno al rededor del otro á manera de corneta, ni enroscados tampoco. 


\section{Análisis dicotómica de las tribus.}

1. Estambres libres, 2. - Estambres soldados entre sí, 3.

2. Flores de cáliz con 4-5 lóbulos, corola con 4-5 pétalos, muchos estambres distintos, ovario con dos a algunas celdillas monospermas por causa de aborto; hojas opuestas, con glándulas transparentes y aromáticas. T. I. Eumirteas. A.- Flores algunas raras veces subdioicas, compuestas de un cáliz 4-5-lobo ó 4-5-dentado, corola con otros tantos pétalos: estambres en número definido, 8-10 distintos, con anteras corvas abriéndose por la base á favor de grietas cortas $o$ de poros; fruto carnudo abayado; embrion de cotiledones torcidos, hojas opuestas bien enteras y sin estípulas. T. II. - Menecileas. Mouriria myrtilloides, Poir. Petaloma myrtilloides, Sw.

3. Cáliz con 4-5 lóbulos, otros tantos pétalos forman la corola; muchísimos estambres dispuestos en algunas séries, cuyos filamentos soldados entre sí forman un tubo corto y recto; ovario con 20 ó algunas celdas, conteniendo 2 ó algunos huevecillos, fruto abayado ó seco sin ventallas, con 2 ó algunas celdas conteniendo pocas semillas, cuyo embrion tiene los cotiledones carnudos. Hojas alternas, raras veces opuestas o verticiladas no aromáticas y sin puntos transparentes. T. II. Barrivgtoniens. - Barringtonia. Gustavia augusta. - Flores cuyo cáliz monosépalo tiene el limbo 6-partido y tantos pétalos en la corola; muchísimos estambres en algunas séries dispuestos y monadelfos, cuyo tubo tiene la forma de cartucho $r$ cuyo andróforo natural está como abovedado ; fruto carnudo interiormente y de casco leñoso y durísimo, abriéndose por un opérculo superior; hojas no aromáticas y por consiguiente desprovistas de puntos transparentes, alternas, enteras y con estípulas caducas cuando tiernas; árboles grandes. T. IV. Lecrtideas. Bertholettia exce7sa. - Couroupita guianensis, Aubl.

Estas tres últimas tribus son tenidas ya por familias distintas de la de las Mirtáceas, pero en la misma clase.

A. G. I. Calyptranthes, $\mathrm{Sw}$. 1. Ramitas cilíndricas, 2.-Ramitas comprimidas y como de 2 filos, con puntitos interpeciolares, 3.

2. Arbusto de ramitas lampiñas, de hojas elípticas, obtusitas, lampiñas, con puntitos transparentes diminutos, y por fin opacas, con venas delgalitas formando arcos, largas de 2 l $2-2$ ". Cimas lampiñas, de pedúnculos 1-3 veces 3 -fidos, de ordinario mas cortos que las hojas, de flores cuyos pedícelos simples son larges de 2-3"', de cáliz ovoídeo-mucronado y lampiño, corola ninguna, haya sub-globosa. C. syzygium, Sw. C.rigida, Macf. Mirtus syzygium, L. - Arbol bastante grande cuyas ramitas pubescentes llevan hojas oblongo-lanceoladas, aguzadas y terminadas por una punta estrecha y obtusita, de cara superior lustrosa y lampiña, mientras la inferior es sedosa, con puntitos transparentes muy poco visibles, y por fin opacas, venas aproximadas, delicadas y reuniéndose hácia la márjen, largas de 6-3" sobre 1 [2-1" de ancho; cimas sedosas color de orin, fasciculadas, subsesiles ó cortamente pedunculadas, simples, reducidas ó grupos bracteolados igualando los pic- 
ciolos largos de $3^{\prime \prime \prime}$, algo mas largos que ellas; cáliz ovoídeo-subgloboso, apenas mucronadito, pubescente, color de orin; corola nula, baya globosa, cuyo diámetro es de $3^{\prime \prime \prime}$, con 1 sola semilla. $C$. sericea, Gr. C. T. V., 281.

3. Arbusto de ramitas lampiñas con hojas elípticas o elíptico-lanceoladas, puntiagudas y obtusitas por el ápice, de cara inferior sedosa ó por fin alampiñada, largas de $2^{\prime \prime} 1_{1} 2-11_{\lceil} 4$, casi sin puntitos transparentes, cuyas venas delgaditas se juntan hácia la márjen; cimas cerdosas color de orin, compuestas, abiertas, tricótomas, casi tan largas como anchas, pedunculadas, de flores sesiles ternadas, con cáliz ob-ovoídeo-globoso, redondeado por el vértice obtuso, sedoso y largo de $1^{\prime \prime \prime}$; corola nula, baya globosa. C. pallens, $\mathrm{Gr}$.

G. II. Mrrcra, Dc. 1. Tubo calizinal, prolongándose mas allá que el ovario, baya cóncava por el ápice marjinado, 2. - Tubo calizinal casi tan largo como el ovario: baya de ápice plano por dentro de la márjen ó corona persistente, 3 .

2. Arbusto de ramitas pubescentes color de orin ó alampiñadas, con hojas coriáceas, ob-aovadas ú oval-obtusas, ó escotadas, lampiñas, cortamente pecioladas, de ordinario opacas, con puntos impresos y lustrosas superiormente, cuyas venas se juntan hácia la márjen arrollada ó inconspícuas, largas de $1^{\prime \prime} 1_{[} 2-21_{[} 2$, las superiores son menores con el peciolo de $1^{\prime \prime \prime}-2^{\prime \prime \prime}$; pedúnculos simples saliendo de las axilas de las hojas con 9-3 ó á veces 1 flores de 4-5"' de diámetro; pedícelos abiertos cuya flor central es pedicelada ó sub-sesil, con cáliz de 5 segmentos redondeados, interiormente sedosos; ovario 3-locular; baya globosa de $6^{\prime \prime \prime}$ de diámetro, con 3-6 semillas, cuyos cotiledones son espesitos y muy torcidos. M. coria$c e a$, Dc. De este vejetal hay tres variedades: 1a. Ramitas y pedúnculos densamente pubescentes, hojas opacas; pedúnculos sub-solitarios con 1-3 flores mas cortos que las hojas. $M$. swartziana, Gr. Myrtus coriacea, Sw. M. cotinifolia, Poir.; 2a . De ramitas alampiñadas, hojas opacas con peciolo largo de $1^{\prime \prime \prime}$; pedúnculos lampiños, aproximados 3-7-floros, mas largos que las hojas. M. Jacquiniana, Erb. Eugenia paniculata, Jacq. Aulomyrcia Jacquiniana, Berg.3 . Con ramitas densamente pubescentitas; hojas por fin provistas de puntos transparentes esparcidos; pedúnculos lampiños esparcidos 59-floros, casi tan largos como las hojas, formando cimas corimbiformes esertas. M. imrayana, Grb. C. T. V., 105,

3. Hojas reticulado-venosas, 4. - Venas principales pareciendo costillas, cuya impresion es visible por la cara superior, mientras son proeminentes por la inferior, que es diminutamente areolada; árbol grande de ramitas tomentosas color de orin, llevando hojas tiesas, coriáceas, elípticas, elíptico-lanceoladas ó eliptical-oblongas, puntiaguditas con una puntita muy estrecha, lampiñas y lustrosas superiormente, alampiñadas y tomentosas color de orin inferiormente sobre la costilla y las nervaduras acostilladas reunidas en arcos justa-marjinales, mientras las venas inmersas forman una redecilla muy fina, con puntos transparentes ó por fin casi opacos, ordinariamente largas de 31 [2-2", á veces solamente de 10-12"'; panojas tomentosas color de orin, tricótomas, saliendo de las axilas 
mas superiores, con flores de 4" de diámetro, en grupos, subsesiles, de cáliz tomentoso color de orin, con 5 lóbulos orbiculares; ovario bilocular, baya globosa. M. ferruginea. M. defiexa. M. Humboldtiana, Dc. Eugenia deflexa. E.ferruginea, Poir. E. paniculata, Sieb.

4. Árbol bajito ỏ arbusto de 12 á 15 ' de altura, de ramitas pubescentes con hojas papiráceas, aovado-lanceoladas, ó aovadas, estrechadas en una punta estrecha $\mathrm{y}$ obtusita, lampiñas, lustrosas superiormente y con puntitos transparentes, cuyas nervaduras juntas por la márjen, en donde forman redecilla, algo proeminente por ambas caras, son largas de 2-3" y anchas de 11 [2-8" ; panojas tricótomas, pubescentes, con flores pediceladas de 3-4"' de diámetro, cuya central está á reces sesil, cáliz peludo sedoso inferiormente, con 5 lóbulos redondeados, ovario bilocular; baya globosa roja y de 4"” de diámetro. M. splendens. M. sororia, Dc. Myrtus splendens, Sw. Eugenia periplocifolia, Jacq.

G. III. JAMiBOSA, Rumph. Primorosas flores purpurinas; árbol de 30 ' de altura con hojas oblongas, lanceolado-oblongas, ú ob-aovadooblongas, pecioladas, largas de 6 " á 8 " sobre $3,31_{[} 2,4$ " de ancho, con las venas distantes y formando arcos sinuosos, algo apartados de la márjen; corimbos laterales paucífloros, con los estambres purpurinos persistentes, largos de 8-10" y dos veces mas que los pétalos pronto deciduos; baya turbinada, larga de 3" y otro tanto ancha por el vértice, color carmesí. J. malaccensis, Dc. : C.T. V. 609. Primorosas flores blancas; árbol mayor que el anterior, de hojas lanceoladas, aguzadas, pecioladas, largas de 6-8", sobre $21 \Gamma^{2}$ á $3^{\prime \prime}$ 1 2 de ancho, con las nervaduras acostilladas y formando un arco continuo; corimbos terminales paucífloros, estambres 1 " 1 [ 2 largos $v$ 3 veces mas que los pétalos; baya globosa ordinariamente de 1 " 1 [2 de diámetro, blanco amarillento, con olor de rosa. J. vulgaris, Dc.: C. T. V. 608 .

G. IV. Eugexta, Mich. 1. Ovario casi tan largo como el tubo calizinal, con las celdas ordinariamente multi-ovuladas, 2.--Ovario mas corto que el tubo del cáliz, de celdas hiovuladas; árbol bajito y pequeño, lampiño y de hojas papiráceas, oblongas, con una puntita y puntos transparentes, o por fin opacas, nervaduras sub-acostilladas y lijeramente proeminentes inferiormente, formando un arco flexuoso $y$ algo distante de la márjen, largas de 4 1 $22-2$ " 1 [ 2 con peciolo de 2-3" ; flores en grupos, sesiles, frecuentemente laterales y pequeñitas; baya globosa de $3-4$ " de diámetro. E. coffeifolia, Dc. Myrciaria ramiflora, Beg.

2. Flores agrupadas, fasciculadas ó racemosas, 3. - Flores ordinariamente solitarias ó casi solitarias, precoces, de pedícelos solitarios ó aproximados, acompañados de una bráctea oblonga, situada por su base, mientras su ápice es bi-bracteolado; árbol pequeño ó arbusto lampiño, con hojas membranosas y por fin papiráceas, aovado-lanceoladas, obtusitas, verdes por ambas caras, con puntitos transparentes, $y$ por fin opacas ; nervaduras reticuladas con los principales arcos profundamente sinuosos, largas de 2-1" 1 [2, sobre 1214 "' de ancho, con los peciolos de 2"'; pedícelos largos de 18-8"' 
mucho mas que la bráctea; flores de 6"' de diámetro cuyo cáliz tiene lóbulos linear-oblongos y obtusitos; baya roja globosa, lonjitudinalmente asurcada y ancha de 4-6" $E$. uniflora, L. E. Mitchelii, Lam., etc.: C. T. V., 609.

3. Flores agrupadas o fasciculadas, 4. - Flores racimosas o corimbosas, raras veces acompañadas de flores solitarias; árbol grande cuyas ramitas sedosas llevan hojas papiráceas y por fin solamente coriáceas, lanceolado-oblongas, eliptical-oblongas, puntiagudas ú obtusitas, con puntitos transparentes, de cara inferior lampina ó alampiñarla, mientras la superior es lustrosa; nervaduras acostilladas, lijeramente proeminentes, formando arco flexuoso, largas de $3-4$ " y anchas de $1-1$ " $1_{[} 2$, con el peciolo de 3 " "; racimos simples cuyo eje con el pedúnculo es 2-1", sedosos color de orin, 2-4 veces mas cortos que las hojas, pedícelos por pares distantes casi tan largos como los peciolos y de 2-3"', con bracteitas redondeaditas; flores de 4-5" de diámetro; ovario liso, de celdas con pocos óvulos, baya ob-aovado-oblonga, larga de 6-8" y ancha de 4" por el vértice $E$. reruginosa, Dc. Myrtus ceruginosa, Forsyth.

4. Flores aglomeradas, cortamente pediceladas ó sesiles, los pedícelos interiores de ordinario dispuestos er racimitos diminutos, mientras los esteriores son fasciculados, ó todas las flores sentadas, 5. - Pedícelos siempre fasciculajos y axilares; árbol bajito ó arbusto, con ramitas pubescentitas que llevan hojas papiráceas y por fin coriáceas, aovadas, con una punta obtusita, provistas de puntos transparentes, por fin opacas, lampiñas, nervaduras lijeramente proeminentes y formando un arco flexuoso, largas de 2-1" y anchas de 10 á 15"', con el peciolo de 1"'; hacecillos de 2-6 flores, anchas de 1 " $1_{1} 2$ con pedícelos alampiñados escediendo mucho el peciolo y 2 á 3 veces mas cortos que las hojas; anteras ovoídeas; baya globosa, ancha de 2-3"". E. procera, Poir. E.baruensis, Gr. Myrtus procera, Sw.

5. Arbusto de ramitas lampiñas, raramente pubescentitas con hojas coriáceas, acunado-elípticas, obtusas, opacas, lampiñas, nervaduras apenas visibles superiormente, lijeramente proeminentes inferiormente, con el arco casi continuo y distante de la márjen, largas de 2-1" con el peciolo de 2-3" ; grupos lampiños y rara vez pubescentitos, pedícelos tan largos ó mas cortos que el peciolo, los interiores en racimitos, con flores de 3'" de diámetro, bayas globosas; anchas de 2-1" $1_{1}$ 2. E. monticola, Dc. E. axillaris y fotida, Berg. Myrtus monticola, Sw.

G. V. Pimenta, Lindl., 1. Cáliz 5-lobo; drupa aovado-oblonga ú ovoídea, 2. - Cáliz 4-lobo ; drupa globosa ; árbol de 30 á 40' de altura, cuyas ramitas comprimidas, sub-tetrágonas y alampiñadas llevan liojas oblongas ó lanceolado-oblongas, lampiñas lustrosas, coriáceas, con las nervaduras apenas notables por la cara superior, pero distantes y algo proeminentes por la inferior, lar'gas de 6-2", con el peciolo de 5-6" y anchas de $1,21_{[} 2,3$ "; cimas compuestas corimbiformes, ordinariamente esertas con flores blancas anchas de 3"'; tubo del cáliz tan largo como el ovario. P. vulgavis, W. A. : C. T. V. 280. 
2. Drupa aovado-oblonga; tubo calizinal casi tan largo como el ovario; árbol del tamaño del anterior con las ramitas comprimidas sub-tetrágonas, de hojas ob-aovadas, redondeaditas por el ápice, coriáceas, lustrosas, largas de $3^{\prime \prime}$ y anchas de $6^{\prime \prime \prime}$, arrolladas por la márjen, con las venas apenas visibles superiormente, mientras son proeminentitas y reticuladas inferiormente; cimas cortas mucho mas que los hojas largas de $5^{\prime \prime \prime}$ y anchas de $3^{\prime \prime \prime}$. P. pimento, Gr. Amomis pimento, Berg. - Drupa oroídea, larga de 6-4"' sobre 3$2^{\prime \prime \prime}$ de ancho; tubo calizinal mas largo que el ovario; árbol lampiño de ramitas comprimido-sub-tetrágonas ó tetráquetras, con hojas ovales ú ob-aovado-redondeaditas, lustrosas, largas de 2-3" sobre $1-1^{\prime \prime} l_{1} 2$ de ancho, de cara superior convexa, con puntitos transparentes esparcidos y las venas algo proeminentes y reticuladas, mientras son lijeramente proeminentes inferiormente; cimas fojas igualendo ó escediendo las hojas. P. acris, W. A. Myrtus acris, Sw. Myrcia acris, Dc. Hay dos variedades de esa especie: 1a. Ramitas sub tetrágonas con hojas ovales: Amomis acris, Berg; $2^{\mathrm{a}}$. Ramitas tetráquetras con los ángulos escurridos'desde la márjen de los peciolos; hojas ob-aovadas. P. pimentoides, Greb. Myicia pimentoides, Dc. Amomis pimentoides, Berg.

G. VI. Psidium, L. 1. Ramitas comprimido-cilíndricas, 2.-Ramitas tetrágonas 4 .

2. Lampiñas, 3. - Pubescentes con hojas papiráceas, elípticas ú oval-oblongas; largas de 5-4" y anchas de 21 [ 2-2", de cara inferior pubescentita, con las nervaduras acostilladas y proeminentes y las venas reticulado-transversas; pedúnculos ordinariamente con 3 flores anchas de 1", cáliz cerrado en el capullo, anteras oblongas. $P$. polycar'pum, Lamb.

3. Hojas coriáceas aovadas ú óvalas, redondeadas por ambos estremos ó acorazonadas por la base, sesiles ó cortamente pecioladas, largas de 3-1" 1 [ 2 y anchas de 2-1, con las venas apenas notables; pedúnculos con una ó pocas flores anchas de $8^{\prime \prime \prime}$, de anteras redondeaditas. P. cordatum, Sims.

4. Pubescentes con hojas papiráceas, oblongas o eliptical-oblongas, obtusitas, raras veces lanceolado-puntiagudas, pubescentitas inferiormente, con las nervaduras acostilladas, proeminentes, y los nervios transver'sos, largas de 3-4-2" y anchas de 15-21-6"'; pedúnculos con 1-3 flores grandes de $1^{\prime \prime}$ de diámetro, de cáliz cerrado en el capullo, anteras ovales; bava globosa, óvala, aovada ó piriforme, larga de $2-11_{[} 2-1^{\prime \prime}$ y ancha de $1-1^{\prime \prime} 1\left[2\right.$; árbol bajito, de 10 á $15^{\prime}$ de altura. G. guara, Radd., etc. : C. T. V., 106. Variedad la de hojas lanceoladas $\dot{0}$ lanceolado-oblongas, puntiagudas por ambos estremos, largas de $2^{\prime \prime}$ sobre $6^{\prime \prime \prime}$ de ancho. P. pumilum, V. P. fragrans, Macf. $2^{a}$ Alampiñada, con hojas papiráceas, elípticas ó elíptico-lanceoladas, lampiñas, con las venas lijeramente proeminentes inferiormente, largas de $3-2^{\prime \prime} 1_{1} 2$ sobre $11_{[} 2-1^{\prime \prime}$ de ancho, pedúnculos con 1-3 flores, anchas de $1^{\prime \prime}$, de cáliz cerrado en cl capullo, enteras, cortamente oblongas, baya globosa, ancha de $4-5^{\prime \prime \prime}$; árbol alto. P. montanum, Desc. 
G. VII. Camponanesia aromatica, Gr. Psidium aromaticum, Aubl. Stenocalyx pseudo psidium, Berg. C. T. V., 306.

G. VIII. Caryophyllus aromaticus, L. : C. T. V., 282.

G. IX. Srzygium jambolanum, Dc.: C. T. V., 280. Marlieria elliptica, Gr.

Familia 134. - GRANATEAS. - Arbolitos ó arbustos de hojas simples, alternas, pecioladas, enteras, un poco undulosas por los lados, sin puntitos transparentes; flores terminales agrupadas por á 3 o 4, formadas de un cáliz colorido, coriáceo, adherente, de tubo turbinado, con limbo 5-7-partido, corola con otros tantos pétalos insertos en la garganta del cáliz, elíptico-lanceolados; hay muchísimos estambres, insertos en el tubo calizinal é inclusos en él, de anteras introrsas, biloculares, aovadas y abriéndose por grietas lonjitudinales; ovario ínfero, con un doble verticilo de celdillas sobrepuestas, poliovuladas y de cuyo vértice sale un estilo único simple, con estigma cabezudo; el fruto es una especie de baya esférica. Punica granatum, L. : C. T. V., 107.

\section{CLASE LIX. - ENOTERÍNEAS.}

Familia 135. - SALICARIEAS, SALICARIÁCEAS, LITRARIEAS, LITRARIACEAS. - Plantas herbaceas anuales ó vivaces, matas y arbustos, de hojas sencillas, enteras ó dentadas, opuestas ordinariamente y á veces alternas, sin estípulas; flores siempre hermafroditas, solitarias y axilares ó en espigas y racimos terminales que constan de un cáliz monosépalo, tubuloso ó urceoladovalvar, con 4-6 segmentos ó dientes; corola con igual número de pétalos algo ungüiculados, insertos en la parte superior del tubo calizinal ó ell su garganta, junto con los estambres, cuyo número es duplo de ellos ó indefinido; suele faltar algunas veces la corola; ovario libre, simple, multilocular, polispermo, de cuyo vértice sale un estilo único, simple, con estigma cabezudito. Cápsula cubierta por el cáliz persistente, con una ó muchas celdas conteniendo muchas semillas asidas por el ángulo interno sin endospermo.

G. I. Cufnea, P. Br.-1. De 10 á 12 estambres, 2.-6 estambres inclusos, de los que dos son mas largos, de filamentos cortos y lam. piños, yerba anual de tallo difuso, tendido, largo de 6 á $8^{\prime \prime \prime}$, áspero pubescente, con hojas aovadas ú oblongas cortameute pecioladas, alampinadas ó asperitas, largas de 6.4"', puntiagudas ú obtusitas; flores color purpurino pálido, alternas, sentadas ó cortamente pediceladas, oblícuamente insertas en la axila, como mitad menos largas que las hojas, de cáliz giboso por labase y largo de 2-3"', con dientes diminutos, pétalos 6-7, largos de $1^{\prime \prime \prime}$. C. par'sonsia, R. Br. : C. T. V., 791.

2. Estambres 12 y á veces 8 , con los filamentos velludos, yerba anual de tallo en forma de varita, pubescente-viscosa, de 8 á $10^{\prime \prime}$ de largo, con hojas aovado-lanceoladas, pecioladas, lijeramente ásperas, largas de $8-10^{\prime \prime \prime}$, con peciolo de $2-4^{\prime \prime \prime}$; flores alternas son pedícelos juxta-peciolares mucho mas cortos que el cáliz viscoso, con un espolon corto por la base, cuyos dientecitos diminutos son largos de $4^{\prime \prime \prime}$, pétalos morados, cápsula con algunas pocas semillas. $C$. vis- 
cosissima, Jacq. Lythrum petiolatum. Cuphea melanium, L. - 11 estamlıres, tallo inclinado, un poco áspero, con ramitas pubescentes, de hojas óvales y oblongas á la par, puntiagudas, asperitas, con la base redondeada; flores alternas, con pedúnculo alado, cáliz pelierizadito, corola de pétalos iguales y moraditos, filamentos de los estambres velludos. C. antisifilitica. C. T. V., 791.

G. II. Lawsonia inermis, L. : C. T. V., 335.

Familia 136. - MELASTOMACEAS. - Plantas herbáceas, matas, frutices, arbustos y árboles, de hojas simples, coriáceas, enteras ordinariamente ó dentaditas, lampiñas, con la mayor frecuencia pubescentes, tomentosas, afelpadas y velludas, opuestas, pecioladas, con 3-j-11 costillas lonjitudinales, casi paralelas, muy pronunciadas, de las cuales salen nervaduras transversales y aproximadas, lo que les da un aspecto particular característico de esa familia. Flores siempre hermafroditas, de inflorescencia muy variada, y que constan de un cáliz monosépalo mas ó menos adherente, de limbo entero ó dentado, otras veces con 4-5 divisiones mas ó menos profundas; de una corola con 4-5 pétalos torcidos, de cuyo número siempre es doble el de los estambres insertos en la garganta del cáliz valvar junto y por debajo de los pétalos, doblados en la estivacion de manera que se encorvan por abajo, sea hácia el ovario, sea al fondo del cáliz y ascendentes al abrirse la flor, con anteras anteriores y adheridas al conectivo, ordinariamente abriéndose por poros terminales. Ovario inferior ó adherente al cáliz por medio de líneas lonjitudinales, separadas las unas de las otras por huecos á propósito para alojar las anteras durante la prefloracion y que frecuentemente desaparecen despues; otras veces es libre, con algunas celdillas conteniendo muchos óvulos, de ordinario pegados en el eje de las celdas. El fruto es ó seco y capsular, abriéndose por tantas rentallas septíferas cuantas celdillas tenia el ovario, ó abayado, coronado é indehiscente, con muchas semillas reniformes, de embrion recto ó algo encorvado, pero sin endospermo alguno.

\section{Análisis dicotómica de las tribus.}

1. Fruto abayado mas ó menos carnudo, 2. - Fruto capsular, 3.

Semilla no en caracol, anteras sin conectivo ensanchado, uni ó biporosas; apéndices de ordinario pequeños ó nulos, con ó sin cola, cuando existe está contigua con el filamento. Tr. I. Miconieas.

G. I. Loreya arborescens, Dec. Melastoma arborescens, Aubl Ossea flavescens, Dec. Melastoma flavescens, Aubl.-G. II. Clidemia hirta, Doncl. Crenata, Dc. Mel. hirta, L., etc. - G. III. Miconia holosericea, Dc. Melastoma holosericea, L., etc. : C. T. V., 130. Semillas no acaracoladas, anteras comprimidas ordinariamente, coherentes por las celdas, conectivo ensanchado, con los apéndices, cuando hay, situados por el lado posterior. T. II. Pixidánteas. Blakea laurifolia, Naud. Bellucia aubleltii, Naud.

3. Semillas no en caracol, anteras dehiscentes lonjitudinalmente, con los apéndices situados por su lado posterior, cuando existen. 
T. III. Carianteas. Meriana rosea, Tuss., ete. : C. T. V., 442. Semillas acaracoladas, apéndices, cuando hay, situados sobre el lado anterior de las anteras. T. IV. LASIÁNDREAS.

Familia 137. - RISOFOREAS. - Arbustos ó árboles de mediano tamaño y altura, con hojas simples, enteras, coriáceas, pecioladas, opuestas, con estípulas interpeciolares; flores hermafroditas, en espigas ó en grupos axilares ó terminales, formadas de un cáliz súpero, monosépalo, persistente, con 4-5 divisiones valvares, de una corola con otros tantos pétalos frecuentemente laceraditos y con uñas, ó enteros y sin uñas; estambres $8-15$ insertos por dentro del cáliz; ovario semi-ínfero ó libre, simple, con 2-3-5 celdas, con dos óvulos colgantes, de cuyo ápice sale un estilo simple con estigma bi-partido. Fruto indehiscente unilocular, acompañado por la base del cáliz con una semilla cuya radícula agujerea el fruto para salir por afuera; otras veces es una cápsula 3 -locular abriéndose por tres ventallas, sin endospermo siempre. Rhizophora mangle, L.: C. 'T. V., 160-748. - Cassipourea elliptica, Poir.

Familia 138. - ONAGRARIEAS. - Plantas herbáceas anuales ó vivaces, matas y frutices, de hojas simples, enteras, recortadas ó dentadas, lanceoladas, lampiñas, pubescentes y velludas, sentadas ó cortamente pecioladas, opuestas ó esparcidas ; flores hermafroditas, solitarias ó en grupos axilares; otras veces en espigas ó en panojas terminales, constando de un cáliz monosépalo con 4-5 divisio . nes mas ó menos profundas, de prefloracion valvar, adherente, cuyo limbo está casi articulado ó no, de una corola con 4-5 pétalos un poco inclinados lateralmente $\mathrm{y}$ de prefloracion torcida, con uñas mas ó menos cortas y pegadas en la parte superior de la garganta del cáliz, con cuyos segmentos alternan; suele faltar algunas raras veces; estambres 4-5 ó 8-10 insertos junto con los pétalos, base de los filamentos á veces acompanada de pelos, granos polínicos reunidos por un hilo; ovario inferior de-4-5 celdillas, con muchos huevecillos asidos á su ángulo interno, y de cuyo ápice sale un estilo único terminado por un estigma entero ó partido. Cápsula de 4-5 celdas, abriéndose por otras tantas ventallas septíferas, conteniendo muchas semillas sin endospermo y de embrion homótropo.

Jussiea, L. - 1. Tallo derecho ó ascendente, con hojas subsesiles o cortamente pecioladas, enteras ondeadas, 2. Tallo rastrero ó flotante vivaz, hojas pecioladas, 4 .

2. Cápsula con ángulos obtusos, cilíndrica ó linear-prismática, 3. - Cápsula ob-aovada tetragonal; planta vivaz de tallo fruticuloso, alto de 3-2', ramoso, velludo, pubescente ó alampiñado, con liojas lanceolado-oblongas ó eliptical-oblongas, cortamente pecioladas, con las nervaduras arqueadas y las venas transversas, distantes como de $2^{\prime \prime \prime}$, largas de $4-2^{\prime \prime}$; flores amarillas, pediceladas de cáliz, con 4 - lóbulos, grandes, aovados, largoos de 4-\{"'" y mas cortos que los pétalos ob-aovado-redondeaditos y largos de 8-10"'; cápsula larga como los lóbulos del cáliz ó al̨̧o mas corta que ellos, cuya base se aguza liasta volverse pedícelo largeo de 6-8-3" J. Jirta, IV. : C. T. V., 69I.

3. Planta herbácea, lampiña ó áspero-pubescente superiormente, 
con hojas lanceoladas ó lanceolado-lineares, aguzándose en peciolo corto, largas de 4-1"; flores cortamente pediceladas, de cáliz con 4 y á veces 5 lóbulos, aovado-lanceolados, puntiagudos, largas de 4-3"', una mitad ó dos veces mas cortas que los pétalos ob-aovadooblongos; cápsula larga de 1-1 1 [2, aguzándose gradualmente por la base, en pedícelo largo de 3-4"'. J. angustifolia, Lam. J. salicifolia, Ktk. J. octonervia, Dc. Enothera octonervia, Jacq.

4. Yerba glabra de tallos tendidos por el suelo en que echan raices ó flotando sobre el agua; largas de 1 á 2 ', de ramas ascendentes velludas, con hojas espatulado-lanceoladas ú ovales, ag̣uzándose en peciolo delgado, bien enteras, largas de 6" "y anchas de 21 [ 2 ; flores pediceladas, de cáliz con 5 lóbulos lanceolados, aguzándose, mas cortos que los pétalos ob-aovados, largos de 3-4"'; cápsula obtusamente anguloso-cilíndrica, larga de 8-10" y mas que el pedícelo, aguzada por la base. J. repens, L. J. swartziana, Dc. J. peploides, Kth. J. vamulosa, Dc. C. T. V.. 692.

Familia 139. - COMBRETACEAS. - Arbustos sarmentosos 0 no, arbolillos y árboles grandes y corpulentos, con hojas simples, enteras, coriáceas, lustrosas, cortamente pecioladas, alternas y sin estípulas; flores tan pronto hermafroditas como polígamas, en espigas ó en racimos axilares ó terminales, que constan de un cáliz adherente monosépalo, tubuloso, con 4-5 lóbulos y cuyo tubo parece como articulado en el ápice del ovario; corola con $4-5$ pétalos insertos entre los segmentos del cáliz valvar, pero suelen faltar ordinariamente; estambres por lo comun en número doble de los pétalos y alguna vez que otra mas numerosos; ovario inferior simple, unilocular, con pocos óvulos colgantes del ápice de la celda; estilo simple terminado por un estigma entero. El fruto es una cápsula siliciforme o una especie de drupa unilocular monosperma por causa de aborto de los demas huevecillos; semillas pendientes y sin endospermo.

Tribu $1^{a}$. - Eucombreteas. - Una corola; embrion de cotiledones ordinariamente embrazantes ó tambien juxta-puestos. Combretum.

Tribu 2. - Termináleas ó Mirobálaneas. - Ninguna corola; embrion de cotiledones generalmente foliáceos y convolutos.

G. I. Terminalia, L. - Hojas ob-aovado-oblongas, aguzándose por la base en peciolo largo, alampiñadas o pubescentitas inferiormente, casi sin glándulas por la base, largas de 6-12" y anchas de $3-5^{\prime \prime}$, aproximadas hácia el vértice de las ramitas, frecuentemente con una glandulita ó un pincelito de pelos en las axilas de las nervaduras inferiormente, con peciolo largo de $1^{\prime \prime}$; espigas simples ordinariamente, mitad mas cortas que las hojas, pedunculadas, cilíndricas, cuya parte superior ocupan las flores masculinas, mientras que por la base están las hermafroditas; estambres un poco esertos; drupa elíptica, con una punta, bi-convexa, larga de $11_{1} 2^{\prime \prime}$, de márjen navicular aguda; árbol de $80-100^{\prime}$ de altura, muy coposo y corpulento. C. latifolia, Sw. : C. T. V., 656. - Arbol de 40-50' de altura, curas hojas agrupadas hácia la sumidad de las ramitas son acuñado ob-aovado-oblongas, redondeadas ó sub-acorazonadas por la 
luase aguzada bi-glandulosa, por la cara inferior alampiñadas, mientras la superior es glabra y lustrosa, largas de 5-8" y anchas de $3-4^{\prime \prime}$; espigas simples, pedunculadas, cilíndricas, cuyas flores masculinas ocupan la parte superior y las hermafroditas la inferior; drupa oral-oblonga, redondeada por ambos estremos, comprimida y con las márjenes prolongadas en alas estrechas y de 1-2"', larga de 1 1 $22-2$ " sobre $1 "$ de ancho. C. catappa, L.

G. II. Bucrda, L. - Árbol de 30-40' y mas de altura, con hojas obaovadas ó espatulado-lanceoladas, lampiñas superiormente, sedosas Y alampiñadas inferiormente, largas de 3 á $4^{\prime \prime}$ y anchas de 11 [2 á 2 ; espigas cilíndricas, sedosas ó velludo-pubescentes, con flores sub-distantes de estambres largamente esertos, con anteras acorazonadas y puntiagudas; drupa seca, pequeña, aovado-cónica, coronada por el limbo calizinal persistente, larga de $3^{\prime \prime \prime}$. B. lucei'as, L. B. angustifolia, Dc. : C. T. V., 134. Ucare, Prco. Suministra una goma que participa de las propiedades de la goma arábiga, que puede reemplazar. - Arbol de 40.60' de altura, con hojas espatulado ú ob-aovado-oblongas, de cara superior lampiña, mientras la inferior es alampiñada, con vellito color de orin persistente sobre la costilla y la [márjen, largas de 1-1" $1_{1} 2$ y anchas de 6-8"'; espigas aovadas, largamente pedunculadas, pubescentes, color de orin; largas de 8"' y anchas de 3; estambres cortamente esertos, de anteras redondeaditas ; drupa ovoídea, coronada por el limbo calizinal, por fin decídua, larga de $6^{\prime \prime \prime}$. B. capitata. C. T. V., 134.

G. III. Lagurcularia racemosa, Jacq. Conocarpus racemosus, L. G. IV. Conoc a Rpus erectus, L. C. procumbens, Jacq. : C.T.V.724.

\section{CLASE LX. - CUCURBITÍNEAS.}

F amilia 140. - BEGONIÁCEAS. - Plantas herbáceas anuales $\dot{0}$ perennes, ordinariamente suculentas, con ramos alternos nudoso-articulados que llevan hojas simples, palmatinervias, enteras ó algunas veces palmatílobas, ordinariamente acorazonadas, casi siempre mas ó menos inequilaterales, algunas veces desmediadas, articuladas por medio del peciolo, dísticas y alternas, con estipulas laterales, membranáceas, libres y caedizas; flores axilares en cimas dicótomas $\dot{0}$ en panojas terminales unisexuales, cuyas masculinas constan de un eáliz corolino con 4 sépalos desiguales, siendo los esteriores mayores, planos en la estivacion, aplicados uno á otro y teniendo inclusos los dos interiores alternos, menores y dohlados; estambres muchos amontonados en el centro de la flor, libres ó entresoldados por la base y continuamente terminados en un conectivo obtuso, de anteras estrorsas, biloculares, cuyas celdillas están separadas por el conectivo y lonjitudinalmente dehiscentes. Las femeninas se componen de un periantio corolino tambien, con el tubo claviforme, tríptero y adherente al ovario, de limbo profundamente 4-9-partido, cuyas lacinias son empizarradas en la prefloracion, derechas ó patentes durante la floracion; ovario inferior 2$3-5$-locular, cuyos tabiques alternan con las alas $\mathrm{y}$ las placentas 
proeminentes en el ángulo central de las celdillas, conteniendo muchos óvulos anátropos; del vértice salen 3 estilos cortos, reunidos por la base, gruesos, bífidos y terminados por un estigma engrosado, continuo por la base, tortuoso, flexuoso ó cabezudo y papiloso. Cápsula membranácea coronada del perigonio marcescente, trialada, trilocular, de dehiscencia 3-valvar y loculícida, semillas muchas diminutas, sin endospermo y con el embrion ortótropo, con cotiledones cortísimos y radícula larga en contacto del hilo y centrípeta.

Begonia, L. - 1. Sépalos en número desigual o diferentes en las flores de ambos sexos, 2 . - Sépalos 2 en flores de ambos sexos; 3 estigmas cortamente bífidos, con una faja semilunar, contigua y papilosa; cápsula desigualmente 3 -alada, con placentas bilameladas; tallo corto con estípulas grandes, deltoídeas, largas de $1_{[} 2^{\prime \prime}$, hojas muy grandes, desizual y profundamente acorazonadas, redondeaditas, sinuoso-dentadas, pestañosas y con pelo en las nervaduras inferiormente; las superiores largas de $1^{\prime}$, de peciolo cilíndrico, escamoso y largo; flores en cimas grandes, largamente pedunculadas y de sépalos con 3-4"' de diámetro; alas de las cápsulas obtuso-redondeaditas, cuya tercera es mucho mayor que las laterales. $B$. macrophylla, Dryand.

2. Cáliz de las flores masculinas con 4 sépalos en 2 séries, mientras el de las femeninas tiene cinco, 3.-Flores masculinas con 2 sépalos y femeninas con 5 ; tres estilos bipartidos ó bífidos, torcidos, con una faja continua y papilosa; cápsula desigualmente 3-alada, placentas bilameladas; frutices de hojas cortamente pecioladas, con estípulas y brácteas persistentes; tallo derecho, anguloso, con pelo esparcido, de hojas oblongas, puntiagudas, lijeramente oblícuas por la base, bi-aserradas, peludas por las dos caras, largas de $2-5^{\prime \prime}$ y anchas de $11_{[2-3-31}$ [2; estípulas oblongo-lanceoladas, escediendo los peciolos y largas de $6^{\prime \prime \prime}$; de las alas de la cápsula dos son estrechas y la tercera deltoídea. B. ulmifolia, IV.

3. Estigma 2-partido ó 2 -fido, torcido con una faja continua y papilosa; cápsulas desigualmente aladas; placentas bilameladas; yerbas suculentas ó arbustos, 4. - Estigmas bipartidos, toreidos, enteramente papilosos; ala de la tercera celda de la cápsula estendida y las dos otras reducidas; placentas enteras; yerbas frecuentemente fruticulosas y como sarmentosas; flores en cimas grandes divaricadas; tallo arraigante, trepador, largo de $2-6^{\prime}$, ramoso y lampiño, con hojas aovadas ó aovado-redondeaditas, sub-iguales, lijeramente escotadas por la base, desigualmente dentadas, largas de $3-6^{\prime \prime}$ y anchas de $2-3-4^{\prime \prime}$; cimas pedunculadas desparramadas, cuyas flores tienen sépalos blancos mayores en las masculinas, aovados y largos de $2^{\prime \prime}$; tercera ala de la cápsula aovado-oblonga, obtusa, larga y ancha de $8^{\prime \prime \prime}$, estendida; las otras dos cortamente ascendentes y deltoídeas, obtusitas, anchas de $2^{\prime \prime \prime}$ por su parte superior. B. scandens, Sw. B. glabra, Aubl.

4. 'Tallo de 2-4' de altura, fruticuloso, algo derecho, lampiño y muy ramoso, con hojas semi-acorazonado-oblongas, aguzadas, angulosas y ondeadas, dentaditas, sub-pestañosas, lampiñas por ambas caras, asi como los peciolos, largas de $2-3^{\prime \prime} 1{ }^{2}$ sobre $3{ }^{4}-1^{\prime \prime} 1_{[} 2$ de 
ancho; flores blancas y coloradas en cimas paucífloras, cuyos sépalos de las masculinas mayores $y$ ovales son largos de $6^{\prime \prime \prime}$; dos alas de la cápsula son estrechas y redondeadas, anchas de $1^{\prime \prime \prime}$, mientras la tercera, aovado-oblonga y obtusita, es larga de 6-8"'. B. acutifolia, Jacq. B. jamaicensis, Dc. - Tallo fruticuloso, derecho y lampiño, alto de 4 á $5^{\prime}$, ramoso y con hojas desigualmente acorazonadoaovadas, puntiagudas, ondeadas, sub-enteras ó algo festoneaditas, enteramente lampiñas, así como los peciolos, largas de 5-4" y anchas de 21 [2-2"; cimas abiertas $y$ dicótomas, con flores rosaditas, cuyos sépalos de las masculinas son desiguales, 2 siendo mucho mayores, óvalo-redondeaditos, largos de 6-8"' $\mathrm{y}$ anchos de $6^{\prime \prime \prime}$; ala tercera de la cápsula anchamente aovada, $B$. nitida, Dryand.: C. T. V., 618.

Familia 141. - CUCURBITACEAS. - Plantas herbáceas anuales ó vivaces $\mathrm{y}$ entonces con raices bastantes gruesas, perpendiculares y carnosas, cuyos tallos largos, delgados, ramosísimos y frecuentísimamente velludos y ásperos, están tendidos en el suelo ó volubles y trepadores, siempre con zarcillos sencillos ó ramosos, saliendo del lado de la insercion del peciolo; otras veces son bejucos con tallos mas ó menos leñosos; hojas simples mas ó menos anchas, casi siempre lobadas, mas ó menos profundamente labiadas ó sinuosas, ordinariamente pelierizadas ó sedosas, raras veces lampiñas, siempre alternas y largamente pecioladas, palmatinervias $y$ sin estípulas. Flores unisexuales, ordinariamente monoicas ó dioicas $y$ raras veces hermafroditas, solitarias ó axilares en racimos ó en panojas terminales; constan las masculinas de un cáliz monófilo, de forma y tamaño muy variados, pero las mas veces campanudo, con כ lóbulos ó lacinias mas ó menos largos y cuyo interior y fondo está forado por un disco amarillo; corola monopétala, íntimamente soldada con la garganta del cáliz con que está confundida, mas ó menos grande $y$ con 5 lóbulos poco pronunciados; 3-5 estambres insertos en el hondo y centro de la flor, triadelfos, raras veces libres $y$ de filamentos distintos, con anteras grandes, estrorsas ó marjinales, ordinariamente flexuosas y con figura de $\mathrm{S}$, acostadas ó puestas horizontalmente, uniloculares $\mathrm{y}$ abriéndose lonjitudinalmente por un surco. Las flores femeninas al contrario, se componen de un cáliz adherente tubuloso, con 5 segmentos ó lacinias, de una corola semejante á la de las masculinas é inserta del mismo modo, de un ovario ínfero con 3 celdas ordinarianiente, por causa de las 3 placentas enrolladas, con muchos ó algunos óvulos, cuyo vértice está coronado por un disco hepijínico, de cuyo centro sale un estilo grueso, corto, terminándose por 3 estigmas gruesos y bilobados. El fruto es una peponida de forma, tamaño y color muy variados, mas ó menos carnuda, mas ó menos umbligada por el vértice, con tres celdas que con bastante frecuencia desaparecen al madurarse, $\mathrm{y}$ entónces las semillas mas ó menos numerosas parecen esparcidas en medio de un tejido celular filamentoso ó carnoso, otras veces es una especie de pixidio con 3 celdas polispermas, de semillas cuya figura, tamaño y color son muy variados, pero ordinariamente comprimidas y orladas mas ó menos, con el epispermo como coriáceo y 
á veces casí como leñosito, cubriendo un embrion grueso, homótropo y un endospermo.

Tribu la. - Nandiróseas. - Zarcillos axilares, flores dioicas, con los tres estilos distintos; el fruto es un pixidio con tres celdas cuyas muchas semillas son ascendentes desde la base; bejucos de tallo lleñoso. Ferilea cordifolia, Sw. : C.T. V., 721.

Tribu $2^{\mathrm{a}}$.- Cucurbíteas. - Zarcillos laterales y juxta-peciolares; flores monoicas, dioicas ó hermafroditas, A.

Tribu $3^{a}$. - Sicieas. - Zarcillos laterales; fruto con una sola celda conteniendo una semilla única y colgando del apéndice. Sechium edule, Sw. C. T. V., 667.

A. G. I. Cionandra, Gr. - Hojas pubescentitas, 2. - Vejetal lampiño de tallo anguloso, con hojas 3-lobas, lijeramente sub-acorazonadas por la base, de lóbulos deltoídeos, puntiagudos, dentaditos, cuyos laterales son estendidos, anchas de $3^{\prime \prime}$, las superiores son mas estrechas, membranosas, lijeramente ásperas ó unidas, con 3 venas transversas y los dientes glandulíferos; zarcillos bífidos ó simples; flores masculinas solitarias ó en racimos paucífloros abiertos y de $10^{\prime \prime \prime}$ de diámetro, dientes del cáliz cuyo tubo es turbinado, deltoídeos y pequeños, pétalos anchamente oblongos mitad mas largos que el cáliz, lijeramente tomentosos. C. cuspidata, Gr.

2. Tallo alampiñado, anguloso, con hojas pubescentitas, redondeaditas, contraidas por la base, mucronadas, cuyas inferiores son 3-5-lobas hasta la parte mediana, mientras las superiores son sinuado-sub-enteras y anchas de $3-2^{\prime \prime}$, las superiores mas estrechas $y$ sub-asaetadas, pecioladas; zarcillos 2-3-fidos; flores amarillentas arracimadas, distantes y colgantes: en las masculinas los dientes del cáliz son deltoídeos y distantes; los pétalos aovado-oblongos, tomentosos y tan largos como el cáliz; 3 filamentos cortos hay : las femeninas, largas de $6^{\prime \prime \prime}$; tienen el limbo calizinal ciatiforme, diminutamente dentadito, mitad de lo largo de los pétalos oblongos; baya ovoídeo-oblonga, roja, larga de $5^{\prime \prime \prime}$ y ancha de $3^{\prime \prime \prime}$. C. racemosa, Gr.: C. T. V., 545. - Tallo lampiño, anguloso, de hojas alampiñadas, ásperas, acorazonadas, profundamente 3-lobas, con los lóbulos aguzados, cuyo mediano es aovado-lanceolado, bien entero, mientras los laterales son anguloso-sinuosos por el lado esterior, anchas de de 5-2", con el seno de la base abierto, pecioladas; zarcillos 3-fidos; flores en racimos paucífloros ó solitarias, cuyas masculinas, largas de 9-12"', tienen el cáliz con dientes subulado-filiformes distantes; baya ovoídea, amarillenta, larga de $8^{\prime \prime \prime}$ sobre $6^{\prime \prime \prime}$ de ancho, con 6 : menor número de semillas aovadas, comprimido-asperitas y obtusas por la márjen. C. graciliflora, Gr. : C. T. V., 33.

G. II. Momordic A, L. - Planta abejucada, alampiñada, con hojas profundamente 5-7-lobas, cuyos lóbulos son sinuoso-aserrados, largamente pecioladas, largas de $13\left[4,21_{[} 4,2^{\prime \prime} 1_{1} 2\right.$ sol)re $11_{[} 2,2,3$ de ancho, con el peciolo largo de $32\left[3,2\right.$, $112^{\prime \prime}$. Pedúnculos axilares filiformes, largos de $2-3^{\prime \prime}$, con una bráctea redondeadita entera, situada por encima de la base ó casi hácia la parte media; flores masculinas con los lóbulos calizinales aovado-lanceolados, mas largos que el tubo y mas cortos que la corola larga de 4 á $6^{\prime \prime \prime}$; cáliz de 
las femeninas contraido en tubo filiforme por encima del ovario crestado-tubuloso; fruto oblongo ú elíptico muricado ó tuberculado, largo de 1 á $5^{\prime \prime}$ y ancho de $8^{\prime \prime \prime}-1$ " 1 [2-2". M. charantia, L. : C. T. V., 334 . De esa especie hay dos variedades: 1ª Lóbulos de las hojas dilatados, bráctea inserta en ambos sexos menos de 1" por encima de la hase del pedúnculo; fruto oblongo, un poco aguzado por el vértice. M. operculcata, L. M. pseudobalsamina.-2a Lóbulos de las hojas di latados, con dientes obtusitos; bráctea en las flores masculinas inserta hácia la parte mediana del pedúnculo y por encima de la base en el de las femeninas; segmentos de la corola ob-aovados; fruto elipsoideal-oblongo, puntiagudo, ordinariamente largo de 5 á 6 " y ancho de $11_{1} 2$ á $2^{\prime \prime}$ por la parte mediana, con crestas muy salientes y dispuestas por séries lonjitudinales, de color amarillo casi anaranjado. C. muricata, IV. - Planta alampiñada con hojas profundamente 5-lobas, con los lóbulos dilatados, sinuoso-dentadas, con un diente cuspidado, largamente pecioladas, largas de $13\left[4,2^{\prime \prime}\right.$ sobre $21_{[}^{4}, 2^{\prime \prime}$ de ancho; zarcillos simples: pedúnculos largos de $11_{[} 2-$ $2^{\prime \prime}$, mientras los de las flores femeninas son mas cortos, con una bráctea acorazonado-sentadita y cerrada por la flor, con los segmentos del cáliz de las flores masculinas aovado-lanceoladas mas largos que el tubo y mitad tan largos como la corola, que lo es de $6-8^{\prime \prime \prime}$; fruto elipsoideal, crestado y tuberculado á la vez, largo de $2^{\prime \prime}$. M. balsamina, $\mathrm{L}$.

G. III. Cucumis, L. Fruto mas ó menos grande y sin puas siempre, 2. - Fruto pequeño ovoídeo largo de $1^{\prime \prime}$ y ancho de $8^{\prime \prime \prime}$, provisto de puas tiesas y largamente pedunculado, de color blanco algo amarillento; planta herbácea anual de tallo delgado, largo, ramoso y rastrero, pelierizada, con hojas profundamente $3-5-7$-lobas con los segmentos ob-aovados ó espatulados, obtusos, denticulados, de los cuales 3 son mayores y separados por un seno redondeado; pedúnculos de las flores femeninas largos y delgados ó filiformes. C. anguria, L. : C. T. V., 666.

2. Fruto bastante grueso cuyo tamaño y forma varian mucho, aovado ó sub-globoso con $8-12$ surcos lonjitudinales mas ó menos pronunciados, con la carne blanco-amarillenta ó amarilla, mas ó menos dulce y aromática; yerba de tallo tendido por el suelo, muy ramoso, áspero, con zarcillos y de hojas redondeadas, angulosas, largamente pecioladas; flores masculinas con el tubo calizinal subventrudo por la base $\mathrm{y}$ dilatado por el vértice; estambres inclusos, de anteras mas cortas que el conectivo; estigmas 3-4 cortamente bílobos. C. melo, L.: C. T. V., 603.- Frutos oblongos, sub-tríquetros, casi lisos cuando maduros y lustrosos, largos de 3 á $6^{\prime \prime}$, con los carpelos interiormente distintos y hasta separables, verdes, amarillos, blancos y hasta pintados; tallo herbáceo áspero, con zarcillos. tendido en el suelo y muy ramoso, de hojas acorazonadas oscuramente 5-lobas, con el lóbulo terminal algo mayor, largamente pecioladas; flores cortamente pedunculadas, sub-ternadas, grandecitas, cuyo tubo calizinal de las masculinas es campanudo con el limbo abierto y doblado hícia abajo; pétalos aguditos. C. sativa. L.: C. T. V., 666 . 
G. IV. Luffa, Cav. 1. Frutos largos como de 6 á $8^{\prime \prime}$, con ó sin ángulos y anchos de $22^{\prime \prime} 1[2$, mas ó menos lisos y siempre sin puas, 2. - Fruto ovoídeo largo de $1-1^{\prime \prime} 1_{[} 2$, con una punta por el ápice y provista de puas que despues de seca la fruta se vuelven como aguijoncitos. Planta herbácea de tallo enredadero delgado, muy ramoso, pubescente, pentágono, con hojas profundamente sinuadas ó acorazonado-arriñonadas por la base, casi redondeaditas, aguzadas por el ápice, terminado en una punta obtusita, sinuadas ó 3-5-lobadas, largas de $31_{[} 2-4^{\prime \prime}$, desde la base hasta el vértice y $4{ }_{2}[3$ si se la mide desde la parte mas inferior de los lóbulos prolongarlos de la base hasta la punta. y anchas de $4^{\prime \prime} 1_{[} 2$, con el peciolo $2^{\prime \prime} 1_{[} 2-3^{\prime \prime}$; zarcillos bífidos; cáliz de las flores femeninas con tubo cilíndrico largo de $1^{\prime \prime} 1 \Gamma^{2}$, que despues de la fecundacion se queda un pico que termina el ovario, pubescente así como él ; semillas prietas, óvalocomprimidas, de base un poco puntiaguda y con 4 tuberculitos oblongos situados dos de cada lado y como apareados, separados por una especie de cresta, vértice obtuso y algo mas grueso que la base. L. purgans, Mart. Poppya operculata, Rœm. Cucumis sepium, Мey.: C. T. V., 542.

2. Semillas parduzcas, lisas y ceñidas por una ala estrecha; tallo larguísimo muy ramoso, delgado, pelierizado, con hojas palmeadoangulosas, de un color verde oscuro, pelierizadas, redondeaditas, con 5 lobulos dentaditos; largas de $21_{[} 2,3,4$ " y anchas de $4-2^{\prime \prime} 1_{[} 2$; ásperas por ambas caras; espigas masculinas largas de 10, 14, 18", con las flores grandes ocupando la mitad superior; frutos cilíndricos ú oscuramente trígonos, marcados de 10 líneas ó surquitos lonjitudinales, de color verde mas oscuro, á veces provisto de tuberculitos. L. cylindrica, L. : C. T. V., 541. - Semillas prietas, lisas y sin ala alguna, tallo lampino anguloso, largo y ramoso, con hojas acorazonado-redondeaditas, 5 -lobas hasta su $1_{[} 3$ puntiagudos ásperas ó alampiñadas, largamente pecioladas, largas de 8 á $4^{\prime \prime}$ sobre $4-3$ " 1/2 de ancho zarcillos 3 -fidos ó simples á reces; flores de $1^{\prime \prime}$ 1 2-3 de diámetro con 5 estambres; fruto oblongo, liso y con 10 ángulos, opérculo pequeñito y no desprendiéndose espontáneamente L. acutangula. Roxb.

G. V. Doyerea, R. de Gy. Tallo del tamaño del dedo índice lo mas, sin tener la base mas gruesa, con un solo zarcillo siempre, hojas bastante grandes, blanquecino-pubescentes, asícomo el peciolo estriadito, de cara superior lustrosa y alampiñada, con 5 lóbulos dentaditos. D. emetocathartica, R. de Gy. : C. T. V., 496 bis. - Tallo cuyo tamaño alcanza el del brazo de un niño de un año, saliendo de un crecido cónico que ocupa la base y aplicado sobre el suelo en que echa raices bastante gruesas y poco numerosas, de $3-4-6$ " de diámetro segun la edad del vejetal ; ramitas tiernas, cilíndricas, estriadito-pubescentes y con dos zarcillos por la base de las hojas oblongas y un poco con figura de alabarda, lijeramente ondulosas por los hordes, enteras, puntiagudas por el vértice y acorazonadas por la base, ó mejor con un seno profundo formado por la prolongacion de los dos lados de la base; de cara superior asperita y pelierizadita, verde oscuro con líneas mas pálidas que corresponden con 
las nervaduras muy salientes $\mathrm{J}$ pronunciadas por la cara inferior, blanquecino-verdosa y aterciopelada; de cada lado de la costilla, que es la prolongacion del peciolo, salen 3 nervaduras principales muy pronunciadas, alternas, cuyos nervios se anastomosan entre sí y alcanzan hasta la circunferencia; además el vértice del peciolo cilíndrico á veces algo torcido, pubescente y estriadito parece dividirse y suministrar dos nervaduras que se estienden de cada lado de la base y limitan el seno, saliendo así de la base de la costilla; echan además cada una dos brazos ó nervaduras secundarios, cuyo inferior echa nervios mientras el superior alcanza la circunferencia y echa nervios cuyos superiores se anastomasan con los de la nervadura inferior de la costilla y los inferiores con los superiores de su hermano. D. angosturiensis, R. de Gy. C. T. V., 497.

G. VI. Cronosicys pomiformis, Gr. Trichosanthes pomiformis. C. T. V., 246-841.

G. VII. Lagenaria vulyarï, Ser. C. T. V., 539.

G. VIII. Melothria pervaga, Gr. M. pendula, Sw.: C. T. V., 547.

G. IX. Axguria umbrosa, Kth.: C. T. V., 604.

G. X. Crtrullus vulgaris, Schard. C.edulis, Spach. C. pasteca, Sagret. Cucumis citrullus, L. C. T. V., 604.

G. XI. Cucurbita pepo, L.,, en sus variedades. C. T. V., 66.5.

G. XII. Sicania odorifera, Vellazo. Cucurbita evodicarpa, Hasskarl.: C. T. V., 408.

G. XIII. Cenatosanthes tuberosa, Spreng. Trichosanthes tuberosa, W., y comiculata, Lam.: C. T. V., 215.

\section{CLASE LXI. - PASIFLORINEAS.}

Familic 142. - LOASEAS. - Plantas herbáceas ramosísimas que á primera vista parecen trepadoras pero que no lo son en realidad, con mucho pelo tieso cuya picadura ocasiona con frecuencia, escozor de hojas sencillas, enteras ó lobadas, pecioladas, alternas ú opuestas; flores tan pronto solitarias y axilares como en racimos terminales, siempre hermafroditas, y constan de un cáliz monosépalo tubuloso, libre ó adherente, con 5 divisiones y cuya garganta está algunas veces adoinada con 5 apéndices ó de un borde recortado; de una corola con 5 pétalos iguales, planos ó cóncavos y algo unguiculados, 5 ó mas estambres; ovario único libre ó adherente, súpero ó ínfero, unilocular, con muchos huevecillos insertos en tres placentas parietales, formando diafragma y situados entre las valvas y de cuyo vértice salen 3 estilos delgados á veces reunidos en uno solo, terminado por su correspondiente estigma, simples ó con figura de pincelito. El fruto es una cápsula coronada por el limbo calicinal que al madurar se desprende de ella como si estuviese articulado, y entonces se abre por el vértice desnudado en 3 ventallas por donde salen las semillas algunas veces ariladas, de embrion homótropo alojado en un endospermo carnoso. - Mentzelia aspera, L.: C.T. V., 793 .

Familia 143. - PAPA YACEAS. - Arboles lechosos ordina- 
riamente sin ramas, algo engrosados por la base, coronado su vértice por hojas largamente pecioladas, largas, simples, digitado-pinatífidas $\mathrm{y}$ sin estípulas, amontonadamente alternas superiormente; tales vejetales, que crecen con nucha rapidez y viven pocos años, á primera vista parecen como palmeras por su semblante y aspecto general. Flores unisexuales, dioicas, raras veces monoicas y hasta polígamas, cuyas masculinas están dispuestas en racimos compuestos Y apanojados, otras veces corimbosos, mientras las femeninas forman racimitos paucífloros tambien axilares. Las primeras se componen de un cáliz monosépalo mínimo y 5-dentado; de una corola inserta en el disco, enrodada con 5 lobos de estivacion valvar. Estambres 10 insertos en la garganta de la corola é inclusos, de filamentos lineares complanados, cuyos opuestos á los lóbulos de la corola son casi nulos, anteras entrorsas biloculares, con celdas paralelas y abriéndose lonjitudinalmente. En el centro se ve un pistilo rudimentario terminado en punta. Mientras las femeuinas constan de un cáliz monosépalo libre, semejante al de las masculinas, de una corola con 5 pétalos libres, lineares, insertos en el disco y de prefloracion valvar; pistilo con un ovario libre, único, sentado, aovado-globoso, 1-5-locular, con tabiques completos, muchos óvulos procedentes de 5 placentas parietales y lonjitudinales: estilo terminal cortísimo, terminado por un estigma deprimido bastante grande, radiado y con 5 lóbulos planos y rasgados por el ápice. Fruto por lo comun bastante grueso, es una baya aovado-oblonga con 5 ángulos mas ó menos pronunciados, carnosa, con muchas semillas fijas en las placentas parietales y cubiertas por una membranita fina conteniendo una sustancia líquida, aovadas, rugosas, prietas con tegumento crustáceo cuyo embrion ortótropo está alojado en el eje de un endospermo carnoso, de cotiledones elípticos y foliáceos con radícula corta, rolliza, centrífuga y próxima al liilo.

CARTCA, L. 1. Fruto grande ó solamente del tamaño de una manzana; tallo ordinariamente simple y bastante alto, 2. - Fruto pequeño del tamaño de una nuez; tallo bajito y de ordinario ramoso, como de unos $4-5^{\prime}$ de altura y $3^{\prime \prime}$ de diámetro, con hojas palmatítidas de lóbulos enteros; fruto globoso. $C^{\gamma}$. prosopera, L.

2. Flores en corimbos apanojados axilares grandes; fruto grueso de forma y tamaño bastante variados, aovado, mas ó menos oval, oblongo. Arbol cuyo tronco se eleva á 15 ó $20^{\prime}$, con 4 á $6^{\prime \prime}$ y mas de diámetro, con hojas profundamente 7-lobas, cuyos lóbulos son pinatífidos y puntiagudos, muy grandes y lampiñas, largamente pecioladas; panojas masculinas interrumpicas, de flores largas de $1^{\prime \prime}$; fruto largo de 6 á $10^{\prime \prime}$ y ancho de $3-5^{\prime \prime}$. C. papaya, L.: C. T. V., 844. - Flores en corimbos simples no axilares, pero sí saliendo de la corteza del árbol y en cualquier lugar ; fruto óval algo puntiagudo y del tamaño de una manzana; hojas ó-lobas, cuyos lóbulos mayores son pinatífidos y puntiagudos. C. cauliflora, Jacq.

Familia 144. - PASIFLOREAS. - Plantas herbśceas viraces, matas ó frutices sarmentosos provistos de zarcillos estra-axilares, de tallos muy largos y mur ramosos ordinariamente y delgados, con hojas sencillas, pecioladas, alternas, de figura y tamaño 
muy variados, enteras, dentadas, recortadas, lobuladas y hasta digitadas y pedaladas, cuyos peciolos mas ó menos largos llevan por su cara superior 2-4-6 glándulas de tamaño y figura variados, otras veces están desprovistos de ellas, además su base está acompañada de dos estípulas foliáceas cuya forma y tamaño varian mucho. Flores hermafroditas de ordinario primorosas, bastante grandes y pintadas de mas hermosos colores, solitarias ó en racimos axilares, se componen de un cáliz monosépalo, turbinado por la base, tubulado, con 5 divisiones mas ó menos profundas, de una corola con 5 pétalos insertos por adentro del tubo calizinal $y$ en su parte superior, los cuales suelen faltar algunas raras veces; estambres 5-monadelfos soldados con el ginóforo que pasa por el tubo que forma el andróforo, cuyo vértice lleva J́ filamentos cortos con una antera puesta al través, inserta por la parte mediana de su dorso, vacilante y bilocular, la cual da una vuelta para que en el acto de la fecundacion su cara corresponda al estigma; en el intérvalo que scpara el andróforo de los pétalos se hallan muchos apéndices de forma y tamaño muy variados y pintados, formando así una 2-3 séries ó coronas que salen del orificio ó de las paredes del tubo calizinal, pero suelen faltar bastantes veces. Pistilo formado de un ginoforo largo, filiforme que despues de haber atravesado el tubo androfórico con que está soldado inferiormente, lleva en su ápice un ovario simple, libre, ovaloblongo, unilocular polispermo, de cuyo vértice salen tres estilos gruesos muy engrosados hácia el vértice que se termina en un estigma sencillo, grueso, discoídeo, alguna rara vez sentado. El fruto es una baya mas ó menos gruesa, de forma y tamaño muy variados, corticosa, con muchas semillas, cuyo endospermo carnoso aloja un embrion homótropo y central.

Pasiflora, L. 1. Flores apétalas, 2. - Flores siempre provistas de una corola.

2. Cáliz 5-partido; corona de 2-3 series, cuya esterior ó las dos esteriores son filamentosas; peciolos bi-glandulosos : estípulas lineares cerdosas ó diminutas; pedícelos solitarios ó fasciculados, con la articulacion provista de bracteitas diminutas ó sin ellas es distante de la flor, de cáliz enrodado, amarillento-verdoso, corona pintada de azul ó de rojo, 3. - Cáliz 5-partido, de tubo ciatiforme, corona subtriseriada, cuya série esterior está distante del disco, filamentosa, mucho mas larga que la que ocupa la parte mediana: es sub-entera: peciolos biglandulosos; estípulas lineares y cerdosas ó diminutas, pedícelos bracteolados en la articulacion : flores encarnadas. Planta vellurla con pelo esparcido, con hojas aovadas por la base, aguzándose en punta deltoídea, mucronada, sub-enteras ó lijeramente alabardada-trílobas, largas de $3-2^{\prime \prime} 1_{1} 2,11_{\lceil} 2-1^{\prime \prime}$ de ancho por la base; peciolo largo de 8-6"', con dos glándulas situadas hácia su ápice, estipitarlas y pequeñas; 1 ó 2 pedícelos, largos de $2-1^{\prime \prime} 1_{l} 2$, cuya ar. ticulacion dista $2^{\prime \prime \prime}$ del vértice, mucho mas largos que el peciolo: cáliz color de escarlata, sub-ventrudo por la base, con segmentos lineares, dos veces mas largos que la corona estepior, baya globosa, negra, mitad mas corta que el ginóforo y ancha de $5^{\prime \prime \prime}$. P. regulis, Macf. 
3. Corteza del tallo corchosa, pero de ordinario lisa, lampiña; hojas aovadas, redondeadito-obtusitas superiormente, enteras, largas de $2-1$ " $1[2$, peciolo con doz glándulas sesiles, situadas por su parte media ; 2 pedícelos articulados hácia la parte mediana $3-4^{\prime \prime \prime}$ por debajo del ápice; cáliz amarillento, ancho de 8-10" de corona corta; baya ovoídea, larga de $4^{\prime \prime \prime}$ y casi dos veces mas que el ginóforo, ancha de $3^{\prime \prime \prime}$. P. pallida, L. - Alampiñada, corteza siempre corchosa; hojas redondeaditas ó aovadas, con tres lóbulos aovados ú oblongos, rara vez lanceolados, cuyo peciolo tiene dos glándulas subsesiles situadas por encima de su parte media ; $1-2$ pedícelos articulados, $2^{\prime \prime \prime}$ por rebajo de su ápice, cáliz amarillento, de ordinario ancho de $12^{\prime \prime \prime}$ 6-16, con corona corta; baya ovoídea, larga de 5-6-10"' y ancha de $3-5^{\prime \prime \prime}$, casi dos veces tan larga como el ginóforo. P. suberosa, L.

4. Cáliz sin invólucro alguno y peciolo sin glándulas, 5. - Cáliz 5 -partido sostenido por un involucro, 10.

5. Quinque-partido, de corona con $2-3$ séries, cuya esterior ó las dos esteriores son filamentosas; estípulas lineares, cerdosas ó diminutas; brácteas diminutas ó nulas, cáliz enrodado amarillento ó verduzco-blanquecino, 6. - Profundamente 5-lobo ó 5-partido, con el tubo campanudo ó ciatiforme; corona de 1-2 séries, cuya esterior inserta por adentro de la garganta del cáliz es filamentosa ó entera, mientras la interior es plegada ó laciniada y cubriendo el disco, 8 .

6. Hojas de cara inferior sin glándulas, 7. - Hojas cuya cara inferior está provista de glándulas; planta alampiñada, de tallo anguloso con hojas semi-redondeaditas, apenas 3-2-lobas ú ondeadas por el ápice anchamente trunco; glándulas esparcidas por su cara inferior, cuyos lóbulos laterales ó ángulos son estendidos, largas de 21 " 1 [ 2 y anchas de 4-2"; pedícelos simples $2-1$ articulados por encima de la parte media. Flores anchas de 10-12'", cuyo cáliz escede la corola blancuzca, con las séries esteriores de las 3 que forman la. corona. casi tan largas como los pétalos; baya globosa, lampiña, mas corta que el ginóforo. P. biflora, Lam. P. hemicycla, Mey.

7. Suavemente pubescente, con hojas redondeaditas, bílobas, acorazonalas por la base. cuyos lóbulos son estendidos y puntiagudos, separados por un seno mucronado frecuentemente, con un lóbulo rudimentario, anchos de 2-3", pedícelos simples 1-2 articulados hácia el vértice llevando flores anchas de $2-1^{\prime \prime}$, cuyo cáliz escede á la corola, ambos de color verdoso-blanco; filamentos esteriores de la corona formada de 3 séries, rojizos ó á veces verdes, casi tan largos como los pétalos; baya reluda, ovoídea ó á veces sub-globosa, 6 -costada y por fin mas larga que el ginóforo, roja, larga de $2^{\prime \prime}$ ó mas pequeña. P. rubra, L. P. capsularis, L. P. erubescens, Macf.

8. Cáliz campanudo ó ciatiforme, 9. - Cáliz ciatiforme solamente, rojo, corona entera: planta lampiña con hojas bílobas, ó transversalmente oblongas, 3 mucronaditas, cortamente pecioladas, reticuladas por ambas caras, ojillosas inferiormente por causa de glándulas distantes y dispuestas en dos séries, con los lóbulos redondeados por el ápice, acunadas ó sub-acorazonadas por la base: anchas de 2-1" sobre 1 " de largo y con peciolo de $4^{\prime \prime \prime} ; 1-2$ pedícelos simples, largos de $1-1^{\prime \prime} 1[2$, escediendo mucho el peciolo arti- 
culado casi por la parte media y con bracteitas cerdosas y largas ; cáliz carmesí cortamente ciatiforme mucho mas corto que sus segmentos ablongo-lineares; corona tubulosa, entera, trunca y teniendo encerrada la parte inferior del ginoforo que iguala la flor; baya ovoídeo-globosa. larga de 8-10"' y ancha de 6-8"'. P. mun'ucuja, L: C. T.V., $278-843$.

9. Campanudo solamente y verdoso-blanco; corona formada de una série 12-] 4-partida, con los segmentos un poco engrosados por el vértice, de color anaranjado y mucho mas corta que los pétalos; planta lampiña de tallo estriado, anguloso, con hojas redondeaditas, lijeramente 3-lobas por el vértice sinuoso ó trunco, anchas de $3-2^{\prime \prime \prime}$, de cara inferior ojillosa, con glándulas esparcidas y cuyos lóbulos redondeados y mucronaditos son erguidos; 12 pedícelos simples frecuentemente elongado-pendientes y articulados por debajo de su parte media; flores blancas, largas de $1-1^{\prime \prime} 1_{[} 2$, cuyo cáliz es un poco mas largo que la corola; baya globosa tan larga como el ginóforo y ancha de 10"'. P. penduliflora, Bertr. P. rotundifolia, Sw. - Campanudo ć ciatiforme y rojo; corona filamentosa, de divisiones lineares, obtusas, mucho mas cortas que el cáliz y aproximadas al disco. Planta lampiña, con hojas redondeadito-ovales, enteras, mucronaditas, cortamente pecioladas, reticuladas por ambas caras, cuya inferior es ojillosa por algunas pocas glándulas; largas de $1^{\prime \prime} 1$ [ 2 y anchas de $12-15^{\prime \prime \prime}$, con el peciolo de $3^{\prime \prime \prime}$ nada mas; pedícelos solitarios; largos de 1" y mucho mas que el peciolo articulado hácia su parte media, sin brácteas y racemosos superiormente; cáliz purpúreo de tubo cortamente ciatiforme de $1^{\prime \prime \prime} 1_{[} 2$ solamente y mucho mas corto que los segmentos oblongo-lineares, laryos de 10$12^{\prime \prime \prime}$ y mas; los pétalos tambien son oblongo-lineares; ginóforo igualando la flor y dilatado por el ápice; haya ovoídeo-globosa, larga de $6^{\prime \prime \prime}$ sobre $4-5^{\prime \prime \prime}$ de ancho. P. cuprea, L. P. cavanillessi, Dc.

10. Grande formado de 3 hojas ó 3-fido, persistente, de divisiones enteras; corona formada de 3-5 séries cuya esterior es filamentosa; peciolos siempre glandulíferos; estípulas elongadas frecuentemente foliáceas; pedícelos simples, axilares y no articulados, 11. - Ancho y formado de 3 hojuelas divididas; corona de 3 á 5 séries, cuya esterior es filamentosa; peciolos con glándulas largamente estipuladas ó sin glándula alguna; estípulas de ordinario divididas; 1-2 pedícelos simples axilares y no articulados; flores blanquecinas; planta herbácea velluda y glandulífera, con hojas redondeaditas 3-lobas ó angulosas acorazonadas por la base ordinariamente, pestaĩosas, con pelo y glandulitas situadas por la márjen dentadita ó sub-entera, anchas de 2-5"; estípulas multipartidas; 1-2 pedícelos; flores blaneas con la corona color de rosa, cuya série esterior es mas corta que la corola y la interior entera; cáliz de sépalos oblongos, largos de $I^{\prime \prime}$ o mas cortos igualando los pétalos y mas cortos que el último ó tercer segmento del invólucro cuyas tres divisiones ú hojuelas son pinatipartidas, el cual tercer segmento largamente cerdoso se termina en una glindula; haya ovoídea amarilla, ancha como de 4-3" P. fectida. C. T. V., 336.

11. Hojas enteras pinatinervias, 12. - Hojas palmatífidas y pal- 
matinervias. Planta lampiña con hojas profundamente 5-7-lohas, cuyos lobulos oblongos ú obovado-oblongos son puntiagudos y aserraditos, anchas de 6-4" y largas de 7 a $5 "$, cuyo peciolo, largo de 3-2", lleva hácia su parte media dos glándulas alternas y estipitadas y otro par situado cerca de su vértice, escediendo mucho las estípulas decíduas elongado-filiformes; invólucro 3-fido tan largo como la flor, con los segmentos aovados, mucronados y bien enteros; corona azul con listas transversas blancas, formada de 3 séries tan largas como la corola color de rosa y ancha de $4^{\prime \prime}$; baya globosa y ancha de $2^{\prime \prime}$. P. serrata, L.

12. Lampiñas y de tallo cilíndrico, 13. - Lampiñas con tallo 4alado ramosísimo y fuerte, con hojas aovado-redondeaditas, subacorazonadas por la base, mucronadas, un poco undulosas, bien enteras y con las nervaduras arqueadas, largas de 6-3" y anchas de

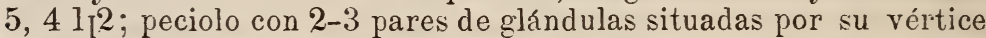
6 por debajo de él, mas largo que las estípulas grandes, aovadas ó aovado-oblongas, largas de 1 " y anchas de 8-10"; invólucro formado de 3 hojuelas aovadas, puntiagudas, bien enteras y membranosas, mas corto que la flor ancha de $3-5-2$ ", con los pétalos y la corola morados, formada de 5 séries, cuyas dos esteriores son mas largas que la corola; baya muy grande, larga de $15-10-6^{\prime \prime}$, sobre 6 , $4,3^{\prime \prime} 1[2$ de diámetro, oblonga ó elíptica. P. quadrangularis, L. : C. T. V., $37 \%$.

13. Peciolo con dos glándulas situadas por el ápice tan largo como las estípulas, espatulado-lineares ; hojas ovales bien enteras, coriáceas, largas de $4-2$ " sobre $3, " 3$ " $1_{1} 2$ de ancho; invólucro con tres hojuelas aovadas, obtusas, ondeadas y provistas de unas glándulas grandes y marjinales hácia su vértice, igualando la flor ancha de $2^{\prime \prime} 1[2$, blanca con manchas coloradas, de corona morada con estrias blancas, formada de tres séries y tan larga como la flor cuyos pétalos igualan al cáliz y están un poco escedidos por los filamentos espesitos de la série media de la corona; baya ovoídea, amarillenta, larga de $3^{\prime \prime}$ y ancha de $11{ }^{2} 22^{\prime \prime}$. P. laurifolia, L. : C. T. V., 606.Peciolo con dos glándulas situadas por encima de su parte media, mas largo que las estípulas lanceolado-lineares; hojas aovadas ó aovado-oblongas, puntiagudas, bien enteras, largas de 6-3" ; invólucro con 3 hojuelas aovadas, cuspidadas, bien enteras membranosas y pubescentitas interiormente, largo de $1^{\prime \prime} 1_{1} 2$, dos veces mas que la fior pintadita $y$ ancha de $3-5^{\prime \prime}$; corona formada de 3 séries cuya media es tan larga como la corola; baya globosa del tamaño de una manzana regular con una impresion en el ápice. P. maliformis, L. P. ornata, Kth.: C. T. V., 564.

Familia 145. - TURNERACEAS. - Plantas herbáceas o fruticulosas, algunas veces sub-frutices y frutices, pubescentes, peludas y ramosas, de hojas simples, alternas, sin estípulas, dentadas, rarísimas veces pinatífidas, y alguna vez que otra con dos glándulas situadas hácia el ápice de su peciolo; flores axilares mas veces lejítimas y de pedícelo libre, otras reces peciolares y de pedícelo reunido con el peciolo, unífloro, articulado hácia su parte media y provisto de dos bracteitas opuestas, á veces sentadas, y en ese caso se 
hallan hácia la base del cáliz; tales flores, ordinariamente amarillas, constan de un cáliz monosépalo frecuentemente colorido, de tubo cilíndrico ó infundibuliforme, sosteniendo un limbo de 5 divisiones aguzadas, iguales $\mathrm{y}$ de prefloracion imbricada; de una corola de 5 pétalos insertos en la parte inferior del tubo calizinal, iguales y de estivacion torcida. Estambres 5 insertos juntos con los pétalos y por debajo de ellos, con que alternan y son mas cortos que ellos, de filamentos libres, con anteras biloculares, oblongas, erguidas y abriéndose por la cara interna á favor de una grieta doble; ovario libre, óval y sub-trígono á la par, de cuyo ápice salen 3 estilos bipartidos por la base y multífidos por el vértice; cápsula con tres ventallas, unilocular, abriéndose desde el ápice hasta la parte media de las valvas que se llevan consigo las placentas multispermas situadas lonjitudinalmente en la parte media de su cara interna: semillas muchas provistas de un arillo muy lateral, delgadísimo y membranoso, crustáceas y reticuladas; embrion sub-encorvado, alojado en el centro de un endospermo carnoso, al go espatulado y cuya radícula se vuelve hácia el hilo, con cotiledones planos y subconvexos á la par.

Turnera, L.-1. Hojas con dos glándulas por su base, 2.-Hojas siempre sin glándulas; yerba anual pelierizada, alta de 5 á 8", muy ramosa, con hojas oblongo-lanceoladas, inciso-aserradas por encima de la base aguzada, con las venas deslizándose entre los dientes, cortamente pecioladas; flores sesiles, largas de 2-3"', color de curtiente, agrupadas en el vértice del peciolo, de cáliz pelierizado, 5 -partido, de segmentos lineares, igualando las bracteitas lineares y enteras, encerrando los pétalos arrollados, ungüiculados y de limbo redondeadito; cápsula casi tan larga como las bracteitas, con semillas encorvadas, profundamente hoyosas. T. pumila, L.

2. Hojas siempre bi-glandulíferas por la base; planta vivaz, fruticosa, alta de $11^{2} 2$ á $3^{\prime}$, con el tallo en varita, derecho y poco ramoso, pubescente, con hojas oblongas, aovadas ó lanceoladas, aguzadas, aserradas por encima de la base cuneiforme, pecioladas, larģas de $21_{[} 2,3,3^{\prime \prime} 1_{\lceil} 2$ sobre 12 , 15 " de ancho; pedícelos cortos peciolares; bracteitas lanceoladas, aserradas inferiormente, algo mas largas que el tubo calizinal; flores amarillas largas de $1^{\prime \prime} 1[2 \mathrm{y}$ anchas de como $12^{\prime \prime \prime}$, de cáliz profundamente 5 -lobo, con segmentos lanceolado-aguzados, un poco mas cortos que los pétalos ob-aovados; cápsula mucho mas corta que las bracteitas; semillas cilíndricas. T. ulmifolia, L. : C. T. V., 278. - Peciolo con dos glándulas por la base, pero que suelen faltar algunas veces. Planta fruticosa, velluda, ramosa y alta de $1 l_{1} 2$ á $2^{\prime}$, con hojas aoradas, obtusitas, bien festoneado-aserradas por encima de su base, cortamente pecioladas, de cara inferior aterciopelada, largas de $2-3$ " sohre 1 1/2 a 2 " de ancho; flores sub-sesiles, libres del peciolo, con las bracteitas lineares, enteras y casi igualando el cáliz pelierizado, 5-lobo, un poco mas corto que los pétalos y largo de $3-4^{\prime \prime \prime}$, cápsula mitad mas corta que las brácteas, con algunas semillas ovoídeo-s]obosas. T. parifiora, Benth. T. tomentosa. Kitl. 
ÓRDEN III. - CICLOSPERHOS.

\section{CLASE LXII. - CACTOÍDEAS.}

Familia 146. - CACTEAS ó NOPÁLEAS. - Plantas carnosas herbáceas, vivaces, mas ó menos leñosas por el centro, mas ó menos altas y ramosas, trepadoras ó rastreras, arbustos y hasta árboles bajitos, espinosos y liasta espinosísimos siempre, de tallos cilíndricos acanalados, estrellados, angulosos ó comprimidos, y en ese último caso compuestos de piezas que parecen articuladas las unas con las otras, con ó sin órden. y simetría, sin hojas ordinariamente, otras veces con hojas lejítimas; flores hermafroditas, casi siempre grandes y primorosas, solitarias y esparcidas por los ramos y saliendo siempre de entre las espinas ó al lado de ellas, rarísimas veces en espigas, las cuales constan de un cáliz monosépalo adherente al ovario ínfero, alguna que otra vez escamoso ó provisto de hojitas esteriormente, de limbo partido en muchísimos segmentos ó lacinias desiguales y que van confundiéndose insensiblemente con los numerosísimos pétalos dispuestos en muchas séries que forman la corola é insertos en la garganta del cáliz, junto con los estambres que tambien son muchísimos, de filamentos libres, larguísimos, filiformes, inclinados de un solo lado ó derechos, con anteras capilares; ovario inferior, unilocular, polispermo, de cuyo ápice sale un estilo simple, filiforme, larguísimo, terminado por 3 ó por mayor número de estigmas dispuestos á manera de radios. El fruto es una baya mas ó menos gruesa, de color, forma y tamaño muy variados, cubierta de espinitas muy punzantes ó sin ellas, umbilicada por el vértice, con una sola celda conteniendo muchas semillas pequeñas, pegadas á las paredes, ó de una placenta central, las cuales contienen debajo de un epispermo doble un emhrion recto ó corvo, sin endospermo ó con uno escaso y central.

G.I. Cereus, Haw. - 1. Tubo calizinal largo, prolongándose mas allá del ovario; estilo tan largo como los estambres inclusos, 2. Tubo calizinal corto y prolongándose mas allá del ovario, estilo eserto; tallo derecho pareciendo columna y con ángulos verticales; areolas provistas de pelo y por fin alampiñadas. Tallo alto de 6 á $20^{\prime}$ y espeso de 2-5", casi simple, obtuso por el vértice peludo, con diez ángulos, proeminentes, obtusos, separados por senos profundos; areolas con 10-8 espinas fuertes, abiertas, cuyas esteriores son mas cortas, largas como de 1", las del vértice del tallo escondidas por pelo; flores largas de $2^{\prime \prime}$, de color rojo pálido y con sépalos esteriores algo imbricados. C. Swartzii, Gr. Cactus peruvianus, Sw. C. fimbriatus, Desc.

2. Tallo con ramas sarmentosas ó rastreras, 3. - Tallo derecho y á manera de columna, alto como de $20^{\prime}$, articularlo y cuyas articulaciones, por fin cilíndricas, están aguzadas por el vértice y distantes de $23^{\prime}$, con 8-10 ángulos obtuso-convexos, curos areolos sin pelo tienen 9-12 espinas, aguijoniformes, largas de $5-2$ "', mientras las 
del tubo calizinal lo son de $8^{\prime \prime \prime}$ : de tales grupos 8 á 10 son dispuestas á manera de radios y estendidas, mientras las 2-1 del centro mas largas son rectas; flores infundibuliformes blancas, largas de $9-6^{\prime \prime}$ y abriéndose de noche; tubo calizinal cubierto de pelo largo. C. eriophorus, Lk. C.repandus, Nacf. Cactus repandus, L.

3. Ramos mas ó menos angulosos, 4. - Ramos cilíndricos con tubérculos dispuestos en 10-12 séries lonjitudinales, con 11-16 espinas cortas, de las cuales 8 ó 10 están dispuestas á manera de radios, y 3-4 mas largas, centrales y derechas, largas de $2 \cdot 3^{\prime \prime \prime}$. Flores color carmesí, infundibuliformes, largas de 2-3". C. flagelliformis. Mill. Cactus flagelliformis, L. C. T. V., 839.

4. Ramos triquetros ó con tres ángulos muy pronunciados y como cortantes, separados por un seno casi llano y profundo; areolos con 2-4 espinas mur cortas, cuya inferior es mas larga y de 1-2"': flores blancas de $\dot{8}^{\prime \prime}$ de diámetro cuando abicrtas, lo que sucede especialmente de noche. C. triangularis, Haw. C. triangularis, L. : C. T. V., 838. - Ramos con 5-7 ángulos, de areolos con 5-12 espinas cortas, casi iguales con el pelo, largas de 2-3"' ; fiores grandes blancas y desprendiendo una fragancia muy agradable, ahriéndose de noche y de 8 a $10^{\prime \prime}$ de diámetro. C. grandiflorus, Haw. Cactus grandiftorus. C. T. V., 48.

G. II. Opuntia, T. - 1. Corola mas larga que los estambres que igualan casi el estilo; embrion espiralmente rollado en derredor de un endospermo escaso; piezas del tallo ó ramos llanos, con tuberculitos provistos de cerdas, vello y de ordinario con espinas en la axila de las hojas abortas reemplazadas por puas carnosas; fiores laterales, 2. - Estambres esertos mas cortos que el estilo; planta alta de. 4 á 8', ramosísima, con piezas planas enderezadas, prolíferas, obaovado-oblongas, areolos muy distantes y por fin inermes y solamente con cerda y pelos, pero las del vértice de las piezas tiernas tienen unas espinas pequeñas y corvas; flores carmesi como de $2^{\prime \prime}$ lo mas de diámetro; de tubo calizinal ob-aovado; estambres rectos, largos de 12-15'" y el ovario de 1-1" 1 2. C. coccinellifera, Mill. Cactus coccinellifer, L. : C. T. T., 663.

2. Tallo derecho, articulado y nunca columnario, echando muchas piezas ó ramas derechas y jamás colgantes, 3. - Tallo columnario, continuo, espinosísimo, echando ramos colgantes y articulados, largos de 4-5', formados de piezas elongadas, oblongo-lineares, largas como de 1'; areolos aproximados con 3-4 espinas largas de $2^{\prime \prime}$, tiesas y aguijoniformes, flores rojizo-anaranjadas, anchas de. 1". O. spinosissima, Mill. Cactus spinasissimus, L.

3. Piezas ó artejos formando el tallo, ovales ú oval-oblongas, 4. - Piezas ó artejos con que se compone el tallo, ob-ovales, con areolos distartes y sin esquinas; planta alta de 4-6', derecha, articulada y prolífera, con las articulaciones espesitas, larsas de 4-8", raras veces con una espina diminuta en los areolos; flores amari. llas de 3-4", con el tubo calizinal claviforme. O. ficus indica, Mill. Cactus ficus indica, L. C. pseudotuna, Macf. : C. 'T. V., 598-664.

4. Vejetal alto de $3-4^{\prime}$, articulado-prolífero, con las piezas ovales, largas de 4-8" de areolos distantes con $4-5^{\prime \prime}$ o á veces $6-1$ espinas 
fuertes, desiguales, cuyas mayores son largas de $1-1^{\prime \prime \prime} 1_{1} 2$, amarillentas; flores amarillas, anchas de $3-4^{\prime \prime}$, con el tuto calizinal obaovado. O. tuna, Mill. Cactus tuna, L. - Planta alta de 3-5', dere(cha, articulado-prolífera, con los artejos oval-oblongos, erizados con muchas espinas bravas, largas de $11_{1} 4-2$ " y blanquecinas; areolos con 1-3-4 espinas tiesas, abiertas y divaricadas ó sub-reflejas, cuya superior es frecuentemente dos reces mas larga que las inferiores; flores rojizas, anchas de $l^{\prime \prime}$ y de tubo calizinal anchamente turbinado O. triacantha, Haw.

G. III. Rhipsalis. - Tallo largo de 1-2', cilíndrico por la base, simplemente ramoso, alado por el vértice, que parece los ramos alternos, largos de 6-12", llanos, oblongos ú oblongo-lineares, apartadamente festoneados y aguzándose por la base estipitado-articulada; flores pequeñas, blanquecinas, anchas de $4^{\prime \prime \prime}$; bayas casi negras, ovoídeo-globosas y puntiagudas por la base; de embrion anular y con el endospermo apenas notable. $R$. suartziana, Pfeiff. Cactus alatus, Sw. - Tallo largo de 1-6', con ramos verticilados ú opuestos, cilíndricos, articulados, colgante y cuyas ramitas largas de $3^{\prime \prime}$ son obtusas por ambos estremos; areolas distantes alampiñadas; fiores blanquecinas pequeñas, anchas de 2 ", baya blancuzca, ovoídeoglobosa y larga de 2-3"'. R. cassytha, G. Cactus pas'asiticus, L.

G. IV. Peirescia, Plum.-1. Flores nunca amarillas, 2.-Flores amarillas y siempre solitarias, saliendo antes que las hojas. Arbol de 15 á $20^{\prime}$ de altura, armado con espinas, largas, fuertes, en grupos esparcidos sin órden por el tronco y los ramos largos, estendidos y divaricados. Hojas ob-aovadas, largas de $1^{\prime \prime} 1$ l 2 y anchas de $8-10^{\prime \prime \prime}$, cortamente pecioladas, con pelo blanco en la insercion del peciolo $y$ una espina solitaria, recta, muy fuerte, subulada y muy punzante, de color como ceniciento, con la punta algo rojiza y transparente. Capullo de las flores piriforme, curos sépalos verdes se terminan por una puntita morada, con pelo blanco por la base. Filamentos de los estambres al abrirse la flor teñidos de morado por el vértice, pero ese matiz no tarda en desaparecer y se quedan anaranjados, mientras la mitad inferior es blanca, de anteras amarillas, basifijas asaeteadas, volviéndose horizontales para verificarse la fecundacion; estilo blanco y amarillento por el vértice, hastante grueso, terminándose por 5 estigmas blancos y glandulosos; fruta amarillenta redondeada, como de $\mathrm{l}^{\prime \prime}$ de diámetro; flores exhalando la fragancia suave y agradable de la Primula grandiflora de Europa, llamada vulgarmente primavera. $P$. guyanensis, R. de Gy. : quizás será una variedad del peirescia bleo? C. T. V., 600.

2. Flores purpurinas, 3. - Flores blancas dispuestas en cimas flojas y terminales; árbol como de $15^{\prime}$ de alto, cuyo tronco está armado con espinas dispuestas en hacecillos y derechas, de ramos largos y como colgantes, con hojas oblongo-elípticas, largas de 1$1^{\prime \prime} 1_{1} 2$, con $1-2$ espinas corvas, situadas por la base pubescente del peciolo, largas de 1-3"'; pétalos ovales; baya con hojitas estrechas. P. aculeata, Mill. C'actus perestia, L.: C. T. V., 601.

3. Flores purpurinas solitarias, baya sin hojuelas; árbol del tamaño de unmanzanode los medianos, con los aguijones morenuzcos; hojas 
obaovado cuneiformes, acompañadas de un aguijon solitario, mientras que en el tallo son fasciculados. Flores solitarias y terminales, con los pétalos escotados, sub-redondos ; fruto globoso retuso, unbilicado, con muchas semillas nęras. P. portulacifolia, Haw.

\section{CLASE LXII.-CRASULÍTEAS.}

Familic 147. - CRASULÁCEAS. - Plantas herbáceas ó arbustos algunas veces, con hojas carnosas, alternas, sin estipulas enteras ó lobuladas. lampiñas ó pubescentes, mas ó menos pecioladas, de flores ordinariamente cimosas v centrífugas en la floracion, hermafroditas y que se componen de un cáliz formado de 3 á 20 sépalos, mas ó menos soldados entre sí por la base, y por tanto multipartido. Corola con tantos pétalos como sépalos y alternos con ellos, inserta en lo mas bajo del cáliz, frecuentemente monosépala, por haberse soldado los pétalos. Estambres insertos con los pétalos y en número igual ó doble, opuestos entónces unos y alternos otros, mas largos y precoces, cuyos filamentos libres y aleznados llevan anteras ovales, biloculares y lonjitudinalmente dehiscentes. Pistilo cuyo ovario es formado de tantos carpillos cuantos pétalos hay y opuestos á ellos en verticilo ó algo entresoldados y uniloculares, pluriovulados, terminados cada uno por su estilo corto y persistente, con su correspondiente estigma; la base de los carpillos está acompañada de escamas nectríferas, algunas veces desvanecidas. El fruto consiste en folículos interiormente dehiscentes, libres ó raras veces entresoldados en forma de caja plurilocular y de ordinario polisperma, cuyas semillas diminutas, de endospermo tenue $y$ carnoso, tienen un embrion recto, con los cotiledones cortísimos y la raicilla dirijida al hilo.

Tribu I. Crasuleas lejítimas ó Eucrasulaes. Carpillos enteramente libres.y dehiscentes por el ángulo interno Bryophyllum calicinum. C. T. V., 662.

Tribu II. Crasuláceas anómalas ó Dimórmeas. Carpillos soldados por la base en forma de cápsula plurilocular.

\section{CLASE LXIY. - CARIOFILINEAS.}

Familia 148. - CARIOFILEAS. - Plantas herbáceas anuales ó vivaces, de base á veces fruticulosa, cuyo tallo nudoso y como articulado lleva hojas simples, sentadas, pequeñas, lanceoladas, mas ó menos coriáceas, opuestas ó verticiladas, con ó sin estípulas. Flores hermafroditas y raras veces dioicas, solitarias, en cimas ó panojas axilares o terminales, constan de un cáliz monosépalo tubuloso. cilíndrico, mas ó menos vejigoso, con 5 divisiones ó dientes; otras veces formado de $4-5$ sépalos distintos; de una corola con 5 pétalos largamente unguiiculados, cariofilada; 5 ó 10 estambres hipojínicos. perijínicos y epijínicos; ovario mas ó menos globoso ú oval, unilocular, con la placenta central, de cuyo ápice salen 2-5 estilos, ter- 
minados por un estigma subulado. Fruto capsular polispermo, cuyas semillas pequeñas contienen un embrion acompañado de un endospermo feculento y central.

\section{Ancilisis dicotómica de las tribus.}

1. Sépalos nunca libres, pero mas ó menos reunidos por la base ó cáliz monosépalo, 3. - Sépalos libres ó reunidos por la base, ¿2.-

2. Cinco sépalos libres ó reunidos por la base; pétalos perijínicos 6 nulos; hojas provistas de estípulas escariosas. T. I. ParoníQUIEAS. A. - Dos sépalos libres y distintos ó reunidos por la base; pétalos hipojínicos: hojas un poco espesas, sin estípulas escariosas. T. II. Portuláceas. B.

3. Sépalos reunidos por la base, formando un cáliz 5-partido; apétalos; cápsula plurilocular; estambres hipojínicos; hojas arrosetadas, con estípulas fugaces ó apenas notables. T. III. MullujíNEAS. C. - Cáliz 5-partido persistente; flores apétalas; estambres perijínicos; hojas sin estípulas y espesitas. T. IV. Frcoídeas. D.

A. Drymaria, W. - Yerbecita anual, lampiña, cuyos tallos débiles y ramosos se elevan á $1-l^{\prime} 1_{[} 2$, cuando están sostenidos por los vejetales circunvecinos, de hojas orbiculares, sub-acorazonadas por la base, anchas de 4-6"" ; pedícelos filiformes dispuestos en cimas laterales; sépalos aovado-lanceolados, aguzados, lampiños y largos de $1^{\prime \prime \prime} 1_{1} 2$; pétalos profundamente bífidos, inclusos; estambres de ordinario 3; cápsula igualando el cáliz, con 2-8 semillas pequeñitas. D. cordata, W. : C. T. V., 32. - Hojas mas pequeñas, de $2^{\prime \prime}$ de diámetro solamente; sépalos una mitad mas pequeños que los de la precedente; estambres 2 solamente; semillas menos numerosas, $D$. diandra.

C. Nolltigo. - Yerba anual, lampiña, muy ramosa y alta de 6 a $8^{\prime \prime}$, sin hojas por la base, las cuales se hallan dispuestas en roseta en los nudos mas inferiores, espatulado-oblongas; flores en corimbos apanojados, con pedícelos filiformes; estambres 5 ; semillas pequeñas granulosas. 1 . nudicaulis, Lam. M. bellidifolia, Ser. Pharnaceum spathu'atum, Sw. Ph. bellidifolium, Desc. : C. T. V., 602.Yerbecita anual, lampiña, ramosa, con hojas espatuladas ú oblanceoladas $y$ arrosetadas sobre cada nudo, pedícelos unífloros dispuestos en umbela; estambres 3; semillas lisas con 3-5 estrias. M. verticilata, L.

B. G. I. Talinum, Ad. - Flores blanco-rojizas ó blancas teñidas de rosado, 2. - Flores amarillas.

2. Planta fruticulosa mas ó menos ramosa, alta de 1' 1 「2 á 2", ó de tallo simple, con hojas alternas ob-aovado-lanceoladas, aguzándose hácia la base sub-sentada; flores en cimas terminales paucífloras sostenidas por un pedúnculo largo, triangular, pedícelos tríquetros con flores anchas de 10 á 12 "', cuyos pétalos redondeados tienen 6"' de diámetro; estambres como 30 ; estigmas divergentes; semillas diminutamente granulosas. $T$. triangulare. T. crassifolium. T. fruticosum, W. Portulaca triangulare. P. crassicaulis, 
Jacq: C. T. V., 658. - Yerha fruticulosa cuyo tallo derecho, de 1 á 2 ' de alto, sale de una raiz algo tuberculosa, hojosa hasta su parte media solamente cuando es florifera, con hojas de ordinario opuestas, largas de 2-2" $1_{1} 2$, con el peciolo de $1_{1} 2$ " y anchas de 1 " 1 [2 á 2 "; flores de color carmin pálido, en panojas terminales, elongadas sin hojas, largas de 10-15-20", un poco inclinadas por el vértice, formadas de cimitas dicótomas, con pedícelos filiformes ; sépalos decídous, redondeaditos, apicillados; pétalos pequeños ob-aovados, largos de 3 " y anchos de $11{ }^{2} 2$ á 2 ", como 15-20 estambres; semillas muy diminutamente granulosas. T. patens, IV. T. fruticosum, Macf. Portulaca patens, P. paniculatum, Jacq. C. T. V., 658.

G. II. Portulaca, Tu. Flores amarillas, 2. - Flores purpurinas; yerba anual fruticulosa, difusa, con ramos simples, largos de 6-8", con hojas sub-cilíndricas, aguzadas, alternas, largas de 2-3"', con lana blanca bastante larga en las axilas; flores en grupos terminales cercados de lana blanca, anchas de 8 a 10"'; de cáliz con las divisiones lineares no aquilladas; pétalos escotados; estambres indefinidos; estilo 5-6-partido; semillas diminutamente granulosas. $P$. pilosa, L.

2. Yerba anual no fruticulosa de tallo mas ó menos ramoso, alto de $8^{\prime \prime}$ á $18^{\prime \prime}$, carnosa, con hojas espatuladas, redondeadas por el ápice, ordinariamente opuestas, con las axilas lampiñas; flores sesiles, agrupadas ó solitarias, de cáliz con las divisiones aquilladas; pétalos escotados, estambres 7-12; estilo 5-partido; semillas diminutamente granulosas. P. oleracea. L.: C. T. V., 657. Variedad con hojas pequeñas, largas de 2-4"', con las axilas á menudo cortamente peludas. P. parviflora, Haw. - Planta anual fruticulosa, difusa, con muchos ramos fastijiados, de hojas cortas sub-cilíndricas, aguzadas, alternas y largas de $2-3$ "', con las axilas peludas; flores en grupos encerrados en lana densa éinvolucrados; divisiones del cáliz linear-oblongas no aquilladas; pétalos escotados; estambres como 20 ; estilo $3-5$-partido; semillas granulosas. $P$. halimoides, L.

G. III. Cla tronia cubensis, Don.C. perfoliata, Bd. C. T. V.,659.

D. G. I. Sesuvium portulacastrum, L.: C. T. V., 660. - G. II. Trianthema monogymum, L.. C. T. V., 661.

\section{SEGGION III. - EPIJINOS.}

\section{CLASE LXV. - UMBELIFERÍNEAS.}

Familia 149. - UMBELIFERAS o APIACEAS. - Plantas generalmente herbáceas, de tallo hueco y estriado, anuales, bisanuales y perennes, á veces frutices y hasta arbustos, de hojas compuestas o descompuestas, mas raras veces simples, alternas con la base del peciolo algo envainadora. Flores siempre hermafroditas, dispuestas en umbelas simples ó compuestas, cuya base se halla frecuentemente acompañada de un invólucro polífilo, que suele faltar algunas veces, constan tales flores de un cáliz monosépalo, adhe- 
rente, con limbo entero ó 5-dentado; de una corola de 5 pétalos alternos con otros tantos estambres epijínicos. Ovario ínfero bilocular, con un solo óvulo pendiente en cada celda, cuyo vértice está coronado por un disco bílobo de cuyo centro salen dos estilos diverjentes, terminándose en un estigma sencillo. El fruto es un aquenio doble de figura y tamaño variados, con ó sin alas por fin ó al madurarse separándose y colgando del carpóforo filiforme y central ó columna que les tenia reunidos; de semilla ordinariamente invertida adherida al pericarpio, de embrion alojado en el ápice de un endospermo grande carnoso ó casi córneo.

\section{Anátisis dicotómica de las sub-irdenes y tribus.}

1. Endospermo esteriormente mas ó menos convexo é interior mente plano. S.-órd. I. Ortosperneas, 3. - Endospermo mas ó menos convexo esteriormente y nunca plano interiormente, 2.

2. Recorvado por los lados al rededor del eje. S.-órd. II. CAMerlospermeas, 14. - Encorvado de la base al ápice. S.-órd. III. $\mathrm{CE}_{\mathrm{E}}$ LOSIERMEAS, 17.

3. Umbelas simples ó imperfectas; fruto sin fajas, 4. - Umbelas compuestas ó perfectas; fruto con varias fajas, rarísimamente nulas, 6.

4. Fruto lateralmente comprimido. mericarpios convexos ó agudos por el dorso; hojas siempre simples. T. I. Hidrocotileas. A. - Fruto nunca lateralmente comprimido; hojas compuestas ó simples, 5 .

5. Fruto contraido hácia la comisura, paralelamente bisurcado; mericarpios complanados por el dorso. T. II. Mulineas. - Fruto aovado-globoso. T. III. SAxiculets. - Eryngium fotidum. L. : C. T. V., 330 .

6. Pauciyugadas, 7. - Multiyugadas.

7. Fruto no lateralmente comprimido ni dídimo tampoco, 8. Fruto lateralmente comprimido ó dídimo. T. I. Ammeas. - Apium gracenlens, L.: C. T. V., 265. - Petroselinum sativum, Hoff. C. T. V., 264-752. - Pimpinella anisum, L.

8. Fruto comprimido por el dorso de los mericarpios, 9. - Fruto no comprimido y en la seccion transversal rollizo ó rollicito ó con mericarpios comprimidos por el dorso. 'T. II. Seselíneas. Fœniculum vulgare, Gœrtn.: C. T. V., 262.

9. Con rafe casi nunca central, 10. - Con rafe casi central y márjenes de los mericarpios prolongadas en alas libres. T. III. ANGELÍCEAS.

10. Con rafe marjinal y márjenes de los mericarpios prolongadas en alas soldadas á manera de una sola. T. IV. Peucedáneas.Con rafe marjinal y márjenes dilatado-engrosadas, enteras ó plegado-dentadas. T. V. Tordilíneas.

11. Fruto comprimido por el dorso de los mericarpios ó... 12.Fruto algo contraido por los lados de los mericarpios con todas las lomas apteras. T. VI. Cuníseas. 
12. Mas ó menos rollizo, 13. - Nunca rollizo, con todas las lomas ápteras, las secundarias á veces casi nulas. T. VII. SileríNEAS.

13. Casi rollizo, con las lomas primarias sobrepuestas á las laterales debajo del plano comisural, y muchas de las secundarias aladas. T. VIII. TAPSIEAS.-Rollizo con las lomas primarias sobrepuestas á las laterales en el plano comisural y las secundarias prolongadas en aguijones libres ó unidos en forma de ala por la base. T. IX. Daucíveas. - Daucus carota, L., C. T. V., 267.

14. Multiyugadas, 15. - Pauciyugadas, 16.

15. Fruto cilindráceo, algo comprimido por el dorso de los mericarpios, con las lomas primarias filiformes y las dos secundarias laterales, aladas. T. I. Eleoselíness. - Fruto lateralmente comprimido ó rollizo, con las lomas primarias sobrepuestas á las laterales en el plano comisural, y todas las secundarias prolongadas en aguijones ó cerdas. T. II. Caucalíneas.

16. Fruto lateralmente comprimido o contraido, prolongado, frecuentemente picudo. T. III. Escandicíneas. - Anthriscus cerefolium, Hoff.: C. T. V., 266.-Fruto hinchado, lateralmente contraido ó comprimido. T. IV. Esmírseas. - Aracacha esculenta, Dc. : C. T. V., 214.

17. Fruto lateralmente comprimido y dídimo ó globoso, con las lomas primarias y secundarias ápteras y frecuentemente apenas distinguibles. T. . Corlasdreas. Coriandrum sativum, L. : C. T. V., 163.

A. Hynrocotyle, L. Yerba lampiña, de tallo rastrero, filiforme echando raices en el suelo, bastante largo, con hojas abroqueladas por la parte mediana, orbiculares, festoneadas, largamente pecioladas, anchas de 15-12-8-6"', con los peciolos largos de 5-4-3-2-1"; pedúnculos casi tan largos como los peciolos, con una umbela de flores en su ápice; fruto didínamo, escotado por la base, con 5 estrias, cuyas intermedias laterales son apenas notables. $H$. umbellata, L. - Yerba de tallo rastrero y echando raices, con hojas fasciculadas, acorazonado-redondeaditas ó acorazonado-aovadas, con un seno abierto, festoneado-dentadas ú ondeadas y alampiñadas, anchas de 2 á $1^{\prime \prime} 1_{[} 2$ y largas de $1^{\prime \prime} 1_{[} 2$, con el peciolo peludo y largo de $2-3-4-5$ " y mas, escediendo el pedúnculo corto, con umbela contraida formada de algunas pocas flores o de 1 sola; fruto reniforme, de aquenios con 9 estrias y reticulados ; las 5 estrias son mas proeminentes que las demas. H. asiatica, L.: C. T. V., 809. - Variedad : hojas acorazonado-aovadas, dentadas ú ondeadas, largas de 221 l 2 . $1^{\prime \prime} 1_{[} 2$ y anchas de $1^{\prime \prime} 3\left[4 \text { á } 1^{\prime \prime}\right]_{[} 2$, con el peciolo de 7-5-4-3". $H$. repanda, Pers. $H$. brevipes, Macf. 


\title{
APÉNDICE $1^{\circ}$
}

\section{NOTIGIA SOBRE LAS MADERAS ÚTILES DE LAS ANTILLAS}

\author{
$\mathbf{Y}$
}

ALGUNAS DE LA REPÚBLIGA DE TEXEZUELA,

CONSIDERADAS POR SUS APLICACIONES TAN PRONTU Á LA EGONOMíA DOMÉSTICA Y FÁBRICAS DEL CAMPO, Á LAS CONSTRUCCIONES CIVILES Y NATALES, Y AdeMás Á LA EBANistería Y AL ARTE DE TORNEAR; PERO TAMBIEN COMO COMPLEMENTO NECESARIO DE NUESTRA OBRA, QUE CON EL TIEMPO Y UN TRABAJO CONTINuo y Mut ÁRDúo SE HA vuelto COMO ENCICLOPEDIA DE BOTANICA APLICADA.

Al emprender ese trabajo lo hicimos principalmente en obsequio de nuestros numerosísimos amigos y suscritores que nos habian manifestado el deseo de tenerlo, y gustoso echámos inmediatamente mano á la obra; pero inexperto ignorábamos entónces cuan árdua habia de salir esa tarea; en efecto, al llevarla á cabo, hemos ido tropezando á cada momento con dificultades casi insuperables, sea para conseguir las muestras necesarias, sea para dar de ellas la descripcion mas satisfactoria posible, porque una sola madera presenta con la mayor frecuencia diferentes aspectos y á veces hasta otro color, segun el modo con que haya sido labrada ; sus varias edades, la riqueza ó la pobreza del suelo en que se haya criado.y en fin un sin 
número de circunstancias desconocidas hasta ahora. ¿Cuál cosa mas difícil que espresar con palabras sus colores tan variados y ese sin número de matices que un ojo muy ejercido y muy práctico puede solo apreciar, y que sin embargo sirven para diferenciarlas á primera vista, sin que el observador pueda darse razon de lo que ha aprovechado para caracterizarlas así? Además un tinte ó matiz le parece á uno de un color mientras que otro lo percibe de otra manera, r por consiguiente habrá de emplear otras palabras para espresarlo. Sin embargo, hemos seguido adelante, sin que tales dificultades nos desanimen: es verdad que nos han entorpecido $y$ abrumado algunas veces, pero solo momentánea y casualnente; hemos hecho, pues, todo lo posible para salir bien de tan dilícil y hasta fastidiosa pero muy útil empresa.

La hermosa coleccion de maderas perteneciendo á nuestro amigo el señor D. Francisco Sauval, de la Habana, la cual está ahora en el colegio de los PP. Jesuitas de esta ciudad, cuyo eminente director ha tenido á bien ponerla á nuestra disposicion, nos ha facilitado mucho el estudio de las maderas de la isla de Cuba; además nuestro buen amigo rá la vez cuñado el señor D. S. Devenish de la isla de Trinidad; quien largo tiempo hace se ha dedicado al estudio prictico de las maderas de esa isla, de las cuales ha formado una hermosa y numerosísima coleccion cuyas algunas muestras ya han sido mandadas á Inglaterra para la esposicion universal y han sido muy admiradas; no solamerte ese caballero ha tenido la bondad de ponerla á nuestra disposicion, sino que nos ha regalado un ejemplar de ella y además nos ha participado muchísimos datos interesantes con los que hemos enriquecido esta noticia. Muchos amigos nuestros, tanto de Puerto-Rico como de Venezuela, nos han facilitado muchos datos útiles sobre la materia; agradecido, pues, del favor que todos esos señores han tenido á bien dispensarnos, aprovechamos esta ocasion para darles las gracias por su benévola cooperacion.

Para esta noticia empleamos el método alfabético, aplicado á los nombres vulgares españoles de las maderas; cuando no los tienen utilizamos los franceses $\mathrm{y}$ hasta los ingleses; escusado es decir que nunca olvidamos acompañarlos con la sinonimia en esos tres idiomas y en latin ó científica, pero algunas no han sido clasificadas hasta ahora por no haber podido conseguir sus flores ni sus frutas tampoco. La letra $\mathrm{F}$ que sigue á veces á la sinonimia significa $f a-$ milia, con su número correspondiente, y las letras M. D.-Gı, Líétodo dicotímico en el tomo I, con el número del geénero en donde se hallará la indicacion de la familia en que está el vejetal.

\section{A}

Acana, jacana, Cba.; ansubo, Prco.; balata, Trd.; purgo, mis. Or: co. - Contrevent, Antilles françaises; z'os macaque, Trd.; moukey balata, Trd. - Achras disecta, Forst.; sideroxylon pali- 
dum; mimmsops balata, Crucy; m. globosa, Gœrtn., M. D.-G.638. - Arbol muy grande cuyo cañon del tronco alcanza hasta $100^{\prime}$ ó algo menos de altura, con un diámetro de una vara y hasta vara y media, bastante coposo y cuya fruta comestible cuando madura es muy agradable y sabe como á níspero; bastante abundante en ciertos lugares de las Antillas como de Costa-Firme.

La madera es color almagrado ó parecido al de sangre, casi uniforme, pero bastantes veces con vetitas paralelas y algo mas oscuritas, otras veces son mas pálidas, tambien con algunas listas apenas pronunciadas y de un tinte oscuro y á veces morenuzco, otras veces son mas pálidas y mas anchas, de corazon á veces color castaño muy oscuro. Es muy sólida, bien dura, pesa bastante, de grano muy fino, contestura fibrosa y bien apretada: es tenida por incorruptible, susceptible de hermoso pulimento. Su peso específico es de 1,049 y del monkey bones de 1,030. Se la suele emplear para tirantes, armazones, etc. y otros usos en las fábricas civiles y tambien para las construcciones navales; sirve especialmente para cuadros de puertas y de ventanas, tablones, vigas y por fin estacas de cercados.

El árbol llamado contrevent será quizás una variedad del anterior, porque su madera bien pesada, muy dura y tambien de grano apretado y fino, tiene su textura mas fibrosa, su color gris rojizo bastante pálido, mas ó menos teñido tan pronto de oscuro como de mas claro, con algunas vetas irregulares y desiguales achocolatado-rojizas que cortan con el fondo bonitamente veteadito y formado como de dibujos muy lindos.

Abejuelo, Prco. - Ese árbol se produce con abundancia en la parte N. de la isla de Puerto--Rico; su madera es fuerte, de color rosado y se rompe verticalmente; su altura es de 40 á 50 piés; el diámetro del tronco llega hasta un pié; su uso comun es para estanterías de casas.

Abispillo, Prco. - Árbol abundante en toda esta isla, que se eleva como á 40 ó $50^{\prime}$ de altura y cuyo tronco llega á tener 12-24" de diámetro; su madera es quebradiza, de color castaño el corazon, $y$ sus estremos blancos; se rompe oblícuamente; sirve para tablazon de casas.

Aceitillo liso, Prco. - Ese árbol silvestre, que abunda por el X.0 . de esa isla, se eleva hasta $50^{\prime}$ de altura, y el diámetro de su tronco algo torcido es de 3 '. Su madera es muy apreciada para muebles.

Aceitillo labrado, Prco. - Se halla en los mismos lugares que el anterior, cuya altura y tamaño tiene; su madera, aun mas apreciada tambien para muebles, es algo mas dura, de color amarillo primorosamente veteado y rompe verticalmente.

Acetillo. - Esa madera es muy fuerte y muy buena para construcciones y fábricas del campo y casi todas las obras de carpintería que necesitan fuerza; es además bien duradera.

Acetunillo, Cba. - Agotoxicum puntatum? - Ese árbol, que se halla abundante en la isla de Cuba, suministra una madera muy buena para fábricas y construcciones, y por esa razon bastante apreciada. Dicen que sus frutos son venenosos para los cerdos. 
Acoma, mastic, paltiva, Trd. - Sideroxylum mastichodendron, Jacq.; Bumelia palida, Sw.; sidernxylum palidum, Spreng. -Arbol grande $y$ corpulento, que se eleva como á 20 metros de altura, con el tronco largo como de unas 8 á 10 varas, cuvo diámetro es como de 2.5 á $36^{\prime \prime}$, algo mas ó menos. Suministra una madera de buena dureza, de peso algo mas que regular, cuya textura es compacta y el grano bastante fino; de color amarillento ó camuza claro, con vetas ó remolinos algo parduscos ó á veces rojizos saliendo de los nudos poco pronunciados, de manera que á primera vista su color parece casi uniforme, á veces algo jaspeadito; es muy sólida y muy apreciada para cualquiera obra de carpintería que necesita fuerza y resistencia á la vez; se cria en los distritos montañosos.

Aceituna, Prco. - Abundante en la parte E. de la isla, ese árbol se eleva á 35 ó 40' de altura, y suministra una madera blanda, color claro, que rompe oblícuamente y sirve para armazon de casas.

Aguacatillo, Prco., Cba. - Laurus borbonia, L.; nectandra leucantha, Nees. II. D. - G. 359. - Arbol bastante grande y coposo, que se eleva como á $60^{\prime}$ de altura, cura madera es verde claro o blanquecina verdosa, de poca dureza $y^{2}$ sin embargo bien resistente; bastante liviana; se emplea para cajas, tapabocas y algunas obras de carpintería para el forro de las casas. Su fruto sirve para cebar los cerdos.

Aguatacaro, guatequiero, Trd.; guatacare, Gna. - Lecythis idatimon. - Arbol bastante grande que se eleva como á 40 ó $50^{\prime}$ de altura, muy comun en los terrenos arcillosos y algo húmedos y da una madera muy buena y mu apreciada, de color pardusco algo aceitunado, con vetas tan pronto mas oscuras como mas claras, con albura mucho mas pálida $\mathrm{y}$ tan compacta como el corazon, pero sin nada de aceitunado ni de veteado tampoco. Su textura es fibrosa é intricable; su grano muy fino y denso; su dureza mas que regular, y es susceptible de un buen pulimento. Esa madera se emplea para cuadros de puertas y ventanas, para flechas de carretas o carruajes, á causa de su resistencia y flexibilidad; conviene pues mucho para todas las obras de carpintería que requieren á la vez fuerza y elasticidad. Sirve tambien para horcones, pero no son muy duraderos, porque en los suelos algo húmedos se pudren en la parte que corresponde con la superficie del terreno. El tronco de ese árbol tiene l'egularmente como unas 15 á 24 pulgadas de diámetro, algo mas ó menos.

Achiote, Prco.-Bixa orellana, M. D.- G. 890.- Arbolito que se eleva como á $30^{\prime}$, algo mas ó menos de altura, de tronco mas ó menos recto, cuyo diámetro llega cuando mas á 8 ó 10"; de madera casi blanca, porosa, liviana, muy blanda, cuyo peso específico es 0,399; que no tiene aplicacion ninguna; de color blanco lijeramente amarillento y á la vez algo teñido de rojizo y de matiz casi uniforme; sin embargo se reparan algunas vetitas lineares algo mas oscuritas que corresponden con las zonas concéntricas que se observan en su corte transversal.

Aguatapana. - Beef wood, Trd. - Rhopala montana, Schreb.; roupala montana, Aubl. : fam. de las Proteáceas. - Arbol bastante 
comun, de mediana altura y tamaño, que se cria en los lugares montañosos y suministra muy buena madera, de color achocolatado ó rojizo, jaspeadito de mas pálido, cuyo aspecto muy bonito depende del corte que hace manifiestos los muchos radios medulares que contiene, y que la hermosean tanto, se parece un poco al palo de rosa $y$ á veces es como salmoneado. Es muy dura, bastante pesada y cuyo peso específico es de 0,945 , de testura fibrosa, grano muy fino y apretado; esa madera, que es de mucha duracion, sirve en la isla de Trinidad para horcones y estacas de cercas; se utiliza tambien para obras de ebanistería, de torneo, y es susceptible de pulimento.

Abey hembra, Cba. - Prepigia excelsa, A. Rich. - Arbol muy grande y hermoso, cura madera no carece de solidez y fuerza y se utiliza por consiguiente ventajosamente en la construccion de las casas. Sus hojas son muy buscadas por los animales, que se las comen con gusto y son para ellos un buen alimento. No hemos podido conseguir muestra de ella.

Agracejo ó cofá, Cba.-Ardisia cubana, Dc.- Árbol de mediana altura y no muy corpulento, que se cria en los terrenos bajos y arcillosos, suministra una madera bien dura y coloreada que se utiliza para fábricas $\mathrm{y}$ es bastante apreciada; da carbon muy bueno. No la hemos visto.

Agracejo carbonero, Cba. - Exostemma neriifolia. M. D. - G. 719. - Arbol como de unas 8 ó 10 varas de altura, cuyo tronco alcanza el tamaño del muslo de un hombre bien membrudo, de madera bastante dura y resistente, pero muy poco empleada; se utiliza especialmente para leña y carbon, algunas veces sirve para cercas. No la hemos tenido en mano.

Aguedita, Cba. - Picramnia pentandra M. D. - G. 228 bis. Árbol que se eleva solamente á unos 15 ó 25' de altura, con el tronco del tamaño del muslo de un hombre, algo mas ó menos; sirve solamente para leña; pero las propiedades medicirales de su corteza lo hacen muy interesante.

Aguacate, Cba., Prco., Vzla., ete. - Persea gratissima. MI. D.G. 358. - Arbol no muy grande ni muy corpulento tampoco, bastante coposo, y que sin embargo se eleva como á 15 varas poco mas ó menos de altura, cuyo cañon del tronco, largo como de 3 á 5 varas, alcanza un diámetro de media vara cuando mas; suministra una madera poco pesada, cuyo peso especítico es de 0,643 , poco dura, con grano muy fino y de testura fibrosa bastante floja; su color es rojizo morenuzco ó quizás mejor castaño claro, con vetas ó undulaciones muy poco marcadas, mas visibles especialmente en la parte correspondiente á la albura, mientras que el corazon es jaspeadito de mas pálido y parece como moive, con remolinos desiguales dispuestos casi simétricamente y con matices diferentes, de manera que los unos son algo mas oscuros y los otros mas rojizos, lo que comunica á esa madera un aspecto lindísimo, y sin embargo no se utiliza para nada, que sepamos á lo menos; bien que sea bastante quebradiza, se la podria emplear, á nuestro parecer, en la ebenistería. La corteza de ese árbol es muy tosca, muy agrietada, bastante espesa y de color ceniciento. 
Akeesie, riz de veau végétal, Trd. - Blighia sapida. M. D. G. 851. - Bien que natural de Africa, ese árbol se ha aclimatado tambien en las Antillas y especialmente en la Trinidad, donde lo hemos hallado bastante comun, pero á nuestro parecer merece propagarse muchísimo mas tanto porque el arillo de sus semillas es comestible cuanto porque su madera nos parece capaz de reemplazar la del boj de Europa, para ciertas obras de torneo y de ebanistería; tiene casi su color, algo mas blanco, es algo mas liviana y cuyo peso específico es de 0,643 mientras el del boj de Europa es de 0,893; pero de granotan fino, menos dura y un poco menos pesada, con algunas vetitas pardusquitas; esa madera no se ha utilizado todavía pero nos parece que se podria emplear con ventaja en la ebanistería. Cañon del tronco largo como de 3 á 5 varas y cuyo diámetro alcanza hasta mas de media vara, con corteza rugosa ó mejor áspera, pardusco-verdosita esteriormente y como agamuzada interiormente.

Albaricoque de Sto.-Domingo, etc. - Mammea americana, M. D. - G. 876.- Primorosísimo árbol, muy coposo, bastante grancle, cuyo tronco, largo de 3 á 5 varas, alcanza hasta una vara de diámetro algo mas ó menos, con corteza como cenicienta y algo agrietada; suministra una madera de buena dureza, de peso mas que regular, pues que su peso específico es de 0,878 , con grano fino $y$ bastante denso; color rojo subido y oscuro á la vez, ó quizás mejor, como achocolatado, con vetitas undulosas algo mas subidas, las cuales dan á esa madera un aspecto particular y como característico; de corazon mas colarado, algo mas duro $y$ compacto. Estudiada con un lente bueno, se observan en su corte vertical fibras bien marcadas mas ó menos undulosas; hay muestras que las tienen paralelas; tejido ó testura densa y homojénea, con puntitos ó poros de los cuales algunos están llenos de una sustancia como resinosa $Y$ son mas oscuros que los demas que no la contienen; la seccion ó corte transiersal no ofrece nada de particular sino los puntitos ya señalados y su testura es quizás algo mas compacta; zonas circulares muy poco notables, pero que sin embargo dan al corazon un color mas subido. Tal madera es muy buena, tiene bastante fama $y$ se utiliza diariamente para carreterías, duelas, horcones, etc. Nos parece á nosotros susceptible de pulimento y podria por consiguiente servir para muebles.

Alcornoque, Gna. - Boudichia virgitioides. F. 130, s.-f. 1ª Ese árbol, que hemos hallado con bastante abundancia en los chaparrales ó lugares arenosos de la Guayana; no se eleva mucho; sin embarğo algunos mas altos se elevan como á $30^{\prime}$ de altura y su tronco, largo de 2 a 3 varas cuando mas, llega al diámetro de 20 á $24^{\prime \prime}$ y suministra una madera muy apreciada por ser muy fuerte y muy duradera en la tierra, donde se petrifica en lugar de pudrirse; su corazon es negro, muy duro $y$ muy difícil de labrar; sirve para horcones de casas.

Algarrobo amarillo, Prco.; algarrobo, Cba., Vzla. - Courbaril, Ant. fr. - Locust tree, Trd. - IIymenea courbaril. II. D. - G. 1006. - Árbol muy hermoso, muy grande y corpulento que se eleva á como $90^{\prime}$ de altura, y cuyo tronco recto, de 8 á 10 varas de largo, 
Y mas, llega hasta el diámetro de $6^{\prime}$ y aun mucho mas, puesto que Martius refiere haber hallado en las selvas del Brasil algunos algarobos cura circunferencia era tal, que quince indios con los brazos abiertos apenas lo podian envolver. ¿ Cuál habia de ser pues la altura de ese gigante? Su madera es muy dura, de color amarillento con retas verdosas, rompe verticalmente con dificultad, de grano muy fino y denso, muy apreciada tanto por su fuerza y dureza como por su hermosura; su peso específico es de 0,929 ; se utiliza para cualquiera obra de carpintería fina y tambien para ebanistería, y constituye un ramo bastante importante de esportacion para Europa, donde está muy apreciada para muebles de lujo; en las Antillas se la emplea diariamente para fábricas, para trapiches cuyos cilindros y dientes de las coronas se hacen con ella; en fin constituye una de las mejores maderas del pais y de las mas empleadas.

Algarrobo colorarlo, Prco. - A nuestro parecer ese árhol no es sino una variedad del anterior y como él suministra resina copal, pero se diferencia por el color de su madera, que es rojizo-pardusco bastante claro, con vetas desiguales mas ó menos grandes y mucho mas oscuras, susceptible tambien de hermoso pulimento: sirve tambien para los mismos usos.

Alilaila, Prco.; Cinamomo, Cha. - Melia sempervirens. MI. D.G. 941. - Arbolito silvestre que se halla con bastante abundancia Y se siembra en las haciendas para hermosear el campo con sus primorosas flores que se parecen casi á las del lila de Europa; se elera á 15 ó 25' de altura, con las ramas largas desnudas porque llevan hojas solamente por los estremos; el diámetro del tronco es de 5 á $6^{\prime \prime}$; su madera es de color rosado, algo dura, y rompe verticalmente; en el campo la usan para mangos de espadines y azadones.

Almasigo colorado ó blanco, Prco. - Bursera gummifera. Gommier barrière. M. D. - G. 996. - Arbol abundante de mediana altura, bien que lo haramos visto como de 15 varas con el tronco recto, cuyo diámetro liega á $24^{\prime \prime}$, poco mas ó menos; su corteza parece como barnizada y de un color mas ó menos rojizo, con un epidérmis muy delgado, que siempre está desprendiérdose por partes. Madera blanquecina, liviana y casi sin dureza; no tiene aplicacion, sin embargo á nuestro parecer se la podria emplear para forro interior de las casas, cajas, etc.

Almendro de Indias. - Terminalia catalpa, M. D. - G., 270. - Arbol bastante grande que sirve para paseos, á causa de la disposicion en paraguas de su copa, el primor de su follaje y la sombra que da; se eleva como á 40 ó $50^{\prime}$ de altura, y su tronco bastante recto llega como á unos $24^{\prime \prime}$ de diámetro; su madera sin aplicacion, de color morenuzco y cuyo peso específico es de 0,699 .

Almendro criollo, Cba. - Laplacea curtyana. F. Ternstromeniáceas. - Primoroso árbol silvestre como de unas 12 varas de altura, cuyo tronce largo de 15 á 25', con un diámetro de 12 á $18^{\prime \prime}$, sumi istra una madera muy fuerte $y$ bastante dura cuya albura es blanca, mas ó menos teñida de rojo y veteada, mientras el corazon es color almagrado veteado de zonas ó remolinos mas ó menos oscuros, á veces bastante notables y otras veces apenas marcados, cile 
le dan un aspecto muy bonito. Dureza y peso regulares, testura bastante compacta, grano ni muy fino ni muy grueso tampoco. Su corteza cuando seca es bastante pesada y compacta, como de unas dos líneas de espesor, algo mas ó menos; de cara esterior parduscorojiza, con manchas blanquecinas ó cenicientas desiguales y corridas; rugosa $\mathrm{y}$ asurcadita lonjitudinalmente; cara interior de aspecto flbroso, lisa $\mathrm{y}$ de color como achocolatado mas ó menos jaspeado de blanquecino; la parte mediana, formada por las capas corticales, es bastante densa y compacta, solo las mas interiores son algo visibles y se pueden separar de las demas. Se usan con aprecio los palitos hechos con sus retoños olorosos y con olor cie almendras amargas, para mascar y limpiarse la dentadura. La madera de esé árbol, que se halla muy abundante en todos los terrenos de la isla de Cuba, se utiliza ordinariamente en las fábricas de casas, especialmente para junturas y á veces para vigas.

Almendrillo, Cba. - Este árbol, que se parece muchísimo al anterior, no será quizás sino una variedad suya, de que difiere por tener su madera de un color mas encendido.

Almendron, Prco.; cuajaní ó cojani, Cba. - Noyau, Trd. - Cerasus occidentalis. M. D. - G. 1024. - Arbol silvestre que se eleva como á 15 varas de altura algo mas ó menos, de tronco recto y bastante largo, cuyo diámetro llega á 15 ó 18" y suministra una madera muy apreciada, bastante fuerte y elástica á la vez. Esa madera, de peso y dureza regulares, es casi color de caoba pálido, ó gris rojizo, quizás algo anaranjadito, con vetas lineares paralelas, o con remolinos apenas pronunciados, otras veces el color es algo mas oscuro sin nada de anaranjado, mas ó menos teñida de rojizo amarillento; grano y testura bastante finos, observada la testura en el corte vertical, parece bastante fibrosa; en el corte transversal las zonas concéntricas ó circulares son poco visibles porque van confundiéndose para formar el corazon; es muy parecida á la del cerezo de Europa, quizás algo mas oscura; su peso específico es de 0,846 ; corteza delgada, espesa como de una línea escasa, rugosita, casi sin grietas y de color como ceniciento, sobre un fondo canela que es el color de la cara interior ó de sus capas corticales que se separan las unas de las otras con bastante facilidad con forma de fibras; su corte vertical es pardo-rojizo ó algo amarillento. La madera se usa en el campo para estantes de casas, pero á nuestro parecer se la podria utilizar como la del cerezo de Europa, es decir, para la ebanistería y las obras interiores de casas.

Arabo, Cba. - Erythroxyllum havanense. M. D. - G. 950. Árbol silvestre como de unos 35 á 40' de altura, cuyo troneo llega á 12-18" de diámetro; se cria en la costa y en la márjen de los rios. Su madera, de peso y dureza regulares, es de testura fibrosa $y$ sin embargo de grano bastante fino y compacto; corazon de color castaño rojizo clarito, de matiz bastante uniforme, alguna que otra vez con algunas pocas vetas apenas pronunciadas; su albura es blanca teñida de rojizo; no tiene aplicacion que sepamos. Su corteza seca es muy tosca, con grietas lonjitudinales, paralelas, muy desiguales y que se vuelren surcos, reunidas entre sí por otras transversales, 
pero sin simetría ninguna, de color achocolatarlo con manchas cenicientas; epidermis bastante espesa; cara interior lisa y fibrosa, tambien color achocolatado; con muchas estrías blanquecino-parduscas que le dan un aspecto particular, producido por las fibras fuertes y separables que constituyen las capas corticales; tiene como unas dos líneas de espesor.

Arara, jucaro, Cba.; ucar, Prco. - Olivier, Trd. - Olivia white, olivia yellow, Trd. - Bucida buceras. M. D. - G. 350. - Arbol grande y corpulento que llega como á 15 y 25 metros de altura, muy coposo y cuyo tronco, bastante recto y largo, alcanza un diámetro de como 3 á 4', algo mas ó menos; de madera muy pesada, muy dura y muy fuerte, de mucha duracion y resistencia, de manera que es muy apreciada para obras de carpintería, para fábricas, para carretas, trapiches, etc. Su testura es muy compacta y el grano muy fino, de suerte que á nuestro parecer ha de ser susceptible de pulimento; su color es como aceitunado, mas ó menos oscuro ó pardusco, con vetas y undulaciones tan pronto mas pálidas como mas oscuras, pero siempre poco pronunciadas; tiene el deferto de agrietarse con mucha facilidad; su peso específico es de 1,009.

Aromo, Cba.; aroma, Prco. - Vachelia farnesiana. II. D. - G. 296.-Arhol bajito, primoroso á causa de su elegante follaje y de sus lindas flores en bolitas amarillas que embalsaman el aire con su deliciosa fragancia; se eleva como á 6 ú 8 varas de altura, algo mas ó menos, de tronco largo de 2 á 3 varas cuando mas, bastante recto y cuyo diámetro llega á 12 o $18^{\prime \prime}$. Su madera, muy buena y muy sólida, bien dura y de peso mas que regular, es de un color almagrado ó rojizo, con zonas ó remolinos tan pronto mas subidos como mas claros, segun el modo con que haya sido labrada, su edad y los nudos que contiene; su aspecto es muy bonito. Casi todo corazon, porque la albura, espesa como de una puigada, es gris claro y amarillento á la vez, algo veteada; las listas del corazon están separadas las unas de las otras por vetas paralelas, de las cuales unas son almagro puro, mientras que de las demas, unas son mas claras ó mas parduscas, y algunas hasta de color de hoja muerta, con muchos puntitos ó estrias pequeñitas, lo que es de un efecto muy lindo á la vista. En el corte transversal, las zonas concéntricas, color almagro mas ó menos subido, aparecen mas pronunciadas y desiguales: su peso específico es de 1,117. Corteza muy delgada, como de una línea escasa, no muy agrietada, rugosita y color gris ceniciento, algo lustrosa. Se podria utilizar esa madera con mucha ventaja para las obras de carpintería que necesitan á la vez mucha fuerza y una dureza regular; además, á nuestro parecer, podria servir para muebles, que saldrian muy lindos.

Aroma uña de gato, Cba.-Pithecolobium unguis cati. M. D.-G. 295. - Arbol mas pequeño todavía que el anterior, que se cria en los arenales de las Antillas; se eleva como á 3 ó 4 varas de altura, de tronco bastante torcido y poco largo, y del tamaño del muslo de un hombre fuerte. Suministra una madera muy fuerte, muy resistente y de un aspecto particular, casi pareciéndose á la de la precedente. Puede utilizarse del mismo modo y en los mismos términos. 
Ayua macho ó amarilla, ayuda hembra ó blanca, Cba.; ceniza ó cenizo, Prco.; mapurito, Trd., Vzla. - Epineux jaune, Trd., Ant. fr. - Zantoxyllum coriuceum, Zombacifolium, juglandifolium, lanceolatum, fraxineum, etc. M. D., G. 834. - Arboles grandes y coposos, especialmente el zantoxilo masa de hércules, que llega como á 15 ó 20 metros de altura ó algo menos, segun la especie, y cuyo tronco recto, espinoso y bastante largo, llega á 21-30", al co mas ó menos, de diámetro. De madera blanca teñida de ámarillo pálido ó de amarillento, que al airese vuelve jocoá poco mas pálido, pero no desaparece enteramente, con vetas ú ondulaciones algo mas subidas y que á veces parecen tener tendencia para teñirse de pardusco claro, y corresponden con las zonas circulares bien notables que se reparan en su corte transversal; su aspecto es muy bonito y como moiré. De testura fibrosa, grano no muy fino, dureza mediana y bastante liviana, bastante fuerte : se aplica á la construccion de casas de campo; su peso específico es de 0,380. Su corteza seca es pardusco-achocolatada y con surcos desiguales y, verticales, rugosa y cubierta de líquenes, espesa como de una línea y media, mas oscura interiormente; cuando verde $y$ adherida al árbol está armada de aguijones mas ó menos gruesos, segun las especies, porque hay algunas que son inermes.

Azucarero de montaña, Cha.; tabanuco, Preo. - Gommier de montagne, Gpe., Mque. - Heduigia balsamifera, M. D. - G. 997. - Arbol silvestre que se cria en el centro de las Antillas y se eleva como á 15 ó 20 varas de altura, de tronco recto, largo y cujo diá-

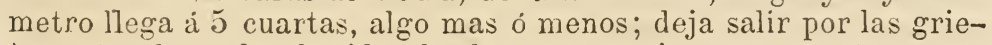
tas naturales ó las heridas hechas á propósito en su corteza, una resina blanca muy aromática. Su madera bastante liviana, de dureza regular, testura fibrosa y grano bastante fino, es de color como rosado, ó quizás mejor como gris teñido de color de carne pálido y algo amarillento, cuyo matiz no es uniforme; en efecto, la parte mas interior del corazon es la mas rozada, jaspeada de mas blanco ó veteadita, las grandes listas que se ven acercándose á la albura, la cual es color blanquecino con matices morenito-rojizos, estín mas teñidas de moreno pálido y separadas las unas de las otras por retas mas ó menos undulosas, de un color mucho mas pardusco y que contrasta bastante, mas ó menos pronunciadas y pocas, con remolinos de agradable efecto producidos por los nudos; se ven en ella además muchísimos puntitos que parecen mas oscuritos y la hacen mas hermosa todavía. Es bastante fuerte, resistente y bien apreciada, porque además de ser bonita dura mucho, pues los insectos no la pican á causa de la resina que contiene; se la utiliza para forrar interiormente las casas y otras obras de carpintería fina.

Ausu. - Arbol silvestre que se produce abundante en la parte

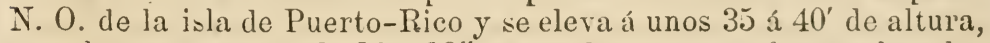
con el tronco grueso de 10 á $12^{\prime \prime}$; su madera es muy fuerte, de color amoratado el corazon y blancos los estremos, rompe verticalmente, es á propósito para estantes de casas.

Ausubo. (Véase acana.) - Añadirémos á lo dicho ya en el párrafo citado, que en la maestranza militar de San Juan de Puerto-Rico 
emplean esa madera en rayos de rueda, ejes de carruajes, durmientes de esplanada, etc. En obras particulares, se emplea en vigas de casas, estanterías, alfajías, etc.

\section{B}

Baga, palo bobo, Cba.; guanabano cimarron, cayure, corcho, Preo. - Cork wood, alligator apple tree, Trd., Jque.- Manin, Gpe. Anona palust?is. M. D. - G. 900. - Arbolito alto como de unas 8 á 10 varas lo mas y el diámetro de su tronco llega solo á 10 ó 12 pulgadas; de madera muy liviana y muy blanda, con testura fibrosa Y grano ni muy fino ni muy grueso tampoco; color gris ó pardusco claro, algo teñido de verdusco, de aspecto lustroso y á la vez como jaspeadito, pero con la esposicion larga al aire se vuelve blanco sucio; su peso específico es de 0,175 para las raices. Se emplea en el campo en balsas para transportar ó conducir efectos; la madera que proviene de las raices que se han desarrollado en los terrenos pantanosos es sumamente blanda y porosa, de manera que se usa en Cuba para alisar las navajas de afeitar y reemplazar el corcho.

Baria, Cba.; capa prieto, Prco.; pardillo, Trd., Gna. - Bois de rose, Ant. fr. - Cordia gerascantoides, Cyp., Trd. M. D.-G. 607. - Ese árbol, que se eleva hasta $60^{\prime}$ de altura y cuyo tronco llega solamente á $18^{\prime \prime}$ de diámetro, suministra una madera muy apreciada por ser á la vez muy fuerte y algo flexible ó elástica, de buena dureza y de peso mas que regular; testura fibrosa, grano fino y compacto, de corazon muy duro, color castaño oscuro, helmoseado con retas mas pálidas y á la vez mas rojizas, mientras la albura es de color gris, amarillento pálido, con vetas lineares mas oscuritas; susceptible de buen pulimento y despues de barnizada se vuelve muy hermosa. Su peso específico es de 0,574 ó 0,752. En la maestranza militar de San Juan de Puerto-Rico se aplica esa madera en cabrias, cureñas, avantrenes, carros fuertes de sitio, de mano, juegos de armas, etc. En talleres particulares hacen puertas, persianas, barras de catres y de carruajes, ligazones de fábricas, cajas de colmenas, harriles, etc. Las abejas apetecen sus flores olorosas, y el ganado vacuno $y$ de cerda sus frutos.

Bariaco, Prco. - Bois rouge. - Reedwood, Trd. - Trichilia moschoxylum. M. D. - G. 932. - Arbol silvestre bastante abundante, que se eleva como á unos $30^{\prime}$ de altura y cuyo tronco llega á $18^{\prime \prime}$ de diámetro; suministra una madera bastante apreciada para olras de carpintería del campo, buena especialmente para fábricas de casas, estantes, vigas, tablas, etc., muebles $\mathrm{y}$ algunos instrumentos de música; bien fuerte y muy resistente, de testura fibrosa y sin embargo bien apretada, grano fino; color gris rojizo disciplinadito ó lijeramente matizado de amarillento, quizás mejor, salmoneado-pálido, con algunas vetas mas oscuritas ó mas elaritas; albura muchísimo mas pálida y apenas rojiza, pero de igual aspecto general; en el corte transversal el color es mas pronunciado; las 
zonas concéntricas bastante visibles y el grano mas compacto; su jaspeado proviene de los muchísimos vasos abiertos al labrarla, y además de la jresencia de muchas manchitas desiguales y transversales, de color almagrado y que no son sino los radios medulares. Corteza espesa como de $2^{\prime \prime \prime}$, bastante compacta, unida y sin grietas, poco rugosa por consiguiente, color ceniziento oscuro, con manchas, de las cuales unas son blanquecinas y las otras morenas; epidérmis fino y adherente; capas verticales color de canela oscuro y casi achocolatado; no se rompe con facilidad, bien que su rotura no sea fibrosa.

Baria carbonera, Cha. - Nadera de buen peso y cuya dureza es regular; su color es blanco amarillento algo teñido de anaranjado y veteado á la vez; no raramente con nudos, de un hermoso color prieto; en el corte transversal se ven las zonas circulares bastante pronunciadas; con el lente el tejido parece bastante flojo y entremezclado de muchísimos radios medulares capilares; testura fibrosa.

Bayua, Cba. - Hermosa madera, bastante liviana y poco dura, cuyo corte vertical es fibroso y lustroso, de color agamuzado con vetas algo mas amarillentas, de aspecto como sedoso y muy agradable á la vista; el corte ó seccion transversal, al contrario, parece solamente amarillento con zonas concéntricas mas subidas y bastante apretadas las unas contra las otras; el corazon es color agamuzado y en su centro se repara el canal medular; testura fibrosa, grano fino y bastante compacto. Nos ha parecido susceptible de pulimento, y despues de barnizada se vuelve muy hermosa, sus vetas y su moere sedoso haciéndose entónces mas manifiestos y visibles.

Bibona, Cba. - Aralia capitata. - F. Araliáceas. - Arbol mediano como de unas 3 á 5 varas de altura y del tamaño del muslo su tronco, que suministra una madera de peso regular y dureza suficiente, cuyo color es blanco-amarillento ó como teñido de agamuzado, con vetas lineares verticales algo mas oscuritas. algunas veces tiene nudos, de los cuales salen vetas mayores ó remolinos que se estienden mas ó menos; de testura fibrosa, grano fino y compacto; en el corte transversal las zonas concéntricas son muy visibles, y bien que lineares hacen el color de esa parte algo mas subido. Corteza seca muy livianita, color gris blanquecino algo sucio, con manchas cenicientas, siendo algunas parduscas y hasta negras, con una línea de espesor; el corte vertical como el transversal, la muestran bastante dura, compacta y de color achocolatado; la cara interior es de color de chocolate ó castaño claro.

Bigueta del Perú, Cba. - Myrospermum peruiferum. M. D.-G. 1008.-- Arbol de como unas 10 o 15 varas de altura y cuyo tronco llega á 18-24" de diámetro, poco abundante y hasta bastante escaso en la isla de Cuba; suministra una madera de peso y dureza muy regulares; su corte vertical es de un color gris aceitunadito, lustroso y como moere, á veces con nudos prietos; no tiene corazon bien malcado, de manera que su color es casi uniforme, á lo menos así es por la muestra que tenemos á la vista; en el corte transversal se reparan las zonas circulares concéntricas algo mas oscuritas y que for- 
man las vetitas ya mencionadas, con el centro mas prieto y teñido de rojizo. Examinada con el lente parece muy compacta, y sin embargo fibrosa, con el grano fino, pero se reparan en ella muchos poritos separados los unos de los otros por muchos radios medulares capilares; es de mucha dureza y de peso regular. Hemos tenido en mano otra muestra menos jaspeada, cuyo color era mucho mas subido, con algo de pardusco $\mathrm{y}$ las vetas mucho mas prietas, lo que provenia sin duda de la edad mayor del árbol de donde habia sido sacada la muestra. Tal madera nos ha parecido susceptible de buen pulimento, $\mathrm{y}$ despues de barnizada se vuelve muy bonita y con reflejos como doraditos $y$ sedosos que le dan un aspecto particularr y muy agradable á la vista. Tos parece que se emplearia con mucha ventaja para muebles y obras de ebanistería ó de carpintería fina. La corteza seca es bastante delgarla, rugosa, de un color ceniciento sucio, espesa como de una línea solamente, bastante compacta; su corte vertical es como achocolatado, de cara interior lisa, color pardusco teñido de rojizo, con vetas mas claras y hasta blanquecinas.

Bijaguara, Cba.: palo mabí, Prco. - Bois mabi, St-Tmas; bois costière, Trd., Ant. fr.-Colubrina reclinata. M. D.-G. 1145.Arbol pequeño cuya madera, de buena dureza y bastante fuerte, sirve á veces en Cuba para construcciones; no hemos tenido en mano ninguna muestra de ella. Su peso específico es de 0,947.

Bois cotelette, Trd. - Elisia. - Arbol silvestre bastante grande que se eleva como á 12 ó 15 varas de altura, y cuyo tronco largo de 5 á 6 varas, algo mas ó menos, bastante recto, llega á 10 ó $12^{\prime \prime}$ de diámetro, yoco mas ó menos, pero con mucha albura: en efecto, hemos visto ramas á lo menos del tamaño del muslo no tener corazon ninguno ó muy poco; la madera es de peso regular, no muy liviana sin embargo, de testura fibrosa y bastante apretada, grano fino y dureza bastante regular, cuya albura es color gris blanquecino, matizada de pardusco amarillento, con vetas mas oscuritas casi paralclas, á veces un poco undulosas, contrastando con el corazon, cuyo color es de un hermoso gris pardusco algo disciplinadito de morado; susceptible de pulimento. Bien apreciada y diariamente empleada para obras de carpintería, especialmente para el interior de las casas. Corteza muy delyrada, de color ceniciento, casi café con leche, y que se desprende por capas desiguales.

Boj de Persia, Cba.; café de la India, Prco. - Murraya exotica. M. D. - G. 866. - Aunque ese primoroso arbusto sea natural de las Indias orientales, se ha naturalizado en las Antillas y en el continente americano, y se halla en la mayor parte de los patios y de los jardines, que hermosea á la par que embalsama el aire que se respira en las casas con la deliciosa fragancia de sus flores. Se eleva como á 3 ó 4 varas cuando mas, con el tronco bastante recto y que llega á veces al tamaño del muslo, pero ordinariamente es un poco menor; suministra una madera que se parece muchísimo á la del boj de Europa, que á nuestro parecer podria reemplazar perfectamente; es de un color amarillento pálido, con el corazon algo pardusco, tiene vetas paralelas y á veces undulosas; de buena dureza y de peso mas que regular; testura $y$ grano muy finos $y$ densos, bien 
fuerte y muy sólida, buena para obras de torneo y susceptible de pulimento. Su peso específico es de 0,979 .

Boje ó quina, Prc. - Coutarea coccinea. M. D. - G. 714. - Árbol silvestre que se halla con bastante escasez por el N. O. de la isla de Puerto-Rico, no muy alto, pues no se eleva á mas de 15 á 20 varas de altura, con el tronco recto, que llega á 18" ó $2^{\prime}$ de diámetro; suministra una madera de buena dureza, de buen peso, muy fuerte y muy apreciada para las fábricas del campo y tambien para obras de carpintería, muebles y armazon de casas; es de color amarillo, quebradiza y se parte horizontalmente.

Brasil, palo del Brasil, Cba.; brasileto, Prco. - Ccesa!pinia bijuga. M. D. - G. 916. - Árbol pequeño que se produce por las costas, como de 3 á 5 varas de altura, y cuyo tronco llega á $18^{\prime \prime}$ de diámetro: madera muy compacta, muy dura, de color rojizo anaranjadito oscuro ó algo abermejado, teñido de anaranjadito y veteado; rompe verticalmente, pero con dificultad, por consiguiente es muy resistente; corteza bastante espesita. Se utiliza en Europa para teñir y sirve además para tornear y para hacer cajas de violin.

Brasil de costa, Prco.; brasilete colorado ó palo de Fernambuco, Cba. - Brasil wood, Trd. - Ccesalpinia crista. M. D. - G. 916.Arbol mas grande que el anterior; se eleva como á $30^{\prime}$ de altura, su tronco, tortuoso y nudoso, llega como á 25 " de diámetro; madera bien compacta, dura, pesada, fuerte $\mathrm{y}$ de color mucho mas oscuro que el precedente, sirve para iguales usos y además se utiliza en Puerto-Rico para tablas, euartones y vigas para casas de campo.

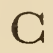

Cabalonga, Cba., Prco.; caruache, Gna.; retama, Pto. Cllo.; quachi quacha, Trd.- Thevetia neriifolia. M. D.-G. 610.-Arbolito como de 10,15 o $20^{\prime}$ de altura, bastante coposo, y cuyo tronco, largo de como dos varas, algo mas $\delta$ menos, vestido de una corteza color gris ceniciento, muy poco agrietada y bastante espesa, llega como á 5 á 6 " de diámetro; su madera, poco dura, de peso regular y sin embargo mas liviana que pesada, de testura fibrosa y grano bastante fino, es de color grisáceo morenusco, tanto mas pálido cuanto mas va acercándose á la albura, que es blançuecina, teñida de igual color, con unas vetas mas oscuritas, las cuales se reparan tambien en el corazon: esa madera no tiene aplicacion ninguna que sepamos. $\mathrm{Su}$ peso específico es 0,813 . Ese rejetal, que hemos hallado silvestre, especialmente en Guayana, se cultiva ordinariamente en los patios, que hermosea con su bonito follaje y sus primorosas flores amarillas que además exhalan un olor muy agradable, parecido al de la primula veris de Europa.

Cabo de hacha, guaban, jubaban, Cba.; guaraguao, Prco.-Trichilia spondioides. M. D. - G. 931. - Arbol grande y coposo que se eleva como á 20 varas, algo mas ó menos, de altura, de tronco recto y bastante largo, que llega á 6 ó $6^{\prime} 1_{[} 2$ de diámetro; suminis- 
tra una madera no muy dura ni muy pesada tampoco, de color oscuro, encarnado, rojizo pálido ó castaño oscuro por el corazon, bastante uniforme y á veces teñida de.amarillento y veteadita; segun la edad del árbol y el terreno en que se haya criado, su color será mas ó menos oscuro: se debe además tomar en cuenta la testura de la parte labrada. Esa madera es bastante apreciada y buena para que se la utilice en la maestranza militar de San Juan de PuertoRico, donde se usa para carros fuertes, carretas y otras obras por ese estilo. En los talleres particulares se aprovecha para tablas, baños, canoas, bateas y fábricas del campo. La corteza seca es color de chocolate, con bastantes manchas blanquecinas ó cenicientas, mas ó menos corridas y estendidas, rugosa y con pocas grietas; su corte transversal hace manifiestas las capas corticales bastante densas y compactas, color de canela oscuro y de aspecto como algo resinoso; su cara interna, casi lisa, tiene casi igual color que las capas corticales, ó quizás algo mas clarito.

Cabra, Prco. - Arbol silvestre abundante en la isla de PuertoRico, cuya altura llega como á $30^{\prime}$ y el diámetro del tronco como á $10^{\prime \prime}$, de madera blanda, de color claro; se usa para barazon de casas de campo.

Calambreña ó calambreño, Prco.-- Cocoloba nivea. M. D. G. 387. - Arbol silvestre que se produce con abundancia por toda la isla de Puerto-Rico; su altura es de como 25' y el diámetro de su tronco llega á 8 o 10"; su madera, que es de color blanco oscuro y de mediana dureza, no tiene otza aplicacion que para leña.

Cafetillo, Prco. - Arbol silvestre del centro de la isla de PuertoRico; se eleva á $36^{\prime}$ de altura y el diámetro de su tronco es de $18^{\prime \prime}$; su madera, de color amarillento, se usa en tablas, cuartones y alfajías.

Café cimarron, cafetillo, Prco. - Arbol de poca altura, como 36', y el diámetro de su tronco es de 18"; su madera, de peso regular y de buena dureza, es de color rojizo oscuro ó pajizo rojizo algo veteado; la hay tambien de color amarillento; testura fibrosa, bastante compacta. La corteza seca es áspera, con grietas, blanquecina con manchas pardusco-verdosas, espesa como de una línea.

Caimitillo, Prco., Cba. - Chrysophyllum microphyllum y chr. oliviforme. M. D. - G. 628. - Arbol silvestre que se eleva como á 40 ó $45^{\prime}$ de altura y mas, cuyo tronco llega á 18 ó $20^{\prime \prime}$ de diámetro, suministra una madera de buen peso y de dureza mas que regular; testura algo fibrosa y bastante compacta, grano bastante fino, de color blanco sucio, otras veces algo achocolatado, mas ó menos pálido y rojizo á la vez, de corazon pardusco oscuro y teñido de rojizo, mientras la albura, mucho mas pálida, está teñida de rojo, con vetas poco pronunciadas. La corteza seca es bastante delgada, rugosa, con muchas grietas y hasta surquitos lonjitudinales, color achocolatado pálido, con muchas manchas cenicientas; su cara interior es lustrosa, lisa, pardusca y veteadita; las capas verticales se desprenden con bastante facilidad. La madera se usa ordinariamente para latas de casas y manos de pilon; además se puede utilizar muy bien en obras de carpintería. 
Caimito, Prco., Cba., Vzla., etc.-Chrysophyllum caimito. M. D. - G. 628. - Arbol frutal silvestre que se produce con abundancia, se parece muchísimo á los anteriores, tanto por su altura como por su tamaño, cuya madera es mas oscura y de color morado, algo recia, no tiene aplicacion, pero á nuestro parecer se la podria utilizar en las mismas circunstancias que la del caimitillo. Su peso específico es de 0,889 .

Canela ó canelo, Prco. - Arbol silvestre cuya altura llega á 35 ó 40', y el tamaño de su tronco á $12^{\prime \prime}$ de diámetro; su madera es de color oscuro, algo dura, y se usa en las casas de campo. Su peso específico es de 0,515 .

Canelilla, Prco. - Arbol silvestre bastante comun, que se eleva como á 25 ó $30^{\prime}$ de altura y cuyo tronco llega á $12^{\prime \prime}$ pulgadas de diámetro; suministra una madera de color verdoso, bastante fuerte y que se emplea en techos de casas de campo.

Cauto.-Bois canaris, Trd.-Hirtela silicea. - F. 131. - Arbol de los montes que se eleva á 10 ó 12 varas de altura y cuyo tronco llega á un diámetro de 6 á 8" y suministra una madera bastante liviana, poco dura, de testura fibrosa no muy apretada, grano regular, de color gris teñido de rojizo algo pardusco, ó quizás mejor matizado de color de carne pálido y variegadito. No tiene aplicacion ninguna que sepamos; sus cenizas, mas ricas en sílice que ninguna otra clase, se utilizan en la fabricacion de las ollas de barro, llamadas vulgarmente canari.

Campeche, palo de campeche, Prco., Vzla. - Log wood, campechy log wood, Trd. - Hematoxylon campechianum. M. D. - G. 1014. - Arbol silvestre que se eleva como á unas 10 á 15 varas, pero cuyo tronco corto, y largo solamente de unas 2 á 3 varas, es muy anfractuoso é irregular, no tarda en prolongarse en ramas gruesas bastante largas y derechas; su diámetro es de 18 á $24^{\prime \prime}$ cuando mas, el de las ramas llega á 8 y hasta 10"; su madera es muy dura y pesada, de testura bien compacta y de grano fino; su color es rojizo, purpúreo oscuro, con vetas mas oscuritas, bastantes veces teñido de anaranjado, especialmente por la parte que corresponde á la albura, la cual es blanquecina, matizada de anaranjado, lo que hace hermoso contraste con el color de la madera. Sin embargo, al tumbar el árbol, su madera labrada es de un color blanco rojizo y no toma su hermoso color sino poco á poco y despues de una larga esposicion al aire: el individuo cuya muestra tuvimos en mano contaba mas de 40 años de edad. Su peso específico es de 0,992. Corteza bastante delgada, espesa solamente de una línea y media, bien compacta, muy rugosa, de color gris mas ó menos claro y á veces ceniciento; su interior parece achocolatado. En Europa esa madera se usa especialmente para teñir, pero tambien puede utilizarse para tornear.

Caña fístola, Prco. - Cathartocarpus fistula. M. D. - G. 1005. - Arbol bajito que se halla bastante comun en todas las Antillas y en el continente americano y se eleva como á 20 ' algo mas ó menos de altura, teniendo su tronco un diámetro de 9 á 10"; suminis- 
tra una madera de color encarnado, de peso y dureza regulares, bien fuerte, pero sin aplicacion ninguna.

Caña fístola cimarrona, Prco. - Cathartocarpus brasiliensis. - Casse caca, bois gris, Trd., Ant. fr. M. D. - G. 1005. - Primoroso árbol que hemos hallado con bastante frecuencia, alto como de 15 á 18 varas, bastante coposo y cuyo tronco, recto y largo como de unas 4 á 6 varas, llega á un diámetro de 12 á $15^{\prime \prime}$; suministra una madera muy bonita, muy fuerte y muy resistente, de peso $\mathrm{y}$ dureza regulares; testura fibrosa $\mathrm{y}$ sin embargo bastante compacta, grano bastante fino. Su peso específico es de 0,816 ; su color es gris algo agamuzado, con hermosas vetas y listas algo mas oscuritas cuando recien labrado, mientras que al aire se vuelve de color canela amarillento; la albura, al contrario, es gris pálido teñido de color de carne, mas ó menos pronunciado, veteadito ó salmoneado; las muchas estrias y poros que se perciben por su superficie y le dan un primoroso aspecto, resultan de los muchos vasos abiertos al labrarla. Bien que no se haya utilizado esa madera hasta ahora, nos parece que no merece el olvido en que se ha quedado, $\mathrm{y}$ que se la podria aprovechar con ventaja para muchas obras de carpintería y quizás de ebanistería.

Capa blanco, Prco. - Varronia alba. M. D. - G. 607. - Arbol bastante grande y bastante coposo que se eleva como á 10 ó 15 varas de alto, con el tronco no muy recto, pero bastante largo, y que llega á un diámetro de una vara, algo mas ó menos; de madera muy dura y muy fuerte, de color amarillo oscuro, rompe oblícuamente; es muy duradera y de mucha estimacion, se emplea mucho en la maestranza militar de San Juan de Puerto-Rico para el cureñaje, cubo y piñas de ruedas, bancos de carpinteros, prensas, etc. En el real arsenal se hace mucho uso de ella; en talleres civiles sirve para muebles de lujo $y$ se emplea en la construccion de edificios $y$ para las fábricas de campo.

Capa prieto, Prco. - Cyp., Trd. - Cordia gerascanthus. M. D. - G. 607. - Arbol silvestre cuya altura llega como á 40', de tronco recto, y largo como de 7 á 9 varas y mas, cuyo diámetro es de 18"; se cria ordinariamente en lugares montañosos. Su madera es de peso regular, ni muy pesada ni muy liviana tampoco, muy fuerte $y$ elástica á la vez, de color como de hojas muertas pálido, con vetas algo mas parduscas, otras veces es gris amarillento, pardusco y veteado; testura fibrosa y grano bastante fino. Su peso específico es de 0,574 . Es muy apreciada; se emplea en la maestranza de San Juan de Puerto-Rico en cabrias, cureñas, avantrenes, carros fuertes de sitio, de manos, juego de armas, etc. En talleres particulares se hacen con ella puertas, persianas, barras de catres, atadores, brancales y flechas de carruaje y de carretas, tapa-bocas, brazos de trapiches, etc., y muebles ordinarios.

Capa sabanero, Prco. - Arbol silvestre. que se eleva como á unos $30^{\prime}$ de altura y cuyo tronco llegá á $12^{\prime \prime}$ de diámetro; suministra una madera de buen peso, bien dura y fuerte, es de color oscuro y se emplea en casas de campo y estacadas.

Caoba, Prco., Sto. Dgo., Cba., etc.; caoba ó caobo macho hem- 
bra. - Swetenia majogani. M. D. - G. 943. - Este primoroso árbol, que se va destruyendo cada dia mas á causa de las necesidades del comercio, se deberia sembrar en los sitios donde ha de crecer, dejando entre los individuos 30 á 40' de distancia; le conviene una tierra lijera y algo pedregosa; crece bastante pronto y se encuentra en la altura mediana de las montañas, como tambien en las selvas bajas; es poco delicado y necesita poco calor: plantíos hechos con él en escala mayor vendrian á ser una gran riqueza para los que se dedicasen á esa clase de cultivo. Es de altura mayor y su tronco bien recto y muy largo llega hasta dos varas y mas de diámetro; suministra una madera bastante liviana y poco dura, y sin embargo bien fuerte; grano algo grueso ó fino, segun la clase, color rojo oscuro y como pardusco, con ramazon mas ó menos amarillenta, otras veces con remolinos oscuros ó pálidos; esa madera, muy conocida de todos y muy apreciada en Europa para muebles de lujo, se aplica además en los paises donde se cria para obras de fábricas de casas; su peso específico es de 0,819.

Caobilla. - Variedad de la caoba, de inferior calidad y solidez, de color mucho mas pálido; madera regular, pero que no es tan apreciada ni tan buena tampoco como la caoba lejítima; se usa especialmente en tablas y tablones.

Carapa, crapo. - Crapaud, Trd. - Carapa guyanensis. M. D. G. 929.-Primoroso árbol muy coposo, que se eleva á 15 ó 20 varas de altura, con tronco recto, pero no muy largo, sin echar ramas, cuyo diámetro llega á $3^{\prime}$ y hasta algo mas; suministra una madera apreciada, de peso regular, no muy dura, pero bastante fuerte, tiene el aspecto y el color de la caoba, pero sin sus hermosos remolinos ni sus vetas grandes; no tiene tampoco el matiz amarillento particular á esa madera, es tambien fácil para labrar; su peso específico es de 0,689 y 0,661 . La variedad de color mas claro sirve para muebles, se utiliza en tablas y tablones; se parte con facilidad, de manera que con los cuños se saca de ella tablillas, tajamaníes y duelas apreciadas.

Caracolillo, Cba.; caracolillo labrado, Prco. - Arbol silvestre cuya altura llega á $60^{\prime}$ y el diámetro de su tronco como á $3^{\prime}$; suministra una madera trabada de color amarillento veteado, formando encuentros, nudos ó remolinos á manera de caracoles: de esa circunstancia ha sacado su nombre; muy buena para fábricas $\mathrm{y}$ bastante empleada para estantes de casas, estacones, etc.; pero su uso comun es para muebles; hay mucha estraccion de ella en PuertoRico para el estranjero.

Caracolillo liso, Prco. - Nos parece solamente una variedad del anterior, al cual se asemeja enteramente, tanto por su aspecto, altura y tamaño, como por el color y los usos de su madera; tambien hay mucha estraccion de ella para el estranjero,

Caracolillo, Cba. - Se llama tambien así á una variedad de caoba. (Véase esa palabra.)

Carey, vaca-buey, careicillo, Cba., chaparro, Trd., Gna. Feuilles rudes, Ant. fr. - Curatella americana. F. Dilleniáceas. Arbol muy abundante en Trinidad y en Guyana, provincia de la 
República de Venezuela. Se cria en los terrenos arenosos y pedregosos, que entónces se llaman chaparrales; se eleva como á $20^{\prime}$ de altura, algo mas ó menos, y el tamaño de su tronco, poco largo y no muy recto, es de 6 á $8^{\prime \prime}$, raras veces mas; suministra una madera bien pesada y de buena dureza, de color como castaño algo rojizo y jaspeado, con nudos y vetas mucho mas oscuros; el color de la albura, mucho mas pálido, contrasta con el del corazon; sin embargo es algunas veces tan oscuro. Hay en el corazon hermosos remolinos formados por los nudos; el aspecto y color varian mucho segun la manera con que haya sido labrada, porque su jaspeado proviene de los muchos radios medulares que se ven en su corte transversal; su peso específico es de 0,805. Corteza bastante rugosa, con grietas verticulares paralelas, dispuestas con bastantc regularidad; color grisáceo, amarillento y algo ceniciento á la vez, espesa como de unas dos líneas ó algo mas; epidermis poca; su corte transversal y el vertical es de color canela claro, así como su cara interior, que además está veteada con líneas mas oscuras y como achocolatadas. Esa madera no tiene aplicacion que sepamos, sirve solamente para leña, pero nos parece que se la podria aprovechar para algunas obras de carpintería. En las Antillas y en Guyana aprovechan sus hojas para pulir las maderas y algunos metales.

Carne de doncella, sangre de doncella, Cba.; doncella, Prco. -Surette marron, surette grand bois, bois tan, Trd.-Byrsonima spicata y $B$. lucida. M. D. - G. 949. Arbol silvestre bastante comun por el monte, en donde se eleva como á unos $40^{\prime}$ de altura y cuyo tronco, bastante recto, llega al diámetro de 12 á $15^{\prime \prime}$; suministra una madera de buen peso y de dureza muy regular; testura algo fibrosa, compacta y uniforme, grano bien fino, de color acanelado rojizo mas ó menos pálido, con algunas vetas paralelas y lineares, muy pálidas y á veces su color es como rosado. Es muy fuerte, bastante apreciada y se emplea en el campo para tablazon y armaduras de casas, etc.; su peso específico es de 0,812.

Caro hembra, Gna. - Enterolobium cyclocarpum. - M. D. G, 1051.-Arbol silvestre muy grande y muy corpulento que hemos hallado con bastante abundancia en las Misiones del Caroni, provincia de Guyana, República de Venezuela; se eleva como á 90 ó 100' de altura y cuyo tronco, recto y largo como de 8 á 10 varas y mas, llega á un diámetro de 2 á 3 varas y mas. Sus grandes y gruesas ramas estendidas cubren á veces un espacio tal, que se han visto 200 reses ponerse debajo de su sombra; suministra una madera muy resistente y elástica á la vez, con las fibras entremezcladas, pero no muy apretadas; es de un color pardusco mas ó menos amarillento, 6 casi del color del nogal pálido de Europa, veteado y jaspeado á la vez, con muchos poros que dan á su corte transversal un aspecto. punteadito muy bonito. La albura sola se halla acometida por los gusanitos y no se meten nunca en el corazon, que es muy duradero y solo se debe emplear para las obras de carpintería. Esa madera, bastante liviana, se emplea para canoas, y las hay muy grandes; en efecto, nuestro amigo el señor don Serapio Marchado, vecino de la ciudad Bolívar, nos ha referido haber visto una como de 25 tonela- 
das y en que cabian pipas atravesadas; otras personas fidedignas han confirmado el hecho. Además de ser muy fuerte y muy liviana, esa madera es casi imputrecible en el agua, y sus tablas serian, á nuestro parecer, por esa circunstancia, muy útiles y muy convenientes para las construcciones navales; hemos visto algunos de esos árboles viejos abandonados en el suelo desde mas de 15 años, cuya superficie sola estaba un poco alterada, mientras que el interior habia permanecido muy sano y muy bueno; sirve tambien para bateas, para puertas; es apenas combustible, de manera que el fuego ataca solamente su superficie, sin pasar mas adelante, porque se apaga solo con la mayor prontitud. Ese árbol, que crece bastante pronto, se cria en los terrenos areniscos; las reses apetecen mucho sus frutos, con los que engordan bastante; las bestias suelen comerlos tambien; los hombres comen las semillas despues de haberlas puesto al rescoldo durante algun tiempo, y los indíjenas las aprecian bastante.

Cartan, Gna. - Centrolobium robustum. M. D. - G. 1034. Arbol silvestre bastante grande y corpulento, muy abundante en la provincia de Guyana, y especialmente en las montañas del Caroni, junto con los cedros blancos y dulces; tambien se hallan en las cercanías de la ciudad Bolívar y en otras partes de la Republica de Venezuela, donde se aprecia mucho su madera; se eleva como á 20 ó 25 varas de altura, y su tronco de cañon largo y bien recto llega á un diámetro de una vara á una vara y media, y á veces algo mas. Madera de un hermoso color rojo pálido en los árboles tiernos, y rojo muy oscuro, que se parece casi al de la madera del Brasil, en los individuos viejos ó cuando haya permanecido largo tiempo al aire; tiene mucho corazon y poca albura, como una pulgada y media algo mas ó menos, es blanca, mientras el corazon, segun su edad, su esposicion mas ó menos prolongada al aire y al agua á la vez, será tan pronto de color amarillento rojo, jaspeado ó veteado de amarillento claro ó de rojizo claro, segun la manera con que haya sido labrado, ó en fin de color mucho mas oscuro y hasta volverse de color de sangre venoso, y entónces veteado de mas claro; en el mas pálido se ven vetas de color bruno rojizo: con el aire y el agua se vuelven gateado rojo y otras veces gateado amarillento muy oscuro. Su corte vertical es de testura fibrosa, y en el transversal se ven muy bien las zonas concéntricas, siendo la mayor parte de ellas de un color rojo claro y las demas rojo oscuro, desiguales, con el centro ocupado por el canal medular pentágono y cuyo diámetro es de media línea. Corteza tosca agrietada y dispuesta casi á manera de redecilla, sin simetría ó irregular, de epidermis espeso como de una línea; es bastante dura y está formada de capas sucesivas, de manera que su corte transversal presenta esas capas mas ó menos numerosas, desiguales y de color diferente, de suerte que las mas esteriores son color de hoja muerta y brunas las otras, separadas entre si por partes color almagrado; la cara interior es negruzca, lisa y como barnizada; se rompe con facilidad; esteriormente es de un color blanco ceniciento, tiene capas corticales en la corteza fresca, con puntitos de color almagrado que no tardan en dejar salir un líquido como 
resinoso, de igual color y muy astrinjente. Madera escelente, muy fuerte y elástica á la vez, muy resistente, mas bien liviana que pesada, casi incorruptible y que no pican los insectos, muy apreciada y muy empleada para obras de carpintería, como vigas, tablas, tablones, etc.; puesta en el suelo no se pudre y dura mucho tiempo; ha de ser muy buena tambien para construcciones navales, porque además de endurecerse en el agua, los moluscos no lo atacan; una balandra construida con ella ha durado mas de 40 años; los Indios la usan para hacer sus arcos; es buena para cabos de hacha, arcos de violin; sus tablas bien secas son muy buenas para entablados, porque siempre permanecen bien juntas, no es pues higrométrica, lo que es muy ventajoso, especialmente en los paises cálidos. Hemos visto vigas de mas de 12 varas de largo, colocadas como desde unos 20 años, tan sanas como el primer dia, sosteniendo tejados bastante pesados, no habian sido labradas y su color habia llegado á parecerse mucho al del brasil. A nuestro parecer esa madera seria digna de esportarse para Europa, donde se la aprovecharia con mucha ventaja en muchas obras y hasta para hacer muebles.

Castaño. (Véase palo de pan.)

Cedro blanco, hembra colorado, macho, Prco., Cba.- Cailcedra, Cba. - West India cedar, Trd. - Cedrela odorata. M. D. - G. 942. - Se denominan así con esos tres nombres tres variedades del mismo vejetal, que es un primoroso árbol silvestre que se eleva á 60,90 y $100^{\prime}$ de altura y cuyo tronco recto y muy largo llega al diámetro de $41_{[} 2,5$ y $6^{\prime}$ y aun mas. Sembrado este árbol seria un manantial de riqueza para su dueño; animados con tal pensamiento algunos han principiado ya en la isla de Cuba á hacer algunos plantíos de ese árbol, ejemplo que se debería seguir en las demas Antillas, porque no solamente crece con mayor prontitud que la caoba lejítima, sino que es además mucho menos delicado que ella y puede prosperar en todos los terrenos, aunque prefiera un suelo limpio y liviano en las crestas y llanuras; no temela humedad sino cuando el agua se estanca en la superficie del terreno. Se le multiplicará, sea con semillas, sea con sus vástagos ó estacas; á los 40 años habrá llegado ya á su desarrollo y entónces se le podrá tumbar y sacar de él muy buen provecho para la esportacion. Su preciosa madera, de olor agradable, es tenida por incorruptible y niuy duradera por consiguiente, mas pesada, mas compacta y mas oscura que la caoba lejítima, á la cual se parece mucho cuando pertenece á la variedad llamada cedro macho, mientras que cuando proviene de la variedad conocida con el nombre de cedro hembra, es mucho mas liviana, menos compacta, menos dura y de color mucho mas claro. La primera se utiliza para muebles, obras de carpintería en el interior de las casas, y en este último caso se la prefiere á la caoba lejítima por ser mas liviana y mas fácil de labrar; tiene la gran ventaja de no hallarse nunca picada por los insectos; se usa tambien para brancales, en rejas, balcones, etc. En la maestranza militar de PuertoRico sirve para cajones, envases de pólvora, sombreros para morteros de artillería, etc. La segunda clase es muy á propósito para iguales usos y además se emplea muchísimo para cajas de cigarros; 
su peso específico es de 0,474 y 0,461 . Corteza seca, rugosa, con grietas irregulares verticales, á veces bastante pronunciadas, de color ceniciento con partes algo pardusco-rojizas, bastante blanda y cuyo corte vertical es de color achocolatado, veteado de blanco.

Ceniza ó cenizo, Prco. - Zantoxylum clava Herculis. M.D.-G. 834. - Arbol silvestre bastante abundante, cuya altura es como de unos 35 á 40, con un diámetro de 10 á $12^{\prime \prime}$, que suministra una madera de mediana dureza, de color blanco, y se parte verticalmente, la cual es aplicable á la construccion de casas de campo. Su corteza sirve para teñir de amarillo.

Cenicero, Trd. - Peridium cenizero. - Arbol silvestre, alto de 20 á $25^{\prime}$ y cuyo tronco alcanza el diámetro de 1 á $2^{\prime}$; suministra madera de buen peso, de dureza mas que regular, de testura fibrosa y sin embargo bastante apretada, grano fino; de color gris parduscorojizo muy pálido, con vetas y listas, siendo morenitas la mayor parte de ellas, otras blancuzcas, tambien hay algunas color de rapé, teñido en general de acaneladito. Parece susceptible de pulimento y buena para obras de carpintería; apenas tiene albura y esta es casi de igual color; su peso específico es de 0,885. Corteza espesa como de una línea y media, rugosa, de color pardo achocolatado con manchas color de ceniza; cara interior pardusca con estrías blancas.

Cerillo, cera amarilla, Cba. - Madera de peso mas que regular, de buena dureza, de testura fibrosa y sin embargo bien compacta, grano fino; de color amarillento muy pálido, otras veces como anaranjado o azafranado, con vetas lineares algo mas subidas, algunas muestras son de color casi uniforme, mientras que otras tienen ondulaciones que las hacen como moires; la albura es mucho mas clara. Corteza delgada como de una línea ó algo mas, bastante lisa y con pocas grietas, algo rugosita sin embargo, color grisáceo ó pardo blancuzco teñido de castaño rojizo ó de aceitunado, cara interior castaño muy claro matizado de blanquecino, bien dura y quebradiza, cuyas capas verticales son color de canela. Esa madera parece susceptible de pulimento y es muy buena para obras de carpintería; se emplea tambien para bastones por sus graciosas vetas; hecha astillas sirve á los pescadores para alumbrarse.

Ceiba, seiva, Cba., Prco., etc. - Silk cotton, Trd.-Eriodendron anfractuosum. M. D. - G, 918. - Arbol silvestre bastante abundante, cuýa altura es de 40 á $50^{\prime}$ y á veces mas, con el tronco derecho, á veces bastante largo y muy grueso; en efecto, su diámetro llega á 12 ' y mas; su parte inferior tiene inferiormente dos ó mas canales ó estrías grandes y profundas que forman por la base una especie de estrella de tres ó mas puntas gruesas, casi equidistantes entre sí, de cuyas puntas salen las raices y se estienden debajo de la tierra, terminándose superiormente por ramas muy gruesas dispuestas casi á manera de paraguas como por pisos y que se estienden mucho horizontalmente. La madera es bastante blanda, muy liviana, blanca, bastante fuerte y bastante duradera en el agua; sirve para hacer canoas de una sola pieza; sin embargo, las piraguas ó bongos hechos de esa madera no son tan duraderos como se 
piensa generalmente; en el Apure, donde se usan mucho, se suele untarlas por dentro con manteca de tortuga para hacerlas durar mas tiempo, pero á pesar de eso se pudren por el fondo y en el momento menos pensado se desbarata esa parte por pedacitos á manera de carton y se va á pique: cuidado pues con esas canoas; sirve además para baños, bateas, etc.; su peso específico es de 0,520 .

Ceibon, Cba.; corcho, Prco. - Tacarigua, cork wood, Trd., Gna. - Bois flot, Ant. fr. - Ochroma lagopus. M. D. - G. 919. - Arbol silvestre bastante abundante, cuya altura es de 30 á $40^{\prime}$, y el diámetro del tronco llega como á un pié ó algo mas. La madera, de color oscurito, es decir, blanco algo teñido de rojizo, con aspecto lustroso y como sedoso á la vez, es muy porosa y mas liviana que todas las demas maderas y que el corcho lejítimo; en efecto, mientras el peso específico de ese último es de 0,240, el suyo es de 0,120 , fibrosísima y tan poco dura que se corta con la mayor dificultad $y$ casi no se puede labrar, porque las muchas hebras que la forman impiden la accion de las herramientas. Se emplea en el campo para balsas de transportar ó conducir efectos. En Trinidad y otros lugares, constituye un ramo de comercio para los pescadores, que la emplean para reemplazar el corcho lejítimo en sus redes. Los Indios la emplean para volver sus canoas ó piraguas insumerjibles cuando tienen que pasar raudales ó lugares donde el mar está siempre muy bravo.

Cereza, cerezo comun ó de la tierra, Prco. - Surette, Trd. Cicca distica. M. D. - G. 150.- Arbol pequeño que se eleva como á 7 ú 8 varas de altura algo mas ó menos, y cuyo tronco llega á 6 ú $8^{\prime \prime}$ de diámetro; suministra una madera muy bonita despues de labrada, pero que no tiene, hasta hoy dia, ninguna aplicacion; de peso regularcito, testura fibrosa y bastante apretada, grano flno, dureza poca; con escasa albura, la cual es de color amarillento muy pálido, mientras el corazon es de color gris rojizo, moreno claro, con remolinos ó listas mas ó menos claritas, otras veces de un hermoso moire algo mas oscurito; siempre se queda con alguna médula en el centro; su peso específico es de 0,577. Corteza de color gris algo ceniciento con manchas, siendo blanquecinas la mayor parte de ellas y las otras pardusco-amarillentas, con tuberculitos y sin grietas, bien compacta, apenas espesa como de una línea; mucho mas pálida interiormente.

Cigua, Cba. - Arbol silvestre, de tamaño regular, cuya madera, de poco peso y sin embargo de buena dureza, es de color amarillento y pardusco muy pálido á la vez, con vetas de igual color, pero algo mas oscuritas, cuyo poco corazon es algo mas pardo; testura fibrosa y grano bastante fino; se parece bastante al fresno de Europa.

Cocorron, Prco. - Arbol silvestre que se produce por el E. de la isla de Puerto-Rico con poca abundancia, se eleva como á 30 ó 35' de altura, su tronco es del diámetro de $l^{\prime}$ á lo mas y suministra una madera de mediana dureza, de color amarillo y se parte verticalmente; sirve en la construccion de casas de campo.

Cojobana, cobana, Prco. (Véase caobilla.)

Cojoba ó palo de hierro, Prco. - Arbol silvestre que se produce 
por el E. de la isla de Puerto-Rico con alguna escasez y tambien en la de Biques, y se eleva como á 40 ó 50' de altura; su diámetro es de $2^{\prime}$; suministra una madera muy dura llamada hierro ó quiebra hacha; de color encarnado, se parte verticalmente con mucha dificultad, se aplica en curbas de buques, martinetes y estantes de casas, por ser de una duracion estraordinaria, y empleada en ese último caso, tiene.la particularidad de retoñar.

Coral, Prco.; coralitos. - Coral wood, Trd. - Adenanthera pavonia. M. D. - G. 284. - Arbol silvestre de los cerros, cuya altura es de 30 á $40^{\prime}$; su tronco llega como á 12 ó 14 pulgadas de diámetro y suministra una madera bastante fuerte, de color rosado o rojizo, que se aplica en soleras y barazon de casas de campo, y frecuentemente para tornear; sirve además para teñir.

Corazon, Prco., Cba.; riñon, Vzla. - Anona reticulata. M. D. G. 900.- Arbol frutal silvestre, no muy abundante, pero que sin embargo no escasea; se eleva como á 25 ó $30^{\prime}$ de altura, es bastante coposo, su tronco, ordinariamente bastante derecho, tiene un diámetro de 10 á 14"; suministra una madera liviana, poco dura, pero bastante resistente, de testura fibrosa no muy apretada, y sin embargo de grano no muy grueso, de color amarillo muy claro, con vetas un poco undulosas, cuyo color amarillo es mas oscuro, con bastantes estrías lineares, producidas por vasos abiertos al labrarla; de aspecto bonito, lustroso, con zonas de matiz variado, lo que produce un efecto agradable á la vista; hasta ahora no tiene aplicacion.

Corazon cimarron, Prco.; anoncillo, Upta. - Cachiman marron. - Rollinia multiflora. F. 95. - Arbol silvestre que se eleva como á 25 o $30^{\prime}$ de altura, con tronco bastante recto y largo que llega como á 8 o 10 pulgadas de diámetro y suministra una madera bastante liviana, de poca dureza, de testura fibrosa y sin embargo bastante apretada, grano no muy fino, de un hermoso color gris oscuro o como de hoja muerta pálido, bien lustroso, matizado de amarillento en la parte correspondiente con el corazon, que no difiere de la albura sino par ser algo mas rojizo o achocolatado; no tiene aplicacion que sepamos; su peso específico es de 0,509. Corteza blanca sobre un fondo moreno, rugosa y algo agrietada, espesa como de unas tres líneas, de cara interior pardo oscuro. Se usa esa madera en el Apure y en la Guyana, para costillas de techo de casas del campo, para lo cual es muy duradera; hemos hallado ese árbol con abundancia en Guacaima, montañas del Caroni.

Cojon de Verraco, Gna. - Tabernemontana latifolia. M, D. G. 652. - Arbol silvestre que hemos hallado con bastante abundancia en el canton de Upata, donde se aprecia mucho su madera; se eleva como á 10 varas de altura, no es muy coposo, de tronco recto y bastante largo que llega á 10 ó $12^{\prime \prime}$ de diámetro poco mas ó menos, con corteza tosca, agrietada y verdosa, espesa como de unas dos líneas, con la epidermis de $\mathrm{I}_{14} 4$ de línea, de un color blanco amarillento cuando fresca, y entonces se ven en su corte transversal muchos puntitos mas oscuritos que dejan salir una leche abundante y muy pegajosa. La madera es de peso regular, no muy dura. de testura fibrosa. albura cspesa como de $1_{1} 2$ pulgada: es blanca, 
mientras el corazon es color aceitunado pálido, frecuentemente con hermosas vetas mas oscuras y á veces formando como dibujos. En el corte transversal se ven las zonas concéntricas bien pronunciadas; su peso específico es de 0,599 , es muy fácil de labrar y sin embargo de buena resistencia y susceptible de un hermoso pulimento, por eso se la emplea con mucha ventaja en obras de ebanistería, para fusiles, y además para hormas de zapatos, etc.

Copaiba, Cba.; palo de aceite, Prco.; copaivi, Trd. - Copaifera officinalis, M. D. - G. 392. - Arbol silvestre bastante grande y coposo que á primera vista se parece un poco al nogal de Europa y se eleva como á 40 ó $50^{\prime}$ de altura y cuyo tronco bastante recto y largo tiene 12 á 18 pulgadas de diámetro y suministra una madera muy buena, muy bonita, bastante dura, de buen peso, de testura fibrosa, pero bastante compacta y grano fino; es de color general pardusco ó quizás como de hoja muerta, con remolinos negros que provienen de los nudos y la hacen muy hermosa y casi parecida á la del nogal de Europa; de aspecto como moere y algo jaspeado á la vez; su raspadura huele á aceite de palo ó bálsamo de copaiba; sirve para obras de carpintería de fábricas, ruedas de carruajes y carretas, para tornear y obras de adorno del interior de las casas, puede además servir para muebles; su peso específico es de $0,77 \%$. En la ciudad de Bolívar hemos visto despachar en las bodegas su segunda corteza seca y vuelta correas ó tiras largas con el nombre de curucai, y se usa diariamente para sujetar y atar las varas y varitas que se emplean en la construccion de las casas del campo y es muy duradera; parece una especie de cuero vejetal; para emplearla se remoja y entónces se ruelve muy flexible y muy fuerte, exhalan entónces el olor particular del aceite de palo.

Copey, Cba.; cupey, Prco. - Clusia rosea. M. D. - G. 874. Árbol silvestre que principia por ser parásito produciéndose en las grietas de otro árbol cualquiera, que las mas veces mata ahogándole, y sigue vejetando así hasta que sus raices bajan entrelazadas en el tronco y prenden en la tierra; otras raices que bajan tambien, pero solas $y$ sin sostenerse por tronco ajeno, se vuelven ellas mismas en poco tiempo troncos muy rectos y muy fueries despues de haberse prendido en el suelo. Cuando se haya criado terrestre solamente su tronco no será tan alto pero sí mas grueso y el árbol mas coposo; su diámetro es como de 18 á $24^{\prime \prime}$ y llega á una altura como de 30 á 40 piés; su madera es de color rojizo y solo sirve para leña; su peso específico es de 0,876 .

Cordoban, Cba. - Miconia pyramidalis. M. D. - G. 1090 bis. Árbol de unos 15 á $20^{\prime}$ de alto y cuyo tronco llega como á 6 ú $8^{\prime \prime}$ de diámetro y suministra una madera muy buena, muy fuerte y muy apreciada para cualquiera obra de carpintería con que puede corresponder su poco diámetro: no la hemos visto.

Cotorra, Prco. - Arbol silvestre que se produce con abundancia en toda la isla de Puerto-Rico ; su altura es de 30 á 35 piés, y el diámetro de su tronco de 8 á 10 pulgadas; suministra una madera de mediana dureza, de color amarillo canario y se parte verticalmente, 
se emplea en armazon de casas de campo, empalizadas y otras aplicaciones de esa especie.

Cucubano, Prco. - Arbol silvestre que se produce con abundancia por toda la isla de Puerto-Rico, se eleva como á 35 ó 40' de altura y el diámetro del tronco es de $1^{\prime}$; madera un poco sólida, de color blanco cenizo y se parte verticalmente; se emplea en la construccion de casas de campo.

Cucuyo, ojo de cucullo, jiguí, Cha. - Bumetia nigra. M. D.-G. 641. - Arbol silvestre de mediana altura y de poco diámetro, que suministra una madera muy sólida, fuerte, dura. de color entre amarillo y negrusco, muy apreciada para horcones. Hay otra variedad mas pequeña todavía, pero cuya madera mas fuerte y mas sólida suele utilizarse para horcaduras.

Cuaba blanca, Cba.; tea, Prco. - Amyris silvatica. M. D. - G. 997. - Arbol silvestre cuya altura es de 25 á $30^{\prime}$ y el diámetro de su tronco de 5 á 8 " lo mas; suministra una madera aromática, fuerte, sólida, de color blanquecino y rompe verticalmente; sirve en las fábricas del campo para estantes; además, como es muy resinosa, la usan en el campo como hachones, en astillas, con lo que se alumbran en la pesca de las hicoteas y aun los pobres del campo se alumbran con ella en sus chozas; tambien es buena para muebles.

Cucurito, Gna.; cocorito, Trd. - Maximitiana regia. M. D. G. 92. - Primorosa palmera que hemos hallado con abundancia en Trinidad y en las misiones del Caroni, provincia de Guyana, la cual se eleva á 40 ó $50^{\prime}$ de altura y el tronco llega á 12 ó $15^{\prime \prime}$ de diámetro; suministra una madera color de chocolate tanto mas pronunciado cuanto mas inferiores y esteriores son las partes de que proviene, mientras que en el caso contrario eś el resultado de muchísimas vetitas paralelas pero sin simetría ninguna, mas ó menos agrupadas entre sí, cuyo color es rojizo pardusco, irregularmente interrumpido por el fondo cuyo color es camuza pálido, lo que es de un aspecto muy hermoso. Su peso específico es de 1,063 y de 0,991 . Esa madera labrada sirve esclusivamente para bastones primorosos; bien dura y muy fuerte, pero sin embargo, como se rompe con bastante facilidad, no es muy á propósito sino para embutidos en los muebles de lujo, especialmente para mesas, roperos, etc., además, en Trinidad, utilizan las tablas que con el hacha y la cuña sacan de esa palmera, del carat sabal, del groo groo acrocomia sclerocarpa del manaque, Euterpe oleracea y otras, para fábricas del campo.

Curucai. - Encense tree, Trd. - Amyris trinitensis. M. D. G. 997. - Arbol silvestre de la altura y tamaño de la cuaba blanca, que da una madera mas liviana que pesada, de poca dureza, de testura fibrosa y sin embargo no muy floja, grano regular; de color gris rojizo teñido de achocolatado, como salmoneadito, con vetas lineares, otras veces con listas mas rojizas y bastante grandes, mas ó menos disciplinadita, casi sin albura y apenas perceptible, porque es casi de igual color: no tiene ninguna aplicacion que sepamos.

Curbana, canela blanca, Cba. - Canela alba. M. M. - G. 940.Árbol silvestre y poco abundante en las Antillas, mientras que es muy comun en ciertas partes de la Guyana, en las montañas del 
Caroni y de Upata, donde lo hemos hallado durante nuestras peregrinaciones por esas comarcas ; se eleva comoá 30 ó 40 piés y el diámetro de su tronco es de como 12 á 18 pulgadas; suministra una madera bien pesada y de muy buena dureza, de color acanelado ó pardusco claro bastante uniforme, $y$ sin embargo, con algunas vetas muy poco pronunciadas; no tiene ninguna aplicacion que sepamos.

Cuero de zapo, Prco. - Arbol silvestre que se eleva á unos 40' de altura y cuyo tronco llega á un diámetro de un pié y medio; su madera es de color pajizo, no tiene aplicacion y la usan en el campo para leña.

Chicharron, Cba.; Chicharrona intermedia, Rich. F. Combretáceas. - Árbol silvestre bastante grande y coposo, que suministra una madera muy apreciada por ser sólida y buena, de testura fibrosa y bastante porosa á la vez, de albura color aceitunado oscuro salpicada de unos puntitos prietos, mientras el corazon es de un hermoso color prieto, mucho mas duro, y quizás se espresaria uno mejor diciendo que su color es de rapé veteado de pardo mas oscuro ó jaspeado y de aspecto muy bonito; es susceptible de pulimento y despues de barnizada su color se pone mas subido; tambien la hay amarilla; es muy á propósito para carruajes, carretas, ruedas de molino para descascarar café y otros usos.

Chino. Véase naranjo.

Chuspa. Véase cuspa ó cusparé.

Cuspa, cusparé, quina de las misiones del Caroni, etc. - Bonplandia trifoliata. M. D. - G. 838. - Árbol silvestre que hemos hallado con abundancia en las montañas cercanas de Upata, cabecera del canton de ese nombre, provincia de Guyana, República de Venezuela, es social y situado como á 6 ú 800 varas sobre el nivel del mar; se eleva como á 25 ó 30' de altura, su tronco recto llega como á 6 ú 7 " de diámetro lo mas; suministra una madera bien pesada, bien dura, bien compacta, muy fuerte, de grano muy fino, de un color amarillento algo mas pálido que la del boj de Europa, á la cual se parece mucho y que, á nuestro parecer, podria suplir muy bien para las obras de torneo y de carpintería correspondientes con su corto diámetro; el color del corazon es mas subido. Los Indios de Cumaná y de Barcelona, provincias donde se halla con abundancia, lo emplean para mangos de harpones, para flechas ; se utiliza tambien para horcadura de casas; se hacen con él bastones muy bonitos y muy fuertes; es muy amargo.

Cuajaní ó cojaní, Cba. - Véase almendron.

Cují. - Véase aroma.

Cytero, Cba. - Pomme cythère, Trd. - Spondias cytherea.M. D. - G. 276. - Arbol cultivado solamente por sus frutos bastante apreciados ; se eleva como á 30 ó 35' de altura y el diámetro de su tronco llega á $l^{\prime} l_{1} 2{ }^{\circ} 2^{\prime}$; se parece bastante al jobo; de madera amarillenta con vetas ó undulaciones algo mas oscuras; dureza regular, buen peso, testura bastante compacta y grano fino. Nos ha parecido susceptible de pulimento y sin embargo no tiene aplicacion que sepamos. 


\section{$\mathrm{D}$}

Doncella. (Véase carne de doncella.)

Dividivi, Gna. M. D. - G. 1018. - Árbol silvestre que hemos hallado con bastante abundancia en la Guayana, en las provincias de Cumaná y de Barcelona, República de Venezuela; se eleva á 45 ó 50' de altura, porque sus ramas son muy gruesas y grandes: es por consiguiente muy coposo, de tronco recto, pero poco largo: de 3 ó 4 varas lo mas, pero llega á un diámetro de 24 á 30"; su madera es bien pesada, muy compacta, de grano muy fino; es tan dura que las herramientas se rompen al labrarla; su albura, poco espesa, es blanca, mientras que el corazon es negro; sirve para rollos de trapiches; podria además, á nuestro parecer, utilizarse con mucha ventaja para tornear y especialmente para ruedas de moton.

Dagame, Cba. - Calycophyllum candidissimum. M. D. - G. 723. - Arbol silvestre de mediana altura y tamaño que se eleva como á 8 ó 10 varas de altura lo mas, y cuyo tronco, largo de 3 á 4 varas, llega á un diámetro de $10^{\prime \prime}$ y suministra una madera bastante pesada y dura, fibrosa y sin embargo bastante compacta; de color agamuzado con vetas algo mas oscuritas; en el corte transversal el color es mas subido y se ven las zonas concéntricas, pero no muy pronunciadas, mientras que en el corte vertical se reparan muchos poritos separados los unos de los otros por muchos radios medulares filiformes; es susceptible de pulimento y despues de barnizada se parece algo al boj de Europa, tanto por el color, como por el grano. Es muy fuerte y muy sólida, de suerte que se utiliza diariamente para las obras de carpintería del campo y se la prefieren para ejes, timones, arados, etc. El ganado come sus frutos.

Daguilla, lagetto, Cba. - Lagetta lintearia. M. D. - G. 389. - Arbol de 8 á 10 varas de altura, cuyo tronco llega como á 6 ú $8^{\prime \prime}$ de diámetro, su madera no tiene aplicacion ninguna que sepamos, y solo sirve para leña; pero su interés lo saca de su corteza que se puede utilizar muy bien para cordelería y tejidos y cujo liber parece encaje.

Dobla uña, Cba. - Madera bastante dura, pero no muy pesada, de testura fibrosa bastante compacta y grano fino, de un color gris teñido de amarillento pardusco, con vetas algo mas oscuras. Nos ha parecido susceptible de pulimento, y sin embargo no se ha utilizado hasta hoy dia que sepamos.

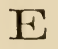

Ebano de Oriente ó real, Cba. - Accacia Lebbec, y propinqua. M. D. - G. 298. - Arbol silvestre que se eleva á 40 ó $45^{\prime}$ de altura y cuyo tronco bastante derecho y largo llega al diámetro de 12 á $15^{\prime \prime}$ y suministra una madera preciosa para muebles finos é instru- 
mentos; es incorruptible, de dureza regular y buen peso, testura compacta y grano fino; susceptible de hermoso pulimento; su color es negro teñido de pardusco mas pálido y veteado, con la albura blanca.

Emajagua. (Véase majagua.)

Enemosco ó nuez moscada del país. - Monodora myristica. M. D. - G. 885. - Arbol silvestre, que se produce en toda la isla de Puerto-Rico, pero con bastante escasez; su altura es de 25 á $30^{\prime}$ y el diámetro de su tronco es de 8 á $10^{\prime \prime}$; su madera es de color amarillento, bastante fuerte, pero no tiene aplicacion ninguna.

Enrubio, Prco. - Zanthoxylum lanceolatum. M. D. - G. 229. - Arbol silvestre no muy comun que se eleva á unos 25 ó $30^{\prime}$ de altura; el diámetro de su tronco es de $10^{\prime \prime}$, su madera muy dura, colorado el corazon, con la albura blanca: no tiene aplicacion que sepamos.

Espino amarillo, Prco. - Zanthoxylon. M. D. - G. 229. - Arbol silvestre abundante en toda la isla de Puerto-Rico; su altura es como de $50^{\prime}$ y el diámetro de su tronco como de $2^{\prime}$; suministra una madera de color amarillo claro y cuyo uso es solo para tablazon de casas; quizás será la ayua de Cuba?

Espino blanco, Prco. - Zanthoxylon. M. D. - G. 229. - Arbol silvestre que se parece mucho al anterior, tanto por su altura como por su diámetro; su madera es de color mas claro, tambien sirve comunmente para tablazon de casas; quizás será la ayua blanca de Cuba?

Espino rubial, Prco.; espino Cba. - Fagara pterota. M. D. - G. 835. - Arbol silvestre que se produce con abundancia casi por toda la isla de Puerto-Rico, cuya altura es de 40 ó $50^{\prime}$ y el diámetro del tronco, de $1^{\prime}$, su madera algo fuerte y sólida, de color amarillo verdoso ó de rapé, con gateados preciosos amarillos; sé emplea en tablazon de casas, puertas, etc. En la maestranza militar de San Juan de Puerto-Rico sirve para arcones de efectos; en los talleres particulares sirve para hacer cubichetes, pisos, puertas, ventanas, etc.

Espinillo ó juso, Prco. - Arbol silvestre que se halla con abundancia en las costas de la isla de Puerto-Rico; se eleva como á 35' de altura, y el diámetro del tronco es de un pié; su madera es color verdoso ú oscuro con vetas amarillentas y su uso comun es para es tantes de casas, balaustres, etc.

Espejuelo, Prco. - Arbol silvestro poco abundante, cuya altura es de unos $30^{\prime}$ y el diámetro del tronco de 8 á $12^{\prime \prime}$; su madera recia es de color amarillento y se usa para estantes de casas y estacadas. Espejuelo amarillo, Prco. - Arbol silvestre abundante por el N. O. de la isla de Puerto-Rico, cuya altura es de 40 á $50^{\prime}$ y el diámetro del tronco de $1^{\prime}$; su madera es fuerte, pesada, de color a marillo con vetas negras cuando está fresca, pero á pocos dias de labrada su color se pone toda de un color casi negro; se emplea en estantes de casas.

Encina, Cba.; roble, Prco. - Catalpa longisilicua. M. D. - G. 526. - Arbol silvestre bastante abundante en las Antillas y en el continente americano; se eleva comóa 45 ó $50^{\prime}$ de altura y su tron- 
co llega al diámetro de 15 á $30^{\prime \prime}$, suministra una madera muy dura, muy fuerte y muy buena para obras de carpintería del campo, carretas, etc.

\section{$\mathrm{F}$}

Frijolillo amarillo y prieto, Cha. - Saronette jaune, Trd.Lonchocarpus latifolius y sericeus. F. 130. - Arbol silvestre que se halla especialmente por la costa y se eleva á como 30 ó 40' de altura, con el diámetro del tronco de 15 á $24^{\prime \prime}$; dos clases de frijolillos hay, una que tiene el corazon prieto y la otra que lo tiene amarillo: esta última es mucho mas comun que la primera. La madera del frijolillo prieto es de peso y dureza muy regulares; su corazon es prieto con hermosas vetas ó undulaciones mas pálidas ó como achocolatadas, que le comunican un aspecto veteado ó jaspeado muy bonito; la albura es color de chocolate muy pálido; testura fibrosa y sin embargo bastante compacta, muy sólida y bastante apreciada; su peso específico es de 0,720 . Corteza seca muy tosca y muy rugosa, color pardusco-rojizo, epidermis bastante espesa; capas corticales muy pocas y mas pálidas ó blanquecinas ; cara interior pardusca y con jaspeo escaso y blanquecino.

Fustete, Cba.; mora, Prco. - Bois z'orange, Trd. - Maslura tinctoria. M. D. - G. 220. - Ese árbol silvestre, bastante comun pero que crece con asaz lentitud, se eleva como á 50' de altura, y el diámetro del tronco es de $1^{\prime} 1_{[} 2$ ó $2^{\prime}$; suministra una madera primorosísima por su bonito color amarillo anaranjado y jaspeado á la vez, pero que con el tiempo y la esposicion al aire se va poniendo poco á poco mas pálido, hasta volverse amarillento sucio, lo que se evita barnizándola cuando se emplea para muebles; su peso específico es de 0,711. Es de mucha estimacion para el arte de teñir, en que se la emplea mucho, de manera que constituye un ramo de esportacion para el estranjero. En los paises en donde se cria se la emplea para estantes de casas de campo, para piñas y radios de ruedas de carruajes y carretas y para eualquiera obra de carpintería que•necesita fuerza y resistencia.

\section{G}

Gía blanca ó brava, jía blanca ó brava, Cba. - Casearia alba y ramiflora. F. 87. - Arbol silvestre que se eleva á 15 ó $25^{\prime}$ de altura, con el diámetro del tronco de 8 á $10^{\prime \prime}$. Nadera de buen peso y buena dureza, cuya testura es bastante compacta y el grano regularmente fino; su color es casi como el del boj de Europa, es decir amarillo pálido, de matiz casi uniforme algo veteado; las zonas concéntricas que se ven en su corte transversal son muy poco pronunciadas y casi de igual color; es bastante apreciada; su peso especí- 
fico es de 0,762. Su corteza seca tiene como una línea escasa de espesor, es de color achocolatado con manchas cenicientas, áspera, con muchas grietas transversales y pocas verticales, bastante compacta, quebradiza y no fibrosa ; capas corticales color de canela pálido; cara interior pardusco rojizo pálido.

Gaita, Prco. - Arbol silvestre cuya altura es de 20 piés y el diámetro del tronco de 18 pulgadas; suministra una madera blanca que se emplea en estantes de casas y vigas.

Garrocho, palo de garrocho, Prco. - Myrodia turbinata. M. D. - G. 920. - Arbol silvestre que se produce con abundancia por toda la isla de Puerto-Rico, cuya altura es de 25 á $30^{\prime}$ y el diámetro del tronco de 6 á $8^{\prime \prime}$; su madera es bastante floja, liviana y de color ceniciento; no tiene aplicacion.

Gateado, Prco.; gatia, Trd. - Letter wood, leopard wood, Trd. - Brosymum guianensis. M. D. - G. 114. - Arbol silvestre cuya altura es como de unos 20 ó 30', y el diámetro del tronco de 10 á 12 pulgadas ó algo mas; el de Puerto-Rico tiene la madera de color encarnado con vetas negras; es bien compacta y hastante dura, mientras el de Trinidad la tiene de un color moreno amarillento veteado ó jaspeado de pardusco bastante oscuro, con muchos radios medulares; bien dura, compacta y muy pesada: nos ha parecido susceptible de un buen pulimento, buena para obras de carpintería fina y de ebanistería; su peso esprecífico es de 1,352.

Gasparil, gasparillo, Trd. - Esenbeckia. F. 111. - Arbol silvestre cuya altura es de 20 á $25^{\prime}$ y el tamaño del tronco 6 á $8^{\prime \prime}$ á lo mas; suministra una madera muy fuerte y elástica, que se parece mucho á la del boj, cuyas propiedades tiene, y que puede por consiguiente reemplazar para obras de torneo ; se usa tambien para pilares y estantería de casas cuando el tamaño del árbol lo permite ; sirve además para bastones muy bonitos y muy fuertes; su peso específico es de 1,106 .

Geo geo, Prco. - Árbol silvestre que se eleva como á 25 ó 30' de altura, con el diámetro del tronco de $1^{\prime}$; da una madera floja, de color oscuro, que sirve solo para leña.

Goao, Cba. - Rhus metopium. M. D. - G. 988. - Árbol silvestre que se eleva de 25 á 40' de altura, con el diámetro del tronco de $15^{\prime}$ á $24^{\prime \prime}$; madera de peso regular, de dureza mediana, testura'muy apretada y grano fino; su color es de un hermoso rojo oscuro, con vetas aun mas oscuras, que se vuelve algo mas pálido con su esposicion prolongada al aire; hemos tenido en mano muestras de color mucho mas pálido; su albura es de color blanquecino teñido de rojizo, y cuyo matiz es á veces bastante uniforme : nos ha parecido susceptible de pulimento, y sin embargo no tiene aplicacion que sepamos.

Gongolí, Prco. - Árbol silvestre que se eleva como á 25 ó $30^{\prime}$ de altura, con el diámetro del tronco de 10 á $12^{\prime \prime}$; suministra una madera compacta y fuerte, de color encarnado; rompe oblícuamente; su uso comun es para armazon de casas y estacadas.

Granadillo, Cba. - Brya ebenus. F. 130. S.-F. I. - Árbol silvestre que se eleva como á 20 ó $25^{\prime}$ de altura y cuyo tronco, largo de 
$12^{\prime}$ á lo mas, llega al diámetro de 6 á 8" y suministra una madera bien apreciada en la isla de Cuba por ser dura y bien resistente; se usa en la construccion de las casas; se utiliza tambien para bastones, muebles de lujo $y$ carpintería fina, porque es bonita. Sentimos no poder dar de ella ninguna descripcion, por no haber tenido en mano ninguna muestra de ella.

Gris gris, Trd. - Desmonchus, F. 14. - Hermosa palmera muy comun en la isla de la Trinidad, cuyo tronco, largo de 15 á $25^{\prime}$, llega al diámetro de 10 á $12^{\prime \prime}$ ó algo mas; suministra una madera casi tan pesada como la piedra, y por lo menos tanto como la del guayacan, durísima, de color prieto con vetitas lineares pardo oscuras ó quizás mejor, formado de vetas desiguales alternativamente negras y pardusco-achocolatado claras; hay algunas mas finitas, de color blanco sucio. Sirve para tablas muy duraderas que se emplean para sobre suelos ó pisos muy hermosos, y á nuestro parecer se la podria utilizar muy bien para la ebanistería fina: el tronco se emplea para estantes de casas y de establecimientos del campo.

Guacamuya, Cba.; clavellina, Prco. - Poinciana pulcherrima. II. D. - G. 1018. - Bien que el tronco de ese arbusto solo llega á unas 3 ó $4^{\prime \prime}$ de diámetro; citaremos su madera por ser muy bonita $y$ quizás susceptible de utilizarse para la ebanistería fina; su color es anaranjado veteado; es de poca dureza, $y$ sin embargo de testura y grano bastante finos; su peso específico es de 0,389 . No pasaremos adelante sin señalar otro árbol del mismo género, natural de Madagascar, pero perfectamente bien aclimatado en las Antillas como árbol de adorno: es la Poinciana regia; Rchl.: flamboyant de los Franceses; crece con bastante prontitud, su altura llega á mas de $30^{\circ}$ y el diámetro del tronco como á 8 ó $10^{\prime \prime}$; de madera amarilla algo veteadita, bonita y fuerte; no tiene todavía aplicacion ninguna; su peso específico es de 0,828 .

Guacima ó guazima, Prco., Cba.; guacimo, Vzla. - Guazunu ulmifolia. M. D. - G. 922. - Arbol silvestre muy comun en todas las Antillas y tambien en el continente americano vecino, que se eleva como de 30 á $40^{\prime}$ de altura y cuyo tronco, bastante recto, llega al diámetro de 15 á $18^{\prime \prime}$; el de la especie de hojas pequeñas ó de las sierras es algo mas alto y corpulento; suministra una madera bastante liviana, y sin embargo bien resistente, de testura fibrosa $y$ poco apretada, grano poco fino, de color gris blanquecino lijaramente matizado de rosado ó de color de carne, con vetas desiguales cuyas centrales, juntándose las unas con las otras, producen un aspecto bonito, con muchas líneas muy finitas y mas oscuritas; esa madera no tiene corazon y en algunas muestras es gris rojizo, jaspeado casi uniformemente; no tiene aplicacion, pero nos parece propia para setos y otras obras interiores de casas, bajo techos, etc. Sirve para leña, y el carbon muy liviano que produce seria bueno para fábricar pólvora; su peso específico es de 0,552 . Corteza rugosa color pardusco ceniciento, muy agrietada, espesa como de 2 á 3 líneas; cuando seca, sus capas corticales cortadas transversalmente son color de chocolate; se separa con facilidad en hebras poco fuertes. 
Guacina amarilla, caria, Cba. - Xilopia cubensis. M. D. - G. 898. - Arbol silvestre de madera muy liviana, muy blanda, cuya testura es floja y fibrosa á la vez, de color blanquecino teñido de amarillento y de rojizo á la par, con vetas irregulares y lineares, á veces bastante pronunciadas, pardusco-prietas ó pardusco-rojizas; no tiene aplicacion que sepamos.

Guaguací, Cba. - Letia apetala. F. 87. - Árbol silvestre que se eleva á 20 ó $30^{\prime}$ de altura, con el diámetro del tronco de 8 á 15" ; suministra una madera muy sólida pero bastante quebradiza, de peso y dureza regulares, testura bastante densa y grano fino; su color es blanco amarillento, amarilloso muy pálido ó blanquecino apenas veteadito; muy apreciada en la isla de Cuba, se utiliza diariamente para tirantería y ligazones. Corteza rugosa muy agrietada transversal y verticalmente á la vez; espesa como de una línea, color gris pardusco, quebradiza y como resinosa.

Guajanilla amarilla, Prco. - Arbol silvestre que se produce con abundancia por el sur de la isla de Puerto-Rico, cuya altura es como de unos 40', y el diámetro de su tronco de 12 á $15^{\prime \prime}$; su madera es fuerte, de color amarillo oscuro, y se parte verticalmente; su uso comun es para estantes de casas.

Guajanilla prieta, Prco. - No es sino una variedad del anterior, de que se diferencia solo por su color amarillo oscuro con vetas pardas.

Guama, Prco., Cba. - Pois doux, Ant. fr. - Inga vera. M. D. - G. 291. - Arbol silvestre frutal muy comun en las Antillas y en el continente americano vecino; hay muchas especies botánicas de ese género, siendo unas mas grandes que otras; se eleva entre 40 y $60^{\prime}$ de altura, de tronco bastante recto, con un diámetro que varía entre 1 á $2^{\prime}$; suministra una madera con la albura de color ceniciento ó blanquecino sucio teñido de amarillento, mientras el corazon es de color gris teñido de pardusco rojizo muy claro, con muchas vetas capilares mas parduscas; de peso y dureza regulares; testura fibrosa $y$ sin embargo bastante apretada, grano fino; parece bastante fuerte $y$ resistente, sin embargo solo se emplea para carbon y leña; su peso específico es de $0,50 \check{5}$.

Guama de costa, majagua, Cba.-Lonchocarpus sericeus. F. 130. S.-F. I. - Arbol silvestre que se eleva á 20 ó $30^{\prime}$ de altura lo mas, con el diámetro del tronco de 12 á $15^{\prime \prime}$. Madera primorosa, de buen peso, dureza regular y grano fino, de color canela claro con vetas lineares ó listas mas oscuritas, con muchos surquitos capilares llenos de una sustancia como gomosa, lo que le da un aspecto particular; con el lente se ve en el corte vertical que los surquitos señalados no son sino vasos abiertos al labrarla; la seccion transversal es de igual color algo mas subido, con muchísimos poros llenos de una sustancia gomosa que la hace como barnizada, y muchas zonas concéntricas cuyas mas centrales son de color mas subido; muchos radios medulares muy finitos y mas pálidos, lo que le da un aspecto muy bonito; es muy fuerte y resistente, lo que la hace apreciar bastante para muchas obras de carpintería, para fábricas del campo y otras cosas; su peso específico es de 0,720. 
Guanabano, Preo., Cba., etc. - Anona muricata. MI. D. - G. 900. - Arbol frutal silvestre no muy abundante $\mathrm{y}$ del cual hay algunas variedades; su altura es como de 3. á $40^{\prime}$, y el diámetro de su tronco, recto y no muy largo, llega á $1^{\prime} 1$ [2 lo mas; da una madera blanda, de color claro, la cual se rompe horizontalmente, no tiene aplicacion ninguna y cuyo peso específico es de 0,397.

Guara, Cba.-Cupania glabra y triquetra, C. castanæefolia, Plm., o C. tomentosa, Sw. - Castaño de las Antillas francesas. M. D. G. 852. - Arboles silvestres, como de 35 á 40' de altura, cuyo tronco recto y bastante largo llega á un diámetro de 10 á $15^{\prime \prime}$ ó algo mas; suministran una madera dura y fuerte, bastante apreciada en Cuba para obras de carpintería y carretería; sirve además diariamente para arcos de toneles, porque es muy resistente y muy flexible á la vez.

Guaraguao, Prco. - Bullet wood, Trd. - Bois à balles, Ant. fr. - Gaurea trichiloides. - Muse ó alligator wood, Jca. - Trichilia moscata. M. D. - G. 931. - Arbol silvestre y abundante que se eleva como á $70^{\prime}$ de altura, cuyo tronco recto y bastante largo llega al diámetro de 6 á $6^{\prime} 1_{[} 2$; suministra una madera bastante dura, bien pesada, de testura bien densa y apretada, cuyo color es encarnado oscuro, se parte oblícuamente ; es muy apreciada para construccion de carros fuertes, de carretas, fábricas del campo y muchísimos trabajos de carpintería.

Guarema, Prco. - Arbol silvestre cuya altura es de 30' y de 2 ' el diámetro del tronco; suministra una madera fuerte, compacta y de color oscuro, la cual se usa comunmente para armaduras de casas.

Guasa, Prco. - Arbol silvestre que se eleva comoá unos 3.j' de altura, con el diámetro del tronco de $1^{\prime}$; suministra una madera algo floja, pero resistente, de color blanco, y se parte verticalmente; su uso comun es para tablazon de casas de campo.

Guasávara, Prco. - Arbol silvestre bastante abundante, cuya altura es de $60^{\prime}$ y el diámetro del tronco de $1,1^{\prime \prime} 1_{[} 2$; suministra una madera fuerte y compacta de color encarnado, y se parte oblícuamente, su uso comun es para estacadas y leña.

Guasimilla, Prco. - Arbol silvestre que será sin duda una variedad de la guacima; su altura es de $35^{\prime \prime}$ y su tronco tiene 12 " de di metro; su madera es blanca, floja, y se parte verticalmente; su uso comun es para armazon de casis de campo.

Guatacare, guatequere y guatequero, Trd. - Lecytis idatimon. - F. Lecitídeas. - Arbol silvestre bastante grande, que se eleva como á 40 ó $45^{\prime}$, cuyo tronco bastante largo y recto tiene como 12 á 18" de diámetro; se cria en los terrenos arcillosos y húmedos; suministra una madera bastante apreciada, bion dura, de buen peso, de testura compacta bastante entremezclada y fibrosa, muy flexible; corazon de un color pardusco, como de hoja muerta, con listas casi achocolatadas que lo separan de la albura, mucho mas pálida, pero tambien teñida de pardusco; muy apreciada para marcos de puertas y ventanas, así como para muchas obras de carpintería, para las fábricas de casas y otros usos en que la fuerza ha de hallarse unida á la elasticidad, como por ejemplo, flechas y brancales de carretas y 
carruajes; es susceptible de pudrirse al nivel del suelo, especialmente empleada en lugares húmedos; su peso específico es de 0,899.

Guatamare, cereypo, Trd., Vzla. - Myrospermum frutescens. M. D. - G. 1008. - Arbol silvestre que hemos hallado muy abundante en las montañas del Caroni, canton de Upata, provincia de Guavana, república de Venezuela; lo hemos encontrado tambien, pero con escasez, en la isla de Trinidad y en Puerto-Rico, pero sembrado, y sin embargo tan hermoso y tan grande como en la Guyana; se eleva como á 50 ó 60' de altura; es muy coposo, de tronco recto bastante largo, mas de $25^{\prime}$, que llega al diámetro de $\left.1^{\prime}\right]_{[} 2$ y á veces mas, suministra una madera fuertísima, muy dura bastante, pesada, de testura compacta y grano fino; el corazon es como de color castaño veteado de pardo; es muy apreciada para todas las obras de carpintería que necesitan á la vez mucha fuerza y duracion; tambien podria aprovecharse en obras de ebanistería y de torneo; su peso específico es de 0,980 .

Guatapaná, Prco. - Arbol silvestre que se eleva á unos 24 o 30' de altura, con el tronco de 12 " de diámetro; da una madera sólida y resistente, de color oscuro, la cual se emplea para estantes y embarcaciones.

Guayabo, Prco., Vzla. - Psidium pomiferum. M. D. - G, 1112. - Arbol frutal silvestre muy abundante en todas las Antillas y en el continente americano correspondiente, que se eleva á una altura de 15 á $20^{\prime}$ y el diámetro de su tronco no es mas que de $6^{\prime \prime}$; suministra una madera de testura fina y compacta, bien pesada y grano fino; su color es gris pardusco y rojizo á la vez, con vetas paralelas y undulosas mas pálidas, que la hacen como jaspeada y muy bonita á la vista, con nudos pardos; es muy apreciada para las obras de carpintería que corresponden con su poco tamaño y que ne. cesitan á la vez fuerza y elasticidad; sirve pues para los instrumentos de agricultura, $\mathrm{y}$ se utiliza tambien en las fábricas del campo; su peso específico es de 0,696.

Guayabito. - Bois caraïbe, Trd. - Campomanesia aromatica. II. D. - G. 1121. - Arbol silvestre y frutal, puesto que da la guayabita de arrayan, que se eleva á 25 ó $30^{\prime}$ de altura, se cria en las montañas y su tronco llega á 6 ú $8^{\prime \prime}$ de diámetro; suministra una madera muy dura y muy fuerte, de grano muy fino y testura compacta; su color es gris pardusco, casi café con leche, de aspecto muy bonito á la vista, aunque bastante oscuro á causa de sus primorosas vetas mas ó menos pálidas y formando dibujos muy variados; no tiene aplicacion que sepamos, pero á nuestro parecer se podria utilizar en las mismas circunstancias que la anterior; su peso específico es de 0,847 á 0,914 .

Guayabota roja, Prco. - Arbol silvestre bastante abundante; su altura llega á $36^{\prime}$ y el diámetro del tronco es de $12^{\prime \prime}$; su madera es de color rojo, algo blanda y de poca duracion; se rompe oblícuamente; su uso comun es para armazon de casas de campo. Hay una variedad que se llama solo guayabota, cuyo color es mas claro.

Guayabacon, Prco. - Arbol de las costas, cuya altura es de unos $30^{\prime}$ y el diámetro del tronco de $18^{\prime \prime}$; su madera compacta y fuerte 
se rompe con dificultad y es de color rosado, se emplea en soleras y vigas de casas de campo.

Guayacan, Prco., Cba., Vzla. - Guayacum officinalis. M. D. G. 862.-Arbol silvestre que se halla por las costas y se eleva como á 45 ó 50' de altura, y el diámetro del tronco llega á 12 ó $15^{\prime \prime}$ á lo mas; suministra una madera muy dura, muy apretada, de testura muy compacta y trabada, grano fino; su albura, casi tan dura, es color de boj, es decir, amarillento claro, mientras el corazon es de color pardusco oscuro matizado de verdoso, con vetas mas oscuras; es muy apreciada y forma un ramo de comercio para la esportacion; se labra bien con la sierra, y sin embargo, á pesar de su testura fibrosa y muy trabada á la vez, se puede tambien hender con el hacha y especialmente cuando está el árbol recien tumbado, porque entónces su madera es mucho mas blanda y se labra con mucha mas facilidad: se endurece pues mucho con su esposicion al aire, y entónces es difícil labrarla. Se usa mucho para maquinaria, ebanistería y obras de tornear, en fin, en todas las obras que necesitan á la vez dureza y resistencia, como dientes de trapiche, ruedas de palanques, mortarios, ejes de carretas, etc.; es susceptible de hermoso pulimento; su peso específico es de 1,080, cuando verde seco 1,354 á 1,360 .

Guayacancillo, Prco. - Variedad del anterior ó quizás otra especie. - Guayacum verticale.

Guayo, Cba. - Ehretia bourreria. M. D. - G. 608. - Árbol silvestre bastante grande, que se eleva á 30 ó $40^{\prime}$ y cuyo tronco alcanza el diámetro de 12 á $18^{\prime \prime}$; madera de peso regular y buena dureza, testura fibrosa no muy compacta y grano bastante fino, de color canela ó aleonado pálido, jaspeado y veteado á la par, algunas de sus vetas mayores ó listas son parduscas; se parece mucho al ébano colorado de Europa.

Güira criolla, güira cimarrona, Prco. (Véase totumo.)

Güitaran, Prco. - Arbol bajito y silvestre que crece por las costas y se eleva como á 18 o $20^{\prime}$ de altura, y cuyo diámetro del tronco llega á unas 10 ó $12^{\prime \prime}$; su madera es de color rosado y con facilidad se rompe verticalmente; no tiene aplicacion.

\section{$\mathrm{H}$}

Haya, Prco. - Arbol silvestre bastante abundante, que se eleva á unos 30 ó $35^{\prime}$ de altura y cuyo tronco llega al diámetro de 8 á 10"; su madera es de color blanco oscuro, flexible y se parte verticalmente; su uso comun es para remos de botes y varazon de casas de campo.

Hatillo, Cba. - Madera de buen peso y de dureza regular, testura bastante apretada y grano bastante fino; de color amarillento pálido y muy parecida á la del boj de Europa, aunque algo mas pálida y con algunas vetas ó listas desiguales teñidas de pardusco mas ó menos oscuro. 
Hicaquillo. - Icaque grand bois, Trd. - Licania incana, Aubl. F. 131. - Arbol silvestre que se eleva á 40 ó 50' de altura, cuyo tronco bastante largo y derecho llega al diámetro de 8 á $10^{\prime \prime}$ á lo mas; suministra una madera bien dura, bien pesada, de testura fibrosa, y sin embargo bastante compacta, grano fino; su color es de carne, no muy rojo, ó quizás mejor, color de flor de melocoton, con vetitas ó remolinos muy poco pronunciados, que le dan un aspecto jaspeado muy bonito; no tiene todavía aplicacion, pero sin duda se utilizará algun dia, porque es bastante fuerte y hermosa; su peso específico es de 1,050 .

Higuerillo, Prco. - Árbol silvestre que se eleva á $30^{\prime}$ de alto y cuyo tronco llega al diámetro de 14 ó 16"; da una madera de regular resistencia, de color ceniciento y que se rompe verticalmente; su uso comun es para estantes de casas, viguetas, cuartones, tablas, etc:

Higueron, higuerote, Vzla. - Ficus glabrata y demas especies. M: D. - G.111. - Arboles silvestres, grandes, corpulentos y muy coposos, cuyo tronco recto y bastante largo llega á veces al diámetro de 6 á $8^{\prime}$, de madera bastante fuerte, no muy dura, de testura fibrosa bastante compacta, y sin embargo no muy pesada; de color blanco amarillento; no tiene aplicacion, pero á nuestro parecer se podria aprovechar para bateas y otras cosas por ese estilo y quizás en tablones para el interior de casas; su peso específico es de 0,450 .

Higuera blanca o criolla. (Véase totumo.)

Hoja menuda, Prco.; eugenia. M. D. - G. 1125. - Árbol silvestre que abunda por las costas; su altura llega á unos $12^{\prime}$, y el diámetro del tronco á $10^{\prime \prime}$; suministra una madera fibrosa muy fiexible y bien resistente, cuyo color es ceniciento; su uso comun es para hacer estacadas y carbon.

Hortegon labrado, Prco. - Arbol silvestre que no se halla muy abundante y solo en el N. O. de la isla de Puerto-Rico; se eleva á unos $60^{\prime}$ de altura, y el diámetro del tronco, bastante largo y derecho, llega solo á $2^{\prime}$; suministra una madera muy recia, de muchísima duracion, de color de carne, y se rompe verticalmente con dificultad; su uso comun es para estantes de casas.

Hortegon prieto. - No es sino una variedad del anterior, porque lo único que le diferencia es el color pardo de su madera; tiene tambien iguales usos.

Hucar blanco, Prco.-Bucida buceras. M. D.-G.389 lis.-Arbol silvestre abundante por toda la isla de Puerto-Rico y demas Antillas, muy alto y muy corpulento; en efecto se eleva á $80^{\prime}$ de altura 'y su tronco recto llega al diámetro de 4 á 5 '; suministra una madera de color blanco amarillento, muy fuerte y flexible, cuyo uso comun es para estantes de casas, mazas te trapiches, mazas de martinetes; se emplea para cabos y piñas de ruedas á falta de copa blanco; en la marina sirve para curbas de embarcaciones.

Hucar prieto, Prco. - Es una variedad del anterior, del cual no difiere sino por el color ceniciento oscuro de su madera.

Hueso, Cba. - Drypetes glauca. F. 106. - Arbol silvestre de larguísima vida que se halla bastante abundante en Cuba, Puerto- 
Rico, Mont-Serrato, Dominica, etc.; suministra una madera enteramente blanca que no tiene aplicacion ninguna.

\section{$\mathrm{J}$}

Jaboncillo, Cba.; paraparo, Vzla. - Savonnete jaune, Trd. Sapindus saponaria. M. D. - G. 853. - Arbol silvestre comun en las Antillas y en el continente americano vecino; se eleva á una altura de $60^{\prime}$ y su tronco bastante largo y recto llega al diảmetro de 15 á 18", suministra una madera que es una de las mejores de esos paises, por ser fuerte y flexible á la par que resistente y no muy pesada: se deberia utilizarla para fábricas de casas y muchísimas obras de carpintería. Además, sus propiedades la hacen muy á propósito para piñas y radios de ruedas, etc.

Jacana, Prco. - Arbol silvestre cuya altura es de unos 40', y el diámetro del tronco tiene $2^{\prime}$; suministra una madera de color claro,

- flexible $y$ bastante fuerte; sin embargo no tiene aplicacion y se emplea solo para leña.

Jacaranda corulea. M. D. - G. 530. - Arbol silvestre que hemos ballado en Trinidad y la Guyana. pero que se podria propagar con facilidad en las demas Antillas como árbol de adorno y tambien por su buena y hermosa madera; se eleva como á 40 ó $50^{\prime}$ de altura, y su tronco, derecho y bastante largo, llega al diámetro de 10 ó $12^{\prime \prime}$, suministra una madera muy hermosa, cuyo color es gris amarillento pálido, jaspeado y como moere de igual color, pero algo mas oscurito; parece bien fuerte, de buena resistencia, dureza regular, buen peso, testura fibrosa, $y$ sin embargo de grano fino, y por esa razon nos ha parecido susceptible de pulimento; tambien nos ha parecido no tener albura ninguna. A nuestro entender se la podria aprovechar para carpintería fina y para muebles de lujo; reemplazaria con ventaja el fresno de Europa. Su corteza es muy delgada, rugosa y de color pardusco blanquecino sucio, cuya epidérmis se desprende con facilidad, dejando en pos de sí una mancha mucho mas pálida, blancuzca ó amarillenta; su parte interior es morena y achocolatada; su peso específico es de 0,652 .

Jagua, Prco., Cba.; caruto, Trd., Vzla. - Genipa americana. M. D. - G. 728. - Arbol silvestre abundante en todas las Antillas y en el continente americano vecino; es de la altura de unos $50^{\prime}$, y el diámetro del tronco, bastante largo y bien derecho, tiene unos 15 á $20^{\prime \prime}$; suministra una madera no muy dura y bastante liviana, pero de mucha fuerza y rosistencia, bien flexible y de testura fibrosa; su color bastante uniforme, blanquecino teñido de pardusco rojizo pálido; sc parece mucho al fresno de Europa, cuyas propiedades posee, y por tal razon es muy á propósito para cajas, lanzas y brancales de carruajes, y muchas obras de carpintería que necesitan á la vez fuerza y elasticidad; hacen con ella cedazos, hormas de zapatos, etc. En la maestranza militar de San Juan de Puerto-Rico la emplean 
para cajas de fusil y aros de cajas de guerra, etc.; su peso específico es de 0,873 .

Jaguey, mata palo, Prco. - Ficus dendricida, $F$. radula, etc. M. D. - G. 111. - Arbol silvestre bastante abundante, cuya altura es de 40 á 50', y el diámetro del tronco, bastante largo y recto, llega á $6^{\prime}$; suministra una madera bastante liviana, poco dura, de testura fibrosa y algo floja, grano poco fino de un color amarillento mas ó menos pálido, otras veces es canela pálido con muchas vetas lineares y paralelas que le dan un aspecto muy bonito; corazon $\mathrm{y}$ albura de igual color; á veces las vetas son mas pálidas ó mas oscuritas, formando entre sí especies de arabescos ; su uso comun es para cayucos ó curiaras, baños, bateas para lavar, etc.; su peso específico es de 0.450 .

Jaimiquí, almiquí, Cba.-Achras. MI. D.-G. 635.-- Arbol de la isla de Cuba que suministra una madera muy fuerte, bien pesada $y$ muy dura, testura bien compacta y grano fino, de color rojizo pardusco con vetas algo mas oscuritas hácia el corazon, lo que la hace muy bonita y agradable á la vista; muy apreciada para las obras de carpintería que requieren á la vez fuerza y dureza.

Jia brava, amarilla ó blanca, Cba. (Véase Gia.)

Jarabacana, jarabaguana y jarabaina, Cba. - Madera de muy buen peso y durísima, de testura fibrosa $y$ no muy apretada, de color amarillento pálido con vetas mas ó menos pronunciadas, segun la disposicion del corte de la madera, cuyo color es azafranado pálido, ó quizás mejor anaranjadito, con la albura mucho mas pálida, lo que le da un aspecto particular. La muestra que hemos tenido en mano estaba ya un poco carcomida por los gusanillos; se utiliza para horcones.

Javillo, Prco., Cba. - Sand-box, Trd. - Hura crepitans. M. D. - G. 126. - Arbol silvestre bastante comun en las Antillas y en el continente americano; se eleva á unos $50^{\prime}$ de altura, es muy ramoso y primoroso, y por tal razon muy á proposito para arboledas, pues da una sombra muy agradable; su tronco, bastante largo y recto, llega al diámetro de 24 á $30^{\prime \prime}$ y á veces mas; suministra una madera bastante liviana $y$ blanda, de testura fibrosa, bien resistente y de mucha duracion en el agua; su color es blanco, apenas teñido de majon, con vetas parduscas que corresponden con el corazon; hay una variedad cuyo color es pardusco y es mas apreciada, porque las canoas que con ella se hacen son mucho mas fuertes y mas duraderas que las que se hacen con la otra; su peso específico es de 0,465 . Sirve tambien para tablas para forrar las casas y otras obras interiores. A! labrarla se debe evitar que su aserrin caiga en los ojos y se introduzca en las narices, porque puede determinar irritaciones fuertes que podrian degenerar en inflamaciones de alguna consideracion; basta para eso cubrirse la cara con una gasa.

Jigüera, Cba. (Véase güira cimarrona.)

Jiquí, jequí, Cba. - Bumelia nigra. M. D. - G. 641. - Arbol silvestre comun en la isla de Cuba, que se eleva á 35 ó $40^{\prime}$ de altura y el tronco llega al diámetro de 12 á $15^{\prime \prime}$; su madera es nuy fuerte, durísima y de mucha duracion, hecho tan conocido en cia isla que 
ha dado oríjen á una espresion vulgar muy usada, especialmente entre los hacendados y la jente del campo; en efecto, cuando uno quiere señalar una cosa muy fuerte dice : "Es un jiquí, ó es como jiquí.» Esa madera, de grano fino y muy compacta, es color de rapé ó amarillento oscuro. Puesta en el suelo se la tiene por imputrefactible y dicen que se petrifica; su uso comun es para horcones; cuesta mucho trabajo para labrarla.

Jocuma, Cha. - Bumelia palida, Swtz. M. D. - G. 641. (Véase acana, ausubo, etc.)

Jobo, Prco., Cba., Vzla. - Hog plum, Trd. - Moubin, Ant. fr. - Espondias lutea. M. D. - G. 276. - Arbol frutal silvestre muy abundante en las Antillas y en el continente americano, cuya altura es como de unos $40^{\prime}$, con el tronco bastante largo y recto, de un diámetro de 12 á 18"; suministra una madera liviana, poco dura, pero bastante fuerte y elástica á la vez, de color amarillento pardusco, punteadito y como moere, muy agradabie á la vista; no tiene aplicacion; sirve solamente para leña; su peso específico es de 0,508 .

Jucaro martelero, Cba. (Véase hucar.)

Jucaro prieto ó bravo, Cba. - Bucida capitata. (Véase hucar.)

Juya. - Arbol silvestre abundante por toda la isla de PuertoRico, cuya altura es de $40^{\prime}$ y el diámetro del tronco de $12^{\prime \prime}$; suministra una madera bastante fuerte, de color amarillento, cuyo uso comun es para armazon de casas y para remos de embarcaciones menores.

\section{L}

Lacre. - Bois sang, Trd. - Vismia guyanensis. - F. Hipericíneas. - Arbol silvestre que se eleva como á 25. o $30^{\prime}$ de altura, cuyo tronco poco largo llega al diámetro de 5 á $\tau^{\prime \prime}$; suministra una madera bastante liviana, de una dureza regular, bien resistente, grano fino $y$ testura fibrosa, muy bonita $y$ de un hermoso color, como flor de alberchigo ó melocoton pálido, ó quizás un color que vendria á ser como el resultado de la mezcla de los dos colores gamuza y carne pálido, veteadita de igual color algo mas subido y á la vez moere; no tiene albura ninguna; no se emplea todavía, pero á nuestro parecer podria servir para muebles de lujo; su peso específico es de 0,664 . Corteza agrietada y como formada de capas toscas que parecen sobrepuestas las unas á las otras, poco espesa, de línea ó línea y media escasa, color rapé; sale de ella una sustancia resinosa particular color de lacre y que á nuestro parecer se podria aprovechar para barniz.

Laurel blanco y prieto, Prco. - Laurier cyp, Trd. - Arbol silvestre que se eleva á mas de 60 o $70^{\prime}$ de altura, y cuyo tronco, recto Y largo, llega al diámetro de 6 á $8^{\prime \prime}$; suministra una madera muy fuerte y muy resistente, bastante liviana, testura fibrosa $y$ sin embargo no muy floja, grano bastante fino, poco dura, exhala un olor aromático bastante agradable, de color amarillento grisáceo ó aca- 
nelado muy claro, casi de hoja muerta, con hermosos nudos parduscos, de los cuales salen remolinos ó vetas parduscas mas ó menos pronunciadas, que al juntarse forman especies de dibujos de aspecto mur bonito, sedoso y lustroso á causa de las muchas vetitas filiformes que provienen de los vasos abiertos al labrarla; su peso específico es de 0,658 . Es incorruptible, y por esa razon la emplean para piraguas y embareaciones mayores con que se navega en el rio Negro y en el Orinoco; es muy buena tambien para carpintería de casas y otras, puertas, ventanas, etc.

Leche prieta, Prco. - Arbol silvestre del interior de la isla de Puerto-Rico, cuya altura es de unos $20^{\prime}$ y el diámetro del tronco de unas $2 \tau^{\prime \prime}$; suministra una madera compacta. de color rosado, la cual se rompe con dificultad; su uso comun es para estantes de casas.

Lechecillo, Prco. - Arbol frutal silvestre que se eleva como á unos $40^{\prime}$ de altura y el diámetro de su tronco llega á $12^{\prime \prime}$; su madera es rosada, dura y rompe verticalmente; su uso comun es para estantes de casas; sirve tambien para carbon inmejorable para fraguas.

Limoncillo, Prco. - Calyptranthes paniculata. M. D.-G. 1119. - Arbol silvestre cuyas hojas estrujadas huelen á limon; se eleva como á 50 ó $60^{\prime}$ de altura y el diámetro del tronco llega á 18"; su madera es muy dura, flexible y de color morado, rompe con dificultad verticalmente; su uso comun es para estantes de casas, estacones de puertas, etc.; su peso específico es de 1,112.

Libisa ó lebisa, laurel leviza ó laurel blanco, Cba. - Oreodaphne alba. M. D. - G. 225. - Arbol silvestre bastante grande que suministra una madera muy fuerte que se emplea en la isla de Cuba para ejes de carretas.

Limon agrio, Prco., Cba.; limeta, Cba.; naranjo chino, Preo.Citronnier, limette, oranger, Ant. fr. - Limon tree, lime tree, orange tree. Ant. ingl. - Citrus limonium, C. limeta, C. aurantium. M. D. - G. 97\%. Arboles frutales silvestres que se crian con abundancia en las Antillas y en el continente americano; se elevan á 20 ó $25^{\prime}$ de altura y el diámetro del tronco llega á 8 ó $10^{\prime \prime}$; suministran una madera muy fuerte, flexible, bien compacta, de buena dureza y resistencia, pero que es mas objeto de curiosidad que de utilidad; sin embargo, se utiliza en ebanistería para filetes y embutidos de muebles de lujo. La de limon es de peso muy regular, de buena dureza, de testura fina y bastante compacta, de color amarillento pálido, veteada ó jaspeadita casi uniformemente; su peso específico es de 0,833 . La del naranjo comun ó chino es tan fuerte, tan dura y pesada como la anterior, con albura blanquecina amarillenta, mientras el corazon es de color pardusco muy pálido teñido de amarillento pálido; su peso específico es de 0,815 . En la maestranza militar de San Juan de Puerto-Rico sirve para mangos de herramientas.

Lirio blanco, lirio silvestre, Cba.; tabaiba, Prco. - Plumiera alba y P. nivea. M. D. - G. 653. - Arbol silvestre que se halla por las costas, se eleva como á 30 ó $35^{\prime}$ de altura, y el tronco, bastante recto, llega al diámetro de 6 á $8^{\prime \prime}$, vestido de una corteza color 
gris ceniciento ó blanco sucio, poco rugosa, espesa como de $2^{\prime \prime \prime}$ y muy lechosa cuando verde, de madera bastante apreciada para ciertás obras de carpintería que necesitan á la veż flexibilidad y resistencia; es de un color blanco amarillento ó gris amarillento pálido, con undulaciones desiguales, al cunas claritas, mientras otras son un poco mas oscuritas, y hasta pardusquitas, cuando salen de los nudos, lo que le da un jaspeado bastante bonito; su testura es fibrosa y compacta, y el grano fino: tiene el defecto de que el canal medular persiste durante larguísimo tiempo y raras veces desaparece del todo.

Lirio colorado, Cba.; alelia, Prco. - Plumiera bicolor y rubra. M. D. - G. 653. - Ese árbol de adorno es mas pequeño que el anterior, puesto que solo se eleva á unos $20^{\prime}$ y que el tronco no llega mas que á 5 o.$^{\prime \prime}$ de diámetro; su madera se parece enteramente á la del lirio blanco que acabamos de describir; no tiene aplicacion ninguna, pero se podria utilizar en iguales circunstancias; su peso específico es de 0,853 .

Lombricero, Trd. (Véase llaba.)

Lombricero del monte, Trd. - Angelin grand bois, Trd. - Diplotropis brachipetala, Trd. F. 130, S.-F. I.-Arbol silvestre que se eleva á 45 ó 50' de altura y cuyo tronco llega al diámetro de 15 á $18^{\prime \prime}$; suministra una madera muy fuerte, bien duradera, de buena dureza y que se emplea con ventaja para las fábricas del campo, es muy bonita y casi de color de hoja muerta pálido, con muchas vetas desiguales mas ó menos paralelas, de color pardusco rojizo oscuro ó aleonado; albura blanquecino-amarillenta.

\section{LL}

Llaba, Cba.; lombricero, Trd.; pilon, Gna.; moca, Prco. - Angelin, Trd. - Partredy wood y bastard cabbage wood., Jca. Andira racemosa. M. D. - G. 1082. - Arbol silvestre que se halla bastante abundante en todas las Antillas y en el continente americano; se eleva á 45 ó 50' de altura y su diámetro de 12 á $18^{\prime \prime}$; suministra una madera bastante dura y cuyo color varia mucho, de manera que la hemos visto tan pronto de color rojizo ó encarnado, como pardusco y hasta prieto, otras veces amarillento: por esa razon la llaman en Puerto-Rico una moca colorada y otra moca amarilla, aunque producidas por el mismo árbol. Los varios colores mencionados, juntando sus tintes de un modo mas ó menos regular y hasta caprichoso forman vetas capilares diversamente matizadas, lo que le da un aspecto particular bastante bonito; hemos tenido en mano una muestra rojiza ó gris rojiza con muchas vetitas mas oscuritas y en ciertos lugares como aleonaditas; su peso específico es de 0,748 . Se utiliza con mucha ventaja para piñas de ruedas y despues de hecha tablas ó tablones es propia para pisos y tablados como para cualquiera otra obra de carpintería. Én otro tiempo la empleaban en el Brasil para la construccion de buques. En Puerto-Rico 
su uso comun es para estantería de casas de campo. Se esporta para Europa, en donde se usa para bastones, caña ó mango de paraguas y de quitasol, se emplea tambien en ebanistería y para tornear.

Llama, Cba. - Madera de peso y dureza regulares; testura fibrosa, de color rojizo ó de rapé de España con vetas mas oscuras, las cuales se vuelven á veces listas undulosas; despues de pulida y de barnizada se pone muy agradable á la vista. La epidermis de la muestra que hemos tenido en mano se habia desprendido y entónces el color de la corteza era canela un poco mas amarillento interiormente, sus capas corticales se podian separar enteras las unas de las otras con mucha facilidad; espesa como de una línea y media.

Llocuaje, Cba. - Madera de corazon bastante duro, de color rojizo veteado algo mas subido, con la albura mas bianda y de color gris rojizo teñido de verdoso; aspecto fibroso; segun el modo con que le toca la luz, se vuelve bastante lustrosa, y la albura parece entónces como sedosa. Su corte vertical examinado con el lente parece bien fibroso, mientras el transversal parece de un color mucho mas subido; es bastante compacta y sin embargo con muchos poros bien finitos; sus zonas concéntricas están muy pronunciadas; es susceptible de pulimento, y despues de barnizada el corazon toma un color amarillento veteadito y la albura se vuelve de color aceitunado con vetas verdosas.

Lloron, Cba. - Pigeon wood, Jca. - Gotarda lucida y G. speciosa. M. D. - G. 751. - Árbol silvestre que se eleva á 25 ó $30^{\prime} \mathrm{y}$ suministra una madera de buen peso y de dureza mas que regular, con testura fibrosa poco compacta y de grano bastante grueso; su corazon es de color pardusco algo acanelado y jaspeadito á la par, mientras la albura es mucho mas pálida, algo a marillenta y veteada. - En Jamaica es bastante apreciada para obras de carpintería, para el interior de las casas y tambien para tornear; el color de la se gunda especie es pardusco anaranjado.

\section{$\mathbf{M}$}

Maboa, Cba. - Bastard manchinell, Trd.-Cameraria latifolia. M. D. - G. 650. - Arbol silvestre que se eleva como á 35 ó $40^{\prime}$ de altura y el tronco bastante recto llega al diámetro de 8 á $12^{\prime \prime}$; suministra una madera buena y que se parece bastante al ébano, pero no es tan negra, bien pesada y cuyo corazon, muy duro, es de color pardo castaño bastante uniforme y casi sin vetas, las cuales, cuando existen, son poco pronunciadas, mientras la albura es gris algo teñido de rojo, y hace así contraste con el corazon; es tambien bastante dura. Corteza tosca y rugosa, de color ceniciento sobre un fondo achocolatado, con capas corticales compactas, bastante duras y parduscas; cara interior mas parda. Esa madera se utiliza para timones de carruajes y obras de carpintería.

Macaliuan, Cba. - Madera de poco peso, testura fibrosa y floja, dureza regular, de color y aspecto de la yaya de Europa, es decir, 
rojizo muy pálido, con jaspeado mas oscurito, cuya albura es blanquecina y apenas teñida de rojizo. Corteza lugosa, bastante pesada, espesa como de línea y media, de color pardo achocolatado, con manchitas blanco-amarillentas que parecen producidas por una sustancia resinosa, quebradiza y de rotura blanca $y$ brillante; epidérmis poca; las capas corticales parecen bien compactas, pero muy poco duras; su corte vertical es color de canela jaspeado de blanquecino; cara interior de igual color, pero un poco mas pálida.

Macurije, Cba. - Cupania opositifolia. M. D. - G. 852. - Arbol silvestre que se eleva á 3 ó $^{\prime} 40^{\prime}$ de altura; se cria en los lugares montañosos y su tronco recto llega al diámetro de 12 á 18 " ; suministra una madera bastante apreciada para bajo techo, varas y cercas ; es dura, de buena resistencia, poco pesada y tiene el aspecto, la testura y el color del álamo de Europa; es decir, que tiene el corazon gris algo rojizo ó color de carne pálido, con zonas irregulares algo mas oscuritas, y la albura blanquecina ; de rotura limpia; exhala un nlor fuerte; sirve para fábricas de casas, ya en las armaduras, ya en las puertas y ventanas; se utiliza tambien en obras de carretería. Las hojas de ese árbol son apetecidas por las vacas y caballos; sus frutos son un buen alimento para los cerdos, y de sus flores sacan las abejas una miel deliciosa.

Maga, Prco. - Thespesia grandiflora. M. D. - G. 969. - Arbol silvestre no muy abundante, que se deberia propagar como siendo de adorno y á la vez de utilidad por su madera; se eleva como á $50^{\prime}$ de altura, y el tronco, recto y bastante largo, llega al diámetro de $30^{\prime \prime}$; la madera es de color de rosa cuando nueva y negra cuando vieja; es fuerte y se parte verticalmente. Su uso comun es para estantes de casas; se emplea tambien para hacer flautas, flautines, clavijas de guitarra y otras obras de esa especie; sirve tambien para muebles; es de mucha duracion bajo la tierra y se considera como la mejor para las obras de madera curos cimientos hayan de ser de lo mismo; su peso específico es de 0,677 .

Majagua, Cba. - Paritium elatum. M. D. - G. 972. - Árbol silvestre cuya altura es solo de 25 á $30^{\prime}$, y el diámetro del tronco recto de 6 í $8^{\prime \prime}$; suministra una madera blanca cuyo corazon lejítimo es color ceniciento algo azulado, un poco veteadito, de aspecto muy bonito y agradable á la vista; su peso específico es de 0,095 ; es muy porosa, muy flexible y sin embargo muy resistente ; por esa razon se emplea diariamente en la Habana para varas de quitrines y volantes, especie de carruajes especiales de ese pais y muy á propósito para transitar por los malos caminos, porque nunca se vuelcan y son muy agradables por su balanceo, que se puede comparar al de las hamacas de que tanto se usa. Corteza muy tosca de color chocolate pálido y cuya parte interior es cenicienta; epidermis bastante espesa; capas corticales como de línea y media, muy fibrosas y separándose fácilmente en muchísimas hebras o tiras; cuando pertenece á vástagos como de dos años es muy buena para sogas.

Magüira, masgüira, Cba. (Véase güira cimarrona.)

Madera de lanza, Cba. - Lance wood, Trd. - Bois lance, Ant. 
fr. - Guatteria virgata. F. 95. - Arbol silvestre que se eleva como á $25^{\prime}$ de altura, y cuyo tronco derecho solo llega al diámetro de $6^{\prime \prime}$; suministra una madera de grano fino, testura fibrosa y dureza regular; es muy flexible, elástica y bastante resistente á la vez; de color amarillo mas pálido que el boj de Europa ; se hiende con facilidad; se utiliza para lanzas y varas de coche, tacos de billar, arcos de violin y para resortes; espuesta á la accion del calor ó del agua hirviente se dobla con facilidad; sirve además para armaduras de casas, bajo techos, etc. De Cuba y de Jamaica la mandan á Euroya en pestigas largas, cuyo diámetro es de 3 á 6 pulgadas ; corteza muy delgada.

Tambien llaman bois de lance á la rollinia multiflora, de la cual ya. hemos hablado con el nombre de corazon cimarron, cuya madera se utiliza con frecuencia para reemplazar el corcho, aplicándola á las redes de pescar.

Malagueta, Prco.; pimiento, Prco., Cba. - Bois d'Inde, Ant. fr. - All spice tree, Jca., Trd. - Pementa vulgaris. M. D. - G. 112. - Arbol silvestre que se eleva de 45 á $50^{\prime}$ de altura y mas, cuyo tronco, derecho y bastante largo, llega al diámetro de 15 á 18 y $24^{\prime \prime}$; suministra una madera bien dura, bien pesada, de testura fina $y$ compacta, cuya albura es color majon ó rojizo muy pálido, con vetas mas oscuritas y hasta morenitas, mientras el corazon es pardusco rojizo, otras veces casi moreno, algo castaño, y en fin hasta casi negro por causa de los nudos; susceptible de buen pulimento; su peso específico es de 0,909. Es una de las maderas mejores y mas apreciadas de esos paises; muy fuerte y muy duradera; sirve para obras de carpintería, de ebanistería; su uso comun es para estantes de casas; se esporta bastante. Corteza poco rugosa, color de ceniza, con manchas ó trechos desiguales, los unos mas blanquecinos y los otros mas oscuritos, cuando la epidérmis no se ha desprendido aun, como suele hacerlo, por placas á manera de la del plátano de Europa; en el acto de desprenderse la epidérmis vieja es espesa como de un milímetro; color gris pardusco esteriormente y como de hoja muerta interiormente; es como cornea y quebrarliza, deja por debajo de sí la nueva epidérmis ya formada, muy fina, de un color amarillento verdoso ; la corteza despues de seca es espesa de una línea, con las capas corticales de color chocolate; olor propio.

Mamey colorado, mamey sapote, Cba. - Lucuma mamosa. M. D. - G. 634. - Arbol frutal silvestre abundante en las Antillas y en el continente americano; se eleva á 45 ó $50^{\prime}$ y su tronco recto llega al diámetro de $12^{\prime \prime}$; suministra una madera de buen peso, de dureza muy regular, bien compacta y de grano fino; su color es bastante parecido al de la caoba, pero mas uniforme y mas rojizo, algo jaspeadito de oscuro; su peso específico es de 0,588. Su uso comun es para estantes de casas, pero á nuestro parecer se la podria utilizar para la carpintería y la ebanistería; su corteza fresca huele á almendras amargas.

Mamey amarillo, mamey de Sto. Domingo, Cba.; mamey macho, la variedad, ó mejor los individuos estériles; mamey, Prco. (Véase albaricoque de Sto. Domingo.) 
Mamon, Cba. (Véase corazon.)

Mamoncillo, amoncillo, mamon, Cba. ; maco, Trd. - Quenepe, Ant. fr. - Melicoca bijuga. M. D. - G. 854. - Arbol frutal silvestre que se eleva á 40' de altura y mas; su tronco, bastante recto, llega al diámetro de 12 á $15^{\prime \prime}$; suministra una madera de buen peso, de dureza mas que regular, de testura fibrosa y sin embargo bastante compacta, con el grano fino, de color blanco teñido de amarillento, con muchas vetitas capilares algo mas subidas que le dan un aspecto disciplinado muy bonito; tenemos á la vista una muestra de color un poco mas amarilloso, con primorosos remolinos que provienen de la presencia de nudos. En el corte vertical el canal medular está visible durante largo tiempo, pero va disminuyéndose poco á poco y acaba por desaparecer enteramente; en el corte transversal se ven las zonas concéntricas separadas por vetas capilares de color algo mas oscurito ; corteza áspera como de media línea, ni rugosa ni agrietada tampoco y casi unida, de color moreno algo verdoso, cuyas capas corticales parecen casi de igual color que la madera y con el lente se reparan en ella vetas color de azufre; esa madera no tiene aplicacion alguna, al menos que sepamos. Su peso específico es de 0,901 .

Mangle amarillo. - Mangle jaune. - Jellow mangrove, Trd. Arbol bajito y tortuoso de los lagones, cuyo tronco corto llega al diámetro de 4 á $6^{\prime \prime}$; suminisira una madera de muy buen peso, de dureza mas que regular, de testura fibrosa y compacta, grano fino, de color gris muy claro, algo teñido de color de hojas muertas y jaspeadita, cuya albura escasa es mas amarillenta y menos jaspeada; es muy fuerte y parece muy conveniente para obras de carpintería de casas, como ligazones y armaduras; sirve para curvas de canoas; corteza rugosa no muy agrietada, pero sí un poco prieta, espesa como de $2^{\prime \prime}$ escasas, cuyas capas corticales se separan fácilmente en capitas delgaditas, de color parduzco moreno cuando están juntas en el corte transversal.

Mangle blanco, Prco., Cba. - White mangrove, Trd. - Avicenia tomentosa y laguncularia racemosa, Gœrtn. M. D. - G. 566.Arbol bajito que se cria con abundancia en las orillas de los lagos, lagunas y en los sanitrales; se eleva como á 20 ó $25^{\prime}$ de altura y el diảmetro del tronco llega á $11^{\prime \prime}$; su madera es muy buena, bien dura y bien pesada; testura fibrosa y compacta, de un color gris, con vetas ó undulaciones algo parduzcas, y cuando salen de los nudos forman remolinos, ordinariamente poco pronunciadas $\mathrm{y}$ con $\mathrm{mu}$ chísimos puntitos mas oscuritos, que le comunican una vista muy agradable; sirve para viguetas y ligazones de casas, pero su uso mas comun es para carbon bastante bueno y para leña; el peso específico del primero es de $0,867^{\circ} \mathrm{y}$ el del segundo de 0,860 .

Mangle boton. Prco.; mangle botoncillo. - Button mangrove. Mangle roche, Trd. - Conocarpus erecta. M. D. - G. 383. - Arbol silvestre que se produce con abundancia á las orillas del mar, cuya altura es de 20 á $25^{\prime}$ y el diámetro del tronco llega á 9 ó $10^{\prime \prime}$; suministra una madera muy dura, muy pesada, de testura fibrosa y. sin embargo bien compacta y grano fino; recien labrada es de color 
rris teñido de achocolatado claro, con muchas vetas capilares mas pálidas, mas ó menos undulosas y que le hacen como disciplinadito; otras veces es color pardo, cuando haya sido labrado ha un tiempo bastante largo ; albura bastante espesa, de color blanquecino-rojizo claro; la madera conserva durante largo tiempo el olor pantanoso particular de los lagones; su peso específico es de 1,009; se utiliza en la construccion de las canoas y de las lanchas cuyas curvas suministra ; se emplea para estantes de casas siendo muy durable cuando el terreno es arenoso ; sirve tambien para carbon de fragua; su corteza es espesa como de una línea escasa, tosca y agrietala, de color moreno con trechos algo mas pálidos y con algo de ceniciento; su interior es color de chocolate.

Mangle negro, Trd. - Nos parece á nosotros igual al anterior, del cual difiere por el color mas oscuro de su madera que tiene iguales aplicaciones.

Mangle colorado ó zapatero, Cba., Prco. - Red mangrove, Trd. - Rizophora mangle. M. D. - G. 1146. - Arbol acuátil abundante por las costas; se eleva á 25 ó $30^{\prime}$ de altura y el tronco llega al diámetro de 10" ; suministra una madera de color rosado oscuro, la cual, por causa de su gran fuerza, se utiliza diariamente para fábricas de casas y otras obras de carpintería correspondiente con su poco tamaño, pero no dura mucho así, mientras que es casi incorruptible en el agua, especialmente cuando está casi sumerjida en ella; su uso mas comun es para carbon, que es bueno, y para leña; es muy á propósito para calentar los hornos’de panadería, y las hojas sirven para curtir la suela, siendo mejor aun la corteza; su peso específico es de 1,028.

Mango, Prco., Cba., etc. - Mangotina. - Mangifera indica. M. D. - G. 273. - Arbol frutal natural de las Indias Orientales, pero que se ha vuelto casi silvestre en las Antillas y en el continente americano. Se le planta en las alamedas y caminos reales á propósito para ese objeto. por ser coposo y agradable su sombra; su altura llega á 50 ó $60^{\prime}$ y el diámetro de su tronco, recto y no muy largo, á como 24 ó 30" ; madera liviana, poco dura, de testura fibrosa, poco compacta, de color gris algo pardusco, con puntitos y vetas irregulares, formando en ella como dibujos pardos que contrastan con el color general; despues de barnizada parece casi nogal pálido; esa madera resistente y elástica á la vez puede reemplazar al fresno de Europa y servir pues para iguales usos, culatas de escopetas, curvas de carruajes, etc.; pero no se utiliza tanto como se deberia hacerlo; su peso específico es de 0,864 .

Marañon, Cba. (Véase pajuil.)

Mahagua, mahault, Trd. - Stercularia caribea. M. D. - G. 265. - Arbol silvestre bastante alto y que se cria con abundancia en la isla de Trinidad, en donde su corteza se aprovecha para sogas ; suministra una madera muy floja, muy liviana, muy blanda $y$ muy fibrosa, de un color blanco lijeramente teñido de pardusco rojizo muy pálido, con muy pocas vetas; corteza espesa de línea y media cuando seca, bastante lisa, de color ceniciento con las capas corticales 
fibrosas y que se separan con facilidad en hebras ó tiras fuertes; el peso específico de esa madera es de 0,516.

María, Prco. (Véase ocuje.)

Maricao, Prco. - Arbol silvestre que se eleva como á $45^{\prime}$ de altura y el tronco llega á $2^{\prime} 1_{1} 2$ de diámetro; suministra una madera de color oscuro que se emplea en la maestranza militar de San Juan de Puerto-Rico para cajas de fusil; en los campos su uso comun es para armazon de casas, tablas y leña.

Masa, Prco. (Véase copaiba.)

Matillo, Prco. - Arbol silvestre cuya altura es como de unos 30' y el diámetro del tronco llega á $18^{\prime \prime}$; su madera es de color rojo y sirve para tablas.

Mangle de uña, Cba. - Madera de peso y de dureza regulares, cuya albura, mas ó menos blanca, está teñida de rojizo que va volviéndose mas subido á medida que se va acercando al corazon, cuya parte esterior es casi color de caoba, mientras el centro es color castaño rojizo ó como achocolatado, con vetas, de las cuales la mayor parte son mas pálidas y las otras mas oscuras, lo que la hace muy bonita; testura como fibrosa y grano regular. Corteza bien compacta y bastante pesada, tosca, casi sin grietas ó con muy pocas, de color ceniciento, con manchas amarillentas ó color de ceniza, dispuestas sin simetría sobre un fondo pardusco; epidermis delgadito; capas corticales densas, bastante duras y quebradizas, de color de canela, con vetas prietas y puntitos blanquecinos.

Manzanillo, Prco., Cba., Vzla. - Manchinell, Trd. - Hypomane manzanilla. M. D. - G. 123. - Arbol silvestre de las costas que se eleva como á 25 ó $30^{\prime}$ de altura, cuyo tronco recto y bastante largo llega al diámetro de 10 á 15", y suministra una madera muy apreciada para muebles de lujo y tan fácil de labrar como la caoba, cuyas propiedades y duracion tiene; de dureza y peso regulares, testura algo fibrosa y compacta, grano fino; es de primoroso color gris amarillento teñido de pardusco, y quizás mejor color de hojas muertas pálido, con algunas vetas mas parduscas $y$ á veces casi negras, que le dan un aspecto muy bonito y agradable á la vista; examinada con el lente, su corte vertical parece bien fibroso y con muchas líneas capilares que no son otra cosa que vasos abiertos al labrarla, y con muchos puntitos mas oscuritos que parecen provenir de la presencia de una sustancia como resinosa; en el corte horizontal el color es mas oscuro y se ven las zonas concéntricas bien pronunciadas y mas oscuritas por el centro ó corazon; con el lente se reparan algunos poros. Hemos tenido en la mano otra muestra de esa madera, con igual testura, dureza y peso, pero de color mucho mas pálido y de matiz casi uniforme, con las zonas concéntricas apenas visibles en el corte transversal, lo que proviene, á nuestro parecer, de que esa muestra salia de un árbol mas jóven; tal madera no se debe labrar sino despues de bien seca y de una larga esposicion á la intemperie; su peso específico es de 0,674.

María. (Véase ocuje.)

Merey. (Véase pajuil.)

Moca colorada, moca amarilla, Prco. (Véase llaba.) 
Mora, Pren. (Véase fustete.)

Mora. - Nora wood, Trd. - Mora excelsa. M. D. - G. 935. Arbol silvestre social que se halla en la isla de Trinidad y en la Guyana, se eleva como á $80^{\prime}$ de altura y su tronco, recto y muy largo, llega al diámetro de 18,20 y á veces $30^{\prime \prime}$; los mas gruesos tienen siempre el corazon hueco, lo que es un defecto de bastante consideracion, y como no se puede quedar en tierra mas de 3 á 4 años sin pudrirse no está puesto entre las mejores maderas en ese concepto, pero al contrario tiene la propiedad de conservarse muchos años sumerjido en el agua sin dañarse; es muy bueno y muy conveniente para las construcciones navales, y para eso ya se la esporta para Inglaterra; sirve tambien para puertas, pisos y muchas otras obras de carpintería; esa madera no es muy dura y se parece bastante á la caoba hembra, pero su grano es mas fino y su testura mas fibrosa, de color rojizo oscuro ó pardusco y como veteado y jaspeado á la vez. Es mas conveniente que el roble de Europa para las construcciones de buques y sus ramas, naturalmente encorvadas, se aprovechan con ventaja para curbas de buques; su peso específico es de 1,029.

Moral, Prco. - Arbol silvestre bastante abundante en la isla de Puerto-Rico, en donde se eleva como á unos 50' de altura, y el tronco largo y recto llega al diámetro de $24^{\prime \prime}$; suministra una madera de color claro y rompe horizontalmente; no tiene aplicacion.

Moruro, tengue, Cba. - Pithecolobium filicifolium. II. D. - G. 1,050. - Arbol silvestre de las selvas montuosas, que se eleva á 50' de altura y cuyo tronco alcanza un diámetro de 18 á $24^{\prime \prime}$; suministra una madera muy dura que se utiliza diariamente en la isla de Cuba, en donde se la aprecia bastante para mazas de carruajes, sollas y otras obras de carpintería; hay de ella dos clases, una blanca y otra rojiza.

Monkey bones. - Z'os macaque, Trd. - Arbol silvestre muy comun en los montes de la isla Trinidad; se eleva á 45 ó 50 piés de altura, el tronco recto y bastante largo llega al diámetro de 10 á 15 pulgadas y suministra una madera muy pesada, muy dura, de testura bien compacta y grano fino; su color es pardo teñido de rojizo con vetas mas pálidas; muy fuerte, muy resistente y por tal razon muy apreciada para muchas obras de carpintería, y especialmente para varas de carretas á que se aplica diariamente; su peso específico es de 1,030.

Multa, Pren.; Eugenix. M. D. - G. 1125. - Árbol frutal silvestre que solo se eleva como á 15 ó $20^{\prime}$ de alto á lo mas, y el diámetro del tronco es de $8^{\prime \prime}$. Su madera, que es bastante dura y resistente y de color claro, sirve únicamente para carbon.

Musara, Trd. - Brosimum alicastrum. M. D. - G. 114.- Arbol silvestre que se eleva á 50 ó $60^{\prime}$ y cuyo tronco alcanza un diámetro de como $2 t^{\prime \prime}$; suministra una madera muy bonita, muy fuerte, muy resistente y muy apreciada para carpintería del campo y tambien para obras mucho mas finas; de peso muy regular; de dureza regular, testura fibrosa, bastante compacta y grano fino; de color gris rojizo ó quizás mejor teñido de color de carne, con vetas parduscas ó del mismo color, pero algo mas oscuritas; la parte corres- 
pondiente á la albura es á reces amarillenta, otras veces del mismo color, pero algo mas pálida.

Muñeco, Prco. - Arbol silvestre que se produce con abundancia por el 0 . de la isla de Puerto-Rico; se eleva á 30 ó $35^{\prime}$ de altura y el diámetro del tronco es de $12^{\prime \prime}$, y suministra una madera floja de color cenizo y rompe verticalmente, cuyo uso comun es para tablazon de casas de campo.

Huneco de costa, Prco. - Arbol silvestre cuya altura es de $30^{\prime}$ y el diámetro del tronco de $12^{\prime \prime}$; su madera, de mediana dureza, es de color amarillo y rompe verticalmente y solo sirve para leria.

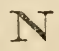

Naranjo ágrio, Prco., etc. (Véase limon.)

Negra lora, Prco. - Arbol silvestre que se eleva á 30' de altura y cuyo diámetro del tronco es de 10 á $12^{\prime \prime}$; su madera, de color encarnado y recia, rompe verticalmente; es porosa; su uso comun es para construccion de casas de campo y estacadas.

Nogal ceniciento, Cba.; nuez, Prco. - Juglans cinerea. MI. D. G. 140. - Arbol silvestre frutal que se cria en el interior de las grandes Antillas y en el continente americano. Se eleva á 40 ó $45^{\prime}$ de altura, y el tronco derecho y bastante largo llega al diámetro de 18 á 24"; suministra una madera algo porosa pero muy bıena y que participa de las propiedades del nogal europeo; es de color rojo oscuro y rompe verticalmente; se emplea en tablas y cuartones para obras de carpintería de casas.

Nazareno, Cba. - Hymenea floribunda. M. D. - G. 1006. Arbol silvestre bastante grande y corpulento, cuya madera, de peso y dureza regulares, testura fibrosa y compacta, grano fino de color canela claro, con vetas ó undujaciones algo mas oscuritas; la de Costa Firme es color de violeta; susceptible de pulimento, muy propia para embutidos, para bastones muy bonitos, flexibles y á la vez muy fuertes. En Cuba, su corteza hervida con agua sirve, segun dicen, para teñir de amarillo canario bien sólido.

\section{$\mathrm{O}$}

Ocuje, Cba.; maría, Prco.; galba, Trd.; cachicamo, Vzla. - Calophyllum calaba. M. D.- G. 877. - Arbol silvestre muy hermoso y muy coposo, que se eleva á 55 ó $60^{\prime}$ de altura y cuyo tronco largo y recto llega al diámetro de 3 ' y mas ; suministra una madera tenida por incorruptible, bastante liviana, de poca dureza, de testura fibrosa, de color rojizo algo mas pálido que la caoba hembra y que se parece mucho al álamo colorado de Europa, tanto por su aspecto general como tambien por su testura y grano; el corazon es mas colorado que la albura, la cual lo será tanto menos cuanto menos 
vecina esté de él, y vice-versa. En su corte vertical examinado con el lente se ven muchísimas líneas capilares que son vasitos abiertos al labrarla, conteniendo una sustancia resinosa formando así un sin número de vetitas mas oscuritas; la corteza seca es parduzca, con vetas prietas interiormente, esteriormente tosca, mas pálida con manchas blancas, espesa como de $11 \Gamma^{2}$ pulgada; su peso específico es de 0,655. Esa madera es muy apreciada para fábricas y obras de carpintería; se usa diariamente para soleras, llaves, construcciones navales, y cuando el tronco es de tamaño mayor entónces sirve para curiaras ó canoas de una sola pieza. Sembrado en líneas sirve á la vez ese árbol para alamedas hermosísimas $y$ cercados muy buenos, cuyas ramas inferiores se pueden quitar periodicamente y aprovecharse entónces para leña, como se suele hacer en Europa para el álamo y otros árboles empleados para cercas y que de ese modo se vuelven muy derechos y muy hermosos; lo que sucederia igualmente para ese árbol, que, llegado á su tamaño regular, se tumbaria para sacar provecho y utilidad de su madera; esa operacion ha de repetirse periódicamente de siete en siete años; se la podria tambien aplicar con ventaja al mango, al mamey, cada rez que se desea tener sus troncos bien rectos; se debe siempre tener cuidado de dejarle una copa bien fornida á fin de no entorpecer la vejetacion y por consiguiente el desarrollo ulterior.

Ortegon, Prco. (Véase hortegon.)

\section{$\mathbf{P}$}

Pajuil, Prco.; marañon, Cba. - Merey, Trd., Vzla. - Caschew tree. - Anacardium occidentale. M. D. - G. 277. - Arbol frutal silvestre tan abundante en las cercanías de la ciudad Bolívar, que estos lugares y en otros de la república de Venezuela se llaman mereyales, abundante tambien en los lugares arenosos de las Antillas, è donde se eleva á 25 y $30^{\prime}$ de altura y el tronco llega al diámetro de 10 á $20^{\prime \prime}$. Suministra una madera muy fuerte, muy dura y que se aprecia mucho para solas, mazas de carruajes, yugos y otras obras de carpintería del campo; su color es rosado; su uso comun en Puerte-Rico es para carbon y leña; su peso específico es de 0,488.

Palma real, Cba.; palma de yagua, Prco.; tacarigua, Trd. y Vzla. - Oreodoxa regia y O. oleracea. M. D. - G. 99. - Primorosos árboles silvestres que dan á la vejetacion de esos ricos paises su semblante particular y característico. Se elevan derechos á 70' y mas de altura, $y$ el tronco, verdaderas columnas rejetales, llega al diámetro de 12 á $15^{\prime \prime}$; suministran tablas mur buenas y muy duraderas para pisos y paredes de casas de campo, y especialmente para fabricar cocinas, caballerizas y cercados, etc. Se emplean sin labrar y como se sacan del árbol, de manera que la parte esterior y la mas dura, siempre un poco convexa, se pone siempre por afuera. Despues de labrada esa madera es primorosísima y durisima, muy compacta, de testura fibrosa y de color achocolatado pálido, con algunas vetas 
lineares y paralelas mas oscuritas; ordinariamente una de las caras es mucho mas pálida que la otra; tenemos á la mano, al escribir estos renglones, una muestra cuyo color es pálido amarilloso como el de hojas muertas ó gris amarillento con vetas parduzco-rojizas de las que unas son mas oscuras que las otras, mientras que la cara opuesta es casi de color uniforme, las vetitas siendo casi del color del fondo.

Palma de coco, cocotero, Prco., Cba., Vzla. - Cocotier, Ant. fr. - Cocoa nut tree, Ant. ingl. - Coccos nucifera. M. D. - G. 91.Arbol frutal que se produce especialmente en las orillas del mar, pero que se estiende bastante lejos en el continente americano: en efecto, lo hemos hallado en el interior de las misiones del Caroni, en las cercanías de la ciudad de Bolivar, como á 80 leguas de la embocadura del Orinoco y hasta en San Fernando de Apure, 80 leguas mas arriba, en fin, en Carácas; pero en este último lugar, bien que á primera vista el árbol sea tan vigoroso y lozano como en los demas lugares, sin embargo en verdad no es así, porque sus frutos mas pequeños están reducidos á la concha y no tienen carne, están vacios y por consiguiente abortados, por causa sin duda de la altura sobre el nivel del mar y de la temperatura, consecuencia natural de ella. Se eleva hasta mas de $60^{\prime}$ de altura y el tronco llega al diámetro de 5 á $6^{\prime \prime}$. Suministra una madera que se usa en tablas como la de palma de jugua y de la cual la parte que corresponde con las raices es mucho mas apreciada por ser mas honita $\mathrm{y}$ mas dura $\mathrm{y}$ sirve para obras de lujo; su peso específico es de 0,501 y 0,865 .

Palo blanco, Cba. - Cuassia, Ant. fr. - Bitter ash, Trd. - Quasia amara. M. D. - G. 865. - Arbol silvestre bastante comun en Trinidad y Guyana y mas escaso en las demas Antillas; se eleva como á unos $20^{\prime}$ de altura y el tronco llega al diámetro de 4 á 6" á lo menos. Suministra una madera muy liviana, muy blanda, de testura fibrosa y floja, grano grueso, de color blanco amarillento, desigualmente teñido de pardusco y solo en las partes que corresponden con el corazon ó con los nudos; de gusto muy amargo y de un olor muy particular no desagradable; como madera no tiene uso, pero se hacen con ella copas torneadas que sirven para echar agua que se bebe como estomacal despues de haberse quedado en ellas algun tiempo.

Palo bobo. (Véase baga.)

Palo de caja, Cba. - Smidelia cominia. M. D. - G. 267. Árbol silvestre que se eleva como á 15' de altura y cuyo tronco llega al diámetro de 15 á 18" y suministra una madera que no resiste á la esposicion á la intemperie, pero que es muy á propósito para estantes, varas, cajas, duelas, etc., y se emplea bastante para esos usos en la isla de Cuba.

Palo de clavo, Prco., Cba. - Geroflier, Ant. fr. - Cloves wood, Trd. - Caryophyllus aromaticus. M. D. - G. 1,115. - Arbol de las Indias Orientales, aclimatado en las Antillas, especialmente en Trinidad, Granada, Martinica y Guadalupe; se eleva á 25' de altura y el tronco bien derecho llega á 4 o $5^{\prime \prime}$ de diámetro y suministra una madera de muy buen peso, de dureza mas que regular, de 
testura fibrasa y compacta y grano fino, de color variado; en efecto, la parte correspondiente con la albura blanca es casi color canela oscuro, despues viene una lista grande aceitunado muy claro, y por fin otra casi majon pálido, con algunas vetas poco pronunciadas, de las cuales algunas se juntan entre sí por el centro; además es algo jaspeada: no tiene aplicacion ninguna; corteza de como 2 líneas de espesor, poco rugosa, con muchas grietecitas desiguales, blanca, cuya epidermis se desprende con facilidad y deja en pos de sí una superficie lisa : su interior es color de chocolate algo clarito; sin olor ni sabor cuando seca; su peso específico es de 0,897 .

Palo de moscada, moscadero. - Muscadier. - Nutmeg wood. Myristica moschata. M. D. - G. 215. - Primoroso árbol de las Indias Orientales, aclimatado perfectamente en las Antillas y especialmente en Trinidad, Granada, Martinica, Guadalupe, etc.; se eleva como á $30^{\prime}$ de altura, en forma de pirámide, con los ramos estendidos y largos, de los que los primeros están como á 5 ó $6^{\prime}$ del suelo; el tronco llega en su parte inferior á 5 y $6^{\prime \prime}$ de diámetro y suministra una madera de peso regular, poco dura, de testura fibrosa y fioja, $y$ sin embargo grano muy fino, de color gris un poco como de hojas muertas claro, teñido de moradito hácia el centro, sin albura perceptible, con muchas vetas paralelas bastante pronunciadas y mas oscuritas; parece muy fuerte; corteza rugosa apenas agrietada, de color gris pardusco verdoso, cuya parte interior ó capas corticales son color de chocolate algo claro, espesa como de $1^{\prime \prime \prime}$, sin olor ni sabor tampoco cuando seca; su peso específico es de 0,597.

Palo de pan, castaño, Prco., Cba. - Pain bois, Ant. fr. - Brednut, Trd. - Artocarpus incisa. M. D. - G. 113. - Arbol frutal natural del Japon, pero perfectamente bien aclimatado en las Antillas $\mathrm{y}$ en el continente americano, en donde se halla con bastante abundancia; se eleva como á $70^{\prime}$ de altura, con"gruesas ramas estendidas; el tronco, bastante largo, mas ó menos derecho, llega al diámetro de 25 á $30^{\prime \prime}$; suministra una madera de un eolor gris amarillento, teñido de pardusco mas ó menos oscuro, con zonas ó undulaciones bastante grandes y blanquecinas : tenemos á la vista otra muestra mas liviana y muchísimo mas amarillenta, de la cual el corazon es color como de hojas muertas ó casi mas oscuro, y la albura de un amarillo que tira un poco al canario, con manchas rectitas que la dan un aspecto disciplinadito muy bonito. Mas liviana que pesada, poco dura, pero sí bien fuerte, resistente y elástica. Es muy apreciable para muebles, para fábricas de casas; además los chinos la emplean mucho en las construeciones navales; criándose con facilidad casi en cualquier clase de suelo y creciendo con hastante prontitud, si hubiese necesidad de propagar ese árbol seria con bastante provecho y utilidad. Corteza bastante lisa ó poco rugosa y de culor de ceniza; su peso específico es de 0,495 .

Palo de gallina, Prco.; palo de pollo, Cas. - Acnistus arborescens. H. D. - G. 627. - Arbol silvestre que hemos hallado en Puerto-Rico, Trinidad y hasta Carácas, de 15 á 25' de altura, con el diámetro del tronco de 4 á $6^{\prime \prime}$; suministra una madera blanda, de color blanco oscuro y que rompe verticalmente: su uso comun es 
para leña y armazon de casas del campo; saca su nombre de eso que las gallinas y pollos que comen sus frutos se mueren.

Palo hueso, Prco. - Se elera á 40' de altura y el díámetro del tronco llega á 24"; el color es blanco oscuro; su uso comun es para leña y armazon de casa.

Palo pollo, Prco. - Pterocarpus draco. MI. D. - G. 1033. Arbol silvestre que se eleva como á 40' de altura y cuyo tronco llega al diámetro de 14 á $18^{\prime \prime}$; suministra una madera de color blanco y que rompe horizontalmente. En la maestranza de San Juan de Puerto-Rico se construyen guarda fuegos con ella: los particulares solo se sirven de ella para leña; su peso específico es de 0,554 y el de la madera sacada de las raices de 0,138.

Palo santo, Prco. - Arbol silvestre cuya altura es de $30^{\prime}$ ó mas, y el diámetro del tronco de 8 á $12^{\prime \prime}$; suministra una madera floja de color ceniciento y que parte verticalmente: se usa en varazon de casas y estacadas.

Palo de rosa, Prco. - Vieques, etc. - Cordia gerascanthus. M. D. - G. 607. - Arbol silvestre que se eleva á 30' de altura y cuyo diámetro del tronco es de $18^{\prime \prime}$; suministra una madera color rosado y rompe verticalmente: se emplea en la construccion de casas de campo y en la de buques; es muy apreciada tambien para muebles. Se ha aplicado el nombre de palo de rosa á algunas maderas diferentes llevadas de la América del Sur á Europa Una de ellas es el palissundre de los franceses; otra muy poco usada y llamada por los ingleses rose woord, candel rood y tambien sueet wood, proviene deì amyris balsamifera. El palo de rosa de los ingleses es el amyris montana, que llaman tambien yellow candel y yellow sander en Jamaica. Se ha llamado así tambien al erithroxyllum areolatum; por fin, en la isla de Trinidad se llama palo de rosa ó hickory á la brownea, á causa del color de sus flores: su madera, de dureza regular y testura fibrosa, es muy bonita y de un color gris amarillento; sirve para arcos muy buenos.

Pandanus candelabrum.-Pandano como candelabro. MI. D.- G. 206. - Arbol del Japon, pero que está bien aclimatado en las Antillas, en donde se cultiva para el adornode los patios y de los paseos públicos; se eleva como á $30^{\prime}$ de altura y el tronco tiene un diámetro de 5 á $\tau^{\prime \prime}$; suministra una madera que á primera vista parece la de una palmera, pero mucho mas compacta y mas dura, de aspecto muy particular, disciplinada, con líneas mas ó menos larguitas irregularmente dispuestas y desiguales, de color canela pálido, sobre un fondo gris amarillento muy pálido. La parte que corresponde á la corteza de los demas árboles es muy dura, muy desigual y rugosa, de color gris pardusco con manchas blánquecinas ó cenicientas; otras hay color rojo, sangre de buey, que se comunica á la madera correspondiente á ellas, lo que la hermosea mucho: es susceptible de pulimento; no tiene aplicacion, pero á nuestro parecer se la podria utilizar en ebanistería para embutidos de lujo; su peso específico es de 0,929.

Paraiso, prusia, Cba. (Véase lilao.)

Pataban, Cba. - Nos parece, segun lo que nos ha sido referido. 
una especie de mangle: la muestra que hemos tenido en la mano no es ni muy liviana ni muy pesada tampoco; de dureza regular, testura fibrosa y grano bastante fino, de color de canela claro ó pardusco rojizo, jaspeadito ó con vetas mas oscuritas ó mas pálidas y formando encuentros en el corazon. Corteza muy tosca con surcos irregulares y grandes, de color pardo oscuro con manchas mas $\delta$ menos estensas y cenicientas, epidermis poca; capas corticales casi color de chocolate; espesa como de $2^{\prime \prime}$; cara interior pardusco claro con vetas prietas.

Pata vaca, Trd. - Bauhinia megalandra. M. D. - G. 945. A rbol silvestre que se eleva como á 25' de altura y el tronco, bastante corto y no muy derecho, llega al diámetro de 6 "; suministra una madera de peso y dureza algo mas que regulares, muy flexible y sin embargo bien resistente, de color rojizo algo teñido de amarillento, con vetas parduscas; tiene un poco el aspecto del álamo colorado de Europa, pero no tan rojizo, y algo mas oscurito, con hermosas vetas capilares que al juntarse forman listas pequeñas mas oscuritas y hasta morenas, las cuales se vuelven remolinos primorosísimos que toman aspecto jaspeadito; albura poca, blanquecina y haciendo así contraste con la madera; su peso específico es de 1,023. Corteza espesa de $1 l_{1} 2$ ó 2 líneas, muy tosca, con grietas grandes y profundas; de color gris ceniciento oscuro sobre fondo achocolatado: se hacen con esa madera arcos muy apreciados y muy buenos.

\section{Pardillo. (Véase capa.)}

Pama, Trd.; mapou. - Pisonia nigricans. M. D. - G. 302. Arbol silvestre que se eleva á 24 ó $30^{\prime}$ á lo mas de altura y cuyo tronco llega al diámetro de 4 á $5^{\prime \prime}$ y suministra una madera muy liviana, muy floja, de testura muy fibrosa, elástica y cuyo aspecto á primera vista la hace parecer de una palmera, de color casi uniforme, gris amarillento muy pálido, sin albura; corteza delgadísima muy pegada á la madera, poco rogusa y casi sin grietas, de color pardusco oscuro teñido de rojizo ó achocolatado. Sirre para los tacos de los remos de las embarcaciones pequeñas.

Palo mulato. - Wild tamarind, Trd. - Bois mulâtre, Mart. Penthaclethra filamentosa. M. D. - G. 285. - Arbol silvestre que se eleva como á 50' y mas de altura y cuyo tronco, largo y derecho, llega al diámetro de 15 á $18^{\prime \prime}$; suministra una madera no muy apreciada, pero que sin embargo tiene algunas aplicaciones, y sin duda para nosotros seria susceptible de muchas otras; de grano muy fino, de testura compacta, de peso mas que regular, dureza buena, de un color moreno pálido algo teñido de rojizo, con zonas ó listas mucho mas claras, en las cuales el color moreno se ha casi desvanecido para dar lugar al rojo que le reemplaza: parece casi el manzano de Europa; sus semillas son muy oleojinosas y quizás se podrian utilizar para sacar aceite; su peso específico es de 1,076.

Pendejuelo, Prco. - Arbol silvestre que se eleva á 50' de altura y el tronco llega al diámetro de 18"; suministra una madera de color ceniciento y rompe oblícuamente: su uso comun es para tablas de casas de campo.

Péndula, Prco. - Citharexyllum cuadrangulare, M. D. - G. 
560. - Arbol silvestre cuya altura llega á 50' y el tronco, bastante recto, al diámetro de 18"; suministra una madera bastante dura, de color pajizo y rompe oblícuamente; tiene esa particularidad que el epidermis, espeso y color ceniciento, va desprendiéndose de la corteza bajo forma de tiras largas que se quedan bastante tiempo colgantes al rededor del tronco y de las ramas ya viejas. Su uso comun es para tablas, viguetas, cuartones, alfajías, etc. : la jente del pais hace con ella sus tiples o guitarras; su peso específico es de $0,753 \mathrm{y}$ 0,722 .

Pimiento, Cba. (Véase malagueta.)

Pino, Cba. - Pinus occidentalis. II. D. - G. 105. - Arbol especial de la isla de Pinos y que se halla tambien en la isla de Cuba, bastante alto, cuya madera se aprovecha y es tenida por muy buena, de buen peso y de dureza regular, testura fibrosa y bastante compacta, grano bastante fino, de color de canela muy claro, algo rojizo, con vetas lineares mas oscuritas y algunas cintas o listas verticales algo mas pálidas.

Piñon espinoso, Trd. - Erythrina corallodendron. - Madre del cacao, Trd. - Bucare, Vzla. - E. umbrosa. M. D. - G. 1080. Primorosos árboles que crecen con mayor prontitud y se elevan, el último especialmente, como á $50^{\prime}$ de altura y suministra una madera liviana, poco dura, bastante quebradiza, de la cual no se saca utilidad; sin embargo, da un carbon regular. Sirve el último especialmente para dar soml ra al cacao.

Pico de gallo, Cba. - Cynometra cubensis. F. 180. - Arbol silvestre que suministra una madera de peso muy regular, de buena dureza, testura compacta y grano fino. Hemos tenido á la mano algunas muestras de ella y eran de diferentes colores: una era de color pardusco rojizo, algo jaspeadita de mas oscurito, cuya parte esterior ó albura era mas pálida; otra mucho mas clara, casi sin estar teñida de rojozo, pero sí jaspeadita; en fin, la ultima era gris amarillenta ó quizás mejor aceitunada, con vetas mas oscuras. Corteza tosca y rugosa, de color chocolate con manchas cenicientas; epidermis poca; capas corticales espesas como de $1^{\prime \prime \prime}$, bastante densas y duras; cara interior mas oscura.

Pomarrosa, Prco., Cba., Vzla. - Pomme rose, Ant. fr. - Jambosa vulgaris. M. D. - G. 1119. - Arbol frutal silvestre abundante en las Antillas y en el continente americano; se eleva á 40' de altura, cuyo tronco mas ó menos largo y derecho llega al diámetro de 15 á $18^{\prime \prime}$ y suministra una madera bien flexible y fuerte á la par, de testura fibrosa, bastante pesada, bien compacta y grano fino; de color gris rojizo casi uniforme, con pocas vetas undulosas que se juntan hácia el centro, poco pronunciadas; albura apenas distinta por ser casi de igual color; corteza como de $2^{\prime \prime \prime} l_{1} 2$, poco rugosa con grietas, de color ceniciento y las capas corticales de color casi como de chocolate pálido. Su uso comun es para arcos de bocoyes y barriles, y para carbon de fragua; su peso específico es de 0,792 .

Poma malaca. - Jambosa malacensis. - Primorosísimo árbol frutal, naturalizado en las Antillas y muy comun en la Trinidad; se 
eleva come á $35^{\prime}$ ó algo mas de altura y el tronco llega al diámetro de 12 á 15"; suministra una madera de poco peso, poca dura, de testura como fibrosa, no muy compacta y grano bastante fino, de color pardusco rojizo claro, con vetas undulosas muy poco pronunciadas, algo moiré; albura mucho mas floja; corteza muy rugosá, espesa como de $1^{\prime \prime \prime} 1_{1} 2$, oscura, de color pardusco, con manchas cenicientas, cuyas capas corticales son color chocolate: esa madera no tiene aplicacion y pesa 0,588 .

Pui, Trd.; arajuaney, Gna.; flor amarilla, Vzla. - Ébène vert, Tecoma serratifolia. - T. Leucoxylon. M. D. - G. 531. Arbol silvestre que se eleva á 45 ó $50^{\prime}$ de altura y hasta mas, cuyo tronco largo y derecho llega al diámetro de 18,24 y hasta $30^{\prime \prime}$ : se conocen tres variedades de la misma especie botánica ó quizás tres especies que se suelen solo diferenciar por el color de la madera: son el blanco, el negro y el verde, que es la mas apreciada. La madera es muy dura, de mucha fuerza y duracion, muy densa, bien pesada, testura compacta y grano fino, de un color gris pardusco, con vetas algo mas oscuras : tiene de particular que tocada con una sustancia alcalina, sea por ejemplo el amoniaco, se vuelve al momento rojizo-amarillenta; sucede lo mismo á las manos despues de haberla labrado, cuando se las lava con jabon. Muy apreciada para fabricas de campo y de las ciudades; muy á proposito tambien para obras de carpintería fina, para tornear y además para ebanistería; su peso específico es de 1,215.

Pois doux marron, Trd. - Arbol silvestre que se eleva á 40 o $45^{\prime}$ de altura y cuyo tronco, largo y derecho, solo llega al diámetro de 18 á 20 " y suministra una madera primorosa, de dureza y peso regulares; de testura fibrosa bastante compacta y grano fino; de color gris agamuzado, con vetas paralelas algo mas oscuras á veces hermoseada con remolinos que parecen algo moivé; albura poco mas pálida y mas amarillenta ; corteza espesa como de 11 [2 línea, bastante rugosa, muy poco agrietada, color pardo ceniciento ó pardo morenusco, cuyas capas corticales algo fibrosas soñ color canela. Esa madera, que parece bien fuerte y de buena resistencia, no tiene aplicacion, á lo menos que sepamos; sin embargo nos parece á propósito para obras interiores de casas.

Purgo macho. (Véase acana.)

\section{2}

Quiebra hacha, Cba. - Copaifera himenafolia. M. D. - G. 392. - Arbol silvestre que se eleva á $35^{\prime}$ de altura y cuyo tronco llega al diámetro de 12 á $15^{\prime \prime}$; suministra una madera de mucha dureza, muy primorosa y casi todo corazon, de un color moreno rojizo, con vetas mas oscuras; albura escasa blanquecina y tanto mas dura cuanto mas cercana esté del corazon: susceptible de buen pulimento; es muy apreciada por su grande fuerza y su mayor duracion en el agua, de suerte que se dice que se petrifica en ella. Por tales razones se la emplea mucho en las fábricas del campo. 


\section{F}

Rabo-junco, Prco. - Arbol silvestre que se eleva á unos $30^{\prime}$ de altura y cuyo tronco llega al diámetro de 12 á $14^{\prime \prime}$ y suministra una madera flexible de color blanco, que se utiliza en armaduras de techos de casas de campo.

Roble. - Por esta denominacion se señalan muchos rejetales diferentes y que varian casi con la isla ó la comarca en que uno está viajando: en efecto, el roble amarillo es el citharexylon caudatum. M. D. - G. 560;

El roble blanco, Cba., el tecoma pentaphylla. M. D. - G. 531.Árbol silvestre que se eleva como á $30^{\prime}$ y cuyo tronco llega al diámetro de 6 á $8^{\prime \prime}$; suministra una madera de dureza y peso regulares, testura fibrosa bastante compacta y grano bastante fino, de aspecto muy bonito y á veces como moiré, de color gris pardusco teñido de amarillento ó color de canela claro, disciplinado de mas pálido, casi sin albura, por ser de color uniforme la muestra entera; otras veces la hemos visto de un hermoso color gris aceitunado y con jaspeado algo mas pardusco; con aspecto moiré ; corteza muy tosca, parduscogrisácea, algo verdosa, sobre un fondo mas oscuro; capas corticales color de chocolate. Esa madera, muy fuerte y muy resistente, se puede utilizar para obras de carpintería fina y tambien para algunas del campo.

Roble prieto, Cba.; roble, Prco. - Catalpa longisilicua. M. D. - G. 526. - Primoroso árbol silvestre que se eleva á mas de 50' de altura y cuyo tronco, bastante recto, llega al diámetro de $18^{\prime \prime}$; suministra una madera de testura fibrosa y trabada, poco blanda de color pajizo: su uso comun es para cartones y tablas y es de mucha duracion en los techos de tejas de las casas.

Roble bombo, Cba. (Véase capa.)

Roble real ó de olor, Vzla. - Chelone. - Arbol silvestre que se eleva á mas de $50^{\prime}$ de altura y cuyo tronco, largo y recto, llega al diámetro de 25 á $30^{\prime \prime}$ y hasta mas; suministra una madera tan dura, que se rompen las herramientas al'labrarla, muy pesada, muy fuerte y muy resistente; testura muy compacta y grano fino; de color canela, á veces uniforme, mas ó menos veteada de bruno y hasta de negro, pero que con el tiempo, algunos 15 ó 20 años, se vuelve muy negro ; es casi incorruptible y sirve para rollos de trapiche de azúcar, para muebles y para tornear.

Roble, Trd. - Platimicium platystachium. F. 130. S.-F. I.Arbol silvestre cuyas primorosas flores amarillas y papilonáceas exhalan olor de violeta que embalsama el aire; se eleva á 50' de altura, y el tronco, bastante largo y recto, llega al diámetro de 18 á $24^{\prime \prime}$; suministra una madera de testura fibrosa, de buena dureza, de peso regular, compacta y de grano fino; de color rojizo moreno y reteado, con nudos prietos, de los cuales salen remolinos parduscos ó blanquecinos, lo que es muy bonito; otras reces su color moreno es naranjeadito, de olor agradable cuando recien labrada: tenemos 
á la mano una primorosa muestra, cuyo color de la mezcla de las vetas un poco undulosas. las cuales salen de la albura bastante espesa y blanquecina, es pardo-rojizo, alternativamente mas oscuras y mas rojizas; despues de eso viene una hermosa cinta muy clara, seguida de otras vetas y de unos remolinos que corresponden á la parte mediana, despues vuelven á principiar las vetas y las undulaciones casi en el mismo órden; en el corte transversal las zonas concéntricas son prietas, algo rojizas y bien pronunciadas; su peso específico es de 1,031. Es madera muy apreciada que se emplea diariamente para obras de carpintería, sea rústica, sea fina, y hasta en ebanistería, para reemplazar al algarrobo, cuyas propiedades posee, por tal razon hay que desear que su uso se estienda mucho mas de lo que está hoy en dia.

Raspa lengua, Ćba. - Casearia hirsuta. F. 87. - Árbol silvestre que se eleva á 25 o $30^{\prime}$ y el tronco llega al diámetro de 8 á 10"; suministra una madera poco dura y de poco peso, testura fibrosa $y$ poco compacta; sin embargo, de grano bastante fino, cuyo color es blanco sucio ó algo amariilento, un poco veteado de oscuro, con albura pardusca y bastante dura; parece susceptible de pulimento y despues de barnizada se vuelve casi del color del boj de Europa, pero mas veteada, menos amarillenta y menos dura por supuesto: en el centro está casi siempre el canal medular; su peso específico es de 0,762 .

Ramonillo, Prco. - Arbol silvestre que se eleva como á $30^{\prime}$ de altura y el tronco llega al diámetro de 18"; suministra una madera compacta, de color blanco veteado y rompe con dificultad, que se emplea en varazon de casas de campo.

Retamo, Prco. - Arbol silvestre cuya altura llega á 50' y el diámetro del tronco á $18^{\prime \prime}$; madera blanca que rompe oblícuamente y que sirve para tablas para las casas del campo y diferentes objetos.

Sabicú, Cba.; savico ó savicu,'Ingl. - Acacia formosa. M. D. G. 298. - Arbol silvestre que se eleva á 55 ó $60^{\prime}$ de altura y cuyo tronco largo y derecho llega al diámetro de 15 á 18"; suministra una madera muy apreciada en Inglaterra para las construcciones navales y tenida casi por incorruptible; en efecto, el buque de guerra el Gibraltar de 80 cañones, botado al agua en el año 1751, cuya quilla de esa madera se conservó en tan buen estado que á los cien años el señor W. Simonds quiso utilizarla para una fragata nueva. Es bien dura, de muy buen peso, de testura fibrosa, bien compacta, muy fuerte y casi todo corazon ; cuya albura es poca, de dureza y peso regulares, es de color blanquecino teñido de canela, con puntitos mas oscuros, mientras el corazon, mucho mas duro, es color de canela con listas lonjitudinales, desiguales y poco simétricas, mas oscuras, entremezcladas con vetas algo mas subidas; tiene casi el aspecto general de la caoba, pero no tan rojo como ella; en 
el corte horizontal se ven muy manifiestas las zonas concéntricas y mas pardas. En el corte vertical se ven con el lente muchas líneas pequeñas desiguales, mas visibles en la albura en donde están llenas como de goma, y no son pues otra cosa que vasos abiertos al labrarla; los del corazon al contrario están vacíos; dan á la madera un aspecto muy bonito; despues de barnizada la albura se vuelve color blanco amarillento con puntitos parduzcos, y el corazon solamente algo mas oscurito. Hemos tenido á la mano otra muestra de esa madera cuyo color era muy diferente; en efecto era de chocolate veteado, quizás porque provenia de un árbol mas viejo ó que habia vejetado en un terreno mas pobre, pero cuya testura, dureza y peso parecian iquales.

Sabina, Cba. - Madera muy apreciada en la isla de Cuba por ser incorruptible, segun dicen; sirve para muebles, tablazon y horcadura; de grano fino y testura compacta no fibrosa; de peso y dureza muy regulares, cuyo corazon es de un hermoso color de chocolate claro ó rojizo ó quizás mejor como acanelado, veteado tan pronto mas oscuro como mas claro é irregularmente; la albura es un poco color de caoba, otras veces blanquecino-amarillenta, ó por fin rojizo pardusca; con el lente se ven en su corte vertical fibras finísimas, bien apretadas las unas contra las otras, de aspecto lustroso y como algo sedoso; en el corte transversal aparecen las zonas concéntricas mas parduzcas y bien pronunciadas.

Sangre de doncella. (Véase carne de doncella.)

Sponia mollis, Trd. F. 40. - Arbol silvestre que se eleva á 30 ó $40^{\prime}$ de altura, cuyo tronco bastante largo y recto llega al diámetro de 6 á $8^{\prime \prime}$ y suministra una madera liviana elástica y resistente, de testura fibrosa, grano fino, de color gris teñido de rojizo, mas ó menos pronunciado, otras veces casi blanca con vetas rojizas poco pronunciadas y que ran juntándose hácia la parte mediana; tiene un poco el aspecto del álamo blanco de Europa. No se utiliza que sepamos, pero á nuestro parecer seria muy á propósito para carpintería y obras interiores de casas.

Sapote, Cba.; nispero, Prco., Vzla.; sepodilla, Trd. - Sapotiller, Ant. fr. - Sapota achras. M. D. - G. 635. - Arbol frutal que se eleva hasta $40^{\prime}$ y mas de altura, muy ramoso, y cuyo tronco, no muy largo, sin ramas, llega al diámetro de $12-15$ y hasta 20 " y suministra una madera muy buena, de buen peso y dureza mas que regular, testura compacta y grano fino, de color rojizo claro veteado de mas oscuro, cuyas vetas irregularmente dispuestas $y$ desiguales son paralelas y algo teñidas como de color de carne. Es tan fuerte $y$ tan buena como la de balata ó purgo y la podria muy bien reemplazar si se criase silvestre $y$ mas abundante. La corteza es rugosa, agrietada y de un color gris ceniciento; su peso específico es de 1,021.

Seivilla, Prco. (Véase eebillo.)

Seiva, Prco. (Véase ceiba.)

Sieniguillo, Prco. - Arbol silvestre que se produce á manera de una capa, cuya altura es solo de 9 á $12^{\prime}$ y el diámetro del tronco de $3^{\prime \prime}$; suministra una madera flexible y sólida que los naturales del pais úsan en garrotes y varazon de casas de campo, etc. 
Siete cueros, Prco. - Arbol acuátil de mar, cuya altura es de $30^{\prime}$ y el diámetro del tronco de 12 "; suministra una madera dura, fibrosa y bien fuerte que en la marina se utiliza para curbas de lanchas y canoas.

\section{$\mathbf{T}$}

Tabaco, Cba. - Arhol de la isla de Cuba, de color variando del amarillo lindo al moreno; es muy apreciado solamente para bastones; es muy terso cuando labrado.

Tabacon, Prco. - Arbol silvestre cuya altura es de $40^{\prime}$ y el tronco llega al diámetro de 3 cuartas; suministra una madera de color rosado bastante fuerte y resistente, pero floja, que se emplea en tablas y cuartones para casas de campo.

Tabanuco.

Tabloncillo, Prco. - Arbol silvestre que se eleva á 45' de alto y el tronco llega al diámetro de $36^{\prime \prime}$; suministra una madera compacta de color blanco veteado, que se usa en tablas, taljlones y alfajias para casas de campo.

Tapana, Trd. F. 106. - Arbol silvestre grande y corpulento, que se eleva como á $60^{\prime}$ de altura y su tronco largo y recto llega al diámetro de 25 á $30^{\prime \prime}$; suministra una madera bastante dura, de peso regular, testura fibrosa no muy compacta, de un color de chocolate claro ó de canela rojizo, con algunas listas parduscas mas ó menos pronunciadas y á veces mas pálidas, otras veces mas oscuras sin volverse pardas; teñida de rojizo con muchos puntitos ó pequeñas líneas capilares mas oscuritas, que son vasos abiertos al labrarla, que la comunican una vista muy bonita y casi moiré; parece mucho á la caoba hembra, pero algo mas rojiza que ella; siendo muy fuerte y flexible á la vez, es muy apropiada para las obras de carpintería y además para las construcciones navales.

Tachuelo, Prco. - Arbol silvestre, abundante en las sierras, que se eleva como á $40^{\prime}$ de altura y el tronco llega al diámetro de 10 á $12^{\prime \prime}$; suministra una madera de color amarillento, durísima y muy fuerte, de mucha duracion, cuyo uso comun es para estantería de casas, estacadas, tejamanies, etc. Cuando el árbol es viejo hay que ponerle fuego para servirse de él, por resistirse á todas las herramientas y medios conocidos para labrar maderas.

Tamarindo, Prco., Cba., Vzla. M. D. - G. 1039. - Primoroso árbol de las Indias Orientales, pero que se ha naturalizado tan bien en las Antillas y en el continente americano, que ahora se le considera como de esos paises; se eleva á 45 ó $50^{\prime}$ de alto y el tronco recto y no muy alto llega al diámetro de 10 á 15"; suministra una madera de buen peso, de dureza mas que regular, testura bastante compacta y grano fino, de color blancuzco sucio o algo amarillento con ó sin nudos, y cuando existen son de color moreno rojizo, echando por la madera vetas rojizo-acastañadas, á la par hay pequeñas líneas negras mas ó menos desiguales y pronunciadas que 
simulan dibujos á manera de mapas de geografía, lo que la dá un aspecto particular y original; no tiene aplicacion; su peso específico es de 0,948 .

Tamarindo espurio. (Véase palo mulato.)

Tengue, Cba. - Acacia arborea. M. D. - G. 298. - Arbol silrestre que se eleva á $45^{\prime}$ de altura y cuyo tronco bastante largo y recto llegáa á 12 ó 15" de diámetro; suministra una madera de buen peso, de dureza mas que regular, testura compacta y grano fino, cuyo color es almagre rojizo, con albura tambien bastante dura y de color gris teñido de rojizo, tanto mas notable cuanto se va acercando mas al corazon, con que contrasta mucho, porque él es almacrado oscuro hermosamente veteado y con muchas líneas pequeñas capilares, lojitudinales proviniendo de los vasitos abiertos al labrarla, mas visibles y en mayor número en la albura que en el corazon. Corteza espesa como de 1 á $1^{\prime} l_{[} 2$, escasa, rugosa, pero no agrietada, de color parduzco bastante oscuro, con líquenes que la vuelven en los lugares correspondientes color ceniciento; epidérmis delgado; capas corticales bastante duras y compactas color chocolate, cara interior mas pálida, siendo muy fuerte y muy resistente; sirve para construcciones civiles y tambien para tablas y tablones.

Teta de burra, Prco. - Chrysophyllum oliviforme. N. D. - G. 629. - Arbol silvestre frutal cuya altura es como de 30 piés y el tronco llega al diámetro de 10 pulgadas. Suministra una madera de color de carne muy fuerte y sólida, y sin embargo no utilizada, porque su uso comun solo es para carbon de fragua, que es muy apreciado.

Toco, Trd., Vzla. - Cratava tapia. M. D. - G. 881. - Arbol silvestre que se eleva de 30 á 40', cuyo tronco bastante largo y recto llega al diámetro de 18 á $23^{\prime \prime}$; es de los montes especialmente y suministra una madera muy liviana, poco dura, de testura fibrosa, bastante trabada $\mathrm{y}$, segun dicen, bien resistente, de un hermoso co. lor gris amarillento, algo teñido de rojizo pálido, con algunas vetas irregulares algo undulosas. Tenemos á la vista otra muestra mucho mas amarillenta en général, con listas bastante grandes y pronunciadas, cuya parte mas amarillosa corresponde á la albura y se va disminuyendo á medida que se acercan al corazon, y las listas que al principio estaban alternativamente mas amarillas y mas pálidas con vetitas rojizas van desvaneciéndose y la madera se vuelve como la de la primera muestra descrita, un poco undulosa, con un punteadito mas oscurito que le da un aspecto mas hermoso á la vista ; no tiene aplicacion que sepamos, pero á nuestro parecer se la podria muy bien utilizar para obras de carpintería en el interior de las casas. Corteza de $11{ }^{2}$ á $2^{\prime \prime \prime}$, rugosa, pero sin grietas, morena sobre un fondo blanquecino mas ó menos ceniciento, que las mas veces es el único; epidermis muy delgado; capas corticales compactas, bastante duras y quebradizas, blanquecino-agamuzadas; con el lente se ven en su corte transversal muchos puntitos amarillos esparcidos sin órden ninguno, los cuales en el corte vertical son líneas ó vasitos abiertos llenos de una sustancia que parece resinosa; cara interior casi color de gamuza bastante lisa y algo lustrosa. 
Toro, Prco. - Arbol silvestre que se eleva á 25 ó 30' de alto y su tronco llega al diámetro de 8 á $10^{\prime \prime}$. Suministra una madera algo fuerte y de color colorado, cuyo uso comun es para leña y armazon de casas de campo.

Tortugo blanco, Prco. - Arbol silvestre abundante cuya altura es de 50 á $60^{\prime}$ y el diámetro del tronco $24^{\prime \prime}$. Suministra una madera de color amarillento cuyo uso comun es para estantes y armazon de casas.

Tortugo amarillo, Prco. - Nos parece una variedad del anterior, cuya altura y tamaño del tronco tiene; crece en los mismos lugares y se diferencia solo por su madera compacta de color amarillo subido, es muy fuerte y cuyo uso comun es para muebles de lujo.

\section{$\mathrm{Z}$}

Zapatero, Gna.- Sapater, puple hart, Trd. - Bois violet, amaranthe, Ant. fr. - Pao colorado, Brl. - Peltogyne paniculata. F. 130. S.-F. 2. - Primorosísimo árbol nuy coposo y bastante corpulento, que hemos visto, en las montañas y serranías del Caroni, elevarse á 50 y $60^{\prime}$, con el tronco muy derecho sin rama alguna y largo de 35 á $40^{\prime}$, con el diámetro de $15,20,30^{\prime \prime}$ y hasta mas; suministra una madera muy bonita de un hermoso color morado, con venas $\delta$ estrías lonjitudinales alternativamente mas oscuras y mas pálidas, pero sin regularidad ni simetría dispuestas, lo que le da el aspecto como algo fibroso, á veces es como lustroso ; pero con una larga esposicion al aire, y especialmente á la luz, su color se vuelve uniforme, mucho mas oscuro y por último se hace como bruno moraduzco. Bien compacta, de testura bastante fina, de buena dureza, muy fuerte y resistente, muy duradera en cualquier sitio que se la emplee, de buen peso; cn efecto su peso específico es de 1,069. Esa madera es con razon muy apreciada y muy á propósito para cualquiera obra de carpintería que requiera á la par mucha fuerza, resistencia $y$ duracion; se emplea pues con mucha ventaja en las construcciones civiles y además sirve para muebles. Segun el señor Riollet Junior, esa madera contiene una sustancia particular sin color al principio, pero que, bajo la influencia de los ácidos, de la luz ó del calor, puede volverse una materia colorante rojo-morada capaz de aplicarse para teñir los géneros y para imprimir sobre ellos en rosado, morado, aceitunado, castaño, bronceado y negro. Los colores morado y lila, que se obtienen con ella, ticnen un brillo que puede competir con ventaja con el que da la orsella preparada, pero son mas duraderos al aire y á la luz. 


\section{- APÉNDICE $2^{\circ}$}

\section{RESÚMEN ANALÍTIGO DE AGRIGULTURA}

APROPIADA

\section{A LOS PAISES INTERTROPIGALES.}

Atendiendo á nuestros cortos conocimientos en agricultura, nunca nos hubiéramos atrevido á estender este resúmen, si nuestros numerosísimos amigos y suscritores no nos le hubieran pedido como un favor, y gustosos en complacerles en todo lo posible, asentaremos aquí algunas consideraciones generales sobre esta parte de la Botanica. Además, lo emprendemos persuadido de que tendrá alguna utilidad para facilitar la aplicacion práctica de los principios de Botánica que tenemos estendidos en el discurso preliminar de esta obra y tambien en la parte de ella que trata de los elementos de esta ciencia y que hará nuestra obra mucho mas completa. La agricultura no es otra cosa sino una aplicacion de la Botánica, como lo tenemos ya señalado en el discurso preliminar de la Flora médica y útil de las Antillas, y sin embargo constituye por sí misma una ciencia muy vasta, porque saca partido de las demas ciencias, tanto físicas como químicas, cuyos principios se apropia y aprovecha para sus incesantes adelantos. Se puede decir pues que la agricultura es la ciencia que trata de hacer criar á la tierra el mayor número posible de vejetales útiles en un espacio dado y determinado de terreno. Tiene pues por objeto producir en suficiente cantidad las sustancias rejetales que han de remediar, sea directa ó indirectamente, las necesi- 
dades del hombre. Los vejetales son pues, comolo tenemos ya dicho, el laboratorio que la naturaleza tiene escojido para volver el corto núrnero de elementos metaloídeos que han de entrar en la composicion de los animales, agrupándoles moleculadamente $\mathrm{y}$ haciéndoles entónces cuerpos compuestos, cuaternarios ó quinarios, nacidos bajo la influencia poderosa de las fuerzas vitales, capaces de cumplir con tan importantísimo papel. Considerada bajo ese concepto, la agricultura no será pues para nosotros otra cosa que una especie de fábrica natural dirijida por el hombre, de donde han de salir en primer lugar los vejetales, y en segundo lugar y como consecuencia necesaria los animales. En efecto, de los vejetales producidos, los unos sirven para la alimentacion directa ó indirecta del hombre y los otros para proporcionar á la industria los medios de remediar sus innumerables necesidades. Los que se utilizan para la alimentacion directa del hombre son aquellos que suelen comerse diariamente, sea crudos y tales cuales se los brinda la naturaleza, sea despues de cocidos, de asados ó de preparados como conviene para hacerlos mas alimenticios, mas fáciles de dijerir ó para privarlos de unos principios, sea desagradables al paladar, sea mas ó menos nocivos que contienen; los que al contrario sirven mediatamente á la alimentacion del hombre constituyen ese sinnúmero de plantas que entran en la fabricacion de la carne de los animales de que se alimenta el rey de la creacion. En efecto, como lo tenemos ya dicho, todos los animales sacan los elementos de su nutricion de los vejetales, sea directamente, como lo hacen los herbívoros, los roedores, etc., que les comen, las aves gallináceas y demas que viven de frutos y de semillas, sea indirectamente alimentando un sinnúmero de animalitos que tienen por objeto servir de alimento á su vez á otros seres que por su medio sacan del reino vejetal los principios inmediatos necesarios para su desarrollo normal y para que puedan cumplir con el objeto que les ha sido repartido por el Todopoderoso Hacedor.

De la agricultura tiene pues que nacer neces propu aturalmente el comercio, ese manantial inagotable de la rifar much los estados y hasta de los pueblos, y tambien de los indivic mucha ve setes, las naciones mas comerciales deben ser al mismo auebles. Seçnas agrícolas, sea por ejemplo la Inglaterra: ¿qué nac de los ácidelantar mas la agricultura, tanto práctica como científic de los ácid a tarnbien el gobierno, así como los sabios, han entrai para imprimi senda y se han establecido muchas fincas, modelo, de para imprimir ${ }^{\prime}$ salido ya muy buenos agricultores y escelentes obras a ticnen ura, publicadas por sus sabios directores.

Las Antillas, en las que estamos escribiendo estos "renglones son, como todos lo saben muy bien, paises esencialmente agrícolas y á la sola agricultura, perfeccionada como conviene y como es de desear, toca hacerlos ricos y felices. En efecto, esas comarcas se hallan en las circunstancias físicas y climatéricas mas favorables para la mayor produccion posible de vejetales útiles; además la escasez de brazos, hacierido en general la mano de obra demasiado cara, vuelve improductivas la mayor parte de las fábricas que se plantan 
en tales paises cuando no tienen relacion íntima é inmediata con la agricultura del pais, como la tiene la fabricacion del azúcar, etc. Puesto que es del suelo ó de la tierra que se ha de entregar al cultivo ó volver fábrica regular de productos vejetales, cualquiera que sea el objeto á que se les destina, depende enteramente el buen éxito de tales empresas. Todo lu que acabamos de decir para las Antillas se debe aplicar para el continente americano. Principiaremos por manifestar algunos pormenores sobre tan importante asunto y procuraremos señalar en las menos palabras posibles los principales caractéres físicos que pueden guiar para reconocer las varias clases de suelo ó terreno. Seria preciso en primer lugar enseñar los procedimientos empleados para hacer el análisis químico de la tierra que ha de cultivarse, pero no podemos engolfarnos en tales descriciones, porque los pocos que podrian aprovecharlas hallarán tales métodos mucho mas completos en las obras que tratan de la química agrícola y porque eso no seria de ninguna utilidad para la mayor parte de nuestros lectores, que no tienen ninguna práctica de las manipulaciones químicas.

La capa mas superficial de la tierra es la parte de que debe ocuparse para la agricultura y constituye lo que se suele llamar terrenos agrícolas, á la geolojía agrícola toca dar de ella buenas disposiciones y sobre todo hacerlas de tal manera que estén al alcance de todos; pero por desgracia tales trabajos no han sido publicados hasta ahora, á lo menos que sepamos, y lo sentimos en el alma : tendremos pues que limitarnos á dar un resumen sucinto de lo que se ha escrito sobre el particular hasta hoy dia.

La composicion ó constitucion de la capa superficial o arable de la tierra, aunque resulta de la mezcla de varias rocas vueltas polvo mas ó menos fino por medio de los diferentes cataclismos que han trabajado nuestro planeta en las diferentes épocas geolojicas que ha tenido que atravesar, y además de eso sigue esperimentando diaria y continuamente, bajo la influencia poderosa de los ajentes físicos y químicos naturales, una desagregacion mas ó menos completa de sus partículas, varia muchísimo. Tal variacion ó diferencia en la composicion química y física de las tierras arables proviene de que las varias capas que la constituyen, no teniendo igual oríjen, habrán de tener una composicion diferente segun la constitucion geolójica de los lugares en donde se estudia, bien que muchas veces la composicion de los suelos arables no corresponde con la del terreno geolójco en que está descansando.

En primer lugar tenemos que señalar los terrenos formados en el sitio mismo donde se ha descompuesto ó pulverizado la roca que los sostiene; tales terrenos en general son muy poco espesos y su feracidad es muy mediocre. Las fuerzas físicas y químicas naturales que obran de manera que se desagreguen las rocas á fin de que sus detritos se vuelvan tierra arable, son las siguientes: la pesadez, la electricidad, el calórico, la accion continua o repetida de las aguas llovedizas, del oxíjeno del aire, del ácido carbónico, las propiedades mas ó menos hygrométricas de sus partes, las raices de los vejetales que van introduciéndose por sus grietas, etc.; pero tales cau- 
sas obran muy poco á poco, y su accion se va disminuyendo rápidamente á medida que una capa formada de sustancias orgánicas, despojos vejetales, va cubriendo mas la roca y hasta desaparece por completo cuando la tienen enteramente privada de la influencia directa de tales ajentes. Los terrenos de aluvion, cuya formacion es muy reciente y que presenciamos casi diariamente, están formados de cascajo, arena y limo, sustancias arrastradas por los rios que las dejan sentarse en algunos lugares, de modo que constituyen así terrenos compuestos de capas sobrepuestas y correspondientes con las varias crecientes que tuvo el rio. Tales terrenos, que constituyen las vegas de las Antillas y del continente americano, son muy feraces y será siempre muy provechoso facilitar artificialmente su formacion. Los vientos y las corrientes hacen lo mismo en ciertos lugares de las orillas del mar, dejando sentarse tierras y arena arrastradas por los rios y llevadas por las olas; tales terrenos son tambien muy fértiles, pero estando siempre al nivel de las grandes mareadas, es preciso, para aprovecharlos para la agricultura, diques y obras muy costosas que les defiendan contra la invasion ulterior del mar, lo que no se podria emprender con alguna ventaja en las Antillas á causa de lo caro de la mano de obra y porque hay todavía en estos paises mayor proporcion de terreno riquísimo no entregado á la agricultura por falta de brazos y de caudales suficientes.

Los Mogates ó Méganos, que ocupan en Francia una estension bastante considerable en la costa del Océano, son formados de granos de arena cuarzosa muy finos; no son muy raros tampoco en ciertos parajes de las Antillas, como por ejemplo en la costa norte de la isla de Puerto-Rico, Camuy, verbigracia, en donde les hemos observado, provienen de la accion de los nortes que obligan las olas á arrastrar las arenas y á amontonarlas.

Los terrenos paludosos, cuyo nombre señala bastante su oríjen, gozan propiedades tan variadas como lo son las diferentes circunstancias locales que les han dado lugar: tales terrenos son muy comunes en las Antillas, en la América del Sur, y la facilidad con que se les puede mejorar las mas veces ha de llamar sobre ellos la atencion de los agricultores.

El espesor de la capa del suelo en que penetran, viven y se desarrollan las raices de los vejetales es muy variable; en efecto, reducida á algunos centímetros en los terrenos malos y pobres, alcanza para los buenos de 0 m. 25 c. á 0 m. 35 c. y mas, ó de 10 á 12 pulgadas. Segun el señor de Gasparin, agrónomo francés muy distinguido, se llama suelo la capa superior del terreno hasta la profundidad en donde principia á cambiar su composicion mineralójica. Tal suelo se puede dividir en suelo activo ó la parte que se mezcla con el mantillo, recibe la influencia atmosférica y las sales solubles y en la cual se verifican los fenómenos de la vejetacion y que está bajo el imperio de los labradores; por debajo de esta capa se encuentra el suelo inerte, que aunque teniendo igual composicion mineral no está aprovechada por el cultivo por ser demasiado profundo; despues de aquella segunda capa del momento que aparece una composicion mineral diferente, aquí principia el sub-suelo, que puede estar 
tambien compuesto de algunas capas diferentes, cuya composicion mineral ó geolojica puede variar tambien hasta que se halle la última ó la capa impermeable: en ciertos casos particulares el suelo puede descansar sobre la capa impermeable, el sub-suelo faltando mas ó menos.

El espesor del suelo activo depende pucs esclusivamente de la mayor ó menor profundidad de las labores, de manera que será siempre ventajoso que sea lo mas espeso posible; no se puede poner ninguna regla general sobre la conveniencia ó utilidad que habrá de mezclarle mas ó menos frecuentemente con el suelo inerte: lo que está evidentemente sugeto á la composicion mineral relativa á estas dos partes del suelo general. Si el suelo activo está por ejemplo ya estenuado, mientras el suelo inerte goza de mucha feracidad, mezclarlos será en ese caso muy provechoso, y vice-versa.

El sub-suelo, especialmente cuando está vecino de la superficie, tiene mayor influencia sobre la bondad del terreno, sea por causa de su propia naturaleza, sea por la influencia ó accion que tiene sobre el desagüe : en efecto, comarcas enteras hay que son estériles únicamente por causa del sub-suelo.

Los terrenos que se pueden cultivar difieren entre sí, químicamente, mucho mas por las proporciones relativas de las sustancias minerales que les constituyen que por la naturaleza química de estas mismas sustancias : tales terrenos tienen en general la composicion química siguiente : sílice, alumina, cal, magnesia, potasa, sosa, óxido de hierro, óxido de magnesio, azoe, mantillo y agua; esas sustancias están en tales suelos, tan pronto mas ó menos aisladas y así entremezcladas, como combinadas entre sí y tambien con algunos ácidos.

No hablaremos en particular de ninguna de estas sustancias, porque eso nos llevaria muy lejos de nuestro objeto y porque esos conocimientos se encuentran en las obras de química: diremos lo mismo del análisis químico de los terrenos, que se compone de operaciones químicas delicadas, las cuales necesitan conocimientos químicos bastante estensos y además bastante práctica del laboratorio.

Sin embargo nos parece conveniente y útil decir al paso algunas palabras sobre el humus ó mantillo, porque constituye la parte mas rica del suelo y la por consiguiente de que saca su valor y su feracidad. Tal sustancia resulta de las alteraciones de los detritos vejetales determinadas por la accion combinada del oxíjeno del aire, de la humedad y del calórico; tales sustancias abandonadas al aire pierden de su agua de composicion y una proporcion relativamente menor de su carbono, de tal suerte que el producto de esta especie de fermentacion pútrida incompleta es mas rico en carbono que las sustancias vejetales de que proviene y constituye el mantillo. Ese cuerpo proviene de oríjenes variados y habiendo nacido en circunstancias muy diferentes no es nunca bien definido ni idéntico tampoco. Tratado por el agua de potasa se disuelve y el líquido se vuelve prieto mas o menos oscuro; con unas gotas de un ácido cualquiera echadas en ese líquido deja separarse y sentarse una 
sustancia prieta y coposa que se llama ácido úlmico, húmico, humus, ulmina, etc.; tal cuerpo es casi insoluble en el agua, pero puede esperimentar un segundo grado de fermentacion que le vuelve soluble y le transforma en estracto de mantillo; durante esta segunda alteracion hay produccion de ácido carbónico y de algunos ácidos orgánicos. La propiedad que goza de absorver el oxíjeno del aire para producir ácido carbónico, da razon muy bien del papel ventajoso y muy importante que tiene en la vejetacion. Los terrenos mas feraces contienen en general desde 0,05 ó $5[100,0,08$ ó 8 [100 de este cuerpo y la feracidad se va disminuyendo á medida que la proporcion va aumentándose, de tal manera que los terrenos que contienen de él como 0,25 ó 25 [100 son casi siempre estériles, necesitando por consiguiente de un abono particular y de un modo especial de cultivo. Cuando haya sido producido por la descomposicion de rejetales muy ricos en tanino contendrá un poco de ese ácido, tal terreno se llama agrio, como sucede diariamente en los platanales y es impropio para muchos cultivos; se remedia ese inconveniente con mayor facilidad al favor de la cal con que se le abona. A la presencia del mantillo en proporcion bastante fuerte en su suelo, las Antillas y el continente americano en general deben una gran parte su lozana vejetacion y su admirable feracidad, por esa razon hemos hablado de él un poco mas detenidamente.

Es preciso tener en cuenta la densidad de las tierras que han sido clasificadas por Shübler, como sigue, segun su composicion. A rena calcarra, 2,822; - id. silicosa, 2,753; - barro flaco, 2,701; id. gordo, 2,632 ; - tierra arcilnsa, 2,591; - id. de jardin, 2,$332 ;$ - mantillo, 1,225. El harro flaco contiene 40[100 de arena silicosa fina. El barro gordo $24[100$ y la tierra arcillosa $10,75[100$; la arcilla pura no contiene arena, su color es gris azulado y al tomarla entre los dedos es suave á manera de los cuerpos grasos ó mejor del jabon. La tierra de jardin es liviana, prieta y feraz; contiene 52,4 de arcilla; 36,5 de arena silicosa; 1,8 de arena calcárea; 2 de carbonato de cal y 7 de humus ó mantillo.

Bien que no se pueda sacar exactamente la composicion de una tierra de su densidad, es posible sin embargo adivinarla así aproximadamente; diremos aquí pues en general que las tierras mas densas son las mas ricas en silice, mientras las mas livianas contienen mayor proporcion de mantillo y al favor de esos dos términós ó datos estremos se podrá juzgar los intermedios. Eso puesto, el conocimiento del peso de un metro cúbico de tierra, así como se la halla en el campo mismo que hay que entregar al cultivo; suministra datos muy útiles para la ejecucion dé los trabajos agrícolas haciendo adivinar su composicion y por consiguiente conocer los abonos que hay que emplear para volverla mas apropiada á los vejetales que se quiere producir, pero se debe tener presente que la tierra despues de sacada ocupa en general un volúmen ó tamaño $1_{[} 10$ mayor que cuando estaka en el campo. Para que se pueda sacar provecho de estos datos en la práctica agrícola, ponemos aquí el cuadro del peso de un metro cúbico de algunos suelos: Arena fina y seca, 1,399 kilógramos á 1,428 hil.; - id. húmeda, 
1,900 kil.; - arena fósil arcillosa, 1,713 k. á 1,799k.; - tierra vejetal liviana, $1,214 \mathrm{k}$. á $1,400 \mathrm{k} . ;-\mathrm{id}$. arcillosa, $1,600 \mathrm{k}$; barro, 1,900 k.; - mantillo, 0,828 k. á 0,857 k.; - tierra mezclada con arena y con cascajo, 1,860 k.; - id. gorda ó barrosa mezclada con piedrecitas, $2,290 \mathrm{k}$.

Se llama higroscopicidad á esa propiedad que tienen las tierras para detener en sus partículas mas ó menos agua, sin dejarla escurrir; tal propiedad proviene á la par del estado físico y de la composicion química de las partículas de la tierra y favorece muchísimo la feracidad de los suelos; bien que el grado de higroscopicidad no pueda dar razon esacta de la feracidad de un terreno, por su medio se pueden sin embargo sacar mayores ó menores probabilidades de ella. Segun Schübler, el poder higroscopico de las varias clases de tierras es como sigue: 100 partes de arena silicosa contienen 25 ; id. de yeso, 27; - id. de arena calcárea, 29 ; - de barro flaco, 40; - de barro gordo, 50;- de tierra arcillosa, 60 ; - de arcilla pura, 70 ; - de tierra calcárea fina, 85 ; - de mantillo, 190 ; - de carbonato de magnesia, 456 ; - tierra de jardin, 89 de agua.

La permeabilidad de las tierras ó esa propiedad que tienen de dejar pasar el agua con mayor ó menor facilidad por entre sus partículas no está en razon directa con su higroscopicidad. Tal propiedad es de mayor importancia para la agricultura, porque teniendo relacion casi directa con la capilaridad, favorece mucho y facilita el movimiento de los gases y de los líquidos por entre las partículas de los terrenos, y por esa razon su papel es muy importante en las operaciones que necesitan el drenage ó desagüe y las irrigaciones.

La frescura es una propiedad de mayor consideracion para la agricultura y está en relacion casi directa con la higroscopicidad de los varios elementos que forman el suelo, su esposicion y la composicion del sub-suelo; para que una tierra esté considerada por sana es preciso que 2 ó 3 dias despues de un chubasco fuerte no contenga sino una mitad mas de higroscopicidad que en su estado normal, $y$ para que no se llame seca es preciso que durante la estacion seca, despues de 8 dias de sequia, se quede todavía con 10[100 de agua. El señor de Gasparin llama frescas á las tierras que habitualmente contienen 15 á 25 [100 de agua, y secas á las que detienen menos de 10 [100 de ese líquido. La facilidad que tienen las tierras para volverse secas al aire está casi en relacion inversa con su higroscopicidad. Cuando una tierra se va desecando, su tamaño disminuye, va encojiéndose, y así tiene mas veces una accion mecánica nociva sobre las raices que pueden estar dañadas, aplastadas y hasta heridas. Segun Schübler, 1,000 partes de las tierras siguientes esperimentan al desecarse la disminucion ó encojimiento siguiente : Tierra calcárea fina, 50 ; - barro flaco, 60 ; - id. gordo, 89 ; - tierra arcillosa, $114 ;$ - id. de jardin, $149 ;$ - arcilla pura, 183; - mantillo, 200 .

Las tierras espuestas al aire húmedo gozan la facultad de absorver una cierta cantidad de agua, lo que es muy favorable, porque conservan la proporcion de humedad necesaria para una buena vejetacion, y constituye, especialmente en los paises cálidos, una cali- 
dad preciosísima. Bajo ese punto de vista Schübler clasifica las tierras como sigue, principiando por las que absorven menos: Arena silicosa, id. caliza ; barro flaco, id. gordo; tierra caliza fina, id. arcillosa, id. de jardin; arcilla pura; humus ó mantillo.

Las tierras no se limitan á chupar la sola humedad del aire, sino que á la vez absorven los gases húmedos. Lo que ha sido estudiado solamente para el oxíjeno quie pierden al desecarse para volver otra vez á condensarle cuando cojen liumedad, y las cosas siguiendo así favorecen muchísimo los actos de la vejetacion, como lo tenemos ya señalado mas arriba en el discurso preliminar, de esa parte. Segun los trabajos de Schübler, 100 partes de las tierras señaladas aquí habian, despues de un mes de esposicion, absorvido el oxíjeno como sigue : Arena silicosa, 1,6; - id. caliza, 5, 6 ; - barro flaco, 9,3;tierra caliza flna 10,8 ; - barro gordo, 11,0; - tierra arcillosa, 13,6 ; - arcilla pura, 15,3 ; - tierra de jardin, 18,0 ; - humus ó mantillo, 20,3.

La constitucion física de las tierras y su composicion química influyen muchísimo sobre la facultad que poseen de detener el calórico y por consiguiente sobre su calórico específico; consideradas bajo ese punto de vista Schübler las coloca como sigue : Arena calcárea, 1,00; - id. silicosa, 9,56; - barro flaco, 7,69; - id. gordo, $7,1 \mathrm{I}$; - tierra arcillosa, 6,88; - arcilla pura, 6,67 ; - tierra de jardin, 4,48; - tierra caliza, 6,18; - humus ó mantillo, 4,90.

El calentamiento de las tierras por el sol constituye una propiedad de mayor consideracion para la práctica agrícola y depende por el mismo lugar, de la naturaleza de la capa superficial del suelo, de su composicion química, de su grado de humedad y en fin de su inclinacion. El color del terreno tiene mucha influencia sobre su calentamiento, $y$ se ha observado que, con igual esposicion al sol, los suelos coloridos daban cosechas mas prontas que los blancos; los mismos terrenos secos o húmedos han ofrecido, despues de esperimentos comparativos hechos con cuidado, una diferencia de 7 á $8^{\circ}$ menos para los últimos, lo que proviene sin duda de la evaporacion que se verifica en su superficie.

Pero no es todo el conocer aproximadamente la naturaleza y las propiedades mas ó menos favorables al cultivo de un terreno dado $y$ bien que tales conocimientos basten para escojerlo, necesita entónces otras cosas para estar apropiado; para recibir las siembras y hacerlas prosperar á fin de sacar de ellas todo el provecho posible. Para sembrar es preciso siempre preparar el suelo despues de haberle escojido convenientemente para el mayor producto de los vejetales que hay que cultivar, tomando en cuenta lo que tenemos dicho mas arriba, y su composicion química que estamos prontos para señalar. ¿Pero quién en las Antillas se ocupa de preparar el suelo como conviene? quién ha pensado solamente en hacerlo! En general se limpia mas 6 menos el terreno, $y$, despues de escarbado las mas de las veces como las gallinas, se le entrega la semilla, y tan poderosa es su fertilidad que á pesar de tan inaudito descuido y de tan perjudicial abandono, produce cosechas muy regulares y hasta abundantes muchísimas veces. Cuando uno se toma el trabajo de es- 
plicar á los labradores de tan afortunados paises el cuidado con que en Europa se prepara el suelo antes de sembrarle, le miran como maravillados y casi atontados y contestan: "Eso es mucho trabajo, costaria un dineral; en fin, la tierra nos da bastante tal cual la cultivamos y nos basta así. " Error de mayor consideracion que es un obstáculo casi invencible á los adelantos y á las mejorías agrícolas de esas comarcas y que aprovecha solo á la pereza y á la vagabundería, que son como dos llagas crónicas, no diremos incurables, pero que hacen muchísimo perjuicio á esos paises en favor de los cuales estamos hace ya muchos años gastando nuestros desvelos.

Supongamos un terreno vírjen y por consiguiente montuoso, es decir, cubierto de bosques; lo primero que hay que hacer es desmontarle; se principiará pues por cortar todos los árboles útiles para las construcciones navales ó civiles, tales son los ausubos, los capas, los ucaros, los majuguas, los cedros, las caobas, las yabas, chicharrones, quiebra-huesos, los robles, algarrobos, ébanos, guayacanes, etc. y demas cuyos troncos se han de labrar cuadrados cuando son bastante gruesos, casi en el acto de tumbarlos, y se han de depositar en parajes donde no estén espuestos á la accion de las lluvias ni á la del sol tampoco. Tal faena demanda gastos que espantan á la mayor parte de los que se dedican al cultivo de las tierras, pero no reparan que así tendrian un tesoro guardado para el dia en que se necesitará de él. Todos los demas árboles y los trozos inútiles así como las ramas fuertes, se habrán de reducir á carbon despues de sacadas de ellos buenas soleras, ejes y viguetas: así practicada la industria del carbon bastariá para cubrir todos los gastos del desmonte y se quedaria además libre el valor de las maderas útiles. Muchos se niegan á dedicarse á la fabricacion del carbon, porque faltando con demasiada frecuencia buenas vias de comunicacion, es costoso llevarle á las ciudades á donde se venderia con mucho provecho, pero se le puede muy bien tener guardado en montones cubiertos de yerbas y tierra hasta que se presente la ocasion favorable para aprovecharle y sacar de él la debida utilidad, lo que necesariamente debe suceder algun dia.

Es costumbre en las Antillas y tambien hasta en Europa entre los campesinos que las cortes de los árboles que han de servir para fábricas han de practicarse cuando la luna está en su cuarto menguante : si hemos de creer en la esperiencia diaria de los que viven en el campo, si debemos tener confianza en lo que nos han referido y de las comparaciones hechas con varias maderas de la misma clase, de las que unas haljian sido cortadas en cualquier época, mientras las otras lo habian sido en el menguante de la luna, tenemos, á pesar de lo que dicen los sabios, alguna tendencia para participar de tales ideas, que se pueden seguir muy bien porque tal práctica no lleva detras de sí ningun perjuicio.

Las maderas útiles así recojidas, el carbon vendido ó guardado, seria preciso, como en Europa lo hacemos siempre, pero que casi nunca se ha practicado en estos paises, destronconar y estirpar las raices, lo que serviria para producir mucho carbon de la mejor calidad : tales fragmentos quedándose en la tierra son un estorbo muy 
grande para el uso de los instrumentos y ustensilios de labor perfeccionados, que tantos brazos ahorran en el cultivo de las tierras; $y$ quizás el abandono en que está tal práctica en las Antillas es una causa poderosa del atraso en que se encuentra el cultivo por la gran cantidad de brazos que se necesita y que escasean. Tal operacion no se debe ejecutar en los terrenos muy inclinados porque no permiten el uso del arado ni de los demas instrumentos que remueven el suelo y desmenuzan la tierra, $\mathrm{y}$ además en ese caso su presencia es útil, porque se opone á que las aguas llovedizas se lleven consigo la tierra arable, como sucede tantas veces. Para ese trabajo bastan la hacha, la cuña y el estirpador. En lugar de seguir lo que acabamos de señalar, despues de tumbados todos los árboles se los suele quemar, así como todas las malezas, y eso hecho se escarba mas ó menos la tierra y se procede á la siembra: qué barbaridad!

En los terrenos inclinados se debe principiar por abrir una zanja transversal á la parte superior y despues algunas otras, segun la estension de la ladera ó pendiente, á fin de desaguar las aguas de lluvias, cortando así las corrientes que descarnan el terreno y suelen dejarle enteramente desnudo de capa vejetal y con surcos profundos que son otros tantos espacios inútiles y conductores de la tierra á los llanos; tales terrenos no son propios sino para pastos artificiales con yerba de Guinea, cuyas raices fijan el suelo, que vuelto movedizo con otras siembras se lo llevarian las aguas consigo.

Si el terreno que hay que entregar al cultivo está tan bajo respecto á los que le rodean que en él se detengan ó se estanquen las aguas desbordadas de los rios ó avenidas de las alturas, es preciso rodeario y cruzarlo con zanjas mas ó menos anchas $y$ mas ó menos profundas, segun el mayor ó menor cúmulo de agua que pueda invadirlo. Con las tierras que se estraen de tales zanjas se nivelan las desigualdades á fin de evitar estancaciones parciales; tales terrenos tienen por lo general el sub-suelo todo formado de barro tenaz que no consiente la filtracion de las aguas, de tal modo que para aprovecharles es preciso desaguarles por el drenaje, tan empleado en Europa, donde lo hemos visto producir maravillosos efectos y que consiste en colocar de cierto modo y á cierta profundidad en el terreno tubos de barro porosos, lo que es muy costoso en Europa misma, y por esta razon, á nuestro corto parecer, de aplicacion difícil en las Antillas, en donde se les puede reemplazar muy bien, muchísimo mas barato, abriendo zanjas con el arado y el ci haron tirado por una mula, buey ó caballo. Tal operaçion fácil y ec rómica permite aprovechar terrenos muy feraces porque son así todos aquellos en que el agua estancada ha dejado su depósito, y además de eso tales lugares se vuelven mucho mas saludables para el hombre y tambien para los animales, haciendo desaparecer con los miasmas que se exhalan de ellos, como lo tenemos dicho y esplicado en el discurso preliminar del Compendio de terapéutica vejetal de las Antillas, que constituye la segunda parte de esta obra. Las zanjas del rededor han de quedar abiertas, cuidando de limpiarlas cuando se necesita, mientras las que van cruzando el terreno se han de llenar de piedrecitas angulosas, dejando entre sí vacíos ó especies de ca- 
nalitos subterráneos por donde ha de correr el agua; si escasean las piedras se las reemplazará por maderas incorruptibles como la yaya, el mangle negro, la quiebra hacha, etc., hechas pedazos, y por encima se aplicará una capa de ramitas de los mismos árboles dispuestas en haces, $\mathrm{y}$ en fin se llena y nivela con la parte correspondiente de la tierra sacada; de esa manera han desaparecido las zanjas cuya superficie se cultiva, y sin embargo existen los conductos subterráneos necesarios para el desagüe y las aguas se reunen en las zanjas abiertas y de estas van á algun paraje mas bajo, hoyo, sumidero, laguna ó rio, etc.

Los terrenos cuyo suelo contiene muchas piedras mayores que el cascajo exijen composicion previa antes de la siemhra: la faena consiste entónces en recojer el mayor número de ellas y especialmente las mayores, y convertirlas en cal cuando están á propósito ó amontonarlas sóbre el campo mismo, segun las circunstancias. Los montones, dice el señor licenciado Dau, han de ser circulares, dispuestos en cono y como de unas 2 varas de diámetro por la base y colocados en líneas paralelas á fin de no estoríar la labranza. Sabido es en efecto que muchas piedras, aunque sueltas, son un estorbo grande para el arado, para el escarificador, la grada, el desyerbador y demas instrumentos necesarios para los trabajos agrícolas y que reemplazan con tanta ventaja y economía á la azada, por desgracia tan empleada todavía, y que no deberia emplearse mas sino en los lugares en donde no se pueden aplicar los utensilios señalados. Segun el antedicho señor Dau, tales montones de piedras se pueden aprovechar, de manera que en lugar de disminuir la estension del terreno la aumentan al contrario: basta para eso reunida la primera camada de piedras, arrojar sobre ellas tierra y estiércol para llenar los intersticios que habrán natural y necesariamente quedado entre ellas; puesta la segunda camada se adereza tambien con tierra y estiércol, y así seguidamente hasta concluir cada monton $\mathrm{y}$ despùes se siembra yerba de Guinea, introduciendo la raiz con una parte de su tallo entre las piedras: tales montones serán pues otros tantos montículos que producirán bastante forraje y no se derrumbarán porque las raices tend rán sugetas las piedras, que así guardadas se podrán aprovechar un dia ú otro, tan pronto para construir calzadas, fabricar casas, como para hacer cercas, que en tal caso se podrian sembrar como los montones y hasta de maiz, ó convertir en cal cuando se necesitara: además sirven para guarecer las plantas contra los vientos. El suelo no puede rendir buenos y abundantes productos si no se prepara la tierra vejetal como conviene.

Despues de desmontado el suelo es preciso limpiarle de todas las malezas que le cubren y amontonarlas en tantos montones cuantos sean suficientes para cubrir la mayor parte de la superficie de la tierra: á tales montones se deben agregar para mejor efecto malezas traidas de los caminos reales, en lugar de dejarlos podrir en ellos, ramas de las cercas, plantas nocivas y parásitas arrancadas, pencas de palmas y cuantas materias vejetales análogas se pued.3 encontrar á la mano: despues de seco bien todo, se le aplica el fuego á fin de que todo arda bien, reduciéndose á cenizas : tal combustion 
se ha de practicar de noche, porque hay menos viento y porque la combustion siendo entónces y por esta causa algo mas lenta, todo se quema mejor y la tierra se encuentra algo torreficada, lo que le hace mucho favor: además de las cenizas que se quedan en su superticie y que son para ella un abono magnífico, las semillas malas son destruidas por el fuego y así perecen á la vez muchísimos iusectos ó sus huevos y crisalides.

Todo eso hecho se trata de abonar el suelo si ya ha producido muchas cosechas ó si necesita alguna composicion particular apropiada á la clase de vejetal que se ha de cultivar en él; pero en la mayor parte de las grandes Antillas especialmente, no se habla de abono, porque hasta ahora se han podido siempre escojer para las siembras terrenos muy ricos, mientras que en las de barlovento ya ha llegado para algunas de ellas el tiempo de abonar las tierras y de cambiar anualmente las cosechas. En efecto, en las circunstancias ordinarias, y cuando es posible, se debe evitar con mayor cuidado estenuar el terreno, y para conseguir tal objeto es necesario variar los cultivos de tal manera, que cada cosecha restituya al suelo lo que la precedente habrá sacado de él, y para eso se ha de hacer suceder las plantas las unas á las otras de tal manera, que se produzca mayor proporcion de sustancias orgánicas útiles en el tiempo mas corto y con el menos abono posible; pero como se han de reparar á la vez en el valor intrínseco del producto, de modo que salga siempre el mayor posible, es preciso al sembrar los vejetales escojer siempre por amalga la especie mas productiva y la que conviene mejor á las costumbres y clima del pais en donde se trabaja.

Se llama abono á toda sustancia, cualquiera que sea su orijen, capaz de conservar y hasta aumentar la feracidad del suelo, restituyéndole lo que los vejetales sacan de él cada año ó mejor cada cosecha, $y$ además mezclando con él mayor proporcion de alimento para las plantas que hay que sembrar á fin de que den el mayor producto posible : el abono ha de corresponder pues con la composicion química de las cenizas de las plantas que han de ser cultivadas en él. Sabido es en efecto que la composicion química de los vejetales varia mucho, no tanto por los principios elementales que contienen, sino por las varias sales minerales que necesitan para su normal vejetacion y su mayor alimentacion. Las sustancias de oríjen orgánico proporcionan al descomponerse oxíjeno, hidrójeno, carbono y mas ó menos azoe, cuya mayor proporcion sacan de la atmósfera, como ya lo tenemos dicho en el discurso preliminar : tocante á los óxidos minerales y á las sales, les encuentran en el suelo sea naturalmente, sea por medio de los abonos que se mezclan con él á fin de remediar lo que le falta naturalmente ó sus pérdidas y necesidades, consecuencia necesaria del cultivo. Los vejetales tienen la propiedad de escojer en el suelo las sales que les corresponden y retienen solamente aquellas, como resulta de los esperimentos agrícolas y los muchos análisis de los Sres. Boussingault. Payen, etc., y demas sabios: en efecto, entre las plantas, las unas se cargan de sal marina en un suelo en que otras sacan solamente una pequeña proporcion de tal sustancia, mientras se cargan de otra 
mas á propósito para su organizacion. Supuesto esto, se habrá pues de conocer la naturaleza del suelo que se quiera esplotar y tambien la composicion química de las cenizas de las plantas que hay que cultivar, á fin de poder escojer el abono mas á propósito para sacar de ellas el mayor producto posible. Tales datos se encuentran reunidos en las obras de química que tratan de la agricultura; sentimos en el alma no poderlos tener aquí reunidos, pero eso nos llevaria demasiado lejos de nuestro objeto y quizás hemos ya dado demasiada estension á ese párrafo.

Se da el nombre de abonos naturales á los que se componen del estiércol de los animales domésticos, sea empleado solo, sea mezclado préviamente y como conviene con tierra y con cal, y despues de trabajado como conviene se lo estiende en la superficie del suelo que hay que abonar; pero como en las Antillas el sistema de estabulacion es desconocido y muy raras veces aplicado, habrá siempre muy poco estiércol de que disponer.

Pero no será así de los ahonos artificiales, que se pueden casi siempre preparar en el lugar mismo donde se necesitan : en efecto, basta para eso reunir sustancias orgánicas, tan pronto vejetales como animales y mezclarlas con algunas minerales, tales como la cal mas ó menos cáustica, los fosfatos ó huesos pulverizados, la arena mas ó menos fina, especialmente si el suelo que hay que abonar es muy compacto y barro desmenuzado, cuando el terreno es demasiado esponjoso. Tales compuestos se preparan del modo siguiente: debajo de un techado de yaguas se forma un círculo como de unas cuatro varas de diámetro, con estacas clavadas en el suelo verticalmente, como de 2 varas de largo, distantes una de otra como de unas 9 á 12 pulgadas y por la parte interior se forran con yaguas ú otra cosa cualquiera á propósito. Todo así dispuesto, se pone dentro del círculo una camada de 9 pulgadas de espesor formada de toda clase de estiércol ó despojos animales y por encima se estiende otra capa espesa como de 4 pulgadas, formada de arena fina; despues viene otra camada de estiercol igual á la primera y en seguida una de arena y se sigue á estratificarlas así hasta que esté lleno el círculo: toda esta aglomeracion ha de mantenerse húmeda, rociándola por arriba todos los dias con agua, ó si posible es, con orines y con todas las aguas domésticas, que no se deben desperdiciar nunca, porque contienen siempre sustancias orgánicas en disolucion y en suspension á la vez, y por eso constituyen un abono muy bueno; se ha de emplear cantidad suficiente de líquido para humedecer el monton, pero no tanto que se derrame ó se escurra por su base: tal operacion sirve para hacer desarrőllar en la masa la fermentacion pútrida ó descomposicion cuyo objeto es convertir todas estas sustancias empleadas en humus artificial. Lleno y prensado un depósito se procede á formar otro ú otros, segun la cantidad de abono fertilizante que se necesita para las tierras compactas y tenaces. Los depósitos ó círculos preparados ya como lo tenemos enseñado se estiende por encima : $1^{\circ}$ una capa de estiércol; $2^{\circ}$ otra de arena igual en espesor á la anterior; 3" otra de estiércol de 3 á 4 pulgadas; $4^{\circ}$ una de cal que no debe pasar de una arroba; $5^{\circ}$ otra de ceniza; 
$6^{\circ}$ una de sal de comer, como 5 libras bastan, luego estiércol, etc.; con este mismo orden hasta llenar el círculo, prensando toda la masa y humedeciéndola como queda referido. Se puede reemplazar la arena con el cisco de carbon vejetal, el cocó, el polvo calcáreo ó de granito recojido en las calles y calzadas, el polvo de ladrillos y hasta barro tostado: así se obtiene un compuesto fertilizante y estimulante á la vez, propio para abonar las tierras compactas muy tenaces.

Para las tierras demasiado esponjosas se preparará un compuesto estimulante y fertilizante á la vez, lo mismo que el que se aplica á las tenaces, con la diferencia de que en lugar de emplear arena se la reemplazará por barro bien desmenuzado: tales suelos antes de haber sido abonados como conviene, no adhieren bastante á las raices de los vejetales y se secan hasta tal grado, que las plantas perecen por falta de humedad: lo contrario sucede con los suelos compactos y demasiado tenaces.

Segun el señor Dau, á todo compuesto para cualquiera clase de suelo se le ha de agregar precisamente cierta proporcion de azufre en polvo finísimo para matar los insectos contenidos en él y precaver su reproduccion: dos á tres onzas de flor de azufre esparcidas con igualdad sobre cada camada de las diferentes sustancias que la forman, son bastante. Los terrenos ferrujinosos necesitan mayor proporcion de cal en su abono.

Siempre, segun el señor licenciado Dau, de la Habana, se da á la tierra una fertilidad estraordinaria y muy duradera, haciendo sufrir al terreno la accion del fuego hasta torreficarle, y ese señor indica un método muy injenioso y económico para hacerlo, pero sentimos no poder referirlo aquí, porque eso nos llevaria algo lejos de nuestro objeto. La incineracion así practicada destruye completamente los insectos y las semillas de las plantas perjudiciales que existen en el terreno, calcina las conchas, caracoles, la arena $y$ las piedras calcáreas que están mezcladas con él, y este agregado de cal, unidas á las cenizas resultantes de la combustion de las sustancias vejetales empleadas, forman un compuesto magnífico. Sabido es en efecto de todos los labradores que en los lugares donde hubo hornos de carbon ú hogueras hechas con montones de jerbas secas y raices sacadas de los campos arados, hay mayor lozanía en la vejetacion de las plantas, que dan mucho mayor producto, y sin embargo, en tales lugares la tierra no ha recibido nada mas que el beneficio de la torrefaccion. En Cuba los vigueros echan sus semillas en esta tierra y á pesar de no gozar de sombra moderada, produce hermosas posturas de tabac:o, sin que las molesten la germinacion de las otras semillas ni los insectos que no existen en ella, porque han sido destruidos por el fuego.

En China admira la paciencia de los labradores, que reunen cuantas materias combustibles pueden encontrar, las amontonan en muchos puntos de la superficie que se ha de cultivar, cubren esos montones con hojas grandes y por encima echan una capa de tierra de cierto espesor : aplican fuego al combustible y entretienen la combustion todo el tiempo que les es posible, para que la tierra sufra 
un cierto grado de torrefaccion, tan convencidos están de la escelencia de ese procedimiento; en Cataluña y en otras muchas partes se hace lo mismo.

Segun los esperimentos con cuidado hechos en Europa, el mejor abono para una planta son sus mismos despojosverdes y jugosos que se entierran á su pié cuando vivaces, y es tambien el mas económico. Para que una planta pueda cultivarse con ventaja y utilidad por abono verde es preciso : 10 que esté apropiada al clima y á la naturaleza del suelo; $2^{\circ}$ que vejete con vigor, sin necesitar de abono ninguno y que prospere en un terreno casi estéril ó muy poco feraz; $3^{\prime}$ que su semilla sea barata; $4^{\circ}$ que se pueda desarrollar enteramente durante el discurso de una estacion ó dos lo mas; $5^{\circ}$ que produzca un volúmen grande de raices, tallos y hojas; $6^{\circ}$ que tape perfectamente el suelo con sus tallos $y$ sus hojas á fin de que las malas yerbas estén ahogadas y no puedan vejetar; $7^{\circ}$ que se pueda enterrar con facilidad con los instrumentos aratorios; $8^{\circ}$ que sus tallos y sus hojas contengan una proporcion fuerte de sustancias azoadas; $9^{\circ}$ que despues de enterradas en el suelo se descompongan con facilidad y prontitud; 10, y en fin que contengan bastante humedad. Todas las plantas herbáceas pueden en general servir para abonar la tierra enterrándolas en olla cuando están aun verdes y próximas á florecer: todos los agrónomos de mas reputacion las tienen en efecto por tan fertilizantes como los mejores compuestos; son los mas económicos, mas fáciles de conseguir y no exijen de parte de quien los emplea conocimientos científicos, lo que es una rentaja que no hay que despreciar. En Nueva-Orleans se suele abonar con matas y con frijoles prontos para florecer: se pueden usar para eso los frijoles caballeros y los de bollo ó de carita, pero con el cuidado de enterrarles cuando están para florecer, porque si se les queda parir para sacar producto de ellos se ha desperdiciado enteramente el abono, y quienobra así se hace á sí mismo un perjuicio de consideracion. Los vigueros de la vuelta de abajo en Cuba y todos los labradores saben tambien que arando la tierra cuando está plagada de yerbas bien verdes y jugosas adquiere buenas cualiciades, y que tanto el tabaco como cualquiera otra planta que allí se siembren dan mejores resultados. Se rompe la tierra con el arado águila americano que entierra al momento las jerbas, habas, frijoles, etc., ó demas plantas sembradas á propósito, y una sola labor basta con tal instrumento para tapar bien todo lo verde que habia en el terreno. Tambien se sacan los mejores resultados del modo de ałonar, que consiste en enterrar al pié de las plantas cultivadas sus propios despojos estando verdes, lo que no es otra cosa sino la primera práctica, y surte mejor efecto, como está probado en Europa para los viñedos, y en las Antillas se la ha de aprovechar para el cultivo de la caña de azúcar. El malojo de maiz es un abono verde superior, cuya descomposicion se efectua pronto y en menos de un mes: se ha de cortar y de enterrarle cuando va á soltar la espiga: las pencas de Maguey constituyen tambien un buen abono, el malojo de mijo, el añil, los frijoles verdes, etc.; pero las plantas de la familia de las leguminasas son tenidas por los 
agrónomos como las que suministran mejores resultados; por consiguiente cuando será posible habrá que darlas la preferencia, y especialmente al añil, porque se cria en cualquier suelo y que es además natural de las Antillas.

El abono con plantas verdes se puede ejecutar de varios modos : u se le siembra en el terreno mismo que dehen fertilizar, ú otras veces se le tiene sembrado fuera de él, pero lo mas pronto posible, lo que se hará cuando el suelo que ha de ser abonado estará tan esquilmado que no produzca la planta verde con que se debe vigorizarle. En ese último caso, antes que la maloja, el añil, etc., se hayan de cortar ó de arrancar, preciso será preparar el terreno desvirtuado con tres ó cuatro labores ejecutadas con el arado, lo mas profundo posible; en efecto, comolo dice tan juiciosamente el agrónomo inglés Leonardo Wray, cada labor que se da al suelo con el arado es una mano de abono atmosférico que recibe: así preparada la tierra, se abre un surco con el arado en un lado y en la misma orilla, se trae el abono verde cortado al mismo tiempo, se llena el surco y al abrir el segundo está cubierto de la tierra suficiente y se sigue así hasta que todo el campo esté abonado: se dice que el terreno que tiene muchas malvas, malvaviscos, cadillos todavía herbáceos y no vueltos leñosos, queda bien abonado arándolo y enterrándolas allí mismo: se pudren pronto.

Cuando el malojo o el añil se destinan para abonar el suelo en que se han criado, es preciso sembrarles en líneas rectas con la mano ó mejor y mas económicamente con la carretilla sembradora, separadas una y otra por un espacio ó calle de media vara y 2 ó 3 pulgadas de intérvalo de una mata á otra sobre la línea y cuando ya está en el estado conveniente se abre un surco retirado como de unas 9 á 12 pulgadas de la primera línea y de la parte de afuera del plantío y á lo largo de ella, tendrá tal surco como 8 á 12 pulgadas de profundidad y lo menos 14 de ancho en la parte de arriba: detrás del arado que le va abriendo siguen uno ó dos hombres cortando ó arrancando la maloja ó el añil de la primera línea y poniéndola tendida á lo largo del surco que despues se llena con la de la primera línea, abriendo otro surco igual que se llenará con la de la segunda línea, mientras el de la primera se encuentra cubierto con la tierra del segundo surco que le arroja la vertedera y se continúa así hasta haber concluido la tarea. Las malas yerbas que no se pueden emplear para abonos verdes por una causa ó por otra, se pueden sin embargo aprovechar por abono compuesto muy bueno, del modo señalado mas arriba al hablar de los abonos artificiales ó solamente disponiéndolas por capas con cal viva y tierra por encima.

El mes de agosto es en las Antillas el primer mes del año agrícola y en Cuba los labradores le llaman el mes de los locos, porque es la época en que efectuan los arrendamientos de predios rurales. En agosto pues se preparan las tierras para las siembras de invierno, limpian el terreno, queman las maniguas y aran, pero sin pensar en ningun modo en abonarlas, porque en general son bastante ricas todavía, mas algun dia tal descuido se ha de pagar carísimo.

Despues de la operacion de limpiar el terreno y de quemarle en 
la forma que tenemos esplicada mas arriba, porque es sin contesta- cion ninguna la mejor, se han de traer los abonos ó compuestos fertilizantes convenientes al suelo que se trata de disponer y á la clase de planta que hay que sembrar en él y de distribuirles con igualdad sobre el terreno: bastan por lo regular de 5 á 6 libras de tales abonos, cuya preparacion tenemos enseñada algo mas arriba, páj. 429, por cada vara cuadrada, y hasta menos en muchos casos.

La primera labor se ejecuta con el arado sin vertederas ó con el'as; consiste en romper solamente el suelo $y$ se ha de practicar á medida que se van estendiendo los abonos que se deben siempre enterrar el dia mismo que han sido repartidos, porque secarse á la superficie del terreno les hace sufrir mucho perjuicio; los surcos de-ben estar muy unidos y la reja cortante del arado habrá de penetrar en la tierra solo de 3 á 4 pulgadas.

La segunda labor se llama cruzar : consiste en cortar, con el mismo arado con vertedera la primera en cruz; los surcos han de estar unidos y la reja profundizará de 6 á 8 pulgadas, segun sea mas ó menos compacta la tierra, que volteada sobre el abono impide mas su disecacion y principia ya á mezclarle con él suelo.

Despues de como 8 dias de suspension del trabajo se da la tercer labor ó segundo cruzado, que consiste en cortar en cruz con el arado provisto de su vertedera la segunda labor; unidos los surcos y de 12 hasta 14 pulgadas de profundidad. Con la cuarta labor ó tercer cruzado se corta en cruz la tercera, entónces el arado con su vertedera puede profundizar tanto cuanto es posible y hasta atacar el subsuelo en ciertos sitios, porque es siempre útil que un poco de él se mezcle con el terreno, para que la parte escrementicia de las raices de las plantas anteriores, sufiriendo la accion de los ajentes físicos y quimícos del aire se vuelva abono: véase en el discurso preliminar lo que tenemos dicho al hablar de las raices; además de eso la tierra vejetal y los abonos descienden siempre y se depositan en los surcos practicados en el sub-suelo, en que las raices que mas profundizan les encuentran para nutrirse; por ese motivo usan los agrónomos ingleses, alemanes y franceses el arado de sub-suelo, que es casi como el cubano, muy abierto y sin orejas.

La grada se pasa por lo regular despues de la cuarta labor: sus dientes de hierro penetrando en las tierras como unas 9 pulgadas, desbaratan los terrones, desmenuzan bicn la tierra é incorporan bien los ahonos; no es otra cosa sino el rastrillo de los jardineros puesto en mayor escala. Seria muy bueno emplearla tambien despues de cada una de las dos labores primeras, porque estirpa y recoje las raices de las plantas perjudiciales, que basta amontonar y quemar allí mismo, lo que es mucho mas provechoso que arrojarlas afuera, como se suele hacer $\mathrm{y}$ lo que empobrece algun tanto el suelo de donde salen.

Como lo tenemos ya pronunciado en nuestro discurso prelimirar, sin agua ó humedad en cantidar suficiente no hay vejetacion posible y será tanto mas lozana cuanta mas humedad le acompañe, con un calor suficiente y sostenido, lo que es la condicion de los paises intertropicales y equatoriales, pero por desgracia el agua 
no está uniformemente repartida en ellos; en efecto, la parte norte de las Antillas está favorecida de un número crecido de rios, de arroyos $\mathrm{J}$ de cursos de agua, en relacion ordinariamente con su estension territorial, mientras en su parte meridional escasean los cursos de agua ó son muy poco caudalosos y padece por consiguiente sequía, á veces horrorosa, unos meses seguidos, durante los cuales, la tierra, como esterilizada, no produce nada; de tal manera que las cosechas perecen por falta de humedad, y que los animales, es decir, los ganados, no solo van enfiaqueciendo poco á poco y el azote llega hasta tal grado de intensidad, que se les ve morir de hambre y de sed á la vez. Entónces los campesinos arruinados se lamentan de tal calamidad, $\mathrm{Y}$ sin embargo, despues de pasada la tormenta, muy pocos hacen lo necesario para evitarlo en lo sucesivo y casi ninguno se ocupa de establecer en sus posesiones un buen sistema de irrigacion, alimentado sea por rios ó lagos naturales, sea por medio de pozos, aljibes ó de lagos artificiales, sacando el agua del suelo por medio de las máquinas á proposito ó teniendo guardadas en depósitos, dispuestos como conviene, las abundantes aguas de las lluvias que se desperdician ó causan perjuicios, ó porque vienen en tiempo inoportuno ó porque en un tiempo dado son en demasiada cantidad, y en fin, porque están muy mal repartidas : en efecto, pocas comarcas hay en donde no caiga en el discurso del año una cantidad de agua suficiente para remediar las necesidades de los vejetales que es capaz de criar. Pero, engolfarnos en la descripcion de los tan variados y tan numerosos aparatos y trabajos hidráulicos publicados sobre el particular nos llevaria demasiado lejos de nuestro objeto; por tal razon nos limitaremos á aconsejar se proporcionen las obras que traten de la materia, y cualquier gasto que se haga relativamente con la importancia y con la estension de las fincas, si con él se consigue suficiente agua distribuida como corresponde, les pagará en el céntuplo lo gastado.

El agrónomo Vray dice que el riego de los cañaverales es asunto de suma importancia para los hacendados; pero siento decir que este es uno de los que la generalidad desconoce; sin embargo, lo hemos visto aplicado con mayor provecho en la isla de Puerto-Rico, especialmente en el partido de Ponce. La necesidad del riego se nota en efecto mucho mas en un pais tropical que en otro cuyo clima sea templado y húmedo, como Inglaterra, verbigracia, en donde sin embargo es indispensable para los jardines, pastos, etc. ¿Cuánto mas urjente no será pues ejecutarlo en un clima donde ocurre á veces que desaparece casi toda la caña del campo á causa de la sequía y de la quemante accion de los abrasalores rajos del sol? Lo que el agrónomo inglés dice de la caña de azúcar debe aplicarse á todas las siembras y hasta á los pastos, cuando la disposicion del terreno lo permite.

Es espectáculo bien triste el ver á los hacendados y labradores, cuando contemplan el mal estado de su plantacion, el estado miserable de sus ganados, por causa de una sequía prolongada que siempre acarrea una pérdida que no baja de los dos quintos de la cosecha. To pocas veces causa una disminucion de mas de la mitad, y 
otras veces llega hasta aniquilarla casi enteramente, como lo hemos presenciado demasiadas veces en Guayama de Puerto-Rico, en donde hay sin embargo riego posible, mientras que en otros partidos de la misma isla hemos visto riegos bastante regulares, pero casi siempre insuficientes, porque se ha limitado siempre á aprovechar los solos cursos de agua naturales, por desgracia poco caudalosos, sin pensar en utilizar la estacion de las lluvias para conducir la que se desperdicia en lagos artificiales, comunes á algunos vecinos que habrian concurrido á su formacion y que tendrian en tales depósitos una riqueza guardada para suplir á los rios cuando son insuficientes, y de este modo tendrian siempre cosecha segura. Sabido es que el agua facilita muchísimo la transformacion de las materias escrementicias de las raices en humus ó en sustancias abonantes; regar en estacion seca y caliente trae en pos de sí otro efecto que influye materialmente mucho en las plantas: en efecto, el vapor tibio que levanta el sol de las tierras regadas, cuando sube pasa por dentro del follaje, buscando para irse al aire, pero al pasar así es chupado poderosamente por las hojas y demas partes verdes de las plantas y las hace muchísimo favor.

Cualquiera agua, por pura y clara que sea, podemos siempre saturarla artificialmente con todos los principios fertilizantes que traen consigo las mejores aguas de los rios; para esto conviene hacerla pasar por un estanque apropiado antes de esparcirla sobre el suelo que se intenta regar; en tal estanque se habrá de poner cal cáustica, cenizas ó potasa, estiércol, etc., y penetrando por esas sustancias disuelve las solubles y se las lleva consigo al suelo en el cual penetra, volviéndose así abono líquido, que como todos lo saben es el mejor de todos.

Ahora que tenemos estendidas las consideraciones generales sobre los terrenos, las propiedades físicas y químicas de las ticrras arables, sobre el modo de apreciarlas para el cultivo, sobre los abonos, las irrigaciones, etc., aplicaremos esos datos al cultivo de los vejetales que se cultivan ordinariamente en las Antillas, á fin de que la aplicacion, estando al lado de la teoría, haga nuestro trabajo mas provechoso para nuestros suscritores. Principiaremos por los cereales que se cultivan en las Antillas, es decir, por el arroz y el maiz, y seguiremos por la caña de azúcar, etc., y demas vejetales cultividos en mayor escala ó que podrian serlo con ventaja.

Las cereales, perteneciendo todas á la gran familia de las Gramíneas, necesitan un terreno bien labrado y bien abonado, porque para que su grano contenga mayor proporcion de gluten ó de sustancia azoada que le reemplaza, teniendo en la alimentacion humana igual $\delta$ semejante papel, es preciso que el terreno contenga, sea naturalmente. sea por medio de los abonos, muchos productos nitrojenados y tambien fosfatos calcáreos, y se debe ordinariamente alternar su cultivo con otros vejetales que permitan al suelo descansar y le restituyan con los abonos o por medio de sus escreciones lo que ha perdido; sin esa precaucion indispensable el terreno no tarda en esquilmarse y entónces no produce sino cosechas raquíticas y apenas productivas. 
Arroz, M. D. - G. 223. - Al arroz convienen los terrenos húmedos ó que se pueden regar con facilidad, y su cultivo es muy provechoso, porque no esquilma el suelo y no necesita ningun abono ó muy poco: todos los terrenos convienen al cultivo de ese precioso vejetal, en la intelijencia que se le podrá regar cuando lo necesitará: en efecto, sabido es que no se puede desarrollar bien y como conviene sino en el agua ó en los terrenos muy húmedos; será siempre muy ventajoso meter los sacos que contienen la semilla en agua durante unas 8 ó 10 horas antes de entregarla á la tierra, especialmente si el suelo no está muy húmedo. Dos ó tres dias despues de sembrado, si el terreno está cubierto de una capa lijera de agua, lo que es la condicion mas favorable, se han de abrir las zanjas á fin de que el agua pueda escurrirse enteramente, para que gozando el calor del sol tenga lugar su pronta germinacion y que su desarrollo se haga del modo 'mas favorable: prosperará muy bien con irrigaciones periódicas hechas de manera que el terreno se quede solamente algunos dias seco cada vez; de ese modo la cosecha será mas segura y abundante siempre: es preciso desyerbarlo á lo menos dos ó tres veces, porque las malas yerbas son para él un enemigo terrible; por tal razon se deberá preparar el suelo con mucho mas cuidado que lo que se suele hacer ordinariamente, á fin de limpiarle perfectamente con la grada de las yerbas, raices, y desmenuzar bien la tierra; despues de amontonadas y quemadas, como lo tenemos dicho mas arriba, se esparcen las cenizas como abono sobre el terreno. Le hemos visto con mucha frecuencia reemplazar al tabaco en las vegas de Puerto-Rico, sin que los labradores preparasen el terreno como conviene y sin pensar nunca en regarle, $\mathrm{y}$ sin embargo, daba cosechas muy buenas por causa de la estacion de las lluvias. Cuando por casualidad se encuentra sembrado en terrenos á próposito, es decir, húmedos como corresponde, la misma tala puede dar dos y husta tres cosechas de seguida, como lo hemos presenciado algunas veces; se necesitaria solamente desyerbarla despues de cojido el arroz y entónces retoñaria la planta con muchísimo vigor y pariria otra cosecha muy regular; en ese caso es preciso cortar la paja á un pié del suelo ó algo menos: raras veces toman tal trabajo y los retoños se destinan para pasto. En Puerto-Rico las mas veces se siembra el arroz en los desmontes, sin reparar en la proximidad del agua, solamente se escoje para entregarle en el suelo; que bien que vírjen, con frecuencia, ó casi así, no está casi nunca preparado como conviene, al principio de la estacion de las lluvias, y sin embargo, produce bastante, sobre todo si las aguas son abundantes, mientras que en el caso contrario no se saca casi nada ó muy poca cosa, pues que no se ha tomado nunca ninguna disposicion para regarle. Para obviar tanto cuanto es posible tal estado de cosas, se deberia escojer la variedad de arroz llamada arroz de montaña, seco ó de Cochinchina, porque no necesitando de irrigaciones, se cultiva con mucha ventaja en tales lugares, y es casi la misma variedad cultivada en la Carolina del Sud: es el oriza nepalensis ó mutica de Boxburg.

Se cultiva el arroz regado en las tierras de labor, como se hace 
para el trigo en Europa, o plantado en los bosques recien derribados y muy feraces por naturaleza, lo que se practica como sigue: preparado el terreno se ahila y sub raya á distancia de una vara de calle, sembrándolo por la sub-raya con el plantador, á tres cuartas de distancia, y poniendo solamente de 5 á 6 granos en cada hoyo, porque cuanto mas desahogado esté el arroz, tanto mas encepa y carga. Se ahila y sub-raya el terreno de la manera siguiente: se tienden dos cuerdas paralelas afirmadas en los estremos por dos estacas distantes tres cuartas de vara una de otra y en la misma direccion; dos trabajadores, cada uno por su cuerda, de vuelta encontrada, de manera que terminen á un tiempo á los estremos opuestos, irán raspando el suelo sub-rayándolo á la anchura de la azada, mudando las cuerdas y continuando así la sub-raya hasta su término; en seguida se practicará la siembra, hoyando lijeramente por la sub-raya con una pua de palo á tres cuartas de distancia, poniendo en cada hoyito 4 o 6 granos, que se cubrirán de tierra cuidadosamente. Para que esta operacion sea mas pronta, conviene que detrás del hozador vaya un niño poniendo y cubriendo la semilla; tal procedimiento tiene dos ventajas: se aprorecha mejor el terreno por la rectitud de las hileras y se economiza un desyerbo ó se hace menos premioso.

A cada tres calles de arroz y despues de habérsele dado el primer desyerbo, como á los 15 dias puede ponerse una de maiz para aprovechar el terreno, dándole la distancia de dos varas y á 3 granos en cada hoyo. Antes de brotar el arroz la espiga, lo que se dice que está cogollando, es mur necesario desyerbarlo para darle ventilacion y desahogo. La cosecha viene á los cuatro meses, regularmente por agosto ó principios de setiembre, $y$ se verifica cortando las espigas sin caña para tener menos que cargar $y$ aprovechar mejor la paja para forraje, que así fresca la comen muy bien las bestias. Las espigas recojidas en un dia se amontonan en un cuarto $y$ se dejan en pila todo el dia siguiente para que acaben de madurar los que están bien en sazon, lo que manifiestan en el color amarillo que toman todas igualmente; al tercer dia se ponen al sol, esparcidas por el patio, se recojen por la tarde, $y$ se continua el asoleo hasta que se haya disipado toda la humedad para almacenarlas y desgranarlas despues que se haya reunido toda la cosecha. Se desgrana el arroz con el azote llamado vulgarmente mandador, y luego que está bien molida la paja con las varas ó el azote se renueva el monton y se va recojiendo la vasura por encima hasta donde se pueda sin arrastrar los granos; el residuo se rentea para guardar el arroz en conchas, despues es menester volverlo á asolear para pilarlo y limpiarlo de la concha. Para esta operacion hay máquinas, pero la costumbre del país á falta de aquellas es pilarlo con algunas hojas de mais desmenuzadas que contribuyen con su roce á separar el grano de su cubierta, soplándolo despues en bateas.

El arroz que se destina para semilla se guarda en concha $y$ debe preferirse al que se desprende espontáneamente de la espiga, ya sea el que queda en la troje ó en el patio cuando se seca al sol, ó ya el que cae sacudiendo las panojas secas, porque este es el mas en sa- 
zon. Cuando el arroz se siembra regado en las tierras labradas, se ha de dividir el terreno en cuadros y cada cuadro se debe rodear de un pequeño dique ó calzada con la misma tierra, de como una tercia de alto $\mathrm{y}$ dos de ancho, $\mathrm{y}$ es necesario que tenga bastante fuerza para detener el agua $y$ resistir el regador que debe pasar con frecuencia por encima. Fistos cuadros deben regarse de manera que el agua entre en ellos dormida $y$ se estanque sin estraviarse por grieta alguna. En los terrenos nuevos en que se ha derribado un bosque espeso, los terrenos $\mathrm{y}$ despojos que no ha consumido bien $\in$ l fuego hacen la siembra algo mas difícil, y en este caso se planta al ojo poniendo por delante miras ó guias en línea recta que sirvan de ausilio al sembrador para guardar en lo posible el mismo órden en los piquetes, porque no se puede sub-rayar.

A un almud de tierra sembrada de arroz y maiz, como queda dicho, le corresponde de semillas $I_{1} 4$ de almud del primero y $l_{1} z$ almud del segundo, y regularmente produce 30 fanegas de arroz en cosecha, que se quedan reducidas á 15 despues de limpio y 6 de maiz.

Cosechados esos frutos de invierno se siembra de nortes el mismo terreno, de maiz y guaracaros ó frijoles y producirá en esta segunda siembra 8 fanegas de maiz y 5 de frijoles, etz.

El arroz limpio es muy propenso á picarse, pero con su concha y resguardado del aire se conserva bastante tiempo. En el campo se acostumbra á conservarlo en zurrones formados con el cuero de una res; el mejor método para conservarle mucho tiempo seria en silos, de que hablaremos en el párrafo siguiente, al tratar del maiz.

Maiz. M D. - G. 172. - Segun el señor La Rosa, lo que han considerado los botánicos como especies no son mas que variedades conocidas en América bajo los nombres siguientes : maiz de espiga ramosa, la cual no es otra cosa que el maiz comun sembrado en terrenos muy ricos y de vejetacion exuberante: lo hemos observado algunas veces. El maiz blanco, que rinde mucha harina, de sabor dulce, es preferido para fabricar la chica ó cerveza de maiz y tambien para arepas. - Maiz flor de harina es una variedad del maiz blanco, de grano grueso y hendido por el medio, muy semejante al maiz fofo. - Maiz manchado ó chinesco, llamado vulgarmente pinto, cuyo grano varia de color, aunque provenga de granos rojos, amarillos ó blancos, y casi nunca es todo de un color, á vecés es azulado. - Maiz piedra de fusil, variedad que da mazorcas de ocho filas de granos blancos ó amarillos, ordinariamente amarillos, duros, transparentes y brillantes como el pedernal de donde ha tomado su nombre. - Maiz amarillo grande y pequeño que forma dos variedades que se cultivan en el medio dia; el pequeño requiere mejores terrenos, se da en tallos mas bajos y pesa mas que el grande. Maiz de gallinas ó de palomas, variedad muy precoz de granos pequeñitos muy á propósito para la cria de las aves domésticas. - Maiz tremes, el cuarenteno de España; se cosecha de secano en mayor cantidad que las demas variedades. - Maiz tardío ó maiz de riego, que es la variedad mas fecunda y mas vigorosa y la mas generalmente cultivada. 
En la familia de las cereales ese vejetal es sin contestacion el mas provechoso y de mayor producto en el suelo americano, porque es el mas á propósito para sacar de una superficie limitada de terreno una cosecha abundante y que además es orijinario del nuevo mundo, ya que Cristóbal Colon lo encontró cultivado, ya en Cuba y demas lugares de América. En Jamaica, donde es cultivado en escala mayor, produce con frecuencia dos y hasta tres cosechas al año, porque se puede sembrar en cualquiera estacion, en la intelijencia que debe haber llovido bastante antes de entregar las semillas á la tierra.

Las cenizas de ese vejetal son muy ricas en alcalis, en efecto contienen 71,00 de potasa y de sosa; 6,50 de cal y de magnesia; 18,00 de sílice y ácidos fosfórico, sulfúrico y unos orgánicos en combinacion con esas bases; por esta razon se ve que el maiz necesita un terreno bastante rico, bien abonado y bien preparado. Prospera en las tierras fuertes y tambien en las livianas: tal cultivo necesita pues abonos ricos en sales alcalinas y calizas ó terrosas. Se juzga que para una cosecha que produzca 100 kilógramos de paja y semilla es preciso emplear 333 kilógramos de abono. En el Piamonte se emplean todos los 4 años 24,343 hilógramos de estiercol para cada hectárea, y sin embargo en las Antillas no hemos visto nunca abonar el terreno que se le tiene destinado, lo que á nuestro parecer es la causa de que bastantes veces da cosechas medianas, eso se remediaria con mayor facilidad preparando el terreno con el número necesario de labores, quemando todas las yerbas raices despues de recojidas, amontonadas y secas como conviene, juntándole las mas posibles sustancias rejetales desperdiciadas y tan abundantes ordinariamente en el campo, y despues de eso esparciendo sobre el terreno estas cenizas mezcladas con la tierra torreficada correspondiente y pasar la grada para mezclar ese abono con el suelo, mejor seria todavía, en los terrenos ya cansados de producirle, emplear los abonos verdes del modo que tenemos enseñado mas arriba, pájina

Sabido es que se ha de sembrar ese vejetal en líneas rectas distantes las unas de las otras como de una vara y media y los hoyos á como una vara los unos de los otros y algunas veces mayor intervalo, segun la clase sembrada y la riqueza del terreno. Cuando está echando su quinta hoja y que tenga como un palmo de alto, es preciso desyerbarle y binarle. Se arrancarán con cuidado entónces los piés demasiado cercanos de los demas, y se remediarán los vacíos sembrando en ellos una variedad mas tempranera. Ese primero desyerbo se ha de hacer con mucho cuidado, á fin de no dañar las nacientes plantas y donde la azada no pueda correr sin ese peligro debe aplicarse la mano á la nueva cepa antes de apocarla, con delicadeza, de manera que no quede enteramente cubierta, eso se reduce á un pequeño aumento de gastos, pero da una recompensa mayor. Como unos 15 ó 20 dias despues de esta operacion se ha de aporcarle; cuando las matas tendirán como una vara de alto se deberá volver á desyerbar, amurillar y á aporcar las cepas; en la época de su floracion se deben quitar los retoños que suelen salir de sus nudos inferiores y hacer entónces el último desyerbo que es 
muy importante y no se debe descuidar; entónces se hace el deshojeo o separacion de los piés raquíticos que no prometen fruto. Despues de echadas las espigas ó mazorcas $y$ de verificada la fecundacion, lo que se conoce por estar marchita la especie de barba ó pelo blanco que sale de ellas, se suele cortar la parte superior ó las flechas que se aprovechan para los animales que las comen con gusto y para los cuales constituye un buen forraje. En Jamaica se suele sembrar el maiz en las lomitas que se hacen en los cañaverales al sembrar la caña de azúcar. $y$ tambien lo hemos visto hacer en las demas Antillas; pero, á nuestro corto parecer, tal asociacion no es muy buena, porque ese rejetal saca del suelo los mismos elementos que la caña de azúcar $y$ no se debe hacer mas que en los terrenos muy ricos ó bien abonados; con frecuencia se siembra tambien junto con los muñiatos o batatas, con las calabazas, "con los frijoles, etc., y sale muy bien, pero en tales casos no se le debe considerar sino como cultivo secunciario, que sin embargo da bastante utilidad.

Cuando se quiere el maiz como maloja se le ha de sembrar en mayo ó en junio, que es el principio de la estacion de las lluvias, y se llama entónces siembra de agua, mientras la otra, que se hace en octubre ó en noviembre, cuando están principiando los chubascos de los nortes, se dice siembra de frio; á los cuarenta dias, si el tiempo ha sido favorable y que haya llovido bastante, está ya la maloja bastante crecida y dispuesta á brotar la espiga, y se encuentra buena para servir como abono verde $y$ para enterrar en el suelo, como lo tenemos ya dicho mas arriba, páj. 431 ; ha debido sembrarse en ese caso en líneas rectas separadas una de la otra por un espacio ó calle de media vara y dos ó tres pulgadas de una mata á otra; es tambien muy buena para forraje y paga bastante cuando las fincas son vecinas de las ciudades en donde se le vende con mayor facilidad para los caballos. Ninguna de las plantas que forman los prados artificiales ó naturales contiene tantos principios alimenticios ni gusta tanto á los animales de toda clase, como el malojo ó maiz verde; es el alimento mas sano y mas sustancioso que se les puede dar, lo prefieren á todos los otros y seco y rociado con agua algo salada, bien picado tanto el malojo como las hojas secas de las mazorcas, $\mathrm{y}$ las mismas puntas de la mata, cuando no hay malojo fresco, constituyen un escelente forraje para el ganado; las vacas le comen muy bien así y dan muy buena leche, engordan los bueyes con esos despojos. El cultivo del malojo se reduce á sembrar el maiz muy unido casi como en almacigo, para que no se desarrolle demasiado y sean mas tiernas y mas dulces las cañas; pero no se ha de cortar antes de estar bien espigado, porque demasiado tierno serviria de purgante en vez de alimento ; la siembra se hace á una tercia de distancia $\mathrm{y}$ de 6 á 8 granos en cada hoyo; los terrenos algo húmedos ó que se pueden regar con facilidad son muy á propósito para ese cultivo.

Para obtener buenos resultados es indispensable escojer la semilla y para eso las mazorcas mas gruesas y que contengan los grano. mas grandes saliendo de los lugares mas asoleados y bien sazonadis son las mas á propósito; deben guardarse por separado en un lugar 
seco y colgadas de dos en dos, atadas con sus mismas hojas. Se habrá de dar la preferencia á las de última cosecha y cuando se vayan á desgranar para sembrar se desecharán los granos de las puntas, tomando solamente los de la parte mediana de la mazorca. Conviene remojar el maiz por doce horas, aunque sea en agua sin sal, antes de sembrarlo, para separar los granos vanos que sobrenadan; pero es mejor hacer ese remojo con agua y sal, agua de estiercol ó de escrementos de vaca $\dot{o}$ de caballo y un poco de ceniza y cal, lo que favorece mucho la germinacion y la planta se desarrolla con mas vigor.

El maiz que no echa mazorca ó no fructifica se debe cortar para mallojo, y conserva su dulce durante su vejetacion, mientras que el que fructifica lo pierde á medida que se va formando el grano. Despues de la fecundacion, es decir cuando se habrá marchitado la panoja y que los estilos ó barba antes sedosos se habrán desecado y vuelto negruzcos y que el jilote se habrá separado un poco del tallo á que estaba casi pegado; entónces se acostumbra á despuntar las cañas para forraje y para acelerar la madurez del grano; se descabeza el maiz cortando el tallo por la parte superior desde arriba de la hoja inmediata á la mazorca mas alta. Don Luis de la Rosa al hablar de ello dice : Parece que el despunte del maiz se debe hacer siempre que convenga acelerar la madurez del grano y tambien cuando hay escasez de forraje, de tal manera que el valor del que da la punta del maiz compense los castos del despunte y la disminucion del grano y deje una utilidad considerable; se le omitirá cuando ese forraje no tendrá valor por la abundancia de posturas ó por la falta de consumo.

El corte de los retoños cuando estos son estériles ó prometen muy pocas mazorcas, es muy útil en los terrenos medianos, pero en los fértiles solo se suprimirán las canas que no hayan fructificado, pues en tales terrenos algunos retoños dan casi tantas mazorcas como la caña principal. Los jilotes abortivos tambien se deben quitar para que no se desperdicie la savia que han de aprovechar las buenas mazorcas.

Es necesario tener mucho cuidado con quitar las malas yerbas arrancándolas de raiz cuando la tierra está húmeda y cortándolas cuando no pueden arrancarse; los labores de escardo no solo se dan para quitar las malas yerbas $y$ proporcionar mayor cantidad de abono atmosférico, sino tambien para que sus articulaciones inferiores echen nuevas raices, así es que por el número de nudos que hayan brotado raices se puede conocer el de los labores que se le han dado. Pueden sembrarse con él otras semillas intercaladas en las matas, como frijoles, habas, papas, etc., si las tierras son bastante fértiles.

El maiz se siembra de regadio ó de secano, $y$ esta última siembra se hace de tres modos distintos, á saber: de húmedo, de aventurero y de temporal, el grano que se elije para la de regadio es el de maiz tardío, el de húmedo es una variedad parecida al de riego, que se siembra al comenzar la primavera en los terrenos húmedos constante $y$ moderadamente; el dicho aventurero es una variedad dél tardío, que tambien se siembra en la primavera en las tierras hu- 
medecidas por las lluvias de invierno ó por las que suelen caer en el veraro; la siembra del temporal, que es una variedad del precoz, se hace en tiempo de aguas cuando el terreno está húmedo, ó en tierras secas, en cuyo caso la siembra se llama en polvo, si hay esperanzas de que llueva.

El maiz es una planta gastadora y muy exigente, por cuy, motivo se hace preciso alternarla con otras que no le sean análogas, ó de familias diferentes, para no esquilmar las tierras que deben abonarse con estiercol ó restos orgánicos bien podridos. Los suelos en que predomina la arena y la arcilla sobre la caliza teniendo cantidad de humus conveniente es la mejor para ese cultivo. Conviene siempre esperar, para comenzar la siembra de ese vejetal, á que la tierra haya adquirido cierto grado de calor y está en este estado á fines de abril ó principios de mayo, á lo menos que las aguas anticipen á principios de abril, que entónces será necesario sembrar inmediatamente, și el tiempo da muestras de continuar lloviendo. Cuando ya todo esté preparado y haya llegado el momento de sembrar, se irá hoyando en línea recta, si es posible por cuerda á distancia de una vara y dos pulgadas de profundidad, poniendo en cada hoyo tres ó cuatro granos solamente y cubriéndoles hien con tierra. Se acostumbra poner en cada hoyo, sin preparacion alguna, 6 á 7 granos por los vanos que no nacen y los que danian las hormigas y los pájaros, teniendo despues que deshijar las plantas que salen débiles; inconvenientes que se evitan en parte con la preparacion de la semilla, como lo tenemos dicho mas arriba; por medio de las calles se pueden sembrar frijoles, guaracaros, yuca, para aprovechar el terreno sin perjuicio del maiz.

Sembrado de esta manera caben en el almud de tierra ó media fanega (la fanega de tierra conteniendo 400 estarlales ú once piés cuadrados y en las dehesas 500), 7,500 cepas de á 3 y 4 matas, cuyo producto probable en una tierra nueva sin accidente alguno seria el de dos mazorcas en eada mata; lo hemos visto bastantes veces de cuatro, pero suponiendo por término medio cuatro mazorcas y media por cada cepa, tendriamos en el terreno dado un producto de 33,750 mazorcas que, á 600 por fanę̃a, son 55 fanegas ó 100 quintales'.

Se siembra tambien el maiz grano á grano y á distancia de media vara por todos lados; cabrian entónces en la misma área 40,000 matas que á 1 y á 2 mazorcas darian un producto mucho mayor, aunque entónces no podrian cultivarse otros frutos en los espacios; pero en este caso la produccion mayor recompensa su falta. Varios autores, como Lelieux y Gothard, son de parecer que no debe sembrarse otra cosa en el maizal, porque las otras plantas, asi como las malas yerbas, quitan al maiz la ventilacion y una parte de su alimento; participamos nosotros de tal parecer. Las matas débiles que no van á producir ó que dan mazorcas muy pequeñas deben quitarse con precaucion, á fin de no lastimar las raices de las vecinas: eso es lo que se llama deshijar.

La perfecta madurez del maiz se conoce por la aspereza y sequedad de las hojas de la planta y de las que cubren las mazorcas, las cuales se entreabren, entónces es conveniente doblar las mazorcas, 
si no se les puede cosechar inmediatamente. El maiz sembrado á principios de mayo estará maduro en setiembre y el de los nortes ó sembrado á principios de octubre lo será por febrero. Se han de cojer las mazorcas por un tiempo seco, despojándolas de la mitad de las cubiertas, haciéndose pequeños montones, y cargándoles inmediatamente á la casa. Reunida la cosecha, se separan las mazorcas averiadas, para el gasto, se asolean las buenas uno ó dos dias para guardarlas en la troje que se ha construido en la cocina para recibir el humo. Bien se guarda el maiz á media hoja, bien enteramente pelado, y la principal condicion que ha de llevar el granero para su conservacion, es que esté bien seco, porque con la humedad se calienta y se pica muy pronto. Cuando sea necesario desgranar una cantidad considerable de maiz se habrán de emplear las máquinas á propósito y si no se las tiene se formará una troje á la altura de 3 [ 4 de vara en forma de cajon y abierta por el frente; se echan en ella cuantas mazorcas quepan enteramente limpias de sus hojas y sobre ellas se descargan golpes con un palo de alguna consistencia y de dos varas de largo; á cada golpe va cayendo el maiz debajo de la troje, $\mathrm{y}$ se sigue así hasta que se queden las tusas sin grano, y los que no hayan quedado enteramente limpios se repasan á la mano á medida que se van arrojando fuera. Para una cantidad menor hay un procedimiento mas sencillo, que consiste en atar un cuero en forma cilíndrica, echar dentro las mazorcas y pilarlas sacando las tusas que vayan quedan sin grano hasta concluir con todas. Pero así el pilado como el de la troje debe ventearse despues para que quede aseado y en disposicion de ir al mercado. Para guardar por mucho tiempo el maiz desgranado en grandes cantidades no hay otro medio seguro sino ponerle en silos herméticamente cerrados, en donde no solo se conserva por muchos años al abrigo de los insectos, ratas y humedad atmosférica, lo que principia á practicarse de nuevo en Francia para la conservacion del trigo, y lo que se habria de hacer tambien para el arroz y otros granos. Ese procedimiento data de la mas remota antigüedad y se ha practicado en Espaina, en Arjelia entre los árabes que siguen todavía con ese método, etc., y demas lugares. En los graneros comunes es conveniente y hasta indispensable la fumigaciones con humo de leña sola ó sulfurosas, porque aseguran su conservacion.

Los mijos son cosechas tropicales ó intertropicales que en las Indias Orientales ocupan el segundo rango, siendo el arroz el primer cereal de esos paises; en Ejipto se los tiene por el mas importante cereal, $y$ en el Africa Occidental constituyen el principal alimento sacado de los cereales, se siembran en los mismos terrenos que el maiz y necesitan igual cultivo: véase lo que tenemos dicho de sus semillas en la parte médica de esta obra, núm. 181.

Holcus saccharatus. M. D. - G. 259. - Este vejetal ha sido, pocos años hace, introducido en estas Antillas de las Indias Orientales, de la China y de la Cochinchina, en donde se cultiva para sacar azúcar de él, mas en las Antillas no se da tan dulce como en su propio pais, de tal manera, que no puede bajo ese concepto competir de ningun modo con la caña de azúcar; sin embargo, se le puede 
cultirar con bastante ventaja y utilidad para forraje, además sus semillas siendo muy buenas para las aves de corral y para los caballos, reemplazan perfectamente el maiz para ese objeto. El terreno que le corresponde mejor ha de ser seco y liviano; se le preparará del nismo modo indicado para el cultivo del maiz $y$ se sembrará de la misma manera tambien al principio de las lluvias y está ya madura á los tres meses de sembrado; despues de cortado retoña con facilidad y da una segunda cosecha, y para que salga buena basta dar tierra ó aporcar las cepas y limpiar el suelo de las malas yerbas.

Sorgo. - Sorghum vulgare.M. D. - G. 261. - Bien que natural de las Indias orientales, aprovecha muy bien el clima y el terreno de las Antillas en donde se cultiva especialmente paraalimentar y hasta cebar las aves de corral, $y$ en ciertos lugares de Jamaica se cultiva en escala regular. Necesita del mismo terreno y de igual cultivo que el precedente, pero se ha de sembrarle especialmente entre setiembre y noviembre, está maduro entónces en enero y despues de cortado retoña y cuidado como lo tenemos dicho para el Holcus sacchavinus, produce una segunda cosecha muy buena. El señor C. Bravo le sembró regado para cosecharle verde y produjo una gran cantidad de forraje magnífico, muy nutritivo y muy apreciado de los bueyes $y$ vacas que se le comian golosamente; hizo la siembra en un suelo muy pobre, sin ningun abono y que antes de arado no producia otra cosa sino yerbas malas: segun este señor es muy bueno para abono verde $\mathrm{y}$ vuelve el suelo feraz.

Preparado el terreno se ahila y sub-raya como para el arroz. á distancia de tres cuartos de vara y se echa en cada hoyito media pulgada de semilla, que se cubre de tierra cuidadosamente; de este modo se aprovecha mejor el terreno por la rectitud de las hileras y se economiza un desyerbo o se hace menos premioso. Así sembrado, no se desarrolla tanto el vejetal y la panoja no se tuerce con el peso de la semilla, y se queda por consiguiente mucho mejor para la fabricacion de las escobas, que es su mayor producto. Luego que la semilla está sazonada, que es á los tres meses, poco mas ó menos, se cortan las panojas con un palmo de la caña, dejando la planta en pié. porque despues de esta cosecha brotan nuevas espigas por las articulaciones ó nudos de la caña, saliendo de la axila de las hojas, un poco mas pequeñas, pero que tambien dan semilla y se utilizan en la fabricacion de las escobas. Recojidas las panojas se ponen al sol dos ó tres dias seguidos, hasta que se emblanquece el tallo verde: luego se estrae la semilla de manera que no se maltrate la panoja que ha de servir para hacer escobas: para eso se las tiende en una mesa ó en una tabla y se les pasa el lomo de un cuchillo repetidas veces, volteando la espiga hasta que se quede limpia. Para que la semilla se conserve mas tiempo y esté mejor preparada para los usos domésticos, conviene limpiarla de la basura que arrastra consigo al separarla de la espiga : para eso se pila y se ventea; pero no se pulirá la que se destine para sembrar. El sorgo, como el trigo, merece guardarse en granero ó silos con esmero, como una reserva de pan. 
Las escobas, que dan mucha utilidad, se fabrican del modo siguiente : la primera operacion será acopiar los palos de un grueso proporcionado, lisos y derechos, de vara y media de largo, quitándoles la corteza y dejándoles secar á la sombra 15 dias antes de emplearlos, por lo menos, para que la escoba no se afloje despues de hecha, lo que sucederia si se fabricase con el palo verde; despues se le atraviesa una estaca de dos pulgadas, mas abajo del estremo mas grueso, que sobresalga un dedo por cada lado, ó se le ponen dos pequeños clavos que hagan igual efecto. Preparados así los palos se escoje la espiga mas sana y de mejor figura para la cubierta ó capa y de lo restante se hacen los manojos para la armadura interior $\dot{0}$ tripa. A la espiga de capa se le da un corte en la caña y á la raiz de la espiga, semejante al tajo de una pluma de escribir y que termine á tres pulgadas de largo, sacándole el corazon: los manojos para tripa serán mas ó menos gruesos, segun el tamaño que se quiera dar á la escoba, pero lo regular es darle solamente seis pulgadas de sircunferencia. Un poco antes de fabricarlas se mojarán las cañas. tanto de la tripa como de la capa, para que no revienten al amarlarlas; preparado así el material se fija una cuerda en una de las puntas salientes de la estaca ó clavo y con ella se atan fuertemente dos manojos, unó frente á otro, pasando la cuerda ya en contorno, ya entre el palo y el manojo, para que quede bien firme: las cañas sobrantes de la amarra se cortan contra el palo una línea mas abajo, y con la misma cuerda se irán sugetando las espigas de capa, procurando que cada espiga que se va colocando pise el corte de pluma de la caña de la siguiente, í la que se dobla el corte del otro lado para que queden bien unidas y bien cubierta la amarra, y despues de darles dos ó tres vueltas con la cuerda, se van enrejando si se quiere llevar la obra hasta la perfeccion, pisando unos cabos y levantando otros, en la estension de una pulgada, terminando con dos ó tres vueltas de cuerda, rematando con un clavo pequeño que pise y asegure el término de la cuerda : concluida esta operacion restan las costuras con que se recoje la espiga, la una como cuatro ó cinco dedos mas arriba de donde empezó á amarrarse la cubierta y la segunda dos ó tres dedos mas alto. Para que la escoba quede mas asentada y dé mejor figura conviene ponerla en prensa : al dar las costuras se van asentando las cañas de las espigas suavemente con un mazo : otras veces se hacen las escobas mas sencillamente, atando toda la espiga al palo en un solo manojo sin escojer, dándole despues las costuras.

En un cuadro de tierra de cien varas ó diez mil varas cuadrarlas, que es una fanega, á las distancias dadas de tres cuartos de calle y inedia vara por la hilera, caben 25,000 cepas : si consideramos que cada cepa contiene dos ó tres plantas solamente y que cada una con sus correspondientes retoños da 4 ó 5 espigas, no será exajerado el cálculo de 10 espigas por cepa, que son 250,000 espigas, y empleándose en cada escoba 70 espigas, poco mas ó menos, son 3,507 escobas finas; al precio medio de dos reales una, hacen la suma de 876,75 pesos. Cada escoba ha dejado 4 libras de semilla ó 148 quintales á 10 reales uno ó 175 pesos, montando las dos partidas á 1,05$]$ 
75 pesos; siendo los gastos de 284, 53 pesos, quedan 767,22 pesos de utilidad. Si á este producto neto se agrega el trabajo personal que debe hacer una familia de campo, es indudable que un solo tablon de cien varas asegura su subsistencia, sin que esta empresa le impida cultivar el maiz y los demas frutos anexos al establecimiento. Aunque las aves domésticas comen el grano, no es con tanto apetito como el que tienen por el maiz, y para que las bestias le coman bien se le mezcla con un poco de agua $y$ sal. Al principio les repugna un poco, pero no tardaan en acostumbrarse á esa comida que les es de mas provecho que el maiz, porque es mas sana.

Coix lacryma. - Lágrima de Joh. - Aunque este vejetal sea natural de las Indias Orientales, se cria con la mayor facilidad en las Antillas, en donde lo hemos visto perfectamente bien aclimatado, y está pariendo todo el año y por consiguiente muchísimo, y le hemos hallado casi silvestre en muchos sitios de la isla de la Trinidad, en donde sus semillas sirven únicamente para hacer collares, mientras que en las Indias Orientales se utilizan por alimento. Aconsejamos pues su cultivo en las Antillas, sea por sus semillas, que se pueden dar á los caballos ó á las aves domésticas para reemplazar el inaiz; pero como es durísima cuando madura, será preciso antes ablandarla poniéndola por algun tiempo en agua, sea fria ó mejor caliente.

Será muy útil como forraje, que los animales apetecen muchísimo: como retoña con mayor facilidad, se le podrá cortar algunas veces seguidas, con el cuidado cada vez de dar tierra á la cepa, y de limpiar el suelo; de ese modo se puede sacar mucho provecho de él para alimentar los caballos; se le ha de cultivar como lo tenemos ya dicho para el maiz ó malojo.

Caña de azúcar. M. D. - G. 326. - Ese precioso vejetal es sin contestacion ninguna el manantial mas caudaloso é inagotable de la riqueza de las Antillas; aunque bastantes vejetales, perteneciendo á otras familias vejetales, sirvan para producir azúcar, ninguno, sin embargo, puede competir de una manera ventajosa con la caña de azúcar. Para ese objeto se cultivan en las Antillas algunas variedades de caña; la comun ó criolla, que se considera como la mejor; la amarilla de Otahití, que es muy buena tambien; la amarilla de Borbon, la purúrea ó morada de Otahití y la de cintas; estas últimas no son tenidas ni por tan buenas ni por tan productivas. El señor. Vray, en su Practical sugar Planter, aconseja la introduccion en las Indias Occidentales ó Antillas de otra variedad escelente de caña de azúcar conocida con el nombre de caña de Salangore, porque considera que retoña mucho mejor que ninguna otra clase y porque su rendimiento ó producto es, término medio, de 3,600 libras de azúcar por acre.

Nos parece útil señalar aquí la composicion química de las cenizas del azúcar pardo ó moscabado, á fin de que se pueda apreciar mejor la clase de suelo que será mas conveniente para su cultivo: 1,000 granos de azúcar moscabado han dado despues de la incineracion 7 1 2 granos de ceniza, que han dado con el análisis químico los resultados siguientes : sílice 1,78 ; - fosfato de cal 3,41 ; — peróxido de hierro y arcilla 0,17 ; - carbonato de potasa 1,$46 ;$ - sulfato de 
potasa 0,15 ; - carbonato de magnesia 0,43 ; - sulfato de cal 0,06 .

Todos los terrenos que pueden recibir labores con el arado, son útiles para el cultivo de la caña de azúcar, siempre que les compongan y preparen como conviene : muchísimos hay que solo exijen la preparacion para recibir la caña y será siempre preciso darles la preferencia por causa de la escasez de brazos y del costo considerable de la mano de obra.

Por causa de la importancia grandísima del objeto, nos parece necesario asentar aquí algunas consideraciones prácticas sobre los suelos, mirados bajo el concepto de dedicarlos al cultivo de la caña. Los terrenos graníticos son muy buenos para tal cultivo; en efecto, los minerales que les constituyen siendo feldespato, mica y cuarzo, formados ellos mismos de sílice, alumina, potasa, cal, sosa, magnesia, proxido de hierro, un poco de protóxido del mismo metal, óxido de magnesio y ácido fluórico, suministran al descomponerse todos los elementos minerales que pueda necesitar ese vejetal para su mayor y mas perfecto desarrollo; pero como á veces contienen poco mantillo, es preciso abonarles con materias vejetales descompuestas, 6 mejor y mas barato con los abonos verdes, del modo ya indicado mas arriba, páj. 431. Tales terrenos son muy fértiles, dan poco trabajo en el desyerbo, aporcado, corte y acarreteo de las cañas, facilitan mucho la elaboracion del azúcar, que sale de primera calidad. Si el sub-suelo ro fuera arcilloso ó barroso bastante, seria muy útil y hasta necesario darle este elemento para que tuviera coherencia suficiente para la vida de las plantas, cada vez que se le podrá ejecutar con poco costo. Los terrenos cubiertos de rocas calcáreas son muy favorables para el cultivo de las cañas, que se producen hermosas y dan un guarapo muy fácil de clarificar $y$ muy rico; pero en tales suelos no se puede trabajar mas que con la azada, trabajo largo, penoso y costoso, aunque por desgracia es el mas vulgarizado en las Antillas. Se ha de inferir de tal dato, $y$ la esperiencia diaria está acorde para corroborarle, que será siempre, no solamente bueno, pero muy necesario en los terrenos no calcáreos, hace entrar bastante cal en sus abonos. Terrenos con piedras ferrujinosas : tales suelos, que son por decgracia bastante comunes en las Antillas, contienen piritas ó sulfuros y piedras de próxido del mismo metal, con ácido colúmbico y alumina: de la misma clase son las tierras formadas de piedras ferrujinosas, de barro colorado y las de piedras ferrujinosas y de sílice colorada, las cuales consisten en paróxido colorado de hierro mas ó menos mezclado con materias estrañas. Luego siguen los suelos compuestos de piedras ferrujinosas y de barro amarillo: se conocen con el nombre de hidroperóxido de hierro, son de varios colores, desde el amarillo oscuro hasta llegar á ser casi negros: contienen peróxido de hierro hidratado, algo de peróxido de magnesio y sílice, algunas veces un poco de alumina: tales terrenos son poco á propósito para el cultiro y nunca se habrá de dedicarles á tal objeto; pero cuando pertenecen á haciendas ya plantadas es preciso que se compongan como conviene, dándoles abonos que les suministren lo que les falta, es decir, cal con bastante cantidad, á fin de destruir el mal efecto de los sulfuros de hierro. 
sales de potasa y de sosa, ó cenizas de la misma caña y estiércol mezclado con sustancias vejetales en descomposicion, esos últimos se reemplazarán con mucha ventaja por los abonos verdes empleados como lo tenemos dicho mas arriba, páj. 431.

Tambien los terrenos que vulgarmente se llaman de polvillo, con perdigones ó pirritas de proto-sulfuro de hierro en mayor ó menor cantidad, ó formados de sulfuro cúbico de hierro, lo que es el bisulfuro de ese metal : tales suelos, por desgracia bastante comunes en las Antillas, son muy malos. Cuando no se desagüen bien los terrenos que contienen perdigones, especialmente de proto-sulfuro de hierro, son muy perjudiciales á la vejetacion, porque suministran mucho sulfato de hierro y ácido sulfúrico por causa de la reaccion química que esperimenta el proto-sulfuro de hierro en presencia del oxíjeno húmedo de la atmósfera; tales tierras se dicen vulgarmente agrias: despues de desaguado como conviene, es decir, lo mejor posible, es preciso para remediar tal estado de cosas aplicarles mucha cal, y hacer entrar en los otros abonos fertilizantes que pueden necesitar los álcalis que necesitan y tambien fosfato de cal o huesos pulverizados.

Los labradores chinos, dice el agrrónomo Vray, no encuentran inconveniente en cultivar las tierras agrias en los estrechos de las Indias Orientales; en efecto, cuando un chino cultiva un terreno, parte generalmente del principio de que mas provechoso es cultivar un acre de tierra con todo esmero, que dos de un modo imperfecto, $y$ en eso son mucho mas sabios que la mayor parte de los hacendados de las Antillas, que al contrario creen sacar mayor producto de muchas cañas cuidadas así así y casi siempre en demasiada proporcion relativa con los brazos de que pueden disponer, lo que es un error de mayor consideracion, y sin embargo admitido: de ese modo los chinos obtienen en efecto de un acre de tierra tanto como lo que rinden dos y hasta tres acres cultivados ni bien ni mal. Siempre constante en seguir ese principio, el labrador chino escoje un pedazo de tierra que el puede manejar; corta las malezas, las deja secar y luego las quema, despues se pone á secar con mucho cuidado los troncones, las raices de los árboles y de las mismas malezas, les amontona, les cubre de tierra y les deja secarse, y cuando están bastante secos los montones les pega fuego y les asiste con constancia mientras estén ardiendo, á fin de que todo se consuma bien. Las cenizas y la tierra quemada que resultan de esta operacion las esparce con mucho cuidado sobre el terreno, depues cara la tierra y mezcla todo con el mayor esmero. En seguida abre una zanja en derredor y con lo que de ella saca levanta un buen camellon sobre el terreno que ha preparado, para tenerle siempre bien desaguado y evitar que entren las aguas de los terrenos adyacentes; finalmente vuelve á cavar el suelo y siembra en él sus cañas, así es que nunca se ve á un chino quejarse de aridez en su terreno arreglado así; hemos referido ese método de los chinos á fin de que se rea el cuidado con que se debe preparar el suelo antes de confiarle las semillas, y sin embargo muy pocos lo hacen como conviene, y tal abandono es, á nuestro corto parecer, especialmente en los suelos poco 
apropiados, la causa de la poca utilidad que se saca de las haciendas de azúcar, que se quedan la mayor parte muy empeñadas y raras veces pueden salir del mal paso en que se encuentran.

Los terrenos que contienen sal de comer ó cloruro de sodio en cierta cantidad, producen cañas hermosísimas, pero cuyo azúcar está espuesto á humedecerse y se vuelve deliquescente, lo que le perjudica mucho y proviene de que una cierta porcion de aquella sal se ha cristalizado con él haciéndole higrométrico; por tal razon las tierras bajas que están en las costas del mar no son útiles para este cultivo, á menos que se les haga zanjas bastantes para bien desaguarlas y camelones altos de tierra para protejerlas contra la invasion de las mareas. Los suelos de tierra colorada mas ó menos compacta, bastante comunes en las Antillas, son muy buenos para el cultivo de la caña de azúcar; están compuestos de arcilla, de sílice, de fragmentos menudos de piedras calcáreas, de carbonato de cal, de alumina, de materias vejetales en parte descompuestas y de óxido de hierro muy colorado. Tales suelos reposan rara vez sobre subsuelos de barro, lo mas general es que sean de roca, de cascajo ó de coco y por esa razon necesitan bastante riego, porque se dejan penetrar con mucha facilidad por el agua que se escapa fácilmente. Cuando son compactos se mejoran muchísimo con la cal, con los abonos en que se encuentran sales alcalinas de potasa, de sosa y fosfato de cal, ó huesos reducidos á polvo; los abonos verdes les convienen tambien mucho. De todo lo que tenemos dicho se ha de inferir que el suelo mejor para el cultivo de la caña es aquel formado de calcáreo silicoso ó feldespático, con bastante mantillo ó humus, algo de hierro peroxidado, con bastante humedad, sin ser pantanoso ni demasiado húmedo, ni demasiado bajo tampoco, y cuando no tenga una composicion análoga será preciso volverle así artificialmente por medio de los abonos correspondientes con la clase de terreno que se habrá de entregar al cultivo de ese vejetal.

Despues de preparado el terreno como conviene, se divide en cuadros de á 100 varas, se surca en líneas paralelas de una y media á dos varas, segun la localidad, para hacer en ellos la plantacion. que se hace de tres maneras. Por estacas : este medio se ha de practicar solo en las tierras nuevas recien desmontadas y pendientes que no se pueden arar, y endonde no seria conveniente remover el suelo por temor que las lluvias arrastrasen lo movido; en este caso se va hoyando por cuerda, con un plantador á proposito, de media en media vara, plantando en cada hoyo una estaca, continuando así en hilera, con vara o vara y media de distancia unas de otras, Como la caña necesita de mucha humedad y en los terrenos descolgados no hay regularmente riego y aunque lo hubiera pasa con demasiada rapidez para dejar la humedad suficiente, se debe hacer esta siembra en la primavera, despues de establecidas las lluvias y en donde nortee con abundancia : en tales lugares se ha visto durar las cepas de caña hasta 15 años, dando cortes bien productivos sin renovarlas. El segundo sistema, ó de Patuco, consiste: despues de el terreno preparado y dividido á propósito, en ahilar y poner estacas colrespondiendo eada una al hoyo que tiene que abrirse, con vara á vara y 
media de distancia entre cada hoyo y por todos lados; así dispuesto todo, se hacen con el azadon hoyos cuadrados de como 10 á 12 pulgadas de ancho y sobre como 6 de hondo, colocando horizontalmente en ellos cuatro toletes ó estacas, uno por cada lado y uno atravesado en el medio; eso hecho se les cubre con un poco de tierra, y cuando ya la caña ha salido y tiene la planta 12 á 18 pulgadas de alto ó algo mas, se da un desyerbo y á la vez se apoca, llenando así el hoyo con la tierra sacada al abrirle.

En fin, el tercer método ó tendida consiste en pasar en el terreno, dividido como hemos dicho ó dispuesto en tablones, despues de dadas las rejas necesarias, el desterronador, que es un grueso cilin. dro de hierro dentado que halan dos yuntas de bueyes ó mas y que gira sobre su eje, seguidamente se planea con la grada ó la rastra para igualar el terreno, despues que con el peine ó arado dentado se haya limpiado de toda la basura : entónces se surca á la distancia de vara y media ó dos varas y á una profundidad como de 10 á 12 pulgadas y dentro de los surcos se va tendiendo la semilla, distante entre sí como de un palmo en los terrenos propios, pero en los menos feraces puede irse acercando hasta tocarse; eso hecho se cubren las semillas lijeramente con dos pulgadas de tierra y se riegan. En lo alto de los canelones, entre surco y surco ó entre hoyos, la tierra sacada al abrirlos, dispuesta á propósito, se puede aprovechar el terreno con maiz y caraotas ó frijoles, segun la temperatura, y para que el maiz no sofoque la caña se ha de poner un canelon de maiz y otro de legumbres y así alternativamente.

Cualquiera que sea el método de siembra que se escoja, la semilla será siempre la misma, es decir, que consistirá en toletes, cortos trozos de como un palmo ó 10 á 12 pulgadas de largo sacadas de la punta de las cañas, provistos de dos ó tres ojos ó yemas bien vivos. Cuando los renuevos tengan como un palmo de alto, se da un desyerbo, si las cepas han nacido muy apiñadas, se destruyen las que sean necesarias para dar el desahogo á las demas y se vuelve á sembrar de nuevo las que no han salido. Así que la caña principie á cerrarse se le da otro desyerbo y se cosechan las legumbres y el maiz; los riegos se darán segun la estacion, de manera que no falte á la caña la necesaria humedad, ni sea escesiva porque la aguachine. Ese vejetal guajana ó echa las flechas ó flores en el mes de octubre ó algo mas tarde; cuando está así no se le debe cosechar, porque para florear ha perdido la mayor parte de su dulce y el jugo se ha vuelto muy acuoso; es preciso pues esperar que se seque la panoja y que se haya vuelto otra vez dulce. Cuando las cañas están casi maduras y que su caña principia á volverse amarillenta, entónces se suelen quitar las hojas inferiorea y secas á fin de facilitar la madurez; pero se las deja en el suelo á fin de abonar el cañaveral y seria mucho mas provechoso si se las pudiera enterrar. Sazonada ó madura la caña, lo que sucede á los 12,15 o 18 meses de sembrada, se procede al corte hilera por hilera á algunas pulgadas del nivel del suelo, dividiéndolas despues de quitadas las hojas y de despuntadas en algunos trozos de como vara y media de largo; eso hecho se la lleva al trapiche para molerla y elaborar el azúcar, ope- 
racion muy importante, pero que no podemos describir porque nos llevaria demasiado lejos de nuestro objeto. De la punta de la caña así separada se saca la semilla, y la parte terminal que lleva las hojas del vértice sirve de forraje para los bueyes y caballos.

Cacao. M. D. - G. 923. - Dos ó tres especies, ó quizás variedades, se creian naturales en las selvas de la isla de Trinidad, á saber: el Theobroma silvestris, el guianensis y otra clase. Ese árbol se conoce con el nombre de criollo y de forastero: el primero ha sido, segun unos piensan, sacado de Méjico é introducido en las Antillas; da un producto mejor que el segundo, que proviene del Brasil, y suministra mayor cantidad de fruto : esas dos clases se cultivan en las Antillas y algunas personas dan la preferencia al criollo; pero es en Venezuela donde se cultiva en escala mayor, y ese pais suministra el cacao mas apreciado y mejor.

Ese árbol principia á parir á los cuatro años de sembrado y cada año va produciendo mas, hasta que haya alcanzado la edad de 9 á 10 años, en que principia á dar mayor producto, y sigue así muchísimos años casi sin trabajo ni gasto ninguno otro sino el necesitado para cosechar y preparar el cacao. El cultivo de ese rejetal es el mas conveniente para los de corto capital, porque necesita poco trabajo y por consiguiente muy pocos gastos. El baron de Humboldt dice, haciendo alusion á los Españoles de la América del Sur, que los plantíos ó haciendas de cacao pertenecen en general á personas de condicion humilde y no muy acomodadas, que con sus hijos preparan, con tal cultivo, por sí mismos una fortuna lenta, pero segura; necesitan muy pocos jornaleros para ayudarles, y 30,000 palos de cacao, una vez llegados á la edad de su mayor producto, aseguran bienes de fortuna muy regulares para una generacion y media; por esta razon se deberian dedicar mas en las Antillas á ese producto que lo que se ha hecho hasta ahora. Para ese cultivo se han de escojer los terrenos de aluvion ó vegas, con preferencia á los valles, en donde esté al abrigo de los nortes fuertes, desde el nivel del mar hasta 50 varas de elevacion: es bueno, cuando se puede hacerlo, buscar una lijera esposicion al norte y en los lugares vecinos de los cursos de agua, á fin de que el suelo tenga siempre bastante humedad durante la estacion seca y se pueda fácilmente desaguar durante la de las lluvias: es preciso escojer siempre con preferencia, cuando es posible, los terrenos que pueden recibir el beneficio de las irrigaciones, sin que sean sin embargo espuestos á las crecientes ó avenidas, de las cuales se ha de defender el plantío por medio de camellones dispuestos á propósito.

Escojido una vez el terreno, se tumban los árboles, escepto los erithrinas ó búcares y los ingas ó guamas, que se pueden dejar, porque su sombra es muy buena para el cacao: se cortan las malezas y malas yerbas y hecho todo eso, tales sustancias, amontonadas como conviene y como ha sido enseñado mas arriba, se queman; concluida esta operacion se prepara el terreno con las labores necesarias, estirpando lo mejor posible los troncones, las raices de las malezas y de las yerbas, que entónces se quemarán tambien. Preparado el terreno se disponen los cordeles en línea recta, á una distancia una 
de otra que habrá de variar de 9 hasta 14 varas ó de 30 hasta 40 piés, segun la clase de árboles que se empleará para protejer el plantío y la feracidad del suelo, y como 5 á 6 varas de un palo al otro, lo que se señala por medio de estacas puestas á esa distancia las unas de las otras y tambien en línea recta, cruzando las primeras; todo así dispuesto, se principia por sembrar en el espacio que separa en la línea dos piés de cacao, un plátano y en el otro una erithrina ó búcare, ó un guama; en la otra línea se coloca un plátano entre cada cacao, sin búcare ni guama ninguna, y se sigue así hasta que todo el campo esté arreglado, y cuando estos vejetales, sembrados así de antemano, den bastante sombra, se hacen los hoyos en los lugares correspondientes y se les deja abiertos durante dos meses antes de sembrar las posturas que se sacan del semillero. El búcare anaveo, erithrina umbrosa, ó el búcare peonio, $E$. corallodendron, se siembran de estaca, que se ha de cortar en el menguante de la luna, conservar á la sombra hasta el creciente, tiempo á propósito para colocarlas en la tierra, sea en el mismo campo, sea en un semillero á propósito, de donde se les sacará cnando se necesiten.

Para los semilleros de posturas de cacao se necesita un terreno muy bueno, bien preparado, en donde el agua no se quede estancada, pero bastante húmedo ó que se pueda regar con facilidad; debe estar abrigado del sol. Se hacen en él montoncitos de tierra, en el vértice de los cuales se colocan dos semillas recien sacadas de la cápsula madura, porque sin esa precaucion indispensable no salen. Durante los 20 primeros dias de sembradas, se las debe dejar tapadas con hojas de plátano ú otras y es preciso regar el suelo y evitar con cuidado que el agua no se estanque. La estacion mas favorable á la siembra es el mes de noviembre : si por casualidad no fuera fácli regar el semillero, entónces se esperará la estacion de las lluvias para confiar la semilla á la tierra : otros colocan las dos semillas en canastitos de bambú hechos á propósito, rellenos de tierra, y les entierran, y cuando se ha de trasplantar la postura se lleva dentro de su canastito y se la coloca así en el hoyo dispuesto para recibirla : hay algunos que no hacen semillero ninguno, pero la echan de una vez en la tierra del modo siguiente: despues de haber escojido la semilla como sigue: se toman los mas hermosos y mas grandes frutos enteramente maduros y se echan las semillas al sacarlas en una vasija ó cubo conteniendo agua: las que sobrenadan se han de arrojar, mientras las otras, bien limpias de la pulpa que las tiene envueltas, se vuelven á echar en el agua hasta que se siembran en hoyos escarvados á propósito y dispuestos en líneas rectas, como lo teriemos ya dicho, de un pié cuadrado y como de 6 á 8 pulgadas de profundidad y distantes los unos de los otros como de unos 10 á 12 piés á lo largo de las líneas; abiertos de antemano se les forrará con una hoja de plátano ú otras como las del úbero del mar ó de alguna palmera, etc., de tal manera que sus lados salgan algunas pulgadas por encima del nivel del suelo, y despues de dispuesto así á manera de cajita, se llena el hoyo ó mejor esa especie de cajita de tierra y tres semillas son entónces colocadas triangularmente en la tierra 
con el dedo y á como unas dos pulgadas de profundidas, de manera que el gérmen encuentre por donde salir. Entónces se le tapa con el molde ó cajita, doblando la hoja por encima y con una piedrecita puesta sobre su vértice se impide que pueda abrirse: á los 8 o 10 dias la joven planta aparece algo por encima del suelo: es preciso entónces abrir un poco las hojas á fin de darla luz y aire, bien que quedando protejida contra los rayos del sol, lo que no se ha de descuidar : necesitará de tal sombra artificial durante 5 á 6 meses : no me parece necesario hacer observar que el suelo preparado ya como lo tenemos señalado mas arriba, está provisto de los vejetales protec tores ya bastante crecidos para dar la sombra útil: llegando los tres arbolitos ya como de 17 á 20 pulgadas de alto, se corta uno por su parte mas inferior; los otros dos si son diverjentes se pueden dejar, pero mas reces se deja uno solo. Cuando la postura del semillero habrá alcanzado como 30 á 36 pulgadas, lo que tendrá lugar como á los dos meses de sembrada la semilla, se trasplantará en los hoyos dispuestos como lo tenemos dicho mas arriba, se la habrá de arrancar con mucho cuidado y en maceta, para no dañar las raices.

Al quinto año, cuando el cacao se hace frutal, se destruye el plantanal. Es preciso arrancar los plátanos con cuidado, á fin que al caerse no dañen los palitos de cacao, porque entónces los búcares sembrados hácia el Sud-Oeste dan bastante sombra: tal operacion tiene pues por objeto dar mas aire al plantío á fin que vejete con mas fuerza y vigoi.

Cuando los árboles de cacao habrán alcanzado como unos 4 piés de alto, se arreglará el tallo, y para eso si hay por casualidad algunos ramos que hagan al arbolito demasiado lozano, se les reducirá solamente á 3 , dispuestos á igual distancia y segun el vigor del pié; las hojas que de ellos salen se han de sacar ó se dejan : si tales ramos se inslinan hácia el suelo, se les agrupa en ramillete ó haz y se les ata así alzados, de tal manera que el tron tortuoso; algunos meses despues de arreglados así, se les corta como á dos dedos del árbol y se tiene en seguida cuidado en quitar todos los retoños que suelen salir de él y viven á sus espensas.

Para conservar en buen estado una hacienda de cacao es necesario, además de lo dicho, resembrar constantemente, tanto el cacao que falle como la sombra: este trabajo es de todo el año y cada vez que se da una limpia, sin dejarlo para despues, mas en cuanto á la sombra, cuando los búcares están cerrados ya no se pueden reponer, porque los nuevos se mueren por causa de la demasiada sombra; entónces se ha de reemplazarles con aguacates; pero como esos árboles no se esparcen ni se elevan tanto, es preciso á la altura de tres varas se descogolle, dejándole y manteniéndole en dos coronas de á tres ó cuatro barazos cada una, forzándolo así á robustecer y esparcir estas ramas. El orore y el guano tambien prosperan debajo de la sombra, pero su incremento es mas lento; sin embargo pueden ponerse algunos de estos árboles salteados cuando las fallas se repiten demasiado.

Los enemigos del árbol de cacao son en primer lugar el sol, cuyos rayos le pueden hasta matar: algunos gusanos le atacan, royendo 
su corteza, y al penetrar en su interior le hacen perecer: el único remedio que hasta ahora se ha empleado con buen éxito consiste en matarlos, y para eso se ha de reunir á los peones que les buscan : otro gusano se come las hojas tiernas al principio de la estacion de las lluvias; hay años en que su abundancia es tal, que todo el peonaje empleado basta apenas para destruirle; tiene como cuatro pulgadas de largo y el tamaño del dedo; la mariposa de donde proviene pone sus huevecitos sobre las hojas del cacao dispuestas en grupos que figuran una peseta; se les debe buscar y destruir con mucho cuidado; los que por desgracia se escapan se vuelven crisálides que al año siguiente producen otras mariposas que se destruyen haciendo hogueras de manera que no puedan dañar á los árboles, pero cuya luz les llame de modo que se caigan en ella ó que se les mate en su derredor. Los aserradores parecen los primeramente señalados, bien que sean un poco mayores y blanquecinos: se alimentan encima de los ramos, en donde se les ha de buscar para matarles; en fin, otro insecto llamado vachaco ocasiona mas perjuicio todavía porque se come los pétalos ú hojas de las flores; para destruirle es preciso ir á buscarle en la tierra, y para eso se ha de echar agua en los lugares donde se sospecha la presencia de sus nidos y removiéndola á manera de mezcla se les mata; de ese modo el mal está disminuido, sino enteramente remediado.

A los insectos siguen los pájaros y los cuadrúpedos: los loros y los conotos se comen el fruto, lo mismo que las ardillas que dañan muchas mazorcas. Ha de estar siempre pues en un cacagual un hombre destinado esclusivamente á la destruccion de estos animales por medio de la escopeta: escusado es decir que además debe estar bien cercado á fin que el ganado no entre en él. Además de todo eso es preciso tener mucho cuidado en que los palos de cacao estén siempre limpios de las plantas parásitas, de los bejucos y enredaderas, de los musgos y líquenes que las invaden con tanta frecuencia viviendo á sus espensas ó ahogándoles, y tambien de los chupones y renuevos.

Los cacaos llegados á dar mayor producto están dispuestos á ser atacados por una enfermedad llamada mancha; entónces en su parte inferior aparece un matiz ó una mancha negra dispuesta á manera de anillo y que abädonada á sí misma le mata. El modo de remediar el daño que puede hacer esa enfermedad consiste, al principiar las manchas, en hacer una lijera incision que penetre en la corteza; pero si á pesar de tal operacion la mancha sigue estendiéndose, entónces se debe estirpar toda la parte invadida, despues de curada la corteza, se queda sin embargo moradita en los lugares que han padecido.

Reasumiendo lo dicho se verá que para conservar en buen estado de producto $\mathrm{y}$ de vejetacion un plantío de cacao, es preciso que siempre tenga sombra é irrigacion ó humedad suficiente, que sus ramos estén siempre bien limpios de las yerbas enredaderas y bejucos: es indispensable que los canales ó zanjas de irrigacion se profundicen en proporcion del crecimiento de los árboles, á fin de que las raices estando al nivel del agua puedan recibir la humedad necesaria. Los 
riesgos deben darse siempre con la fresca, es decir, desde las cinco de la tarde hasta el anochecer, ó en los dias que no sea el sol fuerte; en cuanto á los desagües se abrirán por medio de las calles para no lastimar las raices. Con tales cuidados se hace el plantío mas hermoso, mas productivo y mas duradero: cuando los árboles paren bien no se les debe quitar ningun ramo, porque aunque esta operacion haga la cosecha siguiente mas abundante, tal esfuerzo fatiga el vejetal y puede hasta morirse, segun la calidad del suelo mas ó menos rico en que vive y el número de ramas quitadas. Cuando los ganados pisan el suelo, el plantío se hace con eso menos duradero mientras las irrigaciones hechas con intelijencia tienen el efecto enteramente contrario.

Tres causas hay que perjudican la cosecha haciendo secarse el fruto sobre el árbol é impidiéndole así llegar á su tamaño y á su madurez: la $1^{\text {a }}$ consiste en que el plantío se haya quedado anegado durante largo tiempo, bien que algunas veces se ha visto suceder solamente despues de 30 horas de inundacion; $2^{\mathrm{a}}$ las lluvias abundantes, especialmente en los valles por sí mismos ya húmedos: se remedia tal inconveniente con bastante facilidad por medio del desagüe del terreno, hecho por medio de un buen desaguadero dispuesto de antemano: en fin, la falta de bastante humedad ó su irrigacion intempestiva, es decir, durante que los rayos del sol estén ardiendo con mayor fuerza, porque el vapor que se exhala entónces mata á las frutas: si ha llovido durante algun tiempo y que despues de eso el agua caiga á cántaros, el fruto se seca; eso sucede tambien cuando el árbol pare mas frutos que los que puede criar naturalmente; se remedia con facilidad quitándole una parte de ellos, y especialmente aquellos cuyo aspecto es menos bueno: la mala calidad del terreno produce tambien ese mal efecto: en ese caso los frutos contienen á la vez semillas buenas y malas ó abortadas, lo que se llama cocosearse; se puede remediar tal estado de cosas suministrándole el abono necesario.

Ese árbol empieza á fructificar á los 4 años: va progresivamente aumentando hasta los 8 , en que llega á su robustez: permanece por 15 ó 20 años, segun el sitio y la fertilidad del terreno, y de los 30 adelante empieza á decaer, hasta su muerte que llega á los 40 ó 50 años; cuando se va á derribar un ahilado para reponerlo por viejo ó improductivo, el año antes se le da una poda formal para que su última cosecha sea abundante, y despues se muere.

Tales árboles dan dos principales cosechas al año: la $1^{\text {a }}$ hácia San Juan, y la otra á fines de diciembre; sin embargo, como el árbol está echando unas flores todo el año, hay siempre algunos frutos maduros que se han de recojer á medida que se hallan buenos, mas los propietarios suelen hacer de tal suerte que no se cosechan sino al menguante de la luna, porque tienen observado que de este modo el cacao es mas sólido y menos sujeto á dañarse ó á podrirse. Por término medio una cuerda de tierra tiene sembrados 868 piés de cacao, que produce cada uno como dos libras de habas al año ýa veces algo menos; otras veces produce mas y se han visto palos privilejiados parir hasta 10 libras, segun lo dice Purdié, para la Tri- 
nidad. Lunam refiere que en Jamaica ha observado piés de cacao producir hasta 20 libras y en suelos malos y pobres 8 : tal producto nos parece á nosotros algo exajerado y tales árboles no pueden seguir así sin morirse pronto estenuados.

En la casa de habitacion debe haber dos cuartos y dos corredores destinados al beneficio del cacao; los corredores han de mirar uno al naciente y otro al poniente, por lo que el cañon de la casa debe estar de norte á sur. Esta situacion tiene por objeto que en la estacion lluviosa en que no se puede echar el cacao al patio esté estendido y reciba en estos corredores el sol de la mañana en el del Oriente, y el de la tarde en el de Occidente. Además se abrirán dos patios, el uno natural con su suelo de tierra, y el otro enladrillado, para echar en el primero el cacao fresco como sale del debabadero á recibir el dia del sol y á soltar la baba, y en el segundo los siguientes dias á recibir la condicion.

Como ya lo tenemos dicho, el cacao fructifica todo el año, pero con mayor abundancia en los meses de julio y de diciembre, lo que se llama la cosecha de San Juan y Natividad; así es que todos los meses han de recojerse las mazorcas sazonadas, lo que se llama pasar vara. Los peones ó peonas que han de hacer la recoleccion del cacao ó la cosecha deben ir hilera por hilera y mata por mata, $y$ despues de haber examinado si hay algun insecto perjudicial ó dañino en el árbol, que pueda repararse, procederan á descargar el fruto, armados de una desjarretadera en hastada en una vara de 9 piés de alto, para con ella derribar las mazorcas que no alcancen con la mano, dejándolas caer al pie del árbol: se han de escojer para esta operacion las mas intelijentes y de mejor vista, para que acierten á derribar solamente las maduras y las ya sazonadas, aunque no estén en toda su madurez; detras de cada vara irán una ó dos mujeres ó jóvenes, que no ganen el jornal entero, con un canasto recojiendo las mazorcas del suelo que irán depositando y apilando en un punto dado, hasta que la distancia requiera otro punto de depósito, procurando que estos depósitos ó montones estén lo menos posible en cada ahilado. Concluido el paso de vara ó la operacion anterior ó recoleccion de las mazorcas se procede al desgrano; para eso se prepara y se limpia el suelo cerca del monton y cubriéndolo despues con hojas frescas de plátano que se llaman cama. Ese trabajo se divide en dos operaciones, picando unos las mazorcas del monton y otros recibiéndoles en la cama para abrirlas y desgranarlas; los picadores deben ir examinando las mazorcas, desechando las podridas y picadas, poniéndolas á un lado con las que no están bien sazonadas y procurando que al darles los piquetes cruzados, no llegue el corte á dañar los granos. Los desgranadores ó desgranadoras procurarán que en la cama queden los granos solos sin pedazos de concha, y para facilitar esta operacion se armarán de una paletita de madera que limpie las cajitas de las mazorcas. Concluido el desgrane, se carga el cacao fresco en baba, para reunirlo en el cuarto destinado para desbabadero, donde se acumula todo lo sacado, y así se sigue de pila en pila. Las mazorcas apartadas por no estar maduras se reunen y se cubren con las hojas en un solo monton, y á los 
dos ó tres dias se pican, se desgranan y agregan al depósito. Al dia siguiente $\delta$ al inmediato en que haga buen sol, se echa en el patio de tierra, si está seco, para que chupe y absorva la baba del cacao, estendiẻndolo muy delgado; si el tiempo no es muy favorable, y si aunque no esté lloviendo el patio está húmedo, se echará en el hormigon 6 ladrillo rastrillándolo á menudo, cuidando sobre todo que no llueva sobre él. En esta primera tendida se recojen las pelotas en que hayan quedado los granos unidos para desunirlos; con el primer dia de sol se vuelve á poner en pila en el otro cuarto y se deja así 48 horas; entónces se vuelve al patio de hormigon en donde se ha esparcido tierra colorada, ladrillo molido y almagre; allí se echa el cacao y se remueve para que todos los granos se hallen igualmente en contacto con la tierra; despues de este segundo dia en que solo se le darán cuatro horas de sol, se le dan dos o tres al siguiente, y si aun no queda bien seco se le dará otro rato despues. El cacao en condicion debe estallar la concha al partirlo y la almendra en lo interior como en la superficie pelada de un morado oscuro y que no presenta ningun punto blanco interiormente. En este estado se guarda en el almacen y está disponible para su venta, pero antes se le limpia de la tripa y pasilla ó pedazos de concha que ha traido del campo y se hayan escapado durante la seca. Si se descubre en el almacen alguna palomilla ó grano picađo, se le echará un poco de sal molida, como una libra por cada cuatro fanegas, paseándolo de un estremo ol otro del almacen, que debe mantenerse cerrado, mientras el cacao pueda remitirse al mercado.

Despues de secas las habas como conviene, se las debe tener guardadas erı almacenes de madera bien secos y sin luz ni humedad ninguna, cuyo suelo de madera ó entablado estará como á unos dos pies de tierra. Las habas de cacao que principian á dañarse se preservan de una entera descomposicion aplicándolas una pequeña cantidad de salmuera, removiéndolas despues para que se mezcle igualmente con ellas.

Todo lo que acabamos de decir corresponde al cacao criollo ó lejitimo de Carácas ó de Venezuela; ahora hablaremos del cacao de Trinidad ó de Carúpano. El árbol es mas corpulento, mas abundante en producto, por consiguiente ocupa mayor espacio de terreno, resiste mas la mala estacion, no padece enfermedad y no está tan acometido por los insectos, pero requiere el grano seis dias de calent:s ra despues del primer dia de sol, en lugar de dos que necesita el crisllo para que el cocimiento penetre el grano, que es mas duro y mas amargo. No se le debe mezclar en la recoleccion en los cacaguales en que está mezclada la arboleda con el criollo, porque en este caso ó se pasaria de cocimiento el uno, o quedaria crudo el otro. El beneficio del cacao de Trinidad es igual al otro y varia solo en su cultivo en la distancia, que por ser el árbol mas corpulento debe dársele media vara ó tres cuartas mas.

Suponiendo, dice el señor don José A. Diaz en su obra titulada: "El Agricultor Venezolano, " que en cada año se funden cinco mil árboles, los gastos los ha dado la misma fundacion en los frutos menores con escepcion de los del caporal, del cocinero y manutencion 
de estos y del dueño, y como el cultivador de frutes mayores no ha debido desdeñar ni la cria de aves, ni la ceba de cerdos, puerle computarse su gasto adicional en 350 pesos al año, que son en los primeros cuatro años 1,400 pesos; el gasto ó costo de la casa y patios necesarios en 2,600 pesos, que con la suma anterior hacen 4,000; ya para el quinto año, el primero y el segundo ahilados, producen para cubrir el primer cálculo y por total resultado tendremos al fin un capital de 20,000 pesos que vale la hacienda adquirida con 4,000, y una renta de 2,000 pesos anuales de los diez años en adelante, calculada la fanega del cacao al módico precio de 25 pesos; para ese cálculo se han considerado en detalle todos los trabajos.

Café : árbol ó palo de café. M. D. - G. 738. - El cultivo de ese vejetal conviene tambien mucho á los que tienen un capital corto, porque los gastos que necesita son pocos, será pues por tal razon sin duda que este ramo de agricultura va estendiéndose mucho en la isla de Puerto-Rico.

Los terrenos como sigue son los mas á propósito para ese cultivo: en primer lugar, el suelo de las selvas poco espesas en que se halla una capa considerable de detritus orgánicos, de humus ó de mantillo por consiguiente: en tales sitios el cafetal es muy duradero; en segundo lugar viene el terreno de color parduzco oscuro y hasta casi negro, que, sin tener mucha arcilla, parece á la vista que contiene madreporos ó sustancias calcáreas; los suelos con depósitos calcáreos, rojizos ó amarillentos son inmejorables para ese cultivo; en efecto, los cafetales en tales terrenos duran bastante y son muy productivos, pero tienen el inconveniente que las posturas tienen difitultad para hacer penetrar sus débiles raices en él, lo que con frecuencia los hace perecer; se puede, sin embargo, remediar ese inconveniente con bastante facilidad por medio de bastantes labores que desmenuzan la tierra como conviene; en tercer lugar, el terreno desmenuzable, como se le encuentra generalmente en las cercanías de las tierras volcánicas; tal clase es muy á propósito para el cultivo del café, pero tiene el inconveniente de contener muy poco alimento orgánico para el árbol: de tal manera que dichos cafetales son poco duraderos si no se les abona con sustancias orgánicas empleadas en suficiente cantidad. En fin, los terrenos muy arcillosos y pedragosos á la vez no son á propósito para esa clase de cultivo.

Segun Ponac, el bagazo que se queda despues de la estraccion del aceite de coco constituye un abono estimulante muy bueno y muy á propósito para los cafetales: tiene solamente el inconveniente de durar poco; la cal es de aplicacion diaria para ese cultivo, especialmente en los suelos compactos, y además hay que saber que ese vejetal contiene 60[100 de esa sustancia en sus cenizas; los huesos reducidos á polvo son para él un abono magnífico, pero cuyo inconveniente consiste en su carestía; el estiercol es muy bueno y mas veces conviene mucho el emplearle; el guano no parece muy apropiado á ese cultivo; la pulpa que proviene de su uba despues de medio podrida constituye un abono muy bueno para él.

Los sitios elejidos para plantar cafetales han de estar protejidos contra los vientos del sud-este y del norte, cuya influencia es bas- 
tante mala, y la mejor esposicion para ellos es la del oeste y la del sud-oeste; deben tener una cierta sombra ó estar protejidos durante los rayos ardientes del sol por medio de los mismos árboles señalados para igual uso en la plantacion de cacao, á saber los bucares y los guamos. Los llanos no le convienen tanto como los lugares altos cuya elevacion se encuentra entre 1,000 á 4,000 pies por encima del nivel del mar con una temperatura de 75 á $90^{\circ}$ farenlieit ó como 23 á $25^{\circ}$ centígrados; el sol al salir es muy favorable para ese vejetal. Despues de limpiado el terreno de las yerbas y bejucos, durante la estacion seca, y arrancadas las raices y troncones, todo eso seco se quema y las cenizas que provienen de esa operacion se han de esparcir por encima del terreno; eso hecho se pasa el arado si el terreno lo permite, pero mas veces se limitan á escarbar los hoyos con la azada dispuestos en línea recta, á la distancia de como 6 á 8 piés el uno del otro en las tierras calientes, mientras que en los terrenos mejores, con temperatura mas bajita, el intervalo habrá de ser de 7 á 9 piés de un palo á otro, quedándoles abiertos durante algunos meses antes de la siembra, para que la tierra que ha de colocarse en contacto con las raices pueda aprovechar la influencia atmosférica; además se habrá de repartir la ceniza con la tierra de los hoyos ó los abonos si se necesita alguno; tales hoyos han de tener un pié cuadrado y otro tanto de hondo; las líneas á lo largo de las cuales están dispuestas estarán como á 12 piés una de la otra ó de calle; todo listo de antemano se saca el plantel del semillero ó almacigo que ha sido dispuesto á propósito, cuando tiene como un pié de alto, sea á la mota, sea á la mano : ese modo es el mas usual y el mas económico bien que defectuoso; el primer método de sacar la postura á la mota consiste en cortar oblícuamente la tierra con el chicuron como á 2 pulgadas y media en derredor del tallito y hasta como 5 pulgadas de profundidad; se levanta entónces el plantel con la tierra húmeda adheriendo á sus raices y se la envuelve con una hoja de plátano ú otra para que no se caiga la mota, se les coloca en especies de canastos á propósito y se les lleva con cuidado al sitio elejido y preparado para la siembra; entónces se coloca uno en cada hoyo cuya tierra bien movediza está aplicada en cantidad de unas 6 á 8 pulgadas al principiar la estacion de las lluvias. Ordinariamente en Puerto-Rico se saca la siembra de los cafetales ya en producto hace algunos años, arrancándolas con la mano, despues de haber volcado con una estaca el terreno donde está á fin de que no se rompan las raices, se las junta como en número de 50 ó 100 matitas, cuyas raices se envuelven en hojas de plátano mojadas y se las ata, llevándoselas al lugar dispuesto para recibir la siembra y se la hace del modo ya señalado para los planteles de cacao en mota. No es preciso decir que la sombra que necesita el cafetal se la da del mismo modo indicado al hablar de los cacaguales; pero en Puerto-Rico se suelen sembrar los cafés por debajo de los árboles sin tumbarlos, limitándose á limpiar por debajo de ellos el suelo como corresponde, tumbando solamente algunos árboles á medida que el cafetal necesita del aire dejando los guamas y otros cuya sombra es favorable. 
Se prepara cerca del ahilado ó terreno dispuesto para formar el cafetal un pedazo de iierra capaz para un almacigo ó semillero de doble número de plantas al de las estacas puestas, porque se debe tener siempre sobrantes. Este terreno se pica, planea y riega, si no lo han humedecido ya suficientemente las lluvias, despues se va con una estaquita hoyando por cuerda á distancia de una tercia, colocando un grano en cada hoyito, cubriéndolo de tierra; si el almácigo está hecho al descubierto, como es natural, el primer año, se cubre formando troje de vara y media de altura, sobre la cual se tienden unas hojas de plátano, las que á medida que se van secando dejan penetrar algunos rayos del sol que son muy convenientes para robustecer la planta; estos almácigos deben conservarse regados y frecuentemente limpios para cuyas labores se ha de emplear la pequeña escardilla.

Se pondrán los plátanos, cambures ó topochos por el medio de las calles á cuatro varas y los bucares en la misma direccion entre plátano y plátano, pero dejando dos claros vacíos, de manera que estén los bucares á la distancia de 12 varas entre sí por todas partes, á cuyo fin se dejarán tambien dos calles sin bucare, dejando las estacas en su puesto marcando el lugar que deberá ocupar el café en los nortes ó en el siguiente año. Esos trabajos han de hacerse á entradas de las aguas por mayo; los ahilados de cada edad deben dividirse y nominarse; así se hará tambien para el cacao y se aprovechará el vacío de las calles con dos hileras de maiz, cada una á vara y media de distancia y á tres granos en cada piquete, y por la hilera de estacas, entre unas y otras, dos palos de yuca equidistantes; se hará lo mismo para el cacao.

Cosechado el maiz y puesto el café se mantendrá el ahilado siempre limpio á azada, repitiendo la siembra de frutos menores en cuanto lo permita la sombra de los plátanos que pueden conservarse cinco años, despues de los cuales conviene destruirlos, porque impiden la corriente libre del aire; á los seis años está el café perfectamente frutal, sin haber dejado de dar algunas cosechas en los anteriores. En los terrenos fértiles ó que convienen á tal cultivo, ese vejetal se desarrolla y crece bastante pronto.

Algunos agricultores piensan que el árbol del café se descogolle ó cape á la altura de dos varas y aun menos en las tierras frias y se mantenga en este porte, quitándole constantemente los renuevos; otros que se descogolle y se mantenga un año desretoñado para que robustczca el tronco, dejándolo despues vejetar en libertad, y, por fin, hay otros que son del parecer de no descogollarle, dejándole natural. El medio término entre esas varias opiniones será lo mejor en la zona templada y aun en la cálida y el primero en la fria. Despues que el café es frutal necesita tres labores anuales, un desyerbo de azada en enero ó febrero, despues de la cosecha; otro de•machete en junio, despues de las primeras aguas, y otro de azada ó machete, segun la estacion, al aproximarse la cosecha de setiembre ó á principios de octubre. Cuando pasados algunos años y á pesar de las distancias dadas las ramas muy crecidas y chupones se doblan y caen sobre las calles, cruzándose éimpidiendo el tránsito, se ponen pcones 
con machete en mano, á aclarar la calle, cortando los ramos de uno y de otro lado, sin atender á si están lozanos ó secos, que no hay temor que este corte le perjudique, antes por el contrario produce mejores efectos, retona, se viste de nuevo y sus renuevos duplican la cosecha; estos piquetes despues se repiten cada tres años ó cuatro, se. gun lo requieran los estorbos. En las pendientes deben economizarse los desyerbos de azada, por el inconveniente de llevarse las aguas la tierra removida, y en los desyerbos necesarios de las plantillas procurar que vayan los despojos acordonados de arriba abajo por las hileras de café, dejando las calles limpias á que sirvan de cauce. El fruto que con mas utilidad se puede sembrar para aprovechar la tierra de las fundaciones en la zona fria, es la caraota. En PuertoRico ordinariamente no se suele descogollarle.

Debe haber patios y corredores correspondientes con la cosecha. El patio puede reducirse si se decereza, porque entónces se seca con tanta prontitud como el cacao; pero si no se descereza $y$ que se queda trillado ó en parapara, se necesita para secarle 15 dias de buen sol, y en el discurso de la cosecha se puede hacer solo tres tendidas, así es que una cosecha de 300 quintales necesita un patio que contenga 100 quintales, y conteniendo cada treinta y seis varas un quintal en cereza ó parapara, resulta que el patio relativo á la cosecha supuesta debe tener la estension de 10,800 varas cuadradas ó un cuadro de 60 varas. Además de las ventajas de pronta seca y ahorro de patios, el café descerezado tiene la especial de mas valor en el comercio, regularmente en un quince por ciento, aunque para el uso el en parapara bien seco, guardado algun tiempo, conserva mas aroma y es de mejor gusto; el café se descereza con máquinas á propósito.

Si se ha de descerezar el café, debe cojerse el grano maduro ó que ya esté amarillo próximo á madurar ; los cojedores ó cojedoras deben ir suficientemente provistos de canastos y sacos para que no lo echen en el suelo. En la recoleccion del fruto, cada cojedor tomará una hilera por su cuenta, y un vigilante ó mas, segun la tendida de la gente, irá revisando por detras, á fin de que no quede en la mata grano maduro y que recojen del suelo uno á uno los que hayan caido. Junto á la máquina de descerezar habrá un pequeño patio enladrillado y muy aseado, donde se mida y deposite el café que se va á descerezar. Despues de descerezado, lavado en un estanque á propósito para quitarle una sustancia mucosa que adhiere el pergamino, se le amontona para que escurra el agua, y poco tiempo despues se echa bien estendido en el patio enladrillado; si ese primer dia de seca hace un buen sol se recoje por la tarde y se trae al corredor; al siguiente vuelve al patio, se le da medio dia de sol removiéndole con el rastrillo dos ó tres veces; al tercer dia se le da otro medio dia de sôl y se vuelve á retirar; entónces se examina si está en condicion de guardarlo, para lo cual se le quita el pergamino que le cubre y se prueba mordiéndole ó a licándole la uña; si estrella en el diente ó no cede á la presion de la uña, está perfectamente seco y en estado de ir al almacen; en el caso contrario, se le debe dar otro rato de sol. Si durante este beneficio sobreviniere mal tiempo, se 
abrirá y removerá en los corredores hasta que haga sol, y con esta precaucion no sufrirá ningun perjuicio

El café en parapara, concha ó ubas, se recoje del mismo modo, graneado si la maduracion está muy desigual, pero si proviene de un fioreo igual y unos granos están maduros, otros pintones y el resto, aunque verdes por defuera, ya tengan bastante cuerpo, ya estén jojotos, se puede recojer todo á la vez. Si la recoleccion es menos de 10 quintales diarios se reunirá en el patio, amontonándola de dos dias para que con el calor acaben de sazonar los granos mas atrasados. Entónces la temperatura se eleva bastante y determina en el suco de las ubas una especie de fermentacion ó quizás una madurez mas perfecta, cuyo resultado es facilitar mas luego su disecacion y hacer mas fácil la separacion de una película, como plateada, que está adheriendo á la semilla por adentro del pergamino y que no se puede quitar de una sola vez, el café que se queda todavía con esta película se llama en el comercio café gris, y es de un precio algo inferior á la buena clase limpiada. Si escede de 10 quintales se estenderá diariamente lo mas delgado posible. Si el tiempo está bueno, se le empezará á dar pila todos los dias á las tres de la tarde y estension á las nueve de la mañana; de esta manera conservará toda la noche el calor recibido del sol durante el dia y el patio está ya caliente cuando se vuelve á estender, continuando la seca sin interrupcion; da por último resultado el café amarillento tan apreciado en Francia. De ese modo se puede trillar café de parapara en condicion con un tiempo favorable en 12 dias. Si entre tanto llueve y el café solo tiene cinco ó seis dias de sol, se deja á merced del tiempo, pues, con tal de que se remueve, no se desmejora á menos que se prolongase demasiado la mala estacion; en la zona cálida se necesitan á veces hasta 18 dias para que esté en condicion. En Puerto-Rico se usan secadores de cajon muy buenos y útiles, pero solo por una cosecha escasa, que tienen la ventaja de evitar el mal tiempo y de aprovechar cualquiera rato de sol. Se conoce que el café está bastante seco del modo siguiente: tomado un manojo de café se acerca la mano al oido y al sacudirle la haba ó semilla debe hacer ruido libremente en el casco, ó se ensaya mordiéndose la parapara con los dientes, y si el casco es muy frájil y si la semilla se rompe tambien con bastante facilidad y está crispada, eso indica que el fruto ya está bastante seco. Así preparado, el café se coloca en el almacen dispuesto para recibirlo y tenerlo guardado hasta que se le trille, pile ó machaque para quitarle el casco. Pero, á nuestro parecer, se deberia mandarle á Europa en casco la parapara, á fin que se conservase mejor el café, fuese de calidad muy superior y se aprovechase allá el casco, como lo tenemos dicho ya en el Compendio de terapéutica vejetal.

Hay tres procedimientos para despojar el grano de las conchas : el primero consiste en emplear una máquina apropósito llamada trilla: es el mas económico; en el segundo se emplea el mandador, para eso se estiende el café lo mas seco posible en capas de media vara ó una tercia sobre un patio de tierra. Allí los peones, dando vueltas al rededor de la tendida, descargan los mandadores, procu- 
rando que la operacion vaya igual en las orillas y en el centro; cuando se habrá estendido demasiado se volverá á reunir el café y se repetirá la operacion hasta que quede la mayor parte de los granos despojados, porque si se esperaba que lo fuesen todos muchos se quebrarian lo que se debe evitar. Zarandeado entónces se sopla y se lleva á la escojedura; se ventea en venteador ó á brazo en bateas, á falta del primero. En fin, el tercero es el del pilon á brazo, que es mas costoso que los dos primeros. Las máquinas de trillar y ventear son de necesidad solo en una cosecha que pase de 300 quintales, pero en una cosecha menor no merece la pena en cuanto á economía. Despues que el café está trillado ó pilado, soplado y desparaparado o despojado en la zaranda de los granos que no se desconcharon ya no se puede depositar en el suelo, porque se blanquearia ó desmereceria ; para eso se deben tener preparados cajones ó sacos, etc. En ese estado se procede entónces á la escojedura, para cuyo trabajo son mas á propósito las mujeres, á cada una de las cuales se le entrega una batea pequeña de ventear y dos ó mas canastos vacíos, segun su capacidad; si los canastos son de seis almudes bastan dos, y se le entrega para escojer un quintal del depósito; esta mujer ha de repetir la operacion de ventearle en pequeña batea y en pequeñas porciones, soplándolo y cerniendo para quitar el resto del polvo, basura, las piedrecillas y cualquier otro cuerpo estraño, y así lo va repasando y depositando en uno de los dos canastos; concluida esta operacion toma la zaranda de alambre número 5 , y en esta vuelve á repasar todo el café, cerniéndole y quitándole la pararita menuda y granitos enconchados que salieron ó pasaron en el primer zarandeo por ser iguales á los granos mondados; esto así purificado se ra pasando al otro canasto, y está ya en disposicion de echarse en la mesa de escojerlo; entónces se va repasando todo quitándole los granos negros, los blanqueados y con cualquiera diferencia notable se encuentra entre ellos, de manera que estendida la porcion ya escojida se presenta igual á un golpe de vista; entónces se va pasando al otro canasto vacío para entregarlo al inspector que debe ser el dueño ó el mayordomo y está en disposicion de marchar al mercado. La tarea regular para una mujer es de un quintal, pero esta varia segun el estado del café; en efecto, si es bueno porque se habrá cojido en sazon y se habrá secado con buen tiempo, tiene menos que hacer y por consiguiente rinde mas y puede escojer hasta dos quintales; pero hay ocasiones en que por haberse cojido muy verde $y$ haber hecho mal tiempo durante su seca, está tan malo que apenas las mas intelijentes y prácticas pueden componer dos almudes, que es la tercera parte de un quintal. Por la zaranda número 5 pasa el cisco ó cerecere, que es el café casi quebrado por el pilon ó el mandador, que separadamente se vende por la cuarta parte del precio del bueno ó se deja para el gasto de los trabajadores, que es lo mas usual. La escojedera de los granos negros ó averiados da el café llamado de tercera, y se vende por la mitad del precio del de primera. Un cojedor esperto, en una arboleda medianamente cargada, recoje, de las 6 de la mañana á las 4 de la tarde; doce almudes, de lo que resultará la tercera parte de un quin- 
tal, y para que una cosecha sea bien recojida debe calcularse un peon ó peona por cada 10 quintales; pero por esmerada que sea la recoleccion, y aun en esta proporcion de trabajadores, se pierde en el campo 1 [15 por ciento. En el café que se descereza se pierde mas porque como solo se ha de cojer el maduro, en cada una de las matas hay granos que aunque están sazonados no están pintones, y muchos de estos se escapan al cojedor, los cuales ya han caido cuando llega el segundo repaso y lo mismo sucede en este para cuando llega el tercero.

En las haciendas de sequero solo se puede descerezar media cosecha, porque si se espera á que se madure para recojerlo cuando vaya á los últimos repasos, ya se habrá caido la mitad del todo. En los cafés regados hay la ventaja que ha floreado dos ó tres veces por razon de los riegos y la maduracion es mas desigual. El café secado en parapara despues de limpio y escojido ha disminuido seis veces su volúmen primitivo quedando reducido á seis almudes de ley bien medidos óllenos los diez y ocho sacos sin trillar. El beneficio ó trilla por el mandador economiza sin duda, porque á cada peon se le ponen 36 almudes ó dos quintales, mas tiene la desventaja que como ese trabajo se hace á campo raso, recibe el calor del sol de todo el dia, perdiendo algo de su color y disminuyendo tambien de peso y de brillo por la tierra que necesariamente se le adhiere en el patio, lo que se podria remediar con facilidad haciendo esta operacion debajo de un rancho entablado ó no.

En la temperatura de $23^{\circ}$ y á la altura de 500 varas, produce cada mata de café dos libras al año, unos con otros; en los terrenos mas bajos coll riego de una á una y media ; en la zona fria á la altura de 1,500 varas, media libra, y á 2,000 varas un cuarto de libra solamente; pero como las distancias respectivas van disminuyendo á proporcion de la altura, de manera que en el último término la arboleda se pone á rlos varas, cuando en el primero se puso de tres y media á cuatro resulta una produccion semejante en una estension igual de terreno. En los terrenos bajos cálidos, secos y sin riego es muy variable la produccion. El fruto tarda en madurar de cinco á seis meses desde la aparicion de la flor, segun la esposicion, los riegos y la vida de la planta cultivada con intelijencia en un buen suelo, con regular humedad, despojada constantemente de sus ramas secas y recortadas en sus épocas, en los periodos que marca su decadencia no conocemos su término, porque hay cafetales de mas de 70 años de edad y de 50 que se conservan fructificando con regularidad y que apenas han sido sembrados en su tercera parte.

En un cuadro de 100 varas á 3 varas por hilera y á 4 de calle, caben 825 matas y es la siembra de la zona cálida y suelo fértil, que darán libra y media cada una.

Plátano. M. D. - G. 448. - Además del plátano comun, Musa paradisiaca, y del guineo, Musa sapientum, se cultiva en Jamaica el plátano tigre ó manchado $M$. maculata, y el plátano negro $M$. sylrestris; Lindley enumera hasta 10 especies de plátanos, de las cuales hay algunas que alcanzan hasta como 25 y 30 piés de alto; pero la clase de mayor producto y valor es el que proviene de la 
Musa C'avendischii, que no alcanza mas de 4 á 5 piés de altura, segun dicen.

El baron Von Homboldt dice que un acre de tierra vuelto platanal produce casi 20 veces mas que igual terreno sembrado de trigo en Europa y que ningun rejetal de producto comestible; necrsita menos cuidado y gastos menores de cultivo una vez sembrado en suelo feraz y á propósito; dice además que sus frutos contienen 44 veces mas sustancia nutritiva que las papas y 133 mas que el trigo, y que no paren en los sitios que se encuentran situados á una altura mayor que 3,000 piés ó 1,000 metros por encima del nivel del mar y cuya temperatura media del año está mas baja que $68^{\circ}$ de Farenheít o $20^{\circ}$ centígrado: se ven sin embargo platanales á 4,600 piés de elevacion producir frutos perfectos, pero eso depende mucho de su esposicion: en la parte alta y fria de la isla de Puerto-Rico hemos visto platanales muy estensos magníficos y dando mayor producto. que en esa isla es el alimento casi esclusivo de la jente pobre y hasta poco acomodada : ayuda mucho á la manutencion de la esclavitud. Cuanto mas cálida será la temperatura, la:planta será mas robusta, por consiguiente el fruto; así es que los plátanos de las costas del mar son los mejores.

En una memoria leida delante del Instituto de Francia sobre ese vejetal, dijo el señor Boussingault: " $\mathrm{El}$ plátano es el fruto mas útil de la zona equatorial; es el sustento de los habitantes de las rejiones cílidas. Entre los trópicos su cultivo es tan importante como lo es en las zonas templadas el de las gramíneas ó cereales y de las plantas farináceas. La facilidad de su cultivo, el poco espacio que ocupa, la seguridad y abundancia de las cosechas, la variedad de alimentos que el plátano procura segun sus diferentes grados de madurez, hacen de este vejetal un objeto de admiracion para el viajero europeo. Bajo un clima en que el hombre necesita apenas vestirse $y$ abrigarse, se le ve recojer sin trabajo un alimento tan abundante como sano y variado. Al cultivo del plátano se debe sin duda el proverbio que tantas veces he oido repetir por todas partes entre los trópicos: "ninguno se muere de hambre en América, " palabras consoladoras que jamás he visto desmentidas. En la choza mas pobre se recibe hospitalidad $y$ se da de comer al que tiene hambre.» Dice además que el plátano produce sobre el mismo espacio de tierra mas sustancia nutritiva que el árbol del sagú, que da 8,000 libras de harina al año en 4,020 metros cuadrados, pues que ha visto un platanal producir por cada 100 metros cuadrados 1,233 libras de fruto.

En una fanega de tierra, que son 10,000 varas cuadradas, y á 4 varas de distancia, caben 625 plátanos, que producen á los 10 á 12 meses de sembrados, y que del segundo año en adelante producirín lo menos dos racimos por cada cepa, despues de enceparse con los retonios y contando cada racimo unos con otros de 25 plátanus, resulta una produccion de 1,210 racimos ó 31,250 plátanos, que usados como pan á 6 diarios por cada persona, proveerian de pan á 14 personas anualmente, con la ventaja de preparar el pan sin mas beneficio que arrimar la fruta al fuego; su conservacion solo costaria 8 
Ł 10 pesos, ó mejor dicho, nada cuesta á una familia campestre. Platanales hay, dice Codazzi, de mas de 80 años, produciendo siempre con abundancia, sin que la mano del hombre les haya hecho ningun beneficio, pues por su sombra y muchos renuevos no permite el plátano que se desarrollen otras plantas.

Diremos aquí algunas palabras acerca de las diferentes variedades ó especies de plátanos, tomando acerca del particular lo que dice don José A. Diaz : el plátano topocho ó variedad del plátano comun ó musa del paraiso, parece tener medio término entre el plátano y el cambur morado ó musa color de rosa; se acerca al primero por el gusto de la fruta y al segundo en la robustez de la planta, en la figura del cambur y la resistencia al tiempo seco. El topocho y el cambur morado se prefieren por esta última cualidad para levantar fundaciones de café de sequero. Pinton y maduro le comen bien las bestias, y maduro las gallinas, patos y pavos. El cambur morado difiere del topocho en el color de los tallos y la fruta que es del color que la califica. Su fruta es la mas propia para pasarla al sol ó preparar orejones. El plátano dominico es muy semejante al plátano comun, tanto en la planta como en el fruto, aunque un poco mas pequeño: se produce en todas las zonas como el cambur.

Cambur criollo ó pequeño: la planta es mas pequeña que la del morado y del plátano topocho $\mathrm{y}$ tiene el tallo manchado de puntos $\mathrm{y}$ vetas negras: el fruto, tambien mas pequeño, es mas agradable para comerlo crudo, y verde es el mas á propósito para la olla como recado. Cambur manzano: entre todas las especies o variedades este es el mas delicado: tiene los peciolos de las hojas y el tronco color de rosa, $\mathrm{y}$ las hojas mismas inclinan su verdor á este color; el fruto, tan pequeño como el cambur criollo, y mas delicado, tiene un sabor especial. Cambur pigmeo: apenas crece la mata á la altura de 5 piés y el racimo es tan enorme, que descollando como los demas por la parte superior de la planta, á veces toca al suelo y necesita de una estaca para sostenerle, y el fruto es mayor que el del criollo y su gusto es semejante.

El terreno mas á propósito para el cultivo de ese vejetal es una tierra vírjen recientemente desmontada, arcillosa y con mucho mantillo, pero cualquiera suelo de calidad regular, sea arcilloso, calcáreo, etc., ú otro, desde el momento que sea provisto de una fuerte capa de sustancias orgánicas en descomposicion, es decir, de humus ó de mantillo, le convendrá bastante bien, especialmente siendo bastante húmedo. Siempre dará mayor producto en los terrenos feraces, y allí el platanal puede durar hasta $20 \mathrm{y}$ mas años, mientras que en las otras clases de suelos menos ricos dura solamente 7 á 8 años: le gusta un terreno un poco húmedo. Despues de desmontado el terreno como lo tenemos dicho, limpiado y quemadas las malezas, yerbas malas, etc., se tiran líneas rectas con el cordel á lo largo de las cuales se hacen hoyos cuadrados como de pié y medio, distantes el uno del otro como de unas 8 varas y dentro de los cuales se coloca un hijo de plátano. Es preciso tener el platanal limpio de las yerbas y á los 12 meses ya la mayor parte de los piés dan producto; cuando se corta el racimo es preciso tambien cortar 
el tronco, á fin de que la cepa retoñe mas pronto: las mas veces esos seudo-troncos y las hojas se dejan podrirse en el platanal para abonarle, mientras que se les podria muy bien utilizar para el alimento del ganado en tiempo de escasez de yerba; de los peciolos de las hojas se sacan fibras finas que dan un hilo duradero. Para evitar la enfermedad que ha destruido ese rejetal en algunos paises de América y especialmente en la Guyana inglesa algunos años hace, el señor A. Garnet aconseja cultivarle del modo siguiente: se prepara el terreno en acírates ó cuadrados largos, anchos como de unas 12 raras, separados los unos de los otros por zanjas hondas como de 30 pulgadas, ó como de una vara; despues de dispuesto así se siembran. sobre cada vara cuadrada dos hileras de plátanos, de los que cada pié está distante de sus vecinos como de unos 18 piés ó como unas 6 varas y en quiconce, á fin de que haya una muy buena ventilacion. El platanal así establecido se ha de dar una labor á la parte no sembrada del suelo entre las líneas, con el azadon, y se le siembra de maiz, de ñames, de caña de azúcar, de frijoles, de yautias, ete., alternativamente.

En la costa Este de Demerara, los platanales duran mas de 20 años en el mismo suelo, sin abono ninguno, algunas veces se le aplica cal, lo que hace mejor efecto, y han seguido asi lozanos, dando mucho producto y no han pasado ninguna enfermedad; lo mismo sucede en Puerto-Rico, como lo tenemos observado, y nunca se abonan los platanales; sin embargo, cuando se podrá proporcionar cal á precio barato ó fabricarla allí mismo, será muy bueno emplerala, porque sus propios detritus hacen con el tiempo el suelo agrio, lo que no es favorable para la rejetacion.

Los renuevos, de cualquier tamaño que sean, constituyen la semilla: se despegan los hijos de la madre con un chicuron ó con otro instrumento, por la parte de afuera y á flor de tierra; se separan y para trasplantarlos se les tróncha por la mitad del mástil, pero no se han de sacar antes de la fructificacion de la mata primitiva ó fundadora de la macolla, porque sufren mucho, tantos los hijos como la madre. Las cabezas de las plantas que ya están demasiado crecidas y que apuntan ya los retoños tambien, se sacan dividiéndolas en tantas partes cuantas son las puntas que manifiestan los retoños, y cada uno de aquellos pedazos se siembra: en cuanto á las cabezas y retoños se sembrarán los ojos á flor de tierra.

Mientras el platanal es claro y nuevo cria yerbas y es necesario limpiarlo con el machete, pero despues que está cerrádo del segundo año en adelante, apenas necesita un macáneo de machete que remueva la hojarasca y corte algunas yerbas que salgan, pero es necesario todos los años repasarle para quitarle las hojas y conchas secas, dos veces, una á entrada de aguas y otra á la entrada de nortes, la primera por abril y la segunda por setiembre. El primer año de la siembra puede aprovecharse la tierra con yuca, frijoles o garbanzos ó con una siembra de maiz. El platanal teme los vientos fuertes $y$ la mucha sequedad y no ticne mas enemigos que las be:tias, tanto vacunas como caballares, pues aun sus hojas no son muy 
apetecidas, sin embargo les place desgarrarlas y comerlas. Debe estar pues bien cercado.

Los plátanos verdes, cortados en pedacitos y desecados al sol, forman un ramo de comercio de bastante consideracion en algunas Antillas, tales como Jamaica, especialmente cuando hay abundante cosecha de esa fruta, que por tal razon está muy barata en muchos lugares del interior de la isla de Puerto-Rico, en donde está baratísima, de tal manera que á veces se les emplea hasta para engordar los cerdos; se les podria aprovechar así hasta para la esportacion ó para vender en la misma isla y de este modo sacar de ellos mayor utilidad. El plátano verde se debe cortar cuando ha llegado á su mayor tamaño y desarrollo, entónces quitada la corteza ó cáscara, sea con la mano, sea mecánicamente, partidos en ruedas se les secará al sol del mismo modo empleado para el café ó el cacao, ó quizás mejor á favor de una estufa dispuesta á propósito, especialmente si se tenia que trabajar en escala mayor: así secos se pulverizarán y se pasará el polvo por una criva, entónces se liabrán vuelto harna de plátano, llamado coquin tay en Jamaica; en tal estado ha adquirido una fragancia particular parecida á la del heno fresco ó del té de la China. Bien preparada y bien seca se podria quizás hacer entrar en la alimentacion europea y llegada á Europa se la volveria mas fina moliéndola de nuevo mecánicamente y pasándola por tamices á propósito. El aroma de ese producto depende del cuidado $y$ de la prontitud con que se han preparado y desecado los frutos; por esta razon tal operacion no se debe hacer sino con tiempo seco y en el caso contrario ha de valerse del horno ó de la esiufa, segun la cantidad mayor ó menor que se ha de preparar: su color es siempre dañado por los instrumentos de hierro ó de acero que suelen usarse para descascarar y cortar el fruto y para moler y tamizar la harina, por esta razon seria mejor emplear útiles de niquel ó de aluminio: las cribas de alambres de cobre bien estañado serian á propósito: si se plantaba una fábrica en escala mayor habria de valerse de una máquina muy sencilla establecida sobre el mismo principio que la con que se parten en Europa los nabos y las zanahorias destinadas para el alimento de los animales, y se sacaria tambien la cáscara mecánicamente : de esa manera saldria el producto mucho mas barato $y$ por consiguiente dejaria mayor utilidad.

Yuquilla-maranta. - Maranta arundinacea ó indica. C. T. V. No 198. - El cultivo de tales vejetales da mucho provecho para el que dedica á él solamente algunos acres de tierra, 3 ó 4 , verbigracia; en efecto, puede sacar de su trabajo como unos 85 pesos, algo mas ó menos, término medio. Conviene mucho á ese cultivo un suelo colorado y rico, abundantemente abonado: el estiércol es el abono que mejor le favorece y despues de él vienen las plantas marinas ó basuras del mar, formadas de algunas clases de algas ó fucos que se han de emplear, el agua de mar que las moja, no escurrida todavía, cuando es posible hacerlo así : se las entierra en el suelo en los lugares correspondientes con los hoyos, es mejor estender el abono sobre el terreno y darle la labor inmediatamente.

La mejor estacion para la siembra de esa vianda es el mes de 
abril, pero se la puede sembrar desde marzo hasta mayo, antes de la Noël está espucsta á no salir tan buena : tal cultiro se hace de dos modos, sea escarvando hoyos con el azadon ó bien abriendo surcos con el arado en un terreno abonado y preparado como conviene: tales surcos, abiertos en línea recta como á 2 piés de intervalo y los hoyos pequeños hechos dentro de ellos con un piquete ó con un plantador, distantes los unos de los otros como de unas 6 julgadas, colocando en cada uno de ellos un hijo fuerte ó dos chiquitos, y se les tapa con un poco de tierra bien desmenuzada: en la primavera se debe desyerbar con la mano, porque de otro modo se podria cortar o dañar alguna matita, que despues no volveria tan vigorosa como antes. Necesitando un año para madurar sus tubérculos, se puede sembrar con ese vejetal papas, onion, sandías ó maiz, pero aquel último al parir no es muy favorable al plantío de yuquilla, mientras que será el contrario si se le corta verde para forraje. Se conoce que está bueno para cosechar en que sus hojas se marchitan, se vuelven amarillentas y se desprenden del tallo, lo que sucede á los 10 o 12 meses de sembrados los hijos; entonces se arrancan los tubérculos con el azadon, se deben limpiar de la tierra adherente con ellos, así como rle las raices y de su corteza, antes de elaborar la yuquilla ó arrow-root, que se prepara con mayor escala y con mucho provecho en la isla de San Vicente y con método perfeccionado y máquinas á propósito.

El lairen o lleren, C. T. V. No 199. - Se cultivará del mismo modo $\mathrm{y}$ en los mismos terrenos; se reproduce de los mismos tubérculos, como las papas, y será uno de los recursos para suplir el pan en caso de escasez, se le debe pues cultivar.

El capacho. - Canna edulis, coccinea, achiras y glauca. (Véase C. T. V. No 200. - Tales vejetales. que se cultivan en escala muy regular en las islas francesas, en Barbada y en San Cristóbal, suministran una clase de yuquilla ó arrow-root, llanada tous les mois en el comercio, que le aprecia mucho. Producen tubérculos bastante gruesos, que á veces alcanzan hasta el tamaño de la cabeza de un niño. Necesitan para su cultivo, que se hace como lo tenemos indicado para la maranta, terrenos feraces y muy ricos, y entonces su tallo alcanza hasta unos 12 á 14 piés de altura.

Aracacha ó apio de América. C. T. V. No 214 . - Este vejetal requiere un terreno negro, suelto y profundo, que se preste al de:arrollo de su raiz: para propagarle se corta en pedazos la caheza de la raiz, de manera que quede á cada uno un ojo ó yema y plantándolos así separadamente. La estacion propia de los terrenos naturales de sequío es en las dos primaveras de mayo y de octubre, $y$ en las de labor y riego se puede sembrar en todo el año, manteniendo la planta muy bien aseada, regada y amurillada, como planta jardinera: despues de tres o cuatro meses de vejetacion las raices están bastante desarrolladas para usarlas en la cocina; si se les deja mas tiempo adquieren mayor volúmen, sin perder nada de su sabor. Las aracachas, como las papas, no prosperan en los lugares muy cálidos, mientras que en los templarlos se producen regulares y mucho mejor en los trios ó á una temperatura de 15 á $17^{\circ}$ centígrado. Puede 
cultivarse desde las 500 varas, aunque con poca utilidad, y desde aquí se va mejorando gradualmente en su ascenso, siendo el terreno suelto, cargado de humus y bien removido.

Names. C. T. V. 189-190. - Les hay colorado, negro, blanco y criollo, suministrados por la Dioscorea triphylla; el name de Guinea proviene de la Dioscorea aculeata; el de la Barbada de la $D$. alata; el comun de la $D$. sativa, etc. Esos rejetales, cuyo cultivo es muy sencillo, se acomodan mejor de un suelo liviano, rico ó arenoso bien abonado con estiercol ó demas sustancias orgánicas rejetales en descomposicion que se meten en el hoyo hecho á propósito y por encima se amontona la tierra como de pié á pié y medio de alto, á fin que la raiz perpendicular que ha de volverse tuberculosa tenga mayor facilidad para desarrollarse y echar sus raicillas; se siembra un pedacito de tubérculo en un hoyito hecho en la parte superior del montoncito, se le tapa con dos ó tres pulgadas de tierra y se coloca una ó dos estacas para que sus tallos se puedan enredar y se queden así sostenidos; los piés se colocan ordinariamente como á una, dos ó tres varas de intervalo el uno del otro y segun el cultivo. accesorio que se quiera juntar con el primero. Los rames de Indias, de Barbada y el colorado se han de sembrar en mayo y se cosechan en enero siguiente; si al arrancarlos no ban sido lastimados los tubérculos amontonados con cenizas y bien envueltos en ella se pueden conservar buenos en un sitio seco; los primeros como nueve meses y los segundos como 12 y por consiguiente esportarse con facilidad embarrilados con ceniza y polvo de carbon. Los names de Guinea ?el portugués se han de sembrar en enero y se arrancan en setiembre, mientras el criollo y los malangas se cosechan en enero y las batatas sembradas con ellos desde enero hasta marzo.

Se puede sacar de todas las clases de name y especialmente de la variedad Buckyam de los Ingleses, una fécula de calidad superior; esta última clase, criada en un suelo rico y bien liviano, es tan buena $y$ tan harinosa como las batatas, pero tiene el inconveniente de no poder conservarse sino poco tiempo, y por tal razon no se puede esportar sino despues de partida en ruedas y desecada.

Un acre de tierra sembrado de ñames y de batatas á la vez en terreno á propósito abonado como conviene, es capaz de producir $4 l_{[} 2$ toneladas de cada clase de tubérculos en el intervalo de 12 meses, lo que hace 9 toneladas de ambas raices, producto magnífico.

Yautia, malanga, tanias, taro, etc. Arum esculentum y Colocasia, etc. Véase C. T. V., núm. 174. - Esos vejetales, bien que de buen producto, no han sido cultivados en escala mayor; sin embargo, en las Islas francesas se siembran para dejar descansar el suelo despues de arrancadas las cañas, y esa vianda sirve para la manutencion de la clase laboriosa y poco acomodada, y por consiguiente es muy poco apreciada de los ricos que apenas la utilizan, aunque seria de mucho provecho para los hacendados que tienen que mantener un numeroso peonaje; además ese vejetal no encontrándose perjudicado ni por la seca, ni por la humedad tampoco, ni por ninguna otra cosa que arruina y destruye los platanales, batatales y las sementeras de maiz será siempre prudente $y$ útil tenerle al menos co- 
mo cultivo secundario, á fin de que supla á las otras viandas si por acaso faltasen ó que su producto saliera escaso. Todos los suelos convienen á tal cultivo, y especialmente un terreno liviano algo arenoso y algo húmerlo á la vez, sin serlo demasiado sin embargo; se le siembra raras veces solo, pero de ordinario junto con los demas vejetales alimenticios; su cultivo es sencillísimo; en efecto, basta hacer en el terreno destinado para los hoyos como de un pié cuadrado y otro tanto de hondo y colocar en esa tierra bien desmenuzada unos dos ó tres hijitos distantes de como 6 pulgadas el uno del otro y triangularmente puestos, tapándoles con unas cuatro pulgadas de tierra; tales hijos han de estar como á tres piés y algo mas los unos de los otros por causa de sus grandísimas hojas; cuando se siembra como cultiro secundario, entónces se esparcen las cepas por el campo de manera que su sombra no puede perjudicar á los vejetales con que se le junta, y será bueno escojer siempre aquellos cuyos tallos crecen mucho mas altos que él, tales como los ñames, plátanos, maiz, etc. Principia á dar producto á los trece ó catorce meses de sembrado y la misma planta puede, con un poco de cuidado y el cultivo mas sencillo, dar dos y hasta tres cosechas al año; basta para eso sacar con cuidado los tubérculos maduros ó llegados á su tamaño, de manera á no lastimar los hijitos y bien arreglar el suelo despues de esta operacion. Ese vejetal esperimentó en Jamaica, algunos años hace, una enfermedad análoga á la que en Europa acometió á las papas y por poco acabó con ese cultivo.

Un solo hombre trabajando durante como unos 15 dias puede cultivar una cantidar suficiente de esa vianda sembrada en un suelo á propósito para la manutencion de seis á siete de familia. Por tal razon, despues de la emancipacion de la esclavitud en las Islas inglesas y francesas tambien, muchos negros han sostenido su vida y la de su familia con ese alimento único, porque entónces no miraban la libertad que habian recibido sino como el medio de no trabajar y de entregarse á su apatía, abandono y pereza naturales.

Batatas. C. T. V. núm. 210. - Ese cultivo se hace en escala mayor en las Antillas, en donde se aprecia mucho; tal vianda, que se come con abundancia y casi únicamente en algunos lugares por la gente pobre y poco acomodada, tambien se pone en la mesa de los ricos, que no la desprecian. Los terrenos mas á proposito para tal cultivo han de ser de clase liviana y arenosa con mantillo rico, desmenuzable y negro, ó un sub-suelo pedragoso; se crian muy bien en las pendientes de las colinas, en las orillas de las quebradas pedragosas y hasta en los lugares estériles y casi hasta inútiles para otra clase de cultura; sin embargo, será siempre bueno abonar los suelos pobres que se dedican para ese cultivo, del modo ya indicado mas económico con los abonos verdes, las plantas marinas ó basura del mar, las que se crian en las sanitrales, las malezas herbáceas, etc., puestas en el suelo con abundancia le convienen mucho. Para sembrar tal rejetal se han de hacer surcos con el arado pequeño, cuando la naturaleza del terreno lo permite, en línea recta y como á una vara de intervalo y la semilla se coloca como á un pié de distancia una de otra, y los mejores tubérculos para siembra son los de 
á 8 ó á 12 por libra; si pertenecen á la clase blanca y de tallo enderezado, se ha de arrancarlos al principio de marzo y tenerlos guardados así durante un mes, á fin de que se sequen un poco antes de entregarlos á la tierra; pero se emplean para propagarlas ordinariamente los bejucos que han de proporcionarse mas vigorosos y mas recientes ó frescos posible y bastante largos para que tengan seis nudos, de los cuales tres o cuatro se colocan en la tierra preparada como conviene, mientras dos se quedan con sus hojas por afuera del suelo; los surcos abiertos en el terreno abonado y bien preparado con labores anteriores se les meterá en la tierra, á un pié de intervalo el uno del otro; tales surcos se deben hacer en tiempo seco, y si durante ese trabajo el tiempo se pusiera lluvioso, no se deberia demorar la siembra que se habria de efectuar lo mas pronto posible ; se puede sembrar mucho en el intervalo de un dia; la estacion mejor para la siembra principia á fines de agosto hasta principios de setiembre. Algunos dicen que quitando las flores, los tubérculos se criarian mucho mayores.

Yuca dulce y brava. - Jatropha Loeflengii, y J. manihot. M. D. - G. 135̃. - Un suelo seco y mezclado es el mas á propósito para el cultivo de esos vejetales, que prosperan sin embargo en el suelo mas pobre, de tal suerte que en Puerto-Rico se suelen dedicar los arenales para esa cultura que da mucha utilidad; si el terreno empleado estaba húmedo, seria preciso, para tener la cosecha buena y abundante, desaguarle por medio de zanjas buenas hechas á propósito. Tales vejetales estenuan bastante el terreno para no cultıvarles mas de dos á tres veces de seguido en el mismo lugar, y se sacaria siempre mayor provecho de esa cultura haciéndola alternar con otras y abonando el terreno con abonos verdes ó con sustancias vejetales en descomposicion y prontas para volverse humus ó mantillo, que le conviene mucho. Se puede cultivarla hasta la altura de 3,200 piés por encima del nivel del mar, y se dice que un acre de tierra sembrado de yuca brava da tanta sustancia nutritiva como seis acres de trigo en Europa ; para los indios y los negros esa vianda reemplaza muy bien los cereales. Se necesita muy poco gasto y poco trabajo para plantar un yucal de alguna estension; en efecto, basta, despues de limpiado el terreno como conviene, hacer con el azadon hoyos cuadrados como de un pié de largo y de otro tanto de hondo. Guarnecidas de mantillo ú otro abono puesto en su parte superior que se queda abierta; dispuestos así se colocan dentro de cada uno de ellos, distantes como una vara el uno del otro, dos ó cuatro estacas que se sacan de los tallos en completa vejetacion $y$ se les tapa con dos ó tres pulgadas de tierra; se debe escojer para esa siembra el principio de la estacion de las lluvias. Basta entonces desyerbar de cuando en cuando, hasta que haya alcanzado la altura ordinaria; al primer desyerbo se aporca un poco, y despues se amontonan las yerbas al pié de cada mata para servirle de abono; mejor seria enterrarlas en derredor con cuidado para no lastimar las raices; álos ocho ó nueve meses por lo regular, los tubérculos ya han llegado á su madurez y están buenos para arrancar ócosechar, pero se pueden quedar mas tiempo en la tierra sin perjudicarse. 
Se esporta de la isla de Sta. Lucia mucha harina de manilıot, de casahe y de tapioca, así como de las Islas francesas; se cultiva tambien en Puerto-Rico esas viandas en escala regular y se fabrica casabe especialmente, que se vende en el pais sin esportarla afuera; pero los medios empleados para tal operacion necesitarian perfeccionarse mucho, y se hahrian de aplicar á esa industria maquinarias á propósito, si se quisiera plantarla en escala mayor y con economía, á fin de sacar mas utilidad de ella. Pocos años hace, el señor James Glen ha puesto en la lıacienda Hagobrh, en Demerara, una maquinaria con el objeto de elaborar almidon de yuca brava y ha enviado ese artículo á Inglaterra por cantidades considerables, en donde se le ha pagado un precio tal, que le dejaba una utılidad mayor que el cultivo de la caña de azúcar. En Essequibo, un acre de tierra buena, arenosa y permeable ha producido 25 toneladas de yuca verde, lo que es maravilloso. Se cultiva muchísimo en la Guyana, en donde el casabe es el único pan de la gente poco acumodada, de todos los del campo y de los indios. Diremos pues que por el poco costo de su cultivo y.jor la mayor utilidad que deja el producto que de él se saca, conviene mucho ese cultivo á los que para trabajar tienen un capital corto.

Heliunthus tuberosus. Ese vejetal, que es natural del Brasil, se puede cultivar con provecho en las Antillas, en donde se cria perfectamente bien y suministra muchos tubérculos muy buenos para comer y bastante alimenticios; se sembrarán hijos en un terreno bien rico y como arcilloso rojo, ni scco, ni húmedo; es mas cultivo de jardin ó en corta que en mayor escala y á los 6 meses de sembrado se puede cosechar.

Frijoles. M. D. - G. 1077. - Los frijoles y las habichuelas, las caraotas, no se cultivan en escala mayor en las Antillas, $y$ sin embargo seria muy provechoso hacerlo así, porque no solo se gasta muy poco para su cultivo y que deja bastante utilidad, sino que tambien por la razon que constituren un alimento muy rico en azoe, y por consiguiente muy á propósito para la manutencion de la gente pobre ó poco acomadada que vive casi esclusivamente de vejetales feculentos y de bacalao, casi sin comer nunca carne ninguna que reemplazarian hasta cierto punto. Además esos vejetales sacando mucho de la atmósfera dejan en el suelo con sus raices y demas despojos casi tanto cuanto han sacado de él, de tal manera que su cultura necesitará muy poco abono; se les utiliza tambien con muchisimo provecho para abono verde, como lo tenemos ya señalaéo mas arriba, páj. 431. Se siembran en líneas rectas, despues de haber dado tres labores al suelo que ha de ser rico ó bien abonado con estiercol y bien desmenuzado, al principiar la estacion de las lluvias o desde mayo. Tales líneas han de estar distantes las unas de las otras como de $0,30 \mathrm{~m}$. a $0.40 \mathrm{~m}$., ó como 10 pulgadas hasta un pié ó algo mas 14 julgadas, y cada matáa $0,15 \mathrm{~m}$. ó $0,20 \mathrm{~m}$. la una de las otras á lo largo de la hilera, ó 5 á 7 pulgadas; cuando el vejetal habrí ya alcanzado como $0,06 \mathrm{~m}$. á $0,08 \mathrm{~m}$. de alto, ó tendrá de tres á cuatro pulgadas se desyerba el terreno y se le aporca lijeramente; se debe volver á binar y á aporcar el plantío cuando las matas es- 
tán para echar las flores; en fin se les bina por la última vez como tres semanas despues. Cada vez que el suelo estará desecado hasta como á tres pulgadas de profundidad, será muy bueno y muy ventajoso regarles por infiltracion, introduciendo el agua en las regueras ó surcos que se encuentran entre las líneas y que provienen de las operaciones del binar y aporcar las matas; en fin, la cosecha se hará arrancando á la mano las matas por tiempo seco, y cuando la mayor parte de las vainas se haliarán maduras; se limpian las matas así arrancadas de las pocas hojas que adhieren todavía y de las partes demasiado verdes; se las reune en paquetitos ó manojos que despues de atados se cuelgan de pertigas dispuestas á propósito en $u n$ rancho ó tinglado para que se sequen con facilidad; su esposicion al sol durante algunas horas antes de sacarlas para sacar las semillas. Se admite que para conseguir una cosecha abundante de ese cultivo se consume bastante abono; en efecto 100 kilógramos de semillas y paja junta cosechados han gastado, segun los esperimentos hechos con cuidado, 367 kilógramos de abono normal, lo que corresponde como á 16,000 kilógramos por cada hectárea; al parecer del agrónomo Crud, ese cultivo, al contrario, estenua poco el suelo. Los garbanzoś no se han cultivado en las Antillas, hasta ahora, en escala mayor. Su cultivo es semejante al de las caraotas y frijoles en los terrenos naturales de montaña ó rastrojo, si se quiere hacer una siembra formal. En los terrenos de labor, despues de haberlos abonado suficientemente y haberles dado dos rejas, al dar la última una mujer ó un muchacho va detras del arado, sembrando en el canal de los surcos, dejando caer los granos, al paso que va caminando, uno á uno ó dos á dos, sin cuidar de las distancias; concluida la siembra, se pasa la grada para que el suelo quede igual y la semilla cubierta. Durante el incremento de la planta, se le dará uno ó dos desyerbos aporcados, $y$ cuando se empiecen á marchitar las matas y las vainas, ó á ponerse amarillas, se arrancarán de raiz como las caraotas, se secarán y entrojarán del mismo modo para desgranarlas. Las bestias comen bien la paja, pero es preciso dársela con economía y mezclada con la de arroz, porque es muy cálida y puede darles toroson, lo que sucede con el maiz crudo, cuando se les da con esceso ó que tienen sed.

Guaracaros. - Lablab vulgaris.- Pois souche. M. D.-G. 1,070. - Se siembras como las caraotas, pero á la distancia de una vara por la hilera y vara y media de calle, teniendo cuidado de clavar al lado de cada planta una estaca que sobresalga, y dos varas ó mejor una rama seca que tenga algunas horquitas; se aprovecharán los claros con una calle de maiz y otra de frijoles alternadas. La siembra se hará precisamente en agosto $y$ á la vez los frijoles para cosecharlos antes de las lluvias de noviembre, tan perjudiciales para ese fruto. Se cosechan como el frijol, porque sus flores y semillas vienen alternativamente, y se secan, guardan y desgranan del mismo modo. En todos estos granos, los mejores para las semillas son los que se caen espontáneamente en el patio donde se secan ó en el granero en que se guardan, porque son los que se desprenden de las vainas mas sazonadas, las cuales revientan por sí solas. En cuanto al maiz, 
no se debe sembrar antes de octubre; como el maiz crece con rapidez y que para entónces el guaracaro está desplegando sus rejos, es necesario pasear la siembra para guiar los tallos que se desvian de su apoyo, asiéndose del maiz naciente como de los frijoles ya avanzados, porque los sofocarian.

Coco, palma de coco. - Cocos nucifera. M. D. - G. 91. - Ese vejetal necesita, segun Marschal, para vejetar con lozanía y dar mayor producto, una temperatura media que no baje de $72^{\circ}$ furenheit, ó $+22^{\circ} 3 \mathrm{c}$. centígrados; un terreno húmedo, arenoso y mas ó menos rico, pero especialmente situado lo mas cerca posible de las orillas del mar, y hasta en los sanitrales ó arenales mas ó menos bañados por sus aguas; tal árbol principia á parir como á los 4 ó 5 años y sigue así durante 80 y 100 años, y puede alcanzar como unas 25 ó 30 varas de alto; á los 8 ó 10 años ya es de buen producto en los suelos buenos ó que convienen mejor á ese cultivo. En los suelos, al contrario demasiado secos y mas apartados de las orillas del mar, no principian á echar flores sino á los diez años y algunas veces mas tarde. Sin embargo se puede cultivar, mas con mucho menos provecho, hasta la altura de 500 varas. En Carácas echan sus frutos, pero sin comida, y por consiguiente son imperfectos é inútiles. Lo hemos hallado lozano y bien productivo en las misiones de bajo Orinoco, á como 50 leguas del mar, en los alrededores de Angostura ó ciudad de Bolívar, á como 80 leguas del mar y hasta en San Fernando de Apure, como 120 leguas de la embucadura del Orinoco. En los terrenos á propósito está produciendo anualmente 100 cocos hasta 40 ó 50 años, pero desde esta edad empieza á decaer gradualmente su produccion, pero nunca se esteriliza enteramente aun en la mas avanzada.

El abono mas conveniente á ese cultivo es las cenizas, el pescado salado podrido y que ya no puede aprovecharse para la alimentacion; el lodo salado y las basuras del mar ó algas empapadas de agua salada. El terreno escojido mas á propósito posible, es decir á las orillas del mar, si se puede algo húmedo ó que se pueda regar con agua salada, se principia por limpiarle de las yerbas y arbustos que despues de amontonadas y desecadas al sol se queman, conservando las cenizas para echar en los hoyos en el momento de la siembra, los cuales se harán en línea recta como á 9 ó 13 varas de intervalo por todos lados, segun el terreno será mas ó menos conveniente para ese cultivo, lo que dará como 58 palmas en el primer caso y solamente 44 en el segundo por acre de tierra, y se colocaraín en ella los cocos sacados del semillero; antes se suele echar en el fondo del hoyo un puñado de sal; las algas ó basuras del mar, á nuestro parecer, son mas útiles y saldrian mucho mejor ; se les puede echar en tierra á mediados ó á fines de enero, cuando el semillero se formó en octubre ó en noviembre, y en octubre cuando se le hizo en junio; durante los dos primeros años de sembrados es muy conveniente abonar el suelo y sus alrededores con lodo salado, cuando se puede proporcionarlo con facilidad y á poco costo, ó bien con plantas marinas ó basuras del mar en los lugares en donde la mar les amontona en sus orillas; se debe además tener el cocal lim- 
pio de las yerbas, de los bejucos y de los arbustos, á fin de que reciba bastante aire, y seguir así hasta que estén suficiente crecidos los cocoteros para no sufrir ningun perjuicio de las yerbas y arbustos que pronto estarán ahogados y despues se quedará por debajo de ellos un pasto muy regular que se utilizara con ventaja. Entonces no habrá mas cuidado que el de cosechar los frutos maduros, cargarlos en los establecimientos y elaborar el aceite.

Una palma de coco echa un racimo cada mes y tiene por consiguiente siempre frutos maduros y secos que cojer, frutos verdes $y$ flores; produce pues en termino medio al año unos 80 á 100 cocos, de los cuales un ciento da, estraido como conviene, á lo menos 21 [2 galones de aceite. Si el cocal tuviera por ejemplo 100 acres de terreno contendriá en el primer caso 5,800 palmas, y en el sezundosolamente 4,400 que, á 50 cocos cada pié en término medio, darán al año 290,000 á 220,000 nueces, que suministrarán, á $21 / 2$ galones el 100 , como 7,250 á 5,500 galones de aceite que, calculados solamente á como 5 ó 6 reales cada galon, libres de gastos, dan $5,435,50$ pesos a 4,468 ; pero si por otra parte, en lugar de producir 50 nueces, término medio, cada palma pare hasta 80 , como sucede las mas veces á los cocales, cuyo terreno es á propósito y situado á las orillas del mar, con irrigaciones bastantes, entónces la utilidad será mucho mayor, y si los establecimientos están planteados como conviene para la mejor fabricacion posible; además habrá que tenerse en cuenta el azúcar que se podrá sacar del agua contenida en las nueces al abrirlas ó del alcohol que provendrá de su fermentacion: el bagazo ó panac, que es el residuo que queda despues de la estraccion del aceite que se evalua como á $l_{[} 4$ de libra por cada nuez, ó sea quizás algo menos, y que se utiliza para alimentar y hasta para cebar cualquiera clase de animales, sea para abonar los terrenos, como ya lo tenemos señalado mas arriba, páj. 458, y se puede evaluar como á unos 50 pesos la tonelada ó quizás á nuestro parecer algo menos, pero que pagará casi el costo de la elaboracion del aceite que se vende muy bien en Inglaterra, en donde se le podrá mandar despues de preparado como conviene; el valor de la parte fibrosa sacada por medio de la fermentacion de la concha, despues de quitado el casco, que tambien se puéde aprovechar y que se podrá mandar á Europa en forma de hilo ó de estopa, como se hace en Ceylan, de donde se esporta para Inglaterra tal producto, bajo forma rle cuerdas, de hilo y de estopa, en escala mayor, y deja bastante utilidad.

Cuando se trata de plantear un cocal suele principiarse pordisponer un semillero, lo que se hará de la manera siguiente : se colocan los cocos maduros y secos en el suelo por cuadrados de á 400 y se les cubre con una capa de arena ó de lodo salado espesa como de 1 a 2 pulgadas, con el cuidado de regarlos diariamente hasta que revienten, lo que sucederá á los tres meses en un suelo propio y á las orillas del mar. pero en el interior y á mayor altura tardará 4 á 6 meses su germinacion. Al aparecer la yema por afuera, serán buenos para sembrar cuando se quiera, pero quizás mejor será esperar á que tengan media vara fuera de tierra y tres á cuatro hojas. Se deben 
escojer para semilla los cocos secos, perfectamente madurosy caidos naturalmente. Los semilleros se establecen sea en junio, sea en octubreó en noviembre. En la isla de Ceylan, en donde hay tantos cocales hermosísimos, no se suelen formar semilleros, pero despues de escojido el terreno, haberle limpiado como conviene, se esparcen en el suelo cocos maduros y se les abona, así siguen todos los periodos de su germinacion, se desarrollan y crecen sin otro cuidado y á los cinco años principian á parir. Se podrá tambien sembrarlos así en las Antillas, pero á nuestro parecer seria bueno $y$ muy conveniente, despues de limpiado el suelo como lo tenemos dicho, disponer hoyos apenas hondos de como tres á cuatro pulgadas y solamente del tamaño de los cocos y en línea recta y distantes los unos de los otros como lo tenemos dicho mas arriba, con cuidado de cubrirlos con una capa de Jodo salado ó de arena, dándoles agua con frecuencia y desyerbando cuando habrán reventado y segun será necesario y cuidando el cocal como lo hemos dicho mas arriba, y ese metodo muy poco costoso saldria muy bien.

Se pueden además cultivar frutos menores en el cocal, porque la desnudez de los altos estipes y lo esparcido de sus frondes ú hojas ni dan una sombra que lo impida ni privan las plantas del aire necesario. Así es que no hay dificultad en que pudiera hacerse en el cocal, cuyas matas están á 8 varas de distancia, una plantacion de café, con tal que se le podria regar en el caso que faltasen las lluvias en la época perentoria y decisiva para asegurar la cosecha; en este caso se conseguirá cultivar dos haciendas en un mismo terreno igualmente productivas. El café debe seguir la misma ahiladura de los cocos á la distancia de tres varas y media por medio de las calles vacías, $y$ un cuadro de tierra de 100 varas á 1,000 varas cuadradas contendrá además de 164 matas de coco ahiladas al cuadro ó 184 al triángulo, 890 matas de café ; las cuales cuidadas y regadas oportunadamente deben producir 13 quintales de ese fruto, que dejará un producto líquido de 91 pesos, que, unidos á los 280 proviniendo de los cocos, de manera que el cuadro así plantado de coco y café producirá 371 pesos anualmente. Como todos los cocos no maduran á la vez en cada racimo, no se debe esperar que caiga espontáneamente porque para alguno de sus usos no son á proposito en toda su madurez, hay que trepar al árbol para descargarlo; pero para ese trabajo bastarín 5 tareas mensualmente ó el gasto de 31 pesos al año y siempre resultará un producto líquido de 350 pesos.

En las Indias Orientales además de estraer el aceite de la carne ó almendra de coco separada del casco que la contiene, suele hacerse desecar al sol, en cuyo estado la llaman copperah, que los maleses, coolies y demas naturales utilizan por alimento, y además se saca de él con mayor facilidad un aceite de bastante valor $\mathrm{y}$ que se pide mucho para varios objetos en Inglaterra, ó se manda el copperah á Europa en, donde se vende muy bien para estraer aceite de él, lo que se hace con mayor facilidad $y$ casi sin gasto, pues que la prensa mas sencilla y puesta en accion con un buey basta: el único cuidado que se necesita consiste en que la presion esté lenta y graduada, á fin de que el aceite al salir lleve consigo la menos cantidad posible 
de pulpa. Para preparar el copperat, despues de sacada la carne del coco $y$ de partida en pedacitos, se la espone al sol colocada sobre esteras á propósito hasta que se haya vuelto rancia, muy blanda y semilíquida, se la embarilla así para la esportacion, que se hace en escala muy regular en Ceylan, pues que en el año de 1852 se mandaron 13,325 quintales ingleses, que son 112,000 libras, de ese producto á Inglaterra, y dejó muy buena utilidad. A nuestro parecer, seria muy provechoso preparar en las Antillas el copperah para la esportacion, porque eso se haria casi sin costo ninguno, economizando así la mano de obra necesaria para la estraccion del aceite y las máquinas á propósito. Cuando se quiera trabajar en escala mayor, nos parece que seria bueno no limitarse á la esposicion al sol, pero disponer secadores de cajon que, vueltos en su lugar de noche ó cuando el tiempo no estaria á propósito, podrian gozar el beneficio de una estufa dispuesta á propósito, cuyo calor así empleado acortaria mucho el tiempo necesario para esta preparacion, que se podria hacer además en cualquiera estacion y por cualquier tiempo y de un modo continuo.

Para el comercio el aceite se estrae, en las Indias Orientales, solamente del copperah, por mas económico y el que se prepara por el método de la ebullicion, como lo tenemos ya señalado en la parte medica de esta obra sirve únicamente para comer. En Puerto-Rico, ese aceite se estrae únicamente por la ebullicion; en la isla de Trinidad, en donde hay cocales de consideracion, costa Este, cuya mayor parte pertenece á la Corona, se emplean medios mecánicos pero poco perfeccionados, mientras en los demas se le saca con métodos muy atrasados y muy poco productivos; á nuestro parecer seria muy ventajoso emplear prensas fuertes y especialmente hidráulicas, porque no solo darian un producto mas abundante, sino tambien porque el panac o bagazo, vuelto entónces como un pedazo de madera casi enteramente desprovisto de humedad y de aceite y conteniendo casi únicamente las demas sustancias orgánicas sólidas, se conservaria perfectamente mucho tiempo sin alterarse y seria mucho mejor $y$ mas saludable para el alimento de los animales que el que se encuentra ordinariamente en el comercio húmedo y fermentando, por no decir medio podrido, que hiede muchísimo y bastantes veces pone enfermos á las animales que se le comen.

El enemigo de los cocales es un coleóptero, el orcytis rhinoceros, que, penetrando por el cogollo en el tronco y viviendo á espensas de su médula, acaba con el árbol cuyas hojas se vuelven amarillas y se muere. Unos cinco á seis años hace que las palmas de coco han sido acometidas en las Antillas por un sinnúmero de insectos de la clase de las cochenillas y que han hecho perecer muchísimos árboles; á nuestro parecer, cuando una palma está atacada por esa plaga es preciso cortar las pencas enfermas, quemarlas, así como las yerbas del cocal y pasar sobre los árboles una mano de la composicion siguiente: cal no carbonatada, agua y azufre en polvo.

Higuereta, ricino. - Ricinus communis. C. T. V.: 503. - Bien que este vejetal sea natural de las Antillas, muy raras veces se ha cultivado en ellas en escala mayor, pero casi siempre como cultivo 
secundario; los terrenos arenosos y de aluvion son los que convienen mejor á su cultura, y las mas veces se ve á ese vejetal salir espontáneo en tales lugares sin necesidad de ningun cuidado. Las semillas pueden sembrarse en setiembre, distantes las unas de las otras como de 10 á 12 piés y en línea recta con un intervalo de 3 á 4 varas entre ellas. Despues de haber preparado el terreno como conviene, con una labor; despues de desyerbado y de quemadas las basuras, será bueno volver á limpiar el plantío de las yerbas cuando la siembra habrá echado su tercera ó cuarta hoja, á fin que no esté ahogada; ya parirá en la estacion siguiente y seguirá pariendo todo el año durante cuatro años consecutivos. Al año de sembrado se podrá muy bien sembrar otro vejetal que siendo mas bajo que él dará producto sin hacerle perjuicio; las batatas, los manis, el ajonjoli y demas vejetales que gustan de igual sueln y que á la vez serán para él un abono. Al madurarse las semillas se vuelven parduzcas mas ó menos, segun la clase, y entónces se ha de recojerlas, cuando la espiga ó racimo que las lleva está seco $\mathrm{y}$ sus cápsulas prontas para abrirse naturalmente. Un acre de tierra sembrado con ese vejetal ó vuelto ricinal, produce al año 100 almudes de semillas, y cada uno de ellos basta para dos galones de aceite de higuereta; el bagazo que proviene de la estraccion de ese aceite no se puede aprovechar para los animales, mientras que constituje un abono regular que se aplica con ventaja á los ricinales. Segun el señor Heuze, ese vejetal empobrece el suelo, que necesita por consiguiente mucho abono.

Mani. - Arachis hipogea. M. D. - G. 1043. - Las semillas de ese vejetal conteniendo la mitad de su peso en aceite magnífico para muchos usos y que no se vuelve rancio, además su cultivo necesitando muy poco gasto, será pues siempre de bastante producto cultivarle en escala regular, sino como cultivo principal á lo menos las mas veces como cultivo secundario.

Un suelo seco, cálido y liviano le conviene mejor que ningun otro; por consiguiente saldrá muy bien en el mismo terreno que la yuca, los ricinos, etc., y en los terrenos de aluvion especialmente que se podrán regar con facilidad durante la estacion seca $y$ cálida. Despues de limpiado el terreno como ya lo tenemos mencionado tantas veces y de quemadas las basuras, se pasa el arado para volcar bien la tierra y se echará la semilla en los surcos abiertos en línea recta y como á media vara de intervalo, 3 á 5 semillas se colocan juntas ; cada surco está distante de los vecinos como de una vara; despues de alcanzada la planta sus seis primeras hojas, se aporca con el azadon y se desyerba á la vez. Se debe aporcar algunas veces, á fin de que los frutos puedan penetrar con facilidad en latierra y madurarse mejor. La siembra se hará desde mayo hasta junio. Ese vejetal está sujeto á estar atacado por los gusanos; será pues bueno vijilarle y además el ganado le apetece mucho, por lo cual se le debe tener bien cercado. Se emplean 250 á 300 litros, es decir 90 á 100 kilógramos ó 180 á 210 libras de semilla para una hectárea, bien se siembre en línea recta ó en hoyos á 12 ó 14 pulgadas de distancia uno de otro. Las vainas están maduras cuando las matas se habrán puesto amarillas, las hojas y tallos hallándose casi secos. Entonces se arrancan 
con la mano, se sacude la tierra y se cuelgan en ranchos á propósito bien secos y venteados; se desgranan por medio de mandadores muy livianos para no dañar los granos. Su producto es bastante variable; en efecto varia entre 1,500 y 4.500 kilogramos ó 3 a 5 mil libras por cada hectárea; el producto medio varia entre 1,800 y $2,500 \mathrm{ki}$ lógramos ó 50 a 70 hectólitros ó 5 á 7,000 libras; un hectólitro de vainas ó frutos pesando 36 á 40 kilógramos 72 á 80 libras, segun su tamaño y calidad. Se saca de los frutos no limpiados de la concha 30 á 34 por 100 de aceite, y de las semillas mondadas ó limpias 45 por 100 y que da en el primer caso $68_{[} 100$ de bagazo y $55_{[} 100$ en el segundo; ese bagazo es blanquecino por causa de que contiene fécula blanca muy fina y además 6 á 7 j 100 de azoe normal, es duro y pesa bastante; se puede aprovechar para el alimento de los animales domésticos; constituye además un alimento muy bueno para el ganado vacuno que aprovecha con gusto sus hojas ; tal residuo es tambien un abono magnífico. Tal cultivo, que deja bastante utilidad. está planteado en escala mayor en muchos lugares de América y se mandan á Europa anualmente muchos cargamentos de esa semilla saliendo de casi todas las partes del mundo.

Las semillas se ponen rancias con facilidad, $y$ viejas ya han perdido mucho aceite; se deben guardar los frutos en lugares o almacenes ni húmedos ni demasiado secos tampoco, porque en el primer caso se enmohecerán y en el segundo perderán en su peso notablemento.

Ajonjolí. - Sesanum orientale. M. D. - G. 540. - Ese cultivo necesita tambien de un suelo liviano, arenoso y seco: los terrenos de alıvion son muy apropiados para él, especialmente si se pueden regar; despues de desyerbados y quemadas las yerbas, malezas y hasta sus raices recojidas despues le las labores, se abren surcos en línea recta y se echa la semilla como á 2 ó 3 pulgadas de intervalo: las hileras deben estar á distancia las unas de las otras como de media vara, despues 4 á 6 hileras formando un acicarate ó cuadro mas ó menos largo y dirijido del Este al Oeste, se a jeja otro tanto terreno vacío para sembrar batatas ú otra vianda y se vuelve á sembrar otro cuadro igual al primero $\mathrm{y}$ se sigue así alternativamente : se pueden obtener dos cosechas al año en el mismo terreno, especialmente si se le puede abonar para la segunda siembra, $y$ al año siguiente se entregará á ese cultivo la parte empleada para sacar otro producto y que alterne con él. La tala sembrada en febrero estará ya buena para cosechar á fines de mayo y la segunda, entregada á la tierra en junio, se recojerá como en setiembre; otras veces se siembra todo el terreno: se dará uno ó dos desyerbos, segun lo requieran las yerbas.

Cuando se han vuelto las matas amarillentas y las cápsulas rojizas, la primeras principiando á re rentarse, se corta o se arranca la planta, se la ata por manojos ó hacecillos que se colocan derechos en el suelo, abriéndoles la base : esta operacion ha de hacerse antes de la madurez completa de todas las cápsulas, y especialmente por la madrugada $y$ por la tarde, porque se desgranan con mayor facilidad: 12 o 15 dias despues de arrancadas las matas, las cápsulas es- 
tán ya secas y buenas para desgranar, lo que se hace azotándolas, despues de puestas sobre una tela á próposito, con unas varitas o mandadores muy livianos; en término medio se cuentan 45 á 50 cápsulas por cada planta, conteniendo 40 á 50 semillas carla una. Ún hectólitro de semilla pesa 62 á 65 lílógramos ó 124 á 130 libras, y contienen 50 á 53 por 100 de aceite, pero no se estrae ordinariamente sino 46 á 48 por 100. El bagazo constituye un abono muy bueno y además se puede aprovechar para alimentar los animales domésticos; segun los trabajos químicos de los señores Soubeiran y Girard, contiene 11/100 ó 3,57 de azoe.

Una hectárea de tierra sembrada con sesamo en Argelia ha producido 14,75 kilogramos de semillas, de las cuales se han sacado 96 pesos de utilidad. La especie de harina que proviene del residuo de la estraccion del aceite sirve para dulces, para reemplazar la harina de almendras, para suavizar el cútis, $y$ además se jodria muy bien utilizar para los animales, que se la comen con gusto: la paja sirve para combustible y para abono. Se manda á Europa de muchos paises en donde se cultiva en escala mayor, anualmènte muchos cargamentos de sesamo, que se venden á muy buen precio y se piden mucho, porque su aceite es inmejorable para las fábricas de jabon.

Tabaco. - Nicotiana tabacum, N.repanda, Cba.; N. paniculata y glutinosa, Prú.; N. pusilla, Vera-Cruz. M. D. - G. 599. - El tabaco se presta á todas las temperaturas, pero prefiere la zona cálida, porque en ella vejeta con mas vigor: requiere un suelo silicioso con capa vejetal, prefiere el litoral, las orillas de las quebradas y de los lagos; en las demas temperaturas sus ventajas son relativas y siempre mayores en los terrenos vírjenes, proviniendo de bosques derribados. Es sabido que la sal da fortaleza á este vejetal y mejora su condicion, por eso sin duda le convienen las orillas del mar. Tardando cinco meses, poco mas ó menos, desde que se hace el semillero hasta su cosecha, y como no es conveniente que llegue esta en tiempo lluvioso, porque la hoja se lava y pierde gran parte de su cualidad, debe calcularse y preveerse desde el principio esta circunstancia, especialmente en los lugares donde nortea. La semilla se debe sacar de los lugares mas distantes y se debe evitar en lo posible repetirla en el mismo sitio.

La primera cosa que se debe atender cuando se quiere cultivar ese vejetal es la naturaleza del terreno, que debe ser muy rico : contener como 10 á 20 por 100 de materias orgánicas vejetales, bien incorporadas en él, arenoso y de aluvion, ni demasiado alto, ni demasiado bajo tampoco, capaz de quedarse con alguna liumedad, como son las vegas por lo regular, lo mas horizontal ó mas llano posible. Bien que este vejetal estenue bastante el terreno, sin embargo, si es rico y que contenga una regular proporcion de mantillo, se le puede cultivar en él durante algunos años seguidos, especialmente si se abona con guano ú otro abono muy rico en materias orgánicas y en minerales calcáreos: se laa calculado, á favor de es- . perimentos hechos con todo el cuidado necesario, que una tala de tabaco saca en tres meses de un acre de tierra como 170 libras de sustancias minerales, lo que es muy superior á la proporcion de 
iguales sustancias sacadas del suelo, sea por el trigo, sea por cualquiera otra clase de vejetal. en el intérvalo de 6 á 9 meses.

Es preciso principiar por formar el semillero ó almácigo, y se habrán siempre de escojer para eso, si se puede, los lugares en donde estuvo una hoguera, ó si no hay, quemar la tierra lo mejor posible, porque, como lo tenemos ya dicho, no solamente la postura saldrá mucho mas vigorosa $\mathrm{y}$ mucho mejor, sino que tambien muy pocas yerbas y muy pocos gusanos vendrán á molestarla y á dañarla. El sitio escojido para semillero se ha de limpiar de todas las yerbas. amontonarlas para que se sequen y llevar á ese lugar todas las yerbas secas, pencas, malezas, etc., dispuestas en montones ó mejor, si se pudiera, cubriendo toda su superficie de una capa bastante espesa, con alguna tierra por encima, y despues de todo dispuesto así, ponerle candela, de manera que todas estas sustancias vejetales se quemen completamente, pero muy despacito, á fin de que el calor pueda penetrar bastante en el suelo para matar á las semillas de las yerbas malas y tambien á los gusanitos ó á sus huevecitos, que se quedan escondidos en ella. Eso hecho se darán al terreno bastantes labores, para que la tierra esté bastante desmenuzable, con el cuidado de sacar de ella todos los terroncitos, las raices y hasta sus pedacitos, que se quitarán entónces con la mano : un rastrillo fino facilitará mucho esta operacion, todas estas cosas amontonadas y secas se quemarán, como lo tenemos ya dicho tantas veces: sus cenizas se esparcirán sobre las acirates ó cuadros, que se harán entónces como 3 á 4 pulgadas mas altos que el nivel general del terreno, anchas como de una vara, algo mas ó menos, pero siempre de modo que estando en la calle que separa los cuadros y cuya anchura es como de 6 á 8 pulgadas, se pueda con la mano limpiar ambos lados del acirate, arrancando las yerbecitas con los decios y cuidando con facilidad la postura, teniendo la tan pronto limpia de las yerbas como de los gusanitos: la estacion mas á propósito para entregar la semilla á la tierra es desde fines de diciembre hasta mediados de enero; sin embargo, algunos lo hacen desde mediados de noviembre: se toma una onza de semilla bien mezclada con 5 partes de ceniza seca ó de arena, á fin rle que esté separada lo mejor posible, $y$ se la echa al voleo ó se la riega sobre los cuadros así preparados y de manera que caiga lo mas regularmente posible y no demasiado espesa: despues de sembrada así se ha de pasar lijeramente el rastrillo por encima, y concluida esta operacion se pisa suavemente la superficie del acirate con la planta del pié, de manera que cargando así con el peso del cuerpo, la tierra adhiere á la semilla de tal suerte, que las lluvias no se la pueden llevar consigo. Si el semillero parece haberse vuelto seco por cansa del viento ó del sol, será necesario darle agua bastante para que el terieno se quede con hastante humedad liasta que la postura haya salido fuera. Si el sol fuese demasiado fuerte por causa de la posicion del terreno, seria - necesario darle sombra con pencas de palmera ú otro vejetal, sostenidas por encima del semillero con varejones y varillas dispuestas á propósito ó haciendo una troja por encima.

Es preciso vijilar la siembra en el almacigo ó semillero con mu- 
cho cuidado, á fin de tenerle muy limpio de las yerbecitas que pueden ahogar la postura y de los muchos gusanitos que se la comen al salirse de la tierra. Cuando el tabaco del semillero tendrá el tamaño de un plantel de col', es decir, como 4 á 6 hojas regulares, lo que sucede á los 30 ó 40 dias, entónces se tratará de arrancarle y llevar la postura al campo dispuesto á propósito para recibirla; esta operacion se debe practicar especialmente al anochecer ó por la tardecita y de la manera siguiente: se debe en primer lugar remover la tierra con cuidado, empleando para eso un palo cuya punta este dispuesta á manera de lanza como de una pulgada de ancha ó una palita de hierro hecha á propósito y de igual forma y tamaño: eso hecho se reunen las hojas de la postura las unas contra las otras y, metiéndolas con cuidado entre los dedos, se la arranca suavemente a fin de no romper las raices y se la coloca en un canasto á propósito para llevarla al campo sin que pueda lastimarse; cuando el terreno que siembrar es muy estenso, se puede sacar la postura por la mañana y por la tarde: despues de liaber arrancado lo que se puede sembrar en el dia, se ha de echar agua al semillero á fin de que la postura que se queda no sufra por esta operacion y que la tierra se vuelva á adherir á sus raices. Inmediatamente despues de formados los senilleros se ha de principiar á preparar el terreno destinado para ese cultivo: si el suelo está recientemente desmontado, lo que es mas favorable para que el tabaco salga de buena calidad y que el producto esté abundante, es preciso arrancar y quitar los mas troncones y raices posible y trabajar la tieria de tal manera que su superficie esté lo mas igual y mas nivelada posible: eso hecho, los troncones, raices y jerbas quemadas como lo hemos ya tantas veces señalado, se ha de esperar para dar al suelo una segunda labor igual á la primera, que las siembras hayan alcanzado como la mital del tamaño necesario para transplantarlas: es necesario esa vez sacar con cuidado todas las fibra: $y$ trocitos de raices que han podido quedarse mezcladas con el terreno, y así se remedia lo mejor josible el estado esponjoso de las tierras nuevas ó vírjenes, que ordinariamente es causa de que el primer año de cultivo sea poco productivo.

El suelo bien preparado y nivelado como conviene, se ha de partirle por cuadros ó acirates muy largos y dispuestos de tal manera que las lluvias no puedan escarbar el suelo ni desarıaigar el tabaco, llevándose el agua la tierra consigo, porque estará algo detenida en las calles que les separan, y la disposicion de los cuarlros ha de corresponder á la situacion del terreno y si no está pendiente el mayor espacio dejado entre las líneas puede cruzar oblícuamente para marcar las líneas á lo largo de las cuales se ha de plantar el tabaco; se colocará en cada estremo un palo ó estaca como de 3 piés de alto, con un cordel atado á su vértice, de modo que corresponda exactamente con la línea de siembra; tales hileras, que han de correr del Este al Oeste y á como 3 piés de intervalo, están señaladas por las estacas puestas de antemano, mientras que el cordel de la primera línea puesto, se la ha de sembrar colocando la postura como á dos piés y medio la una de la otra, formando así otras líneas, cru- 
zando las primeras de Norte á Sur; y se ata al cordel un trapo correspondiente con cada planta: la primera línea sembrada, se coloca el cordel de la segunda, atándole á sus estacas correspondientes, se ponen los trapos, se siembra la postura y se sigue así hasta que esté acabada la siembra; se debe tener cuidado en que, el cordel estirándose el trapo, no se aparte de la postura y que esté mal puesto: las plantas deben estar todas sembradas en igual direccion y distancia á lo largo de todas las líneas. Se debe sacar la postura del semillero despues de un aguacero y la puesta por la mañana en la tierra dispuesta para recibirla, á lo menos que el tiempo esté nebuloso ó lluvioso, se debe tapar inmediatamente, lo mismo se hará para la siembra por la tarde anterior, con pencas de palma ú otras hojas á propósito, á fin de ponerla al abrigo de los radios del sol saliente : será necesario darla agua, especialmente por las tardes, hasta que haya vuelto á levantarse el plantel y á echar raices; al hacer esta operacion se habrá de tener cuidado en reemplazar cada pié marchitado y que está pronto para morirse, de tal manera que todo el plantío esté igual y que todas sus hojas se abran casi juntas y sigan vejetando así del mismo modo. Entónces se ha de remover un poco la tierra en su derredor, aporcándola lijeramente con la mano y la pala estrecha mencionada mas arriba al hablar del semillero.

El primer desyerbo se ha de hacer pues temprano y antes que las yerbas dominen las nuevas plantas, las demas labores amuralladas se darán segun lo requiera el campo. Durante su vejetacion el tabaco está muy espuesto á encontrarse dañado por los 'gusanos, de los que unos se comen la postura al salir las primeras hojas y se quedan escondidos debajo de la tierra; otros salen de los huevecitos que han sido puestos en sus hojas por ciertas mariposas; se llaman gusanos del tabaco; son bastante grandes y viven á espensas de sus hojas; hay otros gusanitos mas pequeños que atacan la yema ó el corazon y que impide así su ulterior crecimiento ; en fin, otros se hallan escondidos entre las costillas, en la horquilla que forman al separarse las unas de las otras y por la cara inferior: se alimentan de los surcos que chupan del vejetal. El único medio empleado para destruirlos consiste en buscarlos en el tabacal por la mañana y por la tarde diariamente, hasta que la planta esté ya bastante crecida; entónces basta ir de cuando en cuando á buscarlos. Los muchachos y much achas de 12 á 14 años convienen mejor para ese trabajo, y premiando á los que traen mayor cantidad de gusanos con una friolera, se acaba pronto con el azote; como algunos hallan demasiado fastidioso rejistrar por debajo de cada hoja y de buscal tambien en la tierra, cuando se necesita, el propietario debe siempre vijilar por sí mismo el aspecto de su tabacal. Los pavos son muy á propósito para la destruccion de los gusanos, porque gustan mucho comerlos, de tal manera que en las grandes plantaciones será muy útil fomentar la cria de pavos para este objeto.

Las plantas de tabaco, teniendo como unas 12 á 14 hojas buenas y llegando ya como á la altura de la rodilla, es bueno detenerlas ó descogollarlas, y para eso se corta con la uña la yema terminal, con cuidado de no dañar las hojitas que la acompañan, las cuales si la 
tierra es rica y la estacion sigue favorable, se vuelven tan grandes $\mathrm{y}$ tan buenas como las demas y llegan á su madurez tan pronto como ellas: de ese modo se pueden aprovechar dos ó mas hojas; así se consiguen hasta 16 y 18 hojas por mata y de 12 á 14 término medio. Esta operacion es indispensable para determinar y favorecer el desarrollo de las hojas, así como para hacer llegar su madurez con mayor igualdad y ser mas completa : tiene además siempre por consecuencia inmediata hacer salir retoños de la axila de las hojas y se les debe quitar cuantas veces aparezcan. Este último trabajo necesita que haya constantemente peones empleados en el tabacal, de manera que semanalmente quede recorrida y arreglada toda la plantacion : estos desretoñadores deben ser á la vez desgusanadores, y entónces se habrán de emplear los que sean necesarios para el doble objeto, de suerte que la recorrida quede hecha cada semana; á los cuatro meses de trasplantado el almízago empiezan á sazonarse las hojas bajeras; su madurez se conoce por el color verde oscuro que toman, con algunas vetas azuladas y amarillentas y por la facilidad con que se quiebran y revientan sus peciolos de los tallos al inclinarlos un poco: tales hojas se recojen separadamente para tripa por ser mas ásperas, mas sucias y enterradas. Desde la capadura ó descogollo hasta la madurez completa transcurre un mes ó mes y medio, á proporcion de la estacion y de lo mas ó menos favorable que sea la esposicion del terreno; la variacion de color, cuyo verde se pierde en jaspes irregulares de un amarillo vivo, el avejigarse é inclinarse las hojas lánguidamente y por último el ponerse ásperas y quebradizas, son las señales mas notables de la madurez del tabaco, es decir, que está ya bueno para recojer.

No se han de cortar las matas nunca antes que haya llegado su completa madurez, lo que se conoce por lo espeso y grueso de las hojas, cuyo aspecto parece como moare : al tocarlas se las halla como gomosas ó viscosas entre los dedos, están cubiertas de una exudacion particular, con olor viroso, su vértice se va doblando por debajo, de manera que parecen mas cortitas que antes. Se debe evitar de cosechar con tiempo húmedo, á fin de no privarse de la sustancia viscosa particular ya señalada, lo que perjudicaria mucho su calidad. Cuando todo está listo ya para principiar la cosecha, los ranchos dispuestos de antemano, sea de un modo duradero, sea temporalmente y en el campo mismo en donde se hace la zafra, como lo hemos presenciado tantas veces en Puerto-Rico, se debe proporcionar un número suficiente de horquetas, largas como de vara y media ó algo menos, las cuales plantadas en el suelo verticalmente sostienen una vara fuerte ó una pértiga, de manera que forman así una especie de caballete en que se colocan las matas atadas por pares al cortarlas, sin que toquen al suelo, y se las deja así espuestas al sol y al aire libre bastante tiempo, para que se amortigüen, de tal manera que se evite estén lastimadas ó dañadas las hojas por su roce 6 contacto con los cuerpos estraños al llevarlas al secadero. Se corta la mata de un machetazo, ó á veces dos, aplicados oblícuamente á la parte inferior y al nivel del suelo, de manera que cortada la planta. no se caiga inmediamente y dé lugar á cojerla antes que se haya 
caido, porque si sucediese eso las hojas podrian lastimarse y hasta dañarse.

Las casas ó ranchos para secar el tabaco han de ser vastas y siempre en relacion con la cosecha que se ha de colgar adentro, con una calle en el medio, corriendo de un estremo hasta el otro para la ventilacion y dar salida al aire; deben además estar provistos por ambos lados de bastantes puertas y ventanas que se puedan tapar cuando sea necesario: los ranchos deben tener igual disposicion y sus lados se tapan con enramadas dispuestas como conviene; en las casas de secar, así como en los ranchos que las suplen en muchos lugares, hay vigas dispuestas á propósito para recibir las matas amortiguadas en el caballote, de donde se las lleva al secadero: ha de quedarse algun intervalo entre las dos matas, suficiente solo para que el aire pueda circular libremente por entre ellas y determinar su desecacion, que no debe ser muy pronta: á medida que se va adelantando tal desecacion, las matas se deben acercarse mas las unas de las otras, de tal manera que haya lugar para las que quedan, para poner en la casa de secar: el aire húmedo ha de ser escluido enteramente del secadero, ni se debe admitir el viento seco y cálido á fin de precipitar esa operacion, que debe verificarse poco á poco y de un modo moderado, esceptuada la estacion de las lluvias y entónces cuanto mas pronto se pueda secar será mejor. Durante que está desecándose el tabaco se afecta mucho por los cambios ó alternativas del tiempo, de tal manera que se mancha y cambia su color natural pardusco en amarillento ó amarillo pálido. Cuando la parte media del tallo está bien seca, se puede quitar la mata del colgadero, y las hojas sacadas entónces se ponen en montones para sudarse, á fin de volverlas tabaco, porque antes de esta última operacion que hace desarrollarse sus mejores cualidades, las hojas están muy sujetas á ser afectadas por el tiempo y no se las puede mirar ccmo otra cosa sino como hojas comunes secas, participando de la naturaleza del tabaco, pero no siendo todavía tabaco lejítimo.

La recoleccion ó cosecha se hace tambien por hojas que se arrancan, comenzando por las mas inferiores, de manera que se desprendan del tallo sin llevar consigo ninguna astilla de él. Una vez arrancada la hoja, se coloca sobre el brazo izquierdo y así se siguen arrancando las demas y colocando las unas por encima de las primeras y en el mismo sentido, hasta completar la brazada, la cual se deposita en un surco determinado ó sobre una tela ó cuero dispuesto á propósito, á fin de llevarlas al secadero con mayor facilidad y sin lastimarlas de ningun modo, l'ecargándolas en él de manera que queden puestas de canto, por ser el modo mas cómodo y conveniente. Como esta separacion se hace solamente con las hojas enteramente sazonadas, se habrá de repetirla dos ó tres veces hasta concluir la recoleccion. Despues de arrimadas así las hojas, se las lleva al secadero y se colocan en el suelo con la punta hácia arriba, arrimadas unas á otras : el piso de los secaderos debe estar entarimado ó al menos cubierto de paja, para evitar que se humedezcan las hojas : se las deja así dos ó tres dias para que pierdan su agua de vejetacion. lo cual se llama sudar, se calientan y principian á ama- 
rillar, poniéndose mas flexibles; entónces se hacen las sartas y para esta operacion se emplean hilos gruesos, con una aguja de arria, ensartándola por el cabo, ó en varitas aguzadas; se hacen tambien las sartas atándolas de tres en tres con una cuerda sacada de la concha del plátano ú otra á distancia de una tercia cada amarra de 3 hojas y así se van colgando en el caney ó rancho dispuesto á propósito.

Una rez colocado, en el secadero, bien sea en sartas ó ahorcadas, el tabaco se deja secar completamente, Io que dura 20 ó 30 dias, segun la temperatura, para formar los manojos y ponerlos á fermen tar, lo cual es la última operacion. La mejor señal para conocer la completa desecacion del tabaco es el estar completamente seco el cabo ó peciolo de la hoja y el no romperse esta, sino que vuelva á estenderse prontamente cuando se oprime en la mano. En tal estado se descuelgan las sartas y se deshacen los manojos con las hojas, igualándolas bien, de manera que ningun cabo sobresalga, y se debe escojer para esa operacion una mañana fresca; cada uno de estos manojos se ata con una hoja, dándola dos vueltas para que la segunda cruce sobre la primera $\mathrm{y}$ sugetando la atadura, pasando por el medio del manojo la punta de la hoja.

Se quitan las hojas de los tallos durante un tiempo lıúmedo ó neblinoso y entónces se manea mas quietamente $\mathrm{y}$ se separan sus varias clases. Las buenas hojas se ponen á parte para capa, y las otras tambien, pero para tripa. Cuando se pone el tabaco en montones se ha de colocar la costilla de las hojas todas vueltas en la misma direccion, á fin de que sea mas fácil cojerlas en la mano; el monton hecho como de uno ó dos piés de alto con una circunferencia ó base de tamaño correspondiente, se guardan todavía hojas para ponerse por encima de las otras y regularizar así la fermentacion ó el sudor: despues de las primeras 24 horas, las de la circunferencia se ponen en el centro $y$ las del centro se colocan en su lugar: eso hecho una vez ó dos, se debe tapar cuidadosamente el monton con sábanas dobladas ó con frisas, á fin de privarle, lo mejor posible, del contacto del aire, y abandonado así tapado, como unos 4 dias, adquieren las hojas un olor bastante fuerte para hacer estornudar y las demas cualidades propias del tabaco lejítimo: despues de eso se hacen manojos de á 24 ó 30 hojas, que despues de bien secos se ponen en bultos para entregar al comercio.

Esta operacion ó la cura seca se hace tambien pasando el tabaco seco al descolgarle á la cama para darle calentura. Esta cama, á falta de un cajon que tenga la capacidad suficiente, puede formarse con varas delgadas bien unidas, con figura de cajon, acomodando allí las sartas, procurando no maltratar las hojas; al fin se cubre y se prensa lijeramente, poniendo encima un peso moderado; se deja en ese estado por veirite ó treinta dias, segun la cantidad de tabaco, que cuanto mayor sea mas pronto suda. Otro método hay para dar la calentura al tabaco, que consiste en abrir un foso cuadrado en un lugar seco y de la capacidad necesaria; se abre en el verano, para que se seque bien al sol; despues se forma sobre él un cuarto techado y cerrado. Cuando se vaya á poner el tabaco en él se cubren con 
esteras su fondo y paredes para que no caiga tierra y allí se pone para esperimentar la calentura. Concluida esta se sacan las sartas y se desatan las hojas, las que se van escojiendo y dividiendo en tres suertes: para capa, capote y tripa; las primeras son las que están enteramente sanas, las segundas las que tengan algunas averías y las últimas las pequeñas y muy averiadas; hecha esta separacion, se las va poniendo separadamente en manillas de á 25 hojas, atadas por sus peciolos con una hoja del mismo tabaco y se amontonan dejando así refrescar por 15 dias, pasados los cuales pueden embalarse para conducirse al mercado; y aunque desde entónces pueda empezarse á labrar, estará mas acondicionada 6 meses despues. Algunos le dan una segunda calentura de 8 dias, rociándole ya con agua y sal, ya con vino y canela, sarapia y otros ingredientes para darle un gusto particular. Tal tabaco, comprado para las fábricas de cigarros, lo trabajan los cigarreros que le embetunan, es decir, que, segun el método particular de cada uno, le dan aromas y gustos particulares, mezclando con él preparaciones mas ó menos barbaramente hechas; pero engolfarnos en tal asunto nos llevaria lejos de nuestro objeto.

Cura negra: estancio ya sazonadas las primeras hojas y despues del último desretoño, se recojen y encaman como para la cura seca, y á las 48 horas, así frescas se despalillan, no en totalidad sino las dos terceras partes, quitándole el nervio central desde la tercera parte de la punta para abajo, quedando la hoja unida en la punta con lo mas delgado del nervio. En esta operacion se va separando la capa de la tripa y en seguida se van formando maromas que se llaman vulgarmente morcillas ó madejas del grueso de los dos pulgares unidos y del largo de 25 á 30 varas, para que con dos se haga el peso de una arroba despues de puesto en condicion. Para formar las maromas se van tomando manojitos de las hojas averiadas sobre las cuales se van acomodando en contorno las capas dobladas á lo largo por la mitad $\mathrm{y}$ de manera que la una quede pisada con la siguiente, y lo mas delgado de la hoja para afuera. Formadas así las madejas se hacen bolas que, se ponen en calentura, hacinadas unas sobre otras en bateas ó canoas, para recojer en ellas el ambir que destilen, con el cual se bañan despues; cada tres dias se han de voltear las bolas, formándolas nuevamente con lo de afuera para adentro, repitiendo la misma operacion todos los tres dias, hasta que ennegrezca el tabaco; entónces se va alargando el voltear de 4 en 4 y de 6 en 6 dias y hasta que esté todo el tabaco negro, hasta la tripa; esta operacion se llama bolear y necesita operarios diestros. En los últimos holeos se sacan las bolas al sol moviéndolas para que lo reciban por todas partes. Curado así el tabaco se desbaratan los emboltorios y se esponen las madejas nuevamente al sol por 4 dias, desde las 9 hasta las 12, volteándolas con frecuencia para que se sequen sin tostarse; á los 4 dias del sol se estienden en el caney ó rancho sobre las varas atravesadas y allí se dejan al aire por 20 ó 30 dias, para que no les quede humedad perjudicial á su conservacion : entónces se forman los rollos del peso de una arroba. Tal es el tabaco apetecido de los mascadores, que tambien lo usan para fu- 
mar. Regularmente se descuelgan las madejas para hacer rollos hasta la entrada de las aguas, á fin de que la humedad atmosférica los suavice y se presten dóciles á la envoltura. Además de todas las precauciones tomadas para la conservacion, si ha de permanecer algun tiempo almacenado, es preciso examinar los rollos abriéndolos un poco por las cabezas y oliéndolas para desbaratar y voltear el que anuncie putrefaccion. La formacion de los rollos requiere intelijencia para que queden de tres cuartas de largo y dos tercias de circunferencia poco mas ó menos. De la misma cura negra han inventado los marcadores otras preparaciones, á saber: la gar'apiña que consiste en una maroma delgada, como el dedo meñique ó algo menos, muy ambirada ó con mucho jugo, que proviene no solo de lo que suda naturalmente el tabaco sino con artificio, haciendo un fuerte cocimiento de los palos y tabaco averiado con que le bañan, algunos le agregan un poco de dulce. El anduyo es ese mismo tabaco doblemente ambirado ó embetunado, encerrado en los canutos de la caña hueca ó carrizo, en que se conserva fresco y en todo su jugo, se va gastando canuto por canuto; la hueva, para esta preparacion se hace uso de ambas curas y consiste en ambirar ó en embetunar las hojas abiertas, volverlas á sacar al aire $\mathrm{J}$ despues prensarlas unas sobre otras en manojos del peso de una libra. El mó y el chimó, de que hemos tratado en el Compendio de terapéutica, son preparaciones que usaban los indios ó indíjenas antes de la conquista.

Se cultiva en Costa-Firme y sale muy bueno y muy apreciado el del Rio-Negro, el de Cumaná, llamado Guácharo, de Upata, de Varinas, etc.

Las cepas de tabaco cosechado no tardan en retonar; entónces se ha de dejar el retoño mas fuerte quitando todos los demas, se limpia el tabaco de los yerbas que salen con los retoños que se han de aporcar y de cuidar despues como se hace para el mismo tabaco $y$ de ese modo se coje una segunda cosecha muy regular, pero cuya calidad es algo mas inferior; se ha de cojer la semilla de las matas no capadas y dejadas á propósito en el semillero ú otro lugar dispuesto para eso ó solamente á uno de los estremos del tabacal cuya estension ha de corresponder con la cantidad de semilla que se necesita sea para la siembra del año próximo, sea para el comercio; la semilla no se debe cojer de los retoños, aunque se suele hacerlo así en Cuba, sin duda por causa de economía.

Sucede con bastante frecuencia que el tabaco pierde todas sus cualidades naturales y degenera por solo haber sido transplantado de un suelo á otro que no le conviene, ó por ser demasiado pobre; en Cuba los mejores terrenos para ese cultivo son colorados, contienen bastante peróxido de hierro y muy poco calcarro. El cultivo del tabaco necesitando mur pocos gastos y dando siempre una buena utilidar conviene á los capitales cortos y hasta á los poco acomodados y á los pobres que suelen tener una tala de tabaco cuya utilidad remedia sus mayores necesidades; en efecto, todo el suceso de ese cultivo depende del cuidado que se tiene en escojer el terreno á propósito y el esmero que se ha de dar á la condicion de la planta como á su preparacion despues de cosechada. 
En una fanega de tierra de 100 varas cuadradas caben á las distancias dadas de 4 á 5 cuartas 800 matas, cuyo producto, consideradas las dos cosechas de la mata principal y retoño, dará un resultado de 4 onzas despues de seco en condicion, ó 20 quintales; si el tabaco se labra jor cuenta del cultivador cada quintal rinde 10000 cigarros.

Añil, indigofera añil, etc. M. D. - G. 1060. - En Honduras, Demarara y en las Antillas, así como en el continente americano el cultivo de ese vejetal puede ampliamente remunerar y premiar el trabajo de los agricultores que se dedican á tal ramo, escojiendo especialmente las especies indijenas ó americanas, porque necesitan muy poco cuidado y muy cortos gastos. La calidad del añil depende tanto de la clase cultivada, del suelo dedicado al cultivo, del clima en que se ha criado $\mathrm{y}$ ha vejetado el vejetal, como del método empleado para la elaboracion. Sentimos no poder engolfarnos en la descripcion de los procedimientos empleados para la preparacion de ese producto pues que se les hallará estendidos en las obras de química industrial, y además eso nos llevaria demasiado lejos de nuestro objeto; nos limitaremos pues á escribir algunos renglones sobre su cultivo.

Cuando se quiere plantar ese cultivo en escala sino mayor á lo menos algo regular, es preciso principiar por elijir un terreno á propósito cuya tierra ha de ser buena y de monte, no muy lejos de la ciudad si es posible; hecho eso se tumban parte de los árboles que se emplean para cercar el terreno, y de la otra parte desmontada la llena inútil se quema, despues de haber aprovechado la que puede utilizarse para fábricas ó por cualquiera otra cosa; hecho eso en la estacion mas seca del año se escarva el suelo abriendo surcos en línea recta, á lo largo de los cuales se echa la semilla con la mano ó con la carretilla sembradora, ó quizás mejor limpio y preparado el suelo se sub-raya por cuerdas paralelas entre sí, á media vara, y por la sub-raya se planta con el plantador á distancia de una tercia, poniendo media pulgarada de semilla en cada piquete. Esta operacion es simultánea, así por la prontitud del trabajo como por aprovechar el descanso de las nuevas yerbas espontáneas por los efectos de la sub-raya; al paso que unos van sub-rayando otros van dando los pi. quetes, y niños ó mujeres van detras poniendo en ellos la semilla y cubriéndola con tierra algo comprimida.

Cuando la nueva planta tenga tres ó cuatro dedos fuera de la tierra se la dará la primera labor, parte con la azada, parte con la mano, muy cuidarosamente para no cortar ni arrancar el plantel ; detras del desyerbo se irán resembrando las fallas: el segundo desyerbo se hará á fines de junio ó á principios de julio, aprovechando un tiempo seco para que esta operacion sea mas eficaz; si las lluvias fuesen escesivas y no pudiere lograrse una buena estacion se le dará un macaneo de machete, pero al acercarse la florescencia á principios de agosto, es necesario la limpia de azada para que al cortar el añil para batirlo no lleve consigo yerbas estrañas á los estanques; desde que apunte la flor se ha de examinar diariamente el estado de jugo que tenga el añil para proceder inmediatamente á la cosecha, 
porque la yerba en buena sazon de rendimiento solo permanece regularmente 15 dias; este estado se conoce partiendo algunos pimpollos: si están lechosos tiene jugo; si al partirles quedan secos, no está de provecho. Con el tiempo muy lluvioso no es conveniente cortar y batir porque además de que la yerba lavada da menos tinta, la zoca ó tronco cuyo retoño se espera para la cosecha siguiente se muere faltándose así la siembra.

Para el corte del añil se necesitan cuchillos á propósito y para el acarreo bestias apareadas con sillones. La planta se ha de cortar á dos pulgadas del suelo y cargarla con la fresca, de las seis á las diez de la mañana, procurando que no permanezca en el campo hacinada, por lo que, al paso que unos van cortando otros van reuniendo y cargando y otro ú otros la reciben en el caney ó rancho situado al lado de la oficina, en donde se acomoda parada $y$ con el desahogo posible, pero unida y sostenida por varas dispuestas á propósito en él. Aunque se trabaje en pequeño siempro convendrá construir una oficina entera por economía y con articipacion á la siembra, á fin de que, cuando llegue la época de batir, estén suficientemente secos y sólidos los estanques para que puedan resistir la fuerza del agua y de la baticion. La oficina debe situarse donde pueda conducirse el agua suficiente para la infusion de la yerba, para lavar los recipientes diariamente, despues de la baticion y para tener llenos los de podrir, prefiriendo el agua de las fuentes puras á la de los rios caudalosos, porque la limpieza y frescura del agua contribuye esencialmente á la cantidad y calidad de la tinta. Una oficina de añil consta de dos estanrues de podrir y dos de batir, con sus correspondientes piletas y tendales para coladores; solo es capaz para batir cómodamente un campo de 20 tablones de á 100 varas cuadradas en el espacio de 30 dias; $y$ si es algo mas estenso el campo y no hay mas que una oficina, para remediar en lo posible el inconveniente se empezará á cortar y á batir antes de la perfecta sazon de la yerba, porque, como dicen los prácticos, mas vale batir jojoto que pasado. El añil jojoto, mas ya apuntando la flor, da menos rendimiento, pero muy buena tinta; el pasado rinde menos y presenta dificultad en su elaboracion. Cortado el añil en su sazon, todo á la vez, puesto á secar para deshojarlo y guardada la hoja seca se batirá cómodamente sin el peligro de que se pase y pierda la hoja en el campo; entónces una tancada de tales hojas producirá cuatro veces mas tinta que la de las yerbas frescas con las matas y ramas, pues es la hoja la que contiene materia colorante, $y$ aunque pierde algo de esta materia en su seca, no hay duda que seria muy cómodo y mas productivo sembrar un gran campo y batirlo así seco en media oficina.

La estacion de las lluvias principiando siempre en mayo, favorece de tal suerte ese cultivo, que el añil está ya bueno para cortarse como hácia mediados de julio ó en agosto; ha necesitado solamente dos meses y medio para llegar á su madurez, lo que se conoce tambien porque se está cubriendo de una harina verduzca. La cosecha del primer año es siempre bastante corta y alguna vez que otra no vale la pena de elaborarse, mientras la del segundo año es magnífica Y muy abundante; la del tercer año sale tambien muy bucna, 
especialmente si se ha tenido el cuidado de desyerbarla. Muchos plantíos de añil duran mas de 8 á 10 años, dando anualmente muy regulares productos sin que haya sido necesario volver á sembrar. Pero para que la siembra se pueda conservar productiva es preciso tener cuidado de desyerbarla oportunamente y de resembrar las fallas inmediatamente despues de cada corte, renovándola cuando las cepas ya fatigadas de la reproduccion forzada por los cortes retoñe sin vigor.

Una manzana ó tablon de 100 varas cuadrarlas, lo que es como unos dos acres, produce generalmente como 100 á 120 libras de añil elaborado. El bagazo ó residuo de tal fábrica, así como las aguas que provienen de esta especie de fermentacion, son, como lo tenemos ya señalado mas arriba, páj. 432, un abono magnífico para los cañaverales; el vejetal mismo se utiliza con mayor ventaja como abono verde. El añil teniendo sus raices perpendiculares, las cuales penetran de como un pié en el suelo, se habrá por tal razon que desmenuzar el suelo hasta igual profundidad, y cuanto mejor estará preparada la tierra que ha de recibir la semilla, mas productiva saldrá la zafra.

El accidente mas grave de ese cultivo es la invasion periódica de los gusanos; esta plaga, fatal para el añil y tambien para el algodon, de que hablaremos á continuacion, aparece cada tres ó cuatro años y con tanta abundancia, que en dos dias acaban con el campo mas estenso; no hay entónces otro remedio que cortarlo todo y batir lo que se pueda, porque lo que mas interesa es el retoño. Cuando ha llovido muchos dias seguidos, aun cuando la planta esté ya en sazon, debe suspenderse el corte y esperar á que levante el tiempo, porque además de que la yerba lavada da poca tinta, se pierde la mayor parte de la zoca y mas vale conservar el vejetal que el pequeño producto de aquel momento. Regularmente se dan tres cortes anuales: en setiembre, diciembre y á principios de mayo: este último á veces es improductivo pero indispensable para que el vejetal retoñe con vigor á las primeras aguas, y así es que los añileros dicen : en mayo se ha de cortar para batir ó para botar. Cuando ese corte es pequeno pero de provecho se recoje en sábanas que se atan por las puntas y así se carga; una tancada de esta yerba menuda produce doble tinta, porque casi todo es hoja.

Los gastos de un tablon de añil desde la preparacion del terreno hasta el estacio de batir, incluso el valor de la semilla, está calculado en 25 pesos; los posteriores, hasta dejar seca la tinta, son muy variables, porque están en relacion con el tamaño de la planta, el numero de tancadas que rinde y su produccion; pero en resúmen se puede contar 7 reales libra por gastos del primer corte de la plantilla y 6 reales por los siguientes, esto es, con tareas de á 3 reales en cultivo, de 4 reales á los batidores y 8 reales al puntero; si estos jornales costaran mas, acrecerá relativamente el costo de cada libra, y esto sin contar con los accidentes que pueden suceder y sin el interés del capital invertido en la construccion de la oficina, de donde se puede racionalmente establecer el costo principal de una libra á 8 reales. 
Ese vejetal prospera á la alturas siguientes por encima del nivel del mar: desde 600-630 hasta 1,0 77 varas, con una temperatura media de $48^{\circ}, 60$ á $40^{\circ}, 61$ farenheit o centígrado desde 10 hasta 15 , pero vejeta perfectamente bien con temperaturas mayores.

Algodon. - G'ossypium barbadense, etc. MI. D. - G. 971. - Los terrenos ricos y aluviales son los que.se adaptan mejor á ese cultivo; sin embargo se puede cultivar con ventaja en otras clases, pero en ese último caso es necesario para sacar utilidad abonar con cal especialmente $y$ abonos naturales ó artificiales fertilizantes. El algodon se produce en todas las temperaturas, no necesita de suelo muy fértil ni demasiado húmedo; por el contrario, le dañan las lluvias en su florescencia y fructificacion y prospera en los lugares secos y abrigados de los vientos del Norte.

Se debe preparar el terreno á fines de febrero ó muy á principios de marzo, del modo siguiente : primeramente, despues de limpiado como lo tenemos dicho ya tantas veces, se deberán hacer las aradas en surcos de á seis ó de á ocho hileras juntas, lo cual se llama era, cuidando de dejar espacios suficientemente anchos, á manera de calles, entre las eras que se van formando. El arado de pala es el que se suele usar mas comuninente para esta operacion ó labor, y por lo general se hacen los surcos de 4 á 5 pulgadas de profundidad. Despues de formadas así las eras se procede á la siembra, la cual se efectua de diversos modos, pero en los algodonales grandes y plantados en escala mayor se sirven generalmente de una clase de maquinaria simple, la cual al mismo tiempo que abre el suelo en la era, va desparramando la semilla donde corresponde. De ese modo las aberturas hechas en los surcos no son profundas y la semilla no queda muy enterrada, que es lo que requiere el algodon; se le puede sembrar, sin embargo, de cualquiera manera, en la intelijencia de que las circunstancias estén iguales para la semilla; pero raras veces saldrá el trabajo tan barato. Despues de completada la siembra se comienzan á arar los espacios de terreno que se habian quedarlo incultos entre las eras. Cuando el ag̣odon habrá crecido como unas dos pulgadas de alto, se debe principiar á podarle; esta operacion consiste en cortar todos los piés ó tallos sobrantes, lo que se hace con arados de mango largo, de tal suerte que haya uno ó á veces dos tallos juntos distantes como de unos 4 piés una mata de la otra. Eso hecho se debe comenzar á arar el terreno de nuevo, procurando que el arado pase tan cerca del algodon que vaya arrojando á un lado la suciedad; eso concluido se repite la misma operacion con la diferencia que esta vez se echan los surcos al lado opuesto; no siendo lluviosa la estacion, tres limpios ó desyerbos son suficientes para una cosecha de algodon; pero si las lluvias fuesen copiosas seria preciso continuar las limpias hasta que los tallos sean de tamaño tal que no impida su progreso la presencia en el algodonal de las otras yerbas; así se cultiva en los Estados-Unidos.

Cultivo en Venezuela: Cualquiera que sea la clase de algodon que se cultive, limpio el terreno y sub-rayado por cuerda, se siembra, con el plantador, por mayo, á la distancia de vara y media por calle $\mathrm{y}$ de una vara por la hilera, en los lugares secos y templados. 
poniendo tres semillas en cada piquete; á los 15 dias nace regularmente y fructifica á los 7 meses. Cirando tendrá un palmo fuera de tierra la planta, se desyerbará el algodonal y se resembrarán las fallas, sembrando una hilera de maiz por medio de la calle; se continuan las limpias de costumbre. Bastarian dos limpias si estuviese solo, la primera al resembrarlo y la segunda al florear ó cuando esté el fruto en boton; pero como en Venezuela se suelen aprovechar los claros de las calles con maices en el invierno y con caraotas $y$ frijoles en los nortes; las limpias ya de azadas, ya de machete, serán relativas al cultivo de tales plantas; lo que importa es que el algodon esté limpio al tiempo de la cosecha. En su fructificacion, al abrir el capullo es menester recojerlo, porque permanece poco tiempo despues en la planta, como unos 5 ó 6 dias, pasados los cuales se desprende de la cápsula y se cae ó el viento se lo lleva en madejas abiertas. En las tierras frias tarda mas de 7 meses en fructificar y $\mathfrak{a}$ la altura de 1,500 varas hasta 9 meses. Si se descogolla la planta á la altura de una vara y despues se hace lo mismo con las ramas, estas se duplican, se multiplica la planta y carga con mas abundancia; los retoños que salgan del pié se deben quitar. En los terrenos feraces de la zona cálida se siembra á mas distancia, dándole dos varas de calle.

La cosecha sobreviene en el verano ó mejor dicho en los meses en que calman y cesan las lluvias, por enero y febrero, segun"ha sido la florescencia. La recoleccion de un canasto bien comprimido da el peso de una arroba, y las manos mas lijeras recojen apenas tres canastos al dia. Como á todo fruto es necesario asolearlo antes de almacenarlo, el algodon florece en los Estados-Unidos durante el mes de junio, y si la estacion ha sido farorable, los primeros capullos se hallan no solamente formados, sino tambien abiertos, manifestando así la blancura del algodon antes de fines de julio. Los capullos que primero se abren son los de las ramas de abajo, y los mas tardíos, que se llaman algodon de cabeza, son los de las ramas mas superiores. Cuando se habrán abierto los capullos suficientemente, se empiezan á hacer las recojidas ó á cosechar el algodon, lo que se ha de verificar tres veces, porque las flores saliendo sucesivamente, los capullos no maduran todos juntos, pero se suceden los unos á los otros de igual manera. Los recojedores al pasar se llevan el algodon que se desprende con mayor facilidad de los capullos abiertos, que despues de tal operacion se quedan vacíos y el algodon cojido así lo echan en un saco colgado de su cuello. Las cosechas duran hasta cerca de Pascua y algunas veces hasta mas tarde. Despues de haber tenido el algodon cosechado, así almacenado por algun tiempo, se le pasa á la máquina que ha de desmotarlo y en seguida se le lleva á la prensa de donde salen los bultos buenos para ser entregados al comercio y á la esportacion.

En un cuadro de 100 varas, á la distancia de una vara á vara y media, caben 7,500 matas, y calculándose á cada una 6 onzas de algodon en bruto, equivalentes á 2 en limpio, deducido el 60 por 100 , peso de las semillas, se tendrá una libra por cada 8 matas y una fraccion, que puede en totalidad quedir todo reducido á 9 quintales 
netos en el cuadro. Como en el vacío de las calles ha debido sembrarse maiz en mayo y caraotas ó frijoles en octubre, se dejará el producto de estos frutos á favor de los gastos de siembra y cultivo hechos en comun $\mathrm{y}$ empezarán los gastos particulares del algodon, solamente desde su recoleccion, que se pueden calcular en 5 pesos quintal $\mathrm{y}$ suponiendo por precio medio del algodon 15 pesos quintal, el producto líquido del cuadro será pues de 90 pesos.

La semilla separada se usa en los Estados-Unidos para alimento de las vacas de leche, durante los meses de invierno; pero mas comunmente se emplea como abono, despues de molida, por lo cual es muy valiosa y en la sementera de maiz produce resultados notables. Se dice en efecto que como abono fertilizador casi no tiene igual y como tal lo emplean en el Sur para hacer productivos los terrenos va estenuados, y que con solo un cuartillo de este abono en una sementera de maiz, hace aumentar en mucho el tamaño de la mazorca r le da además un color mas oscuro y mas lustroso. Además, como lo tenemos ya señalado en el Compendio de Terapéutica rejetal, las semillas contienen bastante aceite para sacarse con provecho, porque muy delgado es propio para el alumbrarlo y las fábricas de jabon, Y el hagazo serviria sea para abono muy bueno, sea para los animales domésticos, para los cuales seria muy buen alimento. En los desmotes se podria pues sacar mucho provecho de esa nueva industria muy poco costosa, pues que se necesitaria solamente una buena prensa de hierro y rle tornillo, como para la esplotacion o estraccion del aceite de ricino o higuereta.

Ese vejetal puede prosperar y dar producto á las alturas siguientes: 630,1077 y 1415 varas, con una temperatura media de 81,17 farenheit, y entónces necesita para dar producto 6 meses y medio, con una de $46^{\circ}$, en ese caso necesita 7 meses, de $40^{\circ}, 61$, y liasta en ese tercer caso 7 meses y meulio, y en fin á 34,61 no llega á parir sino á los 9 meses: en una fanegada de 170 raras, lo que es casi 133 rardas inglesas cuadradas, caben 28,900 matas, que darán de ducto, durante como 3 años y medio, 14,5.50 libras cada mata, proproduciendo al año media libra de algodon limpio.

Mostaza. MI. D. - G. 829. - Esta planta se cultivaria con bastante provecho en las Antillas y en el continente americano, su cultivo no necesitando ningun gasto, pues que basta esparcir un punado de semilla en un terreno que esté algo húmedo y limpio, y ella nace, crece y fructifica sin necesidad de labores, dominando con altivez las yeribas espontáneas. Se cosechará del mismo modo que el ajonjolí.

Quinchonchos. I. D. - G. 1065. - Ese arbusto que fructifica durante algunos dos, tres y mas años consecutivos, debe plantarse en la primavera para que esté mas robusto al florecer en diciembre. Generalmente no se hace una siempra especial de ese vejetal; solo se emplea en guarda rayas ó entre calles, pero es preciso tener presente que se debe hacer un ahiladito de alguna estension cerca de la casa, porque se necesita de su semilla, no solo para el alimento de los hombres, sino tambien para la cria de gallinas y demas aves domésticas, de manera que se podrá sacar de él bastante provecho; en 
este caso se sembraráll á dos varas de distancia por la hilera, y dos y media á tres varas de calle, poniendo con el plantador tres granos en cada hoyo ó piquete y mantenerlos con aseo cuando tema todavía las plantas, porque mas tarde necesitan solo que se les limpie de las plantas tiepadoras, y para que sea mayor el producto se ha de cortar la mata todos los años por abril ó mayo á media vara de altura.

Onoto, achiote, etc. M. D. - G. 890. - Ese arbusto ó arbolito gusta de los terrenos de aluvion, fértiles y frescos, por lo que se le halla silvestre en las orillas de los arroyuelos y de las quebradas; sin embargo, vejeta regularmente en cualquier terreno liviano: si fuera demasiado pobre el suelo seria preciso abonarlo con detritos vejetales, Jerbas verdes, etc., etc. Se reproduce de semilla que se siembra, desde enero hasta mayo, en un suelo recientemente arado, á la distancia de 4 piés en todos sentidos: se echarán tres semillas en cada piquete, que se cubrirán con un poco de tierra sin pesar. Cuando la siembra tenga como de 6 á 8 pulgadas, se arrancarán los sugetos débiles, dejando solamente uno, el mas vigoroso; se limpia y se aporca: al año siguiente al limpiar el achiotal de las enredaderas y yerbas con un macaneo de machete, se les poda como á una vara ó algo mas del suelo, para facilitar la recoleccion de los frutos y se mantiene el tronco á esta altura: el segundo año ya la plantacion tiene toda su fuerza y lozanía y dura así 3 á 4 años; nos parece que con el cuidado de podar las matas convenientemente se las podria hacer durar productivas muchísimo mas tiempo. La cosecha se hace dos veces al año, en junio y en diciembre. Se habrán de recojer las cápsulas maduras, que despues de secas se batirán sobre un suelo bien unido ó una tela grande dispuesta á proposito, con varitas, y las semillas así preparadas se pondrán sobre entablado, para secarse al abrigo de la luz directa del sol y en cuarto ó almacen bien venteado ó seco y despues de eso se pondrán en barriles.

Las, operaciones bastante numerosas y largas que suele hacerse sufrir á las semillas para sacar el achiote ú onoto del comercio, no saliendo siempre felizmente, porque á veces las semillas se pierden, otras veces el tinte se quema durante la evaporacion ó cocimiento; en fin, ya preparado y puesto en panes listos para el comercio, fermenta, pierde de su calidad y hasta se daña, tanto que es preciso botarle. Al ver resultados tan inciertos se ha buscado si se ganaba algo en preparar el achiote de esa manera, $y$ se han asegurado que no habia ventaja alguna, sino para limpiarle de las semillas y disminuir por consiguiente el peso de las 2[3 partes, y por consiguiente otro tanto los gastós de flete para Europa, y para conducirle á los puertos de mar. En efecto, se ha esperimentado que los géneros teñidos con las semillas tales cuales salen de las cápsulas, sea antes, sea despues de su desecacion, han salido tan hermosas y quizás algo mas duraderas. Si se atiende á los gastos que necesitan las operaciones de preparacion del achiote, y si además se hacen entrar en cuenta las pérdidas proviniendo de los inconvenientes mencionados mas arriba, no habrá duda alguna que los agricultores sacarán mucho mas provecho de ese producto en semillas. Además el achiotero, 
siendo arbolito muy bonito y hasta de adorno, se le podrá sembrar en derredor de las casas, en los patios y como cultivo suplementario que no dejará de dar utilidad: su corteza dá curagua y puede servir para tejidos, y especialmente para sogas.

Vainilla. M. D. - G. 422. - Vainilla sativa, Schied.; V. pompona, Schied.; V. planifolia. Hort. Kw., etc.; V. guianensis, Splitgerbert. Tales son las especies botánicas americanas que suministran la vainilla del comercio.

Se hallan en el comercio de la droguería 3 clases de vainilla: $1^{\text {a }}$ vainilla lec, leg ó lejítima, producida por la vainilla sativa, es un poco blanda y viscosa; guardada en un lugar seco se cubre de cristalitos en forma de agujas brillantes, que son formadas, segun el señor Gobley, de vanillina y no de ácido benzoico, como se creia; 2a la vainilla cimarrona ó bastarda, mas corta, mas delgada, mas seca, menos oscura y que no se cubre de cristales y proviene de la vainilla silvestre de Schiede : $3^{a}$ la pompona, mas pequeña todavía, blandita, viscosa y casi negra.

La vainilla, planta á la vez trepadora, carnurla y abejucada, pero sin fuerza, necesita del apoyo de los demas vejetales, por encima de los cuales está trepando, sosteniendo y ayudándose en esta ascension por las manos ó especie de zarcillos que tiene á propósito. Necesita de un suelo rico, cálido y húmedo, á la vez que un poco sombrío, para vejetar lozana y dar provecho. Despues de haber escojidu el lugar á propósito, dice el señor Desvaux en los Anales de las Ciencias naturales, año 1846 , dejando en él los arbustos que dan poca sombra, sin dar ninguna labor al terreno, se siembra al pié de cada arbusto ó árbol un trozo de tallo de vainilla teniendo 3 á 4 nudos, escojiendo para eso la estacion mas cercana de las lluvias; se ha de visitar el vainillal una sola vez al año para limpiarle con el machete de las malezas inútiles y hejucos que le pueden perjudicar, y al tercer año solo principia dianir algun producto. Así se cultiva ese vejetal en el pueblo de Mir coma, situado á como 24 leguas al noroeste de Vera-Cruz. Distinguen 5 especies de vainilla, á saber: la la corriente ó cultivada, de la cual conocen dos variedades, de las que una, muy llena de semillas y de pulpa, de cáscara fina y delgada es la mas apreciada, mientras la otra, llamada cruda, tiene la cáscara mas espesa, no es tan buena, y sin embargo es asaz lejítima; constituyen la vainilla lejítima lec ó leg del comercio; 2 a cimarrona ó silvestre, cuyos frutos son siempre mas pequeños que los de la corricute, se cria en los bosques sombríos, sus cápsulas están menos desarrolladas que las de la anterior, á la cual parece idéntica; sin embargo, maluran con dificuitad, sin duda por causa de la demasiada sombra; 3a la mestiza, cuyos frutos estín manchados de pardusco sobre un fondo verdusco, cuando no están enteramente maduros: sus cápsulas son mas cilíndricas que las de la vainilla lejítina y al desecarse son muy propensas á abrirse; $4^{a}$ la puerca, cuyos frutos sun mucho mas pequeños y cilíndricos que los de la lejítima, de un color verde mas subido, y al prepararla exhala un olor desagradable que le ha valido el nombre de vainilla de cochino; 5 a la pompona, cuya cápsula es mucho mas ancha y mas corta que la de la 
corriente, de corteza delgada, su olor es agradable y bastante pronunciado cuando principia á desecarse, pero sin embargo mucho menos delicioso, á menos que haya sido encajonada con la corriente, pero parece que mas tarde pierde ese olor adquirido artificialmente, por esa razon se la tiene casi como sin valor.

La cosecha ó recoleccion de los frutos se hace hácia el mes de diciembre y su madurez se anuncia por su aspecto ó semblante; en efecto, de verde bastante oscuro se vuelve amarillento. Con frecuencia, sin embargo, se recojen antes del momento á propósito, lo que perjudica muchísimo la calidad del producto, por temor de los ladrones, que en ese pais no escasean. Se tiene siempre cuidado en llevar con el fruto el pedúnculo que lo sostiene. Si la vainilla ha sido recojida antes del tiempo ó prematuramente, su tamaño disminuye mucho durante la desecacion, contiene menos cantidad de tripa y su corteza es menos fina y no tan flexible. Hecha la cosecha ó recoleccion, se deja marchitarse, si se puede decir así, el fruto, y cuando el producto ya no está verde, pero indica un principio de desecacion, se empieza la preparacion de la vainilla del modo siguiente : se ponen esteras sobre un lugar enladrillado ó empedrado, dispuesto á propósito y solvre aquellas se estienden frisadas; cuando el sol habrá vuelto estas últimas bastante calientes, sc colocan sobre ellas las cápsulas de vainilla uniformemente, á fin de que reciban igualmente todos los rayos del sol; cuando el calor habrá hecho desaparecer toda señal de vejetacion posible, lo que la costumbre indica con mucha facilidad, se levantan las frisadas, todavía calientes, se envuelven en ellas los frutos juntos y se depositan así en cajas, con el cuidado de taparlas bien con las frisadas, dejándoles sin embargo espuestos así á la influencia solar. Si la accion del sol ha sido favorable y suficiente, deben tomar en 12 horas debajo de las frisas el color bruno del café; en el caso contrario se repite la operacion del dia anterior, hasta que hayan sudado bien de nuevcpoiern si el tiempo no es favorable para la preparacion de la vainillgngo hará la operacion á favor del calor artificial en un horno cuyo calor debe ser como el en que se quita el pan despues de bien cocido. Para volver la calidad de la vainilla mas perfecta, es necesario, á pesar de la preparacion indicada, durante dos meses seguidos esponer la vainilla al sol diariamente, apartando y guardando las cápsulas á medida que están suficientemente desecadas, y es preciso tener cuidado en no dejarlas secar demasiado, pero solamente al grado conveniente, porque pierden de su peso y de su cualidad, deben tener y conservar un cierto grado de blandura, que se aprende por la práctica y que la costumure y el aspecto enseñan. Así bien preparados los frutos, se ponen en paquetes de á 50, que se colocan en cajitas de hoja de lata; al hacer los paquetitos se les pone con demasiada frecuencia en el centro caliciades inferiores, lo que es un fraude muy culpable.

El cultivo de la vainilla, para sacar un buen partido $y$ buen provecho de él, debe hacerse como sigue : el terreno escojido á propósito ó preparado para darle las cualidades necesarias de fertilidad y de humedad por medio de los abonos, que han de ser humus ó vejetales podridos, y del riego, se dividirá en tablones mas ó menos 
largos, separados los unos de los otros pur una calle, ancha como de vara y media á dos varas, sobre las cuales se plantará un troje ó un emparrado ancho como el tabion, es decir, de vara y media á dos varas, á fin de que se pueda con facilidad alcanzar el medio con las manos, y como de vara ó algo mas de alto, formada de un armazon bastante sólido de madera no labrada y con su corteza, en el cual se dispondrán varas cruzadas de manera que los tallos y ramos de vainilla se puedan estender con facilidad y dirijir á su gusto sobre ella de manera á ocupar el menos espacio posible, sin estar demasiado empinados, sin embargo; se sembrarán los trozos de vainilla provistos de 3 á 4 nudos, á como dos varas los unos de los otros de cada lado del emparrado y alternativamente, al pié de una de las estacas del troje, o si no hubiese se le pondria una para sostener el tallo y guiarle hasta que se haya agarrado al emparrado; se le debe dar sombra, sembrando totumos en hilera recta por el medio de las calles, á como 4 ó 5 varas los unos de los otros y conducirlos de tal manera que no principien á formar su copa sino como á dos varas y media de altura, teniendo cuidacio en que los de una calle alternen siempre con los de las dos vecinas y correspondan con el medio del espacio que les separa. El sernillero de totumos debe estar hecho de antemano, á fin de tener plantel ra listo para sembrar cuando se necesitará. Se dará sombra al emparrado con parchas, parchitas, tapíramos, guarícaros, caraotas y frijoles trepadores, sostenidos por enramadas o estacas, formando como á una vara por encima del troje otro emparrado sostenido como conviene por otro armazon bastante fuerte, hasta que los totumos produzcan bastante sombrá para ayuaarles en los lugares en donde no haya bastante.

Cuando la vainilla vejetará con bastante vigor sin echar flores ni bastantes ramos, entónces se le torcerá el estremo ó capullo, á fin de detenerla y obligarla á florecer, pero no se la deberá hincar como algunos lo han aconsejado, y cuando habrá echado flores será preciso para asegurar el producto acudir á la fecundacion artificial, porque naturalmente se rerifica con bastante dificultad, de manera que la mayor parte de las flores no cuajan, mientras que con esta sencilla, pero minuciosa operacion, todas las flores darán fruto que saldrá mas grande y mucho mas fornido. Para eso será preciso vijilar la fioracion, y cuando se abren aprovechar el tiempo, porque son efímeras, es decir, que duran solo un dia y á la noche se marchitan. Con una pua de madera bien puntiaguda dispuesta á propósito y cuya punta está en la boca, á fin de que esté humeda al servirse de ella, se quita con cuidado, lijereza y destre\%a la membranita que tiene tapadas las celdas de la antera ó estanubre situado en el ápice de la columna ó ginóstemo, impidiendo así á las masas polínicas salir afuera para cumplir con su objeto, lo que es bastante difícil naturalmente, porque la abertura ó boca del estigma se halla por debajo de él en la cara anterior de la columia y ocupando un hondo, disposicion muy poco favorable á la fecundacion, por lo que la mayor parte de las flores permanecen estériles, saliendo fecundas algunas solamente. Para obviar á tal estado de causas y asegurar la fecundacion $\mathrm{y}$ el producto por consiguiente, se toman con la punta 
húmeda de la pua las masas polínicas y se las aplica á la boca del estigma que se las chupa en el acto mismo y ya la fecundacion artificial está verificada, y la prueba consiste en que el ovario crece de mas de una línea en las 24 horas que siguen á esta sericilla, pero muy bonita operacion, y se queda así durante dos á tres meses para despues continuar creciendo, lo que dura como un año; en efecto, entre el momento de la fecundacion y la madurez completa del fruto transcurre un año. Haciéndose práctico puede uno en un dia fecundar algunos cientos flores.

Cuando los totumos hayan echado ya copa $y$ den bastante sombra, se les deberá aprovechar sembrando al pié de ellos dos vainillas, una de cada lado, con el cuidado de limpiarles de los demas parásitos, que les acometen siempre, porque ese árbol es muy á propósito para criar orquídeas; además se sacará provecho de los totumas.

Tal es el método que aconsejamos seguir en las Antillas, Gujana, etc., cultivando la vainilla planifolia, natural de esos paises, y que se presta perfectamente á esta operacion.

To podemos concluir este resúmen de agricultura apropiada á las Antillas sin hablar de los pastos, porque sabido es que todos los terrenos no pueden entregarse al cultivo y que se necesitan tambien mucho pastos para la alimentacion de los animales herbívoros, ganado vacuno, lanar y caballar, ramo que en ciertos lugares como Puerto-Pico es de la mayor consideracion y deja muy buena utilidad; además las esplotaciones agrícolas necesitan bestias que sirvan de motor, á fin de multiplicar el trabajo, disminuir la mano de obra Y tambien para transportar los productos, sea á los almacenes, á las fábricas ó al mercado.

Los pastos pueden clasificarse en naturales ó permanentes y en artificiales ó temporales : los primeros se hallan naturalmente en las Antillas y se llaman savanas, de las que unas muy estensas, son naturales, es decir, que el hombre las ha encontrado así y nadie ha de ocuparse de ellas. Por mas estensas que sean en las Antillas las savanas naturales, no son nada en comparacion de las pampas del Brasil y de las inmensas savanas que hemos visto en el Apure, cuya yerba es tan alta que un hombre á caballo se puede esconder en ella, por cuya razon en esos paises la cria del ganado es maravillosa, pues hay hatos de 80,000 reses, y potreros de 15 á 20,000 bestias; todo el cuidado que se tiene es quemar la yerba cuando está seca, pero en ciertos lugares solamente. Mientras las otras se han formado despues de los desmontes hechos muchos años antes; aquellas que son de estension limitada han de cuidarse si se quiere sacar utilidad de ellas. Cuandoson de buena calidad no senecesita otra cosa que tenerlas limpias de los arbustos y de sus retoños, así como de las malas yerbas que en ellas se crian y que los animales no se comen, pero que son capaces ó de envenenarlos, tales son verbigracia, el tibey, la brinviliers, etc., especialmente porque son mas comunes que ninguna otra clase, ó porque son demasiado duras, con las hojas á veces cortantes, de manera que les lastiman la boca, tales son la yerba de cuchillo y demas cipráceas. Se debe establecer en ellas, cuando será posible, un buen sistema de riego ó de desagüe, segun sean secas 
ó espuestas á padecer sequía, ó que sean húmedas mas ó menos pantanosas, ó que se encuentren espuestas á anegarse. Por lo comun se limita en las Antillas á talar las yerbas ó matas que los ganados no comen, sea porque son ya demasiado duras, sea porque son malas, como las de la familia de las cipráceas, tan comunes en los lugares húmerlos especialmente, y seria bueno, cuando es posible hacerlo sin gastar mucho, arrancarlas, amontonarlas para que se sequen, $y$ en fin quemarlas y utilizar sus cenizas como abono ó quizás mejor cuando se puede volverlas directamente abono, tratándolas con cal, como lo tenemos señalado mas arriba, páj. 429. A lo menos si no se puede abonar el pasto será necesario al talarlo esparcir por su superficie los escrementos de los animales que en ellos pacen, despues de secos. Si el pasto es de mayor estension será muy provechoso dividirle en algunos cercados, cuya estension debe estar en relacion con el número de animales que han de pacer y quedarse en él, y cuyo número habrá de ser tal, que cuando los animales pasarán en el último, la yerba haya tenido bastante tiempo para volver á crecer suficientemente en el $1^{\text {ro }}$ para que el pasto sea de provecho.

Se podrá, como se suele hacerlo er Europa y tambien en las islas inglesas y francesas para los cañaverales, efectuar esa division del terreno ó pasto con alambres de hierro del tamaño del dedo de un muchacho de 6 años, en número de 4 , puestos el primero como á un pié y medio del suelo, y el último como á vara y media, hechos firmes por buenas estacas, sólidamente plantadas en el suelo, provistas de agujeros por donde pasan los alambres, atándoles de trecho en trecho; tales estacas han de estar distantes las unas de las otras como de unas 3 varas. Si el terreno fuese húmedo en demasía necesitando de desagüe, entónces los cercados se deberán hacer con zanjas como conviene $\mathrm{y}$ bastante anchas para que los animales no puedan saltarlas : la tierra sacada al formarlas servirá para abono, ó se amontonará á manera de loma en una de sus orillas, en la cual se deberán sembrar arbustos y árboles á la vez de algun producto y que servirán de obstáculo para impedir á los animales salir afuera, como verbigracia, emajaguas, cedros de olor ú otros, segun la naturaleza del suelo, teniendo siempre cuidado de defenderlos de los dientes de los animales cuando tiernos con una línea de mallas ó mayas; será bueno tambien cuando el pasto no tiene árboles, para que los animales puedan ponerse á la sombra, sembrar en ellos algunos bosquecitos óarboledas, con árboles que puedan suministrar algun alimento, tanto por sus hojas, como por sus frutos: los guacimas y los samanes son muy á propósito, pero será preciso tenerlos cercados durante algun tiempo, porque sin esta precaucion el ganado acabaria muy pronto con ellos. En Puerto-Rico, que es pais de cria, especialmente la parte Este y Sudeste de la isla, se suelen tener los animales atados con sogas, $\mathrm{y}$ á nuestro parecer el modo que acabamos de señalar, cuando se puede ponerle en práctica, ahorraria tales gastos, y así dispuestos los pastos se les podria cuidar con mayor esmero y entónces sacar mayor utilidad de ellos.

En cuanto á arrancar las malas yerbas y los arbustos, seria demasiado costoso, porque hay tantas en el pasto que despues de esta 
operacion pareceria como si fuese arado, entónces es necesario limitarse á cortarles á algunas pulgadas dentro de la tierra de un golpe oblícuo de azadon bien cortante y dispuesto á propósito, arrancándoles despues con la mano y pisando con el pié el suelo en el lugar correspondiente con la cortadura, á fin de que no se queden dañadas las rerbas vecinas; acahada esta operacion bastante minuciosa, y que necesita de alguna intelijencia ó mejor quizás de algun cuidado, se les amontonará para secarse, y despues se les echará candela: no debe limitarse á esta única operacion, porque seria trabajo y gasto perdirlo: en cfecto, no tardan en retoñar, lo que se debe vijilar con cuidado, y cada vez que los retoños habrán llegado á como un pié de alto, se debe volver á cortarlos con el machete lo mas corto posible, pero sin dañar la yerba ni atacar el suelo, siguiendo así durante un par de años, ó mas segun la naturaleza de las plantas que hay que destruir y persiguiéndolas sin cesar al momento casi que vuelven á aparecer, con el cuidado de nunca dejarlas echar flores, ni parir, ni volverse leñosas tampoco, se acabará con ellas bastante pronto: la raiz ó cepa, no pudiendo sacar de la atmósfera lo que necesita, se estenuará produciendo retoños y notardará en morirse; mas uno tendrá su pasto limpio de las malas yerbas y demas vejetales inútiles; cuanto mas cuidado tendrá en estercolarlo y regar si es posible, tanto mas hermoso será y mayor producto sacará. de él, de tal manera que sus propios gastos se volverán dinero á. premio.

Llamaremos pastos artificiales á los que se hacen sembrando, en lugares desmontados á propósito, vejetales propios para el alimento de los ganados que hay que criar en ellos. Aquellos no solo se pueden, pero se deben antes de tumbar los árboles medir por cuadros correspondientes con el tamaño que se quiere dar á los cercados, $y$ las cercas así marcadas se las dejará separadas las unas de las otras por una arboleda natural formada por una hilera de árboles que se quedarán en pié al tumbar los demas; tal hilera deberá tener como unas 5 raras de ancho ó algo mas, segun la disposicion del terreno; no se habrán de desmontar nunca las partes demasiado peñascosas, y por tal razon inútiles y estériles despues de tumbados los vejetales que les cubren y cuyo objeto es llamar á las aguas. Todo dispuesto así, se desmontará entre las arboledas, como lo tenemos ya mencionado mas arriba, páj. 425. Siguiendo ese sistema de desmonte se hallarán las ventajas siguientes: menos costo en el desmonte, ningun gasto para cercar, porciue bastará doblar las ramas bajas de los arbustos y de los árboles, enlazándolas con las enredaderas y bejucos por cada orilla de las arboledas, de tal manera que los animales no puedan salir fuera : se habrá de vijilar á fin de tapar en el principio los boquetes hechos, hasta que los animales estén acostumbrados á quedarse así encerrados: además de eso proporcionarán siempre la sombra necesaria, tan pronto para los mismos animales como para el pasto, que así dispuesto no podrá padecer tanta sequía, y del que algunas partes estarán siempre mas ó menos protejidas contra los rayos abrasadores del sol, de tal manera que proviniendo la humedad de lns chuvascos ó del rocío, tendrán mas tiempo las yerbas 
para aprovechárselas y así estarán siempre mas frescas, padecerán menos sequía y despues de comidas se volverán buenas para pacer mucho mas pronto: las puertas de algunos cercados tendrán siempre que abrirse en una calle principal para hacer mas fácil la mudanza de los animales del uno al otro, y para conducirles á lo menos dos vecès al dia al abrevadero, cuando cada cercado no tenga el suyo propio, ó que un arroyo ó unas quebradas no atraviesen la posesion de modo que se pueda sacar agua de ellos, por medio de canales ó de zanjas dispuestas á jropósito: cuando no haya agua ningruna ó muy poca, lo que es la circunstancia mas perjudicial á tal empresa. será necesario escarvar pozos y disponer estanques ó lagos artificiales para recibir y tener guardada el agua de las lluvias, con ó sin canales de distribucion. Cada vez que la disposicion topográfica del terreno esté á propósito, teniendo aguas abundantes bastante cercanas de él ó atravesándoles, será muy ventajoso establecer un buen sistema de riego, á fin de regar cada cercado en el acto de haber mudado los animales á otro, y así cada 6 á 8 dias, segun la estacion, el estado del suelo y la vejetacion mas ó menos lozana, lo que será siempre de mayor provecho. En efecto, el catedrático Liebig dice: "En la recindad de Liegen (en Nassau) se obtiene de un prado de 3 hasta 5 cortes de heno, y esto se consigue cubriendo el campo con agua de rio que se conduce al prado en la primavera, por medio de numerosísimas zanjas pequeñas; se ha notado eso tan ventajoso que suponiendo que un prado que no recibe este riego rinde 1,000 libras, otro á que se le introduce el agua rendirá de 4 á 5,000 libras. ”

El terreno desmontado y cercado como lo tenemos dicho, las maderas útiles apartadas y las demas vueltas carbon ó quemadas, así como las malezas, cuyas cenizas se esparcirán igualmente, entónces se dará una labor al terreno para unir y nivelarle lo mejor posible, atendiendo siempre á la disposicion topográfica; hecho eso se podrá sembrarle de tabaco, de maiz, de arroz, etc., segun la naturaleza y la disposicion especial del suelo; despues de sacada la cosecha, se le echará semillas de yerba de Guinea, mezcladas con otras de las gramíneas que mas apetecen los animales y que les hacen mayor provecho, mezclando con ellos como una cuarta parte de semillas leguminosas, tales como la alfarfa, trébol comun, sulla ó esparcilla, porque ademís de ser para el ganado un alimento riquísimo, son abono para el suelo que estenuan mucho las gramíneas, y especialmente la yerba de Guinea : en los parajes húmedos y hasta algo pantanosos, habrá de sembrarse la yerba del Para, gramínea que, además de ser para los animales un alimento magnífico, da mucho producto, tiene, por su lozana, continua é invasora vejetacion, la propiedad de dar mas firmeza á tales suelos y de volverlos en el intervalo de pocos años riquísimos y muy productivos; pero será necesario tener siempre mucho cuidado en evitar su contacto con los cañaverales, porque les invade con mayor facilidad, hace mucho perjuicio á la caña por su presencia y además multiplica los gastos, haciendo los desyerbos mucho mas repetidos, y es muy difícil acabar con ella y para eso es necesario arrancarla de manera que no quede en el suelo ningun trocito, y quemarlo todo; no se la debe 
dejar florecer nunca, ni por consiguiente hechar semillas. Hay además otra clase de praderas artificiales, son las que se hacen ordinariamente con yerba de Guinea, que se siembra para cortarla y emplearla eomo forraje: se las puede hacer tambien con maiz, que vuelto malojilla, como ya lo tenemos dicho, se espende en las ciudades para alimento de los caballos; se empleará tambien con ventaja para tal objeto la caña de cintas, porque viene en terrenos malos, resiste bien á la seca y recibe dos cortes al año; rinde además un forraje abuniłante y riquísimo en sustancias nutritivas para cualquiera clase de ganado; se las puede tambien formar con coix lacryma, con alfarfa y con esparcilla de España, segun la clase de terreno que tuviere uno á su disposicion.

La alfarfa necesita un suelo profundo ó á lo menos que su subsuelo sea bien permeable, porque sus raices, largas como de mas de un metro, sacan del sub-suelo una porcion de su alimento; las tierras frias, húmedas siempre, ó las arcillosas fuertes, no le convienen: ese vejetal pide abonos calcáreos, como verbigracia, el yeso y la cal, lo que le conviene perfectamente, $y$ con los cuales da mayor producto. Esa planta constiture un forraje magnífico y abundante, sea verde $\dot{o}$ vuelto heno, ó despues de desecado, lo que se deberia hacer como en Europa, bien que no hara nunca ningun invierno que atravesar, pero porque la seca, que es el azote de los paises cálidos en donde hay una primavera continua, y por consiguiente donde se encuentra mayor imprerision, bien que se haya visto tantas veces al campesino contemplar con semblante que da lástima el estado miserable de sus ganados por causa de una seca horrorosa y prolongada que arrastra siempre en pos de sí las mayores pérdidas; pero apenas pasado el temporal ya todo se olvidó y ninguna medida se toma para remediar tal estado de causas, que se repite con demasiada frecuencia; tales praderas pueden dar un producto muy regular durante unos 5 ó 6 años, teniendo únicamente el cuidado de limpiar el terreno, como se suele hacer para la yerba de Guinea despues de cada corte, especialmente si á los dos años de sembrada, por ejemplo, se le echa cal ó yeso reducido á polvo, sea crudo, sea cocido, pero se ha de preferir este en los lugares donde uno puede proporcionárselo con facilidad $y$ barado, porque favorece mucho la vejetacion de todas las plantas leguminosas; se le hará mucho favor y saldrá mas lozana. Despues de una labor profunda y de un buen abono, si el terreno no es bastante rico, se entregará la semilla á la tierra en la primavera ó algo antes de la estacion de las lluvias, es decir, en abril ó mayo, se sembrará la semilla de amelga ú otras en línea recta. tapándola con el rastrillo ó con la grada volcada y armada de ramas espinosas; cuando la siembra haya alcanzado algunas pulgadas de alto, se deberá principiar á desyerbarla, repitiendo esta operacion todas las veces que fuere necesario. 


\section{FÉ DE ERRATAS}

Pájina 3, lín. 42, en lugar de Desimidieas, léase Dismidieas.

5 , lín. 33, en lugar de haa, léase han.

6, lín. 24, en lugar de poligana, léase poligona.

$\tau$, lín. 27, en lugar de monosifornieas, léase monnsifonieas.

8, lín. 5, en lugar de espondias, léase csporídias.

9 , lín. 39, en lugar de cepveces, léase veces.

13, lín. 18, en lugar de zoospores, léase zoosporos.

18, lín. 35, en lugar de peretechio, lẻase peritscio.

Id. lín. última, en lugar de súlido, léase salido.

22 , lín. 39, en lugar de llenendo, léase llenando.

23, lín. 13, en lugar de amplexicante, léase amplexicaule.

Id., lín. 21, en lugar de claterios, léase elaterios.

24 , en lugar de clase 4, léase clase 6 , por consiguiente las clases siguientes han de llevar dos números mas que el indicado, por equivocacion en la composicion.

26, lín. 3, en lugar de sagittafolia, léase sagittafolia.

Id., lín. 24, en lugar de estreclay, léase estrecha $y$.

Id., lín. 27, en lugar de ovalo, léase óvulo.

Id., lín. 29, en lugar de indeniscente, léase indehiscente.

51 , lín. 40, en lugar de $15^{\prime \prime}$, léase $15^{\prime \prime \prime}$.

52, lín. 30, en lugar de familia $1^{2}$, léase familia 29.

53, lín. 7, en lugar de Jamacensis, léase Jamaicensis.

61, lín. 39, en iugar de siete nervios, léase siete nerrias.

62, lín. 25, en lugar de putitos negros, léase puntitos negros.

64, lín. 42, en lugar de pabescente, léase pubescente.

66, lín. 7, en lugar de ascendentales, léase ascendentes.

68, lín. 22, en lugar de P. Bredemeyeri. - P. Macrophylla, léase A. Bredemeyeri. - A. Macrophylla, y así hasta fines del párrafo, porque se ha seguido á la equirocacion por falta de atencion de los cajistas.

70 , lín. 15, en lugar de nequilaterales, léase inequilaterales.

72 , lín. 38, en lugar de ta lo, léase tallo.

76, lín. 23, en lugar de estio, léase está.

78 , lín. 33, en lugar de cuyo, léase cuyos.

79, lín. 1, en lugar de pelitirnjizas, léase pelitiesas y rojizas. 
Pájina 80, lín. 11, en Iugar de familia 39, léase fanikia 39 bis.

83, lín. 16, en lugar de subuladas, léase subulados.

91, lín. 6, en lugar de volvar, léase valvar.

95, lín. 18, en lugar de j’unidas, léase reunidos.

96, lín. 23, en lugar de fulfuráceas, lease furfuráceas.

97, lín. 23, en lugar de G. III, léase G. II, y en lugar de lase spigas, léase las espigas.

Id., lín. 45, en lugar de famitia 46, léase 47 bis.

99, lín. 32, en lugar de sin ester es, léase sin estériles.

101, lín. 34, en lugar de antumbroso, léase herrumbroso.

104, lín. 47, en lugar de adherid, léase adherido.

106, lín. 8, en lugar de ó 5 estilos 2 etc., léase 5 estilos 02 etc.

10\%, lín. 47, en lugar de despendicular, léase perpendicular.

Id., lín. 9, en lugar de aguza pas, léase aguzadas.

108, lín. 41, en lugar de absortos, léase abortos.

112, lín. 12, en lugar de Arederas, léase Anredera.

114, lín. 18, en lugar de piriforme, léase pisiforme.

115, lín. 36, en lugar de Euxulus, léase Euxolus.

119, lín. 7, en lugar de tatique, léase tabique.

12\%, lín. 24, en lugar de alternos, con lúbulos, léase alternes con los líbulos, etc.

131, lín. 6, en lugar de subsolitarias, léase subsolitarios.

134, lín. 13, en lugar de panojos, léase pannjas.

138, lín. 47, en lugar de capsular, léase cápsulas.

139, lín. 39, en lugar de alesado, léase aleznado.

140, lín. 9, en lugar de panicifloros, léase paucifloros.

Id., lín 36, en lugar de familia 61, léase $62 \mathrm{lis.}$

141 , lín. 15, en lugar de iromeras, léasê isomeras.

142 , lín. 21, en lugar de familia 62, léase 62 ter.

144, lín. 17, en lugar de pergulyvieas, léase pergularieas.

145, lín. 19, en lugar de est eriores, léase esterinres.

Ir., lín. 23, en lugar de Eusclepiadeas, léase Euasclepiadeas.

146, lín. 3, en lugar de paucifioros, léase paucifloros.

151 , lín 9, en lugar de caliiznales, léase calizinales.

160, lín. 1, en lugar de ovalo-lanceolado, léase ovalo-lanceoladas.

161, lín. 27, en lugar de Rorajeas, léase Borajeas.

Id., lín. 33, en lugar de borrayo, léase borrago.

162, lín. 13, en lugar de con una punta entera alampiñada, etc.,

léase con una punta, entras, alampiñadas, etc.

Id., lín. 37, en lugar de rupa, léase drupa.

163 , lín. 18, en lugar de relejos, léase reflejos.

165, lín. 25, en lugar de oral oblongas en espigas, etc., léase oral oblongas; flores en espigas, etc.

171, lín. 3, en lugar de ticn, léase tan.

174, lín. 21 en lugar de vertical, léase transversal.

176 , lín. 35, en lugar de $6,5^{\prime \prime \prime}$, léase $6-5^{\prime \prime}-2 "$.

177, lín. 45, en lugar de pegades, léase pegados.

182 , lín. 15 , en lugar de $8^{\prime \prime \prime} a 4^{\prime \prime \prime}$, léase $8^{\prime \prime} a 4^{\prime \prime}$.

189, lín. 4, en lugar de del toideas, lease deltoideas.

191, lín. 25, en lugar de druputa, léase drupita. 
Pájina 195, lín. 37, en lugar de iguales, con el estilo, léase iguales con el estilo.'

208, lín. 49, en lugar de semlilas, léase semillas.

213, lín. 18, en lugar de pirijino, léase perijino.

214, lín. 13, en lugar de entero posterior, léase antero-posterior.

216, lín. 15, en lugar de siliciforme, léase silicuiforme.

Id., lín. 3.5, en lugar de orimibos, léase corimbos.

219, lín. 5, en lugar de cotiledo nesincumbentes, léase cotiledonos incumbentes.

222, lín. 42, en lugar de valvaries, léase valvares.

230, lín. 35, en lugar de Malvdoideas, léase Malvoideas.

235, lín. 8, en lugar de tanius de cajitas, léase en tantas cajitas.

241 , lín. 25, en lugar de pedínculos, léase peciolos.

214 , lín. 29, en lugar de toridas, léase torcidas.

249, lín. 35, en lugar de florescencia, léase inflorescencia.

260, lín. 34, en lugar de vueltos; androforo, léase vueltos andiforo.

Id., lín. 45, en lugar de muciforme, léase nuciforme.

261, lín. 23, en lugar de augustifolia, léase angustifolia.

271 , lín. 13 , en ligar de $11^{2} 2 \dot{a} \cdot 2$, léase $112^{2} a^{\prime \prime} 2^{\prime \prime}$.

272, lín. 35, en lugar de chadeo, léase chadec.

274, lín. 24, en lugar de hojas largas de cuyos, léase hojas largas cie

$\left.21_{[2-3-3}\right]_{[} 2^{\prime \prime}$ sobre $\left.11_{[2-2}\right]_{1} 2^{\prime \prime}$ de ancho, cuyos.

279, lín. 50, en lugar de corpulentos; frondosos, léase corpulentos, frondoso, etc.

282, lín. 10, en lugar de cucuru, léase cururu.

284, lín. 27, en lugar de cuyo léase con.

Id., lín. 50, en lugar de pedicelos, estériles, léase pedicelos estériles.

285, lín. 46, en lugar de troforpermos, léase trofospermos.

Id., lín. 49, en lugar de azilo, léase arilo.

292, lín. 1, en lugar de euforma, léase es formado.

Id., 35, en lugar de los lados laterales, léase los dos laterales.

293, lín. 9, en lugar de pors, léase por.

296, lín. 30, en lugar de i lampiñado, léase alampiñado.

297, lín. 40, en lugar de ron, léase son.

Id., lín. 44, en lugar de fiores blancas en legumbre, léase flores blancas; legumbre, etc.

300 , lín. 13, en lugar de $1^{\prime \prime}$, léase 1 ".

301, lín. 23, en lugar de fruticuloso, léase fruticulosa.

305 , lín. 8, en lugar de subagudos, léase subagudas.

Id., lín. 16, en lugar de 2112 , léase $2,1112$.

Id., lín. 26, en lugar de dispuestos, léase dispuestas.

306, lín. 1, en lugar de sobro 10 a $8^{\prime \prime}$, léase solve $10 a 8^{\prime \prime \prime}$.

315, lín. 28, en lugar de scleroxipla, léase scleroxyla.

316, lín. 16, en lugar de ginoflo, léase giniforo.

318 , lín. 14, en lugar de $12^{\prime \prime}$, léase $12^{\prime \prime \prime}$.

322, lír. 17, en lugar de largos, léase largo.

325 , lín. 47, en lugar de opacos, léase spacas.

329 , lín. 45, en lugar de son, léase con. 
Pájina 332, lín. 28, en lugar de siliciforme, léase silicuiforme.

333 , lín. 24, en lugar de deciduo, léase decidua.

335, lín. 21, en lugar de labiadas, léase lobuladas.

337, lín. 21, en lugar de aovado-lanceoladas, léase aovado-lanceo-

lados.

339, lín. 20, en lugar de sicania, léase sicana.

Id. lín. 22, en lugar de comiculata, léase corniculata.

346, lín. 7, en lugar de estrellados, léase estriados.

352 , lín. 44, en lugar de 0 ..., léase $\delta$ comprimido por los lados.

353 , lín. 32, en lugar de didinamo, léase didimo.

355, lín. 43, en lugar de ansubo, léase ausubo.

Id. lín. 44, en lugar de Moukey, léase Monkey.

356, lín. 1, en lugar de mimmsops, léase mimusops.

360 , lín. 46, en lugar de tronce, léase tronco.

372 , lín. 12, en lugar de verticulares, léase verticales.

373 , lín. 20, en lugar de se hallan, léase se halla.

:377, lín 33, en lugar de par, léase por.

384 , lín. 37, en lugar de $15^{\prime}$, léase $15^{\prime \prime}$.

389, lín. 20, en lugar de verde seco 1,354, léase verde, seco es de 1,354 .

390, lín. 45, en lugar de copa blanco, léase capa blanco.

393, lín. 11, en lugar de Espondias, léase Spondias.

399, lín. 23, en lugar de suminisira, léase suministra.

405, lín. 23, en lugar de juga; léase yagua.

408, lín. 31, en lugar de 1*ogosa, léase rugosa.

409, lín. 31, en Jugar de rojozo, léase rojizo.

413, lín. 34, en lugar de sepodilla, léase sapodilla.

415 , lín. 13, en lugar de lojitudinales, léase lonjitudinales.

422, lín. 25, en lugar de calcaria, léase calcárea.

450, lín. 7, en lugar de apoca, léase aporca.

Id., lín. 21, en lugar de canelones, léase camelones.

Id., lín. 24, en lugar de canelon, léase camelon.

452, lín. 29-30, en lugar de fá cli, léase fácil.

453, lín. 30, en lugar de insinan, léase inclinan.

454, lín. 8, en lugar de dispuestas, léase dispuestos. 


\section{INDICE DE LAS FAMILIAS}

Abietíneas.

Acantáceas.

Agaricáceas.

Algas.

Alismáceas.

Amarantáceas.

Amarilidáceas.

Amarilídeas.

Amiridáceas.

Amirídeas.

Ampelídeas.

Anacardiáceas.

Anacárdieas.

Anonáceas.

Antidésmeas.

Apiáceas.

Apocináceas.

Apocíneas.

Aquifoliáceas.

Aráceas.

Aristoloquiáceas.

Aristoloquíeas.

Artocarpáceas.

Asclepiadáceas.

Asclepiádeas.

Atriplíceas.

Auranciáceas.

A

Pag.

Baséleas.

110

55

Batídeas.

333

186

Begoniáceas.

183

14 Bitneriáceas. 245

1 Bixáceas.

53 Bixíneas.

212

115

39

Bombáceas.

")

252

160

)

289

Borrajíneas.

287

Burseráceas.

285

221

290

")

Cácteas.

346

223

Cannáceas.

$35 \check{1}$

Caparidáceas.

"

146

Caparideas.

127

)

Caprifoliáceas.

349

205

24

Cariofíleas.

275

Cedreláceas.

82

90 Cesalpíneas.

302

๓ Cicádeas. 56

80 Ciperáceas. 29

142

1)

108

Clorantáceas.

Clusiáceas.

228

Colchicáceas.

332

Combretáceas.

Comelíneas.

Compuestas.

119

Conferváceas.

Balanofóreas. 
Crescencíeas.

Crisobaláneas.

Crucíferas.

Cucurbitáceas.

Cupresíneas.

Cusparieas.

Hipocratáceas.

Hipoxídeas.

Hipoxíleas.

Hongos.

Homaliáceas.

Homálieas.

Diatomáceas.

Dilleniáceas.

Dioscoreáceas.

Diosmeas.

Diospíreas.

Dismidíeas.

Equisetáceas.

Ericáceas.

Eritroxyleas.

Escrofulariáceas.

Esmiláceas.

Espondiáceas.

Esterculiáceas.

Euforbiáceas.

Fabáceas.

Fitolacíceas.

Florídeas.

Fucoídeas.

291

112

\section{G}

Gencianáceas.

Genciáneas.

Goodenoviáceas.

Gramíneas.

Granáteas.

Guttíferas.

\section{H}

Helechos.

Hepáticas.

Hernandiáceas.

Hesperídeas.
Ilicíneas.

Iridáceas.

Irídeas.

\section{I}

205

38

;)

J

Jazmíneas.

Juglandáceas.

Juglándeas.

")

L

Labiadas.

Labiatas.

Lamiatas.

Lauráceas.

Leguminosas.

Lemnáceas.

Licoperdáceas:

Licopodiáceas.

Liliáceas.

Liquenáceas.

Loúseas.

Lobeliáceas.

Loganiáceas.

Lorantáceas.

\section{Magnoliáceas.}

Malnijiáceas.

Malvúceas.

Marcgraviáceas.

Meliáceas.

Menispermáceas.

Henispérmeas.

230

273

221

Mimóseas.

Mioporáceas.

Miricaceas. 22 ? 
Miristíceas.

Mirsináceas.

Jirsíneas.

Nayádeas.

Nelombóneas.

Nictajíneas.

Ninfeáceas.

Nopáleas.

O

Olacíneas.

Onagraríeas. Orquidáceas.

Orquídeas.

Oxalídeas.

N

pag.

222

202

)"

Risofóreas.

Rosáceas.

Rubiáceas.

Rutáceas.

52

220

116

219

346

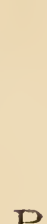

Palmeras.

Pandanáceas.

Papaveráceas.

Papayáceas.

Papilionáceas.

Pasiflóreas.

Pedaliáceas.

Pedalíneas.

Piperáceas.

Pistiáceas.

Plantajíneas.

Plumbajíneas.

Poligaláceas.

Poligáleas.

Poligonúceas.

Potómeas.

\section{P}

273

331

43

262

Salicariáceas.

Salicúrieas.

Salicíneas.

Salsoláceas.

Sapindáceas.

Sapotáceas.

Sauvajésieas.

Sesámeas.

Simarúbeas.

Solanáceas.

Soláneas.

13

219

339

292

340

185

)

58

54

201

)

260

"

103

52

Teofrústeas.

Tifúceas.

Tilandsíeas.

Tiliáceas.

Timéleas.

Triquiliáceas.

Tropæoleas.

Turneráceas.

T

$s$

329

))

89

108

279

207

210

185

265

165

n)

203

25

37

230

102

$2 \div 3$

264

344

U

Umbelíferas.

251

Uredíneas.

Urticíceas.

Uríceas.

120

Valerianáccas.

Valerićneas.

Quenopodiáceas.

Quenopódieas.

Vanilliceas.

Verbenáceas.

Viníferas.

Violariúceas.

Ramnáceas.

Ramneas.

Renunculáceas. 
Zantoxíleas.

Zigofíleas.

Zinjiberáceas.

Zumaquíneas.

Apéndice $1^{\circ}$ ó noticia solure las maderas útiles de las
Pag. 270 268

42

290
Antillas y algunas de la República de Venezuela. $3 \check{4}$ Apéndice $2^{\circ}$ ó resúmen analítico de agricultura apropiada á los paises intertropicales.

FIN. 






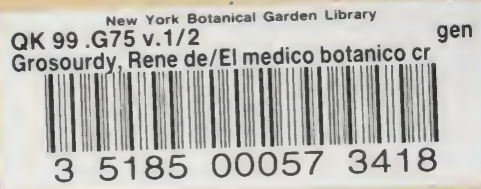


